

\section{UM CASO DE FRONTEIRA NO «DOURO NOVO» CARRAZEDA DE ANSIÃES. PARA A HISTÓRIA DO VINHO DO PORTO}

MARIA OTÍLIA PEREIRA LAGE 
Título: Um caso de fronteira no «Douro Novo»: Carrazeda de Ansiães. Para a história do vinho do Porto

Autoria: Maria Otília Pereira Lage

Prefácio: Gaspar Martins Pereira

Design gráfico: Helena Lobo Design I www.hldesign.pt

Imagem da capa: Trabalhos de poda no Douro Superior. Foto de Leonel de Castro (fotojornalista do «Jornal de Notícias»)

Coedição: CITCEM - Centro de Investigação Transdisciplinar Cultura, Espaço e Memória

Via Panorâmica, s/n | 4150-564 Porto | www.citcem.org I citcem@letras.up.pt

Edições Afrontamento, Lda. I Rua Costa Cabral, 859 | 4200-225 Porto

www.edicoesafrontamento.pt I geral@edicoesafrontamento.pt

N. ${ }^{\circ}$ edição: 1944

Depósito legal: 450313/18

ISBN: 978-972-36-1719-1 (Edições Afrontamento)

ISBN: 978-989-8970-03-9 (CITCEM)

DOI: https://10.21747/978-989-8970-03-9/cas

Porto, dezembro de 2018

Impressão e acabamento: Rainho \& Neves Lda. I Santa Maria da Feira

geral@rainhoeneves.pt

Distribuição: Companhia das Artes - Livros e Distribuição, Lda.

comercial@companhiadasartes.pt

Trabalho cofinanciado pelo Fundo Europeu de Desenvolvimento Regional (FEDER) através do COMPETE 2020 Programa Operacional Competitividade e Internacionalização (POCI) e por fundos nacionais através da FCT, no âmbito do projeto POCI-01-0145-FEDER-007460 


\section{DEDICATÓRIA}

Em memória de meu avô materno, Eduardo Fernandes, rogador do Douro, e de minha mãe, Maria da Conceição Fernandes, que o acompanhava nas rogas, atravessando a pé a «frieira» do planalto com destino às terras durienses da «ribeira» de Carrazeda de Ansiães para o trabalho sazonal das vindimas e apanha da azeitona.

Ambos naturais deste concelho «fronteira» do Douro Vinhateiro, com eles aprendi, cedo, a dar valor aos trabalhos quotidianos e esforçados nas quintas vinhateiras durienses. As muitas histórias que contavam estimularam-me, desde criança, ao conhecimento da espessura histórica desta zona do Douro Superior.

Em sua evocação e de muitos outros com idênticas trajetórias de vida e de trabalho, fica esta homenagem que é de toda a justiça prestar a quantos fizeram a Região Vinhateira Duriense e continuam a mantê-la viva e produtiva.

Inspirou-nos na escrita desta história social de uma parcela do Douro Os Trabalhos e os Dias, livro intemporal do intemporal poeta Hesíodo, uma poética e filosofia do trabalho. Esta obra escrita na tradição oral da Grécia Arcaica e datada do longínquo século VIII-VII a. C., conserva ainda hoje grande atualidade. O seu autor, um dos primeiros escritores conhecidos da Antiguidade Clássica, Hesíodo, ensina-nos, com a sua capacidade de contar histórias de forma concisa e poderosa, que o trabalho só tem a devida compensação se a justiça lhe for aplicada sem distorções. 


\section{AGRADECIMENTOS}

Muitos foram os aliados constantes, indivíduos, entidades e instituições com quem pudemos contar na elaboração deste livro e durante a investigação que o sustenta. De sua insubstituível ajuda somos devedores, pelo que começamos por expressar-lhes os nossos agradecimentos.

Sem que signifique qualquer tipo de esquecimento pessoal e académico de todos quantos nos auxiliaram, decisivamente, uma menção particular é devida a alguns nomes cuja colaboração e apoio durante o processo de investigação acabou por se tornar mais constante e estimulante.

Ao Professor Doutor Gaspar Martins Pereira, a nossa amizade e gratidão por todo o incentivo, apoio contínuo, ensinamentos, leitura crítica e prefácio deste livro.

Aos Professores Doutores Amélia Maria Polónia da Silva, Coordenadora Científica do CITCEM, e Luís Alberto Alves, Coordenador do meu Grupo de Investigação, Memória, Património e Identidades, agradeço a viabilização institucional prestada quer a este nosso projeto de investigação, quer à publicação da presente obra em parceria CITCEM/Edições Afrontamento, editores a quem devemos também público reconhecimento.

No processo de investigação destaco o meu grato reconhecimento à inestimável colaboração, confiança e cedência de documentos e materiais escritos de informação que nos foram concedidas pelos proprietários das quintas durienses em Carrazeda de Ansiães, designadamente: Engenheiro Alexandre Mariz da Quinta da Alegria de Cima, Dra. Maria Luz Serrano Bartol da Quinta Canaes/Bartol, Engenheiro Luís Pizarro de Castro e Dra. Catarina Pizarro de Castro da Quinta do Lubazim e Dr. António João Sampaio, ex-proprietário da Quinta do Zimbro de Cima.

No caso das empresas sediadas em Carrazeda cumpre-nos agradecer também os esclarecimentos e informações que nos foram proporcionados pelos seus proprietários, os enólogos Frederico Meireles da Grambeira e Zito Santos da Douro Ansiães.

Ao nível das informações e documentos importantes para um mais direto e profundo conhecimento das Quintas dos Canais, da Senhora da Ribeira, Chousa e Tua, assim como das empresas suas proprietárias Cockburn Smithes e Symington Family, foi-nos essencial a dedicada e atenta colaboração sempre prestada pela abertura do Engenheiro Luís Martins, quadro superior da Symington Family Group, que nos autorizou visitas de estudo e consulta continuada dos arquivos destas firmas. 
Ainda aos diversos e numerosos informantes privilegiados, proprietários, produtores e trabalhadores vitivinícolas de todas as freguesias vinhateiras de Carrazeda que foram sendo referenciados ao longo deste livro, estamos gratos pela total disponibilidade da sua colaboração ativa nas entrevistas que nos concederam. No que concerne à Região Duriense, deve-se ainda mencionar, na Régua, um agradecimento especial ao Engenheiro António Mesquita Montes, antigo presidente da Casa do Douro e confrade fundador da Confraria do Vinho do Porto, e ao produtor/engarrafador, José Manuel Lopes da Quinta Nossa Senhora da Graça e da marca Pedro Mil Homens, Vinhos DOC, ex-funcionário da Cockburn's para o concelho de Carrazeda, pelas informações que nos prestaram sobre o Douro Vinhateiro e o vinho do Porto, com especial destaque para dimensões e aspetos importantes à escala nacional, regional e local com particular relevo para o caso do estudo aprofundado e contextualizado deste concelho.

No que se refere à pesquisa de documentos de arquivo e disponibilização de fontes históricas, designadamente nas facilidades de acesso, foi particularmente importante, o apoio prestado pelo labor competente e profissionalismo das arquivistas Dra. Isabel Mamede, da Casa do Douro (Régua), Dra. Marlene Cruz, do secretariado do CITCEM, e da Mestre Paula Montes Leal, uma das melhores conhecedoras dos arquivos do Douro e organizadora do Arquivo Histórico do Grupo Symington (Coradas - Gaia), cujo apoio constante nos foi sempre de grande ajuda.

Idêntica colaboração nos foi ainda facultada pelos técnicos de outras instituições e entidades como o IVDP, biblioteca e arquivo, o Centro Português de Fotografia e o Museu de Vinho do Porto, instituições a quem é também devido agradecimento público.

A cedência de fotografias originais e inéditas da zona duriense de Carrazeda de Ansiães, e respetivos créditos, fica a dever-se ao fotojornalista do «Jornal de Notícias», Leonel de Castro, nosso conterrâneo e amigo a quem reiteramos a grande e grata estima.

Por fim, cabe-nos expressar também público agradecimento quer ao Presidente da Câmara Municipal de Carrazeda de Ansiães, professor José Luís Correia e Vereadores, pelo apoio à edição deste livro, quer à CCRN-D, nas pessoas do seu Vice-Presidente, Engenheiro Ricardo Magalhães, e da jurista Dra. Maria do Rosário de Andrade Azevedo, secretária do Programa Operacional Regional do Norte (ON.2), pela disponibilidade manifestada para o apoio logístico ao lançamento público do presente livro. 
PAISAGEM

À memória de meu avô António Araújo

Nestes montes não há nenhumas flores

Nem gota de água para um passarinho

Há rochedos que dão azeite e vinho,

Quinta-essência do suor dos cavadores

É uma terra negra não tem cores

- Lenços bordados como tem o Minho.

O rio que a percorre é um remoinho

Insaciável de vidas e valores.

Amo esta paisagem sepulcral

Como um bom filho ama uma mãe feia,

Que luta por amor, com todo o mal.

Vejo sobre ela a forma giganteia

Da mão que lhe deu forma sem igual,

Erguendo entre água e céu uma epopeia.

13 de janeiro de 1944 


\section{SUMÁRIO}

PREFÁCIO

INTRODUÇÃO GERAL

PARTE I. MARCASE TRAÇOS DA CULTURA DA VINHA E DO VINHO NO DOURO: INSCRIÇÃO ESPACIOTEMPORAL DE CARRAZEDA DE ANSIÃES 25

Capítulo 1. A Região do Douro e o vinho do Porto: processo de desenvolvimento 29

1.1. Carrazeda (d)e Ansiães na história antiga da vinha e do vinho 32

1.2. Construção sócio-histórica da região produtora do Vinho do Porto 34

1.3. Uma longa história, a do «vinho do Porto» 43

1.3.1. Dinâmicas espaciotemporais e diversidade de produção e comércio do vinho do Porto 44

1.3.2. Processo de produção dos vinhos do Porto $\quad 49$

1.3.3. Evolução das técnicas de vinificação do vinho do Porto 51

Capítulo 2. O Douro, Região Demarcada como traço originário $\quad 61$

2.1. Demarcações: expansão do espaço regional de produção e comércio dos vinhos finos durienses 65

2.1.1. Primeira região vitivinícola demarcada e regulamentada do mundo: origem de uma identidade regional 66

2.2. Carrazeda de Ansiães e «Douro Novo»

2.3. Território de Carrazeda na cartografia do Barão de Forrester $\quad 79$

2.3.1. Carrazeda de Ansiães nos mapas do Alto Douro de Forrester 81

2.4. Vinhas e quintas de Carrazeda no «país vinhateiro» do Visconde de Vila Maior 85

Capítulo 3. Matriz da Paisagem Cultural e Património (i)material duriense: geios/socalcos 93

3.1. Os conceitos de Paisagem Cultural e Património (i)material 99

3.2. Matriz e alicerces da Paisagem Cultural Vinhateira do Douro 101

3.3. A construção indispensável dos geios: das fragosas encostas a um imenso anfiteatro $\quad 103$

3.4. O ADV, Paisagem Histórica e Património Cultural da Humanidade $\quad 109$

PARTE II. POSIÇÃO DE CARRAZEDA DE ANSIÃES NO DOURO CONTEMPORÂNEO 111

Capítulo 4. Redefinição da Região Duriense. Regresso à Demarcação e ao Protecionismo Regional 117

4.1. A questão duriense e a nova demarcação da região vinhateira (1907-1908) 118

4.2. Denominação de origem «Douro» e marca «Porto» 128

$\begin{array}{ll}\text { 4.3. O retorno ao protecionismo regional e a agitação social } & 130\end{array}$

Capítulo 5. O Caso de Carrazeda, concelho de «Fronteira» na RDD 135

5.1. Contexto histórico e posição específica de Carrazeda no Douro Vinhateiro 136

5.2. Significado e impacto local das novas demarcações 139

5.2.1. Índices gerais de exportação e indicadores de produção de vinhos generosos do Douro 140 
5.2.2. Panorâmica das quintas produtoras de vinho do Porto localizadas em Carrazeda 142

5.2.3. Carrazeda de Ansiães enquanto produtor de vinhos generosos do Douro 143

5.2.4. O concelho de Carrazeda de Ansiães — espaço económico-social, demográfico e cultural 147

5.3. O vinho do Porto e o problema económico dos viticultores durienses 151

5.3.1. O enfrentar da crise e o domínio de Dona Antónia Ferreira e família... 152

5.3.2. Extensão ao território concelhio duriense de Carrazeda de Ansiães 152

5.3.3. Conjuntura favorável ao regresso da demarcação da região e defesa dos interesses da lavoura duriense 154

5.3.4. Concorrência ao vinho do Porto no mercado britânico e tumultos sociais no Douro 154

Capítulo 6. A «Questão do Douro» e a turbulência social na região 157

6.1. Movimentos sociais e políticos no Douro contemporâneo 158

6.2. Tumultos populares na viragem da Monarquia para a República 160

6.2.1. Contexto e significado histórico das representações e sublevações 162

6.3. Representações, identidade regional e identidades conjunturais 168

PARTE III. AGENCIAMENTO E CONFIGURAÇÃO DA PRODUÇÃO E COMERCIALIZAÇÃO DO VINHO

DO PORTO: QUINTAS E FIRMAS 179

$\begin{array}{ll}\text { Introdução } & 181\end{array}$

Capítulo 7. Constelação de quintas durienses em Carrazeda de Ansiães 187

$\begin{array}{ll}\text { 7.1. Aproximação conjuntural } & 187\end{array}$

7.2. Quinta dos Canais: a maior do concelho de Carrazeda e sua representatividade 196

7.2.1. A Quinta dos Canais: entidade socioeconómica de valor patrimonial 204

7.2.2. Microcosmo social em meio rural: memórias e materiais de memória 223

7.3. Quinta Canaes-Bartol: tradição familiar luso-espanhola no Douro 238

$\begin{array}{ll}\text { 7.3.1. Caracterização histórica e descritiva } & 239\end{array}$

7.3.2. Localização e denominações da Quinta 246

7.3.3. Dinâmica e rentabilidade económica da Quinta Bartol 256

7.3.4. Desenvolvimento e modernização técnica: realizações e constrangimentos 262

7.4. A Quinta da Alegria, continuidade e arquivo: resiliência duriense 267

$\begin{array}{ll}\text { 7.4.1. Localização da quinta e acessibilidades } & 268\end{array}$

7.4.2. Aproximação histórica e arquivística 273

7.4.3. Contextualização espaciotemporal e evolução da Quinta da Alegria 277

7.4.4. História recente da Quinta a partir da administração pioneira de Alexandre Augusto Mariz 284

7.4.5. Significado da Quinta da Alegria no concelho e contexto da RDD 290

7.5. Quinta de Lubazim: A longa duração no Douro Vinhateiro 296

7.5.1. A Casa e Quinta de Lubazim: Origens e evolução histórica 297

7.5.2. Envolvência geográfica, geomorfológica e ambiental da Quinta de Lubazim 305

7.5.3. Património e identidade da Casa e Quinta de Lubazim 307

7.5.4. Produção e cultura vitivinícola de Lubazim 315

$\begin{array}{ll}\text { 7.6. Outras quintas históricas do concelho } & 321\end{array}$

7.6.1. A Quinta da Senhora da Ribeira $\quad 322$

7.6.2. A Quinta do Zimbro 336

7.6.2.1. A Quinta do Zimbro de Baixo $\quad 339$ 
7.6.2.2. A Quinta do Zimbro de Cima $\quad 347$

7.6.3. As Quintas do Tua e da Chousa $\quad 351$

7.6.3.1. A Quinta do Tua (ou Quinta dos Ingleses ou dos Smithes) 354

$\begin{array}{ll}\text { 7.6.3.2. A Quinta da Chousa } & 359\end{array}$

Capítulo 8. Empresas estrangeiras e nacionais no negócio do vinho do Porto em Carrazeda de Ansiães 367

8.1. Antigas firmas: Silva \& Cosens, Dow's, Warre e Martinez Gassiot 368

$\begin{array}{ll}\text { 8.1.1. Silva \& Cosens } & 369\end{array}$

$\begin{array}{ll}\text { 8.1.2. Warre \& Co } & 371\end{array}$

$\begin{array}{ll}\text { 8.1.3. Dow's } & 373\end{array}$

$\begin{array}{ll}\text { 8.1.4. Martinez, Gassiot \& Co } & 374\end{array}$

8.2. Cockburn \& Smithes: protagonismo histórico 376

8.2.1. A firma Cockburn Smithes \& Co., S.A.

8.2.2. O comércio dos vinhos do Porto e as marcas Cockburn 381

8.2.3. A marca em destaque nos mercados internacionais 382

8.2.4. O «estilo Cockburn» e J. H. Smithes 382

8.2.5. A Cockburn's no comércio e produção de vinho do Porto em Carrazeda de Ansiães 383

8.3. Symington Family Estates: liderança e dominância atual 387

8.4. Empresa Grambeira — Vinhos DOC Douro 395

8.4.1. Projeto familiar de empreendedorismo local na fileira dos vinhos 396

8.4.2. Uma nova dimensão económica da região: os vinhos DOC — Douro 398

8.4.3. Uma visão estratégica integradora do e no Douro 399

8.5. «Douro Ansiães»: iniciativa local de vinificação 399

Capítulo 9. Práticas e Saberes de Atores Sociais 405

9.1. Visão empresarial do Douro na atualidade 406

$\begin{array}{ll}\text { 9.2. Perspetiva autárquica do Douro } & 410\end{array}$

9.3. Informantes privilegiados — múltiplas perspetivas 410

9.4. Contribuição para o conhecimento da sociedade duriense na «fronteira» entre o Cima Corgo e o Douro Superior 416

PARTE IV. PROCESSO DE INVESTIGAÇÃO: A SÓCIO-HISTÓRIA E O MÉTODO DO ESTUDO DE CASO ALARGADO 425

$\begin{array}{ll}\text { Introdução } & 427\end{array}$

Capítulo 10. Análise sócio-histórica de Carrazeda concelho «fronteira» no Douro Vinhateiro 431

10.1. O vinho do Porto na «cadeia das mercadorias» 432

10.2. Para a sócio-história de Carrazeda concelho produtor de vinho do Porto 439

10.3. A praga da contrafação e a autenticidade. Denominações geográficas 440

10.4. Construção de identidades: regional e conjunturais/contextuais 448

10.4.1. Aproximação teórica ao processo de «construção identitária» 449

10.4.2. Contextos e processo de afirmação identitária duriense 453

10.4.3. Ecos da República e do republicanismo em quintas durienses de Carrazeda 456

10.4.4. Quintas durienses de Carrazeda de Ansiães: espaço de construção de identidades contextuais em conjunturas

$\begin{array}{ll}\text { republicanas } & 458\end{array}$

10.4.5. Significado do protagonismo histórico republicano duriense em Carrazeda 466

$\begin{array}{ll}\text { 10.5. Espaço fronteiriço e territorialidade social } & 468\end{array}$ 
UM CASO DE FRONTEIRA NO «DOURO NOVO»

Capítulo 11. Enquadramento teórico-metodológico: o «estudo de caso alargado» 473

11.1. O estudo de caso alargado no domínio da sociologia 475

11.2. Mobilização do «estudo de caso alargado» no campo da história 476

11.3. Operacionalização do «estudo de caso alargado» 477

11.4. Infraestrutura documental e construção do conhecimento 479

$\begin{array}{ll}\text { CONSIDERAÇÕES FINAIS } & 481\end{array}$

$\begin{array}{ll}\text { FONTES E BIBLIOGRAFIA } & 489\end{array}$

$\begin{array}{lr}\text { ANEXOS } & 507\end{array}$

$\begin{array}{lr}\text { Anexo I - Cronologia (quadros) } & 509\end{array}$

Anexo II — Quinta Canaes-Bartol $\quad 532$

Anexo III — Quinta de Lubazim $\quad 537$

$\begin{array}{ll}\text { Anexo IV — Quinta da Senhora Da Ribeira } & 540\end{array}$

Anexo V — Quinta do Zimbro $\quad 543$

Anexo VI — Empresa Cockburn \& Smithes $\quad 549$

Anexo VII — Symington Estates Family $\quad 554$

$\begin{array}{lr}\text { Anexo VIII — Entrevistas } & 557\end{array}$ 
PREFÁCIO

GASPAR MARTINS PEREIRA 
$\mathrm{Na}$ já vasta bibliografia sobre o vinho do Porto e a sua região de origem, este livro de Otília Lage traça caminhos novos de investigação, conjugando a análise histórica com perspectivas sociológicas e antropológicas, a partir de Carrazeda de Ansiães, terra de «fronteira» entre o «velho» e o «novo» Douro.

Na periferia do «velho Douro» das demarcações pombalinas, o concelho de Carrazeda, apesar das antiquíssimas tradições vitícolas, só gradualmente viria a conhecer a integração de alguns dos seus melhores vinhedos na região demarcada dos vinhos generosos.

Como refere Otília Lage, esse movimento iniciou-se ainda em finais de Setecentos, no tempo das demarcações marianas, quase em simultâneo com a destruição do Cachão da Valeira, que possibilitou a navegação fluvial e a abertura dos extensos territórios do Douro Superior a novos circuitos comerciais que levavam ao Porto e ao mundo. Porém, por razões institucionais e históricas, tal processo de integração foi bastante lento. À excepção de algumas quintas e vinhas com melhor localização, pela proximidade do canal navegável, Carrazeda continuou voltada para a montanha e para a economia tradicional de subsistência, dos cereais e do gado.

Seria preciso esperar pelos efeitos conjugados de outros factores, que, na segunda metade do século XIX, provocaram uma autêntica revolução no vale do Douro e no sistema do vinho do Porto. A perda de poderes da velha Companhia pombalina e a liberalização da produção e do comércio dos vinhos generosos da região duriense, entre 1852 e 1865, possibilitou a entrada no circuito mercantil de vinhos de áreas limítrofes do «velho Douro», antes excluídas da demarcação. A devastação das vinhas do Baixo e do Cima Corgo pelas doenças da videira — o oídio desde 1852 e, sobretudo, a terrível filoxera nas décadas seguintes — impeliu os comerciantes a alargarem a sua carteira de fornecedores de vinhos a viticultores do Douro Superior e de outras áreas. Não menos importante nesse processo de integração, facilitando a difusão das novidades técnicas e o transporte de homens e mercadorias, videiras americanas, adubos, fitossanitários e alfaias, foi a construção da linha ferroviária do Douro, que chegou ao Tua em 1883 e a Barca de Alva em 1887. Foi nessa fase de crise e renovação que a região vinhateira se reinventou, alargando-se até à raia espanhola e passando a integrar o Douro Superior.

A nova Região Demarcada do Douro, redefinida em 1907-1908, veio consagrar essa expansão. Para os concelhos do Douro Superior, e com maior relevância para os de "fronteira» com o Cima Corgo, como os de Carrazeda e da Pesqueira, a sua integração na região demarcada e no sistema do vinho do Porto não foi simples nem linear e implicou transformações sociais e económicas significativas, como destaca Otília Lage. Por outro lado, como acontece na maioria dos concelhos do Douro, só uma parte do território de Carrazeda integra a região demarcada duriense, ficando o restante na região transmontana, o que define outras «fronteiras» no interior do concelho, entre a «montanha» e a «ribeira», «terra fria» e «terra quente», com diferenças substanciais na economia, nas relações sociais e nos quadros de vida.

O processo de integração regional acelerou durante o período conturbado do final da Monarquia e da I República, o que justifica a maior atenção que Otília Lage dedica a esse 
período. Aliás, este estudo começou a ser desenvolvido no âmbito do projecto de investigação mais vasto sobre O Douro Vinhateiro na I República. Defesa da Denominação de Origem e construção de uma identidade regional, que levámos a cabo no CITCEM - Centro de Investigação Transdisciplinar Cultura, Espaço \& Memória e cujos resultados se corporizaram em diversos artigos, livros e encontros científicos. No caso deste trabalho de Otília Lage, esse período constituiu apenas um ponto de partida, já que a autora avançou para um estudo mais abrangente e transversal sobre a história do vinho do Porto e da sua região de origem, buscando compreender as raízes dos fenómenos que abordou, bem como a sua evolução até aos nossos dias.

Por outro lado, apesar de se centrar em Carrazeda de Ansiães e de dedicar boa parte da sua atenção à micro-história de diversas quintas famosas, como as dos Canais, Bartol, Zimbro, Alegria, Lobazim, Senhora da Ribeira, Chousa e Tua, não se confinou num registo monográfico, antes buscou articular as observações locais no quadro amplo das dinâmicas sócio-históricas da região duriense, bem como nas relações entre quintas produtoras e empresas de comércio de vinhos (Silva \& Cosens, Warre, Dow's, e Martinez Gassiot, Cockburn \& Smithes, Symington Family Estates, Grambeira, Douro Ansiães), numa perspectiva glocal de «estudo de caso alargado». Afinal, como escreveu Torga, «o universal é o local sem as paredes».

Com os pés na terra natal, à qual mantém uma relação íntima, Otília Lage desenvolve neste livro, em «conhecimento situado», mais um dos seus estudos sócio-históricos sobre Carrazeda de Ansiães, com sucessivos zooms que alargam a observação a toda a história do Douro, cruzando uma multiplicidade de fontes (impressas, manuscritas e orais), recolhidas quer em diversas bibliotecas e arquivos públicos e privados quer no trabalho de campo. Em diversos sentidos, trata-se de um valioso contributo para a compreensão do processo de produção histórica da região vinhateira do Alto Douro.

Porto, Fevereiro de 2018 
INTRODUÇÃO GERAL 
O presente livro constitui um contributo para a história da Vinha e do Vinho no e do Douro, e assume-se como um estudo transversal à história e sociologia, sobre o concelho de Carrazeda de Ansiães como produtor de vinho do Porto, localizado na fronteira do Alto Douro e Trás-os-Montes, a partir da sua integração parcial na Região Demarcada do Douro de que representa $10 \%$ do território.

Tem por base uma reconstituição histórica e análise sociológica de Carrazeda de Ansiães, um dos 13 concelhos do Douro Património Mundial, enquanto produtor de vinho do Porto, com enfoque particular nas novas Demarcações da Região do Douro (João Franco e Ferreira do Amaral, 1907-1908), na viragem da Monarquia para a I República. Nessa medida pode considerar-se como um primeiro estudo inédito de sócio-história do concelho de Carrazeda de Ansiães enquanto produtor de vinho do Porto, uma espaciotemporalidade de fronteira representativa da Região Demarcada do Douro e do Douro Património Mundial com uma inscrição e desenvolvimento próprios no longo processo de construção histórica social e cultural do Douro Vinhateiro.

Tenta-se compreender e explicar em que sentido o alargamento da Região Demarcada do Douro (1907-1908) e a integração do concelho de Carrazeda de Ansiães pode ser percecionada como elemento e fator de identidades locais em construção de natureza contextual/ conjuntural no quadro de um território com pressuposta e/ou historicamente assumida identidade regional. Conclui-se pela representatividade deste caso entre as sub-regiões de Cima Corgo e Douro Superior da Região Demarcada do Douro em que ocupa, a nível da investigação teórica e empírica, uma posição de fronteira híbrida e pluridimensional.

Como se procurará demonstrar, com base na investigação entretanto feita durante os últimos cinco anos, o concelho de Carrazeda integrado na sub-região do Cima Corgo mas com vinhas e importantes quintas também na sub-região do Douro Superior, sendo um dos treze concelhos do Douro Património Mundial, embora só parcialmente abrangido por esta classificação, é, a vários títulos, na Região Demarcada do Douro, um espaço híbrido de fronteira, podendo considerar-se, indiciariamente, deter nesta uma posição mediana em relação aos restantes concelhos vizinhos.

Exigindo o seu estudo, com enfoque na compreensão dos processos sociais e históricos, mudanças e movimentos sociais, uma articulação de escalas macro e micro e de dimensões local-regional-nacional, a opção teórico-metodológica adotada assentou no cruzamento de perspetivas histórico-sociológicas, privilegiando o método de observação participante com recolha de testemunhos, memórias e narrativas, e a pesquisa de fontes diretas de diferentes tipos: orais e escritas, locais, regionais e nacionais. Assim, privilegia-se neste estudo de caso alargado o cruzamento de fontes de informação direta, testemunhos, memórias, narrativas locais, documentos de arquivo de entidades reguladoras como a Comissão de Viticultura da Região do Douro (1907-1932), instituição reguladora que atravessa a I República, da Casa do Douro (1933-1974) entidade reguladora central durante o Estado Novo, do Instituto dos Vinhos do Douro e do Porto (IVDP, IP na Régua), e outras fontes históricas e documenta- 
ção de arquivo relativas a quintas e empresas com protagonismo em Carrazeda de Ansiães (Arquivo Histórico do Grupo Symington, Vila Nova de Gaia - Coradas).

O impulso inicial e estímulo constante à longa e difícil investigação que subjaz à elaboração deste livro foram norteados por uma posição teórica baseada no «conhecimento situado» ${ }^{1}$, conhecimento científico considerado sempre parcelar e limitado, atributos que lhe conferem um grau progressivamente elevado de exigência sem perder de vista a necessária humildade e independência de pensamento.

Assenta numa prolongada e intensa investigação ${ }^{2}$ sobre o processo histórico concreto de desenvolvimento vitivinícola deste concelho no quadro alargado do denso processo histórico de construção da Região Duriense, a primeira zona demarcada e regulamentada do mundo como origem e produtora de vinho do Porto, produto nacional de exportação internacionalmente reconhecido nos últimos três séculos.

O trabalho de base realizado em que se seguiu a metodologia do estudo de caso alargado, começou por desenvolver-se interessadamente a partir do «local» como modo essencial em que o global se deixa conhecer. Enraíza-se nessa perspetiva interescalar feita de reenvios espaciotemporais e de apelos a múltiplos domínios do conhecimento, posição científica que há muito prosseguimos, na área dos novos estudos históricos e sociais, a partir da fronteira disciplinar entre história e sociologia.

A delimitação do arco temporal identificado para este estudo 3 que começou por enfocar sobretudo uma época recente, a partir de finais da Monarquia e I República, é em grande parte devedora do projeto de investigação «O Douro Vinhateiro na I República. Defesa da Denominação de Origem e construção de uma identidade regional» ${ }^{4}$. Abarca historicamente

\footnotetext{
${ }^{1}$ Conhecimento situado, ou cognição situada, é construído na interação social e sobre a singularidade das situações. Sendo conhecimento perspetivado e parcelar, não significa que se persiga a parcialidade em si mesma, mas as possibilidades de conexão e aberturas inesperadas que oferece. O único modo de encontrar uma visão mais ampla é estando em algum lugar em particular (HARAWAY, 1995: 30). Ou seja, é possível construir um discurso que se preocupa com formas de tradução entre saberes e com a análise das relações de poder estabelecidas entre diferentes formas de conhecimento. Por outro lado, significa que os dados não existem simplesmente «lá fora», a serem revelados, mas são em si um produto da relação entre o investigador e as suas fontes e informantes. Portanto uma apresentação honesta, da pesquisa requer a inclusão de uma análise explícita do lugar donde se fala e dos dados como produto da colaboração entre um nós, especialmente interessado num objeto, e os nossos dados e informantes. ${ }^{2}$ A investigação desenvolveu-se entre 2012 e 2015, numa primeira fase, com a realização de extenso trabalho de campo local e vasta pesquisa de fontes e informação bibliográfica em arquivos da Casa da Douro, na Régua, do Grupo Symington, em Vila Nova de Gaia (Coradas) e bibliotecas municipais e do IVDP; numa segunda fase, através da escrita e divulgação sucessiva de textos e resultados parciais; e numa terceira e última fase com a organização e interpretação global dos materiais trabalhados, base da conceção e produção do presente livro.

${ }^{3}$ Subprojeto Carrazeda de Ansiães como produtor de vinho do Porto, a partir da I República: Memórias e identidades 'conjunturais'. Estudo de caso alargado (2010-2016), inscrito no Projeto Estratégico do CITCEM (2015-2020) Dinâmicas da Memória e das Identidades - Grupo de Investigação Memória, Património e Construção de Identidades/Coordenador científico Luís Alberto Marques Alves.

${ }^{4}$ Projeto do CITCEM - Grupo de Investigação Memória, Património e Construção de Identidades (2009-2010), coordenado pelo Investigador principal Gaspar Martins Pereira, que visou contribuir para o conhecimento da história da Região Demarcada do Douro num período-chave da afirmação dos modernos mecanismos de denominação de origem, de regulação das atividades de produção e comércio, de certificação e de controlo da qualidade dos seus vinhos.
} 
sobretudo as fases de desenvolvimento, travagem e recuperação (século XIX), estagnação, aceleração, recessão e expansão (século XX) da Região e os $3 .^{\circ}$ e $4 .^{\circ}$ ciclos de recuperação e expansão da produção e comércio do vinho do Porto «o mais importante produto da história económica portuguesa dos últimos três séculos» cujas oscilações comerciais muito dependem das conjunturas de sua exportação $0^{5}$.

A área escolhida para o estudo base do presente livro incidiu neste concelho paradigmático de «fronteira» da Região Duriense que integra também o Douro Património Mundial, em que detém larga tradição na história da vinha e do vinho no/do Douro, com particular relevo na complexa e longa história do Douro Vinhateiro, encontrando-se ainda por fazer o seu estudo sócio-histórico.

Para além do já referido, foram ainda objetivos principais e metodologias específicas da investigação: reunir, compilar, reconstituir, interpretar e cruzar fontes históricas dispersas e materiais de memória utilizando as metodologias adequadas; elaborar uma análise transdisciplinar na fronteira da História e da Sociologia e no domínio específico dos estudos rurais contemporâneos integrando mapas cognitivos da micro-história; estudar, na dimensão de produção vitivinícola de Carrazeda de Ansiães, este concelho rural representativo na e da Região Vinhateira do Douro e da e na história do vinho do Porto; identificar historicamente a posição deste concelho e suas freguesias vitícolas nas sucessivas demarcações e no alargamento e construção histórica da Região Demarcada do Douro visando compreender a sua integração e especificidades, designadamente enquanto elemento e fator de afirmação local de identidades conjunturais na dinâmica histórica e social de construção de uma identidade regional mais alargada; explicitar os modos como os atores sociais constroem ativamente a realidade social, quando falam sobre a região, a sua simbologia ou níveis de identificação e gestão de contradições, conflitos, ruturas e continuidades; analisar no contexto e processo mais vasto das mudanças históricas no Douro Vinhateiro Contemporâneo, mecanismos sociais, políticos, institucionais, económicos, culturais e simbólicos e compreender neste enquadramento as semelhanças e especificidades do concelho de Carrazeda e suas freguesias vinhateiras.

Este livro cuja elaboração foi pensada tendo em conta a sua ampla divulgação junto do público em geral, para além dos contextos académico e educativo, como incentivo a melhor conhecer a nossa História Local e Regional à escala nacional e internacional, encontra-se organizado segundo uma estrutura delineada em 4 partes e 11 capítulos titulados no respetivo índice de acordo com a qual se visou:

\footnotetext{
${ }^{5}$ MARTINS, 1988: 391-429. Esta autora refere, como ciclos histórico-económicos da região, os seguintes: de 1678 a 1725 - Take-off; de 1726 a 1774 - Consolidação; de 1775 a 1810 - Desenvolvimento; de 1811 a 1864 - Travagem; de 1865 a 1886 - Recuperação; de 1887 a 1909 - Estagnação; de 1910 a 1939 - Aceleração; de 1940 a 1964 - Recessão; de 1965 a 1989 - Expansão; de 1990 a 1993 - Recessão; Após 1993 - Recuperação. Estabelece para a produção e comercialização do vinho do Porto os seguintes ciclos de periodização: $1 .{ }^{\circ}$ ciclo (1678 a 1810$)$ — formação, consolidação e organização da produção e do comércio do vinho do Porto; $2 .^{\circ}$ ciclo (1811 a 1864) — estagnação e instabilidade; $3 .^{\circ}$ ciclo (1865 a 1939) — relançamento, diversificação e reorganização; Interciclo (1940 a 1944) — colapso do comércio; $4{ }^{\circ}$ ciclo (1945 a 1987) — recuperação, evolução e expansão.
} 
1. apresentar de forma diacrónica, em múltiplas e encadeadas temporalidades, a inscrição espaciotemporal e progressiva localização geográfico-histórica das freguesias vinhateiras do concelho de Carrazeda através de suas marcas e traços na longa história vitivinícola da Região Duriense observada no seu processo de construção sócio-histórica;

2. analisar as potencialidades específicas e significado histórico próprio de Carrazeda enquanto produtor de vinho do Porto, a partir das demarcações do século XX da Região Demarcada do Douro entendida como denso e complexo produto histórico, político, social, económico e cultural, procurando compreender singularidades e semelhanças do processo dinâmico de pertença identitária dos agentes sociais (produtores, trabalhadores, técnicos, compradores e vendedores) da área de Carrazeda produtora e exportadora de vinho do Porto no contexto da identidade regional duriense;

3. fazer uma abordagem histórica mais recente, e a possível face às fontes diretas disponíveis, relativamente fragmentadas e disseminadas às principais propriedades e quintas (Canais, Lubazim, Senhora da Ribeira, Alegria, Canaes/Bartol, Zimbro, Chousa, Tua, etc.) produtoras de vinho do Porto localizadas no território do concelho de Carrazeda e empresas exportadoras (Silva \& Cosens, Cockburn \& Smith, Symington Family, etc.) que ao longo do século XX agenciaram a recolha, produção e exportação do vinho fino deste território de fronteira entre o Douro Superior e o Cima Corgo;

4. explicitar o processo de investigação desenvolvida na perspetiva sócio-histórica, pelo método de estudo de caso alargado a qual nos permitiu reconstituir a sócio-história de Carrazeda de Ansiães produtor de vinho do Porto nas dimensões anteriormente consideradas.

Se ao nível da exposição na formulação descrita, este livro se encontra organizado em dois planos articulados — o da micro-história de Carrazeda como produtor de vinho do Porto e o do seu enquadramento concreto na história global da Região Vitivinícola do Douro, já ao nível do modo específico da sua escrita seguimos, isomorficamente, um dispositivo de natureza cinematográfica articulando «plongées» e tomadas de vista de grandes planos.

Por sua vez, o processo de investigação cujos resultados essenciais informam o presente livro que lhes dá forma, iniciou-se pelo rastreamento empírico e documental da atual mancha vitícola do concelho de Carrazeda de Ansiães no contexto do Douro Vinhateiro, rastreio acompanhado por extensiva pesquisa, inventariação, organização, tratamento e interpretação de documentos de arquivo e fontes históricas diretas e indiretas, a par do trabalho feito para estabelecer a necessária revisão da literatura e respetivo estado da arte dos estudos nesta matéria. Puderam então identificar-se algumas das marcas e traços da inscrição primitiva e progressiva localização espaciotemporal de Carrazeda na longa evolução da cultura da vinha e do vinho no Douro, reconhecimento concomitante à identificação de mudanças fulcrais na densa história da Região Duriense e de alguns dos principais organismos institucionais e agentes 
intervenientes. Pôde passar-se em seguida à mobilização e operacionalização das informações e dados reunidos de maior relevância, mediante a aplicação das operações próprias do estudo de caso alargado, o que tornou finalmente possível a reconstituição sócio-histórica do caso estudado.

Seguimos assim a perspetiva de que «deve-se, sem dúvida, distinguir, formalmente, o método de exposição do método de pesquisa. A investigação tem de apoderar-se da matéria, em seus pormenores, de analisar suas diferentes formas de desenvolvimento e de descobrir a conexão interna que há entre elas. Só depois de concluído esse trabalho, é que se pode apresentar, adequadamente, o movimento real. Se isto se consegue, ficará espelhada, no plano ideal, a vida da realidade pesquisada ${ }^{6}$. Partilhamos por isso a orientação dialética de que a exposição dos factos históricos é posterior e segue uma linha inversa do processo de pesquisa dos mesmos.

Em síntese, remontando, ao nível da exposição deste caso concreto de estudo, aos tempos mais antigos até chegar aos mais recentes, para estabelecer as linhas fundamentais de uma compreensão geral e abrangente da produção social e histórica da Região Vitivinícola Duriense, origem do vinho do Porto, seu produto de excelência e da respetiva inscrição das terras vinhateiras de Carrazeda de Ansiães nesse longo processo histórico, tornou-se então possível evidenciar um conhecimento mais aproximado da realidade presente na sua ancoragem histórica.

${ }^{6}$ MARX \& ENGELS, 1962: 27. 


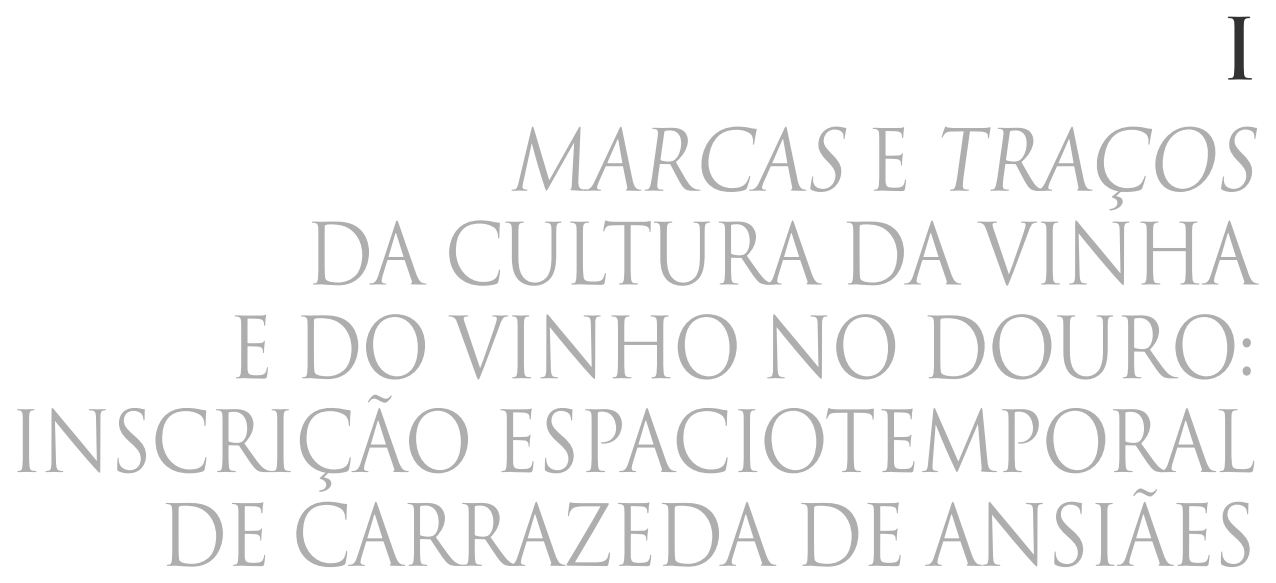




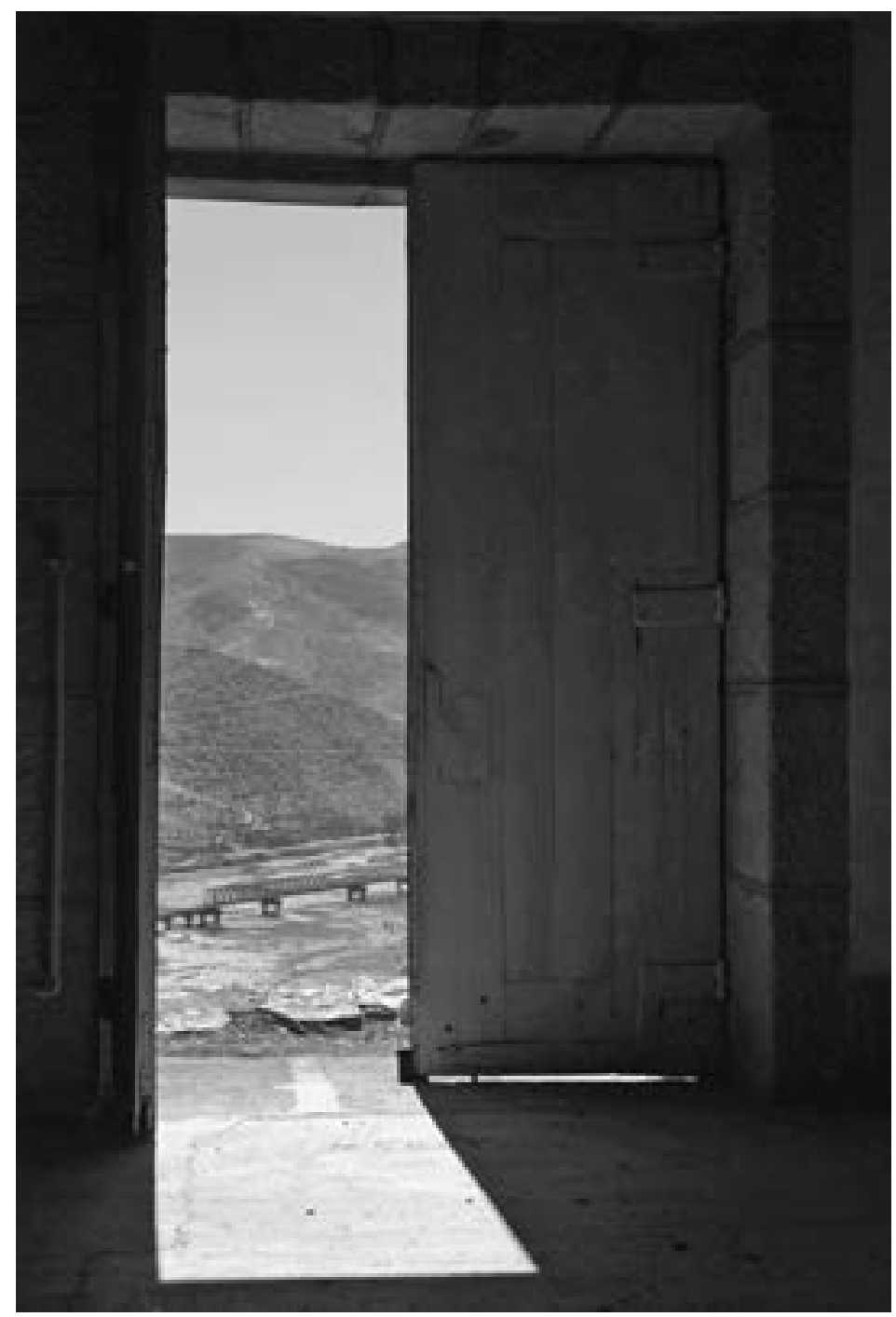

Fig. 1. Vista do Douro a partir da capela da antiga quinta do Mariz na Quinta dos Canais Fonte: Foto de Emanuel Costa, Col. Quinta dos Canais, 2010

Reconstitui-se, a partir da antiga história da cultura da vinha e do vinho em terras do Douro, o longo e complexo processo de construção histórica da Região Vitivinícola Duriense. Este espaço regional do País é obra da ação esforçada de gerações sucessivas da população anónima e de alguns pioneiros, e distingue-se por uma geografia específica de vinhedos, um território natural e cultural onde tem origem o vinho do Porto, produto de excelência e larga exportação, há séculos, um património cultural diversificado e singular, uma paisagem única e uma identidade regional própria tensionalmente (re)construída. 
Percorre-se, sumariamente, a partir de traços e marcas que um passado mais longínquo deixou na história recente, a sua evolução não linear considerada em três dimensões: a construção sócio-histórica da região vinhateira duriense expressa na sua institucionalização reguladora, com uma abordagem à longa história do vinho do Porto; a evolução das suas sucessivas demarcações e processo de regulação desde o século XVIII, como traço originário da sua identidade nacional, observando o alargamento de sua área e limites, expansão e geografia dos vinhedos e emergência dos primeiros estudos científicos de cartografia, viticultura e vitivinicultura; a construção de uma paisagem cultural e histórica «viva e evolutiva» que justificou a sua classificação como Património Mundial ou Património da Humanidade.

Essas dimensões, outras tantas características do longo e complexo processo sócio-histórico da Região do Douro que se tenta reconstruir, são analisadas nos três capítulos em que esta parte se desenvolve. Em todos eles se vai procurando fazer a respetiva inscrição e ancoragem histórica da cultura da vinha e do vinho em terras do atual concelho de Carrazeda de Ansiães enquanto produtor de vinhos finos e generosos, o qual, como zona «de fronteira» entre Cima Corgo e Douro Superior, se entende como um case study na história da Região Demarcada do Douro (RDD) e do vinho do Porto. 


\section{CAPÍTULO 1. A REGIÃO DO DOURO E O VINHO DO PORTO: PROCESSO DE DESENVOLVIMENTO}

Numa perspetiva do local globalmente contextualizado que sempre nos orientará no presente estudo, começamos por posicionar-nos nas marcas ainda visíveis que a longa história do cultivo da vinha e da produção vinícola deixou no atual território do concelho de Carrazeda de Ansiães localizado em Trás-os-Montes e Alto Douro, e cuja área é banhada, em cerca de dois terços, pelo rio Douro e o seu afluente Tua.

Conhece-se a existência da cultura da vinha e produção doméstica de vinho no Douro desde o período romano, matéria que conta já com muitos e importantes estudos especializados. Como bem sintetiza Gaspar Martins Pereira,

Ao longo de quase dois milénios, fez-se, nas encostas xistosas do vale do Douro, uma paisagem vitícola singular, um vinho excecional. Mais do que um dom da natureza, o vinho do Porto é, na sua essência, essa espessura histórica, um património cultural coletivo de trabalho e experiências, saberes e arte, que gerações e gerações acumularam. $O$ vinho do Porto foi é é um produto chave da economia nacional e ainda mais um valor simbólico que distintamente representa a portugalidade no mundo.

A história do vinhedo do Alto Douro é muito antiga. Não faltam descobertas arqueológicas e referências documentais a testemunhar a persistência cultural do empenho vitivinícola de outras eras.

Recuam pelo menos aos séculos III-IV os vestígios de lagares e vasilhame vinário, um pouco por toda a Região Duriense [... $]^{7}$.

Encontram-se estudados e documentados pela Arqueologia vestígios de diversas estruturas da produção de vinho nas antigas terras da Lusitânia e da Gallaecia, em que se destacam lagares durienses de diferentes cronologias (Baixo Império Romano e Alta Idade Média) e de vários tipos (de trave, de alavanca, com fuso e dos cavados na rocha) ${ }^{8}$.

No concelho de Carrazeda de Ansiães, entre os distritos de Bragança e Vila Real, território multifacetado integrante de duas realidades distintas: a Terra Fria que abrange a zona granítica e mais pobre do planalto, domínio da pastorícia e recursos naturais, e a Terra Quente de terrenos xistosos e encostas inclinadas para os rios Douro e Tua, de terrenos agrícolas remotamente laborados pelo homem com culturas mediterrânicas como a vinha e a oliveira, encontram-se vários habitats humanos da Idade do Ferro: os castelos de Pereiros e de Pinhal do Norte, sobranceiros ao curso do Tua e o castro da Senhora da Graça, na aldeia de Samorinha, junto ao planalto de Ansiães.

${ }^{7}$ PEREIRA, 2016. Texto de apresentação do site oficial do IVDP, I.P.

${ }^{8}$ ALMEIDA, coord., 2006: 350-404. 
$\mathrm{Na}$ parcela centro-oriental do planalto de Ansiães, com amplos horizontes, se sediou a vila medieval de Ansiães, com foral concedido no século XI e se implantara o seu castelo, com uma história de ampla diacronia que se estende do Calcolítico à Baixa Idade Média e ocupações intermédias como as da Idade do Ferro e da romanização (vestígios encontrados em Selores, vale fértil no sopé desta fortificação que teve grande importância no período da Reconquista Cristã).

Deixando para trás o planalto e a aldeia de Zedes com a sua anta ou dólmen em cujas imediações se localizou ocupação romana, e a freguesia de Linhares, cujo cume granítico do castelo de S. Miguel denota extensa ocupação entre o Calcolítico e a Idade Média, e seguindo pelos vales do Tua e do Douro, foram encontrados os primeiros sinais de romanização: materiais arqueológicos sugerindo ocupação romana de alguma dimensão, quer nas encostas do Tua, freguesias do Pombal (Mós e Quinta do Barrabaz) e do Castanheiro, em cuja povoação de Tralhariz com extensa propriedade de vinha em socalcos onde terá existido uma villa romana, quer em lugares voltados ao rio Douro, com um conjunto de vestígios notáveis da época romana, nas imediações do Seixo de Ansiães, e na Quinta da Senhora da Ribeira, designadamente em Covas, onde se registou mineração aurífera, no período romano que se situa no Douro entre o século I e o século V.

Em todos estes povoados se registou antiga exploração agrícola de tipo mediterrânico com destaque para o cultivo da vinha que se distendeu ao longo do tempo ao ponto de se manterem hoje ainda como sendo bons produtores de vinho de benefício ${ }^{9}$.

As escavações arqueológicas que prosseguem junto ao vale do Douro, têm descoberto várias «lagaretas» e lagares de vinho romanos escavados na rocha e construções vinárias em adobe ou alvenaria revestida a argamassa, designados lagares de formigão ${ }^{10}$.

Embora a informação não seja muito clara parece ter havido um outro lagar de formigão na villa romana de Tralhariz, localidade do concelho de Carrazeda de Ansiães, localizada no curso final do Rio Tua. A estruturas encontradas, entre as quais se documentam compartimentos revestidos a mosaico, a cerâmica romana, entre a qual de destacavam os dolia, apontam no sentido de ali ter havido uma villa norteada para o plantio da vinha, realidade que é justificada pelo acidentado da orografia voltada ao curso do Rio Tua e pela agressividade das condições climatéricas. Aliás, Leite de Vasconcelos que noticia os achados aqui encontrados, é bem claro quando afirma que «naquele local se cultivava, como hoje, já certamente o vinho» $[\ldots]^{11}$.

Ainda no concelho de Carrazeda no termo da freguesia de Linhares sobranceira ao Douro, no lugar da Escorregadeira (topónimo) se encontra sinalizado como «lagar romano»,

\footnotetext{
${ }^{9}$ ANTUNES \& FARIA, 2006: 264-268.

${ }^{10}$ ALMEIDA, 2011-2012: 485-494.

${ }^{11}$ ALMEIDA, 2011-2012: 485-494.
} 
vestígios de um lagar rupestre, com apenas um tanque que se supõe corresponder ao «lacus», de datação indeterminada.

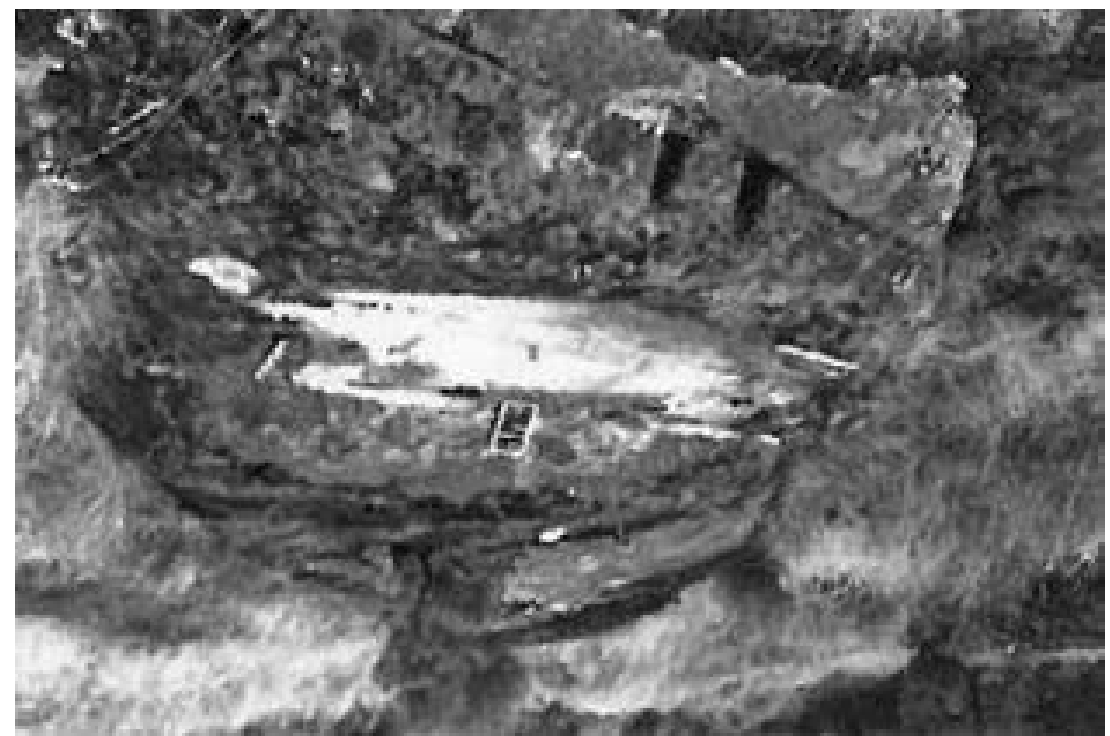

Fig. 2

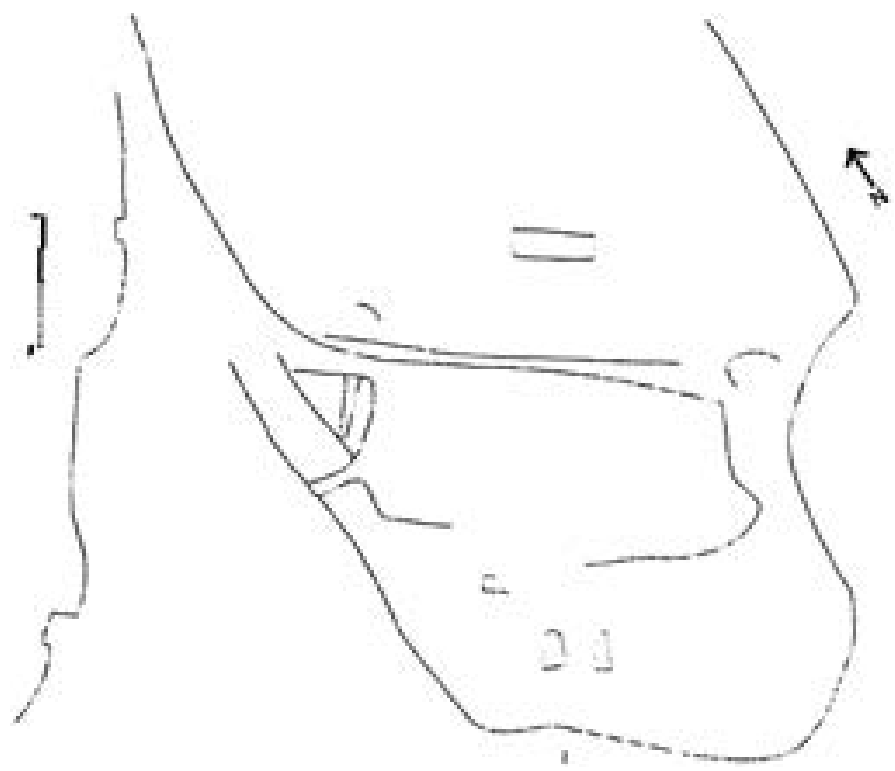

Fig. 3. Lagar de vinho da Escorregadeira — Linhares (Carrazeda de Ansiães) ${ }^{12}$

\footnotetext{
${ }^{12}$ PEREIRA \& LOPES, 2005: 30.
} 


\subsection{CARRAZEDA (D)E ANSIÃES NA HISTÓRIA ANTIGA DA VINHA E DO VINHO}

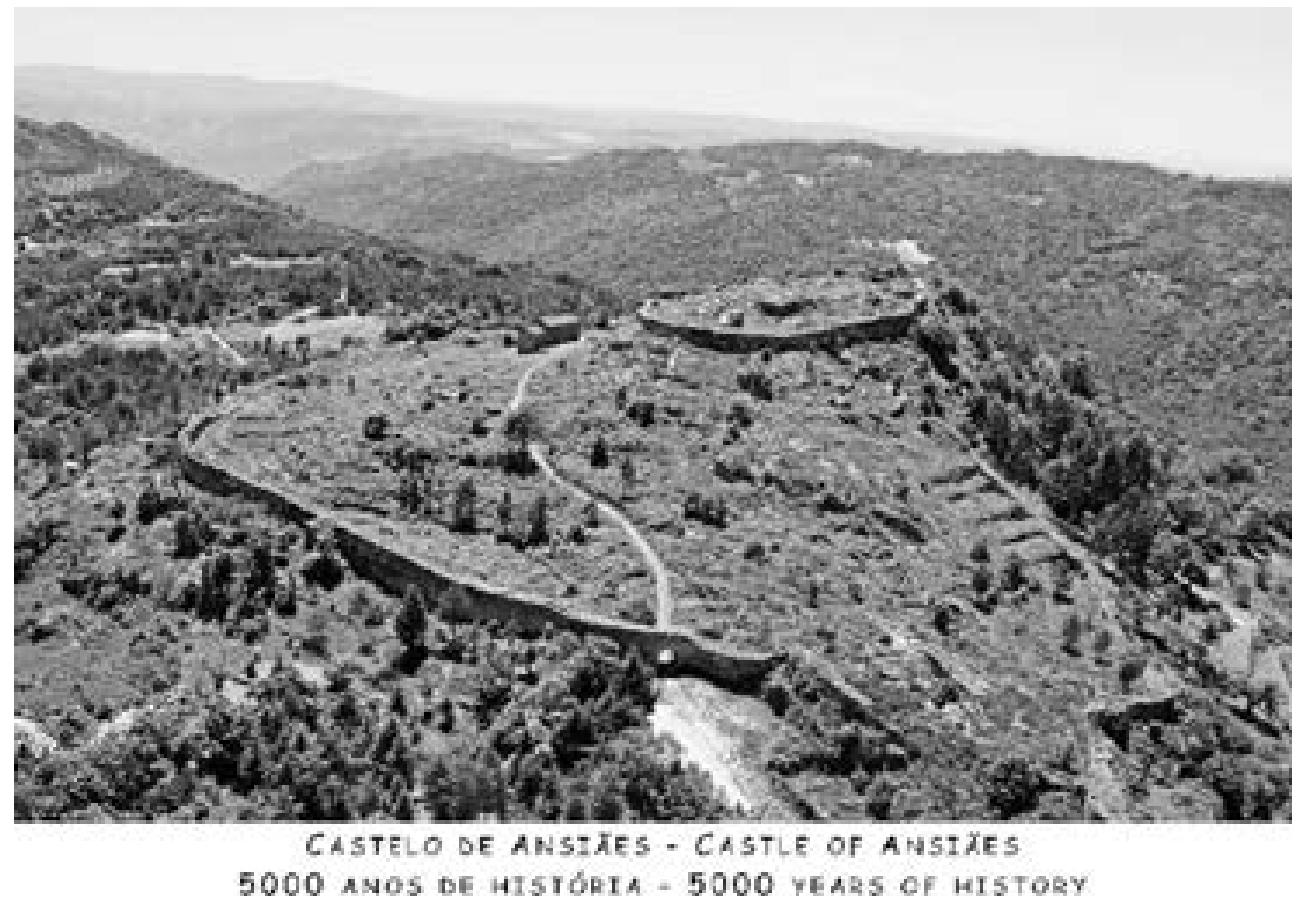

Fig. 4. Castelo de Ansiães

Fonte: Col. centro interpretativo do castelo e vila amuralhada de Ansiães ${ }^{13}$

Carrazeda de Ansiães, unidade concelhia integrada na Região Demarcada do Douro, em 1907 (legislação de João Franco) e hoje um dos 13 concelhos do Douro Património da Humanidade (UNESCO, 2001) — área que representa apenas 10\% da Região Demarcada do Douro -, inscreve-se na longa tradição de viticultura das zonas ribeirinhas do Douro e a sua história vem de há muito tempo ligada, indissociavelmente, à prolongada história da vinha e do vinho na Região Duriense.

Ainda antes da fundação de Portugal, se praticavam já a cultura da vinha e a produção de vinho nas terras de Ansiães a que se refere o Foral do rei de Leão Dom Fernando I ( $o$ Magno), da segunda metade do século XI, entre 1055 e 1065 (s.l.), concedido conjuntamente às vilas de Penela, Paredes da Beira, São João da Pesqueira, Linhares e Ansiães ${ }^{14}$, visando o seu

\footnotetext{
${ }^{13}$ Disponível em <http://3.bp.blogspot.com/-SQJFmt_mxFA/U9kHIHUZxOI/AAAAAAAAu0Y/QmBSVJgQIww/ s1600/carrazeda_1.jpg >. [Consulta realizada em 12/06/2016].

${ }^{14} \mathrm{O}$ conhecimento deste foral chegou até nós pelas sucessivas confirmações que dele foram feitas pelos nossos reis, D. Afonso Henriques, D. Sancho I, D. Afonso II, D. Afonso III e D. Fernando confirmando o anteriormente dado por D. Afonso III.
} 
repovoamento. Aí se estabelecia então como imposto de "parataregis» a paga por cada vizinho, para as despesas do palácio de «duos panes uno de tritico et alio de centeno e tuno almude de vino et alium de cevada» ${ }^{15}$.

Prosseguindo esta aproximação histórica ao tema da cultura da vinha e produção de vinho em terras hoje de Carrazeda de Ansiães (circunscrição territorial-administrativa instituída como concelho apenas em 1736, ano da mudança de sede de concelho, na sequência da extinção do antigo concelho e vila medieval de Ansiães), pode ver-se que a mesma se mantém decorridos alguns séculos. Remetemos por isso para a indispensável leitura do Foral Novo da vila e concelho de Ansiães, outorgado pelo rei D. Manuel I em 1 de julho de $1510^{16}$, e estudo da documentação foraleira manuelina do Vale do Douro, onde encontramos a seguinte referência: «No registo de Ansiães, todo o homem com fazenda pagava um almude de vinho, quem não tivesse casa pagava um alqueire de vinho. A exigência deste foro indica que o vinho existira no lugar, em quantidade apreciável, pois até quem não fosse proprietário, teria maneira de comprar vinho para pagar os seus impostos» ${ }^{17}$.

Segundo o mesmo estudo, também o Foral Novo de Vilarinho da Castanheira, antigo concelho extinto no século XIX e integrado como freguesia no concelho de Carrazeda de Ansiães, embora determine que uma parte dos direitos reais fosse pago em numerário, este, seria "por certo resultante do comércio do vinho pois, nestas paragens o cultivo da vinha, era há muito praticado» ${ }^{18}$.

Quanto à presença da referência ao vinho nos títulos de portagem (e observe-se que esta, de que estavam isentos os moradores dos lugares, os indivíduos e lugares privilegiados, incidia sobre os mercadores estranhos, é de grande importância para o conhecimento das produções agrícolas de um dado lugar, já que reflete a agricultura do lugar e faculta informações sobre o comércio, o artesanato e a pequena indústria local e regional) no que se refere aos registos e forais de Ansiães e Vilarinho o vinho e o vinagre eram onerados de um real por carga maior e de meio real por carga menor ${ }^{19}$.

A existência da cultura da vinha e de um património vitícola num considerável espaço agrícola da antiga vila e concelho medieval de Ansiães que se encontra na origem do concelho de Carrazeda de Ansiães é também descrita no século XVII, num tombo datado de 1648, pertencente ao arquivo da Casa de São Payo, o qual regista o património do morgado da Capela de Nossa Senhora da Graça, anexa à igreja românica de S. Salvador intramuros do castelo de Ansiães. O Tombo da Casa de Ribalonga, da família de Manuel de Mello Sampaio, legítimo e

\footnotetext{
${ }^{15}$ ANTT — Feitos da Coroa, Núcleo Antigo 419, cód. ref.a — PT/TT/FC/001/419.

${ }^{16}$ Foral Manuelino de Ansiães (1512). Estudo e publicação do texto integral por LAGE, 2012 b.

${ }^{17}$ SANTANA, 2003: 11-24.

${ }^{18}$ SANTANA, 2003: 19.

${ }^{19}$ SANTANA, 2003: 21.
} 
perpétuo administrador desse morgado, foi feito por especial provisão de D. Pedro II, dada em Lisboa, a 3 de maio de $1683^{20}$.

Comprova-se assim, desde longa data, a presença e importância continuadas da vinha e do vinho no território de Carrazeda de Ansiães, como fazendo parte regular dos foros pagos à Coroa, em regra solvidos por pequenos casais e por pequenas parcelas de terra, as que eram então cultivadas na região do Douro, que nos alvores da época moderna registava ainda um fraco povoamento.

A partir do século XVI, sobretudo e em grande parte por efeito dos negócios crescentes ultramarinos dos Descobrimentos e a posterior afirmação de um mercado interno sobretudo em torno de Lisboa mas também do Porto, vai expandir-se o vinhedo português, designadamente no Cima Douro e em especial num núcleo de produção de vinhos de cheiro ou cheirantes como então se chamavam em torno de Lamego e Vila Real. Afirmam-se já algumas demarcações naturais regionais e até administrativas durante e após a administração filipina, que visam inclusive resolver conflitos de interesses que se vão manifestando ${ }^{21}$.

Como adiante melhor se verá, o evoluir dos tempos, ora lento ora rápido no decurso do Antigo Regime e já também no período do Douro moderno e contemporâneo, as pequenas mas numerosas parcelas continuaram a estar presentes em toda a região e também no território do concelho de Carrazeda de Ansiães, como o documentam as suas Memórias Paroquiais de $1758^{22}$, localizando-se nos nossos dias algumas das grandes explorações no Cima Corgo e no Douro Superior onde se desenvolveram, sobretudo a partir de finais de Oitocentos no período pós-filoxérico. Todavia a zona de vinha cresceria exponencialmente, passando a ocupar hoje na região uma área efetiva de cerca de $18,2 \%$ da área total ${ }^{23}$. Esta é hoje trabalhada por aproximadamente 25.000 viticultores, possuindo cada um deles, em média, cerca de 1,5 hectares de vinha e uma produção de vinho generoso inferior a cinco pipas. São os pequenos produtores que têm tido um grande peso na produção de vinho do Porto.

\subsection{CONSTRUÇÃO SÓCIO-HISTÓRICA DA REGIÃO PRODUTORA DO VINHO DO PORTO}

No extremo nordeste de Portugal, a antiga província de Trás-os-Montes e Alto Douro, a este do Minho, é formada por terras altas, numa sucessão de monte atrás de monte, cortadas aqui e além por ribeiros e vales profundos, onde correm águas que se encaminham para o rio

\footnotetext{
${ }^{20} \mathrm{O}$ arquivo da Casa de São Payo, hoje custodiado no Arquivo Distrital de Bragança, é descrito e estudado em AFONSO, 2003.

${ }^{21}$ OLIVEIRA, 2006: 155-173.

${ }^{22}$ Interrogatórios realizados pelos párocos no distrito de Bragança, como em todo o reino, em cumprimento do aviso de 18 de janeiro de 1758 do Secretário de Estado dos Negócios do Reino, Sebastião José de Carvalho e Melo (depois, Marquês de Pombal), que os fez remeter, através dos principais prelados, e para todos os párocos do Reino de Portugal, designadamente, para averiguação dos efeitos do Terramoto de Lisboa de 1755, em todo o território nacional.

${ }^{23}$ IVDP - Viticultura, Região. Disponível em <https://www.ivdp.pt/pagina.asp?codPag=16>.
} 
coletor - o Douro. A sua região vitivinícola prolonga-se até ao território espanhol, terminando numa das margens do Douro. O nome Trás-os-Montes refere-se precisamente à sua localização: para lá das serras do Marão e Alvão, a norte do rio Douro. É uma zona montanhosa e de solos essencialmente graníticos, mas com grande presença de xisto nas margens do Douro. Caracteriza-se por grandes diversidades no clima e no relevo, em função dos microclimas em que têm origem (altitude, exposição solar, pluviosidade, temperatura, etc.), que se traduz em vinhos muito diferenciados. As diferenças são tão acentuadas que é possível fazer uma distinção entre Terra Fria e Terra Quente, e zona de planalto.

A Região Duriense, geograficamente, é rodeada pelas serras do Marão e Montemuro, sendo as bacias hidrográficas dos rios Douro e seus afluentes: Tua, Corgo, Varosa, Távora, Torto, Pinhão, Sabor e Coa, onde se encontra hoje a maior parte das vinhas plantadas. Estas dispõem-se do cimo dos vales profundos até à margem do rio constituindo-se numa paisagem singular reconhecida como Património da Humanidade, desde 2001, como adiante melhor se verá.

Dos vinhos aqui produzidos apenas cerca de 50\% é dedicada a "vinho do Porto», enquanto que uma boa parte dos outros $50 \%$ é mais recentemente destinada à produção de vinhos que utilizam a denominação de origem controlada (DOC) «Douro». Merece ainda destaque o Vinho Regional Duriense cuja área de produção é coincidente com a da Região Demarcada do Douro (RDD), e também, embora com menor expressão, o Moscatel do Douro e os Espumantes do Douro.

Os solos durienses são essencialmente compostos por xisto, embora, em algumas zonas, existam solos graníticos. Estes solos são particularmente difíceis de trabalhar e no Douro a dificuldade é agravada pela forte inclinação do terreno. Por outro lado, estes solos são benéficos para a longevidade das vinhas e permitem mostos mais concentrados de açúcar e cor.

A armação do terreno para a plantação dos vinhedos é feita sob três formas distintas: os tradicionais geios, terraços ou socalcos, em patamares, e mais recentemente, o chamado plantio ou vinha ao alto, introduzido por novas tecnologias e facilitador de todo o trabalho de produção, mas que tem vindo a alterar profundamente a paisagem característica do «Douro».

A Região do Douro compreende hoje três sub-regiões, o Baixo Corgo, o Cima Corgo e o Douro Superior. Em cada sub-região há diferenças climáticas, devido à altitude e à exposição solar nos vales profundos. De um modo geral, o clima é bastante seco e os conjuntos montanhosos oferecem às vinhas proteção contra os ventos. No Baixo Corgo o ar é mais húmido e fresco, pois recebe ainda alguma influência atlântica. Além disso, a pluviosidade é mais elevada, ajudando a fertilizar os solos e a aumentar a produção. No Cima Corgo, o clima tem características mediterrânicas sendo o Douro Superior, a área mais a leste, a mais seca de todas, encontrando-se na origem de muitos dos melhores vinhos do Porto vintages. 
Para compreender o valor do património histórico e edificado ${ }^{24}$ das margens do Douro, consubstanciado na modelação da paisagem e na implantação de marcas humanas de vida e de cultura, temos de recuar no tempo para ver como as gentes da região se ligaram a essa metamorfose e amplo processo, em interação evolutiva com o seu envolvimento na cultura da vinha e produção de vinho.

O lavrador duriense moldou a sua região plasmada na qualidade dos seus frutos, nela se fixando, com esforço e riscos elevados, refreando doenças endémicas que reduziam os seus sonhos a profundas inquietações, mas sempre na expetativa da «novidade» de cada ano.

Aqui e ali, na natureza laborada e numa paisagem cerceada, como que bordada pela sabedoria dos seus obreiros, nasceu uma casa, implantou-se uma vinha, um «casal», uma quinta, rasgou-se um caminho, um pontão, uma estrada ou uma linha férrea. Nestas inscrições do trabalho humano se perscruta o movimento de vidas e labuta quotidiana ao longo de todo o ano e a necessidade de escoar os produtos da terra como o líquido precioso feito vinho.

O aparecimento das uvas na região duriense, a que já atrás nos referimos, a propósito da vila medieval de Ansiães, fazem-nos recuar aos tempos do Calcolítico conforme se pode comprovar por achados arqueológicos (Buraco da Pala, Serra dos Passos, Mirandela e outros).

Os romanos redefiniram o uso da terra e reestruturaram as atividades económicas nos vales do Douro: introdução e promoção do cultivo de oliveiras, cereais e videiras (continuando a encontrar-se marcas de produção e armazenamento do vinho); exploração de fontes de água mineral e termal; extração de minerais e minérios; construção de estradas e pontes, templos, fóruns, teatros, estátuas...

A cultura da vinha e a produção de vinho continuaram presentes na história do Vale do Douro, após a formação da nacionalidade, como se comprova pelos forais concedidos a várias vilas da região, onde os seus povoadores cumpriam seus tributos com pagamentos em vinho.

Os mosteiros cistercienses (Salzedas, S. João de Tarouca e S. Pedro das Águias) ${ }^{25}$ para além da sua ação religiosa, desbravaram terrenos propiciadores da fixação da população desenvolvendo atividades de exploração agrícola com plantação de extensos vinhedos e produção de vinhos de qualidade, nas melhores áreas, através de uma rede de granjas ${ }^{26}$, algumas das quais viriam a dar origem a quintas notáveis. No século XIV, o rei D. Fernando obteve receitas para os cofres do Estado, através do lançamento de impostos sobre a exportação de vinhos, escoados sobretudo para França.

\footnotetext{
${ }^{24}$ FAUVRELLE, 2001. Ver também FAUVRELLE, 2014.

${ }^{25}$ ALBUQUERQUE, 2012; DIAS \& DUARTE, coord., 1999. Consultar sobre as granjas cistercienses o estudo de referência de Almeida Fernandes (FERNANDES, 1973); ver ainda sobre granjas cistercienses na Beira Douro, e uma das mais antigas granjas do Mosteiro de S. João de Tarouca, o trabalho de Maria do Céu Tereno (TERENO, 2002). ${ }^{26}$ Segundo Almeida Fernandes (FERNANDES, 1973: 18), existiram duas tipologias de granjas cistercienses, umas de tipo inferior, destinadas exclusivamente à exploração agrícola, que podiam ser arrendadas, e outras de tipo superior, com mestres granjeiros, considerados como centros de cultura intelectual, dotados de carta de povoação, que deram origem a algumas povoações, e que, dessa forma, apoiavam o espírito comunitário e o municipalismo.
} 
No século XVI, a produção de vinhos de qualidade para fins comerciais aumentou, tendo os ingleses passado a exportar alguns dos nossos vinhos, designadamente a partir de Caminha e de Viana do Castelo, continuando os vinhos do Douro a ser exportados pela barra do rio Douro, ou por terra, para Espanha. A procura crescente de vinho para abastecer as armadas levou a uma nova expansão das vinhas regionais, em áreas rapidamente famosas pela qualidade dos seus vinhos.

O conhecido e importante testemunho de Rui Fernandes escrito em 1531-1532 ${ }^{27}$ referia a produção de vinho no Douro como variada, porque proveniente de muitas castas, e abundante, quando avaliada pelos dízimos cobrados em almudes de vinho ${ }^{28}$. À luz destas notas quinhentistas, fonte histórica importante para a época, mas não única ${ }^{29}$, as produções das freguesias junto ao Douro entre Lamego e Régua configuravam já então um espaço de monocultura vinhateira. E já antes do século XVI, conforme dados de Rui Fernandes, só a quinta de Mosteirô (Cambres-Lamego), propriedade do mosteiro de S. João de Tarouca, produzia 15 a 16.000 almudes de vinho de «carregação», o que pressupõe já a existência de antigas e sólidas infraestruturas.

No século XVII, os ingleses estabelecem-se na cidade do Porto para exportar pela barra do Douro os vinhos de Lamego, de Riba Douro e de Cima Douro, oriundos da região ${ }^{30}$. Os ingleses e os escoceses traziam bacalhau e panos e, depois de terem importado vinho, sobretudo de Viana e de Monção, foram-no procurando no interior norte e sul do país. Encontraram no Alto Douro um vinho mais forte e mais encorpado e um rio que permitiria canalizar as pipas até à sua foz para dali saírem para o estrangeiro ${ }^{31}$. Pode-se comprovar documentalmente que a partir de 1651 há mercadores britânicos do Porto envolvidos no negócio de exportação para Inglaterra ${ }^{32}$.

Em 1675, Duarte Ribeiro de Macedo refere a denominação de vinho do Porto para esse vinho e, três anos depois, o nome já constava em registo alfandegário entre os produtos escoados pela barra do Douro. Mas que significaria, à época, a expressão «vinho do Porto», cujo sentido se encontra ainda por explorar devidamente? Porque se tratava de vinho exportado a partir da cidade do Porto? Porque era vinho carregado num porto de exportação, o que poderia ser equivalente às expressões, correntes entre os séculos XVI e XVIII, de «vinho de carregação» ou de «vinho de embarque»? Certo é que, em qualquer dos casos, não seria idêntico aos atuais vinhos do Porto.

Durante esse período da Idade Moderna, a vinha e o vinho foram adquirindo uma importância cada vez maior na economia da região da bacia do Douro até os vinhos durienses se transformarem numa mercadoria de excelência que contribuiu para a afirmação mercantil

\footnotetext{
${ }^{27}$ FERNANDES, 1824: 553.

${ }^{28}$ SILVA, 1997.

${ }^{29}$ SILVA, 1997: 95 e segs.

${ }^{30}$ SILVA, 1990b.

${ }^{31}$ BARRETO, 2014.

32 SILVA, 1997.
} 
da cidade do Porto e num produto reclamado nas mesas aristocráticas dos reinos de Portugal, Espanha e Inglaterra ${ }^{33}$.

No entanto, a nível geral da região do Douro a cultura da vinha e do vinho era então ainda limitada, como assinalava memória anónima apresentada à Academia Real das Ciências em 1782, sobre o estado da Agricultura e Comércio do Alto Douro nos séculos XVII e $\mathrm{XVIII}^{34}$.

No ano de 1681 não tinha o Alto Douro uma tão larga plantação de vinhos: o gosto da Inglaterra inclinado nesse tempo a vinhos doces, fazia que os lavradores, além das vinhas suficientes para consumo interno, só plantassem vinhas em situações escolhidas em as costas das ribeiras mais expostas à força do Sol; isto compreendia pequenas porções de terra destacadas por entre os matos. Não havia as grandes quintas que hoje se veem; os lagares de 3, 4, até 5 pipas ao muito, que naquele tempo havia, e os tonéis das mesmas medidas mostram as pequenas porções, em que consistia a colheita de cada lavrador. $O$ resto das terras pela maior parte estava inculto, e de anos em anos se the cortava o mato, e se queimava sobre a terra para nela semear centeio, com bem pouco lucro dos lavradores que faziam estas sementeiras. Outras terras se traziam semeadas de sumagre, que se cultivava com cuidado; e este era um ramo de comércio de que os lavradores tiravam utilidade. Os olivais ocupavam outra parte da terra, porém como nem toda é própria para esta plantação, se viam muitos lavradores obrigados a esperar oito e dez anos por uma colheita regular de azeite, passando-se... [que] muitos lavradores se foram a pouco e pouco desanimando, até o ponto de deixarem ir a monte os seus olivais. Nas terras altas se produziam castanheiros, e em outros havia pouco maior cultura de pão do que aquela qua ainda hoje se conserva. E deste modo era este Território nos tempos antecedentes um dos mais pobres do Reino... não se vendo hoje nem ainda vestígios de um só edifício antigo magnífico e suntuoso... e muitos bons Templos, tudo isto é de fábrica moderna, achando-se dificultosissimamente um destes edifícios que possa contar cem anos. Este era o estado do Alto Douro no ano de $1681[\ldots]^{35}$.

No início do século XVIII, com o tratado do Comércio celebrado entre as cortes de Portugal e Inglaterra no ano de 1703 - o conhecido e controverso «Tratado de Methuen» que constava de três artigos, em que a Inglaterra se comprometia a adquirir os vinhos de Portugal, pagando estes dois terços dos direitos impostos aos vinhos franceses, enquanto os portugueses se comprometiam a adquirir os panos ingleses, confirmaram-se os termos de

\footnotetext{
${ }^{33}$ SILVA, 1997: 93.

${ }^{34}$ Incluída pela Academia no tomo III das suas Memórias Económicas em 1791, esta memória setecentista foi registada no volume VI do Dicionário Bibliográfico de Inocêncio, tendo sido reeditada e reproduzida na publicação O Douro nos séculos XVII e XVIII, 1937. Encontra-se organizada em 23 pequenos capítulos com desenvolvimento cronológico (VASCONCELOS, 1937).

${ }^{35}$ VASCONCELOS, 1937: 1, 2.
} 
anteriores tratados bilaterais do século XVII (acordos comerciais dos anos 1642, 1654 e 1661) e reafirmaram-se práticas comerciais de exportação vinícola e têxtil que já existiam entre os dois países ${ }^{36}$.

A historiografia recente do vinho do Porto tem minimizado os efeitos deste tratado que não impunha exclusivismo comercial entre ingleses e portugueses, considerando-o mais como um ponto de chegada de uma tendência anterior do que como fator de crescimento das exportações. Haja em vista por exemplo os seguintes dados relativos às exportações vinícolas anuais antes e depois do tratado: em 1693-1702, foram em média de 8.331 pipas e em 1703-1712, de 8.111 pipas $^{37}$.

$\mathrm{Na}$ verdade, e embora os volumes de vinho exportados estivessem, regra geral, em ascensão desde o século XVII até meados do século XVIII, o mercado continuava ainda irregular e o tratado de Methuen, importante acontecimento político do período, não parece ter tido especial repercussão no Douro como teve noutras regiões vinícolas portuguesas que beneficiavam do mesmo tratamento fiscal e aduaneiro ativo por parte do estado. Aliás,

Na procura de melhores oportunidades de exportação, os vinhos do Sul buscam os portos do Norte, Figueira, Viana e sobretudo Porto, onde se organizam os carregamentos para a Europa. Nos últimos anos deste período assiste-se a fenómenos de crise tocando particularmente os vinhos do Douro: diminuição e irregularidade dos volumes exportados; baixa de preços e de rendimentos; quebra de qualidade do vinho exportado. A única entidade regional, ou que como tal possa ser considerada, é privada e pode ser equiparada a um cartel: trata-se da Real Feitoria Inglesa ${ }^{38}$.

Entretanto o aumento da procura fez aumentar, simultaneamente, os preços praticados pelos comissários ingleses bem como o crescimento da plantação de vinhas e da produção de vinho no Alto Douro. Em contrapartida, no início da década de 1750, a diminuição e queda dos preços decorrente quer na sequência de vindimas com uma produção de má qualidade (em especial as dos anos de 1753 e 1754) quer do excesso da oferta sobre a procura, pode contribuir para explicar que uma pipa dos mais finos vinhos do Douro se vendesse para Inglaterra por apenas $10 \$ 000$ réis, entre 1750 e 1755.

A viticultura duriense tinha-se expandido incrementada pelo aumento do escoamento deste seu produto de grande qualidade para os mercados europeus o que induz maior desenvolvimento económico e social na região que não deixará de influir em posterior melhoria das capacidades técnicas de produção vitivinícola.

\footnotetext{
${ }^{36}$ Ver, entre outros estudos historiográficos relevantes, a obra de CARDOSO et al., 2003.

${ }^{37}$ MARTINS, 1990: 217-218.

${ }^{38}$ BARRETO, 1988: 373-390.
} 
A criação da Companhia Geral da Agricultura das Vinhas do Alto Douro (alvará régio de 10 de setembro de 1756) $)^{39}$ que com sede e maioria de acionistas na cidade do Porto, atuaria sobretudo ao nível da produção e comércio interno sem concorrer diretamente com o comércio externo e exportadores que logo contestaram as suas atribuições e privilégios, visou então regulamentar a produção e a venda de vinho e dar início à estruturação da região vitícola, através de: criação de uma Região Demarcada; realização do cadastro e classificação das parcelas e dos vinhos produzidos (vinho de feitoria e vinho de ramo); instituição dos mecanismos de controlo e de certificação de um produto de qualidade. «Uns anos mais tarde (em 1776 e 1777) protegeu-se o comércio da concorrência dos restantes vinhos portugueses, proibindo a exportação destes e reservando a barra do Douro exclusivamente para o vinho do Porto» ${ }^{40}$.

Com a Demarcação da Região Duriense, medida de enorme importância histórica e pioneirismo sociopolítico no panorama vitivinícola internacional de há 260 anos atrás ${ }^{41}$, foram assinaladas as zonas autorizadas a produzir vinho de feitoria que corresponderia ao de melhor qualidade e que serviria para a exportação.

Na segunda metade do século XVIII, o interesse económico e social do Estado esteve sempre do lado do setor do vinho do Porto, o setor mais dinâmico e com maior interesse para o comercio externo da metrópole portuguesa ${ }^{42}$.

À perspectiva tradicional do Estado protector da região do Douro e dos viticultores durienses contra a dominação do sistema do vinho do Porto pelos exportadores, em especial os ingleses, o historiador Borges de Macedo, contrapôs, há mais de meio século, uma interpretação centrada no reforço do centralismo estatal e no alargamento da sua acção nas esferas económica e social. Para Borges de Macedo, a criação da Companhia e a abundante legislação reguladora que se lhe seguiu constituíram instrumentos do Estado absolutista para controlar um sector-chave da economia nacional, bem como para preservar - e, simultaneamente, subordinar — os interesses dos grupos sociais dominantes que lhe estavam associados ${ }^{43}$. Neste sentido, num momento em que se agudizou o conflito de interesses entre o sector produtivo e o sector comercial, procurou garantir aos grandes vinhateiros durienses parte das mais-valias decorrentes da notoriedade alcançada no mer-

\footnotetext{
${ }^{39}$ Sobre a fundação da Companhia Geral da Agricultura das Vinhas do Alto Douro e a difícil conciliação dos projetos portugueses com os interesses ingleses, que desde cedo dominaram o comercio dos vinhos durienses e o negócio de vinhos do Porto, consultar, por exemplo, o estudo de Francisco Ribeiro Silva - Os ingleses e as circunstâncias políticas dos negócios dos Vinhos do Porto (SILVA, 2005: 111-126). Consultar também o artigo de Gaspar Martins Pereira - O vinho do Porto, o Alto Douro e a Companhia na época pombalina (1756-1777), segundo Bernardo José de Sousa Guerra (PEREIRA, 1984).

${ }^{40}$ MARTINS, 1988: 395.

${ }^{41}$ Para se compreender melhor o enorme alcance da criação da Região Demarcada do Douro e sua evolução histórica multidimensional, pluriperspetivada e abrangente, ver PEREIRA, 2006: 175-185. Ver ainda, do mesmo autor, A região do vinho do Porto (PEREIRA, 1996).

${ }^{42}$ MARTINS, 1988: 402-403.

${ }^{43}$ MACEDO, 1982.
} 
cado externo pelo vinho do Porto, mas sem pôr em causa os fortíssimos interesses mercantis que se jogavam no sector exportador, dominado pela importante colónia britânica. Nesta perspectiva, a Companhia Geral da Agricultura das Vinhas do Alto Douro constituiu, essencialmente, um mecanismo de controlo do Estado sobre a região do Douro, sobre os seus vinhos e sobre os interesses sociais que lhes estavam associados. Em contrapartida, certos autores têm continuado a caracterizar, recentemente, o modelo de intervenção pombalino como uma forma de autorregulação. Contrapondo o "princípio da regulação estadual, mediante órgãos da administração directa ou indirecta do Estado; e o princípio da autorregulação, mediante a entrega das tarefas de regulação e disciplina a organismos da própria região», assumem que a Companhia «era sobretudo um instrumento da lavoura da região e nesse sentido era já um instrumento de autorregulação». Vale a pena, por isso, tentar compreender até que ponto e em que aspectos a Companhia era, essencialmente, «um instrumento da lavoura da região» ou, pelo inverso, um instrumento de controlo do Estado sobre a região $[\ldots]^{44}$.

Nos inícios da primeira metade do século XIX, com o advento do regime liberal, apesar da pressão abolicionista dos mecanismos de proteção e controlo dos vinhos do Douro, as dificuldades financeiras do Estado inviabilizaram a adoção de uma política liberalizadora contrária ao modelo pombalino que se foi mantendo. Apenas com a vitória liberal, em 1834, é que a Companhia irá perder, no governo de D. Pedro, os poderes majestáticos e as funções de tutela de que gozava amplamente. Porém, a plena liberdade de comércio dos vinhos do Douro só acabaria por se afirmar a partir de 1865 até 1907, «coincidindo com profundas alterações na viticultura e no comércio de vinhos (ataque da filoxera, expansão vitícola em zonas não filoxeradas, transformações técnicas e reconversão vitícola, aumento da concorrência nos mercados externos, proliferar das falsificações e imitações de vinhos mais prestigiados) $»^{45}$.

$\mathrm{Na}$ segunda metade do século XIX, a praga da filoxera devastou os vinhedos europeus, tendo começado no mesmo ano de 1863 no sul de França e no Douro atingindo também o comércio dos nossos vinhos. $\mathrm{O}$ facto de aparecer muita gente a querer comprar vinho, e de o vinho de qualidade começar a rarear, acabaria por levar à adulteração do produto. No período filoxérico no Douro, muitos lavradores e proprietários, com as suas terras reduzidas a pouco mais que mortórios, recorreram ao crédito hipotecário e, endividados, viram-se obrigados a vender as propriedades muito baratas, ou a largá-las em processos de execução judicial.

Dona Antónia Ferreira, uma das figuras históricas mais destacadas do Douro, adquiriu numerosas e grandes quintas da região e comprou enormes quantidades de vinho a baixos preços, possibilitados pela abundância de produção, revendendo-os, posteriormente, por valores mais elevados.

\footnotetext{
${ }^{44}$ PEREIRA, 2006: 177.

${ }^{45}$ PEREIRA, 2006: 180.
} 
Registou-se assim a constituição de grandes stocks de vinho e, entretanto, desbravaram-se montes, introduziram-se modernas técnicas de vitivinicultura ${ }^{46}$, e ocupou-se o solo com novas culturas, tendo-se verificado a ocorrência de grandes alterações económicas e tumultos sociais.

Os efeitos devastadores das doenças da vinha (oídio, filoxera e míldio), mais intensos no Cima Corgo e no Baixo Corgo que no Douro Superior, originaram a reorganização fundiária e a modernização da vitivinicultura.

As grandes mudanças operacionalizam-se com a afirmação de uma burguesia endinheirada e com uma nova relação que se passa a estabelecer entre os grupos sociais e a terra. A partir da filoxera (abandono de terrenos, crise de muitas quintas, miséria dos proprietários e das populações), verifica-se o aparecimento de novos grupos com poder económico para fazerem investimentos no Douro. Várias quintas mudam de mãos, surgem novas plantações e constituem-se novos interesses no Douro ${ }^{47}$.

O uso do bacelo americano, como solução contra a filoxera, exigiu a alteração das técnicas de plantio da vinha e a enxertia passou a ser uma prática corrente, implicando a seleção de castas a enxertar. Os tratamentos químicos contra o míldio e o oídio tornaram-se obrigatórios.

Nos finais do século XIX (1890-1899) as exportações de vinhos do Porto situaram-se numa média anual inferior a 53 mil pipas.

Na transição dos finais do século XIX para o século XX o Douro viveu uma grande crise comercial e agrícola e generalizou-se uma situação de miséria e conflitos sociais que estão na base de sucessivos tumultos populares.

$\mathrm{Na}$ primeira metade do século XX, as crises comerciais que então se fizeram sentir contribuíram para travar a expansão da vinha no Douro Superior, sem no entanto impedir o reconhecimento da qualidade dos seus vinhos ${ }^{48}$. A área desta sub-região foi alargada até à fronteira, com as novas demarcações de João Franco e Ferreira do Amaral (1907-1908), vindo a ficar a Região Demarcada do Douro, muito semelhante à de então, com seus limites atuais definidos pela Lei de 1921, que voltou a regulamentar a produção e o comércio do vinho do Porto.

A seguir à década de 1950, desenvolve-se o movimento de criação de adegas cooperativas que, nos inícios da década seguinte, abrangerão cerca de $10 \%$ do número de produtores e da produção vinícola regional.

A partir dos anos 1970, mas já com antecedentes nas duas décadas anteriores, desencadeou-se o movimento contemporâneo de profunda transformação, renovação técnica e tecnológica e extensa modernização da região do Douro, em que se destacaram nomes pioneiros como os de José Freitas de Sampaio com quem surgiram, nos anos 1950, as primeiras experiên-

\footnotetext{
${ }^{46}$ PEREIRA, 2015.

${ }^{47}$ Património Mundial Unesco: Alto Douro vinhateiro. Disponível em <http://www.sabrosa.pt/turismo/douro/index. php?idioma $=$ pt $>$. [Consulta realizada em 1/5/2015].

${ }^{48}$ QUADRADO, 2009.
} 
cias de plantação de vinha ao alto, na quinta dos Murças, replicadas, nos anos 1960, em Santa Bárbara, por Gastão Taborda ${ }^{49}$ e depois, desde 1974, nas quintas do Bom Retiro e ErvaMoira, por José António Ramos-Pinto Rosas ${ }^{50}$, fundador da Associação para o Desenvolvimento da Viticultura Duriense (ADVID), entre outros. Desenvolveram-se então e expandiram-se na região duriense novas formas de organização da vinha e de plantio, com particular incidência no Cima Corgo e no Douro Superior; novas técnicas de arroteamento dos solos; novas castas; práticas vitícolas e técnicas de vinificação modernas; maior mecanização da produção e da extração das uvas; técnicos especializados a apoiar o processo; administradores e gestores a governar os negócios das empresas, etc.

Após esta abrangente evolução histórica que se tentou esboçar importará agora fazer ainda uma abordagem breve à antiguidade e atualidade da densa história do «vinho do Porto», marca da mais elevada qualidade e origem certificada na história e cultura da Região do Douro, donde se difundiu pelo mundo, com esse nome e como um dos maiores bens económicos e culturais de exportação do país, sobretudo nos últimos 300 anos, a partir do século XVII.

\subsection{UMA LONGA HISTÓRIA, A DO «VINHO DO PORTO»}

O vinho do Porto foi ée um produto chave da economia nacional e ainda mais um valor simbólico que distintamente representa a portugalidade no mundo $0^{51}$.

$\mathrm{O}$ «vinho do Porto» é um vinho generoso produzido exclusivamente na Região Demarcada do Douro, envelhecido no entreposto de Gaia e exportado da cidade do Porto, que assim, comercialmente, lhe deu o nome, sendo já hoje o seu envelhecimento feito no Douro donde segue para comercialização e exportação. É obtido a partir de uvas tintas ou brancas, cuja fermentação é interrompida com a adição de aguardente vínica, sendo depois transportado para armazéns de Gaia, onde fica a envelhecer. O vinho do Porto pode ter uma graduação alcoólica entre os $18 .^{\circ}$ e os $22 .^{\circ}$ e deve as suas características únicas (sabor, aroma e corpo) às peculiares condições edafoclimáticas da região demarcada do Douro.

A qualidade do vinho do Douro está na razão inversa da quantidade produzida. Os melhores locais raramente produzem mais de duas pipas por cada mil pés. A pipa do Douro, com uma capacidade de 550 litros, correspondente, desde há séculos, a 22 almudes (de 25 litros) é a medida padrão em que se envelhece e exporta o vinho do Porto. O seu envelhecimento pode ser feito em cascos, garrafas ou em ambos, e durante esse processo o vinho do Porto tinto e branco adquire vários e diferentes tons de cor.

\footnotetext{
${ }^{49}$ BARROS, 2008.

${ }^{50}$ ANDRESSEN, 1996: 9-17.

${ }^{51}$ PEREIRA, 2016. Ver também PEREIRA, 2003b.
} 
Os vinhedos, quintas e outras propriedades agrícolas durienses onde se produz o vinho do Porto pertencem, na maioria dos casos, a lavradores que fazem o vinho para os exportadores ou vendem o «mosto» (o sumo fermentado sem a adição de aguardente) aos maiores produtores e exportadores que podem também ser grandes produtores, sendo, neste caso, eles próprios que fazem o vinho.

Os exportadores que sempre se organizaram entre si e tiveram poderosos organismos representativos dos seus interesses, como a Feitoria Inglesa, no Porto, desde o século XVIII, a Associação Comercial do Porto (século XIX, inícios do século XX), o Grémio dos Exportadores de Vinho do Porto — organismo corporativo de inscrição obrigatória, desde 1933 a 1974, quando foi extinto — , criaram depois do 25 de abril, em janeiro de 1975, a Associação de Exportadores de Vinho do Porto, redenominada em 1995, como Associação de Empresas de Vinho do Porto. Têm também vindo a investir na produção comprando quintas e fazendo novas plantações de vinha no Douro.

Por sua vez, alguns produtores passaram a dedicar-se também, autonomamente, à comercialização e exportação direta dos vinhos de produção própria, a partir do Douro.

É de destacar neste movimento o papel pioneiro de produtor/engarrafador independente de Luís Roseira da Quinta do Infantado, desde 1978, quer na comercialização direta dos vinhos do Porto e depois dos vinhos Douro DOC, quer na criação da Associação de Viticultores Engarrafadores dos Vinhos do Porto e Douro (AVEPOD) ${ }^{52}$.

O vinho do Porto apresenta assim uma longa evolução que se encontra inscrita na própria história do seu nome e em múltiplos aspetos que caracterizam a sua produção, genuinidade e qualidade vínica, cujas linhas gerais se justifica traçar.

\subsubsection{Dinâmicas espaciotemporais e diversidade de produção e comércio do vinho do Porto}

Como anteriormente se sublinhou, vem de tempos anteriores aos da nacionalidade portuguesa, a história antiga da vitivinicultura duriense desenvolvida ao longo de séculos, mais precisamente desde a época romana no Douro (entre o século I e o século V) em que foi particularmente importante a expansão da cultura da vinha que se prolongou e desenvolveu com especial evolução durante toda a Idade Média, em grande medida pela ação de mosteiros $^{53}$ e ordens religiosas, como a Ordem de S. Bento e a Ordem de Cister ${ }^{54}$ com grande experiência organizativa de exploração agrícola e produção vitivinícola em terras do Douro $^{55}$.

Nesse contexto de longa duração que se encontra já muito estudado e atravessa toda a história antiga do Douro, o Douro dos prolongados tempos medievais e o Douro da época

\footnotetext{
${ }^{52}$ BARRETO, 2014: 225.

${ }^{53}$ DIAS, 2005.

${ }^{54}$ TEIXEIRA, 2010.

${ }^{55}$ LENCASTRE, 1953.
} 
moderna (séculos XVI a XVIII) até ao período contemporâneo (séculos XIX e XX), emergiu e se desenvolveu também a história de diversidades dinâmicas do «vinho do Porto ${ }^{56}$ designação que remonta em Inglaterra (Port Wine) ao século XVII, inícios do século XVIII, sendo mais tardia em Portugal onde parece ter surgido pela primeira vez em 1675, em documentação relativa à exportação de vinho para a Holanda.

O cônsul britânico no Porto, Walter Maynard, um dos primeiros exportadores e o mais antigo antepassado ilustre dos Symington, comerciantes e empresários de ascendência escocesa que durante várias gerações têm detido importância relevante na história do comércio e produção dos vinhos do Porto ${ }^{57}$, (ver Capítulo 8) terá exportado para Inglaterra, a partir da cidade do Porto, 39 pipas de vinho do Porto, em 1652, que se pode considerar ser ao tempo uma grande exportação.

Haja, no entanto, em vista estudos mais fundamentados sobre a explicação dominante na história do vinho do Porto de que os portugueses produziram o vinho e os ingleses dirigiram o seu comércio ${ }^{58}$.

A partir de meados do século XVIII, as exportações de vinho estagnaram, embora a produção vinhateira tenha continuado a crescer; os preços desceram muito e os ingleses deixaram de comprar vinhos, acusando os lavradores de fazerem adulterações.

Esta crise comercial conduzirá, por pressão dos interesses dos grandes vinhateiros durienses junto do governo do futuro Marquês de Pombal, à instituição da Companhia Geral da Agricultura das Vinhas do Alto Douro, em 10 de setembro de 1756. [Com este organismo tutelar da Região Demarcada Duriense] busca-se assegurar a qualidade do produto, evitando adulterações, equilibrar a produção e o comércio e estabilizar os preços. Procede-se à primeira 'demarcação das serras'. A região produtora é bordada por 335 marcos de pedra com a designação de Feitoria, designação que referendava o vinho da melhor qualidade, único que podia exportar-se para Inglaterra, vulgarmente conhecido por vinho fino ${ }^{59}$.

Desde então, expressões como Alto Douro, Região do Vinho do Porto e outras, têm vindo a andar associadas ${ }^{60}$.

A partir de finais do século XVIII, após o rebentamento da grande formação rochosa do Cachão da Valeira (grandes fragas de xisto a meio do leito do rio, formando cachoeira), a cerca de 6 quilómetro a montante da foz do rio Tua no termo de Carrazeda de Ansiães e S. João

\footnotetext{
${ }^{56}$ Ver exaustiva revisão do estado da literatura sobre múltiplos aspetos e dimensões a conhecer sobre a história do Douro e do vinho do Porto na síntese essencial dos numerosos trabalhos e estudos já realizados designadamente pelo GEHVID - Grupo de Estudos de História da Viticultura Duriense e do Vinho do Porto, que iniciou a sua atividade em 1994, em CARDOSO, 2007.

${ }^{57}$ SYMINGTON, 2007.

${ }^{58}$ Ver, por exemplo, o estudo antropológico de DUGUID, 1996.

${ }^{59}$ PEREIRA, 2016.

${ }^{60}$ Ver sobre várias expressões relacionadas com a região do Douro, VASCONCELOS, 1980: 360-383.
} 
da Pesqueira ${ }^{61}$, desde sempre, barreira natural à navegabilidade do rio Douro, a área oriental duriense até então com reduzida plantação de vinhas, tornar-se-ia economicamente viável, favorecida pela abertura ao tráfego fluvial. Intensificaram-se as relações para leste do Douro e aí se passaram a adquirir e transformar novas propriedades, implantando-se e desenvolvendo-se algumas das melhores quintas da Região como a Quinta de Vargellas, adquirida, mais de um século depois, pela firma Taylor's, cujos vinhos de elevada qualidade se passaram a afirmar. Esta área oriental do Douro ficaria conhecida como o «Douro Novo» ${ }^{62}$ e, mais tarde, Douro Superior ${ }^{63}$, onde o movimento de intensificação e expansão da cultura da vinha só se verificou a partir de meados do século XIX. Para tal terão contribuído «a extinção dos privilégios da antiga Companhia da Agricultura das Vinhas do Alto Douro, o regime de liberdade de exportação pela barra do Douro para todos os vinhos portugueses (carta de lei, de 7 de dezembro de 1865) — regime de liberdade que permitiu acentuar a dependência da agricultura duriense face ao comércio exportador do Porto ${ }^{64}$ - e ainda o grande prejuízo na cultura da vinha nas áreas do Baixo e Cima Corgo provocado pelo oídio (1852) e a partir de 1863, a devastação dos vinhedos pela filoxera, seguida de um surto de míldio em 1893.

A ascensão de grandes propriedades no Douro Superior, uma unidade económica e cultural bem distinta do Alto Douro, como se poderá melhor percecionar nos capítulos seguintes, e o reconhecimento da qualidade dos seus vinhos muito viria a contribuir para reforçar a reputação e prestígio dos vinhos do Porto nos mercados externos ${ }^{65}$.

O alargamento das primeiras linhas de demarcação duriense, nos finais do século XVIII e a posterior instauração do regime de liberdade comercial em 1865 vão permitir a expansão rápida do vinhedo no Douro Superior, onde o ataque da filoxera foi mais tardio e menos violento, como se explicitará nas partes e capítulos seguintes deste livro. Surgiram novas práticas de armação do terreno e de plantação da vinha, selecionaram-se as melhores castas regionais para os enxertos, difundiu-se a utilização racional de adubos, melhoraram-se os processos de vinificação.

Ao longo do século XIX, o setor comercial que já se sobrepunha ao setor agrícola desde a primeira metade do século XVIII, quando a economia vinhateira do Douro passou a ser dominada pelo movimento de exportação dos seus vinhos, conseguiu reforçar o seu domínio

\footnotetext{
${ }^{61}$ Esta histórica obra decorreu durante o reinado de Dona Maria desde 1780 a 1792, continuando posteriormente os trabalhos de regularização do rio, «tendo os primeiros barcos rabelos chegado, finalmente, em 1811, a Barca de Alva», conforme refere REBANDA, 2006: 75.

${ }^{62}$ [História do Vinho do Porto]. Disponível em <https://www.taylor.pt/pt/o-que-e-o-vinho-do-porto/a-regiao-dodouro/solo-e-clima $>$ e $<$ http://www.fonseca.pt/pt/as-vinhas/o-vale-do-douro/história/ $>$.

${ }^{63}$ Rodrigo Morais Soares, 1878 define a divisão do Douro vinhateiro em Douro Inferior (de Barqueiros ao Corgo), Alto Douro (do Corgo ao Tua) e Douro Superior (do Tua à fronteira), subdivisão semelhante à da Carta da Producção dos Vinhos Comuns ou de Pasto de Portugal para Servir na Exposição Internacional de Vinhos de 1874 em Londres e à da Carte Vinicole du Portugal de 1878, mais cuidada, elaborada e rica de informações em relação ao Douro e publicada na obra de Soares. Ver estudo crítico sobre fontes e documentos cartográficos oitocentistas relacionados com a vitivinicultura, em FERNANDES \& MARQUES, 2011.

${ }^{64}$ PEREIRA, 1989: 311-353.

${ }^{65}$ PEREIRA, 1989: 311-353.
} 
sobre a Região Duriense e a cidade do Porto, sobretudo a partir da liberalização do comércio dos vinhos durienses a par de vários outros fatores - como as doenças da videira, a pauperização da região e o endividamento de muitos viticultores, novas condições de concorrência no mercado internacional, abertura da via férrea e mais rápidas e fáceis comunicações entre o Douro e a cidade do Porto, transferência de propriedades durienses, algumas para a burguesia comercial portuense, etc.

O comércio exportador dos vinhos irá a seguir requerer o exclusivo da denominação Porto (1906) para os vinhos modificados em Gaia e defender para a região duriense a denominação dos vinhos correntes «Douro» ${ }^{66}$.

Nos inícios do século XX tiveram lugar em 1907/1908 duas novas demarcações da região de produção do vinho do Porto, as quais passaram a incluir o Douro Superior até à fronteira com Espanha. Como melhor se explicita no Capítulo 2, estas diferentes demarcações, a primeira, por concelhos, do governo de ditadura de João Franco (Decreto de 10 de maio de 1907), cujo alargamento excessivo da área demarcada suscitou polémica, logo modificada no ano seguinte pelo governo do Almirante Ferreira do Amaral (Decreto de 27 de novembro 1908) que optou pela demarcação por freguesias, ficando a área produtora de vinho do Porto reduzida quase ao espaço da demarcação atual (Decreto-Lei, de 26 de junho de 1986) correspondente à estabelecida em 1921 (Decreto de 10 de dezembro). Foi também reconhecida a exclusividade legal da barra do Douro e do porto de Leixões para exportar os vinhos do Porto, ficando a denominação de «vinho do Porto» reservada aos vinhos generosos da região do Douro, com graduação alcoólica mínima de 16,5².

Durante a I República, só no seguimento de forte resistência e revolta duriense, marcada por muitas lutas e mortes (como se desenvolve na Parte II, Capítulo 6) Portugal acabará por assinar, no ano de 1914, um outro tratado com o governo britânico, no qual havia uma cláusula importante que exigia que o vinho do Porto viesse única e simplesmente do distrito do Douro, sendo assim, finalmente, reconhecida a designação de origem «Port» para o vinho generoso duriense.

As exportações do vinho do Porto dependentes em grande medida das alterações sucessivas dos mercados e dos gostos consumidores, aumentaram muito, atingindo, em 1924/1925, mais de 100 mil pipas, quantidade que só seria ultrapassada em finais da década de 1970, passando desde 1979, o volume de comercialização de vinho do Porto a utrapassar sempre as 100 mil pipas ${ }^{67}$.

Em 1926 foi criado o Entreposto de Gaia, como prolongamento da região produtora do afamado vinho, situado em Vila Nova de Gaia, parte sul do rio Douro em frente ao Porto. Lá se encontram ainda hoje os armazéns dos exportadores onde o vinho do Porto chegava (até aos

\footnotetext{
${ }^{66}$ Património Mundial Unesco: Alto Douro vinhateiro. Disponível em <http://www.sabrosa.pt/turismo/douro/ index.php?idioma $=$ pt $>$. [Consulta realizada em 1/5/2015].

${ }^{67}$ LOPES, 1998.
} 
anos 1960), transportado pelos tradicionais barcos rabelos e também desde o século XIX pela linha férrea do Douro.

No regime corporativo do Estado Novo foram criados em 1932 e 1933 três organismos oficiais destinados a organizar o controlo da produção e comercialização do vinho do Porto: a Casa do Douro ou Federação dos Lavradores, resultante do movimento associativo da vitivinicultura duriense ${ }^{68}$ e encarregada de superintender nos assuntos da lavoura e da produção vitivinícola de acordo com o designado sistema de «benefício» apoiado no «método de pontuação», criado pelo engenheiro agrónomo Álvaro Moreira da Fonseca e que começou a funcionar no final dos anos $1940^{69}$, o qual consiste, resumidamente, na atribuição anual a cada viticultor de uma autorização para produzir uma quantidade de mosto determinada, a que corresponde uma certa qualidade (da letra $\mathrm{A}$, o melhor, até à letra $\mathrm{F}$ ) e um preço correspondente, em função da localização, das características do terreno, das castas e da idade das vinhas; o "Grémio dos Exportadores de Vinho do Porto», associação do setor comercial organizado em 1933, com as funções de cuidar da disciplina do comércio deste vinho, devendo todos os exportadores serem seus membros para poderem obter o certificado de exportação; e o Instituto do Vinho do Porto, criado no mesmo ano, com atribuições de estudo, promoção da qualidade, fiscalização e propaganda, entidade fiscalizadora dos outros dois organismos, e única entidade destinada a tratar da publicidade e fraudes e a poder emitir os certificados de garantia do produto vinho do Porto.

Como se referiu já, o Grémio dos Exportadores de Vinho do Porto foi extinto, após o 25 de abril de 1974, mas a Casa do Douro e o Instituto do Vinho do Porto mantiveram as suas funções básicas de defesa da qualidade da marca. Em 1973, foram regulamentadas pelo Conselho Geral do Instituto do Vinho do Porto as seguintes categorias de vinho do Porto:

- Vinho do Porto Vintage (vinho de uma só colheita, produzido em ano de boa qualidade, com excecionais características organoléticas (captadas pelos sentidos: cheiro, cor, sabor, textura, maciez, aparência), retinto e encorpado, de aroma e paladar muito finos, reconhecido pelo Instituto do Vinho do Porto (I.V.P.) com direito ao uso da designação «vintage» e data correspondente, segundo regulamentação própria);

- Late Bottled Vintage ou L.B.V. (vinho de uma só colheita, tinto e com algum corpo, engarrafado entre o $4 .^{\circ}$ e o $6 .^{\circ}$ ano);

\footnotetext{
${ }^{68}$ PEIXOTO, 2001: 197-211. Consultar ainda, sobre a história deste organismo, entre outros trabalhos, designadamente a obra clássica de Vital Moreira, O governo de Baco: a organização institucional do vinho do Porto (MOREIRA, 1998) e o livro de Carla Sequeira A questão duriense e o movimento dos Paladinos, 1907-1932 (SEQUEIRA, 2000).

${ }^{69}$ Nesta época, em que apenas o vinho do Porto tinha relevância no mercado interno e no da exportação, em consequência da grande diversidade de potencialidades orográficas e edaficoclimáticas da Região Demarcada do Douro que proporcionam a elaboração de vários tipos de vinho, de diferentes graus qualitativos, desde os vinhos do Porto tintos e brancos aos DOC Douro tintos e brancos, aos moscatéis e aos espumantes, foi idealizado e criado por Moreira da Fonseca em 1948 um método de zonagem, designado por Método de Pontuação para a classificação de parcelas, em função do seu específico potencial para a produção de vinho do Porto, o qual, com correções e ajustamentos feitos desde então, ainda hoje se mantém em vigor. Consultar Manual de boas práticas vitícolas: Região Demarcada do Douro, [2010]: 28.
} 
- Vinho do Porto com data da colheita;

-Vinho do Porto com indicação de idade.

Assim enraizado num longo e denso processo sócio-histórico, nasceu o Vinho do Porto «Vintage», considerado a quinta-essência dos Portos, e ao qual se vieram juntar os «Single Quinta Vintage Ports» (denominação inglesa), que excluindo qualquer compra de vinhos a terceiros são produzidos a partir de uvas de produção própria (lavradores ou casas agrícolas) o que lhes confere um caráter distinto e específico. Refira-se que só há vintages tintos.

\subsubsection{Processo de produção dos vinhos do Porto}

Complexo e diversificado como o processo histórico de afirmação do Vinho do Porto, vinho nascido na região do Douro, mas essencialmente internacional, considerado famoso embaixador de Portugal de grande prestígio, mas também notável coletor de divisas, é o processo da sua produção que mobiliza saberes e práticas plurifacetadas de técnicos e leigos e tem requerido muito engenho e artes. Em suas múltiplas dimensões, envolve também um avultado empate de capital na plantação de uvas e um custo elevado de granjeio, pouco rentável para o pequeno produtor, o que interessa ainda aqui observar mais minuciosamente, ao nível geral do fabrico dos vinhos e na sua modalidade específica e especializada.

\section{Da vinha ao fabrico do vinho}

Os vinhos são fabricados a partir dos cachos de uvas constituídos pelo engaço (estrutura) e pelos bagos formados por película, polpa e grainhas, com composições e distribuições químicas diversas e sujeitos a evolução e diferentes transformações durante o seu crescimento e maturação. Verificam-se variações muito importantes da concentração e dos tipos de diferentes constituintes: nos cachos de uva, só em função da casta (variedade) e por influência de clima mais solo (terroir); grau de maturação da uva; tecnologias vitícola e enológica o que variar mais as respetivas concentrações ${ }^{70}$.

A qualidade da uva tem grande influência sobre a qualidade e características do vinho. Por isso, torna-se muito importante determinar com exatidão, o que as modernas tecnologias permitem, a data da vindima. Isto requer um estudo prévio sobre a evolução dos bagos de uva, ainda na vinha, para que se possa determinar então a melhor altura para se vindimar. À medida que a uva vai transformando os seus ácidos em açúcares, a acidez vai diminuindo e o álcool vai aumentando. O equilíbrio «açúcares-ácidos» tem que ser respeitado para que se possa obter o melhor equilíbrio possível no vinho.

\footnotetext{
${ }^{70}$ SILVA, 2006. Ver também a obra didática de referência sobre o tema técnico-científico da viticultura geral de Nuno Magalhães (MAGALHÃES, 2015).
} 
O vinho do Porto é um vinho licoroso, e a doçura do vinho advém de açúcares naturais nas uvas não fermentados, sem qualquer concentração prévia. O tempo de fermentação e maceração é muito curto comparado com os outros vinhos (dois a 3 dias) ${ }^{71}$.

Uma vindima precoce pode originar um vinho desequilibrado, com muitos ácidos, poucos açúcares e baixo teor em álcool. Se a vindima for tardia, a uva terá maior quantidade de açúcares, logo dará à partida um vinho rico em álcool e pouca acidez. Cada casta tem o seu ponto de equilíbrio e mesmo cada produtor pode determinar qual a relação que mais lhe interessa. Os fatores fundamentais que influenciam uma boa vindima são: o clima: horas de sol, temperatura, humidade e o designado fator terroir (termo francês): solo, microclima da região e casta.

\section{Vindima e Pisa}

Quando a vindima começa devem assegurar-se as melhores condições de transporte das uvas para a adega. As uvas devem chegar inteiras e não amassadas ou calcadas o que, com o calor pode originar uma fermentação antecipada.

A marcação da data de vindima é feita em função dos resultados obtidos das várias análises efetuadas, com o objetivo de apanhar as uvas no estado de maturação desejado. Cerca de um mês antes da data habitual de vindima, recolhem-se aleatoriamente bagos na vinha, para que se possa, com as amostras recolhidas, fazer uma amostragem dos vários parâmetros — peso dos bagos, teor de açúcares, álcool provável, acidez, pH — necessários para determinar qual o estado de maturação da uva.

Hoje em dia a vindima pode já ser efetuada com a ajuda de máquinas, caso ainda muito raro no Douro. As máquinas de vindimar bastante eficientes são uma preciosa ajuda quando se tem uma grande extensão de vinha para vindimar. No caso de terrenos com relevo, ou na impossibilidade de usufruir deste tipo de equipamento, a vindima manual, tradicional, permite uma primeira seleção dos cachos na vinha.

A tradicional pisa das uvas nos lagares de pedra, nas suas operações trabalhosas e sucessivas fases (primeira pisa ou corte/corta, designado de meia-noite; nova-pisa ou sova, designada a mexa ou trabalhar o lagar; espremedura dos bagaços com prensas verticais) e as modernas técnicas de prensagem levam à transformação das uvas em vinho com as propriedades necessárias para se tornar pronto a consumir, armazenar em boas condições de conservação e comercializar nos mercados nacionais e internacionais, passando por uma série de operações que mais adiante se ilustram num diagrama simplificado do complexo processo de vinificação, com destaque para as operações básicas de produção do vinho e as mais específicas do vinho do Porto.

\footnotetext{
${ }^{71}$ Para descrição detalhada do processo de vinificação do vinho do Porto, consultar o sítio do IVP. URL: http:// www.ivp.pt/pt/Enologia/enologia1.shtm.
} 


\subsubsection{Evolução das técnicas de vinificação do vinho do Porto}

É de destacar que o processo técnico de vinificação dos vinhos generosos do Douro aptos a serem certificados como vinho do Porto atravessou, desde o início da Idade Moderna até aos nossos dias, uma longa e complexa evolução histórica de que dá devida conta a necessariamente extensa transcrição que se segue:

Já em inícios do século XVI, de acordo com a descrição de Rui Fernandes, os melhores vinhos do Douro se caracterizavam por serem «aromáticos» e terem grande capacidade de envelhecimento, reforçando a sua excelência com a idade. Tais vinhos eram produzidos por uvas bem maduras obtidas por vindimas tardias e sujeitas a processos de pisa prolongada (talvez derive daqui a expressão «vinho de pé» utilizada no século XVI; num documento do século XIV, citado por Águedo de Oliveira, encontra-se a expressão «vinho de três vezes o pé posto»). Esse "processo antigo» de vinificação, defendido ainda no século XIX pressupunha a fermentação completa do mosto e, portanto, a obtenção de vinhos secos. Em contrapartida, a tecnologia de produção de vinhos doces, com características próximas dos vinhos do Porto atuais, ter-se-á desenvolvido, a partir de finais do século XVII — inícios do século XVIII, com a adição de quantidades crescentes de aguardente vínica ao mosto para travar a fermentação e, desse modo, conservar a doçura natural das uvas. O aperfeiçoamento contínuo dessa tecnologia de vinificação dos vinhos generosos do Douro constituiu um processo longo e foi muito influenciado pela vocação comercial desses vinhos. O mercado inglês que, entre finais do século XVII e meados do século XX, absorveu a maior parte dos vinhos do Porto, marcou profundamente a evolução do gosto, cor e corpo das categorias produzidas e das respetivas práticas de vinificação, bem como as diversas designações (tawnies, rubies e vintages). Já no século XVIII, os exportadores britânicos sediados no Porto eram acusados de promoverem a elaboração de vinhos retintos, aguardentados, doces e aromáticos. [...]. Certo é que a evolução dos processos de vinificação dos vinhos generosos do Douro acabou por se orientar para este tipo de vinhos doces, mantendo, paralelamente, muitos aspetos da tradição. Desde finais do século XVIII, a emergência de uma cultura enológica inovadora, promovida pelos círculos iluministas, em especial os associados aos memorialistas da Academia Real das Ciências de Lisboa, contou com a participação ativa de académicos originários do Douro, alguns deles viticultores [...] Na segunda metade do século XIX, o aparecimento das doenças da videira (em especial, o oídio em 1852, a filoxera em 1863 e o míldio em 1893) e a introdução e difusão de meios de combate a essas doenças provocaram profundas transformações nas técnicas vitivinícolas. A filoxera obrigou à introdução de porta-enxertos americanos e a novas formas de armação dos terrenos, com a disposição regular dos bardos e a construção de socalcos mais largos, que tiveram quer um impacto decisivo na paisagem quer implicações importantes na cultura da videira. $O$ 
Douro vinhateiro conheceu, na segunda metade do século XIX, uma verdadeira revolução técnica. Novas formas de tratar os solos, novas formas de plantação, novas operações de tratamento [...].

Verificaram-se também, ao longo do século XIX, mudanças decisivas no processo de vinificação. Mas, neste caso, é a própria cronologia que necessita de ser afinada. Há um fundo de verdade na explicação de Forrester, segundo a qual a difusão do novo processo de vinificação estaria relacionada com a excecional qualidade da colheita de 1820, «em que todos os vinhos foram naturalmente (e fora do costume) cheios, doces e saborosos» [...]. Os viticultores, estimulados pela grande procura de vinhos semelhantes aos de 1820, teriam sido levados a imitarem, nas colheitas seguintes, por processos artificiais, esses vinhos. De facto, a evolução para vinhos mais doces, através da prática da adição de aguardente durante a fermentação do mosto, parece ter-se expandido por essa altura. Mas a importância da novidade de 1820 como causa imediata do «novo processo de vinificação» foi exagerada por Forrester. A polémica entre «vinhos secos» $e$ «vinhos doces», que ressurge na primeira metade do século XIX, é bem mais antiga, remontando pelo menos a meados do século anterior, aos tempos da ideação da Companhia Geral das Vinhas do Alto Douro [...] Por outro lado, a produção de «vinhos finos» secos, com pouca ou nenhuma adição de aguardente, correspondentes ao "processo antigo", com um prolongado trabalho de lagar (cerca de 72 horas, os tais «de três dias o pé posto» do século XIV, e, certamente, os «vinhos de pé» de que falava Rui Fernandes, no século XVI), continuará, ao longo do século XIX, a ser cuidadosamente recomendado por alguns grandes proprietários para os seus melhores vinhos $[\ldots]$.

O «novo processo de vinificação» e os vinhos doces acabarão por se impor, na segunda metade de Oitocentos [...].

Nos últimos vinte e cinco anos, o setor do vinho do Porto atravessou mudanças significativas no domínio das práticas vitivinícolas, na estrutura do comércio e na organização institucional $[\ldots]^{72}$.

Ora, se foram assaz longos e bem complexos os processos de evolução da produção e comercialização do vinho do Porto, também não é de modo algum linear o processo técnico do seu fabrico. Este assenta num conjunto de operações, procedimentos e fórmulas de bases científicas $^{73}$ que devem ser seguidas pelos viticultores e observadas por agentes técnicos especializados na produção conveniente dos vinhos generosos do Douro, e cuja ilustração esquemática se apresenta na página seguinte.

\footnotetext{
${ }^{72}$ Transcrição adaptada de PEREIRA, 2005: 185-191.

${ }^{73}$ CARVALHAIS, 1937.
} 


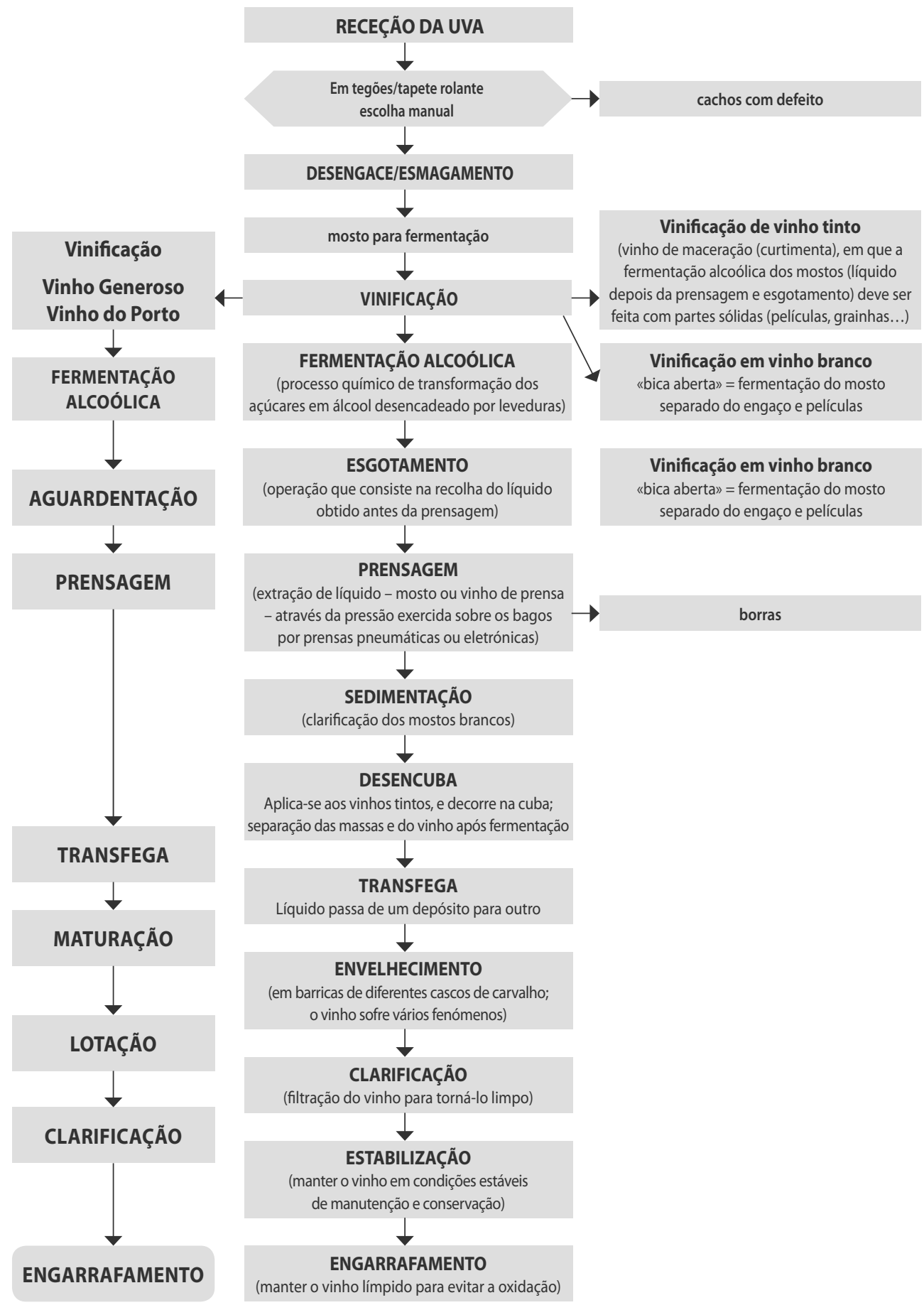

Fig. 5. Processo de vinificação (diagrama) 
Refira-se ainda, a propósito da operação de engarrafamento, que as primeiras garrafas cilíndricas, surgidas por volta de 1770 e hoje em dia vulgarizadas (ao contrário das antigas, largas e de gargalo alto, que se usavam no início do século XVIII), tornaram possível o armazenamento na posição horizontal, ficando o vinho em contacto com a rolha para envelhecimento/amadurecimento (Fig. 6).

No caso do vinho do Porto outras operações de tratamento especializado são mais recentemente efetuadas em caves e armazéns das grandes quintas e propriedades vitivinícolas no Douro, em instalações adequadas próprias e tecnologicamente adequadas.

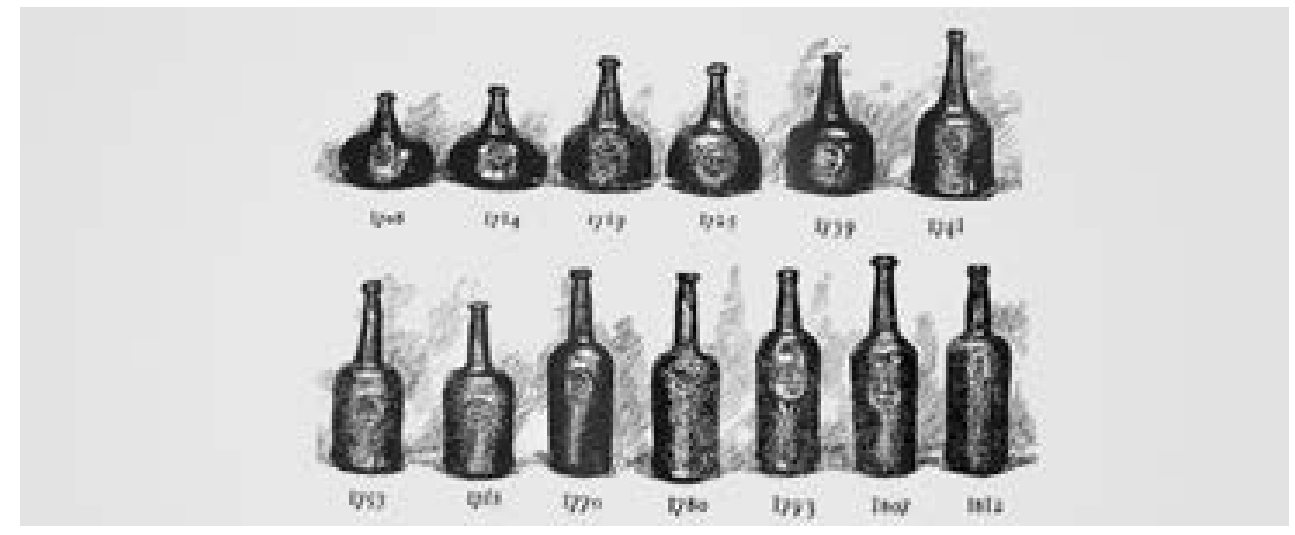

Fig. 6. Garrafas inglesas entre os inícios do século XVIII e do século XIX (evolução) ${ }^{74}$

Os diversos fluxogramas ${ }^{75}$ que se apresentam nas Figuras 7, 8, 9 e 10, com legenda final explicativa de sua leitura, representam e documentam dispositivos de controlo e garantia da gestão de qualidade do produto vínico, observados em vindimas do Douro, nas operações e atividades técnicas, fluxos e decisões do processo de vinificação de vinho tratado e generoso, para produção de diferentes qualidades de vinho do Porto.

Durante séculos o comércio do vinho do Porto esteve dependente do rio Douro, único meio viável de transportar os vinhos da Região Duriense até aos exportadores no litoral norte, Gaia e Porto.

As primeiras referências, ainda de forma inconclusiva, a embarcações com vinho ao longo do Douro reportam-se a tempos muito antigos ${ }^{76}$; no entanto, durante a maior parte da história do vinho do Porto e até meados do século XX, as embarcações que fizeram este transporte fluvial foram os tradicionais barcos rabelos ${ }^{77}$.

\footnotetext{
${ }^{74}$ ALLEN, 1946.

${ }^{75}$ Instruções de trabalho de sistema de gestão de qualidade usadas nas vindimas pelas empresas Cockburn \& Smithes C. ${ }^{a}$ Lda. e Martinez Gassiot \& C. ${ }^{\text {a }}$ Lda. Cópias de dossier de trabalho de J. M. L. facultadas por este informante privilegiado em situação de entrevista.

${ }^{76}$ FILGUEIRAS, 1957: 6.

${ }^{77}$ MATTOS, 1940. Ver ainda CARDOSO, 1998: 117-132.
} 
Aentiver cassoot \& co. LTa.

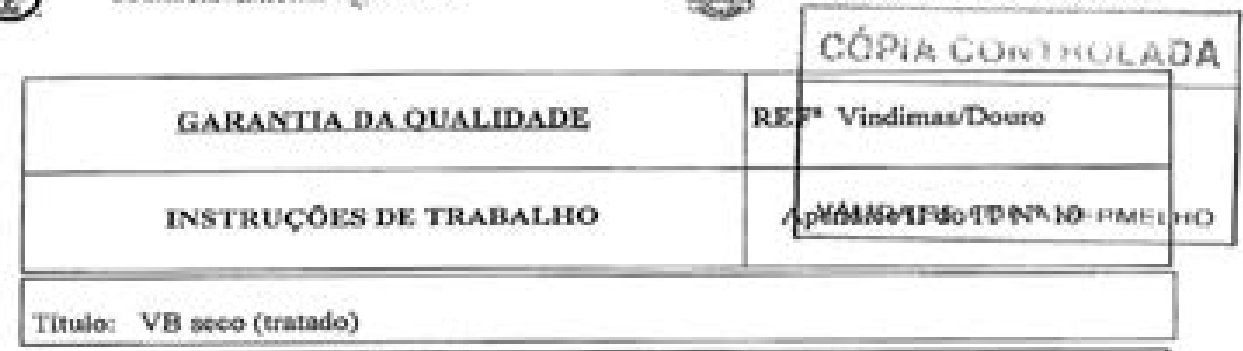

throgos actor
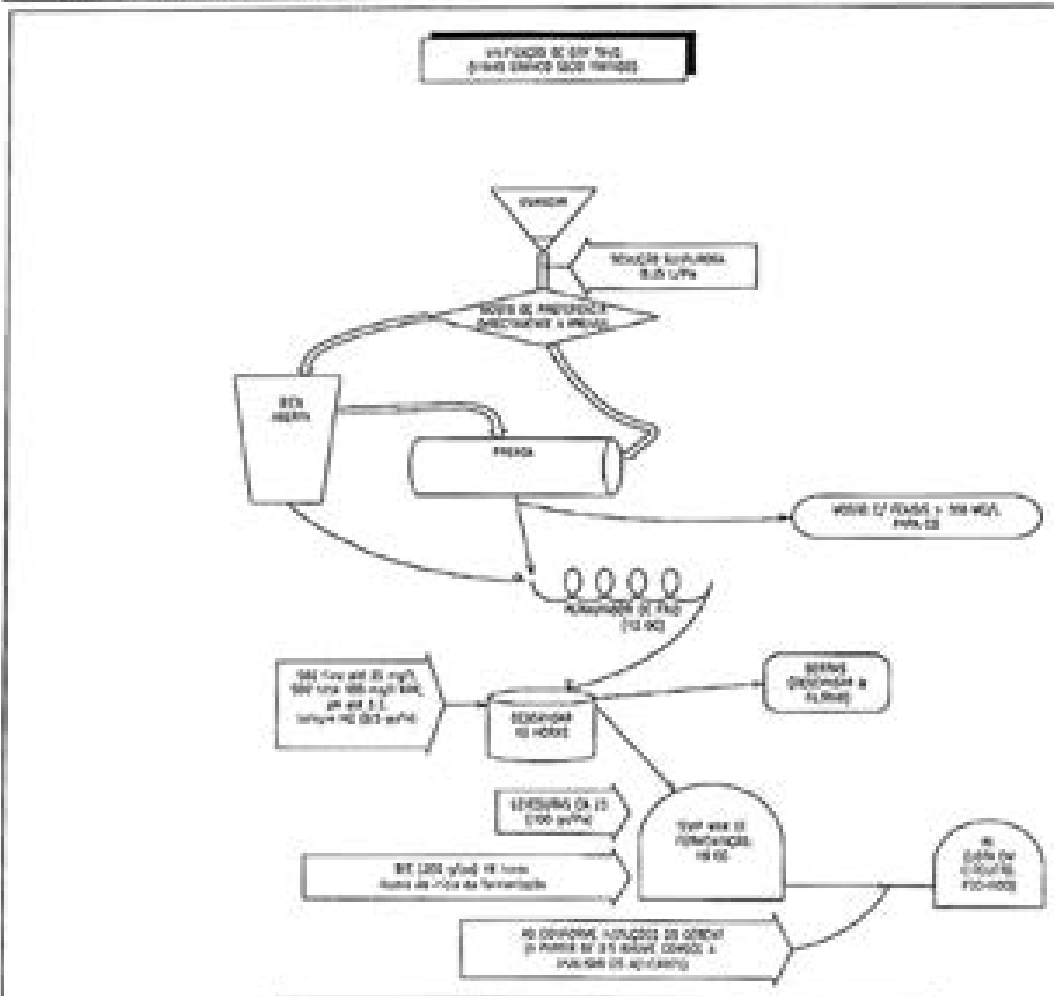

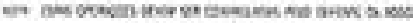

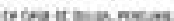

Vindima /Aperodice H-IT10 25 de Agosto de 1997
Elaborado poc: Aprovado por:
Póg. I de 1 EDICĀंO 1 Revisale I

Fig. 7 

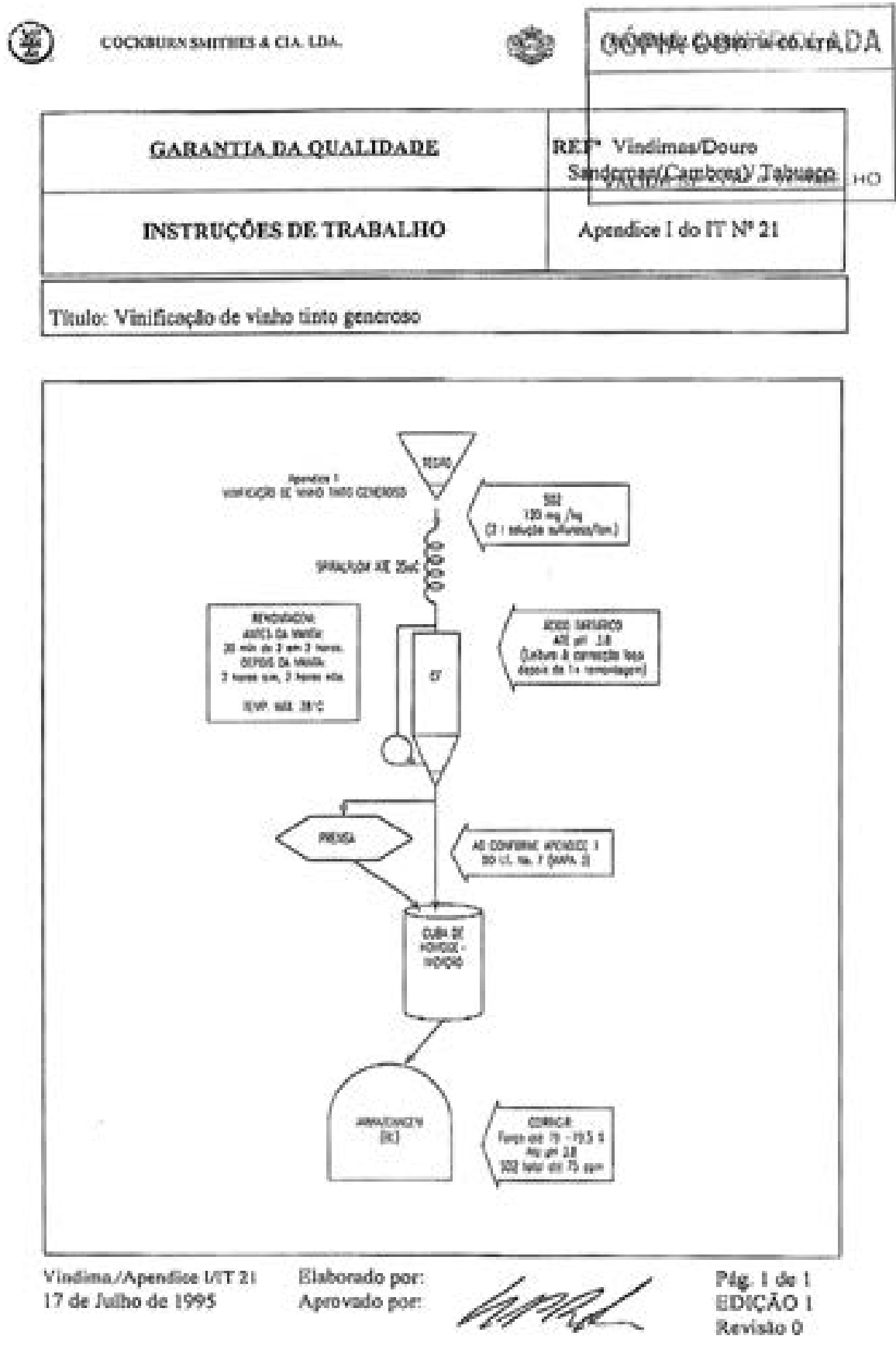

Fig. 8 


\begin{tabular}{|c|c|c|}
\hline GARANTLADA OUALIDADE & RI & 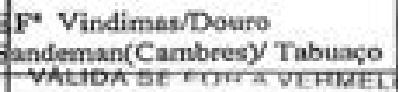 \\
\hline INSTRUCOES DE TRABALHO & & Apendice It do fT $\mathrm{N}^{6} \mathrm{Zl}$ \\
\hline
\end{tabular}

Titulo: Vinificeçäo de vinho branco generoso (meis-curtimenta)

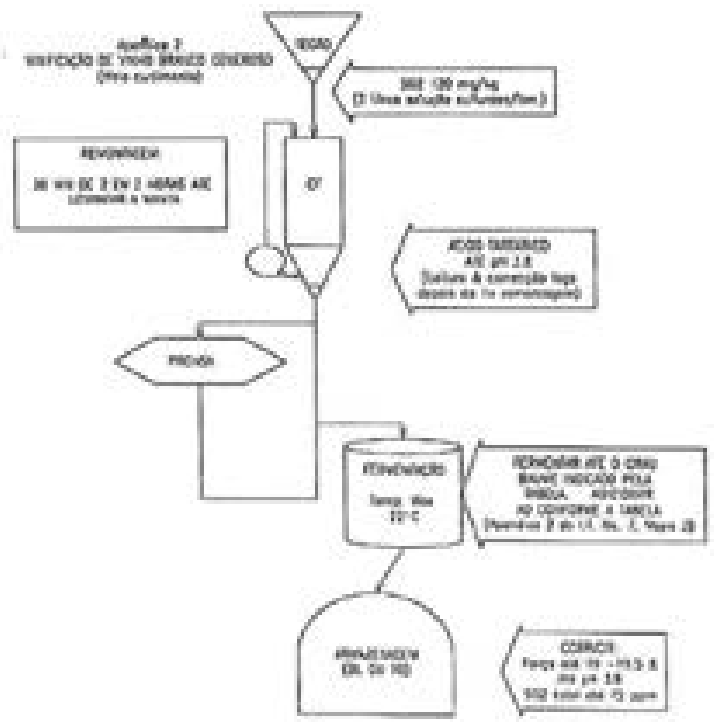

Vindims/Apeadice IVT72 17 de tulho de 1995
Flaborade por: Aprovado por:
Plag 1 de 1

EDICAO 1

Revisto 0

Fig. 9 

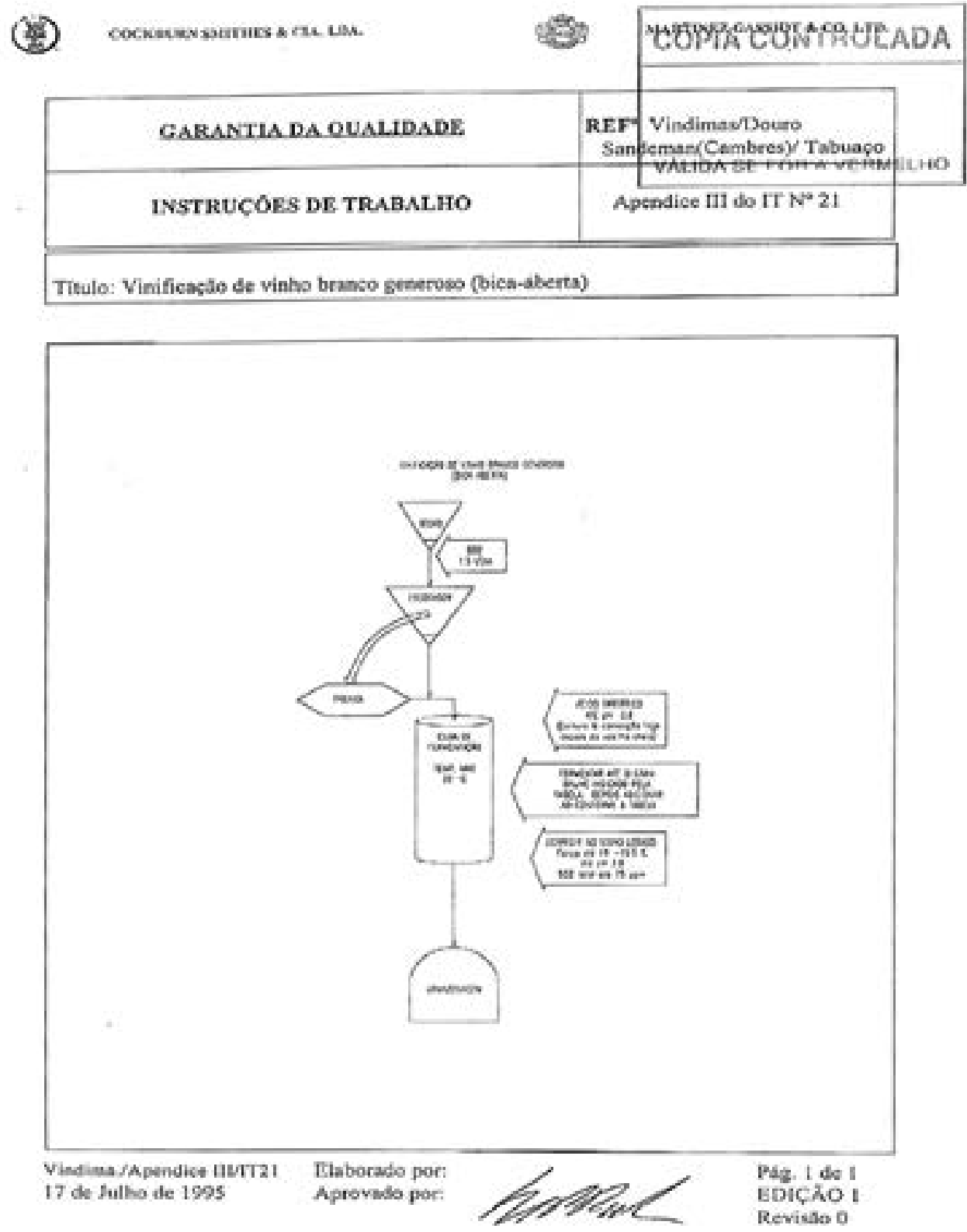

Fig. 10

\begin{tabular}{|l|l|l|}
\hline \multicolumn{2}{|c|}{ Legenda dos fluxogramas } \\
\hline & Indica o início ou fim do processo & Indica os documentos utilizados no processo \\
\hline & Indica cada atividade que precisa ser executada & Indica uma espera \\
\hline & Indica um ponto de tomada de decisão & Indica que o fluxograma continua a partir desse ponto em outro \\
\hline & Ińrulo, com a mesma letra ou número, que aparece em seu interior \\
\hline
\end{tabular}


Quase todo o vinho do Porto era trazido, anualmente, das quintas e armazéns do Vale do Douro para Gaia e Porto, rio abaixo, «rio de mau navegar», pelos barcos rabelos conduzidos por marinheiros e arrais experientes, na primavera seguinte às vindimas, após terem sido de novo passados a limpo, para evitar a exposição do vinho ao calor dos verões secos do Douro que provocariam um envelhecimento do vinho rápido demais.

O transporte das pipas de vinho do Alto Douro para Porto/Gaia passou ainda a ser feito, progressivamente, a partir de 1880, com a abertura da Linha férrea do Douro, por comboio e, já mais tarde, no século XX, com a expansão rodoviária, por camionetas. Depois de 1965 viria a desaparecer, definitivamente, o transporte pelos tradicionais barcos rabelos onde as pipas de vinho do Porto foram, durante séculos, carregadas e descarregadas com o apoio de carros de fabrico artesanal local puxados por juntas de bois, o que se tornaria «atributo obrigatório da paisagem duriense» no dizer do geógrafo Amorim Girão.

As caves do vinho do Porto são armazéns longos, frescos e escuros, com grossas paredes de granito e tetos altos que ajudam a manter o calor e uma temperatura uniforme durante todo o ano. Estas condições garantem que os vinhos envelheçam lentamente e que gradualmente adquiram os sabores e aromas da maturidade. Albergam a maior parte das grandes reservas de vinhos do Porto envelhecidos em tonéis e pipas de 550 litros ou cubas de capacidades variadas e garrafeiras, por vezes abrigadas em túneis, abaixo das caves, onde os Portos Vintage envelhecem em garrafas na posição horizontal para manter as rolhas húmidas. Os milhares de recipientes em madeira das caves onde o vinho do Porto estagia, eram e ainda são, nalgumas grandes empresas (Taylor's, Symington, etc.), obra de equipas especializadas de tanoeiros encarregados de cuidar e manter cascos e de fazer novos, se necessário.

Nos armazéns do Porto e Vila Nova de Gaia, cujo número cresceu muito a partir de 1834, com a afirmação do liberalismo, o vinho do Porto passava ainda pelas operações de trasfega e clarificação, quando necessário sendo entretanto lotado com vinhos da mesma ou de diversas explorações e proveniências e preparação de diferentes lotes e indo depois a repousar nos cascos, balseiros e tonéis, a que se sucedia o engarrafamento e posterior comercialização e exportação dos lotes finais, resultado de misturas e lotações várias.

Os laboratórios, salas de provas e equipamentos necessários ao envasilhamento, rotulagem e encaixotamento do vinho do Porto, localizavam-se em regra nos edifícios das empresas exportadoras onde, nalgumas, ainda subsistem. As casas exportadoras, com sedes geralmente no Porto, enquanto os seus armazéns se situavam na proximidade do rio Douro, sobretudo na margem ribeirinha de Gaia, contribuíram para definir a malha urbana desta zona, como se pode concluir da Memória Paroquial de Santa Marinha de $1758^{78}$, ano em que a Região Duriense estava a ser demarcada, criando-se então a Região Demarcada do Alto Douro ${ }^{79}$, dimensão fundamental da história do Douro e do vinho do Porto que se desenvolve no capítulo seguinte.

\footnotetext{
${ }^{78}$ CAPELA, 2009.

${ }^{79}$ Ver o Douro Reserva Histórica \& o Vinho do Porto: Fotografias do espólio Foto Beleza, 2006.
} 


\section{CAPÍTULO 2. O DOURO, REGIÃO DEMARCADA COMO TRAÇO ORIGINÁRIO}

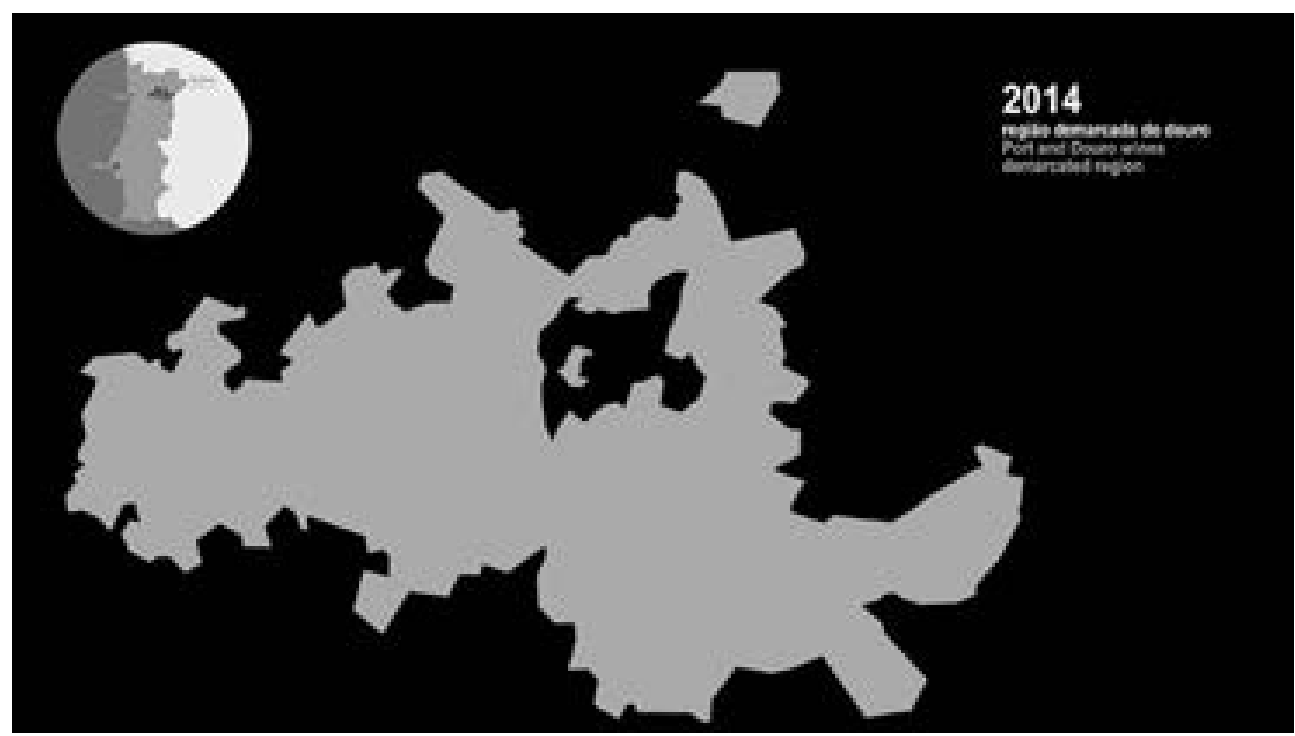

Fig. 11. Região Demarcada do Douro (2014) — Localização e delimitação da área total Fonte: Museu do Douro ${ }^{80}$

A Região Demarcada do Douro (RDD), região vinícola que delimita, atualmente, a denominação de origem controlada dos vinhos do Porto e Douro, com uma área de extensão, à volta de 250.000 hectares, de Barqueiros a Barca d'Alva, estabeleceu-se ao longo do Rio Douro e seus afluentes, tendo-se desenvolvido a partir da delimitação territorial da primeira demarcação das «Vinhas do Alto Douro» (1756) para regular a produção de vinhos fortificados, hoje designados por «Vinho do Porto».

Como bem acentuou o nosso grande geógrafo Orlando Ribeiro, o espaço regional duriense é um "produto histórico». A região do Douro foi sendo alvo recorrente de forte regulação socioinstitucional estatal e objeto de constantes e alternadas medidas protecionistas, desde as leis ditadas pelas filosofias políticas do despotismo iluminado (meados do século XVIII), regime que se iria alterar no liberalismo (século XIX), sendo depois retomado (século $\mathrm{XX}$ ) com a ditadura franquista e posteriormente, de forma mais restritiva, corporativista e duradoura, com o Estado Novo que desenvolveu uma nova política centralista de regulamentação e controlo dos setores da produção e comercialização dos vinhos do Douro. «Caso único na organização pré-corporativa do Estado Novo, a Casa do Douro nascia com a reivindicação social e regional e não por imposição estatal. Talvez por isso mais de 40 anos depois, após a

\footnotetext{
${ }^{80}$ Disponível em <http://www.museudodouro.pt/regiao-demarcada-do-douro $>$. [Consulta realizada em 18/9/2017].
} 
revolução democrática do 25 de abril de 1974, será a única organização a sobreviver à queda do Estado Novo e da organização corporativa $»^{81}$, alterando-se progressivamente em sua orgânica e funções com as políticas de integração de Portugal na União Europeia e a globalização dos mercados, acabando por ser extinta recentemente.

O Alto Douro, considerado como a primeira zona do capitalismo agrário-comercial em Portugal, apresenta uma posição e identidade social «intermédia» ${ }^{82}$ ou «conjuntural» ${ }^{83}$ originada numa agricultura de viticultura intensiva assente no trabalho de jornaleiros pobres, trabalhadores sazonais, camponeses sem terra e pequenos proprietários dominados por grandes proprietários e lavradores, ricos e influentes donos de quintas e explorações agrárias. Mas a história do regime de propriedade no Douro registou tendencialmente profundas alterações até chegar a uma fase de exploração de capitalismo agrário. Os terrenos vinhateiros, inicialmente propriedade das ordens religiosas, da coroa e da nobreza local, passaram, progressivamente, sobretudo a partir do século XVIII a ser adquiridos pelos ingleses que para além de comerciantes se tornaram também produtores do vinho do Porto, o qual, pelas suas mãos, se irá afirmar nos mercados internacionais e em particular na Inglaterra imperial. No século XIX, por efeito das profundas implicações da filoxera e seu impacto na maior revolução social que o Douro então viveu, algumas propriedades dos seus milhares de solos vinhateiros, designadamente, no Douro Superior, foram compradas por uma burguesia portuguesa endinheirada e por diversos negociantes estrangeiros que por esta altura também adquiriram quintas, como mais adiante se explicita.

$\mathrm{Na}$ perspetiva da sociedade duriense, pode verificar-se que nesse enquadramento histórico económico-social tem sido determinante a posição e ação de poderosas elites nacionais e estrangeiras que controlam a produção e o negócio dos vinhos, e em especial do vinho do Porto, principal produto da Região com lugar proeminente na exportação nacional.

As elites de notáveis da sociedade duriense, marcadamente endogâmicas e muito ligadas ao Porto e Gaia, desenvolviam os seus negócios na base de ligações parentais entre as famílias mais importantes. Tal situação favoreceu a grande concentração de riqueza e de negócios na elite agrária duriense com fortes ligações ao poder político da Região e do país e claro apoio às correntes políticas mais conservadoras, em oposição à grande fragilidade financeira de pequenos e médios produtores.

«A desregulação desenfreada, o intervencionismo excessivo, as crises de superprodução e demagogia, tudo isso se conheceu no Douro, em diferentes conjunturas dos séculos XIX e $\mathrm{XX} »^{84}$, definindo-lhe processos históricos diferenciados até aos dias de hoje.

No espaço regional duriense definiu-se historicamente um sistema tradicional de relações económicas e sociais marcado pela oposição de interesses entre viticultores, comercian-

\footnotetext{
${ }^{81}$ MOREIRA, 1996: 77-94.

${ }^{82}$ PARKHURST, 1977: 183-191.

${ }^{83}$ LAGE, 2009a.

${ }^{84}$ BARRETO, 2014: 274.
} 
tes e exportadores e pela posição intermédia de assalariados e pequenos lavradores. Região de monocultura agrária e produção voltada para o comércio internacional, o Douro sempre registou protestos populares e movimentos interclassistas, em que se refletiram as políticas dos sucessivos regimes, principais mudanças políticas e socioinstitucionais, acordos comerciais com o estrangeiro e flutuações dos mercados. Essas dinâmicas foram interferindo na alteração de leis polémicas e lesivas dos interesses regionais bem como na oscilação das políticas do livre Cambismo contestado pela Região e do reclamado protecionismo estatal (cf. Anexo II - Quadro cronológico de crises e movimentos sociais no Douro, do liberalismo à democracia).

Foi-se assim configurando, historicamente, na região duriense um complexo quadro social de contradições dominantes (principais e secundárias) que radicam numa «violência estrutural» resultante da separação da população trabalhadora dos seus meios de produção característica económico-social determinante do capitalismo agrário da história profunda do Douro, complexo que se pode traduzir, abreviadamente, nas seguintes vertentes:

- sucessão de crises seguida de intensa conflitualidade social recorrente perante as difíceis condições de vida, acompanhada de protestos sociais e políticos, violentos ou pacíficos, só aparentemente espontâneos, já que estes continuaram no Douro, a ser estimulados e dominados pelas elites regionais;

- posicionamento geopolítico, derivado de o vinho do Porto ser essencialmente um produto de antiga e vasta exportação para mercados de países do centro da economia e sistema mundo capitalista;

- situação de intensa exploração do trabalho contestada e publicamente denunciada, inclusive por muitos escritores, alguns deles durienses, como Miguel Torga, João de Araújo Correia, Domingos Monteiro, Pina de Morais, e António Cabral, para além de outros, como Alves Redol e Manuel Mendes.

$\mathrm{Na}$ verdade, ainda hoje persistem na Região Duriense, enormes diferenças sociais, fraquezas económicas do setor e desigualdades, não só fundiárias e em vinha, mas também da produção, e grande polarização na propriedade fundiária e no comércio exportador:

os maiores 600 agricultores (individuais ou empresas) possuem cerca de 1/3 da área total da região, onde 3/4 das explorações têm menos de lha e só uma percentagem de 1\%, ou 270 ao todo, dos 25.000 viticultores da região, produzem mais de 150 pipas cada um, sendo responsáveis por quase $28 \%$ da produção de vinho do Porto. No outro extremo, mais de 2/3 (13.800 ou 68\%) produzem menos de 5 pipas, por ano e um total de apenas $14 \%$ do mosto beneficiado. Esta miríade de pequenos produtores na quase totalidade exercendo outras profissões, formam uma imensa legião de fornecedores de uvas (e de cartões de benefício) dos comerciantes e exportadores. Os dois maiores grupos de exportadores, Gran Cruz e Symington, recebem anualmente as uvas de mais de dois mil lavradores cada um. 
Este é em suma o panorama da produção. Mas, do lado da comercialização a polarização é ainda maior e a concentração mais acentuada. Num total de cerca de vinte exportadores e mais duas dezenas de produtores exportadores, os cinco maiores grupos exportadores (Gran Cruz, Symington, Sogrape, Taylor's e Sogevinus são responsáveis por mais de $82 \%$ das exportações $[\ldots]^{85}$.

Apesar das numerosas e enormes alterações visíveis na organização da região e do setor vinícola, resultantes de um complexo, profundo e decisivo processo de mudança, em especial a partir dos anos 1980, continuam a subsistir alguns dos maiores problemas do Douro. A diminuição e perda de força, organização e vitalidade dos pequenos e médios lavradores - uma das partes mais importantes da região e dos mais decisivos protagonistas do setor, os quais, já não falando dos microprodutores, deixaram de ter quem os defenda ou represente, com o fim recente da Casa da Douro. Mantém-se o obsoleto sistema monopolista de formação dos preços do vinho assente num contrato entre vendedor e comprador (em que o preço só se conhece depois da vindima e da entrega do vinho), contribuindo a desorganização da lavoura para a perpetuação deste sistema em que só o setor do comércio exportador, tradicionalmente sediado no Porto e em Gaia se mantém organizado ${ }^{86}$.

Mais adiante se retomará o quadro assim traçado, para análise e interpretação mais aprofundada à luz do presente estudo de caso.

Idêntico sistema de assimetrias e desigualdades económico-sociais e culturais (cuja análise histórico-social prossegue ${ }^{87}$ tendo de ser balanceada, para dar conta das profundas dinâmicas), sempre existiu na Região do Douro, embora entre o Douro Pombalino e o Douro Contemporâneo se tenham registado profundas alterações com inúmeras consequências desde a configuração do espaço, áreas e importância dos vinhedos, propriedades e quintas, até aos regimes legais de regulação, com intermitentes fases de livre comércio. Tais transformações, percetíveis em suas múltiplas e sucessivas representações históricas, foram sendo informadas por diversos estudos clássicos durienses em que foram percursores, designadamente o Barão de Forrester, o Visconde de Villar d'Allen, viticultor duriense que se destacou no combate à filoxera, e o especialista e estratega do Douro, Visconde de Vila Maior, sobretudo a partir de meados do século XIX. Devem ainda ser referidos, pelo pioneirismo das atividades que desenvolveram, o $10^{\circ}$ Visconde de Vilarinho de S. Romão, nas primeiras décadas do século XIX, e Joaquim Pinheiro de Azevedo Leite Pereira, defensor da enxertia de videiras americanas para a reconstrução do vinhedo do Douro, na época da filoxera.

\footnotetext{
${ }^{85}$ BARRETO, 2014: 260-261.

${ }^{86}$ BARRETO, 2014: 270

${ }^{87}$ PEREIRA, 1996a: 155-165.
} 


\subsection{DEMARCAÇÕES: EXPANSÃO DO ESPAÇO REGIONAL DE PRODUÇÃO E COMÉRCIO DOS VINHOS FINOS DURIENSES}

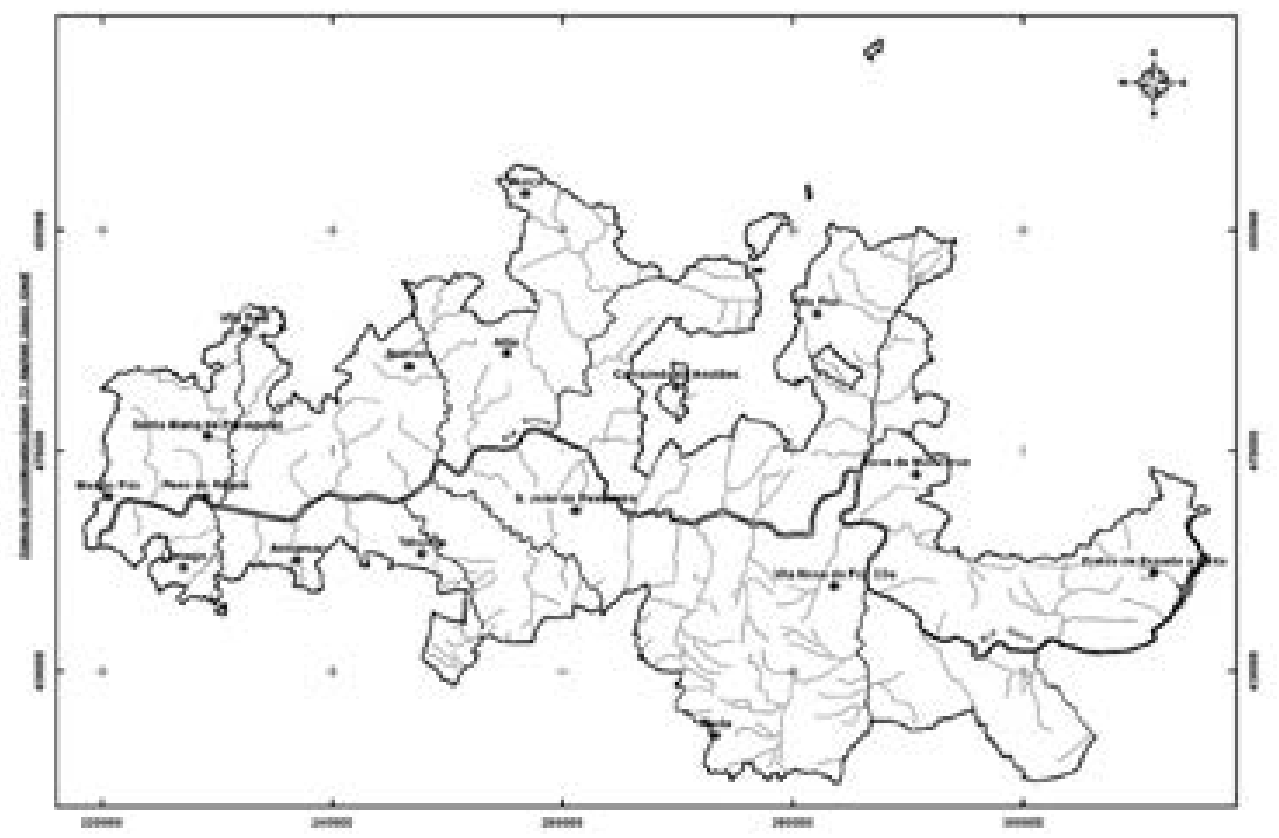

Fig. 12. Região Demarcada do Douro (Sistema de Coordenadas) Fonte:IVDP — Limite_RDD_04_2017 — imagem da RDD ${ }^{88}$

A Região Demarcada do Douro constituiu a "primeira demarcação de uma zona de denominação de origem controlada no sentido contemporâneo do termo» (François Guichard e Philippe Roudié).

Um longo processo histórico da Região Vitivinícola do Douro como espaço regional regulamentado e precocemente subordinado à moderna ideia de «denominação de origem controlada» e defesa da marca Porto, define-se a partir do estabelecimento das primeiras demarcações durienses «pombalinas» (1757-1761). Estas demarcações «primordiais» centraram em torno da Régua a zona produtora dos vinhos finos durienses com correspondente regulamentação protetora da produção e comércio das 3 categorias de vinhos consideradas (de feitoria, de embarque e de ramo), a que sucedem no reinado de Dona Maria as demarcações «marianas ou subsidiárias» (1788-1793), pressionadas pela expansão dos vinhedos, a prosperidade das exportações e a subida de preços e as quais, decorrido mais de um século irão ser alteradas nas suas áreas, limites e legislação reguladora pelas novas demarcações de João Franco e Ferreira do Amaral (1907-1908), justificadas pelas crises e profundas transformações

${ }^{88}$ Disponível em <https://www.ivdp.pt/pagina.asp?codPag $=206 \& \operatorname{codSeccao}=\&$ \&idioma $=0>$. [Consulta realizada em 24/9/2017]. 
da região duriense, grandes alterações e expansão da geografia dos seus vinhedos, induzidas pela ação das moléstias das vinhas (oídio, míldio e sobretudo a filoxera) e novas técnicas, incremento, diversidade e complexidade da produção e comércio do vinho do Porto.

\subsubsection{Primeira região vitivinícola demarcada e regulamentada do mundo: origem de uma identidade regional}

A região vitícola Duriense começou por ser, devido à ação política mercantilista do Marquês de Pombal, em meados do século XVIII, uma das primeiras regiões vitivinícolas demarcadas, à escala mundial, com denominação de origem reconhecida e regulamentada tornando-se assim pioneira no horizonte vitivinícola internacional.

Num contexto de reestruturação dos vinhedos que ocupavam cada vez mais a zona do Cima Corgo (onde o vinho obtido era mais do gosto britânico), de transformação da paisagem com a vinha a dominar a região, e num clima de euforia degenerando em adulteração e caos comercial, associado a uma crise de superprodução, os durienses Luís Beleza de Andrade e Frei João de Mansilha, para além do mercador espanhol Bartolomeu Pancorbo e outros, com projetos muitos diferentes, procuraram encontrar uma solução para o equilíbrio da região, rompendo a tutela britânica e salvando o vinho do Porto através da diversificação de outros mercados para além de Inglaterra e propuseram então ao Primeiro-Ministro do rei D. José I (1750-1777), Sebastião de Carvalho e Melo, futuro Marquês de Pombal, a criação da Companhia Geral da Agricultura das Vinhas do Alto Douro. Esta instituição reguladora viria a ser criada por alvará régio de 10 de setembro de 1756, com o objetivo de garantir a qualidade do produto, fixar os preços e estabelecer a demarcação da Região Vinhateira.

A área demarcada estendia-se a poente do rio Corgo, até Barqueiros, na margem direita do rio Douro, e na margem esquerda deste, polarizando-se no Baixo Corgo, onde se concentravam as maiores produções e adegas, em torno da linha de Lobrigos/Régua/Cambres, e abarcava 34 freguesias, entre as quais se destacavam 5 freguesias: Régua, Godim, S. João e S. Miguel de Lobrigos e Cambres, responsáveis pela produção de quase 1/3 da região demarcada.

Marcos graníticos monolíticos em geral de grande simplicidade, com a face principal gravada com uma marcação própria e a data de colocação ${ }^{89}$, foram implantados sob a jurisdição da Companhia Geral da Agricultura das Vinhas do Alto Douro ${ }^{90}$ assinalam e perpetuam ainda hoje a mais antiga região vitícola demarcada e regulamentada do mundo.

Ao invés de outras demarcações anteriores de regiões vitícolas, como a famosa região de Chianti (Itália, em 1716) e Tokay (Hungria, em 1737), a demarcação do Alto Douro foi

\footnotetext{
${ }^{89}$ Em 1758 foram colocados, em grande parte, os marcos de feitoria e alguns, em menor número, nas adições posteriores da primeira demarcação da região, designadamente as de 1761. Os marcos pombalinos colocados no território duriense para sua demarcação perfazem um total de 335 e foram classificados monumentos de interesse público em 1946.

${ }^{90}$ No século XIX, com a introdução da liberdade comercial, D. Pedro I transformou a Companhia numa mera empresa comercial (30 maio de 1834); proliferaram os vinhos do Porto adulterados, o que, conjugado com a perturbação do mercado inglês e a abertura da barra do Douro a todos os vinhos, provocou uma crise profunda no setor. Em 1838, tem lugar a reabilitação da Companhia e a criação dos portos do Douro exclusivamente para o vinho duriense.
} 
acompanhada por uma ampla legislação regulamentadora e por um sistema de classificação das parcelas e dos respetivos vinhos, procurando atender-se à complexidade do espaço regional de então. Esta demarcação inicial da região incluía a elaboração de um cadastro ou registo das vinhas, nas margens do Douro, autorizadas a produzir vinhos classificados em categorias diferenciadas: vinhos de "feitoria», de primeira categoria, destinados à exportação; vinhos de «embarque» para o Brasil ou Báltico, de qualidade inferior; e ainda vinhos de «ramo» ou «de mesa», de segunda categoria, para consumo nacional.

Assim esta demarcação foi muito para além de uma simples linha de fronteira, originando exclusões e conflitualidades, logo bem longe de ser pacífica como ficou patente nas muitas transgressões ao estatuído, inquiridas e penalizadas pelas sucessivas devassas que a acompanharam e de que é exemplo a célebre devassa de 1771 a 1775, realizada no perímetro Vila Real-Lamego em que foram interpeladas 977 pessoas, das quais, 204 eram voluntários e 773 compulsivos $^{91}$.

As demarcações pombalinas dos inícios da segunda metade do século XVIII, consideradas «primordiais», com uma área de cerca de 40 mil hectares, que duraram quase 30 anos ${ }^{92}$, foram seguidas das demarcações marianas que, durante mais de 80 anos abarcaram uma área de 60 a 80 mil hectares ${ }^{93}$, tendo-se chegado, no início do século XX, às demarcações atuais, com cerca de 250 mil hectares.

Como se pode percecionar, viriam a assumir uma notável continuidade temporal até aos nossos dias, mantendo sempre uma grande carga simbólica na regulação da região do Douro, quer no plano da produção quer no setor do comércio dos seus vinhos:

Os mecanismos de intervenção estatal no setor do vinho do Porto criados na época pombalina (demarcação, arrolamentos e qualificações, fixação de preços, limitação da produção, exclusivo da barra do Porto, controlo do transporte, etc.), como solução para a crise comercial de meados do século XVIII, visavam impor uma rigorosa disciplina da produção e do comércio, em nome da garantia da qualidade e da reputação do produto. [...] Tendo em conta os aspetos essenciais da intervenção pombalina nos vinhos do Douro, a comparação com experiências de regulação de outras regiões vitícolas, nomeadamente as demarcações dos Chianti toscanos (1716) e dos Tokay húngaros (1737) e a classificação dos vinhos de Bordéus 1855), permite perceber o pioneirismo da legislação pombalina que incluiu não só a demarcação de uma região vitícola mas também a elaboração de um cadastro e de uma classificação das parcelas e dos respetivos vinhos, tendo em conta a complexidade do espaço regional, além da criação de mecanismos institucionais de qualificação, controlo e certificação do produto. De facto, o Alvará de Instituição da Companhia Geral da Agricultura das Vinhas do Alto Douro, de 10 de setembro de 1756, estabelece, nos seus 53 artigos, não só as

\footnotetext{
${ }^{91}$ OLIVEIRA \& MARINHO, 1983: 256-257.

${ }^{92}$ FONSECA, 1949-1951.

${ }^{93}$ FONSECA, 1996.
} 
regras de funcionamento dessa companhia majestática mas também os princípios essenciais de regulação da produção e comércio dos vinhos do Douro.

[...] as alterações políticas que ocorreram, com a morte do Rei D. José e a expulsão de Pombal da Corte, não comprometeram, no essencial, poderes tutelares da Companhia sobre a produção e comércio dos vinhos do Douro [...].

Pondo de parte as representações à rainha, desde 1777, para reforma da Companhia $e$ as posições dos negociantes ingleses, em que se destaca o opúsculo de John Croft, que defendiam abertamente a abolição da Companhia, podemos detetar em certas memórias da época, escritas por académicos adeptos das ideias fisiocráticas, uma crítica aos constrangimentos à liberdade de produção e de comércio do vinho. [Porém], o modelo institucional pombalino sobreviveu [...] A dimensão dos negócios da Companhia, a ideia que se formou de ser uma instituição imprescindivel para a «existência da agricultura do Douro», a importância dos direitos que recaíam sobre os vinhos do Porto são algumas razões que justificaram a sua sobrevivência, mesmo quando os ataques à Companhia subiram de tom, a partir da segunda década do século XIX [... $]^{94}$.

A Região Demarcada do Douro foi-se então tornando, posterior e progressivamente, um espaço regional bem mais complexo do ponto de vista da sua regulação institucional, mas também mais extenso e alargado inclusive por força de sucessivos projetos e regulamentos de determinação administrativa central, até chegar à sua configuração atual, muito próxima em termos de área e limites da Demarcação de 1908.

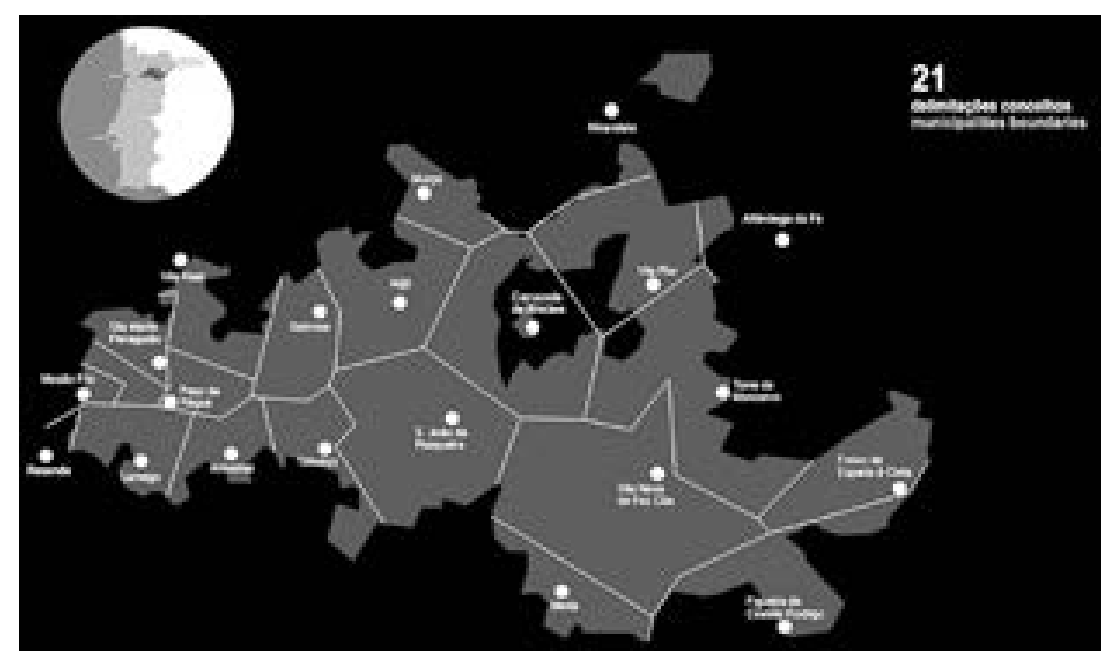

Fig. 13. Região Demarcada do Douro - Concelhos (delimitações)

Fonte: Museu do Douro ${ }^{95}$

\footnotetext{
${ }^{94}$ PEREIRA, 2008.

${ }^{95}$ Disponível em <http://www.museudodouro.pt/regiao-demarcada-do-douro $>$. [Consulta realizada em 19/09/2017].
} 
A atual Região Demarcada do Douro (RDD), definida pelo Decreto-Lei n. ${ }^{\circ}$ 166/86 de 26 de junho de 1986 que aprova também e publica em anexo o regulamento da denominação de origem vinho do Porto, abrange, além de propriedades de Tarouca, vinte e um concelhos. É constituída, na margem direita do rio Douro, distrito de Vila Real, por sete concelhos, três, na sua totalidade: Mesão-Frio, Peso da Régua e Santa Marta de Penaguião e os restantes quatro: Alijó, Murça, Sabrosa e Vila Real (apenas algumas freguesias); distrito de Bragança por algumas freguesias de seis concelhos: Alfândega da Fé, Carrazeda de Ansiães, Freixo de Espada à Cinta, Torre de Moncorvo, Vila Flor e Mirandela; na margem esquerda do rio Douro, distrito de Viseu, por algumas freguesias dos cinco concelhos: Armamar, Lamego, Resende, S.João da Pesqueira e Tabuaço; e no distrito da Guarda por três concelhos: Vila Nova de Foz Coa (totalidade de freguesias) Figueira de Castelo Rodrigo e Meda (algumas freguesias).

Até se chegar a esta recente configuração geográfico-administrativa, desde a primeira regulamentação e demarcação da Região do Douro (1756) que foi sofrendo sucessivas modificações, inclusive por efeito de diversa legislação publicada e orientações reguladoras sucessivas, muitas e profundas alterações visando, nomeadamente, a defesa e valorização da qualidade do vinho do Porto, se verificaram na Região Demarcada do Douro (RDD), que foi ainda objeto de profunda revisão que retomou antigos princípios da política pombalina, com o ditador João Franco, em 1907 (Decreto-Lei n. ${ }^{\circ}$ 1, de 10 de maio), logo reformada em 1908 (Decreto-Lei, de 27 de novembro), no governo de Ferreira do Amaral e, novamente, alterada em posteriores demarcações.

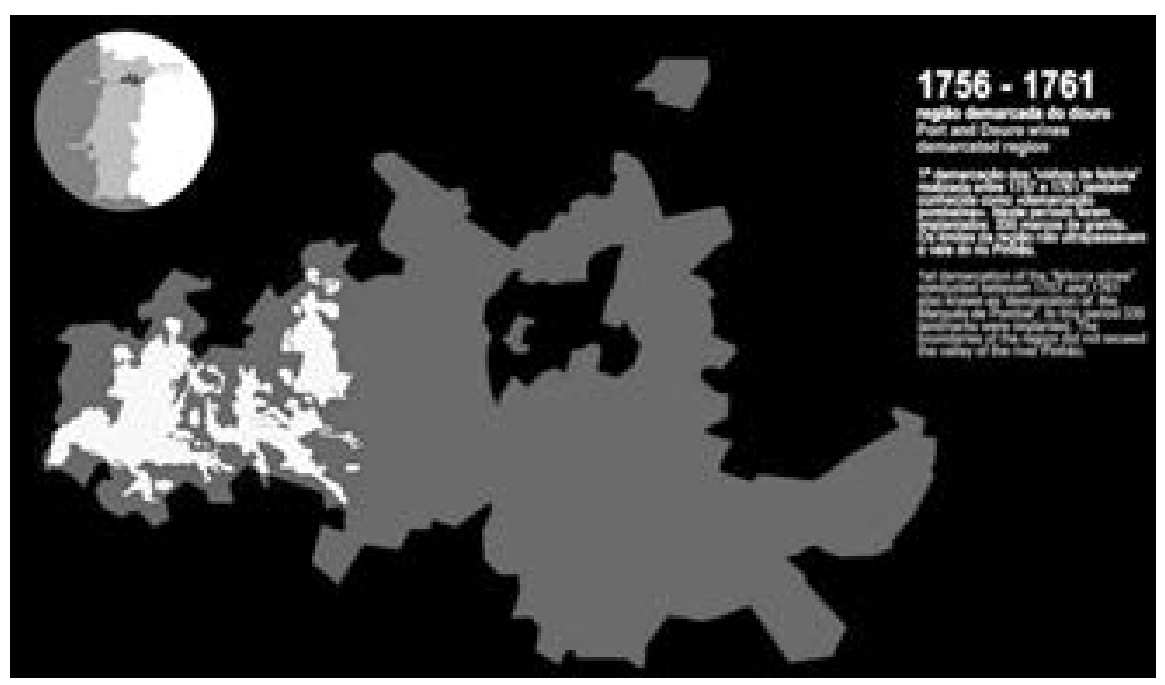

Fig. 14. Primeira demarcação dos vinhos de feitoria ou «pombalina» Fonte: Museu do Douro ${ }^{96}$

\footnotetext{
${ }^{96}$ Disponível em <http://www.museudodouro.pt/regiao-demarcada-do-douro $>$. [Consulta realizada em 18/09/2017].
} 


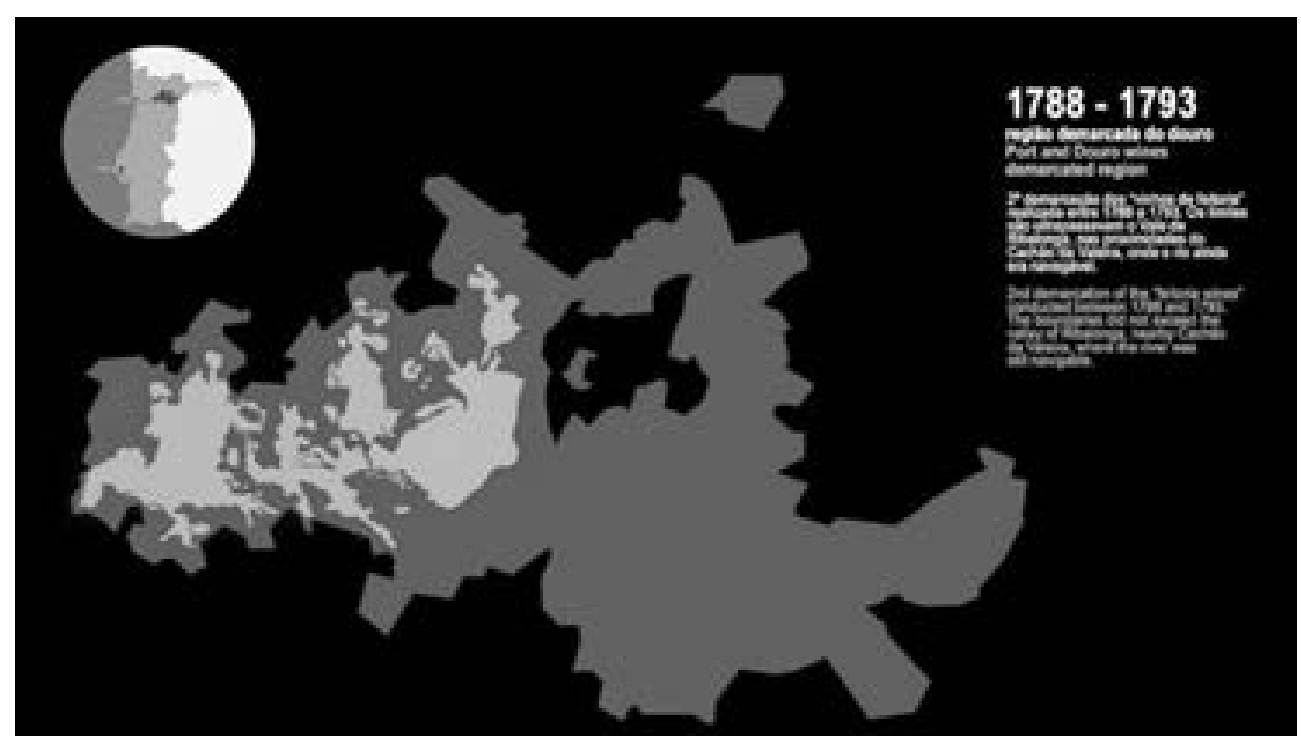

Fig. 15. Segunda demarcação dos vinhos de feitoria Fonte: Museu do Douro ${ }^{97}$

O mapa anterior da atual RDD deve, pois, ser entendido tendo em conta o longo processo histórico de demarcações ${ }^{98}$ (aqui só esboçado, mas retomado adiante), quer à luz dos trabalhos histórico-geográficos que conduziram às primeiras representações cartográficas do Douro, em especial os trabalhos do Barão de Forrester, que se sublinharão no subcapítulo seguinte. A sua leitura mais complexa, pode e deve ainda ser feita, diferenciada e segmentadamente, tendo em conta os mapeamentos e delimitações da região duriense ao nível das sub-regiões nela consideradas, e ainda na perspetiva da sua configuração atual, também enquanto zona classificada pela UNESCO (2001) como "paisagem viva e evolutiva»" ${ }^{99}$, não coincidente com a da área da atual RDD.

Em termos genéricos, a área geográfica da Região Demarcada Duriense (RDD), atualmente com 250.000 hectares e uma área total de vinha de 45.000 há, com cerca de 20 milhões de cepas plantadas, e granjeada por, aproximadamente, 25.000 viticultores, possuindo cada um, uma média de 1,5 hectares, apresenta em média uma produção anual de vinho da ordem das 300.000 pipas (metade de vinho do Porto e metade de vinho consumo ou de mesa), situando-se a produção média por milheiro de cepas, entre 1,5 a 2 pipas ${ }^{100}$.

\footnotetext{
${ }^{97}$ Os limites não ultrapassavam o vale de Ribalonga, em Carrazeda de Ansiães, próximo do Cachão da Valeira, onde o rio ainda era navegável.

${ }^{98}$ Ver PEREIRA, 2010: 9-49.

${ }^{99}$ AGUIAR, 2000.

${ }^{100}$ RIBEIRO, 2000: 11-29.
} 


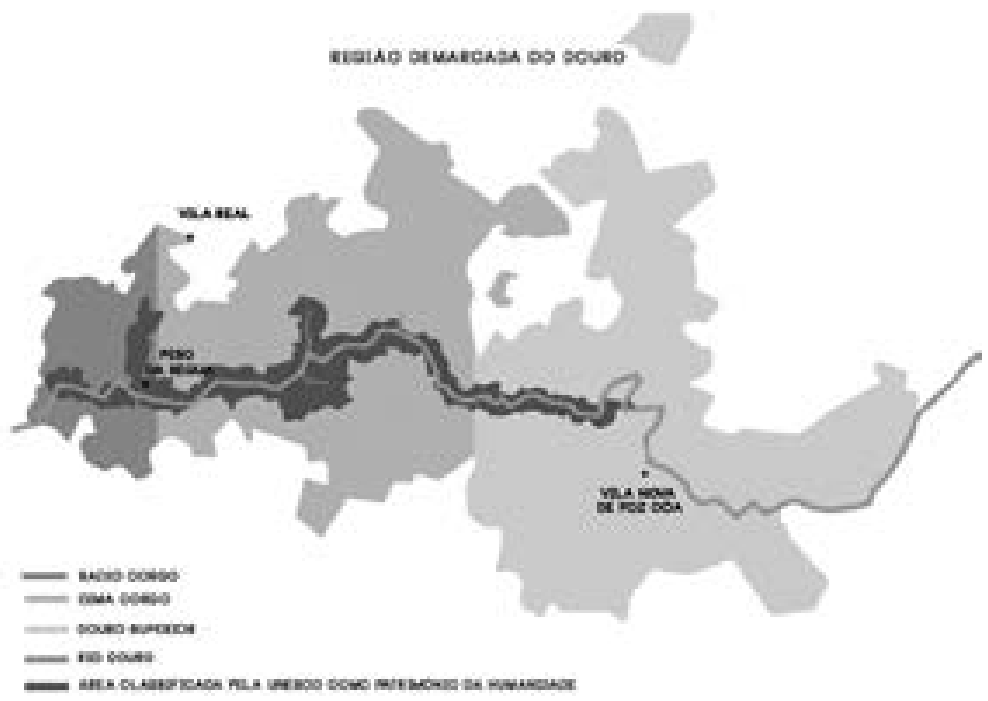

Fig. 16. Sub-regiões da Região Demarcada do Douro e área do Douro Património Mundial Fonte: CCMNEWS, dezembro, $2016^{101}$

A RDD, zona demarcada de produção de vinhos do Porto e do Douro, subdivide-se tradicionalmente ${ }^{102}$, nas seguintes três sub-regiões, diferenciadas por fatores naturais e socioeconómicos ${ }^{103}$ :

- Baixo Corgo, com aproximadamente 51\% da área, ocupada por vinha que assume maior importância (cerca de $29,9 \%$ da área desta sub-região), desenvolve-se, na margem direita do rio Douro, desde Barqueiros ao rio Corgo (concelhos de Mesão Frio, Peso da Régua, Santa Marta de Penaguião e freguesias de Vila Real ${ }^{104}$, do distrito de Vila Real), e na margem esquerda desde a freguesia de Barrô, até ao rio Temi-Lobos, próximo da vila de Armamar (freguesias dos concelhos de Armamar, Lamego e Resende do distrito de Viseu);

- Cima Corgo, com cerca de 36\% de área de vinha, que se apoia na sub-região anterior alarga-se para montante até ao Cachão de Valeira, tendo menor importância a sua área cultivada de vinha. Abrange, na margem direita do rio Douro, parcialmente, o concelho

\footnotetext{
${ }^{101}$ Disponível em <https://www.google.pt/search?q=Demarca\%C3\%A7\%C3\%A3o+do+Douro+-+mapas\&biw>. [Consulta realizada em 4/12/2016].

102 «Com a reforma administrativa de 1936 a própria região do Alto Douro passou a ser designada por Baixo Corgo e Alto Corgo, servindo esta subdivisão [referida ao ponto de confluência dos rios Corgo e Douro] também para diferenciar os vinhos produzidos numa ou noutra sub-região». In IVDP — Viticultura, Região. Disponível em $<$ https://www.ivdp.pt/pagina.asp?codPag=16>. Ver história de outras designações da região duriense em função da área territorial, geográfica e cultural em VASCONCELOS, 1938.

${ }^{103}$ IVDP — Viticultura, Região. Disponível em <https://www.ivdp.pt/pagina.asp?codPag=16>.

${ }^{104}$ Freguesias de Abaças, Ermida, Folhadela, Guiães, Mateus, Nogueira, Nossa Senhora da Conceição (parte), Parada de Cunhos, S. Dinis e S. Pedro.
} 
de Carrazeda de Ansiães ${ }^{105}$ (distrito de Bragança), os de Alijó ${ }^{106}$, Murça ${ }^{107}$ e Sabrosa ${ }^{108}$ (distrito de Vila Real); e na margem esquerda, parcialmente, os concelhos de São João da Pesqueira ${ }^{109}$ e de Tabuaço ${ }^{110}$ (distrito de Viseu);

- Douro Superior, ocupado por área de vinha à volta de 13\% que se apoia na anterior sub-região e prossegue até à fronteira com Espanha. Abrange, parcialmente, no distrito de Bragança, os concelhos de Alfândega da Fé (freguesia de Vilarelhos), Freixo de Espada à Cinta (freguesias de Freixo, Ligares, Mazouco e Poiares), Mirandela (antigas propriedades de Pinto Barroso na freguesia de Frechas e de Clemente Meneres nas freguesias de Avantos, Carvalhais, Frechas e Romeu), Torre de Moncorvo (freguesias de Açoreira, Adeganha, Cabeça Boa, Horta, Lousa, Peredo dos Castelhanos, Moncorvo e Urros) e Vila Flor (freguesias de Assares, Freixiel, Lodões, Roios, Sampaio, Santa Comba da Vilariça, Seixo de Manhoses, Vale Frechoso, Vila Flor, Vilarinho das Azenhas e algumas quintas e propriedades da freguesia de Vilas Boas); e ainda no distrito da Guarda todo o concelho de Vila Nova de Foz Coa, e parcialmente os Concelhos de Figueira de Castelo Rodrigo (freguesia de Escalhão) e o de Meda (freguesias de Fontelonga, Longroiva, Meda e Poço do Canto).

Como se poderá inferir, no que se refere ao concelho de Carrazeda de Ansiães, cujo território, maioritariamente incluído (10 freguesias ribeirinhas do Douro e do Tua) no Cima-Corgo que se prolonga pelo Douro Superior, apresenta a singularidade de, no conjunto dos 21 concelhos da RDD, integra uma faixa, entre a foz do rio Tua e até montante do Cachão da Valeira, em que, historicamente, se tem deslocado a linha divisória destas duas sub-regiões durienses, podendo assim considerar-se, desde logo, a este nível um «concelho de fronteira» da RDD, argumento que se desenvolverá na Parte II deste livro.

\subsection{CARRAZEDA DE ANSIÃES E «DOURO NOVO»}

Como se introduziu já, um dos limites anteriores de Demarcação da Região do Douro separava fisicamente o Alto Douro do que viria a ser o Douro Superior, na zona do Cachão da Valeira, fronteira entre os territórios dos atuais concelhos de Carrazeda de Ansiães e S. João

\footnotetext{
${ }^{105}$ Freguesias de Beira Grande, Castanheiro do Norte, Carrazeda de Ansiães, Linhares, Parambos, Pereiros, Pinhal do Norte, Pombal, Ribalonga e Vilarinho de Castanheira.

${ }^{106}$ Freguesias de Amieiro, Carlão, Casal de Loivos, Castedo, Cotas, Favaios, Pegarinhos, Pinhão, Sanfins do Douro, Santa Eugénia, S. Mamede de Riba Tua, Vale de Mendiz, Vilar de Maçada e Vilarinho de Cotas.

${ }^{107}$ Freguesias de Candedo, Murça e Noura.

${ }^{108}$ Freguesias de Celeirós, Covas do Douro, Gouvães do Douro, Gouvinhas, Paços, Paradela de Guiães, Provesende, Sabrosa, S. Cristóvão do Douro, S. Martinho de Anta, Souto Maior, Vilarinho de S. Romão.

${ }^{109}$ Freguesias de Casais do douro, Castanheiro do Sul, Espinhosa, Ervedosa do Douro, Nagozelo do Douro, Paredes da Beira, S. João da Pesqueira, Sarzedinho, Soutelo do Douro, Trevões, Vale de Figueira, Valongo dos Azeites, Várzea de Trevões e Vilarouco.

${ }^{110}$ Freguesias de Adorigo, Barcos, Desejosa, Granjinha, Pereiro, Santa Leocádia, Sendim, Tabuaço, Távora e Valença do Douro.
} 
da Pesqueira. Esta separação histórica devia-se a uma formação geológica assomando no leito do rio Douro que impedia a navegação para montante, até Barca d'Alva. Esse maciço rochoso entre o monte de S. Salvador do Mundo e o planalto de Ansiães, formava nesse local, numa apertada curva do rio, uma grande cascata (com mais de sete metros de altura), obstáculo inultrapassável à circulação por via fluvial, entre o que viria a ser o Douro Superior e terras situadas a jusante ${ }^{111}$, que constituía, na altura, o extremo navegável do rio Douro.

Assinale-se que, em zona próxima deste local, junto à estação ferroviária da Alegria na linha do Douro, entre as aldeias de Linhares e Ribalonga de Carrazeda de Ansiães, encontra-se o abrigo pré-histórico do Cachão da Rapa com suas enigmáticas pinturas, eventualmente relacionado com manifestações de culto e «associado a um santuário rupestre inserido na mesma rede de povoamento do Castelo de Ansiães ou na de outros povoados similares» ${ }^{112}$ o qual é hoje considerado património nacional.

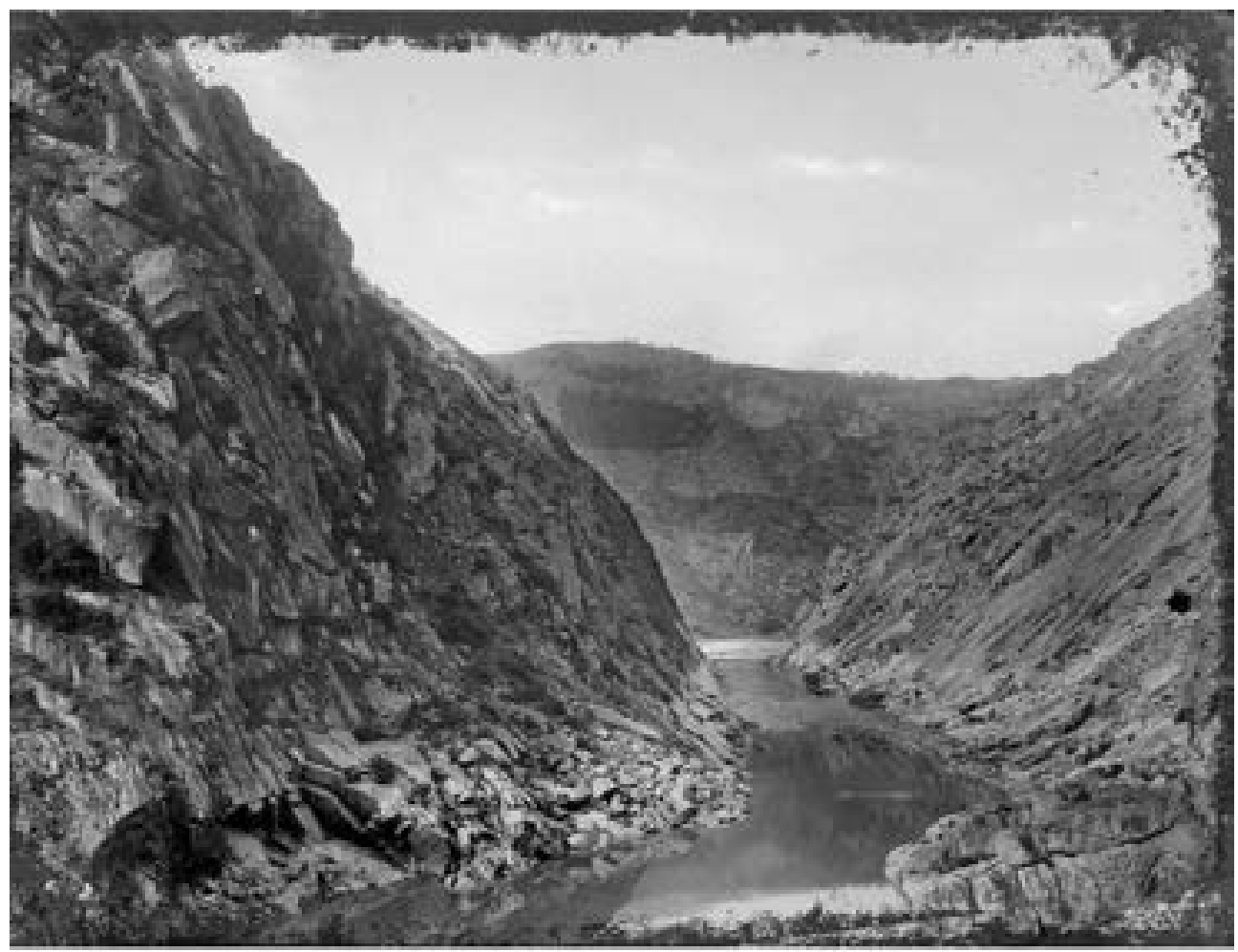

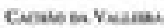

Fig. 17. Cachão da Valeira no rio Douro (finais século XIX). Fotografia de Emílio Biel ${ }^{113}$

\footnotetext{
${ }^{111}$ QUADRADO, 2009.

112 TEIXEIRA, 2014: 57-105.

${ }^{113}$ BIEL, 2016.
} 
Nos finais do século XVIII, a remoção desse bloco de granito, obra de grande dificuldade que decorreu no reinado de D. Maria e durou mais de 10 anos, entre 1780 e 1792, permitiu a abertura de uma galeria transitável no rio, começando as primeiras embarcações a poder atravessá-la, a partir de 1789. Tornou-se então possível a navegação para norte do Douro até à fronteira, embora continuasse ainda por largos anos sujeita a acidentes naturais e grandes perigos, como o do naufrágio que provocou a morte do barão de Forrester, «um dos homens que mais serviços prestou ao Douro..., o qual nos deixou, nas cartas que levantou do curso do rio e do paiz vinhateiro, prova evidente do seu útil talento e aptidão» ${ }^{114}$.

Os transportes fluviais no Douro de produtos, bens e pessoas passaram então a ser mais fáceis e a cultura da vinha irá estender-se a montante, embora continuando a representar nesta nova sub-região duriense uma importância muitíssimo menor do que no Alto Douro. Com a abertura desse desfiladeiro ao tráfego fluvial, esta área ficaria, por largos anos conhecida como o Douro Novo e, mais tarde, Douro Superior, como já anteriormente se referiu.

As demarcações da região vitícola do Douro são fontes históricas relevantes para o conhecimento da evolução do espaço vinhateiro duriense pelo que continuaremos a seguir nelas a inscrição e evolução das terras de Carrazeda de Ansiães e sua transformação progressiva como produtor de Vinho de Porto, concelho entre o Alto Douro e o Douro Superior, como área legal de produção de vinhos finos de embarque, nas demarcações do século XVIII.

\section{Carrazeda de Ansiães nas demarcações primordiais e subsidiárias}

Com as demarcações pombalinas, ou primordiais, a região demarcada, regulamentada e reconhecida do Douro, que abrangia 67 freguesias, embora não chegasse ainda ao Pinhão, como refere Gaspar Martins Pereira, considerava já duas freguesias do concelho de Carrazeda: Castanheiro do Norte e Ribalonga ${ }^{115}$.

Mais tarde, podemos encontrar em Visconde de Vila Maior ${ }^{116}$, no âmbito de uma significação política da demarcação pombalina instituinte do "país vinhateiro», a referência à integração de três freguesias deste mesmo concelho na primeira demarcação da região duriense, as únicas do distrito Bragança registadas.

A natureza deu por certo à região do Alto-Douro as condições essenciais de um rico país vinhateiro, porém o alvará de 10 de setembro de 1756 fê-lo um paiz legalmente privilegiado, e a demarcação, que em virtude d'esse ato de soberania se estabeleceu, constituiu esta região quase como um estado politico, de que ainda conserva as principaes feições, apesar de abolidos todos os seus privilégios legaes. As freguezias, cujas vinhas vertentes ao Douro ou aos seus confluentes entravam na demarcação do paíz vinhateiro, eram as seguintes que

\footnotetext{
${ }^{114}$ VILA MAIOR, 1990: 105.

${ }^{115}$ PEREIRA, 2010.

${ }^{116}$ LAGE, 2013a: 11-17, 103-121.
} 
sucessivamente iremos encontrando a partir do Cachão da Valeira. Na margem direita: Linhares, Riba-Longa e Castanheiro no distrito de Bragança; [... $]^{117}$.

Ainda na descrição deste autor, com alguns erros do ponto de vista histórico, seguem-se, a estas freguesias, localizadas na zona designada de Cima Corgo, na margem direita do Douro, mais 45 freguesias no distrito de Vila Real e na margem esquerda, 21 freguesias do distrito de Viseu.

Para além desta referência a Carrazeda nas demarcações pombalinas ou primordiais, executadas logo a seguir (1758-1761) à instituição da Companhia Geral da Agricultura das Vinhas do Alto Douro (1756), que fixavam os limites da área legal de produção dos vinhos finos de embarque, vamos encontrar também, quando das demarcações marianas ou subsidiárias, realizadas no reinado de D. Maria (1788-1793), num contexto de expansão comercial e valorização dos vinhos da zona entre Pinhão e Tua, nova menção a outras freguesias vinhateiras de Carrazeda de Ansiães (e dos antigos concelhos de Ansiães e Vilarinho da Castanheira que integrara, respetivamente no século XVIII e século XIX). É o caso por exemplo do seguinte projeto de demarcação, relevante fonte histórica cujo estudo se não encontra ainda editado $^{118}$, e a que adiante parcialmente se faz referência.

Este projeto, que não terá sido aprovado ${ }^{119}$, de nova demarcação subsidiária ordenada pela Carta Régia de 28 de janeiro de 1793, alargava bastante a área de vinhos de embarque, revelando a expansão da vinha para zonas exteriores à região demarcada, surgem-nos integradas, para além de vinhas dos ainda considerados concelhos de Ansiães e Vilarinho da Castanheira, os vinhedos das seguintes freguesias: Pinhal, Parambos, Pombal, Paradela, Linhares, Ribalonga, Castanheiro, Marzagão, Beira Grande, Seixo, lugar de Coleja do novo concelho de Carrazeda de Ansiães, e ainda vários nomes de quintas, vinhas e viticultores, em que se verifica predominar um grande número de mulheres proprietárias.

No antigo concelho de Ansiães estavam aí ainda incluídas as seguintes freguesias ribeirinhas do Douro: Beira Grande, Selores e Seixo de Ansiães, e ainda as seguintes povoações situadas no planalto: Pereiros de Malta, Mogos de Malta, Mogos, Carvalho d'Egas, Carrazeda, Samorinha, Velver e Fonte Longa. No antigo concelho de Vilarinho da Castanheira, constavam a vila de Vilarinho e a freguesia da Lousa. Para além dessas, «Em Linhares de Ansiães são arroladas três quintas e 79 vinhas capazes de ser incluídas na demarcação de embarque. Na freguesia do Castanheiro do Norte onde apenas tinham sido incluídas três propriedades na

\footnotetext{
${ }^{117}$ VILA MAIOR, 1990: 107.

${ }^{118}$ Arquivo Histórico do Ministério das Obras Públicas. Relação das Quintas, e vinhos que em execução da Carta Régia de 28 de Janeiro de 1793, acharão capazes de produzir vinho tinto legal de embarque os dous Deputados que fizerão a Demarcação subsidiária, Domingos Martins Gonçalves, e Francisco Baptista de Araújo Cabral Montês, e o Deputado Inspector dos Vinhos Legaes d'Embarque, MR 35, caixa 29/36, n. ${ }^{\circ} 30$. O estudo e trabalho desta fonte ainda inédita encontra-se previsto por Gaspar Martins Pereira, o qual nos cedeu generosamente esta importante informação, que se agradece.

${ }^{119}$ PEREIRA, 2010: 10-49.
} 
Demarcação subsidiária de 1788 (a Quinta da Chousa e mais duas vinhas), registam-se quatro quintas e 579 vinhas na relação de $1793 »^{120}$.

Nesta importante fonte histórica, bastante lacónica como as restantes demarcações que nada dizem da dimensão e produção das vinhas e quintas que apontam, se evidencia então a grande vitalidade vinhateira e a valorização crescente dos vinhos de muitas freguesias do Cima Corgo, as quais se encontravam ainda excluídas das demarcações clássicas (Pombalinas e Marianas), e neste projeto de demarcação se consideravam já aptas a produzir vinhos de feitoria. No que se refere a Carrazeda de Ansiães, o número de viticultores era já considerável para a época.

Porém no vinho arrolado por freguesias segundo as qualificações de 1797, 1805 e 1818, a freguesia de Ribalonga surge-nos respetivamente nesses anos com os seguintes valores, em hl: 128, 193 e 129 e a freguesia de Castanheiro, com 59, 76 e 119, $5^{121}$.

Mas não deixa de se nos revelar também nas demarcações subsidiárias uma tendência do vinhedo regional de qualidade, até então polarizado na área do Baixo Corgo, para a perda relativa de importância face ao conjunto da região produtora ${ }^{122}$.

O concelho de Carrazeda voltará a aparecer-nos, mais tarde, em legislação reformadora cabralista, por referência à produção vinícola da região duriense ${ }^{123}$, no seguinte enquadramento global: Alijó, Mesão Frio, Régua, Sabrosa, Penaguião, Vila Real, Armamar, Lamego, Resende, Pesqueira, Tabuaço, Carrazeda e Foz Coa.

Surge-nos então com produções registadas em todos os anos considerados, o que é situação única, apresentando curiosamente, uma tendência de aumento crescente, entre 1862 e 1892 (ver Quadro 1).

Este período que já foi considerado como «a era do progresso» da viticultura nacional ${ }^{124}$, correspondeu na Região Duriense à mais profunda revolução social da sua história, com a maior transferência de propriedade, numerosos emparcelamentos e enorme concentração de vinhas e quintas. Coincidiu com uma época de crise, mas também de viragem revolucionária da viticultura duriense ${ }^{125}$, obrigada a alterações substanciais nas técnicas da cultura da vinha, em grande medida por efeito da filoxera (inseto que ataca a raiz da vinha e se erradicou por enxertia de bacelo em porta-enxerto americano) cuja invasão e combate se propagou em muitos concelhos durienses entre 1863 e 1885, embora com menor força e mais tardiamente no Douro Superior ${ }^{126}$.

\footnotetext{
${ }^{120}$ PEREIRA, 2010: 24.

${ }^{121}$ Dados extraídos de quadro construído a partir de fonte do ARQUIVO DA REAL COMPANHIA VELHA, Livros de Arrolamentos de Vinhos de Embarque, 1797, 1805 e 1818 apud PEREIRA, 2010, quadro n. 3.

122 PEREIRA, 2010: 24.

${ }^{123}$ MARTINS, 1991: 653-688. Anexo, p. 686 quadro n. ${ }^{\circ}$ 2: Produção vinícola da região duriense. Demarcação de 1843.

${ }^{124}$ MARTINS, 2008a: 77-79.

${ }^{125}$ Embora as doenças da videira que sucessivamente atingiram as vinhas a partir da década de 1850 (oídio, filoxera, míldio, maromba, antracnose, etc.) tenham provocado graves e prolongados prejuízos na produção, aumento de despesas e diminuição de rendimentos dos viticultores, criando assim graves constrangimentos ao desenvolvimento do setor vitivinícola é um facto que acabaram também por contribuir decisivamente para modernizar a vitivinicultura suscitando melhores práticas, técnicas e processos da cultura da vinha e produção do vinho, de que advieram fatores influentes de rejuvenescimento das vinhas, de plantio de novas castas e também da subida de preços dos vinhos.

${ }^{126}$ PEREIRA, 1996b; PEREIRA, 2005; PEREIRA, 2010.
} 
Quadro 1. Produção vinícola do concelho de Carrazeda de Ansiães ${ }^{127}$

\begin{tabular}{|c|c|}
\hline Anos & Produções (milhares de hectolitros) \\
\hline 1862 & 4 \\
\hline $1866^{*}$ & 6,49 \\
\hline 1868 & 8,8 \\
\hline 1869 & 14,9 \\
\hline 1871 & 11,2 \\
\hline 1873 & 11,7 \\
\hline 1881 & 12 \\
\hline 1882 & 17,9 ou $19^{*}$ \\
\hline 1883 & 19 \\
\hline 1884 & 16,9 \\
\hline 1885 & 12,7 \\
\hline $1884 / 1888$ & 18,9 \\
\hline 1892 & 12,9 ou $18,4^{*}$ \\
\hline Obs.: & $\begin{array}{l}\text { *Os dados assinalados com asterisco foram retirados (e convertidos de litros em hectolitros) } \\
\text { a partir de PEREIRA, 2010, quadro } 10 .\end{array}$ \\
\hline
\end{tabular}

Por essa altura, Carrazeda de Ansiães, cujas vinhas foram também atingidas pela praga filoxérica em 1879 (como Lamego, Figueira de Castelo Rodrigo e Vila Nova de Foz Coa), apresentava no ano anterior um quadro vitivinícola específico e diferenciado face a outros concelhos transmontanos, em matéria de preços da cultura da vinha e valores da terra cultivada de vinha.

Tratando-se de um concelho com uma grande área de terrenos graníticos montanhosos e vinhas de difícil granjeio envolvendo custos elevados, onde as cepas tinham de ficar mais espaçadas pelo que cada hectare não comportava em média mais do que 3 milheiros de bacelos (ao contrário de Vila Flor ou Alfândega da Fé que se mostravam mais fáceis e menos dispendiosos como se pode ver pelos seguintes indicadores económicos: « $20 \$ 100$ por milheiro em Vila Flor para 80\$000/milheiro em Carrazeda), o numero de pés de vinha por hectare triplicava, mas o seu valor era sensivelmente idêntico $(400 \$ 000$ a $600 \$ 000) »^{128}$.

Quanto aos custos da exploração vitivinícola «Só as despesas 'normais' de cultura com um hectare de vinha (sem adubações, enxofrações ou sulfatações) oscilavam entre $28 \$ 200 \mathrm{em}$ Carrazeda, $29 \$ 200$ no Mogadouro, 47\$800 em Freixo de Espada à Cinta e 58\$080 em Vila Flor. $\mathrm{E}$ a estas havia ainda que acrescentar as relativas ao fabrico do vinho (pisa, vinificação e enva-

\footnotetext{
${ }^{127}$ Dados extraídos, maioritariamente, de MARTINS, 1991: 686 e PEREIRA, 2010: 204.

${ }^{128}$ MARTINS, 2008a: 77-79.
} 
silhamento) que variavam então entre $1 \$ 200$ por hl em Mogadouro, $1 \$ 800 / \mathrm{hl}$ em Vila Flor, $2 \$ 000 /$ hl em Carrazeda e $2 \$ 500 /$ hl em Freixo de Espada à Cinta ${ }^{129}$.

Já os preços do vinho variavam também com os custos do seu transporte,

o vinho de Carrazeda de Ansiães, que na segunda metade de 1870 só pagava de transporte até ao Porto 4\$000/pipa, conseguindo preços bem mais subidos (41 réis/litro) do que o do Mogadouro (25 réis/litro) que pagava 10\$000/pipa para chegar ao mesmo mercado. E se em Bragança, Vila Real ou Lamego o valor da terra era fixado, sobretudo, em função da sua acessibilidade ao Douro, "o meio mais económico e seguro — senão o único — de transporte» ${ }^{130}$.

Como já referido anteriormente, anos mais tarde, com o ditador João Franco, primeiro-ministro no reinado de D. Carlos I, é traçada, em 1907, uma nova Demarcação, alargando-a a novos concelhos (Alfândega da Fé, Freixo de Espada à Cinta, Mirandela, Moncorvo, Valpaços, Murça, Vila Flor, Figueira de Castelo Rodrigo e Meda), os quais abarcavam, no entanto, algumas zonas de montanha sem aptidão para a produção de vinho, pelo que veio a ser corrigida em 1908 no governo do Almirante Ferreira do Amaral. Com esta outra demarcação, por freguesias, em alternativa à anterior por concelhos, foi assim muitíssimo diminuída a área para produção de vinho do Porto, que passou de 600 mil hectares para cerca de 250 mil hectares, criando, contudo, em paralelo uma demarcação para os vinhos de mesa do Douro.

$\mathrm{Na}$ legislação vitícola de João Franco que foi muito contestada, o concelho de Carrazeda de Ansiães que ocupava, em termos quantitativos, a 10. a posição na produção vinícola calculada dos 13 concelhos considerados no período de 1862 a 1892, parece ter mantido idêntica posição relativa, apesar do aumento da nova área da região demarcada.

Já durante a I República, pelo Decreto n. ${ }^{\circ}$ 7934, de 10 de dezembro de 1921, assinado pelo ministro da Agricultura Antão de Carvalho, político republicano que foi destacado membro dirigente do movimento dos Paladinos do Douro e depois um dos fundadores da Casa do Douro (1932) foi redefinida, com alterações muito ligeiras, a demarcação que alarga a região a novas freguesias, definindo assim os seus atuais contornos.

Cabe sublinhar, ainda, que a Denominação de Origem Douro para produção de vinhos de categoria VQPRD, com sua regulamentação, só viria a ser criada muito mais tarde, através

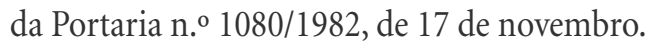

Retomaremos, porém, com outro desenvolvimento e detalhe, a análise concreta do significado das demarcações de 1907/1908 e seguintes tendo, especificamente, em conta o concelho de Carrazeda de Ansiães, enquanto produtor de vinho do Porto (Parte II, Capítulos 4 e 5).

\footnotetext{
${ }^{129}$ Conforme o agrónomo distrital de Bragança, António Xavier Pereira Coutinho (1878: 14-15) apud MARTINS, 2008a: 77.

${ }^{130}$ MARTINS, 2008a.
} 


\subsection{TERRITÓRIO DE CARRAZEDA NA CARTOGRAFIA DO BARÃO DE FORRESTER}

No contexto emergente dos estudos científicos sobre viticultura, cartografia e fotografia no Vale do Douro, um dos mais notáveis percursores terá sido o escocês Joseph James Forrester que, nascido a 27 de maio de 1809 em Kingston upon Hull, morreu em 1861, num naufrágio no Cachão da Valeira, termo do concelho de Carrazeda de Ansiães. Mais conhecido por Barão de Forrester, desenvolveu no Porto e Região Duriense, pioneira e plurifacetada atividade, tendo-se tornado uma das personagens históricas mais destacadas do Douro pelo muito que contribuiu para a dignificação do vinho do Porto e para a projeção e sustentabilidade de toda a região do Alto Douro Vinhateiro ${ }^{131}$.

Segundo os seus biógrafos, fica a ideia de um incansável viandante que percorre o Alto Douro, estudando o rio e a região envolvente, com uma determinação que pressupõe objectivos muito bem delineados. Lança-se numa campanha de propaganda em defesa da qualidade do vinho do Porto. Estuda novos métodos científicos e meios para desenvolver a agricultura e os interesses económicos dos lavradores, defendendo-os em publicações várias, não só em Portugal, como no estrangeiro. Certa é a difusão da sua imagem controversa: grande comerciante de vinho do Porto, lavrador ativo, artista plástico, observador e estudioso, escritor e cartógrafo ${ }^{132}$.

O barão de Forrester marcou decisivamente os estudos cartográficos e históricos durienses, tendo-se destacado, designadamente, como percursor da fotografia duriense, pintor de várias aguarelas, coordenador e autor de mapas notáveis do vale e do rio Douro.

Embora nos arquivos portugueses existisse já então um significativo número de mapas do rio e da região do Douro, da segunda metade de setecentos e contemporâneos dos de Forrester, este deparou-se com obstáculos administrativos e técnicos de produção e publicação dos dois mapas que coordenou com «abundante informação, que lhe trouxeram fama internacional: o Mappa do Paiz Vinhateiro do Alto Douro, editado em 1843, e o Douro Portuguez e Paiz Adjacente [...], publicado em $1848{ }^{133}$.

A projeção que os seus mapas tiveram seria reconhecida pela comissão especial da Câmara dos Comuns inglesa que em 1852 mandou litografar e publicar no Reino Unido a carta topográfica de Forrester, e na Exposição Universal de Paris de 1855 que atribuiu três diplomas de «honrosa menção» às suas cartas: a geológica das margens do rio Douro, a topográfica do curso do rio Douro e a topográfica do país vinhateiro do Alto Douro ${ }^{134}$. A Carta Geológica das margens

\footnotetext{
${ }^{131}$ CLUNY, 2009.

${ }^{132}$ GARCIA, 2009: 4. Este estudo apresenta minuciosa descrição dos mapas e seus conteúdos, informações sobre a sua produção e gravação das várias versões dos mapas e ainda sobre os métodos de sua elaboração.

${ }^{133}$ GARCIA, 2009: 5.

${ }^{134}$ Uma rede de difusão dos mapas que passava por Inglaterra e Portugal foi estrategicamente pensada por J. J. Forrester, fazendo-se clara distinção entre quem fez e gravou os mapas, embora o pagamento da edição ficasse a cargo de quem os elaborou.
} 
do rio Douro, Carta topographica do curso do rio Douro e o Mappa do Paiz Vinhateiro do Alto Douro - «um trabalho primoroso e perfeitamente acabado, rico pela abundância de informação original, (e) pela exatidão e beleza de execução» de «transcendente utilidade para este país», proporcionou-lhe ser agraciado em 1855, com o título de barão de Forrester ${ }^{135}$.

O contributo de J. J. Forrester para o desenvolvimento do Douro Vinhateiro, já bem estudado, foi preponderante, não só como precursor no domínio de estudos e trabalhos de cartografia, fotografia e viticultura (estudo do oídio, moléstia da vinha causada pelo fungo oidium tuckeri, divulgação do uso do enxofre nas vinhas) mas também como pioneiro no desenvolvimento da própria atividade vitivinícola do Douro, do qual tinha uma visão grandiosa.

Encontrou-se sempre ligado ao negócio do vinho do Porto que estava então sujeito a múltiplos entraves e a um regime restritivo que regulamentava a produção e o comércio do vinho do Porto através dos arrolamentos, das provas, das separações, das marcas, dos bilhetes e das guias, privando o lavrador da «liberdade de ação sobre a sua propriedade e, em vez de garantir a pureza do produto, excitam a adulterá-lo», e atravessava uma conjuntura política interna adversa de sucessivas intervenções. Defensor do «free-trade» envolver-se-ia diretamente na «luta» pela liberalização do setor encabeçada, a partir da sua fundação, em 1834, pela Associação Comercial do Porto (ACP), com cujas posições, apesar disso, nem sempre esteve de acordo'.

Denunciou as causas de decadência do comércio do vinho do Porto e sua adulteração, apontando meios de a ultrapassar. Insistiu na necessidade de se voltar a fazer vinhos recuperando o antigo método utilizado no Douro que aprendera com os lavradores que continuavam a seguir a tradição e que ele próprio aplicou no fabrico dos vinhos que produzia nas propriedades e quintas que explorava, por arrendamento, naquela região ${ }^{136}$.

«Produtor de vinhos e arrendatário de propriedades no Douro onde, antes do oídio, colhia mais de um milhar de pipas de vinho todo feito «à antiga» sob a sua direção, Forrester recorria ao seu exemplo, e ao de outros viticultores durienses adeptos, como ele, do «seu» processo de fazer vinho, para fazer proselitismo junto dos seus «irmãos lavradores» e da opinião pública em geral das vantagens de se produzir vinhos do Douro puros. Ou seja, bem fermentados, sem adição de quaisquer substâncias «adventícias» (baga de sabugueiro, jeropiga, açúcar, etc.) e beneficiados apenas com a aguardente indispensável à sua conservação» ${ }^{137}$.

Para além de toda a ação inovadora e pioneira no Douro do Barão de Forrester, foram sobretudo os minuciosos estudos e trabalhos que desenvolveu nos domínios da cartografia,

\footnotetext{
${ }^{135}$ MARTINS, 2008b.

${ }^{136} \mathrm{O}$ sistema de Forrester assentava nos seguintes «princípios»: não se enxertarem as vinhas com «novas» castas e preferirem-se as antigas que produzem vinhos «saborosos e de um gosto especial»; fazerem-se as vindimas no tempo e condições atmosféricas adequadas, sem muita chuva nem "muito sol, e intensos calores, sem chuva alguma»; escolher-se a uva criteriosamente e não se deixar muito tempo no lagar antes da pisa para não ferver e apodrecer; acabar-se com o sistema de pisar as uvas por intervalos «meias noites e meios dias» para que não fique nos lagares mais tempo do que o necessário e não fermente irregularmente; lançar-se o mosto em tonéis de menor dimensão ( 2 a 4 pipas) e proporcionais ao tamanho dos lagares, para que não seja preciso juntar ao vinho que já deu prova outro que ainda a não deu, e taparem-se os tonéis para que não haja evaporação durante a segunda fermentação. ${ }^{137}$ MARTINS, 2008b.
} 
topografia e geologia do território duriense que o inscreveriam definitivamente na história do Douro Vinhateiro.

O seu mais conhecido mapa da região duriense vinhateira «Map of the Wine District of the Alto Douro» ou «Mappa do Paiz Vinhateiro do Alto Douro», apesar de não apresentar qualquer data, sabe-se ter sido concluído em 1842 (a partir de levantamentos originais ou a partir de levantamentos pontuais de cartografia anterior de outros autores, hipótese sugerida em estudo preliminar da cartografia antiga do Douro) e publicado em 1843, por gravação em Londres $^{138}$. Com uma grande e diversificada quantidade de dados repartidos pela imagem, constitui-se como um verdadeiro tratado «estadístico» da região.

No quadro da abordagem anterior e do conhecimento sumário que permite, torna-se agora mais compreensiva a inscrição minuciosa do território vinhateiro de Carrazeda de Ansiães nos célebres mapas do barão de Forrester cuja pertinência continua a manter-se apesar da sua relativa desatualização face às modernas e sofisticadas tecnologias cartográficas.

\subsubsection{Carrazeda de Ansiães nos mapas do Alto Douro de Forrester}

O «Mappa do Paiz Vinhateiro do Alto Douro» (ed. 1843) de que, frequentemente se encontra hoje cópia em grandes quintas e outros «sítios» emblemáticos do Douro, ilustra sobretudo o Baixo Corgo e o Cima Corgo e aí são referidas 79 quintas principais, muitas já hoje desaparecidas, para além de outras tornadas lendárias, nas quais se conta, no concelho de Carrazeda, designadamente a quinta do Síbio ou Forneiras (freguesia de Beira Grande), posteriormente incluída na Quinta dos Canais, hoje a maior quinta do concelho (Fig. 18).

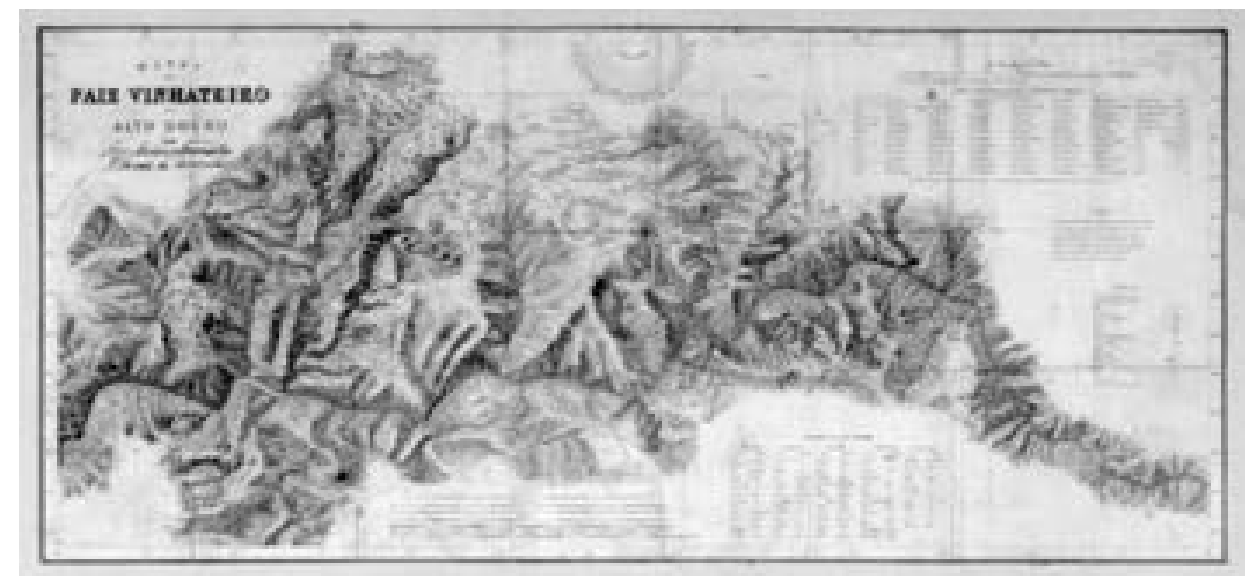

Fig. 18. «Mappa do Paiz Vinhateiro do Alto Douro». J. J. Forrester (1843)

Fonte: Coleção do Instituto dos Vinhos do Douro e do Porto, I. P. ${ }^{139}$

\footnotetext{
${ }^{138}$ MARQUES \& FERNANDES, 2011.

${ }^{139}$ Agradecem-se os créditos fotográficos da imagem deste mapa e das imagens sucessivas do Mapa seguinte, cedidas, gratuitamente, por despacho do Presidente do IVDP.
} 
Por sua vez, no mapa «Douro Portuguez e Paiz Adjacente» (1848), nas secções 1 a 6, que se referem também ao território do concelho de Carrazeda (imagens seguintes), podem ver-se ainda localizadas, de modo mais nítido, por exemplo: Coleja (Fig. 19, secção 1), próximo da foz do rio Tua, a Quinta do Zimbro (Fig. 22, secção 4), o Cachão da Valeira, em desenho ilustrado (Fig. 23, secção 5), para além de Castanheiro e Fiolhal, constantes em «Geological view of the wine district of the Alto Douro» (Fig. 8, secção 6).

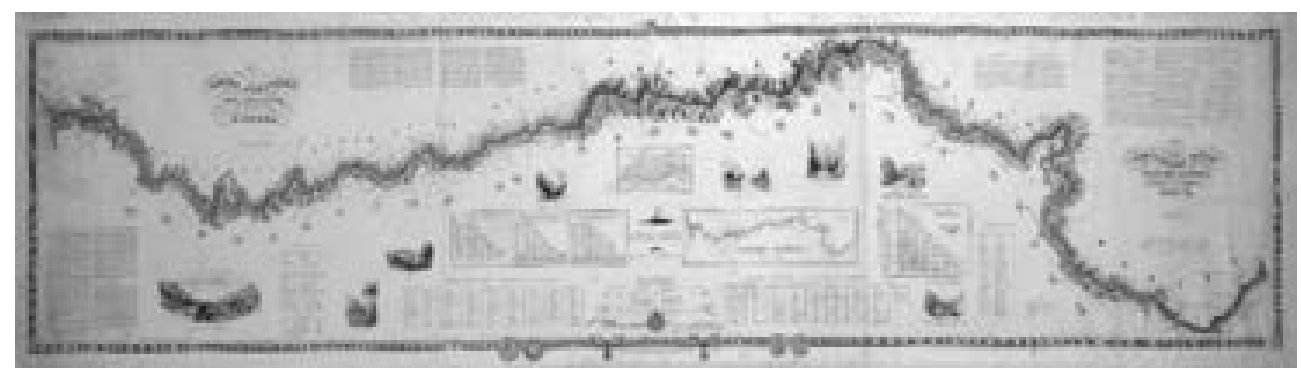

Fig. 19. Mapa «Douro Portuguez e Paiz Adjacente». J. J. Forrester, 1848. (secção 1) Fonte: Coleção Instituto dos Vinhos do Douro e do Porto, I.P.

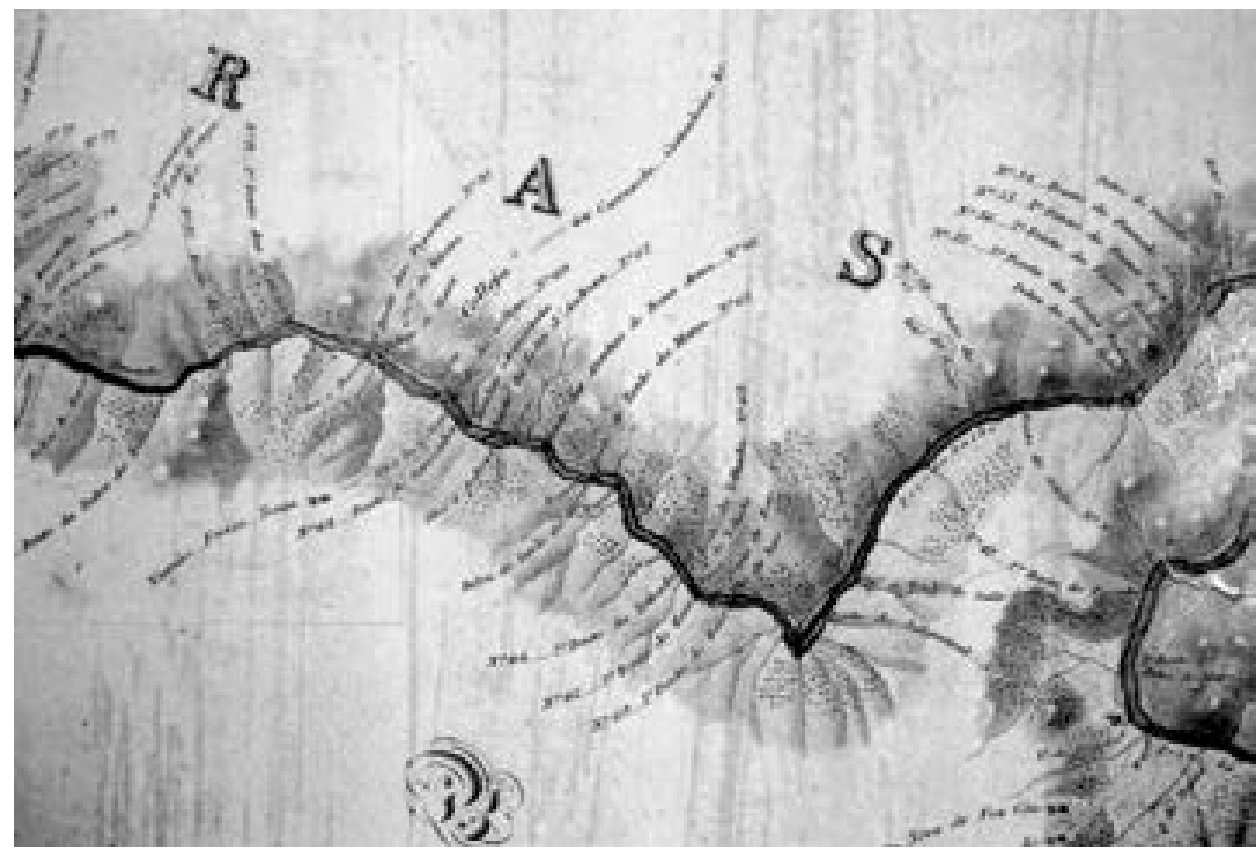

Fig. 20. Mapa «Douro Portuguez e Paiz Adjacente». J. J. Forrester, 1848 (secção 2) Fonte: Coleção Instituto dos Vinhos do Douro e do Porto, I.P. 


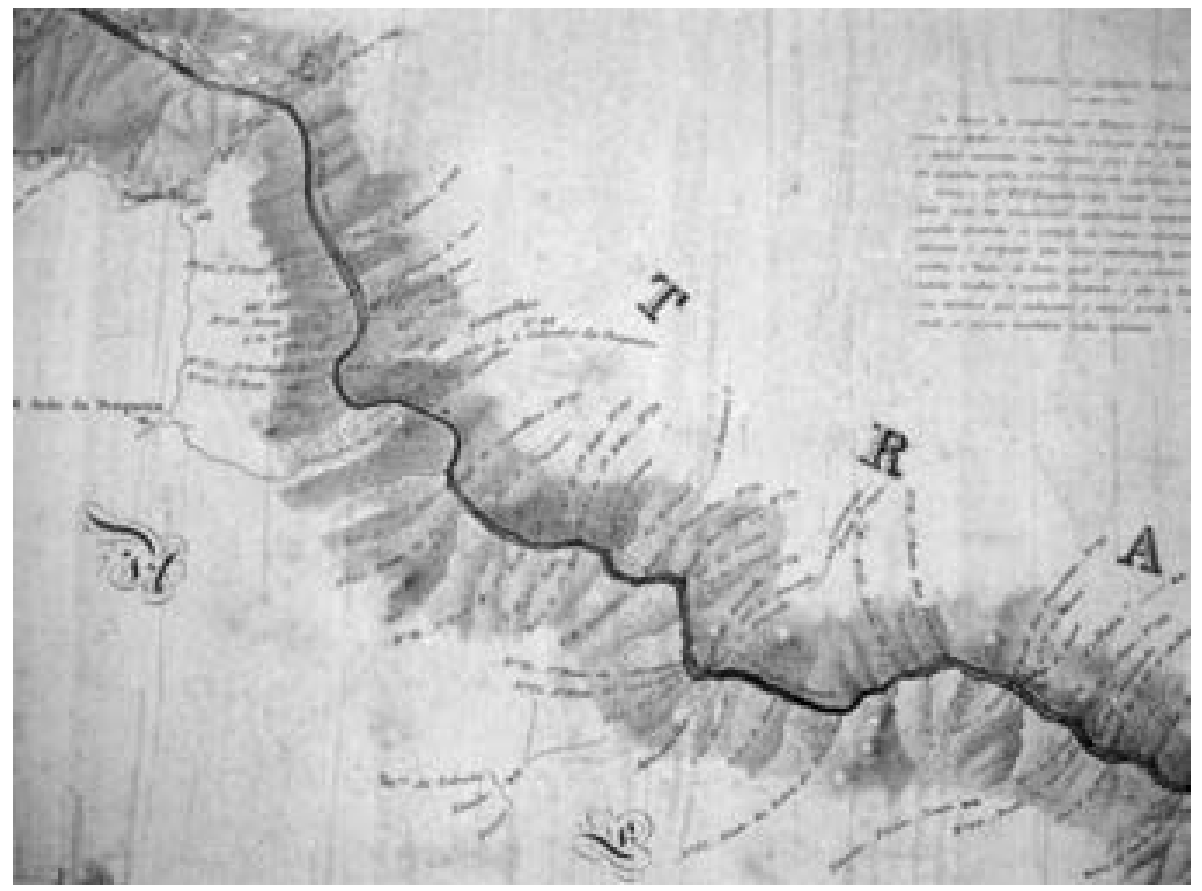

Fig. 21. Mapa «Douro Portuguez e Paiz Adjacente». J. J. Forrester, 1848 (secção 3) Fonte: Coleção Instituto dos Vinhos do Douro e do Porto, I.P.

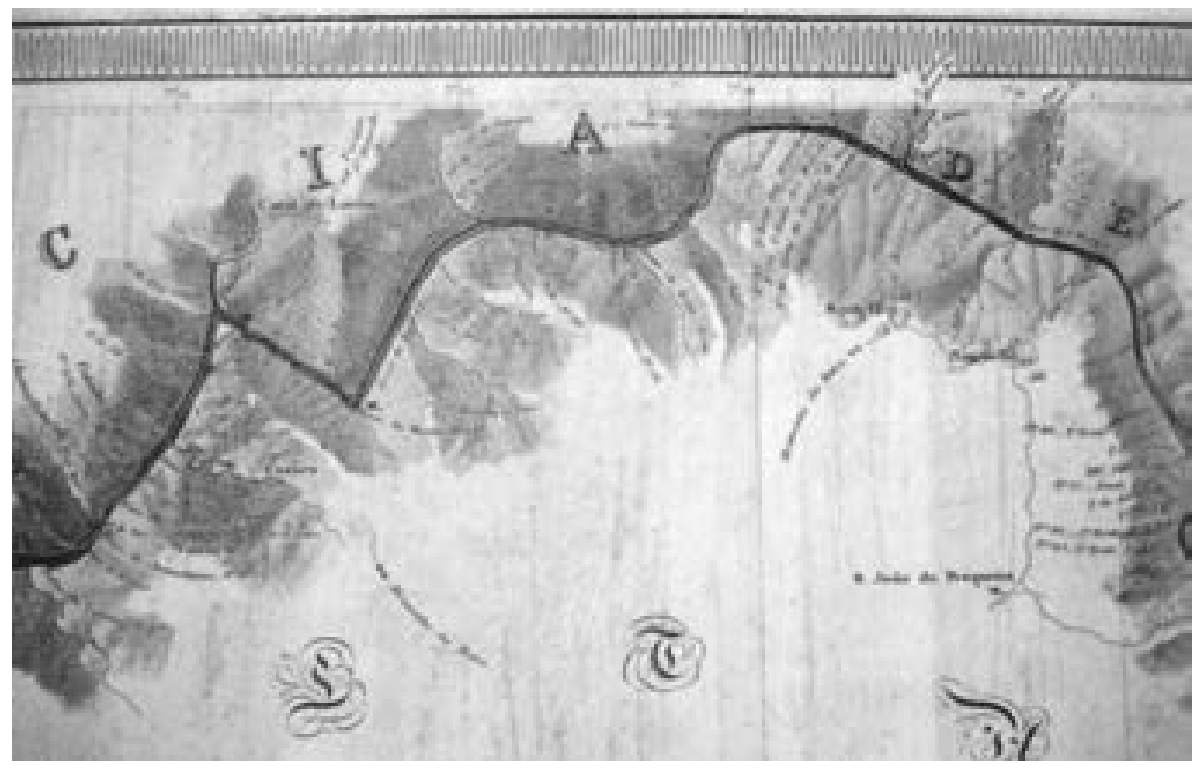

Fig. 22. Mapa «Douro Portuguez e Paiz Adjacente». J. J. Forrester, 1848 (secção 3) Fonte: Coleção Instituto dos Vinhos do Douro e do Porto, I.P. 


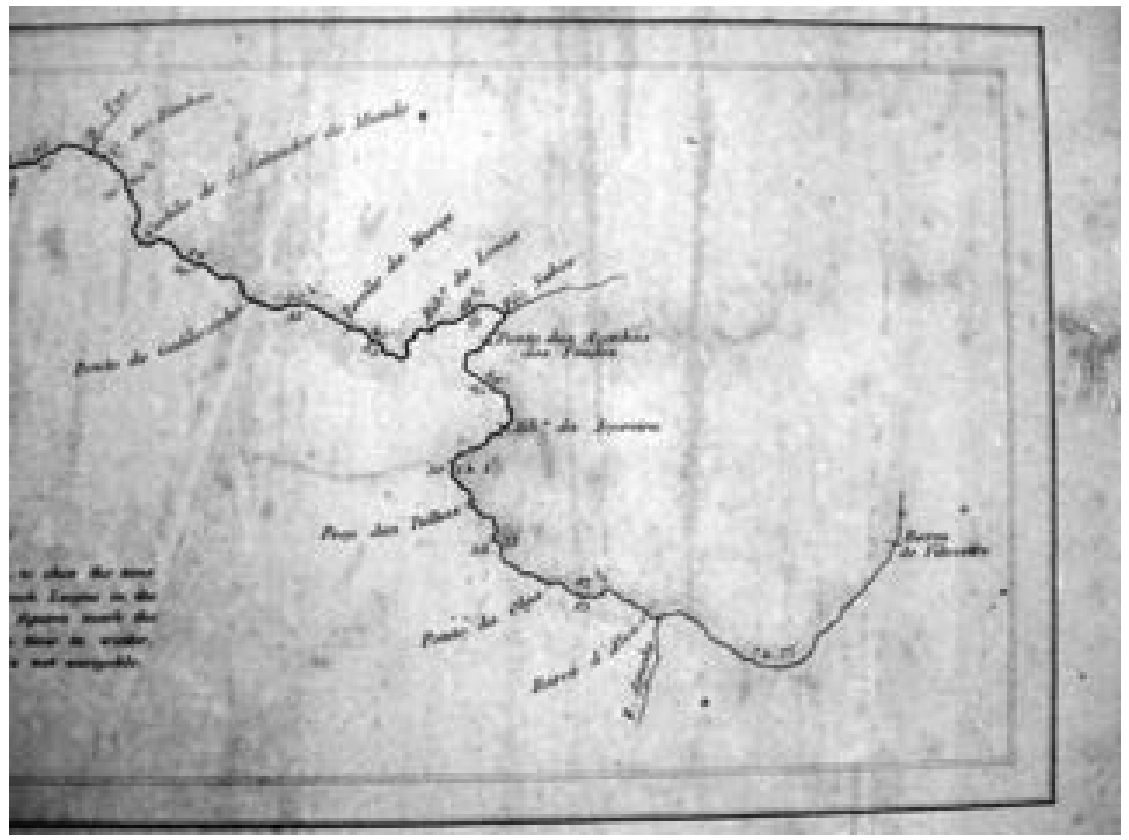

Fig. 23. Mapa «Douro Portuguez e Paiz Adjacente». J. J. Forrester, 1848 (secção 4) Fonte: Coleção Instituto dos Vinhos do Douro e do Porto, I.P.

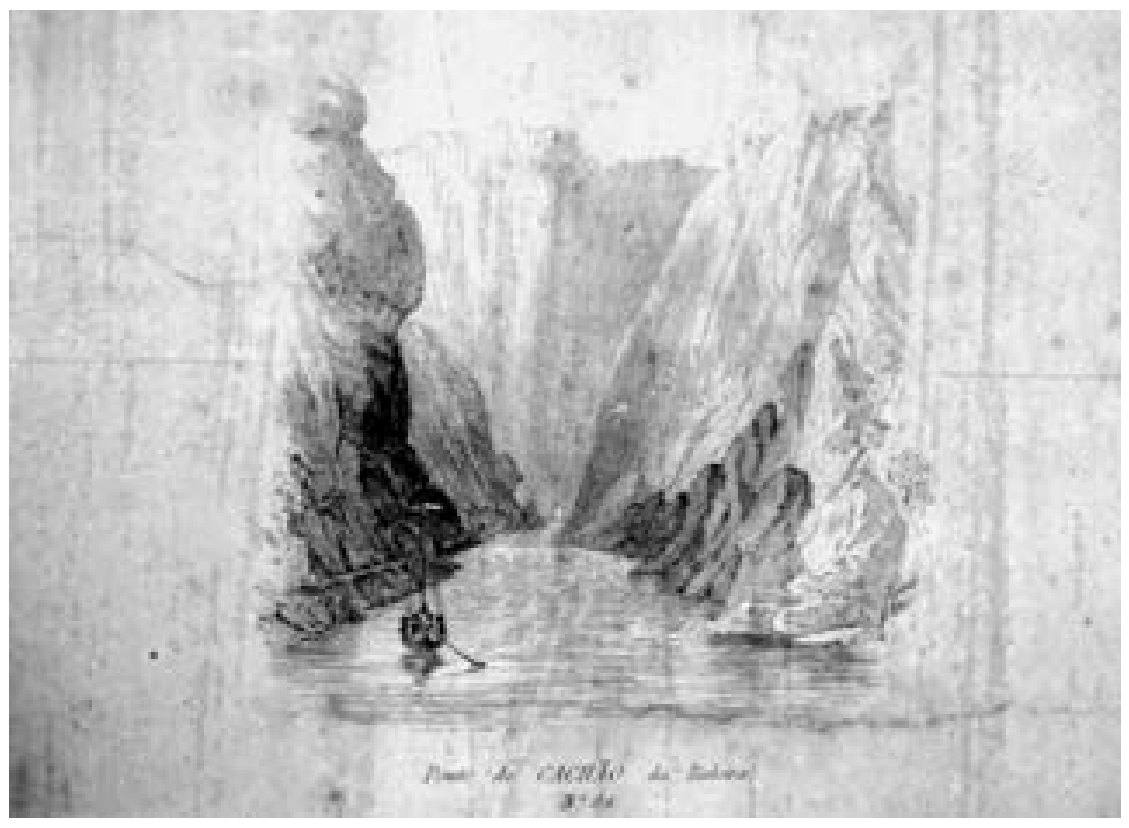

Fig. 24. «Douro Portuguez e Paiz Adjacente». J. J. Forrester, 1848 (secção 5) Fonte: Coleção Instituto dos Vinhos do Douro e do Porto, I.P. 


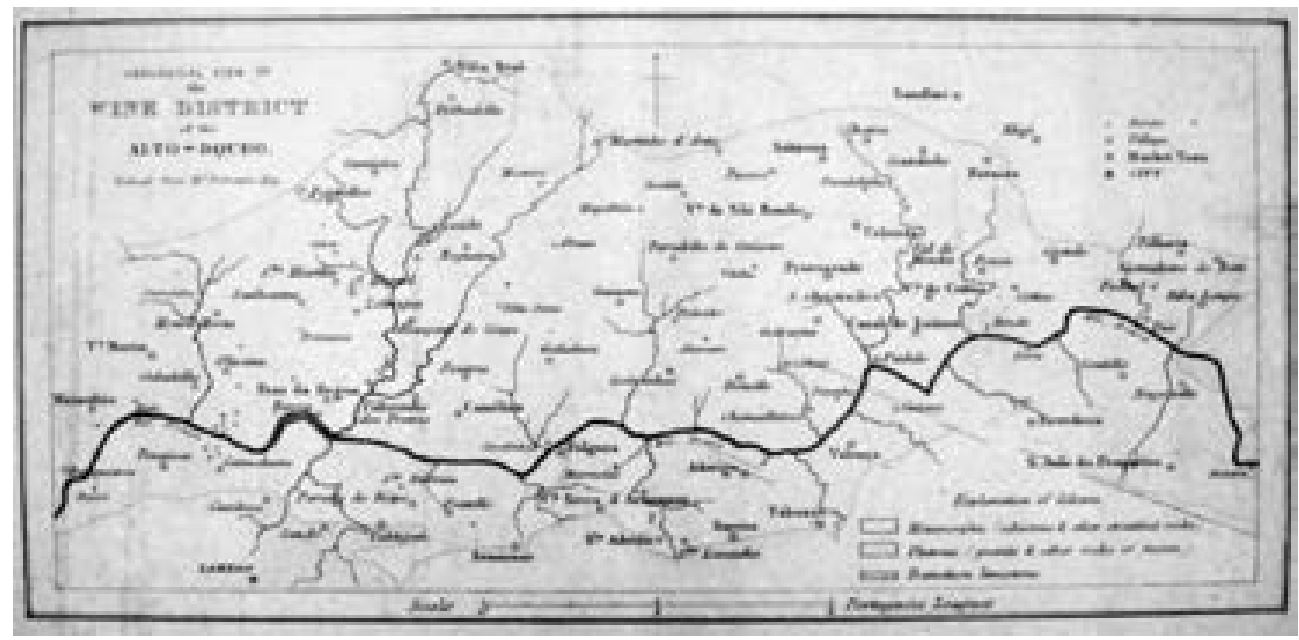

Fig. 25. Mapa «Douro Portuguez e Paiz Adjacente». J. J. Forrester, 1848 (secção 6) Fonte: Coleção Instituto dos Vinhos do Douro e do Porto, I. P.

A elevada importância histórica e científica destes notáveis e pioneiros estudos cartográficos do Barão de Forrester foram retomados como referência de base imprescindível, entre outros primeiros grandes estudiosos da Região Duriense, por Júlio Máximo de Oliveira Pimentel, 2. ${ }^{\circ}$ Visconde de Vila Maior a partir de 1861, ilustre professor e Reitor da Universidade de Coimbra entre 1869 e 1884 e considerado o maior perito histórico do Douro para a nova área duriense que iniciava à época, franco e posterior desenvolvimento, a sub-região do Douro Superior.

\subsection{VINHAS E QUINTAS DE CARRAZEDA NO «PAÍS VINHATEIRO»DO VISCONDE DE VILA MAIOR}

O Visconde de Vila Maior (Professor Júlio Máximo de Oliveira Pimentel, 1809-1884), notável político liberal ${ }^{140}$ natural de Moncorvo, foi um destacado especialista duriense do País Vinhateiro. Autor de uma vasta e diversificada obra especializada, onde se destaca o seu mais conhecido livro O Douro Ilustrado (edição trilingue 1876), ainda hoje um marco referencial da história da Região do Douro, em meados do século XIX, e uma das primeiras descrições da sub-região do Douro Superior que registava já então notável expansão da cultura da vinha. Aí, através da narrativa de uma viagem de barco pelo rio Douro da nascente à foz, ao jeito da «literatura de viagens» então em voga no mundo das letras da Europa Ocidental, descreve minuciosamente os mais variados e múltiplos aspetos característicos do seu "país vinhateiro» duriense de oitocentos, em fase de transição, a partir de cuja perceção se podem intuir a matriz

${ }^{140}$ RAMOS, 2001: 111-114. Ver também: MOTA, 2012; LAGE, 2013a. 
e os alicerces dos vinhedos durienses, paisagem cultural de dimensão patrimonial única, como melhor se verá adiante (Capítulo 3).

Em O Douro Ilustrado livro emblemático de natureza naturalístico-cientifica, podemos encontrar referências concretas à grande quantidade de vinhas e a algumas quintas então existentes no território do atual concelho de Carrazeda de Ansiães, as quais destaca no contexto da descrição minuciosa das principais quintas do Alto Douro e Douro Superior, à época.

Podem ler-se, a seguir, com maior desenvolvimento, algumas dessas passagens mais impressivas:

\subsubsection{Cultura da vinha e do vinho nas terras de Carrazeda em O Douro Ilustrado}

O Alto Douro e o Douro Superior diferem consideravelmente entre si, no estado em que atualmente se acham. Não deriva esta diferença da natureza geológica dos terrenos nem das condições climatéricas, nem das suas aptidões produtivas, mas sim do estado de adiantamento agrícola em que hoje as vemos [... ${ }^{141}$.

Vila Maior, voz discordante das polémicas sobre as designações de Baixo e Cima Corgo, face ao «Douro Superior» que bem conhece e descreve, frisa a importância histórica da origem da região vinhateira do Douro e critica aspetos do regime e leis restritivas da Demarcação Pombalina, à luz da defesa do liberalismo político-económico, justificando aquela divisão com o facto histórico de o segmento oriental duriense ter ficado separado da restante região, até aos finais do século XVIII, pelo obstáculo físico intransponível do Cachão da Valeira.

Sigamos então a descrição narrativa que o Visconde de Vila Maior nos vai fazendo das terras, vinhas e quintas que mais prenderam a sua atenção e de que destacamos as que pertencentes a Carrazeda de Ansiães, se apresentavam já então com maior destaque, no Douro Superior e Alto Douro, ao longo da margem direita do rio Douro e cuja cultura vitivinícola, era considerada de excelente qualidade, «vinhos de $1 .^{\text {a }}$ classe» por sempre «levarem a palma aos da margem esquerda».

\section{Douro Superior ${ }^{142}$ \\ $[\ldots]$}

Ainda que deste lado de Trás-os-Montes se oferecem as situações e exposições mais apropriadas ao estabelecimento de magníficas propriedades vinícolas, é, contudo, na margem esquerda e no concelho de Vila Nova de Foz Côa que hoje se encontram ainda os melhores prédios do Douro Superior [...].

\footnotetext{
${ }^{141}$ VILA MAIOR, 1990. A 1.a edição desta obra está disponível, em texto integral, na Biblioteca Digital da BNP, em http://purl.pt/22659, cota do exemplar digitalizado: hg-5695-v.

${ }^{142}$ VILA MAIOR, 1990: 78-99, 100-101, 106-111. Ortografia atualizada.
} 
Olhemos agora para o Vale da Vilariça [...] uma exceção entre os demais que se abrem sobre o Douro [...]. Não são unicamente as terras de nateiro que dão valor a esta veiga: todas as da planície, ainda mesmo aquelas onde já não chegam as cheias, são notáveis pela sua fertilidade, e nelas se cultivam os cereais sem interrupção. Nas orlas do campo vemos muitos e bons olivedos, e já por muita parte avultam os prédios vinícolas, principalmente nas orlas da zona média do vale, na parte em que ele mais se dilata e nas encostas dos vales contíguos que se elevam para Vila Flôr e para as terras altas de Carrazeda de Ansiães.

$[\ldots]$

Acaba n'este lugar [próximo da serra da Lousa, entre Moncorvo e Vilarinho da Castanheira, com vinhos de excelente qualidade, finos, delgados e espirituosos] a formação granítica; começam novamente os xistos, e com eles as vinhas e as oliveiras, [...]. Mais abaixo passamos o ponto de Lobazim, e vemos, ainda na margem direita, num extenso vale em declive, a quinta chamada do Lobazim, rica pela grande plantação de antigas oliveiras. Não muito longe, na margem oposta, começa já a célebre quinta do Vesúvio, chamada antigamente das Figueiras [...].

Quando na margem direita do Douro se coloca o espectador sobre uma pequena colina, que fica sobranceira à capella da Senhora da Ribeira, limitam-lhe em frente o horizonte os cumes elevados do andar superior da formação granítica do lado da Beira.

[...]

Em frente do Vesúvio está a quinta da Coalheira, que pertence ao sr. Lereno, do concelho de Carrazeda de Ansiães, perfeitamente situada num outeiro de mediana elevação, que domina o rio; abrigada do Norte pelas encostas, que sobem para Vilarinho da Castanheira e terras altas de Ansiães; desfrutando todas as condições naturais propícias à vinha. Produz de 30 a 40 pipas de vinho fino que tem excelente reputação.

Algumas outras vinhas se divisam por essas ladeiras de Trás-os-Montes que principiam já a ser muitas para as podermos nomear a todas. Passemos adiante...

Limitam pelo O. este trato de terreno siluriano o morro de S. Salvador do Mundo e as penedias das margens transmontanas entre as quais corre o Douro para o celebre Cachão da Valeira...

Na margem oposta, nas ladeiras que sobem para as terras altas de Ansiães, vêem-se muitas vinhas de excelente e avultada produção: as do vale de S. Martinho, as dos Canaes e por fim a quinta do Síbio defronte de S. Xisto, que na carta de Forrester tem o nome de Forneiras.

Chegámos ao limite do Douro Superior [...]

O Alto Douro

A formação granítica, por cuja fratura passa o rio no Cachão da Valeira, e que se ergue à direita a 812 metros e do lado esquerdo a 782 acima do nivel do mar, parece estabelecer uma divisão natural entre o Alto Douro e o Douro Superior, e justificar até certo 
ponto o limite da demarcação que a lei fixava para a produção dos vinhos de embarque; porém esta divisão, constituída por um limitado acidente geológico, nada influi sobre as faculdades produtivas dos terrenos das duas regiões a montante e jusante deste ponto... A divisão é puramente convencional, e funda-se principalmente no estado de adiantamento, ou antes no mais amplo desenvolvimento, em que se acha no Alto Douro a viticultura.

$[\ldots]$

Apenas saimos as formidáveis portas do Cachão encontramos de novo um trato de terreno xistoso, limitado ao oeste por outros granitos, [...]; e à direita as quintas da Alegria de cima e de baixo, e sobre estas várias vinhas do termo de Linhares. Produzem todas aquelas quintas vinhos de primeira classe, porém os da margem direita levam sempre a palma aos da margem esquerda; e são principalmente estimáveis os vinhos brancos da Alegria.

Agora a série de propriedades vinícolas é novamente interrompida, na extensão de 3 quilómetros, à margem do rio, pelas escarpas nuas e descarnadas de rocha granitica, rocha que não tornaremos a encontrar senão nos limites do país vinhateiro.

Logo após estes áridos rochedos temos à esquerda o vale de S. Martinho que traz as águas da Pesqueira, e à direita, fazendo-lhe fronteiro, o vale de Ribalonga que vem descendo para o Douro desde o Castanheiro do Norte. À entrada do primeiro destes vales, vê-se uma pequena, mas bem tratada quinta, a chamada de S. Martinho, que pertence ao reverendo reitor de Linhares [...]. Volvendo a vista à direita, antes de ir mais longe, o que principalmente prende a nossa atenção são as quintas do Zimbro e da Chousa. A primeira, que pertence à casa dos Srs. Barros de Sabrosa, é um prédio bem situado, provido de boas oficinas e casa de habitação, bem cultivada e cuja produção se avalia em mais de 30 pipas de vinho de primeira classe.

A quinta da Chousa, que fica logo em seguimento à antecedente, pertence à Sra. Viscondessa de Ervedosa. A última vez que vimos esta propriedade estava ela em completa decadência. Viam-se ainda os restos de um belo pomar de laranjeiras, cujos frutos eram muito gabados pela sua doçura e delicadeza; viam-se grandes oficinas e uma casa de nobre aspeto, mas a vinha estava já decrépita, exausta e morta em grande parte. Tinha sido um prédio de muita nomeada pelos seus finos e generosos vinhos, cuja produção subira noutros tempos a 40 pipas, mas que por fim se achava reduzida quase à décima parte $[\ldots]$.

Em frente do extremo ocidental da quinta dos Ciprestes vemos a pequena povoação de Foz-Tua, assente sobre a margem direita do Douro e esquerda do Tua no ponto da sua recíproca confluência. É uma pequena povoação, mas já antiga e importante por ter sido, antes da abertura do Cachão do Valeira, o último porto do Douro, onde vinham embarcar os produtos agrícolas de Trás-os-Montes, principalmente os da antiga comarca de Moncorvo que abrangia uma grande parte do que é hoje o distrito de Bragança. 
O Tua vem correndo do alto de Trás-os-Montes de NE. a SO, a lançar-se no Douro neste ponto, separando em quase toda a sua extensão os distritos de Bragança e Vila Real [...].

Logo que se transpõe o Tua entramos no concelho de Alijó e vamo-nos aproximando do coração do país vinhateiro, ou da região onde se geram os vinhos mais finos e generosos [...].

Como se pode observar na anterior descrição da área vinhateira relativa ao território concelhio de Carrazeda de Ansiães este é já posicionado por este autor, num «Douro Novo» na fronteira interrelacionada de transição entre o Alto Douro e o Douro Superior.

Vejamos ainda em Vila Maior - Preliminares da ampelografia e enologia do país vinhateiro do Douro $(1866)^{143}$, publicação cientifica anterior, a sua apreciação especializada da viticultura desta zona duriense do planalto transmontano de Carrazeda, na margem direita do Douro, a qual apresenta em termos específicos na fronteira duriense acima e abaixo do Corgo entre Pinhão e Tua, e desenvolve numa perspetiva comparada de diferenças e semelhanças com as terras vinhateiras que lhe ficam defronte na margem esquerda do rio.

Para o caso concreto de algumas importantes quintas durienses de Carrazeda, à época e que ainda hoje se mantêm (Capítulo 8), podemos observar, a já então sublinhada qualidade excecional dos seus vinhos, para além de outras especificidades próprias de contextos históricos e económico-sociais (propriedade, vinhas, plantações e castas, comércio de vinhos) e fatores naturais (climáticos, geomorfológicos, etc.), sucintamente referenciadas.

Na margem direita, entre os granitos do Cachão e os do Mirago, estão as encostas em que se acham situadas as duas quintas da Alegria, e que pertencem à mesma formação, em que assentam as que lhe ficam fronteiras, e de que até agora nos temos ocupado [...].

Os vinhos desta quinta [Alegria de Cima] foram sempre considerados de primeira classe; são pouco encorpados, muito maduros, espirituais e aromáticos, e especialmente são notáveis os vinhos brancos pela sua distinção e superioridade.

A Alegria de Baixo, que pertence atualmente ao sr. João Baptista de Moraes, e que ocupa uma extensão menor do que a antecedente, teve, contudo, a fortuna de ser auxiliada com mais regular cultura, com renovos e enxertias das melhores castas, as quais, agradecendo o bom tratamento, enceparam bem e estão muito vigorosas, podendo d'esta forma fornecer uma produção media regular de 30 ou ainda mais pipas de vinho [...].

Alem das quintas da Alegria, e sobre as encostas que sobem para Linhares e Carrapatosa, há ainda algumas vinhas que podem juntas fornecer de 60 a 70 pipas de vinho suscetivel de ser classificado de primeira classe. Já, porém, de meia ladeira para cima, onde afloram os granitos, as vinhas que sobre eles se acham plantadas fornecem vinhos menos estimáveis e até cada vez mais inferiores, à proporção que elevando-se se afastam do Douro.

\footnotetext{
${ }^{143}$ Obra sobre conhecimentos, à época, de vinha, vinho e enologia, com 44 páginas.
} 
Os terrenos que se formam sobre as rochas graníticas não são de certo impróprias, nem para a plantação e prosperidade da vinha, nem para a produção de vinhos superiores. A vinha não é exigente enquanto à natureza do solo. Vemos que ela prospera e fornece produtos estimáveis em terrenos, cujas rochas subjacentes são de mui diversa natureza, desde as formações mais recentes até às mais antigas;

[...]

Lançando a vista sobre a carta do país vinhateiro levantada pelo barão Forrester, vêem-se abaixo dos sitos que acabo de descrever, duas linhas de agua que se dirigem quase perpendicularmente ao Douro; uma, partindo das proximidades da Pesqueira, denota o vale de S. Martinho, e a outra do lado oposto, descendo do Castanheiro do Norte, indica $o$ vale de Riba Longa. As aberturas destes dois vales ficam quase fronteiras uma à outra, e ambas nos limites da formação grani tica que separa os vinhedos de que ate aqui tenho falado, daquele de que passo a ocupar-me, seguindo as margens do rio até Foz-Tua.

São daqui em diante numerosos os prédios vinícolas; mas se na sua totalidade formam um vinhedo importante e considerável, nem todos eles podem ser parcial e separadamente descritos, nem ainda especificadamente mencionados neste trabalho, que não tem por base um cadastro, que não existe, nem tem as pretensões de suprir essa falta. Abaixo dos penhascos de Nagozelo e nas encostas que formam o vale de S. Martinho, e que ainda se dobram para o Douro, está uma quinta de boa e antiga reputação, que pertence ao rei. O reitor de Linhares, o qual é muito dado à viticultura e nela muito entendido, $e$ como tal grangeia a sua propriedade, tendo-a por isso num satisfatório estado de cultura e conservação. Este prédio é conhecido com o nome de quinta de` S. Martinho. O seu vinho é especial pela sua força e consistência, ou de boa conta, como dizem os comissários, ainda que delgado $[\ldots]^{144}$.

Estava-se então, nesse terceiro quartel do século XIX, numa época de profunda transformação do Douro oitocentista que viu as suas vinhas ciclicamente atacadas por graves doenças das videiras, desde a invasão crónica do oídio (a partir de 1852), cujos tratamentos específicos são referidos em O Douro Ilustrado, até ao período nefasto da filoxera com seus efeitos calamitosos e posterior indução transformadora e mais tarde o míldio (1893), as quais acabariam por contribuir para uma profunda renovação das técnicas de vitivinicultura e vinificação do vinho do Porto.

Ao mesmo tempo, a região duriense debatia-se com uma situação complicada, resultante das dificuldades crónicas das finanças públicas e a incapacidade de o Estado prescindir da enorme carga fiscal que fazia impender sobre o vinho do Porto.

Verificava-se a afirmação progressiva do princípio da liberdade económica que se opunha ao controlo/intervenção reguladora estatal, considerada atentatória dos direitos de

${ }^{144}$ VILA MAIOR, 1876: 157-161. Ortografia atualizada. 
propriedade que se manifestavam em debates e controvérsias entre os defensores do modelo liberal e das marcas comerciais e os protecionistas que se opõem à abolição das medidas restritivas à livre produção e comercialização dos vinhos do Douro. Vitorioso o liberalismo económico, com o fontismo vem abolir-se o que ainda restava do modelo protecionista pombalino já muito alterado pela legislação liberal.

O regime de liberdade comercial dos vinhos do Douro que triunfou com a legislação de 1865, foi alvo da contestação duriense e objeto de novas reivindicações dos viticultores que deploravam a falta de regulação $0^{145}$.

Os donos das grandes propriedades, quintas e vinhedos do Douro passaram a ser em grande medida oriundos de uma nova burguesia enobrecida com os títulos de viscondes, barões e outras comendas que, nalguns casos, vieram substituir no Douro o predomínio da igreja, conventos, mosteiros e elites do antigo regime. 


\section{CAPÍTULO 3. MATRIZ DA PAISAGEM CULTURAL E PATRIMÓNIO (I)MATERIAL DURIENSE: GEIOS/SOCALCOS ${ }^{146}$}

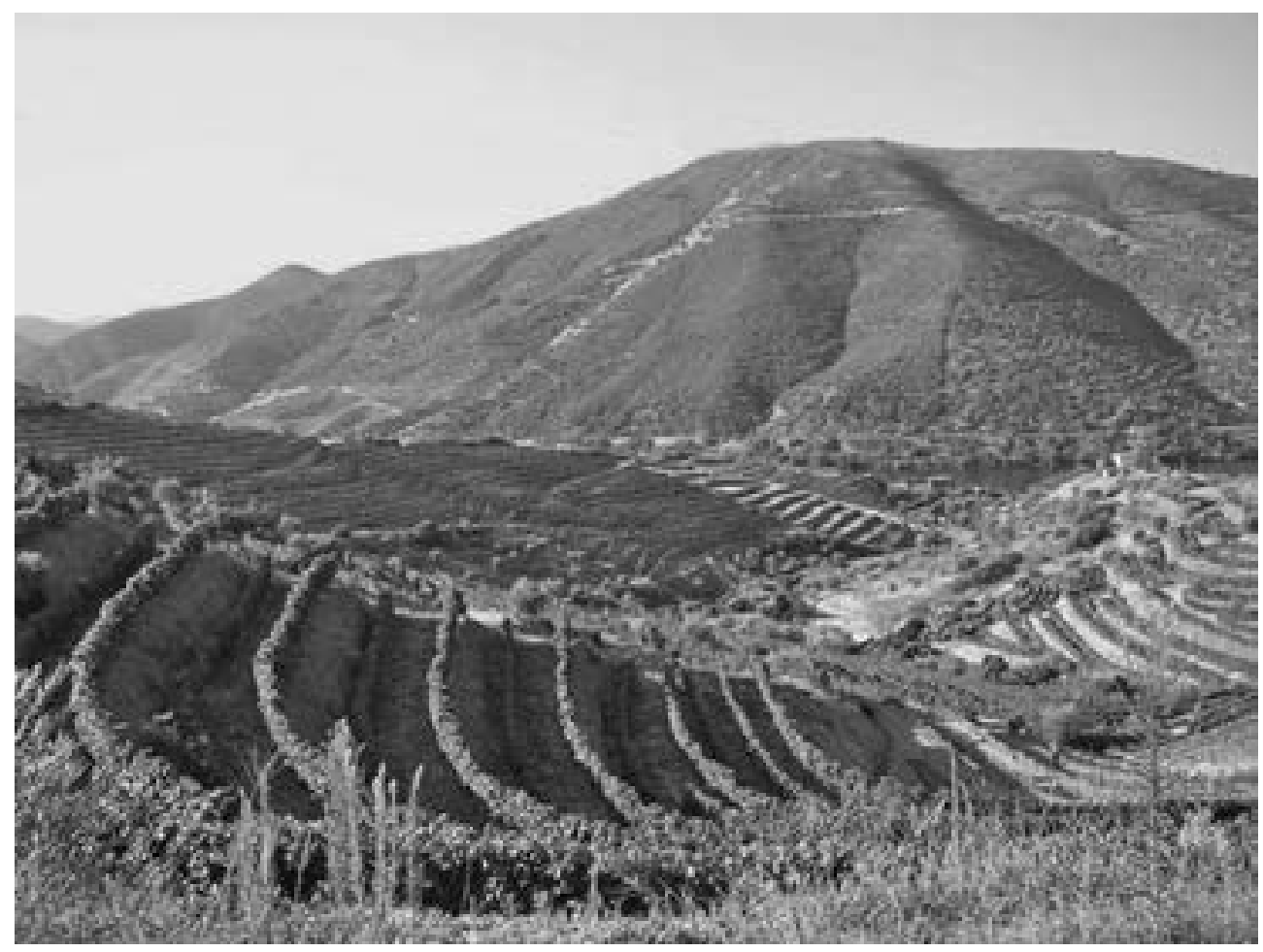

Fig. 26. Paisagem vinhateira em Coleja, Carrazeda de Ansiães

Foto: M. J. F. Lopes

Prosseguindo com uma leitura interpretativa de O Douro Illustrado, iremos observar, em pormenor, a sua minuciosa descrição da notável obra de agrimensura de pedreiros galegos e portugueses nas abruptas encostas que marginam o Vale do Douro. A partir daí procuramos fazer uma abordagem abrangente e compreensiva da importância e significação histórica dos geios e socalcos pré-filoxéricos, armações tradicionais dos terrenos das encostas para a cultura da vinha, os quais se consideram alicerces e matriz da região vinhateira duriense enquanto paisagem cultural património da humanidade.

${ }^{146} 16$. Uma versão preliminar e muito resumida do texto deste capítulo foi apresentada em nossa comunicação ao III Encontro CITCEM: Paisagem. Materialidade e imaterialidade. Porto - Baião, novembro 2013. 


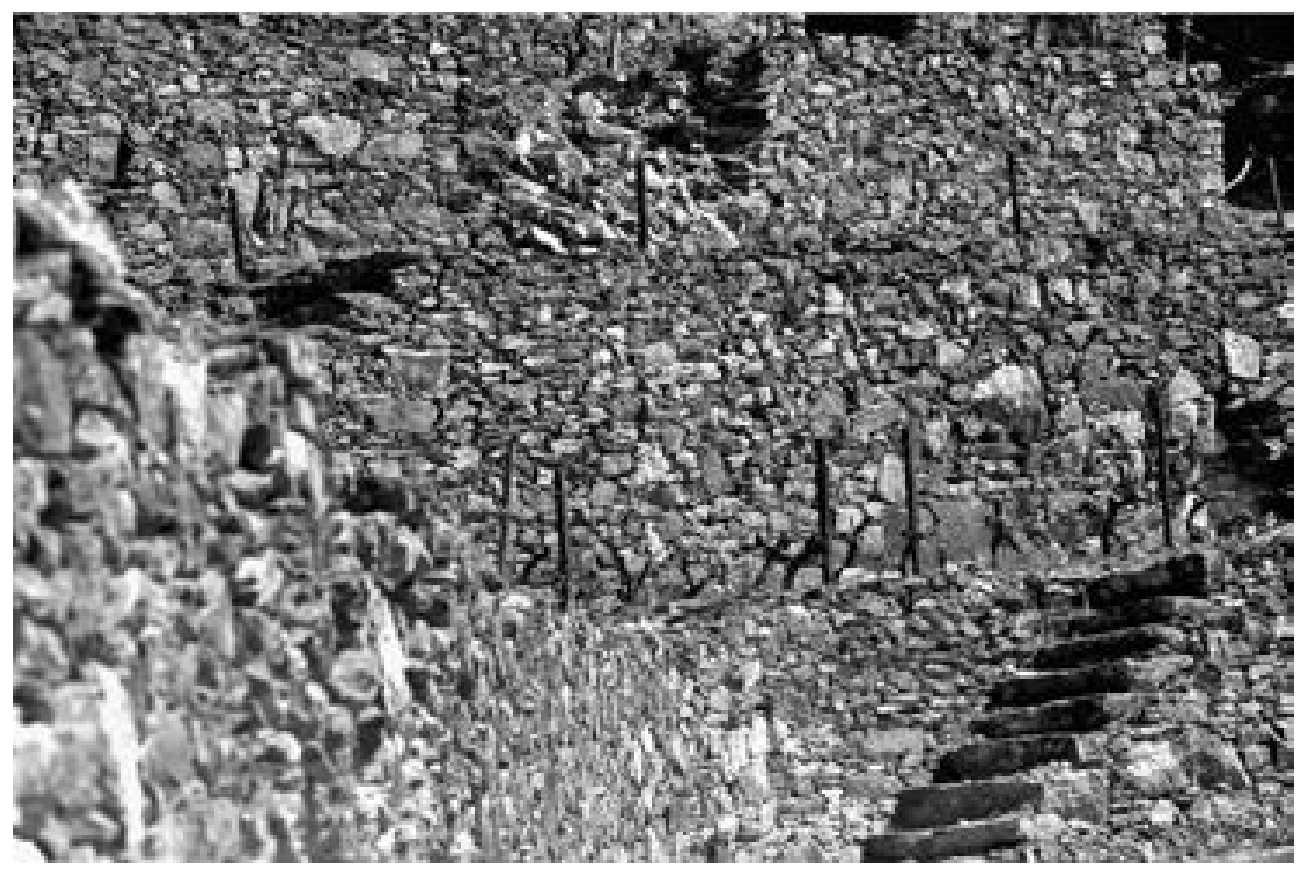

Fig. 27. Quinta do Tua/C. Ansiães - Socalcos antigos, dos mais sólidos do Douro

Foto: E. Beira

A essas formas muradas com enchimento de terras, xistos e pedras miúdas que se estendem ainda hoje por quilómetros das encostas durienses, tão bem descritas por Vila Maior, novas técnicas de adaptação dos terrenos à mecanização e tecnologias mais sofisticadas de plantação e culturas da vinha, vieram juntar-se, sobretudo a partir da década de 1970, os modernos «terraços» que acompanham o declive dos terrenos das encostas, os «patamares» $\mathrm{e}$ as «vinhas ao alto».

Pensando a paisagem como património cultural imaterial construído e atendendo a que este, na definição operacional da UNESCO ${ }^{147}$ «não se resume apenas aos monumentos e coleções de objetos, mas abrange também as tradições, expressões de vida, conhecimentos e aptidões que constituem a cultura e a identidade de cada país», centramo-nos então no presente capítulo na expressão do trabalho humano - práticas, saberes e técnicas de plantação da vinha duriense em calços ou geios na segunda metade do século XIX, dimensão específica que afeiçoou, pelo trabalho incorporado, a paisagem duriense, «cultural, viva e evolutiva» ${ }^{148}$ assim definida na candidatura do Alto Douro Vinhateiro (ADV) a Património Mundial, classificação reconhecida em $2001^{149}$.

\footnotetext{
${ }^{147}$ Convenção para Salvaguarda do Património Cultural Imaterial, aprovada em 2003, e em vigor desde 2006.

${ }^{148}$ AGUIAR, 2002: 143-152.

${ }^{149}$ Consubstanciou-se nesta candidatura o compromisso de proteger eficazmente o património classificado e de preservar as características que lhe conferem um valor universal excecional. Para lhe dar cumprimento, as
} 
O ADV corresponde a uma zona considerada representativa das três unidades de paisagem que caracterizam respetivamente o Baixo Corgo, Cima Corgo e Douro Superior, que se estende ao longo do rio Douro e seus afluentes Varosa, Corgo, Távora, Torto e Pinhão, desde a zona de Mesão Frio até à zona do Pocinho, num total de 24600 ha incluídos em 13 municípios das margens norte e sul daquele rio. A correspondente carta de unidades de paisagem permite constatar que o $A D V$ 'regista internamente diferenças assinaláveis confirmadas também pela diversidade de paisagem cultural'. São 5 as unidades de paisagem, com as seguintes designações, concelhos envolvidos e correspondentes áreas percentuais: Extremadouro - concelhos de Lamego, Mesão Frio, Peso da Régua e Santa Marta de Penaguião (9,3\%); Corgo/ Varosa — concelhos de Armamar, Lamego, Peso da Régua, Santa Marta de Penaguião e Vila Real (11,3\%); Ceira/Távora — concelhos de Armamar, Peso da Régua, Sabrosa, São João da Pesqueira e Tabuaço (21,6\%); Pinhão/Torto - concelhos de Sabrosa, Alijó, Carrazeda de Ansiães, São João da Pesqueira e Tabuaço (32,3\%); Tua/Sabor — concelhos de Carrazeda de Ansiães, São João da Pesqueira, Torre de Moncorvo e Vila Nova de Foz Côa $(25,6 \%)$ [... $]^{150}$.

Para além desses aspetos de caracterização administrativa, por referência aos cursos dos rios (Douro e seus afluentes) da diversidade cultural da Paisagem Duriense, organizada nessas cinco unidades de paisagem, há a salientar: «o caráter único do território, a relação natural da cultura do vinho com a oliveira e a amendoeira e a diversidade da arquitetura local ${ }^{151}$ onde se destaca o considerável e ancestral trabalho das populações na construção de socalcos em xisto das encostas que conforma a genuinidade desta paisagem cultural ${ }^{152}$.

Assim, propomo-nos aqui perspetivar a saga do granjeio da vinha, uma obra de arte meticulosamente construída em anfiteatro ao ar livre por portugueses e galegos, obra pluriperspetivada na relação natureza-ciência-sociedade por Vila Maior em O Douro Illustrado, livro oitocentista de feição cultural e científica documentado por um conjunto de estampas a partir do uso da então ainda recente fotografia.

Porém, prévia à descrição minuciosa dessa dimensão estruturante da paisagem duriense, assim a caracterizava então, este perito notável do Douro, observando-a de longe, do barco

\footnotetext{
Assembleias Municipais dos Concelhos que incluem áreas do ADV, elaboraram e aprovaram um Plano de ordenamento do território do Alto Douro Vinhateiro (PIOT-ADV), ratificado pela Resolução do Conselho de Ministros n. ${ }^{\circ}$ 150/2003, ao abrigo do disposto no artigo $68 .^{\circ}$ do Decreto-Lei n. ${ }^{\circ} 380 / 99$, de 22 de setembro, e nos termos da alínea g) do artigo $1990^{\circ}$ da Constituição, o qual constitui um instrumento de gestão da paisagem cultural e viva da Região, cujas orientações normativas, seguidamente se enumeram. Estas foram posteriormente também aplicáveis à restante área da Região Demarcada do Douro, zona envolvente à Mancha Douro Património Mundial, já que é classificada como Zona Especial de Proteção, de acordo com o artigo n.o 72 do Decreto-lei n. $309 / 2009$ conjugado com o aviso 15170/2010 (Manual de Boas Práticas Vitícolas: Região Demarcada do Douro, [2010]).

${ }^{150}$ Manual de Boas Práticas Vitícolas: Região Demarcada do Douro, 2010.

${ }^{151}$ Manual de Boas Práticas Vitícolas: Região Demarcada do Douro, 2010.

${ }^{152}$ Sobre o processo de organização da candidatura do Douro a Património Mundial, cujo debate foi lançado nos inícios dos anos 1990 pelo IVDP e a ACP, seguido pelo estudo de viabilidade da candidatura da iniciativa da Associação D. Afonso Henriques, em 1998, consultar a obra de referência base Alto Douro Vinhateiro: Património Mundial: Paisagem Cultural, Evolutiva e Viva, 2006.
} 
que descia o rio: «...mal se divisam as feições e lineamentos dos sítios, e o aspeto daquelas paisagens, que ora nos surpreendem pela arrogância das suas formas ora, nos encantam pela graça dos seus contornos e pela beleza da sua esplêndida vegetação» ${ }^{153}$. Isto é, ao tempo, e a um primeiro olhar, uma paisagem ainda pouco alterada pelo homem.

Neste enquadramento, visa-se contribuir para uma perceção sócio-histórica de como a paisagem cultural do Douro vinhateiro, património material e imaterial em que há muito de original, foi histórica e socialmente produzida no granjeio da vinha assente na construção técnica de calços ou geios e valeiras para permeabilidade da terra revolvida em diversas e sequenciais operações preparatórias da plantação da vinha.

Pretende-se evidenciar parcialmente o processo social e histórico de construção da paisagem cultural duriense património mundial, a partir da correlação entre a paisagem duriense em anfiteatro e alguns dos sistemas, métodos e técnicas antigas da sua viticultura.

A originalidade da paisagem rural vitícola do Alto Douro Vinhateiro (ADV) ${ }^{154}$, representativa da Região Demarcada do Douro (RDD) ${ }^{155}$ é historicamente reconhecida na sua especificidade cultural polifacetada, e como tal se nos impõe hoje, na sua distinção universal enquanto património mundial e paisagem cultural evolutiva e viva, resultante de uma conjunção excecional entre natureza e intervenção ancestral/contínua do homem, criando um ecossistema de valor único.

Este facto encerra, desde logo, um duplo significado: reconhecimento universal da autenticidade e integridade da paisagem e património duriense; responsabilidade de velar pela preservação/valorização deste bem de escala mundial, o que passa pelo conhecimento, salvaguarda e transmissão da história tecnológica, económica e social que produziu paisagem cultural e património (i)material, nas suas múltiplas dimensões — territorial, cultural e económico-social.

Como afirma Teresa Andresen «A autenticidade e integridade da paisagem cultural do ADV foram argumentadas em função do caráter da paisagem e da valorização das suas componentes de distinção: a antiguidade da Região Demarcada; os terraços; e o cruzamento de culturas. O caráter da paisagem é determinado por uma sábia gestão da escassez de solo e água e do elevado declive do terreno, resulta da observação permanente e intensa, do ensaio localizado e do conhecimento profundo da adaptação da cultura da vinha a situação tão adversa. É uma paisagem que expressa a determinação e a ousadia humanas» ${ }^{156}$.

Realidade compósita e bela, a região vinhateira do Douro (Alto Douro e Douro Superior) construída, minuciosamente, por uma sucessão de técnicas e saberes do plantio da vinha e outras culturas (oliveira, amendoeira, árvores de fruto e cereal) numa conformação minuciosa

\footnotetext{
${ }^{153}$ VILA MAIOR, 1990: 2.

${ }^{154}$ Abrange uma área de 24.600 ha, ilustrativa da RDD, classificada pela UNESCO em 2001 como Património Mundial. Ver por exemplo, AGUIAR, 2002: 143-152.

${ }^{155}$ A primeira do Mundo a ser demarcada e regulamentada, corresponde a uma área de cerca de 250.000 ha, ao longo do vale do rio Douro, entre Barqueiros (Mesão Frio) e Barca d'Alva (Figueira de Castelo Rodrigo) e abrange freguesias de 21 concelhos. É tradicionalmente dividida em três sub-regiões: o Baixo Corgo, o Cima Corgo e o Douro Superior. ${ }^{156}$ ANDRESEN, [s. d.].
} 
do terreno de elevado declive, tendente a uma gestão racional do solo e águas, foi modelada pelo intenso trabalho humano em ligação com as características climáticas e geológicas locais. É ainda, como salienta Natália Fauvrelle,

uma paisagem cultural polimorfa que apresenta uma grande variedade de formas de armação do terreno vitícola, a par de manchas de vegetação espontânea e de outras culturas que enformam a paisagem. O mosaico da paisagem é assim diversificado, alternando áreas agrícolas - mais ou menos compartimentadas - com áreas de matas e matos e alguns povoamentos florestais [...]. Assim, estamos perante uma paisagem histórica, que conserva diferentes tipos de armação do terreno de diversas épocas, residindo nesta diversidade a sua riqueza $[\ldots]^{157}$.

No caso de Carrazeda de Ansiães, onde os Vales do rio Douro e seu afluente Tua traçam os seus próprios limites naturais a nascente e sul, concelho integrado no Douro Património da Humanidade, deve referir-se que nele se situa, precisamente, uma das 10 paisagens de referência do Douro Património Mundial, a «paisagem de referência foz tua» com uma área de 537,66 ha, a qual é uma das portas de entrada neste concelho, patrimonialmente mais significativa ${ }^{158}$. É ainda oportuno salientar que Carrazeda se encontra posicionada nas duas mais extensas unidades de paisagem cultural: Pinhão/Torto e Tua/Sabor, que em conjunto representam 57,9\% da área total, tal como vimos anteriormente, a propósito das cinco unidades de paisagem cultural consideradas no ADV.

Destacam-se na Paisagem Duriense três aspetos principais ${ }^{159}$ : «0 caráter único do território, a relação natural da cultura do vinho com a oliveira e a amendoeira e a diversidade da arquitetura local». Evidencia-se ainda na paisagem a incorporação do notável trabalho humano na construção de muros em xisto que prolongam as encostas e conferem a autenticidade e integridade da paisagem numa perspetiva assim assumida de paisagem cultural e património a compreender e cuidar em sua ancoragem histórica.

Demonstravam já essa originalidade plurifacetada, os ensinamentos científicos de Vila Maior onde não falta a menção precisa dos saberes, práticas e processos de vitivinicultura em que regista o «muito que há de original no fabrico da vinha e na produção do vinho na região do Douro» ${ }^{160}$. Nesse contexto se destaca a descrição meticulosa e quase milimétrica que este autor oitocentista faz das sucessivas etapas de construção dos geios e bardos do Douro Vinhateiro, técnicas ancestrais de preparação do terreno, que em suas construções, morfologia e ambiente configuram parte significativa da história da paisagem cultural vinhateira do Douro, património mundial.

\footnotetext{
${ }^{157}$ FAUVRELLE, 2007. Ver também FAUVRELLE, 2014.

${ }^{158} \mathrm{O}$ conjunto de paisagens de referência do Douro Património Mundial é assim constituído: Vale do rio Corgo; Chanceleiros; Vale do rio Torto; Vale de Figueira; Oliveira; Cambres e Vale do Varosa; Vale do rio Távora; Vale do rio Pinhão; Foz Tua e Freixo de Numão.

${ }^{159}$ Conforme foi reconhecido na apresentação da sua candidatura à UNESCO.

${ }^{160}$ VILA MAIOR, 1990: 49-59.
} 
Ora, se por um lado, estamos perante uma paisagem de enraizada conformação histórica cujo conhecimento é essencial à gestão e controlo de problemas que podem afetar a sua preservação, por outro lado, verifica-se a necessidade de evidenciar e cuidar do pormenor, o que não é hoje muito sentido entre nós. Daí que, na análise da construção histórica desta paisagem natural e humana que alia formas de arte de construção tradicional que são objeto de criatividade e inovação progressivas, numa difícil coesão territorial, se prefira sobretudo acentuar um enfoque micro. Não se esquece, porém, que as análises macro e meso, são igualmente necessárias, quando, como no caso vertente, se fala de Paisagem Cultural e Património (i)material mundial, noções que nos dão conta de múltiplos fatores, entre outros, os ecológicos que interferem constantemente na paisagem, como por exemplo, o clima.

É então nessa dupla perspetiva e diversidade escalar que, reportando-nos ao «Douro vinhateiro» em meados do século XIX, num período ainda pré-filoxérico, se vai observar em particular o processo de construção dos geios, alicerce desta paisagem-património, o qual se julga tanto mais relevante quanto é inegável a atualidade da relação complexa e interdisciplinar da dimensão material e imaterial da realidade traduzida nesses dois conceitos e sua inter-relação.

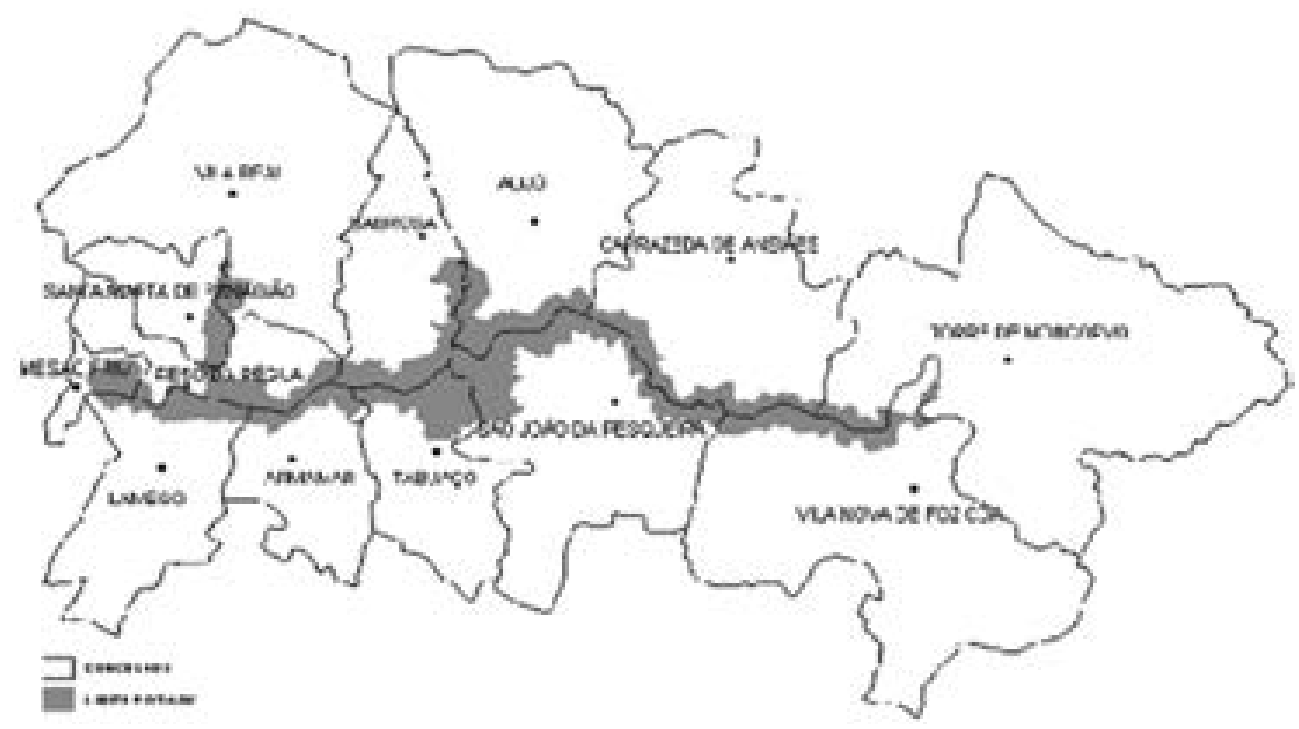

Fig. 28. Área classificada como Património Mundial (UNESCO, 2001) ${ }^{161}$

Contextualizam-se, concetualmente, as noções de paisagem cultural e património (i)material, detemo-nos, em seguida, na descrição da construção dos geios e bardos tradicionais pré-filoxéricos, fundações do grandioso anfiteatro do Douro Vinhateiro, e abordamos, depois,

\footnotetext{
${ }^{161}$ Direção Regional da Agricultura e Pescas. Disponível em <http://www.drapn.min-agricultura.pt/drapn/ela_dv/ eladv_index.html>. [Consulta realizada em 13/10/2013].
} 
alguns preceitos de conservação e gestão da paisagem cultural e património imaterial, numa perspetiva transdisciplinar, refletindo por fim, sobre o possível significado desta abordagem.

\subsection{OS CONCEITOS DE PAISAGEM CULTURAL ${ }^{162}$ E PATRIMÓNIO (I)MATERIAL ${ }^{163}$}

A «realidade aumentada» e a paisagem — olhar, contemplar, ver, percecionar, perceber, sentir, interagir, agir, interferir, preservar, participar, promover — é atualmente um dos mais importantes ativos portugueses e só políticas nacionais esclarecidas, conhecedoras e consistentes, a podem salvaguardar.

Para tanto, a investigação sobre paisagem e património tem de ser historicamente ancorada e transdisciplinar, por forma a abrir um espaço de reflexão em torno desses dois conceitos hoje sobre expostos, devido, em grande medida, às importantes implicações económicas que lhes estão associadas.

Os estudiosos da paisagem são unânimes em evidenciar que este é um conceito de longa evolução ${ }^{164}$ e com muitas consequências na compreensão da cultura.

Segundo Alain Roger ${ }^{165}$, há duas maneiras no processo de conquistar os territórios para a paisagem, transformando o espaço visível através de uma apreciação estética positiva: a primeira é o código inscrito diretamente na materialidade do local, sobre o terreno, a base natural; a segunda, uma forma indireta que opera sob um olhar coletivo, faculta modelos de visão, esquemas de perceção e deleite.

Para Michel Collot, teórico francês que estuda a relação entre a paisagem e a subjetividade lírica, deve considerar-se que:

Não se pode falar de paisagem, a não ser a partir de sua percepção. Diferentemente de outras ideias espaciais, construídas por intermédio de um sistema simbólico, científico (o mapa) ou sociocultural (o território), a paisagem se define inicialmente como espaço percebido: constitui 'o aspecto visível, perceptível, do espaço'. Mas, se essa percepção se distingue de construções e simbolizações elaboradas a partir dela, e exige outros métodos de análise, sua aparente imediatidade não deve fazer esquecer que ela não se limita a receber passivamente os dados sensoriais, mas os organiza para lhes dar um sentido. A paisagem percebida é, portanto, já construída e simbólica [...]. A noção de paisagem é, também, por

\footnotetext{
${ }^{162}$ Considera-se pertinente utilizar aqui, com a devida adequação, a abordagem específica desta classificação desenvolvida pela UNESCO, como se vê na breve evolução deste conceito apresentada no corpo do texto.

${ }^{163}$ Só em 2006, entrou em vigor a Convenção para Salvaguarda do Património Cultural Imaterial, da UNESCO, aprovada no final de 2003.

${ }^{164} \mathrm{O}$ conceito de paisagem, surgido nos Países Baixos, no século XV, como «landskip» e abandonado durante cinquenta anos, foi reabilitado na década de 1980, quando se começou a pôr em causa o modelo de crescimento dominante e os seus impactos desastrosos para o ambiente, acontecendo algo idêntico com a noção de território, que passou também a estar na moda. As iniciativas políticas dos diferentes países europeus acabariam por inspirar uma política transnacional e produzir a Convenção Europeia da Paisagem, que Portugal ratificou em 2005.

${ }^{165}$ ROGER, 2000.
} 
natureza, polissémica; desde sua aparição nas línguas românicas, a palavra significa tanto 'uma extensão de país' como sua representação pictórica; e sua evolução reflete uma ambiguidade constitutiva entre o real e o imaginário, o objetivo e o subjetivo, o geográfico e o estético. Ela se envolve com questões tão complexas como a relação entre homem e mundo, natureza e cultura, arte e ciência, sensivel e sentido, indivíduo e comunidade, invenção e tradição... E a cada momento da história, essas questões surgem em novos termos ${ }^{166}$.

Desta forma, à visão inicial juntam-se outras noções de paisagem provenientes de áreas do conhecimento diversas e o conceito de paisagem ganha novas abordagens constituindo-se, concetualmente, como resultado de uma grafia da subjetividade sobre o mundo no qual se encontra expressa a marca do homem em todos os sentidos. O que obriga a refletir sobre os modos como a paisagem se organiza e é percecionada pelos sujeitos, e entrever esta questão como «um efeito cultural, um modo de ver e pensar identidades e subjetividades numa tensão que transita continuamente entre o dentro e o fora, a ipseidade e a alteridade, o visível e o invisível ${ }^{167}$.

Por sua vez, a noção de património afirmou-se junto do grande público nas décadas de 1970/80, num contexto de profundas transformações económicas e sociais na cultura ocidental. A partir dessa altura, e por indução, a conservação e a transmissão dos patrimónios (i)materiais passou a estar associada às questões da memória e da pertença identitária. Entretanto, a perda acelerada das marcas identitárias com que nos defrontamos, conduziu à situação de se considerar que «tudo é património». Ora, em história este pode hoje definir-se como a passagem de um património de estado e nacional (herdado) para um património de tipo social e comunitário (reivindicado). Por outro lado, ainda, à noção de que «tudo é património», é associada a ideia de «omni-paisagem» (Michael Jakob) o que conduziu a que em seu torno, entretanto, se construísse um importante setor da economia baseado no turismo cultural.

Importa assim ter em atenção as múltiplas metamorfoses da paisagem e os consequentes efeitos de sua patrimonialização ${ }^{168}$, designadamente à luz do desenvolvimento dos mais recentes conceitos de «paisagem cultural» ${ }^{169} \mathrm{e}$ "património cultural imaterial» ${ }^{170}$, em que se inscreve

\footnotetext{
${ }^{166}$ COLLOT et al., 1997.

${ }^{167}$ CUNHA, 2010.

168 SOEIRO et al., 2002: 147-163.

${ }^{169}$ O termo «paisagem cultural», traduzido de «cultural landscape», foi primeiro usado pelo geógrafo alemão Friedrich Ratzel em 1890, significando «paisagem modificada pela ação humana». Em 1920, outro geógrafo, Carl O. Sauer especifica que na modificação da paisagem pela cultura, esta devia ser entendida como o agente atuando sobre o meio (natureza) de cujo resultado deriva a paisagem cultural (WU, 2010; SAUER, 1925). A partir dos anos 1960, o conceito extravasou o âmbito da geografia humana passando a ser usado em várias disciplinas (antropologia, gestão ambiental, etc.) e a sua definição contestada pela vastidão e fluidez concetual. O seu interesse ressurge nos anos 1990 quando a UNESCO, na International Convention for the Protection of the World's Cultural and Natural Heritage, considera a paisagem cultural como mais uma espécie de bens a classificar na categoria de Património da Humanidade (UNESCO, 1996), apresentando, para fins operacionais, orientações específicas e categorias de paisagem cultural intencionalmente criada e concebida pelo homem, evolutiva, relíquia ou fóssil, viva e associativa.

${ }^{170}$ A Convenção para Salvaguarda do Património Cultural Imaterial, da UNESCO, em vigor desde 2006, definiu que o património cultural imaterial não se resume apenas aos monumentos e coleções de objetos, mas abrange também as tradições, expressões de vida, conhecimentos e aptidões que constituem a cultura e a identidade de cada país.
} 
a região duriense, em particular o Alto Douro Vinhateiro, paisagem cultural e património da humanidade.

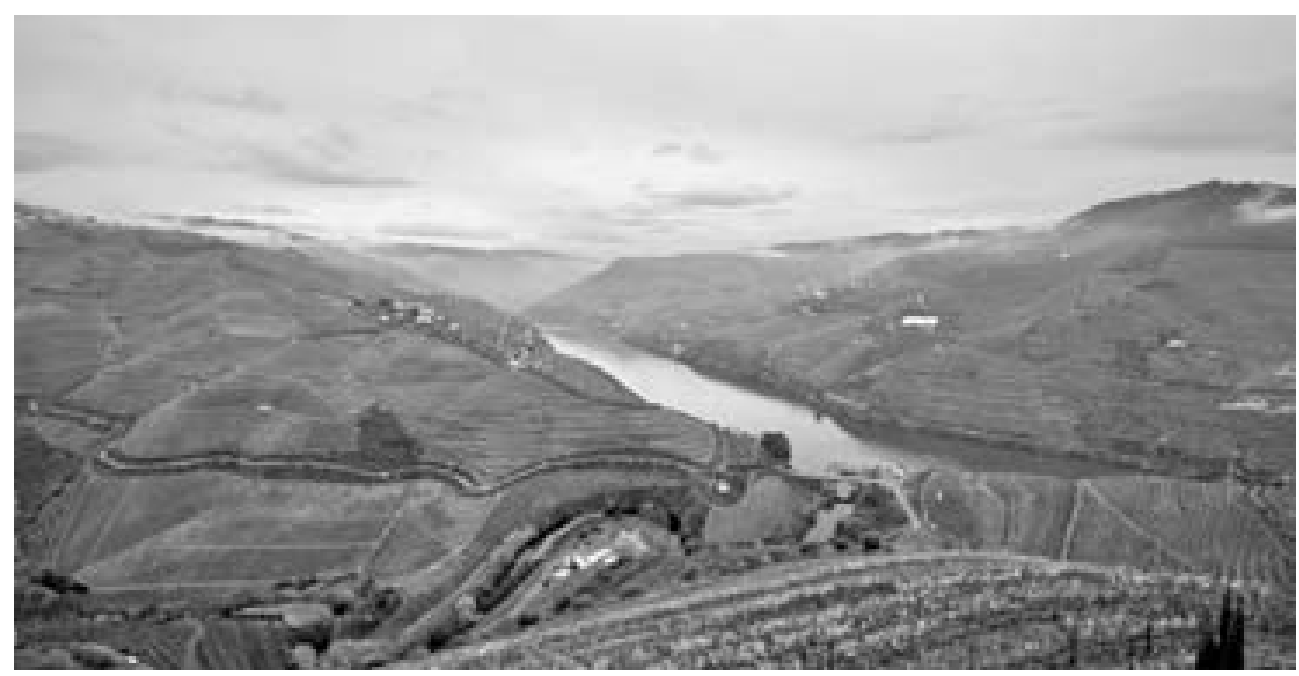

Fig. 29. Paisagem de referência Foz Tua — Douro Património Mundial ${ }^{171}$

\subsection{MATRIZ E ALICERCES DA PAISAGEM CULTURAL VINHATEIRA DO DOURO}

Como era a paisagem duriense, com centenas de quilómetros de socalcos, há pouco mais de 100 anos?

Encontra-se resposta em O Douro Ilustrado (1876) livro amplamente citado e então pioneiro que se pode integrar na corrente da «literatura de viagens», destinada ao comum dos leitores e de grande expansão, a partir de meados do século XVIII. Aí se destacam relatos impressivos da paisagem duriense vinhateira, que revelam não só, uma sensibilidade romântica, comum à época, em obras similares de autores estrangeiros sobre Portugal, na peugada da longa tradição inglesa de relatos de viagem, que se vão tornando mais frequentes ${ }^{172}$, mas sobretudo um notável e então pouco vulgar caráter técnico e científico, neste tipo de descrições gerais de viagens onde se encontra uma panorâmica das características físicas, económicas e sociais do país em várias épocas.

Se é grande fama que ao nosso Douro alcançaram os seus preciosos vinhos; se eles como os de Falerno, de Siracusa e de Chipre, nas antigas eras, levaram o nome do território em que se geram a todas as regiões do globo, onde florescem os hábitos elegantes da vida

\footnotetext{
${ }^{171}$ Imagem disponível em <https://www.google.pt/search?q=paisagem + de+referencia + foztua + douro + patri monio + mundial + quinta + do + tua\&source $=\operatorname{lnms\& tbm}=$ isch\&sa $=$ X\&ved $=0$ ahUKEwih2ObW5uHUAhVLbR QKHbJ HC9w4ChD8BQg GKAE\&biw=1366\&bih=662\#imgrc=a9Rv53MKXXIrSM>. [Consulta realizada em 12/5/2015]. ${ }^{172}$ MATOS, 2012: 59-73.
} 
europeia, é contudo bem certo que a fisionomia original e quase misteriosa desse país privilegiado pela natureza, é ainda hoje quase desconhecida.

Eram ainda bem raros os viajantes que ainda há pouco se aventuravam a percorrer em toda a sua extensão, as regiões que o Douro atravessa dentro do território português.

A aspereza e inviabilidade dos montes, que na sua máxima parte as constituem, e a dificil e perigosa navegação do rio que lhes dá o nome, faziam arriscada a viagem, antes que a abertura de algumas estradas, há poucos anos construídas, houvessem franqueado o acesso à parte mais rica e populosa deste notável país.

Frequentavam apenas uma porção limitada deste território alguns comerciantes ou os seus comissários, preocupados unicamente com a aquisição do valioso produto que ali se cria.

As tradições e as notícias transmitidas de individuo a individuo era o único roteiro dos comerciantes e dos viajantes que os interesses ou a curiosidade levavam àquelas paragens.

Um só que eu saiba dentro dos próprios habitantes do país do Douro - F.P. Rebelo da Fonseca - empreendeu [em 1848] uma descrição corográfica daquela parte do país, que no seu tempo constituía, com o fim de abastecer o comércio de exportação, a circunscrição privilegiada para a cultura da vinha; circunscrição que ainda hoje é conhecida com o nome de Alto Douro: porém nesse trabalho mais estatístico do que descritivo, mal se divisam as feições e lineamentos dos sítios, e o aspeto daquelas paisagens, que ora nos surpreendem pela arrogância das suas formas, ora nos encantam pela graça dos seus contornos e pela beleza da sua esplêndida vegetação $[\ldots]^{173}$.

O objetivo do Visconde de Vila Maior, em O Douro Ilustrado, assim iniciado, com um sumário «estado da arte» da matéria e uma impressiva representação naturalista da paisagem duriense, foi traçar um quadro do país vinhateiro que pudesse satisfazer a curiosidade pública... publicando uma série de vistas traçadas com o auxílio da fotografia, então no início, ... e provocar a curiosidade do viajante em todo o percurso do Douro desde que ele entra em território português até que se perde no Oceano ${ }^{174}$.

Inicia depois a narrativa pormenorizada de sua viagem fluvial a partir de Barca de Alva, descrevendo a par e passo o que de mais notável e de maior relevo, se pode encontrar, numa e noutra margem, opção para comodidade do leitor, convidando este a demorar-se no exame das coisas e dos trabalhos de vitivinicultura, que mais o possam interessar no decurso do «longo, tortuoso e acidentado vale» do Douro. Interrompe, entretanto, a descrição dessa viagem «revelando-se as belezas da paisagem, quase sucessiva e conjuntamente com a riqueza dos prédios», para traçar uma apresentação geográfica e histórica, geológica e climatérica da região, seguida de posterior análise económica da agricultura e comércio do Alto Douro, desde o século XVII, justificando assim a sua celebridade, e analisa, criticamente, o significado da progressiva

\footnotetext{
${ }^{173}$ VILA MAIOR, 1876: 1-2. Procedeu-se à atualização da grafia original em todos os excertos que se seguem, retirados da $1 .^{\text {a }}$ edição da obra O Douro Ilustrado.

${ }^{174}$ VILA MAIOR, 1876: 3-4.
} 
expansão da vinha e das quintas, antes, durante e depois da demarcação pombalina. Prossegue ao longo de todo o curso e vale tortuoso do rio Douro, fazendo demoradas e curiosas incursões por ambas as margens e pelos pequenos vales dos seus afluentes, tudo técnica e cientificamente explicado, em suas características essenciais e numa pluralidade de perspetivas, sempre tornando patente, em sua historicidade, criticamente mobilizada, a riqueza dominante da cultura da vinha e produção do vinho genuíno da região, de excecional qualidade e reputação.

Após esta sólida apresentação da região duriense, debruça-se com demora e minúcia, sobre os processos da cultura da vinha e fabrico do vinho do Porto, realçando a sua originalidade, em cuja análise nos interessa deter-nos pela sua função incontornável de produção (i)material da paisagem histórica do Douro.

A cultura da vinha e a fabricação do vinho que todos conhecem com o nome de vinho do Porto, é a principal e constante ocupação e preocupação dos habitantes do Douro. Ignoramos completamente como e por quem foi introduzida no Alto Douro a cultura da vinha e se os atuais processos e regras que a governam foram importadas de outras regiões ou criados aqui pelos esforços e inteligência dos próprios cultivadores. O que é verdade é que nestes processos há muita coisa original, que se não encontra nas demais regiões vinícolas nossas ou estrangeiras; mas muitas outras coisas práticas que vemos adotadas desde remotas épocas anteriores à colonização vinícola do Douro, em outros países, foram seguramente transportadas para aqui [...]. Seguindo a ordem lógica e natural dos factos é da plantação da vinha que primeiro nos devemos ocupar $[\ldots]^{175}$.

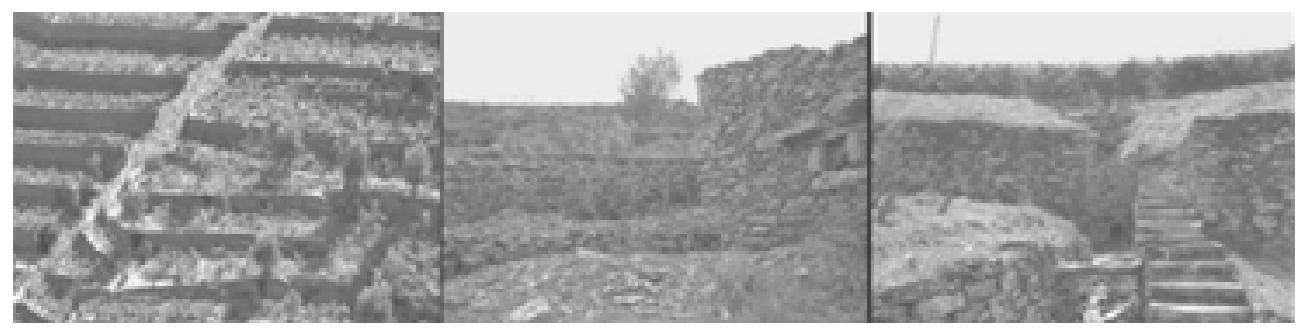

Fig. 30. Imagens de geios ou calços e património vernacular ${ }^{176}$

Fonte: Imagem inserta em texto da Direção Regional da Agricultura e Pescas.

\subsection{A CONSTRUÇÃO INDISPENSÁVEL DOS GEIOS: DAS FRAGOSAS ENCOSTAS A UM IMENSO ANFITEATRO}

Ou de como o gigantesco e meticuloso trabalho de portugueses e galegos se incorporou na paisagem duriense, afeiçoando natureza e cultura, tradições, práticas, técnicas e saberes que produziram a paisagem cultural e património (i)material do Douro Vinhateiro, com base

\footnotetext{
${ }^{175}$ VILA MAIOR, 1876: 48-49.

${ }^{176}$ Disponível em <http://www.drapn.min-agricultura.pt/drapn/ela_dv/eladv_index.html $>$. [Consulta realizada em $13 / 10 / 2013]$.
} 
num sistema de construção em mosaico, suporte fundacional inevitavelmente originado pelo declive fragoso do terreno e a necessidade de controlo dos efeitos das chuvas torrenciais.

Nessa medida os geios ou socalcos durienses configuram uma carga simbólica e metafórica de grande alcance interpretativo pelo que o seu potencial uso cognitivo se pôde já aplicar ao estudo da realidade social e cultural do quotidiano histórico descrito sob forma literária, do trabalho das populações anónimas de uma freguesia central do núcleo inicial da Região Vinhateira e Demarcada do Douro (Santo Adrião de Sever do concelho de Santa Marta de Penaguião) ${ }^{177}$.

A construção secular dos socalcos, fundação dos alicerces da paisagem (i)material do Douro - cultural, histórica, humanizada e tecnológica — , torna-se-nos visível, nas pormenorizadas descrições do Visconde de Vila Maior que se seguem, como um portentoso trabalho de perfeição e sabedoria ancestral que evoca os fundamentos das modernas topografia e engenharia de agrimensura. Os seus relatos técnicos combinam o conhecimento comum do quotidiano da paisagem, localizado e qualitativo, com o conhecimento científico e técnico da produção histórica e social da paisagem que aqui nos surge claramente como «dado não adquirido».

É o que se pode observar daqui em diante pelos excertos transcritos de texto do autor, antecedidos pelo nosso enunciado das sucessivas operações que descreve.

O plantador no Douro não tem à sua disposição - em regra geral — senão encostas mais ou menos ingremes e mais ou menos fragosas para nelas poder cultivar a vinha. Esta fatal disposição do terreno obrigou-o a criar esse modo especial de plantação que dá às suas vinhas o aspeto singular e surpreendente de um imenso anfiteatro em cujos degraus vegeta e frutifica a videira.

- A armação geométrica e rigorosa do terreno, um minucioso e sazonal trabalho artesanal (outubro a abril):

Formam-se estes degraus - que no Douro se chamam calços ou geios - ao passo que se vai fazendo a plantação. Abrem-se para esse fim nas encostas, e em direção paralela ao horizonte, os valados ou valeiras em que se há de fazer o muro de suporte do calço e em que se há de plantar uma fileira de cepas. As dimensões em largura e profundidade que estas valeiras devem ter, podem e devem variar segundo a inclinação e fragura ou aspereza do terreno. Se o declive não é grande nem a pedra muita, dá-se às valeiras a largura de 1m,54 e a profundidade de $0, m 99$ ou $1 \mathrm{~m}, 30[\ldots]^{178}$.

\footnotetext{
${ }^{177}$ LAGE \& LAGE 2005.

${ }^{178}$ VILA MAIOR, 1876: 50.
} 
- Levantamento de muros ou calços, colocação horizontal de socalcos e abertura de valados:

Nos primeiros 0,m 66 da largura, contados da parte inferior do declive se levanta a parede, cuja altura se regula conforme as condições do terreno, tendo em vista que o que se pretende é apoiar nessa parede um socalco ou terrado aproximadamente horizontal. Os restantes $0, m 88$ da largura, que ficam para a parte superior da ladeira são destinados à plantação do bacelo. Nos grandes declives é necessário rasgar mais larga a valeira e fazê-la mais profunda à parte de cima. Quando o terreno é fragoso também a abertura deve ser mais larga, porque tendo de acomodar mais pedra devem necessariamente ser mais amplas as dimensões da parede. O comprimento das valeiras é determinado pelas condições espaciais do terreno.

$\mathrm{Na}$ adoção deste sistema tem-se principalmente em vista garantir às plantas a terra de que elas carecem para prosperar. Neste pressuposto devem dispor-se as cousas de modo que as águas das chuvas, tão frequentemente torrenciais neste clima, não arrastem as terras desarraigando as plantas.

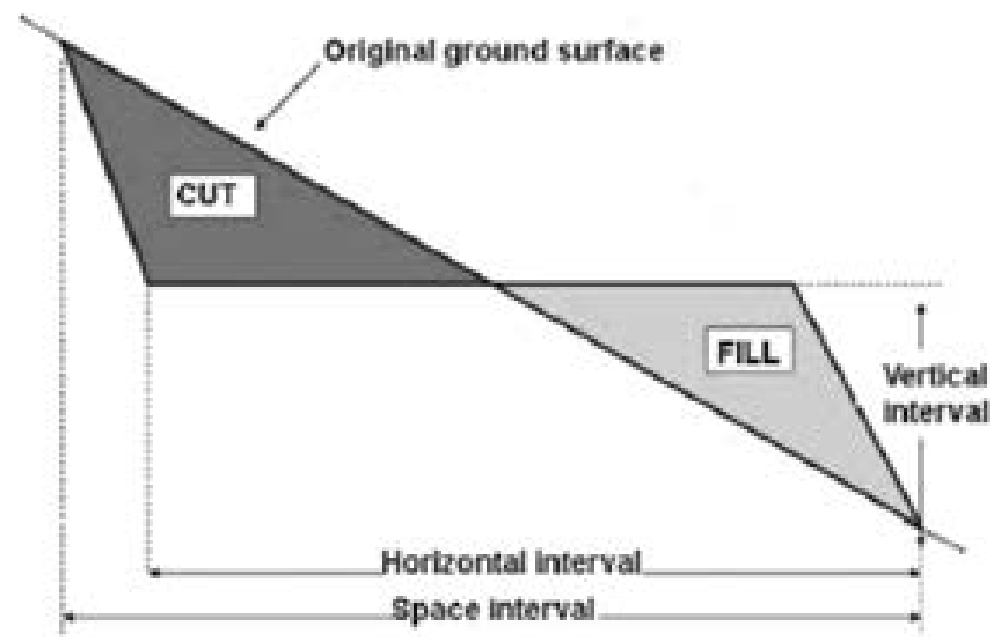

Fig. 31. Estrutura dos socalcos

Fonte:VIEIRA et al., 2103

- Obras de plantação em geios, disposição do bacelo com «rasgosuchio» e escombramento e usos da enxada:

A plantação faz-se em linha dispondo os bacelos separados entre si por intervalos de $0, m 77$ a 1metro. Usam unhar o bacelo, isto é, curvá-lo na extremidade inferior e assentar sobre o fundo da valeira a curvatura, ficando as pontas superiores dos bacelos para a parte 
da ladeira, e a abertura da curva para a parte de baixo. Mantem-se a haste na posição vertical, segurando-a com terra, que se tira do bordo superior da valeira, fazendo neste bordo com as enxadas um rasgo longitudinal de $0, m 66$ de largura com toda a altura da valeira e em todo o comprimento dela. Chama-se a este rasgo suchio varrido, e tem ele por fim tornar móvel e permeável uma faixa de terra ao longo da fileira dos bacelos, ficando estes no meio do solo aberto e revolvido. Completa-se ainda o movimento da terra cavando mais outra faixa de 0,m66 de largo sobre 0,m66 de fundo. Este outro corte tem o nome de escombramento ou escomoramento ${ }^{179}$.

- Dificuldades e custos:

Em cada socalco ou terrado podem plantar-se uma ou mais fileiras, se houver nele largura, contanto que sejam paralelas e razoavelmente distantes umas das outras.

Feitas estas operações e arrasado o terreno, para encher as valeiras, deve ficar plana e horizontal a superfície do geio, ficando também as fileiras dos bacelos regulares e equidistantes.

O custo das plantações, sempre muito elevado nas vinhas do Douro, varia bastante segundo as dificuldades do terreno. Nalgumas vinhas custou a plantação de um milheiro de bacelos $40 \$ 000$ reis, e noutras mais de $200 \$ 000$ reis. A natureza do terreno, a perfeição do trabalho na construção dos muros, a aptidão dos operários, além de outras condições, muitas vezes imprevistas, influem por tal modo no preço destas obras que muitas vezes se apresentam diferenças tão consideráveis entre duas plantações, que à primeira vista parecem semelhantes, que dificilmente se explicam.

- Modalidades de trabalho: empreitada e jornal e trabalhadores/pedreiros: naturais e galegos:

A plantação do bacelo e os trabalhos correlativos são geralmente feitos de empreitada, e, regra geral, os empreiteiros são galegos.

São três as operações principais deste serviço: $1 .^{a}$ a abertura dos valados; $2 .^{a}$ a plantação propriamente dita, com o suchiamento e escombramento; $3 .^{a}$ a construção dos calços ou muros de suporte. As duas primeiras fazem sempre o objeto de uma única empreitada, que se deve computar equivalente a 100 jornais por cada mil bacelos, pagando-se estes pelo duplo do preço corrente e mais uma certa porção de comestíveis. A 3. a também se pode fazer por empreitada; mas atendendo à dificuldade de fazer previamente as medições exatas neste género de trabalhos, preferem muitos mandar executar as obras a jornallio.

\footnotetext{
${ }^{179}$ VILA MAIOR, 1876: 51
}

${ }^{180}$ VILA MAIOR, 1876: 52. 
Os pedreiros que nelas trabalham são arraianos da Galiza, das imediações de Melgaço, cujos bandos, como de aves de arribação, aparecem por estes sítios regular e periodicamente no mês de outubro para de novo se ausentarem para as montanhas no mês de abril seguinte.

- Preços do sistema de plantação em geios:

Em vista de tudo quanto a este respeito temos dito reconhecer-se-á o elevado preço de uma plantação de vinha nas encostas do Douro. Com o sistema - aliás indispensável na maioria dos casos - da plantação em geios, um hectare regularmente plantado não pode levar mais de 4 a 5:000 bacelos, e isto atendendo ainda a algumas modificações que na sua inclinação apresentam as ladeiras em muitos pontos, onde dispensando-se os geios, se podem aproximar mais as linhas da plantação. Em todo o caso, a despesa da plantação de um hectare de vinha nas ladeiras do Douro raras vezes será inferior a $450 \$ 000$ ou $500 \$ 00$ reis.

- Preenchimento de falhas de bacelos e renovação em camas da vinha nas encostas durienses, substituição de castas de videiras, cameação, enxertia e demais trabalhos:

Como na plantação há sempre um certo número de bacelos que não prendem, e que por esse e outros motivos se originam falhas que convém preencher, é bem que digamos como se executa este trabalho. Não falando na substituição por novos bacelos no ano mediato, $e$ que por simples nada tem de particular, descreveremos o método mais geral de renovação da vinha pela mergulhia em camas, quase sempre precedida de enxertia, principalmente quando se pretende substituir uma casta de videira por outra. Este método é muito seguido no douro e tido em conta de excelente e superior a todos.

As camas para mergulhia são covas que se abrem, quanto é possível, na mesma direção do alinhamento das plantas a partir da cepa anteriormente enxertada, cujas varas se querem mergulhar, e para o lado $\mathrm{em}^{181}$ que ela mais facilmente se pode tombar e em que haja falha ou espaço despovoado de videiras. As dimensões médias para a abertura destas covas são: $2 m$ de comprimento e 0,m88 de largura e de profundidade. Nas encostas rápidas e nos terrenos áridos a profundidade é sempre maior do que os $0, m 88$.

A cepa que se quer camear, ocupa a extremidade da cova; tendo-se-lhe descoberto e desembaraçado as raizes laterais, mas deixando intacta a principal. Das suas varas conservam-se ordinariamente três, as mais longas e bem conformadas, que serão as que devem fornecer três novos indivíduos. Deita-se então, cautelosamente, a cepa a longo da cova, e as três varas escolhidas levantam-se sucessivamente, curvando-as até as tornar verticais; primeiro, a mais curta, depois a imediata à distância de 0,m66 ou 0,m88 do lugar

${ }^{181}$ VILA MAIOR, 1876: 53. 
em que se levantou a primeira, e finalmente a igual distância a terceira que é a mais longa, segurando-se todas pela curvatura no fundo da cova com a terra, que se tira da parte superior do solo, e que se calca sobre a porção horizontal das varas. Em torno da cova se cortam ainda com enxadas $0, m 22$ da terra e com ela se enche parte da mesma cova. Nas encostas nunca se enchem totalmente as covas, em que se faz a mergulhia.

Para deixar uma espécie de bacia em que se possam recolher as águas da chuva, que descendo das terras mais elevadas ali depositam um lodo ténue e fertilizante.

A antiga cepa fica inteiramente sepultada na cova, e só do meio se veem surgir as pontas das varas mergulhadas, a que se deixam apenas dois olhos cortando-lhe as extremidades.

A abertura das covas e a cameação, fazem-se ordinariamente por empreitada, como se faz a plantação do bacelo, ficando sempre o milheiro de plantas lançadas um pouco mais caro do que um milheiro de bacelo plantado.

A enxertia faz-se no Douro, como em toda a parte ${ }^{182}$, no princípio da primavera, isto é, desde o fim de fevereiro ate que a arrebentação da vinha se manifesta.

A abertura das covas e a cameação praticam-se desde o fim do outono podendo prolongar-se por todo o inverno.

O granjeio anual da vinha consta das seguintes operações - a escava, a poda, a cava a monte, a empa ou erguida, a redra ou cava rasa, e eventualmente o enxoframento, a cata dos insetos, e a desfolha. A vindima fecha os serviços da vinha e liga-se com os do lagar.

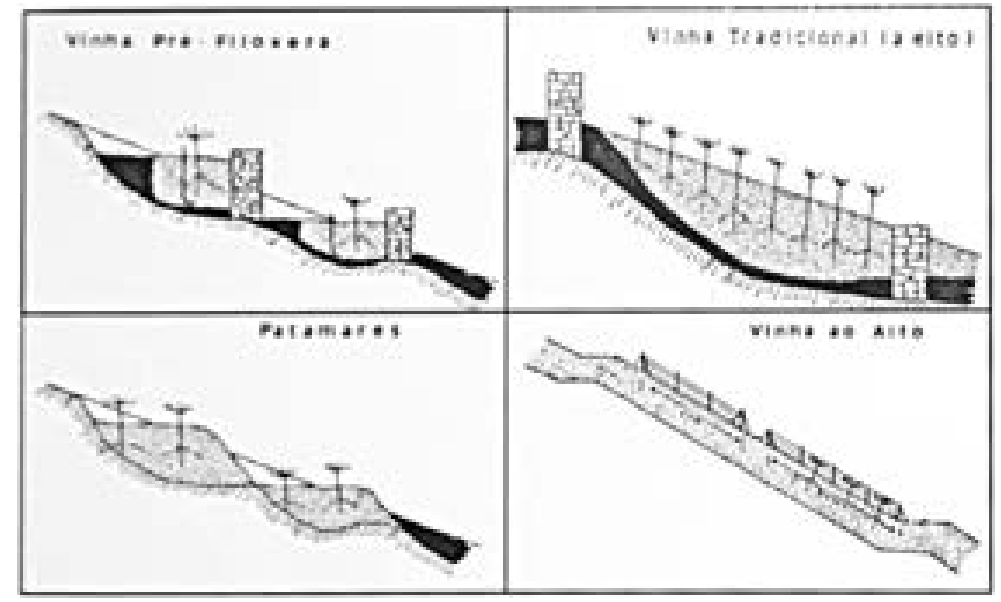

Fig. 32. Sucessivas modalidades de armação do terreno (Almeida, 1990) Fonte: VIEIRA et al., 2103

A essas operações juntou-se depois da invasão do oídio, o enxoframento regular duas vezes ao ano.

${ }^{182}$ VILA MAIOR, 1876: 54. 
Segue-se ainda a descrição de natureza antropológica das operações de granjeio anual da vinha que a maioria dos lavradores fazia, então, no Douro às suas vinhas, ao longo do ano, as quais contribuíram não só para conformar, matricialmente, os alicerces da paisagem, mas também para lhe delinear os contornos inclusive cromáticos, bem como a diversidade de configurações paisagísticas da região duriense.

No seu conjunto, estes relatos de grande especificidade e pormenor técnicos incorporados de um continuum cumulativo e diversificado de saberes, práticas e culturas evidenciam claramente as duas vertentes essenciais da paisagem do Douro Vinhateiro - a sua natureza de paisagem cultural viva e evolutiva e de património (i)material intrinsecamente associado.

\subsection{O ADV, PAISAGEM HISTÓRICA E PATRIMÓNIO CULTURAL DA HUMANIDADE}

A harmonia equilibrada da paisagem do ADV dependeu, historicamente, de uma sabedoria ancestral de gestão artesanal de três fatores essenciais: declive elevado e fragoso do terreno; escassez de solo e água; dinâmicas naturais que garantiram à paisagem uma originalidade cultural polimorfa, uma «natureza» de mosaico multiforme e policromático, alternando áreas agrícolas de matas e povoamentos florestais, o que lhe confere grande riqueza, e notável capacidade de sustentação.

Considerando então, ainda que fugazmente, os riscos a que a mesma tem vindo a ser sujeita e atendendo a algumas orientações do Plano Intermunicipal de Ordenamento do Território, tal como referido por Natália Fauvrelle ${ }^{183}$, o controlo dos principais problemas passa hoje por: a) eficientes sistemas de drenagem com recuperação de práticas tradicionais e adoção de soluções sem impacto na paisagem; b) estudo da viabilidade de novos tipos de armação do terreno (em patamares, forma atualmente mais corrente com grande evolução na sua organização, vinha ao alto, micro patamares que permitem a conservação de muros pré-filoxéricos, etc.).

No que concerne à conservação da polimorfia da paisagem entende-se ser necessário:

a) a definição de um paradigma de qualidade para a conservação da polimorfia da paisagem do ADV;

b) planos de gestão e salvaguarda das explorações vinícolas que contemplem o plantio da vinha, as áreas de mato e património vernacular, bem como a atenção às dinâmicas naturais entre a manutenção de espaços de produção e proteção da paisagem;

c) não destruição de muros de pedra, edifícios vernáculos, calçadas de pedra, mortórios, núcleos de vegetação (sub)arbórea sem justificação em termos paisagísticos.

Propusemo-nos em síntese, redescobrir a cultura intrincada na natureza, seguindo Bruno Latour, referência incontornável dos estudos sociais das ciências e das técnicas que

${ }^{183}$ FAUVRELLE, 2007: 87-96. 
possibilitam uma análise social pertinente não só do autor Visconde de Vila Maior e sua obra, mas também dos socalcos do Douro, enquanto objeto sociotécnico conformador dos alicerces de uma paisagem cultural histórica, património da humanidade. Neste contexto O Douro Ilustrado, obra de referência datada, surge-nos como fonte para o conhecimento e a vivência experiencial da paisagem cultural do Douro Vinhateiro, a partir dos modos como foi documentalmente representada, no século XIX, em suas múltiplas dimensões «naturais», «paisagísticas», históricas, sociais, económicas e técnicas.

Qual genealogia da paisagem vinhateira duriense, permite perceber, revelando-lhe a tessitura de redes locais de seus «rastros», algumas das mais decisivas (i)materialidades deste património e paisagem cultural, em que se destaca que não há senão híbridos de natureza e de cultura que se escalonam entre os dois extremos ${ }^{184}$.

Pensa-se ter assim deixado sugerida a necessidade de desocultar mediações entre as experiências e experimentações concretas e as generalizações e abstrações da paisagem, no que se refere ao Douro Vinhateiro, tal como esta paisagem e património podem e devem ser vistos, também, através do conhecimento das técnicas, saberes e práticas de sua construção histórica, hoje ocultas, mas que continuam a conferir-lhe o seu especial fascínio.

\footnotetext{
${ }^{184}$ RHEINBERGER, 2013.
} 


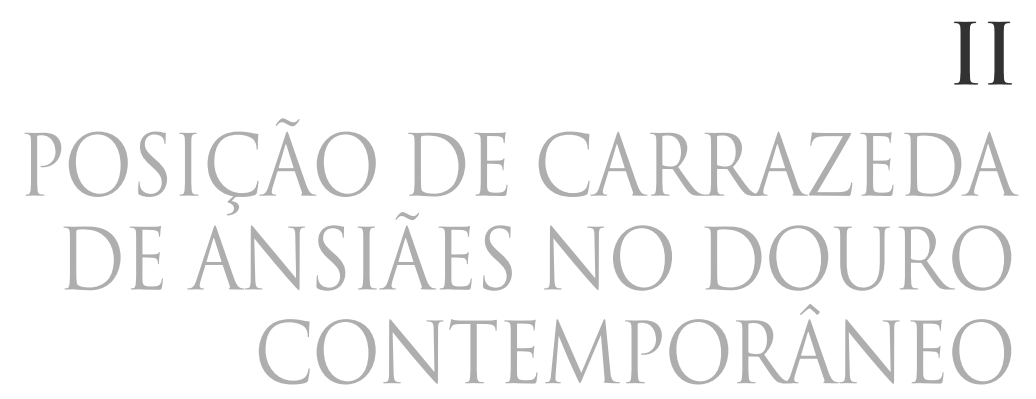




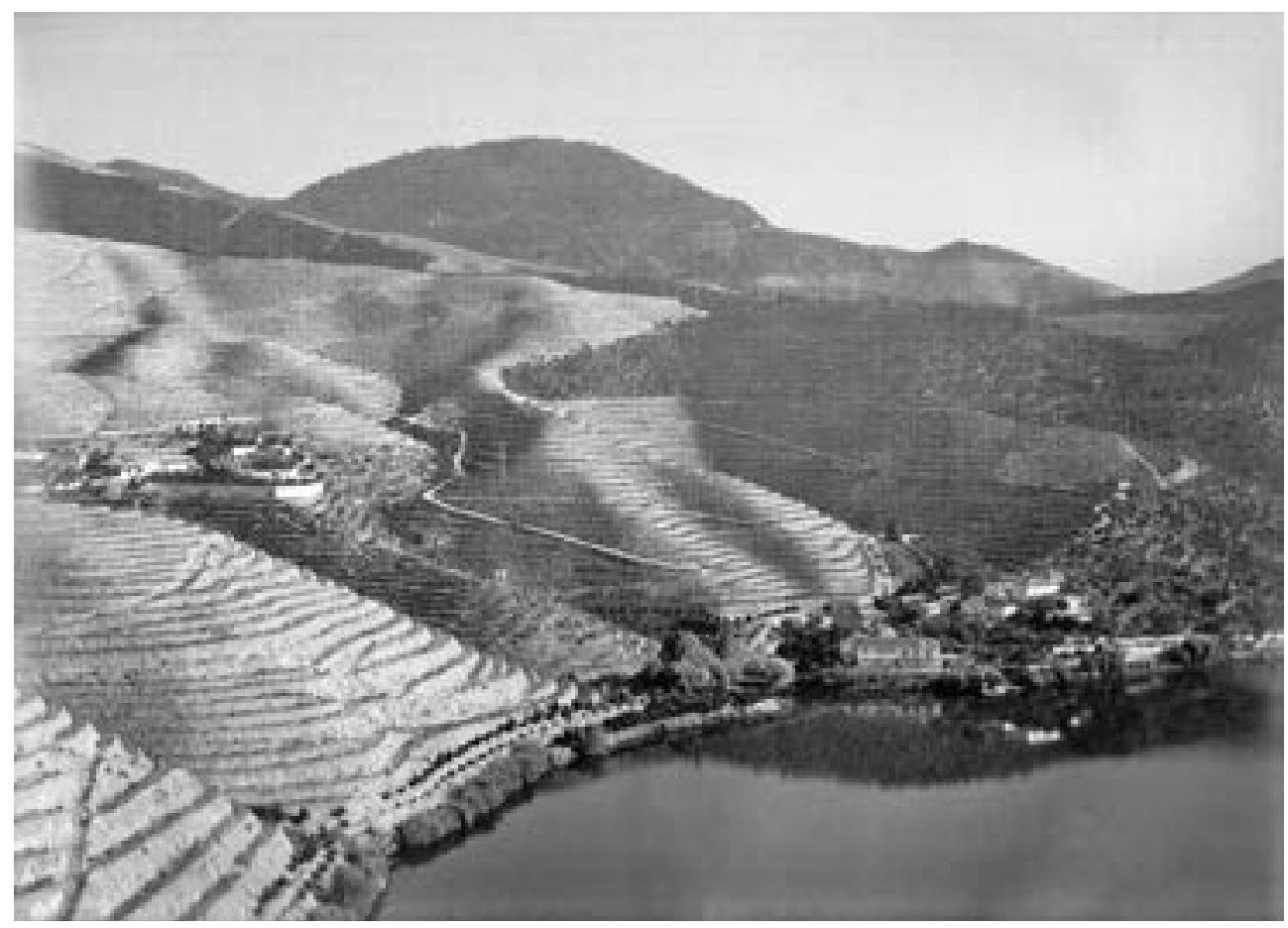

Fig. 33. Quinta dos Canais e Quinta Canaes/Bartol — Beira Grande, Carrazeda Foto: José M. Lopes

Nesta segunda parte em que se visa estabelecer, de modo mais concreto, o estudo de caso de Carrazeda de Ansiães como produtor de vinho do Porto, recentra-se a abordagem histórica deste concelho na Região Demarcada do Douro, a partir da transição da Monarquia para a I República num contexto político-ideológico de matriz republicana em que se acentuou a defesa da denominação de origem Douro e da marca «Vinho do Porto».

O movimento político-ideológico republicano, de génese multifacetada, constituiu-se ao longo da viragem do século XIX para o século XX na base angular da mudança do regime monárquico, tentando mobilizar trabalhadores e setores sociais descontentes com a governação monárquica. Pretendendo construir um bloco social nacional apostado em mobilizar o povo português no sentido do futuro, encontrou plena adesão e justificação, como projeto alternativo ao status quo monárquico. Nos seus eixos fundamentais, as reformas preconizadas, simultaneamente, deveriam obedecer à organização dos poderes do Estado (legislativo, executivo e judicial) e à fixação das garantias individuais (liberdades essenciais, políticas e civis). Foram introduzidos elementos importantes no campo jurídico, ideológico, económico e, mesmo num sentido social progressivo (a melhoria da condição das mulheres e das crianças, cooperativismo, etc.), pugnando pela extinção das estruturas, hábitos, ideias e comportamentos que se consideravam como resquícios do Antigo Regime. A questão religiosa 
surge crescente e criticamente articulada com a questão política e com a opressão económica e social. Na primeira década do século XX, a propaganda republicana foi semeando um imaginário social em que o ideal republicano consubstanciava, ideologicamente, uma espécie de síntese entre a social-democracia à alemã e o respeito pela pluralidade dos interesses à inglesa. A ideia republicana da construção de um Homem Novo, garantia dessa nova ordem societária, pressupunha uma alteração total no plano institucional, uma revolução produtora e reprodutora de novos ritos e valores laicos, baseados na ciência, na moral e na educação cívica-solidária..., onde a escola e a educação, espaços de uma nova sociabilidade, eram essenciais $^{185}$.

Iremos encontrar sinais desta ambiência político-ideológica ${ }^{186}$ mais adiante, por exemplo quando nos referimos à forte adesão nacional às numerosas subscrições de solidariedade promovidas pela imprensa para com a profunda e grave «Miséria Duriense» associada à candente «Questão do Douro», nos finais da Monarquia e início da República, com a Região Demarcada do Douro em processo de transição do livre cambismo para o protecionismo ${ }^{187} \mathrm{e}$ novo modelo institucional.

Analisam-se as implicações e significado histórico da redefinição e alargamento da Região Demarcada do Douro com as novas demarcações de João Franco e Ferreira do Amaral (1907-08), a ação da Comissão de Viticultura da Região do Douro, nova entidade reguladora, em particular na defesa da denominação de origem Douro e marca Porto, bem como as representações às Cortes dos viticultores, no final da Monarquia, os tumultos sociais de 1910 e correspondentes impactos no concelho de Carrazeda, vilas vizinhas e, subsequentemente, de modo mais decisivo no núcleo histórico da região duriense.

Aborda-se o processo de organização económico-social e cultural de produtores, trabalhadores e unidades de produção de vinho do Porto, com destaque para algumas quintas, os efeitos da política reguladora e protecionista do Estado, o papel de firmas exportadoras, de elites locais e de outros atores sociais assim como a construção de identidades na emergência de uma identidade regional no contexto de grande turbulência social que culmina no célebre Motim de Lamego de 1915, acontecimento histórico de particular relevância na defesa nacional e internacional da denominação de origem Douro e da marca Porto. Este movimento de profundas raízes e implicações sociais na Região, abre para a afirmação da defesa dos interesses da Região Duriense pelo Movimento dos Paladinos do Douro em que se destaca, entre outros representantes regionais, a ação de Antão de Carvalho ${ }^{188}$, então um dos mais ilustres represen-

\footnotetext{
${ }^{185}$ CATROGA, 1989; CATROGA, 1991; SERRÃO, 1971.; SERRÃO, Joel; Marques, 1991.

${ }^{186}$ Visíveis também no emprego dos termos solidariedade e fraternidade presentes nas fórmulas protocolares de comunicação e despedimento final em documentos públicos e correspondência institucional.

${ }^{187}$ SEQUEIRA, 2006a.

${ }^{188}$ Advogado e jornalista, republicano convicto, com ideais fortes que o colocaram na linha da frente de inúmeras batalhas, Antão de Carvalho foi Presidente da Câmara Municipal do Peso da Régua, deputado republicano e figura importante da história contemporânea do Douro. Ver Carla Sequeira, designadamente: Antão de Carvalho, a República e o Alto Douro; Antão de Carvalho e os motins do Douro de 1914-1915; A oposição à Ditadura Militar e Estado Novo na Região Duriense (1926-1949); A acção e influência de Antão de Carvalho no republicanismo duriense.
} 
tantes da causa duriense, que foi Ministro da Agricultura de 19 de outubro a 16 de dezembro de 1921, período em que assina a nova demarcação da Região Duriense que em traços largos se mantém ainda atualmente.

Considerando o Douro Vinhateiro durante a I República, cuja evolução política, social e institucional se procura delinear num período mais abrangente entre os finais da Monarquia e o início do Estado Novo, em articulação com o contexto nacional, bem como a afirmação de protagonistas históricos, importantes personalidades pela forma como defenderam os interesses dos vitivinicultores durienses, cujo papel histórico importa ter em devida atenção.

Parte-se da observação das mais recentes demarcações da região duriense e da análise social da Questão do Douro de enorme repercussão a nível nacional, dados inclusive os conflitos de interesses entre esta e outras regiões vitivinícolas do país, com início no período de transição da Monarquia para a I República. Procuram-se compreender, em particular, os seus impactos locais e significado histórico específico e apresentam-se alguns dos principais resultados da investigação e análise parcelares empreendidas, de acordo com os seguintes tópicos:

- reconstituição histórica (caracterização económico-social, demográfica e cultural) e análise sociológica do concelho de Carrazeda de Ansiães reportadas a uma conjuntura em que a questão do Douro se tornara uma questão nacional, com uma abordagem ao significado sócio-histórico da sua integração na RDD, em 1907-1908, primeiro como concelho, e depois, ao nível de apenas algumas das suas freguesias ribeirinhas ${ }^{189}$;

- abordagem aos movimentos sociais e políticos registados em Carrazeda e concelhos vizinhos em 1907, 1909-1910 («representações» de elites locais à Câmara dos Pares e posteriores sublevações populares) contestação e resistência com prolongamento e afirmação plena no Motim de Lamego (1915), aproximando-nos, neste contexto histórico, da emergência e problemática de uma identidade regional e de identidades locais de natureza conjuntural/contextual, cujas dinâmicas de construção e afirmação específicas, se tentam qualificar;

- enumeração global das quintas durienses à época existentes em Carrazeda com destaque para três das quintas mais emblemáticas do concelho, já no período da República: Canais (Beira Grande), Zimbro (Castanheiro: Foz Tua e Ribalonga) e Chousa (Foz Tua), considerados casos-tipo do universo das 26 quintas registadas, entre 1927 e 1931, nos manifestos de produção entrados na CVRD;

- aproximação interpretativa à representatividade de Carrazeda produtor de vinho do Porto na Região Demarcada do Douro.

\footnotetext{
Disponíveis em <http://www.academia.edu>. [Consulta realizada em 17/1/2016]; Antão de Carvalho e a República no Douro. Porto: CITCEM, 2014.

${ }^{189}$ Das antigas 19 freguesias do concelho, reduzidas a 14 freguesias e uniões de freguesias em 2013, 7 situam-se na zona planáltica e 12 são freguesias ribeirinhas que se localizam 4 nas margens e encostas do rio Tua: Parambos, Pereiros, Pombal, Pinhal do Norte, e 8 na margem direita do rio Douro: Castanheiro do Norte, Ribalonga, Linhares, Beira Grande, Seixo de Ansiães, Lavandeira, Pinhal do Douro e Vilarinho da Castanheira.
} 
O interesse em analisar configurações históricas e sociais locais, a partir de uma escala local, mas num plano regional, nacional e internacional, é uma exigência que decorre do próprio objeto de estudo - o vinho do Porto, produto de mercado de exportação, com «denominação de origem» assegurada e «marca» de uma região e de um país com relevante protagonismo socioeconómico e cultural. A procura da representatividade do caso específico em estudo leva-nos a recorrer ao método de estudo de caso alargado o qual, pela «multiplicidade e profundidade das interações que o constituem», permite identificar «a amplitude das incidências estruturais que nele se denunciam», com o que se procurará opor à "generalização pela quantidade e uniformização, a generalização pela qualidade e pela exemplaridade» ${ }^{190}$. As vantagens deste método sociológico, quando comparadas com outros, podem resumir-se em quatro pontos fundamentais que o caracterizam: intersubjetividade (o observador é participante); processo (as observações são projetadas no tempo e no espaço permitindo uma perspetiva enquadradora; estruturação) permite atender às forças extra locais que moldam os acontecimentos e as situações; e reconstrução teórica (parte de um quadro teórico existente e procura descobrir anomalias e testar essa teoria) $)^{191}$.

Tendo assim subjacente uma moldura teórica transversal à história e à sociologia, que mais adiante se explicita e fundamenta (Parte IV, Capítulo 11) e ainda o quadro analítico do «conhecimento situado» ${ }^{192}$ visa-se então aqui um aprofundamento descritivo e analítico do objeto de investigação escolhido, suscetível de alargamento a objetos similares, preservando no entanto o seu caráter unitário e interpretando-o, comparativamente, na sua singularidade e no emaranhado de inter-relações que lhe subjazem.

\footnotetext{
${ }^{190}$ SANTOS, 1983. Desenvolve-se a análise e aplicação desta metodologia no Capítulo 11. Ver também LAGE, $1995: 136$.

${ }^{191}$ MENDES, 2005.

${ }^{192} \mathrm{O}$ "conhecimento situado», ou cognição situada, é construído na interação social e sobre a singularidade das situações. Ver explicitação do conceito na introdução a este livro.
} 


\section{CAPÍTULO 4. REDEFINIÇÃO DA REGIÃO DURIENSE. REGRESSO Å DEMARCAÇÃO E AO PROTECIONISMO REGIONAL}

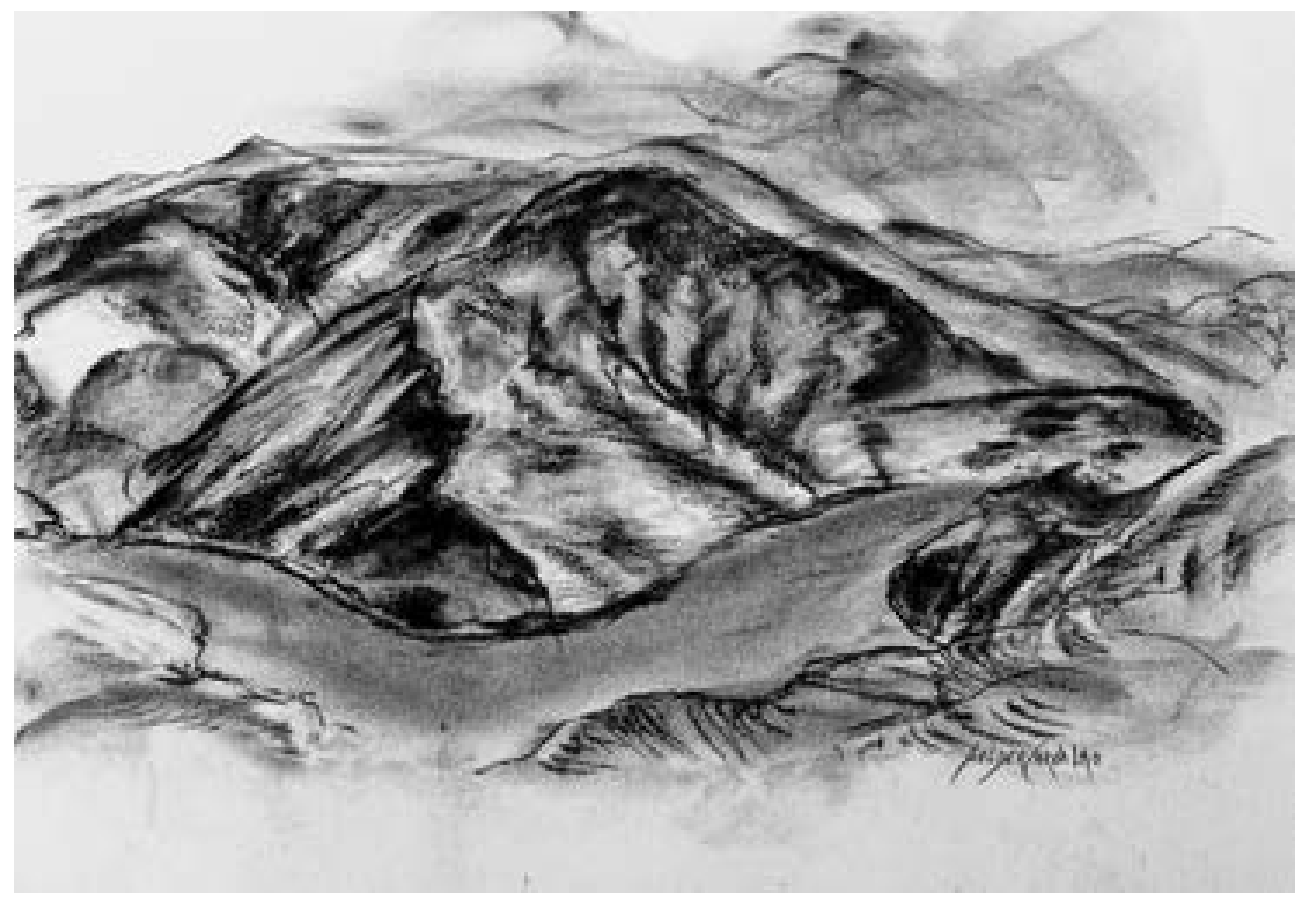

Fig. 34. Desenho do Douro na zona de Carrazeda de Ansiães Fonte: Escultor Hélder Carvalho

O ponto de viragem do Douro pombalino para o Douro Contemporâneo, com profundas mudanças verificadas na viticultura duriense, tem sido comumente situado na segunda metade de Oitocentos. A produção vitícola da área demarcada, seriamente, afetada pelas conhecidas doenças das videiras (oídio, míldio e filoxera) ${ }^{193}$, a miséria de pequenos e médios viticultores e as sucessivas compras e vendas de quintas durienses acabaram por provocar a maior e mais profunda alteração da propriedade fundiária duriense e uma autêntica revolução social no Douro.

No final do século XIX, era já bem visível o impacto da filoxera no reordenamento do espaço regional, que associado à instauração do regime de liberdade comercial (1865) constituiria, ao nível regional, a abertura efetiva da linha de demarcação, permitindo a expansão rápida do vinhedo no Douro Superior, onde o ataque da filoxera foi mais tardio e menos vio-

\footnotetext{
${ }^{193}$ A filoxera reduz a vinha a mortório. O oídio e o míldio podem ser curáveis com fitossanitários.
} 
lento. Surgiram novas práticas de armação do terreno, alteraram-se as práticas de plantação da vinha, selecionaram-se as melhores castas regionais para enxertia, difundiu-se a utilização racional de adubos, aperfeiçoaram-se os processos de vinificação.

\subsection{A QUESTÃO DURIENSE E A NOVA DEMARCAÇÃO DA REGIÃO VINHATEIRA (1907-1908)}

Na passagem do século XIX para o século XX, a Região Demarcada vivia intensamente a designada "Questão do Douro» frequentemente debatida nos círculos políticos e, na sua dimensão social, abundantemente denunciada na Imprensa.

$\mathrm{O}$ vinhedo duriense, reorganizado e estendendo-se a uma área muito maior da região, passou, no entanto, a partir de finais dos anos 1880, por uma outra e profunda crise comercial, tornando-se as imitações de vinho do Porto frequentes nos principais mercados, onde se vendiam os French Ports, os Hamburg Ports, os Tarragona Ports, por preços inferiores aos genuínos Port Wines (designação dada então pelos consumidores ingleses cujo gosto e preferência se inclinavam para estes vinhos mais doces, feitos em "prova doce», isto é, com adição de aguardente aos mostos antes de estar completa a sua fermentação).

A então assim designada «questão duriense», uma das maiores e graves crises da lavoura e do comércio dos vinhos do Douro, e em particular do vinho do Porto, rapidamente se tornou uma verdadeira "questão nacional», tendo começado a ser encarada, de forma prática, pelo Governo, a partir de 1906, na sequência da «forte pressão exercida pelas diversas Comissões de Defesa» que se alargam a toda a Região. Destaca-se aí a Comissão concelhia da Régua que defendia como necessidades prementes: «a restrição da barra» para evitar a exportação pela barra do Douro de vinho do Porto produzido com vinhos de outras proveniências, e a «criação da marca Porto exclusiva para os vinhos durienses». Procurava-se assim conseguir através da implementação de medidas legais, acabar com as fraudes e falsificações ${ }^{194}$, porque o produto ia-se desacreditando e a exportação diminuindo de volume e de valor, com grandes prejuízos para os interesses nacionais e os dos produtores do Douro Vinhateiro, cujos vinhos se vendiam então a preços irrisórios, já que quase todo o vinho do Porto exportado para os principais mercados, à época (que continuavam a ser a Inglaterra e o Brasil ${ }^{195}$ ), com exceção da Inglaterra e Noruega, não era proveniente do Alto Douro, sem que os governos parlamentares conseguissem tomar medidas eficazes para resolver esta situação calamitosa para a região duriense.

Os viticultores do Alto Douro fizeram então um grande comício que reuniu milhares de produtores, no Palácio de Cristal do Porto, onde pediram ao Governo a restituição do bónus do real de água, representativo de 5\$50 em pipa (valor por que se vendia em 1909 a

\footnotetext{
${ }^{194}$ SEQUEIRA, 2011.

${ }^{195}$ Mesmo o vinho exportado para o Brasil era feito em caixas a preços muito inferiores aos das boas marcas de vinhos de consumo do Alto Douro.
} 
pipa de vinho da colheita de 1908), o que acabaria por ser concedido. Já há 8 anos que não havia execuções fiscais na região duriense por falta de pagamento de contribuições prediais, na sequência de uma proposta de Teixeira de Sousa aprovada pelo parlamento, que isentava o proprietário do Alto Douro de execuções fiscais durante 10 anos.

Era esta a situação quando João Franco constituiu governo a que D. Carlos deu poderes ditatoriais.

João Franco enfrentou o problema do vinho do Porto no sentido de acabar com as fraudes que o comércio exportador estava praticando. Para esse fim foram tomadas várias disposições $[\ldots]^{196}$.

O Estado irá assim intervir então na Região para tentar debelar a insuportável situação de profunda crise e acentuada conflitualidade social existente no Douro, através da publicação de profusa legislação de sucessivos governos em que começam por destacar-se os normativos legais promulgados pelo ditador João Franco (1907), presidente do ministério do monarca D. Carlos, logo depois parcialmente alterados e complementados por novos diplomas legais e regulamentares do almirante Francisco Ferreira do Amaral (1908).

Com este regresso à Demarcação da Região Duriense (RDD), segundo um modelo inspirado nos princípios da demarcação original pombalina, alargou-se a área demarcada pela primeira vez e em definitivo a todo o Douro Superior.

Como se introduziu atrás, o Douro Superior que se havia entretanto desenvolvido com a navegabilidade do rio mais facilitada, continuava a intensificar a cultura da vinha e do vinho cuja comercialização se pôde vir a intensificar com novas e melhores acessibilidades e ligações ao exterior, proporcionadas pela abertura e funcionamento sobretudo da linha férrea do Douro (1872-1887) que representou uma alternativa à circulação fluvial no rio Douro.

Com a integração desta nova sub-região económica e cultural bem distinta do Alto Douro, e sem grande tradição de viticultura comercial, viria a confirmar-se a valorização progressiva da zona leste ao Cima Corgo, verificada ao longo do século XIX.

A Região Demarcada do Douro (RDD), na sequência dessas profundas alterações de 1907-1908 passou a estender-se até à fronteira com Espanha, atingindo limites que, independentemente de pequenas mudanças posteriores de outras demarcações, se irão manter até à atualidade.

Documenta-se a seguir a configuração territorial da área abrangida por essas duas novas demarcações da Região efetuadas, primeiro, a de João Franco, por concelho (1907), unidade alterada pela segunda, a de Ferreira do Amaral para a de freguesia (1908), com redução da área produtora de vinho do Porto, na sequência de forte contestação contra a inclusão na RDD de zonas de montanha consideradas impróprias para a produção de vinhos generosos.

${ }^{196}$ CARVALHAIS, 1937, p.14-15. 


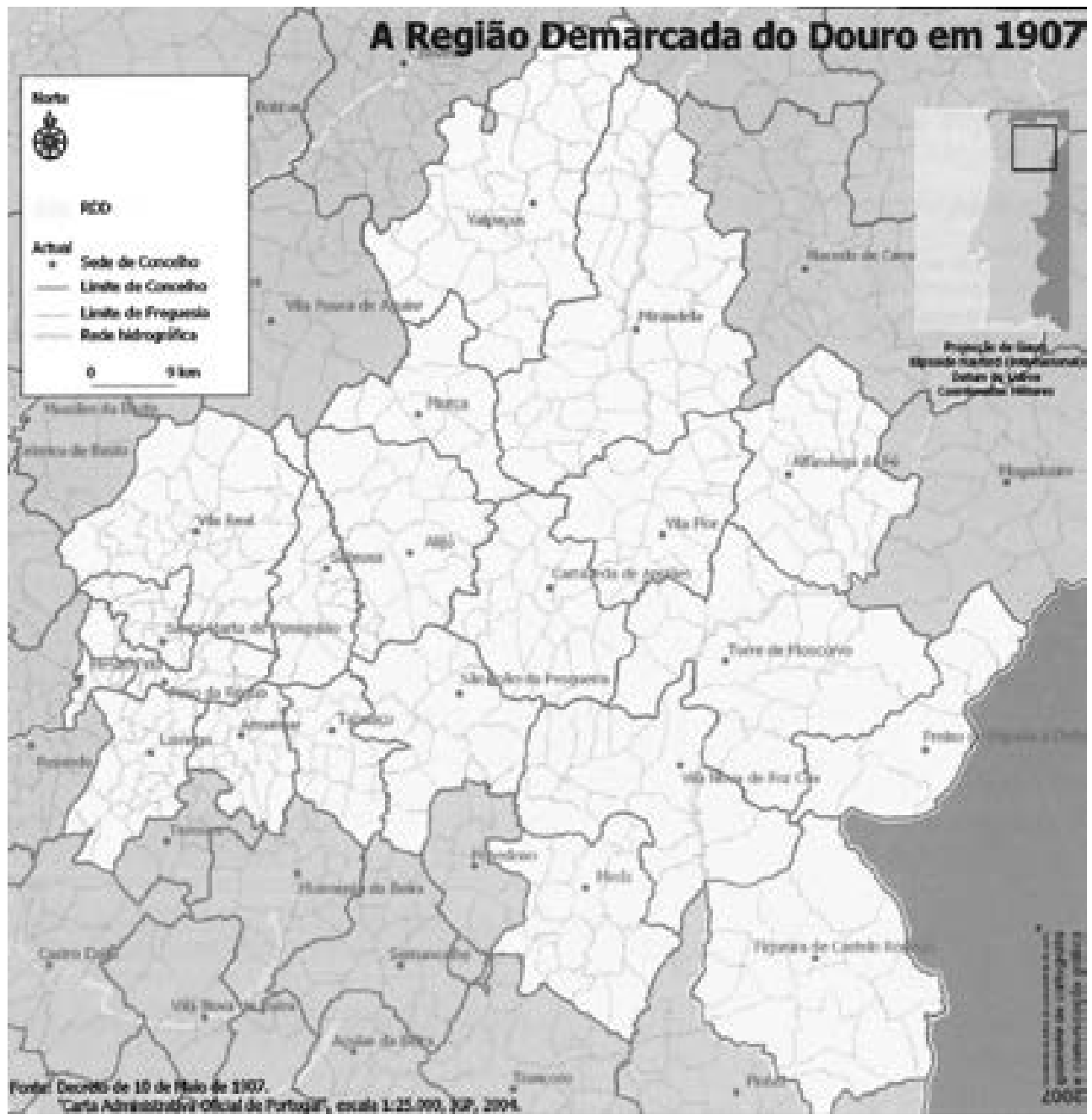

Fig. 35

Fonte: PEREIRA, 2010: IV, 9-49 


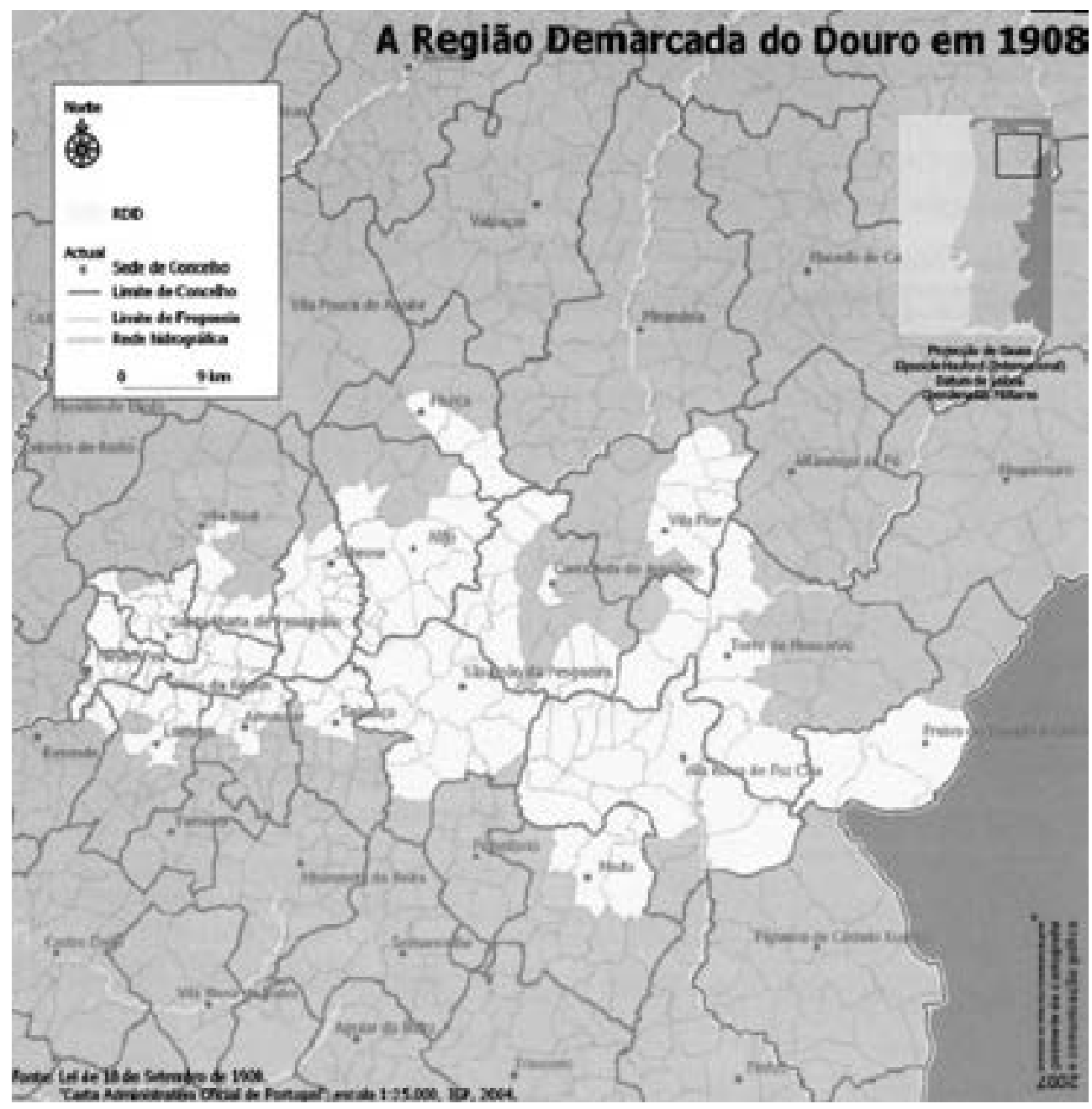

Fig. 36

Fonte: PEREIRA, 2010: IV, 9-49

A observação dos mapas anteriores complementada com a leitura dos seguintes quadros ilustrativos ${ }^{197}$ da totalidade dos 21 concelhos (mais uma freguesia de outro) integrados na Demarcação de João Franco (1907) e do total de 132 freguesias contempladas na posterior demarcação de Ferreira do Amaral (1908) permite constatar que o concelho de Carrazeda de Ansiães, com 11 das suas freguesias contempladas nesta segunda demarcação ocupa aí a quinta posição em número de freguesias incluídas, a seguir a Vila Nova de Foz Coa, S. João da Pesqueira, Sabrosa e Alijó.

${ }^{197}$ PEREIRA, 2010: IV, p. 9-49. 
Quadro 2. Concelhos da Nova Região Demarcada do Douro (João Franco, 1907) ${ }^{198}$

\begin{tabular}{|c|c|}
\hline $\begin{array}{l}\text { Região Demarcada Douro -RDD } \\
\text { (Decreto de } 10 \text { de maio de 1907) }\end{array}$ & Concelhos incluídos na totalidade (21) + 1 \\
\hline & Mesão Frio \\
\hline & Santa Marta de Penaguião \\
\hline & Vila Real \\
\hline & Régua \\
\hline & Sabrosa \\
\hline & Alijó \\
\hline & Carrazeda de Ansiães \\
\hline & Mirandela \\
\hline & Murça \\
\hline & Valpaços \\
\hline & Vila Flor \\
\hline & Alfândega da Fé \\
\hline & Torre de Moncorvo \\
\hline & Freixo de Espada à Cinta \\
\hline & Figueira de Castelo Rodrigo \\
\hline & Vila Nova de Foz Coa \\
\hline & Meda \\
\hline & S. João da Pesqueira \\
\hline & Tabuaço \\
\hline & Armamar \\
\hline & Lamego \\
\hline & Resende (freguesia de Barrô) \\
\hline
\end{tabular}

Quadro 3. Reforma da Demarcação da Região do Douro (F. Ferreira do Amaral, 1908) ${ }^{199}$

\begin{tabular}{|l|l|l|}
\hline $\begin{array}{c}\text { Região Demarcada Douro } \\
\text { (Lei de 18 de setembro de 1908; Decreto Regulamen- } \\
\text { tar de 1 de outubro de 1908) }\end{array}$ & \multicolumn{1}{|c|}{ Concelhos } & \multicolumn{1}{|c|}{$\begin{array}{c}\text { N. } \text { de freguesias incluídas } \\
\text { (132) }\end{array}$} \\
\hline & Mesão Frio & 5 (totalidade) \\
\hline & Santa Marta de Penaguião & 9 (exceto Louredo) \\
\hline & Vila Real & 6 \\
\hline & Régua & 7 (exceto Sedielos) \\
\hline
\end{tabular}

\footnotetext{
${ }^{198}$ Quadro construído a partir do respetivo mapa transcrito e suas notas.

${ }^{199}$ Quadro construído a partir do respetivo mapa transcrito e suas notas.
} 


\begin{tabular}{|c|c|c|}
\hline \multirow{3}{*}{$\begin{array}{c}\text { Região Demarcada Douro } \\
\text { (Lei de } 18 \text { de setembro de 1908; Decreto Regulamen- } \\
\text { tar de } 1 \text { de outubro de 1908) }\end{array}$} & Concelhos & $\begin{array}{l}\text { N. }{ }^{\circ} \text { de freguesias incluídas } \\
\text { (132) }\end{array}$ \\
\hline & Alijó & 12 \\
\hline & Carrazeda de Ansiães & $\begin{array}{l}\text { Castanheiro } \\
\text { Ribalonga } \\
\text { Linhares } \\
\text { Beira Grande } \\
\text { Carrazeda } \\
\text { Seixo } \\
\text { Parambos } \\
\text { Pereiros } \\
\text { Pinhal do Douro } \\
\text { Pinhal do Norte } \\
\text { Pombal }\end{array}$ \\
\hline & Murça & 3 \\
\hline & Vila Flor & 7 \\
\hline & Torre de Moncorvo & 8 \\
\hline & Freixo de Espada à Cinta & 3 \\
\hline & Vila Nova de Foz Coa & 15 \\
\hline & Meda & 3 \\
\hline & S. João da Pesqueira & 14 \\
\hline & Tabuaço & 4 \\
\hline & Armamar & 5 \\
\hline & Lamego & 7 \\
\hline & Resende & Barrô \\
\hline
\end{tabular}

Deixam de constar nesta demarcação para efeito de produção de vinhos generosos os seguintes 4 concelhos: Mirandela, Valpaços, Alfândega da Fé e Figueira de Castelo Rodrigo que, no entanto, são integrados, com todos os anteriormente contemplados na demarcação de 1907 (ver Quadro n. ${ }^{\circ}$ 2), na região demarcada de vinhos de mesa do Douro, fixada pela Lei de 18 de setembro de $1908^{200}$.

Pode igualmente verificar-se, no que respeita a Carrazeda de Ansiães, que não é ainda contemplada a sua zona mais oriental já pertencente ao Douro Superior, designadamente a freguesia de Vilarinho da Castanheira, onde se localiza a Quinta do Lubazim, a mais antiga quinta histórica deste concelho, administrativamente ligada ainda hoje aos concelhos limítrofes de Vila Flor e Moncorvo. Com uma área de 29.220 ha, o concelho de Carrazeda, sendo 
o penúltimo em termos de superfície, no distrito de Bragança, ocupava aí, uma posição mediana $^{201}$. A maioria das suas então 19 freguesias, em número de 11 (descritas no Quadro n. ${ }^{\circ}$ 3), foram contempladas pela demarcação de 1908, todas localizadas nas margens do rio Douro e do rio Tua, seu afluente, acentuadamente produtoras de vinhos generosos e como tal consideradas parte integrante da Região Demarcada do Douro ${ }^{202}$.

A Região dos Vinhos Generosos do Douro, assim redefinida, passou então a integrar 22 concelhos de 4 distritos, com uma área de 598.104 ha, representando 6,6\% da superfície total do país, 11, 6\% de área cultivada (agrícola e florestal) e 18,5\% da superfície agrícola, quase 1/5 da área agrícola do continente ${ }^{203}$.

Uma década mais tarde, a Região Demarcada do Douro (RDD) será sujeita a nova demarcação, com o ministro da República, Antão Fernandes de Carvalho (Decreto n.o 7934, 10 dezembro de 1921), passando a contemplar duas regiões vitícolas durienses: a dos Vinhos Generosos e a dos Vinhos de Pasto, e a abarcar parcelas de 168 freguesias, acrescentando mais 36 às já contempladas anteriormente.

A RDD, alargada a novos concelhos, como por exemplo Mirandela e Alfândega da Fé, no distrito de Bragança, ficava então com 21 concelhos (mais o concelho de Resende com a freguesia de Barrô), de 4 distritos (Vila Real, Bragança, Viseu e Guarda) e uma superfície de 598.104 ha.

O concelho de Carrazeda de Ansiães que viu o seu número de freguesias incluídas na RDD aumentado em mais duas - Lavandeira e Vilarinho da Castanheira, localizadas em pontos opostos - , passou a ocupar no conjunto da região duriense dos vinhos generosos, a quarta posição, logo a seguir a Vila Nova de Foz Coa, englobado na totalidade, e aos concelhos de Alijó e S. João da Pesqueira que lhe são limítrofes (Quadro n. ${ }^{\circ} 4$ ).

Para além da Região dos «Vinhos Generosos do Douro» este diploma (Decreto n. ${ }^{\circ} 7934$, de 10 de dezembro de 1921, D. G. de 16 de dezembro), da Direção Geral do Comércio Agrícola, que publica o regulamento da produção e comércio dos Vinhos do Porto, estabelece ainda, no seu artigo 4. ${ }^{\circ}$, uma segunda região vinícola do Douro, a «Região de Vinhos de Pasto» (também denominados vinhos virgens) constituída por 22 concelhos, (Quadro n. ${ }^{\circ}$ 4) mais Valpaços, no distrito de Vila Real. Nesta região, as freguesias dos referidos concelhos que não integram a região dos vinhos generosos são proibidas de produzir estes vinhos finos durienses. O espaço regional duriense assim novamente demarcado irá manter-se ao longo do século XX e a ele corresponde, genericamente, a atual RDD (Decreto-Lei n. ${ }^{\circ} 166$ de 26 de junho de 1986).

\footnotetext{
${ }^{201}$ Veja-se nossa comunicação De «vinho fino» a 'Port Wine' — Integração de Carrazeda de Ansiães (1907-1908) na Região Demarcada do Douro. Representações e identidades 'conjunturais', na 1. a República., apresentada ao XXIX Congresso da Associação de História Económica e Social, Porto, novembro de 2009.

${ }^{202}$ Carta de Lei de 18/9/1908 e decreto de 27 de novembro do almirante Ferreira do Amaral que alterou o decreto com força de lei de 10 de maio 1907, regulamentado pelo decreto de 16 de maio de 1907, promulgados por João Franco.

${ }^{203}$ Relatório da Comissão Nomeada por portaria de 25 de agosto de 1914, para... o Posto Agrário da Região Duriense, «Boletim da Direcção Geral da Agricultura».
} 
Quadro 4. Região dos Vinhos generosos do Douro — Demarcação de Antão de Carvalho (1921)204

\begin{tabular}{|c|c|c|c|c|}
\hline Distritos & Concelhos (na totalidade) & Concelhos (parcialmente) & & N. ${ }^{\circ}$ de freguesias incluídas \\
\hline \multirow[t]{6}{*}{ Vila Real } & Mesão Frio & & 5 & \\
\hline & Santa Marta de Penaguião & & 10 & \\
\hline & & Vila Real & 10 & \\
\hline & Régua & & 8 & \\
\hline & & Sabrosa & 12 & \\
\hline & & Alijó & 1 & \\
\hline \multirow[t]{7}{*}{ Bragança } & & Alfândega & 1 & \\
\hline & & Carrazeda de Ansiães & 13 & $\begin{array}{l}\text { Castanheiro } \\
\text { Ribalonga } \\
\text { Linhares } \\
\text { Beira Grande } \\
\text { Carrazeda } \\
\text { Seixo } \\
\text { Parambos } \\
\text { Pereiros } \\
\text { Pinhal do Douro } \\
\text { Pinhal do Norte } \\
\text { Pombal } \\
\text { Lavandeira } \\
\text { Vilarinho de Castanheira }\end{array}$ \\
\hline & & Vila Flor & 9 & $\begin{array}{l}+2 \text { quintas e propriedades nas } \\
\text { fregues: Vilas Boas e Vila Flor }\end{array}$ \\
\hline & & Torre de Moncorvo & 8 & \\
\hline & & Freixo de Espada à Cinta & 4 & \\
\hline & & Mirandela & & $\begin{array}{l}\text { riedades da família e Sociedade } \\
\text { nente Meneres nas freguesias: } \\
\text { has, Romeu, Avantos e Carvalhais }\end{array}$ \\
\hline & & Murça & 3 & \\
\hline \multirow[t]{2}{*}{ Guarda } & Vila Nova de Foz Coa & & 15 & \\
\hline & & Meda & 4 & \\
\hline \multirow[t]{5}{*}{ Viseu } & & S. João da Pesqueira & 1 & \\
\hline & & Tabuaço & 10 & \\
\hline & & Armamar & 4 & \\
\hline & & Lamego & 8 & +3 quintas em mais 3 freguesias \\
\hline & & Resende & 1 & Barrô \\
\hline
\end{tabular}

${ }^{204}$ Quadro construído a partir de informações do diploma correspondente (Decreto n. 7934 de 10 de dezembro de 1921, D.G. de 16 de dezembro). 
Para além da Região dos «Vinhos Generosos do Douro» este diploma (Decreto n. ${ }^{\circ}$ 7934, de 10 de dezembro de 1921, D. G. de 16 de dezembro), da Direção Geral do Comércio Agrícola, que publica o regulamento da produção e comércio dos Vinhos do Porto, estabelece ainda, no seu artigo 4. ${ }^{\circ}$, uma segunda região vinícola do Douro, a «Região de Vinhos de Pasto» (também denominados vinhos virgens) constituída por 22 concelhos, (Quadro n. ${ }^{\circ} 4$ ) mais Valpaços, no distrito de Vila Real. Nesta região, as freguesias dos referidos concelhos que não integram a região dos vinhos generosos são proibidas de produzir estes vinhos finos durienses. O espaço regional duriense assim novamente demarcado irá manter-se ao longo do século XX e a ele corresponde, genericamente, a atual RDD (Decreto-Lei n. ${ }^{\circ} 166$ de 26 de junho de 1986).

Importa observar que a precedente análise, sumariamente efetuada, se cingiu ao estipulado nos diplomas das três demarcações referidas na primeira metade do século XX, usando por isso o indicador quantitativo do número de freguesias de cada concelho contemplado que se considera porém em termos comparativos menos pertinente, dadas as diferenças territoriais dos concelhos e das freguesias, do que os indicadores de área vitícola e de produção de vinho, contudo eles mesmos também passíveis de não traduzirem a importância relativa ao nível do valor da própria produção, como mais adiante se procurará melhor refletir (Capítulo 10).

Lembre-se que a região produtora do vinho do Porto possui 250 mil hectares, contribuindo o Baixo Corgo (BC) com 48,7\% da área plantada com vinha, o Cima Corgo (CC) com 27,8\% e representando o Douro Superior (DS) 23,5\%, percentagens estas atualizadas. As castas predominantes são a Touriga Franca, Tinta Barroca, Tinta Amarela/Trincadeira, Aragonez/Tinta Roriz, Malvasia Fina/Boal, Mourisco, Malvasia Rei, Malvasia Preta, Códega, Touriga Nacional, e Rabigato. Apesar do domínio das castas tintas, as brancas (Malvasia Fina, Códega e Rabigato), aparecem principalmente nas encostas de maior altitude, nomeadamente no BC e $\mathrm{CC}^{205}$.

A produção de vinho na RDD, proveniente das diferentes castas de uvas, entre 1980 e 2009, revela uma grande variação interanual, entre as 138 e 353 mil pipas sensivelmente e a média nesse período é cerca de 230719 pipas (550L./pipa). Nos dois anos de maior produção 1990 e 1996 a quantidade de vinho produzido ultrapassou em cada um dos anos as trezentas e trinta mil pipas. Nos anos de menor produção 1981, 1988, 1993 e 1998, a produção foi inferior a 173.000 pipas, com o mínimo de 138233 pipas a ser atingido no ano de 1988.

Dentro dos quatro anos de menor produção, 1981 foi o que registou produção mais próxima da média da RRD nos 30 anos.

A variabilidade verificada é resultado da adaptabilidade das diferentes castas às condições meteorológicas em cada um dos anos [... $]^{206}$.

\footnotetext{
${ }^{205}$ CASTRO, 2013: 101.

${ }^{206}$ CASTRO, 2013: 31, 32, 79.
} 


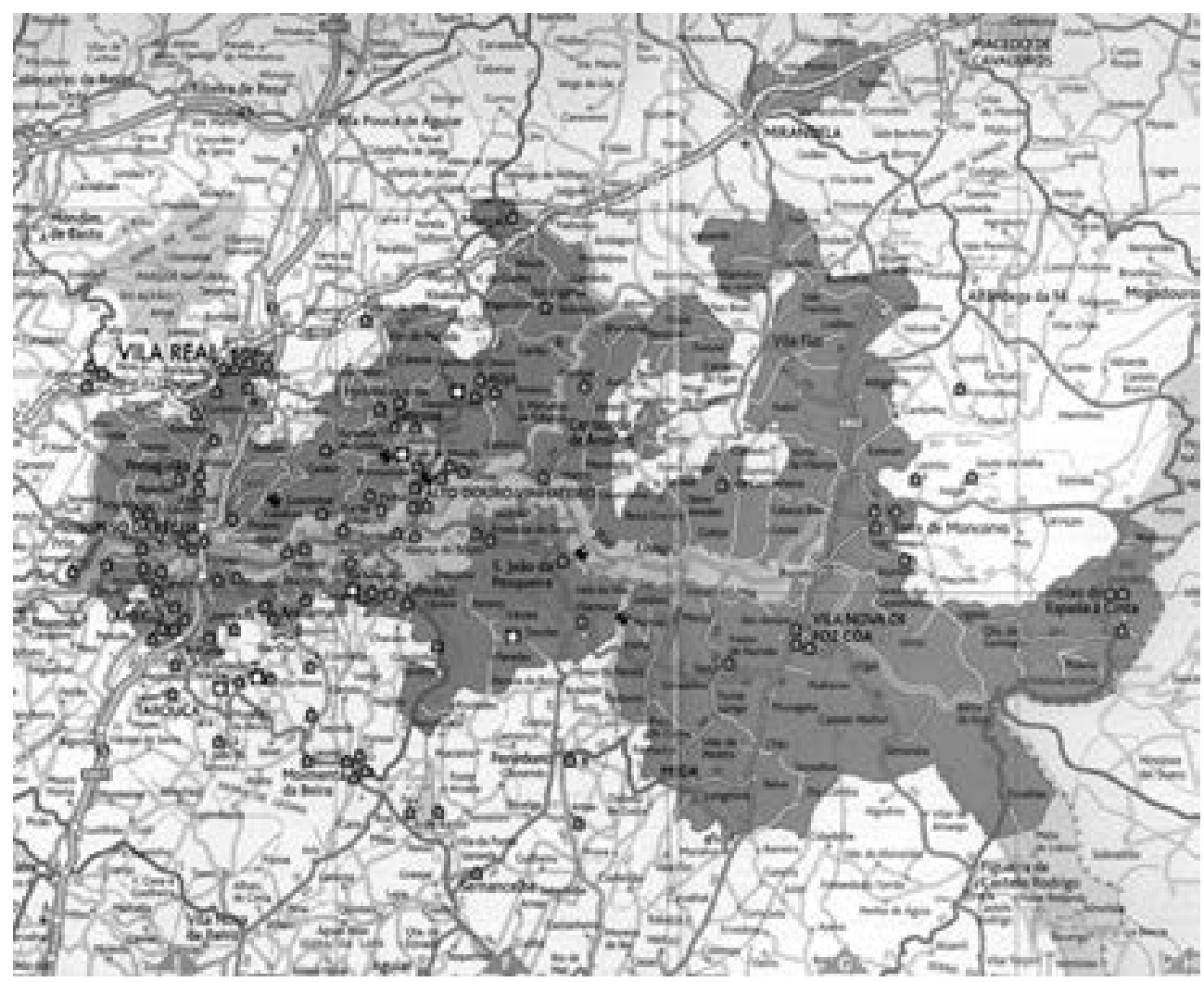

Fig. 37. Mapa da atual RDD 207

Fonte: Casa do Douro

O concelho de Carrazeda, como se disse, com onze freguesias incluídas na atual RDD: Carrazeda de Ansiães, Ribalonga, Castanheiro do Norte, Seixo de Ansiães, Linhares, Lavandeira, Beira Grande, Parambos, Pereiros, Pinhal do Norte e Vilarinho da Castanheira com o lugar de Pinhal do Douro, ocupa aí como se pode ver uma posição relativamente central. Já nos anos 2000, é o único concelho do distrito de Bragança a ser integrado na sub-região do Cima Corgo, onde tem uma área vitícola inferior a Alijó e S. João da Pesqueira, concelhos vizinhos de maior área de vinha da sub-região, enquanto os restantes concelhos brigantinos se encontram incluídos na sub-região do Douro Superior, continuando assim a deter uma posição de fronteira no espaço regional da RDD produtor de vinho do Porto.

\footnotetext{
${ }^{207}$ PEIXOTO, Marco Aurélio - Desdobrável. Edição Casa do Douro. Disponível em <https://www.google.pt/search?q $=$ regi $\%$ C3\%A3o+demarcada + do+Douro+\%281907-1908\%29+mapa\&tbm=isch\&imgil, $>$. [Consulta realizada em $30 / 3 / 2016]$.
} 


\subsection{DENOMINAÇÃO DE ORIGEM «DOURO»E MARCA «PORTO»}

Os princípios e dispositivos que definem hoje a denominação de origem do vinho do Porto encontram-se fixados em regulamento próprio publicado no anexo ao diploma legal (Decreto-Lei n. ${ }^{\circ}$ 166, de 26 de junho de 1986) que estabeleceu a atual Região Demarcada do Douro.

Porém, até se chegar aqui, teve lugar um longo e complexo processo histórico de reivindicações e lutas regionais em defesa da legitimação da denominação de origem Douro e autenticidade da marca Porto em que se destacam por exemplo numerosos tumultos populares com expoente máximo no sangrento Motim de Lamego de 1915, momento histórico de consagração da denominação de origem «Porto» para os vinhos generosos da Região Demarcada do Douro, após sucessivos governos terem desencadeado diversas medidas de protecionismo regional de que foi exemplo o regresso ampliado e reforçado da Demarcação da Região Duriense, com João Franco (1907), como de seguida melhor se explicitará.

Nos inícios do século XX, aquando do regresso à Demarcação, na viragem da Monarquia para a I República, como se disse, o Douro encontrava-se imerso numa profunda crise comercial e da lavoura, assistindo-se aí, social e culturalmente a uma generalização da falta de trabalho e péssimas condições de vida.

Toda a região do Douro Vinhateiro havia registado profundas mudanças determinadas por um conjunto múltiplo de fatores desde uma grande alteração da geografia dos vinhedos, da propriedade fundiária e modernização da vitivinicultura até à grave crise comercial de finais do século XIX, acompanhada da proliferação de fraudes e falsificações do vinho do Porto.

Tentando enfrentar interesses antagónicos que se manifestavam na Região, onde a designada «Questão do Douro» vinha sendo assinalada por diversas pretensões regionais (reuniões, comícios, representações, encontros com membros do governo e contactos institucionais de elites, câmaras e sindicatos agrícolas) algumas das quais registam a participação de Carrazeda, João Franco assinou, como se viu, no início do seu governo de ditadura administrativa, o Decreto-Lei n. ${ }^{\circ}$ 1, de 10 de maio de 1907 que alargou substancialmente a Região Demarcada do Douro instituindo um novo regime institucional de cariz protecionista na Região. Este diploma segue parcialmente o projeto de lei apresentado, em 1906, na Câmara dos Pares pelo Conselheiro e Par do Reino, Teixeira de Sousa. Esse seu projeto de diploma apesar de ter sido «deturpado devido às influências e interesses de outros grupos socioeconómicos sobre o Governo» pode, no entanto, considerar-se que «consagra algumas das reivindicações propostas pela lavoura $»^{208}$. A publicação deste decreto histórico fez prevalecer o projeto do ministro das Obras Públicas, Malheiro Reimão, que defendia a nova demarcação do Douro, reclamada também pelos produtores que queriam proteger a produção vinícola regional, e viria a consagrar na lei algumas das reivindicações do setor produtivo ao visar regulamentar de novo o ciclo da produção, venda, exportação e fiscalização do vinho do Porto, retomando os princípios centenários

${ }^{208}$ SEQUEIRA, 2011. 
da política pombalina de defesa da marca, cuja proteção e fiscalização foi entregue à nova entidade reguladora então criada, a Comissão de Viticultura da Região do Douro (CRVD) ${ }^{209}$.

A legislação de João Franco foi acusada de refletir os interesses dos viticultores do sul do país, tendo acabado por suscitar controvérsias, descontentamentos e contestações ao nível da Região, particularmente em relação ao seu decreto de 27 de junho de 1907, que veio regulamentar o comércio das aguardentes, proibindo a destilação dos vinhos durienses e obrigando a região dos vinhos generosos do Douro a receber e adquirir a aguardente de outras regiões vitícolas, designadamente do sul do país, para beneficiação dos seus vinhos.

Para além de alargar excessiva e indevidamente a área demarcada produtora dos vinhos generosos, o que suscitou também viva polémica, o normativo legal franquista do Douro, definiu ainda um novo regime de produção, venda, exportação e fiscalização dos vinhos generosos de região com nomes tradicionalmente «feitos» (Porto, Madeira, Carcavelos e Moscatel de Setúbal), estabeleceu o exclusivo da marca «Porto» para os vinhos generosos da região do Douro (com graduação alcoólica mínima de 16,5. ${ }^{\circ}$ ), e consagrou o exclusivo da barra do Douro e do porto de Leixões para a exportação desses vinhos, cuja qualidade passou a ser fortemente controlada e fiscalizada.

Assim, com essa nova entidade reguladora, a CVRD, instituição de fiscalização, registo de propriedades, concessão de certificados de procedência, etc., que esteve em funcionamento, desde 1907 (quando foi criada pelo Decreto ditatorial de João Franco de 10 de maio de 1907 e pelo Decreto Regulamentar de 16 de maio de 1907) até 1932 (ano em que foi extinta), apoiada pela Comissão Agrícola e Comercial dos Vinhos do Douro e pela Comissão Inspetora de Exportação do Vinho do Porto, abriu-se um novo modelo institucional de regulação e controlo da produção e do comércio.

Este modelo protecionista, que sucedeu ao regime de liberdade comercial (1865 a 1907) e à abolição dos privilégios da Companhia, tendo contribuído para reconfigurar e alterar profundamente o espaço regional duriense e reinstaurar o intervencionismo estatal na Região Duriense, foi substituído com a instauração da ditadura do Estado Novo, no início dos anos 1930, pelo regime corporativo.

Este outro regime que se prolongará por várias décadas veio reforçar o protecionismo regional aproveitando-se de novas instituições como a Federação Sindical dos Viticultores da Região do Douro ou Casa do Douro (Decreto-Lei n.o 21883, de 19 de novembro de 1932) e o Instituto do Vinho do Porto (Decreto n. ${ }^{\circ} 22.461$, de 10 de 1933) que se mantiveram em funcionamento até aos dias de hoje, embora com alterações, a partir do 25 de abril de 1974 e o regresso à Democracia, a que se seguiram outras mudanças sensíveis, como por exemplo a extinção do Grémio dos Exportadores de Vinho do Porto (Decreto-Lei 443/74 de 12 de setembro), outro organismo corporativo que logo foi substituído pela Associação dos Exportadores de Vinho do Porto.

${ }^{209}$ PEREIRA, [s.d.]. 
Num outro plano de análise, importa realçar que o sistema de demarcações da Região do Douro foi, simultaneamente, pontuado por sucessivas delimitações e alargamento da área da Região Demarcada (1757-1761, 1788-1793, 1907-1908, 1921) e enquadrado por modelos institucionais de regulação que foram sendo, progressivamente, alterados.

Porém, a partir dos anos 1940, passou a assentar numa prescrição aos lavradores que consiste na atribuição do «benefício» ${ }^{210}$, uma espécie de direito de produção de vinho do Porto baseada em dispositivos técnicos que distinguem e graduam um número complexo de fatores (terreno, solo, clima, pluviometria, castas, etc.) que influenciam a biologia da videira determinando a qualidade final da uva e do vinho resultante.

Para efeitos de atribuição de beneficio, ao nível do sistema de pontuação, a RDD foi considerada em 1949, por Moreira da Fonseca, criador desse método único no mundo, em cinco secções, e estas subdivididas em setores em que é destacada no Cima Corgo, a quarta secção que «abrange o centro da Região considerada como a produtora dos melhores vinhos generosos, e engloba as vertentes e vales dos rios Tedo, Távora, Torto, Caêdo, Pinhão, Tua e Tinhela encerrando trinta e oito setores. No que respeita à pontuação, este setor apresenta a variação mais pronunciada de todas as secções, variando dos 50 pontos negativos aos 600 pontos positivos $\aleph^{211}$. É precisamente nessa sub-região considerada produtora dos melhores vinhos generosos que se encontrava então integrada a área vitivinícola de Carrazeda de Ansiães, a este nível considerado um concelho da sub-região de Cima Corgo.

\subsection{O RETORNO AO PROTECIONISMO REGIONAL E A AGITAÇÃO SOCIAL}

O Estado ajudou a fazer o vinho do Porto. Para este produto, o contributo da natureza ou das condições naturais, sendo importante e indispensável, não é, todavia, bastante. Foram os homens, as instituições, as empresas, os regulamentos e o mercado que fizeram este produto com estas características ${ }^{212}$.

Esta asserção histórica e sociológica sobre a multifatorial abrangência da produção e comércio do vinho do Porto em que concorrem também desde cedo políticas de intervenção estatais (cujo interesse predominante é o das receitas fiscais e rendimentos externos) encontra-se corroborada noutras opiniões de diversos autores. Haja em vista por exemplo o notório histo-

\footnotetext{
${ }^{210} \mathrm{O}$ Benefício é medido pela classificação de $\mathrm{A}$ a $\mathrm{F}: \mathrm{A}=1,200$ pontos/F=201 até 400 pontos.

${ }^{211}$ BARBOSA, 2006 p. 29.

${ }^{212}$ BARRETO, 1988: 373-390. Este artigo incide sobre o enquadramento geral da intervenção estatal no vinho do Porto, apresenta as grandes fases de intervenção legislativa, política, diplomática, técnica e científica, económica, fiscalizadora e judicial do Estado no setor do vinho do Porto, em suas formas, modalidades e características, numa periodização global tendencial predominante, desde o século XVII até aos anos 1980 do século XX, com datas aproximadas. Refere-se ainda aos objetivos dessa ação do Estado interessado nas receitas fiscais e rendimentos internos que normalmente reage às crises do mercado e qualidade do produto.
} 
riador Borges de Macedo que em sua obra de referência sobre o governo e o tempo de Marquês de Pombal, ao relevar o papel do estado na dinâmica das elites sociais dominantes, no Douro de então, sublinha: «O Estado de Pombal intervém em defesa do produtor tradicional contra os novos concorrentes encorajados na produção pelo tratado de Methuen, e pela existência de fontes coloniais de consumo» ${ }^{213}$. Como bem explica Gaspar Martins Pereira em meados do século XVIII, a complexa legislação pombalina, na lógica do Estado absolutista, visando por vários meios uma solução para a crise comercial, procurou controlar um setor-chave da economia nacional (produção e comércio do vinho do Porto), preservar e, simultaneamente subordinar os interesses dos grupos sociais dominantes que lhe estavam associados, garantindo aos grandes vinhateiros durienses as mais valias decorrentes da notoriedade alcançada pelo vinho do Porto. Este é aliás considerado um objetivo comum a todas as regiões de denominação de origem ${ }^{214}$.

$\mathrm{Na}$ verdade, durante mais de duzentos anos, a intervenção estatal no Douro e no setor do vinho do Porto, geralmente afirmada em conjunturas de forte crise nos circuitos comerciais e nas condições de produção suscetíveis de afetar os mercados, foi sendo sobretudo reclamada pela lavoura duriense e, limitadamente, pelo comércio, enquanto os grandes exportadores estrangeiros, com relevo tradicional para os ingleses, foram sempre mais reticentes e mesmo opositores, nalguns períodos, embora nunca se rompendo o bom entendimento relativo entre o poder politico nacional e este setor tradicional de interesses económicos na região, de forte dinamismo económico e elites empresariais.

A ação histórica (ou reação, por vezes tardia) dos sucessivos governos, marcada por inflexões favoráveis ou desfavoráveis à produção, ao comércio ou outros interesses, para favorecer a regularidade no setor, abrangeu também vertentes de garantia da estabilidade social em situações de: calamidades climáticas, flutuações dos mercados internacionais e divergências de interesses no Douro entre o comércio, que mantém posição dominante e a produção em que predomina a pequena propriedade com situação preponderante da grande propriedade, para além ainda de outros fatores geradores de instabilidade e dificuldades sociais na lavoura.

Nesta perspetiva de enquadramento genérico, é, todavia, possível detetar a grande tendência de ao protecionismo regional, com forte regulamentação e intervenção do Estado, corresponder mais estabilidade, maior regularidade no comércio, medianos volumes exportados e ligeiro aumento de receitas. À liberdade de comércio e de produção corresponde uma maior irregularidade do comércio, a tendência para o aumento dos volumes exportados e a estagnação ou diminuição tendencial dos preços e receitas. Finalmente, as pressões para a liberdade de comércio fazem-se sentir, em geral, após alguns anos de forte crescimento das exportações e das receitas; enquanto as intervenções do Estado surgem com mais força depois de períodos de crise no mercado, na produção ou nos rendimentos ${ }^{215}$.

\footnotetext{
${ }^{213}$ MACEDO, 1982.

${ }^{214}$ Cf. PEREIRA1996b: 183).

${ }^{215}$ BARRETO, 1988: 390.
} 
Na última década do século XIX, em que avultavam as falsificações e as fraudes, e não apenas em relação aos produtos vinícolas, assiste-se à recuperação de um regime de regulação e protecionista, patente na adesão de Portugal às convenções internacionais, que conduzem ao estabelecimento de um novo enquadramento jurídico internacional.

Tornava-se então necessário regulamentar internacionalmente a proteção das marcas, com cujo objetivo se realizou a Convenção da União de Paris (20 de março de 1883) e o Acordo de Madrid (14 de abril de 1891) de que foi signatário Portugal «como país possuidor de vinhos de fama mundial [...] [precisando] de que se efetivasse a regulamentação do direito ao uso internacional das marcas de origem ${ }^{216}$. A participação de Portugal nestas convenções internacionais configurou-se como uma forma relevante de contraposição às políticas livre-cambistas então em vigor. O político, escritor e historiador Oliveira Martins, o representante português na Convenção de Madrid, demonstrou a importância dada a esta questão, propondo que as indicações de proveniência dos produtos agrícolas fossem alvo de especial proteção, não devendo ser consideradas como designações genéricas, por se tratar de produtos cujas especiais qualidades se devem a condições particulares de solo e clima únicos. A delegação francesa, «tomando em consideração os domínios em que a fraude era mais comum», sugeriu que a proposta portuguesa se restringisse às indicações de proveniência dos produtos vinícolas.

Tais linhas orientadoras viriam mais tarde, na sequência de fortes polémicas e intensos debates regionais entre livre-cambistas e protecionistas e reivindicações pelo regresso ao regime protecionista para o Douro e a ação do Estado face à crise comercial, a ser consagradas nos normativos legais de suporte das novas Demarcações da Região Vinhateira Duriense (1907-1908) como se viu anteriormente.

A estagnação ou mesmo queda das exportações do vinho do Porto nos finais do século XIX e princípios do século XX provocou movimentações políticas de diversa ordem. Face a tal situação de profunda crise comercial do setor verificada a partir da década de 1880, foi reaberto o debate do protecionismo regional e da intervenção do Estado. O exclusivo da barra do Douro foi restabelecido e criado o entreposto privativo de Gaia, evidências da intervenção do Estado no comércio e exportações do vinho do Porto.

No primeiro quartel do século XX, período em grande medida coincidente com o regime político republicano, para além das novas demarcações da Região, assim como das reivindicações da autenticidade e genuinidade dos vinhos do Douro e do vinho do Porto através da defesa da denominação de origem e da marca Porto atrás referidas, assiste-se no Douro, a uma restauração do protecionismo regional, definida por nova regulamentação marcada, porém, pela flutuação da intervenção estatal, a incerteza da aplicação das leis e a desorganização administrativa. Mais tarde, viria a ser criado (Dec. Lei n. ${ }^{0} 12009$, de 31 de julho de 1926) o Entreposto do Douro em Vila Nova de Gaia, destinado ao armazenamento, envelhecimento e

${ }^{216}$ SEQUEIRA, 2006a: 138-146. 
exportação dos Vinhos da Região Demarcada do Douro que acabava, na prática, com a comercialização direta a partir do Douro.

Nova e vasta legislação regulamentadora foi então sendo aprovada e o protecionismo regional entrou em vigor, pelo menos legalmente, pois a situação política nacional não era favorável a uma regularidade da administração corrente, nem tão-pouco à aplicação certa das leis, como vimos, tendo-se mesmo verificado importantes e rápidas alterações dos limites da região demarcada, devido a incertezas e pressões políticas.

Na verdade, a mudança de regime político e a instabilidade governativa da I República fazem desta época, do ponto de vista da intervenção do Estado, um novo período de transição em que vigora o protecionismo regional e a intervenção indireta do Estado é forte, sendo no entanto a sua tradução prática, bastante aleatória. Apesar disso, viriam a atingir-se já em 1924 e 1925, os mais altos valores de exportação até então conhecidos ${ }^{217}$. Aliás, nesses últimos anos de intenso acréscimo das exportações de vinho do Porto que aumentaram a um ritmo nunca esperado, exportaram-se mais de 100.000 pipas de vinho, nível só ultrapassado no fim da década de 1970.

Como se pode intuir a comercialização e exportação do vinho do Porto é um dos casos mais interessantes da nossa vida económica já que este vinho foi talvez o único produto interno que, ao longo dos últimos três séculos, terá originado mais rendimentos para a balança comercial portuguesa, representando a sua venda, mais de metade dos valores obtidos com o comércio nacional externo (quando hoje é apenas de cerca de 2\%).

Porém, entre finais da Monarquia e primeiros anos da I República a difícil situação social e económica da região do Douro não se alterou de modo significativo, tendo a subida dos impostos e dos preços agravado mesmo o ambiente de fome e miséria que se vivia nas aldeias durienses, o que contribuiu fortemente para se generalizar um clima de agitação social e política. Aliás, essa profunda crise do primeiro quartel do século XX, paralela à expansão do ideário republicano, marcou um dos períodos mais turbulentos da história do Douro. Manifestações, comícios, motins, incêndios de comboios com aguardente do Sul, assaltos a Câmaras e Repartições Públicas, como por exemplo os motins registados no concelho de Carrazeda de Ansiães em abril de 1910, com o incêndio da repartição de fazenda perpetrado por mais de 800 homens armados e os arrombamentos na estação do Tua e a destruição de cascos de vinho que vinham do sul, por «uma grande multidão» dos concelhos limítrofes ${ }^{218}$. Estes acontecimentos seguem-se a uma representação apresentada à Câmara dos Pares, pelos viticultores de Carrazeda, em abril de $1907^{219}$ e irão repercutir-se e prosseguir em manifestações idênticas primeiro em Alijó e, pouco depois, em Vila Flor. A estes tumultos populares e seu significado histórico-social nos referiremos em pormenor, mais adiante (Capítulo 6).

\footnotetext{
${ }^{217}$ BARRETO, 1988: 373-390.

${ }^{218}$ Cf. Jornal «O Nordeste» (22 abr. 1910) 2.

${ }^{219}$ Cf.«Diário do Governo», n. ${ }^{\circ} 74: 989$.
} 


\section{CAPÍTULO 5. O CASO DE CARRAZEDA, CONCELHO DE «FRONTEIRA» NA RDD}

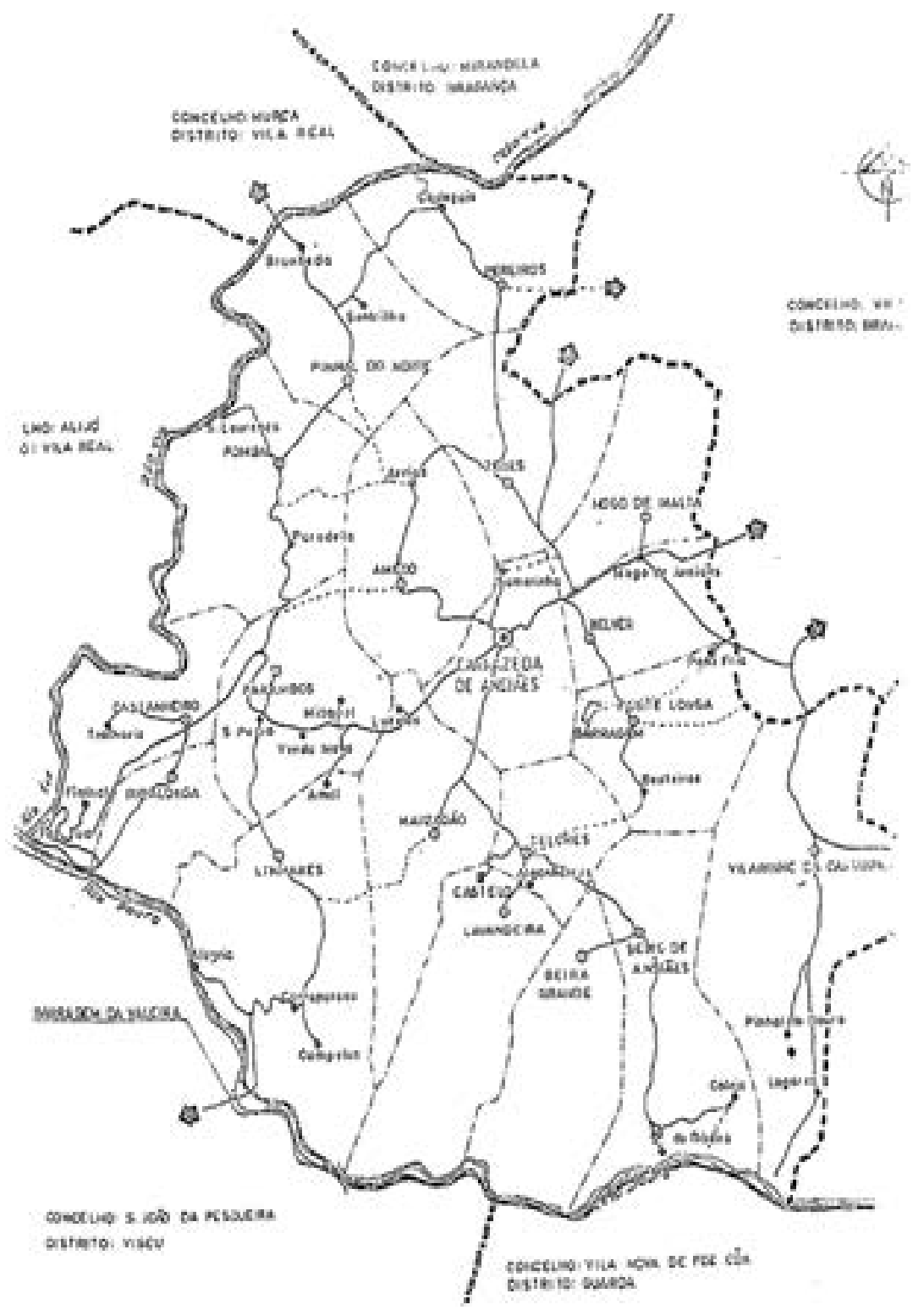

Fig. 38. Mapa do concelho, freguesias e lugares de Carrazeda de Ansiães e suas confrontações ${ }^{220}$

\footnotetext{
${ }^{220}$ Mapa cedido por José Manuel Lopes, natural de Santa Marta de Penaguião, antigo funcionário da Cockburn’s que acompanhou diretamente, durante décadas, a produção do vinho do Porto no concelho de Carrazeda de Ansiães (informante privilegiado em nosso trabalho de terreno).
} 
O atual concelho de Carrazeda de Ansiães com uma área total de 279,24 Km2 para 6.373 habitantes (com 1701 habitantes na vila sede) distribui-se por 14 freguesias e uniões de freguesias (nova reorganização administrativa de 2013), planálticas e ribeirinhas dos rios Douro (margem direita) e Tua (margem esquerda), as quais se encontram, na sua maioria, incluídas na Região Vinhateira Duriense. Todavia, o seu efetivo populacional corresponde a cerca de 3,10\% da população do Douro pelo que se pode considerar não ser dos concelhos menos populosos da região, situando-se num valor mais ou menos mediano dessa variável onde ocupa o 9. ${ }^{\circ}$ lugar no conjunto de 19 municípios da Região Douro ${ }^{221}$.

Porém, a nível micro, o concelho de Carrazeda registou nos penúltimos censos de 2001, um dos maiores crescimentos no polo urbano e, simultaneamente, um dos maiores decréscimos nas freguesias rurais que fora já extremamente forte, entre 1991 e 2001 . Este encontra-se relacionado com um acentuado défice migratório da década anterior e teve como consequência a curto prazo, um saldo fisiológico negativo traduzido por exemplo em aproximadamente 200 habitantes para a sua povoação de Foz Tua, a mais oriental no conjunto consi$\operatorname{derado}^{222}$.

\subsection{CONTEXTO HISTÓRICO E POSIÇÃO ESPECÍFICA DE CARRAZEDA NO DOURO VINHATEIRO}

Com relativa homogeneidade geológica, a região Vinhateira do Alto Douro localiza-se quase toda «no complexo xisto-grauváquico pré-câmbrico, verificando-se praticamente um decalque da demarcação desta região vinhateira sobre a referida mancha xistenta. Neste contexto, Carrazeda de Ansiães, constitui uma exceção, com apenas mais dois locais: Numão (no concelho de Foz Coa) e Sande (no concelho de Lamego), já que aí surgem manchas graníticas intercaladas nessa grande mancha xistosa, sendo a do planalto de Carrazeda, a de maior expressão em área» ${ }^{223}$.

A diferenciação face à Região Vinhateira Duriense do território concelhio de Carrazeda, na fronteira entre o Douro Superior e o Cima Corgo, faz-se a vários níveis que influenciam conjuntamente a melhoria de maturação das uvas e a qualidade da produção dos vinhos em relação às restantes sub-regiões do Douro, configurando assim uma situação específica, considerada um «terroir» (Paul Symington). Essa tipicidade edáfico-climática consiste não só na composição geológica dos solos (xisto e granito) com dois horizontes: o superficial e o da rocha-mãe que tem de ser rompido para que possam vir a tornar-se aráveis, mas reside também nas condições próprias de exposição solar, luminosidade (número de horas de luz) e amplitudes térmicas anuais, (em regra entre $46 .^{\circ}$ diurnos e $25 .^{\circ}$ noturnos), o que se traduz em

\footnotetext{
${ }^{221}$ Por ordem crescente de habitantes: Penedono, Freixo de Espada-à-Cinta, Mesão Frio, Sernancelhe, Murça, Armamar, Tabuaço, Sabrosa, Carrazeda de Ansiães, Via Nova de Foz Coa, Santa Marta de Penaguião, S.João da Pesqueira, Tarouca, Torre de Moncorvo, Moimenta da Beira, Alijó, Peso da Régua, Lamego, Vila Real.

${ }^{222}$ REBELO, et al., 2001.

${ }^{223}$ RIBEIRO, 2000 (2. ${ }^{\circ}$. Disponível em <http://ler.letras.up.pt/uploads/ficheiros/9492.pdf>. [Consulta realizada em 15/1/2015]
} 
teores orgânicos mais baixos, mas em contrapartida, melhor qualidade porque a produção é menor por cepa ${ }^{224}$.

Num arco temporal que abrange os últimos 210 anos, entre 1801 e 2011, os dados populacionais e demográficos deste município são representados pela curva de evolução definida por uma linha ascendente ${ }^{225}$, logo depois infletida em linha descendente constante e muito pronunciada, particularmente agravada a partir de 1981, o que permite observar uma acentuada tendência involutiva do seu efetivo populacional configurando o duplo envelhecimento da população residente. Surpreendentemente, os 6.373 habitantes registados em 2011 encontram-se, em números globais, muito próximos dos 6.330 habitantes contabilizados no ano de 1801, sendo, no entanto, a sua composição profundamente diferente ${ }^{226}$.

Ao nível da respetiva contextualização diacrónica na Região Vinhateira do Douro, o atual concelho de Carrazeda de Ansiães, com parcelas de vinha e olival nas encostas dos rios Tua e Douro, situado no termo do Cachão da Valeira, barreira natural intransponível até ser removida em finais do século XVIII ${ }^{227}$, e na margem direita do rio Douro, fazendo fronteira com o concelho de S. João da Pesqueira (margem esquerda), localizava-se assim também numa posição de «fronteira», na área vinhateira duriense e na antiga Região Demarcada. Era então bem visível a diferença entre as duas zonas, com a grande expansão e desenvolvimento notório da cultura da vinha no Alto Douro, enquanto no Douro Superior predominava a cultura de cereal, só mais tarde passando aí a cultura da vinha a estender-se, representando embora uma importância menor do que no Alto Douro. O Douro Superior que se estende até à fronteira espanhola tem uma área de vinha inferior às do Baixo Corgo e do Cima Corgo, como se pode observar no quadro.

Quadro 5. Caracterização das Sub-Regiões da RDD²28

\begin{tabular}{|l|c|c|c|c|}
\hline \multicolumn{1}{|c|}{ Sub-Região } & Área Total (ha) & $\%$ & Área com vinha (ha) & \% da Área total \\
\hline Baixo Corgo & 45.000 & 18 & 13.492 & 29,9 \\
\hline Cima Corgo & 95.000 & 38 & 17.036 & 17,9 \\
\hline Douro Superior & 110.000 & 44 & 8.060 & 7,3 \\
\hline Total & 250.000 & & 38.588 & 15,4 \\
\hline
\end{tabular}

\footnotetext{
${ }^{224}$ Informação oral do enólogo Zito Santos da Adega Douro Ansiães, Unipessoal Lda.

${ }^{225}$ Apresentando até aos anos 1940 uma relativa estabilidade, mas já em perda populacional, logo nas décadas de 1940 a 1960.

226 CARRAZEDA DE ANSIÃES. Câmara Municipal, 2014; INE: censos de 2001 e 2011. Notas de anos: 1801/1849/1900/1960/1981 — Fonte: ANMP — Associação Nacional de Municípios Portugueses

${ }^{227}$ Em 1779, a Companhia Geral da Agricultura e Vinhas do Alto Douro, é autorizada pela rainha Dona Maria I a cobrar impostos sobre o vinho, aguardente e vinagre que eram transportados pelo rio Douro, com o objetivo de os aplicar em obras que tornassem o Douro navegável. As obras de explosão dos rochedos e demolição do Cachão com posterior alargamento do rio em que trabalhou José Maria Yola, engenheiro hidráulico da Sardenha começaram em 1780, e foram concluídas em 1792, podendo os primeiros barcos começar a transitar aí em 1789.

${ }^{228}$ IVDP - Viticultura, Região. Disponível em <https://www.ivdp.pt/pagina.asp?codPag=16>.
} 
Já quanto à estrutura fundiária, como se pode concluir do quadro seguinte, a vinha ocupa na região duriense uma área efetiva de cerca de $15,4 \%$ da área total. Considera-se que a sua área de vinha é atualmente trabalhada, por menos de 22.000 viticultores. São os pequenos produtores que têm um grande peso na produção de vinho do Porto. As pequenas parcelas estão presentes em toda a região, localizando-se algumas das grandes propriedades no Douro Superior.

Quadro 6. Estrutura Fundiária229

\begin{tabular}{|l|c|c|c|c|}
\hline \multicolumn{1}{|c|}{ Sub-Região } & Prop. & Área de Vinha/prop. (ha) & N. ${ }^{\circ}$ médio de prédios/prop. & N. ${ }^{\circ}$ prédios \\
\hline Baixo Corgo & 13.338 & 1,01 & 4,7 & 62.111 \\
\hline Cima Corgo & 13.690 & 1,24 & 4,1 & 55.753 \\
\hline Douro Superior & 6.052 & 1,33 & 3,5 & 21.198 \\
\hline Total & 33.080 & 1,17 & 4,2 & 139.062 \\
\hline
\end{tabular}

O concelho de Carrazeda de Ansiães, juntamente com os concelhos limítrofes de Alijó, Murça e S. João da Pesqueira, é abrangido pela sub-região de Cima Corgo que inclui ainda Sabrosa e Tabuaço. Esta sub-região de paisagem abrupta com suas encostas agressivas descendo para os vales profundos dos rios e ribeiras cobertas de pinheiros bravos, restos de castanheiros e carvalhos e muitos mortórios entre muros seculares e mato endémico, e com variações microclimáticas, ocupa uma área geográfica de 132.320 hectares, correspondente a $24 \%$ da área total e 18.277 hectares de área de vinha, equivalente a $44,9 \%$ da área total, percentagem maior das 3 sub-regiões que representa quase $1 / 4$ da produção total da vinha cultivada na Região Demarcada do Douro (RDD) ${ }^{230}$. Historicamente, para além das grandes quintas, na sua maioria ligadas a firmas exportadoras, registava-se ainda na década de 1990, uma dispersão de 33.080 pequenos e médios viticultores que cultivavam 38.588 hectares de vinha ${ }^{231}$.

No esboço de ordenamento territorial agrário, estabelecido a partir da cota-limite da vocação vinhateira, o concelho de Carrazeda de Ansiães, que representa 10\% da RDD, apresenta 96,80 km2 incluídos na zona agrária do Douro Superior, o que representa 34\% da área total, e 99,38 km2 na zona agrária do Cima-Corgo, o que corresponde a 35\% do conjunto desta sub-região. Desta nudez dos números e relações percentuais se deduz a importância potencial deste concelho «fronteira» na região duriense tornando-se assim um objeto de estudo relevante para a compreensão diferenciada da Região Demarcada.

Pode-se então considerar Carrazeda de Ansiães como um «concelho de fronteira» a vários níveis: quer do ponto de vista histórico; quer ao nível da sua localização, ora no Norte do país, em Trás-os-Montes e Alto Douro e Beira, entre 4 distritos: Bragança, Vila Real, Viseu

\footnotetext{
${ }^{229}$ IVDP — Viticultura, Região. Disponível em <https://www.ivdp.pt/pagina.asp?codPag=16>.

${ }^{230}$ BARBOSA, 2006: 7-19.

${ }^{231}$ Dados de 1996 do Instituto do Vinho do Porto (2002: 29-30).
} 
e Guarda e 7 concelhos: Vila Flor, Mirandela, Murça, Alijó, S. João da Pesqueira, Moncorvo e Vila Nova de Foz Coa (ver mapa, Fig. 1.) ora no Douro, entre as sub-regiões de Cima Corgo e Douro Superior; quer ainda na posição mediana simultaneamente ocupada, em termos populacionais, de área de benefício abrangida e caracterização socioeconómica, no contexto histórico da sua integração na Demarcação da Região do Douro (1907-1908) que já inclui o Douro Superior só tardiamente identificado pelas entidades responsáveis ${ }^{232}$.

Cruzando agora os vários planos de observação enunciados, tenta-se fazer uma primeira aproximação direta e mais abrangente ao «estudo de caso alargado» ${ }^{233}$ de Carrazeda de Ansiães enquanto produtor de vinho do Porto. O arco temporal de análise coincide, essencialmente, com o período da I República (1910-1926), pelo que se continua a prestar, ao nível da história, particular atenção quer ao ambiente político-ideológico da República, quer à reconstituição dos elementos económicos, demográficos e sociais característicos deste concelho. A conjuntura histórica de análise abarca o movimento local de representações e sublevações de viticultores carrazedenses ocorridas no âmbito da designada «Questão do Douro» e na posterior integração do concelho no novo modelo institucional de controlo da produção e do comércio dos vinhos generosos, na região, com a Comissão de Viticultura da Região do Douro, entidade republicana de controlo e fiscalização que funcionou entre 1907 e 1932, período em que se estabelecera também a garantia da denominação de origem Douro para a marca Vinho do Porto, sendo assegurado o privilégio da Barra do Douro para a sua exportação.

\subsection{SIGNIFICADO E IMPACTO LOCAL DAS NOVAS DEMARCAÇÕES}

Procuram-se identificar algumas das principais características, mudanças e impactos das novas demarcações atrás referidas no espaço económico e social duriense, com particular incidência no concelho de Carrazeda e observar, concomitantemente, a partir desta escala local as representações sociais dominantes e a emergência de identidades «conjunturais», em particular desde os finais da Monarquia e inícios da I República.

$\mathrm{Na}$ viragem da Monarquia para a I República, Carrazeda de Ansiães, como outros concelhos do Douro, foi, pela primeira vez, legalmente contemplado (na sua totalidade depois reduzida a um número crescente das suas freguesias ribeirinhas), na Região Demarcada do Douro, pelas novas demarcações de 1907 e 1908 que, como se viu, alargaram substancialmente a região produtora de vinhos generosos durienses e se viriam a configurar como matriz de futuras demarcações e regulamentação regional.

\footnotetext{
${ }^{232}$ Cf. O Vinho do Porto, 1937. Nesta publicação nunca é referido o Douro Superior mas apenas as duas sub-regiões: Baixo Corgo e Cima Corgo que substituíram a designação de Alto Douro com a Reforma Administrativa de 1936. ${ }^{233}$ Este método sociológico, articulado com a análise histórica, já por nós aplicado em estudos anteriores, decorre da ciência reflexiva, é baseado em metodologias qualitativas (BURAWOY, 1991) e foi pela primeira vez usado em Portugal por Boaventura de Sousa Santos na obra Conflitos urbanos no recife. O caso Skylab (SANTOS, 1983: 9-59). Ver desenvolvimento deste enquadramento teórico e metodológico, na Parte IV, Capítulo 11 do presente livro.
} 
Por essa altura, havia já surgido, à escala internacional, a importância das marcas dos produtos vitícolas, com especial destaque para Portugal e na região duriense, designadamente, face à frequência das fraudes e falsificações, em matéria de produção e comercialização dos vinhos generosos do Douro. A este nível, o «caso de figura» que é o «Vinho do Porto» analisa-se no domínio sociológico da economia das contrafações, atendendo à relação da autenticidade e genuinidade inerente à marca Vinho do Porto. Aborda-se a problemática da afirmação de uma identidade regional, num quadro de articulação identidade-território-fronteira e mobilizam-se dados e argumentos para interpretar a emergência local de identidades conjunturais, contextuais, no concelho de Carrazeda e municípios vizinhos.

$\mathrm{Na}$ viragem do século XIX para o século XX, Carrazeda de Ansiães, à semelhança de outros concelhos do Douro ressente-se da profunda crise do comércio e da lavoura que se abateu sobre a Região e, tentando enfrentá-la, alguns dos seus proprietários e lavradores incrementaram a cultura do tabaco que se prolongaria pelos primeiros anos da República. E não deixou de se destacar também pela sua participação ativa nas representações às Cortes, em reuniões com outros concelhos e nas comissões de defesa dos direitos da região revelando um protagonismo reconhecido na designada «Questão do Douro» e nas reivindicações regionais e locais associadas. A miséria e a fome em grande parte provocadas pela falta de trabalho, o reforço da carga fiscal e a carestia de vida com a subida dos preços dos produtos, vinham-se agravando desde os finais da Monarquia com a profunda crise duriense, não sendo aos mesmos alheias as manifestações republicanas percursoras ocorridas em Carrazeda de Ansiães na feira mensal de 10 de julho de 1881, por ocasião da invasão filoxérica dos vinhedos do concelho e às quais outras se haveriam de seguir como já anteriormente referido mas melhor se explicitará adiante (Capítulo 6).

No plano da intervenção política e cultural republicana destaca-se a fundação, em 1910, do Centro Democrático Republicano de Carrazeda de Ansiães, com sede na vila e estatutos aprovados em assembleia geral de 1-1-1912. Este Centro entretanto extinto ${ }^{234}$, tinha por objetivos: «defender a Pátria e a República, observar o programa político do Diretório do Partido Republicano Português, aceite em Assembleia Geral do Centro; criar escolas e agremiações educativas e instrutivas, realizar conferências, reuniões, palestras e missões de propaganda para radicar o ideal republicano em todas as classes sociais» ${ }^{235}$.

\subsection{1. Índices gerais de exportação e indicadores de produção de vinhos gene- rosos do Douro}

O concelho de Carrazeda de Ansiães, ocupando então uma posição mediana relativamente aos restantes concelhos da Região do Douro Vinhateiro, contribuía, com a sua produção

\footnotetext{
${ }^{234} \mathrm{O}$ carimbo e alguma documentação do Centro continuam na posse de familiares descendentes de um dos seus fundadores, designadamente, o Dr. António de Sampaio Chaves, da freguesia de Parambos.

${ }^{235}$ Consultar documento integral publicado no mesmo ano na Papelaria e Tipografia Académica de L. P. Moreira Lobo em BNL SC7428/8V. Ver adiante (Parte IV, Capítulo 10) breve história e desenvolvimento analítico do protagonismo local deste Centro Republicano.
} 
média de 1.000.000 litros de vinhos generosos para a produção e exportação nacional cujos valores de grandeza, nos primeiros anos da República, constam dos dois quadros seguintes:

Quadro 7. Vinhos generosos do Douro exportados pelas barras do Porto e Leixões (1909-1913)236

\begin{tabular}{|c|c|}
\hline Anos & Exportações (em litros) \\
\hline 1909 & $22.960 .264,84$ \\
\hline 1910 & $30.941 .065,97$ \\
\hline 1911 & $25.385 .767,15$ \\
\hline 1912 & $28.544 .676,87$ \\
\hline 1913 (até 31 de julho) & $16.091 .658,86$ \\
\hline
\end{tabular}

Quadro 8. Dados comparativos de stocks em Gaia, vinho vindo do Douro e declarado por lavradores, consumo nacional e exportação de vinhos generosos durienses (1909 a 1913)237

\begin{tabular}{|c|c|c|c|c|c|}
\hline Anos & Stocks & $\begin{array}{c}\text { Vinho vindo } \\
\text { do Douro }\end{array}$ & $\begin{array}{c}\text { Vinho declarado } \\
\text { no Douro }\end{array}$ & $\begin{array}{c}\text { Consumo } \\
\text { nacional }\end{array}$ & Exportação \\
\hline 1909 & ---- & ----- & 48.873 .224 & ---- & 22.960 .264 \\
\hline 1910 & ---- & ---- & 17.108 .736 & ----- & 30.941 .065 \\
\hline 1911 & 85.018 .299 & 24.372 .750 & 24.624 .105 & 1.344 .825 & 25.385 .767 \\
\hline 1912 & $\begin{array}{c}77.138 .829 \\
\text { (até 31 out.) }\end{array}$ & $\begin{array}{c}23.616 .049 \\
\text { (até 31 out.) }\end{array}$ & 28.473 .418 & 1.283 .277 & 28.541 .676 \\
\hline 1913 & 82.613 .884 & 26.588 .990 & ------ & (até 30 nov.) & (até 31 jul.) \\
\hline
\end{tabular}

Como se pode ver neste quadro, as quantidades de vinhos generosos do Douro exportados pelas barras do Porto e Leixões, em valores significativos, registam subidas e descidas anuais alternadas, no período de 1909 a 1913, coincidente com os primeiros anos da I República, altura em que toda a produção vitivinícola nacional cresce.

$$
\begin{aligned}
& 1909-22.960 .264,84 \mathrm{~L} \\
& 1910-30.941 .065,97 \mathrm{~L} \\
& 1911-25.385 .767,15 \mathrm{~L} \\
& 1912-28.544 .676,87 \mathrm{~L}
\end{aligned}
$$

Pode observar-se ainda, nos primeiros 3 anos, uma subida, embora oscilante, que atingiu uma média superior a 26.000.000 litros, quantidades ligeiramente superiores às de vinho declarado/manifestado.

\footnotetext{
${ }^{236}$ Relatório da Comissão de Viticultura Duriense: apresentado em sessão de 30 de dezembro de 1913. Porto: Empresa Gráfica «A Universal», 1913, p. 60. Acessível no Museu do Douro, Peso da Régua, Portugal.

${ }^{237}$ Relatório da Comissão de Viticultura Duriense: Apresentado em sessão de 30 de Dezembro de 1913, 1913, p. 61.
} 
Verifica-se também no quadro anterior onde se referem dados da produção de vinho generoso do Douro, nos primeiros anos a seguir às Demarcações de 1907/1908, que os valores de produção repõem os dados das existências dos stocks, com exceção do ano de 1909, em que as quantidades de vinho declarado foram mais do dobro das quantidades exportadas, não tendo subido o consumo nacional, que se manteve aliás, muitíssimo pouco significativo. Observe-se que no ano anterior, a colheita de vinhos foi enorme por todo o país, tendo-se chegado no Alto Douro, em 1909, a vender por apenas $5 \$ 00$, cada pipa de vinho dessa colheita ${ }^{238}$.

Recorde-se que a Região Demarcada do Douro, em 1907/1908, representava 6,6\% da superfície total do país, $11,6 \%$ de área cultivada (agrícola e florestal) e 18,5\% da superfície agrícola nacional, quase $1 / 5$ da área agrícola do continente ${ }^{239}$. Neste contexto, o concelho de Carrazeda de Ansiães, com os seus 29.220 hectares, o penúltimo em termos de superfície, no distrito de Bragança, ocupava, em relação ao total dos concelhos da Região, uma posição mediana.

\subsubsection{Panorâmica das quintas produtoras de vinho do Porto localizadas em Carrazeda}

Em meados do século XX, foram recenseadas no Douro 827 quintas ${ }^{240}$, contando-se neste número, 27 quintas de significativa dimensão e importância, pertencentes ao concelho de Carrazeda de Ansiães, à época, constituído por 19 freguesias e 72 povoações.

Para além das pequenas e médias propriedades do concelho com benefício atribuído e produtoras de vinhos generosos, destacam-se então as seguintes 22 quintas, na margem direita do Douro: Aborraceira, Alegria, Coelheira, Cuveta, Lavandeira, Senhora da Ribeira, Ribeira da Vila, Vinhas, Barrabás, Cachão do Arnozelo, Calvário, Comparado, Freixo, Pé Bom, Pousado, Tralhão, Veiga, Canais de Baixo e Canais de Cima, Carris, Lubazim em Vilarinho, Zimbro, em Ribalonga e Chousa, junto à estação ferroviária de Foz Tua. Refira-se de passagem e a titulo ilustrativo que, por exemplo, a Quinta da Chousa era considerada no período da I República, uma quinta modelo, com os seus 25 a 30 hectares, casa principal de habitação, casa para feitor, cardanhos, lagares de vinho e adega em edifícios próprios, e forja, com iluminação a acetileno e água canalizada de mina na casa principal e na do feitor, lagares e adega, sendo-lhe atribuído um preço de venda de $30.000 \$ 00$. Depois de comprada em total abandono, produzindo apenas 1 pipa de vinho, tornou-se, nessa altura, uma quinta bem explorada e com práticas de cultivo de rigoroso método e competência segura, sendo considerada pelos peritos uma quinta escola onde o Estado muito poderia mandar aprender ${ }^{241}$ (Capítulo 7, subcapítulo 7.6.3.).

\footnotetext{
${ }^{238}$ CARVALHAIS, 1937.

${ }^{239}$ Relatório da Comissão Nomeada por portaria de 25 de agosto de 1914, para proceder à escolha de propriedade onde possa funcionar o Posto Agrário da Região Duriense, 1916.

${ }^{240}$ CORDEIRO, 1941.

${ }^{241}$ Relatório da Comissão nomeada por Portaria de 25 de agosto de 1914, para proceder à escolha de propriedade onde possa funcionar o Posto Agrário da Região Duriense, 1916, p. 64, 72-73.
} 
Já depois da I República, desde 1927 a 1931, encontram-se registadas nos manifestos de produção entrados na Comissão de Viticultura da Região Duriense as seguintes quintas no concelho de Carrazeda: Pescoça, Vale Coelho (dada ainda como sendo parte da Quinta do Lubazim), Tua, Andorinha - Tua, Chousa, Zimbro, Canais, Lubazim, Urraca, Alegria, Barreira, Coalheira, Valdranjo, Requeixo, Carris, Senhora da Ribeira, Roca Vales, Costa, S. Martinho, Arnozelo, Ladeira, Comparado e Coveta.

\subsubsection{Carrazeda de Ansiães enquanto produtor de vinhos generosos do Douro}

Observemos, entretanto, com maior detalhe o comportamento global da produção de vinhos generosos do concelho de Carrazeda de Ansiães, no contexto da RDD, num período compreendido entre a I República e os primeiros anos do Estado Novo.

Durante a segunda metade do século XIX, o concelho de Carrazeda, como se pode observar no Quadro n. ${ }^{\text {9, }}$ registara já, num curto período de 16 anos, um aumento muito acentuado da sua produção de vinhos, a qual mais do que duplicou, passando de $649.300 \mathrm{l}$, em 1866 para 1.848.700 1, em 1892, e ocupando a 9. ${ }^{\text {a }}$ posição em relação aos restantes concelhos da Região.

Quadro 9. Produção de vinho no concelho de Carrazeda de Ansiães (anos 1866, 1882 e 1892)

\begin{tabular}{|c|c|}
\hline Anos & Produções (em litros) \\
\hline 1866 & 649.300 \\
\hline 1882 & 1.909 .530 \\
\hline 1892 & 1.848 .700 \\
\hline
\end{tabular}

Já depois da sua integração na Região Demarcada, conforme poderá deduzir-se dos quadros seguintes, a produção do concelho vai revelar-se inferior, em quase todos os anos considerados. Mas comparativamente aos restantes concelhos da Região Duriense, Carrazeda mantém sempre, ao nível da produção, uma posição mediana, enquanto que no capítulo das existências dos vinhos generosos ocupa a 7. ${ }^{\text {a }}$ posição.

Nos anos imediatamente seguintes às Demarcações de 1907/1908, Carrazeda ocupa a 7. , $10 .^{\mathrm{a}}$ e $8 .^{\mathrm{a}}$ posição, em relação ao conjunto dos restantes 18 concelhos considerados, enquanto produtor de Vinhos Generosos do Douro.

Quanto à produção de vinhos generosos registada no concelho, nos primeiros anos do século XX (Quadro n. ${ }^{\circ}$ 10), já depois da sua integração na Região Demarcada do Douro, esta mantém-se inferior em relação aos finais do século XIX, registando mesmo uma descida acentuada, em 1910, para começar depois a subir, nos anos seguintes, sem voltar, no entanto, a atingir os valores de 1909. Comportamento idêntico registou também na globalidade, a Região Duriense onde Carrazeda passa a ocupar a 7. a posição, colocando-se assim acima da média global dos restantes concelhos. 
Quadro 10. Produção de vinhos generosos, concelho de Carrazeda de Ansiães e RDD

$(1909-1913)^{242}$

\begin{tabular}{|c|c|c|}
\hline \multirow{2}{*}{ Anos } & \multicolumn{2}{|c|}{ Produções (em litros) } \\
\cline { 2 - 3 } & Carrazeda de Ansiães & Totalidade da Região \\
\hline 1909 & 1.588 .821 & 48.873 .234 \\
\hline 1910 & 526.400 & 17.108 .736 \\
\hline 1911 & 789.554 & 24.624 .105 \\
\hline 1912 & 1.457 .550 & 28.473 .418 \\
\hline (até 31 jul.) & 1.021 .410 & 28.425 .915 \\
\hline
\end{tabular}

Em matéria de prédios registados e quantidades de produção manifestadas nos anos 1911 e 1912 (Quadro n. ${ }^{\circ}$ 11), Carrazeda continua a manter uma situação intermédia em relação aos 18 concelhos considerados. Detém a 7.a posição, em prédios registados e, na produção declarada, a 10. ${ }^{\text {a }}$ posição em 1911, passando para a 8. ${ }^{\text {a }}$ posição em 1912, ano em que praticamente duplicou as quantidades manifestadas ${ }^{243}$.

Quadro 11. Prédios registados e produção de Carrazeda na RDD (1911-1912)244

\begin{tabular}{|c|c|c|c|c|}
\hline \multirow{2}{*}{$\begin{array}{c}\text { Região Demarcada Duriense } \\
\text { (Dec. de 21 nov. 1908) }\end{array}$} & $\begin{array}{c}\text { Prédios } \\
\text { registados }\end{array}$ & $\begin{array}{c}\text { Produção } \\
\text { provável (litros) }\end{array}$ & \multicolumn{2}{|c|}{$\begin{array}{c}\text { Quantidades manifestadas/ } \\
\text { declaradas }\end{array}$} \\
\cline { 3 - 5 } & Ano 1911 & Ano 1912 \\
\hline Carrazeda de Ansiães & 568 & 898.995 & 789.554 & 1.457 .550 \\
\hline Total da Região & 8.362 & 28.696 .000 & 24.624 .105 & 28.473 .418 \\
\hline
\end{tabular}

Já quanto a existências de vinhos generosos, em 1912, o concelho de Carrazeda com 783.480 litros, num total de 20.628.648 litros no total da região, ocupava o $7 .^{\circ}$ lugar, situando-se acima da média no conjunto dos concelhos da Região Duriense considerados.

Vejamos entretanto mais detalhadamente, no seguinte quadro resumo, o que se passava, em matéria de produções e comercialização de vinhos generosos com o concelho de Carrazeda, por freguesia e quintas, em anos seguintes, décadas de 1920 e 1930.

\footnotetext{
${ }^{242}$ Relatório da Comissão de Viticultura Duriense: Apresentado em sessão de 30 de Dezembro de 1913, 1913, p. 57; Relatório da Comissão Executiva da Comissão de Viticultura Duriense do ano de 1924, 1913, p. 56-57.

${ }^{243}$ Relatório da Comissão de Viticultura Duriense: Apresentado em sessão de 30 de Dezembro de 1913, 1913, p. 59; Relatorio da Comissão Executiva da Comissão de Viticultura Duriense do ano de 1924, 1913, p. 58.

${ }^{244}$ Relatório da Comissão de Viticultura Duriense: Apresentado em sessão de 30 de Dezembro de 1913, 1913, p. 58; Relatorio da Comissão Executiva da Comissão de Viticultura Duriense do ano de 1924, 1913, p. 58.
} 
Quadro 12. Produções e comercialização de vinhos generosos no concelho de Carrazeda de Ansiães (anos 1927 a 1931$)^{245}$

\begin{tabular}{|c|c|c|c|c|c|}
\hline Anos & $\begin{array}{l}\mathrm{N} .^{\circ} \text { global de } \\
\text { produtores }\end{array}$ & Quintas & Freguesias & Compradores & $\begin{array}{l}\text { Quantidades } \\
\text { globais (litros) }\end{array}$ \\
\hline 1927 & 66 & $\begin{array}{l}\text { Pescoça; Vale Coelho - } \\
\text { Lubazim; Tua; } \\
\text { Andorinha; Carris; } \\
\text { Zimbro. }\end{array}$ & $\begin{array}{l}\text { Pinhal Douro; } \\
\text { Vilarinho; } \\
\text { Castanheiro; } \\
\text { Seixo; Ribalonga }\end{array}$ & $\begin{array}{l}\text { Cockburn Smithes \& } \\
\text { L.a; Croft \& C. ; Martinez } \\
\text { Gassiot \& L.a; Casa } \\
\text { Ferrerheerer Brás C. }{ }^{\text {a L.a }}{ }^{a}\end{array}$ & 2. $352.079,550$ \\
\hline 1928 & 54 & & Castanheiro & & $1.030 .200(* *)$ \\
\hline 1930 & $136\left(^{*}\right)$ & $\begin{array}{l}\text { Canais; Lubazim; } \\
\text { Alegria, Barreira; } \\
\text { Coalheira; Valdranjo; } \\
\text { Requeixo; Ribeira; Roca } \\
\text { Vales; Carris; Zimbro; } \\
\text { Costa; S. Martinho; } \\
\text { Arnoselo; Fonte Santa; } \\
\text { Ladeira e Chousa; Tua; } \\
\text { Vale Coelho; Pescoça; } \\
\text { Comparado; Senhora } \\
\text { da Ribeira }\end{array}$ & $\begin{array}{l}\text { Beira Grande; } \\
\text { Vilarinho; } \\
\text { Seixo; Pombal; } \\
\text { Ribalonga; } \\
\text { Castanheiro; } \\
\text { Pinhal do Norte; } \\
\text { Fiolhal; Linhares; } \\
\text { Pinhal do Douro; } \\
\text { Tralhariz }\end{array}$ & $\begin{array}{l}\text { Cockburn Smithes } \\
\text { \& L.a; Croft \& C.a; } \\
\text { Silva \& Cosens; } \\
\text { Martinez Gassiot } \\
\text { \& L.a; Casa A e G } \\
\text { Vinhos do Porto, } \\
\text { Empresa Vinícola do } \\
\text { Douro; João Graham; } \\
\text { particulares locais }\end{array}$ & $1.457 .556\left(^{* * *}\right)$ \\
\hline 1931 & 157 & $\begin{array}{l}\text { Canais; Lubazim; Carris; } \\
\text { Cachão; Coveta;Chousa; } \\
\text { Coalheira; Alegria; } \\
\text { Zimbro; Senhora da } \\
\text { Ribeira; Urraca; Fonte } \\
\text { Santa (Vesúvio). }\end{array}$ & & $\begin{array}{l}\text { Cockburn Smithes \& } \\
\text { L.a; Croft \& C.a; Silva\& } \\
\text { Cosens; Martinez } \\
\text { Gassiot \& L.a (Gaia); } \\
\text { Valente Costa C. }{ }^{\text {(Gaia); }} \\
\text { particulares locais }\end{array}$ & 2.272 .008 \\
\hline
\end{tabular}

Obs: $\left(^{*}\right) 52$ grandes e médios produtores mais 84 pequenos lavradores; $\left.{ }^{* *}\right)$ Vinhos transferidos das estações do Tua e da Alegria, para Devesas e Freiras, V. N. Gaia; ${ }^{* * *}$ ) total de valores agregados por médias de 15.000 e 8.000 litros.

Este quadro síntese ${ }^{246}$ configura uma boa amostra da situação à época, embora os valores de produção dos anos 1930 e 1931 se achem por defeito, na medida em que resultam da contagem de quantidades superiores a 10.000 litros, tendo sido as inferiores achadas em média e por estimativa. Vejamos agora, mais detalhadamente, o que se passava no concelho de Carrazeda, em matéria de produção e venda de vinhos generosos, a partir dos finais da I República, e que em relação a este período nos pode servir de termo de comparação.

Observa-se em primeiro lugar que no ano de 1927, com pouco mais de 60 produtores, a produção de vinhos generosos no concelho mais do que triplica a produção de 1912. Verifica-se por outro lado em quase todos estes anos, uma subida do número de produtores, embora sem correspondência na subida dos valores de produção a qual regista, em contrapartida, uma

\footnotetext{
${ }^{245}$ Constantes do Arquivo da Comissão de Viticultura da Região Duriense, Casa do Douro — Régua.

${ }^{246}$ Construído a partir de dados compilados em manifestos de produção, declarações de produção de vinhos generosos (Decreto n. 569 de 16/6/1914), requisições de certificados de origem, guias de verificação, declarações e contas correntes.
} 
acentuada descida, para cerca de metade, em 1928 e 1930, sendo a produção deste último ano praticamente a mesma da declarada em 1912. Em 1931, ano em que se regista quase o triplo de produtores de 1928, a produção volta a subir quase atingindo os valores de 1927 e o dobro da média registada depois da integração do concelho na Região Demarcada, em 1909 e nos primeiros três anos da I República.

Permite-se-nos ainda concluir por alguns indicadores do quadro anterior, relativos às produções vinícolas do concelho, quais eram então no concelho de Carrazeda as principais quintas produtoras e os compradores mais destacados de «vinho fino». Esta expressão émica do vinho do Porto, com grande carga simbólica de afirmação identitária em relação ao lavrador produtor, é ainda hoje defendida localmente por referência à genuinidade e autenticidade do produto cuja qualidade e garantia é reportada ao universo de produtores de vinhos generosos em Carrazeda de Ansiães. Estes, como melhor se verá (Capítulos 7 e 8 ) a par de uma rede estabelecida de compradores que se iria manter prolongadamente, encontravam-se já relativamente estabilizados no período de viragem da I República para o Estado Novo apresentando a dinâmica local a seguir evidenciada.

Quadro 13. Universo de produtores de vinhos generosos em Carrazeda de Ansiães (1927-1931)247

\begin{tabular}{|c|c|c|}
\hline Anos & Produtores & Quantidades (L.) \\
\hline 1927 & 66 produtores & $2.352 .079,550$ \\
\hline 1928 & 54 produtores & 1.030 .200 \\
\hline 1929 & & \\
\hline 1930 & 136 produtores (52 médios/grandes e 84 pequenos) & 1.457 .556 \\
\hline 1931 & 157 produtores & 2.272 .008 \\
\hline
\end{tabular}

Verificam-se ao longo destes anos algumas ocorrências regulares entre as freguesias produtoras de vinhos generosos e os compradores dos vinhos evidenciando-se uma relativa fidelização ao nível dos comportamentos de compras e vendas. Assim, por exemplo, enquanto que os produtores das freguesias próximas das margens do Douro, como Ribalonga, Beira Grande e Linhares vendem quase sempre à Casa Croft, as povoações de Vilarinho, Fontelonga, Alganhafres e Fiolhal vendem à Cockburn Smithes \& C. a , enquanto que Coleja, Carrazeda e Tralhariz, vendem à Silva \& Cosens e Martinez \& Gassiot. Os produtores das povoações da margem do rio Tua (Tralhariz, Fiolhal, Pombal, Brunheda e Santrilha) vendem maioritariamente a compradores locais. As maiores quantidades foram sobretudo vendidas, às Firmas Croft e Martinez Gassiot ${ }^{248}$.

\footnotetext{
${ }^{247}$ Quadro construído a partir de dados compilados em manifestos de produção, declarações de produção de vinhos generosos (Decreto n. 569 de 16/6/1914), requisições de certificados de origem, guias de verificação, declarações, e contas correntes, documentos constantes do arquivo da Comissão de Viticultura da Região Duriense in Casa do Douro, Régua.

${ }^{248}$ PEREIRA, 2010.
} 
Relembre-se que a zona da ribeira do concelho, com grandes explorações, algumas ligadas a importantes firmas exportadoras e uma maioria de pequenos produtores com 0,5 ha de vinha, em média, mas com grande peso na produção de vinho do Porto, contribuía, já na I República, em que se assistiu a um aumento da produção, com uma produção média de 1.000.000 litros de vinhos generosos.

O mesmo volume de vinho do Porto irá contabilizar, na última década do século XX, a produção própria e compra de vinhos à produção do giro exclusivo da grande firma britânica Cockburn Smithes, empresa que em 1995, só ela transportou para a Régua essa quantidade de vinhos (1.003.678 litros, equivalentes a 2.338 pipas) proveniente de apenas 7 adegas localizadas em 5 das freguesias do concelho (Castanheiro, Seixo, Vilarinho, Linhares, Beira Grande e Ribalonga) e de 9 das cerca de 20 quintas então existentes em Carrazeda (Canais, Alegria de Cima, Zimbro de Cima, Tua, Vale Coelho, Pescoça, Coalheira, Amendoeiras e Vinhais). (Parte III, Capítulos 7 e 8).

\subsubsection{O concelho de Carrazeda de Ansiães — espaço económico-social, demo- gráfico e cultural}

Traçado que foi o enquadramento concelhio e também por freguesias, de Carrazeda de Ansiães ao nível da produção de vinhos generosos, em sucessivos anos, verifica-se que o mesmo, com uma área de 29.220 hectares $^{249}$, se mantém numa posição mediana no conjunto dos concelhos da Região Demarcada do Douro.

Importa então agora apresentar sumariamente a sua caracterização económico-social, demográfica e cultural, incidindo em particular no período até aqui em observação.

Quadro 14. Carrazeda, prédios inscritos na matriz e rendimento coletável (1908)

\begin{tabular}{|c|c|c|c|}
\hline Área do concelho (ha) & $\begin{array}{c}\text { N. }{ }^{\circ} \text { de } \\
\text { prédios }\end{array}$ & $\begin{array}{c}\text { Rendimento coletável } \\
\text { (mil réis) }\end{array}$ & $\begin{array}{c}\text { Dimensão média dos prédios } \\
\text { (ha) }\end{array}$ \\
\hline 29.220 ha & 56.686 & 61.126 & 0,5 \\
\hline
\end{tabular}

O número de prédios inscritos neste quadro subdivide-se em 4.702 prédios urbanos e 51.984 prédios rústicos, ocupando Carrazeda no conjunto dos 22 concelhos da Região Demarcada, respetivamente a $11 .^{\mathrm{a}}$ e a $16 .^{\mathrm{a}}$ posição relativa.

Continua a manter-se o número de prédios inscritos nas matrizes e, sensivelmente o mesmo valor do rendimento coletável que serviu de base à contribuição predial, no ano económico de 1911-1912, cabendo aos prédios urbanos, cerca de 10.791 mil réis e aos rústicos, aproximadamente 49.910 mil réis ${ }^{250}$.

\footnotetext{
${ }^{249}$ Relatório da Comissão nomeada por Portaria de 25 de agosto de 1914, para proceder à escolha de propriedade onde possa funcionar o Posto Agrário da Região Duriense, 1916, p. 20-21.

${ }^{250}$ A partir de dados do Anuário das Contribuições Diretas, do ano civil 1911 e económico 1911-1912, in Relatório da Comissão nomeada por Portaria de 25 de agosto de 1914, para proceder à escolha de propriedade onde possa funcionar o Posto Agrário da Região Duriense, 1916, p. 28-33.
} 
No que se refere ao regime contributivo, designadamente à Contribuição industrial, adicional e outras, a situação de Carrazeda era nos mesmos anos, a seguinte:

— Contribuição industrial e adicional - 1.256\$63, o que correspondia à 17. ${ }^{\mathrm{a}}$ posição, sempre por referência ao conjunto dos concelhos da Região considerados;

— Contribuição de renda de casas - 1.100\$67, valor mediano no total dos concelhos;

— Contribuição de décima de juros - 319\$54, equivalente, no conjunto dos concelhos, à $18 .^{a}$ posição.

Ao nível demográfico, os quadros seguintes permitem observar nalgumas variáveis o comportamento populacional do concelho com as suas 19 freguesias, de que apenas 11 fazem parte da Região Demarcada do Douro, como já se disse.

Quadro 15. População (habitantes e fogos) do concelho de Carrazeda (1890-1930) ${ }^{251}$

\begin{tabular}{|c|c|c|}
\hline Anos & N. ${ }^{\circ}$ de habitantes & N. ${ }^{\circ}$ de fogos $\left(^{*}\right)$ \\
\hline 1890 & 12.935 & 3.353 \\
\hline 1900 & 13.605 & 3.524 \\
\hline 1911 & 13.667 & 3.592 \\
\hline 1920 & 12.082 & --- \\
\hline 1930 & 13.559 & --- \\
\hline
\end{tabular}

Obs: (*) Mais de $60 \%$ dos fogos registados compreendem agregados familiares de 2 a 5 membros.

Com este panorama, Carrazeda era, em 1911, o 7. concelho mais populoso da Região Duriense e o $10 .^{\circ}$ em número de fogos, parâmetro em que registou, entre o século XIX e XX, no período considerado, uma ligeira subida.

Quadro 16. Emigração legal de naturais do concelho de Carrazeda (1887 a 1911)252

\begin{tabular}{|c|c|c|c|}
\hline Anos & Número de Emigrantes & Anos & Número de Emigrantes \\
\hline 1887 & 105 & 1905 & 85 \\
\hline 1893 & 732 & 1906 & 83 \\
& 55 & 1907 & 152 \\
\hline 1901 & 39 & 1908 & 181 \\
\hline 1902 & 51 & 1909 & 148 \\
\hline 1904 & 71 & 1911 & 732 \\
\hline
\end{tabular}

\footnotetext{
${ }^{251}$ Dados INE-Recenseamentos Gerais da População.

${ }^{252}$ Os dados referentes a 1901 até 1911 foram retirados do Relatório da Comissão Nomeada por Portaria de 25 de agosto de 1914, para proceder à escolha de propriedade onde possa funcionar o Posto Agrário da Região Duriense, 1916. p. 27.
} 
Dos 14 concelhos do Alto Douro considerados, Carrazeda de Ansiães apresentava nos finais do século XIX, um número superior de emigrantes, especialmente no ano de 1893, só tendo sido ultrapassado, de perto, por Sabrosa em 1887. Com o mesmo número de emigrantes, era, logo no início da I República, em 1911, o 3. ${ }^{\circ}$ concelho com maior emigração.

Outros indicadores de natureza sociocultural podem ainda ser tidos em conta nesta caracterização do concelho, comparativamente à Região dos Vinhos Generosos do Douro em que se integra. Assim por exemplo, no mesmo ano de 1911, contavam-se 49 cegos, 7 surdos-mudos, 16 doentes mentais (designados idiotas e alienados), percentagens reduzidas no total dos concelhos da Região dos Vinhos Generosos do Douro, com 657 cegos, 291 surdos-mudos, 428 «idiotas» e 100 «alienados». Quanto aos níveis de alfabetização, Carrazeda apresentava então o seguinte quadro e posições na Região que contava um total de 250.839 analfabetos para 77.831 de pessoas sabendo ler, ou seja, uma percentagem de cerca de $1 / 3$ de alfabetizados.

Quadro 17. Carrazeda de Ansiães — Níveis de instrução da população (1911)

\begin{tabular}{|c|c|c|c|c|c|c|c|}
\hline \multicolumn{3}{|c|}{ Número de Analfabetos } & \multicolumn{3}{|c|}{ Número dos que sabem ler } & \multirow{2}{*}{$\begin{array}{l}\text { Percentagem } \\
\text { de analfabetos }\end{array}$} & \multirow{2}{*}{$\begin{array}{c}\text { Percentagem } \\
\text { dos que sabem ler }\end{array}$} \\
\hline Varões & Fêmeas & Totais & Varões & Fêmeas & Totais & & \\
\hline 4770 & 6049 & 10.819 & 1.871 & 964 & 2835 & $79 \%$ & $21 \%$ \\
\hline
\end{tabular}

Em termos comparativos com os restantes concelhos da Região, em que globalmente considerada a percentagem de alfabetizados não ultrapassava um quinto, o concelho de Carrazeda, ao nível da instrução, ocupava a 10 a $^{a}$ posição no parâmetro de analfabetos, apresentado apenas $21 \%$ de alfabetizados, aproximadamente, $1 / 5$.

Novamente se confirma, neste indicador, a situação de fronteira e/ou posição intermédia de Carrazeda de Ansiães, na Região de Produção de Vinhos Generosos do Douro em que está inserida.

A anterior reconstituição histórica, numa perspetiva micro, permite-nos, em síntese, considerar o concelho de Carrazeda como representativo do conjunto dos restantes concelhos da Região Demarcada do Douro, durante o período da I República, curto mas intenso.

Em síntese, decorrente do exposto e ainda por referência aos primeiros e últimos 3 anos da I República, o concelho de Carrazeda com 568 prédios registados, registou, embora com oscilações, quer um aumento da produção e exportação de vinhos generosos (mais de 1.000.000 litros, em média) quer uma subida do número de produtores, que quase triplicou, atingindo nos anos 1920-30 uma média aproximada de 100. Foi igualmente possível verificar que Carrazeda de Ansiães manteve sempre no conjunto dos concelhos da RDD, uma posição, nalguns indicadores acima da média e na maioria, intermédia.

Os dados específicos aduzidos provenientes, maioritariamente, de documentos da Comissão de Viticultura da Região Duriense permitiram uma breve contextualização e carac- 
terização económico-social, demográfica e sociocultural de Carrazeda de Ansiães, enquanto concelho produtor de vinhos generosos do Douro ${ }^{253}$.

Em praticamente todos os indicadores e variáveis de posição em consideração: prédios registados, produção e exportações de vinhos generosos, principais compradores/exportadores, composição de fogos, níveis de alfabetização e taxas de emigração das populações, é possível concluir, globalmente, que Carrazeda de Ansiães detinha, no período em observação, uma situação mediana relativamente aos restantes concelhos da Região do Douro Vinhateiro, ocupando aí, uma posição de «fronteira» dotada de grande representatividade, a vários títulos.

Aliás, idêntica situação de fronteira é replicada no interior do concelho, composto de duas áreas distintas: a da frieira, terras do planalto transmontano e as da ribeira, terras do Douro e Tua, entre as quais sempre se movimentaram sazonalmente as tradicionais rogas da apanha da azeitona e das vindimas no Douro. Tais mobilidades não enfraquecem a identificação e afirmação da pertença identitária local, antes pelo contrário; os que estão mais afastados do poder político e suas instituições identificam-se mais facilmente com as pertenças localistas e a ideia unificadora de região. Assim, esta diferenciação/identificação assente nas relações de trabalho ${ }^{254}$ intraconcelho e interconcelhos e as interações sociais que nesses contextos se produzem, evidenciam diferenças básicas que se tornam, em si mesmas, fator de identidades específicas que adiante tentaremos melhor qualificar.

Por outro lado, e retomando as linhas tendenciais das demarcações da Região do Douro e suas implicações em Carrazeda de Ansiães podemos verificar que a qualidade dos seus vinhos fora já reconhecida, designadamente com as Demarcações Marianas ou Subsidiárias (1788-1793). Estas incluíam já 3 propriedades do concelho (a Quinta da Chousa em Foz Tua e mais duas vinhas), área alargada à freguesia de Linhares de Ansiães em que são arroladas na zona de vinhos de embarque 3 quintas e 79 vinhas e ainda Castanheiro e Ribalonga que foram também pela primeira vez incluídas na zona de Feitoria, segundo as qualificações de $1797^{255}$.

Como se viu anteriormente, a Demarcação Subsidiária de $1793^{256}$ que não terá chegado a entrar em vigor, previa a produção de vinhos de embarque ou de feitoria nas seguintes freguesias durienses de Carrazeda de Ansiães: Pinhal, Parambos, Pombal, Paradela, Linhares, Castanheiro, Beira Grande, Seixo, Coleja, Ribalonga, para além de Vilarinho da Castanheira, na altura ainda concelho. Tal facto indicia claramente que o número de viticultores era bastante

\footnotetext{
${ }^{253}$ Alguns dos quadros foram adaptados a partir de dados incluídos em PEREIRA, 1989: 339-353, mas a maioria deles, construiu-se com dados de relatórios e documentos da Comissão de Viticultura da Região Duriense, in Casa do Douro, Régua.

${ }^{254}$ PARKHURST, 2004.

${ }^{255}$ Cf. PEREIRA, 2010: 23, 24.

${ }^{256}$ AHMO - Relação das Quintas, e vinhos que em execução da Carta Régia de 28 de janeiro de 1793, acharão capazes de produzir vinho tinto legal de Embarque, MR 35, caixa 29/36, n. ${ }^{\circ} 30$. Fonte inédita que se encontra no Arquivo Histórico do Ministério das Obras Públicas. Esta fonte é, como todas as demarcações algo lacónica, pois só indica os nomes de proprietários e comissários e não a dimensão e produção das vinhas e quintas. Agradece-se esta informação ao Professor Gaspar Martins Pereira.
} 
considerável para a época o que demonstra, por sua vez, uma grande vitalidade vinhateira destas freguesias que tinham, no entanto, sido excluídas das demarcações clássicas (Pombalinas e Marianas).

Atendendo a esta retrospetiva histórica das demarcações mais abrangentes da Região Duriense do início do século XX, perguntamo-nos então sobre quais as implicações/repercussões em Carrazeda de Ansiães deste novo modelo institucional protecionista de ação reguladora estatal da organização da produção e comércio do vinho do Porto?

Será mesmo caso para dizer-se que esta nova demarcação da Região Duriense ocorrida na 1. a década do século XX, passaria fundamentalmente por Carrazeda de Ansiães, ainda que levando em linha de conta que os terrenos mais apropriados à mecanização, com propriedade de valor superior, vinho de melhor qualidade e uma pressão sobre a terra maior, se encontram no Alto Douro sendo a participação da vinha do Douro Superior na RDD estimada em apenas 9\%. Todavia, a maior parte dos proprietários com explorações melhor dimensionadas — em regra, as quintas - continuava então a residir especialmente no Porto e fora do Douro, a que tem cabido sobretudo a produção da matéria-prima e a primeira fase do fabrico (parte económica não fundamental do setor reservada à comercialização), não contribuindo proativamente para o desenvolvimento local e regional, nem para o fortalecimento de uma classe empresarial local e desenvolvimento regional equilibrado e sustentado.

\subsection{O VINHO DO PORTO E O PROBLEMA ECONÓMICO DOS VITICULTORES DURIENSES}

A produção e imagem do vinho do Porto tem assentado historicamente numa rede fundiária constituída por um grande número de pequenos viticultores (hoje em dia ainda superiores a 90\% do total das explorações vitivinícolas) e sobretudo das Quintas durienses, algumas, como se referiu já durante muito tempo de exploração absentista, outras de gestão direta dos próprios proprietários, cuja dimensão implica a presença de trabalhadores permanentes ou sazonais quando o volume de trabalhos exige a sua contratação (as antigas «rogas» e modernas «empreitadas»). O restante vinho do Douro não tinha relevância no mercado externo, restringindo-se ao consumo interno na região ou à sua venda como «vinho de ramo».

O número e importância das quintas no Douro crescem particularmente desde finais do século XVII e durante o século XVIII, com o significativo desenvolvimento geográfico da viticultura.

Mas a viticultura duriense, globalmente ainda praticada em moldes tradicionais, sofreu, a partir de meados do século XIX, uma grave crise devido à destruição da maioria dos vinhedos pela sua contaminação pelas doenças das vinhas já referidas, particularmente a filoxera oriunda da América, cujos efeitos económicos e sociais e procura de soluções, designadamente ao nível da sua modernização técnica e fundiária, se prolongaram até final de Oitocentos. 


\subsubsection{O enfrentar da crise e o domínio de Dona Antónia Ferreira e família...}

Entre as numerosas medidas tomadas para debelar os graves problemas dos vinhedos, destaca-se a ação de várias personalidades da época, em regra proprietárias de Quintas no Douro, conhecedoras da viticultura, as quais, sensibilizadas para questão, escreveram sobre o combate à crise vitivinícola que assolava a Região, assim contribuindo também para ajudar a debelá-la. Foi o caso, entre outros, de Pinto de Menezes e Marques de Carvalho (no «Boletim da Direção Geral da Agricultura»), Cincinato da Costa (Portugal Vitícola), Visconde de Villa Maior (Manual de Viticultura Prática). Por sua vez, é de realçar ainda a ação de algumas quintas históricas do Douro (como por exemplo a Quinta do Paço de Monsul, Quinta da Romaneira, Quinta do Convento de S. Pedro das Águias, Quinta da Casa Amarela, Quinta da Pacheca, Quinta da Eira Velha, Quinta de S. Luiz, Quinta de Roriz, Quinta do Seixo, etc.).

\subsubsection{Extensão ao território concelhio duriense de Carrazeda de Ansiães}

Na mesma época, evidencia-se o protagonismo pioneiro de Dona Antónia Adelaide Ferreira (conhecida no Douro pela Ferreirinha da Régua), uma das maiores proprietárias na história da Região Duriense, dona de cerca de 30 quintas, algumas de grande relevância (como por exemplo a dos Aciprestes, a do Vesúvio ou antiga quinta das Figueiras, e as da Boavista, da Granja, do Vallado, e do Vale do Meão, para além de outras) e onde se supõe tenham sido implementados vários aperfeiçoamentos técnicos (aplicação de produtos fitossanitários, construção de muros e de terraços, controlo da erosão hídrica, etc. $)^{257}$.

Para além das compras de casas, terrenos, quintas e outras propriedades, feitas por Dona Antónia Ferreira em Foz Tua-Carrazeda (ver Capítulo 7) o seu domínio estendeu-se ainda à Serra do Seixo de Ansiães no concelho de Carrazeda, a qual se alonga por quase toda a área de delimitação concelhia na margem direita do Douro, e onde a respetiva Câmara detinha o domínio público sobre vinhas, plantações e outros terrenos de cultivo de cereais e o direito de coleta do tributo da décima parte do rendimento anual do produto das colheitas a que estavam obrigadas as populações e rendeiros de diversas aldeias vizinhas que agricultavam essas terras.

É o que a seguir melhor se documenta através da ilustração (Fig. 39) $)^{258}$ e transcrição parcial de uma carta de venda e arrematação em hasta pública, exarada no Ministério da Fazenda em 29 julho 1878 em nome de Francisco José da Silva Torres, 2..$^{\circ}$ marido de Dona Antónia Adelaide Ferreira, com a qual casara, anos antes, em 1856.

Esta venda feita «pela quantia de setecentos e vinte mil e duzentos réis» era referente à arrematação da

\footnotetext{
${ }^{257}$ Ver desenvolvimentos em MAGALHÃES, 2014.

${ }^{258}$ Documento avulso in Maço de correspondência de 1935, da Administração da Quinta do Vesúvio relativa à Quinta da Coalheira, em papel avulso e timbrado da «Companhia Agrícola e Comercial dos Vinhos do Porto Régua (Antiga Casa Ferreirinha (fundada em 1751)» (AHS — Quinta do Vesúvio/Quinta da Coalheira, cx. 2915).
} 
seguinte propriedade que pertencia à Câmara Municipal de Carrazeda de Ansiães... a uma serra denominada serra do Seixo que terá de comprimento um quarto de légua ou 1.250 metros e de largura, meio quarto de légua proximamente, ou 625 metros e mais duas lameiras. Esta serra tem várias vinhas, hortas e árvores que os moradores das povoações do Seixo, Vilarinho, Pinhal do Douro e Coleja possuem, estando na posse de plantar vinhas e fazer a lavoura de pão no resto das terras, estando a Câmara Municipal de Carrazeda de Ansiães somente na posse de receber de cação [comissão] anual de todos os frutos produzidos de cada dez um sobre o produto das colheitas [pagamento da décima] o qual foi calculado em 60 mil réis anuais... O arrematante satisfez na Junta do Crédito Público e na recebedoria do dito concelho em metal a quantia de sessenta e um mil e cem réis de contribuição de registos e adicionais... transmissão por irrevogável venda para a sua posse do dominio que na referida propriedade tinha a mencionada Câmara para que o arrematante, seus herdeiros e sucessores a gozem, possuam e disfrutem como própria. [...] Lisboa, 2 de Setembro de 1878.

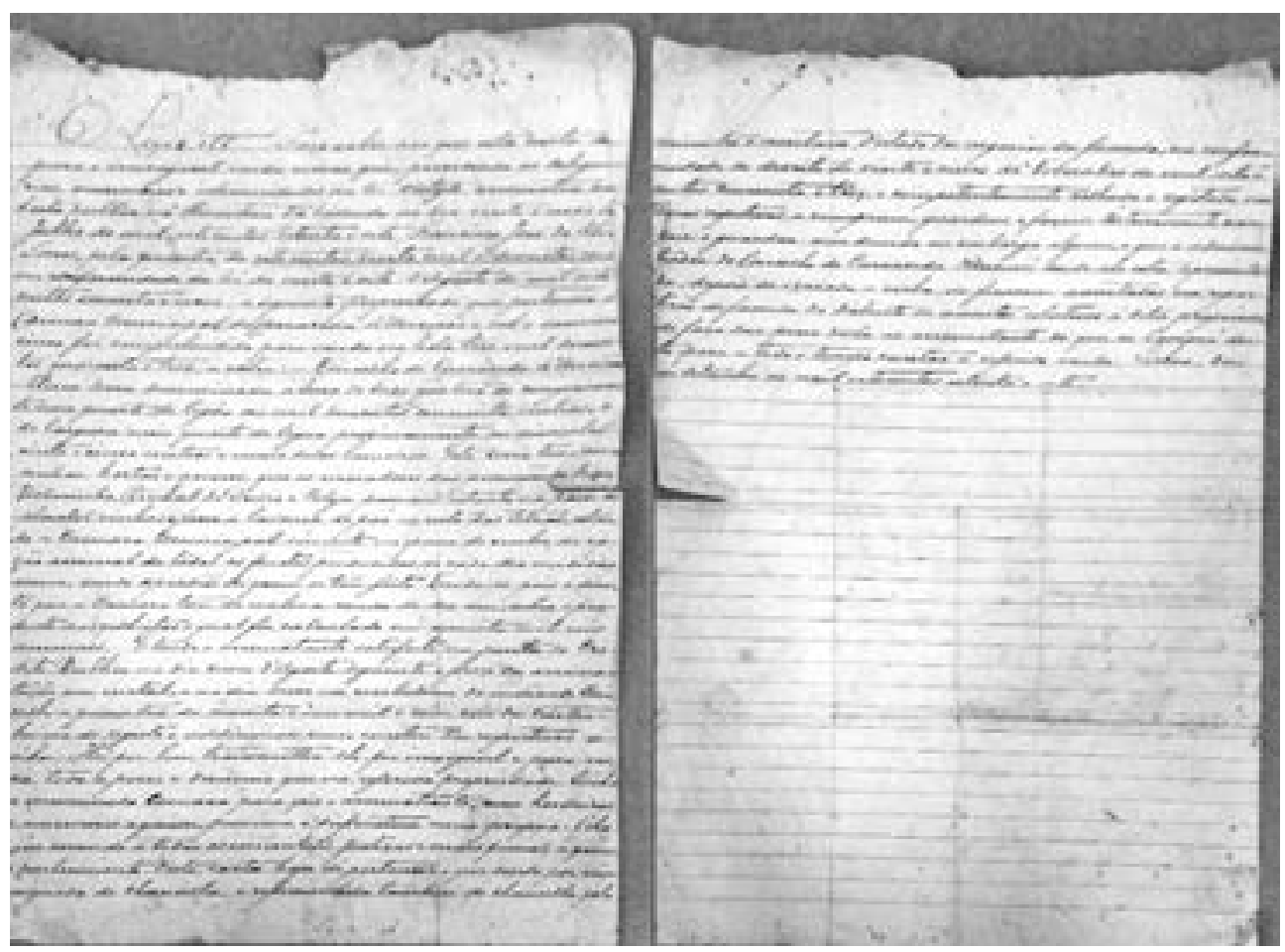

Fig. 39. Carta de venda e arrematação em hasta pública - C. M. C. A. a F. J. S. T. $(1878)^{259}$.

${ }^{259}$ AHS - Quinta do Vesúvio/Quinta da Coalheira, cx. 2915. 


\subsubsection{Conjuntura favorável ao regresso da demarcação da região e defesa dos interesses da lavoura duriense}

Nos finais do século XIX, inícios do século XX, os vinhos do Douro viviam uma situação bastante complexa relacionada quer com a conjuntura do mercado internacional quer com a abundância de vinhos baratos das novas regiões produtoras no centro/sul do país, fazendo-se sentir no setor de comercialização do vinho do Porto o recurso então generalizadamente posto em prática de incorporação de vinhos de outras zonas vitícolas do país como se de vinhos de denominação de origem duriense se tratasse.

Era esta, à época do regresso à Demarcação da Região, a difícil e complexa conjuntura em que se encontrava a lavoura e o comércio do vinho do Porto a qual contribuiu para grandes convulsões sociais de defesa duriense e políticas ziguezagueantes entre interesses antagónicos, ora de restabelecimento na lei, de interesses próprios do Douro ora da adoção de medidas de compensação para outras regiões vinhateiras do país, como a Estremadura, em que se conta, designadamente, a legislação protecionista de João Franco, fortemente criticada e contestada, como se viu. Nas restantes regiões vitícolas nacionais onde a vitivinicultura se desenvolvia com intensidade, destacava-se então a Estremadura, donde era procedente grande parte do designado vinho do Porto exportado, «possuía nessa altura cerca de 30.000 pipas de vinhos licorosos destinados para a venda ao exportador do vinho do Porto $»^{260}$, tendo vindo a conseguir obter, a título de compensação, o monopólio de fornecimento da aguardente à região do Douro, o que provocou aqui, naturalmente, o maior descontentamento e contestação traduzida em tumultos e assaltos a comboios e armazéns de estações de caminho de ferro, como sucedeu em Foz Tua (ver Capítulo 6).

\subsubsection{Concorrência ao vinho do Porto no mercado britânico e tumultos sociais no Douro}

Mais tarde, o Tratado de Comércio Luso-Britânico de 12 de agosto de 1914 que fora proclamado como visando acabar com a enorme concorrência que o vinho do Porto enfrentava no mercado britânico, seu destino privilegiado, face a imitações e falsificações, de toda a ordem e de várias origens, prescrevia na sua base ou artigo $60^{\circ}$ uma redação tão aberta que considerava como vinho do Porto o procedente de Portugal, abrindo de novo, assim, ao usurpar a denominação de origem «Douro» ou «Porto», em proveito eventual de outras regiões vitícolas, o caminho às falsificações nacionais. Isto apesar de Bernardino Machado se ter comprometido, em reunião anterior com uma comissão de representantes do Douro, a que esse Tratado garantiria a marca exclusiva de origem duriense reservando a designação de «Port Wine» para os vinhos daí provenientes e exportados. Mas até que fosse finalmente aclarado o sentido dessa base 6. do Tratado, sucederam-se movimentos sociais contraditórios de contestação ou defesa, pois estavam em posição interesses diferentes de produtores, comerciantes, exporta-

${ }^{260}$ CARVALHAIS, 1937: 15. 
dores e das regiões vitivinícolas do sul do país e do Douro. A redação desta cláusula polémica do Tratado foi contestada pelos viticultores durienses, com repúdio inflexível, sucederam-se manifestações e tumultos populares que se agravaram face às medidas dúbias dos governantes e à conjuntura política nacional instável, vindo a culminar, tragicamente, no histórico Motim de Lamego de julho de 1915, tendo-se por fim verificado, com um alto preço em vidas ceifadas pelas forças militares, a aclaração pretendida pela defesa dos interesses durienses no sentido do reconhecimento oficial a nível nacional e internacional da denominação de origem «Douro» e «Porto» ${ }^{261}$.

São, e foram desde sempre, de vária ordem os problemas económicos com que os lavradores e viticultores do Douro se têm confrontado especialmente no que se refere à produção, comercialização e exportação dos seus vinhos e em particular do vinho do Porto. Para além dos referidos, destacam-se, no que concerne à lavoura, alguns de natureza estrutural, como os resultantes, comparativamente com outras regiões vitícolas, do elevado encargo de investimento de capital inicial e dos avultados custos do granjeio a que acresce o tradicional e ainda vigente modo de formação do preço de vinho ${ }^{262}$ produzido só depois da sua colheita, e ainda o desequilíbrio recorrente entre a produção e o fabrico de vinhos generosos, gerador de frequentes crises de sobreprodução derivadas de uma produção sempre maior que a exportação.

Historicamente, e em especial desde os anos 1930 com a criação da Casa do Douro cuja fundação teve lugar por exigência regional do Douro, os viticultores da Região têm defendido como solução possível e desejada a fixação de um preço justo para os vinhos de pasto ou lisos confiando numa boa orientação, algumas vezes defraudada, das direções sucessivas da Casa do Douro, manifestando-se assim, em regra, a favor de uma política protecionista e de intervencionismo estatal em detrimento das leis da oferta e da procura do mercado.

\footnotetext{
${ }^{261}$ Para maior desenvolvimento ver SEQUEIRA, 2011.

${ }^{262}$ Desde 1997, os preços mínimos são fixados todos os anos.
} 


\section{CAPÍTULO 6. A «QUESTÃO DO DOURO» E A TURBULÊNCIA SOCIAL NA REGIĨO}

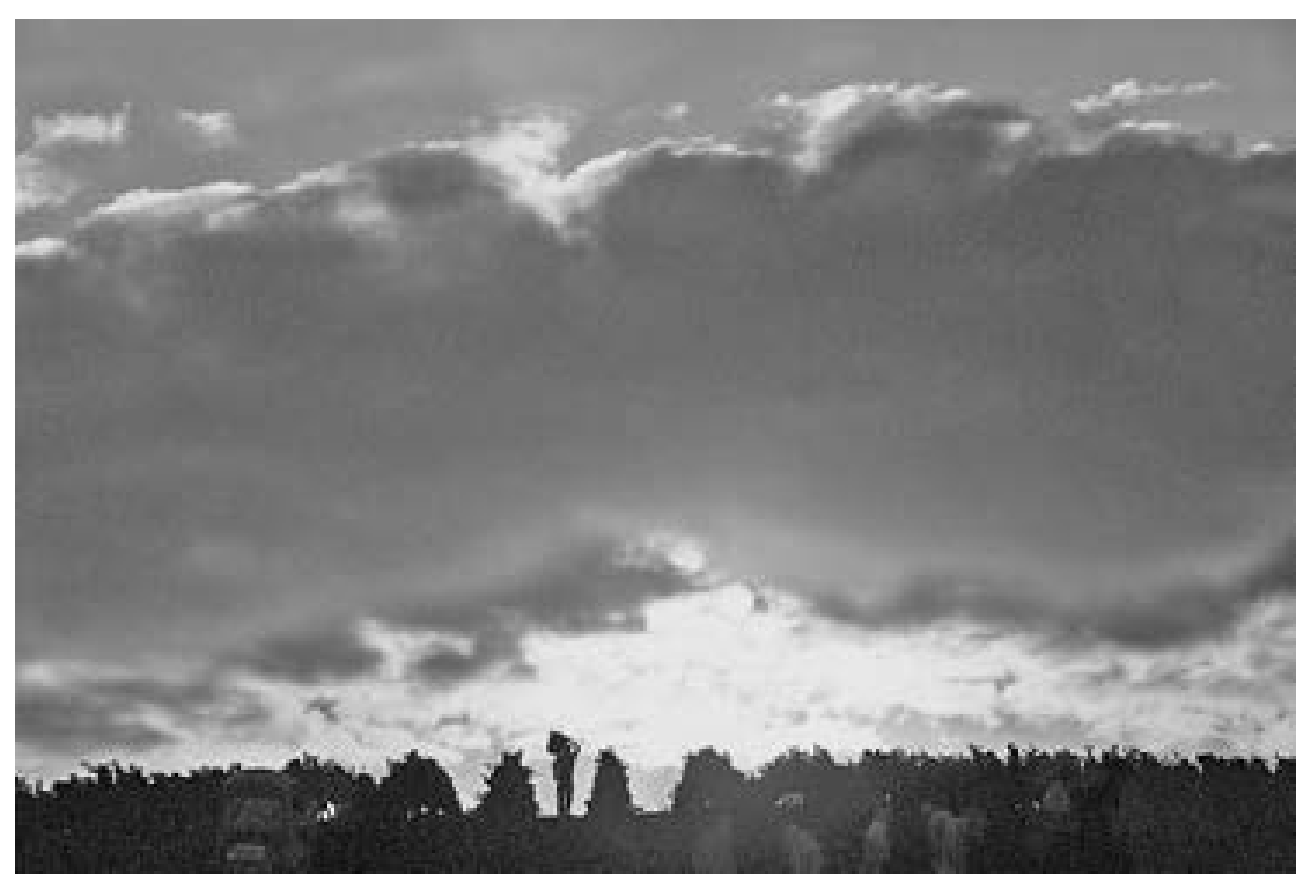

Fig. 40. Foto do Douro do fotojornalista Leonel de Castro

Por dever de ofício, nós e os que andam à jorna, conhecemos o Douro palmo a palmo, quási num mistério, quási numa absoluta conquista de posse. Sentimo-lo através das raizes da carne. Encosta arriba, fragoenta e má, só para bichos de pata leve e dorso elástico, os corpos da gente convertem-se em ângulos duros, os músculos estoiram à flor da pele, o suor corre, corre em bica: tudo, tudo em nós, sob o pesadume dum sol que obriga a terra de pedra a bebê-lo, quer queira, quer não.

Dominadores sem domínios. Encontramo-los por toda a parte, em qualquer refrega da vida. Conscientemente fortes ou não, subjugam a matéria que trabalham sem dela fruírem o condigno prémio da luta. Dir-se-ia que sobre eles pesa um fatalismo legendário que rola há milhares de anos.

Mas aqui, neste Douro atirado para o alto, a espaços num brusco arremesso, montanhas e mais montanhas até os olhos pararem, cansados, os tais dominadores transcendem o humano. Porque, se o Douro, nas suas zonas aspérrimas, dá o que dá, porque, se o Douro é um ver a Deus ali e além, deve-se às inglórias batalhas do homem contra a Natureza 
rebelde e sáfara. Cada parede dos socalcos por aí arriba, sugere, na teoria dos símbolos, uma lápide nua e grosseira, circular e longa, dessas vitórias ignoradas [... $]^{263}$.

Este texto poético faz eco das assimetrias sociais na Região Duriense, antigas, profundas e abissais, dicotomia socioestrutural determinante cujo sentido se perde muitas vezes no emaranhado de contradições que a atravessam. As suas representações históricas requerem uma abordagem analítica própria que aqui se vai apenas introduzir.

Compôs-se anteriormente um abreviado mas denso dossier histórico-económico da Região Demarcada do Douro a partir do qual se tentou retraçar o local como instância de articulação de escalas, requisito de escrita da micro história do concelho de Carrazeda observado em particular. Aí se pode ancorar esta necessária abordagem introdutória à permanente tensão social no Douro marcada por diferentes movimentos sociais e políticos, em articulação com a problemática da afirmação da identidade regional e pertenças identitárias locais, conjunturais ou contextuais, observadas à luz das noções de territorialidade, autenticidade e legitimidade da denominação de origem Douro e Porto da marca nacional e internacional «vinho do Porto». Alguns destes tópicos serão retomados posteriormente (Parte IV), num enquadramento sociológico como elementos de uma análise sócio-histórica de Carrazeda de Ansiães produtor de vinho do Porto.

\subsection{MOVIMENTOS SOCIAIS E POLÍTICOS NO DOURO CONTEMPORÂNEO}

A Região do Douro Vinhateiro é historicamente uma espaciotemporalidade intensamente regulada, desde sempre sujeita a uma política económica central oscilante entre o protecionismo e o livre-cambismo, fatores de uma latente e constante conflitualidade de interesses, melhor ou pior representados, mobilizando fortemente em momentos de ameaça, crise e rutura as populações e elites locais, as quais, em diferentes conjunturas, assumiram formas extremas de manifestações sociais e políticas: motins, tumultos, levantamentos, sublevações populares, comícios e outras formas de protesto que importa estudar no seu conjunto ${ }^{264}$, para melhor compreender o seu significado histórico.

Desde a época moderna que a Região Vinhateira do Douro tem sido um espaço de forte tensão social e palco de recorrentes manifestações populares e movimentos sociais e políticos. A sua análise, enquanto fenómenos isolados ou enquadrados noutras temáticas tem merecido interesse esporádico dos historiadores que os estudam, em regra, sob a perspetiva das suas motivações, consequências e lideranças, em contextos históricos mais latos, e não como

\footnotetext{
${ }^{263}$ LEITÃO, 1944: 39.

${ }^{264}$ Desde o histórico «Motim da Companhia» de 1757, contra a ação da Companhia Geral da Agricultura das Vinhas do Alto Douro, já largamente estudado designadamente em OLIVEIRA, 1930; SILVA, 1990a; CARDOSO, 1996; para outras manifestações, ver por ex.: PINHEIRO et al., 2010; SILVA, 2007; MARTINS, 1996; PEREIRA \& SEQUEIRA, 2004; LAGE, 2013c: 221-229), ver ainda, para uma análise abrangente de conjunto, LAGE, 2016.
} 
fenómeno sócio-histórico autonomamente considerado, embora caracterizado por traços e características gerais próprias, no quadro da Região Duriense, cuja história social, o seu estudo reflexivo e crítico, em concreto, melhor ajudará a iluminar.

Estão nesse caso as reivindicações e revoltas sucessivas que ocorreram em várias localidades do Douro nos finais da Monarquia e primeiros anos da República, período marcado, como se viu, por aguda crise comercial, superprodução e agitada conjuntura social em que teve lugar a nova demarcação franquista, cuja análise se tenta no enquadramento teórico da sócio-história.

Se na segunda metade de Oitocentos a instabilidade social no Douro não resultou em grandes manifestações de violência, o mesmo não aconteceu nos inícios do século XX, marcados por intensa e violenta turbulência social e política ${ }^{265}$.

Por essa altura, o agravamento da crise de exportações e a generalização das fraudes e falsificações dos vinhos da região, contribuem fortemente para fazer proliferar no Douro os movimentos de defesa regional, de reclamação da marca Porto para os vinhos do Douro e de regresso ao protecionismo, com o exclusivo da barra do Douro e porto de Leixões. Tem lugar a realização de numerosas reuniões e comícios, e assiste-se à fundação de vários Sindicatos agrícolas, bem como ao ressurgimento da Comissão da Defesa do Douro, à forte pressão de várias «comissões de defesa», registada sobretudo em 1906, à constituição na Régua, em 1907, da Comissão de Viticultura do Douro formada por Júlio Vasques, António Montes Champalimaud e outros notáveis da Região, à ação de comissões concelhias que se batem pela «genuinidade do vinho do Porto».

Sucedem-se as representações de personalidades e câmaras durienses às Cortes, as denúncias nos jornais e, em vários locais, ocorrem motins e revoltas populares contra os impostos e a concorrência dos vinhos e aguardentes do sul, com invasão de armazéns de vinho, repartições de finanças e queima de matrizes e papéis fiscais.

Assinalando de forma sangrenta o auge da crise e dos agudos conflitos sociais, o já referido Motim de Lamego contra o artigo 6. ${ }^{\circ}$ do Tratado de Comércio Luso-Britânico, que prejudicava o escoamento dos vinhos durienses, mobiliza populações de dezenas de freguesias do concelho de Lamego, elementos do clero e forças partidárias, sendo violentamente reprimido (12 mortos e 20 feridos $)^{266}$. Pouco antes, dera-se na região vitivinícola do Languedoc, significativo movimento de grande amplitude e desfecho trágico, com a revolta de mais de 600.000 viticultores franceses (Montpellier, 10 de junho 1907, com réplicas em Champagne, abril 1911) e consequências políticas nacionais de notável alcance.

Devido à crise vitícola nacional a cultura da vinha foi condicionada no Douro. E a miséria, fome, desemprego e emigração que despovoavam as aldeias do Cima Corgo, a diminuição considerável da produção de vinho generoso no Baixo Corgo e Douro Superior, a generalizada crise social, de produção e comércio levaram os produtores a reclamar leis de proteção

\footnotetext{
${ }^{265}$ Desenvolvimentos em SILVA, 2010: 88-139; BENNETT, 2010: 280-334.

${ }^{266}$ PEREIRA \& SEQUEIRA, 2004.
} 
aos vinhos durienses, reivindicações de que mais tarde se fez eco João Franco ${ }^{267}$, com medidas protecionistas regionais.

A grande instabilidade política nacional e internacional do conflito bélico internacional da I Guerra Mundial, em que Portugal participa, reflete-se também no Douro que viveu então uma conjuntura económica e comercial muito difícil, de crise vinícola e a concorrência desleal de outras regiões vinhateiras do país. Agrava-se aí a conflitualidade social e política e intensifica-se o espírito regionalista duriense de personalidades locais que vão liderar o Movimento dos Paladinos do Douro.

\subsection{TUMULTOS POPULARES NA VIRAGEM DA MONARQUIA PARA A REPÚBLICA}

A situação no Douro, no início do século XX, caracteriza-se por uma profunda miséria geral provocada por um vasto conjunto de dificuldades: problemas de produção, escoamento e comercialização dos seus vinhos com especial destaque para o vinho do Porto, principal produto de exportação, e respetiva legislação reguladora. Nesse ambiente de crise generalizada e confrangedora desgraça, geradora de solidariedades prementes, fraternidade e intervenção humanitária, designadamente em toda a imprensa, a «Miséria do Douro» era denunciada, através dos males sociais que atingiam a região, as suas populações e centenas de trabalhadores e lavradores: fome, doença, morte, promiscuidade primitiva dos casebres, emigração crescente, despovoamento, fisco implacável, velhos, mulheres e crianças à espera da caridade alheia, num quadro generalizado e pavoroso a que era urgente valer. Caldeava-se assim um pano de fundo social gerador de peditórios públicos e campanhas de solidariedade através da imprensa e, em casos limite, revoltas e motins populares.

Nos finais da Monarquia e durante os primeiros anos da República, milhares de trabalhadores e pequenos proprietários da Região Vinhateira do Douro manifestaram-se em revoltas sociais e motins populares que tiveram lugar sucessiva e alternadamente em diferentes lugares, designadamente, Régua, Santa Marta de Penaguião, Foz Tua, Carrazeda de Ansiães, Vila Flor, Alijó e muitas outras, com expoente máximo em Lamego.

As contestações populares sobre as quais se abateu a violência oficial, com prisões, traduziram-se em regra por assaltos a repartições de finanças, incêndios dos seus documentos em praça pública, invasão de armazéns e destruição de barris de vinho e aguardente, configurando um dos aspetos sociais e políticos mais relevantes da designada «Questão do Douro».

É neste processo social da história contemporânea do Douro, profusamente informada pela imprensa, mas nesta perspetiva ainda insuficientemente debatida, que se centra agora o nosso interesse.

\footnotetext{
${ }^{267}$ Início da ditadura de João Franco em 1907 que impõe novo regime geral para a produção, venda, exportação e fiscalização dos vinhos, reserva a barra do Douro para os vinhos do Porto, alarga a RDD e cria a CVRD para controlo da lavoura e comércio dos vinhos do Douro. A 1 de fevereiro de 1908 dá-se o Regicídio, segue-se a demissão de João Franco a que sucede Ferreira do Amaral que diminui a área da RDD (as freguesias substituem os concelhos), e cria o Grémio dos Exportadores do Vinho do Porto e a Comissão Agrícola Comercial dos Vinhos do Douro.
} 
Faz-se então uma aproximação aos movimentos sociais populares, verificados em Carrazeda de Ansiães, Vila Flor, Alijó e Lamego, nos anos de 1907, 1909-1910, 1912, 1914-1915, observando-se, no contexto da «Questão Duriense», tornada questão nacional ${ }^{268}$, e da defesa da «marca regional» Douro e Porto, a emergência de identidades locais de natureza conjuntural/contextual, cujas dinâmicas de construção e afirmação específicas, se tentam qualificar.

\section{Perturbações sociais e imprensa}

Analisa-se aqui a cobertura que os jornais nacionais e regionais fazem dos acontecimentos na medida em que, mais do que apenas «noticiar», os referidos periódicos exibiram alinhamentos que nos permitem identificar diferentes posições que eles próprios assumiam perante (e no interior) das lutas sociais, bem como identificar a cultura política de agentes regionais e locais, reivindicações dos setores populares, representações sociais e identidades emergentes no processo desses movimentos.

Dada a importância e protagonismo dos órgãos de comunicação social no contexto dos movimentos populares em observação (Régua, Santa Marta de Penaguião, Armamar, Carrazeda, Alijó, Vila Flor e Lamego com episódios idênticos noutros concelhos), num arco temporal de 5 anos, desde 1910 a 1915, a fonte principal a usar haverá de ser sempre a imprensa da época.

De facto, tendo sido alvo de vasta cobertura da imprensa nacional, regional e local, estas manifestações podem ser reconstituídas, recorrendo-se aos seus registos jornalísticos, embora seja delicada a tarefa do historiador. A «voz jornalística» sempre pretende conferir objetividade nas suas opiniões particularistas induzidas pelos interesses financeiros, políticos e contextos sociais em que os jornais agem e tentam sobreviver, sem se afastar muito do universo de seus leitores cuja opinião pretendem formar.
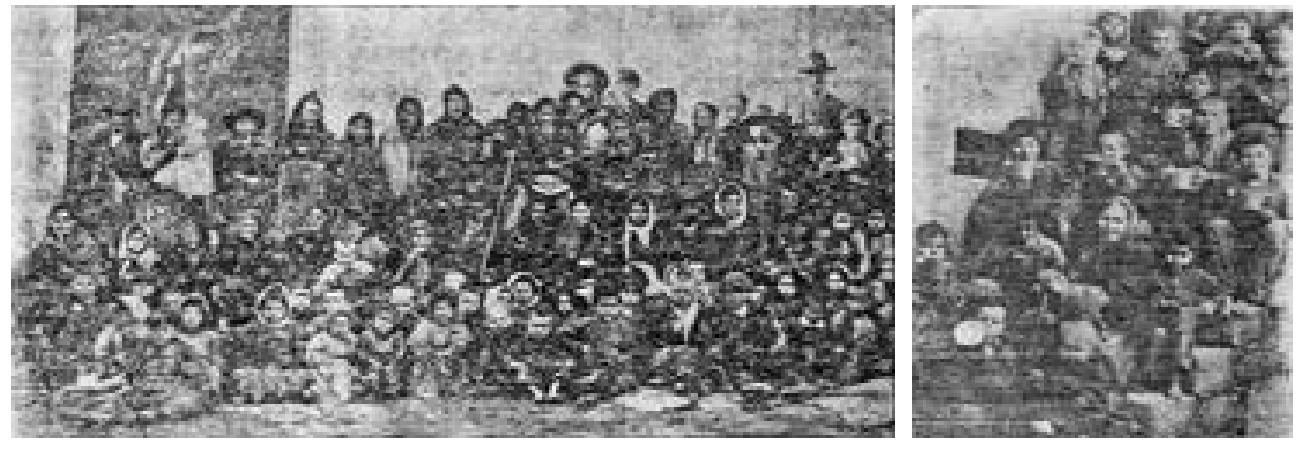

Figs. 41 e 42. Imagens da fome nas ruas de Favaios

Fonte: «O Primeiro de Janeiro» (2 fev. 1909)

${ }^{268}$ SEQUEIRA, 2010. 
Sabe-se que os meios de comunicação estão em constante disputa pela sua sobrevivência que reside nos seus públicos, cujas necessidades tentam conhecer não para satisfazê-las, mas para os não perder, móbil do caráter empresarial do jornalismo ${ }^{269}$.

Tal não inviabiliza porém o uso destas fontes, pois se podem encontrar em suas páginas - «os rostos» da multidão, notícias, opiniões díspares, editoriais sobre o assunto, etc. - informações valiosas sobre as descrições dos acontecimentos, tentativas da explicação dos factos, mesmo que parcelares e faciosas, conhecimento de como a cobertura foi feita, de como chegou ao público leitor, quais as posições dominantes, como explicá-las e ainda poder descobrir características da composição social dos revoltosos e lideranças.

Antes mesmo e para além disso, é ainda de considerar a imprescindibilidade de pesquisa e análise das notícias jornalísticas sobre as revoltas sociais pela exiguidade ou até inexistência de outras fontes diretas sobre tais acontecimentos.

\subsubsection{Contexto e significado histórico das representações e sublevações}

A situação geral no Douro é de miséria tal que no concelho de Carrazeda de Ansiães, o frio, a fome e as exíguas condições de vida, por falta de trabalho que nem a cultura do tabaco então aí iniciada atalhou, chegaram a provocar vítimas mortais. Pode ler-se no «Primeiro de Janeiro» de fevereiro de 1909:

Escrevem-nos de Carrazeda de Ansiães a propósito da miséria que lavra naquele concelho. [...] traçando depois o quadro de infortúnio que ali presencia dia a dia, jornaleiros e pequenos lavradores não têm pão para comer. Os últimos ainda têm algum vinho mas é quase o mesmo que não ter nada, visto que oferecem $7 \$ 000$ réis por cada pipa posta em Foz-Tua. Ora só carreto custa $2 \$ 500$ réis [...] A nossa leitora pede-nos que lembremos [...] que se examine com mais atenção e justiça, a área demarcada da região privilegiada do Douro, afim de serem atendidos os pobres daquela comarca [...].

Aqui se denuncia a miséria dos trabalhadores vinhateiros e algumas das suas causas mas aflora também a invocação de justiça para este concelho e para a Região Demarcada do Douro.

O ambiente generalizado de profunda crise e confrangedora desgraça geral da «Miséria do Douro» tornara-se questão nacional premente de solidariedade e fraternidade, em toda a imprensa:

Enquanto sobre a desgraça do Douro se manteve um silêncio relativo, e as instâncias sociais, acumulando promessas, que sistematicamente deixavam de cumprir, iam iludindo a fome de centenas de trabalhadores, esse quadro apavorante de miséria manteve-

\footnotetext{
${ }^{269}$ MARCONDE FILHO apud CHARLESTON, 2010: 10.
} 
-se, até certo ponto, velado [...] Mas a agonia serena desse povo atingira o máximo de intensidade...no Douro havia quem morresse à falta de pão. Nos casebres apinhados, numa promiscuidade quase primitiva, os velhos, as mulheres e as crianças aguardavam que a caridade se lembrasse deles [...] Os homens válidos desertavam do lar, e iam pelos caminhos, batendo às portas dos lavradores à procura de trabalho ou de pão. A emigração aumentava espantosamente. As aldeias despovoavam-se. A doença ia dizimando famílias inteiras. E o fisco implacável continuava a reclamar imperturbavelmente a sua parte do património negativo dos famintos [...] A desgraça é enorme e nós temos muita pressa em valer-lhe $[\ldots]^{270}$.

Enquanto isto, a Câmara de Carrazeda, lançava na ata de sessão extraordinária um agradecimento ao «Século» pela generosa subscrição para a região duriense e telegrafava ao rei a pedir se lembre deste concelho na distribuição de verba de 50 contos.

Por sua vez, a Liga dos Lavradores do Douro representava ao Governo, em 4 de fevereiro de 1909, pronunciando-se sobre as contradições da nova legislação dita em favor do crédito de genuinidade no consumo e exportação dos vinhos desta região: «a desgraça do Douro afeta todos os proprietários mas que poderá minorar-se dentro de prazo mais ou menos longo, pelo exato cumprimento da nova legislação e pela abertura de novos mercados para os vinhos da região e a expansão dos já existentes». Denunciam preceitos da lei sobre as permissões restritivas de plantação de novas vinhas, bem como a sua má interpretação e deplorável execução. E advogando a causa dos operários pedem ao «Estado que auxilie os operários com obras nos caminhos que são ainda quase os mesmos da época em que se iniciou o comércio dos vinhos do douro há quase 300 anos» ${ }^{271}$.

A mesma edição de «O Primeiro de Janeiro», com uma grande foto de crianças famintas de Favaios, comendo caldo à porta de um lavrador, publica uma carta de um transmontano à redação, com o seguinte alvitre:

É sabido que há milhares de pipas de vinho sem sequer ter pretendentes e que ainda não se fixou preço a cada pipa, devido a não ter aberto preços a 'Companhia Geral da Agricultura das Vinhas do Alto Douro', conhecida vulgarmente por 'Companhia Velha' que é a reguladora dos preços dos demais compradores [...].

Não admira pois que às recorrentes representações dos viticultores e interesses vinhateiros às Cortes, contra as fraudes e para influenciarem leis que o Governo preparava para publicação, se sucedessem os motins e sublevações de centenas de indivíduos em Carrazeda, na sua povoação e cais de Foz Tua, no vizinho concelho de Alijó, em abril de 1910 e, em 1912, em Vila

\footnotetext{
270 «O Primeiro de Janeiro» (2 fev. 1909). Idêntico tipo de notícias se publicaram também no mesmo jornal nos dias 12,16 e 18 de fevereiro.

${ }^{271}$ «O Primeiro de Janeiro» (2 fev. 1909).
} 
Flor, concelho limítrofe de Carrazeda, com atos incendiários contra as fazendas locais. Estes acontecimentos eram assim noticiados na imprensa regional e nacional:

Os arrombamentos da Estação do Tua - Na noite de sexta para sábado da semana passada, uma grande multidão [...] de perto de oitocentos homens dos concelhos limitrofes da estação de Foz-Tua, invadiram o recinto dela, exigiram pela violência, do chefe da estação que thes fosse abrir o cais fechado, e uma vez ali retiraram e fizeram em estilhaços três cascos de vinho, que vinham do sul para os Cortiços do concelho de Macedo de Cavaleiros. $O$ ato daqueles indivíduos constitui um crime grave e sem que haja atenuantes a desculpá-lo porque os Cortiços ficam fora da região do Douro, e aonde por isso, nos termos do regulamento, podem dar entrada vinhos de fora desta região. [... $]^{272}$.

Claro que não refere o jornalista a proximidade geográfica deste concelho de outros integrados na Região, como o de Carrazeda a que pertence o Tua e o concelho vizinho de Alijó e correspondentes facilidades de transição interconcelhia dos vinhos do Sul, concorrência potencialmente atentatória da autenticidade e identidade dos vinhos do Douro que o ato popular noticiado visa combater.

Outra notícia do mesmo dia e jornal dá conta do

Incêndio da repartição de fazenda de Carrazeda — Na madrugada de domingo, 17 do corrente, uns oitocentos homens armados entraram na vila de Carrazeda de Ansiães, arrombaram a golpes de machado as portas da repartição de fazenda e recebedoria, trouxeram para a praça todos os livros, documentos e papéis e até a mobilia, [...] e depois de tudo regado com petróleo, lançaram-lhe o fogo. Alguns da turba vigiavam as casas para impedir que alguém se atrevesse a espreitar, e se alguma janela se abria, atiravam para dentro pedras e balas.

A proximidade deste facto com o da estação do Tua, o mesmo número aproximado de indivíduos, os vivas à Pesqueira e a Alijó e principalmente a Presandães, um lugarejo deste último concelho, fazem presumir que daqueles concelhos sejam também os incendiários. Partiram para Carrazeda contingentes de cavalaria e infantaria e também o governador civil do distrito para dirigir as investigações policiais.

Ficaram porém iludidos em seus projectos os incendiários...os magistrados procurarão reconhecê-los através das máscaras, com que alguns cobriam os rostos; também na repartição de fazenda do distrito existe a relação das dívidas relaxadas... e existem todas as cadernetas para a reconstituição das matrizes $[. . .]^{273}$.

\footnotetext{
272 «O Nordeste» (22 abr. 1910: 2 ).

273 «O Nordeste» (22 abr. 1910: 2 ).
} 


\section{Dos tumultos em Carrazeda de Ansiães aos de Alijó e Vila Flor... (1910-1912)}

Decorridos apenas dois anos, novo motim se verifica então no concelho vizinho de Vila Flor, sendo os acontecimentos de Carrazeda de novo e acerrimamente criticados na imprensa regional, nos seguintes termos e suposições de conotação política:

Os incendiários de Vila Flor - [...] um magote de dementados do concelho de Vila Flor veio, com o incêndio posto aos papéis da secretaria e tesouraria de finanças daquele concelho, acrescer a má fama, que os anais da justiça penal tem criado à gente do nosso distrito [...] E o crime foi premeditado e preparado com muita antecedência, como se revela do facto de ser praticado por indivíduos de diversas povoações e todos os actos serem dirigidos a toque de apito por um comandante [...]. Quando dos incêndios de Alijó e Carrazeda de Ansiães todos atribuíram o facto a questão política. Seria agora a mesma causa? Mas nesse caso é um acto de rebelião [...] Se os incendiários de Carrazeda tivessem sido punidos [...] já agora não haveria tanta facilidade de se cometer o crime de Vila Flor [...] E não é só aos incendiários de Vila Flor que é necessário fazer justiça: é também aos de Alijó e de Carrazeda [...] e a República não pode deixar ficar esquecidos os crimes cometidos mesmo antes da sua proclamação [...] Como suspeitos estão já presos sete indivíduos e parece que alguns se resolvem a falar $[\ldots]^{274}$.

Esta sucessão de rebeliões contra a entrada na região do Alto Douro de vinhos do Sul e instituições públicas do fisco, autêntico garrote das populações e dos pequenos lavradores, a grande maioria dos proprietários durienses, não deixou de ter repercussões noutros concelhos do Douro, em que se destacam o Motim de Lamego, em 1915, saldado por 12 mortos e inúmeros feridos e os motins de centenas de pessoas na Régua, com incêndios da Conservatória do Registo Predial e das Finanças, para onde foi também deslocado um grande aparato de forças militares $^{275}$.

Essa fortíssima onda social de queixas aflitivas, denúncias de males «in extremis», recorrentes representações dos viticultores e proprietários às Cortes, contra as fraudes e visando influenciar as leis que o Governo preparava, acaba por explicar a súbita e sucessiva emergência de motins e sublevações de milhares de indivíduos e o alastramento da excitação popular, de umas povoações a outras.

Em 1914, cresce ainda mais, no Douro, a agitação social (imponentes comícios em Vila Real, Régua...) reclamando do governo maior fiscalização e proteção para os seus vinhos generosos e garantias de exportação do vinho do Porto, cuja proveniência de origem se defendia face às fraudes e concorrências protegidas por leis, contestadas por não garantirem a marca exclusiva dos vinhos durienses, circunstâncias agravadas pela escassez das colheitas de anos anteriores, falta de trabalho e miséria dos trabalhadores.

\footnotetext{
274 «O Montanhês do Norte» (10 nov. 1912: 2).

275 «A República» (18 e 19 jul. 1915).
} 
Motim de Lamego de 1915: «o cortejo da fome» ou «o grito de revolta do cavador» ${ }^{276}$

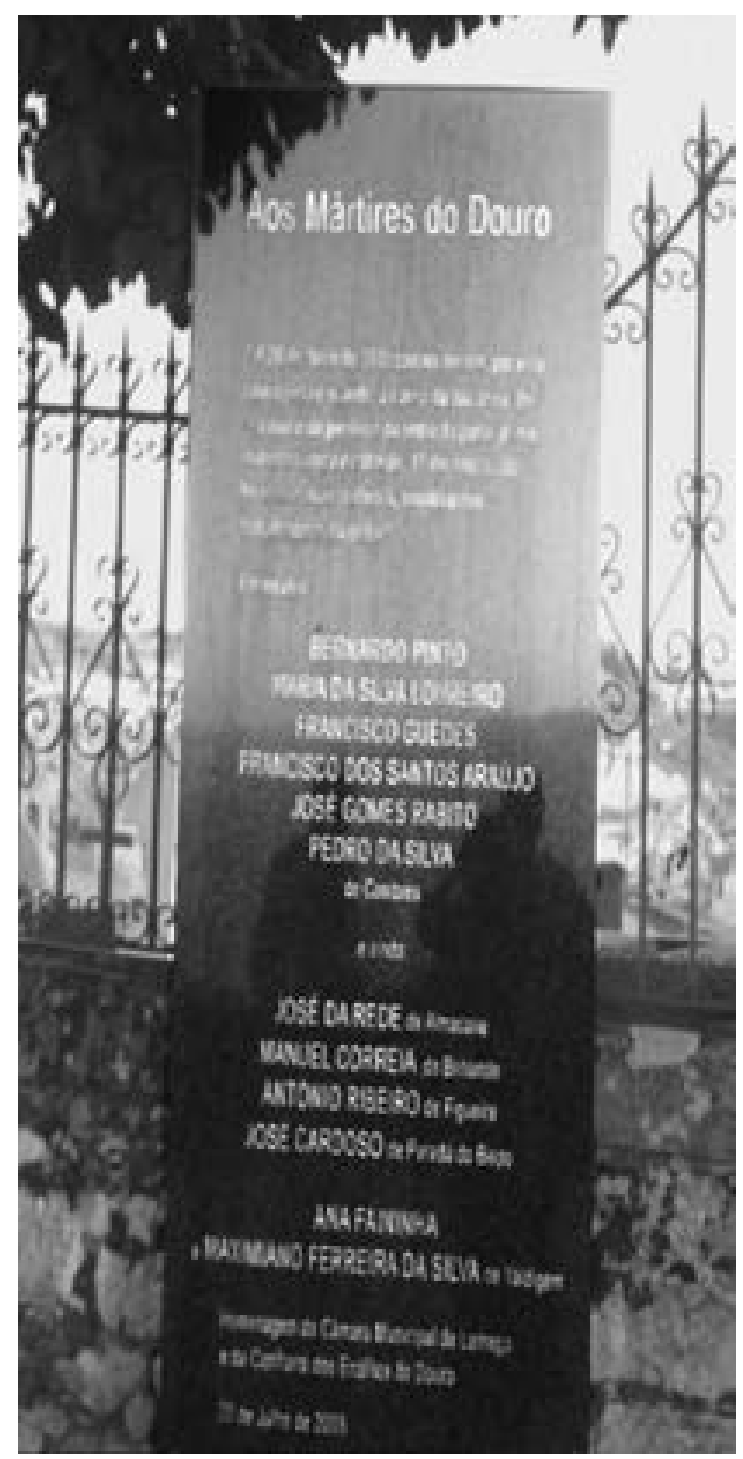

Fig. 43. Homenagem aos Mártires de Lamego: placa evocativa do Motim de 1915 no cemitério de Cambres

Numa primeira fase, a «Missão de Alijó» conferenciou com sindicatos, associações e várias câmaras da região, com reuniões na Câmara de Lamego, gerando-se um forte movimento institucional visando a alteração do art. ${ }^{\circ} 6$ do Tratado de Comércio Luso-britânico 
(12 de agosto de 1914) de forma a garantir os direitos da região do Douro como único produtor do vinho do Porto para exportação. Numa segunda fase (janeiro-junho de 1915), perante o impasse das negociações com o governo, a carestia e escassez de géneros intensificada pelo alastrar da Guerra na Europa, assiste-se ao Motim de Lamego, expressão máxima de enorme exaltação popular.

A 20 de Julho de 1915, o povo das aldeias de Cambres, Valdigem, Sande e Figueira, formando 'uma marcha da fome' de cerca de cinco mil pessoas, dirigiu-se à cidade de Lamego, manifestando-se em frente ao edifício da Câmara. No momento em que a comissão de representantes se encontrava a conferenciar com a Comissão executiva da Câmara de Lamego, ocorreu a tragédia. De acordo com os relatos dos jornais ('A Fraternidade', Lamego, 24 de Julho de 1915, p.1) tudo corria pacificamente, quando de repente, a população foi atacada com bombas, caindo mortos ou feridos vários manifestantes e debandando a maioria. Com a população em fuga, mais nove pessoas seriam atingidas, mortalmente pelas costas, por tiros disparados das janelas traseiras da câmara ${ }^{277}$. O balanço trágico do 'motim de Lamego' somou doze mortos e vinte feridos.

As entidades oficiais, a começar pela Câmara Municipal de Lamego, procuraram atribuir as culpas aos manifestantes, posição adotada também por parte da imprensa de Lamego, afecta ao Partido Democrático ${ }^{278}$. O povo era acusado de ter provocado as forças militares com desacatos. Por outro lado, conferindo um carácter político aos acontecimentos, afirmava-se que os manifestantes se deixaram aliciar por elementos monárquicos que pretendiam derrubar a República $[. . .]^{279}$.

Enquanto que relatórios e pareceres judiciais acusavam o povo de ser portador de armas brancas e de fogo, de provocar as forças militares e os poderes instituídos e de premeditar repetir os acontecimentos de Armamar e da Régua, tornou-se bem diferente a perceção regional do Motim de Lamego, que viu na ação popular, um ato heroico em defesa dos interesses da Região, considerando os mortos «mártires» da causa que unira na luta as populações do Douro.

Recentemente, por ocasião do centenário de tais acontecimentos estes foram evocados em público, e prestada homenagem, no cemitério de Cambres, a estes «Mártires do Douro» através do descerramento de uma placa em tributo à sua memória. Desta efeméride se fez assim eco alguma imprensa diária:

A Confraria dos Enófilos da Região Demarcada do Douro, em colaboração com a Câmara de Lamego, evocou ontem a morte de dez homens e duas mulheres em 1915, frente aos Paços do Concelho, momento que ficou conhecido mais tarde como o 'Motim de Lamego'.

\footnotetext{
277 «A Defesa do Douro» (2 jul. 1915: 3).

${ }^{278}$ "A Tribuna» (25 jul. 1915); «A Tribuna» (29 ago. 1915) 1.

${ }^{279}$ PEREIRA \& FERREIRA, 2004: 71-73.
} 
Há 90 anos, várias dezenas de explorados pelos grandes proprietários do Douro foram recebidos a tiro por um destacamento militar, quando se dirigiam à autarquia para reclamar melhores condições de vida.

Mesquita Montes, da Confraria dos Enófilos da Região Demarcada do Douro, contou ao JN o significado da evocação 'Serve para lembrar aqueles que, numa altura em que o Douro vivia uma crise que parecia inultrapassada, apenas pediam pão e trabalho nas vinhas. Mas as forças da ordem, por razões que não tem qualquer tipo de explicação, acabaram por metralhar gente de chapéu'.

O principal objectivo com esta cerimónia foi homenagear estes mártires do Douro e chamar a atenção dos cidadãos de hoje e viticultores para o facto de estarmos numa situação dramática, relativamente à vinha e ao vinho, acrescentou Mesquita Montes.

Os cemitérios de Cambres, Souto Covo, Parada do Bispo, Valdigem, Figueira e Britiande foram locais de romagem, com deposição de um ramo de flores. Em Cambres foi colocada uma lápide evocativa do dia, onde constam os nomes das vítimas. Uma outra lápide foi descerrada numa avenida de Lamego, que se chama, desde ontem, Avenida dos Defensores do Douro [... $]^{280}$.

$\mathrm{Na}$ sequência das revoltas vinhateiras do início do século XX, em que o Douro enfrentou uma crise comercial aguda e o país vivia uma conjuntura económica depressiva ${ }^{281}$, tem-se defendido ${ }^{282}$ a existência de «uma empenhada intervenção das elites regionais» na liderança dos movimentos populares e «um marcado caráter regionalista» nos protestos durienses de 1914-1915, pela defesa da denominação de origem de vinho do Porto, para os vinhos produzidos no Douro.

\subsection{REPRESENTAÇÕES, IDENTIDADE REGIONAL E IDENTIDADES CONJUNTURAIS}

O anteriormente exposto, é ponto de partida para uma análise em concreto que, balizada pelas noções de representações sociais ${ }^{283}$ e identidades ${ }^{284}$, vamos agora fazer dos discursos trans-

\footnotetext{
${ }^{280}$ «Jornal de Notícias» (21 jul. 2015).

${ }^{281}$ Texto disponível em <http://ler.letras.up.pt/uploads/ficheiros/9644.pdf>. [Consulta realizada em 3/1/2012]. Ver da mesma autora o artigo Do poder local ao poder regional: o movimento dos paladinos do Douro. Disponível em $<$ http://academia.edu/1368742/Do_poder_local_ao_poder_regional_o_movimento_dos_paladinos_do_Douro $>$. [Consulta realizada em 10/1/2012].

${ }^{282}$ PEREIRA \& SEQUEIRA, 2004.

${ }^{283}$ Representações sociais, elementos simbólicos, sistema de interpretação da realidade, de composição polimorfa, são um conjunto de conceitos, proposições e explicações com origem na vida quotidiana no desenrolar das comunicações interpessoais (MOSCOVICI, 2003) isto é, «comportamentos em miniatura» (LEONTIEV, 1978). São aqui tomadas como saber popular, mitos, crenças, costumes, condensados de memórias e expressão de identidades múltiplas, convergentes e contraditórias que confluem num senso comum e que são histórica e socialmente partilhadas.

${ }^{284}$ Identidades sociais definidas num processo de identificação em que os atores se integram num conjunto mais vasto de referência/pertença através do qual tendem a autonomizar-se e diferenciar-se socialmente, por mecanismos de identificação a dois níveis: produção de identidades concorrentes — identidades locais e regional — que coexistem sem se anular; e consolidação da identidade social, pelo acesso ao mercado gerando instabilidades e rebeliões.
} 
critos de alguns jornais que noticiaram, denunciando, em regra, como violentas estas manifestações populares e reclamando forte repressão das forças da ordem para se lhes pôr cobro.

As sublevações e tumultos populares ocorridos em Carrazeda, Alijó, Sabrosa, Vila Flor, Santa Marta, Armamar, Régua e Lamego (1910-1915) foram amplamente noticiados na imprensa da época.

Em abril de 1910, decorridos 5 dias sobre os levantamentos populares de Carrazeda, estes e o assalto aos armazéns do Tua, eram assim objeto de notícias construídas a partir de informações telegráficas daí recebidas ${ }^{285}$ :

Tumultos em Carrazeda de Anciães - a questão duriense - assalto à repartição de Fazenda — documentos e mobília reduzidos a cinzas — situação alarmante [...]

Depois dos acontecimentos do Tua recrudesceu a indignação entre o povo de Carrazeda queimando a repartição de fazenda e arrombando as portas da recebedoria.

São tantas as calamidades que assolam o povo que já ninguém pode conter a onda de revolta que o enlouquece [...].

Carrazeda de Anciães, 17, às 9h da manhã - Pela uma hora da noite, mais de oitocentos homens armados com espingardas, cacetes e machados, entraram nesta vila e arrombaram as portas da casa onde está a repartição de fazenda e recebedoria retirando de lá tudo quanto existia para o meio da praça onde lhe pegaram o fogo, deitando-lhe algumas latas de petróleo para ajudar.

Alguma gente que tentou chegar às janelas foi obrigada a retirar-se, ameaçada pelas espingardas e pedras.

Às quatro horas, depois de estar a papelada e móveis queimados, retiraram-se, fazendo grande algazarra e dando tiros para o ar.

Carrazeda de Anciães, 17 -

Consta que chega hoje aqui uma força de infantaria,

Na recebedoria não ficou coisa alguma; no gabinete do escrivão da fazenda deixaram duas secretárias cujas gavetas foram para as fogueiras com tudo o que continham; os retratos da família real que ali existiam foram esfaqueados e depois lançados também nas fogueiras. Os tinteiros foram quebrados contra as paredes. O cofre da recebedoria ficou intacto.

Parece que tentaram entrar pelas janelas, chegando ainda a quebrar os vidros; meteram depois os machados contra uma porta fazendo-a em pedaços. O mesmo aconteceu à porta do gabinete do escrivão, de que só ficaram as dobradiças.

Em todas as ruas havia homens armados que não deixaram sair pessoa alguma de casa, nem mesmo assomar às janelas.

[...] Uma das janelas do amanuense da administração ficou com os vidros todos partidos.

O secretário da administração foi obrigado a retirar-se sob a ameaça de morte.

\footnotetext{
285 «O Villarealense Folha Regeneradora» (21 abr. 1910).
} 
Durante o tempo que durou a fogueira, os assaltantes dançavam, descarregavam armas, corriam à volta da praça com os livros da fazenda a arder, espetados nos cacetes.

A repartição de fazenda e recebedoria sofreram uma limpeza completa. Até o pobre [...] lavatório do escrivão foi destruído. Eram quatro horas quando tudo se retirou fazendo uma balbúrdia infernal.

Estes acontecimentos são comentados nestes termos pelo jornal «As Novidades» do mesmo dia:

a miséria do Douro é grande mas não há miséria que justifique os factos criminosos referidos nos telegramas de Carrazeda de Anciães. Mais de uma vez aqui temos dito que se torna absolutamente indispensável a presença da força pública em numerosos lugares do Douro sobretudo onde é preciso guardar as repartições públicas e adegas de negociantes estrangeiros, que no Douro são numerosos. Aí de mistura com a miséria e a ruína há evidente anarquia nos espíritos que ninguém já pode modificar e cujos impetos somente podem ser contidos pela presença da força pública, à semelhança do que se passa há mais de um ano em Sabrosa, onde a tropa ocupa a repartição de fazenda e recebedoria.

Aqui deixamos de novo consignado o nosso protesto contra o vandalismo de incendiar repartições públicas, o que além de ser um gravíssimo crime, tira à causa do douro a simpatia que ela devia merecer aos poderes públicos [...].

Também em publicações periódicas da especialidade vinícola foram no mesmo ano, noticiados e comentados os «Motins no Douro». Assim se lhes refere, por exemplo F. d'Almeida e Brito em abril de 1910:

Na madrugada do dia 16 deste mês deram-se na Estação do Caminho de Ferro do Tua, no Douro, graves tumultos que provam bem o estado de excitação desta província.

Cerca de 2.000 pessoas, armadas dirigiram-se à Estação do Tua, fizeram levantar o chefe da Estação, obrigaram-no a abrir-lhes as portas dos armazéns e verificando que aí se encontrava vinho, proveniente do Sul, do Valado, arrombaram as pipas a machado e rolaram outras para o rio.

O chefe da Estação querendo participar o facto aos seus superiores e pedir socorro, foi violentamente impedido de cumprir este dever.

O vinho que se achava em trânsito dirigia-se para o distrito de Bragança, Estação de Cortiça, linha de Mirandela.

O decreto com força de lei, de 1 de Outubro de 1908, no seu art.o $5 .^{\circ}$ proíbe a entrada de vinhos de pasto, sem serem engarrafados, nas regiões de vinho licoroso, e de vinho de pasto, anexa, portanto, desde que as autoridades e a Comissão da Régua não vigiam esta determinação, os povos do Douro exercem por suas mãos, e violentamente, essa fiscalização. 
Mas o que o facto sucedido mostra é a tristíssima situação em que o Douro se encontra. Sem vender as suas colheitas ou obtendo por elas preços miseráveis os povos estão no último extremo.

Olhe bem o governo para este perigosíssimo sintoma. Nós bem sabemos que el pouquíssimo poderá fazer para salvar o Douro.

A lei do exclusivo da Barra do Douro, tão ardentemente solicitada, proclamada nos comícios como o único salvatério! já não presta!

Pois se não há quem beba muitos vinhos do Porto no Estrangeiro, como há-de o Douro vender bem a sua produção?!

E poderá o governo obrigar os mercados externos a consumir vinho do Porto? Decerto não.

Poderá obter convenções comerciais que diminuam os extraordinários direitos, que todos os parlamentos têm votado para a entrada dos vinhos. Isso sim e não será fácil tarefa, pelas condições especiais emque se encontra a indústria do país. Mas tomar providências para alargar a venda dos vinhos, nada pode o governo conseguir.

Em todo o caso pense bem o governo os motins do Tua, pondere a situação aflitiva do Douro e cumpra, com exactidão e energia, as providências tomadas para proteger essa região $[\ldots]^{286}$.

Essa sucessão de rebeliões que uniam populações de vários concelhos contra os efeitos perniciosos das fraudes, concorrência desleal, desemprego e miséria absoluta de trabalhadores, o fisco, autêntico garrote dos pequenos lavradores, e outras circunstâncias adversas, como a não aplicação ou ausência de fiscalização de novas leis e a inconsequência dos governos, repercutiu-se não só em Lamego mas também na Régua, com motins de centenas de pessoas, incêndios da Conservatória do Registo Predial e das Finanças, para onde foi deslocado um grande aparato de forças militares ${ }^{287}$, como sempre aconteceu nas rebeliões durienses.

Observando as motivações, espaços, lideranças, resultados e significados destas sublevações populares com manifestações violentas e violentamente reprimidas, verifica-se que: 1 - os factos referidos de natureza mais ou menos espontânea a que certa imprensa atribui caráter de premeditação e motivos políticos, ou uma situação de crise social generalizada, apresentam lideranças difusas e difusamente identificadas, com base na suspeição e delação; 2 - ocorreram numa vasta e disseminada área da região duriense; 3 — tendo-lhe sido atribuídas diversas causas ou motivações: miséria generalizada; inconsequência dos governos face à resolução dos graves problemas de produção e comércio dos vinhos durienses, acusados de favorecerem os vinhos e aguardentes do Sul contra os do Norte; legislação regulamentadora de 1908 de nova demarcação e exclusivo da Barra do Douro, sua não aplicação efetiva, e deficiente fiscalização, dificuldades extremas de escoamento da produção, por sua vez em crise profunda.

\footnotetext{
${ }^{286}$ "A Vinha Portuguesa», ano 25, n. ${ }^{\circ} 4$ (abr. 1910) 117-118.

${ }^{287}$ «A República» (18, 19 jul. 1915).
} 
Quanto aos resultados e consequências, para além das imediatas destruições, prisões, feridos e mortos, a generalidade da imprensa apenas regista avisos ao governo para que tire dos tumultos as ilações necessárias para tomar providências acertadas e medidas enérgicas para proteger a Região do Douro, necessidade considerada premente, e unanimemente reconhecida.

As peças noticiosas que se referem são genericamente de denúncia e crítica dos atos considerados criminosos e violentos, premeditados e preparados com antecedência, em que o povo é induzido por forças e interesses desconhecidos e defesa insistente da repressão pelas forças militares e judiciais destes movimentos supostamente organizados, e seus líderes delatados e perseguidos, julgados e presos.

É neste contexto mais amplo de lutas populares que importa conhecer melhor as suas implicações e repercussões no concelho de Carrazeda, nomeadamente ao nível de: desafios e falências da organização local/regional, objetivos, reações e formas de resistência dos distintos grupos de produtores de vinho do Porto, perfis e trajetórias de elites locais e simples viticultores, movimentações sociais, riscos de fragmentação mas também capacidade de mobilização, articulação, consolidação/dissolução de elementos identitários e contradições suscitadas pela intervenção do Estado na organização da produção e comércio vitivinícola.

Dão-nos um princípio de resposta as «representações» à Câmara dos Pares, em 1907, de uma elite política local esclarecida representante dos viticultores do concelho de Carrazeda, propondo medidas para atalhar a crise vinícola e denunciando a recente regulamentação do comércio das aguardentes que proibia a destilação dos vinhos durienses, obrigando o Douro a receber de outras regiões vitícolas a aguardente para beneficiação dos seus vinhos ${ }^{288}$, bem como os tumultos populares de protesto contra as contribuições prediais vinícolas, aqui também verificados em $1910^{289}$ com assalto à Repartição de Finanças, queima dos documentos em praça pública e arrombamento de armazéns em Foz Tua, acontecimentos que se alastraram a Vila Flor e que já se tinham verificado antes nos concelhos vizinhos de Alijó e Murça, em janeiro e fevereiro de 1909. Observe-se que, curiosamente, o número de contribuintes registados então no concelho é idêntico ao dos manifestantes e revoltosos (à volta de 800 ), o que pode indiciar uma revolta em massa dos produtores vitivinícolas.

Prosseguindo em maior detalhe a análise interpretativa desse movimento de sublevações ocorrido em várias povoações da Região dos Vinhos Generosos do Douro, socorremo-nos das noções de representações e identidades sociais, optando por falar em «identidades conjunturais» no sentido de que a identidade é conjuntural, relacional e não essencial, como um processo em constante reconfiguração com particular visibilidade em situações de crise, identidades que aparecem e desaparecem, em função de interesses conjunturais.

A prioridade dada aos modos de construção de identidades, como políticas e estratégias de natureza conjuntural, tem em particular atenção que «as identidades sociais» devem ser concebidas como realidades dinâmicas que se constroem e se deformam face aos problemas

\footnotetext{
${ }^{288}$ Representação de 16/3/1907. «Diário do Governo», n. o 74 (1907-04-05) 989.

${ }^{289}$ Notícias. «O Nordeste» (22 abr. 1910) 1-2.
} 
com que os atores sociais são confrontados, como formações que se não podem compreender senão examinando o seu desenvolvimento no decurso de um período suficientemente longo. Paralelamente, a definição do político não é separável da organização de um campo de forças instáveis e que não cessam de ser reclassificadas. O exercício do poder é a recompensa dos que sabem explorar os recursos de uma situação e tirar partido das ambiguidades e tensões que caracterizam o jogo social» ${ }^{290}$.

Por sua vez, numa observação de conjunto das notícias selecionadas, verifica-se que são recorrentes as seguintes representações sociais, no que se refere aos tumultos populares de Carrazeda, Vila Flor e outras localidades: indignação; onda de revolta; incendiários; dementados; punir e fazer justiça; quem os iludiu?; crime grave sem atenuantes; factos criminosos que nem a grande miséria justifica; aviso ao governo; graves tumultos; estado de excitação desta província; violentamente impedidos [chefes] de cumprir seus deveres; reclamando-se a perseguição e repressão feroz dos manifestantes.

Pode dizer-se que emerge assim um processo de construção e pertença identitária nas populações do Douro Vinhateiro, forjado em numerosas lutas reais da Região, com as mesmas motivações mas diferentes níveis de identificação e experiências que se enraízam em problemas que vão do local ao internacional, em que as relações com as instituições do poder são fator fundamental na estruturação e diferenciação de estratégias de procura da unidade possível, num contexto de diferenciação/identificação que são as relações de trabalho e mobilidades em que os mais afastados das instituições do poder político se identificam, mais facilmente, com as pertenças localistas/regionais, que afloram em contextos de crise geradores de rebeliões e solidariedades. Foram, aliás, as crises económicas desta região que levaram à criação sucessiva das suas instituições enquadradoras: Comissão de Viticultura da Região Duriense (1907), e a Casa do Douro (1932), cuja ação sobre a produção, comércio, qualidade e marca do vinho do Porto têm desencadeado manifestações sociais e populares.

Evidenciam-se fatores comuns à Região, numa base forte de identificação local/regional com problemas fiscais, dificuldades de trabalho e subsistência de jornaleiros e pequenos proprietários, em tensão subterrânea com fortes interesses e influências económica, social e política de grandes proprietários, comerciantes e exportadores do vinho do Porto, com condições de liderança nacional/global.

\section{Dinâmicas de construção de identidades (aproximação sociológica)}

Apesar das medidas de relançamento económico da política protecionista republicana ${ }^{291}$, a situação na Região do Douro Vinhateiro não se alterou significativamente, tendo mesmo a subida dos impostos e dos preços agravado o problema da miséria que levou a uma forte agitação social e política.

\footnotetext{
${ }^{290}$ LEVI, 1989: 1320.

${ }^{291}$ Tais medidas contribuíram para um intenso aumento das exportações de vinho do Porto que atingiram em 1924/1925, mais de 100.000 pipas, número só ultrapassado nos finais da década de 1970.
} 
A interpretação aqui apenas esboçada tem presente essa moldura histórica e social bem como a relação da autenticidade e genuinidade inerente à marca vinho do Porto, com a problemática da identidade, que têm significativas implicações ao nível da análise sociológica. Esta deverá por isso assentar em duas noções essenciais: a de identidade, densamente debatida, e a de objeto de fronteira aplicadas, quer à posição de Carrazeda na Região Demarcada do Douro, quer à própria história do vinho do Porto, com seus atributos e problemas inerentes num processo e contexto de movimentos sociais associados.

No que se refere à Região do Douro, concordamos com o princípio estruturante de uma identidade própria, cujo processo de afirmação histórica é assim explicado por Gaspar Martins Pereira «a demarcação pombalina, que nunca correspondeu a qualquer entidade administrativa, acabou por conceder à região do Alto Douro uma identidade que veio até aos nossos dias» ${ }^{292}$. E atendendo à sua classificação pela UNESCO (2001) enquanto «paisagem cultural viva e evolutiva» poder-se-á então atribuir ao Douro Vinhateiro uma identidade original, diferenciada e assente numa territorialidade singular que foi sendo construída ao longo de séculos.

Pressupomos, no entanto, numa perspetiva integrante do social que «a identidade é itinerante» (M. Foucault), na medida em que tal dá melhor conta do que procedendo nela por larga medida de relações com o exterior, e sendo portanto justificativa do relacional e do formal, constrói todavia estas relações ou se constrói, de maneira a fundar a continuidade entre os sujeitos individuais e coletivos. É por isso «um processo cambiante e provisório, construído e conjuntural» ${ }^{293}$.

Quanto ao conceito de «objetos de fronteira» ${ }^{294}$, visa «objetos, linguagens, instrumentos de observação, intervenção e de contabilidade flexíveis, reapropriáveis em contextos diversos e mantendo, ao mesmo tempo, a sua identidade, através dessa passagem entre contextos e constitui um meio privilegiado de pôr em relação mundos sociais diferentes». A sua identificação permite «materializar convergências e inter-relações entre zonas de transação, permitindo construções heterogéneas e articulações» ${ }^{295}$.

Com recurso a estas duas noções faz-se então uma primeira e breve aproximação analítica aos repertórios interpretativos dos atores, visando compreender e clarificar os modos como estes constroem ativamente a realidade social, quando falam sobre a região. Confrontando o discurso oficial com os discursos regionais/locais, memórias, narrativas e testemunhos, tenta-se apreender simbologias ou níveis de identificação e gestão de contradições e conflitos, ruturas e continuidades entre imagens oficiais da história e, sobretudo, mecanismos sociais, político-institucionais, culturais e simbólicos de formação/dissolução conjuntural/contextual de identidades, associadas à emergência, consolidação/dissolução de

\footnotetext{
${ }^{292}$ Apud SOUSA, 2006.

${ }^{293}$ CLIFFORD, 1988.

${ }^{294}$ Conceito definido em STAR \& GRIESEMER, 1989: 387-420.

${ }^{295}$ STAR \& GRIESEMER, 1989.
} 
dinâmicas regionalistas, na fronteira das demarcações e dos processos sociais e históricos que as acompanham.

Subjaz a esta abordagem uma leitura «desconstrutiva» da retórica argumentativa presente em relatórios da Comissão de Viticultura da Região do Douro, instituição reguladora que atravessa a I República, encarregada de apoiar os lavradores do Douro, fazer o registo das propriedades e fiscalizar a produção e comércio dos vinhos generosos, curando da proteção da denominação de origem e defesa da marca «vinho do Porto», assente na organização burocrático-administrativa de registos de produção, contas correntes e certificados de procedência, para obviar a falsificações.

O quadro legislativo sobre a Região Demarcada do Douro de 1907/1908 define um novo modelo institucional de partilha de interesses e problemas comuns que subjaz à produção de identidades sociais num processo de identificação dos atores num conjunto mais vasto de referência ou de pertença. Os agentes tendem a autonomizar-se e a diferenciar-se socialmente, funcionando os mecanismos de identificação ao nível da produção de identidades concorrentes que coexistem sem se anular reciprocamente.

Ora numa região demarcada, com uma regulação e disciplina especiais, território particular essencialmente unificado pela história, tradições e propósitos político-económicos subjacentes, não há identidades puras. As identidades hibridizam-se, fazem apropriações, desvirtuando ou acrescentando novos contextos, tão pertinentes e significativos como "o original». As populações existem e representam-se a si mesmas sob a forma de longas e contínuas narrativas, cujas origens se ancoram no passado.

Entre espaço e atores, sob o controlo estatal e do mercado de uma região com denominação de origem do produto e gestão de redes de clientelas, duas lógicas interagem: a da legitimidade tradicional e a da legitimidade moderna. Recorde-se, a propósito, a Representação à Câmara dos Pares, em 5 de abril de 1907, dos viticultores do concelho de Carrazeda de Ansiães, um mês antes da publicação da legislação franquista.

A designada identidade regional em construção na Região do Douro, neste período, não deixa de ser ainda, noutra perspetiva, uma «identidade imaginária ou secundária que se manifesta numa identificação forte com a localidade», considerando-se «o regionalismo como um discurso ideológico sobre o território, produto e produtor de lutas simbólicas entre agentes interessados num espaço», e um processo contínuo de "produção identitária que se cruza com as produções contínuas de identidade de diferentes atores sociais, em que a memória coletiva alimenta as memórias individuais e é permanentemente reconstruída por elas, numa dinâmica permanente» ${ }^{296}$.

Os protestos violentos que tiveram lugar em vários concelhos da RDD evidenciam fatores comuns à Região Duriense e revelam a importância de uma base forte de identificação em problemas fiscais exprimindo tais manifestações a força subterrânea de construção de uma

${ }^{296}$ MENDES, 1996: 127-142. 
identidade social a partir de um contexto identitário conjuntural com uma componente fortemente social e política ligada às extremas dificuldades de vida e trabalho comuns a jornaleiros e pequenos proprietários.

Como síntese final importa sublinhar algumas linhas de interpretação e análise sócio-histórica das sublevações populares na Região do Douro, historicamente precedidas e seguidas de outras formas de protesto e movimentos sociais e políticos mais abrangentes ${ }^{297}$. Poderão em geral interpretar-se, na linha do pensamento de E. P. Thompson a quem se deve a noção de «economia moral» ${ }^{298}$, segundo a qual os levantamentos sociais de ação direta das multidões de pobres se orientam por pressupostos éticos e morais referendados num senso popular, nos costumes e na tradição os quais ao serem desrespeitados, geram comportamentos de indignação popular.

Assim, também os motins durienses tendo ocorrido em situações de crise e emergência levaram à obrigação «moral» de "protestar» ${ }^{299}$ podendo melhor ser compreendidos na apreensão de lutas de convergência específicas em que se constituíram.

Estes movimentos sociais podem ainda ser analisados à luz da «rebeldia primitiva» ${ }^{300}$ de Hobsbawm e da coexistência de ações de agitação social arcaicas com reivindicações de natureza moderna.

Para além dos contributos teóricos destes autores, a análise dos movimentos de contestação que se têm sucedido na Região Demarcada Duriense e cujo enquadramento sócio-histórico abrangente se traça adiante (Anexo I), ganha mais ampla e clara inteligibilidade, no âmbito da sociologia histórica de I. Wallerstein, a qual, à luz da luta de classes e do jogo de poderes que operam na estrutura do «sistema mundo capitalista ${ }^{301}$, permite esclarecer as suas características gerais e significados históricos precisos. Este sociólogo identifica as dinâmicas dos movimentos sociais contemporâneos das quais se destacam para o caso em apreço a dificuldade desses levantamentos manterem a sua intensidade e o alcance dos seus protestos que tendem a ser absorvidos pelas forças dominantes, desviando-os dos seus objetivos, sem que no entanto, deixem de representar um lastro na historia da luta das populações mais desfavorecidas ${ }^{302}$.

$\mathrm{Na}$ sequência deste entendimento global, podem caracterizar-se genericamente assim as rebeliões populares durienses, ocorridas nos inícios do século XX: todas apresentam tonalidades próprias quer da arena política quer da arena social; nelas se encontram em confronto vários grupos e diversos interesses conflituais, mais ou menos antagónicos; apresentam momentos de repressão mas ocasionalmente também de cedência e concessão relativas por

\footnotetext{
${ }^{297}$ LAGE, 2016: 9-20.

${ }^{298}$ THOMPSON, 2008.

${ }^{299}$ THOMPSON, 2008.

${ }^{300}$ SILVA, 2007: 26, 27.

${ }^{301}$ Recorremos aqui à perspetiva dos novos estudos sociais e históricos, estabelecida por I. Wallerstein, sociólogo americano, diretor do Centro Fernand Braudel, reportando-nos a sua análise atual dos mais recentes levantamentos populares em vários países do mundo, que caracteriza em 5 aspetos principais. Consultar WALLERSTEIN, 2012. ${ }^{302}$ LAGE, 2013c: 221-229.
} 
parte do poder politico; todas prosseguem objetivos concretos de maior justiça, registam uma evolução e escalada com variações com implicações na mudança.

Tentando aplicar o princípio geopolítico da sociologia histórica de Wallerstein e transpor essas características para o movimento de revoltas populares durienses descrito, podemos concluir que o mesmo se pode enquadrar nesse conjunto de traços genéricos, entendimento que se vê corroborado pela situação de grande conflito internacional à época, a I Guerra Mundial em que Portugal tomou parte ativa. Esse aspeto geopolítico tornou-se mais visível por exemplo no Motim de Lamego com a contestação de clausula do tratado luso-britânico de efeitos nefastos nas exportações do vinho do Porto e na salvaguarda da denominação de origem Douro e Porto.

Procurámos que esta cartografia sumária dos movimentos de protesto contra as injustiças sociais desde sempre vividas na Região Vinhateira do Douro e inerente afirmação de pertenças identitárias, terminasse como começou, com uma homenagem aos «Gigantes do Douro ${ }^{303}$ seus trabalhadores e populações anónimas. Na verdade, «....as proporções da montanha e a estatura do homem dessas bandas não se contemplam a frio, obrigam por força a cismar... [no] destino deste homem tão indigente como heróico, diante de cujo trabalho e sacrifício temos de nos vergar com respeitosa admiração» ${ }^{304}$ (ver Parte IV, Capítulo 10).

\footnotetext{
${ }^{303}$ Título de filme inacabado que foi impedido de realizar no âmbito de um projeto cinematográfico sobre trabalhadores do Douro (IVP, 1934) desenvolvido pelo cineasta português Manuel de Oliveira, amante da região do Douro que imortalizou no cinema, com o documentário Faina do Douro e os filmes Aniki Bóbó e Vale Abraão. ${ }^{304}$ MENDES, 1964: 10, 24-25.
} 


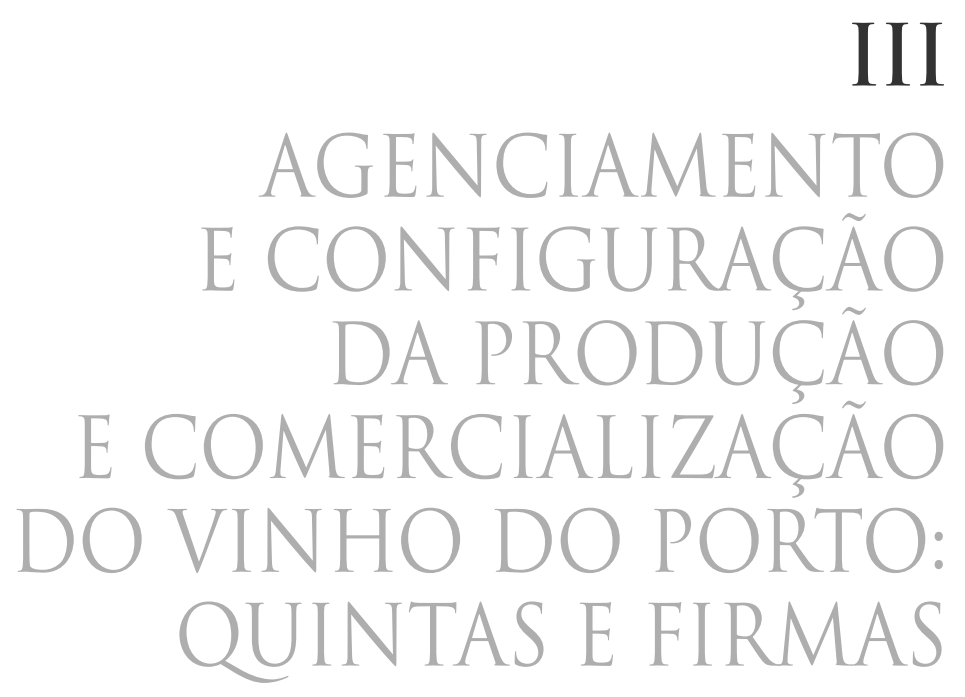




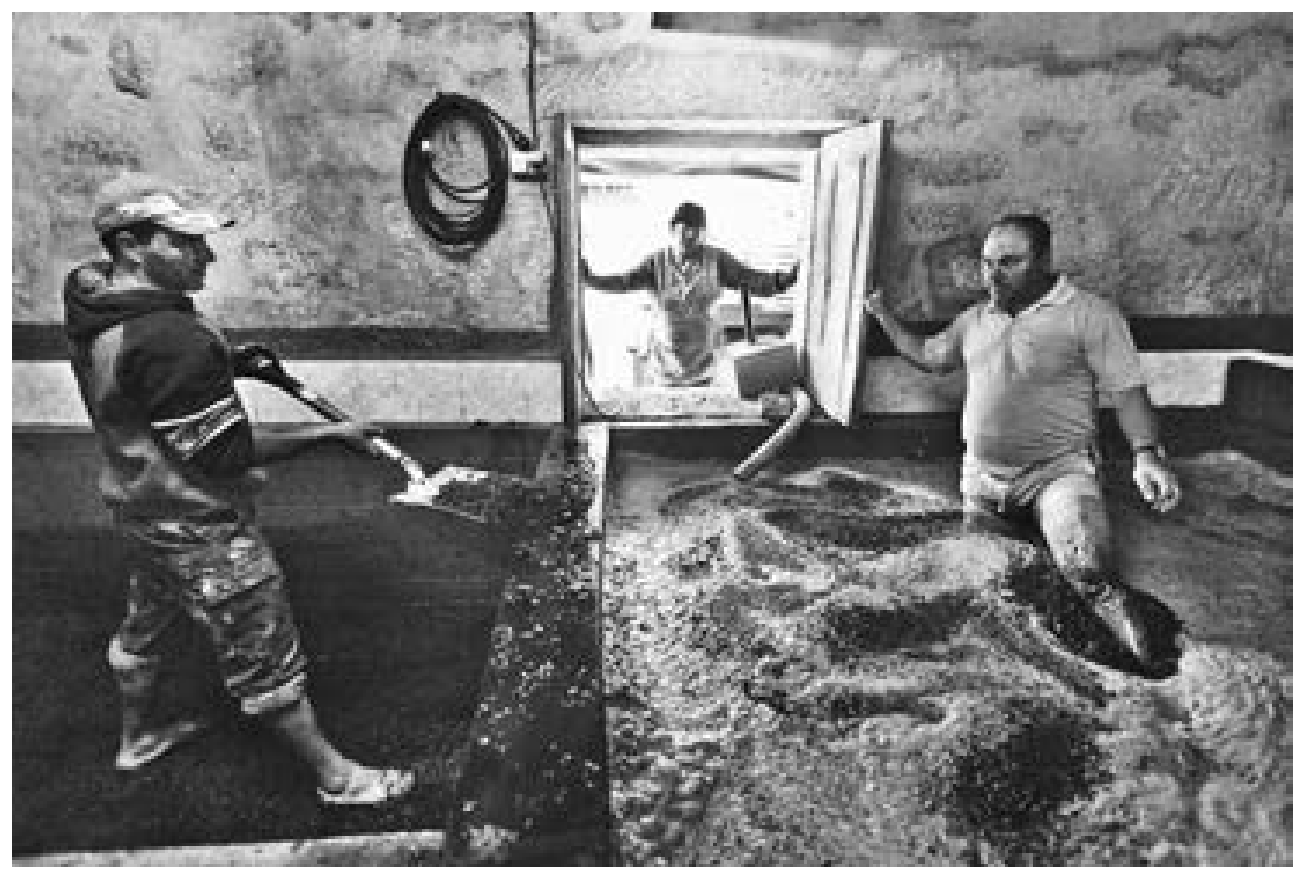

Fig. 44. Pisa das uvas - Lagar tradicional no concelho de Carrazeda Fonte: fotografia de Leonel de Castro

\section{INTRODUÇÃO}

Como se viu nas duas partes precedentes, a história densa da produção e comercialização dos vinhos do Alto Douro com destaque para o vinho do Porto é bem antiga, como o testemunha a persistência cultural do trabalho vitivinícola na região.

Nos finais do século XVIII, conseguiu-se a navegabilidade do Douro por barcos rabelos desde Barca d'Alva (na fronteira de Espanha) até ao Porto.

No século XIX, é publicado o Mapa do Douro por James Forrester. Porém, a filoxera veio atingir a raiz das videiras e devastar os vinhedos durienses, dando origem a muitos «mortórios», os agricultores vendem as suas terras infestadas ou atacam esta moléstia da vinha com o uso de sulfureto de carbono e a plantação de vinhas novas com porta-enxertos de vides americanas. Termina em 1887 a linha ferroviária ao longo do rio Douro, que veio facilitar a melhoria das acessibilidades das pessoas e do transporte de mercadorias.

No século XX o vinho do Porto é exportado através do Entreposto de Vila Nova de Gaia, criado em 1926, como prolongamento da região produtora, é fundada a Federação Sindical dos Viticultores da Região do Douro — Casa do Douro (1932), organismo destinado a proteger e disciplinar a produção, e é organizado o Grémio de Exportadores de Vinho do Porto (1933), associação do setor comercial para vigiar a disciplina do comércio. As atividades destes dois organismos passam a ser coordenadas pelo Instituto do Vinho do Porto, criado na mesma 
altura, com autoridade para estudar e controlar a qualidade e melhorar a divulgação do produto vínico.

As quintas mais famosas do Douro tendem a ser património das casas/empresas de vinho do Porto como a Quinta de Vargellas da Taylor's, a Quinta da Rôeda da Croft, a Quinta do Panascal da Fonseca, ou, em Carrazeda, as Quintas do Tua, da Senhora da Ribeira, de Vale Coelho e dos Canais, propriedade da Cockburn's e hoje da Symington Family Estates.

A maior parte dessas empresas só se estabeleceu no Douro a partir de finais do século XIX, mas já com atividade na zona de Carrazeda, a partir de meados do mesmo século, são de referir outras empresas como a Martinez Gassiot (com negócios do vinho do Porto em 1834, mas fundada em 1797), e a Silva \& Cosens, para além da Cockburn's Smith e dos Symington Family, os maiores proprietários do Douro, atualmente.

As quintas de vinho do Porto, algumas, pelas suas edificações de reconhecido interesse histórico e arquitetónico, tornam-se local escolhido pelas empresas para receberem os seus convidados e figuras destacadas da política em visita ao Douro, e representam no seu conjunto, gerações de tradição vitivinícola produtoras de um estilo de vinho definido e reconhecido como da mais alta qualidade, os clássicos Porto Vintage das empresas ou o «Single Quinta», vinho do Porto elaborado a partir da produção de uma única propriedade, com o seu nome no rótulo.

Historicamente, a produção vinícola duriense estimulada pela crescente procura estrangeira, tentou adaptar-se, desde cedo, às novas exigências dos mercados o que se refletiu na dinâmica e história das quintas da Região do Douro Vinhateiro.

Assim, complexas unidades de vocação comercial de escala nacional e internacional as quintas durienses representam também uma importante dinâmica local na produção vitivinícola. Dotadas de infraestruturas produtivas que se vão progressivamente modernizando e de uma zona residencial eminentemente funcional, junto aos lagares e aos armazéns, por vezes na cota mais elevada do terreno coberto de vinhedos, olivais e pomares, são um património natural, sociocultural, familiar e arquivístico, cuja sócio-história importa reconstituir. As populações foram adaptando as quintas e as suas povoações ao meio envolvente e ao processo de produção, tendo surgido, nessa implementação, um conjunto de marcas de identidade e do memorial coletivo que constituem o património construído vernacular: aglomerados e quintas, casas de habitação e anexos de produção, terraços de vinhedos e olivais, caminhos e conduções de água, cais de embarque, lagares, armazéns, azenhas... ${ }^{305}$; e o património imaterial: cantigas populares, crenças, hábitos, rituais, saberes e técnicas...

As quintas estenderam-se ao longo do rio do Douro e seus afluentes, surgindo em locais onde o vinho apresentava as melhores características e qualidade. Muitas delas hoje com produção e fabrico altamente técnicos e tecnologizados, foram-se constituindo historicamente como complexos heterogéneos e relativamente autónomos de produção e transformação,

${ }^{305}$ AGUIAR, 2000: 116. 
celebração de contratos, locais de atração e encontro de pessoas de aldeias vizinhas e distantes, polos de partilha de valores e tradições culturais, dinamização da vida económica, social e cultural das comunidades locais.

As quintas, com as povoações envolventes, em regra pequenas e hoje muito desertificadas e com uma população envelhecida, são unidades primárias e centrais do território e da paisagem da região, entidades estruturantes da história do Douro Vinhateiro, com pessoal recrutado nas aldeias vizinhas ou em lugares mais distantes para a execução das tarefas regulares e constantes que o trabalho das vinhas e do vinho exigem.

Em certas épocas do ano de maior azáfama, como na vindima e na apanha da azeitona, recorria-se a pessoal de outras regiões ou até de fora do país, como outrora, os galegos «cujos bandos, como de aves de arribação, aparecem por estes sítios regular e periodicamente no mês de outubro para de novo se ausentarem para as suas montanhas no mês de abril seguinte» ${ }^{306}$. Desde os inícios do século XVIII, desciam ao Douro, onde tiveram enorme importância, contribuindo com o seu trabalho melhor remunerado, de construção meticulosa de geios/socalcos, plantação do bacelo e outros. Esta realidade histórica da presença dos galegos na região duriense, alguns dos quais acabariam por aqui se fixar, perdurou no imaginário transmontano e duriense.

Atualmente, tem-se recorrido em algumas quintas à contratação de outras empreitadas de trabalhadores sazonais, em que se têm destacado nalgumas zonas durienses, como por exemplo no concelho de Carrazeda, os imigrantes da Europa de Leste.

A cultura do «vinho tratado» chegou a ser «um dos mais importantes polos de modernização da economia e da administração pública» ${ }^{307}$ do país, quando o Douro era a sua mais moderna zona agrícola, e a produção do «vinho fino» uma das maiores riquezas da região além de azeite, amêndoa e fruta — , que exige e sempre exigiu uma atividade intensa, ao longo do ano, nas quintas onde os trabalhadores encontravam trabalho pago em numerário e uma forma de garantir a sua sobrevivência. Mas, se nas margens do Douro se produzia essa grande riqueza nacional de exportação internacional, era também aí que se encontravam alguns dos concelhos mais pobres e periféricos do país (Cinfães, Resende, Armamar, Sabrosa, Tabuaço, Carrazeda de Ansiães...), onde o poder de compra era mais baixo que o da média nacional e onde mais de $90 \%$ dos trabalhadores eram pequenos agricultores que viviam da vinha e do vinho ${ }^{308}$.

As quintas durienses, unidades logísticas e estruturantes da região vinhateira em múltiplas dimensões e microcosmos económico-sociais e culturais marcantes da paisagem e património histórico do Douro, são complexos agrícolas multidimensionais organizados em função da produção e escoamento dos vinhos e em torno de diversos núcleos polifuncionais que integram e inter-relacionam diversas áreas e espaços:

a) áreas tradicionais de residência (casa senhorial em regra só habitada ocasionalmente, casa do caseiro e cardanhos para os trabalhadores sazonais);

\footnotetext{
${ }^{306}$ VILA MAIOR, 1876: 52.

${ }^{307}$ BARRETO, 1993.

${ }^{308}$ VISEU, 2007: 143-144.
} 
b) espaços de produção (vinha e vinhedos requerendo trabalhos contínuos e/ou cíclicos de natureza);

c) área de transformação e de armazenamento: lagares para a pisa das uvas e armazéns onde o vinho é armazenado até ser transportado para o entreposto comercial de Vila Nova de Gaia, donde engarrafado e rotulado haverá de ser canalizado para os mercados interno e de exportação nacionais e estrangeiros;

d) área de comercialização e de administração, reguladora do processamento de uvas e vinhos e negociações entre donos das quintas e firmas exportadoras, que começou por ser no escritório (pequena repartição da quinta, onde caseiro e feitor registavam quantidades de vinho, nome dos trabalhadores, dias de trabalho, salários e géneros alimentícios, despesas gerais, importâncias a pagar), etc.

e) área cultural só ocasionalmente existente nalgumas das maiores e mais abastadas quintas para apoio a trabalhadores permanentes ou às populações locais das aldeias e lugares de pequenas comunidades envolventes.

Tradicionalmente, quem tratava nas quintas da maior parte dos seus negócios regulares eram os caseiros, a quem os donos confiavam a gestão da casa, a contratação do pessoal, compras e pagamentos, «no cofre milhares de escudos» ${ }^{309}$.

O rogador, capataz da «roga», angariava e contratava as pessoas que iam trabalhar para as quintas, mal alimentados, trabalhando de sol a sol, com jornas miseráveis.

Os trabalhos das quintas que sempre requereram maior concentração simultânea de mão de obra sazonal, quando terminavam, eram assinalados por refeição melhorada dos trabalhadores servida na quinta e por manifestações momentâneas de alegria e convívio social, festas e cultura popular, ambiência sociocultural considerada típica das tradicionais vindimas do Douro. Esta foi sendo recriada por diversos autores das letras e das artes, como por exemplo o escritor transmontano duriense Miguel Torga, quer em A Vindima (1945), quer no conto homónimo publicado anos antes (1941).

As maiores quintas continuam a ser, especialmente durante as vindimas, um importante mercado de trabalho local na região, não só das populações vizinhas, embora hoje menos, dada a desertificação populacional local, e ainda e cada vez mais ao longo de todo o ano, de quadros técnicos superiores licenciados: engenheiros, agrónomos, enólogos, o que constitui uma importante inovação e profunda transformação no Douro Vinhateiro.

Com a modernização técnica e tecnológica da vitivinicultura, registada mais intensamente a partir de finais da década de 1980, foi-se transformando o Douro tradicional das antigas quintas a que aqui se aludiu, e cujas marcas e traços vamos encontrar na micro-história das oito quintas durienses de Carrazeda que a seguir se apresentam.

${ }^{309}$ GIBBONS, 2004: 329. 
Estas, entidades económico-sociais em meio rural de progressiva e atual complexidade, têm sido, do ponto de vista da investigação histórica, um tema menos estudado enquanto constructo transdisciplinar.

Ao seu estudo e análise mais detalhada se procede no Capítulo 7 ao qual se segue, complementarmente, no Capítulo 8, uma abordagem histórica específica a empresas destacadas de vinho do Porto, mormente duas antigas firmas britânicas exportadoras e produtoras de maior relevo e especial protagonismo na história vitivinícola do concelho de Carrazeda e duas jovens empresas concelhias de vinificação, iniciativas de empreendedorismo e afirmação local.

Encerra-se esta Parte III com uma amostragem de saberes competentes de peritos e leigos, considerada representativa da «superfície social» e «agentes eficientes» no local, a partir de um conjunto significativo de entrevistas e narrativas de informantes privilegiados cuja análise histórico-sociológica se faz no 9. ${ }^{\circ}$ e último capítulo. 


\section{CAPÍTULO 7. CONSTELAÇÃO DE QUINTAS DURIENSES EM CARRAZEDA DE ANSIÃES}

\subsection{APROXIMAÇÃO CONJUNTURAL}

No início da primeira metade do século XX, no concelho de Carrazeda de Ansiães conforme registado em fontes diversas, existia já um grande número de quintas durienses, localizadas em diferentes freguesias, muitas das quais e algumas mais antigas tinham já nos finais do século XIX, relativa dimensão e importância (ver quadros seguintes).

Em 1943, de um universo de 827 quintas existentes no Douro, contavam-se no concelho de Carrazeda, 27 quintas antigas e mais conhecidas localmente, na sua maioria com atividade regular durante a República. Presentemente, conforme arrolamento público municipal, esse número terá decrescido para 22, nas quais se incluem mais 6 quintas, 3 situadas na freguesia de Marzagão, anteriormente não referenciadas (Quadro 21).

Porém, é de ressalvar que, por vezes, os nomes das mesmas quintas, geralmente fixados a partir de topónimos de antigas propriedades que as constituem, mediante compras/vendas/ heranças e de particularidades orográficas dos locais onde se situam, podem ser mudados para novas designações relacionadas com a sua localização, compra e fusão ou com antigos e novos proprietários, mudanças também frequentes.

Por sua vez, às quintas antigas do concelho de Carrazeda, de maior ou menor dimensão, muitas das quais ainda hoje existentes, junto ao rio Douro e ao seu afluente rio Tua, andam associados topónimos, velhos ou mais recentes, mas todos bem conhecidos localmente (Quadro 18).

Quadro 18. Quintas com nomes associados a topónimos locais

\begin{tabular}{|c|c|c|c|}
\hline 1 & Quinta da Aborraceira & 12 & Quinta do Comparado \\
\hline 2 & Quinta da Alegria & 13 & Quinta do Freixo \\
\hline 3 & Quinta da Coelheira & 14 & Quinta do Lubazim \\
\hline 4 & Quinta da Cuveta & 15 & Quinta do Pé Bom \\
\hline 5 & Quinta da Lavandeira & 16 & Quinta do Pousado \\
\hline 6 & Quinta da Senhora da Ribeira & 17 & Quinta do Tralhão \\
\hline 7 & Quinta da Ribeira da Vila & 18 & Quinta do Veiga \\
\hline 8 & Quinta das Vinhas & 19 & Quinta dos Canais de Baixo \\
\hline 9 & Quinta do Barrabás & 20 & Quinta dos Canais de Cima \\
\hline 10 & Quinta do Cachão do Arnozelo & 21 & Quinta dos Carris \\
\hline 11 & Quinta do Calvário & & \\
\hline
\end{tabular}

Podem ainda hoje verificar-se situações de reconstituição recente de primitivas quintas inativas ou quase desaparecidas. É o caso por exemplo da Quinta do Calvário, (número 11 do quadro), uma quinta já existente no século XIX (ver Capítulo 8, subcapítulo 8.5). Esta antiga 
quinta encontra-se localizada na área concelhia de Carrazeda da mais antiga produção de vinho do Porto, «terra de particular desenvolvimento da vinha... de vinho bom e de qualidade que se cultiva intensamente com destino à exportação como é o caso do vinho de ramo de Ribalonga $\aleph^{310}$.

No panorama das quintas de Carrazeda, cuja esmagadora maioria se localiza na margem direita norte do Douro (e em menor número, no Vale do Tua - exemplo, as quintas do Veiga e do Tralhão na freguesia de Pinhal do Norte), salientam-se pela sua maior antiguidade e continuidade de posse das mesmas famílias, as seguintes quintas: a de Lubazim, uma das mais antigas do Alto Douro, pertencente desde o século XIV à família dos Castros de Vilarinho da Castanheira; a Quinta do Zimbro dos Melo Vaz de Sampaio; a da Alegria de Cima da família Mariz de Linhares; a Canaes/Bartol, na posse da mesma família luso-espanhola, a partir de 1889; a do Tua, que fora propriedade de Dona Antónia Ferreira e a de Vale Coelho (originariamente integrada na quinta do Lubazim), adquiridas em finais do século XIX pela Cockburn \& Smith, empresa hoje fundida no Grupo Symington, o maior proprietário fundiário atual do Douro e deste concelho.

Pode depreender-se dos quadros a seguir apresentados que o número de quintas existentes em Carrazeda, sempre superior a duas dezenas, se manteve estável, persistência historicamente significativa, como se melhor se demonstrará adiante.

Quadro 19. Quintas no concelho de Carrazeda de Ansiães (1927-1931) $)^{311}$

\begin{tabular}{|c|c|c|}
\hline Anos & Quintas produtoras Vinho Generoso & Freguesias \\
\hline $1927 / 28$ & $\begin{array}{l}\text { 1-2. Quintas do Vale Coelho (na Quinta do Lubazim), e da Pescoça } \\
\text { 3. Quinta do Tua } \\
\text { 4. Quinta da Andorinha (Tua) } \\
\text { 5. Quinta dos Carris } \\
\text { 6. Quinta do Zimbro }\end{array}$ & $\begin{array}{l}\text { Vilarinho da Castanheira/ } \\
\text { Pinhal do Douro } \\
\text { Castanheiro } \\
\text { Seixo de Ansiães } \\
\text { Ribalonga }\end{array}$ \\
\hline 1930 & $\begin{array}{l}\text { 7. Quinta dos Canais } \\
\text { 8. Quinta do Lubazim, e quintas de Vale Coelho e Pescoça. } \\
\text { 9. Quinta da Alegria } \\
\text { 10-17. Quintas da Barreira, Coalheira, dos Carris, Valdranjo, } \\
\text { Requeixo, Ribeira, Roca Vales } \\
\text { 18. Quinta do Zimbro, } \\
\text { 19-24. Quintas do Costa, S. Martinho, Arnoselo, Fonte Santa, Ladeira } \\
\text { 25-26. Quinta da Chousa e do Tua } \\
\text { 27-28. Quintas de Comparado e Senhora da Ribeira }\end{array}$ & $\begin{array}{l}\text { Beira Grande } \\
\text { Vilarinho da Castanheira } \\
\text { Linhares } \\
\text { Seixo/Pombal/Castanheiro } \\
\text { Ribalonga } \\
\text { Pinhal/Fiolhal/Tralhariz } \\
\text { Ribalonga } \\
\text { Seixo de Ansiães }\end{array}$ \\
\hline 1931 & $\begin{array}{l}\text { 29. Quintas do Lubazim e da Urraca } \\
\text { Quinta dos Canais } \\
\text { 30-39. Quintas: Carris, Cachão, Coveta, Chousa, Coalheira, Alegria, } \\
\text { Zimbro, Senhora da Ribeira, Fonte Santa (Vesúvio) }\end{array}$ & $\begin{array}{l}\text { Vilarinho da Castanheira } \\
\text { Beira Grande } \\
\text { Seixo de Ansiães/Linhares/ } \\
\text { Ribalonga }\end{array}$ \\
\hline
\end{tabular}

\footnotetext{
${ }^{310}$ CAPELA, 2007.

${ }^{311}$ Dados recolhidos em documentos manuscritos e impressos de registo de produtores e produções de vinho generoso nos anos referidos (Arquivo da Comissão de Viticultura da Região Duriense, Casa do Douro, Régua).
} 
Quadro 20. Quintas em Carrazeda de Ansiães, em $1941^{312}$.

\begin{tabular}{|c|c|c|c|}
\hline Nome da Quinta & Freguesia & Proprietário & Histórico \\
\hline 1. Alegria de Cima & Linhares & Alexandre Augusto Mariz & $\begin{array}{l}\text { Fundador: } \\
\text { Luíz António Sampaio, } 1800\end{array}$ \\
\hline 2. Alegria de Baixo & Linhares & $\begin{array}{l}\text { Dr. Álvaro Ferreira } \\
\text { Pontes* }\end{array}$ & 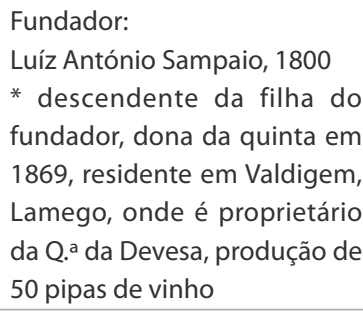 \\
\hline $\begin{array}{l}\text { 3. Cachão } \\
\text { de Arnozelo }\end{array}$ & Beira Grande & Luís Gouveia Moutinho & \\
\hline 4. Canais & Beira Grande & $\begin{array}{l}\text { Francisco Manuel } \\
\text { da Costa }\end{array}$ & $\begin{array}{l}\text { Anexa a antiga quinta } \\
\text { da Forneira }\end{array}$ \\
\hline 5. Canameira & Linhares & $\begin{array}{l}\text { Dona Maria Leonor } \\
\text { Pereira Caldas de Barros }\end{array}$ & \\
\hline 6. Carris & Beira Grande & $\begin{array}{l}\text { Dr. António Júlio } \\
\text { Crispiniano de Lacerda* }\end{array}$ & * Residente em Alijó \\
\hline 7. Chousa & Castanheiro do Norte & António de Castro & \\
\hline 8. Coalheira & Seixo de Ansiães & Pedro Augusto Ferreira* & $\begin{array}{l}\text { * da Casa Ferreirinha, } \\
\text { residente no Porto }\end{array}$ \\
\hline 9. Coalheira & Seixo de Ansiães & Dr. João Trigo Moutinho & \\
\hline 10. Comparado & Seixo de Ansiães & $\begin{array}{l}\text { João da Cruz Sampaio } \\
\text { e João Armindo Figueiredo }\end{array}$ & \\
\hline 11. Comparado & Seixo de Ansiães & Armando Maria Sobral & \\
\hline 12. Coveta & Ribalonga & $\begin{array}{l}\text { Dr. Ferrand Pimentel } \\
\text { de Almeida* }\end{array}$ & *Residente em Coimbra \\
\hline 13. Ferradosa & Linhares & $\begin{array}{l}\text { Banco Borges \& Irmão, } \\
\text { sede Porto** }^{* *}\end{array}$ & $\begin{array}{l}\text { ** área de } 120 \text { ha, alambique, } \\
\text { armazém e + instalações, pro- } \\
\text { duz } 45 \text { pipas de vinho, } 4 \text { de } \\
\text { azeite, amêndoa, fruta e muita } \\
\text { cortiça }\end{array}$ \\
\hline 14. Fonte Santa & Seixo de Ansiães & João Barreiras & \\
\hline 15. Forneira & Beira Grande & $\begin{array}{l}\text { Francisco Manuel } \\
\text { da Costa }\end{array}$ & $\begin{array}{l}\text { Quinta anexa à Quinta } \\
\text { dos Canais }\end{array}$ \\
\hline 16. Lobasim & $\begin{array}{l}\text { Vilarinho } \\
\text { da Castanheira }\end{array}$ & $\begin{array}{l}\text { Dr. Manuel de Castro } \\
\text { Pereira Teixeira Lobo Pizarro }\end{array}$ & $\begin{array}{l}\text { Residente na Foz do Douro } \\
\text { — Porto }\end{array}$ \\
\hline
\end{tabular}

\footnotetext{
${ }^{312}$ Dados compilados, na sua maioria, a partir de CORDEIRO, 1941.
} 


\begin{tabular}{|c|c|c|c|}
\hline Nome da Quinta & Freguesia & Proprietário & Histórico \\
\hline 17. Pescoça & $\begin{array}{l}\text { Vilarinho } \\
\text { da Castanheira }\end{array}$ & $\begin{array}{l}\text { Firma Cockburn } \\
\text { \& Smithes C. }{ }^{\text {a Lda., }} \\
\text { sede em V. N. Gaia* }\end{array}$ & $\begin{array}{l}\text { * a estação ferroviária mais } \\
\text { próxima é a de Freixo de } \\
\text { Numão. Produção de } 6 \text { pipas } \\
\text { de vinho; tem armazéns com } \\
\text { cubas e tonéis - capacidade } \\
\text { de } 230 \text { pipas. Faz parte da Q. }{ }^{\text {a }} \\
\text { de Vale Coelho, mas tem insta- } \\
\text { lações separadas de armazéns } \\
\text { e lagares }\end{array}$ \\
\hline 18. Pousado & Seixo de Ansiães & $\begin{array}{l}\text { António Luiz Sobral Ribeiro } \\
\text { e Dona Maria Augusta } \\
\text { Azevedo Sobral Ribeiro }\end{array}$ & \\
\hline $\begin{array}{l}\text { 19. Senhora da } \\
\text { Ribeira }\end{array}$ & Seixo de Ansiães & $\begin{array}{l}\text { Firma Silva \& Cosens Lda, } \\
\text { Gaia* }\end{array}$ & $\begin{array}{l}\text { * Adquirida em } 1889 \text { por } \\
\text { George Acheson Warre, antigo } \\
\text { sócio da firma proprietária. } \\
\text { Fica na margem direita do } \\
\text { Douro, próximo da estação } \\
\text { do Vesúvio. Tem boas instala- } \\
\text { ções, boa casa de habitação e } \\
\text { capela. Produção apreciável } \\
\text { de vinho, azeite, amêndoa e } \\
\text { fruta diversa }\end{array}$ \\
\hline 20. Tralhão & Pinhal do Norte & $\begin{array}{l}\text { Dona Luiza de Castro } \\
\text { Ramires da Veiga }\end{array}$ & \\
\hline 21. Tua & Castanheiro do Norte & $\begin{array}{l}\text { Firma Cockburn } \\
\text { Smithes \& C. }{ }^{a} \text { L. }{ }^{\text {a }} \text { Gaia* }\end{array}$ & $\begin{array}{l}\text { * Antiga propriedade de Dona } \\
\text { Antónia Ferreira, conhecida } \\
\text { também por Q. }{ }^{a} \text { dos Ingleses, } \\
\text { tem produção de } 20 \text { pipas } \\
\text { de vinho e algum azeite. Tem } \\
\text { modelares instalações, arma- } \\
\text { zéns com vasilhame - toneis } \\
\text { e cubas - com capacidade de } \\
500 \text { pipas }\end{array}$ \\
\hline 22. Zimbro de Cima & Ribalonga & $\begin{array}{l}\text { Dr. António Sampaio } \\
\text { Chaves }\end{array}$ & \\
\hline 23. Zimbro & Ribalonga & $\begin{array}{l}\text { Firma Silva \& Cosens Lda., } \\
\text { Gaia }\end{array}$ & \\
\hline
\end{tabular}




\begin{tabular}{|c|c|c|c|}
\hline Nome da Quinta & Freguesia & Proprietário & Histórico \\
\hline 24. Zimbro de Baixo & Ribalonga & $\begin{array}{l}\text { Dr. António Melo } \\
\text { Vaz de Sampaio* }\end{array}$ & $\begin{array}{l}\text { * Residente no Porto. Esta } \\
\text { quinta, desde } 1684 \text {, pertence } \\
\text { à família do atual proprietário. } \\
\text { Possui } 5 \text { ha de área e é servida } \\
\text { pela estrada nacional 16-2. a e } \\
\text { estação do Tua. Produção: } 10 \\
\text { pipas de azeite e } 20 \text { de vinho } \\
\text { tinto. Castas predominan- } \\
\text { tes: Tinta Touriga, Tinta Roriz, } \\
\text { Mourisco da Semente, Souzão, } \\
\text { etc. O armazém tem toneis na } \\
\text { capacidade de } 40 \text { pipas. A } \\
\text { casa de habitação tem capela } \\
\text { anexa }\end{array}$ \\
\hline 25. Bartol & Beira Grande & D. Juan Vicent Bartol* & $\begin{array}{l}\text { * Residente em Vitigudino, } \\
\text { Espanha }\end{array}$ \\
\hline 26. Requeixo & Seixo de Ansiães & Dr. João Trigo Moutinho & \\
\hline 27. Valdroujo & Seixo de Ansiães & Dr. João Trigo Moutinho & \\
\hline
\end{tabular}

Quadro 21. Quintas durienses atuais em Carrazeda de Ansiães ${ }^{313}$

\begin{tabular}{|l|l|l|}
\hline \multicolumn{1}{|c|}{$\begin{array}{c}\text { Freguesias/ } \\
\text { Localidades }\end{array}$} & \multicolumn{1}{|c|}{ Quintas } & \multicolumn{1}{c|}{ Observações } \\
\hline Linhares & 1. Quinta da Alegria de Cima* & $\begin{array}{l}\text { * Propriedade atual do Eng. Alexandre Mariz } \\
\text { Há referências a: Quinta da Alegria de Cima/ } \\
\text { Quinta da Alegria de Baixo/Quinta da Alegria Nova }\end{array}$ \\
\hline $\begin{array}{l}\text { Castanheiro do } \\
\text { Norte }\end{array}$ & $\begin{array}{l}\text { 2. Quinta do Dr. Manuel } \\
\text { 3. Quinta das Avoengas } \\
\text { 4. Quinta da Coveta } \\
\text { 5. Quinta da Lavandeira* }\end{array}$ & * Propriedade atual da família Ferrand \\
\hline Ribalonga/Tua & $\begin{array}{l}\text { 6. Quinta do Zimbro } \\
\text { 7. Quinta da Chousa* } \\
\text { 8. Quinta do Tua* }\end{array}$ & * São propriedade atual do Grupo Symington \\
\hline $\begin{array}{l}\text { S. Quinta da Senhora da Ribeira de } \\
\text { Ansiães }\end{array}$ & $\begin{array}{l}\text { 10. Quinta das Amendoeiras } \\
\text { 11. Quinta dos Carris }\end{array}$ & Propriedade atual do Grupo Symington \\
\hline
\end{tabular}

\footnotetext{
${ }^{313}$ Quadro construído a partir de arrolamento municipal recente e de outras informações e dados compilados a partir de diversas fontes diretas.
} 


\begin{tabular}{|c|c|c|}
\hline $\begin{array}{l}\text { Freguesias/ } \\
\text { Localidades }\end{array}$ & Quintas & Observações \\
\hline $\begin{array}{l}\text { Beira Grande/ } \\
\text { Lavandeira }\end{array}$ & $\begin{array}{l}\text { 12. Quinta dos Canais* } \\
\text { 13. Quinta Bartol** } \\
\text { 14. Quinta do Comparado }\end{array}$ & $\begin{array}{l}\text { * resultante da concentração de } 6 \text { antigas propriedades } \\
\text { com o capitalista português Francisco M. Costa, natural } \\
\text { de S. João da Pesqueira, dispunha de guarda florestal em } \\
\text { 1930, foi comprada em } 1941 \text { pelo Eng. Ramiro Sobral de } \\
\text { Viseu e vendida pelas suas filhas herdeiras, em 1989, à } \\
\text { firma inglesa Cockburn \& Smith Lda. que a venderia em } \\
2002 \text { ao Grupo Symington } \\
\text { ** Adquirida pelo galego Ramon Franqueira, c. } 1889\end{array}$ \\
\hline Marzagão & $\begin{array}{l}\text { 15. Quinta da Aveleira } \\
\text { 16. Quinta da Gricha } \\
\text { 17. Quinta da Manjafra }\end{array}$ & \\
\hline $\begin{array}{l}\text { Vilarinho } \\
\text { da Castanheira }\end{array}$ & $\begin{array}{l}\text { 18. Quinta do Lobazim* } \\
\text { 19. Quinta do Vale Coelho** } \\
\text { 20. Quinta da Urraca*** } \\
\text { 21. Quinta dos Lagares } \\
\text { 22. Quinta da Pescoça }\end{array}$ & $\begin{array}{l}\text { * propriedade da antiga família Castro Pizarro, com solar } \\
\text { brasonado e capela barroca do século XVIII } \\
\text { ** propriedade atual do Grupo Symington que a comprou } \\
\text { à firma Cockburn \& Smithes que a tinha em sua posse, } \\
\text { desde fins do século XIX, quando a comprara à Quinta de } \\
\text { Lubazim a que pertencia e onde estava encravada } \\
\text { *** propriedade da família Mesquita Lobo desde o início } \\
\text { dos anos } 1940\end{array}$ \\
\hline
\end{tabular}

Entre os proprietários estrangeiros de quintas em Carrazeda de Ansiães, na viragem de Oitocentos para o século XX, contam-se, designadamente, George A. Warre e Silva \& Cosens das Quintas da Senhora da Ribeira e do Zimbro, e Cockburn's Smith das quintas do Tua e Vale Coelho, simultaneamente dois dos principais compradores dos vinhos generosos de uma grande maioria dos lavradores do concelho e donos de conhecidas firmas exportadoras de vinho do Porto, e ainda Juan Vicente Bartol (farmacêutico espanhol) proprietário da designada Quinta dos Canaes/Bartol, originariamente do empreendedor galego Ramon Franqueira que casou na aldeia e freguesia de Fontelonga, Carrazeda de Ansiães ${ }^{314}$.

Cotejando os quadros anteriores pode observar-se que a grande maioria dessas quintas se manteve, tendo um escasso número delas continuado na posse das mesmas famílias (quintas de Lubazim, Bartol, Alegria, Cuveta). Não deixou, porém, de registar-se uma tendência evolutiva de concentração e mudança de mãos da propriedade, devido a heranças familiares e, mais frequentemente, à compra/venda das maiores e mais importantes quintas por grandes empresas inglesas com destaque para a Silva \& Cosens, e a Cockburn \& Smithes com presença marcante em Carrazeda e, mais recentemente, o Grupo Symington, proprietário atual de 8 quintas do concelho como se verá adiante.

A presença duradoura de estrangeiros, particularmente ingleses, na extensa área vitivinícola do concelho de Carrazeda produtor de vinho do Porto, onde exerceram e exercem ainda ação relevante e configuradora, a vários e importantes níveis, teve ainda eco na produ-

\footnotetext{
${ }^{314}$ Ver subcapítulo seguinte Quinta Canaes/Bartol: tradição luso-espanhola no Douro.
} 
ção literária de autoria inglesa sobre esta zona duriense, outra fonte documental a considerar na abordagem geral a este universo das quintas durienses que se vem esboçando. É o caso por exemplo, do escritor inglês John Gibbons (1882-1949) que nos finais dos anos 1930, se fixou temporariamente em Coleja, tradicional povoação ribeirinha duriense de Carrazeda, onde escreveu, durante a sua permanência, o livro Não criei musgo ${ }^{315}$ que recebeu o Prémio Camões em 1939, referente à melhor crítica em língua estrangeira acerca de Portugal, instituído pelo então SNI (Secretariado de Propaganda Nacional) ${ }^{316}$. Este autor, integrado no modo de vida quotidiana e tradições dessa comunidade local da época, que observa em seu olhar distanciado de estrangeiro, narra e descreve, com traços da ideologia do Estado Novo, mas evidente pormenor e sensibilidade etnográfica, esta zona de vinhas classificadas para benefício com letras superiores e melhores litragens, e de grande concentração de quintas durienses do concelho de Carrazeda, produtor de vinhos de elevada qualidade. Sobre a ambiência, principais características e funcionamento destas quintas, J. Gibbons que, por esta altura, visitou algumas delas como por exemplo a Quinta do Tua, de que traçou a seguinte panorâmica histórico-etnográfica típica desta zona nos anos 1930-1940:

As famosas quintas do Douro estendem-se ao longo do rio, por uma extensão de cerca de uma hora de caminho, mas, cá mais no cimo, não há vinho que valha a pena exportar ou vender sequer nas lojas. Há vinho em todas as regiões de Portugal e dentro de alguns anos, até o haverá em excesso. A quantidade é superior à que se poderia vender e, mesmo os produtores das melhores castas, são praticamente obrigados a desperdiçar a maior parte da produção. Para facilitar o escoamento desta superprodução, a lei portuguesa indica que os hotéis e restaurantes devem servir a acompanhar cada refeição uma determinada quantidade de consumo, que não tem nome nem rótulo. É vinho puro, feito pelo próprio lavrador ou negociado com o seu vizinho [...].

Aqui, as quintas, para além dos terrenos, são compostas pela casa senhorial, por uma casa mais pequena para alojar o caseiro português que aí vive permanentemente e por um aglomerado de pequenas casinhas para os trabalhadores efetivos. Este pessoal, suficiente para as necessidades da quinta durante o ano, torna-se mais escasso para os trabalhos a fazer na altura das vindimas. Noutros tempos era a Galiza espanhola. Pobre e superpovoada, com uma elevada taxa de emigração, que fornecia a Portugal a mão-de-obra necessária nessa época do ano. Os galegos não eram excecionalmente inteligentes nem tinham um alto nível de vida e trabalhavam por baixo preço. Deslocavam-se às centenas para Portugal [...] por ocasião das ceifas. Os socalcos mais antigos do Douro foram talhados por eles, mas os tempos mudaram; as vindimas são hoje feitas exclusivamente por portugueses [...].

\footnotetext{
${ }^{315}$ GIBBONS, 1984.

${ }^{316}$ Ver sobre esta obra I gathered no Moss, 1939 (título da versão inglesa), MATOS, 2012: 59-73.
} 
Os trabalhadores, deslocando-se de todas as aldeias vizinhas, instalam-se nas quintas em abrigos toscos [...]. As uvas são primeiramente vindimadas nas propriedades da firma e depois acrescidas das compradas a quintas pertencentes ao Estado e a particulares das redondezas, depois de devidamente selecionadas. Feita a vindima, as uvas são espremidas pelo sistema tradicional de dança sobre o mosto de pés descalços [...].

Os trabalhos de engarrafamento, rotulação, etc., são mais tarde feitos no Porto [...].

O transporte dos pipos até aos carros de bois é facilitado por um mini-caminho-de-ferro; cada Quinta possui um sistema de iluminação próprio, à base de gás carbónico (gasómetros), e até de uma capela católica para os trabalhadores residentes [...].

Hoje (1938), a Grã-Bretanha controla cerca de 80\% do comércio de vinho do Porto, e os ingleses conservam as casas geralmente fechadas, vindo, de semanas a semanas do Porto, para as arejarem ${ }^{317}$.

[...] O negócio não é hoje tão próspero como em tempos. O consumo do vinho diminuiu, alguns mercados, (como por exemplo o Russo), estão agora completamente vedados, e começa a existir competição dentro do país. Portugal abriu um pouco os olhos, e cerca de $20 \%$ do comércio do vinho está hoje nas suas mãos [... $]^{318}$.

[...] nunca vi ingleses com melhor situação do que a dos que se dedicam ao comércio do vinho do Porto. O dinheiro permitiu-lhes comprar o que de melhor existe nos dois países: um solar português enorme e o recheio confortável de móveis e utensílios ingleses [... $]^{319}$.

Conforme era então tradição no Douro, a generalidade dos proprietários das grandes quintas mantinha entre si relações de família e cordialidade e residia fora, no Porto e outros centros urbanos de Portugal e estrangeiro, deslocando-se à quinta, durante as vindimas ou ocasionalmente. Ao longo do ano, era o caseiro, residente na quinta com a família, que se encarregava da gestão corrente dos negócios locais e outros assuntos diários (contratação e pagamento da mão de obra, supervisão dos trabalhos, compras de mantimentos, utensílios e ferramentas, manutenção, conservação e melhoramentos).

As populações vizinhas destas quintas de um e do outro lado do Rio Douro (concelhos de Foz Coa, S. João da Pesqueira e Carrazeda de Ansiães), naturais e/ou residentes nas margens opostas do rio que frequentemente atravessavam de barco, mantiveram relações regulares de trabalho e convivência com os trabalhadores permanentes destas grandes propriedades vinhateiras, importantes polos de atração socioeconómica e cultural. É por exemplo o caso, defronte da aldeia de Coleja atrás referida, da Quinta de Vargelas e Quinta do Vesúvio ${ }^{320}$ em cuja capela

\footnotetext{
${ }^{317}$ GIBBONS, 2004: 37.

${ }^{318}$ GIBBONS, 2004: 99-100.

${ }^{319}$ GIBBONS, 2004: 145.

${ }^{320}$ Quinta do Vesúvio, Numão - Cedovim. Histórica e importante quinta duriense, que foi propriedade, durante várias gerações, da família de Dona Antónia Ferreira, a «Ferreirinha» figura lendária do Douro e do vinho do Porto. Atual Proprietário: Grupo Symington. Ano de aquisição: 1989. Disponível em <http://paginas.fe.up.pt/porto-ol/ jmg/98lgcqd17.html >.
} 
era costume assistirem às missas dominicais, quando não tinham pároco residente. Mas já a partir de finais de Oitocentos, com a chegada do comboio à região duriense, estas duas grandes quintas da margem esquerda do Douro, à semelhança de outras unidades idênticas, passaram a ser servidas por apeadeiros ferroviários da linha do Douro, tornando-se para as comunidades mais próximas, verdadeiras portas abertas ao mundo ${ }^{321}$.

Assim, um estudo necessariamente denso das quintas do Douro, como as de mais antiga e significativa representação no concelho de Carrazeda, exige só por si investigação abrangente, específica e autónoma, o que extravasa o âmbito e limites do presente estudo de caso ${ }^{322}$.

Consideramos, porém, que este livro bem como à investigação subjacente à sua escrita, ficariam muito incompletos sem uma aproximação específica à análise concreta e particular das principais quintas durienses localizadas no território de Carrazeda de Ansiães, cujo conhecimento mais detalhado e compreensivo é essencial para a caracterização e entendimento deste concelho enquanto produtor de vinho do Porto.

Daí que se apresente na parte seguinte deste trabalho, em subcapítulo próprio, extensivamente desenvolvida, uma constelação de quintas históricas mais destacadas do concelho de Carrazeda. Estas evidenciam, na sua generalidade, como poderá ver-se, um padrão idêntico à matriz das quintas do Douro: microcosmos e unidades produtivas de monocultura vitivinícola de produtos qualificados (vinhos generosos e de consumo) com «casa e por vezes também capela», zona residencial eminentemente funcional, junto aos lagares e armazéns, por vezes em cotas mais elevadas do terreno de vinhedos, olivais e pomares.

Configuram-se assim as quintas durienses como exemplares de grande e complexa especialidade com valor de património natural, económico-sociocultural e familiar assaz significativo na e da história do Douro, à escala local, nacional e internacional. Compreendendo-as então como um constructo transdisciplinar, procuramos descrevê-las e analisá-las em função de dois eixos fundamentais: seu papel e posição à escala local e, adensando a abordagem, sua representatividade numa escala mais ampla, enquanto fenómeno económico, social e cultural de produção vitivinícola no mundo rural português.

\footnotetext{
${ }^{321}$ Designadamente através da expedição/receção de correio, encomendas e circulação de pessoas, bens e mercadorias e todo um outro conjunto de serviços diários bem documentado numa diversidade de fontes históricas avulsas existentes no Arquivo Histórico Symington (V. N. de Gaia, Coradas). Este trabalho da nossa investigação empírica tem-nos permitido o acesso a um manancial de dados e informações relativos à organização e funcionamento local e translocal de várias quintas durienses bem como sobre os quotidianos de vida e trabalho das populações locais vizinhas.

${ }^{322}$ Sendo a história das quintas um tema menos tratado na e da história da vinha e do vinho do Douro inclusive porque se defronta com vários obstáculos como por exemplo a dispersão dos arquivos das próprias quintas e a inexistência e/ou dificuldade de acesso a fontes diretas, temos em desenvolvimento no CITCEM-FLUP (2015-2019), no âmbito desta temática específica, o seguinte projeto de investigação que coordenamos «Os trabalhos e os dias no Douro Património Mundial. Estudo comparativo de quintas durienses em margens opostas do rio: Quintas da Alegria de Cima, e da Coalheira (Carrazeda de Ansiães) e Quinta do Vesúvio (Foz Coa)/(3. ${ }^{\circ}$ ciclo do vinho do Porto, 1860-1865 a 1939)».
} 


\subsection{QUINTA DOS CANAIS: A MAIOR DO CONCELHO DE CARRAZEDA E SUA REPRESENTATIVIDADE}

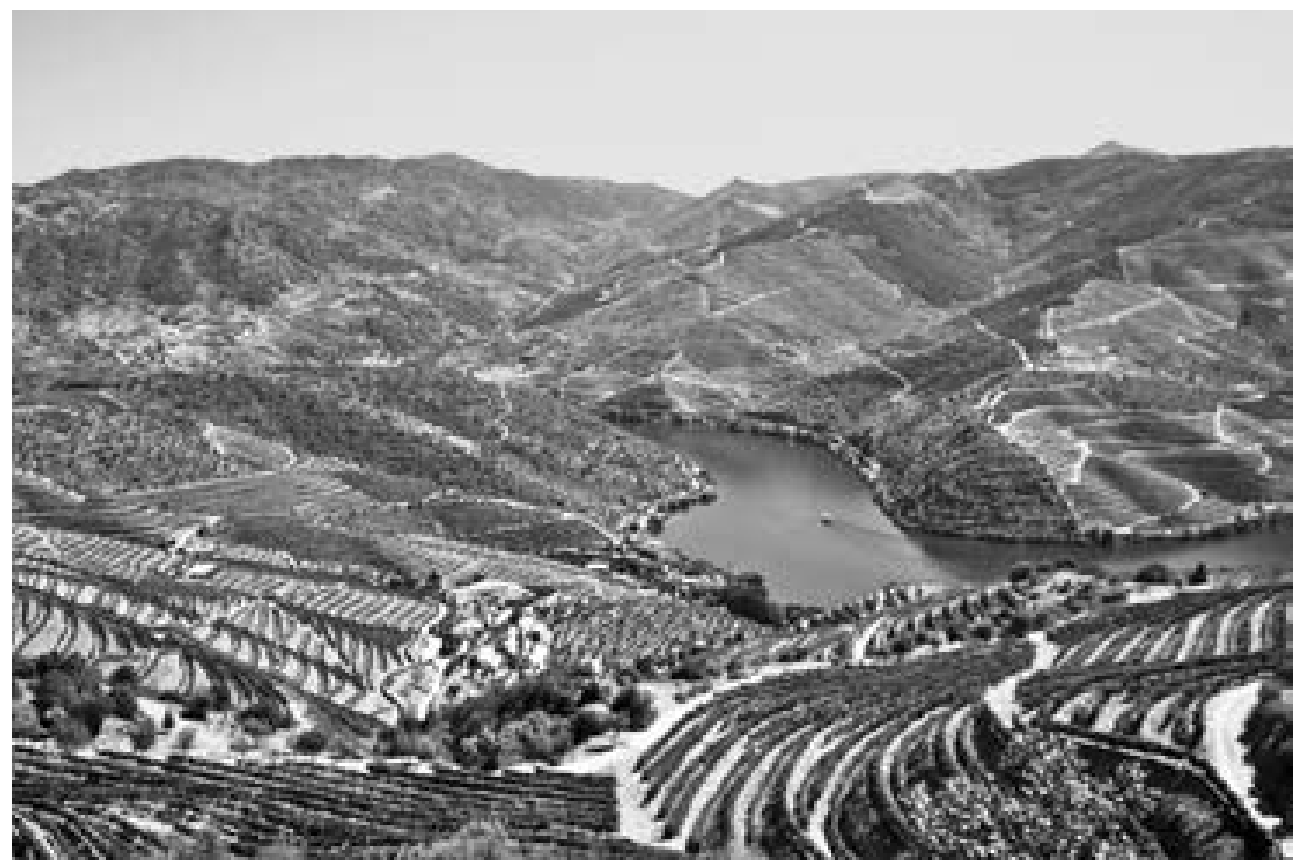

Fig. 45. Localização da Quinta dos Canais, margem direita norte do Douro Fonte: Fotografia João Pedro Silva

A Quinta dos Canais, nome que deriva da existência no seu limite superior norte, de uma extensão quilométrica de canais que a circunda, sistema de rega com o manancial de água do ribeiro do Síbio que a atravessa na longitudinal, e lhe confere individualidade exemplar, é tida como uma das quintas maiores, mais singulares e inesquecíveis ${ }^{323}$ entre as quintas durienses de Carrazeda e mesmo do Douro Vinhateiro, onde se localiza na fronteira das sub-regiões de Cima Corgo e Douro Superior. Esses canais foram construídos em granito ainda no século XIX, para irrigação da propriedade através do aproveitamento das Quedas de Água do Síbio que se precipitam de grande altura a partir do enorme maciço granítico que aflora na encosta norte da quinta, e cujo esplendor e grande beleza se pode apreciar ainda hoje sobretudo nos meses de outono, inverno e primavera. Nos finais do século XX, foi planeada a construção de uma estação mini-hídrica para aproveitamento de energia a partir dessas quedas de água, pelo seu então proprietário, a firma inglesa Cockburn's ${ }^{324}$ uma das principais exportadoras de

\footnotetext{
${ }^{323}$ LIDDELL \& PRICE, 1992: 163.

${ }^{324}$ ESTEVES, 2008: 396-400. Ver designadamente, neste livro atual, historicamente abrangente, mas com informação especializada ao nível das recentes tecnologias e experiências na vitivinicultura duriense, as referências à Quinta dos
} 
vinho do Porto, com particular protagonismo na história desta e outras quintas históricas de Carrazeda, como adiante se poderá ver com mais detalhe.

A Quinta dos Canais, situada na margem do Douro, com relativa área de extensão à beira-rio e exposição solar a sul e sudoeste, localiza-se na freguesia da Beira Grande, sendo vizinha, a poente, da Quinta Bartol e, em frente, margem esquerda do rio, da quinta de Vargellas (Taylor's) com que sempre manteve relações e comunicação por barco.

Com uma área atual de 300 hectares, resultante da compra e integração de primitivas quintas, em que a maior era a Quinta do Síbio, designada no mapa de Barão de Forrester por quinta da Forneira, e da posterior aquisição e concentração sucessiva de outras pequenas propriedades e parcelas, é hoje a maior quinta duriense neste território concelhio, contando com 140 hectares de vinha da letra A.

Nos finais do século XIX, inícios do século XX, foi adquirida, em ruínas, à Condessa da Taboeira ${ }^{325}$, pelo capitalista Francisco Manuel da Costa, de S. João da Pesqueira, que mandou replantar e tratar as suas vinhas destruídas pelo oídio (terrível doença da videira surgida em 1852) e manteve em sua posse durante a I República até ao início dos anos 1940, período em que esta propriedade vinhateira era localmente designada por «Quinta do Costa». Durante a II Guerra Mundial (1939-1945), Francisco Costa, conhecido como maçon e republicano, vendeu a quinta, em 1941, ao engenheiro de minas Ramiro Sobral, natural e proprietário de empresas mineiras do distrito de Viseu ${ }^{326}$, o qual a terá comprado com capitais provenientes da intensa

Canais, algumas imprecisões, na rubrica Tuella (p. 393-404) referente à história da empresa estrangeira Cockburn \& Smithes, C. ${ }^{a}$ S.A. (sede na Rua das Coradas, V. N. de Gaia).

${ }^{325}$ A Condessa de Taboeira (1861-1945) foi casada com João Cardoso Valente (1859-1903), deputado da Câmara dos Deputados, nas legislaturas de 1884-87 e 1889, depois $1 .^{\circ}$ conde de Taboeira, título criado por D. Carlos I, em 1901, em seu favor, válido em vida. Dona Maria Aurora Ângela Benigna Inês Santíssima Trindade de Muñoz y Puig Peñalver y Fernandez — Condessa de Taboeira — nasceu em 1861 em Zamora e faleceu em 1945 em Lisboa, sem descendentes. Aos 44 anos já viúva do Conde de Taboeira de quem herdou o título nobiliárquico, ficou com a responsabilidade de administração de inúmeros bens que possuía dispersos pelo país. Dedicou-se à publicação de artigos diversos sobre educação moral e a obras de beneficência junto dos doentes e necessitados de Tabueira, onde a sua antiga casa ainda hoje tem o respeito geral da população. Foi agraciada pelo rei Afonso XIII de Espanha, enquanto descendente de espanhóis ilustres e ainda enobrecida em Portugal, com o grau de dama da Secular Ordem Italina do Santo Sepulcro. (CONDE, 1997; LEMOS, 1997).

${ }^{326}$ Ramiro da Costa Cabral Nunes de Sobral, natural de Ranhados, concelho da Meda, distrito da Guarda, onde nasceu em 1905-10-09, licenciou-se em Engenharia de Minas — Universidade do Porto em 1938. Membro da Ordem dos Engenheiros, fez estágio profissional no Complexo Mineiro da Bejanca, com fortes ligações à Companhia Mineira das Beiras que, na II Guerra Mundial, operou na intensa exploração e comercialização de volfrâmio no concelho de Carrazeda de Ansiães. Foi diretor técnico das Minas de Carris, empreendimento mineiro de capitais alemães, próximo do Complexo Mineiro da Borralha, concelho de Montalegre, maioritariamente gerido por capitais franceses — polos históricos da indústria extrativa nacional de estanho e sobretudo volfrâmio. Tendo residência fixa na cidade de Viseu, Ramiro Sobral colaborou tecnicamente, em exclusividade, e/ou em acumulação, com agentes económicos nacionais e estrangeiros de diferentes quadrantes políticos, designadamente: no Couto Mineiro de Bodiosa (Viseu) e no do Malhão (Seia), ambos na posse da grande empresa britânica Beralt Tin \& Wolfram, Lda, proprietária do maior complexo mineiro de volfrâmio em Portugal, as Minas da Panasqueira; no Complexo Mineiro de Sangarinhos (Viseu), pertencente à empresa germânica Minero-Silvícola, Lda.; no Couto Mineiro de Lagares (Vila Nova de Paiva), pertencente à Companhia de Estanho do Vale do Vouga e à Companhia Portuguesa de Minas, Lda. Foi nesta fase de intensa atividade técnica mineira, que adquiriu (1941), a então já grande e conhecida Quinta Duriense dos Canais. Nos finais de 1945, tornou-se o maior empresário mineiro das Beiras com a aquisição, à Beralt Tin \& Wolfram, Lda, dos Coutos Mineiros de Bodiosa e do Malhão e de mais 4 concessões. Enquanto coproprietário da Sociedade Mineira 
exploração do volfrâmio português, que se fazia então sentir também em todo o concelho de Carrazeda de Ansiães particularmente dotado de recursos minerais e reservas de volfrâmio e estanho. Decorridos mais de 40 anos, as filhas de Ramiro Sobral e herdeiras da Quinta dos Canais, então dotada de novas construções e infraestruturas e mais conhecida por "Quinta do Engenheiro», acabariam por vendê-la já como Sociedade Agrícola dos Canais (constituída e registada em seu nome em 1988), no ano seguinte, à firma Cockburn's que a adquiriu para manter garantido o acesso aos seus vinhos que já comercializava desde a década de 1930, tendo-se tornado na espinha dorsal dos afamados vinhos do Porto Vintage Cockburn's. A Quinta dos Canais tornou-se então na «joia da coroa» e sala de visitas desta empresa que a transformaria profundamente, com novo património edificado e remodelação de antigas instalações, plantação da vinha reestruturada em patamares, e viticultura modernizada sob a orientação especializada do então diretor Miguel Corte-Real (1999-2006). A Cockburn's acabaria por vender a Quinta dos Canais, em 2002, e todo o seu património, em 2006, à Holding Symington Family Estates a que pertencem hoje outras importantes quintas de Carrazeda, como a Senhora da Ribeira (Seixo de Ansiães), a chamada Quinta dos Ingleses ou dos Smithes (em Foz Tua) e a vizinha Quinta da Chousa, e ainda a quinta de Vale Coelho outrora pertencente à antiga Quinta de Lubazim, cuja história se apresenta adiante em subcapítulo próprio.

Ficou assim, diacronicamente, traçado o perfil económico-social dos seus proprietários ao longo de todo o século XX, o qual evolui de uma condição social oriunda de uma burguesia enobrecida como a condessa da Taboeira da quinta dos Canais, que a herdara do seu marido, nobilitado por D. Carlos I, para uma nova burguesia nacional mais empreendedora e recentemente enriquecida, como Francisco Costa, «brasileiro de torna viagem», casado com uma senhora brasileira de considerável fortuna, ao qual sucede o Eng. de Minas Ramiro Sobral, industrial com elevados capitais provenientes do volfrâmio, mineral estratégico da II Guerra Mundial, até terminar com as transferências mais recentes da quinta, nos finais do século XX, inícios do século XXI, na posse de capital estrangeiro nas mãos das tradicionais e grandes firmas inglesas do Douro exportadoras do vinho do Porto, como a Cockburn's e a Symington Family Estates que adquiriu a sua marca após breve transição pelo capital multinacional da empresa norte-americana Beam Global Spirits \& Wine, Inc.

Essa sucessiva concentração, transmissão e mudança de estrutura social da propriedade que se verificou na história contemporânea da Quinta dos Canais, com a transição do capital

do Paiva Lda., promoveu a criação, em Travanca de Bodiosa, do Complexo Industrial Mineiro (fim da década de 1940), de que foi sócio, técnico e diretor. Esta unidade industrial mineira (extração, separação, transformação e comercialização dos minérios) conhecida como «Separadora de Travanca» manteve-se em laboração até 1986, ano de seu encerramento, com 48 operários no ativo, por falta de cotação do volfrâmio no mercado internacional, tendo as suas instalações sido alienadas e adaptadas a outros ramos da indústria e do comércio. Foi um apoio de inúmeros agentes económicos do distrito de Viseu e de outras zonas mineiras do país, tendo dinamizado a economia local e regional, com centenas de postos de trabalho de muitos agregados familiares cujos filhos seguiram estudos na Escola Comercial e Industrial e no Liceu de Viseu. Persistem na região memórias vivas dessa dinâmica industrial mineira e do seu principal agente, o Eng. Ramiro Sobral, recordado pelo seu contributo para o desenvolvimento da mineração regional e nacional. (VALE, [no prelo]: 95-96). 
nacional para o capital internacional e a sua globalização, faz também dela uma quinta emblemática na história do Douro.

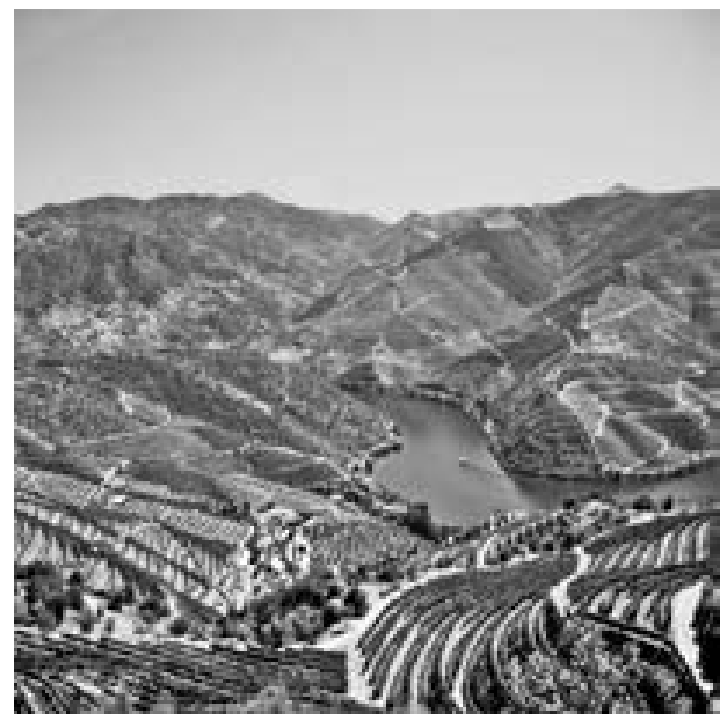

Fig. 46

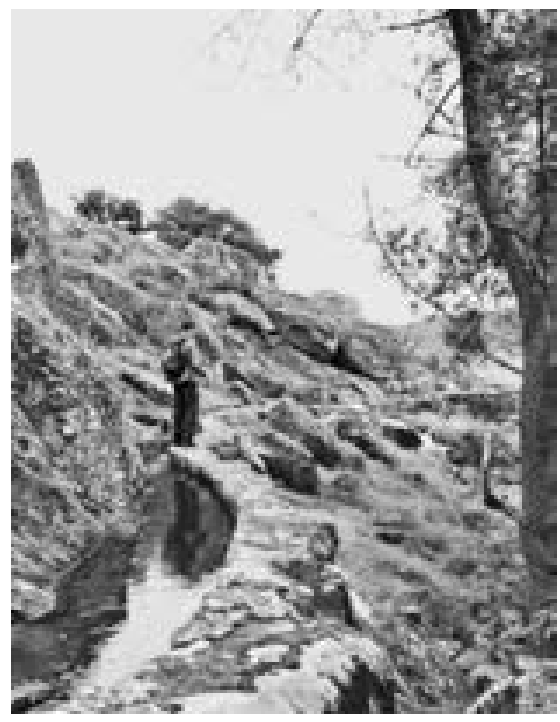

Fig. 47

A persistência histórica de alterações sucessivas da titularidade da propriedade registada na Quinta dos Canais, ainda hoje se verifica nas quintas durienses, como observa Paul Symington, um dos maiores e atuais proprietários e especialistas do Douro.

Mas se pelas suas características naturais, cultura vitícola e produção vinícola de grande qualidade destacada nos mercados do vinho do Porto, a Quinta dos Canais é considerada também um autêntico «terroir» único e específico do Douro, pela combinação de microclimas e características do solo, ideais para produzir as melhores uvas para o Vinho de Porto, já enquanto fenómeno económico-social caracteriza-se também por uma longa e significativa evolução histórica que ganhou novo e decisivo impulso com as transformações ocorridas ao longo do século XX, em que se podem destacar duas fases principais do seu desenvolvimento. A primeira regista-se com o proprietário Francisco Manuel da Costa, durante a I República ${ }^{327}$, período marcado pela proteção dos vinhateiros durienses «mediante a isenção de contribuição predial e o condicionamento do mercado externo» ${ }^{328}$ e pela conjuntura bélica da I Guerra Mundial (1914-1918) que «veio beneficiar a vitivinicultura portuguesa, ligada aos mercados externos, pela contração dos produtores concorrentes devido à redução da área vinhateira em França e Itália» ${ }^{329}$.

\footnotetext{
${ }^{327}$ MONTEIRO, 1911: 15-16.

${ }^{328}$ PEREIRA, 2016: 164.

${ }^{329}$ PEREIRA, 2016: 164-165.
} 


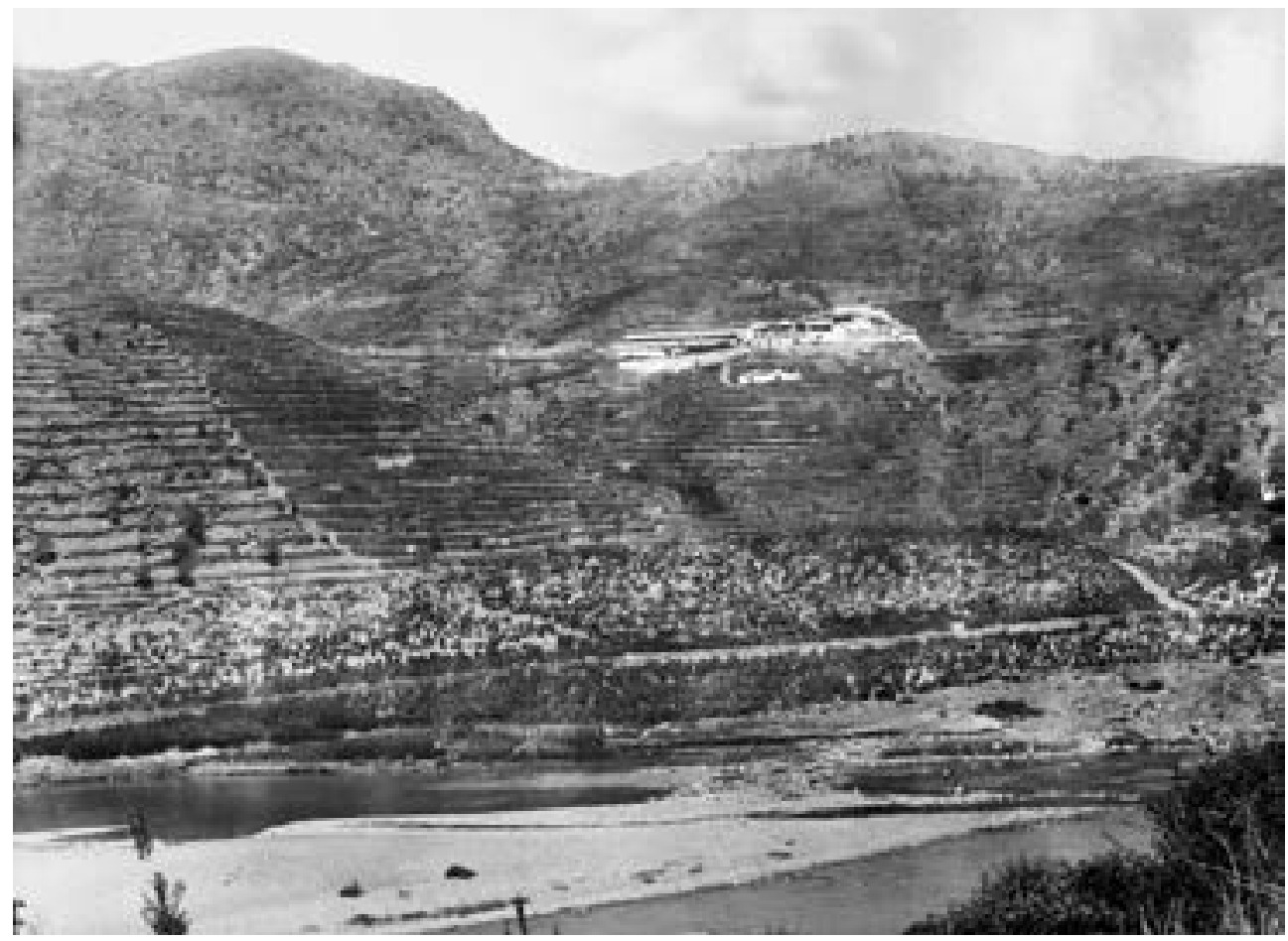

Fig. 48. Quinta dos Canaes: Vargellas, Douro, [1870-1915] Fonte: Emílio Biel ${ }^{330}$

Uma segunda etapa de transformação da Quinta vai verificar-se no quase meio século seguinte com o seu proprietário Ramiro Sobral (1941-1989) e as mudanças ocorridas no Douro, designadamente, durante a ditadura nacional do Estado Novo e a reforma corporativa dos mecanismos de controlo da produção e circulação dos vinhos, e se fazem sentir os efeitos da II Guerra Mundial que acarretou uma crise comercial internacional que se repercutiu nas exportações do vinho do Porto, afetando o seu principal mercado consumidor, a Inglaterra que proibiu a sua importação em 1942. Vivia-se então um período de grande crise no Douro com diminuição da cultura da vinha e dos vinhos, baixa de produção de cerca de 40\%, devido em parte à falta de adubos e sulfatos. Ilustra esta situação crítica da produção vinhateira igualmente verificada nessa altura, no concelho de Carrazeda de Ansiães, o Visconde de Alcobaça, grande proprietário duriense desta zona do Douro, quando em 1939, «concluiu que para produzir 3.108 litros de vinho gastou 5.063 escudos e recebeu 4.662 ou seja, teve um prejuízo de 399 escudos» ${ }^{331}$. Nessa altura, o Visconde de Alcobaça, Manuel de Mello de Sampaio, também com ligação à Quinta do Zimbro de Baixo, residia já há 10 anos na sua Casa Grande de Ribalonga,

\footnotetext{
${ }^{330}$ Creditação: (C) Centro Português de Fotografia/DGLAB/SEC, PT/CPF/BIE/000019.

${ }^{331}$ BARRETO et al., 2016: 58.
} 
povoação próxima da Quinta dos Canais que é a aldeia vinhateira mais antiga deste concelho já incluída na Demarcação Primordial Pombalina. Foi membro destacado do poder municipal de Carrazeda no período da Ditadura Militar em Portugal (1926-1933), tendo sido nomeado pelo Governador Civil de Bragança presidente da Comissão Executiva da Câmara em 1930/31.

A retração do comércio internacional do vinho do Porto com suas inúmeras consequências, provocada pela II Guerra Mundial irá manter-se até aos anos 1960, verificando-se a partir daí a ocorrência de um crescimento em que foram batidos os recordes de exportação de vinho do Porto dos três séculos anteriores.

Ora é precisamente nesta nova e bem diferente conjuntura histórica dos finais do século XX, inícios do século XXI que se abrirá na Quinta dos Canais uma outra e decisiva etapa de desenvolvimento empresarial marcada pela passagem de propriedade fundiária de capitalistas portugueses para uma nova organização sob forma societária, primeiro incipiente e ainda de capital nacional (destinada quiçá a obter melhores condições de venda e transmissão, ainda com as herdeiras de Ramiro Sobral), mas entrando logo a seguir num processo acelerado e complexo com a abertura à internacionalização da propriedade e sua empresarialização.

Após o anterior enquadramento multifatorial necessário à contextualização histórica da Quinta dos Canais, importa agora salientar a sua especificidade enquanto grande propriedade rural, no que se pôde dar a perceber da tensão que se estabelece entre o seu estudo concreto no concelho de fronteira onde se localiza, e a relação com o espaço histórico convencionalmente demarcado que a quinta sempre bordejou. Ainda o Douro Superior não estava integrado na RDD e já a Quinta dos Canais aparece no Mapa do País Vinhateiro de 1843, do Barão de Forrester, tendo-se hoje transformado numa das maiores quintas do Douro Superior ${ }^{332}$.

Como se sinalizou já, a Quinta dos Canais, antiga propriedade da Condessa de Taboeira passou então desta antiga proprietária para as mãos do «abastado Sr. Francisco Manoel da Costa», «opulento cavalheiro» que com destacada coragem de empreendimento, pôs

a sua enorme fortuna ao serviço da sua decidida vontade [...], transformou-a, enriqueceu- $a$, e melhorou- $a$, em absoluto, convertendo-a numa propriedade economicamente considerável e encantadora. Assim, dezenas e dezenas de contos de reis foram sumidas e continuam a sê-lo, garantindo o pão, quase anualmente, de cem a duzentos trabalhadores, ou seja, nestes tempos de crise e miséria, a felicidade bastante de outros tantos lares, para desentranhar do chão ingrato e de aparência tão desconsoladora a verdejante florescência das plantações [...]. Se é certo que cada S. Miguel, se envasilham cerca de cem pipas de vinho, na sua maior parte consumido pela conceituadíssima casa Sandeman de Inglaterra, não é menos certo que é necessário possuir um radicado amor, que chega a ser fanatismo, por essa quinta para nela se realizar o prodígio, semelhante ao das lendas, que o gosto do seu proprietário realizou. A casa nobre, o heráldico solar com sua capela tem um ar de

\footnotetext{
332 PEREIRA, 2010: 33.
} 
espanto não só pela sumptuosidade que o enche, como pela ridência que o circunda. E o visitante, depois de tudo examinar e tudo passar em revista, desde o conforto do interior do edifício, aos formidáveis trabalhos de culturas e de exploração de águas, às necessárias dependências para albergue de serviçais e obreiros e às devidas instalações e respetiva utensilagem vínica e oleicola, aparta-se também com pasmo desse retiro formoso defendido do norte e organizado à custa de uma energia inquebrantável e de somas estupendas. A quinta da Forneira, pegada à dos Canaes e que produz vinhos afamados, [uma das mais antigas quintas integradas nos Canais] foi ultimamente adquirida pelo Sr. Costa [... $]^{333}$.

A identificação pessoal e ideológico-política de Francisco Manuel da Costa, proprietário vinhateiro emblemático da Quinta dos Canais, no período da Primeira República Portuguesa, em que integrou o poder municipal republicano em Carrazeda, como vereador efetivo da Comissão Administrativa, eleito para a Câmara Municipal no triénio de 1917/1919, encontra-se esboçada em alguns fragmentos do depoimento oral de uma mulher octogenária da aldeia da Lavandeira, ex-trabalhadora nos Canais, desde criança, nos anos 1920-1930, durante o chamado «tempo da miséria»:

o Costa falava com todos... era de Custóias do Douro, a última terra da Pesqueira que pertence a Foz Coa... foi para o Brasil onde casou com a viúva de um embaixador e ela é que lhe deu o ser... veio para cá e comprou a Quinta dos Canais junto à quinta da espanhola... depois é que comprou a quinta da Samorinha, a das Forneiras e a do Carvalho... o antigo dono que vendeu ao Costa acho que era um tal Valente... os Canais são a terceira maior quinta do Douro... o Costa vivia na quinta e enganou essa Joaquina que era filha dos caseiros da quinta do Mariz, dos Marizes de Marzagão... esta quinta foi também comprada pelo Costa... essa história do incêndio na quinta... o Costa combinou com o guarda e pegaram o fogo para enganar o seguro... e estavam presos e iam para Moncorvo... mas voltou para a quinta $e$ esteve lá muitos anos... diziam que o Costa era maçónico... nessa altura, a capela no Mariz funcionava... ele mandou deitar os santos ao rio... dizia que os santos eram de pau...

...quem fazia ruim o Costa era a Joaquina... a embaixadora era brasileira e ele dava-lhe maus tratos e desprezava-a... um dia deixou-a fechada num quarto... o pessoal tirou-a pela janela com uns lençóis e ela atravessou o Douro e desapareceu... no comboio que o trouxe a ele seguiu ela para o Porto e nunca mais voltou... o Costa acho que morreu no Porto... ele ia muitas vezes ao Porto... já vendiam o Vinho para lá...

...o Costa era político e tinha inimigos... um dia veio uma porção deles d'além do rio e queriam-no matar, mas ele fugiu... andava lá metido na política... mas nunca teve soldados $[\ldots]^{334}$.

\footnotetext{
${ }^{333}$ MONTEIRO, 1911.

${ }^{334}$ Entrevista feita em abril de 2011, na sua casa, a C. D., natural e residente na freguesia da Lavandeira, junto ao castelo e antiga vila medieval de Ansiães, donde era proveniente o essencial da mão de obra sazonal da quinta dos Canais. Ver também LAGE, 2012c.
} 
A essa fase da "Quinta do Costa», durante os anos 1920/1930 em que «o vinho do Porto registara bons resultados nos mercados externos para onde vendeu 74 e 81 mil pipas, em 1936 e 1937, respectivamente, o que correspondia em quantidade, a mais de metade das exportações nacionais de vinho» e o Douro «arrastado pelo exterior parecia uma ilha de prosperidade» ${ }^{335}$, sucedem-se os tempos da então designada «Quinta do Engenheiro» em que ficariam célebres as grandes caçadas, os jantares solenes oferecidos a convidados ilustres ${ }^{336}$, e outras reuniões sociais de figuras destacadas da política e do jornalismo nacional, ai organizadas, particularmente nas décadas de 1950 e 1960, pelo Eng. Ramiro Sobral, seu proprietário durante quase meio século (1941-1989) em que era também diretor e sócio de várias empresas mineiras no Distrito de Viseu, com funções político-administrativas em organismos públicos corporativos como as de membro do Corpo de Engenheiros dos Serviços de Fomento Mineiro e as de Procurador à Câmara Corporativa.

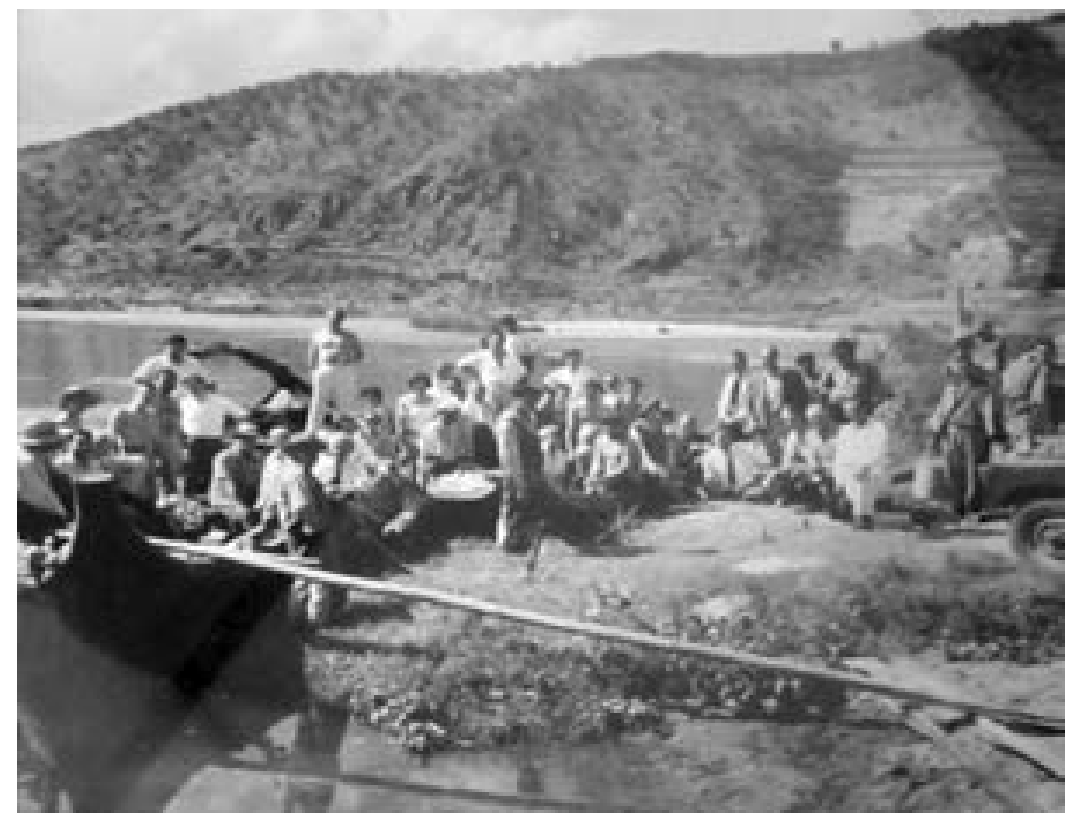

Fig. 49. Fotografia de grupo de caçadores convidados da Quinta dos Canais, 1963 Fonte: Espólio da Quinta do Tua

Os depoimentos, testemunhos e memórias de antigos trabalhadores da Quinta dos Canais, fazem-se eco dessa intensa ação empresarial mineira do Eng. Ramiro Sobral, subentendida na designação de «Quinta do Engenheiro» que lhe atribuíram durante décadas. Porém

\footnotetext{
${ }^{335}$ BARRETO et al., 2016: 58.

${ }^{336}$ Por exemplo, aí celebrou também o fim da II Guerra Mundial, com um lauto jantar oferecido a destacadas personalidades dos dois campos beligerantes do conflito armado: países do Eixo e Aliados (VALE, [no prelo]: 95-96).
} 
não deixam de manifestar, como mais adiante se verá, críticas à administração e gestão da Quinta, à época, nas acusações feitas a este proprietário de ter mandado arrancar toda a vinha da Quinta quando a comprou, para substitui-la pela plantação de olival, cultura menos exigente que a da vinha, em termos de cuidados e trabalhos agrícolas, mas de rendimento mais demorado. Poder-se-ão correlacionar tais aspetos diferenciais de rentabilidade económica da Quinta dos Canais, com as opções económicas do seu então dono, Ramiro Sobral, proprietário fundiário de acentuada vocação e carreira empresarial mineira sempre fortemente relacionada com a exploração do volfrâmio no Norte de Portugal, país detentor dos maiores jazigos deste mineral na Europa, em atividade técnico-económica rentável até aos anos 1980, e um dos maiores à escala mundial ${ }^{337}$.

O conjunto pluridimensional e multifacetado de fatores e atributos próprios da história da Quinta dos Canais que se tem vindo a enunciar confere-lhe uma singularidade paradigmática, com características de uma verdadeira e representativa amostra, como a seguir se procura evidenciar e demonstrar, na sua representatividade, à escala local e regional, enquanto entidade vitivinícola bem percetível ao nível das construções, produção, condições de vida e de trabalho do pessoal que configuram dimensões essenciais do processo polimórfico da sua construção social e histórica.

A abordagem descritiva e analítica mais concreta e detalhada desta Quinta que se desenvolve adiante em dois subcapítulos (7.2.1. e 7.2.2.) vai centrar-se em dois eixos essenciais que melhor e mais especificamente a definem quer como entidade socioeconómica: construções, edifícios e instalações; produção e pessoal; história e dinâmica evolutiva própria (ponto de partida para a análise de memórias e representações sociais) quer enquanto microcosmo social (que se reconstitui a partir do mapeamento descritivo e analítico de materiais de memória recolhidos em entrevistas feitas a antigos trabalhadores da quinta).

\subsubsection{A Quinta dos Canais: Entidade socioeconómica de valor patrimonial}

Do ponto de vista da investigação sócio-histórica, pese embora o acervo de estudos nacionais e estrangeiros já disponíveis sobre a história da cultura vitivinícola do Douro, é ainda escassa a literatura sobre as Quintas do Douro, constructo pluritemático e transdisciplinar, cujo conhecimento importa desenvolver.

Partindo da bibliografia existente sobre as quintas, ainda escassa, se individualmente consideradas $^{338}$, este estudo reconstitutivo da história da quinta dos Canais assenta em tra-

\footnotetext{
${ }^{337}$ Esta questão económico-social multidimensional mais vasta e complexa, que se não pode aqui desenvolver, merece porém ser equacionada para futuras investigações designadamente no campo da sócio-história em que se poderá, correlacionando vínculos sócio-históricos, melhor analisar aspetos e inter-relações relevantes da história particular de algumas quintas durienses (ex. Canais, Zimbro, Vesúvio...) e do negócio do vinho do Porto com a história da exploração do volfrâmio português (cuja intensa procura, altas cotações e acumulação de elevados lucros geraram nos anos 1939-1944, um movimento extraordinário que contribuiu para alterar de modo profundo a fisionomia económica e social do país e uma acentuada mudança nos estilos de vida). Ver a este propósito LAGE, 2002.

${ }^{338}$ LIDDELL \& PRICE, 1992: 13; PEREIRA, 2003a: 139-143; PEREIRA et al., 2011.
} 
balho de campo com realização de entrevistas e observação direta e suporta-se também na pesquisa de arquivos, organização e tratamento de fontes históricas diretas, com vista a fazer uma análise descritiva da quinta em dois eixos principais: inserção e características da quinta ao nível local e sua representatividade na região do Douro Vinhateiro património mundial.

A Quinta fora como se viu já, propriedade da Condessa de Taboeira, destacada figura de Aveiro, que a vendera a Francisco Manuel da Costa, natural de Custóias do Douro e era um «celebrado capitalista cujo entusiasmo pelos Canais o levou a gastar uma fortuna na sua reabilitação, empregando nela 100/200 trabalhadores e tendo resultado desses gastos prodigiosos a produção anual de 100 pipas de vinho comprado pela Sandeman ${ }^{339}$. «O Costa», como este proprietário era designado entre os trabalhadores mais antigos da quinta, ficou conhecido na mentalidade tradicional das populações rurais locais, como maçon e republicano responsável por ter deitado fogo à quinta para receber seguros e por ter vandalizado a capela atirando os santos ao rio, donde acabariam mais tarde por ser recuperados para as igrejas da Beira Grande e Lavandeira ${ }^{340}$.

Em 1941, a Quinta foi por este vendida ao Eng. Ramiro Sobral que aí desenvolveu a plantação de oliveiras, acabando a produção de vinho reduzida a 30 pipas anuais. Entre outros empreendimentos, mandou recuperar a antiga capela construída em 1860 que se encontrava em ruínas e onde casou uma das filhas, em 1958, data de inauguração da capela remodelada. Manteve-se como seu proprietário até 1989, ano em que, já como Sociedade Agrícola dos Canais, a propriedade foi vendida à Cockburn Smithes, firma inglesa que aí, sucedendo à Sandeman, comprava e comercializava já os vinhos do Porto dos Canais desde 1935.

Com os seus patamares e terraços tradicionais e típicos do Alto Douro, a quinta dos Canais produz vinhos de qualidade superior comprados pela Cockburn's durante quase todo o século XX e que foram a espinha dorsal dos seus afamados e premiados Vintage. No sistema de classificação regional os seus vinhedos receberam a mais alta classificação. Em 2006 foi vendida à Sociedade Anónima Symington Vinhos S. A., negócio intermediado pelo grupo norte-americano Beam Global, o melhor comprador dos vinhos Symington, que mantém por mais 20 anos, a estratégia, marketing e vendas do vinho do Porto da quinta dos Canais e cuja marca continua na posse da Cockburn's, engenharia comercial partilhada com a Beam que exporta metade da produção anual da Quinta dos Canais ${ }^{341}$. Configura-se aqui uma problemática bem atual e complexa, que a par da questão da «denominação de origem controlada» (DOC), merece uma abordagem autónoma e pluridisciplinar nos domínios jurídico ${ }^{342}$, histórico e sociológico ${ }^{343}$.

\footnotetext{
${ }^{339}$ LIDDELL \& PRICE, 1992: 163.

${ }^{340}$ Entrevista realizada a Sr. O. atual caseiro da quinta dos Canais onde trabalha desde 1993 e a Sr. F. antigo caseiro da quinta durante mais de 50 anos desde 1944 até 1998.

${ }^{341}$ Entrevistas com o atual caseiro e engenheiro responsável da Quinta dos Canais, realizadas em maio e agosto de 2006. A Cockburn's e a Beam mantêm-se ligadas aos negócios da quinta onde, designadamente, continuam a usar os seus barcos, um chinês, atracado no cais da Senhora da Ribeira, e outro na quinta do Vesúvio, propriedade atual da Symington, hoje detentora de mais 25 importantes quintas do Douro.

${ }^{342}$ Ver entre outros, por exemplo ALMEIDA, 1999-2000.

${ }^{343}$ Ver história destas duas firmas inglesas de vinho do Porto, Capítulo 8.
} 
Desde o início do século XX, que esta Quinta é designada em documentos oficiais dos Serviços de Finanças por Quinta dos Canais de Cima, sendo assim diferenciada da Quinta Canais de Baixo, ou Quinta do Bartol, atualmente na posse dos herdeiros Franqueira/Bartol, que mantendo a versão de a sua quinta ser a antiga Quinta dos Canais adquirida pela família por volta de 1889, reclamam ainda o direito à designação histórica de Canais/Canaes, como se verá adiante na historia desta outra antiga quinta limítrofe da Quinta dos Canais.

\section{Enquadramento espacial}

Considerada uma das maiores quintas da sub-região do Cima Corgo, fica próxima do histórico Cachão da Valeira, na margem norte do rio e constituiu-se como propriedade única com a atual configuração territorial, na viragem do século XIX para o século XX, através da integração de antigas quintas: Síbio ou Forneiras, junto ao rio, Carvalho, Mariz de Cima e de Baixo, Alexandre, e Samorinha, a que se juntou, ao longo do século XX, a compra de pequenos casais seguida de mudanças sucessivas de confrontações. Com cerca de 300 ha, em 1989, atualmente «é a maior quinta do Douro do concelho de Carrazeda com mais de 100 ha de vinha quase toda nova e produz 500 pipas de vinho generoso por ano ${ }^{344}$. Possui, para além de importante reserva de caça, água em abundância de 5 nascentes nela existentes e das quedas de água do ribeiro do Síbio.

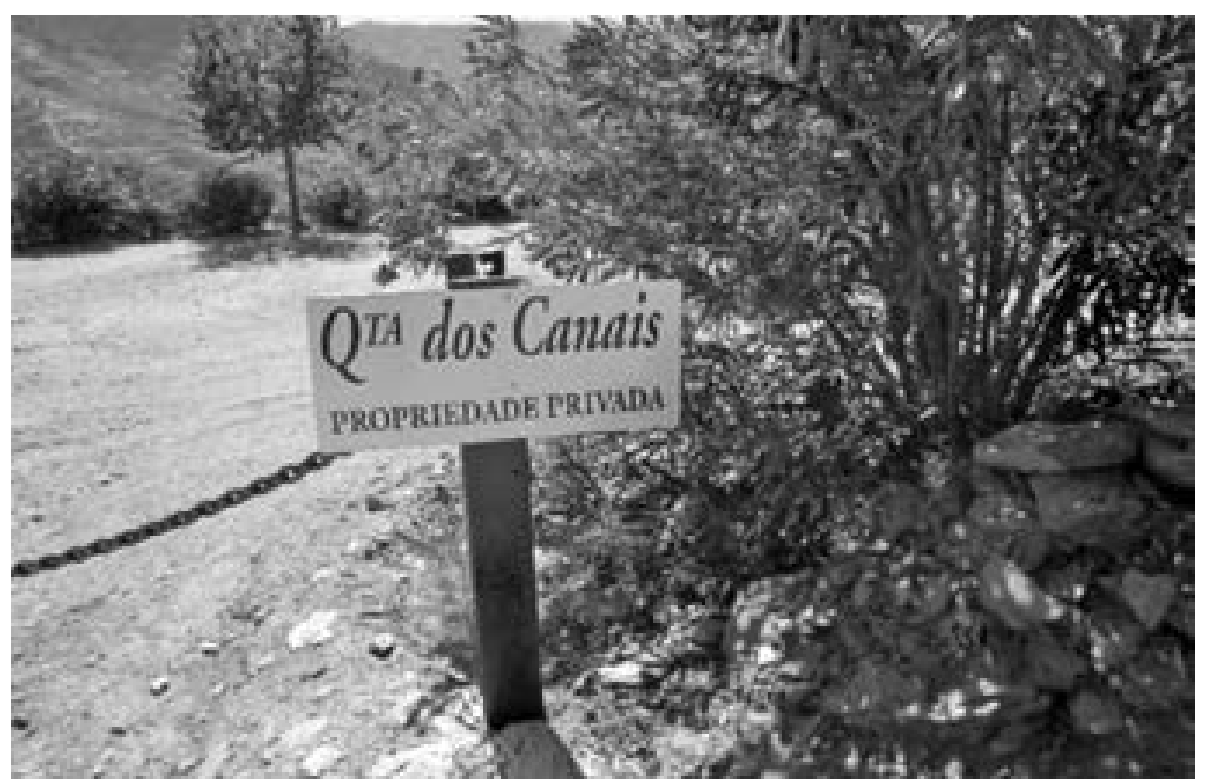

Fig. 50. Entrada principal na quinta pelo lado Norte ${ }^{345}$

\footnotetext{
${ }^{344}$ Entrevista referida feita ao Sr. O., feitor da Quinta dos Canais (agosto 2010).

${ }^{345}$ Milhares de espilradeiras (nome popular), plantas venenosas floridas da entrada, foram plantadas no início dos anos 1990, nos cerca de $3 \mathrm{~km}$ do estradão de acesso aos edifícios da quinta.
} 


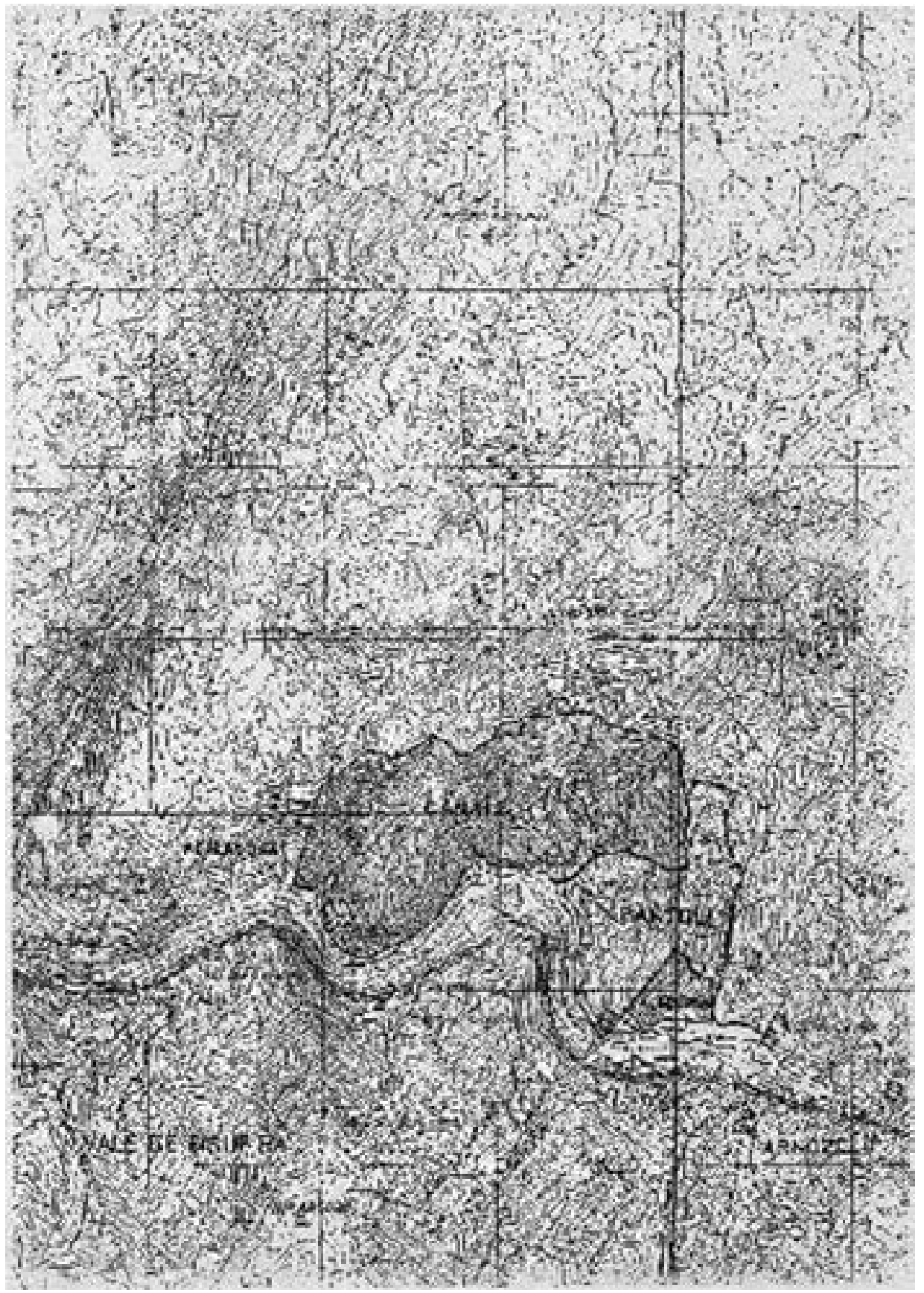

Fig. 51. Localização cartográfica da Quinta dos Canais ${ }^{346}$

${ }^{346}$ AHS — Fundo Cockburn's, Dossier de documentos compilados da Quinta dos Canais. 


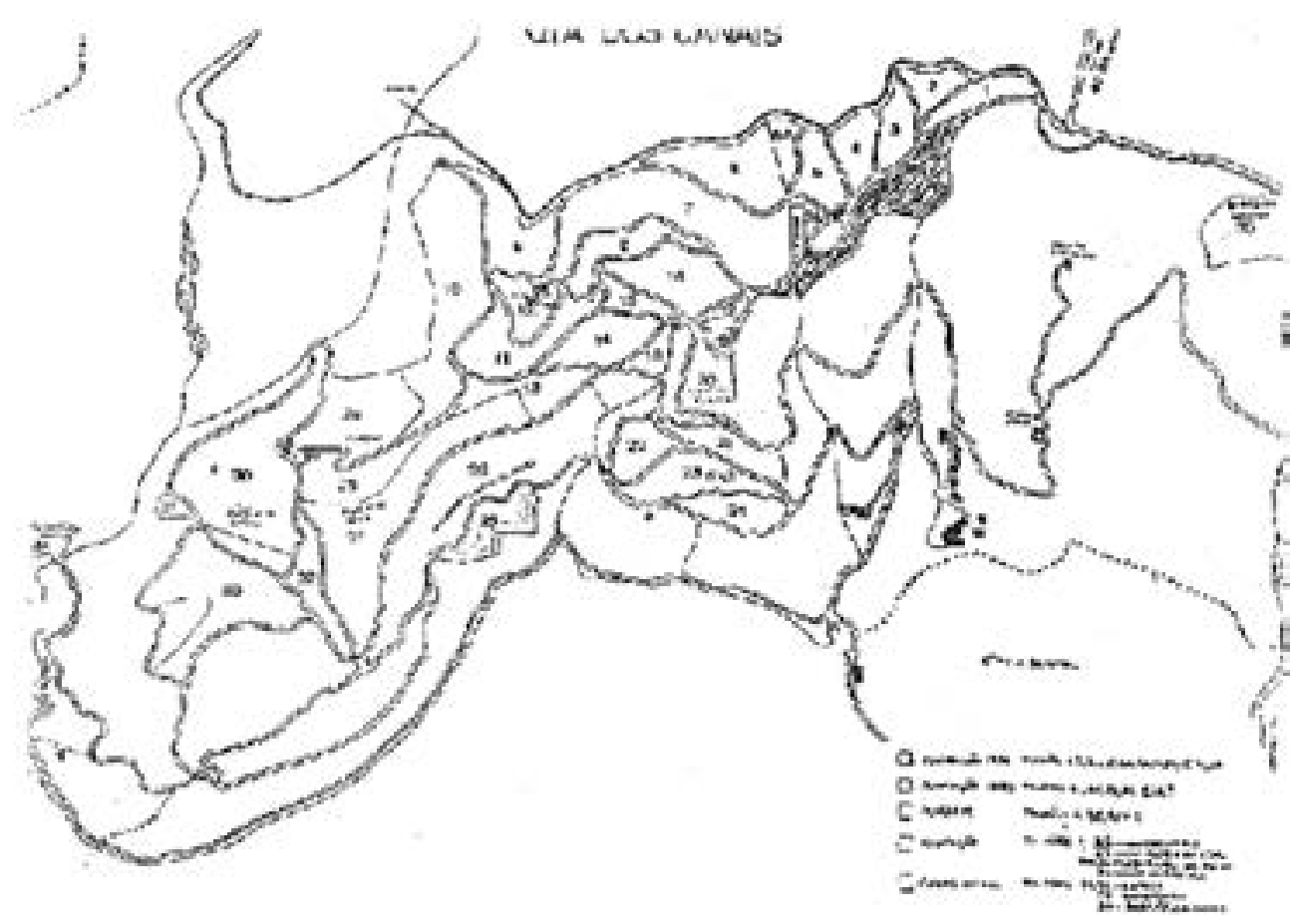

Fig. 52. Planta da Quinta ${ }^{347}$

\section{Tendência e indicadores fiscais da concentração e transmissão da propriedade}

Já durante o século XX, período em que a posse dos Canais pertenceu, como se disse já, pelo menos a três proprietários: dois capitalistas portugueses e a firma inglesa Cockburn's, uma das maiores empresas exportadoras de vinho do Porto, o rendimento coletável da propriedade dos Canais, então de Francisco Manuel da Costa, foi avaliado, em documentos fiscais de 1914 , em 6,16 escudos ${ }^{348}$.

Em registo de transmissão em 18/4/1942, feito por Francisco Manuel da Costa para Ramiro da Costa Cabral Nunes Sobral ${ }^{349}$ é assim descrita:

Propriedade com a área de 2.400 .000 m2, produção de vinho 50.000 litros, 8.000 litros de azeite, $800 \mathrm{~kg}$ de amêndoa, pomar, figo e laranja.

Rendimento coletável: Vinho-52.750\$00, Azeite-23.600\$00, Amêndoa-1.152\$00, Pomar, figo - 1.350\$00, Laranja - 450\$00. Foi-lhe atribuido rendimento de $450 \$ 00$ líquidos ao armazém, abegoarias e casa de arrumações. À casa de habitação foi atribuído o rendimento

\footnotetext{
${ }^{347}$ AHS — Fundo Cockburn's, Dossier de documentos compilados da Quinta dos Canais.

${ }^{348}$ AHRFCA — Livro de Matrizes, vol. II, 1929, da freguesia de Beira Grande, com encerramento em 24 de janeiro de 1913, art. $^{\text {os }} 2304$ e 2534.

${ }^{349}$ AHRFCA — Livro de Matrizes, vol. II, 1937, da freguesia de Beira Grande, Carrazeda de Ansiães, art.o 2534.
} 
de 1.400\$00. É composta de vinha, oliveiras (9.000), amendoeiras (800), algumas figueiras e outras árvores de fruta, casa de habitação de proprietário...; casa para empregados...; 3 armazéns, abegoarias, 2 casas de malta, azenha de fabricar azeite e dispensa para o azeite.

As confrontações da quinta eram então: pelo nascente com D. Juan Vicente Bartol; pelo norte, com caminho público; pelo sul com o rio Douro e pelo poente com José Maria Cabral e outros.

Em 1988, Ramiro Sobral vende à Sociedade Agrícola dos Canais Lda., Beira Grande, a Quinta, na altura assim descrita: propriedade de $2.133 .840 \mathrm{~m} 2$ composta de 2 casas de habitação, terras de centeio, vinha, com 389.878 cepas, 8.476 oliveiras, sendo 82 de outros donos de diferentes aldeias ribeirinhas do concelho, 2.108 amendoeiras, 315 figueiras, 200 laranjeiras, sendo 75 em criação, horta, pastagem e 150 sobreiros, com mudança de confrontações a poente para Borges \& Companhia e variação de produção relativa: Vinho: 60.914 litros 62.915\$00. Azeite: 17.788 litros — 88.940\$00. Matéria coletável: $158.520 \$ 00 »^{350 .}$.

Comparando as suas confrontações a poente, nos anos de 1942 e 1988, é de realçar o fenómeno da concentração e mobilidade da propriedade, com mudança de mãos de proprietários individuais para a seguinte firma aí referida: Borges \& Companhia, Sociedade dos Vinhos Borges \& Irmão.

Outros exemplos desse fenómeno nesta área, de que é paradigma a própria constituição da Quinta dos Canais, podem ser encontrados ainda nas sucessivas compras de «casais» e oliveiras feitas pelo seu antigo proprietário, Eng. Sobral, nos anos $1950^{351}$.

No fim da década de 1980, paralelamente às grandes transformações mormente de legislação, de efeitos profundos na Região Demarcada do Douro, a Quinta dos Canais, passa de propriedade individual a societária, e entra num processo de decisiva empresarialização.

De 1988 a 1990, ocorrem diligências notariais para efeito de transferência da propriedade dos Canais para a Cockburn's, operações efetuadas pela então constituída Sociedade Agrícola dos Canais Lda., gerida pelas duas filhas e herdeiras do Eng. Sobral. Assim, em abril de 1988, a quinta pertencente a Ramiro Sobral, natural de Ranhados, concelho da Meda, residente em Lisboa, foi vendida à Sociedade Agrícola dos Canais, Lda., sociedade comercial por quotas de responsabilidade limitada, com sede na Quinta.

No «contrato de constituição da sociedade» ${ }^{352}$ com o objeto de exploração agrícola e vinícola, o capital social, integralmente realizado em dinheiro é de $400.000 \$ 00$ divididos em duas quotas iguais, uma de cada sócia. A gerência e administração da sociedade ficam a cargo de ambas as sócias, nomeadas gerentes e respondem por todas as despesas incluindo a aquisição da raiz.

\footnotetext{
${ }^{350}$ AHRFCA — Livro de Matrizes, vol. II, 1937, da freguesia de Beira Grande, Carrazeda de Ansiães, art.o 2022.

${ }^{351}$ AHRFCA - Livro de Matrizes, vol. II, Matriz Predial Rústica da Beira Grande, Carrazeda de Ansiães, lv. n.o 3, p. 517-523.

${ }^{352}$ Documento in AHS - Fundo Cockburn's, Dossier da Quinta dos Canais (cópia gentilmente cedida por Eng. Luís Martins).
} 
Pela «escritura de compra e venda», de 26 de abril de 1988, o preço da venda dos Canais, foi de 4.700.000\$00.

Por procuração de 29/9/1989, de Ramiro Sobral feita a favor da Sociedade Agrícola dos Canais, este renuncia ao usufruto que detinha da Quinta ${ }^{353}$.

O pacto de constituição da Sociedade Agrícola dos Canais, terá sido, entretanto objeto de alteração, prévia à cessão de quotas feita a favor da Cockburn Smithes \& C. ${ }^{a}$ Lda., entre 29 de janeiro e 2 de fevereiro de 1990, em cumprimento de contrato de promessa de cessão de quotas ${ }^{354}$.

Significativas do valor patrimonial desta Quinta, são algumas considerações sobre a mesma, que se encontram em documentos internos da Cockburn's, peças do processo de negociações para compra da quinta, que reúne inclusive notas sobre o estudo de mercado e evolução dos preços de algumas das principais quintas da região. Observe-se neste contexto, por exemplo as seguintes recomendações e informações:

«Recomenda-se que a aquisição da Quinta dos Canais seja seriamente considerada em ordem a proteger a manutenção de um componente vital dos lotes do Cockburn's Vintage» ${ }^{355}$; e ainda «Segundo informação do feitor, os proprietários esperarão receber uma verba próxima dos 400.000/450.000 contos fortemente sugestionados pela venda do Vesúvio...» $»^{356}$.

\section{Perfil económico-social e tecnológico dos Canais}

\section{Construções $^{357}$}

Estas e sua evolução ténue, ao nível estrutural, já minuciosamente referidas, encontram-se documentadas em sucessivas descrições ${ }^{358}$ que traduzem dois fenómenos marcantes: o da substituição de olival por vinha, com diminuição até quase ao abandono da produção de azeite, traduzido por exemplo no encerramento da azenha e o da transformação de mão de obra intensiva com a moderna mecanização de quase todas as operações, com o abandono de uma das casas de malta, o cardenho dos homens.

Do conjunto patrimonial edificado, algum encontra-se já em ruínas, enquanto que a maior parte foi objeto de melhoramentos, remodelações e modernização, em função das novas necessidades económicas e sociais.

\footnotetext{
${ }^{353}$ Procuração feita em Leça, Matosinhos. AHS — Fundo Cockburn's, Dossier Quinta dos Canais da firma Cockburn's. Ibidem.

${ }^{354}$ Carta de advogado de 19/12/89 à Cockburn Smithes. Dossier Quinta dos Canais da firma Cockburn's. Ibidem.

${ }^{355}$ Documento em inglês referente à «Quinta dos Canais». AHS — Fundo Cockburn's, Dossier Quinta dos Canais da firma Cockburn's. Ibidem.

${ }^{356}$ Documento «comentários» do mesmo processo relativo à «Quinta dos Canais». AHS — Fundo Cockburn's, Dossier Quinta dos Canais da firma Cockburn's. Ibidem.

${ }^{357}$ Fotografias do património construído e equipamentos da quinta. Coleção particular de fotos sobre a Quinta dos Canais da autoria de J. P. S. e E. G.

${ }^{358}$ Documento apenso a carta para a firma Cockburn's, 24 de maio de 1989 e documento interno da firma sobre existências, culturas, avaliação e contas da Quinta dos Canais do ano 1989. AHS - Fundo Cockburn's, Dossier Quinta dos Canais da firma Cockburn's. Ibidem.
} 
Hoje, num plano superior, vê-se a residência dos proprietários, usada apenas uma ou duas vezes ao ano, com os armazéns por baixo; ao lado, o edifício dos lagares e cubas de fermentação e armazenamento; mais acima, as casas do caseiro e feitor, com um edifício atrás onde havia uma turbina para aquecimento da água, a cozinha e refeitório do pessoal; e mais afastados, na encosta, os cardenhos arruinados dos homens; mais acima os anexos para alfaias, o alambique e a antiga azenha em ruínas, o lagar de azeite e a casa do guarda, desativados, a antiga capela; e mais ao fundo, despontando na encosta, um pombal restaurado sem uso. O antigo cardenho das mulheres, próximo da zona residencial central da quinta mantém a função de dormitório ocasional. As antigas cortes dos porcos servem agora para guardar produtos agrícolas.

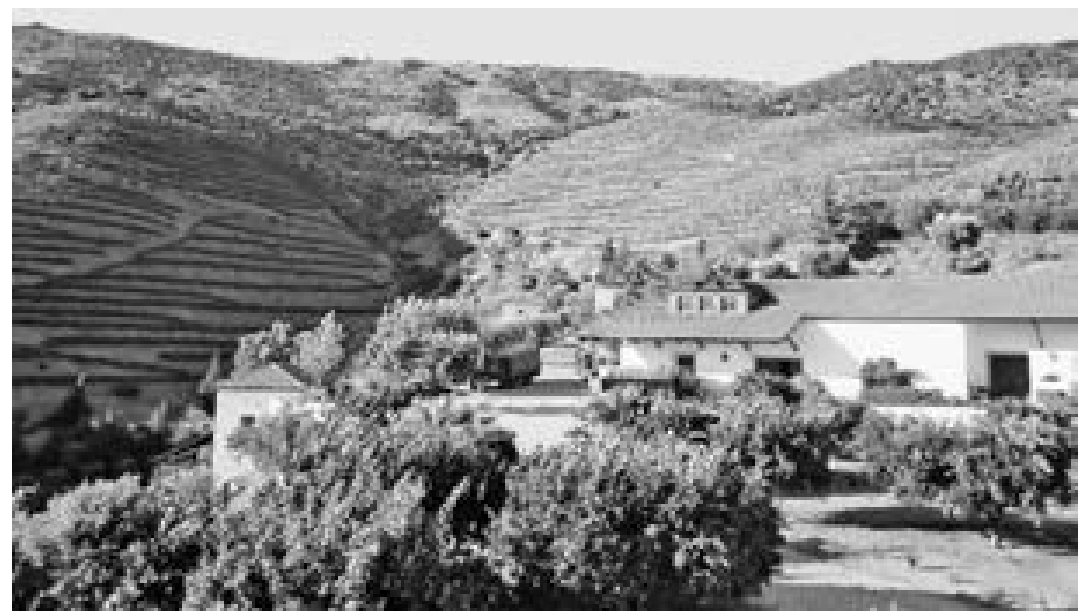

Fig. 53. Instalações: lagares, cubas de fermentação, laboratório e escritório

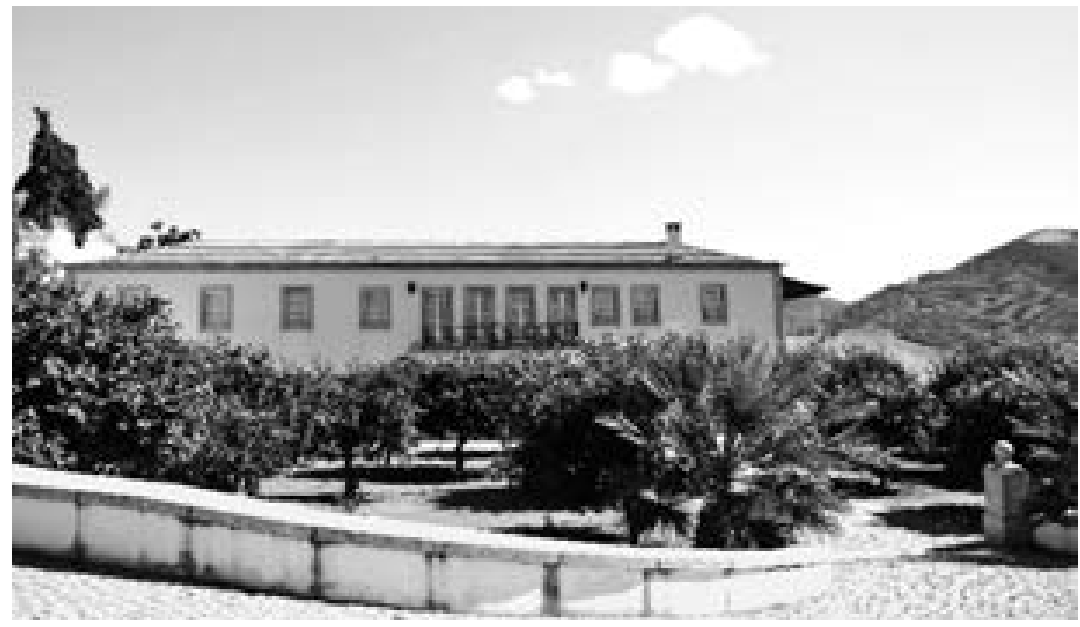

Fig. 54. Residência principal — «Casa dos Patrões» 
A casa de residência principal do proprietário reconstruída e completamente renovada, em 1993, com 6 quartos com WC, 2 casas de banho, salas de jantar e de estar, escritório, quarto de empregadas e casa das máquinas, substituiu a antiga casa em ruínas, a qual, parcialmente de madeira destruída por incêndio dispunha de 1 quarto com lareira, 1 quarto de empregadas, 2 grandes salas, 1 enorme dispensa e a adega, ao lado.

A habitação principal caracteriza-se por uma frontaria de amplas portas envidraçadas na larga varanda coberta por alpendre, com vista panorâmica sobre o rio Douro. Sendo hoje principalmente um centro de visitas de natureza privada, encontra-se equipada com aquecimento central e todo o conforto urbano. Nas paredes da sua sala de estar encontram-se expostas quatro pinturas originais da autoria do Barão de Forrester ${ }^{359}$.

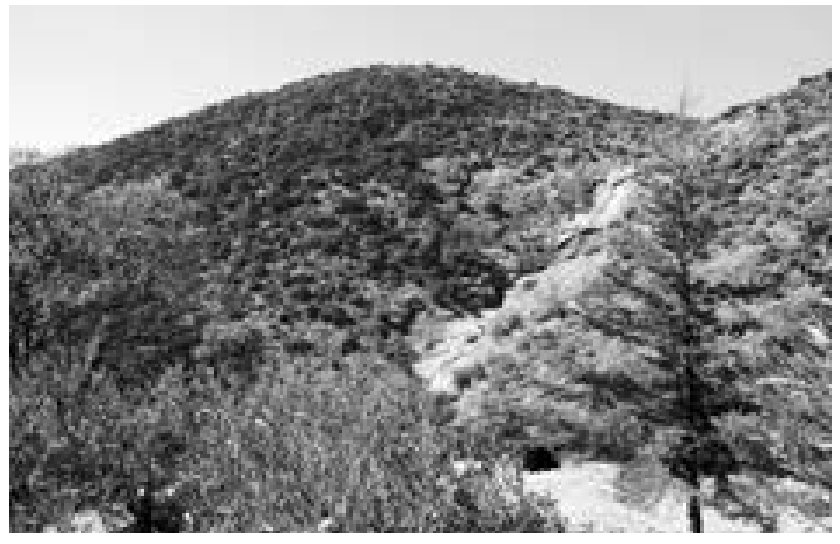

Fig. 55. Cachoeira do Síbio que atravessa parte da quinta

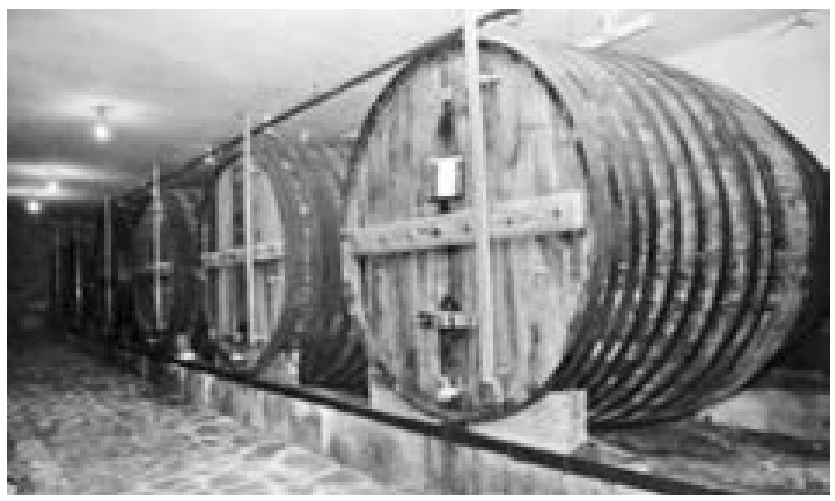

Fig. 56. Armazém — Tonéis

\footnotetext{
${ }^{359}$ Dada a raridade hoje dos originais do Barão do Forrester, será de todo o interesse fazer-se a identificação destas quatro pinturas originais de Forrester, propriedade atual da Quinta dos Canais, conforme informação oral do caseiro da quinta, que nos guiou em extensa e detalhada visita de estudo a todas as instalações da mesma, exceto ao interior da habitação principal com entrada indisponível.
} 
Os armazéns, no piso inferior da casa dos patrões, estão equipados com nove tonéis cada um com capacidade média de 18.600 litros, cerca de 300 pipas.

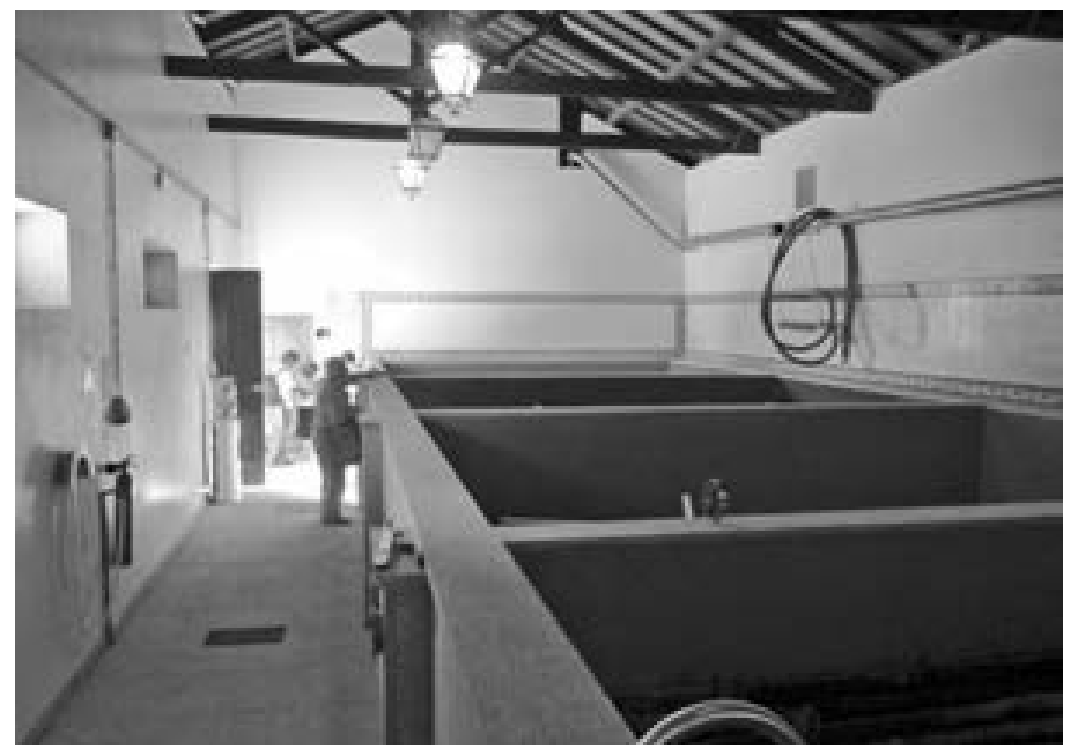

Fig. 57. Lagares de granito (capacidade simultânea 60 pipas de mosto)
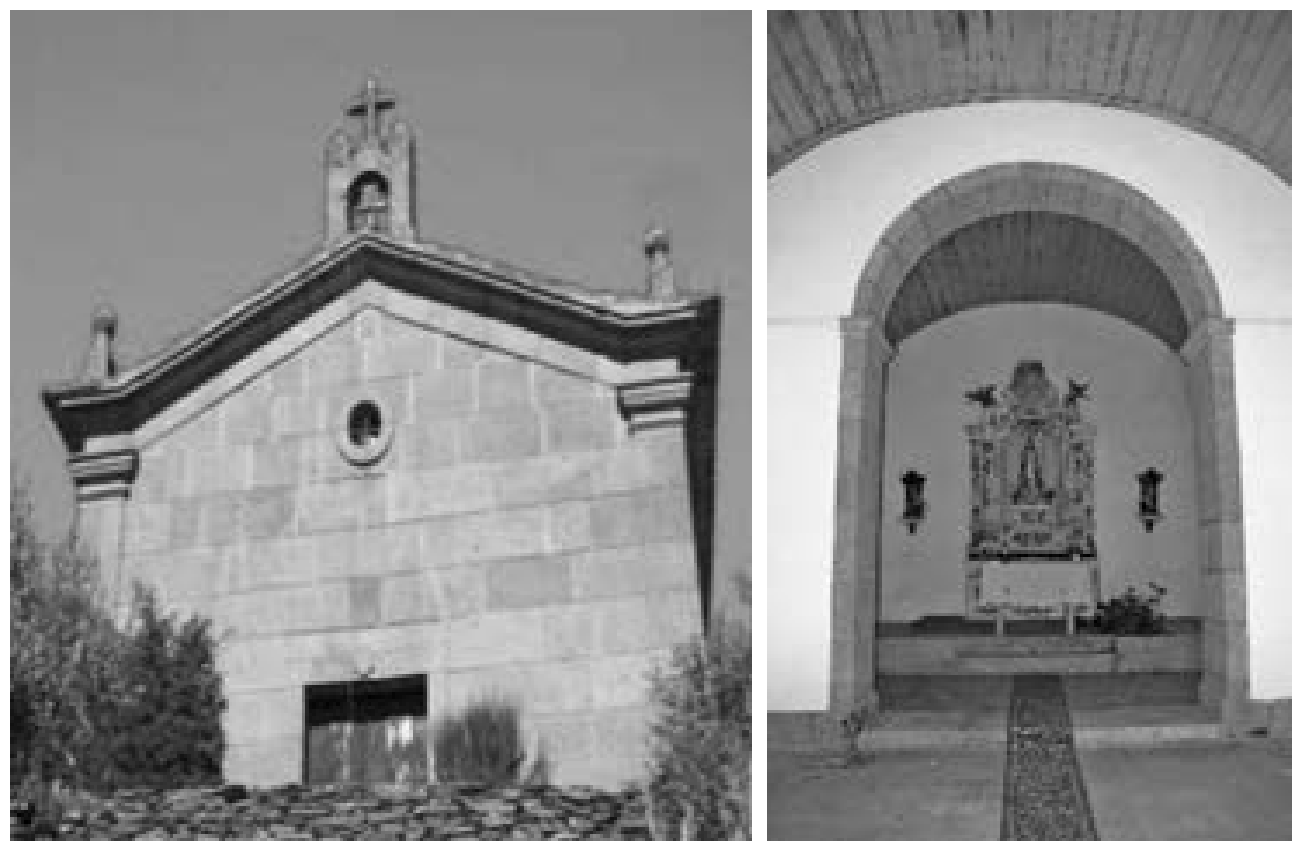

Fig. 58. Capela da Quinta dos Canais (construção, 1860; restauro, 1958) 
Grande parte do trajeto de cerca de $4 \mathrm{~km}$, desde a casa principal de residência até ao local das ruínas do velho solar brasonado e antiga capela da primitiva quinta do Mariz, onde permanece, remodelada, a atual Capela da Quinta do Canais é ladeado por plantações de tílias onde se podem ainda hoje surpreender algumas perdizes.

Esta capela, com uma excelente visão panorâmica da paisagem duriense, caracteriza-se por uma história emblemática que foi possível reconstituir através de fontes diretas e orais. Tendo sido regularmente utilizada pelo pessoal da quinta e populações vizinhas, na sua prática religiosa tradicional, foi afetada pelo grande incêndio que atingiu a quinta e o seu recheio vandalizado nos anos 1920/30, tendo a partir de então entrado em ruína. Objeto de obras de remodelação e restauro na década de 1950, nela se realizaram em 1958, as cerimónias do casamento de uma das filhas do Eng. Ramiro Sobral, à época, dono da quinta. Segundo fontes religiosas credenciadas teria sido outrora, nesta zona, um importante ponto de passagem do Caminho de Santiago ${ }^{360}$. A sua utilização, hoje esporádica, foi parcialmente apropriada pelos trabalhadores da quinta que dela cuidam com flores e velas ${ }^{361}$.
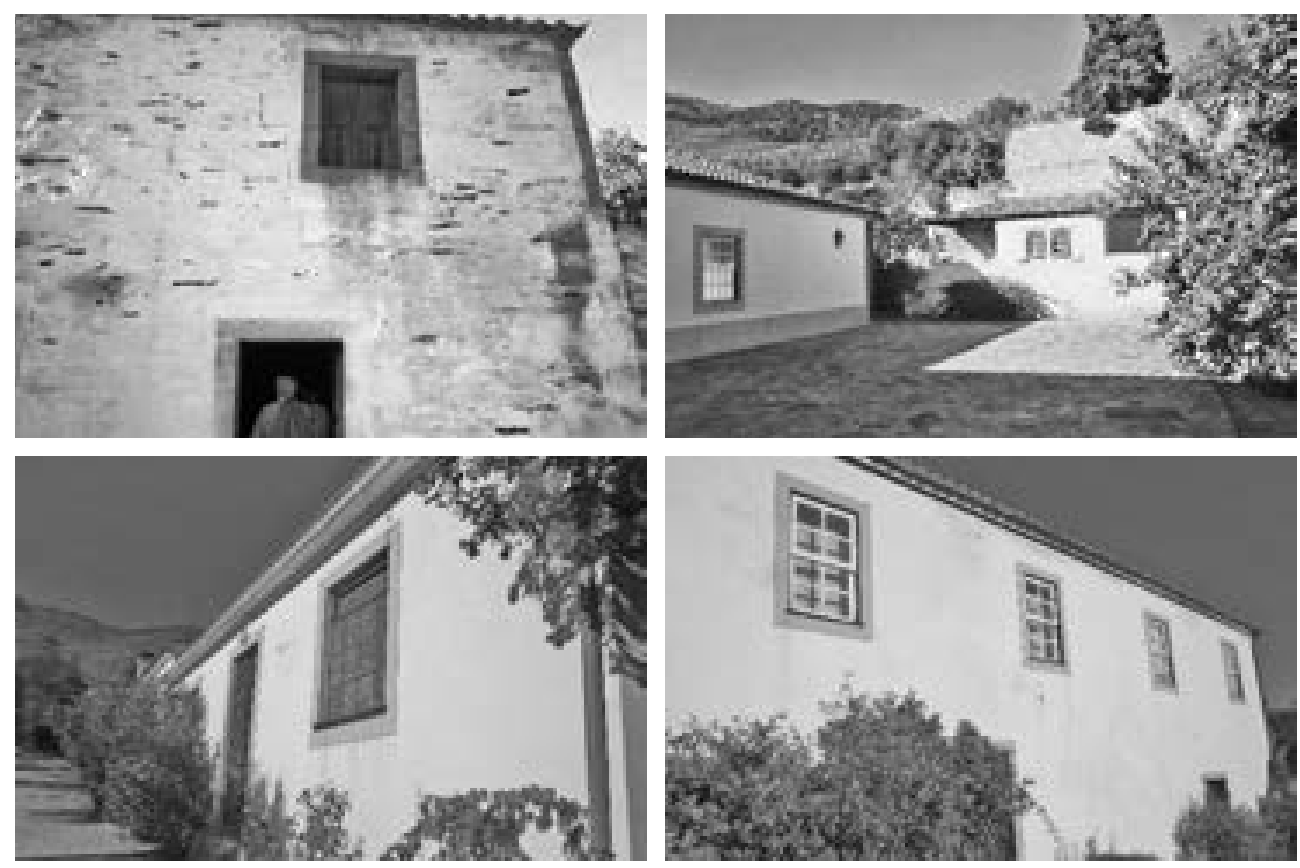

Fig. 59. Casas do caseiro e do feitor e cozinha do pessoal

\footnotetext{
${ }^{360}$ Informações orais do Sr. Padre Bernardo, natural e residente em Zedes, aldeia do concelho de Carrazeda de Ansiães, que foi capelão e tenente-coronel da força aérea. Pároco respeitado e apreciado, durante décadas, em muitas das aldeias do concelho, continua a superintender em atos e cerimónias religiosas, e a presidir em solenidades públicas da igreja. É reconhecido como destacado e ativo impulsionador cultural, com uma vasta cultura, erudição e saber histórico, em especial, sobre a região que conhece e divulga como poucos.

${ }^{361}$ Entrevista ao atual caseiro dos Canais, Sr. O. realizada em agosto de 2010, numa visita de estudo à Quinta.
} 
Do núcleo funcional das instalações da quinta fazem ainda parte, para além da antiga azenha e de uma moderna estação de tratamento de águas residuais (ETAR), a casa do caseiro, os antigos cardenhos, a modernizada adega para o vinho do Porto completamente renovada com lagares novos de granito.
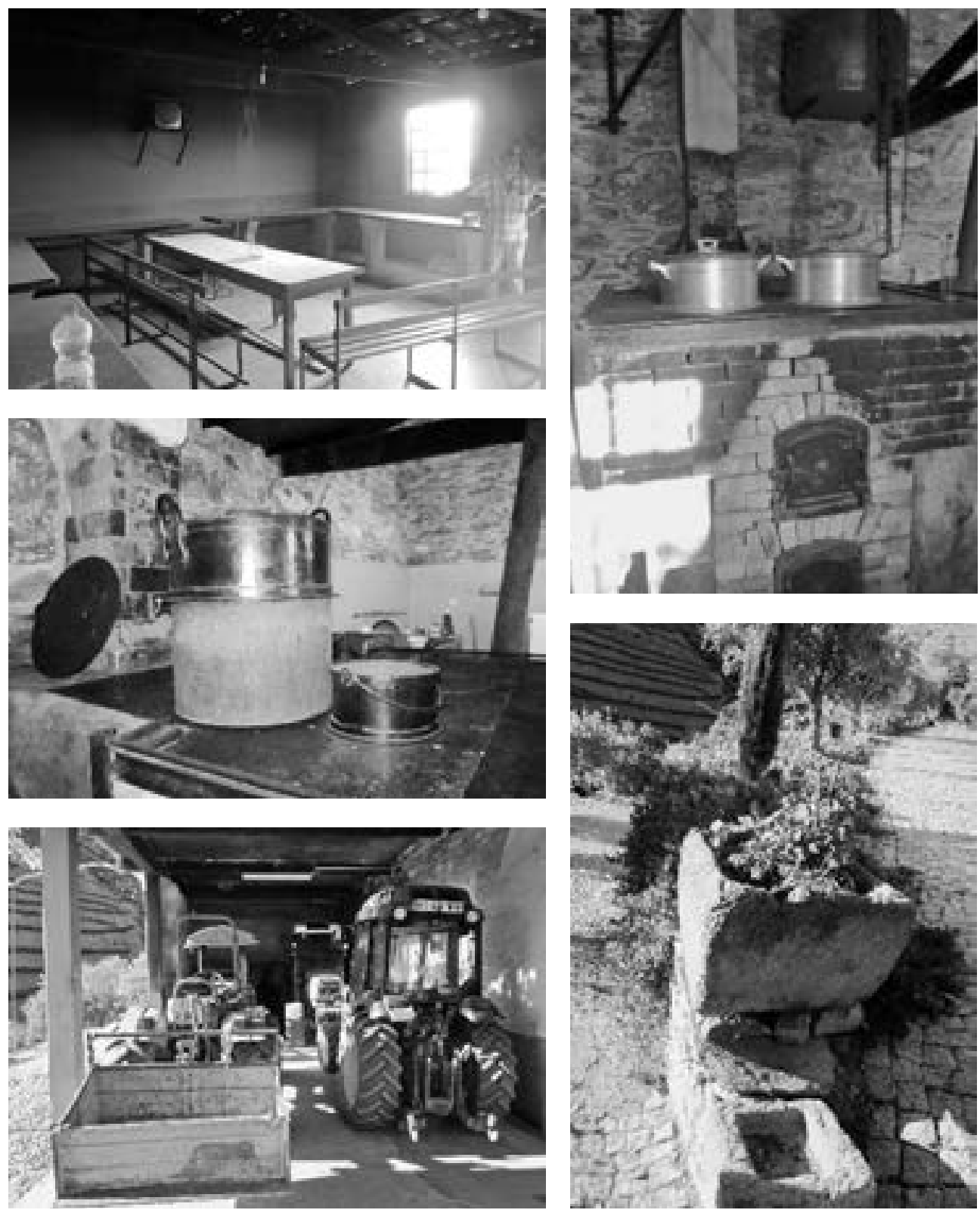

Fig. 60. Cozinha e refeitório do pessoal, antigas abegoarias, velhas salgadeiras 

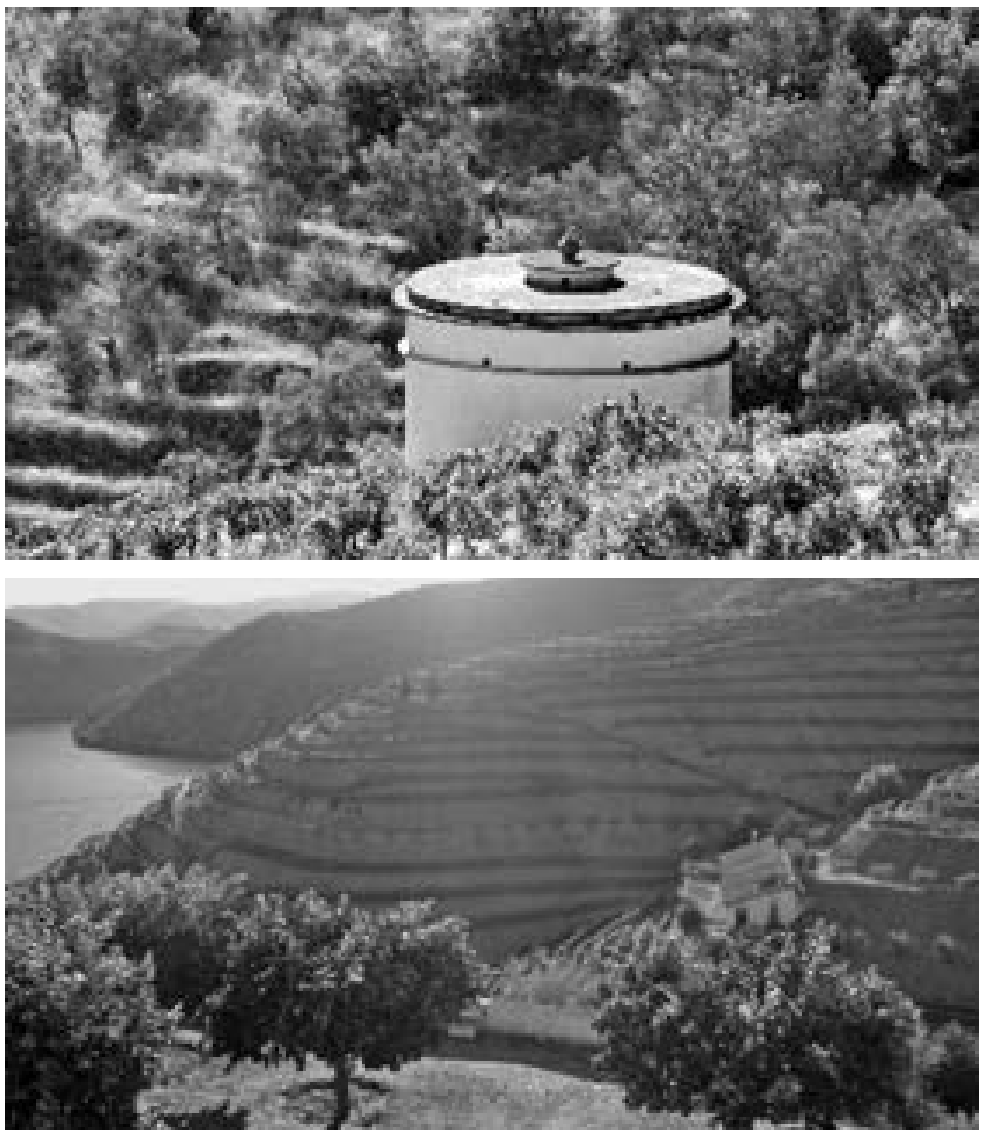

Fig. 61. Antigo pombal ${ }^{362}$ e cardenhos ${ }^{363}$ restaurados

\section{Indicadores de produção e custos}

Em maio de 1988, a Sociedade Agrícola dos Canais apresentou a várias firmas proposta de venda da Quinta dos Canais, onde esta é sumariamente descrita, designadamente, ao nível da produção e maquinaria então existente (tratores lagarteiros, alfaias, bombas, jeeps e camionetas) entretanto renovada ${ }^{364}$.

\footnotetext{
${ }^{362}$ Os pombais, construções complexas edificadas em suportes duradouros, como a pedra, escolhida consoante o substrato geológico local, são importantes habitats para a nidificação de aves das regiões onde se localizam e em cujo interior se produz estrume em quantidade e valor relevantes, fertilizante orgânico que na falta de adubos químicos, permitia produções abundantes na vinha, nos olivais, amendoais e hortas.

${ }^{363}$ Os cardenhos, tradicionais construções comuns nas quintas durienses, são casas modestas para descanso noturno dos trabalhadores sazonais que aí chegavam nas antigas rogas. Dividem-se numa zona destinada às mulheres e noutra para os homens, podendo ser também divididos por estratificação dos trabalhadores em camarata coletiva ou individual para os trabalhadores mais especializados.

${ }^{364}$ Documento anexo a minuta de carta assinada pelas gerentes da Sociedade Agrícola dos Canais e remetida da Beira Grande, em 24 de maio de 1989, à firma Cockburn's, onde se realçam as boas relações comerciais e de amizade
} 
Quanto à produção anual, a quinta com uma autorização de benefício para produzir 150 pipas de vinho do Porto, nesse ano de 1989, produzira em anos anteriores 85 pipas. Calculava-se então que devidamente gerida, a produção poderia ascender a 120 pipas $^{365}$.

No que se refere à vinha ${ }^{366}$, embora do cadastro original da quinta constasse a existência de 198.000 videiras, porém em 1983, após denúncia de que a Quinta dos Canais estava a comprar uvas de fora, e posterior reverificação, foram apenas contabilizadas 145.000 videiras (95.000/95.500 com mais de 4 anos e 49.500 americanos ou bacelos e enxertos), provocando assim um corte grande no benefício. Em 1989 foram contadas ainda 15.800 cepas dispersas no olival (sem direito a benefício). De vinhas novas havia cerca de 9 hectares de PDRITM, 19.750 videiras de 1986 e 13.000 de 1987. O benefício era então de cerca de 115 pipas, prevendo-se que em 1995 pudesse ser de 250, números aproximados face à confusão do cadastro. Do total da área com vinha, cerca de 30 hectares não eram mecanizáveis.

Em outubro de 1989, em plano projetado ${ }^{367}$, para os próximos 10/11 anos, até 2000, com vista a aumentar a produção anual da quinta de 120 pipas/mosto para 500 pipas de vinho beneficiado, previa-se a seguinte evolução anual da produção, a partir desse ano até 2000, conforme consta do quadro 22 abaixo.

Quadro 22. Produção (1989-2000)

\begin{tabular}{|c|c|c|c|}
\hline Ano & $\begin{array}{c}\text { Número de pés existentes } \\
(\mathbf{m i l )}\end{array}$ & $\begin{array}{c}\text { Número de pés } \\
\text { em produção (mil) }\end{array}$ & $\begin{array}{c}\text { Benefício/produção } \\
\text { pipas/mosto }\end{array}$ \\
\hline 1989 & 168. & 120. & 120 \\
\hline 1990 & 193. & 120. & 157 \\
\hline 1991 & 227. & 139. & 201 \\
\hline 1992 & 261. & 152. & 205 \\
\hline 1993 & 295. & 152. & 240 \\
\hline 1994 & 318. & 168. & 284 \\
\hline 1995 & 318. & 193. & 344 \\
\hline 1996 & 318. & 227. & 404 \\
\hline 1997 & 318. & 261. & 464 \\
\hline 1998 & 318. & 295. & 500 \\
\hline 1999 & 318. & 318. & 500 \\
\hline 2000 & 318. & 318. & \\
\hline
\end{tabular}

mútua com Ramiro Sobral (AHS — Fundo Cockburn's, Dossier Quinta dos Canais; cópia cedida pelo Eng. Luís Martins).

${ }^{365}$ Documento interno em inglês de 1989, sobre aquisição da Quinta pela firma Cockburn's (AHS — Fundo Cockburn's, Dossier Quinta dos Canais; cópia cedida pelo Eng. Luís Martins).

${ }^{366}$ Documento interno da Cockburn's de 1989, do processo de aquisição da Quinta dos Canais (AHS — Fundo Cockburn's, Dossier Quinta dos Canais; cópia cedida pelo Eng. Luís Martins).

${ }^{367}$ Documento interno da autoria de Miguel Corte-Real Gomes da Cockburn Smithes \& Cia. Lda (AHS - Fundo Cockburn's, Dossier Quinta dos Canais; cópia cedida pelo Eng. Luís Martins). 
Para se atingirem estes valores tornava-se imperioso proceder nos 5 primeiros anos a novas plantações sendo certo que o respetivo custo designadamente de implantação de 1 ha de vinha em patamares rondava 1.750.000\$00 (1 milhão, setecentos e cinquenta mil escudos), divididos conforme consta do Quadro 23, a seguir.

Quadro 23. Custos de implantação de vinha

\begin{tabular}{|c|c|c|c|}
\hline Ano & Meses do ano & Custos (milhares de escudos) & Trabalhos e mão de obra \\
\hline $\mathbf{1 .}^{\circ}$ ano & & & \\
\hline & out./dez. & 750. & surriba e preparação do terreno \\
\hline $\mathbf{2 .}^{\circ}$ ano & dez./jan. & 150. & bacelo \\
\hline & & & mão de obra diversa \\
\hline & jan./fev. & 100. & enxertia \\
\hline Total & out./mar. & 250. & postes \\
\hline $\mathbf{3 .}^{\circ}$ ano & & 1250. & arame \\
\hline & mar./abr. & 100. & mão-de-obra diversa \\
\hline & abr./mai. & 100. & \\
\hline
\end{tabular}

Em 1992, ano estimado como um dos mais secos nos últimos 100 anos, tornou-se necessária, para impedir que uma grande percentagem das vinhas secasse e a ruína da produção, a atribuição de verba extra a várias quintas do Douro Superior, entre elas a Quinta dos Canais, calculada em 1.500 contos (equivalente a $+/$ - 1 pipa de vinho), destinada a: construção de 2 tanques em locais estratégicos; reparação/aproveitamento dos existentes; tubagem para levar a água do rio aos tanques; reparação/aproveitamento de bomba antiga muito potente existente — infraestruturas de caráter permanente úteis para futuro ${ }^{368}$.

Nos últimos anos, as culturas da vinha e do vinho da Quinta dos Canais passaram por um grande desenvolvimento, afirmando-se em toda a região a sua inovação pioneira. Tem sido considerada como uma das primeiras quintas do Douro a introduzir o lagar robótico, inovação tecnológica que terá sido introduzida nas décadas de 1950/1960 na Quinta dos Lagares em Cheires e mais recentemente na Quinta do Noval.

A mecanização, experimentação e projetos de automação, alguns já referenciados, estão bem patentes na unidade moderna e sistema totalmente automatizado de elevação e trituração das uvas e encaminhamento dos mostos de que a Quinta dos Canais já dispõe.

\footnotetext{
${ }^{368}$ Fax da Cockburn Smithes \& CIA. Lda. de 17/03/1992, remetido para os serviços da firma, em Gaia, a partir da Quinta do Ataíde (AHS — Fundo Cockburn's, Dossier Quinta dos Canais; cópia cedida pelo Eng. Luís Martins).
} 


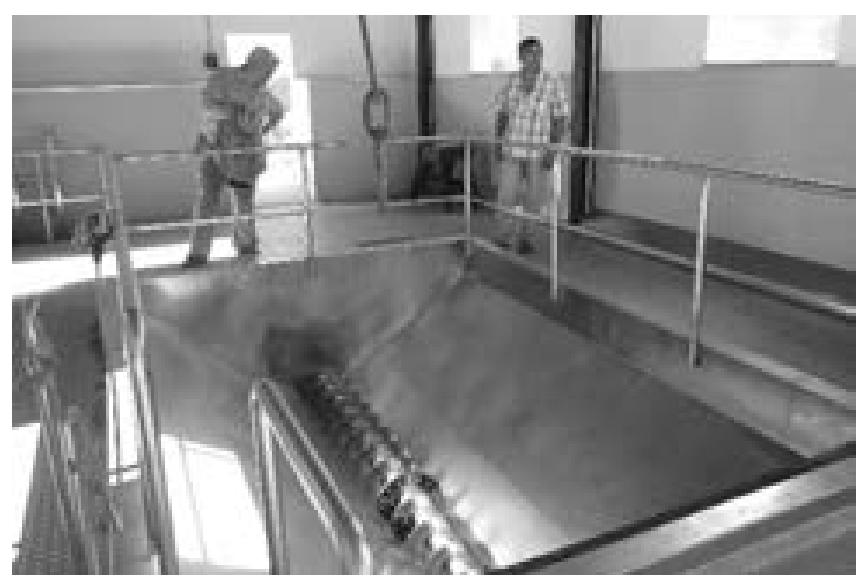

Fig. 62. Nova unidade mecanizada de apoio ao transporte e transformação das uvas

Às castas clássicas ou antigas: Tinta Roriz, Tinta Barroca, Touriga Nacional, Touriga Francesa ou Franca, Mourisco e Tinta da Barca, juntaram-se outras como a Bastardo, a Tinta Amarela, a Tinta Francisca e a Sousã $0^{369}$, em que recentemente se tem apostado muito.

Conforme se pode observar neste mapa afixado no laboratório da quinta dos Canais, destacam-se aí, em tons rosa, as castas Touriga Nacional, Touriga Franca, Bastardo, Tinta Francisca e Sousão e nas manchas a azul e verde as castas Tinta Roriz e Tinta Barroca.

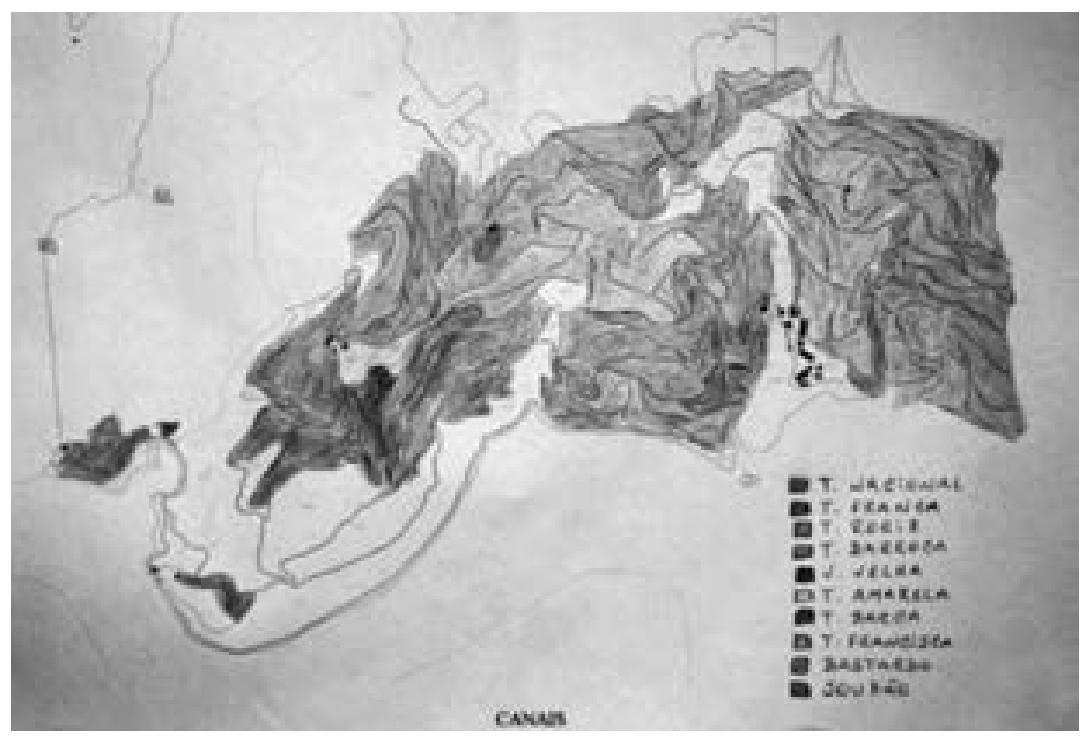

Fig. 63. Mapa da implantação das castas principais dos Canais ${ }^{370}$

\footnotetext{
${ }^{369}$ Entrevista ao caseiro atual da quinta Sr. O. realizada em agosto de 2010.

${ }^{370}$ Ibidem.
} 
Na generalidade, já que há castas encaminhadas para a produção de vinho de consumo, produzem o vinho generoso, tinto, de elevada qualidade qualificado como a «espinha dorsal ${ }^{371}$ dos Cockburn Vintages distinguidos por vários prémios ${ }^{372}$.
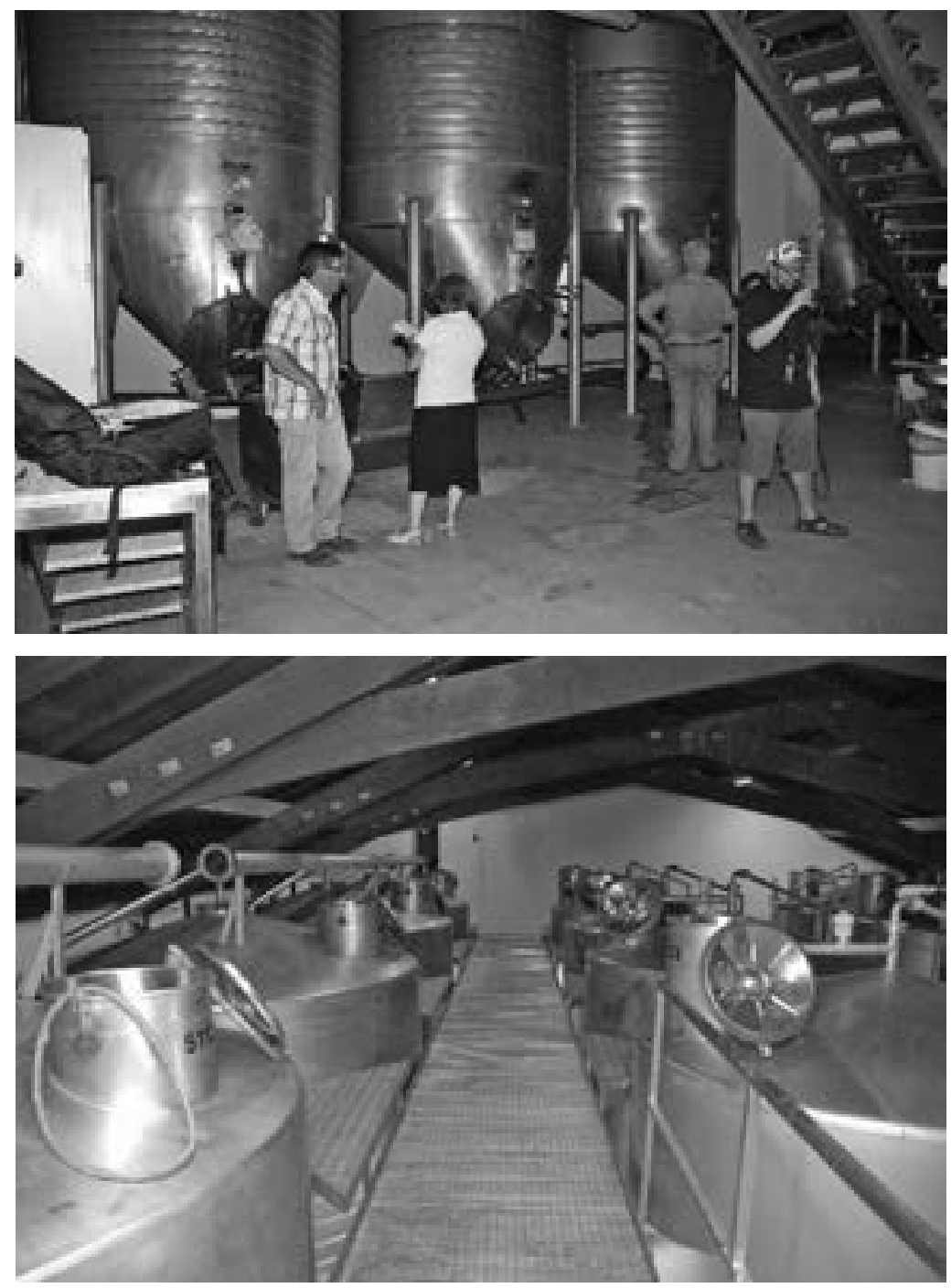

Fig. 64. Cubas de fermentação capacidade de 15.000 litros

\footnotetext{
${ }^{371}$ Documento particular de Gordon Guimaraens de 12 de julho de 1990, AHS — Fundo Cockburn's (cópia gentilmente cedida por Eng. Luís M. Martins).

${ }^{372}$ Refira-se, por exemplo, o Quinta dos Canais Single Vintage (tinto) - Cockburn Smithes \& C. ${ }^{\text {a }}$, S. A. com a medalha de prata no $3 .^{\circ}$ concurso Internacional de Vinhos cidade do Porto, em 1999, e o Quinta dos Canais Porto 2001 - Cockburn's, com a medalha de bronze no International Wine and Spirit Competition 2005.
} 


\section{Pessoal}

A Quinta dos Canais tem um corpo de pessoal fixo e permanente (engenheiro, caseiro, trabalhadores rurais, tratorista, motorista) constituído por 18 pessoas e 3 funcionários do quadro. Para além deste pessoal permanente que reside habitualmente na quinta, continua ainda a recrutar, temporariamente, mão de obra sazonal. Contrata para as vindimas e apanha da azeitona, trabalhadores locais sobretudo das aldeias mais próximas (Beira Grande, Lavandeira, Seixo, Marzagão e Selores) recrutados através de redes familiares a partir dos trabalhadores fixos ${ }^{373}$.

Estes são os principais recursos humanos alocados às necessidades locais do fabrico e produção, pelos quais não passam aspetos determinantes da dinâmica da quinta, designadamente os relativos à exportação e comercialização dos vinhos, a cargo do staff da empresa em Vila Nova de Gaia.

As principais tarefas, operações e trabalhos que a cultura da vinha exige, e o número de dias destinados a cada operação, são ilustrados no seguinte gráfico onde se evidencia também a utilização de mão de obra feminina na generalidade das tarefas, para reduzir custos em operações demoradas e caras.

Pode observar-se que em 1990 se gastaram na pré-poda, tarefa que facilita a poda feita com mão de obra especializada e cara, 704 dias/mulher/homem, num custo estimado de $1.760 .000 \$ 00$.

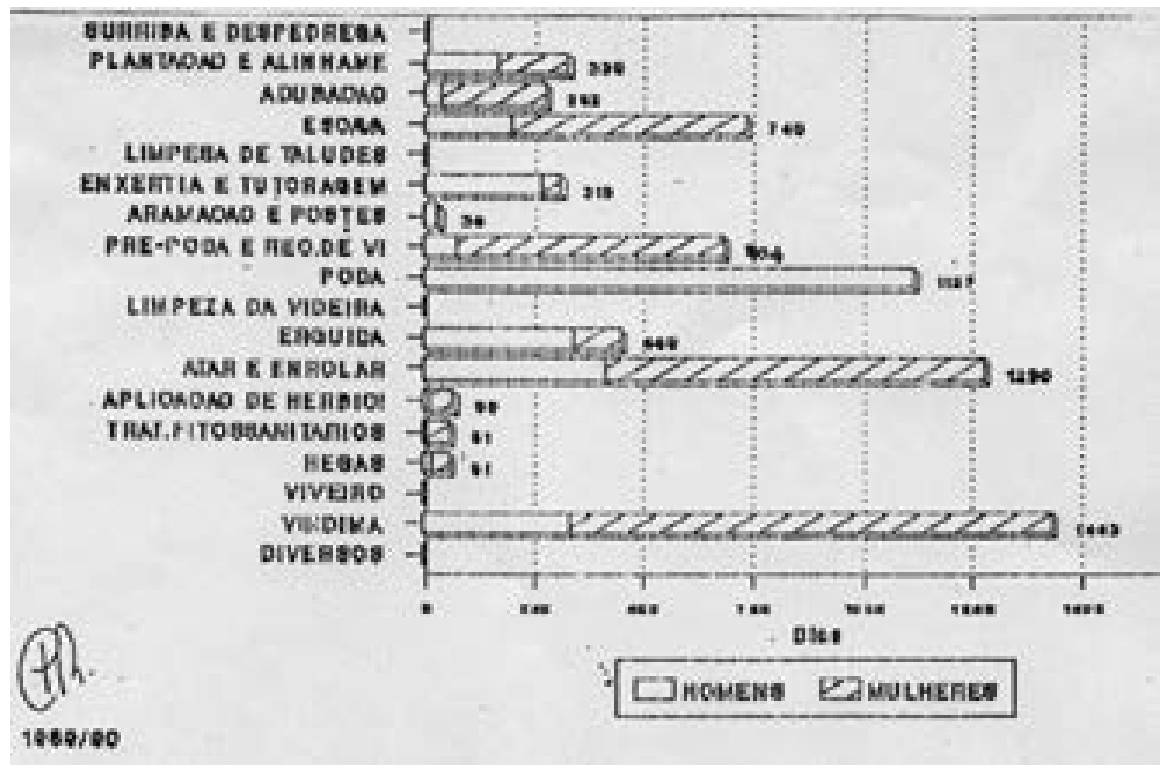

Gráfico 1. Trabalhos da cultura da vinha e distribuição por género (M/F) $)^{374}$

\footnotetext{
${ }^{373}$ Entrevista a Eng. R. C., técnico superior responsável local da Quinta dos Canais, maio de 2010.

${ }^{374}$ Documento interno (1989/1990) da firma Cockburn's (AHS — Fundo Cockburn's, Dossier Quinta dos Canais; cópia cedida pelo Eng. Luís Martins).
} 
Assim se compreende e justifica também o processo de mecanização crescente destas operações que visa fundamentalmente a redução de custos com o pessoal.

Numa aproximação ao número de trabalhadores que a Quinta dos Canais ${ }^{375}$ empregava, nos anos 1990, horas e dias de trabalho mensalmente gastos, observemos abaixo o Quadro 24 que nos permite confirmar, por amostragem, que são os meses de julho e agosto os de menor ocupação de mão de obra.

Quadro 24. Pessoal, horas e dias de trabalho/mês e ano

\begin{tabular}{|c|c|c|c|c|c|}
\hline \multicolumn{2}{|c|}{ Trabalhadores fixos } & \multicolumn{4}{|c|}{ Trabalhadores regulares/sazonais } \\
\hline Mês & N. ${ }^{\circ}$ & N.o & Trabalho completo & Horas de trabalho & Dias de trabalho \\
\hline \multicolumn{6}{|c|}{ Ano 1994} \\
\hline setembro & 3 & 39 & 21 & $3965 \mathrm{~h}$ & 496 \\
\hline outubro & 3 & 30 & 18 & $3399 \mathrm{~h}$ & 425 \\
\hline novembro & 3 & 43 & 29 & $5.692 \mathrm{~h}$. & 711 \\
\hline dezembro & 3 & 47 & 31 & $5.944 \mathrm{~h}$. & 743 \\
\hline \multicolumn{6}{|c|}{ Ano 1995} \\
\hline janeiro & 3 & 73 & 43 & $8.216 \mathrm{~h}$ & 1.027 \\
\hline fevereiro & 3 & 76 & 42 & 8.027 & 1.003 \\
\hline março & 3 & 73 & 56 & 10.681 .0 & 1.335 .1 \\
\hline abril & 3 & 41 & 27 & 5.147 .0 & 643,0 \\
\hline maio & 3 & 57 & 34 & $6.455,0$ & 807,0 \\
\hline junho & 3 & 62 & 36 & $6.900,0$ & 863,0 \\
\hline julho & 3 & 28 & 11 & $2.051,0$ & 256,0 \\
\hline agosto & 3 & 25 & 11 & $2.063,0$ & 258,0 \\
\hline
\end{tabular}

Quanto à vida dos trabalhadores na Quinta dos Canais, são bem sugestivos os fragmentos de um testemunho do antigo caseiro, onde começou como despenseiro, passando depois a feitor e, seguidamente a caseiro e administrador, para além de outros testemunhos de ex-trabalhadores na quinta que a vivenciaram diretamente durante décadas e se transcrevem nos Mapas II e III da cartografia de memórias e representações sociais que compõem o subcapítulo seguinte em que se analisa a quinta enquanto microcosmos social. Aí, onde se reconstituem e analisam memórias e materiais de memória que nos foi possível recolher em numerosas entrevistas feitas em demorado trabalho de campo realizado em aldeias vizinhas desta Quinta, com as populações que lá trabalharam, melhor se poderá ver como muitas outras vozes de antigos trabalhadores produzem, no seu dialogismo, uma memória social incontornável para o conhecimento mais profundo desta Quinta.

\footnotetext{
${ }^{375}$ Mapas mensais do Departamento de Pessoal relativos à Sociedade Agrícola dos Canais (AHS — Fundo Cockburn's, Dossier Quinta dos Canais; cópia cedida pelo Eng. Luís Martins).
} 


\section{A Quinta dos Canais, tradicional complexo agrícola no Douro Património Mundial}

Componentes da região do Alto Douro são representativas de toda a gama de atividades associadas à vinificação — terraços, quintas (complexos agrícolas produtores de vinho), aldeias, capelas e estradas $[\ldots]^{376}$.

Este é um dos três critérios considerado pela UNESCO, para classificação, em 2001, do Douro Vinhateiro como património mundial ou da humanidade, em que se referem as quintas, modalidade de apropriação territorial fundamental na produção do vinho generoso e complexo diversificado de atividades, práticas e saberes, ligado ao cultivo da vinha, produção e comercialização do vinho do Porto, como uma das componentes importantes da história e património do Alto Douro.

Neste enquadramento, a Quinta dos Canais é exemplo do valioso património material e cultural do Douro pela sua grandeza, enquanto propriedade vitivinícola, história, valor patrimonial e posição destacada dos seus vinhos na produção e mercado do vinho do Porto, onde ocupa posição de relevo. Sendo um caso paradigmático das quintas do Douro como várias dimensões atestam, conforme se tem procurado demonstrar, a sua representatividade assenta num processo polimórfico de construção social e histórica que lhe confere condições e recursos para a sua patrimonialização cultural como quinta do Alto Douro Vinhateiro e, enquanto tal, parcela viva do Património Mundial.

\subsubsection{Microcosmo social em meio rural: memórias e materiais de memória}

Para além de uma topografia fotográfica produzida sobre a quinta: terrenos, produção, edifícios e construções, tecnologias de viticultura e vinificação, objetos e artefactos de produção e domésticos, aqui apenas evocada, esta nossa outra pesquisa empírica sobre a Quinta dos Canais desenvolveu-se junto de um universo de homens e mulheres, de idades e situações socioprofissionais diversificadas. Esses atores sociais estiveram envolvidos no granjeio e produção da Quinta dos Canais que, por esta via, se reconstitui como microcosmo social, por aí também procurando pistas de análise da sociedade rural envolvente.

O estudo desse complexo processo exige que, para além das atividades desenvolvidas pela quinta, se suponha o que a transborda, mas com ela mantém intrincada relação, como, a jusante, o trabalho das populações nela envolvidas. Excluir esse trabalho corresponderia a privar-nos de um tipo de fontes imprescindíveis à compreensão da quinta, na sua complexidade. A análise circunscrever-se-ia a uma «economia restrita», tendo como consequência impedir o acesso à «economia geral» da quinta, quadro absolutamente necessário para dar conta da movimentação social que teve nela o seu dínamo local/regional/nacional.

\footnotetext{
${ }^{376}$ Property Alto Douro Wine Region - Id. N 1046 - State Party Portugal (Report of the World Heritage Committee WHC-01/CONF.208/24, p. 45). Classificação segundo a Convenção para a Proteção do Património Mundial, Cultural e Natural, de 1972.
} 
Cruzando pontos de vista da história e da sociologia, trabalha-se um material heterogéneo (entrevistas informais, sujeitas a guiões prévios, mas de adaptação contingencial, testemunhos, histórias de vida e observações fragmentárias), contextualizado no passado/presente.

Esta opção metodológica serve não tanto para fabricar um tecido de provas, mas, para percecionar em ação o entrelaçar de redes de identidades, interações, estratégias e estruturas diversas, organização e mudança social, indivíduos, sociedade e relações recíprocas, com audácia e imaginação exigidas pelo trabalho de terreno sobre objetos históricos, «sem deixar de fazer surgir a evidência do documento e experimentar pesquisas originais» que abrem, por sua vez, múltiplas potencialidades para outras linhas de pesquisa designadamente no âmbito dos estudos rurais contemporâneos ${ }^{377}$.

$\mathrm{O}$ acervo de narrativas, parte significativa da infraestrutura informacional mobilizada, permite traçar uma cartografia ${ }^{378}$ de representações sociais da vida e do trabalho na quinta, assente num «arquivo de palavras» construído, mediante procedimentos e princípios da etnometodologia e do interacionismo simbólico, sobre o registo áudio e escrito de testemunhos orais.

Sete mapas, todos de grande escala (porque representam uma área circunscrita, a propriedade rural, realidade pouco reduzida e com bastantes pormenores), compõem a cartografia das representações sociais e coletivas da Quinta dos Canais e do contexto local de inserção.

Esta cartografia desenvolvida em sete mapas e construída sobre «configurações e reportórios ${ }^{379}$, reconfigurando espaços-tempos, saberes e memórias, dá a ver, por entre uma multiplicidade de práticas, experiências e protagonismos, a pluralidade de significados do objeto sócio-histórico Quinta dos Canais, enquanto «objeto de fronteira»local.

Evidencia-se quer a representação local da Quinta dos Canais nos seus diversos tempos e modos de designação, diferentes e sucessivas produções (olival/vinha) por que se tornou familiar das populações envolvidas, diferentes confrontações e mobilidades, quer a sua representação geral nas modalidades de sua apropriação cognitiva e sócio-histórica, assim se mapeando, na linha descontínua da grande escala, os trabalhos agrícolas e rurais d(n)a quinta, os comportamentos sociais diferenciados, as vivências e recordações de miséria ou alegria, as estratégias de adaptação e as memórias individuais ou de grupo. Deste modo se torna «completa», para os efeitos pretendidos, a representação social da Quinta que nas suas componentes básicas se analisa.

Com este modelo de análise ${ }^{380}$ procede-se a seguir ao estudo da designada «metamemória, conceito que define as representações que o indivíduo faz do que viveu e que acentua as características inerentes à chamada memória coletiva e histórica» ${ }^{381}$.

\footnotetext{
${ }^{377}$ LAGE, 2011.

${ }^{378}$ Sobre a linguagem cartográfica sociológica que releva noções como espaço-tempo, escala, simbologia, projeção e cuja tradução livre e esquemática se operou, veja-se por exemplo, SANTOS, 1988: 193-172; NUNES, 1993.

${ }^{379}$ NUNES, 1995.

${ }^{380}$ Esta metodologia foi por nós já aplicada noutros trabalhos designadamente em LAGE, 2002: 172-278.

${ }^{381}$ CATROGA, 2001: 15-16, 21-22.
} 


\section{Memórias e representações sociais: uma cartografia}

A memória individual é formada pela coexistência, tensional e nem sempre pacífica, de várias memórias (pessoais, familiares, grupais, regionais, nacionais) em permanente construção devido às consequentes alterações ocorridas no campo das representações do presente.

Partindo dessa asserção e com base nesse pressuposto pomos em ato trajetórias de vida, estratégias e memórias do trabalho (pessoais, familiares, grupais) e das condições de vida dos trabalhadores, acomodações, salários e alimentação, na Quinta dos Canais em diferentes momentos históricos, coincidentes com quatro etapas definidas em função dos sucessivos proprietários da quinta, ao longo do século XX, conforme se evidencia na diversidade de narrativas/ depoimentos/testemunhos que cobrem um arco temporal desde os anos 1930 à atualidade ${ }^{382}$.

Recorre-se por isso a um traçado de «mapas» ou construções mentais elaboradas a partir do real cuja interpretação e reelaboração objetivam; através das trocas interpessoais, em especial da fala, opera-se a sua construção sujeita à influência das relações sociais e da realidade material, social e imaginária sobre a qual também interfere. Procede-se aí à (re)construção dessas narrativas sobre diversas espaciotemporalidades, (re)lidas com um olhar distanciado e crítico, capaz de tecer algo mais do que apenas a história dos indivíduos em suas inter-relações complexas.

Começamos por uma narrativa referente ao conjunto das quintas na linha de fronteira entre a sub-região do Cima Corgo e do Douro Superior, onde a Quinta dos Canais se localiza em que se descreve o modus vivendi e modus operandi ${ }^{383}$ nesta Quinta.

\section{Mapa I. Os Canais, «Quinta dos Ingleses», anos 1970-1980 (o cobrador da luz elétrica)}

Faz-se aqui uma contextualização impressiva da Quinta dos Canais e evidencia-se a tradicional e regular mobilidade de mão de obra entre as diferentes sub-regiões da RDD, em que se observa a movimentação de pessoal agrícola especializado das terras do Baixo Corgo, de integração mais antiga na RDD, para as quintas de Cima Corgo e Douro Superior. Este mapa, traçado a partir de uma narrativa de visão exterior da quinta, assinala ainda as motivações específicas da opção pelo trabalho na quinta, por aí se acentuando também a natureza de objeto de fronteira da quinta.

As quintas dão a volta ao termo do concelho de Carrazeda do lado do Douro o consumo da luz era grande mais quando faziam a lota do vinho e do azeite tinham no meio da quinta, no regato, no vale, um lagar de azeite ali era quase tudo olival o consumo da luz nos Canais era maior do que o da Franqueira (quinta Bartol, ao lado) para as vindimas, o pessoal ia lá ter, em rancho, tudo a pé pelos caminhos e carreiros levavam de casa uma tigela de litro que era para a sopa de feijão bichoso às vezes, ao meio dia davam 2 sardinhas a cada

\footnotetext{
${ }^{382}$ Doze entrevistas informais realizadas em 2010 e 2011 com antigos e atuais trabalhadores da Quinta dos Canais, cuja história recente muitos deles testemunharam durante uma vida inteira.

${ }^{383}$ MOYSES, 1994.
} 
um que assavam nas pedras de lousa, com aquele calor para cima de $40 .^{\circ}$ o pessoal dormia lá nas tarimbas numas faixas de palha encostados uns aos outros com o 25 de abril tiveram de modificar parte das coisas os cardanhos tinham as tarimbas à face do chão uns $50 \mathrm{~cm}$ distante do chão eram umas tábuas nesses cardanhos eram candeias a azeite que tinham e de petróleo a eletricidade era só para a casa dos patrões e do caseiro nas vindimas estavam lá 15 a 20 dias sem virem a casa às vezes na azeitona era 1 mês faziam uma fogueira no cardanho onde enxugavam a roupa o trabalho por ai, era só cavar e assim, mas só um dia por outro, e sem terem nada de comer em casa nas quintas, não, trabalhavam seguido e ainda thes davam de comer e dormir ganhavam 5 ou 6 escudos por dia só de 1980 em diante é que passou para 12 escudos e tinham de trabalhar de sol a sol na frieira ganhavam 10 escudos a cavar todo o dia e sem comida [...] das quintas, traziam aqueles 100 ou 200 escudos que naquela altura era muito dinheiro $[. . .]^{384}$.

Nos mapas seguintes, cronologicamente ordenados, materializam-se recordações e memórias individuais internas à quinta, sucessivas ou justapostas no tempo, que permitem cartografar representações sociais multifacetadas da Quinta dos Canais numa linha diacrónica, e registar indícios e traços de uma memória histórica e identidade cultural que embebem todas as narrativas.

\section{Mapa II. A Quinta do Costa, 1930 (a ajudante na cozinha do pessoal)}

Os fragmentos desta narrativa ${ }^{385}$ bem ilustrativa do trabalho das mulheres e das crianças na quinta mas também da cultura e ambiência popular local, são expressão nítida de experiências e protagonismos, mundividências e solidariedades femininas, de comportamentos populares e trabalhos agrícolas, para além de uma descrição pormenorizada, profundamente afetiva e com densidade vivencial do ambiente do dia-a-dia na quinta que assim se torna bem percetível enquanto microcosmos natural, social e cultural fechado sobre as suas dinâmicas, funcionalidades e idiossincrasias internas.

[...] Fui para lá para a quinta do Costa era assim que chamávamos aos Canais com 12 anos, a arrastar potes de um almude 25 litros o pessoal que lá trabalhava na altura era muito as mulheres ganhavam 2.50 escudos ao dia e 3.00/4.00 escudos, o homem, nunca fui à escola fui para a cozinha a governanta era a Joaquina, da Beira Grande que era muito má morreu na miséria foi amante do Costa o patrão que a enganou com 14 anos por isso ninguém lá parava aquilo que se fazia na cozinha do pessoal eram as viandas [comida dos porcos] batatas com casca e tudo um dia estavam lá umas tigelas com batata miudinha

\footnotetext{
${ }^{384}$ Fragmento de entrevista feita em agosto, 2010, o Sr. M., funcionário da EDP reformado, 78 anos de idade e bom conhecedor das quintas do Douro do concelho de Carrazeda que visitou durante anos como contador e cobrador da luz elétrica.

${ }^{385}$ Entrevista realizada em abril de 2011, na sua casa, a C. D., mulher de 88 anos, natural da Lavandeira onde reside e residente muitos anos em Lisboa e Angola.
} 
para o pote e eu deitei-as na canastra ela disse-me: agora vais lá apanhá-las e deitá-las no pote então fugi-lhe um dia peguei o fogo à casa, mas sem querer, porque punha muita lenha e o fogo foi à trave e pegou-se o Costa disse-me: vai depressa cá chamar o Bernardo, que era na altura o feitor era de Vila Marim que venha apagar o fogo encheu um caldeiro de água e apagou-o logo[...] o Costa falava com todos era de Custóias do Douro foi para o Brasil onde casou com a viúva de um embaixador que lhe deu o ser [...] veio para cá e comprou a Quinta dos Canais junto à quinta da espanhola depois é que comprou a quinta da Samorinha, as Forneiras e o Carvalho o antigo dono que vendeu ao Costa acho que era um tal Valente ele vivia na quinta e enganou essa Joaquina que era filha dos caseiros da quinta do Mariz, dos Marizes de Marzagão esta quinta foi comprada pelo Costa aí por 1935/36. Andei lá a trabalhar bastante tempo o pessoal comia uma tigela de caldo de manhã e ao meio dia, feijão cozido, massa de feijão o pão era à nossa conta quando íamos para a quinta, levávamos a colher para comer só davam água-pé era o tempo da miséria estávamos lá toda a semana e aos sábados à noite, já com as estrelas vínhamos a casa á segunda tínhamos de lá estar ao romper do dia [...] depois fui para a corte dos animais e andava no campo a tirar vides, a apanhar as amêndoas, a azeitona, na vindima amanhávamos a lenha das amendoeiras e das oliveiras cartava lá muita urtiga era uma quinta que dava muito trabalho andávamos meses à azeitona e a vindima também era mais de um mês era a maior que havia por aí era em setembro, depois da festa da Lavandeira de 15 para 16 depois de recolher a Santa Eufémia, íamos lá dormir andávamos muitas mulheres [...] cartavam as uvas para o lagar [...] não entravam dentro no lagar [...] os homens tocavam harmónio quando outros pisavam [...].

«Ó morena cor de cana

teu amor é o que me engana

és do meu gosto, és da minha opinião

Hei-de amar a moreninha, da raiz do coração [...]»

...eram os homens que cantavam assim quando as moças entravam com os cestos das uvas enversavam aquilo de muitas maneiras iam para lá de outras quintas dançar porque tinham lá as namoradas Também vinham para ali trabalhar aquelas raparigas de Custóiase Foz Côa ...Olas é da freguesia de Vale da Figueira ....Carrazeda é fronteira ali na Quinta ... pega com três distritos Guarda, Viseu e Bragança ... ia muita gente do concelho de Carrazeda, mas só na azeitona e na vindima ...os Canais são a 3. a maior quinta do Douro [...] nessa altura havia mais oliveiras agora já não há lá nenhuma [...] havia laranjas, figos, amêndoas [...] essa história do incêndio na quinta [...] o Costa combinou com o guarda e pegaram o fogo para enganar o seguro [...] foram presos para Moncorvo diziam que o Costa era maçónico [...] nessa altura, a capela no Mariz funcionava mas ele mandou deitar os santos ao rio e dizia que os santos eram de pau [...] a embaixadora, a mulher dele era brasileira e ele dava-lhe maus tratos e desprezava-a [...] um dia deixou-a fechada o pessoal tirou-a pela janela com uns lençóis e ela atravessou o Douro e desapareceu o Costa era político e 
tinha inimigos [...] um dia veio uma porção deles de além do rio para o matar a quinta ainda era o que valia à pobreza, por aqui [...].

Trata-se de um testemunho de evidente significado, pelas referências precisas à origem e proveniência quer do proprietário da Quinta quer de seus trabalhadores permanentes. Releva-se o facto de a quinta, pela sua localização geográfica, fazer fronteira com 3 distritos (Bragança, Guarda e Viseu), o que contribui também para explicar melhor a natureza de «fronteira» do concelho de Carrazeda, acentuada à partida, pela sua topografia e localização geográfica. Evidencia ainda um significativo interesse para o registo/preservação de elementos de identidade, cultura popular e património cultural imaterial local, pelos indícios relevantes a este nível que aí se podem identificar. Assente numa memória ainda viva e precisa produtora de um registo descritivo pormenorizado e de uma narrativa de especial valor informativo, possibilita o seu entendimento como fonte histórica oral cujo tratamento e interpretação crítica revela assim um duplo significado que permite corroborar argumentos desenvolvidos a partir dos conceitos de fronteira e identidades em corelação com a territorialidade historicamente produzida ${ }^{386}$.

\section{Mapa III. Os canais ou «Quinta do Engenheiro», anos 1940-1980 (o caseiro)}

Relativamente às condições salariais, alimentares, situações de trabalho, lazer e vida social na quinta é bem ilustrativo o testemunho do antigo caseiro que a vivenciou diretamente durante meio século, desde o início da década de 1940 até ao final da década de 1980, primeiro como despenseiro, depois como feitor, a seguir como caseiro e administrador ${ }^{387}$ :

os salários variavam de mês para mês e de ano para ano houve tempos que era de sol a sol 8 escudos por dia os homens, 4 escudos por dia as mulheres 20 escudos por dia era na azeitona em 1959 o que já era uma admiração e depois passou a ser também na vindima a azeitona era mais cara porque era a seco [...] havia 3 refeições: o pequeno almoço, às 8/9 h, o almoço ao meio dia e o jantar quando o sol se punha de manhã era sopa de feijão, arroz e massa, ao almoço, sopa e apresigo e à noite sopa e apresigo o apresigo era arroz, feijão, massa e batata nas vindimas havia uma sardinha de barrica ao meio dia ou à noite e à meia noite, no lagar o vinho ia todo para Gaia e depois para Inglaterra ultimamente também já ia muito para França nos armazéns só havia pipas e tonéis, cubas não [...] só mais recentemente é que começaram a trabalhar até às 2 horas e iam com o dia ganho porque madrugavam já depois do 25 de abril havia desentendimentos entre os empregados havia muitos ciumes e invejas a quinta tinha um guarda que era severo e meteu-se-lhe na cabeça que havia de ficar de caseiro e então corria com todos era das redondezas do Pinhão esse guarda intrigava junto do engenheiro estava lá um feitor já do tempo do Costa

\footnotetext{
${ }^{386}$ PARKHURST, 2004.

${ }^{387}$ Entrevista ao antigo caseiro da Quinta dos Canais, Sr. F. realizada em julho de 2010, em sua casa, na sua aldeia natal do concelho de S. João da Pesqueira.
} 
que se virou a ele «quem vem dar aqui os dias santos sou eu» caseiro é uma profissão boa mas muito invejada os melhores momentos que guardo da quinta são os bailaricos ia gente de outras quintas perto para lá dançar tocavam muito realejo a quinta tinha dois barcos, um para o pessoal e outro para os animais havia 2 machos de trabalho, 2 juntas de bois, 2 cavalos de regalo, 1 para o patrão e outro para a patroa quando havia muito pessoal, fazia de feitor tomar conta do pessoal, dizer o que se havia de fazer o rogador era o que fazia de feitor junto do pessoal e relacionava-se bem com o feitor da quinta ia vigiar o trabalho do pessoal quando não trabalhavam eram castigados com multas como quando fossem apanhar fruta se fosse apanhado a pegar um figo pagava 10 escudos ...se calhar não ganhava isso por dia ...e se fosse apanhado a pegar outra fruta a multa era mais cara, mas as multas e o valor delas era por hábito, costume.

[...] dos Canais vendiam tudo para os armazéns do Porto mandavam os bidões do Porto e enchiam-se na quinta de azeite mandavam os cascos de Gaia para a Quinta onde se enchiam de vinho e iam depois no comboio a aguardente vínica para fazer o Vinho do Porto vinha da empresa de Gaia para a Quinta a aguardente e figos secos ao mata bicho era só para os empregados, os feitores na quinta havia 2 feitores, um para os homens e outro para as mulheres [...].

\section{Mapa IV. A Quinta do Engenheiro Sobral, 1940/1950 (o homem de todo o trabalho)}

Este depoimento ${ }^{388}$, típico de um ex-trabalhador filho de pequeno proprietário rural que, na Quinta, exerceu múltiplos trabalhos, é expressão da identidade cultural local do pessoal trabalhador das quintas durienses, e da ambiência geral da Quinta dos Canais em seu quotidiano de trabalho e lazer, nas décadas de 1940 e 1950, período em que o olival e produção do azeite se sobrepunham à cultura da vinha e produção vitivinícola. É ainda elucidativo das condições de trabalho infantil na quinta, das diferenciadas formas de pagamento, das mobilidades geográficas e sociais, das modalidades e áreas geográficas de recrutamento do pessoal rural, «as ranchadas» que a quinta ocupava nos diversos trabalhos igualmente descritos com os meios de seu desempenho e controlo.

Fui para lá para nós era a quinta do engenheiro com 11 anos trabalhava diariamente nos invernos e primaveras até abril/maio. O Fausto era o despenseiro e o irmão, era o administrador que depois foi para uma empresa do Eng. Ramiro na Guiné [...] Há 30 ou 50 anos atrás todos os da Lavandeira lá trabalhavam. Como tínhamos uns bocadinhos, tirávamos uns dias para ir trabalhar para a quinta quando iamos lá para baixo tínhamos de levar o pão, a colher e o garfo tigela eles davam de chapa ou zinco o almoço, ás 9 horas

\footnotetext{
${ }^{388}$ Entrevista feita em março de 2011, na Lavandeira ao Sr. A. S., 75 anos, em sua casa. Largos anos trabalhador permanente e sazonal da Quinta dos Canais, desde os 11 anos de idade este entrevistado, trabalhou vários anos em Moçambique, donde regressou em 1975, tendo depois trabalhado até se reformar como cantoneiro da Câmara Municipal de Carrazeda de Ansiães.
} 
da manhã, era 1 tigela de sopa batata, berças, feijão bichoso; o almoço ao meio dia eram 2 tigelas, 1 de sopa e outra de aprezigo que era massa e migas, tudo solteiro a única carne era o bicho dos feijões. O arroz vinha para a quinta em sacos de $100 \mathrm{~kg}$ e o feijão e as pessoas tiravam-no dos sacos e ia direto para os potes de ferro de 60 e 70 litros. Andava na frente do boi de paquete esse foi o meu primeiro serviço. Os mais novinhos iam para ao pé das mulheres apanhar vides e ervas andávamos à azeitona, mas isso quando já tinha 16 anos e ganhava ao preço de um homem, 25 tostões por jorna. Na azeitona eram 60 a 70 pessoas 2 camaradas da azeitona 10 ou 6, 15 ou 8 pessoas e 2 juntas de bois 2 ranchadas para a azeitona e outra na vindima. Nessa altura era mais azeitona depois arrancaram o olival quase todo. De 1947, quando fui para a quinta, até aos 22 anos, em 1957/1958 ou mais, havia na quinta sempre trabalho diário por aí à jeira era trabalho de biscates $e$ não se arranjava dinheiro então íamos até à quinta para comprarmos um saco de pão e às vezes até pedíamos abono pagamento adiantado. As jeiras eram a 12 quando fui para lá os homens ganhavam 7 escudos e as mulheres era sempre metade os do Seixo iam para a Quinta da Sra. da Ribeira os da Beira Grande para a Quinta do Espanhol ou do Bartol, às vezes trocávamos de quinta, mas era por causa das raparigas. Na capela da Quinta quando fui para lá tinham um palheiro ao lado onde o pessoal na azeitona dormia depois o Eng. mandou compor aquilo também comprou a quinta do Carvalho onde estavam os Caralhetos de Besteiros e que era dos Carvalhos aqui da Lavandeira venderam aos Canais os lugares da Forneira mais modernamente, os ingleses compraram aos filhos do Moura, um ricaço daqui, a Quinta da Barreira que juntaram aos Canais custou 30 ou 40 mil contos. Quando lá trabalhava ainda pequeno nem podia erguer o cântaro do sulfato que caia por cima de mim como paquete andava à frente dos machos, e a tigela era só meia esperavam até ao fim para serem servidos "deixa aqui que é para um homem» ainda agora uso esta expressão depois fui para ajudante da cozinha levava as tigelas aos homens, ajudava a lavar a louça e fazia o que era preciso hoje aquilo já mudou muito fizeram obras, melhorias. A partir dos 16 anos passei a receber como homem e fazia todo o trabalho. Cumpri lá o meu serviço militar e a caneta com que aprendi a escrever era a enxada. Muitas cantigas daqui lá cantávamos assim:

«Nós somos da Beira Alta

Onde a broa não nos falta

Viemos para o Alto Douro

Enfiados em cantigas

O diabo das formigas

Roeram a pele ao couro $[. .]$.$» .$

Vinham p'ra lá trabalhadores de Viseu e de Vila Marim a estes chamávamos «os foleiros», por causa da pronúncia falavam axim alguns casaram por cá ou eram pedreiros ou hortelãos [...]. 
Nas quintas aprendia-se de tudo um pouco no cardanho falavam alto, contavam anedotas e malandrices era o que havia para nos distrairmos primeiro as camas eram só palha, mas depois já havia tarimbas e umas camitas quando era da azeitona dormiam mulheres a um lado e homens a outro às vezes havia um casal ou dois primos que ficavam ao meio a separar nos Canais era uma miséria só pulgas uma porcaria às vezes os homens compravam metade de um trigo, partiam uma lasquinha e punham em cima do pão centeio, duro, a fazer de peguilho, como se fosse queijo ou outra coisa nos Canais, andávamos do nascer do sol até as estrelas piscarem a azeitona era a partir dos 10 de novembro, dezembro, janeiro, fevereiro e 2 ou 3 semanas de março na azenha eram aqueles moinhos puxados com bois a gente na frente dos bois descansava os braços nos cornos dos bois, a assobiar um dia, o engenheiro veio a cavalo, ao pé de mim e disse zangado "com que então andas a dar senha aos outros que eu venho aqui?...». Todos os anos se faziam lá batidas de caça iam muitos convidados faziam fila os paquetes e os caçadores faziam batidas a cria fugia para o lugar do Judas, ao fundo da quinta, havia muitas perdizes ainda há tantos trabalhos que lá passei mas era uma festa quando nos juntávamos a cantar e a contar aquelas façanhas [...].

\section{Mapa V. Os canais nos anos 1960 e 1970 (o ajudante de tratorista e barqueiro)}

Os fragmentos desta narrativa ${ }^{389}$ ilustram saberes leigos e antigos trabalhos rurais exigidos pela cultura da vinha, e narram recordações, experiências individuais, ocupações e características da vida e do trabalho na Quinta e suas diferenças nas várias épocas. Constitui, com o testemunho seguinte, um exemplo dos frequentes namoros e casamentos entre os trabalhadores da quinta como local de encontro e espaço de convivialidade relevado pelos atores sociais.

Fui pedir trabalho ao Fausto que era o caseiro estive entregue aos animais, à cria eram 2 juntas, 4 bois, 2 machos e 1 burro andava sempre no trator com o Sebastião que ainda lá está lá namorisquei com esta e lá casámos trabalhei lá na quinta do engenheiro até ir para a tropa andava com os animais, depois com os atomizadores 2 ou 3 ao princípio eram pulverizadores com um motor atrás para fazer ar e é mais rápido eram precisas 2 mulheres para acarretar água para eles deitávamos primeiro o enxofre e depois o sulfato quando as videiras já tinham grãos de chumbo quando lá trabalhei a quinta já tinha muito vinho sulfatar era no princípio de abril/maio era sempre 1 ou 2 homens, durante 1 mês ou mais 2 ou 3 voltas. Também lavava os tonéis nós não bebíamos o vinho fazia-se água pé e era o que se dava ao pessoal o Fausto às vezes ainda dava um copito de vinho aos lavradores quando andavam a lavrar [...]

Sabe porque é que há tantas roseiras no meio dos bardos? É que as roseiras apanham mais depressa o míldio quando víamos que a roseira estava a ser atacada era sinal que se

\footnotetext{
${ }^{389}$ Entrevista feita em março de 2011, na Lavandeira ao Sr. I. A. L., 61 anos, trabalhador na quinta dos Canais durante alguns anos, onde casou com uma trabalhadora, filha do pastor da quinta. Fez a guerra colonial em Angola e Moçambique, como comando, e emigrou com a família para França, onde esteve 36 anos e foi dirigente de uma Associação Cultural Portuguesa, perto de Estrasburgo.
} 
tinha de tratar a vinha o sulfato é para o mildio e o enxofre para a farinhota ou oídio o barqueiro ia todos os dias [...].

\section{Mapa VI. Quinta dos canais, anos 1960 e 1970 (a pastora)}

A narrativa feminina de que se extraíram os excertos que se seguem ${ }^{390}$ indicia vários aspetos de demografia e história das populações pouco referenciados na história das quintas durienses: práticas frequentes de nupcialidade entre trabalhadores, exemplos da vaga migratória portuguesa clandestina para a Europa nos anos 1960 e da guerra colonial em África, fatores decisivos de transformação da oferta de mão de obra local disponível para os trabalhos da quinta. São de realçar os materiais de memória viva do pastoreio na Quinta dos Canais e a descrição dos trabalhos agrícolas em que se ocupavam as mulheres, com salários idênticos aos das crianças, «os paquetes», inferiores aos dos homens.

Fui para os Canais com 15 anos o meu pai sempre foi pastor e tinha gado éramos da Lavandeira e então o Fausto propôs-lhe ir para lá, a meias tínhamos casa, terrenos e eu andava lá à jeira e quando era preciso separar os cordeiros das mães eu ia ajudar o meu pai andávamos com os rebanhos na quinta toda metiam-se nas vinhas quando já não havia uvas comiam as ervas tirávamos o leite o curral ficava no Mariz, perto da capela os animais também serviam, para estrumar o rebanho tinha para aí 150 ou mais cabeças vendiam-se todos os que nasciam afastávamos as ovelhas das crias, um mês e meio, para tirar o leite e vender "redolhos» eram os do tarde e havia os do cedo o leite ia todo para a quinta a Sra. Maximina, mulher do Fausto, é que o media fazia queijo e vendia para fora ordenhava de manhã e à noite andei nos Canais dos 15 aos 18 anos lá o conheci (indica o marido, Sr. I.) namorámos e casámos em 6 meses na quinta fazia tudo apanhava as vides na altura da poda apanhava e britava amêndoa acarretava o sulfato apanhava as azedas das paredes para fazer salada aqui o I. com o Sr. S. que ainda está lá iam no jipe que já tinha os travões fracos prendiam-lhe uma corda no atrelado transportavam as uvas nos cestos vindimos para os carregar os homens usavam a trouxa, uma correia que prendia na testa com uma espécie de lona e nas costas tinha uma espécie de lona com palha era um travesseiro comprido que parecia uma almofada o Fausto dizia às mulheres: «ó besta quadrada» quando britavam amêndoas para comer trabalhávamos nos Canais às vezes 30, 40, 50 e mais na vindima era mais gente iam muitos daqui da Lavandeira e de Baião, Mesão Frio, Vila Marim talvez porque eram mais sofisticados para essas podas a «descava» era tudo à enxada a videira estava desenterrada e a «redra» fazia-se para enxertar para cortar as raízes na moquinha onde é o enxerto para cima [...] é o manso para baixo [...] a moquinha a «redra» fazia crescer a vinha quantas mais redras mais a uva cresce o pó da terra é tipo enxofre lavrava-se ao toro para tapar a descava fazia-se em fevereiro, março; a

\footnotetext{
${ }^{390}$ Entrevista realizada em março de 2011, a D. M. J., esposa de I., anterior entrevistado, em sua casa, na Lavandeira.
} 
redra era em junho, julho hoje estas operações já não se fazem porque não há mão de obra hoje usam-se os herbicidas só podem ser postos junto aos toros das videiras e no meio para o trator passar com as alfaias (ganchos) hoje fazem a redra os tratores agricultura integrada hoje também as enxertias ficam mais no ar e já se fazem pouco compram as vides enxertadas as vides botam as folhas para baixo por causa da filoxera [...].

\section{Mapa VII. Os canais, anos 1970 (o paquete)}

O testemunho ${ }^{391}$ que compõe este último mapa, alusivo ao trabalho infantil, narra «uma aventura na Quinta dos Canais» de um «paquete», moço que andava à frente dos animais, mondava as ervas na vinha e levava a comida ao pessoal, na faina agrícola. Representa uma iniciação à idade adulta e mundo do trabalho das crianças que só depois faziam todo o trabalho de um homem:

para os miúdos a Quinta dos Canais era uma aventura havia lá laranjas, via-se passar o comboio, havia baile, andavam rapazes e raparigas na altura da Páscoa fui e estive lá 3 semanas tinha 11 anos nesse tempo os paquetes como eu era ganhavam $10 \$ 00$ ao dia, que era o mesmo preço das mulheres os homens ganhavam 15 e $20 \$ 00$ nos dias que lá andei ganhei $220 \$ 00$ quando vim de lá tive de ir ao médico vinha quase tísico as comidas eram fracas e o calor muito depois das $10 \mathrm{~h}$ já ninguém aguentava o que lá ganhei foi todo para o doutor e xaropes na farmácia [...].

Todas estas vozes, como muitas outras de que são exemplo, confluem, em seu dialogismo, na construção de uma memória social incontornável para um conhecimento mais «por dentro» e profundo desta singular Quinta representativa do Alto Douro Vinhateiro. Do ponto de vista da abordagem cartográfica, o preceito comum de seguir os atores, implica não só localizar a escala em que estes constroem e representam os fenómenos relevantes para a sua atividade, mas também o modo como reduzem as outras escalas a objetos à mesma escala, manipuláveis, recombináveis e transformáveis ${ }^{392}$.

A abordagem cartográfica que se veio traçando e agora se analisa, mais especificamente, permite e exige uma leitura não linear do exposto, o que se faz segundo alguns vetores sempre reportados à quinta e às memórias da sua história que, simultaneamente, as iluminam e a seu propósito se constroem.

Pode verificar-se, numa primeira instância de análise, que a complexidade e densidade do estudo das memórias, dos processos sociais, das identidades, motivações, escolhas e estratégias não exclusivamente económicas e políticas dos agentes sociais, concorre para desocultar

\footnotetext{
${ }^{391}$ Entrevista feita em abril de 2011, na Lavandeira, a R., Presidente da Junta de Freguesia, reformado como agente da Guarda Nacional Republicana, em Lisboa, 54 anos, a residir na Lavandeira, sua terra natal e meu informante privilegiado junto das populações da sua aldeia que trabalharam nos Canais.

${ }^{392}$ NUNES, 1996: 28, 66.
} 
atores sociais que têm permanecido na obscuridade e cujas narrativas são tão ou mais esclarecedoras que as dos grandes e ou afamados proprietários. As suas memórias individuais, não isoladas e com referência frequente a pontos externos ao sujeito, tendo na quinta a matriz referencial estruturante, encontram-se relacionadas, em seu suporte, às perceções produzidas pela memória coletiva e pela memória histórica.

Prosseguindo a análise pluridimensional e polifacetada que assim se nos impõe, pode intuir-se que a quinta tem segregado as suas elites e categorias de trabalhadores (mapa IV) cujas trajetórias, identidades, representações e comportamentos sociais importa compreender em suas singularidades e diversidade. No que respeita às populações anónimas em observação, as suas experiências, trajetórias e histórias de vida e de trabalho tornam-se, pelo seu registo e interpretação, fontes de história rural contemporânea e estratos de um património (i)material e cultural a preservar, já que neles se ancora uma importante dimensão de história oral desta quinta duriense.

Ressalta a importância decisiva que essas vivências do trabalho desde cedo em relação estreita com a quinta têm na formação e pertença identitária de todos os atores sociais, apreensível nas suas memórias e narrativas (mapas I a VII), com que que se pode construir parte significativa da nossa compreensão da própria quinta enquanto entidade económica e social nuclear no tecido sócio-histórico do Alto Douro Vinhateiro.

Decorre daí o segundo vetor de análise que, focalizado agora na própria quinta, possibilita em primeiro lugar dar conta de como se opera a sua reconstituição social e histórica através de memórias individuais e sociais, identidades conjunturais e representações sociais referentes a seus diversos espaços-tempos. A perceção dessas espaciotemporalidades em que se evidencia a dinâmica caleidoscópica da Quinta dos Canais, característica marcante desta, é-nos também proporcionada pela leitura geral dos anteriores mapas simbólicos, os quais estabelecem as necessárias coordenadas para a sua identificação.

Continuando a seguir a teoria mobilizada e sua aplicação ao material empírico selecionado no conjunto apresentado de narrativas/recordações múltiplas e fragmentadas, surge-nos ainda a possibilidade de observar a inscrição aí sempre presente da ideia de redes, fluxos e interações que nos permite a apreensão das continuidades e mutações, trajetórias biográficas, ambiências vivenciais, estratégias de sobrevivência, condições e relações de trabalho (mapa III) que caracterizam a Quinta dos Canais, ao mesmo tempo que documentam e ilustram aspetos marcantes da sua história social, em larga medida representativa das quintas durienses.

Pode também compreender-se como a quinta, enquanto exploração em meio rural, é um microcosmo socioeconómico e cultural de ancoragem de uma pluralidade de tradições e oportunidades (mapa II), tensões e solidariedades, interesses conflituantes e opções polémicas de exploração olival/vinha, e perceber como com os seus processos de viticultura, parte ativa da agricultura rural local, estreitamente interligados aos processos de vitivinicultura típicos de uma exploração comercial multi-escalar (regional-nacional-global) ela se configura enquanto unidade empresarial capitalista. 
Mais difícil de apreender do que as simples estruturas de propriedade, conhecidas através de sucessivos cadastros, mas cujos indícios vimos emergir nalguns dos anteriores mapas de memórias e representações sociais (mapa IV), o processo histórico e social desta estrutura de exploração agro-comercial, cujo estudo assim se viabiliza, é essencial ao entendimento da sociedade e economia rural.

Foi sendo possível observar mudanças sociais que foram ocorrendo no seu interior e na comunidade local, indiciadas nas narrativas das trajetórias individuais e familiares das populações entretecidas nas memórias dos atores sociais entrevistados.

A realidade de exploração rural encontra-se ligada a opções proto industriais da região do Douro, mobilidades sociais e formas de pluriatividade visível nas modalidades de trabalho e mobilidades sazonais, dimensão que igualmente se depreende desta abordagem.

Observe-se no entanto que, como se pode ainda deduzir das narrativas dos trabalhadores da quinta, nas relações de trabalho que aí se estabelecem e, designadamente, no recrutamento, o princípio de grandeza é, de forma marcante, o da «confiança», próprio de uma «lógica doméstica», exercida de forma mediada através do caseiro, do feitor ou de quem permanece fixo ao seu serviço. Este aspeto é tanto mais de realçar quanto ao longo dos últimos anos a Quinta dos Canais tem vivido períodos de transformação tecnológica relevando da «lógica industrial» em que o princípio de grandeza é o da «eficácia» que se mantém a par do aprofundamento da «lógica mercantil» em que, por sua vez, o princípio é o da «oportunidade».

Porém, não se podem aqui desenvolver algumas outras vertentes essenciais à construção da sócio-história da quinta, o que limita esta análise preliminar. Por exemplo, a teoria e metodologia adotadas só cobram todo o seu alcance heurístico quando puder ser feita a articulação dos mapas das representações sociais de grande, pequena e média escala que possibilitam dar visibilidade a saberes como os indireta e localmente referenciados pelo caseiro atual dos Canais, ao salientar a mais recente plantação dos milheiros e as enxertias de castas novas, e ainda propiciar a observação dos indicadores de controlo de qualidade do produto. Por outro lado, na perspetiva dos produtos e mercados, poderá ver-se como a inserção da quinta no mercado abre fileiras que podem induzir desenvolvimento, reconversões e especializações regionais e locais de produtos e culturas tradicionais. Ao nível dos "produtos», mesmo sendo a especialização quase total, permitirá o estudo de parcerias com empresas, instituições reguladoras da produção e comércio do vinho do Porto e outras entidades ligadas ao setor vitivinícola do Douro.

Em matéria de modernização técnica, tecnológica e inovações, várias interrogações continuam ainda a carecer de resposta. Quais os dispositivos de modernidade técnica e agrícola do desenvolvimento da quinta? Em que consiste a modernização agrícola agida pela quinta, também recordada nas narrativas (mapa VI), ao nível técnico, mecanização, novos métodos de plantação e preparação de cepas? Há, para além dos indícios detetáveis em alguns dos mapas traçados, diversas modalidades de in(ter)comunicabilidade entre a quinta, outras quintas, comunidades rurais envolventes e entidades ligadas ao setor da exportação e de formação? 
Como se equilibram e equilibraram as lógicas económica, social e cultural próprias desta e de outras quintas durienses?

Ora, se os materiais de memória aqui em análise não permitem responder a todas estas questões importantes para o estudo sócio-histórico da Quinta dos Canais, como de outras quintas durienses, podem, no entanto, ajudar a estabelecer uma relação entre o que é lembrado e/ou esquecido na inteligibilidade do passado histórico. Trata-se, em suma, de toda uma história social que é preciso continuar a fazer sobre as quintas do Douro, para o que concorre o seu conhecimento social denso que as narrativas e memórias do trabalho, como as que aqui analisamos, permitem apreender.

Em síntese, é de realçar que nesta abordagem destacamos conteúdos do espaço-tempo, registados no mundo material ou vividos, transmitidos e reinterpretados pelos próprios atores sociais, agentes de uma autêntica «história vivida» ${ }^{393}$ dos trabalhadores que durante décadas decisivamente contribuíram em suas funções e tarefas, para a construção social e histórica da quinta, sua dimensão fulcral.

Trabalharam-se elementos constitutivos materiais e simbólicos de memórias e identidades produzidas em torno da Quinta dos Canais em seu contexto local/regional e conjunturas históricas.

Evidenciaram-se os elos de ligação entre memórias, materiais de memória e identidades por referência às condições de vida e de trabalho nesta paradigmática quinta duriense, ao longo do século XX.

Mobilizaram-se «metodologias do tempo presente», potenciadoras da dinâmica do conhecimento da memória individual, social e da experiência vivida e discursiva da identidade individual, local, regional e coletiva. A conjugação pluridisciplinar de métodos possibilitou a reconstrução reflexiva do acontecimento histórico e a «reposição» de elementos indiciários e des(re)construtivos de eventos em sua possibilidade de reescrita suscetível de conferir inteligibilidades mais vivas do passado.

No tópico da(s) memória(s) e identidade(s), noções de filiação simbólica, não estáticas nem essencialistas, mas efeito de interseções históricas e relações sociais estratégicas, constantemente (re)negociadas, nos discursos e narrativas de autodefinição que as produzem, ao dizê-las, ensaiámos aproximações complexas que no âmbito específico da análise histórica e sociológica, nos impuseram precauções para evitar os efeitos enviesados de conceções simplistas. A memória e a identidade são representações da realidade resultantes de elaborações subjetivas, mantendo entre si relações próximas mas não se equivalendo nunca. Dessas relações faz parte, por exemplo, a forma como a história é interpretada e apropriada pela memória que é sempre uma produção retroativa.

${ }^{393}$ Esta noção de «história vivida» (Pomian) encontra-se explicitada para o Douro Vinhateiro em LAGE \& LAGE, 2005. 
A abordagem sinteticamente apresentada teve também em devida atenção que o que se incrusta na memória não são os acontecimentos, mas a sua representação complexa e ambivalente do que e da forma como aconteceu.

Uma última reflexão se nos impõe. Sendo todo o trabalho de investigação científica sempre parcial e limitado, e a história um labor em sucessiva reformulação, a densa reconstituição histórica ensaiada sobre a Quinta dos Canais permite-nos perceber como a mesma se transformou numa grande quinta vitícola vocacionada para a exportação.

A combinação otimizada da sua localização geoclimática, das condições geomorfológicas do terreno, da escolha criteriosa das castas nela cultivadas e do trabalho humano incorporado na cultura das suas vinhas, no fabrico dos seus vinhos e nas experiências piloto da sua viticultura permitem qualificá-la como um «terroir» singular na região do Douro.

Assim, com uma espessura histórica e um papel especial na história do Douro e do concelho de Carrazeda, antigo produtor de vinho do Porto, onde se mantém como a sua quinta duriense de maior dimensão, a Quinta dos Canais e o seu estudo pluriperspetivado e multifacetado adquirem um significado referencial para o estudo de outras quintas do concelho em suas especificidades e importância próprias.

A análise articulada do seu conjunto permitirá então uma compreensão integrada e um conhecimento mais vasto e sólido desta constelação de quintas, alicerce fundamental para o conhecimento histórico e patrimonial do Douro Vinhateiro Património Mundial.

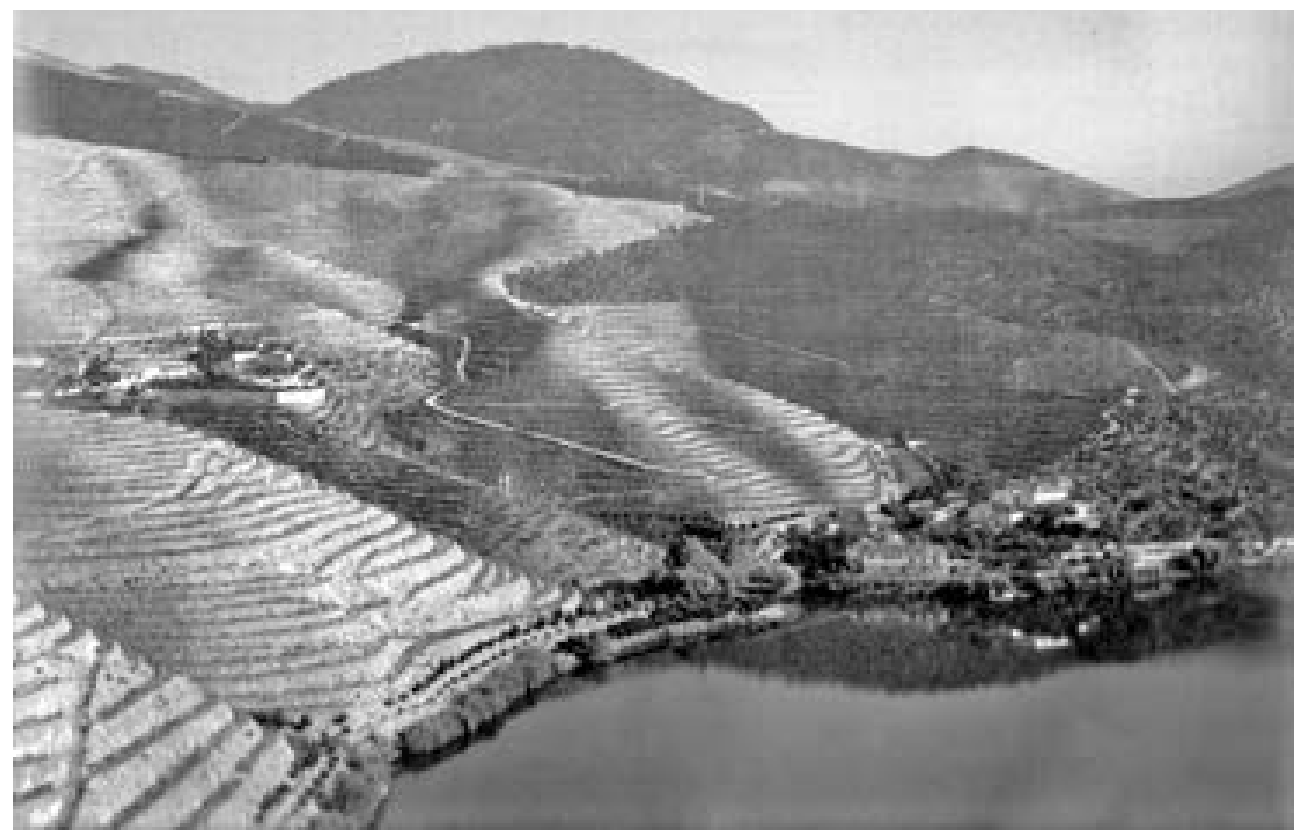

Fig. 65. A Quinta dos Canais (encosta do Douro) e a Quinta dos Canaes/Bartol (junto ao rio) Fonte: Fotografia de JML 


\subsection{QUINTACANAES-BARTOL:TRADIÇÃO FAMILIAR LUSO-ESPANHOLA NO DOURO}

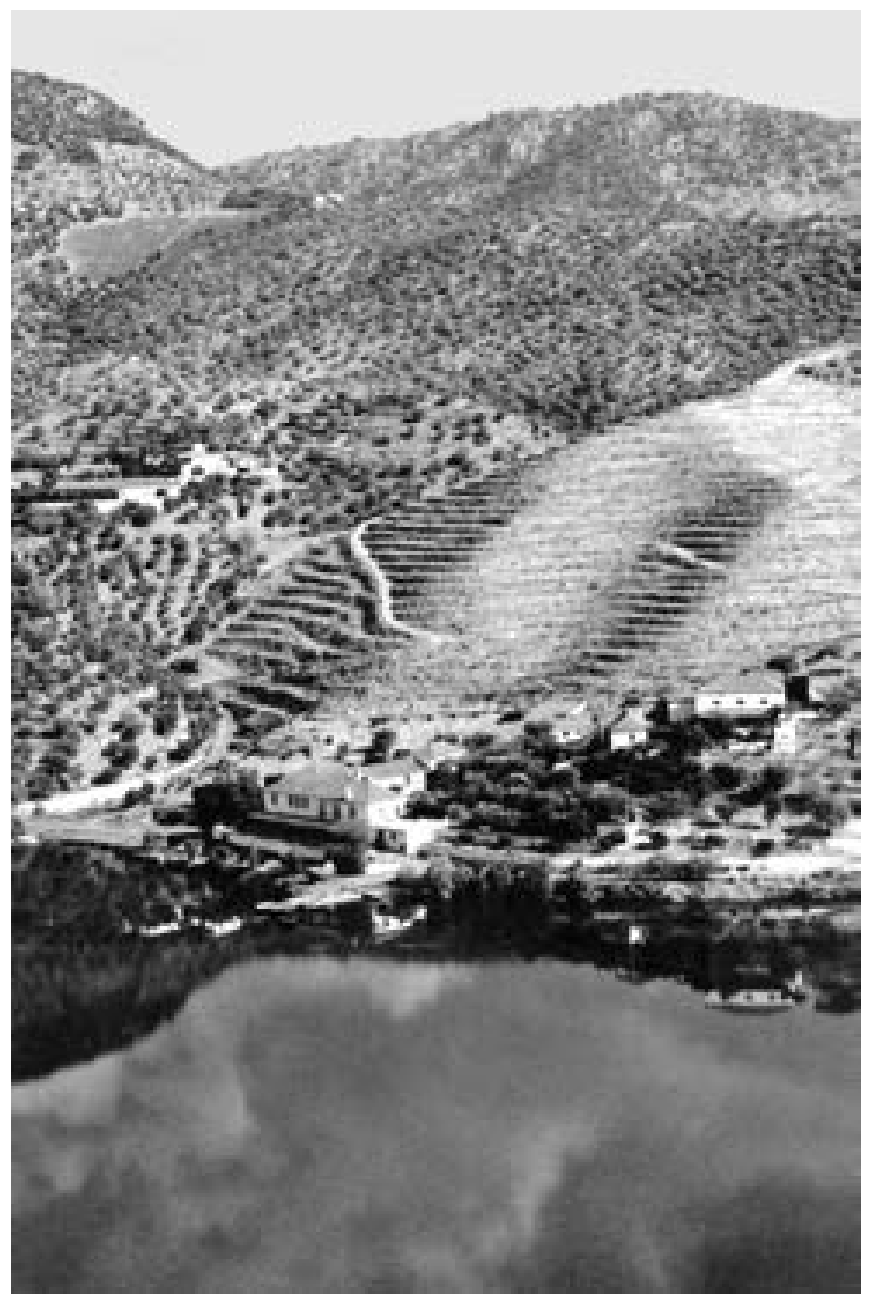

Fig. 66. Quinta Canaes/Bartol no ano de 1987: localização no Douro Fonte: Fotografia de Maria Luz Serrano 394

A Quinta Bartol integrada na sub-região duriense do Cima Corgo, com o objeto social de atividades agrícolas e hoteleiras, registada em nome de Maria Luz Egido Franqueira Serrano, descendente direta dos fundadores, desde 1987, ano em que nela se fazem novos saibra-

\footnotetext{
394 Todas as fotografias da Quinta Bartol aqui incluídas (exceto a dos antigos lagares, devidamente referenciada) são da autoria da Dra. Maria Luz Egido Franqueira de Campos Serrano, atual proprietária da quinta. Os créditos das fotografias publicadas, inclusive as dos membros de sucessivas gerações da família, foram-nos também generosamente cedidos pela Dra. Maria Luz Serrano a quem se agradece.
} 
mentos, e encontra-se há mais de 150 anos na posse da família Franqueira y Bartol de origem espanhola que se cruzou, por casamento, com família portuguesa natural da freguesia de Fontelonga do concelho de Carrazeda, na segunda metade do século XIX.

É, a vários títulos, caso único e exemplar das quintas durienses em Carrazeda, de notável tradição familiar luso-espanhola cuja reconversão de produtora original de cereal, olival e vinha em propriedade vinhateira em expansão com a produção e negócio de vinho do Porto de superior qualidade e posterior desenvolvimento sustentado se iniciou, a partir da crise filoxérica, tendo registado sucessivas ampliações, melhoramentos materiais e técnicos de relevo, nas décadas de 1960 a 1990.

\subsubsection{Caracterização histórica e descritiva}

A propriedade desta quinta, após a morte dos seus primeiros donos, o galego Don Ramon Franqueira, oriundo de Orense, e sua mulher Dona Maria da Anunciação Nunes Franqueira, natural da aldeia e freguesia de Fontelonga, concelho de Carrazeda de Ansiães, transmitiu-se por herança aos seus filhos e filhas, tendo vindo a concentrar-se, particularmente, durante o período da I República, por efeito de transmissões de propriedade inter vivos ou mortis causa, fixando-se por fim nas mãos de João Vicente Bartol, de nacionalidade espanhola, genro dos primitivos proprietários e nas de sua esposa Dona Adelaide Nunes Franqueira, aos quais esta Quinta passou a pertencer na sequência de partilhas (escritura de 18 de maio de 1922) ${ }^{395}$. Posteriormente, já durante o Estado Novo, a propriedade da Quinta Bartol transmitiu-se por herança do casal João Vicente Bartol e Adelaide Nunes Franqueira aos seus 3 filhos e filha: Lourenço Vicente Franqueira, Ramon Vicente Franqueira, José Vicente Franqueira e Maria Esperança Vicente Franqueira os quais, em 1941, com sua mãe, Dona Maria Adelaide Franqueira, viúva de J. Vicente Bartol, eram referenciados como coproprietários da Quinta ${ }^{396}$.

Maria Esperanza Vicente Franqueira, casada com o médico Dr. António Egido, espanhol exilado em Portugal, no contexto da Guerra Civil de Espanha em que, «do ponto de vista político não tendo pertencido ao lado republicano» foi vítima de «ato persecutório por ter tido um cargo de destaque no Hospital de S. Carlos em Madrid, no tempo da República espanhola ${ }^{397}$. O Dr. António Egido que fixara residência com a sua família restrita, na Quinta Bartol foi indigitado administrador dos negócios da quinta, em 1944, na qualidade de procurador dos restantes familiares e de sua esposa, Maria Esperanza Franqueira Egido, também nascida em Espanha, onde viveu e continuou a passar frequentes períodos de tempo, e se tornou em

\footnotetext{
${ }^{395}$ As sucessivas transmissões familiares da propriedade da Quinta Bartol encontram-se detalhadamente referenciadas em documento jurídico particular do Arquivo Privado da Família proprietária da Quinta Bartol, cujo acesso se agradece.

${ }^{396}$ Matrizes da freguesia de Beira Grande no Arquivo de Finanças de Carrazeda de Ansiães. Na sequência da Reorganização Administrativa do Território das Freguesias em 2013 (Lei n.o 11-A/2013, de 28 de janeiro) e influência das alterações do novo ordenamento jurídico na atividade administrativa em geral e na vida dos cidadãos.

${ }^{397}$ Informação de seu neto, por via materna, o Eng. Carlos Serrano, formado em Engenharia em Inglaterra, a quem se agradece a colaboração generosamente prestada no acesso a informações e alguns documentos sobre a história da Família da Quinta Bartol.
} 
1964, pouco antes do falecimento do marido, a única proprietária da Quinta até à sua morte, em 7 de novembro de 1986.

Ainda em 1986, após partilhas entre as duas filhas do casal Maria Esperanza Franqueira e António Egido, Dras. Maria Luz e Dolores Egido Vicente Franqueira, tomou posse da Quinta Bartol, então considerada em situação periclitante, a irmã mais velha, a Dra. Maria Luz E. V. F. de Campos Serrano que representa, atualmente, a família na administração e gestão dos assuntos da quinta. A Dra. Maria Luz Egido Franqueira de Campos, jurista de formação, casou com o empresário industrial português, José de Campos Rodrigues Serrano, falecido em 26 de dezembro de 2005, sendo mãe de quatro filhos e avó de 9 netos. O seu marido, homem de grande empreendedorismo e iniciativa empresarial, especializado em «Engenharia Alimentar, curso industrial que concluiu em França e com estágio em Itália» ${ }^{398}$, foi um dos membros recentes da família proprietária da quinta que muito contribuiu para o seu revigoramento produtivo, nas décadas de 1980 e 1990. Não só aí passou a «investir nas novas plantações de vinha nos anos 1980, com recurso a capitais próprios» como influenciou a introdução de «importantes melhorias, tendo modernizado totalmente a antiga fábrica de azeite construída ainda no século XIX e reapetrechando-a com novas prensas e as mais modernas máquinas ${ }^{399}{ }$.

A proprietária atual da Quinta Bartol, Dra. Maria Luz Egido Franqueira de Campos Serrano, mantém a sua antiga e resiliente tradição luso-espanhola e continua a assegurar a administração e supervisão de quase todos os assuntos desta propriedade, tendo herdado de sua mãe, Dona Maria Esperanza Bartol, avó materna, Dona Maria Adelaide Franqueira Bartol, e de sua bisavó materna, Dona Maria da Anunciação Nunes Franqueira, um especial interesse e notável posição no acompanhamento da gestão, administração e desenvolvimento da quinta, componente feminina da história da Quinta Bartol e da família proprietária, caso aliás praticamente único no Douro Vinhateiro (ver Anexo II).

Aprazível e próspera propriedade vitivinícola situada no coração do Douro Património Mundial, a Quinta Canaes-Bartol, designação histórico-familiar que a sua proprietária atual preserva, caracteriza-se por vários aspetos: uma longa e densa história, forte identidade familiar assente no cruzamento de famílias tradicionais portuguesas e espanholas, estas radicadas em Portugal, na primeira metade do século XX; uma antiga e constante produção de vinhos generosos considerados de alta qualidade; e um peculiar património (i)material e paisagístico em que se destacam os bonitos jardins em socalcos de antiga construção, as casas de residência dos patrões, de arquitetura tradicional, as acomodações simples para os trabalhadores e as instalações funcionais de apoio às atividades correntes da cultura vitivinícola como os armazéns, os lagares de granito e a velha forja, típicos da generalidade das quintas durienses de média dimensão.

\footnotetext{
${ }^{398}$ Informação de seu neto, por via materna, o Eng. Carlos Serrano, formado em Engenharia em Inglaterra, a quem se agradece a colaboração generosamente prestada no acesso a informações e alguns documentos sobre a história da Família da Quinta Bartol.

${ }^{399}$ Testemunho de sua esposa, Dra. Maria Luz Serrano.
} 
Como as fotografias da quinta ilustram e documentam, os vinhedos, com ótima exposição solar, dispõem-se ao longo de uma cota mais elevada do terreno abaixo da qual, em cotas inferiores descendo para o rio, se construíram as instalações de residência, armazenamento, lazer e trabalho.

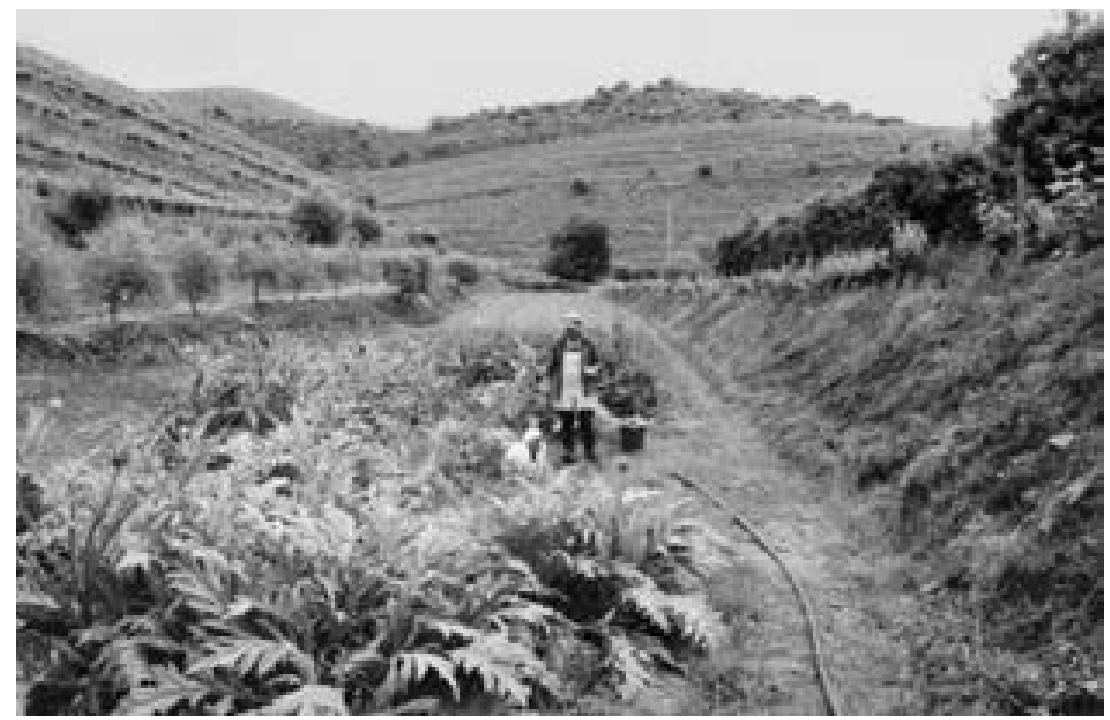

Fig. 67. Vinhedos, oliveiras e plantação de alcachofras Fonte: Fotografia de Maria Luz Serrano

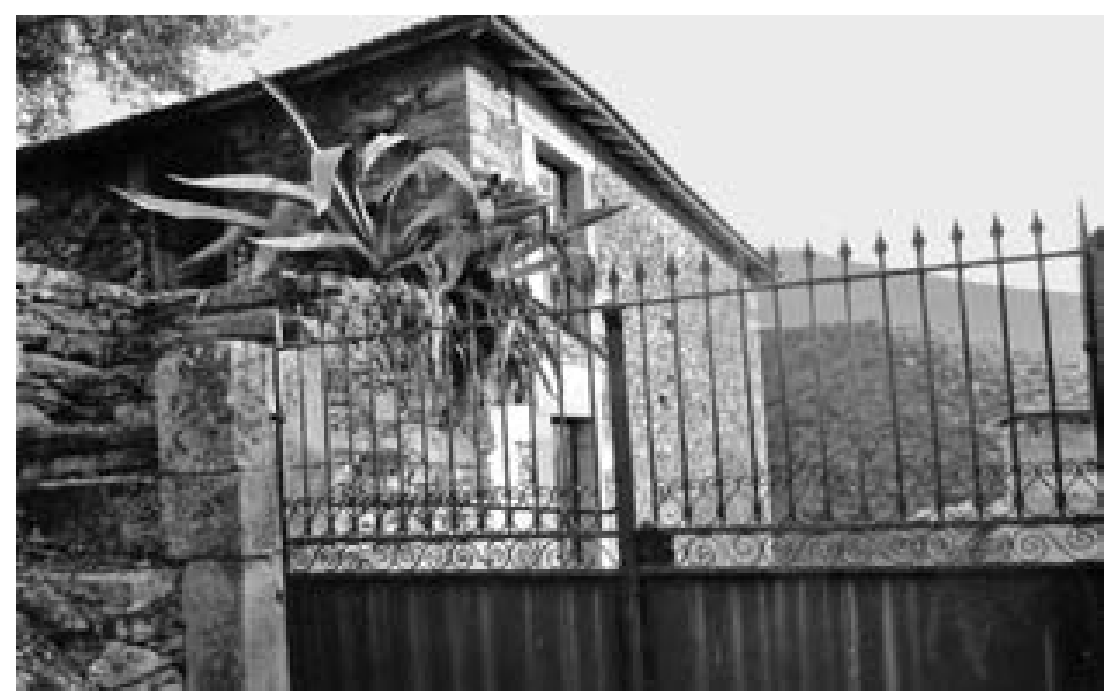

Fig. 68. Portão e instalações parciais da Quinta Bartol Fonte: Fotografia de Maria Luz Serrano 


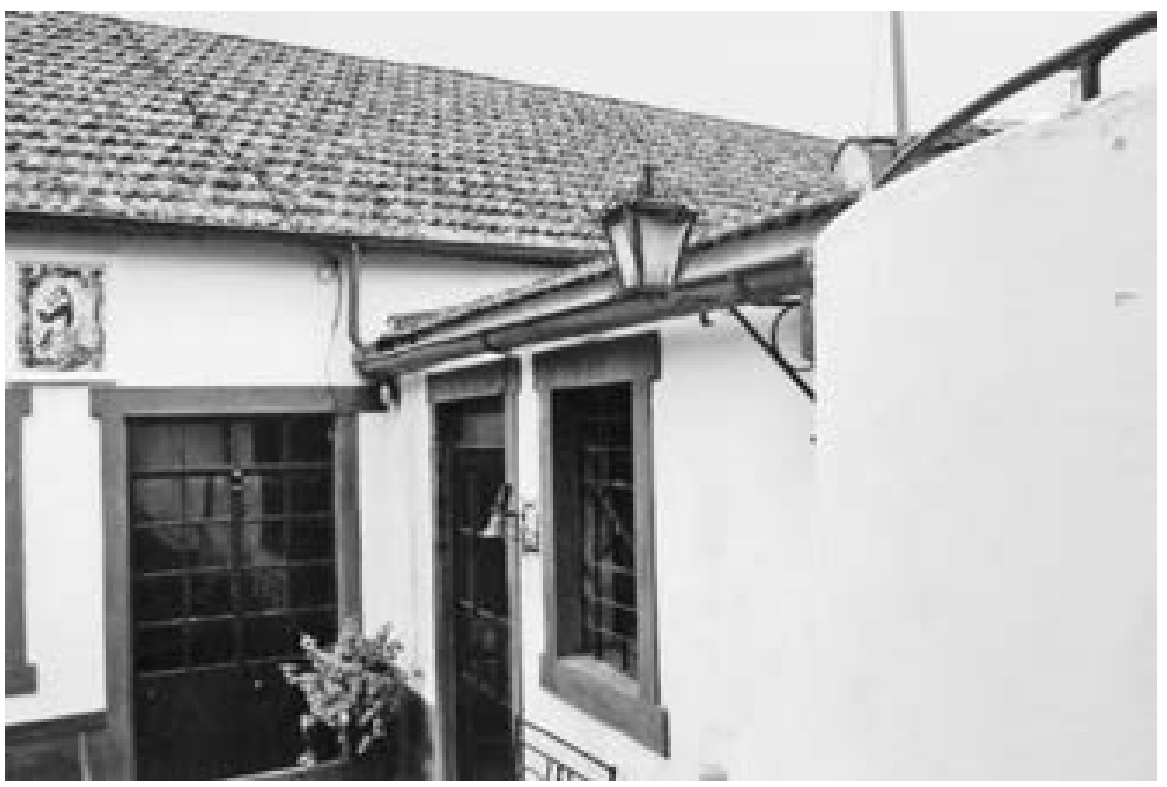

Fig. 69. Casa antiga dos primitivos patrões Fonte: Fotografia de Maria Luz Serrano

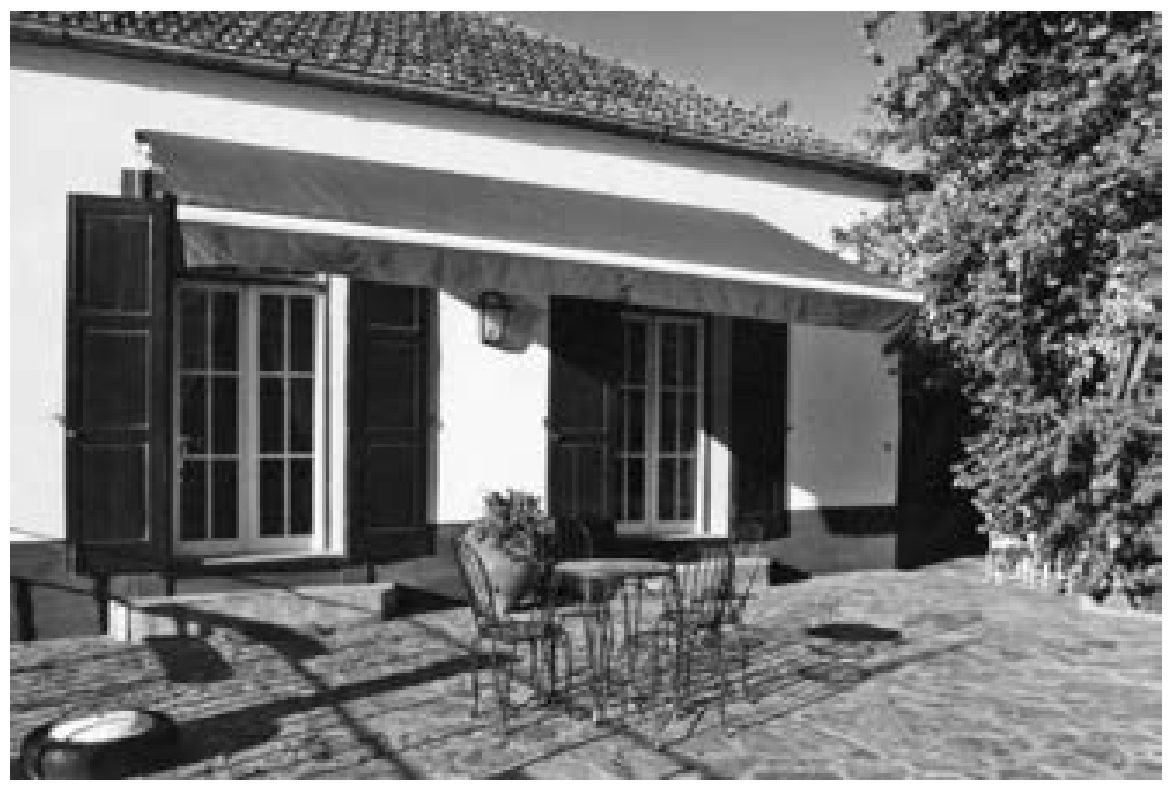

Fig. 70. Casa principal ampliada Fonte: Fotografia de Maria Luz Serrano 


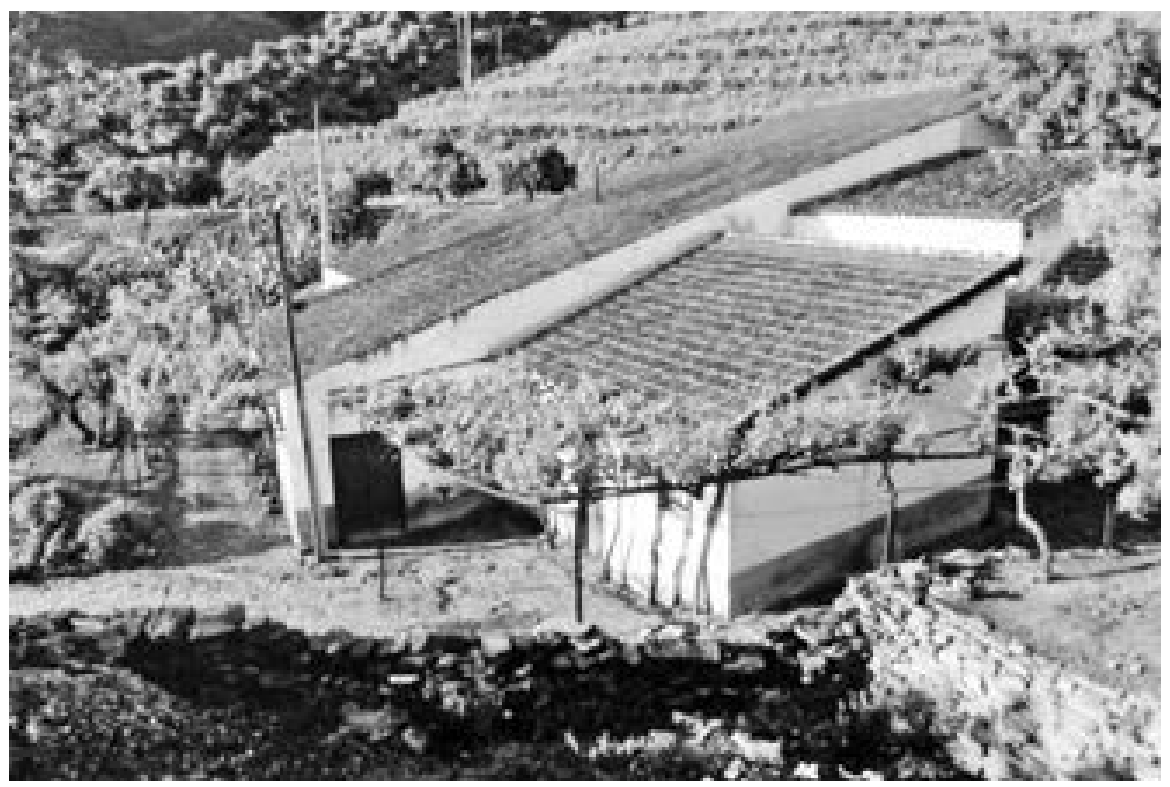

Fig. 71. Antigo armazém de azeite

Fonte: Fotografia de Maria Luz Serrano

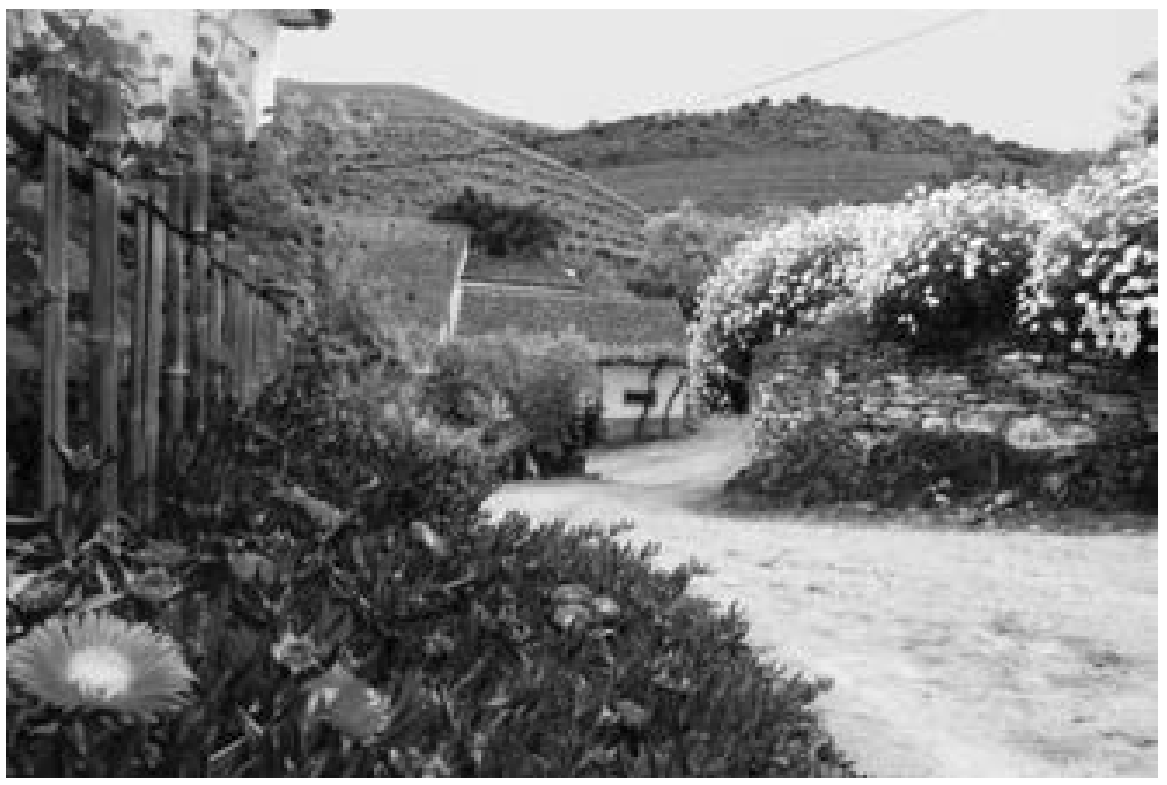

Fig. 72. Armazéns, lagares e forja antiga

Fonte: Fotografia de Maria Luz Serrano 


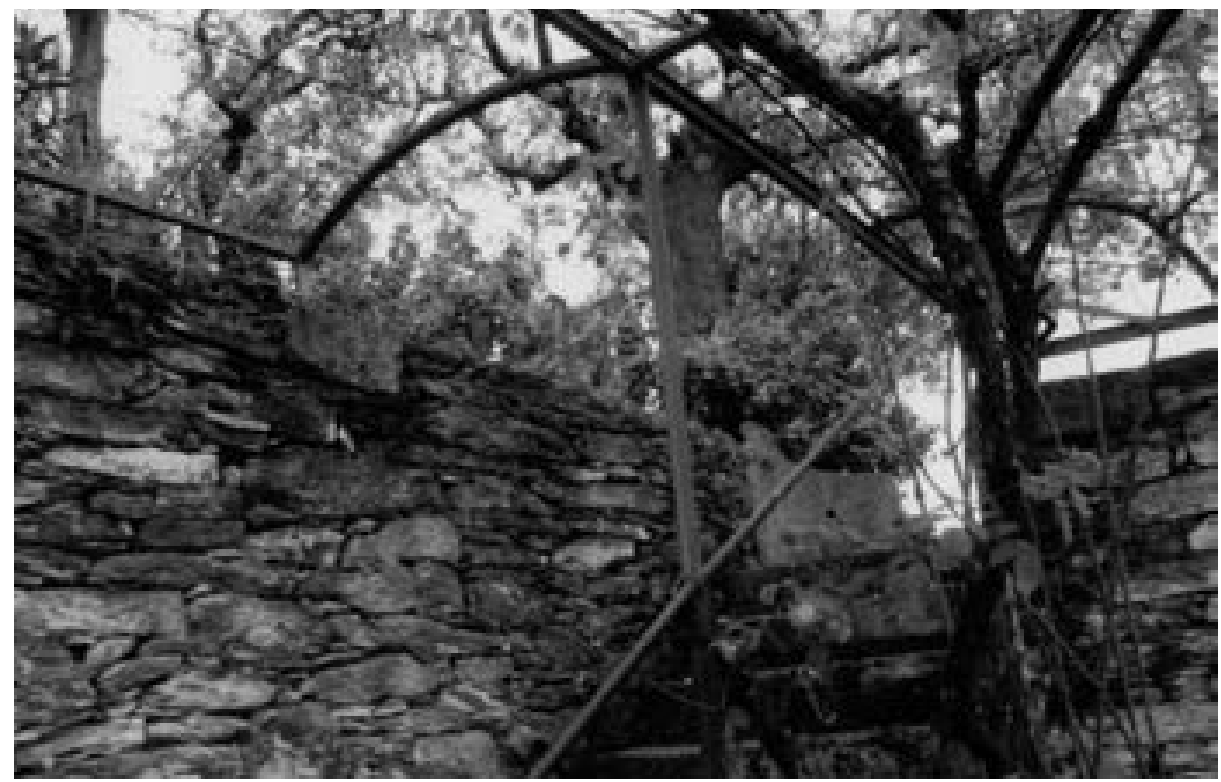

Fig. 73. Ramada em ferro entre socalcos

Fonte: Fotografia de Maria Luz Serrano

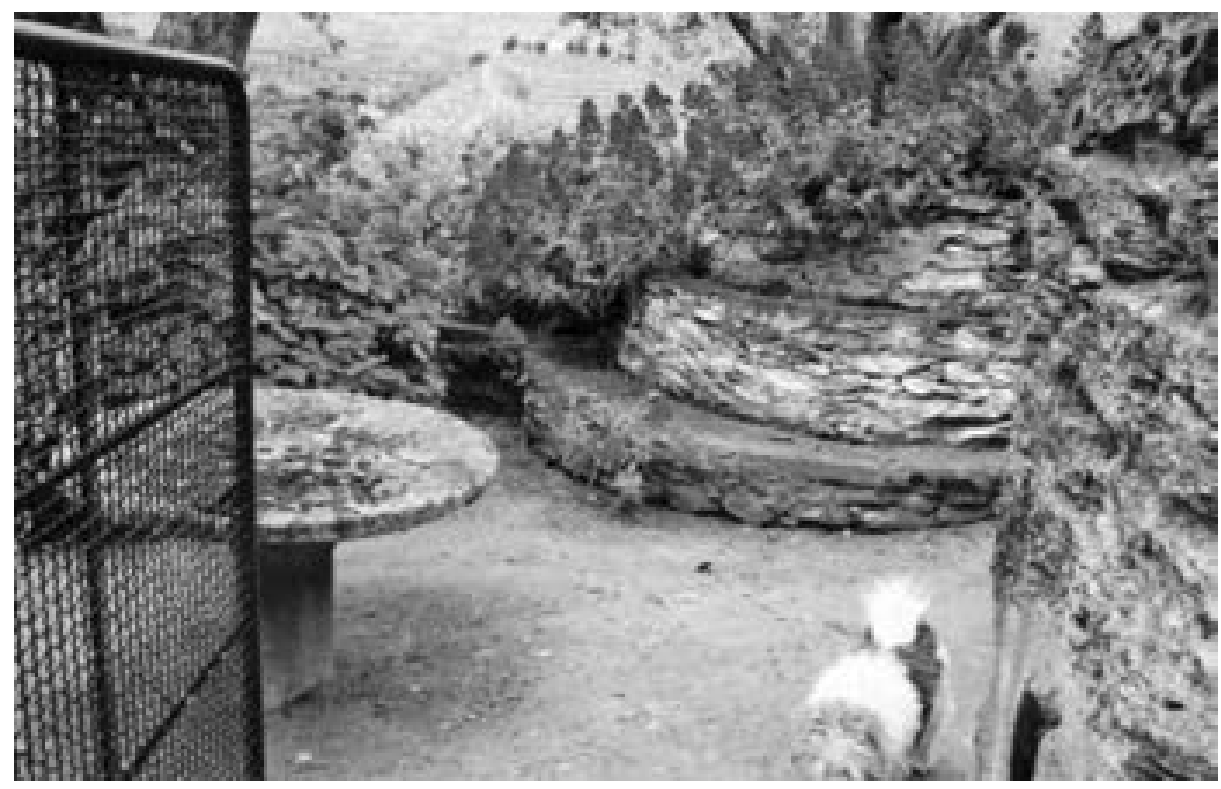

Fig. 74. Jardins em calços

Fonte: fotografia de Maria Luz Serrano 


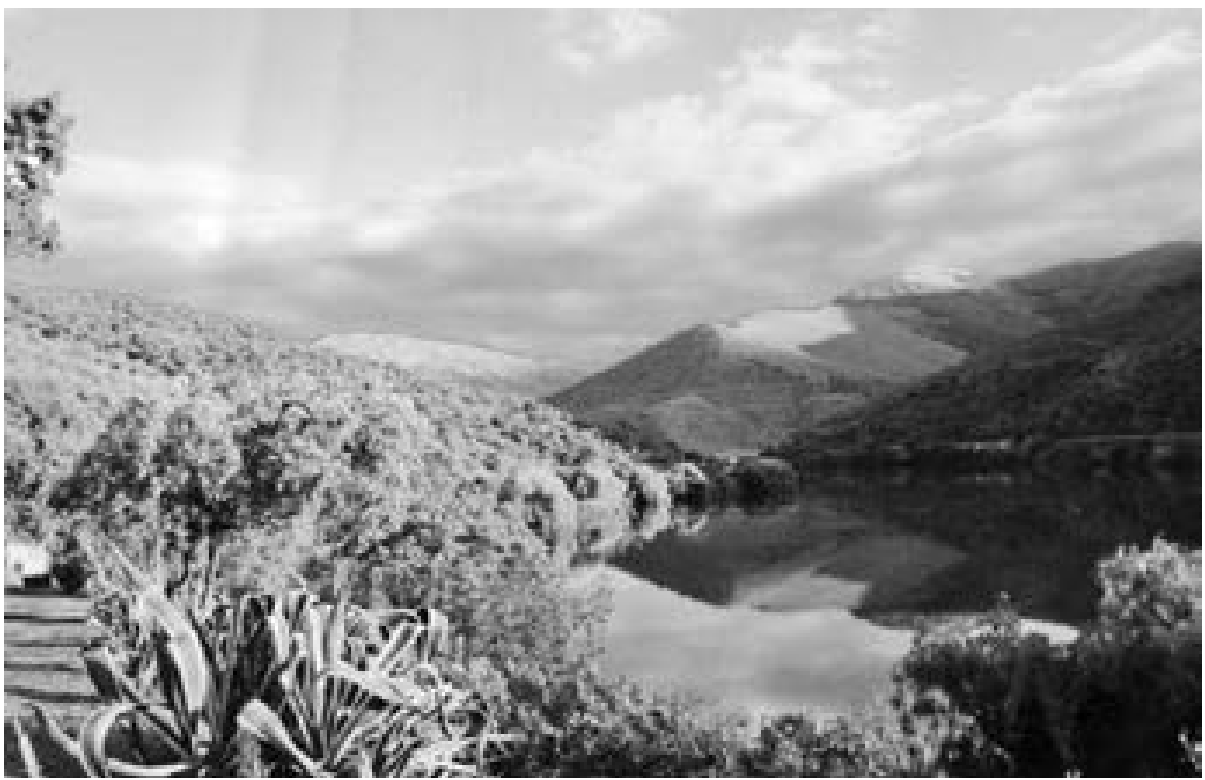

Fig. 75. Vista do Douro a partir da Quinta Fonte: fotografia de Maria Luz Serrano

Na década de 1980, a Quinta Bartol tinha já «uma área de 88.0368 ha composta por uma propriedade com casa de recolha, armazém atravessado por caminho, vinha com 61.434 cepas, 9.298 oliveiras, (sendo 171 alheias), 2.455 amendoeiras, 22 laranjeiras e 10 figueiras, confrontando a norte com caminho, a sul com o rio Douro, a nascente com ribeiro e a poente com Ramiro Sobral». Presentemente «encontra-se inscrita na correspondente matriz predial rústica no artigo 4558 rústico da União de Freguesias de Lavandeira, Beira Grande e Selores que corresponde ao artigo 2014 rústico da freguesia de Beira Grande» ${ }^{400}$.

Tem produzido, e produz ainda, uma média anual de 80 pipas de vinho generoso (tinto e branco) considerados de alta qualidade, produção da colheita anual de uvas próprias a que, tradicionalmente, junta grande quantidade de uvas compradas a seus «arrobeiros» e pequenos lavradores vizinhos.

Os vinhos provenientes dos seus vinhedos têm sido, como desde os anos 1960, predominantemente classificados nas letras A e B, cerca de 30.000 litros e, na letra D, cerca de 1000 litros.

Presentemente, o gerente da Quinta Bartol, responsável pela sua cultura e produção vitivinícola, é o engenheiro Frederico Meireles (enólogo) dono da Empresa de Vinhos Grambeira em Carrazeda de Ansiães ${ }^{401}$, que exerce as mesmas funções na quinta, desde a década de 1990.

\footnotetext{
${ }^{400}$ Documento do arquivo particular da Quinta Bartol, baseado na análise das respetivas cadernetas prediais, cuja consulta nos foi disponibilizada pela Dra. Maria Luz Serrano a quem se agradece.

${ }^{401}$ Ver apresentação e breve história da empresa Grambeira no Capítulo 8.
} 
A Quinta Bartol tem vendido, sucessivamente, a sua produção vinícola reconhecida como de especial qualidade a diferentes firmas estrangeiras exportadoras de vinho do Porto: a Croft, a Martinez Gassiot, empresa que inaugura na Régua, em 1977, o primeiro grande armazém de maturação do vinho do Porto, situado na RDD, a Cockburn \& Smiths, os Symington e, atualmente, a Taylor, proprietária da Quinta de Vargelas que lhe fica em frente na margem oposta do rio Douro, com estação ferroviária na Linha do Douro, correio e cais fluvial, meios de acesso e comunicação com esta e outras quintas durienses próximas, localizadas na margem direita, concelho de Carrazeda de Ansiães.

\subsubsection{Localização e denominações da Quinta}

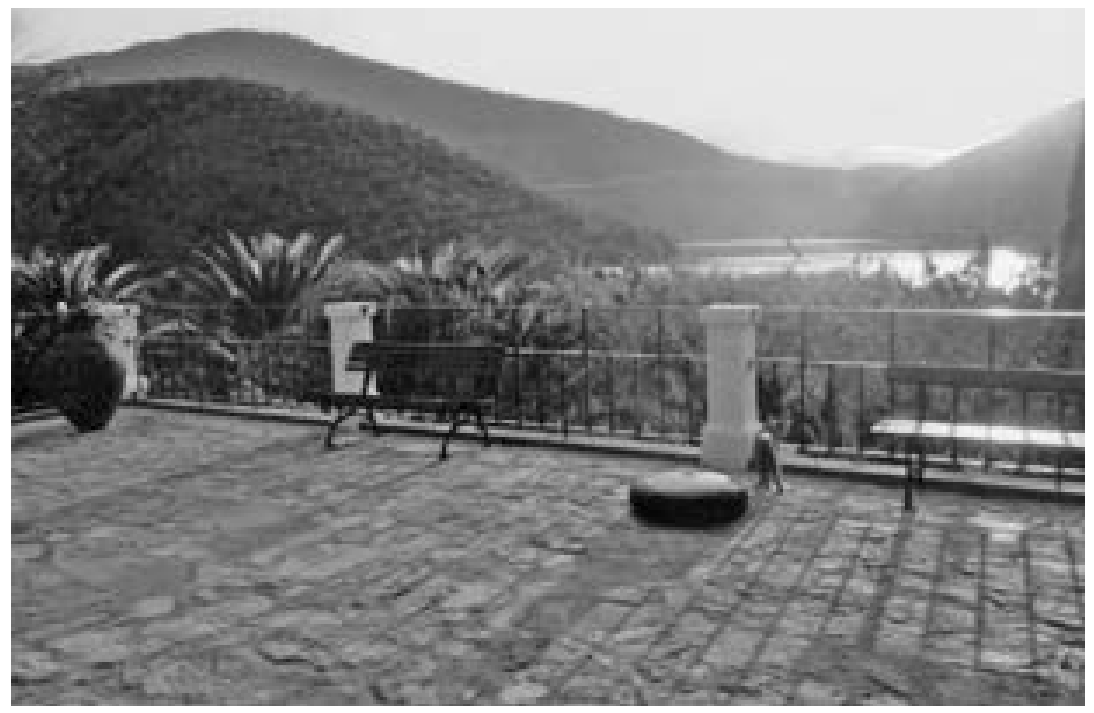

Fig. 76. Miradouro da Quinta Bartol

Fonte: Fotografia de Maria Luz Serrano

Debruçada sobre o Douro que margina ao longo de $2 \mathrm{~km}$, esta quinta, dotada de nascentes próprias de água, apresenta ótima localização e situação privilegiada na margem do rio, limite da Beira Grande, ex-freguesia de Carrazeda de Ansiães.

Confina com a Quinta dos Canais, denominação moderna derivada da antiga palavra Canaes que a quinta Bartol tem reclamado para si, historicamente, tendo-a mesmo mantido na nova designação «Quinta dos Canaes-Bartol», em 1937, data em que, por decisão de D. João Vicente Bartol ${ }^{402}$, foi assim averbada na matriz predial rústica correspondente, nos Ser-

\footnotetext{
${ }^{402}$ Segundo memórias de sua neta, a atual proprietária da quinta, Dra. Maria Luz Egido Vicente Franqueira de Campos Serrano, tal decisão deveu-se à necessidade de regularizar a normal receção na quinta do seu correio que aí chegava de barco, a partir da estação de Vargelas, evitando as frequentes perdas de correspondência por extravios para a vizinha Quinta dos Canais, então propriedade de Francisco Costa.
} 
viços de Finanças de Carrazeda, reunindo-se então num só número matricial as matrizes dispersas das propriedades da família nesse local junto ao Douro: quintas da Barreira e do Padre Vitorino, para além da antiga Quinta dos Canaes mais outras terras e prédios contíguos.

A atual Quinta Bartol encontrava-se inscrita na Repartição de Finanças de Carrazeda, para pagamento de impostos, pelo menos desde os anos 1930, como Quinta dos Canais de Baixo, diferenciada da Quinta dos Canais de Cima, quinta, já à época, de Francisco Manuel da Costa, proprietário «brasileiro» de torna-viagem, cujo nome continua ainda hoje localmente a ser conhecido como antigo dono dos Canais com grande influência por pertencer à Maçonaria. A essa antiga denominação «Quinta dos Canaes» se refere ainda em carta de 1979, para a empresa Martinez Gassiot, a sua então proprietária, Dona Esperança Franqueira Bartol. A designação Quinta dos Canais continuou a ser disputada entre as duas quintas limítrofes: Bartol e Canais, de diferentes proprietários, mas ambas localizadas na mesma zona do rio Douro, outrora chamada «quintas dos canaes».

Foi e é ainda hoje também chamada, localmente, de «Quinta do Doutor Espanhol» por referência à tradição familiar de seu administrador nos anos 1940, o médico espanhol Dr. António Egido Vicente, casado com Dona Maria Esperança V. Franqueira y Bartol de Egido, herdeira, com os irmãos, da quinta e pais da atual proprietária. Tendo aí vivido largos anos exilado, o Dr. António Egido tornou-se muito conhecido e respeitado entre as populações desta zona e numa vasta área da região do Douro como clinico reputado, experiente de vasta sabedoria e grande dedicação a seus doentes que vinham de longe a pé até à quinta para serem consultados por ele que operara algumas vezes no hospital de Coimbra e fora assistente na Universidade de Salamanca, onde se licenciou, tendo sido depois convidado para diretor dos serviços de cirurgia no Hospital D. Carlos de Madrid onde exerceu, com relevo, clinica especializada, tendo acabado antes de falecer por ser reabilitado como médico em Espanha.

\section{Antecedentes históricos e sucessão dos titulares da Quinta}

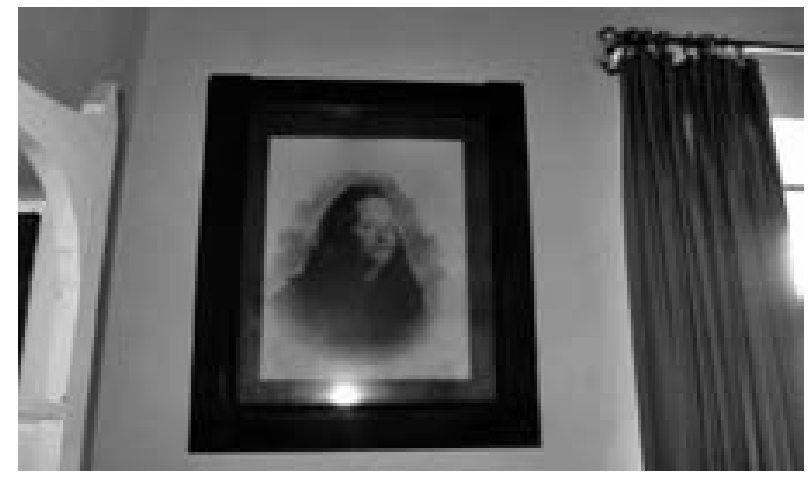

Fig. 77. Dona Maria da Anunciação Nunes, viúva de Ramon Franqueira Fonte: Fotografia de família 
Trata-se de uma antiga quinta duriense que mudou de mãos por ocasião do surto de filoxera que se manifestou no concelho de Carrazeda em 1879, tendo aqui também originado, como por toda a região do Douro, grande movimentação de compra, venda e junção de propriedades, seguida de intensa migração galega, na sua maioria, canteiros experimentados no trabalho da pedra e ligada à construção dos históricos geios e socalcos dos vinhedos durienses ${ }^{403}$.

Se bem que haja quem registe para o século XVIII, como antigos proprietários da «Quinta de Canais de Baixo [...] constituída por terras de cereal, olival, canhameiras [canas de cânhamo] junto ao rio e dentro dele uma azenha com três rodas», os morgados de Alganhafres, pequena povoação de Carrazeda, próxima da quinta, que a teriam vendido a Ramon Franqueira ${ }^{404}$, é este, com sua esposa, Dona Maria da Anunciação Nunes, natural da aldeia de Fontelonga que são considerados pelos seus descendentes, como os proprietários mais antigos, fundadores e obreiros principais do desenvolvimento da Quinta Canaes-Bartol.

Ramon Franqueira que se tornou num dos grandes proprietários não só da freguesia de Fontelonga onde casara (como duas de suas filhas, também casadas com cidadãos espanhóis) ${ }^{405}$, mas ainda do concelho de Carrazeda onde adquiriu numerosos bens. Nestes destacam-se as quintas dos Canais de Baixo e da Barreira, que aumentou intensificando a sua produção então essencialmente de cereal e azeite.

Com grande visão empreendedora e iniciativa, Ramon Franqueira foi ainda empreendedor quer na cultura do bicho da seda quer no fabrico de brandy, produtos com que participou, em representação de Portugal, na Exposição Universal de Filadélfia de $1876^{406}$, conservando-se ainda hoje na quinta os antigos cascos de tamanho reduzido destinados a armazenar essa bebida $^{407}$.

Documentam essa participação pioneira de Ramon Franqueira (Fontelonga), as duas páginas seguintes do catálogo dessa Exposição ${ }^{408}$. Saliente-se que aí a representação portuguesa com produtos de origem vegetal (brandy e vinho) se resumia a ele, a Dona Antónia Ferreira e a um viticultor de Nogueira e, nos artigos de origem animal do distrito de Bragança, Trás-os-Montes, só ele aparecia, com casulos do bicho-da-seda, para além de outro produtor do concelho de Carrazeda, José de Almeida Veiga (com lã).

\footnotetext{
${ }^{403}$ Alguns destes galegos viriam a casar em terras de Carrazeda de Ansiães, por aqui se tendo radicado e mantendo-se seus descendentes ainda hoje em certas povoações do concelho onde são conhecidas famílias de origem galega como no Fiolhal os Benigno, Hernandez e Vasquez ou, na vila de Carrazeda, os Saavedra. (Fontes orais).

${ }^{404}$ MORAIS, 2014: 57.

${ }^{405}$ ADB - Paróquia de Fontelonga, Registo de casamentos, Registo de casamentos 1845-1887, fl. 53; Registo de casamentos 1894/1894, fl. 2.

${ }^{406}$ Esta Exposição, inaugurada pelo Presidente dos EUA e pelo imperador do Brasil, D. Pedro II, evocativa do centenário da independência americana e em que foram apresentadas invenções como o telefone de Bell, marca o início do caráter evocativo-comemorativo das exposições universais que se realizaram na segunda metade do século XIX, como «lições de coisas» em que a sociedade industrial então se estruturava.

${ }^{407}$ Informações de sua bisneta, atual proprietária da quinta e de um de seus filhos.

${ }^{408}$ Agradece-se cópia destas páginas do catálogo da Feira Universal de Filadelfia ao seu trineto, Eng. Carlos Serrano.
} 
PORTUGAL.

Animat and Vegetable Prodects.

952 Oulando, Joso Buptista Ribatio.

9ss Galvas, Sabino Joas M. dev Anjos. Aneirs, Clates - whe

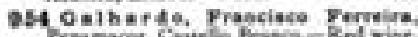

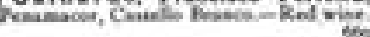

955 Cuedan Antonie Pinto de Carvalibo.

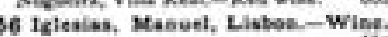

057 Jones, Jast Aloass, Requengo. Jon

95s Mello, Bente de Casure Ceritho 9.

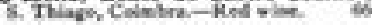

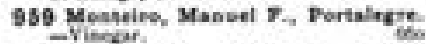

961 Evieves, Marcel to Mirunda, Ce 82 telaste, Jeep Moric te Magaltaes.

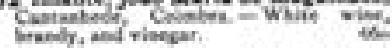

0ej Sotrvy. Jeas Mancel, Condernis, 964 Kebe, E, A Co., Oporte-Part tise.

9es Drack, Joue kibeirs Ouimarare.

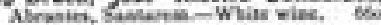

946 Prabsetirs. Rewaea, Peaselenca.

967 Verre, Narcies Telasira Martiks:

9ss Yerreira A Doursed, Operte--Pegs wine

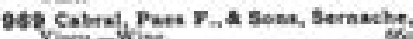
Viavu-Wine.

970 Yerreira, Antosia Adelaids, Oedim.

971 Feries, Jost Maric, Santar, Visey.

972 Yaria, M. A. P. Mamos, Colerles de

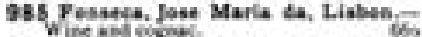
ose France, Matuet Antuaes, Certe-

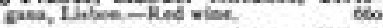
Os7 Verrari, Oustawe, Liabea-Wing.

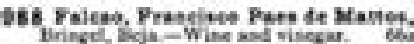

9s9 Yerreira, Josguan icnotia, Liebon.

998 Doarte, Jutie Cenarie Perreirs, AF.

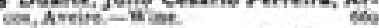

999 Dias, fese da Fenates, OEivaline do 1009 Deas, Joas Rodrifues de, Terres

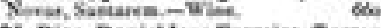
1001 Dian, Daniel Jone Ferrain, Terres 1602 Dearte, Jase Baptiasa, Casiello 1003 Deris, Jeas, Heja.-Wine. 1004 Deris B, Covisha, Castelle 1005 Dejange \& Ce., Bom Sactanes, 1006 Coalho, Jr, Antonla Vereas, Cal.

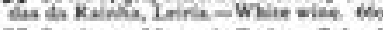
1007 Cardoso, Manuet Patro, Sebrat

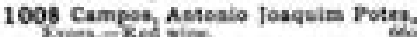
1009 Cartilhs, Aateale de, Vula Soeigg. 1010 Copks Freneises, Celleres, Lit: 1011 Dias Masust 1cnacio, Cons, Co-

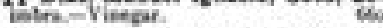
1012 Dursts, Lais Assealo, Persede. 1013 Dow a Ca, Oporto- Port wine.

Textile Substances, Eegineering and Adminiatration.

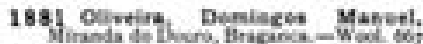

13:2 Vascoseelles, Barbobemeu

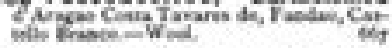

1383 Mirabla, Asterie Auceste Labe 484 Bocatas, Jos Josyalm, Vale.

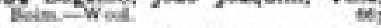

1835 Bello, Francince Severtanne Car.

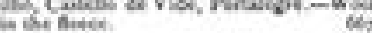

1895 Coetho, Luin Pires, Bardes! 987 Quimseres, Visserise Narbeso. Tresilal, Opons,-Wost.

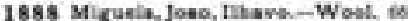
1899 Castal Drance, Franclioce Dareeta

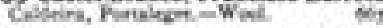

1890 racse, terare Demin cas, Reves,

togt Geraldes. Mosued Var Proty.

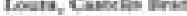

1892 Veige, Joue drAimeids, Anciaes;

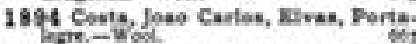

1895 Cie, Jeat Icsotie, Miraselli.

1394 Ceatrat Comelusias of the Diatrict Vines, viaes.

is Whit

1897 Nents, Antonis Neswet, Chacim,

1893 Frascualirn, Kowas, Carrasede. recatica monowest

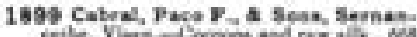
900 sita Manofasturise Campasy.

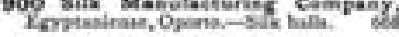

Agriestsaral Periaetriag and Ad. nivintrative.

1901 Recha a Cov Lisbon,-Artiscla! crikhs a a Con, Liobon,-Aniskis 1002 Alwssolir of Lisbos, Nicantars.

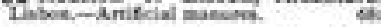
1904 Thoupbarite Cempany, Mar 1905 Deart of Publis Feecate, Listes. Cardes woth.

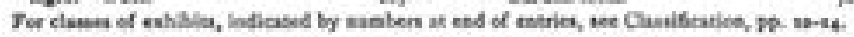


Natural de Santa Maria de Vilar de Ordelas, em Orense (Galiza), Ramon Franqueira veio para Portugal por motivos políticos, na 1. ${ }^{a}$ metade de Oitocentos, durante a 2. ${ }^{a}$ Guerra Carlista em Espanha ${ }^{409}$, tendo casado em 1858, em Fontelonga, freguesia de Carrazeda de Ansiães, com Dona Maria da Anunciação Nunes, natural desta aldeia ${ }^{410} \mathrm{e}$ herdeira de propriedades agrícolas, na margem direita do Douro. Anos depois, em 1877, comprou por «um conto e duzentos mil réis em metal sonante», a Dona Silvina Malheiro e marido, Francisco Ferreira, enfiteutas nos Canaes, residentes na comarca de Penafiel, o «domínio útil ${ }^{411}$ ou prazo da quinta composta de casas, vinha, olivais, terra de cereal e confinante a nascente e norte com João Cardoso Valente e sul com Ramon Franqueira ${ }^{412}$.

Como se deduz das confrontações, dom Ramon possuía já terras nesta zona do Douro, tal como João Cardoso Valente que, ao que se pôde apurar, viria a ser deputado e agraciado com o título de conde de Taboeira e cuja viúva ${ }^{413}$ viria a vender nesta mesma zona, a antiga quinta da Forneira, integrada na Quinta dos Canais como aí já referido.

Em 1889, a então designada Quinta dos Canaes era assim descrita: «uma propriedade no sítio de Canaes, denominada quinta dos Canaes, que consta de terra de lavradio, vinha, olival, montez, casa de habitação, casas para caseiros, armazéns e lagares de fazer vinho, azenha, forja, diferentes casas para recolher alfaias e instrumentos agrícolas e mais pertenças, tudo unido pelo norte e poente com Francisco Carmo Valente, do Porto, sul com o rio Douro e do nascente com ribeiro do Vale do Martinho» ${ }^{414}$.

\section{- Transmissão intrafamiliar da propriedade da quinta}

Por morte de Ramon Franqueira, em 24 de novembro de 1889, sucederam-lhe os 4 filhos do casal, Dona Maria da Luz Franqueira, casada com António La Puente, Guilherme Nunes Franqueira, solteiro, Dona Cândida Amélia Nunes Franqueira Gonçalves, casada com António Gonçalves Júnior e Adelaide Nunes Franqueira, solteira menor, tendo-lhes cabido, designadamente a propriedade da Quinta dos Canaes nas seguintes proporções: a meação de 4/8 à viúva e 1/8 a cada um dos 4 filhos, do remanescente.

\footnotetext{
${ }^{409}$ Guerras Carlistas em Espanha (1.a guerra 1833-1840; 2. a guerra 1846-1849; 3.a 1872-1876) guerras de sucessão ao trono, entre partidários do pretendente absolutista D. Carlos Maria Isidro de Bourbon e apoiantes liberais de Dona Isabel II e da Regente Dona Maria Cristina e, mais tarde, do rei D. Afonso XII.

${ }^{410}$ ADB — Paróquia de Fontelonga, Registo de Casamentos, Registo de Casamentos 1854-1887, fl. 7.

${ }^{411}$ De acordo com o Artigo 1491 do Código Civil, o antigo ordenamento jurídico de emprazamento, aforamento ou enfiteuse hoje abolido em Portugal, consiste no desmembramento do direito de propriedade em dois domínios, denominados direto e útil. O titular do domínio direto é designado por senhorio; o do domínio útil: foreiro ou enfiteuta. O prédio sujeito a enfiteuse diz-se prazo e pode ser rústico ou urbano (apud CORDEIRO, 2008: 285-315). ${ }^{412} \mathrm{ADB} / \mathrm{ANCA}$ - Livro do Tabelião José de Morais, 1877, fl. 4v-7.

${ }^{413}$ Dona Aurora Muñoz Puig Valente (1861-1945), casada com João Cardoso Valente (1859-1903), deputado da Câmara dos Deputados, em 1884-87 e 1989, depois $1 .^{\circ}$ conde de Taboeira, título criado por D. Carlos I, em 1901, em seu favor, válido em vida.

${ }^{414}$ Verba 81 do Inventário de menores instaurado em 10 de dezembro de 1889, no Tribunal Judicial do Julgado de Carrazeda de Ansiães, referido em documento particular do Arquivo Familiar da Quinta Bartol, cuja consulta nos foi facultada generosamente pela representante atual da quinta Dra. Maria da Luz Serrano a quem se está grata, por todo o importante apoio prestado.
} 
Em finais do século XIX, inícios do século XX, a viúva de Ramon Franqueira, Dona Maria da Anunciação Nunes Franqueira, tomou conta da gestão e administração da quinta que continuou a ampliar através da compra sucessiva de novas propriedades, até ao seu falecimento em 8 de fevereiro de 1916, já durante a I República.

Ainda em 1912, Dona Maria da Anunciação aparece ${ }^{415}$ como coproprietária das quintas Canais e Barreira e outras terras dispersas, juntamente com um dos seus genros, João Vicente Bartol, de nacionalidade espanhola ${ }^{416}$, entretanto casado em Fontelonga, aos 30 anos, com a jovem de 17 anos, Maria Adelaide Franqueira, uma das filhas de Dona Maria da Anunciação Nunes Franqueira e de Romão Franqueira ${ }^{417}$. Com as alterações verificadas no estado civil desta filha e de seu irmão Guilherme Franqueira, neste ínterim, casado com Dona Maria Amélia Ferraz de Azevedo, os filhos herdaram os 4/8 da mãe na propriedade desta Quinta também na proporção de $1 / 8$ cada um.

Em 29 de setembro de 1917, por escritura de compra e venda, a metade da Quinta pertencente a Guilherme Nunes Franqueira com sua esposa, Dona Maria Amélia Ferraz de Azevedo Franqueira e a sua irmã, Dona Cândida Amélia Nunes Franqueira, com seu marido António Gonçalves Júnior Martinho, foi vendida aos proprietários da outra metade, João Vicente Bartol e esposa Dona Adelaide Nunes Franqueira e a António La Puente ${ }^{418}$ e esposa Dona Maria Luz Franqueira.

Embora, em 1918, a Quinta dos Canaes fosse dada como propriedade conjunta de D. João Vicente Bartol, e afins Guilherme Franqueira, António Sá Puente e António Gonçalves Martinho ${ }^{419}$, na verdade, a totalidade da quinta ficara a pertencer em 1917 a João Vicente Bartol e António La Puente com suas respetivas esposas, filhas dos falecidos Romão Franqueira e Dona Maria Anunciação Nunes Franqueira. Dona Maria Luz Franqueira, entretanto viúva de António La Puente, veio a falecer por sua vez, a 17 de fevereiro de 1921, tendo deixado testamento onde instituía seus únicos e universais herdeiros D. João Vicente Bartol e sua esposa Dona Adelaide Nunes Franqueira aos quais esta Quinta foi adjudicada por escritura de partilhas a 18 de maio de $1922^{420}$.

\footnotetext{
${ }^{415}$ AHRFCA — Livro Antigo de Matrizes, Registo da Matriz de 1912, da freguesia de Beira Grande, Carrazeda de Ansiães.

${ }^{416}$ Da mesma localidade espanhola - Vitigodino, província de Salamanca — eram também oriundos seus pais, D. José Vicente e Dona Gumersinda Bartol bem como seu cunhado, António La Puente.

${ }^{417}$ ADB — Paróquia de Fontelonga, Registo de Casamentos, Registo de Casamentos 1894/1894, fls. 2-2v.

${ }^{418}$ Trata-se do negociante D. Miguel António de Sá Puente, filho de D. Lazaro de Sa Puente e Dona Gabriela Gonçalves, naturais de Vitigodino, casado aos 26 anos em 1879, na aldeia de Fontelonga, concelho de Carrazeda, com Dona Maria da Luz Franqueira, filha de Roman Franqueira e esposa Dona Maria Anunciação.

${ }^{419}$ AHRFCA — Livro Antigo de Matrizes, Registo de matriz de 1918, da freguesia de Beira Grande, Carrazeda de Ansiães.

${ }^{420}$ Sucessivas transmissões familiares da propriedade desta quinta referenciadas em documento particular do Arquivo Privado da família proprietária da Quinta Bartol.
} 


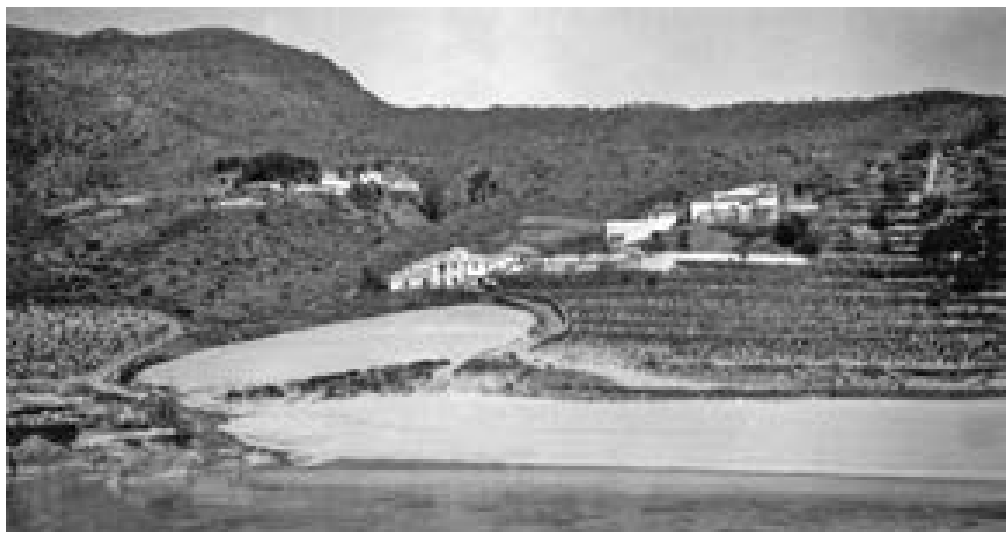

Fig. 79. Quinta Canaes-Bartol com o areal junto ao Douro (anos 1910-1920) ${ }^{421}$

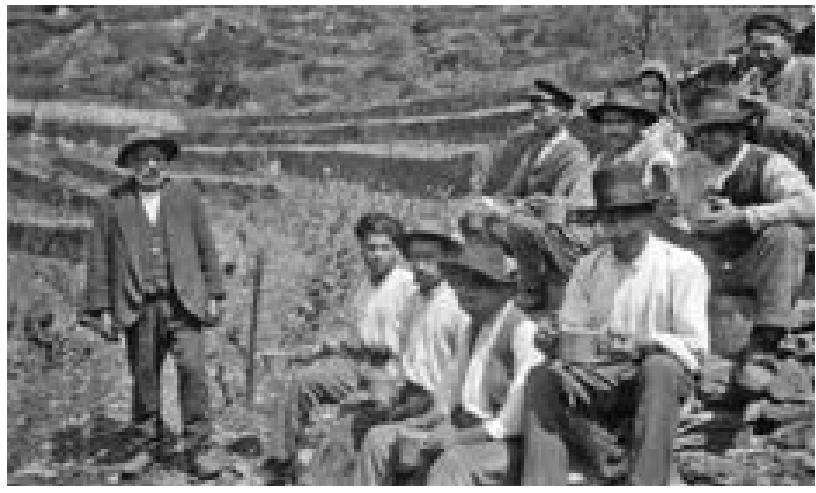

Fig. 80. Quinta Canaes-Bartol — trabalhadores na hora da refeição (anos 1910-1920)

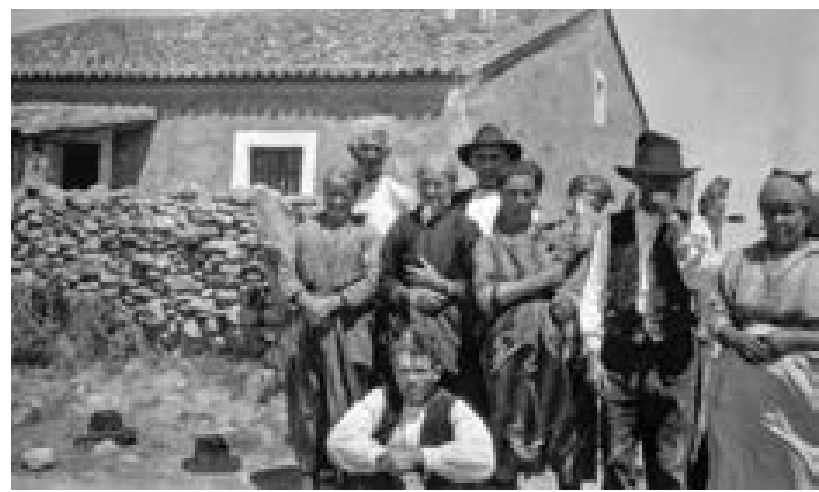

Fig. 81. Quinta Canaes-Bartol — famílias de trabalhadores (anos 1910-1920)

${ }_{421}$ Fotografias de época, do Arquivo da Família Bartol, gentilmente cedidas para publicação pela atual proprietária da quinta. 


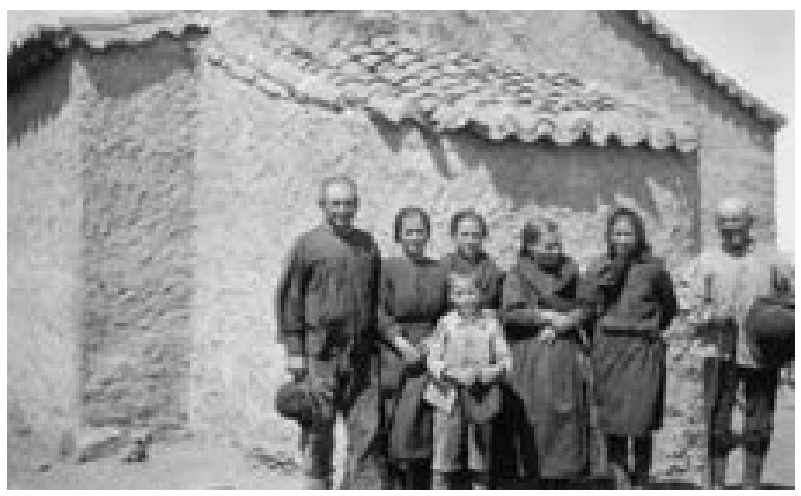

Fig. 82. Quinta Canaes-Bartol — grupo de trabalhadores (anos 1910-1920)

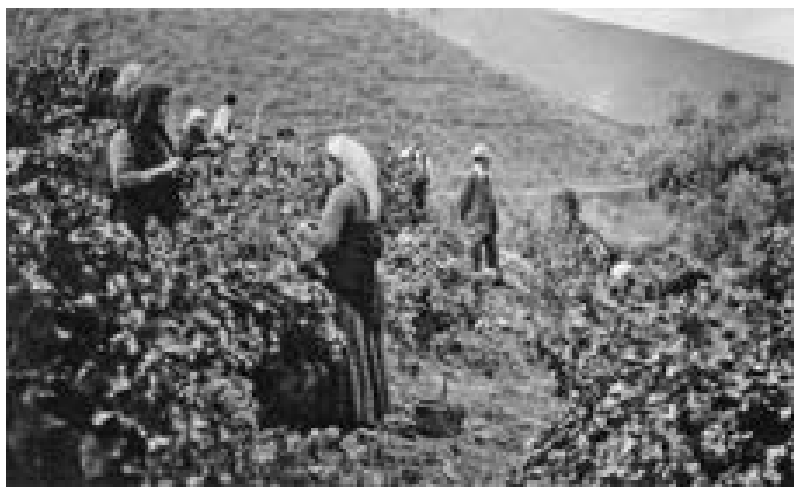

Fig. 83. Quinta Canaes-Bartol — vindima (anos 1910-1920)

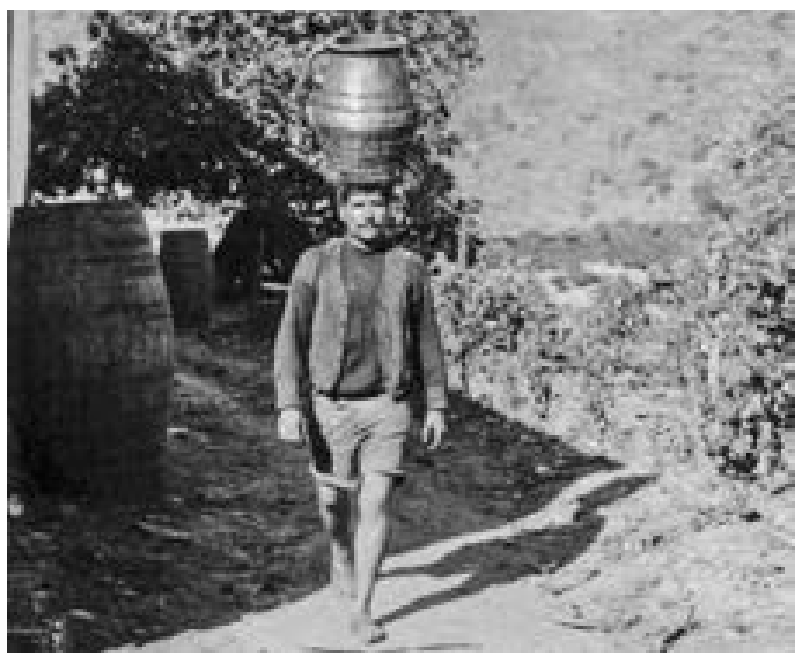

Fig. 84. Quinta Canaes-Bartol — trabalhador com almude à cabeça (anos 1910-1920) 
Em meados do século XX, a Quinta Bartol era considerada pela então sua proprietária, Dona Maria Esperanza Vicente Franqueira y Bartol Egido, filha de D. João Vicente Bartol e Dona Adelaide Nunes Franqueira, esposa do Dr. António Egido, como uma

caríssima propriedade onde deixaram tantos seus queridos marca da sua presença e também amigos [...] para quem a quinta continua à disposição para a caça às perdizes nos seus montes [...], [da qual] ficou dona [...] saindo os irmãos para Tânger na maior harmonia depois de liquidado o negócio.

Assim sugestivamente se refere à Quinta Bartol, em 1964, Dona Maria Esperanza Egido em carta de 19 de novembro desse ano para a direção da empresa Martinez Gassiot ${ }^{422}$, com a qual mantinha as melhores relações comerciais e de amizade hospitaleira.

Já então, Dona Maria Esperança Bartol, natural de Salamanca, residente na Rua de Gondarém, Foz do Douro (Porto), ainda casada com o médico espanhol António Egido, nomeado procurador da família em 1944 e falecido em novembro de $1967^{423}$, se encarregava de todos os assuntos da quinta onde sempre acompanhava os trabalhos da vindima e apanha da azeitona, deslocando-se também com frequência a Espanha (Salamanca e Madrid) onde passava algumas temporadas.

Quanto à representação intrafamiliar é documento relevante a seguinte procuração para constituição de procurador de membros da família, com delegação de poderes para exercício da gestão e administração regulares, nesta unidade de exploração agrícola vinhateira emitida, em 23 de maio de 1944,

na quinta Bartol e casa de morada de Don Juan Vicent Bardol, escritura lavrada pelo notário Armindo Ferreira com cartório em Carrazeda de Ansiães, sendo testemunhas e outorgantes:

$1 .{ }^{\circ}$ s outorgantes - Don Juan Vicent Bardol, proprietário e esposa, Dona Adelaide Franqueira Bardol, doméstica, moradores na quinta;

2. outorgante - Don Ramon Vicente Franqueira, casado, advogado, morador em Tânger;

3. outorgante - Don José Vicente Franqueira, solteiro, advogado, morador em Madrid;

\footnotetext{
${ }^{422}$ Carta remetida da Quinta Bartol para Reginald Cobb da Martinez Gassiot (AHS — Fundo Cockburn's, Dossiers, processos e documentação avulsa, cx. 1743, u.i. 5973-5994, mç. 7; Dossier de Correspondência, 1964-1979, entre Martinez Gassiot e Maria Esperanca Bartol Egido).

${ }^{423}$ Carta de condolências de 30 de novembro de 1967 enviada pela firma Martinez Gassiot à viúva, Maria Esperanza Bartol Egido (AHS — Fundo Cockburn's, Dossiers, processos e documentação avulsa, cx. 1743, u.i. 5973-5994, mç. 7; Dossier de Correspondência, 1964-1979, entre Martinez Gassiot e Maria Esperanza Bartol Egido).
} 
$4 .^{\circ}$ outorgante - Don Lourenzo Vicente Franqueira, casado, farmacêutico, morador em Vitigodino, província de Salamanca.

Pelos outorgantes foi constituído seu procurador, o seu genro e cunhado, Dr. António Egido Vicente, casado, médico, morador na quinta, com poderes para: gerir e administrar bens, dar em arrendamento bens; despedir e aceitar novos arrendatários; representá-los em tribunal e perante a Fazenda Nacional e Finanças; requerer registos nas Conservatórias do Registo Predial; requerer e autorizar cancelamentos; fazer e dar baixa de manifestos, depósitos e levantamentos de dinheiro em Bancos, Caixas Económicas e Montepios, e representá-los perante a Casa do Douro e outros organismos do Estado e ai fazer compras e vendas de aguardentes, vinhos e outras bebidas; emitir perante a Casa do Douro os votos dos outorgantes e representá-los em todos os assuntos na Casa do Douro; para pagar impostos e requerer pagamentos antecipados de impostos sobre doações nas Repartições de Finanças; assinar e praticar todos os atos e subestabelecer em advogado habilitado. Testemunhas: pessoal doméstico feminino da Quinta ${ }^{424}$.

Como se pode depreender, sobressai, nessa altura, o papel fortemente regulador da Casa do Douro, nalgumas matérias importantes da atividade produtora corrente da quinta.

No entanto, para conhecimento das origens e evolução histórica da Quinta Canaes-Bartol bem como sobre a história da sua família espanhola, parcialmente de origem galega, que se mantém proprietária e impulsionadora desta quinta, ao longo de sucessivas gerações de linhagem mista com grande paixão pelo Douro, desde meados do século XIX até ao presente, é fundamental a leitura do depoimento escrito da Dra. Maria Luz Serrano, que integralmente se transcreve no Anexo II.

Este depoimento é, como se pode ver, importante e expressivo documento pessoal e familiar, impregnado de acontecimentos históricos relevantes de finais do século XIX e primeira metade do século XX, vividos em Espanha e Portugal, de elementos fulcrais da genealogia dos Franqueira/Bartol, famílias bilingues, com dupla residência e nacionalidade, espanhola e portuguesa, mas também na história das quintas durienses, da produção e negócio do vinho do Porto na região do Douro, e ainda nas sucessivas migrações e longa permanência de galegos no Douro, Vinhateiro particularmente desde inícios do século XVIII até $1940^{425}$.

\footnotetext{
${ }^{424}$ Escritura notarial do Cartório de Carrazeda de Ansiães (1944). AHS — Fundo Cockburn's, Dossiers, processos e documentação avulsa, cx. 1743, pasta 5994; cx. 269, u.i.1426-172-269.

${ }^{425}$ A história dos galegos na Região do Douro é toda uma outra história do Douro que continua por fazer, como salientou Gaspar Martins Pereira em sua comunicação «Trabalhadores galegos no Douro Vinhateiro» apresentada

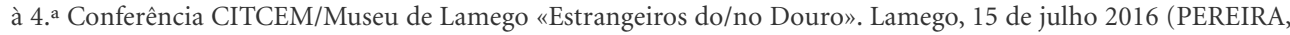
2016).
} 


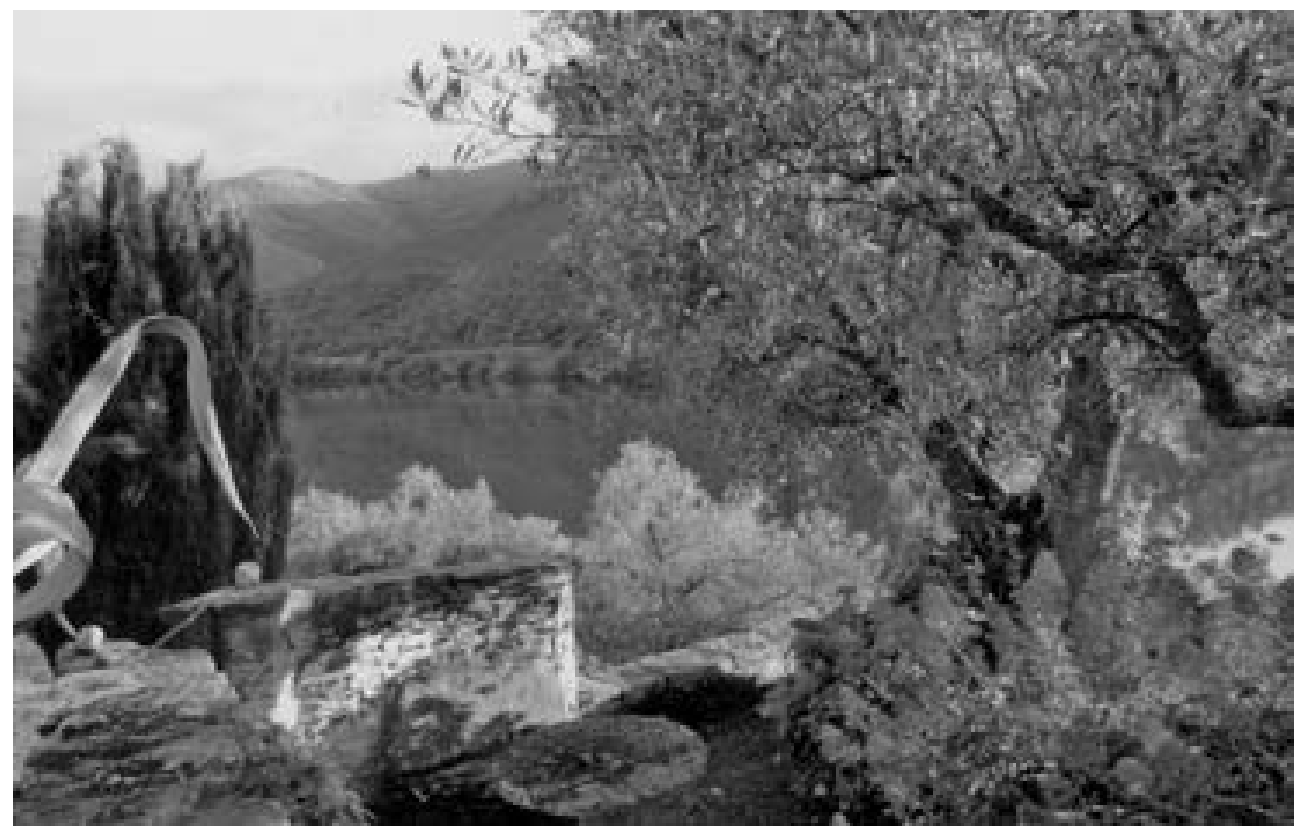

Fig. 85. Recanto da Quinta Bartol junto ao rio Douro Fonte: Fotografia de Maria Luz Serrano

\subsubsection{Dinâmica e rentabilidade económica da Quinta Bartol}

Podem intuir-se dimensões da dinâmica institucional, económica e administrativa da Quinta, através deste notável depoimento e ainda pela descrição da respetiva diversidade de obrigações e poderes de gestão, administração e representação nos negócios vitivinícolas e procedimentos envolventes outorgados na escritura anterior pela família ao então seu representante oficial, o médico Dr. António Egido Vicente casado com Dona Maria Esperanza Vicente Franqueira y Bartol de Egido, pais da atual dona e responsável principal da quinta.

Esta propriedade rústica, hoje com uma área superior a 100 hectares, dos quais 30 ha são vinhedos com muito boa exposição solar, mas propensos às neblinas do rio que tradicionalmente se supõe poderem enfraquecer os vinhos generosos, caracteriza-se por elevada dimensão produtiva vitivinícola, em especial vinho do Porto de reconhecida e superior qualidade. Tem seguido por isso, a prática antiga de fazer as vindimas na segunda quinzena de setembro, época não demasiado tardia, condição reputada como importante na produtividade vinícola e no processo de vinificação, fator também de relevo nas negociações entre a quinta e as firmas exportadoras compradoras dos seus vinhos. Parcialmente reconvertida em monocultura vinhateira, possui ainda algum olival que produz azeite «fino», pomares, horta, jardins e reserva de mata e caça. 
Com as novas plantações de vinha realizadas nos anos 1980, a área de vinha da quinta cresceu muito, atingindo uma capacidade de produção anual de 105 pipas de vinho, das quais 80 pipas são de vinho com benefício atribuído pela Casa do Douro.

Outros aspetos relevantes da atividade corrente e dinâmica própria desta quinta, com incidência particular em meados do século XX, problemáticas de fundo recorrentes, principais problemas enfrentados, iniciativas e medidas tomadas, podem ser detetados na correspondência comercial assiduamente trocada entre Dona Maria Esperança Franqueira Bartol proprietária e administradora da Quinta Bartol e a firma exportadora Martinez Gassiot compradora dos seus vinhos nas décadas de 1960 e 1970 na qual se dá conta da velha amizade persistente e recíproca entre os responsáveis desta quinta e dessa empresa ${ }^{426}$.

\section{Produção e comercialização anual de vinho do Porto «famoso néctar do Douro desgraçado» ${ }^{427}$}

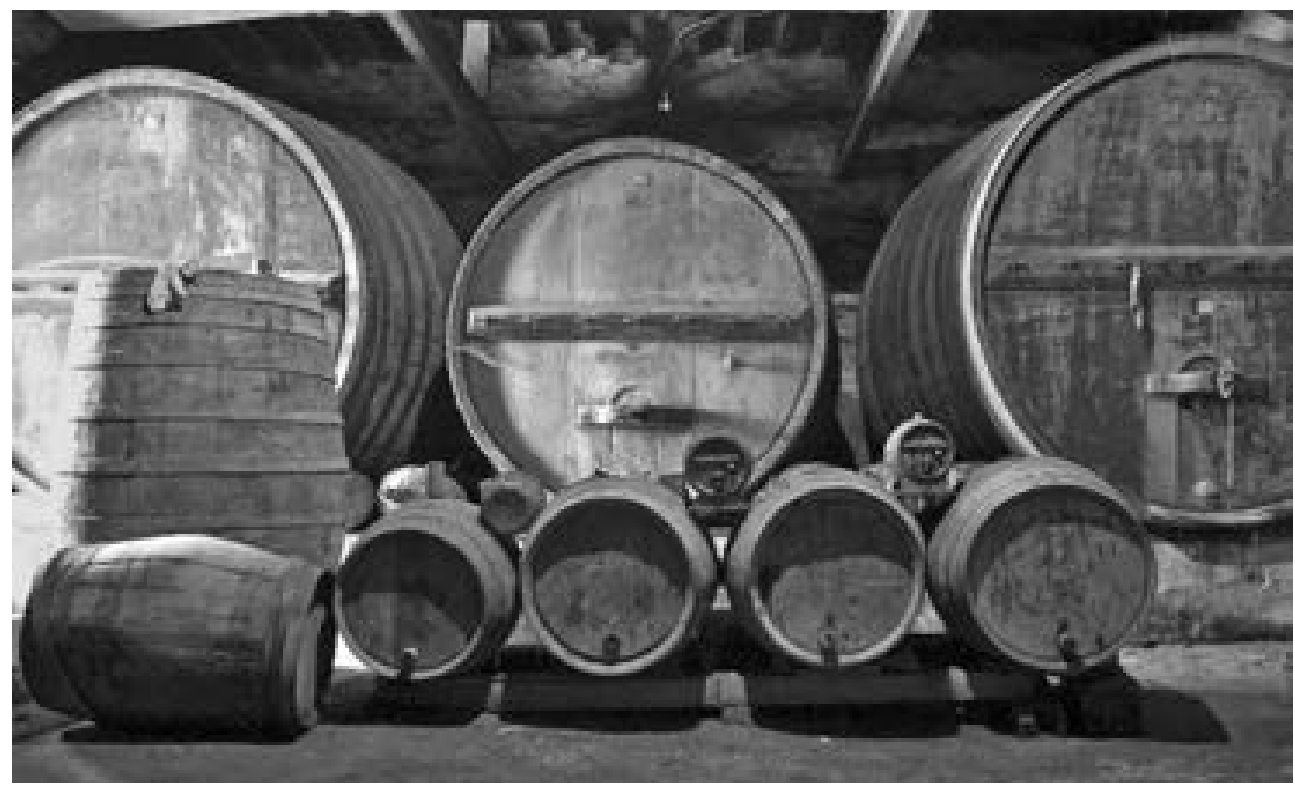

Fig. 86. Antigos tonéis e pipos no velho lagar da Quinta Bartol Foto de Juan Ramon Roca Vicente Franqueira ${ }^{428}$

\footnotetext{
${ }^{426}$ Documentos epistolares (ofícios, cartas e cartões) (AHS - Fundo Cockburn's, Copiador de Correspondência, 1963-1979, cx.1743, u.i. 5973-5994, mç. M7-5994, cota 1/6/B/5).

${ }^{427}$ Expressão de Dona Esperanza Franqueira Bartol Egido, em carta para a firma Martinez Gassiot (AHS - Fundo Cockburn's, Copiador de Correspondência, 1963-1979, cx.1743, u.i. 5973-5994, mç. M7-5994, cota 1/6/B/5).

${ }^{428}$ Descendente de Ramon Franqueira, primo da atual proprietária da Quinta Bartol, professor de técnicas audiovisuais e responsável pelos ciclos formativos do Instituto de Educación Secundaria (IES) Luis García Berlanga em Alicante, fundador e diretor até 2011 do Festival de Cinema de Alicante.
} 
Os índices de produção, comercialização e rendimento anuais dos vinhos generosos da Quinta Bartol podem ser encontrados a partir dos dados registados anualmente, por ocasião das vindimas marcadas com antecedência, aqui em regra entre meados e fins de setembro e previamente preparadas em colaboração com pessoal da firma compradora regularmente enviado para a quinta e que aqui acompanhava o trabalho da vindima e supervisionava o processo inicial da fabricação dos mostos e vinho.

Feitas as medições das litragens produzidas, a partir da unidade pipa (550 1.), as deduções da aguardente fornecida pela firma compradora dos vinhos e o cálculo do valor a pagar "por conta» em 3 prestações em diferentes datas ao longo do ano: Sinal (setembro), 1. a e 2. ${ }^{\text {a }}$ prestações (janeiro e março do ano seguinte), era apurado o saldo a receber pela Quinta que ficava disponível para levantamento na Casa do Douro, a partir dos finais de junho. Para além da intervenção neste processo da Casa do Douro que, a montante, também fixava e atribuía à quinta o beneficio e respetivas letras, quase sempre as primeiras, como se pode deduzir de talão de beneficio de 1977 da Quinta Bartol (que atribuiu à letra A - 25.880 1. e à B — 410 1.), o Instituto do Vinho do Porto, fixava e emitia em comunicado as condições de compra das uvas e do vinho.

Alguns dos indicadores de base e respetivos valores para os anos de 1964 a 1979, constam do seguinte quadro de vindimas e colheitas da novidade da quinta, contratados os prazos e condições de realização da vindima de cada ano, entre os donos da quinta e o comprador de seus vinhos generosos, a firma exportadora Martinez \& Gassiot, conforme registo em documentos de arquivo, para um período de 16 anos, entre inícios dos anos 1960 e fins de $1970^{429}$.

As negociações que este processo envolvia entre esta quinta produtora e essa firma compradora, desde 1963, ano de fraca produção e qualidade dada a mistura das uvas da quinta com as de proprietários vizinhos e arrobeiros, não deixaram de continuar a revestir-se por vezes de uma certa tensão provocada pelos interesses contraditórios e protagonistas diferentes em jogo como se pode deduzir das observações e comentários complementares e subsequentes ao quadro seguinte.

\footnotetext{
${ }^{429}$ Conjunto numeroso de documentos epistolares (ofícios, cartas, cartões) (AHS — Fundo Cockburn's, Copiador de Correspondência, 1963-1979, cx. 1743, u.i. 5973-5994, mç. M7-5994, cota 1/6/B/5).
} 
Quadro 25. Contas da vindima e venda dos vinhos da novidade (1964-1979)

\begin{tabular}{|c|c|c|c|c|c|c|c|}
\hline \multirow[t]{2}{*}{ Anos } & \multirow{2}{*}{$\begin{array}{l}\text { Vinho T./B. } \\
\text { medido à } \\
\text { carregação } \\
\text { (em litros) }\end{array}$} & \multirow{2}{*}{$\begin{array}{c}\text { Aguardente } \\
\text { a deduzir } \\
\text { (em litros) }\end{array}$} & \multicolumn{3}{|c|}{ Vinho pagável } & \multirow{2}{*}{$\begin{array}{c}\text { Pago } \\
\text { por conta }\end{array}$} & \multirow{2}{*}{$\begin{array}{c}\text { Saldo } \\
\text { a receber }\end{array}$} \\
\hline & & & $\begin{array}{c}\text { Quantidade } \\
\text { (em litros) }\end{array}$ & Valor/pipa & Valor total & & \\
\hline 1964 & 36.020 & 6.600 & 29.420 & $2.700 \$ 00$ & $144.425 \$ 50$ & $107.400 \$ 00$ & $37.025 \$ 50$ \\
\hline 1965 & 38.646 & 7.630 & 31.016 & $2.700 \$ 00$ & $152.260 \$ 40$ & $121.200 \$ 00$ & $31.060 \$ 40$ \\
\hline 1966 & $(*)$ & & - & - & - & - & $\longrightarrow$ \\
\hline 1967 & 35.467 & 6.975 & 34.492 & $3.100 \$ 00$ & $122.500 \$ 00$ & $84.000 \$ 00$ & $38.091 . \$ 30$ \\
\hline 1968 & 42.472 & 8.872 & 33.600 & $\begin{array}{c}2.800 \$ 00 / \\
3.100 \$ 00\end{array}$ & $180.872 \$ 70$ & $137.000 \$ 00$ & $43.872 \$ 70$ \\
\hline 1969 & 35.000 & 7.201 & 27.879 & $\begin{array}{c}3.400 \$ 00 / \\
3.000 \$ 00\end{array}$ & $164.342 \$ 90$ & $134.000 \$ 00$ & $30.342 \$ 90$ \\
\hline 1970 & 38.440 & 7.022 & 31.418 & $\begin{array}{c}4.100 \$ 00 / \\
3.700 \$ 00\end{array}$ & $227.357 \$ 50$ & $160.000 \$ 00$ & $67.357 \$ 00$ \\
\hline 1971 & 41.160 & 7.478 & 33.682 & $\begin{array}{l}4.800 \$ 00 / \\
4.200 \$ 00\end{array}$ & $281.208 \$ 00$ & $196.000 \$ 00$ & $85.208 \$ 00$ \\
\hline 1972 & 48.940 & 9.799 & 39.141 & $6.000 \$ 00$ & $491.041 \$ 60$ & $364.500 \$ 00$ & $126.541 \$ 60$ \\
\hline 1973 & 54.612 & 9.979 & 44.633 & $7.500 \$ 00$ & $\begin{array}{c}1.420 .141 \$ 00 \\
(* *)\end{array}$ & $918.018 \$ 00$ & $502.122 \$ 00$ \\
\hline 1974 & +31.000 & & $\begin{array}{c}30.806 \\
(* * *)\end{array}$ & & & & \\
\hline 1975 & +31.000 & & $\begin{array}{c}\text { c.30.806 } \\
(* * *)\end{array}$ & $13.000 \$ 00$ & & & \\
\hline 1976 & 31.860 & 6.467 & 25.393 & & $419.909 \$ 10$ & $386.400 \$ 00$ & $64.845 \$ 50$ \\
\hline 1977 & 17.500 & 3.627 & 13.873 & & $325.051 \$ 90$ & $232.000 \$ 00$ & $93.051 \$ 00$ \\
\hline 1978 & 32.990 & 7.345 & 25.645 & & $743.778 \$ 30$ & $744.168 \$ 70$ & $\begin{array}{c}390 \$ 40 \\
(* * * *)\end{array}$ \\
\hline 1979 & 27.793 & 5.786 & $\begin{array}{l}22.007 \\
(* * * * *)\end{array}$ & $\begin{array}{l}21.000 \$ 00 / \\
24.000 \$ 00\end{array}$ & $892.400 \$ 00$ & $629.138 \$ 00$ & $263.265 \$ 50$ \\
\hline
\end{tabular}

Fonte: Mapas de contas do vinho da novidade elaborados nas vindimas da Quinta Bartol ${ }^{430}$

Notas ao quadro: (*) Não se apuraram dados de contas de 1966; (**) Ano 1973 com bónus de $500 \$ 00$ por pipa, relativo ao total =40.575\$50; $\left(^{* * *}\right)$ valores idênticos das vindimas de 1974/75 e 1975/76, compra de mosto - autorização e benefício da Casa do Douro; $\left({ }^{* * *}\right)$ no saldo a favor da empresa há a deduzir $390 \$ 40$ na próxima vindima resultante da diferença entre quantidades finais e estimadas, o que resulta da estimativa feita da produção da quinta ser superior à quantidade medida à carregação; $\left(^{* * * *}\right)$ era de 27.500 I. o vinho medido à carregação, segundo previsão da firma.

\footnotetext{
${ }^{430}$ Mapas anuais de contas de vinhos da Quinta Bartol (AHS — Fundo Cockburn's, Dossiers, processos e documentação avulsa, cx.1743, pasta 5944; cx. 269-u.i. 1419-1432, cota 1/1/72; u.i.1426-172-269).
} 
Observando o quadro, verifica-se uma relativa tendência de crescimento ainda que não regular da produção de mostos tintos e brancos da quinta Bartol, a que são em regra adicionadas uvas dos pequenos produtores vizinhos que preferem vender as uvas brancas reservando as tintas para a produção de vinho consumo, bem como uma ligeira subida dos preços por pipa, mais acentuada nos finais da década de 1970 a que não é estranha a inflação.

Sabe-se ainda que em $1975^{431}$ se verificou uma quebra sensível de preços em relação a 1974, para o que terão concorrido dois fatores: a) segundo princípio geral de comunicado do IVP, o aumento drástico do preço das aguardentes - de $20 \$ 56$ para $40 \$ 00$ por litro - que implicou a consequente redução de preços dos mostos; b) condições gerais dos mercados internacionais que explicam que os preços de exportação não tenham subido, antes hajam registado uma descida de 1974 para 1975. Os exportadores não podiam, em 1975, ultrapassar o preço final de $13.000 \$ 00 /$ pipa de vinho feito.

Em 1976, o preço dos mostos desceu para 9.280\$00 nos vinhos tintos letra A e para 7.480\$00, nos vinhos brancos, sendo considerado que muitas das uvas recebidas para preencher litragem da quinta não terão sido classificadas na letra A e o vinho foi inferior ao da reconhecida alta qualidade do da Quinta Bartol ${ }^{432}$.

Quanto às quantidades de vinho compradas à quinta pela referida firma, pela quantidade oficialmente autorizada e no preço fixado de acordo com o critério geral usado tendo em atenção a qualidade, medida na sala de provas, e as despesas inerentes à fabricação, foram fixadas oficialmente para compra à Bartol, em 1977, 49 pipas de mosto tinto e 13 pipas de mosto branco, podendo a quinta juntar outras uvas de lavradores vizinhos com benefício, mas não pagas ao mesmo preço dos vinhos da quinta e apenas com base na sua qualidade ${ }^{433}$.

Em matéria de rendimento anual vitícola pode verificar-se no quadro que a quinta registou, ao longo dos anos considerados, um crescimento constante, sendo o seu melhor ano em 1973 o que se ficou a dever-se à subida dos preços por pipa, seguindo-se-lhe, por ordem decrescente, embora ainda bastante acima dos restantes, respetivamente, os anos de 1978, 1972, 1976 e 1977.

Subjacentes às contas das colheitas do vinho da novidade das vindimas desta série cujos dados constam do quadro, eram frequentes as negociações e desentendimentos entre o produtor e o comerciante, em matéria de determinação de quantidades de produção e/ou atribuição de benefício e de fixação de preços do vinho e das uvas. O que se comprova pelas seguintes informações díspares em relação ao benefício: a Casa do Douro costumava atribuir à Quinta

\footnotetext{
${ }^{431}$ Ofício de 2 de julho de 1976, da Martinez Gassiot para Dona Esperança Bartol, que acompanha a conta de vinho de 1976 e dados da vindima de 1975. Dossier de correspondência comercial entre Quinta Bartol e Martinez Gassiot (AHS - Fundo Cockburn's, Dossiers, processos e documentação avulsa, cx. 1743, pasta 5944; cx. 269-u.i. 1419-1432, cota $1 / 1 / 72$; u.i.1426-172-269).

${ }^{432}$ Ofício de 1 de setembro de 1976 da Martinez Gassiot para Dona Esperança Bartol (AHS — Fundo Cockburn's, Dossiers, processos e documentação avulsa, cx.1743, pasta 5944; cx. 269-u.i. 1419-1432, cota 1/1/72; u.i.1426-172-269).

${ }^{433}$ Ofício de 22 de julho de 1977 da Martinez Gassiot para Dona Esperança Bartol (AHS — Fundo Cockburn's, Dossiers, processos e documentação avulsa, cx. 1743, pasta 5944; cx. 269-u.i. 1419-1432, cota 1/1/72; u.i.1426-172-269).
} 
Bartol 54.800 litros, cifra considerada alta pela firma, mas concretizada pelo produtor com a precisão de que em 1966, foram atribuídos à quinta, 35.760 litros enquanto no ano anterior o valor se fixara em 33.780 litros. Na vindima de 1966, a pedido da quinta, a Martinez Gassiot emitiu em nome daquela uma nota de crédito no valor de $5.340 \$ 00$ correspondente ao aumento de $100 \$ 00$ por preço de pipa do mosto vendido, o que é considerado pelo produtor «fraquito aumento».

Correspondência trocada em meados de 1969, início de 1970, entre John H. Smithes, diretor da Cockburn's, a firma Martinez Gassiot e o então administrador da Quinta Bartol, Alberto de Oliveira Gonçalves (residente na Quinta da Louzada, Godim-Régua), este questiona a desigualdade dos preços muito inferiores praticados na Quinta Bartol, com uma classificação para a letra «A» comparativamente com os praticados na Casa do Douro, ou nos vinhos de qualidade idêntica na vizinha Quinta dos Canais e noutras quintas do Cima Corgo e insiste na revisão dos preços para a Quinta Bartol, com colheitas anuais consideradas ótimas, propondo-se mesmo, da vindima de 1969, fazer por conta própria 10 cascos de vinho generoso ${ }^{434}$.

No mesmo contexto, Dona Maria Esperança Bartol considerando que a «Quinta Bartol é a mais antiga freguesa da Martinez Gassiot» lamenta manter-se a desconsideração em relação ao vinho da quinta Bartol que mesmo em ano de má colheita não é considerada mal pelo diretor Smithes, havendo coincidência nos números da carregação medidos pelo encarregado da quinta, Oliveira Gonçalves e pelo encarregado da empresa compradora, Sr. Guimaraens «pessoa correta e agradável».

Dona Esperança reitera porém a sua amizade e esperança de ser respeitada e considerada como filha de D. Juan Vicente Bartol já com relações comerciais e de amizade com os srs. Cockburn e Smithes, Lda. ${ }^{435}$ empresa exportadora com que se fundiu a Martinez \& Gassiot em 1968 a cujo diretor Sr. Smithes, logo escreverá a seguir, face ao conhecimento que teve dessa fusão, manifestando também o seu interesse em querer ser continuada a manter-se como a freguesa e amiga de antes, esperando ser tratada nos negócios 'iguais aos outros' e com a razão que 'me acompaña' pois sou espanhola. Mas não de Gibraltar, e menos inimiga dos ingleses.

Nesse ano de 1968, conforme carta de J. H. Smithes para Dona Esperança Franqueira Bartol, de 19 de julho, sabe-se que os vinhos da Quinta Bartol foram assim classificados: na letra B - 28.880 litros (ao preço de 2.800\$00 fixado pela Casa do Douro) e na Letra D - 1.100 litros (ao preço de 2000\$00 da Casa do Douro), sendo os mesmos vinhos pagos pelo comerciante ao produtor pela média total de $3.100 \$ 00$ por pipa (5501). Porém, logo em carta subsequente, a dona da quinta queixa-se de que os seus vinhos são misturados com os da Quinta dos Canais, mas injustamente pagos por preços inferiores.

\footnotetext{
${ }^{434}$ Carta de 26 de julho de 1969, para John H. Smithes, de Oliveira Gonçalves, recém-contratado administrador da Quinta Bartol (AHS - Fundo Cockburn's, Dossiers, processos e documentação avulsa, cx. 1743 , pasta 5944; cx. 269-u.i. 1419-1432, cota 1/1/72; u.i.1426-172-269.

${ }^{435}$ Carta de 3 de julho de 1970 de Dona Esperança Bartol para a firma Martinez Gassiot. AHS — Quintas dos Canais, da Senhora da Ribeira, do Tua e do Zimbro (AHS - Fundo Cockburn's, Dossiers, processos e documentação avulsa, cx. 1743, pasta 5944; cx. 269-u.i. 1419-1432, cota 1/1/72; u.i.1426-172-269.
} 
Finalmente, em oficio que recebe da empresa, a dona da quinta toma conhecimento de que os preços irão ser aumentados para a vindima de 1970, marcada para 21 de setembro e com instruções para o fabrico de empregado da empresa enviado na véspera, decisão tomada na sequência das condições reguladas por nota oficiosa do Instituto do Vinho do Porto, fixando os preços do mosto, nas diversas letras, em valores substancialmente superiores aos que vigoraram na vindima anterior, aumentos com que a empresa concorda e a Quinta declara também aceitar.

Os preços das uvas, durante a vindima, estabelecidos pela empresa em 1973 foram os seguintes em função da sua classificação por letras: letras A e B - 19\$00/kg; letras C, D, E, F - 17\$50/kg. ao que Dona Esperança Bartol, responde em carta de 23 de novembro de 1973 dizendo aguardar que marquem preços dentro do contrato e comentando a propósito constrangimentos inerentes: «Conheço bem aquela gentinha e se for mais terei de o dar, se for menos, será difícil tornar a ser meu. Se as casas inglesas não pagam, eu mini proprietária devo esperar e para mais certeza espero uma resposta».

No entanto a discussão em torno da fixação dos preços das uvas e vinhos generosos entre a quinta e a firma manter-se-á nas décadas de 1960 e 1970, chegando a atingir níveis de grande discordância por parte da quinta como se pode constatar em carta de Dona Esperança Bartol, residente na Foz do Douro (Rua de Gondarém) para a empresa, em 3 de agosto de 1976, em que compara o baixo valor pago por uma pipa de vinho do Porto, com alguns índices da carestia de vida e os custos das vindimas:

se eu não tivesse o sangue Espanhol creio que tinha ido ao chão, é possivivel que em estes tempos que por um quilo de vagens pagamos $32 \$ 00$ e uma torta de amêndoa na Minhotinha $125 \$ 00$, uma pipa do famoso néctar do Douro só tenha o valor de $10.000 \$ 00$ e $7.500 \$ 00$ ? Creio há confusão Sr. Guimaraens. Sou velha amiga e muito discreta para ir com os percantes a Lisboa a pedir socorro para este desgraçado Vinho do Porto, mas com toda a consideração e amizade venho dizer-lhe que esse preço não cobre os gastos das duas vindimas que passou de 125 contos para o de fora. O Sr. Guimaraens me diz a pipa era a $13.000 \$ 00$ e o Sr. Simthes na segunda vindima diz-me o vinho é bom e com esta espera me deixa satisfeita [...]. Confiei e acreditei e tem que haver um remédio. Um Inglês tem palavra como uma Espanhola a tem e espero uma resposta amiga.

E em carta posterior dá conta das dificuldades então vividas pela quinta, cuja venda chegou a ser equacionada.

\subsubsection{Desenvolvimento e modernização técnica: realizações e constrangimentos}

Alguns dos projetos e realizações para desenvolvimento e modernização da quinta contaram com o apoio mas também certas restrições da empresa Martinez \& Gassiot e a orienta- 
ção técnica do seu diretor, John H. Smithes que ficou célebre no Douro pelas suas experiências piloto na cultura da vinha e no fabrico e produção de vinho do Porto.

Atesta o bom trato, grande cordialidade e mesmo amizade, de longos anos, o convite para uma visita à quinta acompanhada de "prova do seu vinho 'Relíquia W' dos tempos dos seus 'saudosos ausentes', depois da vindima, época de muito trabalho e da saída dos seus 'hóspedes'», que em 1968, Dona Esperança Franqueira Bartol, endereçou aos então novos diretores da Martinez Gassiot, Srs. Cockburn \& Smithes.

\section{Projetos e novas realizações}

No ano de 1967, para modernizar equipamentos e facilitar os trabalhos da pisa das uvas e dos lagares, dada a crise de mão de obra que se verificava na região, com a intensa emigração para a Europa que se reflete igualmente na quinta inclusive com a saída do antigo caseiro que emigrara para «o paraíso» da França e o problema dos homens não quererem trabalhar nos lagares foi equacionada pela dona da quinta, Dona Esperança Bartol a compra de uma esmagadeira de mão Hipólito (e não elétrica conforme sugestão da Gassiot) igual à da quinta do Tua e cuja instalação se fez, mas posteriormente foi adquirido um esmagador elétrico, através da Martinez \& Gassiot, empresa que era então colaboradora do fabricante, a Metalúrgica de Cambra. A Quinta ficou assim a contar com essa «ajuda de tão grande validez» apesar de, como diz Dona Esperança «eu não entendo nada e como aqui não fica artista nenhum não sei como resolver o assunto...», constatando assim o problema de manutenção e assistência técnica às máquinas com que a quinta começava a defrontar-se para além dos sempre elevados custos a pagar e da constante variação dos preços do vinho, entre $19.000 \$ 00$ e $21.000 \$ 00$.

E Dona Esperanza Bartol, subtil, mas frontal como «autêntica espanhola» de que se reclama, conclui: «...pois este Douro é de força e arranca tudo...».

Nos lagares da quinta, usavam já desde 1967 uma máquina Movimosto para o trabalho e fabrico de bom vinho, de que Dona Esperança soubera, como refere, pelo seu amigo Sr. Trigo de Negreiros, então proprietário da Quinta das Amendoeiras (Seixo de Ansiães) vizinha da quinta Bartol e o qual exerceu diversos cargos políticos no Estado Novo de que foi Ministro do Interior (1950-58), com vasta ação na rede hospitalar e área de assistência social.

Essa máquina fora então instalada na Quinta Bartol pela Martinez \& Gassiot, compradora dos seus vinhos, e era vistoriada por um técnico eletricista da mesma firma, passando a fazer grande parte da vindima.

A aposta na mecanização estendeu-se também à ideia da introdução de cubas de fermentação ou autovinificadoras, projeto que foi desaconselhado pela empresa para o caso da produção de vinho do Porto da quinta, contrapondo-lhe um sistema de cubas abertas e de refrigeração, como se verá.

Ao nível de outras realizações, posteriormente, levadas a efeito sabe-se ainda por carta da Martinez \& Gassiot para o administrador da quinta, Alberto de Oliveira Gonçalves, em 1970, que fora dada por essa firma à Câmara de Carrazeda de Ansiães, uma contribuição no valor de 
5.000\$00, para abertura de uma estrada na Quinta Bartol. Este melhoramento introduziu alterações benéficas nos acessos a vias mais cómodas que as dos bois, barcos e outras. Igualmente se verificaram outras melhorias com o grande saibramento e a plantação de 12 milheiros de bacelos.

Observe-se no entanto que dada a natureza das fontes históricas aqui usadas, sobretudo correspondência trocada entre a quinta e a empresa compradora dos vinhos, em que se manifestam os conflitos de interesses nestes casos frequentes, ressaltam em maior quantidade e evidência não tanto os projetos e realizações da quinta mas sobretudo os condicionamentos e assuntos críticos existentes exigindo constantes negociações entre as duas partes envolvidas, como se pode ver.

\section{Constrangimentos e situações críticas}

Naturalmente, a Quinta Bartol foi enfrentando diversos obstáculos, para além dos já abordados, problemas da fixação dos preços e outras condições exigidas pelos compradores da sua produção vitivinícola, que interferem nos compromissos da quinta com os «arrobeiros» para a compra das uvas.

A intensa e regular correspondência trocada entre a quinta e a firma compradora dá conta de alguns desses constrangimentos, designadamente na segunda metade da década de 1960 e durante toda a década de 1970, de que se faz eco uma carta para a empresa do administrador Oliveira Gonçalves que propõe novos melhoramentos e equipamentos:

Já com a apanha da azeitona foi de espantar de só quererem fazer o que muito bem desejam, outros largaram para a França. O que acontece com a azeitona acontece com o serviço de vindima e cada vez pior. Com duas cubas de fermentação resolvia o assunto. Há muitas casas compradoras que assim fazem. Para o armazenamento temos vasilhame de madeira muito boa.

A estas considerações objeta a empresa com os seguintes argumentos: não se concorda com a ideia de construir cubas de fermentação na quinta; o vinho não servia para a casa devido ao estado do lagar; o ano de 1969 foi fraco; o vinho feito na Bartol não é igual ao dos Canais e não o será no futuro imediato; as vinhas levam anos a fazer-se.

Aliás, em carta subsequente da firma exportadora e de John H. Smithes para o mesmo administrador da quinta, a questão da introdução das cubas de fermentação continua a ser assim rebatida por aquela, com argumentos técnicos e, subjacentemente, financeiros:

As auto-vinificadoras (cubas de fermentação) têm dado problemas com as temperaturas de fermentação o que obrigou a modificações nas cubas para tentar controlar o problema - ponto nevrálgico no fabrico do Vinho do Porto - principalmente quando se trata de uvas maduras de alta qualidade do Cima Corgo. [caso da quinta Bartol]

É mais simples fazer em lagar com pessoal, metodicamente, mais do que mecanicamente, mas mesmo assim tem-se perdido grande quantidade de vinho; não aconselhamos essas cubas para o vinho tratado, mas sim cubas abertas preparadas com sistema de remon- 
tagem de vinho, com controlo de temperatura, com refrigeração por meio de instalação própria de refrigeração. Recomendamos usem nos lagares a máquina Movimosto que têm usado e também usamos na nossa quinta do Tua para fazer centenas de pipas nos lagares [...] sigam as instruções que enviamos em anexo.

Depreende-se daqui um outro constrangimento relevante e contradição de fundo com que a quinta se debate as quais resultam em grande medida do conflito latente de interesses existente.

Por outro lado, os acessos à Quinta, situada próximo do rio Douro mas encravada entre quintas e propriedades de vários donos, eram também problemáticos. Enquanto os acessos fluviais eram assegurados por barco e barqueiros que a ligavam à região e ao país através da estação ferroviária e da quinta de Vargelas na margem esquerda, os acessos terrestres na margem direita mantinham-se críticos. Assim, em 1970, Dona Esperança Bartol denuncia a «invasão de caminhos e acessos à Quinta Bartol por parte do Sr. Gouveia e Dona Antónia Aguilar e seus empregados que se pegaram de razões por causa disso com os da quinta Bartol. Meteu advogado, exigiu negociações mas sem nada se resolver». Nessa sequência, pede a intervenção do Sr. Smithes «para o bem de todos».

No mesmo ano, em carta de 16 de abril para John H. Smithes o administrador da Quinta Oliveira Gonçalves, residente na quinta da Louzada (Godim - Régua) e funcionário da Casa do Douro, abordando o constrangimento recorrente dos preços dos vinhos, pede que o vinho da Bartol seja pago ao mesmo preço do Eng. Ramiro Sobral proprietário da vizinha Quinta dos Canais já que considera tratar-se de qualidade idêntica.

A 27 de agosto de 1972, ano de uma colheita estimada de vinho generoso, de 80 pipas, Dona Esperança Bartol em carta para a firma, dá conta do conflito de interesses na compra local das uvas tintas «às gentes daquelas regiões exigindo-lhes em primeiro lugar as uvas tintas pois são as que mais apreciam para o vinho consumo [...] para que tenham o prazer de pensar que nos enganaram». E considerando «os tempos são maus...» insiste em assuntos já anteriormente apresentados:

preciso que me destinem um tanoeiro como os de tempos antigos de que dispunha a Gassiot e preciso de contar com pessoal disciplinado, pois não tenho ninguém na quinta que saiba alguma coisa de armazéns e como os tempos são outros, o sistema mais justo e independente para as duas partes seria o 'sistema de aluguer' até meus netos terem capacidade de se ocupar da quinta. Agora com a barragem tenho que intensificar as vinhas, doutro modo terei de abandonar tudo e isso é que não faço pois não sou cobarde e V. Exas que o digam pois também são lutadores [...].

Ainda noutra carta de 31 de julho de 1973, para a empresa datada, Dona Esperança Bartol sentindo-se injustiçada, contesta denunciando a concorrência local: 
não posso aceitar o que pretendem de só vender tintos porque o ano passado fiquei de mal com alguns dos meus 'arrobeiros' [...] Para este ano tenho a afronta da Quinta dos Canais já ter comprado as uvas aos 'meus arrobeiros', todo o branco e tinto sem qualquer escoTha. Em face disto não suporto tais decisões - para mim o objetivo de ter só tinto e para os Canais tudo que aparecer, sem distinção de qualidade e cor $[. . .]^{436}$.

Em agosto do mesmo ano, face aos problemas então vividos pela quinta inclusive alguns atritos com a vizinha Quinta dos Canais, grande modificação das condições de maturação das uvas provocada pelas chuvas e baixa de temperaturas e a falta de pessoal interno «que se não encontra», como os "delicados trabalhadores e educados e que deixaram saudades», ao contrário dos enviados pela empresa nos últimos 3 anos, Dona Esperança Bartol chegou mesmo a apresentar uma oferta de aluguer da quinta, com preferência, à empresa Martinez \& Gassiot a qual recusa, mantendo confidencialidade, por não «dispor de pessoal que tome conta da quinta e a mesma ficar muito fora de mãos» para eles. Em resposta, Dona Esperança Bartol reitera os problemas com pessoal — «'crises de criados' durante 6 meses» — que considera catastróficos e informa da manifestação expressa de interesse na compra da Quinta Bartol por parte da casa inglesa Taylor Fladgate \& Yeatman, queixando-se que «a vida de hoje faz ter saudades da paz antiga e dos barcos rabelos».

Em 1976, registou-se uma grande cheia do rio Douro que cobriu todas as relvas e pomares da quinta, sem, porém, chegar a atingir os armazéns, a qual associada às dificuldades de mão de obra agravou os problemas da Quinta Bartol que teve de contratar novos caseiros para substituir o anterior emigrado em França, como outros trabalhadores locais. A constante reivindicação expressa de que a quinta possa normalizar e passar a contar com preços de compra da produção «máximos, justos e iguais» a outras quintas durienses, tanto mais justificado quanto o vinho das anteriores vindimas (duas, uma para as uvas da quinta e outra para as uvas compradas aos produtores vizinhos, conforme recomendação técnica do Sr. Smithes), deixara este conceituado administrador/diretor da Cockburn bem satisfeito «por ser todo muito bom».

Em síntese, podem por fim salientar-se duas ideias-força relevantes da dinâmica estrutural desta Quinta e sua representatividade, numa leitura e compreensão da história da produção e comercialização do vinho do Porto, especialmente na sub-região do Cima Corgo em que se localiza a Quinta Bartol e outras quintas durienses do concelho de Carrazeda de Ansiães:

1. Papel fulcral de uma diplomacia negocial entre o produtor de vinhos, a Quinta Bartol, e o comerciante exportador, as firmas Martinez \& Gassiot e Cockburn \& Smithes, fundidas em finais dos anos 1960;

2. Esta diplomacia construía-se através de relações complexas dados os pressupostos externos do negócio do vinho do Porto, muitas vezes eles próprios discutidos pelas

\footnotetext{
${ }^{436}$ Sublinhado na própria carta.
} 
partes com interesses económicos divergentes quanto à sua interpretação e aplicação e os efeitos de tensão conjuntural delas resultantes sobre terceiros, como os pequenos proprietários vizinhos, vendedores da sua produção de uvas e vinho e os «arrobeiros», intermediários locais entre estes e os médios e grandes produtores.

A tradução atrás ensaiada de uma situação socioestrutural vivida e documentada permite, pela própria qualidade e posição relativa dos intervenientes nas relações comerciais, assim estabelecidas, assentes em contratos clássicos entre duas partes, perceber como refletem e lhe subjazem outras redes de relações locais e nacionais envolvidas e não representadas, necessariamente, a nível contratual. O que, aliás, configura um traço marcante e permanente da história do Douro Vinhateiro, particularmente desde os séculos XVII e XVIII até aos nossos dias.

\subsection{A QUINTA DA ALEGRIA, CONTINUIDADE E ARQUIVO: RESILIÊNCIA DURIENSE}

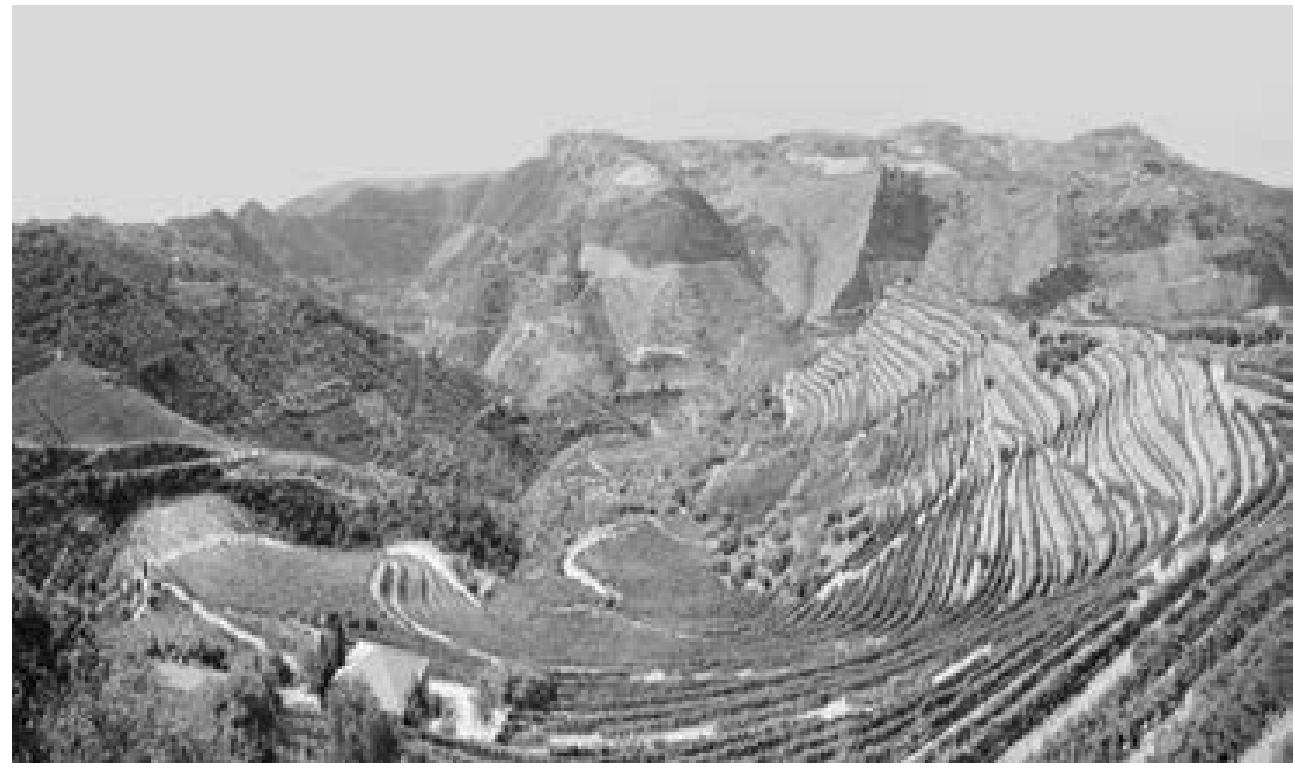

Fig. 87. Vista aérea da Quinta da Alegria

Fonte: Fotografia de Alexandre Augusto Mariz, atual proprietário

Ensaia-se aqui uma aproximação à micro-história da Quinta da Alegria ${ }^{437}$, fundada em 1800, na freguesia de Linhares do concelho de Carrazeda de Ansiães que se manteve sempre nas mãos da mesma família, embora mais tarde subdivida nas quintas da Alegria de Cima e

${ }^{437}$ Texto adaptado, desenvolvido e atualizado a partir de LAGE, 2014 
Alegria de Baixo, por efeito de sucessões, partilhas e mudanças de proprietário. Esta unidade produtiva rural bicentenária, é propriedade desde o início do século XIX da família Mariz, uma antiga e conhecida família de proprietários abastados não só deste concelho mas ainda de outras zonas de Trás-os-Montes.

\subsubsection{Localização da quinta e acessibilidades}

Localizada na margem direita do Douro, entre as sub-regiões do Cima Corgo e Douro Superior e na fronteira dos concelhos de Carrazeda de Ansiães e S. João da Pesqueira, esta antiga quinta fica próxima do histórico Cachão da Valeira, local onde foi construída, nos anos 1960, a barragem da Valeira. Encontra-se também próxima das famosas gravuras rupestres pré-históricas do Cachão da Rapa, classificadas como património arqueológico nacional, localizadas num penhasco sobranceiro ao Douro, entre as estações da Alegria e a de Foz Tua da linha férrea do Douro que atravessa, junto ao rio, a parte ribeirinha da Quinta da Alegria.

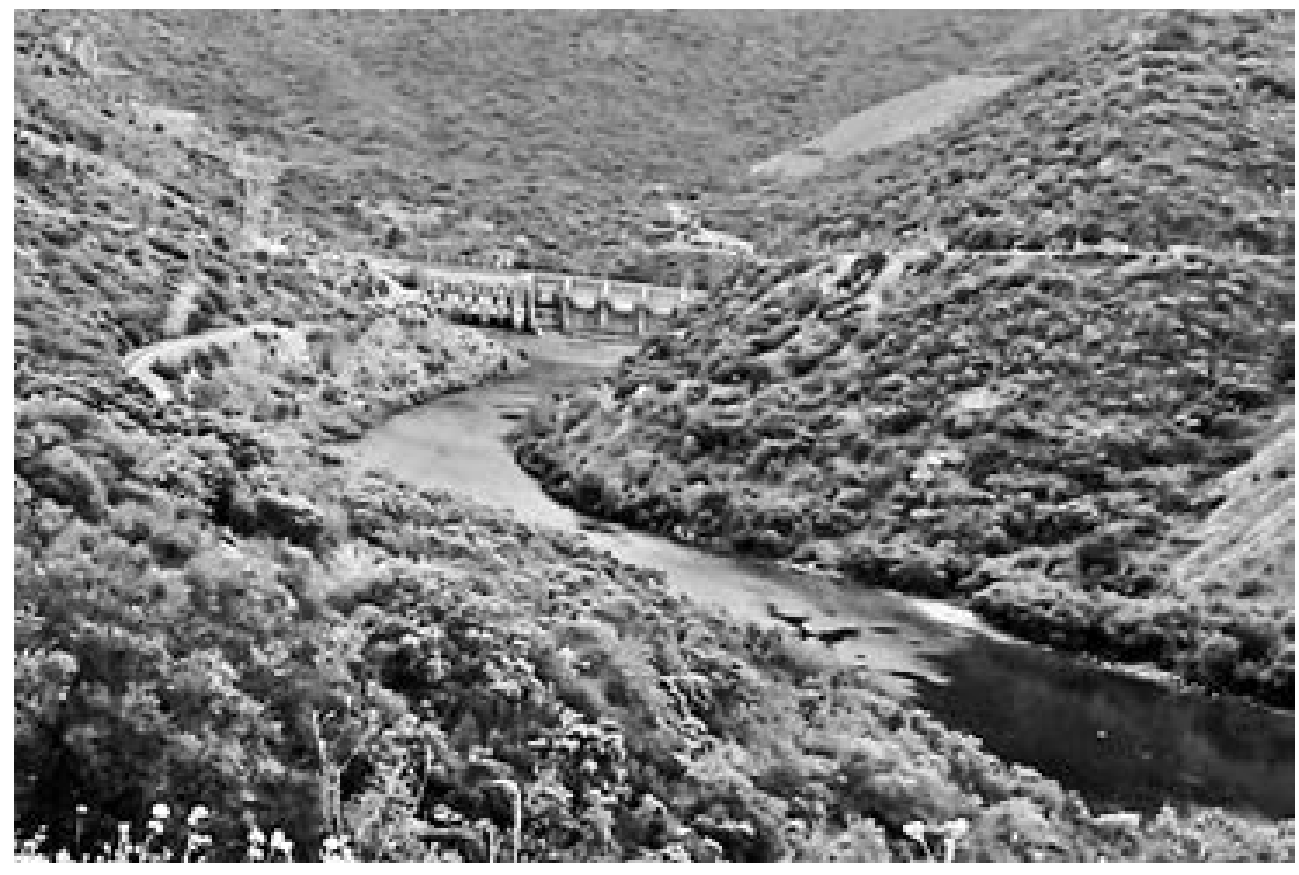

Fig. 88. Barragem da Valeira, concelhos de Carrazeda e S. João da Pesqueira Fonte: Fotografia O. L.

Descendo a estrada municipal estreita, sinuosa e de acentuado declive que liga a freguesia de Linhares (Carrazeda de Ansiães) ${ }^{438}$ onde se localiza a Quinta da Alegria, à barragem da

\footnotetext{
${ }^{438}$ Esta freguesia que integra a aldeia de Linhares e os lugares de Arnal, Campelos e Carrapatosa, dista 9,3 km a sudoeste da sede de concelho, e tem acesso através das estradas municipais 632 e 633.
} 
Valeira, em visita de reminiscências espaciotemporais ${ }^{439}$, em direção à ribeira de Linhares e barragem da Valeira, deixamos para trás, do lado esquerdo, o lugar de Campelos, com cerca de 50 fogos e a povoação de Carrapatosa (reduzida a pouco mais de 5 fogos dos 50 que tinha nos anos 1950 então), «tudo casebres de pequenos lavradores e trabalhadores das quintas». Sucedem-se, do lado direito, os pinheiros, as giestas e os carrascos numa larga extensão toda semeada de cereal (centeio) nessa mesma época de grande reserva de mão de obra para todo o trabalho muito antes do nascer do sol nas grandes propriedades e quintas que se estendem pelas encostas abaixo, «tudo isto do lado de cá e de lá do rio, era aqui uma escravatura, naquela vida da altura dos ricaços e dos escravos que andavam por estas arribas a pé e com escadas de cordas».

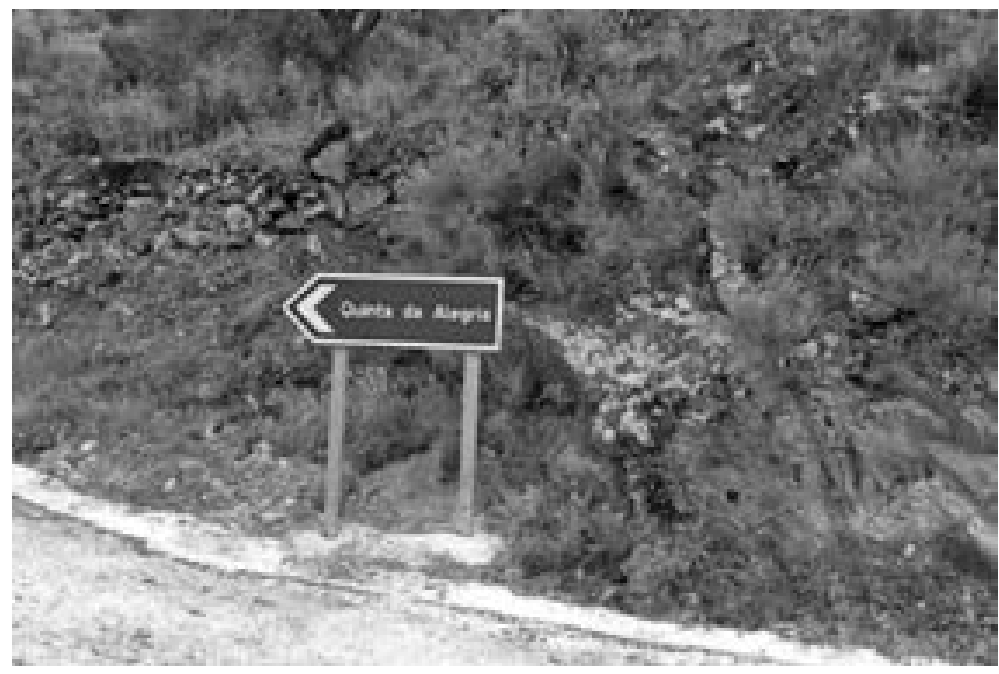

Fig. 89. Placa de sinalização pública no estradão de acesso à quinta Fonte: Fotografia O. L.

Surge-nos do lado direito a Quinta da Alegria de Cima ligada a esta estrada por um estradão serpenteante, obra do Município de Carrazeda de Ansiães, que atravessa os 10 ha de vinhedos dos 20 ha da área da quinta até «às casas de residência e os dormitórios antigos cardenhos restaurados» e aos lagares e armazéns, «grandes e antiguíssimos» mas apetrechados com modernos equipamentos. Esta quinta confina com a Quinta da Alegria de Baixo, numa extensão de 100 ha até ao rio, junto à Estação da Alegria, outrora muito concorrida por carros

\footnotetext{
${ }^{439}$ Entrevista informal de 13 de maio de 2017, com visita guiada à área geográfica concelhia de envolvência desta quinta, com Fernando dos Anjos, nascido em 1939 no lugar de Carrapatosa da aldeia e freguesia de Linhares. Este entrevistado, um dos 8 filhos de pequeno proprietário local de minúsculas leiras e umas poucas oliveiras, trabalhou, dos 13 aos 18 anos, nas vindimas e outros trabalhos da vinha na Quinta da Alegria de Cima (na do Dr. Pontes de Valdigem, casado com a Dona Maria Helena Morais Frias Pontes Ferreira de Almeida, na dos Guilhar e na do Mariz), na Quinta do Castelinho (S. João da Pesqueira) em frente, e ainda, já como «uma espécie de feitor», na Quinta da Alegria de Baixo (do Dr. Morais, médico fundador dos serviços púbicos de saúde, em Carrazeda). No final dos anos 1950, ingressou na CP onde se reformou como maquinista da Linha do Tua.
} 
de bois que transportavam as pipas de vinho tratado, cada junta 1 ou 2 vezes ao dia, por estes fraguedos abaixo em que "carreiros» morreram esmagados entre as pipas e as rodas dos carros que as levavam para a Estação onde aportavam também as barcas da Quinta do Castelinho em frente, na outra margem do rio.

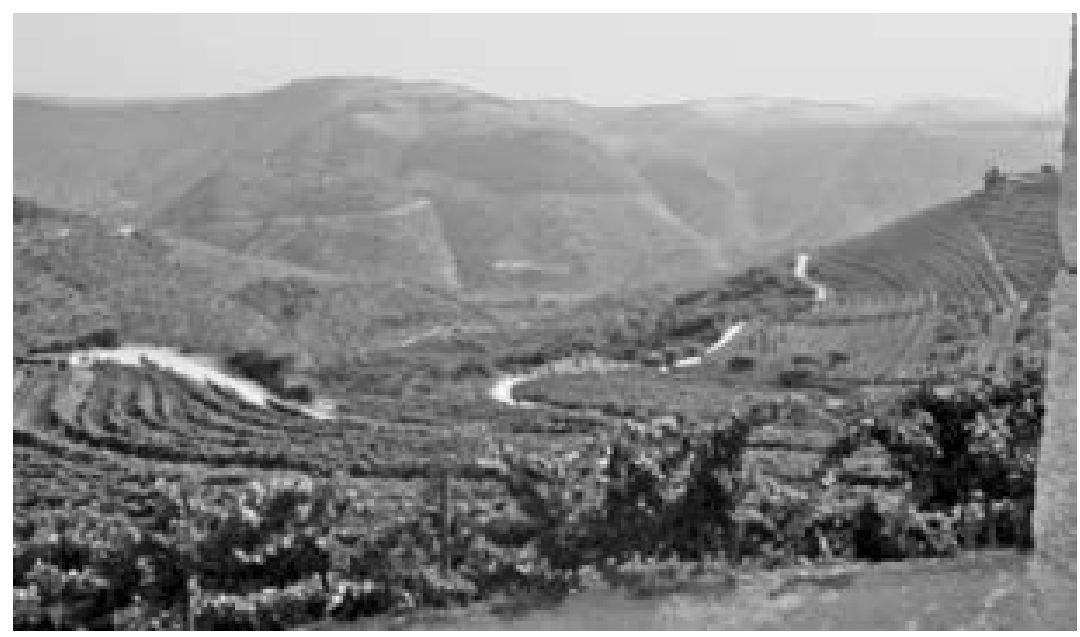

Fig. 90. Vinhedos da Quinta da Alegria de Cima e novo estradão Fonte: Fotografia O. L.

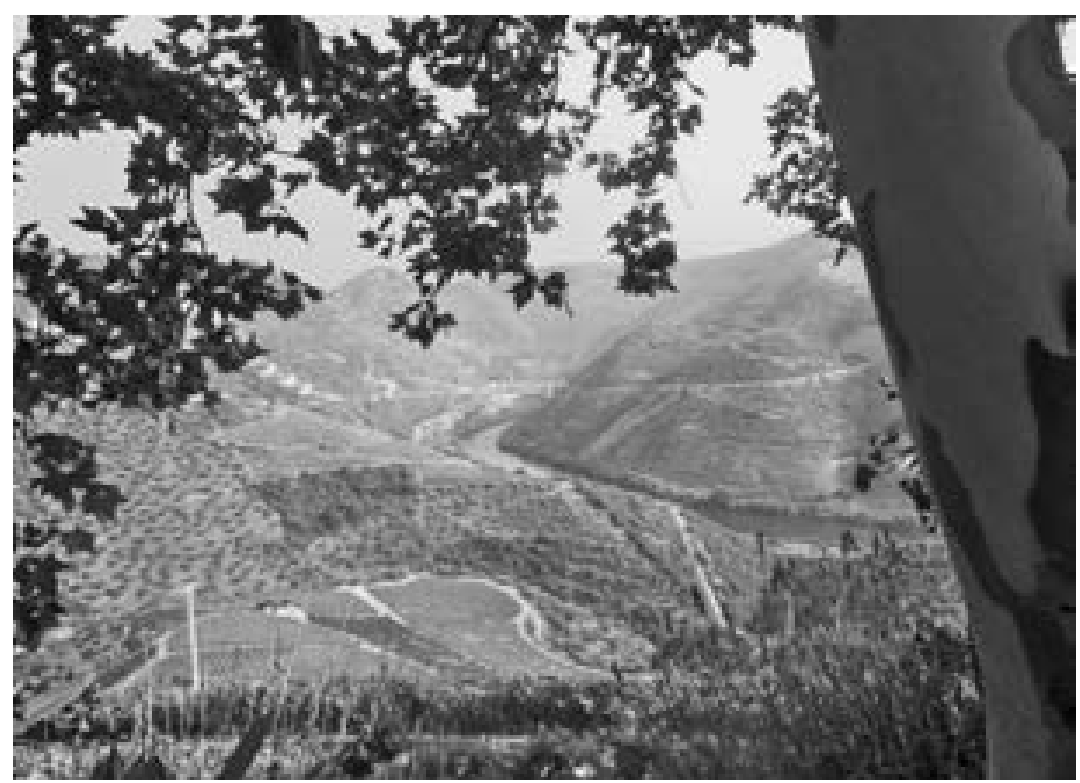

Fig. 91. Quinta da Alegria de Cima e mortório da Quinta da Canameira Fonte: Fotografia O. L. 
Ladeia toda a área da Quinta da Alegria ao longo de toda a parte esquerda da encosta, até à barragem da Valeira, mortório de grande extensão, antiga vinha afetada por doenças da videira, onde crescem carrascos e persistem algumas oliveiras da Quinta da Canameira ${ }^{440}$, propriedade de João dos Santos Pereira Ribeiro, de Sabrosa, desde o período da I República (1925), que terminava num fértil lodeiro de meloal e hortas junto ao Douro, e se encontrava ainda com atividade vitivinícola nos finais dos anos 1930, tendo sido adquirida em 2002 pela Vranken Pommery Monopol, Grupo francês de champanhe ${ }^{441}$.

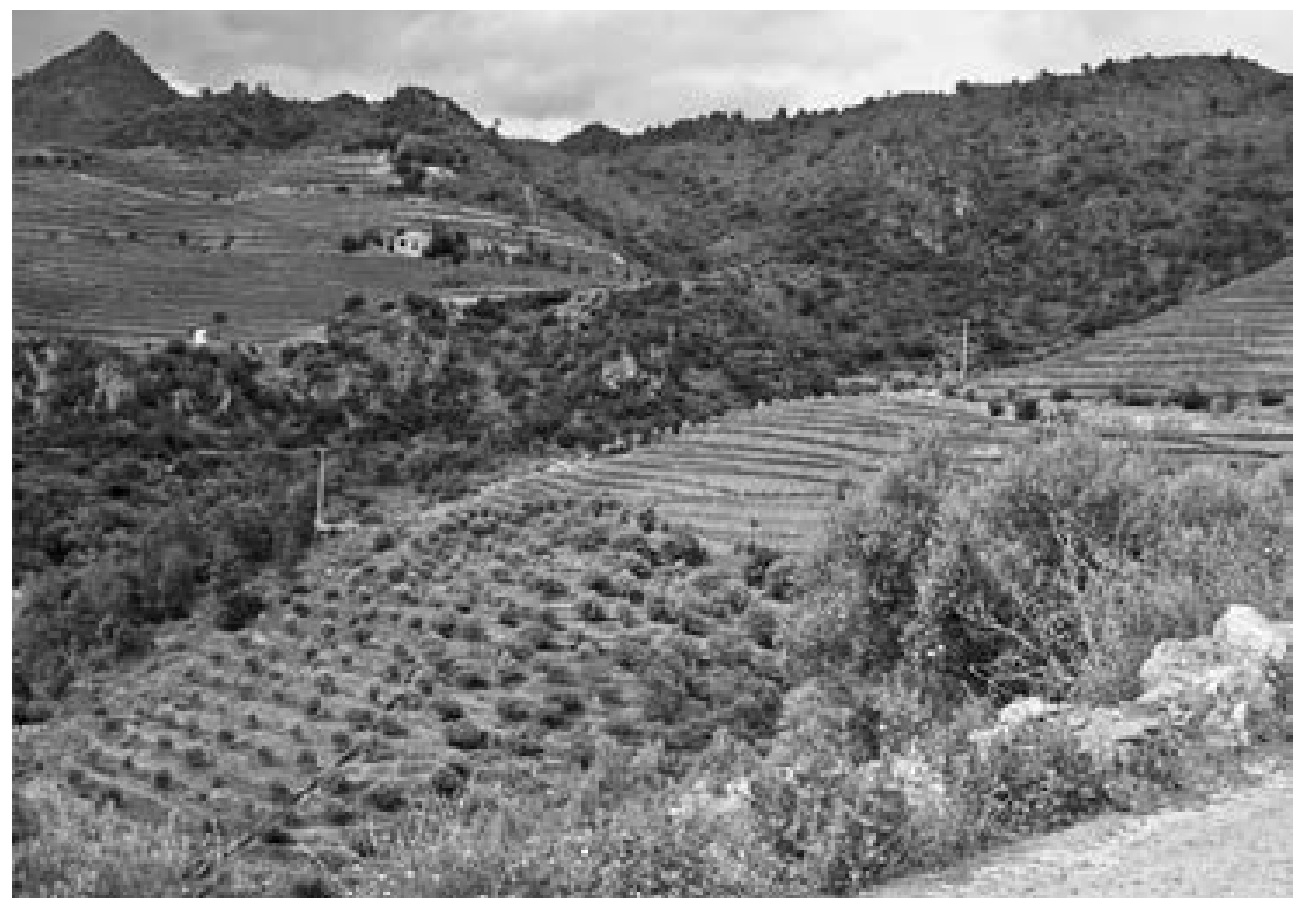

Fig. 92. Quinta da Alegria de Cima e «Castelo de Linhares de Ansiães»

Fonte: Fotografia O. L.

\footnotetext{
${ }^{440}$ Esta quinta, com uma área de quase 100 ha — vinha, olival e laranjal, casas de habitação, armazéns e lagares — pertencera no final do século XVIII e meados do século XIX, respetivamente a José António de Barros Teixeira Lobo (também dono da Quinta do Zimbro em Ribalonga) e a Gonçalo Lobo Pereira Caldas de Barros, ambos naturais de Sabrosa (ADB/ANCA — Livro de Notas do tabelião Cristóvão José de Sampaio e Sousa Pimentel (1793-1796), fl.120-124v.; Livro de Notas do tabelião Jóse de Morais (1855-1856), fl.125-128). A área mais próxima à direita da barragem da Valeira foi e é hoje considerada área protegida.

${ }^{441}$ Desde 1999 que este grande grupo detém a marca Rozès, que continua assim após 150 anos a ser liderada por franceses. No final de 2002, procedeu-se à fusão jurídica das sociedades Rozès e S. Pedro das Águias (também esta última uma empresa produtora e exportadora de vinho do Porto e fundada em 1986 pelo grupo Vranken Pommery Monopole), da qual resultou a Rozès S.A., com uma maior projeção comercial nos vários mercados, uma melhor transparência nos capitais investidos, uma melhor especialização da mão de obra existente e melhor rentabilização dos investimentos em curso. Para mais informação, consultar: http://www.dodouropress.pt/index. asp? idedicao $=66 \&$ idseccao $=899 \&$ id $=8336 \&$ action $=$ noticia .
} 
A Quinta da Alegria de Cima tem agora «toda a vinha replantada e "muito boa" tendo também em Linhares na parte mais alta e granítica 2 ha de vinha da casta Arinto com que produz hoje os seus vinhos brancos de mesa comercializados com a marca 'Tranquilo'. Conserva-se ainda "em casa da família Mariz de Linhares", na aldeia vizinha da Carrapatosa, no velho lagar de azeite da quinta, um grande tonel de granito encimado por uma espécie de funil também em pedra que ligava ao antigo lagar cujos alicerces ainda hoje se podem aí ver, foto abaixo" $0^{422}$ o qual "servia para receber o vinho e depois até já serviu para guardar lá cereal e fumeiro"».

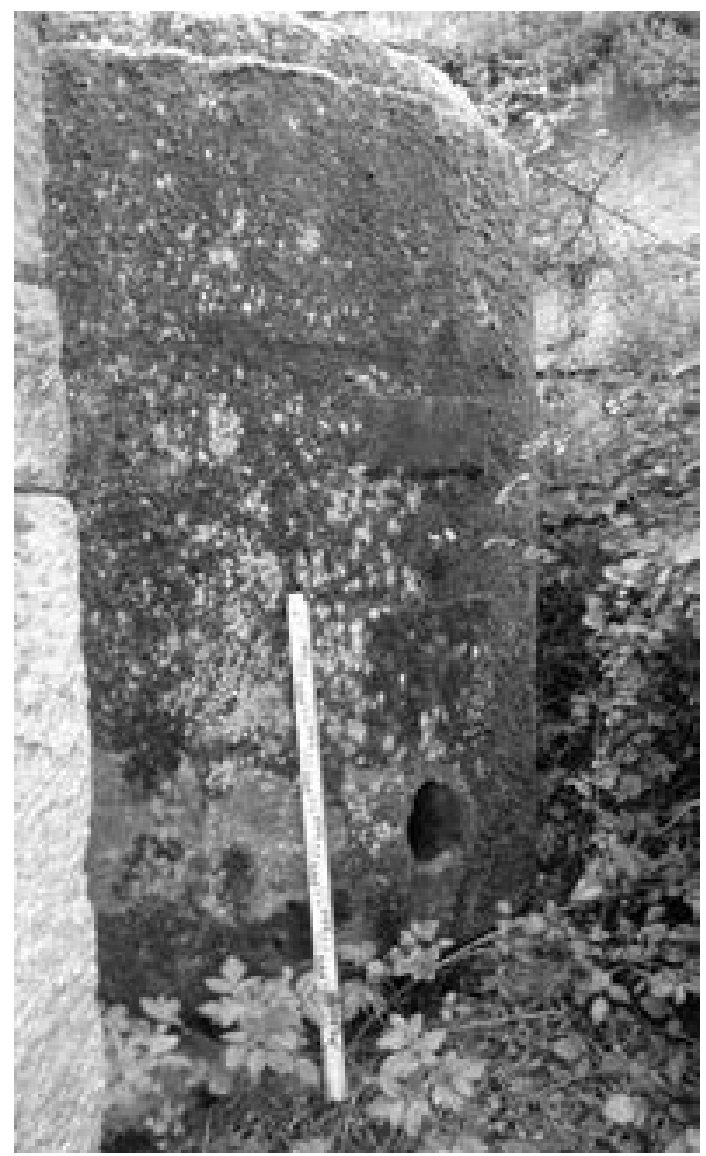

Fig. 93. Carrapatosa, Carrazeda de Ansiães - Tonel de granito Fonte: Fotografia Pedro A. Pereira

\footnotetext{
${ }^{442}$ Sobre esta curiosa construção em pedra que parece ter sido feita a partir de um bloco, peça única de granito depósito de apoio à produção vinícola —, foto inclusa cujos créditos se agradecem ao arqueólogo Pedro Pereira, este esclarece poder a mesma datar de finais do século XIX/inícios do século XX, altura em que este tipo de equipamento foi experimentado no Douro, sendo hoje já muito raro ou mesmo impossível encontrarem-se outros exemplares, entretanto abandonados e/ou destruídos.
} 


\subsubsection{Aproximação histórica e arquivística}

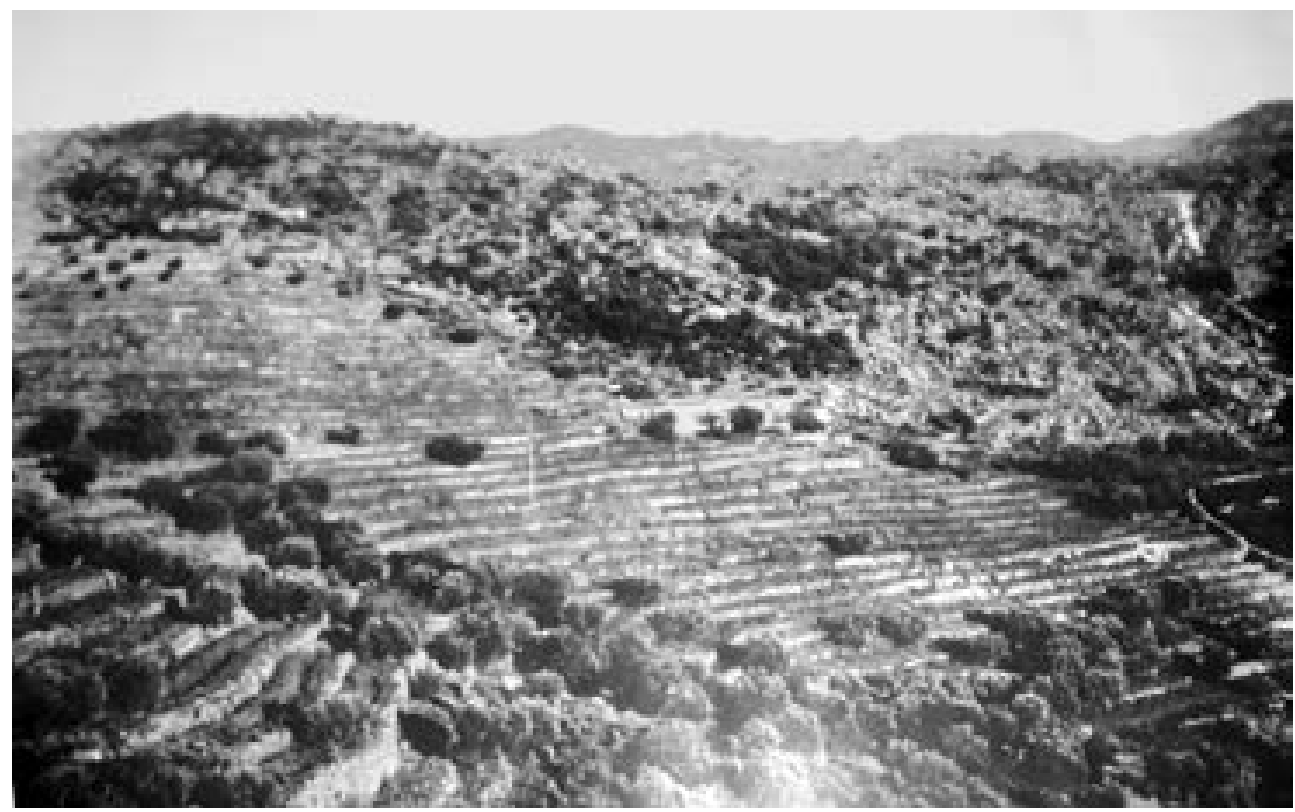

Fig. 94. Quinta da Alegria de Cima: olival, vinha, casas e cachoeira

Fonte: Fotografia histórica existente na quinta

Para a abordagem histórica desta quinta recorremos a fontes diretas, perspetivando-se o seu futuro desenvolvimento a partir da pesquisa dos seus arquivos privados.

Assim, importa refletir previamente sobre o interesse destes arquivos das quintas durienses na sua relação com novas práticas historiográficas, por referência à importância deste género de património arquivístico regional para investigação e análise de quintas do Douro emblemáticas localizadas no concelho em Carrazeda de Ansiães ${ }^{443}$.

É de realçar a generosa disponibilidade intelectual do atual proprietário, da Quinta da Alegria de Cima, Alexandre Mariz que com os seus relevantes e seguros conhecimentos da quinta e também da história da vinha e do vinho no concelho e na Região do Douro, tem sido nosso aliado fundamental neste estudo, tanto mais quanto uma das grandes dificuldades com que nos debatemos é, para além da reduzida bibliografia sobre esta vertente da história do concelho, a extrema carência de arquivos, fontes diretas e informações locais/regionais disponíveis, com uma enorme dispersão e deficiente organização e inacessibilidade. Esta constrição é precisamente a questão prévia a qualquer investigação histórica, em particular sobre as quintas durienses que enformam decisivamente a história milenar do Douro cujo conhecimento mais denso e profundo ganhará com o contributo de um maior número de estudos monográ-

${ }^{443}$ LAGE, 2014; LAGE, 2009a; LAGE, 2010a; LAGE, 2011: 51-73. 
ficos sobre outras quintas durienses, designadamente as de zonas de fronteira, nas sucessivas delimitações da RDD, como é o caso das de Carrazeda de Ansiães.

Do ponto de vista da investigação histórica sobre a Quinta da Alegria, em que são referência obrigatória alguns dos melhores trabalhos sobre as quintas do Douro ${ }^{444}$, entendemo-la, à semelhança de outras quintas durienses do concelho, como um constructo transdisciplinar, parte de uma rede de microcosmos de valor patrimonial e sociocultural, a observar numa perspetiva interescalar (do local ao global) e na longa diacronia.

Recorrendo então à ainda reduzida bibliografia específica disponível, desenvolve-se também a abordagem histórica desta quinta, em dois eixos: sua posição e papel à escala local e, adensando a abordagem, sua representatividade numa escala mais ampla, enquanto fenómeno económico, social e cultural de produção vitivinícola em meio rural na fronteira entre o Alto Douro e o Douro Superior.

\section{Dos arquivos particulares das quintas durienses à construção da micro-história}

A importância dos arquivos particulares das quintas durienses, sem reporte público tão estrito como o dos arquivos empresariais, e a especial relevância dos arquivos pessoais dos seus proprietários, tornam essa massa documental incontornável para o conhecimento da história intensiva destas unidades económicas originalmente de matriz familiar e seus respetivos impactos locais e regionais. Sem prejuízo, no entanto, de as sucessivas demarcações da Região Vinhateira do Douro e as várias instituições oficiais próprias (igualmente produtoras de documentos, mas de arquivos públicos) serem também fautores da produção e salvaguarda de importante património arquivístico essencial à investigação historiográfica.

Pela história das quintas do Douro e dos seus arquivos privados passa uma parte fundamental da história da vinha, do vinho do Porto e da Região do Douro Vinhateiro, Património Mundial. Por aí poderá passar também uma renovação das práticas historiográficas e uma revivificação da história económica, social, cultural e rural ao nível local, da região duriense e do comércio globalizado do vinho do Porto. É inegável o seu possível contributo para a abertura de novas pistas de investigação, para além do esclarecimento de temas tradicionais: «a produção e comércio vitivinícola, geografia dos vinhedos, técnicas e tecnologias de fabrico, evolução dos processos produtivos, racionalização do trabalho, questões de propriedade, gestão e administração destas unidades económicas, etc.» ${ }^{445}$.

O estado do património documental das quintas durienses, é assim resumido, a par da sua importância, na sólida revisão da literatura que Gaspar Martins Pereira fez já desta matéria (2002):

Disperso, na sua maior parte vedado aos investigadores, desorganizado e, em certos casos, em risco, a importância desse património justifica medidas urgentes de preservação

\footnotetext{
${ }^{444}$ PEREIRA, 2011.

${ }^{445}$ PEREIRA, 2003a: 139-143.
} 
e valorização, quer através do seu tratamento especializado, quer através do seu estudo. Deve, no entanto, sempre que possível, promover-se a sua conservação nas casas ou quintas que os produziram, já que a sua descontextualização poderá representar perdas de significado e de função. Em relação a essas coleções privadas, sejam familiares ou de empresas, penso que seria de todo o interesse promover ações de cooperação entre os respetivos proprietários, os organismos responsáveis pelo património arquivístico, centros de investigação e unidades universitárias, com vista a mobilizar recursos técnicos e humanos adequados para a preservação, estudo e divulgação desses acervos [... $]^{446}$.

E porque esta reflexão possui um caráter interdisciplinar — situando-se entre a História, a Arquivologia/Arquivística e o Património Arquivístico - é a essa luz que as fontes históricas e os arquivos privados precisam também de ser debatidos, dada a sua relevância para um melhor entendimento da relação Memórias, Património Cultural e Arquivístico.

Não se pode no entanto ignorar a bibliografia especializada entretanto produzida sobre a importância da preservação e organização técnica destes arquivos, que entre nós tem vindo a aumentar, sobretudo desde 2001/2002, designadamente, com o novo estatuto académico da Ciência da Informação, e o relevante contributo de novos estudos e trabalhos arquivísticos e historiográficos sobre alguns arquivos de quintas históricas durienses, melhor conservados ${ }^{447}$. Saliente-se embora o facto de muitos dos arquivos privados das quintas se encontrarem dispersos ou diluídos parcialmente nos arquivos de empresas do Douro e vinho do Porto, por força do grande movimento neste setor de compras, vendas, fusões e consequente centralização de propriedades, bens e documentos. Tal dinâmica pode mesmo explicar a importância e significado que tem hoje o Arquivo Histórico do Grupo Symington Family Estates no qual se conservam hoje vários fundos e núcleos documentais provenientes de antigos e importantes arquivos das muitas unidades económicas que foi adquirindo no Douro Vinhateiro. É aliás de destacar a atenção e cuidado que este Grupo, o maior proprietário atual do Douro, confere à sua relevante documentação de arquivo em matéria de competentes serviços de conservação, organização técnica e acesso ${ }^{448}$ destas fontes históricas que são um recurso essencial para o estudo de empresas e quintas durienses.

No caso de Carrazeda de Ansiães ${ }^{49}$, há a salientar a abertura de acesso que obtivemos no arquivo histórico Symington a fontes e documentos aí existentes sobre diversas quintas do

\footnotetext{
${ }^{446}$ PEREIRA, 2003a: 139-143.

${ }^{447}$ Ver referência de alguns desses trabalhos em Gaspar Martins Pereira, ob. cit. e outros investigadores do Douro. Ver também a posterior produção no domínio arquivístico publicada no âmbito da BAD e no contexto de licenciaturas, mestrados e doutoramentos de algumas universidades e politécnicos nacionais com formação superior e pós-graduada em ciências da informação e documentação.

${ }^{448}$ Realce, neste âmbito, para o trabalho arquivístico desenvolvido sobretudo pela Dra. Paula Montes Leal e ainda a Dra. Marlene Cruz, arquivistas e investigadoras do CITCEM.

${ }^{449}$ Não dispõe ainda o concelho de Carrazeda de Arquivo Municipal próprio e a documentação referente à sua história e do concelho medieval de Ansiães, encontra-se mal acautelada em termos de preservação e organização, para além de pouco acessível e muito dispersa em diferentes locais: arquivos distritais de Bragança, Braga e Vila
} 
concelho, incluindo a Quinta da Alegria ${ }^{450}$, mas também e muito em especial o bom estado de preservação do arquivo privado da importante Casa Agrícola da Família Mariz, proprietária longeva da Alegria, bem como a disponibilização ao seu acesso e digitalização, por parte do seu proprietário, o Eng. Alexandre Mariz.

Todavia, a atual situação ao nível arquivístico, na sua generalidade (localização, descrição e análise documental e teor informativo, organização técnica e divulgação), e a acessibilidade dos historiadores aos arquivos privados das quintas durienses, mormente, em Carrazeda continuam a revelar-se uma dificuldade até certo ponto intransponível, embora sejam uma exigência maior das novas práticas historiográficas, como se disse. Para tal concorrem vários fatores: o ainda deficiente estado geral de conservação/organização, uma generalizada inacessibilidade e a dispersão de documentos da mesma proveniência orgânica, por diversos arquivos públicos municipais e distritais, onde os arquivos privados não são incorporados nem inventariados ou sequer referenciados, devido à sua natureza de propriedade privada com frequentes transmissões de propriedade das próprias quintas pela sucessão de heranças, partilhas, casamentos, compras e vendas, o que dificulta a conservação e transmissão destes arquivos e concorre para o seu desmantelamento e desaparecimento.

É por isso imprescindível a proatividade integrada de arquivistas, historiadores e outros agentes da cultura e da investigação na salvaguarda e estudo dos espólios arquivístico-históricos que ainda se conservam nas casas e famílias de origem, o que requer estratégias oficiais de sensibilização dos seus proprietários, mas também uma mudança substancial das políticas públicas sobre este relevante segmento do património arquivístico do país, dinâmicas de interesse público e valor imprescindível para a investigação científica histórica, cuja realização não tem instrumentos plasmados na legislação nacional arquivística ${ }^{451}$ que consigna ao Arquivo Nacional/Torre do Tombo (ANTT) amplas atribuições na preservação, organização e acesso público a todo o património arquivístico nacional.

Ora, considerados no seu conjunto, os arquivos particulares apresentam um largo espetro de tipologias podendo ser técnicos, privados e comerciais ${ }^{452}$ mas ainda familiares, empresariais e mistos. Constituem em regra miscelâneas de monografias e revistas esparsas, dossiers de trabalho, cópias de documentos oficiais (escrituras, testamentos, inventários, contabilidade...) documentos diversos avulsos e outros papéis impressos ou manuscritos, notas e apontamentos, cadernos, relações e róis de tudo ou quase tudo desde mobiliários, equipa-

\footnotetext{
Real, Museu Abade Baçal, em Bragança, ANTT e Biblioteca Nacional em Lisboa, outros arquivos públicos, privados e pessoais e ainda espalhada por vários particulares.

${ }^{450}$ Refiram-se ainda, a título de exemplo, designadamente para esta quinta a sua assídua e diversificada correspondência dos anos 1920 e 1930 com as empresas Cockburn \& Smith e Silva Cosens e para as outras quintas: Canais, Canaes/Bartol, Zimbro, Tua, Senhora da Ribeira e Coalheira, inventários de bens e propriedades, produções, investimentos em plantações, melhoramentos e pessoal, negócios de uvas e vinhos com as mesmas empresas, etc. ${ }^{451}$ Portaria n. ${ }^{\circ}$ 192/2012, de 19 de junho, e Despacho n. ${ }^{\circ}$ 9339/2012, de 11 de julho, e as competências formais dos arquivos distritais, de incorporação, preservação, inventariação, catalogação e difusão do património documental de cada distrito, conforme Despacho n. ${ }^{\circ} 18$ 834/2007, de 22 de junho.

${ }^{452}$ PRADO, 1968: 154
} 
mentos domésticos e empresariais, roupas, produções agrícolas, salários, contratação de mão de obra, e mesmo relações de objetos furtados, diários pessoais, recortes de jornais, correspondências, e outras espécies documentais que fazem parte do trajeto de vida das unidades produtoras e das pessoas a elas ligadas (certidões de nascimento e casamento, fotos, telegramas, cartões postais, álbuns de família, etc...). Estes documentos, geralmente pré-organizados por critérios leigos e individuais, encontram-se em estado «inorgânico» de arquivo privado em locais inapropriados à sua conservação ou esquecidos em armários, cómodas e recônditos antigos no interior de casas, sendo até de difícil localização para os possuidores atuais.

É toda uma importante história que por aí perpassa a exigir reconstituição. Tendendo a registar e apresentar aspetos relativos à história das famílias proprietárias dominantes, as memórias depositadas nesses arquivos revelam experiências e vivências de pessoas destacadas e/ou comuns essenciais à história quotidiana do vivido. Propendem em geral, para a intimidade, já que quando produzidos não se lhes exigiu o nível de oficialidade ou notoriedade que caracteriza outros tipos de documentos de arquivo.

Não é fácil, para o historiador que pretende estudar também essa história, romper os múltiplos segredos da privacidade. É nas fontes privadas (geralmente escondidas nos segredos da vida e ação pessoais, não catalogadas nem prontas a serem pesquisadas) que residem as memórias dos homens comuns, pelo que há que ultrapassar as barreiras de localização/acesso a estas fontes particulares para que se possa construir essa outra dimensão mais atual e significativa da história.

Aliás, tal desiderato, no caso específico das quintas durienses, firmas e famílias suas proprietárias que a interrogação dos respetivos arquivos particulares permite revelar, especialmente ao nível das memórias, identidades e culturas, pode mesmo contribuir decisivamente para a sua transformação significativa enquanto potencialidade estratégica propiciadora de vantagens competitivas relativamente a outros concorrentes no mercado, como, aliás, a história das empresas feita a partir dos seus arquivos próprios têm vindo a demonstrar ${ }^{453}$.

\subsubsection{Contextualização espaciotemporal e evolução da Quinta da Alegria}

A inscrição espaciotemporal desta quinta, assim como a referência às suas origens, encontram-se, sumariamente documentadas em mapas antigos do Douro Vinhateiro, nalgumas fontes históricas e em escassa bibliografia publicada ${ }^{454}$.

\footnotetext{
${ }^{453}$ MENDES, 2001-2002: 379-388. A preocupação com a proteção dos arquivos privados relativos às empresas foi já alvo de publicação de legislação específica — ver Decreto-Lei n. ${ }^{\circ} 429 / 77$, de 15 de outubro.

${ }^{454}$ As referências mais conhecidas são aqui citadas e parcialmente transcritas. Recentemente, MORAIS, 2014 : $312-$ -316, refere genericamente sob a mesma designação de Quinta da Alegria, mas em diferentes sub-rubricas da aldeia de Carrapatosa (freguesia de Linhares, Carrazeda), as seguintes propriedades com nomes (alguns topónimos locais antigos), histórias e dados diversos dificilmente compagináveis: quinta da Alegria e Picoto; quintas da Alegria, Olgas, Olival Velho e Ribeira; quinta da Alegria de Baixo; quinta da Alegria de Cima; quinta da Alegria/ Canameira.
} 


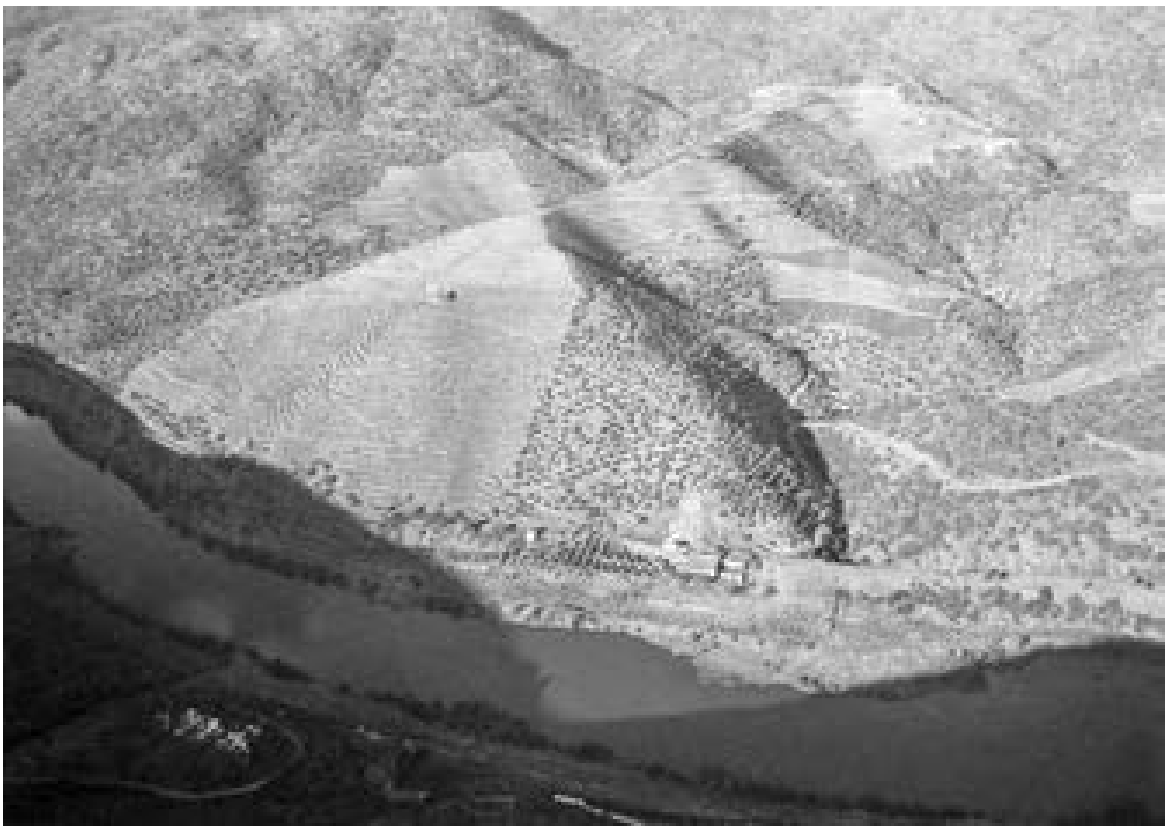

Fig. 95. Vista panorâmica da Quinta da Alegria de Cima Fonte: Fotografia do atual proprietário

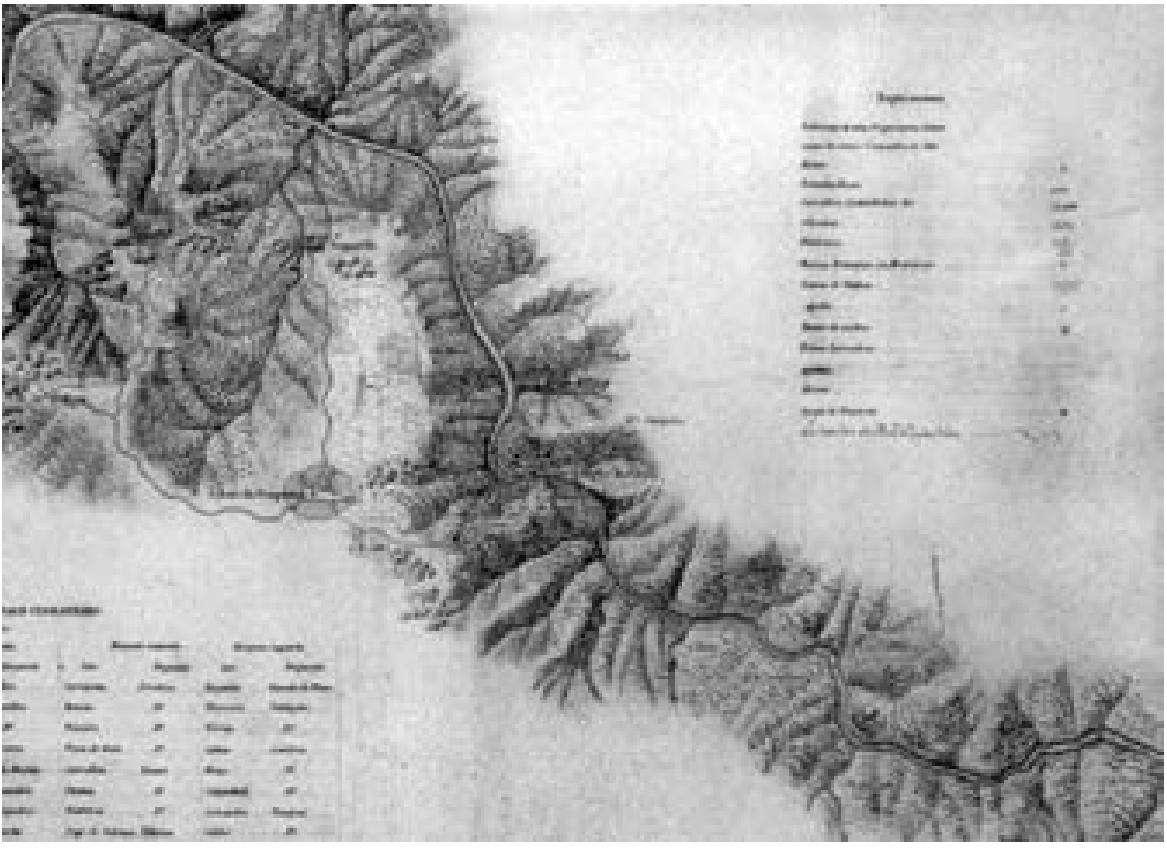

Fig. 96. Mapa de património arqueológico no País Vinhateiro e localização da Quinta da Alegria 
No século XVII grande parte dos terrenos da área da Quinta da Alegria estava a monte e os que se encontravam agricultados eram-no em cereal, para além de algumas oliveiras. Supõe-se que esses terrenos andavam então vinculados ao Morgadio de São João de Linhares ${ }^{455}$.

No decurso do século XVIII, ter-se-á desenvolvido a plantação da vinha nesta zona próxima de Ribalonga, única freguesia de Carrazeda incluída na «Demarcação Pombalina da Região do Douro» levada a cabo pelos Deputados da Junta da Administração da Companhia Geral da Agricultura das Vinhas do Alto Douro ${ }^{456}$.

No século XIX, a Quinta da Alegria, cuja fundação remonta a 1800, vai sendo aumentada até 1860, por sucessivas compras de terrenos, aquisições acompanhadas da construção de socalcos e plantação de novas vinhas. A sua propriedade concentrara-se nos filhos de António José de Sampaio, à sua morte, por herança da metade, e por testamento do tio falecido sem filhos.

No início da invasão do Douro pela praga da filoxera (1863) que afetaria mais tardiamente o concelho de Carrazeda, trabalhava na Quinta da Alegria, no ano de 1863, um número então muitíssimo elevado de trabalhadores: 20 feitores, 20 «empreiteiros», 236 pedreiros, 39 paquetes e 695 trabalhadores indiferenciados ${ }^{457}$.

E, mais precisamente, entre os anos de 1861 e 1865, eram também em grande número os galegos que se encontravam aqui a «compor muros, levantar calços, abrir estradas e encavar uma mina na Quinta da Alegria e a levantar paredes no Zimbro e Coalheira ${ }^{458}$, duas antigas quintas vizinhas da Alegria.

O Visconde de Vila Maior, autor de referência incontornável anteriormente relevada em subcapítulo próprio, nos seus estudos especializados e pioneiros de ampelografia e enologia do País Vinhateiro do Douro (1865) ${ }^{459}$, apresenta mais detalhadamente a Quinta da Alegria, salientando as extensas plantações aí feitas em circunstâncias pouco favoráveis, as condições que reúne para ser um dos melhores prédios do Douro e a excecional qualidade dos vinhos que já então produzia. Reporta a sua fundação aos inícios do século XIX e o seu desenvolvimento a uma conjuntura histórica, verificada à época, de grande prosperidade da viticultura nesta região duriense, grande aumento da exportação dos vinhos do Douro e extraordinária subida do preço dos vinhos generosos.

\footnotetext{
${ }^{455}$ MORAIS, 2014: 312-316.

${ }^{456}$ Da associação da Companhia Geral da Agricultura das Vinhas do Alto Douro, fundada em 1756, com a Real Companhia Vinícola do Norte de Portugal, fundada em 1889, vai resultar a Real Companhia Velha, designação do século XX.

${ }^{457}$ Carta de 12 de julho de 1868 do Administrador da Quinta do Vesúvio para o escritório da Empresa Ferreirinha no Porto. Ficha registo n. ${ }^{\circ}$ 5046, base de dados Dona Antónia Ferreira. Agradecem-se estas informações à arquivista e investigadora do CITCEM, Dra. Paula Montes Leal.

${ }^{458}$ Documentos em «conta de caixa», maio de 1861 (AHS - Quinta do Vesúvio. Correspondência de António Dias de Magalhães, administrador da Quinta do Vesúvio para António José Claro da Fonseca no escritório da Empresa Ferreirinha do Porto, cx. 2934, pasta 2, u.i. 10067).

${ }^{459}$ VILA MAIOR, 1865: 157-160.
} 
Na margem direita, entre os granitos do Cachão e os de Mirago, estão as encostas em que se acham situadas as duas quintas da Alegria [...] No princípio deste século, um abastado cavalheiro das terras de Ansiães, o Sr. Luís António de Sampaio [...] empreendeu a plantação destas encostas em larga escala, e lançou então os fundamentos do que hoje são as duas quintas da Alegria de Cima e de Baixo. [...] A Alegria de Cima, tendo de 90 a 100 milheiros de cepas, raras vezes produziu de 50 a 60 pipas, e orçava-se a sua produção regular unicamente de 30 a 40 pipas. Acha-se atualmente administrada pelo Sr. A. J. Ferreira Pontes, marido da Sra. Dona Flora de Sampaio e Mello, filha do fundador. [...] É grande a sua extensão, excelente o solo e magnifica a exposição das suas encostas que olham desde o leste ao sul. Além da vinha, que ocupa uma grande área, possui muitos terrenos pelos quais se podem alargar novas plantações; tem pomar de laranjeiras e uma recente plantação de amoreiras [...] Um grupo importante de edificações enobrece esta propriedade. Compõe-se este de bons lagares e grandes adegas com a suficiente capacidade para recolher todos os vinhos que neste sitio se podem produzir, de casas de habitação para os donos, de acomodações para trabalhadores, de abegoaria e oficinas para diferentes serviços, e alem disto, possui sobre o rio uma azenha para moenda de cereais. Os vinhos desta quinta foram sempre considerados de primeira classe; são pouco encorpados, muito maduros, espirituosos e aromáticos, e especialmente são notáveis os vinhos brancos pela sua distinção e superioridade. Alegria de Baixo, [...]. As condições físicas desta parte da Alegria diversificam um pouco das que se notam na anterior. Algumas das ladeiras que ela ocupa têm uma exposição menos favorável, e sendo nelas ao mesmo tempo o solo mais fundável; as uvas que ali se produzem não adquirem maturação tão perfeita como na Alegria de Cima, são por isso menos sacarinas, e fornecem vinhos menos generosos e balsâmicos. Contudo estes vinhos apresentam muito corpo e robustez, e ainda que não sejam artificialmente aguardentados, desenvolvem bastante força e espirito, que lhes garante longa conservação, permitindo-lhes sucessivo aperfeiçoamento e a manifestação de excelentes qualidades para deverem ser considerados bons vinhos de primeira classe para exportação e frasqueira. Esta vinha, principalmente nas partes menos soalheiras, tem disseminadas muitas oliveiras e amendoeiras. As suas oficinas são suficientes para o serviço da quinta, porém não passam de modestas [... $]^{460}$.

Como veremos, já bem mais tarde, nos anos 20 e 30 do século XX, a administração da Quinta da Alegria de Cima anda associada à da Quinta do Zimbro em Ribalonga, ao nível das colheitas anuais, produção e venda dos seus vinhos a firmas inglesas com quem tratava então, direta e conjuntamente, o conceituado proprietário da Alegria, Alexandre Augusto Mariz, de reconhecido espírito republicano e acentuada propensão para o desenvolvimento técnico da época.

${ }^{460}$ VILA MAIOR, 1865: 158-159. Transcrições do texto com atualização da ortografia. 
Aliás, depois de a Quinta da Alegria ter sido supostamente vendida a Alexandre Tomaz da Costa Pinto, em 1883, é Alexandre Augusto Mariz que vai surgir, em 1921, como seu proprietário e a manter a posse da mesma em 1938 até à posterior transmissão a seu filho único sobrevivo, pai do atual proprietário, co-herdeiro, com mais três irmãos, da Casa Agrícola.
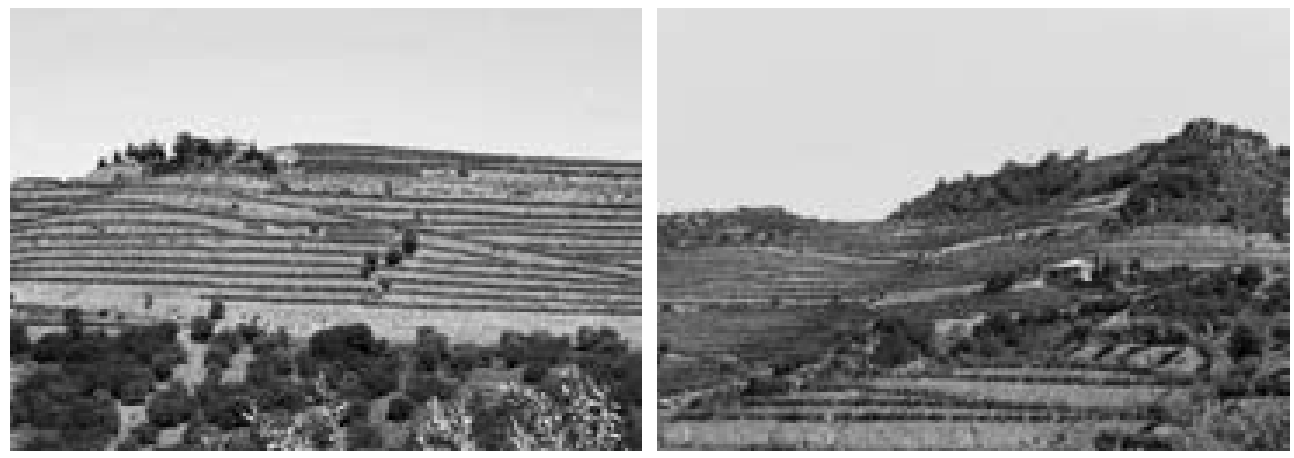

Fig. 97. Perspetivas da Quinta da Alegria de Cima, Linhares - Carrazeda de Ansiães.

Fonte: Fotografias de A. J. F.

A envolvente espaciotemporal da Quinta da Alegria, cuja história brevemente se resumiu, era, por sua vez, assim descrita nos alvores da I República Portuguesa.

O vértice reentrante do angulo que o Douro aqui forma e onde está o ponto do Cachão aproxima-se: de além a verticalidade irregular e sinistra prolonga-se e sobe indefinidamente para os ápices em que se encarrapita S. Salvador do Mundo; d'aquém dá-se um imprevisto desvio na linha de projeção e os penhascos tisnados e pardos aparecem... Numa fraga da esquerda já se apercebe a lapide comemorativa do rompimento dos rochedos do Cachão no último quartel do século XVIII que intercetavam a navegabilidade do rio. Descreve-se uma curva e o leito alarga, amplifica-se, desafoga-se mais, além de que, na reentrância, volta a aparecer a cor sorridente das cepas pertencentes à quinta da Alegria que possui também terrenos de sementeira e horta e dá o nome ao apeadeiro do caminho-de-ferro ${ }^{461}$.

No Estado Novo, início dos anos 1940, Alcino Cordeiro ${ }^{462}$ descreve, abreviadamente, em Carrazeda de Ansiães 29 quintas, algumas das quais eram então propriedade das conceituadas firmas de Vinho do Porto, Silva \& Cosens e Cockburn \& Smithes, hoje fundidas no Grupo Symington (Capítulo 8), e refere assim a Quinta da Alegria de Cima, em Linhares (Carrazeda): «[...] Proprietário: Sr. Alexandre Augusto Mariz [...] Foi fundada em 1800 pelo Sr. Luiz António Sampaio; em 1869 pertencia ao Sr. João Baptista de Morais e a sua produção em vinho era de 30 pipas $[\ldots] »$.

\footnotetext{
${ }^{461}$ MONTEIRO, 1998: 24-25. Atualização da ortografia do texto transcrito.

${ }^{462}$ CORDEIRO, 1941: 3 .
} 
$\mathrm{Na}$ mesma freguesia e concelho é igualmente referenciada nestes termos a Quinta da Alegria de Baixo, confinante com a da Alegria de Cima, um pouco mais abaixo em relação ao curso do Douro:

\section{Proprietário: Sr. Dr. Álvaro Ferreira Pontes, residente em Valdigem.}

'E servida por caminho de acesso à estação de Alegria, a mais próxima. A sua produção é de 15 pipas de vinho (tinto) e 10 pipas de azeite, cereais e frutas diversas. Tem azenha, alambique para destilação de bagaço e armazém com vasilhame na capacidade de 120 pipas. Esta quinta foi fundada em 1800 pelo Sr. Luiz António Sampaio e em 1869 era propriedade da filha do fundador, Sra. Dona Flora de Sampaio e Melo, casada com o Sr. A. J. Ferreira Pontes. A sua produção nessa data era de 50 pipas de vinho [...].

Como se pode deduzir, estamos originariamente em presença de uma única e mesma Quinta da Alegria que, remontando embora a sua mais antiga história já aos séculos XVII e XVIII, fora constituída em 1800 por Luís António Sampaio e mantida pelos seus descendentes até aos anos 1940. A divisão posterior desta grande propriedade ter-se-ia ficado a dever a heranças e casamentos enquanto que as designações «de cima» e «de baixo», se poderão explicar pelo afastamento ou proximidade em relação ao rio Douro da sua localização geográfica, na encosta que desce do planalto de Carrazeda de Ansiães para a margem direita do Douro, tal como é frequente nesta zona do concelho.

Aliás, ainda nos nossos dias se verificam algumas situações idênticas de transmissão geracional e reprodução familiar, o que é caso raro na história da generalidade das quintas do Douro. A atual Quinta da Alegria de Baixo é propriedade de descendentes do falecido Dr. Morais Fernandes da família Morais Fernandes de Linhares ligada por casamentos à família Mariz, médico conhecido, fundador e proprietário do primeiro colégio particular existente em Carrazeda, na década de $1960^{463}$.

Segundo informação de Alexandre Mariz, atual proprietário da Quinta da Alegria de Cima, esta, localmente conhecida por Quinta da Alegria do Mariz, sempre nas mãos da sua família, a família Mariz ${ }^{464}$ que recebe a propriedade da quinta por herança de seu pai, António Augusto Fernandes Mariz, engenheiro com longa e destacada carreira profissional na EDP,

\footnotetext{
${ }^{463}$ Joaquim Morais Fernandes, nascido a 5 de julho de 1917 na freguesia de Linhares, concelho de Carrazeda, filho de Carlos Augusto Morais e Maria Augusta Fernandes, foi Delegado de Saúde em Carrazeda de Ansiães onde fundou o Centro de Saúde e o Ensino Secundário Liceal e autor de dois livros de poemas sobre vivências de sua terra: Fogo e Lágrimas e Fogo e Lágrimas 2, edição de autor, o último publicado em Linhares, maio de 1997.

${ }^{464}$ A família Mariz tem ligações com os ramos Mariz da freguesia do Amedo e Sampaio do mesmo concelho. Tem as suas origens na casa-mãe localizada na freguesia de Água Revés, concelho de Valpaços, distrito de Vila Real, hoje designada por Casa de Mariz e Sarmento. Esta tem anexa a capela barroca de S. Caetano, para ali deslocada cerca de 1730, e foi recentemente restaurada e classificada, em 2012, como património de interesse público, pela Direção-Geral do Património Cultural, sendo propriedade da família Taveira de São Payo ou São Payo Alcoforado, grandes proprietários da região que se uniram por matrimónio aos Mariz Sarmento Pimentel por volta de 1720. Ver também sobre as ligações da família Sampaio Mariz, MORAIS, 2014: 28-33.
} 
o qual, por sua vez, a herdara já de seu pai, Alexandre Augusto Mariz. Este, proprietário inovador e empreendedor emblemático da quinta da Alegria e da casa agrícola familiar, era, por sua vez, filho de João António Sampaio Mariz que pertencia também à antiga família Sampaio e Mello, sendo descendente direto do fundador da Quinta da Alegria no início do século XIX. Alexandre Augusto Mariz (1896-1978), órfão de pai aos 16 anos, ainda adolescente, foi, pelo menos desde 1912 e durante décadas, o proprietário e grande empreendedor da Quinta da Alegria de Cima que contava já em 1938 com uma área de 50 hectares, mais de metade da antiga área total da Quinta da Alegria, ainda indivisa. Lavrador muito respeitado e introdutor de várias inovações na sua casa agrícola, casou com Adelaide Fernandes da família Morais Fernandes (Linhares) cuja principal propriedade era a Quinta da Alegria, atravessada pela linha férrea do Douro, junto ao apeadeiro homónimo. Republicano democrata de mentalidade científica e aberta ao progresso técnico, exerceu ainda participação ativa e destacada na vida política e cívica local, tendo-se tornando uma personalidade histórica duriense a vários títulos carismática (Capítulo 10).

Descendentes atuais da família Morais Fernandes, pela linha materna, encontram-se hoje ligados à família Costa que em S. João da Pesqueira se mantém na produção de vinhos com a marca Quevedo (criada em 1990), não tendo, porém, já nada a ver com a família Mariz do presente proprietário da Quinta da Alegria de Cima. Esta propriedade, como se verá, completamente modernizada está em plena atividade, ao contrário da Quinta da Alegria de Baixo que se mantém, mas agora em ruínas e totalmente desativada.

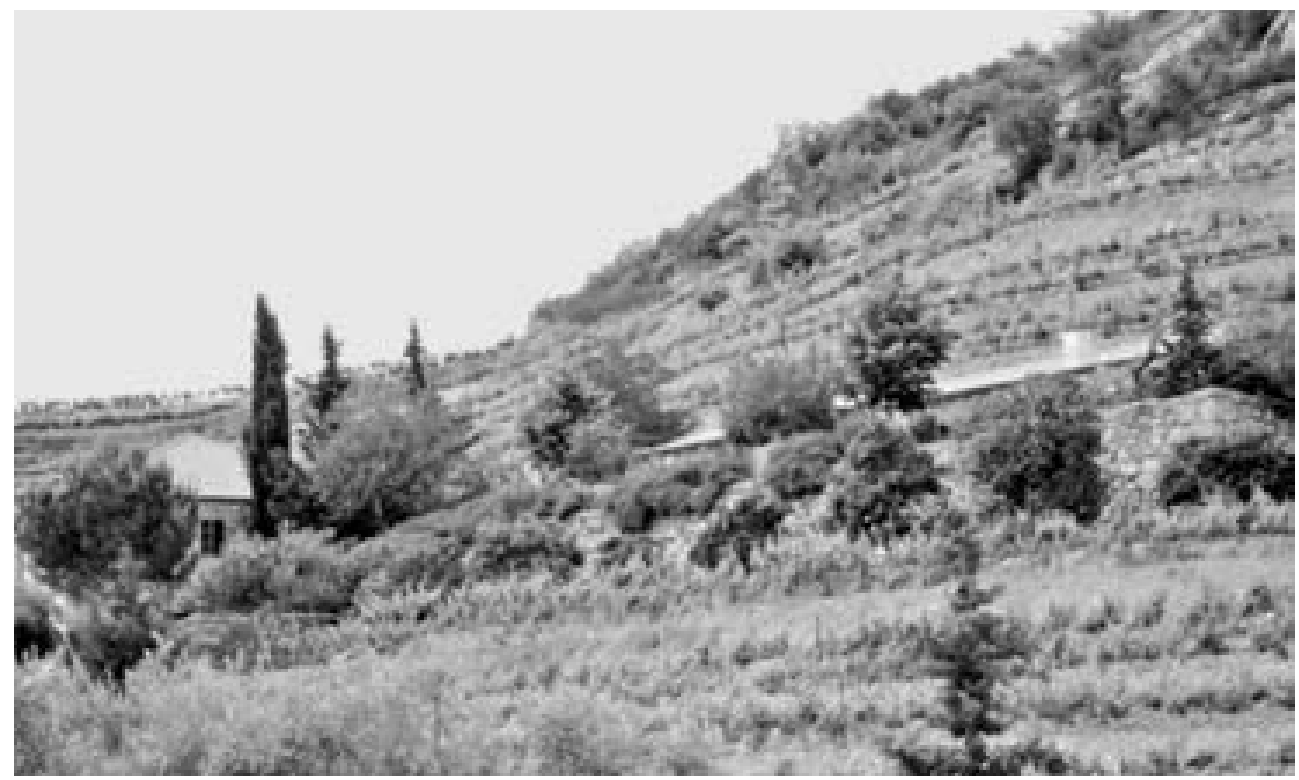

Fig. 98. Quinta da Alegria de Cima - casas de residência e antigos cardenhos remodelados Fonte: proprietário da quinta 
A Quinta da Alegria de Cima surge-nos hoje como uma espécie de pequeno oásis na área concelhia de Carrazeda onde é referência de uma propriedade bem cultivada, cuidada e rentável, nas mãos de abastados proprietários locais, a família Mariz, há mais de 200 anos. Inicialmente uma única e grande propriedade, com mais de 80 ha, confinando com um caminho que ligava a terrenos da família Morais Fernandes de que descendia a avó, por linha paterna do atual proprietário, esta quinta sofreu ao longo dos tempos grandes transformações por força de partilhas e casamentos, compras e vendas e sucessões familiares, mas continuou sempre na posse da originária família proprietária.

\subsubsection{História recente da Quinta a partir da administração pioneira de Alexandre Augusto Mariz}

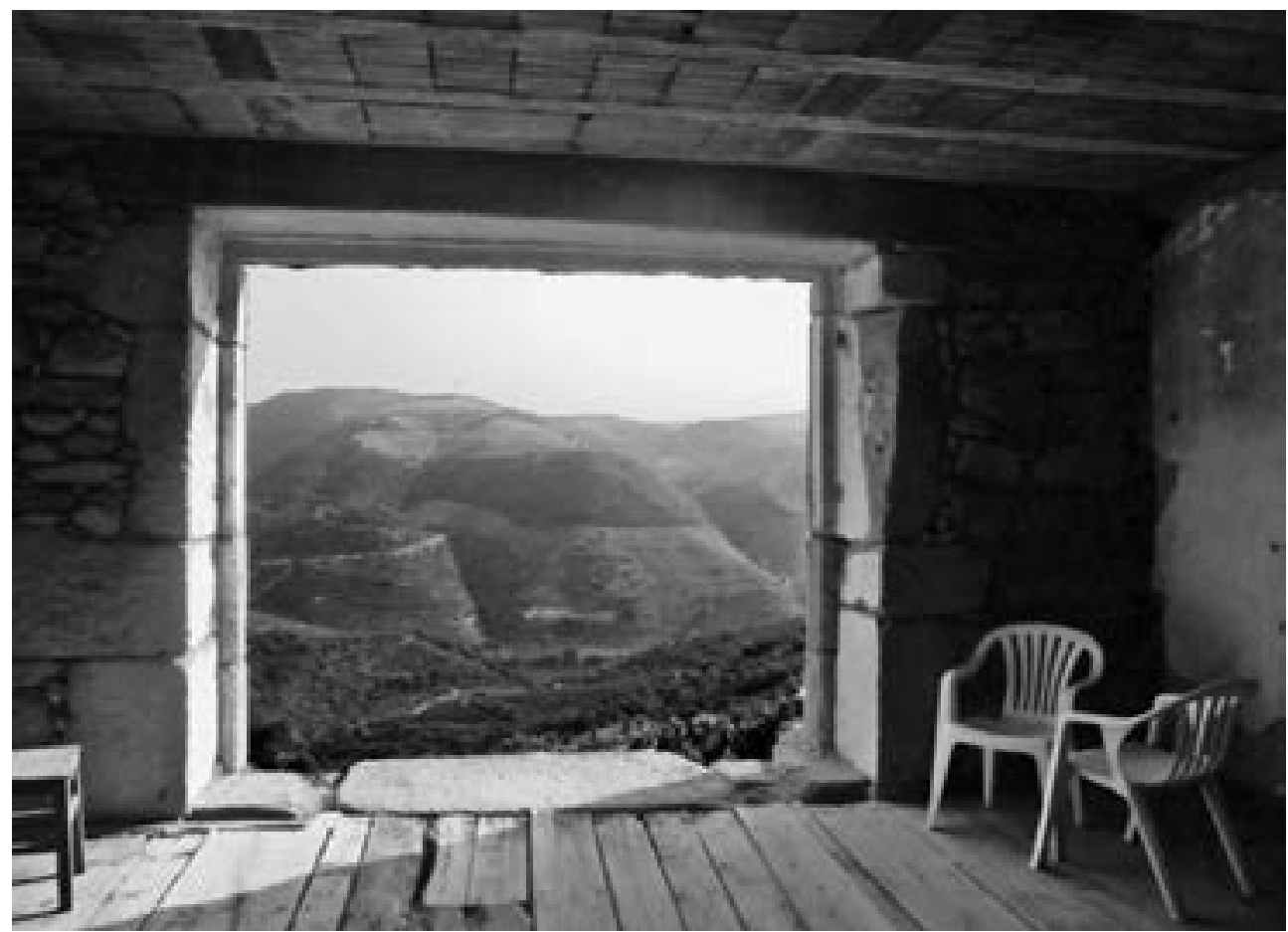

Fig. 99. Janela panorâmica para o Douro de antiga casa da quinta, em restauro.

Fonte: Fotografia O. L.

Como se viu, Alexandre Augusto Mariz, republicano e emblemático proprietário duriense distinguiu-se, enquanto figura tutelar da Quinta da Alegria de Cima, Alexandre Augusto Mariz, avô por ascendência paterna de Alexandre Mariz, hoje dono da quinta, o qual foi, desde muito jovem, o responsável decisivo pelo desenvolvimento e destinos do património da casa agrícola da família. 
Tendo sido sempre um produtor vitivinícola excecional, para além de notável empreendedor agrícola de elevado espirito técnico e inovador, Alexandre Augusto Mariz tornar-se-ia amigo de longa data do Sr. Smithes da Cockburn, notável comerciante dos afamados vinhos do Porto da Casa Cockburn \& Smithes, reconhecido e respeitado provador de vinhos e destacado especialista da cultura vitivinícola duriense que muito admirou sempre essas suas qualidades.

Aliás esta amizade (foto conjunta), ilustrativa da convivência entre produção local e comércio estrangeiro na região do Douro Vinhateiro, em geral e em particular na área vitivinícola por excelência do concelho de Carrazeda veio a sedimentar-se nas prolongadas e boas relações comerciais entre a Quinta da Alegria (à semelhança de outras quintas neste concelho) e a conhecida firma inglesa Cockburn \& Smithes cuja atividade aqui viria a suceder a anteriores firmas e empresas estrangeiras (Capítulo 8).

Este conceituado proprietário da Quinta da Alegria tratava em 1927 e 1930, com a Casa Croft e a W. John Graham \& C. a, as vindimas anuais da Quinta da Alegria e da Quinta do Zimbro cujo fabrico vitivinícola fazia por conta própria, negociando com as mesmas a compra/venda dos seus vinhos generosos, conforme consta de respetiva correspondência, como se exemplifica nas seguintes cartas então trocadas ${ }^{465}$.

Para preparação da vindima e colheita das duas quintas do ano de 1927, a empresa W. J. Graham \& C. a diz enviar para a Alegria o empregado da firma Sr. Teixeira e proceder ao fornecimento do metabisulfato, ambos pedidos e a serem pagos pela quinta. Com «boa vontade mas sem se comprometer», prevê então vir a comprar a produção desse ano «se tratados os vinhos destas duas quintas por conta própria do produtor».

Em cartas enviadas por Alexandre Augusto Mariz, em agosto e setembro de 1928, para a Casa Croft que então se desvinculara da compra dos vinhos de seus fregueses novos (os lavradores de Linhares, Ribalonga e Luís Assunção do Tua) o mesmo dá conta da sua decisão de tratar por conta própria da produção vitícola das duas quintas - Alegria e Zimbro —, incubado a 7 ou 8 e com 4 almudes de aguardente por pipa, conforme orientação da empresa e informa esta que os seus cálculos para a colheita desse ano eram de 48 pipas: 14 de moscatel e 34 pipas da Alegria (22 de tinto e 12 de branco). Na mesma correspondência trata ainda da venda dos vinhos generosos da Quinta do Zimbro que vinham sendo comprados pela Casa Croft.

Fica-se assim a saber por esta correspondência que neste período a família Mariz era não só proprietária e administradora da Quinta da Alegria de Cima mas ainda de uma parte central da antiga Quinta do Zimbro, a chamada Quinta do Zimbro do Mariz, herdada por uma das duas irmãs do atual proprietário da Quinta da Alegria de Cima que dela ainda continua encarregado de tratar (ver mapa de localização, subcapítulo 7.6.2. relativa às três designadas Quintas do Zimbro).

Em 1929, continuava a ser notória a confiança de ambas as partes, nos vinhos da Quinta da Alegria nesse ano com uma produção mais fraca, por falta de chuva, ainda de cerca de 30

\footnotetext{
${ }^{465}$ AHS — Fundo Cockburn's, Dossier de Correspondência n. ${ }^{\circ} 8479$, cx. 2562, cota 1/8/4/1.
} 
pipas mais 12 pipas de moscatel de Linhares, tendo o preço/pipa sido aumentado e fixado em $800 \$ 00$ na adega, conforme aviso de compra fixado, como habitualmente, antes do S. João.

Em 1930 a produção média da Quinta da Alegria mantinha-se em 30 pipas de vinhos generosos, aproximadamente, 20 de tinto e 10 de branco, para além das 12 pipas de moscatel (450\$00 por pipa na adega) que faziam ainda parte da produção da Casa Agrícola da Alegria.

A exemplar trajetória de vida e ação pioneira de Alexandre Augusto Mariz, em sua representatividade local/regional e particular relevância na história da Quinta da Alegria de Cima, é assim esboçada pelo neto Alexandre Mariz, atual dono da quinta ${ }^{466}$ :

ficou órfão de pais, aos 16 anos, deixou de estudar e começou a tomar conta das propriedades, ajudado pelo tio que era o dono da casa grande de Marzagão, junto à igreja, no centro da aldeia que foi o que deu a casa de meus pais em Linhares, onde eu nasci [...] todos os anos ia comprando propriedades e fez o património da casa agrícola grande. A Quinta da Alegria vem do lado da minha avó Adelaide Fernandes e por casamento passou para a família Mariz. Lembro-me de que o meu avô me contava que havia no meio das duas partes da quinta da Alegria terrenos dos Fernandes, em que havia um senhor, irmão da minha avó que gastava tudo quanto tinha e então os terrenos foram a praça pública e ele pediu então ao meu avô para comprar todos os terrenos [...] aquilo foi muito dividido porque eram famílias extensas [...] pelo contrário, quer o meu pai quer o meu avô foram filhos únicos e a familia era mais restrita, ao contrário do lado materno que era mais extensa [...] a minha mãe era da família Sampaio [...] eu até costumo dizer que sou Sampaio ao quadrado, pois a família do meu avô paterno também era Sampaio, o pai do meu avô era João António Sampaio Mariz, dos Sampaios da Fontelonga, do Dr. Cabral, médico muitos anos e delegado de saúde em Carrazeda [...] vinham dos Sampaio e Mello [...]

O Sr. José Augusto Veiga Guilhar ainda começou por comprar parte desses terrenos [...] o Dr. Morais [médico da família Morais Fernandes] era casado com uma irmã desse Sr. Guilhar cuja família esteve muito tempo em África ou no Brasil [...] muitas das quintas no Douro foram compradas por gente que ganhou dinheiro nas roças de cacau e café de S. Tomé, e por dinheiros vindos do Brasil [...] o que explica esses chalés que aparecem no Douro [...] e também dinheiro das minas [...] por exemplo, a mulher do eng. Ramiro Sobral da Quinta dos Canais era inglesa e o pai dela dono das minas de Penedono donde veio o dinheiro para os Canais, porque o eng. Ramiro Sobral natural de Arranhados era de família muito pobre e foi criado por uma senhora que tomou conta dele na Senhora da Ribeira [...] sim a antiga Quinta do Mariz, com capela, hoje integrada na Quinta dos Canais foi vendida por um Mariz mas do ramo do Amedo, já em ruinas e comprada por outro Mariz que a recuperou e depois a vendeu ao dono da Quinta dos Canais [...] eles como nós somos originários da casa mãe em Água Revés, cuja casa e capela foram recentemente restauradas pela família [...].

${ }^{466}$ Entrevista concedida em Carrazeda de Ansiães, a 17 de maio de 2014 por Alexandre Mariz, de 60 anos de idade, natural e residente em Linhares, casado, pai de um filho, com formação e profissão de engenheiro. 
O que aconteceu no Douro depois de 1870 com as falências da filoxera também atacou a Quinta da Alegria que apesar de atingida e dizimada se manteve [...] é que a recuperação do Douro precisava de dinheiro e o dinheiro tinha de vir de algum lado [...] veio dos têxteis dos condes de Vizela os mais antigos donos de Serralves [...] a Quinta dos Malvedos foi comprada pelos indivíduos da Vista Alegre [...] a elite do Porto, os comerciantes do princípio do século vêm para o Douro [...] fazia parte do status ter uma quinta no Douro [...] Mas voltando ao meu avô, ele já tinha eletricidade em casa há mais de 100 anos, produzida por um aerodinamo que mandou vir diretamente da América, lia muito e estava sempre bem informado [...] também mandava vir diretamente do estrangeiro as máquinas de que precisava para a casa agrícola que já era grande [...] era um agricultor já muito moderno, empreendedor e inventivo e sempre trabalhou bastante mas também se resguardava [...] todos os anos ia para as termas de Vidago. O Sr. Smithes gostava muito de conversar com ele e ficava admirado do que ele fazia e sabia [...] este meu avô era um visionário, excecional, uma pessoa muito engraçada e extraordinária [...].

Este relevante depoimento é corroborado por documentos de arquivo que atestam a prolongada atividade desenvolvida pelo grande proprietário duriense Alexandre Augusto Mariz, na produção vinhateira e na sólida gestão e administração da grande Casa Agrícola da família Mariz integrante das quintas da Alegria de Cima e do Zimbro e de muitas propriedades em Campelos e Carrapatosa.

A sua ação exemplar é seguida por Alexandre Mariz, seu neto e herdeiro em todos os sentidos, hoje dono também da casa agrícola da família agora com uma área de 99 ha (bem superior à área primitiva da Quinta da Alegria, no seu todo) a qual seu avô impulsionara, decisivamente, seu pai manteve e ele tem vindo a aumentar, enriquecer e modernizar o património, restaurando antigos edifícios, replantando vinha e modernizando instalações e equipamentos, sempre investindo capitais próprios.

A Quinta da Alegria de Cima que desde sempre teve, para além de sementeiras e horta, plantio de vinha, começou cedo a produzir vinho generoso da melhor qualidade, cuja produção atual de 120 pipas (vinho tinto, generoso e de mesa), sendo 100 pipas de vinho generoso, é hoje exclusivamente vendido à Symington Family Estates, como anteriormente o fora à firma Silva \& Cosens, de início, e logo a seguir, durante 73 anos consecutivos, à Cockburn \& Smithes.

O vinho é, e sempre foi, todo feito na quinta, desde os tempos do avô, em lagares tradicionais mantidos e recuperados, sendo hoje a pisa já feita com robôs (ver fotos).

Esta quinta, com uma área inferior à da Quinta da Alegria de Baixo, rondando entre $40 \mathrm{a}$ 50 ha, conta hoje, com uma área registada com 20 ha (terrenos de vinha, zona de caça, culturas e propriedades anexas) e 15 ha de vinha cujas castas selecionadas são: Touriga Nacional de que o avô era fã e que passou de 72\% para 73\%, Touriga Francesa, Tinta Roriz, Bastardo e Sousão.

A sua evolução tem sido constante, desde finais do século XIX. Parte das vinhas plantadas na quinta durante a administração do antigo proprietário Alexandre Augusto 
Mariz, e seu filho, foram mais recentemente mecanizadas pelo atual dono da quinta, Alexandre Mariz.

No que se refere aos vinhos de mesa, a Quinta da Alegria de Cima fornece vinho para duas marcas registadas da Douro Prime, afirmadas no mercado nacional: o «Inquieto» (vinho tinto) e o «Tranquilo» (vinho branco feito com uvas da produção mais próxima do planalto de Linhares).

O pessoal regular da quinta é presentemente constituído por 4 trabalhadores permanentes, ocupando, na época das vindimas, ao longo de cerca de 1 mês, mais 10 trabalhadores sazonais.

Dispõe de quatro lagares antigos de granito que mantendo os elementos tradicionais se encontram já totalmente modernizados e informatizados, com pisa mecânica ${ }^{467}$ robotizada, adega com a capacidade de 6 tonéis antigos de madeira mas recuperados, e modernas cubas inox, casas e cavalariças antigas em remodelação, lagar de azeite antigo, casa de habitação, cozinha e cardenhos para o pessoal já remodelados com duas «suites» e beliches, em substituição dos antigos.

O sentido de toda esta evolução assente em constantes investimentos e numa forte dinâmica de modernidade aliada à preservação atualizada da tradição ancorada em memórias e saberes ancestrais, que se mantém desde os tempos do grande agricultor e empreendedor de craveira invulgar, avô do presente proprietário, é uma marca de forte identidade familiar, local e mesmo regional, denotando uma grande consistência o que permite que esta unidade económica singular se configure como um autêntico «case study».

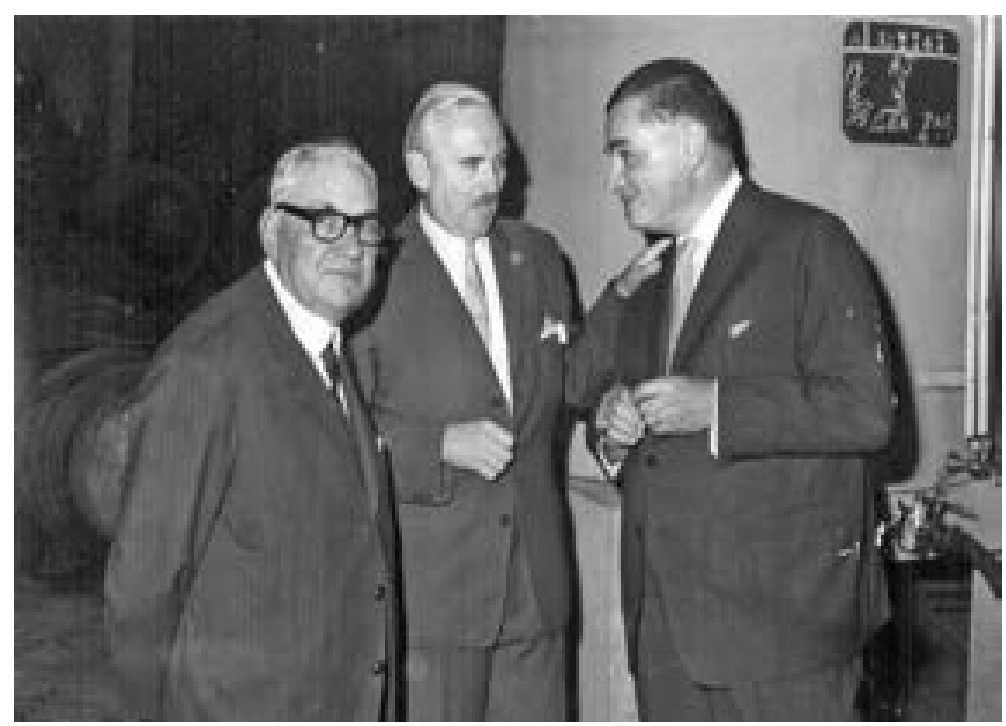

Fig. 100. Alexandre Augusto Mariz, J. H. Smithes e António Pizarro, 1963, ano Vintage ${ }^{468}$.

\footnotetext{
${ }^{467}$ As antigas prensas de varas, anteriores à filoxera, evoluíram na era industrial para as prensas de fundição e, depois, para a pisa mecânica.

${ }^{468}$ Fotografia de família, cedida pelo proprietário atual da Quinta, Alexandre Mariz, a quem se agradece.
} 
A estreita relação estabelecida desde longa data entre o conceituado produtor da elite local e o representante de uma das principais e mais antigas firmas exportadoras de vinho do Porto assente no respeito mútuo e consideração recíproca está bem representada neste registo fotográfico simbólico, logo patenteado na respetiva data comemorativa de ano vintage.

A mesma filosofia de construção identitária assente na qualidade da produção, na manutenção de um património familiar e no desenvolvimento modernizado da Quinta, é também firmemente seguida por Alexandre Mariz que continua a preservar ativas ligações entre a produção local e o comércio globalizado do vinho do Porto, para além de manter e reinventar práticas simbólicas de uma secular identidade vitivinícola, local e regional.

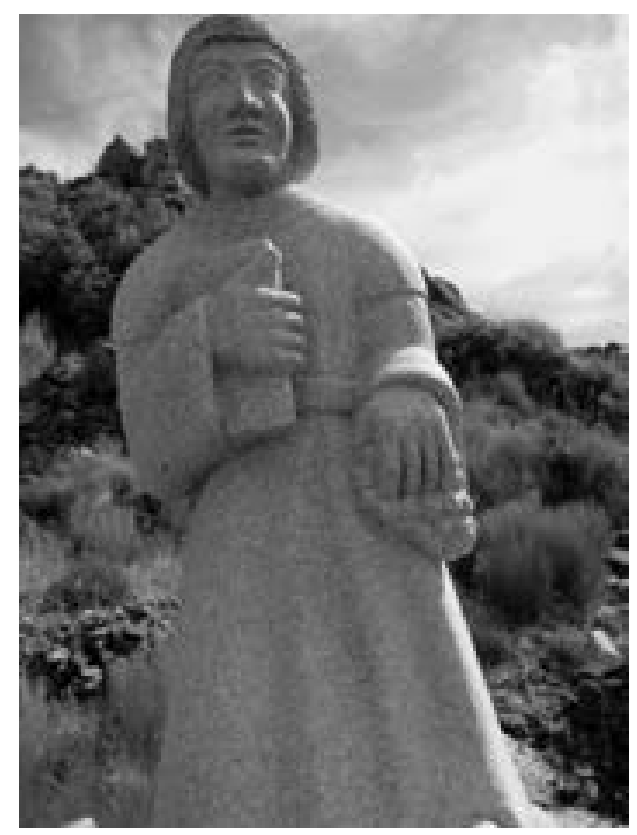

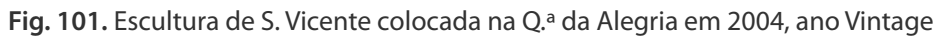
Fonte: Fotografia de Alexandre Mariz

É assim que, nesse plano simbólico, nos surge na Quinta da Alegria de Cima, a escultura de S. Vicente (com missal na mão direita e cacho de uvas na esquerda) ${ }^{469}$, considerado o padroeiro dos viticultores e vinicultores.

Esta peça artística foi mandada construir e colocar no cimo da encosta da quinta pelo seu atual proprietário, em 2004, ano em que os seus vinhos foram declarados de qualidade superior. Poder-se-á dizer que tal decisão representa ainda, em si própria e simbolicamente,

\footnotetext{
${ }^{469}$ Cristão mártir do império romano, no início do século IV, seu nome é invocado há séculos, estando também ligado aos vários trabalhos da vinha e do vinho, ao longo do ano, segundo as variações nos hemisférios Norte e Sul. O seu culto encontra-se associado à igreja Saint-Germain-des-Prés em Paris.
} 
a sedimentada orientação estratégica do atual desenvolvimento da Quinta que se pauta pela perfeita simbiose entre tradição e modernidade.

Todavia, essa promissora visão estratégica de desenvolvimento integrado que o atual proprietário da quinta, na peugada do avô, continua a prosseguir, manifesta-se também a outros níveis, mais pragmáticos, desde a aplicação de novas técnicas de cultivo da vinha, à introdução de modernas tecnologias de produção e fabrico do vinho (ver fotos).

\subsubsection{Significado da Quinta da Alegria no concelho e contexto da RDD}

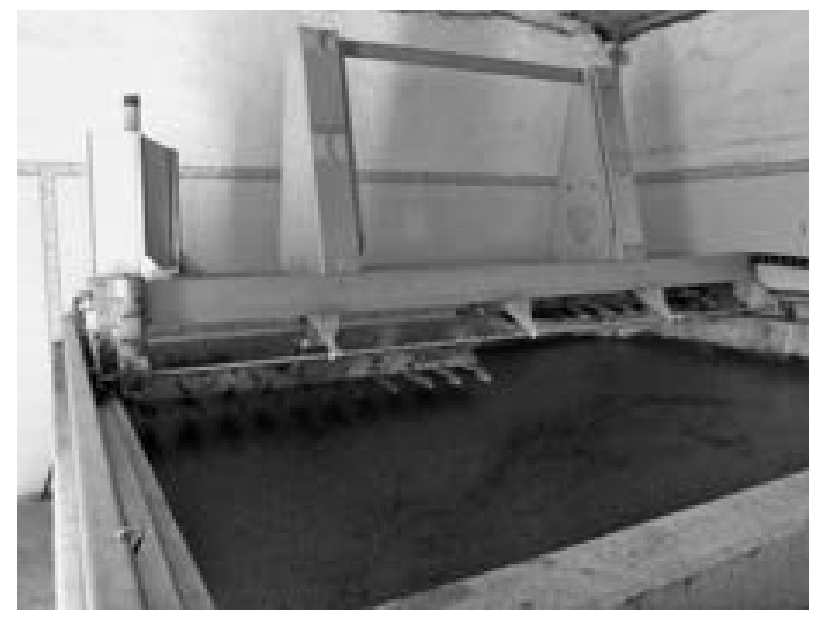

Fig. 102. Quinta da Alegria — Lagar com sistema informatizado e pisa mecânica robotizada Foto de Alexandre Mariz

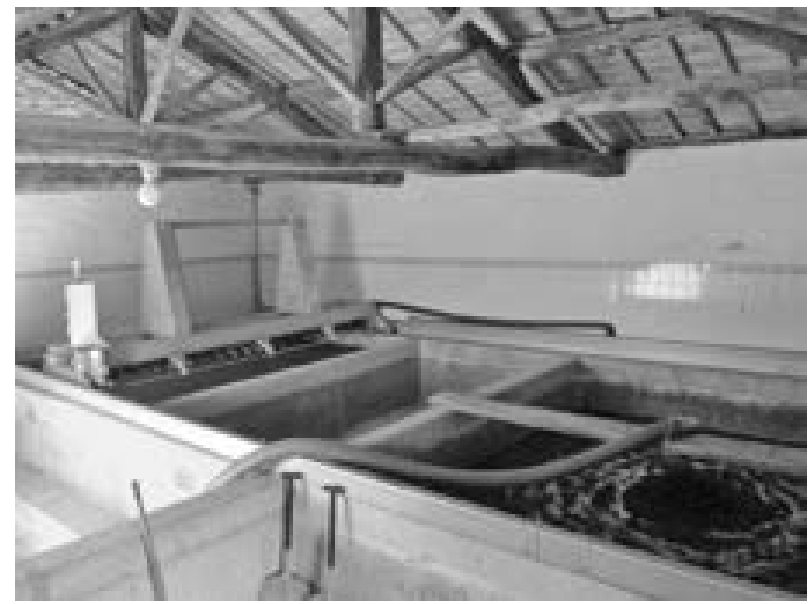

Fig. 103. Lagares tradicionais recuperados e modernizados Foto de Alexandre Mariz 
Como se pôde ver, a Quinta da Alegria (Linhares), uma das quintas históricas de Carrazeda na fronteira do Cima Corgo e Douro Superior é, por algumas das suas características já introduzidas, uma das mais singulares na zona da ribeira do concelho de Carrazeda de Ansiães e hoje ainda uma das suas quintas de que se diz localmente que o seu vinho generoso vai todo, como sempre, para exportação. Tem por isso destaque próprio na Região Demarcada do Douro.

Bem conhecida e representativa de um especial terroir deste concelho do Douro, produz os tintos «Inquieto», que são muito apreciados na restauração de qualidade, garrafeiras e lojas de topo. A sua promoção publicitária combina um elegante «marketing» sem prejuízo da informação rigorosa e explicitação técnica, apelativas da tradição histórica.

Os vinhos tintos da marca INQUIETO são produzidos a partir de vinhas velhas da Quinta da Alegria, no Douro Superior, complementadas com uvas provenientes de pequenos produtores localizadas na sua periferia. Localizam-se estas propriedades na margem Norte do rio Douro, todas elas entre os 300 e os $400 \mathrm{~m}$ de altitude, estando classificada qualitativamente como Letra A, segundo o método Moreira da Fonseca. As vinhas

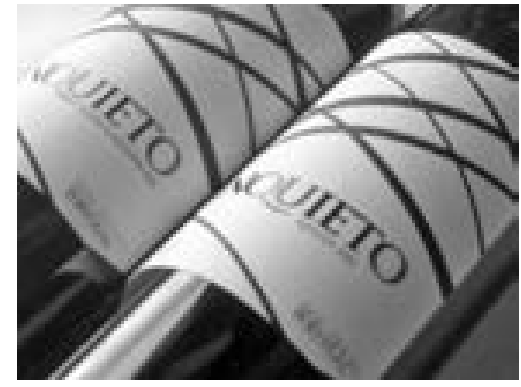

Fig.104 estão conduzidas em bardos aramados de 1,5 $\mathrm{m}$ de altura segundo o sistema de poda de 'Cordão Bilateral', com um mínimo de 8 e um máximo de 12 gomos por videira. Predominam as castas Touriga Nacional e Touriga Franca complementadas com uma pequena percentagem de Sousão [...] A vinificação é feita em antigos lagares de pedra de granito onde foi adaptada a pisa mecânica [...]. Após a fermentação ambos os vinhos têm um estágio inicial em aço inox e, nos últimos 6 a 12 meses anteriores ao engarrafamento, passam para barricas de carvalho francês com $225 \mathrm{l}$. de capacidade cada. O engarrafamento é feito apenas após concluídos os dois primeiros anos de maturação em inox e madeira de carvalho, mas antes da rotulagem e saída para o mercado os vinhos passam ainda mais 8 a 12 meses em garrafa $[\ldots]^{470}$.

Todo o processo de produção, bem organizado e a preparação dos vinhos continuam a ser feitas integralmente na Quinta, sendo a sua gestão, administração e comercialização, atualmente asseguradas pela empresa «Douro Prime, Ld. ${ }^{a}$, constituída em 2008, por quatro sócios fundadores: Miguel Côrte-Real (produção e comercialização), Manuel Matos de Carvalho (diretor de enologia), Alexandra Martins (área financeira) e Alexandre Mariz, responsável pela produção, todos amigos e antigos funcionários prestigiados da Cockburn \& Smithes que

\footnotetext{
${ }^{470}$ Informação disponível em <http://douroprime.com/inquieto/>. [Consulta realizada em 20/5/2014].
} 
trabalham em equipa multidisciplinar, contando com o apoio tecnológico e cientifico da Universidade do Porto. Em resultado do seu crescimento e recente evolução, a partir de 2016, a composição social da empresa ficou reduzida a dois sócios: Alexandre Mariz e Manuel Matos de Carvalho.

Esta empresa ${ }^{471}$ vem beneficiando das sinergias e centros de inovação empresarial deste tipo de cluster que contribuiu para o desenvolvimento atual e continuidade da Quinta da Alegria de Cima, a qual tem vindo a crescer a partir de recursos e investimentos próprios em complementaridade entre produção e comercialização parcialmente sustentada por esta experiência piloto.

Sintetizando, a história da Quinta da Alegria de Cima destaca-se, no concelho de Carrazeda, onde é referência, e também no Douro Superior, pela sua continuada solidez económica e pela superior qualidade de produção de vinho generoso comercializado ao longo dos tempos por algumas das mais importantes e históricas firmas de exportação inglesas de vinho do Porto. Caracteriza-se também por uma equilibrada articulação entre tradição e inovação, em termos de administração e produção, de notável estabilidade, estratégias de gestão e desenvolvimento autónomo, práticas e técnicas modernas de vitivinicultura, pelo menos no que concerne aos últimos 100 anos. Realça-se ainda a especificidade desta quinta de, contra uma geral tendência para a frequente transferência de propriedade verificada no território duriense, em regra associada a compras e vendas em períodos de crise seguidos de novos investimentos e modernização, a mesma se ter mantido durante dois séculos, na posse da mesma família, fruto em larga medida da capacidade demonstrada para acompanhar as mudanças e o desenvolvimento.

O seu atual proprietário, Alexandre Mariz, descendente direto e continuador dos esforços de gerações da família Mariz, destaca-se como o principal protagonista dos destinos da Quinta da Alegria de Cima e seu antigo e relevante negócio de vinho do Porto e vinhos de mesa Douro de superior qualidade, cuja liderança estratégica assenta num profundo e alargado conhecimento especializado dos mais variados assuntos relacionados com a longa história da vinha e do vinho da Região Vinhateira Duriense a que tem estado sempre ligado e conhece como poucos, sendo um insubstituível aliado no processo de investigação histórica que se prossegue, pesquisando, numa próxima fase, os bem conservados arquivos particulares da família e da sua importante casa agrícola de que faz parte a Quinta da Alegria de Cima, cuja preservação é de todo o interesse garantir através da respetiva digitalização e disponibilização.

\footnotetext{
${ }^{471}$ Desenvolveu recentemente um projeto de produção de molhos para saladas, cujos testes, estudos e ensaios laboratoriais beneficiaram de investigação I\&D.
} 


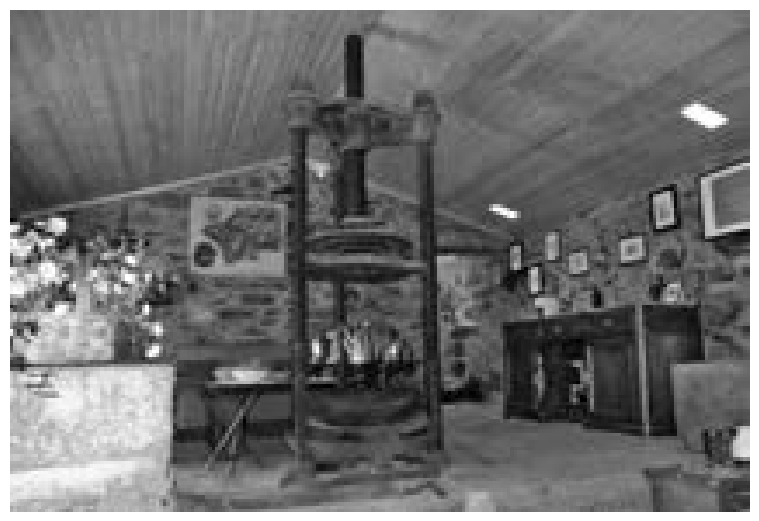

Fig. 105. O velho lagar de azeite com antiga prensa, transformado em sala de estar Fonte: Fotografia de O. L.

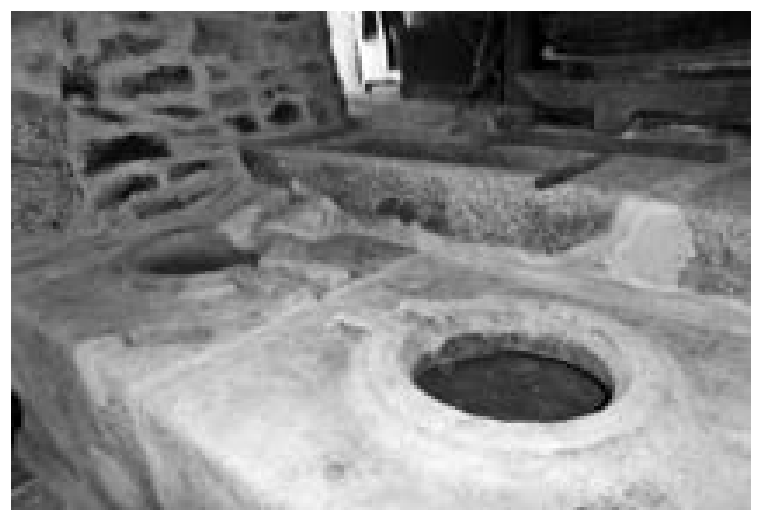

Fig. 106. Peça de cantaria do sistema de separação azeite-água

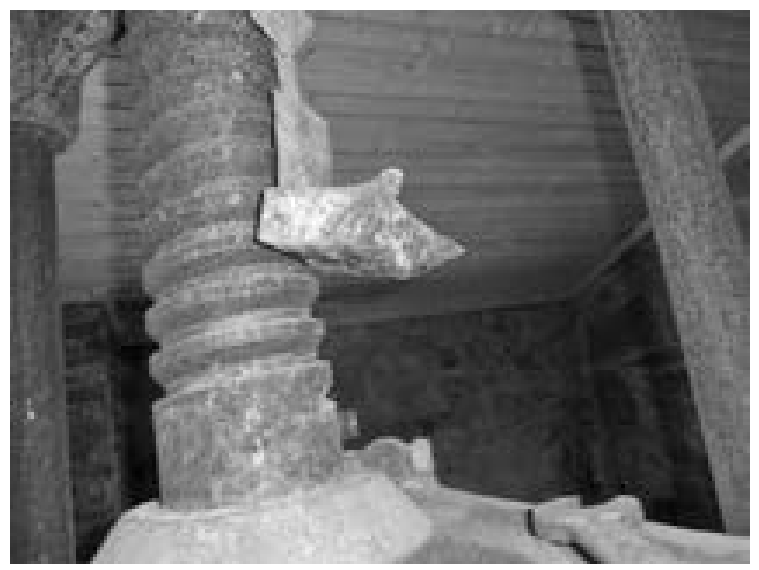

Fig. 107. Antiga candeia de dois bicos 


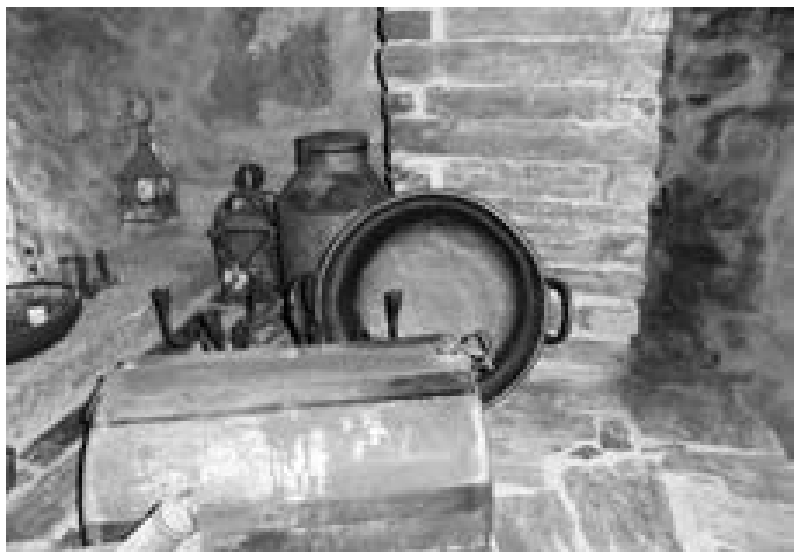

Fig. 108. Apetrechos da prensa, utensílios e vasilhame do antigo lagar de azeite Roda de esmagamento da azeitona
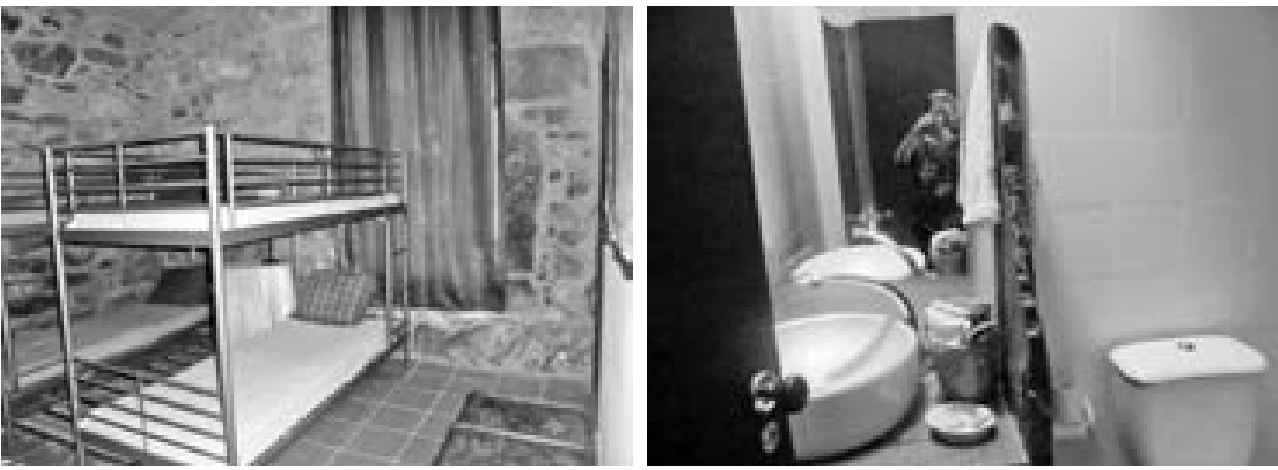

Fig. 109. Antigos cardenhos restaurados e remodelados como «suites»

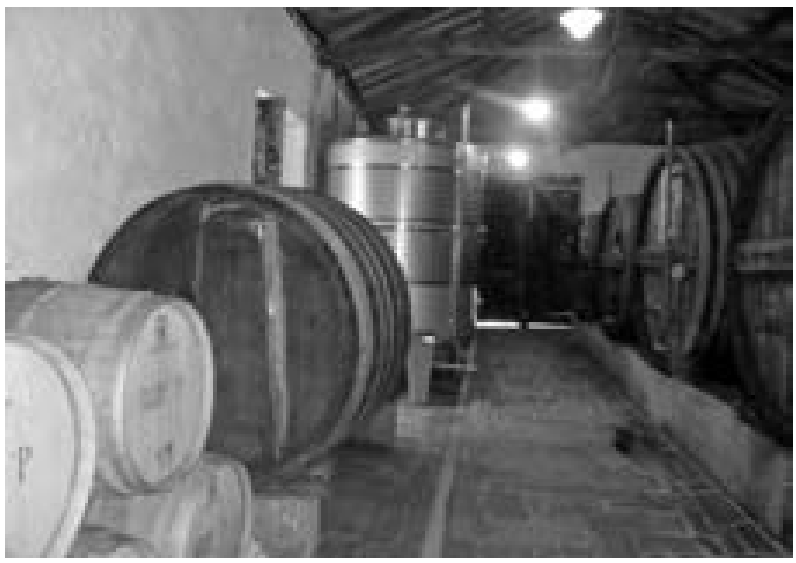

Fig. 110. Armazém antigo restaurado com pipos para vinho Douro Prime, tonéis e cubas 


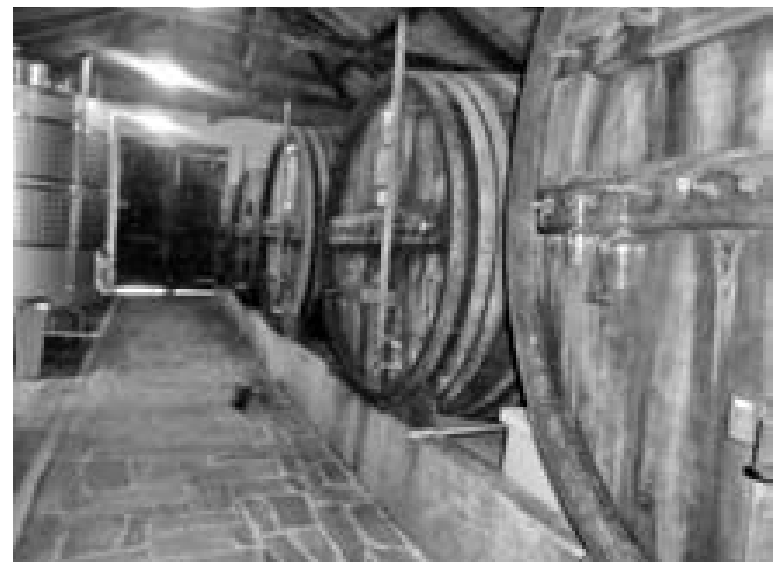

Fig. 111. Antigos tonéis de vinho do Porto

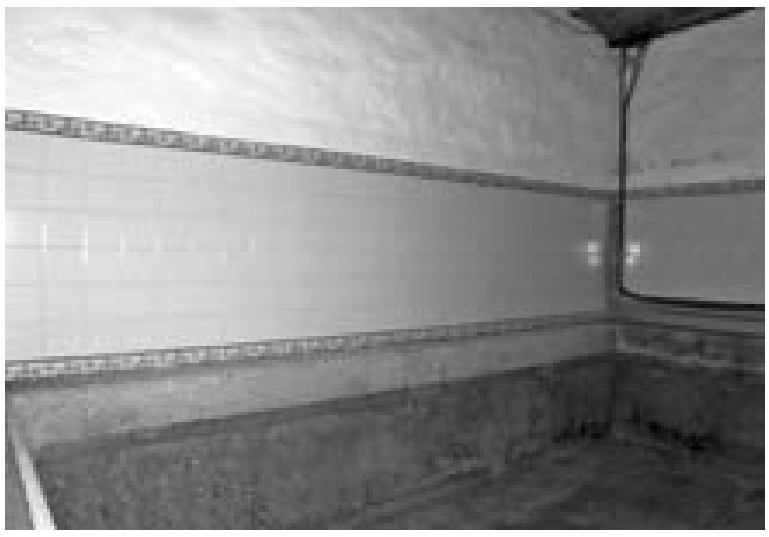

Fig. 112. Lagar antigo de granito adaptado a pisa automática robotizada

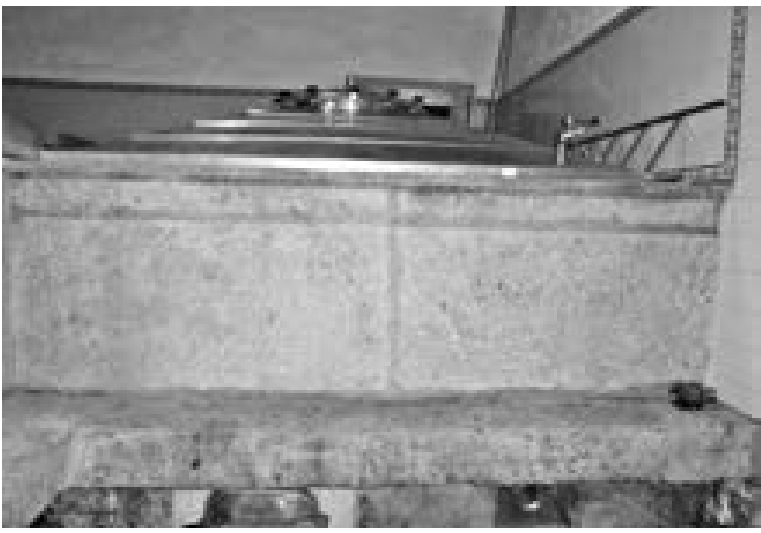

Fig. 113. Lagar localmente adaptado para cuba 


\subsection{QUINTA DE LUBAZIM: A LONGA DURAÇÃO NO DOURO VINHATEIRO}

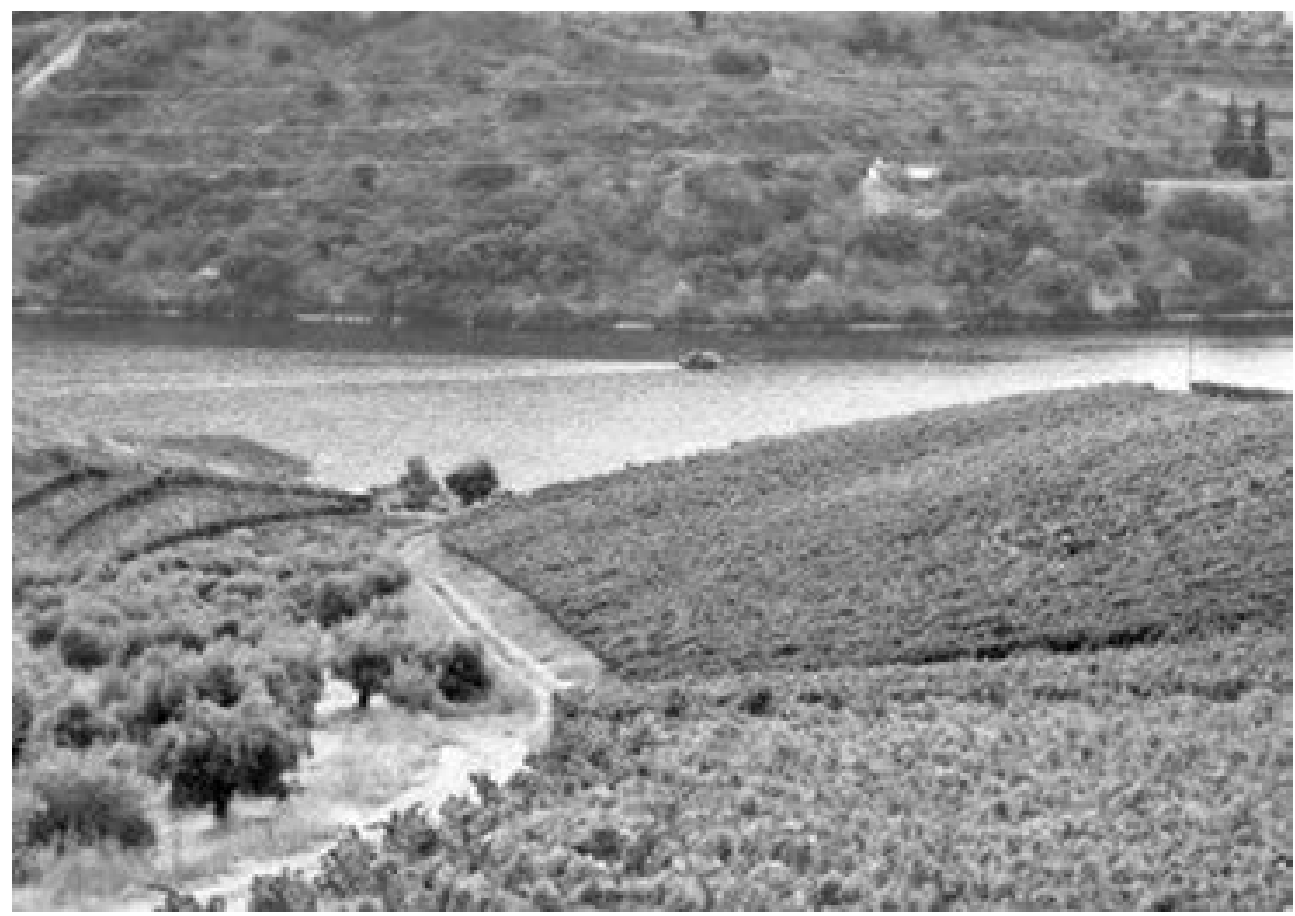

Fig. 114. Quinta de Lubazim — Vinha e olival na área mais próxima do Douro

A designação oficial da Quinta de Lubazim — Lupucinus ${ }^{472}$ parece ter derivado de toponímia muito antiga alusiva à antiga «villa» romana Lupucini - genitivo de Lupucinus e diminutivo de lupus - lobo ou lobeco, animal então frequente na região. Esse nome é também associado à delimitação geográfica — «foz de Lobazim» — a sudoeste do concelho medieval de Vilarinho da Castanheira no foral que lhe fora outorgado por D. Afonso II (6-XII-1218) A este antigo concelho transmontano extinto no século XIX, e grande produtor de azeite e vinho com numerosos lagares, andaria estreitamente associada, em diferentes momentos históricos, a notável genealogia da nobre família proprietária da Casa/Quinta de Lubazim, com origem no extenso senhorio de Lobazim de doação régia, remontando ao advento da Dinastia de Avis (século XIV), durante a Baixa Idade Média.

\footnotetext{
${ }^{472}$ Informação reorganizada a partir do site oficial da Quinta disponível em $<$ http://www.quintadelubazim.com/ site/index.php/pt/historia-3/a-nossa-historia>, atualização de 2012. [Consulta realizada em 16/4/2014].

${ }^{473} \mathrm{O}$ concelho de Vilarinho da Castanheira foi extinto em 1853 tendo passado a fazer parte, como freguesia, do concelho setecentista de Carrazeda de Ansiães, criado em 1734, após extinção do antigo concelho de Ansiães com sede na vila medieval homónima, no seu vetusto castelo.
} 


\subsubsection{A Casa e Quinta de Lubazim: origens e evolução histórica}

Incorporando na sua antiguidade essas primitivas origens de sua designação e relevo da família fundadora, a Casa e Quinta de Lubazim, surgem nessa época recuada em que o feudalismo europeu entrou em desagregação com o desenvolvimento de novas técnicas agrícolas (uso do arado e aperfeiçoamento dos moinhos hidráulicos) que possibilitaram a ampliação das áreas produtivas, a criação de excedentes de produção e sua comercialização, condições económico-sociais e culturais que induziram a transformação das sociedades rurais assentes na exploração servil.

Tal é a conjuntura histórica onde se inicia o longo processo histórico-social de construção da Casa e Quinta de Lubazim que viria a transformar-se numa grande e importante unidade agrícola regional com atividade pecuária e produção de vinha, olival, amendoal e laranjal. Nos finais de Oitocentos destacar-se-ia, designadamente, pela construção e posse dos maiores e mais notáveis armazéns e melhores lagares da região onde os pequenos lavradores locais faziam os seus vinhos, os quais se justificavam pela sua já então elevada produção própria de Vinho do Porto de grande qualidade, comercializada pelos ingleses da Cockburn \& Smithes, com quem manteve sempre as melhores relações.

A Quinta do Lubazim que permanece, há mais de 700 anos, na posse ininterrupta da família Castro de Vilarinho de Castanheira, oriunda da velha nobreza portuguesa, começa assim por caracterizar-se pela sua densidade histórica feita de inúmeras, profundas e complexas transformações ocorridas no longo arco temporal que vai da Idade Média, atravessa a Idade Moderna e prossegue na Época Contemporânea em que acaba por se afirmar como uma das mais antigas quintas do Alto Douro, contando-se entre as mais importantes e conhecidas propriedades vinhateiras do Douro Superior e a primeira grande quinta duriense do concelho de Carrazeda de Ansiães (a que passou a pertencer no século XIX, após incorporação parcial do território do extinto concelho de Vilarinho).

Conforme reconhece o Eng. Luís Pizarro de Castro, descendente direto da antiga e nobre família Castro e atual proprietário da Quinta de Lubazim, esta, protagonista de considerável longevidade marcada por crises e encruzilhadas, duras batalhas e difíceis renovações, chegou à altura das mais recentes partilhas familiares, já no decurso dos anos 2000, em relativo estado de declínio, encontrando-se «tudo numa situação muito má ao ponto de praticamente só vendermos o benefício. Isto é, cuidava-se da vinha e pouco mais $»^{474}$.

Por essa altura, e já desde a década de 1980, registava-se na região do Douro uma grande transformação com a introdução de mudanças tecnológicas e organizativas vitivinícolas (construção de novas encostas, socalcos e drenagens do terreno, especializadas técnicas vitivinícolas de produção e vinificação, produção tecnicamente intensiva e voltada para o mercado global, como é a do vinho do Porto, intensificação produtiva e comercialização direta dos Vinhos DOC com marcas prestigiadas nos mercados internacionais). Este processo de profunda alte-

${ }^{474}$ CRUZ \& MONTEIRO, 2015: 3. 
ração de métodos produtivos e comerciais acompanhado da diminuição drástica de mão de obra nacional indiferenciada e barata contribuiu para uma desruralização, sucedendo-se aos antigos lavradores e proprietários a ação mais dinâmica de novos empresários agrícolas.

Nessa nova conjuntura histórica a Quinta de Lubazim tenta sair da encruzilhada em que se encontrava: a premente «reinvenção» ou «morte da Casa». Conseguiu vencer este desafio extremo por que passaram muitas outras quintas do Douro, e manter-se na posse da mesma família, enfrentando com reconhecido sucesso a difícil batalha de dar voz própria à produção independente da casa familiar face às grandes empresas exportadoras que, em geral, têm vindo a comprar muitas quintas na região ou pagam as uvas a um preço muito inferior ao do custo de produção.

Explorando as suas vantagens comparativas, a Quinta de Lubazim vai então desencadear uma pequena mas decisiva revolução económica assente na mecanização, estudo da orografia do terreno para a plantação selecionada de vinhas novas e na especialização da sua produção vitivinícola direcionada desde 2005 para nichos de mercado e mercados internacionais onde a reconhecida qualidade dos seus vinhos se tem vindo a afirmar cada vez mais. $\mathrm{O}$ arranque deste novo projeto de profunda reestruturação e modernização da Quinta de Lubazim contou com o aconselhamento especializado de outros grandes e antigos proprietários do Douro, como Cristiano van Zeller da Quinta do Vale de Dona Maria.

Para a revitalização da Quinta registada na última década, contribuiu também decisivamente a determinação da Dra. Catarina Maria Mendes de Albuquerque Rodrigues Pizarro de Castro, licenciada em Relações Internacionais, pós-graduada em Gestão Pública e Autárquica e com grande experiência de relações públicas no Consulado Geral de Portugal (Valência e Venezuela) e na Fundação Ricardo Espírito Santo. Mulher recém-entrada na família Pizarro de Castro, pelo seu casamento com o filho do atual proprietário do Lubazim, o Dr. José Manuel Guimarães de Noronha Pizarro de Castro que conhecera na Guiné, optou por se radicar no Solar dos Castros em Vila Flor, empenhando-se em dar continuidade à ação empreendedora de outras mulheres da família que, em diferentes períodos, se destacaram na condução dos assuntos da Casa e Quinta de Lubazim, como Dona Maria Guilhermina Pinto de Lemos Sampaio e Melo de Noronha, avó paterna de seu marido.

Membro do Conselho Interprofissional do Instituto do Vinho do Porto, Catarina de Castro enfrentou a difícil situação estrutural da Quinta do Lubazim, «pérola em risco de ser desperdiçada», apostando, com a aprovação entusiasta da família, no desenvolvimento de "ponta» do Lubazim traduzido em novas plantações e seleção de castas que conduziram a um aumento elevado da produção vitivinícola da quinta.

Esta enorme transformação registada nos últimos anos só foi possível com avultados investimentos e sob os auspícios do Eng. Luís Pizarro de Castro que a enraíza na sólida convicção de que o Lubazim «tem capacidade para produzir dos melhores vinhos, devido à sua localização e especiais características» ${ }^{475}$.

${ }^{475}$ CRUZ \& MONTEIRO, 2015: 15. 
O Eng. Luís Pizarro de Castro, com 75 anos de idade, mantém-se à frente da Quinta de Lubazim, atualmente com uma área total de 200 hectares resultantes do reajustamento dos 100 hectares iniciais de velhos mortórios originados pela filoxera, com outras quintas propriedade da família, e um potencial de cerca de 100 ha de novas plantações de vinhedo em patamares largos onde se cultivam castas nobres da região (Touriga Nacional, Touriga Franca, Tinta Roriz, Tinta Amarela, Bastardo, Barroca, etc.), prosseguindo o seu desenvolvimento tecnológico com novas iniciativas e projetos de modernização da produção e comercialização, equipamentos e serviços de vitivinicultura especializados em diferentes áreas desde a agronomia à enologia.

Este descendente dos Senhores da Quinta de Lubazim que persiste em manter viva e reatualizada a secular memória familiar, faz questão de ver-se como lavrador arreigadamente ligado a Trás-os-Montes. E justifica assim esse entrelaçamento vital de gerações que explica a continuidade: «somos chamados pela terra e a terra faz parte de nós».

Engenheiro civil de formação, dotado de especial sensibilidade e formação artística ocupa atualmente parte do seu tempo com a prática regular de atividades artísticas e literárias. É de sua autoria este poema de acentuada propensão biográfico-introspetiva e sentir reflexivo:

\section{Quem sou eu?}

Não sei... como o hei-de dizer?

Sobre a vida que vivi posso escrever,

[...]

É estranho, muito estranho, mas fui sem o ser, só uma aragem que passa, que nem se chega a perceber Desenhei sem ser desenhador, e pintei sem ser pintor. Fiz versos sem ser poeta, Desenhei casas sem ser arquiteto, e procurei interpretar a Bíblia sem ser teólogo. Estudei o comportamento das pessoas sem ser psicólogo, e a vida dos povos sem ser historiador [... ${ }^{476}$.

A sua vocação para a escrita, a poesia e a arte do desenho, pintura e retrato que exercita com frequência ${ }^{477}$, fortalece-se na preservação do nobre passado familiar, preservando nichos

\footnotetext{
${ }^{476}$ CASTRO, 2015: 17.

${ }^{477}$ Luiz Pizarro de Castro, para além de bons retratos de alguns dos seus familiares, ilustres figuras da história portuguesa, que podem apreciar-se no solar da família em Vila Flor, é ainda autor de numerosas publicações ilustradas com desenhos e pinturas também de sua autoria designadamente sobre a Ordem de Malta. Sendo uma Ordem de aristocratas, nunca teve entre os seus cavaleiros quem não pertencesse à fidalguia, aceitando atualmente
} 
de narrações transmitidas aos seus vindouros, em que visa perpetuar a força do nome dos seus maiores, já que como ele próprio lembra: «A minha família nunca foi de deixar muitos escritos». Assume assim como sua principal responsabilidade a transmissão desta herança maior como elo de perpetuação da sua linhagem.

\section{Linhagem da Família Castro - Senhores de Lubazim}

Garante da memória de seus antepassados, o Eng. Luís João de Noronha Pizarro de Castro, Cavaleiro de Honra e Devoção da Ordem de Malta, atual representante dos Senhores da Quinta do Lubazim e patriarca da família Castro, tem-se empenhado na metódica reconstituição longitudinal e horizontal da genealogia familiar e no estudo minucioso dos seus percursos, ligações, casamentos e andanças, em seu complexo encadeamento.
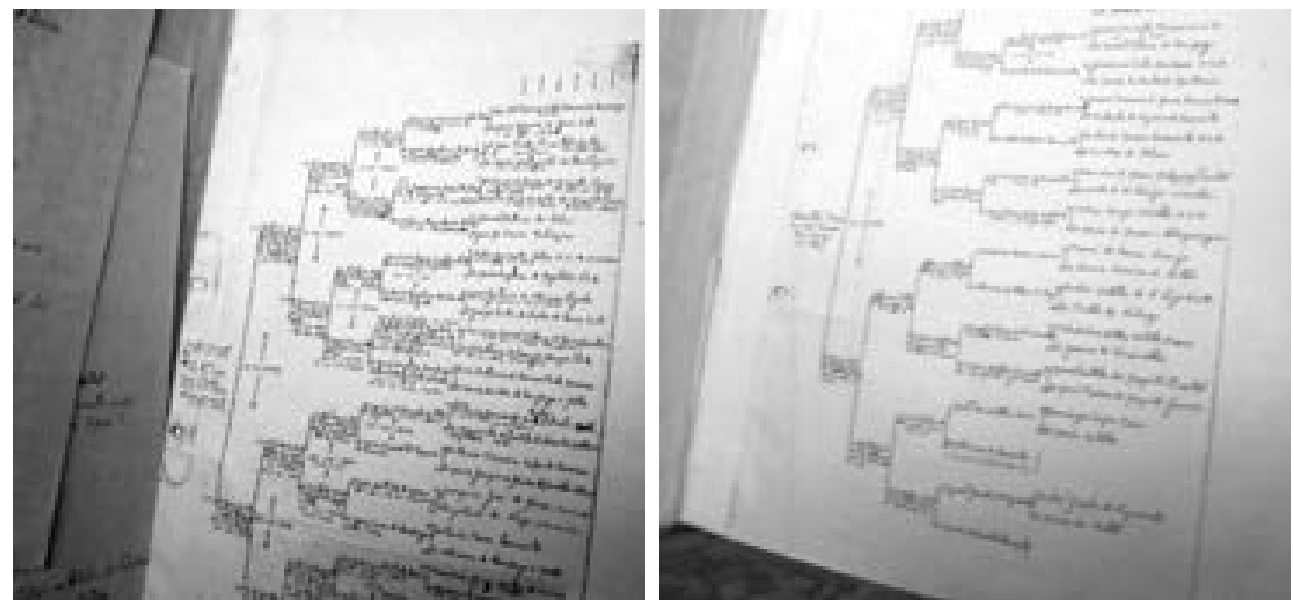

Fig. 115

Tradicionalmente arreigada ao Douro e Trás-os-Montes, esta antiga família dos Senhores da Casa/Quinta de Lubazim, a família Castro Pereira de Vilarinho da Castanheira (Carrazeda de Ansiães) da melhor nobreza de Trás-os-Montes ${ }^{478}$ cruzou-se com outras famílias nobres portuguesas, ao longo das suas 22 gerações em que se salientam varões ilustres, fidalgos da Casa Real e Cavaleiros da Ordem de Malta detentores de cargos importantes, destacados liberais, como o Visconde de Lemos, um dos bravos do Mindelo ${ }^{479}$, ou Manuel de Castro Pereira da Mesquita, outro ilustre senhor de Lubazim que participou na Campanha da Rússia com Napoleão, para além de outras personalidades eminentes.

os que considere serem da Nobreza Civil. Hoje a Ordem de Malta é uma conhecida e reputada organização religiosa e humanitária soberana internacional a que Luís Pizarro pertence como Cavaleiro o mesmo sucedendo também com seu filho. Ver, a título de exemplo: CASTRO, 1998-1999.

${ }^{478}$ ALVES, 1983.

${ }^{479}$ Local do desembarque histórico das tropas fiéis a D. Pedro, em julho de 1832. 
Consta da versão histórica oficial da Quinta que D. João I agraciou João Gomes pelos seus feitos na batalha de Aljubarrota em 1385, doando-lhe, em recompensa, o Senhorio de Lubazim, no Alto Douro, cujas terras se estendiam à época por vários concelhos. Uma filha sua viria a casar com Gonçalo Vaz de Castro, neto de Pedro Lourenço de Castro, meirinho-mor do Rei, dando assim origem aos Senhores de Lubazim descendentes da família Castro.

Nos séculos XVII e XVIII foram senhores da Casa e Quinta de Lubazim e de outras propriedades, membros da mesma família da antiga nobreza, alguns dos quais exerceram, entre outros, o cargo de capitão-mor do antigo concelho de Vilarinho da Castanheira.

Na primeira metade do século XVIII, destaca-se como figura prestigiada dos Senhores de Lubazim Manuel de Castro Pereira de Mesquita Pimentel Cardoso e Sousa, filho de Manuel de Sousa Cardoso e Castro, nascido em Freixo de Numão a 14 de outubro de 1778, e que frequentou a Universidade de Coimbra e a antiga Academia da Marinha. Tendo formado a expensas suas uma companhia de cavalos, foi capitão do regimento de dragões de Chaves. No início das Invasões Francesas fez parte, já como major, do quartel general de Massena e mais tarde do $3 .^{\circ}$ regimento na expedição organizada em Portugal por Napoleão (1808-1813) e com ela marchou para a Rússia. Nesta expedição, perdida a totalidade do seu efetivo, conseguiu desertar e obter asilo em Moscovo, donde regressou a Portugal onde publicou em 1814 uma descrição rigorosa da «Legião Portuguesa em França» ${ }^{480}$. Durante o período liberal, foi em 1821 encarregado de negócios em Madrid, lugar que com a sua larga experiência adquirida na Europa lhe criou condições para ser nomeado, em 1837, Ministro dos Negócios Estrangeiros, atividade política que o levará a ser eleito deputado, em 1939, cargo que já exercera entre 1834 e 1836, e senador, em 1840. Maçon e setembrista foi ainda Governador Civil de Braga, Porto, Bragança e Vila Real. Participou na revolta da Maria da Fonte e na Patuleia, sendo nessa altura presidente da Junta Governativa de S. João da Pesqueira. Casou em Lisboa com Dona Maria Clara Braamcamp, irmã de Anselmo Braamcamp. Morreu em 1863, com 85 anos, sem filhos tendo instituído seu herdeiro universal o sobrinho, Dr. Luís de Castro Pereira ${ }^{481}$.

Outros membros da família Castro Pereira cujas propriedades rústicas e urbanas se estendiam pelos concelhos Freixo de Numão, S. João da Pesqueira e para a outra margem do Douro, vão aparecer como figuras destacadas com influência económica, política, social e cultural, em Freixo de Numão, a partir do casamento de Manuel António de Castro (sargento-mor de Freixo de Numão) com Dona Ana Maria Pereira filha de Manuel Luís Pereira. O casal teve uma filha e dois filhos, o último dos quais, Dionísio de Castro Pereira, capitão-mor de Freixo de Numão e membro efetivo do Conselho Municipal de 1846 a 1849, figurava em 1851 entre os 10 eleitores mais coletáveis. Proprietário dos mais abastados de Freixo de Numão, Dionísio de Castro Pereira foi pai do Dr. Luís de Castro Pereira, casado com Dona Delfina Augusta da Silva de Castro Pereira, bacharel em Direito pela Universidade de Coimbra, que exerceu, entre outros, o cargo de Presidente da Câmara de Freixo de Numão, em 1854 (quando

${ }^{480}$ VENTURA, 2007.

${ }^{481}$ COIXÃO et al., 1985: 35. 
este município acabou integrado em Vila Nova de Foz Coa), o qual foi, em 1865, com a idade de 36 ou 37 anos, o fundador da Filarmónica ou Banda Musical de Freixo de Numão (coletividade cultural que iria perdurar mais de 100 anos) e em 1868 será o Delegado do Correio de Freixo de Numão. Entre os motivos que o terão influenciado na fundação da Banda contam-se, para além da sua vivência coimbrã na altura da célebre «Questão Coimbrã», as influências militares familiares designadamente de seu pai e de seu tio Manuel de Castro Pereira, um dos grandes proprietários durienses de quem herdou a sua enorme fortuna e o gosto pelos fardamentos militares e Bandas musicais. O Dr. Luís de Castro Pereira acaba por ir residir na vila de S. João da Pesqueira, onde faleceu, sendo os seus filhos, herdeiros de grandes «casais», por toda esta vasta área. A sua ideologia liberal ou mesmo republicana ter-se-á manifestado em público por altura da implantação da República a 5 de outubro de 1910, ao apanhar o comboio ate á estação de Freixo de Numão para ir realizar aí um comício ${ }^{482}$.

Ainda no século XIX, a família Castro Pereira cruzara-se com a também antiga e ilustre família dos Pizarros ${ }^{483}$, através do casamento, em S. João da Pesqueira a 2/4/1883, de Sebastião Teixeira Lobo Pizarro, descendente do ramo dos Pizarros de Gouvinhas de Sabrosa, com Dona Maria da Purificação de Castro Pereira da Mesquita, nascida e batizada na Gateira (Vila Nova de Foz Coa) em $1866^{484}$ e dona da Quinta de Lubazim, a quando do seu casamento. Deste casal só há conhecimento de um filho, o Dr. Manuel de Castro Pereira Teixeira Lobo Pizarro (1884-1944), como se verá adiante.

Logo depois das guerras liberais em que irmãos da mesma família Castro se encontraram em campos opostos (miguelistas e liberais), mas mantiveram as suas moradias, destacou-se Sebastião Teixeira Lobo Pizarro, arrojado empreendedor dos negócios da Quinta de Lubazim, ainda hoje assim lembrado pelo seu gosto pela diversão e lado perdulário:

enquanto muitas famílias procuravam desfazer-se de tudo através da venda de património, ele optava pela diversão pura e total. Fazia memoráveis viagens ao Porto, transportado em coches. Ao chegar à cidade estoirava o dinheiro todo. Passava nas ruas, metia a mão no pote e atirava libras de ouro para quem as quisesse apanhar ${ }^{485}$.

Nos finais do século XIX, com o incremento da cultura da vinha, Sebastião Teixeira Lobo Pizarro, filho de Francisco Teixeira Lobo Tavares de S. Payo, senhor da Casa da Porta da Vila, casado com Dona Purificação de Castro Pereira de Mesquita, filha e herdeira de Luís de Castro

\footnotetext{
${ }^{482}$ COIXÃO et al., 1985: 34-39, 49.

${ }^{483}$ Ver sobre a história e genealogias dos numerosos ramos e gerações da remota família Pizarro disseminada pela América (México, Perú, Brasil) e Portugal continental e insular em que muitos dos seus membros se tornaram figuras principais na história nacional, ver a muito pormenorizada e profusamente documentada obra de MACHADO, 1970.

${ }^{484}$ Livro de Batizados, ano de 1866, fls. 23 v. e 28, na Conservatória do registo Civil da Meda (nota extraída pelo genealogista António de Castro Pizarro), apud MACHADO, 1970: 470.

${ }^{485}$ CASTRO, 2015: 2.
} 
Pereira de Mesquita, senhor da Casa/Quinta de Lubazim, procurou atrair os Ingleses para o Lubazim, cedendo-lhes Vale Coelho, uma pequena parte da Quinta que «já produzia vinho e estabeleceram uma relação de longos anos com a Cockburn's casa à qual vendiam a produção destinada a Vinho do Porto ${ }^{486}$.

Foi seu filho único Manuel de Castro Pereira Teixeira Lobo Pizarro, em cuja genealogia ascendente se destacam: sucessivos capitães-mor de Vilarinho do Castanheiro que foram senhores de Lubazim; vários morgadios instituídos na quinta; a ligação das famílias Castro Pereira e Pizarro e figuras de vulto; o encadeamento de cruzamentos genealógicos com respetivos domínios e feitos principais (Anexo III).

Durante o século XX, a extensa e complexa genealogia dos Senhores de Lubazim vai prosseguir com o Dr. Manuel de Castro Pereira Teixeira Lobo Pizarro, senhor da Quinta e Casa de Lubazim e da Porta da Vila. A sua genealogia descendente irá então cruzar-se, como se verá, com famílias destacadas do concelho de Carrazeda de Ansiães em que se contam os avós e pais do proprietário da Quinta de Lubazim, Eng. Luís Pizarro de Castro. Manuel de Castro Pereira Teixeira Lobo Pizarro natural de Vilarinho da Castanheira casou a 2 de outubro de 1905 com Dona Corina Vilhena de Moura Carvalhais Pegado (senhora de raras qualidades morais, de bondade, humildade e desapego aos bens materiais), filha de José António de Magalhães Pegado de Seabra e de D. Maria Teresa de Vilhena de Moura Carvalhais. Deste casamento nasceram três filhos, sendo o primogénito António Manuel Alexandre Sebastião Pegado de Castro Pereira da Gama Lobo Pinto Pizarro, e o último Dona Maria Manuela do Céu de Castro Pereira Pizarro, que faleceu com 9 anos na Quinta do Lubazim em 04/10/1916.

O seu filho, António Pegado de Castro Pereira da Gama Lobo Pinto Pizarro Teixeira Lobo, senhor das Casas da Quinta de Lubazim e da Porta da Vila, nasceu em Travanca (Macedo de Cavaleiros), em 26 de agosto de 1906 e teve mais dois irmãos que morreram cedo. Casou, em 20 de maio de 1939, com Dona Maria Guilhermina Pinto de Lemos Sampaio e Melo de Noronha, filha do Dr. Carlos de Noronha Botelho de Magalhães, médico em Carrazeda de Anciães e ex-Governador Civil de Bragança e de sua mulher Dona Maria Palmira Miller Pinto com ascendência na família Botelhos de Magalhães; neta paterna de Carlos Augusto de Noronha Botelho de Magalhães, natural de Pombal, freguesia de Carrazeda e de sua mulher Dona Isabel de Morais Frias de Sampaio e Melo, nascida em Fontelonga (Carrazeda de Ansiães) em 22/1/1857; neta materna de António de Vasconcelos Pinto de Lemos, de Vila Flor, e de sua mulher Dona Sofia de Magalhães Miller, também nascida em Vila Flor.

António Pegado de Castro Pizarro Teixeira Lobo, por morte de seu pai Manuel de Castro Pereira Teixeira Lobo Pizarro, em 14/08/1944, tomou-se, aos 38 anos, o 15. ${ }^{\circ}$ Senhor da Quinta de Lubazim, tendo falecido em 06/09/1985 $5^{487}$. Do seu matrimónio com Dona Maria Guilhermina Sampaio e Melo de Noronha, residentes na Foz do Douro, nasceram 4 filhos:

\footnotetext{
${ }^{486}$ CASTRO, 2015: 2.

${ }^{487}$ Dados retirados da genealogia dos Senhores de Lubazim (disponível em <http://geneall.net/pt/forum/116191/ senhores-da-quinta-de-lobazim/>. [Consulta realizada em 2/6/2016]) e de ALVES, 1983: 528-529. Em nota, o Abade
} 
a) Carlos Manuel de Noronha Teixeira Lobo, nascido no Porto em 22/5/1940, que estudou engenharia na Universidade do Porto;

b) Eng. Luís João de Noronha Pizarro de Castro, também nascido no Porto a 29/5/1941 e que cursou engenharia civil na Universidade do Porto;

c) Dr. Nuno Duarte Pinto de Lemos Pizarro, igualmente nascido no Porto em 10/7/1942 e aí formado em Medicina;

d) José Paulo de Noronha Pegado Pizarro, irmão gémeo do anterior e casado no Mosteiro dos Jerónimos, Lisboa, em 11/8/1967, com Dona Maria de Jesus Ribeiro de Almeida, nascida em Vila Real a 21/6/1948. Este casal teve dois filhos gémeos: Duarte Nuno e Ricardo Paulo, ambos batizados na Igreja Nossa Senhora de Fátima a 29/6/1968 ${ }^{488}$.

A Casa e Quinta de Lubazim continuaram na posse destes DE LUBAZIM

Fig. 116 mais recentes descendentes dos Senhores de Lubazim da família Castro Pereira Mesquita Pizarro ${ }^{489}$. Foram entretanto realizadas partilhas entre os irmãos, herdeiros legitimários: Nuno Pizarro de Castro, gémeo de Paulo Pizarro de Castro (já falecido), médico, residente em Lisboa; Carlos Manuel de Noronha Pinto Pizarro Teixeira Lobo; e Luís João de Noronha Pinto Pizarro de Castro Teixeira Lobo, que comprou aos irmãos a sua parte, atual dono da Quinta de Lubazim e do solar dos Castro Pizarro em Vila Flor.

Numa síntese final retrospetiva e atualizada dos Senhores de Lubazim ${ }^{490}$ são destacados ainda os seguintes nomes com respetivos títulos:

1. Dr. José Manuel Guimarães de Noronha Pizarro de Castro, licenciado em Gestão, nascido a 13 de outubro de 1974, a residir em Vila Flor, Trás-os-Montes e Alto Douro, Cavaleiro de Honra e Devoção da Ordem de Malta, é casado com a Dra. Catarina Maria Mendes de Albuquerque Rodrigues Pizarro de Castro, licenciada em Relações Internacionais, com pós-graduação em Gestão Pública e Autárquica. O Pai desta Senhora é da Beira Alta, Vila Ruiva e Fornos de Algodres (dos Albuquerques da Beira) e a mãe é de Ponte da Barca, Minho. O casal tem duas filhas: Maria de Albuquerque de Noronha Pizarro de Castro e Maria Teresa de Albuquerque e Noronha Pizarro de Castro;

2. Eng. Luís João de Noronha Pizarro de Castro, licenciado em Engenharia Civil, Cavaleiro de Honra e Devoção da Ordem de Malta;

\footnotetext{
de Baçal referencia assim a sua fonte. «Ao Ex.mo Sr. Fulgêncio Lopes da Silva, primeiro oficial da Biblioteca Pública Municipal do Porto, agradecemos as informações que nos deu para este estudo, extraídas da Memória Genealógica, de Carneiro de Fontoura (ver «Lamas de Orelhão», p. 246.).

${ }^{488}$ MACHADO, 1970: 472-473.

${ }^{489}$ Outras informações são acessíveis no link da genealogia oficial dos Senhores de Lubazim (Disponível em <http:// geneall.net/pt/forum/116191/senhores-da-quinta-de-lobazim/\#a116361>. [Consulta realizada em 02/06/2016]).

${ }^{490}$ CASTRO, [s.d.].
} 
3. D. António Manuel Sebastião Pegado de Castro Pereira da Gama Lobo Pinto Pizarro, Cavaleiro de Honra e Devoção da Ordem de Malta;

4. Dona Maria da Purificação de Castro Pereira da Mesquita;

5. D. Luís Joaquim Pereira de Castro Pereira da Mesquita — o irmão estava com Napoleão na retirada da Rússia;

6. Dona Ana Maria de Castro da Mesquita Pereira;

7. D. Manuel António de Castro da Mesquita Pereira Pimentel;

8. D. Manuel de Souza Cardoso de Mesquita e Castro;

9. D. Manuel Tavares Mesquita e Castro;

10. D. António de Castro Mesquita - Fidalgo da Casa real;

11. D. Francisco de Castro Monteiro de Castro;

12. D. António de Castro da Mesquita;

13. D. Gonçalo Vaz de Castro — Fidalgo da Casa real;

14. D. Vasco Lourenço de Castro — Fidalgo da Casa real;

15. D. Pedro Lourenço de Castro;

16. D. Vasco Lourenço de Castro;

17. D. Pedro Lourenço de Castro que veio da Galiza no tempo de D. João I.

\subsubsection{Envolvência geográfica, geomorfológica e ambiental da Quinta de}

\section{Lubazim}

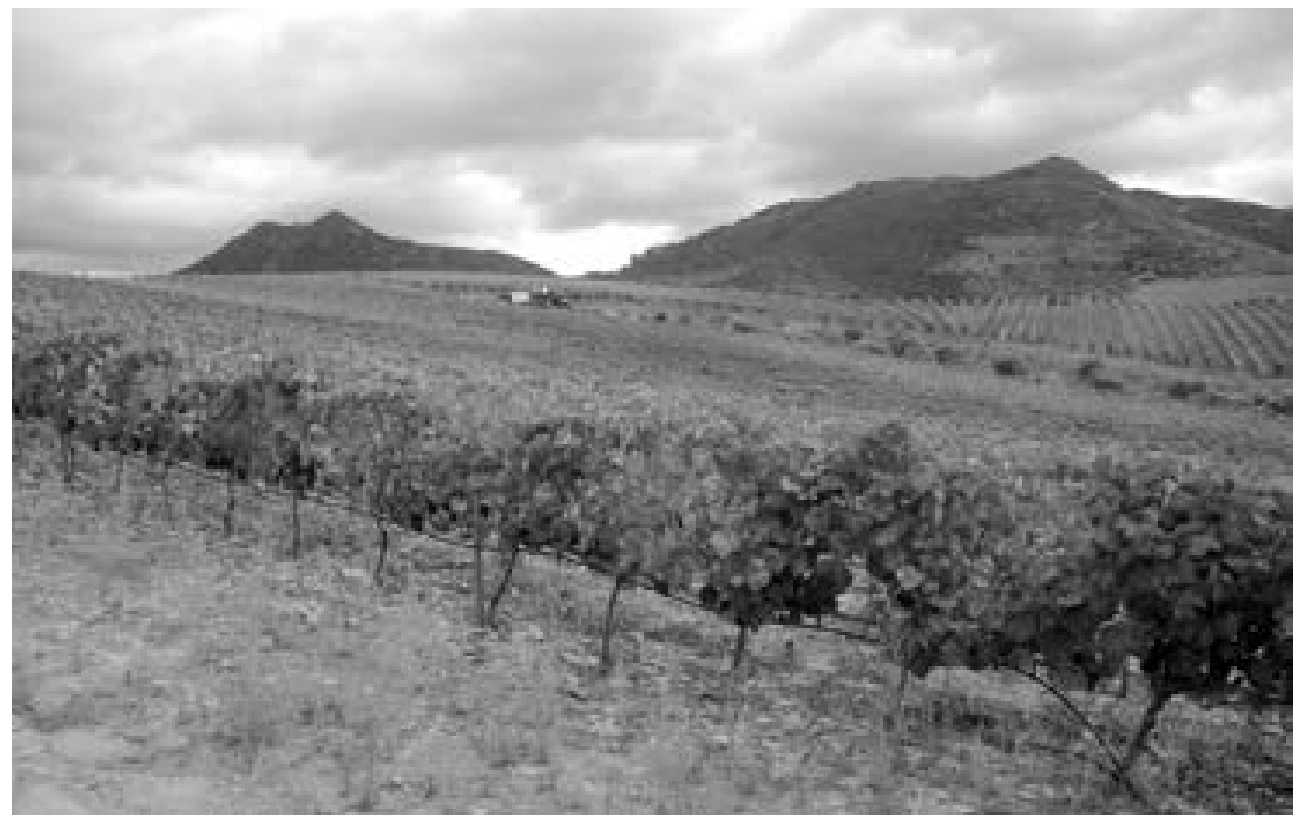

Fig. 117. Vista parcial da Quinta de Lubazim junto à Serra da Lousa 
Esta quinta do Douro Superior, cuja área territorial se estende hoje por três municípios vizinhos do distrito de Bragança: Carrazeda de Ansiães, Vila Flor e Torre de Moncorvo, estende-se até ao rio Douro, na sua margem norte, num ponto que sempre foi o de mais fácil travessia fluvial como se atesta na existência aí de vestígios de uma antiga estrada romana ${ }^{491}$ que serviu de base à nova estrada municipal de acesso às povoações mais próximas de Pinhal do Douro e Vilarinho da Castanheira do concelho de Carrazeda.

Localiza-se na região interior de Trás-os-Montes e Alto Douro Vinhateiro, na depressão entre a Serra da Lousã e o cume de Bulfata, seus limites naturais. Os seus solos junto ao rio são constituídos por xisto, argila e limo. Nas zonas mais altas existem terrenos de transição com granito.

Quando esta grande propriedade agrícola se começou a desenvolver, o crescimento populacional do território português, com especial relevo para o norte do país, foi decorrente em grande medida das sucessivas políticas régias de ordenamento e povoamento, traduzidas inclusive na concessão de cartas de foral a numerosos e antigos concelhos.

O ecossistema e biodiversidade desta região foram-se também transformando de modo profundo, paulatino e decisivo. O seu coberto vegetal, bem como a fauna e a flora autóctones foram-se alterando, lentamente, até mudarem quase por completo.

Da antiga abundância de azinheiras, carvalhos ou sobreiros, medronheiros, zimbros e plantas de menor porte - o jasmim-silvestre, a esteva e o trovisco, passou-se gradualmente para culturas com intensa e organizada intervenção humana.

Com o povoamento sempre em crescendo, a fauna autóctone foi-se também modificando consideravelmente, verificando-se o progressivo desaparecimento quer de grandes herbívoros, como os veados e os corços quer de animais predadores como o lobo, o maior predador da Península Ibérica, gatos bravos, saca-rabos ou manguços e genetas - que foram progressivamente rareando, até se extinguirem ou entrarem em vias de extinção.

Das muitas espécies de aves selvagens que outrora povoavam os territórios desta região, poucas perduraram, inclusive com o abandono progressivo e ruína subsequente dos muitos pombais existentes nesta zona do país.

No entanto, entre as raras espécies dessas aves que ainda se conservam, encontram-se por exemplo as corujas brancas ou corujas das torres, que continuam a procurar como abrigo o pombal da Quinta de Lubazim onde vão nidificar. Trata-se de uma ave predadora noturna, de penas brancas no peito e alaranjadas com manchas cinzentas no dorso, plumagem fina nas longas asas que facilitam o seu voo o qual aliado à sua muito penetrante visão noturna (quase dez vezes superior à do homem) lhe permite capturar de modo rápido e definitivo as suas presas $^{492}$.

\footnotetext{
${ }^{491}$ Ver ESTEVES, 2008: 261 -263.

${ }^{492}$ Alguns destes dados foram consultados no documento «Quinta do Lobazim: Alto Douro» (10 páginas, ilustrado) que nos foi facultado pelo Sr. Eng. Luís Pizarro de Castro a quem são devidos os nossos agradecimentos, extensíveis à cedência de alguns livros de sua biblioteca, às muitas e importantes informações sobre a história da sua família, Casa e Quinta do Lubazim, e também à sua cortesia de uma visita guiada ao interior do Solar dos Castros em Vila
} 


\subsubsection{Património e identidade da Casa e Quinta de Lubazim}

A Casa e Quinta de Lubazim, com outras propriedades da família Castro Pizarro (quintas Velha em Vila Flor, do Castelar e do Carrascal no vale da Vilariça) representa hoje um considerável património agrícola com modernas culturas vitivinícolas que se foram construindo ao longo de mais de seis séculos e uma densa tradição familiar enraizada na antiga nobreza nacional, o que lhe confere uma longevidade e identidade histórica própria que contribuem para explicar a singular posição que ocupa no grande universo das quintas durienses.

Na segunda metade do século XIX, com a franca expansão dos vinhedos para o Douro Superior a cultura vitivinícola registou um notável incremento. Nesse contexto de profunda mudança duriense, a Quinta de Lubazim que fora também afetada pela praga filoxérica, vai recuperar com arrojadas iniciativas, novos saibramentos e replantação dos vinhedos, destacando-se então como seu proprietário, Sebastião Teixeira Lobo Pizarro ${ }^{493}$, o qual procurou atrair as boas relações comerciais e de amizade dos ingleses. Neste âmbito, nos finais de Oitocentos, acabaria por ser vendida à firma britânica Cockburn \& Smithes, o Vale Coelho, área encravada na Quinta de Lubazim mais próxima do rio Douro, onde viria a ser constituída a Quinta de Vale Coelho, mimosa propriedade produtora de vinho do Porto de elevada qualidade, por essa empresa. Por essa altura, foi também construído no Lubazim um enorme armazém com lagares em granito que ainda hoje se conserva, embora inativo, como se documenta fotograficamente.

Da introdução do plantio da vinha e produção de vinho na Quinta do Lubazim, então com uma grande área que se estendia das margens do Douro até muito perto de Vilarinho do Castanheiro onde ainda existem pedras de armas da família Castro, dá-nos conta, em 1887, o Abade de Miragaia num curioso trecho descritivo desta notável propriedade:

[...] É hoje absolutamente a primeira e a mais importante desta freguesia e deste concelho [Vilarinho da Castanheira] e uma das primeiras do Alto Douro e desta província, porque a sua produção dominante foi sempre azeite: costuma produzir a bagatela de oitenta a cem pipas de 550 litros por ano; tem 25 a 30 mil oliveiras, duas casas de habitação brasonadas e dezanove com abegoarias e outras oficinas; mede cinco quilómetros ao longo do Douro, no qual tem as azenhas de Dona Maria, com três rodas de moinhos, que andam arrendadas por cem alqueires de pão; apascenta mil cabeças de gado lanígero; produz também mil a 1.500 medidas de centeio de quinze litros, e vinte a trinta arrobas de amêndoa; tem, final-

Flor, que nos proporcionou em setembro de 2016, com permissão de fotografar documentos, peças e retratos do seu espólio particular.

${ }^{493}$ Sebastião Teixeira Lobo Pizarro, senhor da Casa da Porta da Vila, nasceu em Sabrosa em 1861, herdeiro dos seus pais e irmãos (6), casou com Dona Purificação Castro Pereira da Mesquita, nascida em 02/04/1865, filha e herdeira do Dr. Luís de Castro Pereira da Mesquita, Senhor da Casa e da Quinta de Lobazim, casado com Dona. Delfina Augusta da Silva Cunha; era neto paterno do Dr. Dionísio de Castro Pereira da Mesquita e de sua mulher Dona Maria de Castro herdeira de Lobazim e dos vínculos de Santa Luzia e de Nossa Senhora da Purificação de Longroiva -Vilarouco. 
mente, um forno de telha na margem do Douro e magnificas lodeiras que, plantadas de vides, podem dar cem a duzentas pipas de vinho por ano [...].

Como já se referiu, desde finais do século XIX que a Quinta de Lubazim forneceu durante quase 100 anos, os seus vinhos generosos à Cockburn's, até à recente compra desta firma inglesa pelo atual maior grupo do Douro «Symington Family Estates» que lhe sucedeu quer como proprietário da referida quinta de Vale Coelho, localizada a poente da Quinta de Lubazim, junto ao rio Douro, e de outras quintas maiores que essa antiga firma inglesa possuíu em Carrazeda de Ansiães, quer na comercialização e exportação do vinho do Porto de grande número de produtores do mesmo concelho.

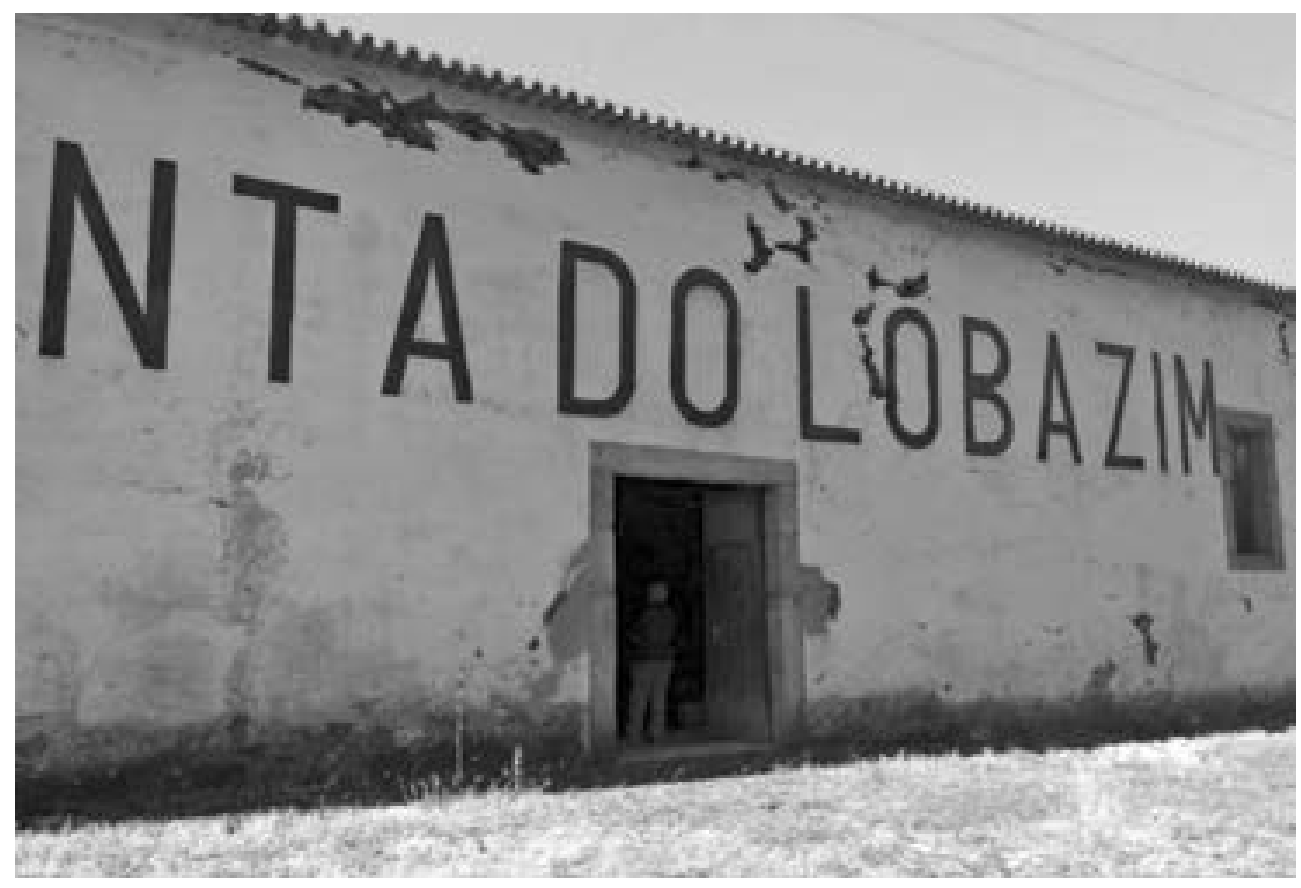

Fig. 118. Armazém Oitocentista da Quinta Fonte: Fotografia de D. L.

Este antigo e grande armazém situado na ampla frente que a Quinta tem para o rio Douro é uma construção com o interior em 2 pisos, encontrando-se no piso superior os lagares que intercomunicavam com o rés do chão para o direto armazenamento dos vinhos numa enorme quantidade de tonéis de várias capacidades onde ainda se pode hoje ler escrito a giz o nome da firma Cockburn's. Numa das paredes interiores do armazém, pode ler-se também o seguinte poema alusivo ao lotar de um tonel, da autoria do antigo tanoeiro da quinta, Santana, que assim curiosamente assina. 


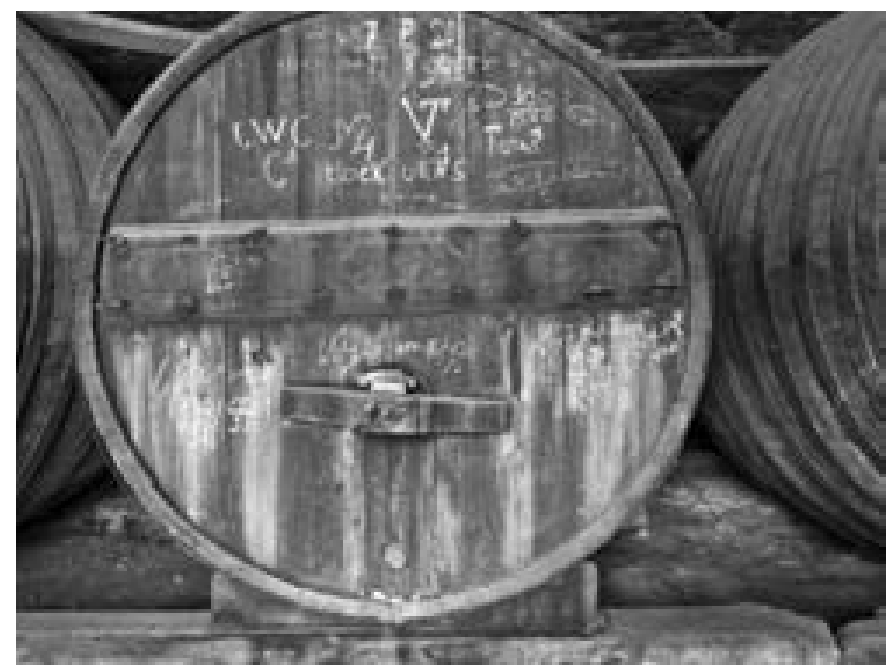

Fig. 119. Tonel (Cockburn's) no antigo armazém da quinta Fonte: Fotografia de D. B.

Ao lotar o tonel 7

Na quinta de Lubazim

Olhei para o rio, e disse-me:

Pró - ano não sou assim.

Pró - ano não sou assim.

Já tenho outro efeito

Pois obrigam-me a sair

Dentro em breve no meu leito.

Vou a ser mais corpulento

Vou a ser um campeão

Pró - ano não me conheceis

Nem tu nem mesmo o patrão!

Resposta

Se não te podes vir ver

Por qualquer coincidência

Saúda-me ao Sr. Pizarro

À família por Excelência.

\section{Fui-Eu-Santana ${ }^{494}$}

\footnotetext{
${ }^{494}$ CASTRO, 2015: 29.
} 
A área territorial da Quinta do Lubazim, outrora pertencente ao extinto concelho de Vilarinho, passaria mais tarde a estar, administrativamente, dividida por três limítrofes e atuais autarquias: Carrazeda de Ansiães, Torre de Moncorvo e Vila Flor, o que contribui para dificultar a resolução corrente de assuntos administrativos e fiscais da sua atividade polifuncional de produção, comercialização e prestação de serviços em agricultura, pecuária, viticultura, olivicultura, silvicultura, apicultura e turismo rural.

É, aliás, em Vila Flor que a quinta mantém a sua sede oficial e se encontra ainda hoje bem conservado o elegante solar da Família Castro Pizarro, em cujos salões e recantos do interior se conserva um notável espólio familiar: coleções de valiosos documentos, muitos retratos, óleos e outros pertences pessoais, peças de mobiliário histórico e ricos objetos indo-europeus ou de outras proveniências que, no seu conjunto, se podem configurar como património (i)material único e memória viva de conhecidos factos da história nacional em que se destacaram alguns dos Senhores do Lubazim.

Este palacete em cantaria de fachada Oitocentista (estilo neoclássico com ornamentos barrocos) apresenta um destacado brasão com as armas dos Castros, dos Sousas, dos Mesquitas e dos Pereiras ${ }^{495}$, por baixo do qual se pode ler a data de 1846.

Imagens de exterior do Solar da Casa/Quinta de Lubazim em Vila Flor:

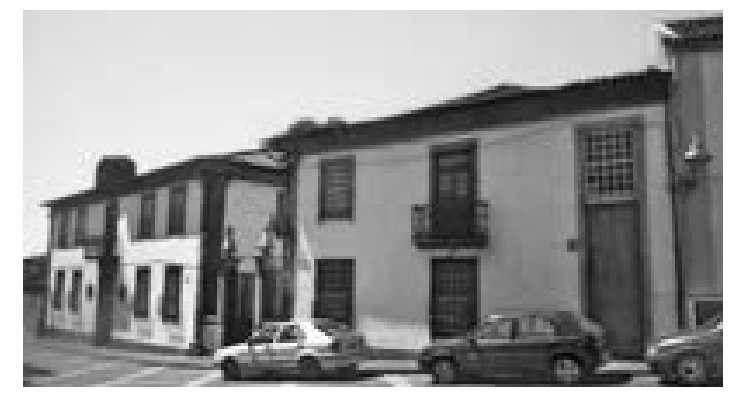

Fig. 120

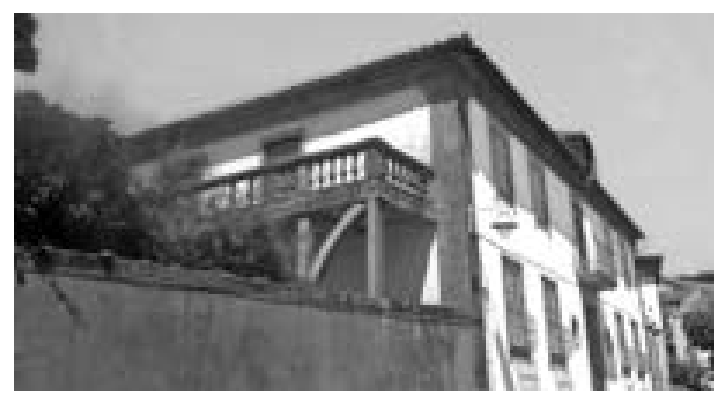

Fig. 121. Solar da Família Castro da Quinta de Lubazim. Largo do Rossio, Vila Flor Fonte: Fotografia G. P.

${ }^{495}$ Ver ALVES, 1983: 782, nota 147. 


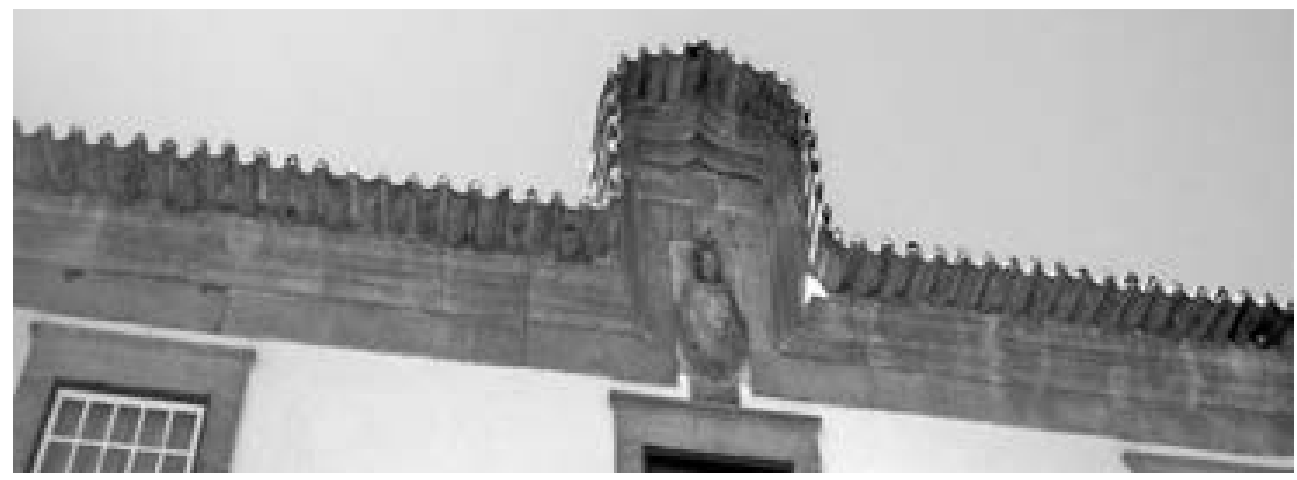

Fig. 122. Brasão da família Pizarro de Castro com inscrição do ano 1846 Fonte: Fotografia G. P.

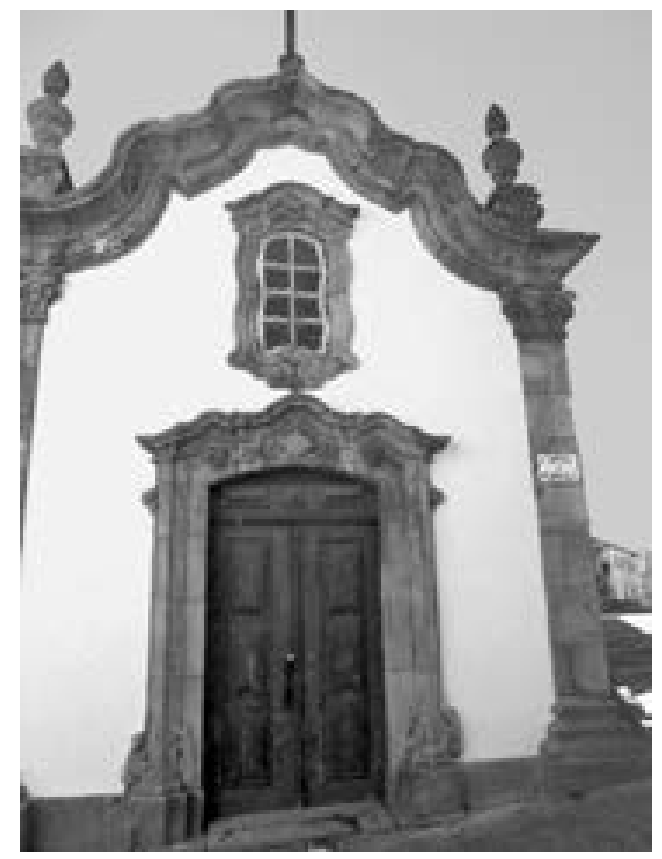

Fig. 123. Capela da Família próxima do Solar. Fonte: Fotografia G. P.

Tem-se feito remontar a história deste solar de grande valor patrimonial, material e imaterial, ao século XVII, quando Francisco dos Santos Monteiro de Castro, $1 .^{\circ}$ capitão-mor de Vilarinho da Castanheira, instituiu em 1618, o morgadio de Santa Luzia, continuando a existir na quinta uma capela brasonada do mesmo nome (Capela de Santa Luzia). Numa das cantarias da fachada principal do solar pode ler-se a inscrição do ano de 1732, pelo que se presume ser dessa altura a construção da sua ala mais elegante. 
Na segunda metade do século XVII, outro Senhor de Lubazim, o 3. ${ }^{\circ}$ capitão-mor de Vilarinho da Castanheira, Manuel Tavares de Mesquita e Castro, juntamente com sua mãe, Dona Isabel de Mesquita e Castro instituiu o vínculo da Purificação, por escritura de fevereiro de 1669, existindo também a capela de Nossa Senhora da Purificação em Vilarinho.

Encontra-se ainda na quinta, outra capela com a fachada principal e as paredes laterais arruinadas, ao que consta, por ter sido profanada, no princípio do século XIX durante as invasões francesas, tendo-se mantido até hoje por restaurar ou reconstruir.
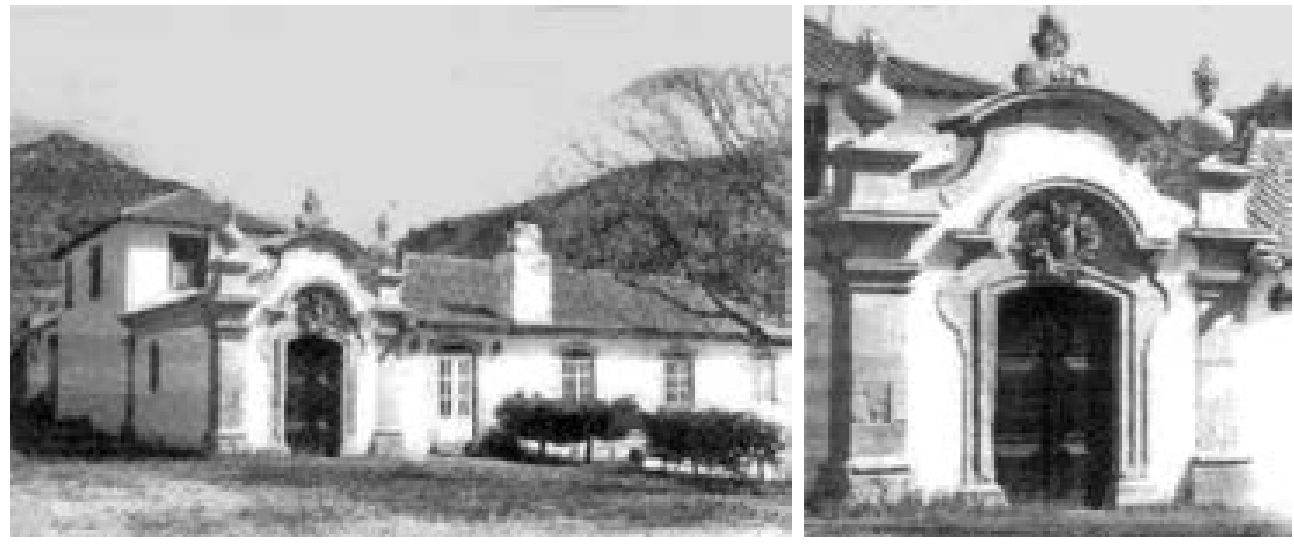

Figs. 124 e 125. Antigo Solar com capela brasonada na Quinta do Lubazim ${ }^{496}$

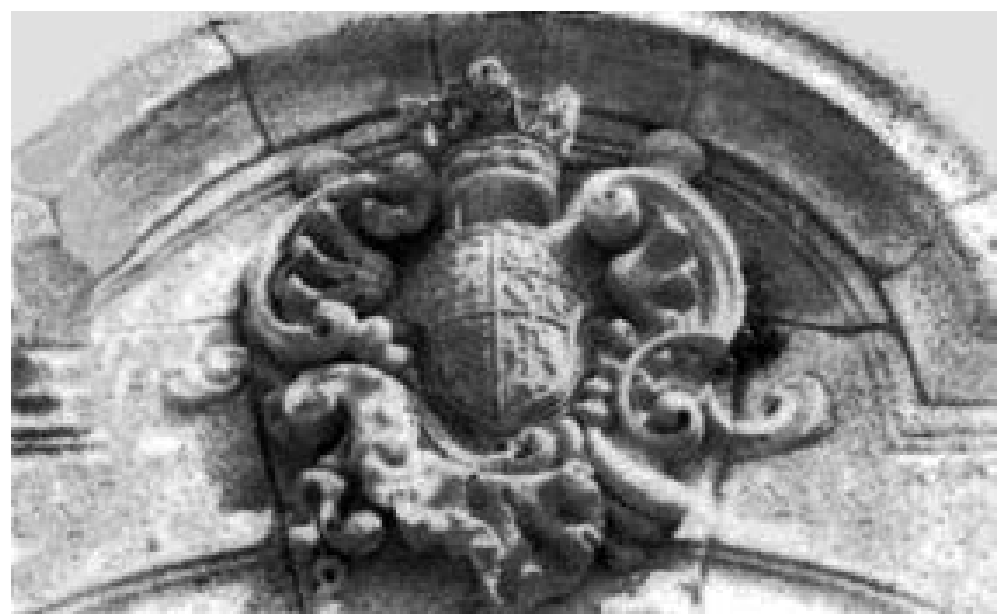

Fig. 126. Brasão da família Pereira de Castro ${ }^{497}$

\footnotetext{
${ }^{496}$ CASTRO, [s.d.]. Documento inédito de 8 páginas, ilustrado. Cópia facultada, para além do acesso a outros documentos, pelo Eng. Luís Pizarro de Castro, cuja generosa disponibilidade se agradece.

${ }^{497}$ CASTRO, [s.d.] — descrição deste brasão.
} 
A pedra de armas é em granito e esquartelado: no primeiro quartel as armas dos Castros com treze arruelas; no segundo quartel as armas dos Sousas esquartelado; no terceiro as armas dos Mesquitas e no quarto as dos Pereiras. Este conjunto pertence a século XVIII com ornatos barrocos em cantaria.

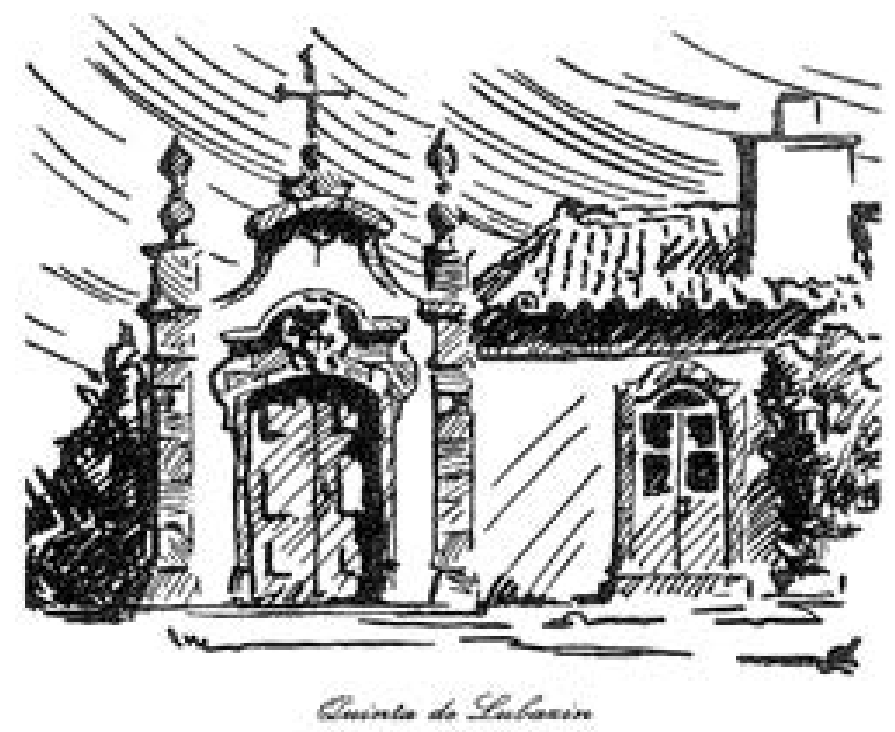

Fig. 127. Desenho a tinta da china da autoria do Eng. Luís Pizarro de Castro ${ }^{498}$

Como escreveu o notável erudito transmontano Abade de Baçal:

Está [o brasão] em Vilarinho da Castanheira, concelho de Carrazeda de Ansiães, na quinta de Lobazim, pertencente ao doutor Manuel de Castro Pereira Teixeira Lobo Pizarro. No 2..$^{\circ}$ quartel as armas dos Castros, com a anomalia de o besante isolado estar no meio da pala central. No $4 .^{\circ}$ as armas dos Mesquitas. O mesmo possui também casa brasonada na quinta das Portas da Vila, em Vila Real, onde se vêem as armas dos Sousas, Lobos, Pintos e Sampaios.

A mesma família possuía também outra casa brasonada em Vilarinho da Castanheira, mas vendeu-a e mandou picar as armas para não irem para um pastor, diz a tradição.

O pastor que pelo seu trabalho honrado se habilita a comprar casa brasonada é bem mais digno do escudo do que muitos fidalgos que, por má administração, vinho, batota, orgia e amores fáceis, arruinaram nobres solares. É certo que aos Pizarros de Lobazim não tem aplicação o conceito ${ }^{499}$.

\footnotetext{
${ }^{498}$ Imagem digitalizada a partir do original que nos foi gentilmente emprestado pelo autor a quem é devido o nosso agradecimento público.

${ }^{499}$ ALVES, 1983: 782, nota 147.
} 
Tal descrição desta outra casa e capela, hoje em ruínas, como antigas instalações agrícolas que as rodeiam dentro dos terrenos murados de uma grande propriedade privada situada no atual centro histórico de Vilarinho da Castanheira, permeia ainda a memória e narrativas atuais de alguns idosos desta aldeia como se constatou em entrevistas informais.

Com base no cruzamento de fontes diversas: testemunhos orais; dados da inscrição: «MCPM/1852», visível no umbral de pedra da porta principal da casa defronte da capela; registos genealógicos da família Castro de Vilarinho, nessa época; observações do atual encarregado da limpeza e conservação desta propriedade privada, é possível inter-relacionar elementos de informação dispersa e deduzir que esta grande casa agrícola terá supostamente pertencido, em meados do século XIX, a Manuel de Castro Pereira da Mesquita (nome abreviado na inscrição datada), membro desta nobre família e Senhor de Lubazim, tio do Dr. Manuel de Castro Lobo Pizarro, destacado proprietário da Casa e Quinta de Lubazim, nos finais de Oitocentos.

Em finais do século XIX, o Dr. Manuel de Castro Lobo Pizarro, dono da Quinta de Lubazim, iria incrementar consideravelmente o desenvolvimento e modernização vitivinícola da Quinta, continuando a manter como seu pai e antecessor proprietário, Sebastião Pizarro, boas relações com os «ingleses» Cockburn \& Smithes que já então tinham implantado os seus negócios de vinho do Porto nesta sub-região do Douro Superior, onde eram os principais compradores.
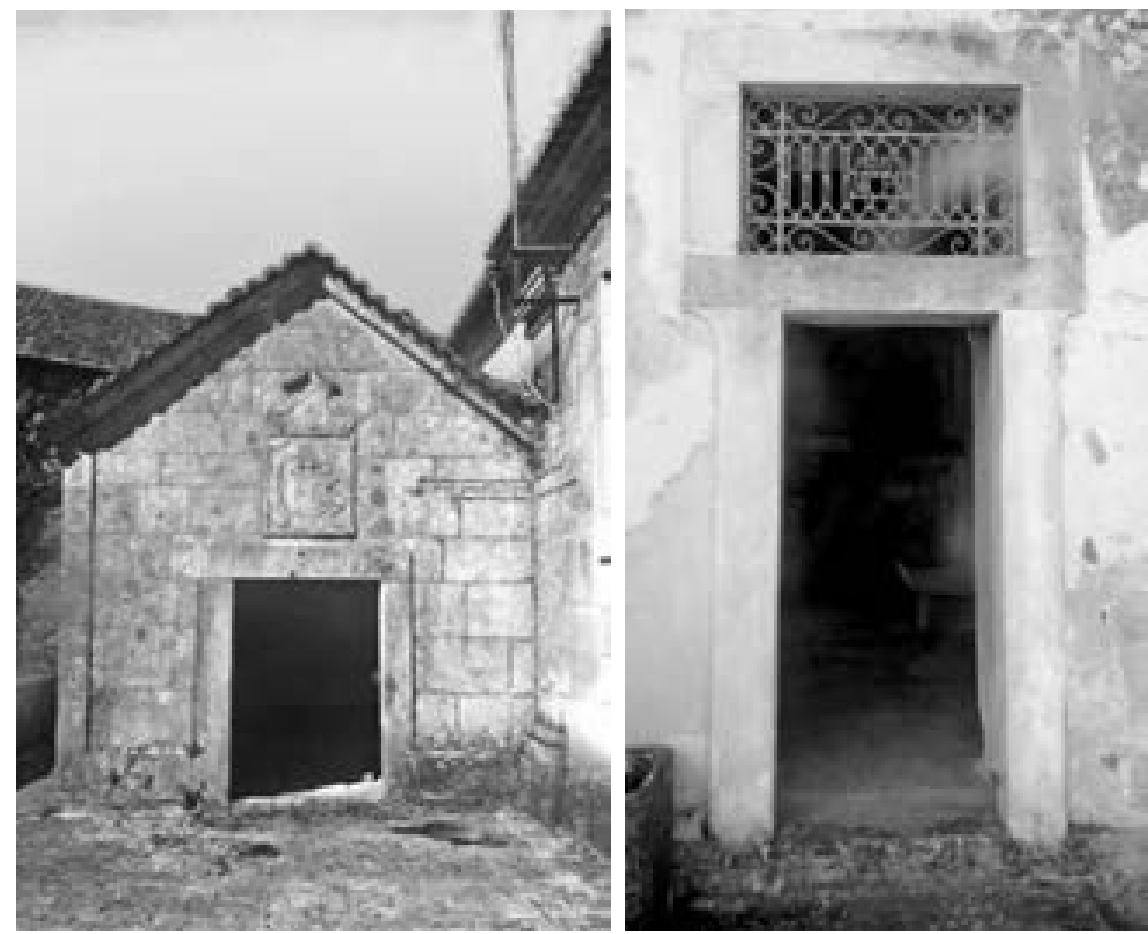

Fig. 128. Capela com brasão picado e porta principal da antiga casa com inscrição «M.C.P.M. 1852» em Vilarinho 

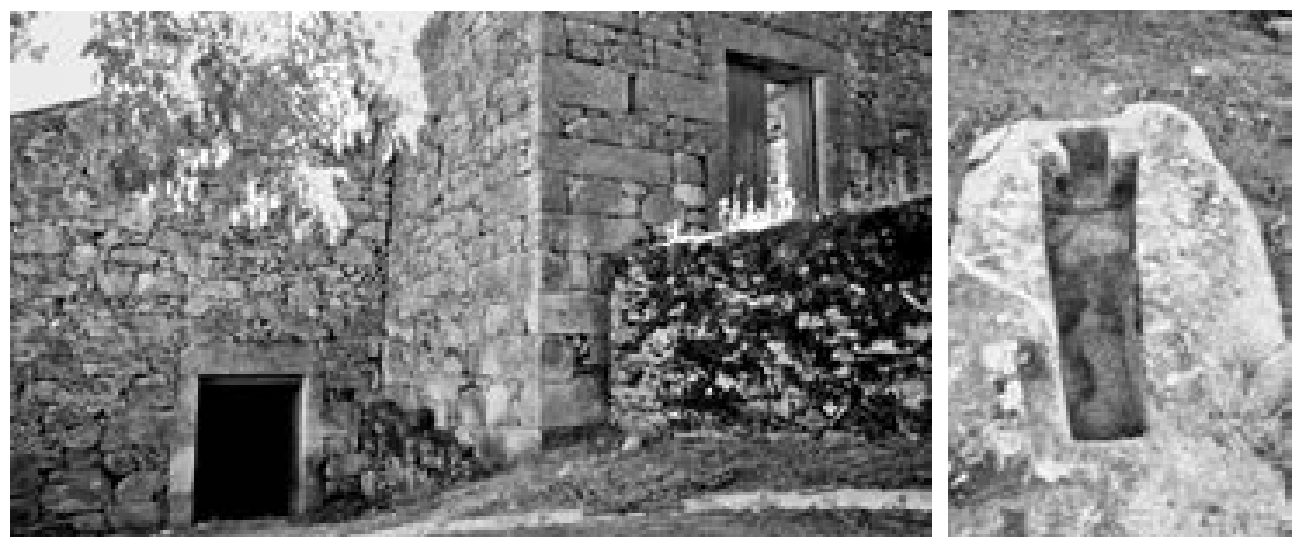

Fig. 129. Armazéns da antiga casa agrícola de M.C.P.M. (1852)

Sepultura rupestre em terrenos adjacentes

Manuel de Castro Pizarro não só mandou plantar vinhas novas em antigos socalcos de paredes de xisto, como investiu, junto à margem do rio Douro, na construção de um moderno e enorme armazém, à época, um dos maiores do Douro, com largos lagares de pedra no piso superior e grandes tonéis de madeira no piso inferior para tratamento e armazenamento dos vinhos da quinta e dos lavradores daquela região.

Em meados do século XX, foi construído no extremo norte da quinta um novo e grande lagar de azeite.

Na década de 1960, decorrente da construção da barragem da Valeira, a jusante, cuja albufeira submergiu muitas das vinhas existentes na encosta junto às margens do rio Douro, foram feitas na Quinta de Lubazim terraplanagens em cotas superiores e plantação de vinhas novas.

\subsubsection{Produção e cultura vitivinícola de Lubazim}
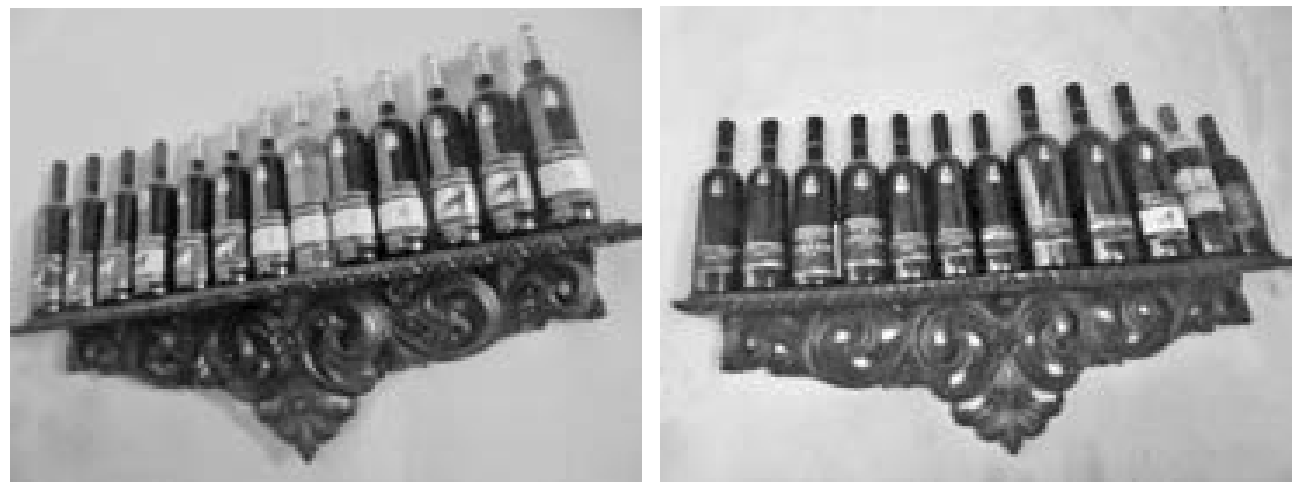

Fig. 130. Expositor dos Vinhos «Lupucinus»e «Quinta de Lubazim Reserva» no Solar de Lubazim (Vila Flor) 
Presentemente, a Quinta de Lubazim que constitui um terroir específico possui uma área total de 200 hectares resultantes do reajustamento dos 100 hectares iniciais (velhos mortórios provocados pela filoxera e 14 ha de vinhas velhas com mais de 100 anos em terraços pós-filoxéricos com muros de xisto) com outras quintas, propriedade da família. Cerca de 100 ha são de novas plantações de vinhedo em patamares largos com 3 a 6 bardos (mandados construir pelo Eng. Luís Pizarro de Castro, a partir de 1974) onde se cultivam castas nobres da região (Touriga Nacional, Touriga Franca, Tinta Roriz, Tinta Amarela, Bastardo, Barroca, etc.).

Nos últimos anos foi desenvolvida na zona velha da quinta, a uma outra altitude, a plantação de 17 ha de vinhas novas, com 49 castas antigas e nobres da região.

A produção da Quinta de Lubazim que rondava uma média anual de 80 pipas de vinho (60 de vinho do Porto e 20 de vinhos DOC) triplicou em 2010 e quintuplicou em 2012. Em 2015, antes da vindima desse ano, contava com 25 mil garrafas por ano, o que sendo, relativamente significativo da recente ampliação dos seus negócios vitivinícolas, numa escala familiar, é ainda bem inferior aos dos grandes produtores e exportadores de vinhos do Douro.

Continua a ser produtora reputada de antigos Vinhos do Porto de superior qualidade, sempre vendidos a grandes firmas exportadoras estrangeiras e nacionais.

Nos últimos anos, a Quinta optou por investir tecnologicamente na criação dos seus próprios vinhos do Porto e Douro DOC, divulgando-os e procurando a sua comercialização mais direta através de uma presença assídua e constante em feiras, exposições e outros espaços de mostra, nacionais e estrangeiros, com vista a conquistar novas oportunidades de acesso ao mercado dos vinhos cada vez mais disputado, concorrencial e globalizado.

Vende hoje os seus prestigiados vinhos Douro DOC, não só em Portugal, mas também no mercado internacional, onde estão bem colocados em vários países estrangeiros desde a França, Suíça e Luxemburgo, ao Canadá (Toronto), e China (Macau) onde vêm alargando a sua presença.

Apresenta um significativo volume de vendas em que se destacam as marcas próprias dos tintos: «Lupucinus» e «Quinta de Lubazim» que vêm sendo sucessivamente galardoadas e cuja primeira vinificação teve lugar em $2005^{500}$.

Os prémios recebidos de reconhecimento da qualidade dos seus vinhos são de grande importância para os negócios da Quinta e a sua afirmação no oceano da produção vinhateira duriense, com redobrado estímulo para a experimentação e inovação.

Com uma boa, diversificada e vasta exposição solar, a quinta mantém moderna tecnologia de vinificação, cujos serviços especializados tem contratado à Quinta do Conquinho de Maria Adelaide Melo e Trigo, antiga exploração agrícola familiar do Douro Superior situada na Horta da Vilariça, Torre de Moncorvo. Em 2016, estes serviços foram contratados em Alijó,

\footnotetext{
${ }^{500}$ Dentre os vários prémios e medalhas de ouro e prata que nos últimos anos os seus vinhos têm recebido, destacam-se os seguintes: Quinta de Lubazim Grande Reserva 2007, 2008, 2009, 2012, 2012 Novo; Lupucinus Reserva 2007, 2008, 2009-2012 e 2011-2012; Lupucinus Selection — Novo Vinho Branco 2013 e Lupucinus Grande Reserva 2011-2012; Lupucinus Selection — Novo 2013; Lupucinus Selection 2012-2014.
} 
à empresa Gran Cruz detida pela multinacional francesa La Martiniquais e que possui na Região Demarcada do Douro duas grandes adegas de qualidade excecional.

Para além das mudanças e tecnologias introduzidas, é de relevar o facto de a produção vitivinícola da Quinta de Lubazim poder contar ainda com a grande colaboração e sábia experiência do enólogo Manuel Carvalho, antigo responsável da Cockburn's para o Douro Superior.

As uvas continuam ainda a ser vindimadas e escolhidas à mão, para caixas de 25 quilos quando apresentam uma maturação excelente, o que permite maiores concentrações aromáticas e polifenólicas, sendo os compostos polifenólicos de fundamental importância nas características dos vinhos ${ }^{501}$. Após as operações de esmagamento brando e desengace total, as uvas são fermentadas em cubas, com vista a conseguir-se que os seus constituintes de qualidade passem suavemente para o vinho DOC Douro. Este estagia em barricas novas de carvalho francês de 200 e 300 litros, durante aproximadamente 12 meses. A fermentação malolática que acontece geralmente depois da fermentação alcoólica, quando os vinhos são passados já «limpos» para as cubas de armazenamento, onde essa fermentação ocorre, tem por função amaciar os vinhos, provocando, no entanto, uma diminuição dos aromas primários provenientes das uvas.

No final destes processos de vinificação, as notas de provas salientam as seguintes características enológicas de elevada qualidade dos vinhos Lubazim: «cor púrpura e com boa profundidade, aromas muito complexos e distintos onde predominam o caráter frutado e floral com notas muito frescas, a madeira aparece muito discreta e bem integrada no vinho». $\mathrm{O}$ sabor a fruta, «complexidade e uma bela estrutura, com taninos de grande nível conferem-lhe um longo final de boca».

Esta combinação equilibrada de poder e elegância contribui para o potencial de envelhecimento dos vinhos, pelo que estes beneficiam com alguns anos em garrafa.

À frente da área de «marketing» e relações públicas da Quinta de Lubazim que evidenciam também grande e inovador sentido de iniciativa e modernidade, encontra-se a nova empresária agrícola Dra. Catarina Castro cujo empreendedorismo é reconhecido pelo sogro, Eng. Luís Pizarro de Castro.

Em síntese, é esta combinação equilibrada de inovação e moderno desenvolvimento com uma sólida tradição ancorada na densa tessitura histórica do Lubazim, que melhor pode explicar-se a forte identidade patrimonial e histórica de expressiva carga simbólica desta singular quinta, propriedade moderna na posse secular de uma nobreza nacional de olhar voltado para a contemporaneidade como adiante se ilustra ${ }^{502}$.

\footnotetext{
${ }^{501}$ CABRITA et al., 2003.

${ }^{502}$ Fotos: cortesia de Catarina de Castro Pizarro.
} 


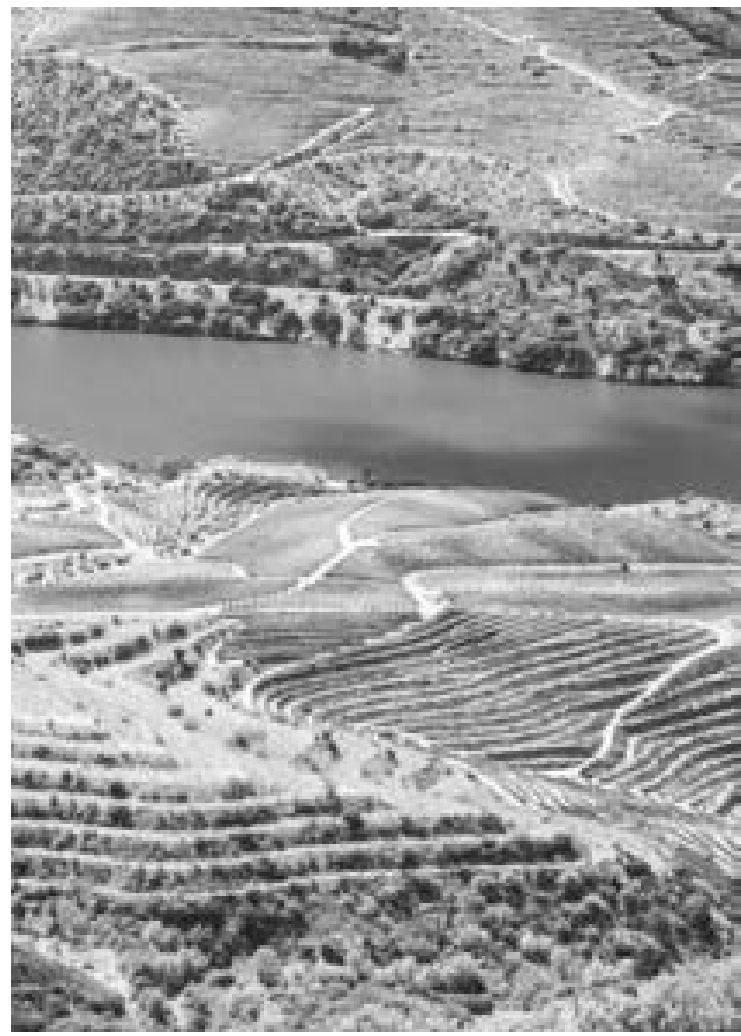

Fig. 131. Vista parcial da Quinta do Lubazim, junto ao rio Douro

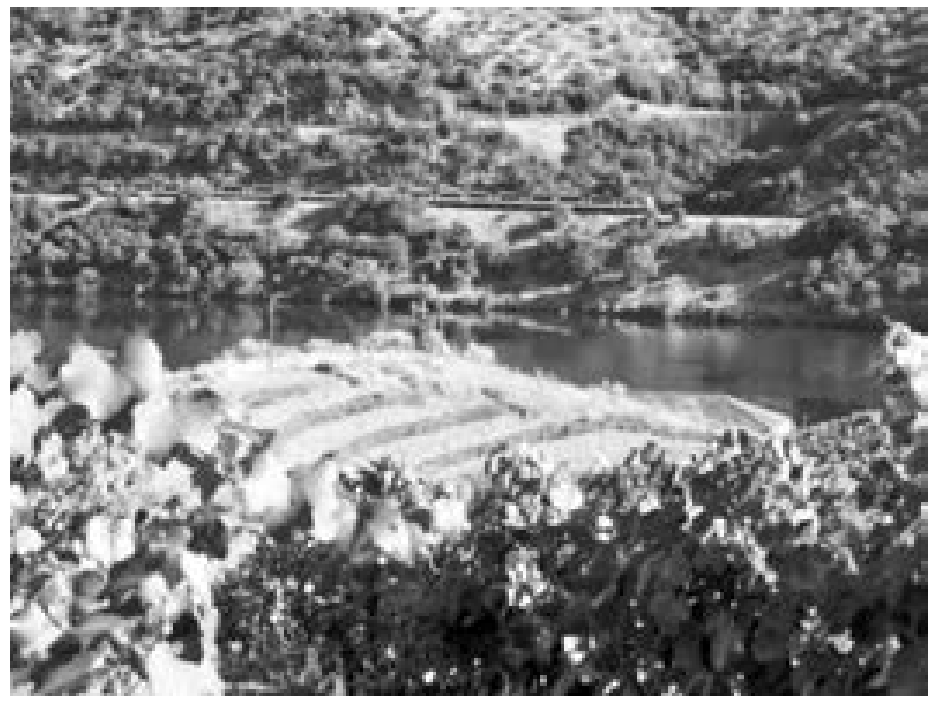

Fig. 132. Quinta do Lubazim — Vinha nova em bardos na margem norte do rio Douro 

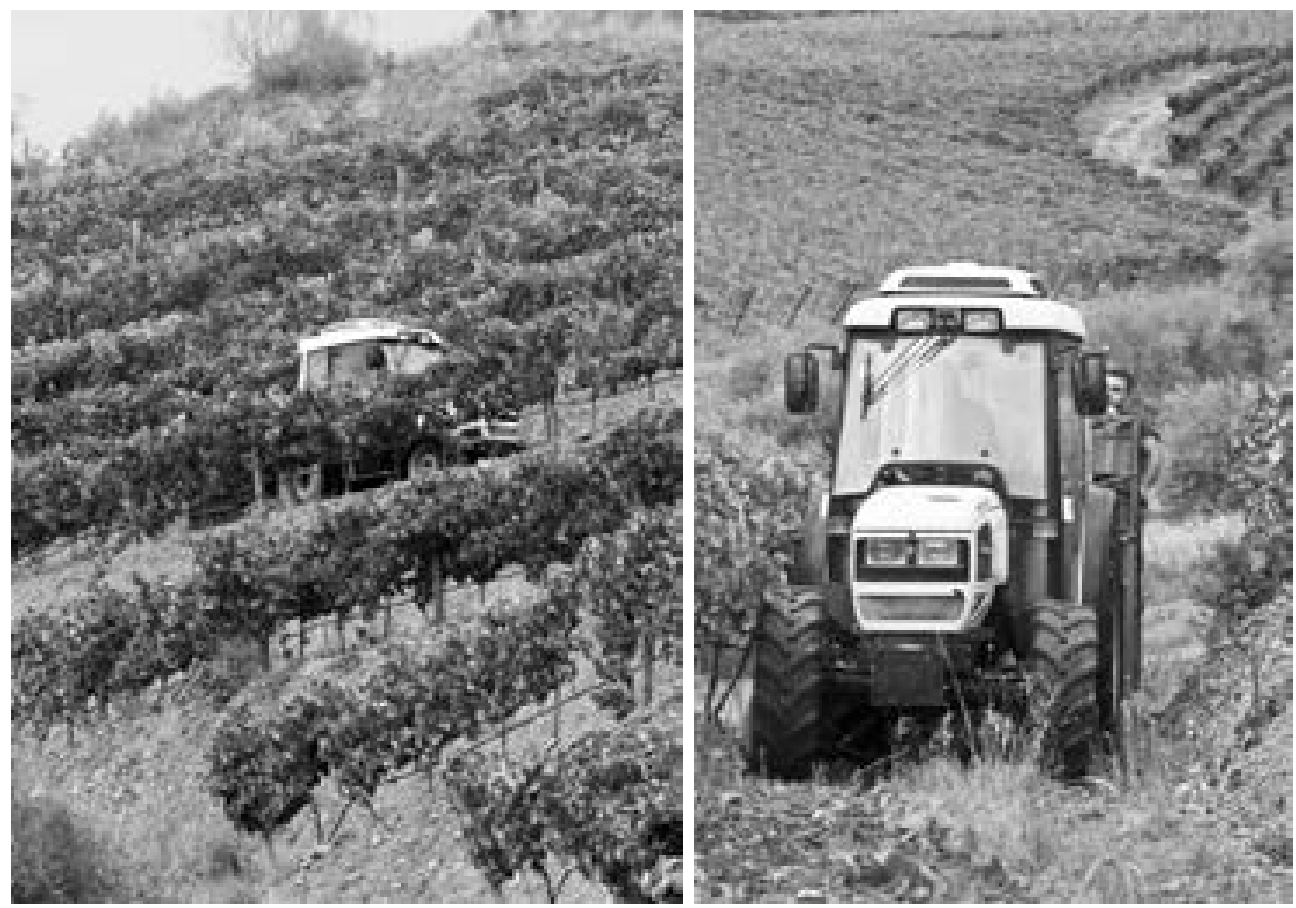

Fig. 133. Mecanização dos trabalhos vitícolas na Quinta de Lubazim

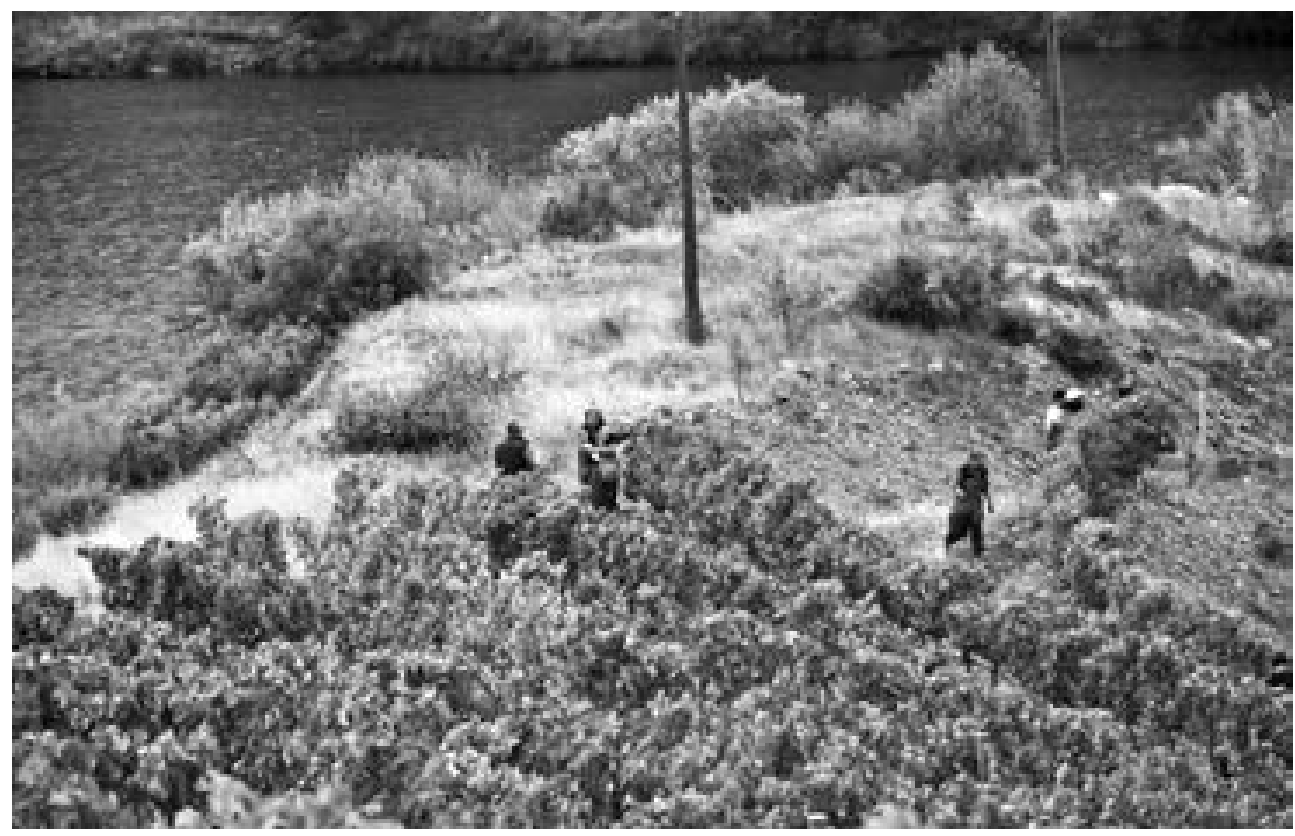

Fig. 134. Trabalhos na quinta em 2014 — Proprietários (esquerda) e trabalhadores (direita) 


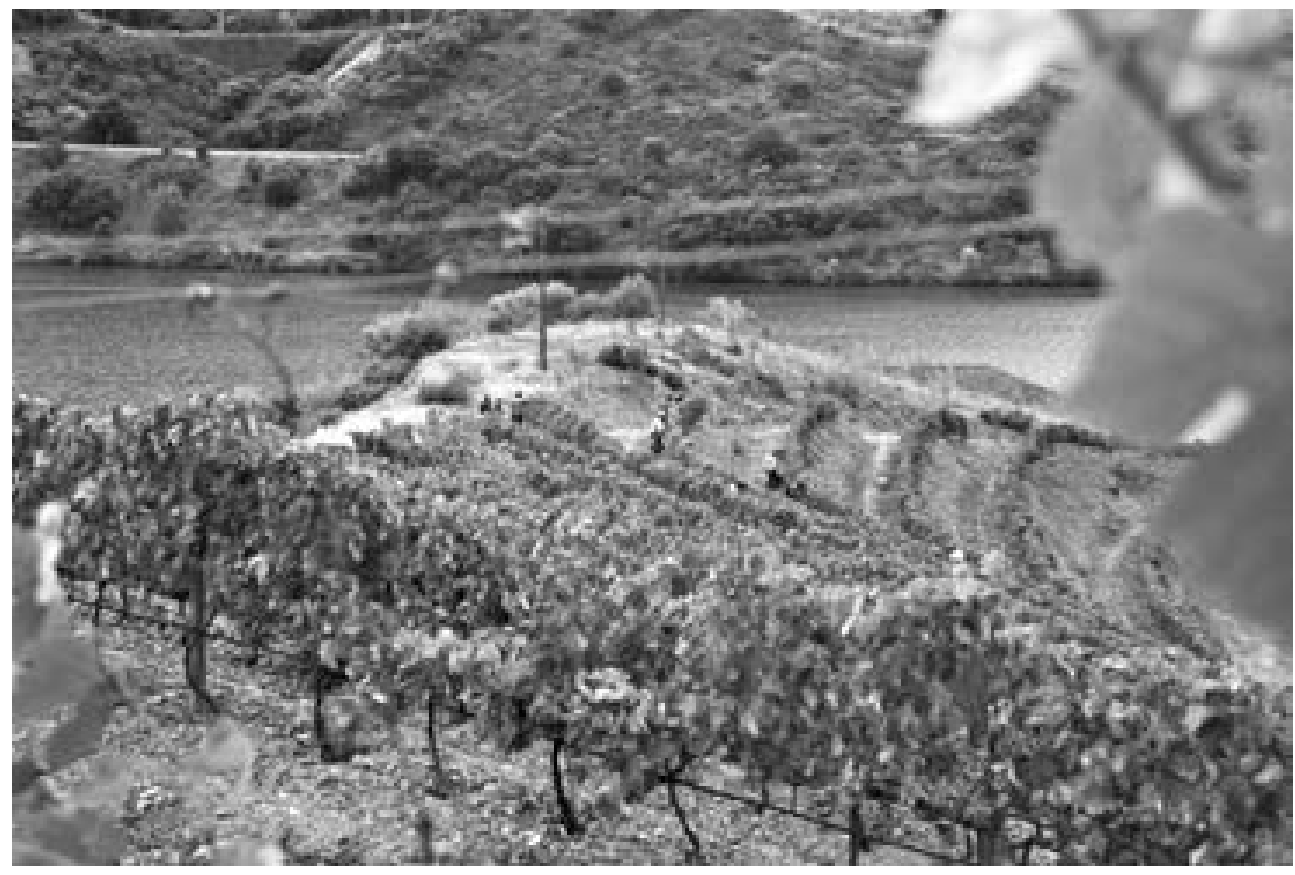

Fig. 135. Cultura da vinha em bardos junto ao rio Douro

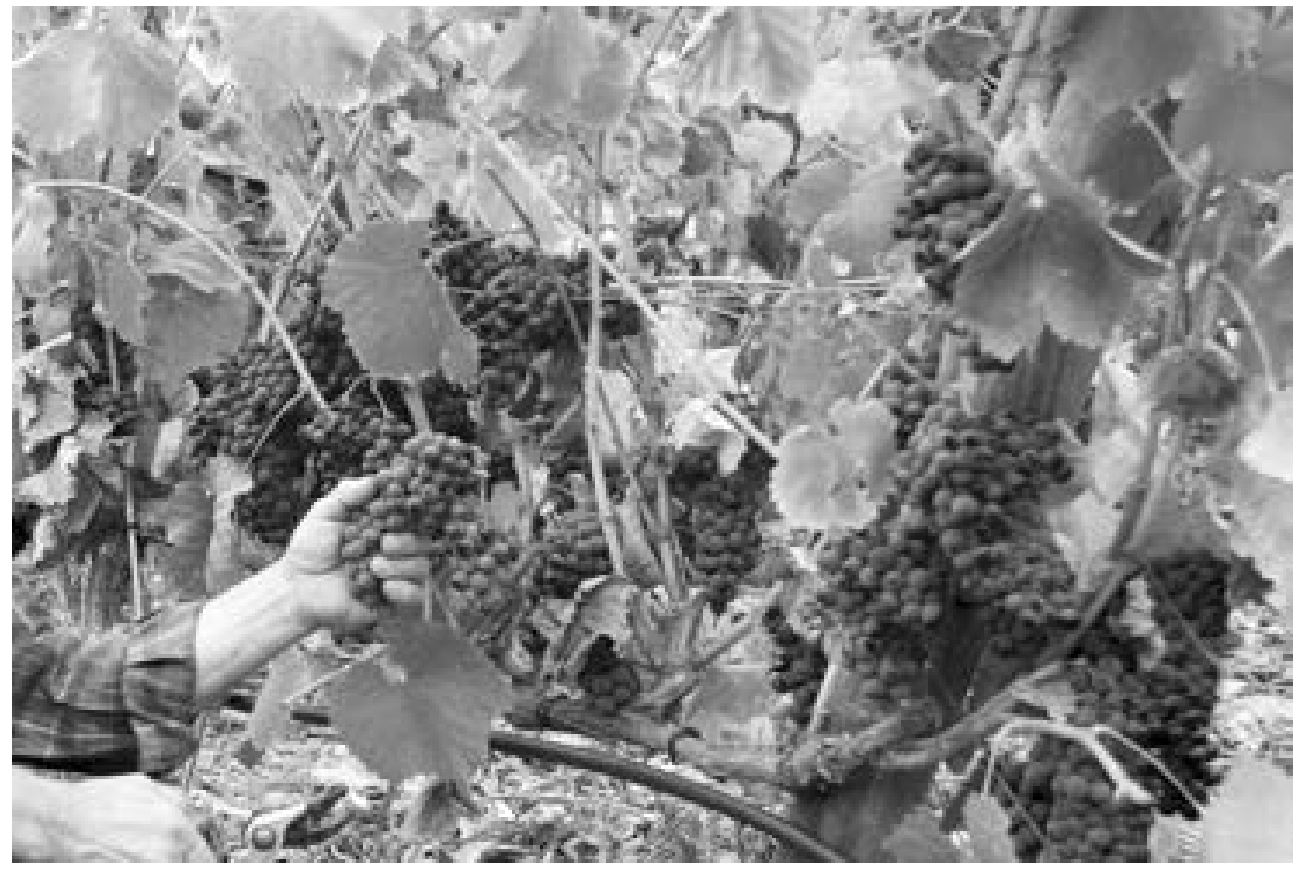

Fig. 136. Vindima de 2015 - Corte dos cachos de uvas 


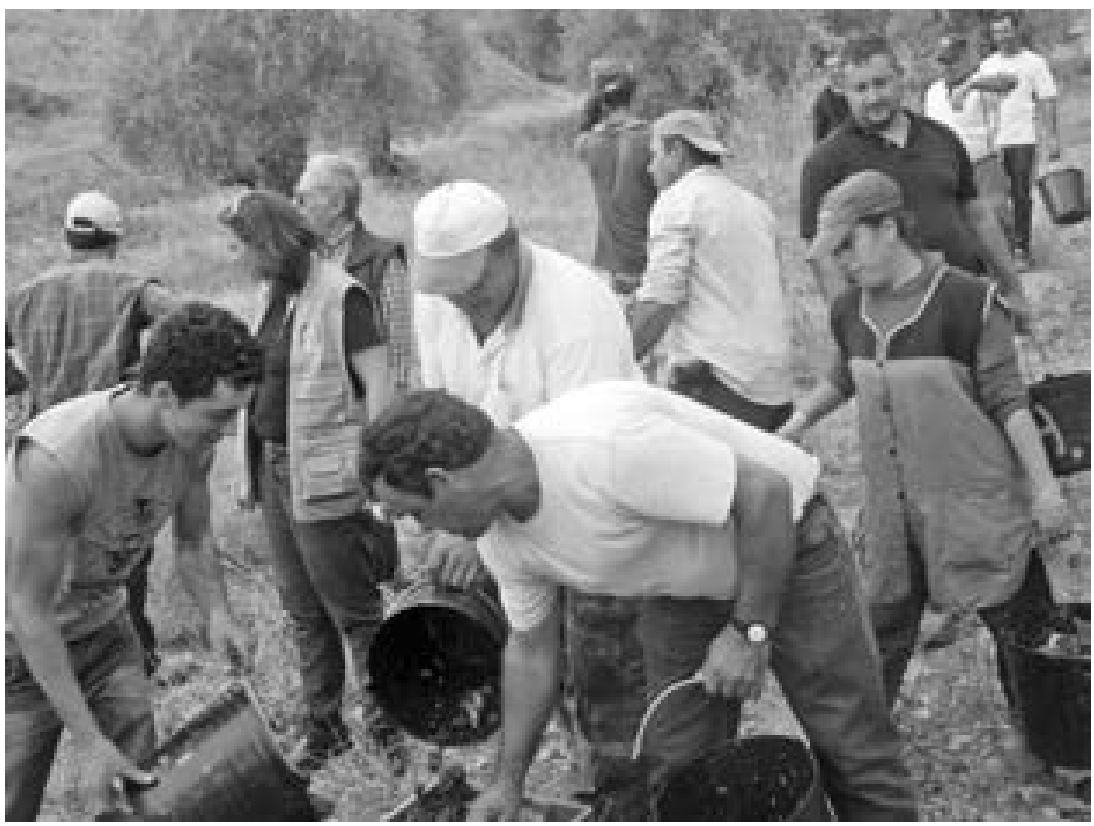

Fig. 137. Quinta do Lubazim — Vindima de 2015, proprietários e trabalhadores sazonais

Refira-se, em síntese reflexiva, que o estudo das quintas durienses requer uma abordagem sócio-histórica ancorada numa reconstituição micro-histórica em múltiplas escalas, remontando às suas particularidades e afinidades matriciais (meios e recursos próprios, condições geomorfológicas e históricas), e orientada por um enfoque sociológico-histórico de longa duração, nas suas múltiplas inter-relações económico-sociais (produção-mercado) e relações de poder envolventes (centro-periferia).

Com esse entendimento, a precedente autonomização do estudo da Quinta dos Canais, da Quinta Bartol, da Quinta da Alegria e da Quinta de Lubazim impôs-se na medida em que dela emana a possibilidade de traçar as balizas de um dispositivo gnosiológico do objeto em estudo - o concelho de Carrazeda enquanto produtor do vinho do Porto.

Por sua vez, permite evidenciar linhas de força que contribuem para uma compreensão mais ampla da singularidade desta zona vinhateira duriense, na sua globalidade e múltiplas dimensões, considerada de fronteira.

\subsection{OUTRAS QUINTAS HISTÓRICAS DO CONCELHO}

Como se referiu anteriormente, no final da I República encontravam-se registadas em Carrazeda de Ansiães, 24 quintas localizadas nas freguesias ribeirinhas do concelho ${ }^{503}$. Neste

\footnotetext{
${ }^{503}$ Enumeração descritiva constituída a partir de dados dos Manifestos de produção de Carrazeda entrados na Comissão de Viticultura da Região Duriense (1927-1931) — Arquivo da Casa do Douro, Régua (Documentação consultada, em 2009).
} 
já então considerável número de quintas durienses que evidenciava a importância destas unidades vitivinícolas essenciais ao processo de produção/exportação do vinho do Porto, neste concelho, maioritariamente de pequenos e médios proprietários de vinhas com produção de vinhos generosos quase sempre vendidos aos mesmos compradores locais e/ou exportadores estrangeiros, destacam-se quatro antigas quintas que, pela sua importância e especificidade histórica se configuram como novos casos de estudo a desenvolver: a Quinta da Senhora da Ribeira (Seixo de Ansiães), a Quinta do Zimbro (Ribalonga/Tua), a Quinta do Tua que fora de Dona Antónia Ferreira e depois mais conhecida por Quinta dos Ingleses e Quinta dos Smithes (posteriormente seus proprietários) e a vizinha Quinta da Chousa (ambas na confluência dos rios Douro e Tua, seu afluente). Todas situadas na margem Norte do rio Douro, com uma relativa proximidade geográfico-histórica entre si, nelas se fizeram sentir desde o século XIX a tradicional presença de reputados negociantes e exportadores ingleses, desde a Georges Acheson Warre e a Silva \& Cosens, até à Cockburn \& Smithes, que chegaram a deter a propriedade de algumas, logo a seguir, a terem sido atacadas pela filoxera. Todas são hoje, à exceção da Quinta do Zimbro, em Ribalonga/Castanheiro, propriedade da Symington Family Estates, líder dos Vinhos do Porto e Douro e maior proprietário das quintas do concelho de Carrazeda e da Região Demarcada do Douro.

A breve abordagem a estas outras quatro quintas históricas, que adiante se esboça, para além dos aspetos específicos de contexto enunciados, centrar-se-á, particularmente, em características mais destacadas do seu desenvolvimento sobretudo a partir da I República, o qual se considera, até certo ponto modelar e pioneiro, na medida em que algumas foram consideradas quintas-modelo no período republicano e outras viriam a ser posteriormente uma espécie de laboratórios tecnológicos de modernas experiências e ensaios de vitivinicultura no Douro contemporâneo.

\subsubsection{A Quinta da Senhora da Ribeira}

Esta antiga e importante quinta vinhateira de Carrazeda de Ansiães, uma das mais belas do Vale do Douro, localiza-se na freguesia de Seixo de Ansiães, margem direita norte do Douro, a nascente numa posição intermédia face às Quintas dos Canais e de Bartol e a Quinta de Lubazim e dela se avista, na margem oposta do rio, a histórica e famosa Quinta do Vesúvio, atual propriedade da Família Symington ${ }^{504}$. À mesma família que detém, hoje, e a seguir à Taylor's, a segunda mais antiga empresa inglesa presente em Carrazeda e em toda a Região do Douro, pertence também a Quinta da Senhora da Ribeira, a qual, após conturbado processo de compras e vendas alternadas, acabaria por conservar como uma das suas mais emblemáticas propriedades familiares ${ }^{505}$.

\footnotetext{
${ }^{504} \mathrm{O}$ universo de suas propriedades durienses que se tem vindo a alargar, progressivamente, inclusive no concelho de Carrazeda, inclui já 29 das melhores e mais antigas quintas do Douro, perfazendo um total de área de vinha que ronda os 1,2 mil ha, valor de grandeza enorme, face aos 125 mil hectares do Douro todo.

${ }^{505}$ Informação de Paul Symington, facultada nas IV Conferências do CITCEM/Museu de Lamego, julho de 2016.
} 


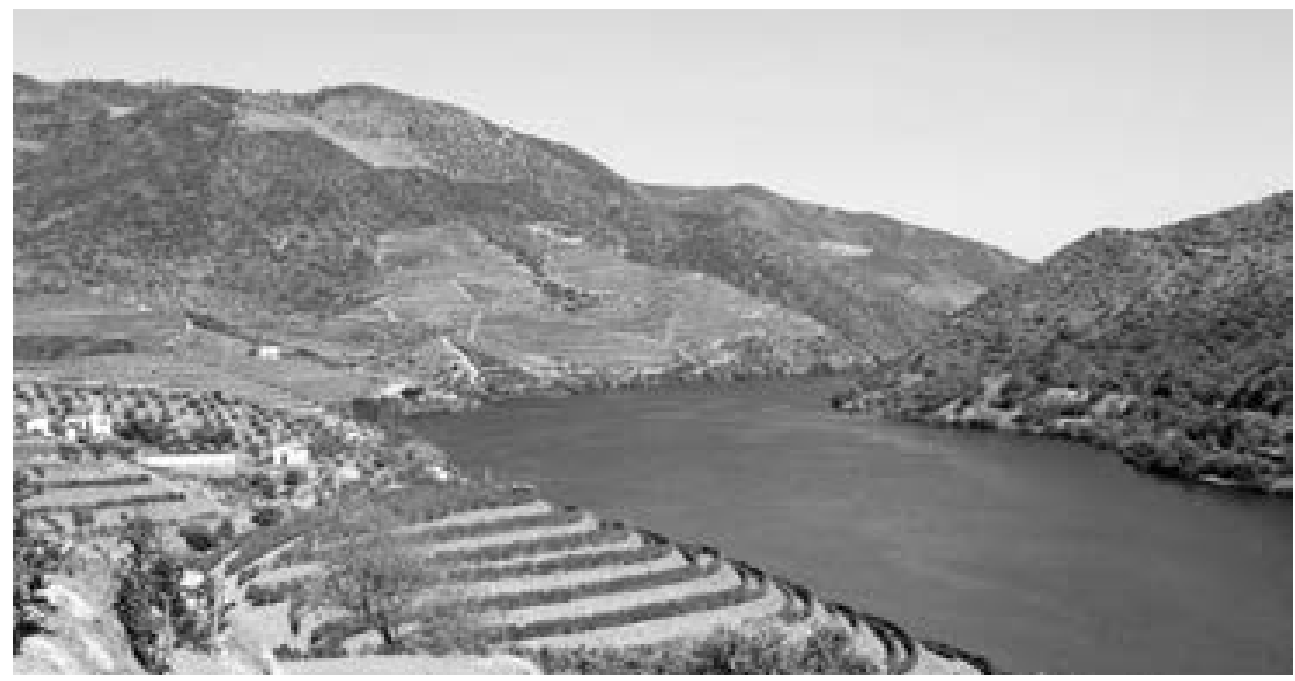

Fig. 138. Vista panorâmica da localização da Quinta da Senhora da Ribeira Fonte: Fotografia da Câmara Municipal de Carrazeda de Ansiães

A designação desta Quinta advém da sua localização no lugar da Senhora da Ribeira que integra com o lugar de Coleja a freguesia de Seixo de Ansiães situada na encosta do Vale do Douro. A 9,4 km a sudeste da sede do concelho, encontra-se perto de um pequeno cais, tradicional ponto de ligação fluvial entre as margens opostas do Douro, principal porta de acesso ao rio dos naturais e visitantes de Carrazeda e um dos seus mais conhecidos e aprazíveis pontos de atração.

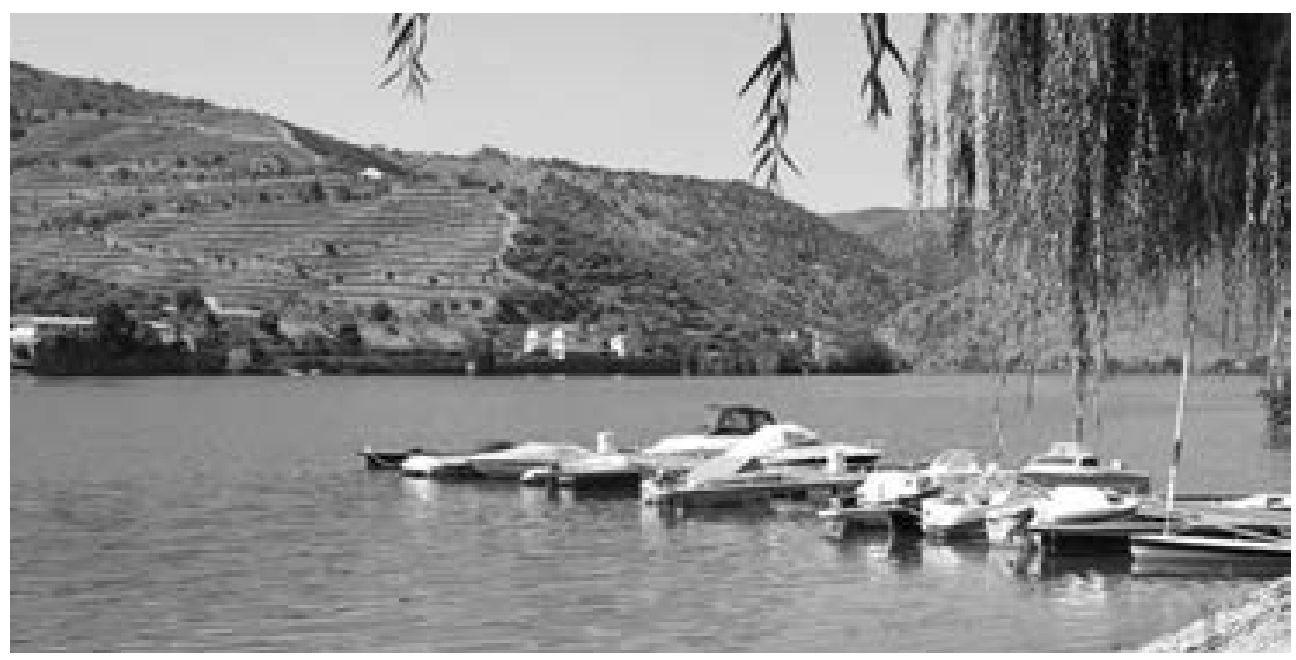

Fig. 139. Cais da Senhora da Ribeira

Fonte: Fotografia da Câmara Municipal de Carrazeda de Ansiães 
O cais da Senhora da Ribeira localiza-se no pequeno povoado do mesmo nome, hoje quase desabitado, mas cuja remota origem histórica remonta a um importante povoado mineiro de exploração de ouro e outros recursos minerais à beira-rio cuja atividade extrativa vinda da época do império romano se manteve ainda durante a Idade Média ${ }^{506}$.

No cais da Senhora da Ribeira, atual ponto de acostagem de pequenos barcos de recreio de uso particular e grandes embarcações turísticas, durante largos anos do século XX se encontravam também atracados dois barcos, com as matrículas 2246 e 2247 que pertenciam à Quinta da Senhora da Ribeira e eram usados para seu serviço particular ${ }^{507}$, enquanto esta fora propriedade, na primeira metade do século XX, da Silva \& Cosens, antiga e importante firma comercial luso-britânica de Vinhos do Porto.

Nessa altura era ainda a partir deste Cais que se atravessava o Douro de barco até ao apeadeiro ferroviário da Quinta do Vesúvio na linha do Douro, por onde chegavam, em baixa velocidade, a partir da Estação de Ermesinde em que então se faziam as grandes cargas, materiais para os trabalhos nas quintas próximas das margens opostas do rio.

Comprova-o, por exemplo, uma carta de 21 de outubro de 1924, assinada com a fórmula republicana «Saúde e Fraternidade», e enviada por Abel de Carvalho, administrador da Quinta da Senhora da Ribeira durante quase meio século, para o Chefe de Serviços de Fiscalização do Caminho de Ferro do Minho e Douro, onde reclamava da cobrança a mais no transporte de remessa de pequena velocidade de 1000 tijolos de barro com $2.500 \mathrm{~kg}$ de Ermesinde ao Vesúvio, pedindo retificação e reembolso ${ }^{508}$.

A Quinta da Senhora da Ribeira, entre densos laranjais, encontra-se implantada no pequeno e fértil vale da Senhora da Ribeira, uma das áreas de maior concentração de quintas durienses que se prolonga até Coleja, na muito antiga zona da «ribeira» concelhia: Quinta dos Vinhais, Quinta da Coelheira, Quinta da Fonte Santa, Quinta das Amendoeiras e outras unidades vinhateiras, tradicionalmente produtoras de vinhos generosos vendidos a negociantes e empresas estrangeiras responsáveis pelos mais reputados vinhos do Porto (Dow’s e Cockburn's), aqui sucessivamente presentes desde finais de Oitocentos.

\footnotetext{
${ }^{506}$ LEMOS, 1993. Ver também PEREIRA \& LOPES, 2005: 64. A sudoeste da Quinta da Senhora da Ribeira, num terraço que se estende ao longo do rio numa área superior a 2 ha foram encontrados, dispersos e à superfície, numerosos e variados materiais arqueológicos que testemunham a existência de um «habitat» com ligação ao núcleo de exploração mineira de Covas dos Mouros, localizado a cerca de 200 metros para norte, o que permite concluir estar-se em presença de um típico povoado mineiro do período romano já que nas imediações, junto à capela de Santa Maria situada no perímetro da Quinta da Senhora da Ribeira, foi ainda encontrada uma ara votiva romana, consagrada a uma divindade indígena dessa época. O sítio arqueológico onde se encontraram estes vestígios desenvolve-se ao longo de um pomar de laranjeiras, abaixo das casas da Quinta da Senhora da Ribeira.

${ }^{507}$ Ofício da empresa Silva \& Cosens, enviado a 2 de abril de 1951, do Pinhão onde possuía também a Quinta do Bomfim, dirigido ao engenheiro responsável da 1. a Divisão Hidráulica do Douro, em que refere ser possuidor desses dois barcos para serviço particular e pede a sua mudança de categoria para uso particular (AHS — Correspondência, u.i. 6198).

${ }^{508}$ Carta enviada do Pinhão (AHS - Correspondência, u.i.6198).
} 


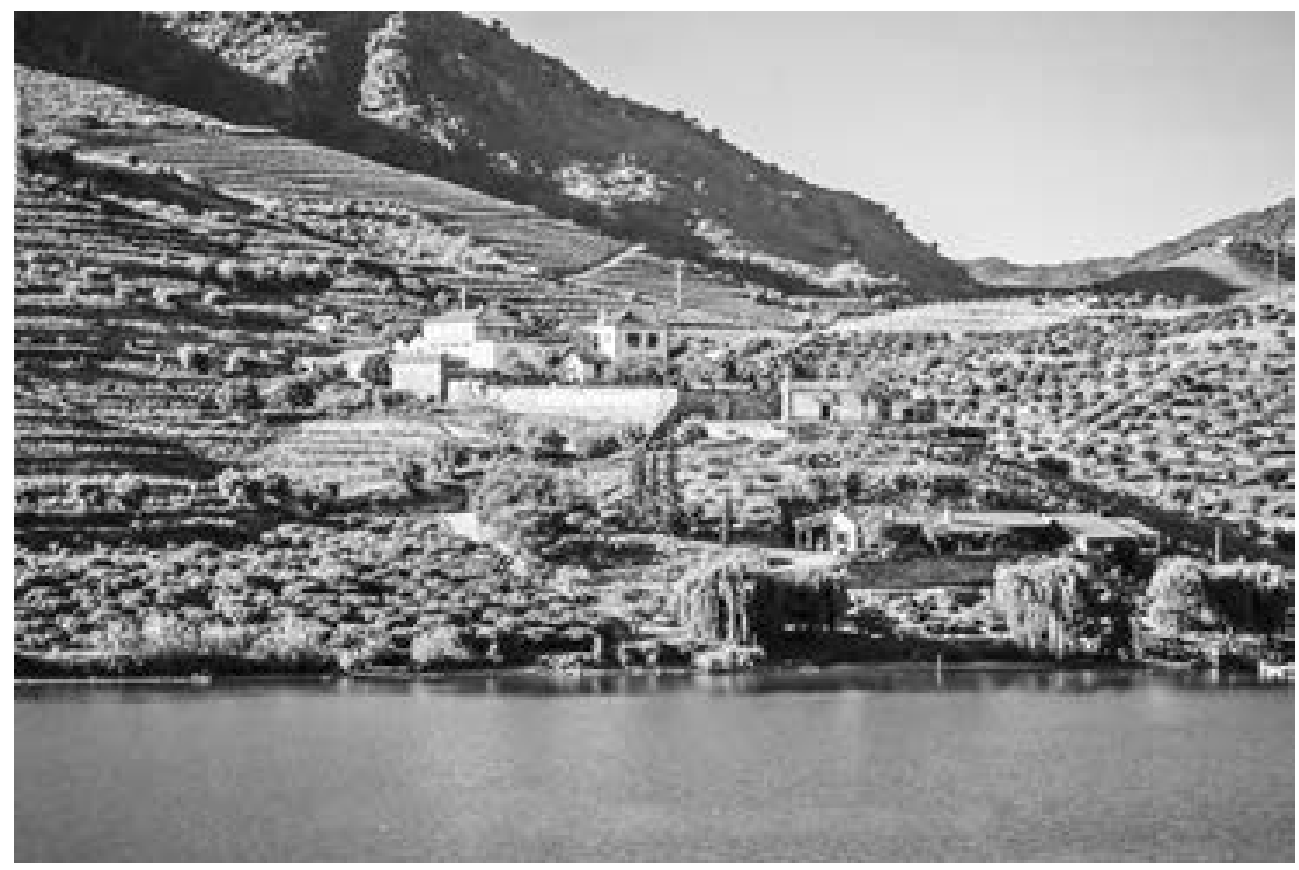

Fig. 140. Quinta Senhora da Ribeira, Carrazeda de Ansiães Fonte: Fotografia de Jorge Carlos ${ }^{509}$

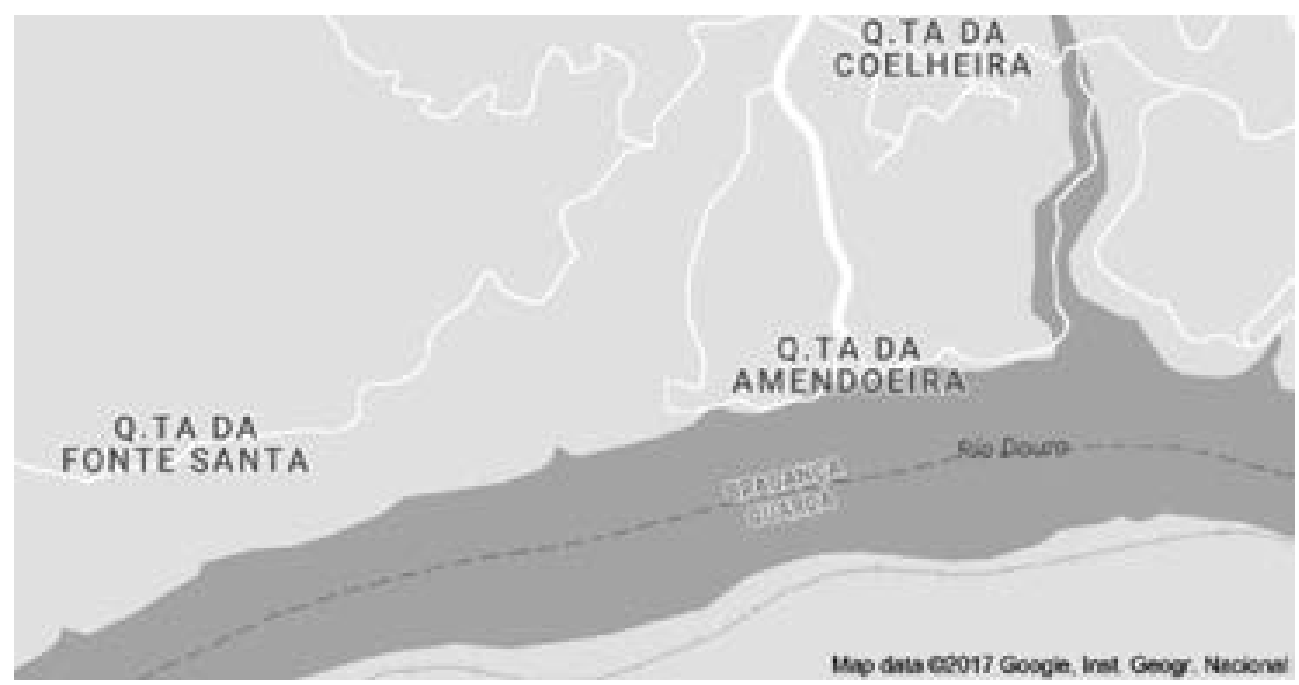

Fig. 141. Zona envolvente da Quinta da Senhora da Ribeira

${ }_{509}$ Disponível em <https://www.facebook.com/notes/mapa-de-portugal/mapa-fotogr\%C3\%Alfico-do-altodouro/ $566888520121411 />$. 
Destacam-se nesse grupo de negociantes estrangeiros do Vinho do Porto, desde cedo compradores dos vinhos generosos desta zona, as seguintes quatro empresas inglesas que detiveram a propriedade da Quinta da Senhora Ribeira, em diferentes períodos: Georges Acheson Warre, de Londres, cuja família estava envolvida no comércio de vinho do Porto, sendo já desde 1868 sócio dos dois fundadores da Silva \& Cosens $^{510}$ e a cuja firma se associou, em 1905, o escocês Andrew James Symington, o primeiro ascendente da família Symington a instalar-se em Portugal (1882) ${ }^{511}$; a firma comercial luso-britânica Silva \& Cosens, fundada em 1862, importadora e exportadora de Vinhos do Porto que esteve na origem da firma Dow Port Wine C. ${ }^{\circ}$; a empresa inglesa Cockburn's Smithes e a Symington Estates Family, grupo em que foram, posteriormente, incorporadas, como se verá (Capítulo 8).

Entre finais do século XIX e inícios do século XX, a Quinta da Senhora da Ribeira pertencia, com outras propriedades e bens na mesma zona, a Georges Acheson Warre negociante britânico do Porto e era administrada pelo seu procurador, Abel de Carvalho, residente na quinta e mandatado para, entre outros assuntos, reclamar junto dos serviços da administração fiscal de Carrazeda de Ansiães, e requerer anulação de indevida inclusão na matriz da contribuição predial de vários prédios que lhe não pertenciam ${ }^{512}$.

Pela relação dos prédios rurais adquiridos na Senhora da Ribeira, entre 1891 e 1908, (Quadro 26) ${ }^{513}$ que fornece indicadores para os preços de venda da propriedade fundiária então praticados nesta área, pode observar-se a grande frequência de vendas, o valor total das propriedades adquiridas, a disparidade de quantias pagas e a sua diferenciação por tipologia e/ ou área dos prédios, com valores bem superiores para os terrenos de vinha.

Pode ainda concluir-se daí, a concentração de propriedade rural dominantemente vitícola e respetiva transmissão para comerciantes ingleses de vinho do Porto, com negócios no Porto e Gaia, factos a que não foram alheios os efeitos devastadores das doenças da videira, mas que se irão intensificar e prolongar em períodos subsequentes.

Ainda durante o ano de 1906, George A. Warre teria mandado comprar através de Abel de Carvalho, seu administrador na Quinta da Senhora da Ribeira, uma elevada quantidade de oliveiras de Francisco Lopes, viúvo, morador em Alganhafres e de outros proprietários individuais, que se encontravam nos terrenos desta quinta, conforme se ilustra, na tabela síntese, na página seguinte ${ }^{514}$.

\footnotetext{
${ }^{510}$ Frederick William Cosens, grande comerciante de vinhos e importador de sherry, e Edward da Silva, filho de John da Silva e neto de Bruno da Silva (falecido em 1850) que foi casado com uma senhora inglesa. Este estabeleceu-se, em Londres, com uma primeira firma de importação de vinho do Porto, em finais do século XVIII.

511 SYMINGTON, 2007: 287-296.

${ }^{512}$ Procurações de 18 de março de 1893 e de 22 de abril de 1898 de G. A. Warre, súbdito britânico, residente no Porto, em nome de A.de Carvalho, para administrar a Quinta da Senhora da Ribeira e outros bens. Ver outras procurações passadas ao mesmo administrador, em 1908 e anos seguintes, pela firma Silva \& Cosens, então dona da Quinta da Senhora da Ribeira, Quinta do Zimbro (Carrazeda) e Quinta do Bomfim (Pinhão), para comprar e ou arrematar bens em hasta pública no concelho de Carrazeda e concelhos limítrofes (AHS - Dossiers de documentação diversa - Silva \& Cosens, u.i. 6200).

${ }^{513}$ Elaborado a partir de dados de documento [s.d.] (AHS — cx. 2490, pasta 6.200, u.i.6194).

${ }^{514}$ AHS — Dossier de documentos de vendas. Quinta da Senhora da Ribeira, u.i. 6196.
} 
Quadro 26. Propriedades compradas na Senhora da Ribeira nos anos 1891 a 1908

\begin{tabular}{|c|l|c|c|}
\hline Datas & \multicolumn{1}{|c|}{ A: (designação/situação dos prédios) } & \multicolumn{1}{|c|}{ Por: } & Quantia: (em réis*) \\
\hline 1891, mar. & Isidro Soares (Relva de Cima) & Dr. Casimiro & 360.000 \\
\hline 1894, jan. & António Pereira de Castro (Carrascal) & Idem & 10,000 \\
\hline 1896, ago. & Francisco António Fonseca (Cabanais) & Idem & 10,000 \\
\hline 1898, jan. & António Fernandes (Miantigo) & Idem & 10,000 \\
\hline 1899, jun. & António Cerejo, de Coleja, e José Luis (Moinho) & Idem \\
\hline 1899, ago. & Francisco Meneses (Carrascal) & Idem & 1500,000 \\
\hline 1902, mar. & João Moutinho (Miantigo) & Idem & 35,000 \\
\hline 1902, mar. & Maria Joaquina dos Reis (olival no Miantigo) & Idem & 380,00 \\
\hline 1903, mar. & António Fernandes (Eira da Garenta) & Idem & 80,100 \\
\hline 1905, out. & Em praça (sobrado - foz do ribeiro e casa do Isidro) & Idem & 13,500 \\
\hline 1906, fev. & Henrique Teixeira da Silva (monte) & Idem & $1.200,000$ \\
\hline 1906, fev. & Francisco António Fonseca (vinha) & Idem & 600,000 \\
\hline 1908, jan. & Luís de Sousa Laveno (vinha) & Idem & $3.609,200$ \\
\hline
\end{tabular}

* Real (no plural: reais ou réis) — unidade de moeda de Portugal desde cerca de 1430 até 1911 . Foi substituído pelo escudo (após implantação da República em 1910) a uma taxa de 1000 réis $=1$ escudo.

Quadro 27. Compra de oliveiras nos terrenos da Quinta da Senhora da Ribeira (1906)

\begin{tabular}{|l|l|}
\hline \multicolumn{1}{|c|}{ N. ${ }^{\circ}$ de proprietários } & \multicolumn{1}{c|}{17} \\
\hline Procedência dos vendedores & $\begin{array}{l}\text { Freguesias e aldeias do Concelho: Senhora da Ribeira, Seixo de Ansiães, Selores, } \\
\text { Alganhafres, Fontelonga, Carrazeda e Belver }\end{array}$ \\
\hline N. ${ }^{\circ}$ de oliveiras vendidas & 145 \\
\hline Valor total da compra & $249.140,000$ \\
\hline
\end{tabular}

Sabe-se no entanto que, aquando da implantação da I República Portuguesa em 5 de outubro de 1910, uma parte da Quinta da Senhora da Ribeira pertencia ao Dr. João Trigo Moutinho, grande proprietário duriense, de família abastada com propriedades fundiárias no Seixo e Mogo, freguesias do concelho de Carrazeda de Ansiães, o qual foi também figura de republicano influente a nível político, sendo mesmo o proprietário do semanário republicano «O Transmontano», de Carrazeda de Ansiães que começou a ser publicado em 12 de fevereiro de 1911, e se prolongou regularmente ao longo desse mesmo ano, com a saída de pouco mais de 30 números.

Porém, no mesmo ano de 1911, por documento lavrado a 26 de setembro nos Serviços de Finanças de Carrazeda de Ansiães ${ }^{515}$, para efeitos do imposto de sisa ${ }^{516}$ : declaração de pré-

\footnotetext{
${ }^{515}$ AHS — Relação de prédios relativa a Imposto de Sisa (1911) da Fazenda de Carrazeda de Ansiães Quinta da Senhora da Ribeira, u.i. 6197.

${ }^{516}$ Sisa - Imposto direto que incidia sobre as transmissões, a título oneroso, do direito de propriedade e de outros direitos equiparáveis sobre bens imobiliários. Foi substituído em 1 de janeiro de 2004 pelo IMT (Imposto Municipal sobre as Transmissões Onerosas de Imóveis).
} 
dios urbanos e rústicos na freguesia do Seixo de Ansiães do mesmo concelho, do proprietário Georges Acheson Warre, fica a saber-se que a Quinta da Senhora da Ribeira se encontrava já novamente na posse deste negociante inglês, juntamente com mais 5 artigos e outras propriedades na mesma área (ver Quadro 28), sem quaisquer foros ou outros encargos que as onerassem, com um total de rendimento líquido anual de 633.000 réis, num valor total para sisa de 12.600 réis. Isto, para além da Quinta do Zimbro, em Ribalonga, a aldeia vinhateira mais antiga do concelho de Carrazeda, e ainda de mais outras propriedades nos vizinhos concelhos durienses de Sabrosa e Alijó, com um valor total de rendimento líquido anual, de 9.500,000 réis e de 438.100,000 réis, respetivamente.

A Quinta da Senhora da Ribeira, conforme respetiva descrição sucinta aí contida, apresentava, então, uma caracterização a nível de culturas a que se destinava, para além das instalações construídas e das confrontações geográficas. Era já, nessa altura, uma típica quinta duriense bem definida, com áreas de vinha, olival e árvores frutíferas, possuindo casas de habitação, armazéns, lagares para vinho e azeite, casas para o gado e diversas arrumações e jardim com água encanada. Os seus terrenos confrontavam, a Nascente, com caminhos públicos e a Poente, com herdeiros de Dona Antónia Adelaide Ferreira (ver mais adiante posterior descrição da Quinta).

Quadro 28. Prédios urbanos e rústicos de G. A. Warre em Seixo de Ansiães (set.1911)

\begin{tabular}{|c|c|c|c|c|c|}
\hline $\begin{array}{l}\text { Situação } \\
\text { prédios }\end{array}$ & $\begin{array}{l}\text { Designação } \\
\text { e culturas }\end{array}$ & $\begin{array}{l}\text { Rendimento } \\
\text { líquido anual } \\
\text { (em réis) }\end{array}$ & $\begin{array}{c}\text { Foros } \\
\text { e } \\
\text { encargos }\end{array}$ & $\begin{array}{c}\text { Valor } \\
\text { p/ sisa } \\
\text { (em réis) }\end{array}$ & $\begin{array}{l}\text { Propriedades } \\
\text { noutros concelhos }\end{array}$ \\
\hline $\begin{array}{l}\text { Senhora } \\
\text { da Ribeira } \\
\left({\text { art.o n. } .^{\circ} \text { ) }}\right.\end{array}$ & $\begin{array}{l}\text { Quinta Senhora da Ribeira } \\
\text { — vinho, azeite }\end{array}$ & 180.000 & nada & 3.600 & $\begin{array}{l}\text { Sabrosa - rendimento } \\
9.500,000 ; \\
\text { Alijó - rendimento } 438.100\end{array}$ \\
\hline $\begin{array}{l}\text { Senhora } \\
\text { da Ribeira } \\
\left(\text { art.o n. }^{\circ} \text { 2) }\right.\end{array}$ & $\begin{array}{l}\text { Vinha e oliveiras. Confronta } \\
\text { com caminhos públicos e } \\
\text { herdeiros de Inácio Moutinho }\end{array}$ & 60.000 & Idem & 1.200 & --- \\
\hline $\begin{array}{l}\text { Senhora } \\
\text { da Ribeira } \\
\text { (art.o n. }{ }^{\circ} \text { 3) }\end{array}$ & $\begin{array}{l}\text { Vinha. Confronta a Nascente } \\
\text { com Sebastião Moutinho e } \\
\text { António Fonseca, a Poente } \\
\text { com Luís Sobral }\end{array}$ & 50.000 & Idem & 1.000 & --- \\
\hline $\begin{array}{l}\text { Senhora } \\
\text { da Ribeira } \\
\text { (art.o n. }{ }^{\circ} \text { ) }\end{array}$ & $\begin{array}{l}\text { Vinha no «Lodeiro de Cima» } \\
\text { conf. c/ caminhos públicos e } \\
\text { Luís Sobral }\end{array}$ & 60.000 & Idem & 1.200 & --- \\
\hline $\begin{array}{l}\text { Senhora } \\
\text { da Ribeira } \\
\text { (art.o n. }{ }^{\circ} \text { ) }\end{array}$ & $\begin{array}{l}\text { Vinha, árvores de fruta, horta } \\
\text { c/ água, terreno inculto, } \\
\text { cardenhos e + dependên- } \\
\text { cias no sitio da Senhora da } \\
\text { Ribeira e Piorquinho - con- } \\
\text { fronta c/ ribeiro do Sobrado } \\
\text { e caminhos públicos }\end{array}$ & 100.000 & Idem & 2.000 & --- \\
\hline
\end{tabular}




\begin{tabular}{|c|c|c|c|c|c|}
\hline $\begin{array}{l}\text { Situação } \\
\text { prédios }\end{array}$ & $\begin{array}{l}\text { Designação } \\
\text { e culturas }\end{array}$ & $\begin{array}{l}\text { Rendimento } \\
\text { líquido anual } \\
\text { (em réis) }\end{array}$ & $\begin{array}{c}\text { Foros } \\
\text { e } \\
\text { encargos }\end{array}$ & $\begin{array}{c}\text { Valor } \\
\text { p/sisa } \\
\text { (em réis) }\end{array}$ & $\begin{array}{c}\text { Propriedades } \\
\text { noutros concelhos }\end{array}$ \\
\hline $\begin{array}{l}\text { Senhora } \\
\text { da Ribeira } \\
\text { (art. }{ }^{\circ} .^{\circ} 6 \text { ) }\end{array}$ & $\begin{array}{l}\text { Touça c/ oliveiras em «Vale } \\
\text { das Covas» - confronta c/ } \\
\text { herdeiros de Maria Ferraz e } \\
\text { António Pereira de Castro }\end{array}$ & 2.000 & Idem & 40 & --- \\
\hline Cabanaes & Terra lavradia & 452 & Idem & 5 & --- \\
\hline $\begin{array}{l}\text { Ribeiro } \\
\text { Largo }\end{array}$ & $\begin{array}{l}\text { Moinho e horta no sitio da } \\
\text { ponte, açude }\end{array}$ & 3.000 & Idem & 58 & --- \\
\hline Miantigo & $\begin{array}{l}\text { Terra com oliveiras, figueiras } \\
\text { e outras árvores - confronta } \\
\text { c/ terras grandes de António } \\
\text { Trigo Moutinho }\end{array}$ & 3.000 & Idem & 50 & --- \\
\hline $\begin{array}{l}\text { Miantigo } \\
\text { e Ansiães }\end{array}$ & $\begin{array}{l}\text { Vinha grande, dois carde- } \\
\text { nhos, oliveiras, figueiras, } \\
\text { mato, água nascente. }\end{array}$ & 140.000 & Idem & 2.800 & --- \\
\hline Miantigo & Vinho e água nativa & 20.000 & Idem & 400 & --- \\
\hline $\begin{array}{l}\text { Senhora } \\
\text { da Ribeira }\end{array}$ & $\begin{array}{l}\text { Casa desmoronada e vinha } \\
\text { à foz do ribeiro de Sobrado }\end{array}$ & 15.000 & Idem & 300 & --- \\
\hline \multicolumn{2}{|c|}{ Total rendimento líquido anual } & \multicolumn{4}{|r|}{633.000} \\
\hline \multicolumn{2}{|c|}{ Total valor para Sisa } & \multicolumn{4}{|r|}{12.600} \\
\hline
\end{tabular}

Curiosamente, todos os prédios descritos no quadro anterior constam também de um documento de novembro de 1910, enviado ao escrivão da Fazenda de Carrazeda de Ansiães, pela Firma Comercial Silva \& Cosens, relativo ao pagamento de contribuição devida pela compra desses mesmos prédios que a mesma fizera a G. A. Warre, por 2.500 mil réis $^{517}$.

Logo a seguir, no início do ano 1912, a firma comercial Silva \& Cosens, por procuração passada em V. N. de Gaia a 20 de janeiro, confere a Abel de Carvalho, administrador da Quinta da Senhora da Ribeira aí residente, todos os poderes para efetuar compras de diferentes bens situados nos concelhos limítrofes de Carrazeda de Ansiães, Alijó e Sabrosa, que lhes vão ser vendidos pelos Senhores George Acheson Warre e esposa, então residentes em Inglaterra ${ }^{518}$. Neste mesmo ano, e antes de regressar a Londres, G. A. Warre já havia entregado a Andrew James Symington a direção dos seus negócios portugueses através de uma cota de $30 \%$ na Silva \& Cosen $s^{519}$.

\footnotetext{
${ }^{517}$ Documento da Silva \& Cosens, 1910, relativo a compra de prédios na freguesia do Seixo de Ansiães. (AHS — [Doc. Div. Quintas da Senhora da Ribeira, Zimbro e Bomfim], cx. 2490, u.i. 6194).

${ }^{518}$ Documento da Silva \& Cosens, 1910, relativo a compra de prédios na freguesia do Seixo de Ansiães. (AHS — [Doc. Div. Quintas da Senhora da Ribeira, Zimbro e Bomfim], cx. 2490, u.i. 6194).

${ }^{519}$ ESTEVES, 2008: 380.
} 
Daí se pode concluir que a propriedade da Quinta da Senhora da Ribeira e de outros bens andou entre um e outro destes dois negociantes ingleses em curtos intervalos de tempo, o que é exemplo da acelerada rotação da propriedade fundiária nesta zona vinhateira do Douro, neste período histórico de transição de regime entre a Monarquia e a República.

Abel de Carvalho, proprietário de Fontelas, comarca da Régua e administrador da Quinta da Senhora da Ribeira, onde residiu durante 50 anos, desde 1893 até 1942, foi procurador legalmente instituído, para administrar localmente a quinta e outros bens e tratar dos inerentes e mais variados assuntos económicos, fiscais e administrativos, primeiro de G. A. Warre (entre 1893 e 1911) e depois da firma Silva \& Cosens que progressivamente se foi afirmando, com cada vez mais vasta e forte implantação na produção e comércio dos vinhos generosos desta zona de fronteira norte da Região do Douro, entre o Cima Corgo e o Douro Superior. Aqui deteve, para além da Quinta da Senhora da Ribeira, ainda, duradouramente, a propriedade da Quinta do Zimbro em Carrazeda e da grande Quinta do Bomfim (Pinhão) de que Abel de Carvalho viria também a ser administrador.

A profusão e variedade de documentos institucionais, particulares e oficiais de suporte ao criterioso processo de gestão, administração e funcionamento regular destas quintas durienses, produzidos ao longo de décadas, acumulados e guardados no arquivo corrente da empresa Silva \& $\operatorname{Cosens}^{520}$ foram por nós trabalhados como fontes diretas para a reconstituição da sua micro-história. Permitem-nos assim traçar uma caracterização e evolução mais completa e detalhada da Quinta da Senhora da Ribeira que iremos acompanhar, designadamente através da sua valorização progressiva constante de documentos fiscais e do crescimento do seu património acumulado que se torna mais percetível a partir dos sucessivos inventários que a sua frequente mudança de mãos até certo ponto justifica.

Franqueando agora as portas do «habitat» da Quinta da Senhora da Ribeira através do respetivo inventário para os anos 1909-1912, elaborado aquando da sua compra pela Silva \& Cosens $^{521}$, temos acesso a todos os espaços e instalações funcionais e domésticas edificadas, equipamentos e mobília, com valores atribuídos (Quadro 4, Anexo IV), ficando assim a conhecer as suas infraestruturas básicas de organização e funcionamento. Para além disso, é-nos ainda possível percecionar, pelos objetos, o interior desta quinta e indícios dos modos de vida rural quotidiana, nos inícios da I República.

No período de transição da I República para o Estado Novo, a Quinta da Senhora da Ribeira era já uma grande e bem equipada unidade produtiva vinhateira, tendo uma área aproximada de $320.000 \mathrm{~m} 2$, com 75.010 cepas, 2.270 oliveiras e 400 amendoeiras, que registava uma grande produção principalmente de vinho e azeite, e apresentava também um significativo património construído, máquinas, equipamentos e utensílios agrícolas próprios.

\footnotetext{
${ }^{520}$ Encontram-se incorporados e organizados no Arquivo Histórico Symington.

${ }^{521}$ AHS - Livro Silva \& Cosens - Inventários do Douro, cx. 1772, u.i. 6094-6097, cota 1/3/10/6, p. 60-94, $102-115$.
} 
Do conjunto das suas instalações funcionais e casas de residência adequadas e bem equipadas, destacava-se, respetivamente, esta relação abreviada ${ }^{522}$ :

a) Instalações funcionais: Tanoaria e Armazém com 13 tonéis de capacidades variadas entre 12 e 39 pipas; Lagares ( 3 prensas, 3 esmagadores de uvas, etc.); Azenha ( 1 alambique, 1 prensa, etc.) e 7 latas de azeite de capacidade entre 228 e 600 litros; Forja; Cozinha agrícola com baixela; Cozinha comercial; Casa e Loja de arrumações; Diversos (7 colmeias).

b) Casas de residência: Casa de fora - 5 Quartos (quarto azul com 2 camas, quarto azul pequeno, quarto liláz com 2 camas, quarto verde com 1 cama grande e 1 de criança, quarto cor de rosa); Sala de jantar com baixela; Escritório; Quarto de banho com banheira; Despensa; Corredor com armário/Casa dos Caseiros/Quarto dos tanoeiros (3 camas)/Quarto dos feitores (3 camas)/Diversos - 1 geladeira, passadeiras, etc.; roupas de casa e de quartos; roupa de criados.

A tendência de conservação e evolução destas infraestruturas de apoio ao funcionamento da propriedade vitivinícola e vida na quinta, com todo o recheio doméstico e agrícola de época e de diversos ofícios tradicionais, diferenciado segundo os usos e posição na hierarquia social dos senhores, criados, trabalhadores rurais e artesãos ao serviço, torna-se percetível noutro inventário de cariz retrospetivo e cumulativo, mais atualizado e completo ${ }^{523}$, que se reporta ao período compreendido entre 1922 e 1943 (Quadro 5, Anexo IV).

A leitura global dos dois quadros anteriormente referidos (consultar Anexo IV) permite-nos ter uma imagem bastante impressiva da capacidade instalada de apoio ao funcionamento da Quinta da Senhora da Ribeira ao longo da primeira metade do século XX, mais precisamente, entre as décadas de 1920 e 1940.

Já quanto à avaliação da quinta enquanto unidade vitivinícola duriense na sua totalidade, (capacidade instalada, capacidade produtiva e valorização atribuída), para este mesmo período, conhecem-se alguns valores, cuja atualização se poderá calcular ${ }^{524}$, que foram atribuídos à Quinta da Senhora da Ribeira. É o que pode agora observar-se nos dois quadros seguintes que ilustram correspondentes avaliações para efeitos fiscais, conforme se exemplifica, a partir da contribuição predial urbana de 1927 e de 1929 (Quadro 29) ${ }^{525}$ e da matriz predial rústica e matriz predial urbana de 1942 (Quadro 30) ) $^{526}$.

\footnotetext{
${ }^{522}$ AHS — Inventário resumido da Quinta da Senhora da Ribeira [1920-194?], cx. 2830, u.i.6154.

${ }^{523}$ AHS - Inventário geral da Quinta da Senhora da Ribeira, 1922-1943, cx. 1777, u.i. 6113-6118, cota 1/3/11/6.

${ }^{524}$ Coeficiente de desvalorização da moeda entre os anos de 1903 e 2005. Disponível <http://www.igf.min-financas.pt/inflegal/bd_igf/bd_legis_geral/Leg_geral_docs/PORTARIA_0429_2006.htm>. [Consulta realizada em 06/02/2017].

${ }^{525}$ AHS - Contribuições e matrizes prediais da Sociedade Comercial Silva \& Cosens, cx. 2490, u.i.6194.

${ }^{526}$ AHS — Contribuições e matrizes prediais da Sociedade Comercial Silva \& Cosens, cx. 2490, u.i.6194.
} 
Quadro 29. Quinta da Senhora da Ribeira — Valores atribuídos (1927-1929)

\begin{tabular}{|l|c|c|}
\hline \multicolumn{1}{|c|}{ Descrição } & Valores & Base de cálculo \\
\hline $\begin{array}{l}\text { Prédios rústicos } \\
\text { (área coberta de prédio com 132 m2) }\end{array}$ & $990.000 \$ 00$ & $\begin{array}{c}\text { Média } 90 \text { pipas } \\
\text { a } 11.000 \$ 00\end{array}$ \\
\hline $\begin{array}{l}\text { Prédios urbanos } \\
\text { (prédio c/ } 3 \text { andares c/ as seguintes divisões: } 5 \text { no } 1 .^{\circ} \text { andar, } 2 \text { no } 2 .^{\circ} \\
\text { andar, } 5 \text { no } 3 .^{\circ} \text { andar; mais área de logradouro: pátio, jardim, quintal) }\end{array}$ & $460.000 \$ 00$ & $\begin{array}{c}600 \mathrm{~m} 2 / \text { rendimento } \\
\text { coletável } 9.018 \$ 00\end{array}$ \\
\hline Tonéis & $39.4500 \$ 00$ & $150 \$ 00 /$ pipa \\
\hline Alambique & $12.000 \$ 00$ & $23.000 \$ 00$ \\
\hline Mobília & & \\
\hline Total: $1.524 .450 \$ 00$ & & \\
\hline
\end{tabular}

Quadro 30. Quinta da Senhora da Ribeira — Rendimento coletável (1942)

\begin{tabular}{|l|l|c|}
\hline Designação & \multicolumn{1}{|c|}{ Descrição } & Rendimento coletável \\
\hline Prédios & $\begin{array}{l}\text { Quinta composta de vinha, } 1140 \text { oliveiras, } 216 \text { amendoeiras, } 39 \\
\text { figueiras e pequeno pomar; mais uma vinha grande no sítio das } \\
\text { Arsães demarcada no extremo por marcos de cal havendo aí uma } \\
\text { nascente de água que vai encanada para as casas da Quinta. }\end{array}$ & $41.497 \$ 00$ \\
\hline urédios & $\begin{array}{l}\text { Casa de habitação do Seixo de Ansiães na Quinta da Senhora da } \\
\text { Ribeira, com altos e baixos com 16 divisões, uma em baixo e 15 em } \\
\text { cima para habitação. } \\
\text { Casas de habitação - 1.0 andar (escritório, sala de jantar, pequeno } \\
\text { quarto de arrumação e ao lado outra meia sala); } 2 .^{\circ} \text { andar (5 divisões } \\
\text { e ao lado mais 2 divisões para dormitórios de empregados)/1 casa e } \\
2 \text { quartos para arrumações/abegoarias para diferentes animais/casa } \\
\text { de malta/palheiro/7 lagares para vinho/azenha tipo antigo/arma- } \\
\text { zém com diferentes tonéis. } \\
\text { Confronta de Nascente com o ribeiro ou regato, de Norte com caminho } \\
\text { público, de Poente com vários proprietários e do Sul com o rio Douro. }\end{array}$ & $1.260 \$ 00$ \\
\hline
\end{tabular}

Quanto à exploração e capacidade produtiva da Quinta da Senhora da Ribeira a sua compreensão ganha em ser comparada e contrastada com a da Quinta do Zimbro de Baixo, propriedade vitivinícola de menor de dimensão, uma vez que se encontravam sob a mesma administração da Silva \& Cosens a que ambas pertenciam, nesta altura.

Em matéria de rendimentos provenientes da produção destas duas quintas e, particularmente, no que se refere aos preços praticados à produção de uvas, é muito significativa da sua evolução e variações, uma longa série de preços das uvas ${ }^{527}$ (Quadro 31) que cobre todo o período da I República e os inícios da Ditadura, atravessando os anos da I Guerra Mundial, período em que se registam algumas falhas de dados.

${ }^{527}$ AHS — Lista de preços de uvas compradas nas Quintas da Senhora da Ribeira e do Zimbro, 1911-1929, u.i.6200. 
Quadro 31. Preços uvas compradas — Quinta da Senhora Ribeira e Quinta do Zimbro de Baixo (1911-1929)

\begin{tabular}{|c|c|c|}
\hline \multirow{2}{*}{ Anos } & Quinta da Senhora da Ribeira & Quinta do Zimbro \\
\hline & Valores & Valores \\
\hline 1911 & $33 \$ 00-36 \$ 00$ & $31 \$ 00$ \\
\hline 1912 & $33 \$ 00-36 \$ 00$ & --- \\
\hline 1913 & $30 \$ 00-33 \$ 00$ & --- \\
\hline 1914 & --- & --- \\
\hline 1915 & $30 \$ 00$ & $30 \$ 00$ \\
\hline 1916 & --- & --- \\
\hline 1917 & $42 \$ 00-45 \$ 00$ & $45 \$ 00$ \\
\hline 1918 & $75 \$ 00-78 \$ 00$ & $78 \$ 00$ \\
\hline 1919 & $260 \$ 00-270 \$ 00$ & $290 \$ 00$ \\
\hline 1920 & $470 \$ 00-480 \$ 00$ & $490 \$ 00-$ c. $510 \$ 00$ \\
\hline 1921 & $354 \$ 00-360 \$ 00$ & $400 \$ 00-$ c. $450 \$ 00$ \\
\hline 1922 & $625 \$ 00-650 \$ 00-700 \$ 00$ & $825 \$ 00-$ c. $930 \$ 00$ \\
\hline 1923 & $1.200 \$ 00-1.400 \$ 00-1.500 \$ 00$ & $1.800 \$ 00-2.000 \$ 00$ \\
\hline 1924 & $1.300 \$ 00-1.400 \$ 00-1.500 \$ 00$ & $-\cdots$ \\
\hline 1925 & $950 \$ 00-900 \$ 00-1.20 \$ 00$ & $1.000 \$ 00-1.300 \$ 00$ \\
\hline 1926 & $840 \$ 00-900 \$ 00$ & $800 \$ 00-1.000 \$ 00$ \\
\hline 1927 & $650 \$ 00-700 \$ 00-800 \$ 00$ & $900 \$ 00-1.100 \$ 00$ \\
\hline 1928 & $550 \$ 00-575 \$ 00-600 \$ 00$ & $550 \$ 00-650 \$ 00$ \\
\hline 1929 & $600 \$ 00-650 \$ 00$ & $600 \$ 00-700 \$ 00$ \\
\hline
\end{tabular}

A leitura do quadro anterior permite detetar, para além das variações menores, um muito significativo aumento dos preços das uvas nas duas quintas a partir do imediato pós-guerra seguida de uma grande e sempre constante subida durante grande parte da I Republica, até 1923-1924, anos em que se registam os mais elevados valores. A partir daí os preços começam novamente a descer e de modo mais acentuado já nos anos relativos ao período da ditadura. Ora, variando os preços em função da lei da oferta e da procura, sem prejuízo do fator inflação, pode observar-se que os anos de maior procura de uvas se começaram a verificar precisamente no período do pós-guerra com uma subida crescente até voltar a diminuir a partir de 1926, com o fim do período da I República.

Comparando os preços das uvas das duas quintas nota-se que os relativos à Quinta do Zimbro mais próxima da Estação de Foz Tua, na confluência das Linhas férreas do Douro e Tua, são ligeiramente superiores em relação aos praticados na Quinta da Senhora da Ribeira, entre 1919 e 1929, durante 10 anos sucessivos, o que poderá ficar a dever-se a um menor custo de transporte. 
Quanto ao desenvolvimento vitivinícola, com respetivos rendimentos e custos, quer da Quinta da Senhora da Ribeira quer desta Quinta do Zimbro com que se compara, que se traduz em várias dimensões como, por exemplo, as (re)plantações e trabalhos da vinha, os manifestos e preços dos vinhos, os custos com jornas e sustento do pessoal, tal pode ser verificado através dos seguintes indicadores para alguns anos:

Em 1929-1930, a área de vinha da Quinta da Senhora da Ribeira foi acrescida com 3.602 cepas americanas no valor de $851 \$ 60$, tendo o trabalho de execução exigido 1.517 jornas com o custo de $6.934 \$ 75$ acrescido de $2.981 \$ 42$ relativo à alimentação do pessoal o que tudo perfez o montante global de $10.727 \$ 77^{528}$.

Por esta altura, foram estimados os seguintes custos do pessoal agrícola (caseiro, feitor e outros) que trabalhou de 1928 a 1929, na Quinta da Senhora da Ribeira.

Quadro 32. Quinta da Senhora da Ribeira — Custos com pessoal (1928-1929)

\begin{tabular}{|l|c|c|c|c|}
\hline & Dias de trabalho & Valores & Sustento-valores & Totais \\
\hline Caseiro e respetiva mulher & 730 & $2.400 \$ 00$ & $1.200 \$ 00$ & $3.600 \$ 00$ \\
\hline Feitor & 365 & $1.800 \$ 00$ & $1.200 \$ 00$ & $3.000 \$ 00$ \\
\hline Pessoal agrícola & \multicolumn{2}{|c|}{ Sustento - média calculada em 43\% por referência aos anteriores } \\
\hline
\end{tabular}

As plantações de vinha nova igualmente efetuadas em 1929-1930, na Quinta do Zimbro, após alguns saibramentos no Lodeiro e Vinha Grande, foram assim contabilizadas: área de vinha acrescida com 1.948 bardos americanos e 1.527 enxertos (Lodeiro) no valor de $459 \$ 60$, tendo o trabalho de execução exigido 1.482 geiras (rapazes/2\$00, mulheres/4\$00, homens $/ 5 \$ 00$ ) com o custo total de $6.117 \$ 25$ acrescido de $2.639 \$ 10$ relativo à alimentação do pessoal, perfazendo o montante global de $9.235 \$ 95^{529}$.

Como se pode verificar, em termos comparativos, os valores relativos e globais dos trabalhos realizados e respetivos custos foram no Zimbro genericamente inferiores, mantendo-se assim a tendência já verificada em anos anteriores, designadamente em 1928/29.

Quanto aos ordenados e alimentação do pessoal de apoio e enquadramento praticados por essa altura, nestas duas quintas, é ilustrativo o quadro seguinte ${ }^{530}$.

À época, já ambas as quintas dispunham de armazéns de retém para os vinhos de sua produção e de vinhos comprados a outras unidades vitivinícolas e lavradores da zona, como se depreende dos manifestos de vinhos das décadas de 1920-1930.

Toda a replantação e desenvolvimento moderno da Quinta da Senhora da Ribeira, que se viria a tornar um exemplo para toda a região do Douro, verificou-se quando foi dirigida pelos irmãos Maurice, John e Ronald da Família Symington ${ }^{531}$, no período entre as duas Guerras

\footnotetext{
${ }^{528}$ AHS - Documentos avulsos, cx. 2490, u.i.6194/6200, cota 1/8/1/5.

${ }^{529}$ AHS - Documentos avulsos, cx. 2490, u.i.6194/6200, cota 1/8/1/5.

${ }^{530}$ AHS - Documentos avulsos, cx. 2490, u.i. 6.200.

${ }^{531}$ SYMINGTON, 2007: 287-296.
} 
Mundiais do século XX. No pós-II Guerra Mundial (19139-1945), os seus sucessores voltaram-se, com sucesso, para a promoção da internacionalização do comércio do vinho do Porto.

Quadro 33. Ordenados e alimentação nas quintas da Senhora da Ribeira e do Zimbro (1926/27)

\begin{tabular}{|c|c|c|}
\hline Ordenados & Quinta da Senhora da Ribeira & Quinta do Zimbro \\
\hline Caseiros & $120 \$ 00 / m e ̂ s$ & 90\$00/mês \\
\hline Feitores & $40 \$ 00 /$ mês & ----- \\
\hline Criadas das quintas & $20 \$ 00-18 \$ 00 /$ mês & $20 \$ 00-15 \$ 00 /$ mês \\
\hline Cocheiro & $35 \$ 00 /$ mês e de comer & ---- \\
\hline Paquete & $30 \$ 00 /$ mês & ---- \\
\hline Criada Etelvina & $20 \$ 00-25 \$ 00$ & \\
\hline \multicolumn{3}{|c|}{ Alimentação } \\
\hline Feitores & \multicolumn{2}{|c|}{ Batatas, bacalhau, caldo, sardinha } \\
\hline Homens/mulheres & \multicolumn{2}{|c|}{$\begin{array}{c}\text { Caldo, sardinha e arroz (meia tigela); } 1 \text { tigela de arroz seco para } 5 \text { homens } \\
\text { e } 1 \text { tigela de arroz seco para } 10 \text { mulheres. }\end{array}$} \\
\hline
\end{tabular}

O processo de aquisição definitiva da Quinta da Senhora da Ribeira pelos seus atuais proprietários, a Família Symington, resulta de uma sucessão de compras e vendas da mesma relacionada com a progressiva fusão das principais empresas inglesas que historicamente detiveram a sua propriedade. A partir dos anos 1960, a Família Warre que tinha gerido, conjuntamente com a Symington a firma Warre \& C. a, retirou-se do negócio do vinho do Porto, tendo vendido, nessa sequência, a posição que detinha na Silva \& Cosens, já então e em boa parte, propriedade da Família Symington. Esta, para poder resgatar a parte que Warre ainda tinha na Silva \& Cosens e que pusera à venda, viu-se obrigada a vender a António Trigo Moutinho ${ }^{532}$, em 1952, numa conjuntura desfavorável à exportação de vinho do Porto, a Quinta da Senhora da Ribeira.

No entanto, durante muitos anos, como parte do acordo dessa venda à família Moutinho do Seixo, a Dow's, detida pelos Symington desde 1961, pôde fabricar os vinhos e comprá-los, dando assim continuidade ao «Dow's Vintage Ports». Posteriormente, numa conjuntura tendente a uma maior concentração de propriedade na região duriense, a quinta foi readquirida pelos Symington. Desde então, os seus vinhedos dispostos em patamares que ocupam metade da área total da quinta (42 hectares), têm sido restruturados, mecanizados e dotados das castas adequadas às características e cotas do terreno (com cerca de 1/3 de Touriga Nacional). Nos terrenos da quinta, a Nascente, mantém-se a cultura de olival, encontrando-se também pre-

\footnotetext{
${ }^{532}$ De acordo com informações orais recolhidas em entrevista informal com o Dr. João de Sampaio, em 13 de fevereiro de 2017, este outro comprador da Quinta da Senhora da Ribeira, pertencia à Companhia Algodoeira de Moçambique, supondo-se que, como o republicano Dr. João Trigo Moutinho, antigo dono da Quinta da Senhora da Ribeira, em 1910, seriam da mesma família de proprietários e lavradores abastados com bens no Seixo de Ansiães e também em Mogo de Malta, outra aldeia do mesmo concelho de Carrazeda de Ansiães, com reconhecida tradição local republicana.
} 
sente para além da produção de azeite, as de amêndoa e de citrinos, principais culturas desta zona da região duriense ${ }^{533}$.

Sob o impulso empreendedor e inovador mais recente da Família Symington e no âmbito do seu planeamento global das quintas no Douro, «a Quinta da Senhora da Ribeira, é, com a Quinta do Tua, um dos principais pontos de receção das uvas desta zona para cujo processo de transformação se encontra dotada com três lagares robóticos de grande eficiência que simulam com bastante proximidade a tradicional pisa a pé» ${ }^{534}$.

Esta tendência crescente para a mecanização de diversas operações das culturas da vinha e do vinho cedo verificada nesta quinta, na década de 1970, devido em parte à crescente diminuição de mão de obra e subida da sua remuneração, viria a ser acompanhada pela criação de uma nova vitivinicultura no Douro e o desenvolvimento da produção vitícola sustentada na experimentação vitivinícola através de ensaios e outros estudos realizados em algumas quintas em que se destaca também, pela sua importância neste domínio, a Quinta da Senhora da Ribeira. Estas novas linhas de trabalho aí promovidas foram impulsionadas pela Associação para o Desenvolvimento da Viticultura Duriense (ADVID), fundada em 1982 sob a Administração de algumas Empresas de vinho do Porto.

\subsubsection{A Quinta do Zimbro}

Esta é outra histórica quinta duriense do concelho de Carrazeda, na fronteira do Douro Superior com o Cima Corgo, cuja designação abrange, como veremos, uma extensa área vinhateira geograficamente diferenciada e repartida por três famílias de proprietários locais. Estende-se pelas encostas do Douro e ao longo do rio entre o Vale de Ribalonga e Foz Tua, localidade onde parte dos seus terrenos à beira-rio foram cortados pela construção da Linha do Douro, cerca de 1883, ano em que chegou a Foz Tua, e junto da qual se pode ver ainda hoje um antigo armazém da Quinta do Zimbro de Baixo que a ferrovia separa da antiga casa residencial com capela brasonada ${ }^{535}$.

Historicamente, caracteriza-se também esta quinta pela sua antiga tradição vitivinícola de elevada qualidade, tendo declarado em 1875, ano de excelente vintage ${ }^{536}$ o seu Porto-Vintage-Quinta do Zimbro. Esta superior qualidade dos vinhos das quintas do Zimbro fora logo assinalada pelo Visconde de Vila Maior, notável especialista do Douro e de seus vinhos:

\footnotetext{
${ }^{533}$ FIGUEIREDO, 2012: 5.

${ }^{534}$ Entrevista ao Eng. Luís Martins, diretor dos Recursos Humanos e do Arquivo Histórico da Symington, realizada em 21 de abril de 2016, na sede do Grupo Symington, em Vila Nova de Gaia.

${ }^{535}$ Para a reconstituição da história desta Quinta do Zimbro, consultaram-se, entre outras, numerosas fontes históricas diretas dos anos 1909-1912 e 1922-1942 (AHS — [Inventário Geral, 1922-1943], cx. 1777, u.i. 6113-6118, cota 1/3/11/6).

${ }^{536}$ IVDP. Disponível em <https://www.ivdp.pt/pagina.asp?codPag=98>. [Consulta realizada em 05/03/2017]. Observe-se que o registo de marcas se iniciou em Portugal, com a publicação da Carta de Lei de 4 de junho de 1883, a qual vigorou até 1940, quando entrou em vigor o designado Código da Propriedade Industrial de 1940 (Decreto n. ${ }^{\circ}$ 30.679, de 24 de agosto), posteriormente substituído pelo Código de 1995, cujas incorreções levaram à sua substituição pelo atual Código de 2003 (Decreto-Lei n. ${ }^{\circ}$ 36/2003, de 5 de março). Disponível em <http://www. jpereiradacruz.pt/pt/geral.asp >. [Consulta realizada em 05/03/2017].
} 
«as quintas do Zimbro pertenciam à Casa dos srs Barros de Sabrosa, sendo um prédio com boas casas, bem cultivado e uma produção de 30 pipas de vinho de primeira classe ${ }^{537}$.

A Casa dos Barros de Sabrosa, distrito de Vila Real, donde deriva a firma Porto Barros que se destacou na história do vinho do Porto, desde 1913 até à sua integração em 2006 na Sogevinus, um dos cinco maiores grupos atuais dos negócios do vinho do Porto, foi detentora de grandes rendimentos provenientes da produção e negócios do vinho, para além de proprietária de moradias em zonas luxuosas do Porto e solares setecentistas em Sabrosa e nas suas muitas quintas do Douro e várias localidades da região a que se estenderam os seus domínios. Pertencia a duas das maiores famílias desta antiga vila do Alto Douro, os Barros e os Canavarros que se cruzaram, por casamentos, dando origem aos Canavarros de Barros. «Esta família foi deveras próspera, chegando a passar o período de inverno em Londres, em íntima familiaridade com os monarcas ingleses e toda a nobreza da Corte Britânica. A família detinha uma opulência enorme, que lhe permitiu oferecer ao município de Sabrosa as casas do tribunal $»^{538}$.

Nos finais da segunda metade do século XIX, a Quinta do Zimbro de Baixo era assim descrita pelo Visconde de Vila Maior, por comparação com a Quinta da Senhora da Ribeira, ambas já então nas mãos do importante cidadão britânico, George A. Warre, um dos primeiros negociantes de vinho do Porto a comprar quintas durienses em Carrazeda, concelho desta zona do Cima Corgo/Douro Superior. Como se pôde ver antes, os destinos destas duas quintas andariam muitas vezes associados.

A quinta do Zimbro é a que o Sr. Warre há mais tempo possui e é a que menos the produz, vinicolamente falando. Também o plantio da Senhora da Ribeira foi muito mais abundante e numeroso. Nela colhe ainda o seu dono azeite e amêndoa.

Esta quinta encontra-se, como a anterior, na riba direita do Douro após o valezinho do riacho de Ribalonga que a limita pelo nascente, a pouca distância da estação do Tua.

O caminho-de-ferro divide-a, passando junto à casa de habitação e armazém a quem serve na carga e descarga do vasilhame e vinho por meio de um cais, que se estende em frente à fachada ocidental, com o seu escadoz e patamar engrinaldados de glicinia, e com a qual se alinha a frontaria puramente rocaille da capella [...].

Procede o titulo da quinta deste raro exemplar do Juniperus communis que os antigos consagravam a Apollo e é o símbolo do asilo [... $]^{539}$.

O zimbro é uma espécie resinosa de árvore indígena da flora portuguesa e este tipo, vulgo zimbro-comum ou zimbro-anão, quase sempre de porte arbustivo, «é característico das maiores altitudes das serras do Gerês e da Estrela e distribui-se pelas regiões mais frias de todo

\footnotetext{
${ }^{537}$ VILA MAIOR, 1876: 109.

${ }^{538}$ Ver sobre o Arquivo da Casa dos Barros depositado e à guarda no Arquivo Distrital de Vila Real, a respetiva história institucional em MAIO, 2009: 50-51 e seg. e anexos.

${ }^{539}$ VILA MAIOR, 1876: 109.
} 
o hemisfério Norte. Com as suas "bagas" produz-se a aguardente de zimbro e condimentam-se pratos regionais» ${ }^{540}$.

\section{As Quintas do Zimbro — Localização geográfica e contexto histórico}

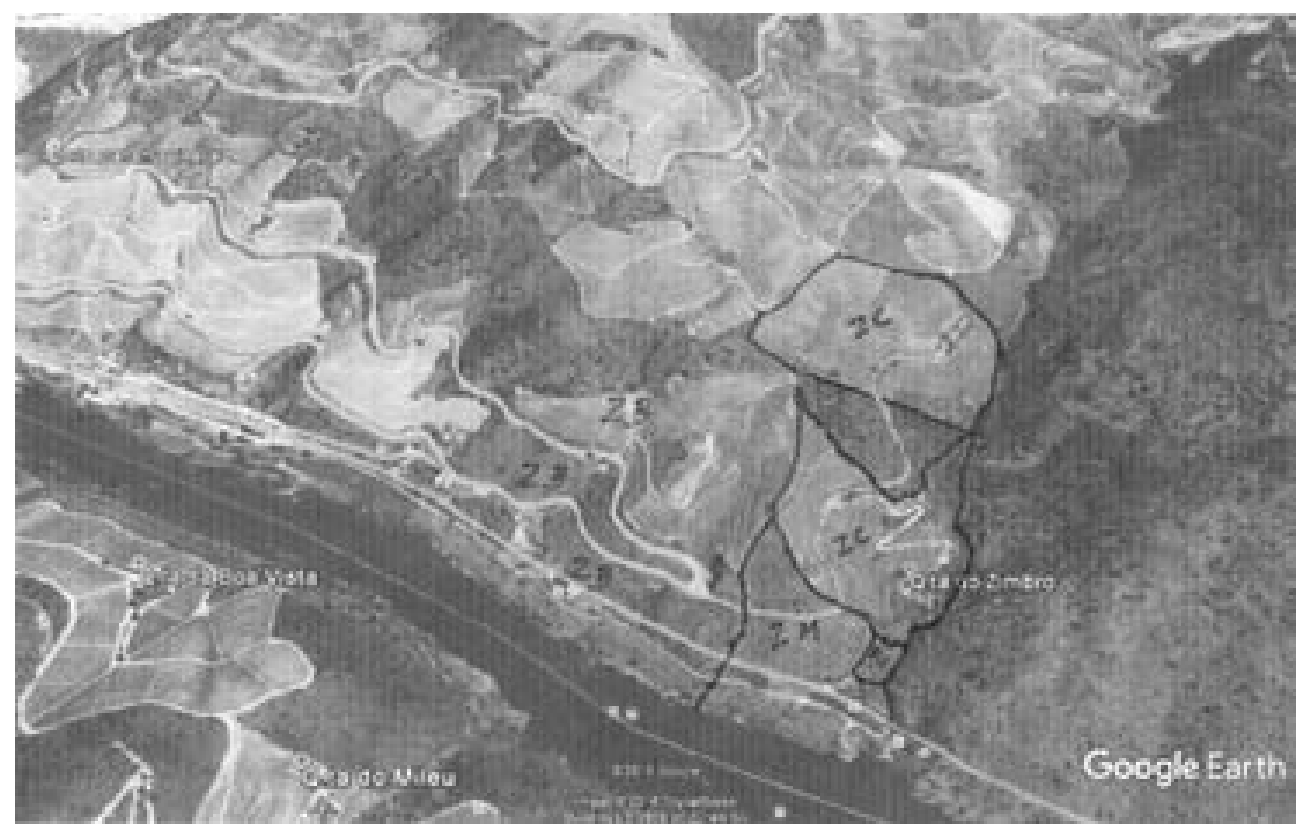

Fig. 142. Legenda: ZB — Zimbro de Baixo; ZM — Zimbro do Mariz; ZC — Zimbro de Cima ${ }^{541}$

Depreende-se das referências do Visconde de Vila Maior, que havia já no último quartel do século XIX, nesta zona do Douro, mais do que uma quinta com o mesmo nome, como se explicita neste mapa e respetiva legenda.

A área de extensão global destas três quintas do Zimbro: Zimbro de Baixo, Zimbro de Cima e Zimbro do Mariz, desenvolve-se pela margem direita do rio Douro de Foz Tua ao Vale de Ribalonga e estende-se pela encosta do Douro em direção ao planalto de Carrazeda até à estrada municipal que liga Foz Tua a Ribalonga, uma das antigas aldeias vinhateiras de Carrazeda, já incluída nas Demarcações Pombalinas como produtora de vinhos de ramo, à semelhança de muitas outras terras do Douro.

\footnotetext{
${ }^{540}$ PORTUGAL. ICNF, 2016. Na flora característica dos matos e matas da região do Douro, o zimbro e a azinheira, dada a sua rusticidade, são das únicas espécies que conseguem resistir especialmente na zona entre o Cima Corgo e o Douro Superior, mas sobretudo nesta última sub-região caracterizada pela sua aspereza mediterrânica mais limitativa ao desenvolvimento vegetal. Ver FARINHA-MARQUES \& FERNANDES, 2014.

${ }^{541}$ Mapa de localização das 3 quintas do Zimbro, conforme desenho de Dr. A. João R. de Sampaio, antigo proprietário da Quinta do Zimbro de Cima. Entrevista realizada em Matosinhos, 13 de fevereiro de 2017.
} 
Estas quintas do Zimbro são geralmente diferenciadas nesta zona quer pela sua localização geográfica que se estende a partir do rio pelas encostas do Douro quer por terem pertencido historicamente a diferentes proprietários de notáveis famílias nobres locais: a Quinta do Zimbro de Baixo, na posse dos Mello Vaz de Sampaio, desde o século XVII até finais de Oitocentos; a Quinta do Zimbro do Mariz que pega com o Zimbro de Baixo, pelo Douro até à estrada, ligada à família de Alexandre Augusto Mariz (Linhares) da Quinta da Alegria e grande proprietário também em Campelos e Carrapatosa; a Quinta do Zimbro de Cima no vale de Ribalonga que pega com a estrada municipal entre Foz Tua e Ribalonga ligada às famílias Lopes da Cruz e Sampaio Chaves (Linhares e Parambos).

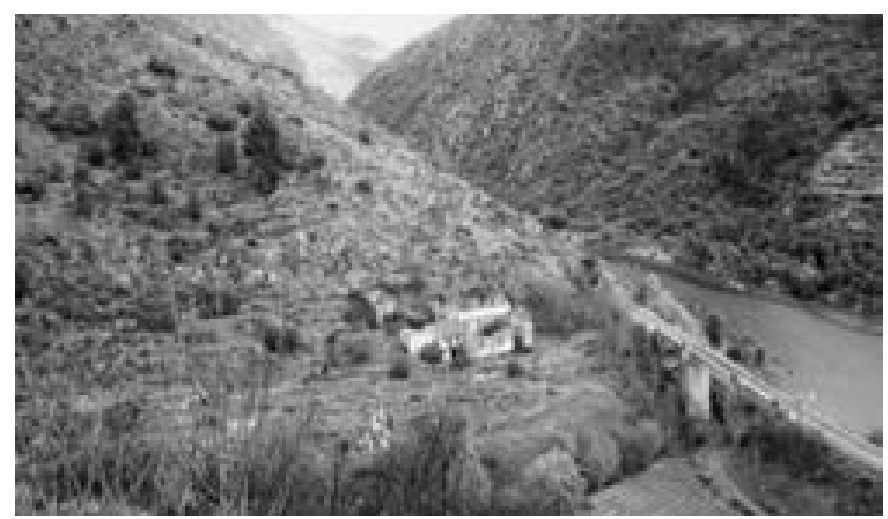

Fig. 143. Quinta do Zimbro do Mariz — Ribeiro de Ribalonga Fonte: Fotografia J. J. S.

\subsubsection{A Quinta do Zimbro de Baixo}

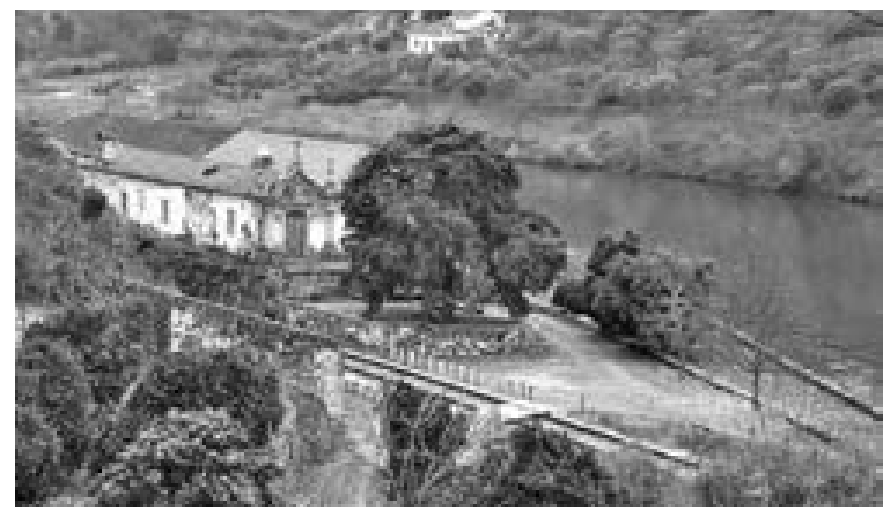

Fig. 144. Quinta do Zimbro de Baixo — Foz Tua Fonte: Fotografia de Daniel Vilar ${ }^{542}$

\footnotetext{
${ }^{542}$ Disponível em <https://pt.pinterest.com/pin/372109987937089193/>. [Consulta realizada em 14/3/2017].
} 
No último terço do século XIX, a conjuntura vivida na região do Douro era altamente depressiva: carestia dos géneros de primeira necessidade, carestia da mão de obra, aumento dos custos de produção em virtude do investimento na luta contra as doenças da vinha, e em particular a partir de 1863, a filoxera, de múltiplos e radicais efeitos para a história moderna e contemporânea do Douro.

A partir de finais de 1879, muitas das vinhas das numerosas quintas deste concelho são devastadas pela filoxera e os seus terrenos reduzidos a mortórios, o mesmo tendo sucedido na Quinta do Zimbro, cujos vinhedos foram completamente destruídos. Neste contexto, a Quinta do Zimbro de Baixo foi adquirida pouco depois, em finais de Oitocentos, pelo produtor e exportador de vinhos do Porto G. A. Warre que se manteria como seu proprietário ainda no início da I República.

Sendo Warre sócio maioritário da empresa Silva \& Cosens, a Quinta do Zimbro de Baixo passaria, entretanto, a ser propriedade desta firma comercial que a replantou com vinha americana enxertada das melhores castas do Douro, e a manterá na sua posse até 1955.

Assim, e como se referiu, durante largo período do século XX, a história desta Quinta do Zimbro de Baixo andou, parcialmente, associada à da Quinta da Senhora da Ribeira, enquanto a sua história mais antiga se encontrou ligada à da Quinta do Zimbro de Cima até pelo facto de a propriedade de ambas ter pertencido à Casa Barros de Sabrosa antes de ser comprada por G. A. Warre, em data anterior a 1886. É a partir desta altura, já nos finais de Oitocentos, que as Quintas do Zimbro de Baixo e do Zimbro de Cima vão seguir percursos históricos separados e diferentes como se explicitará.

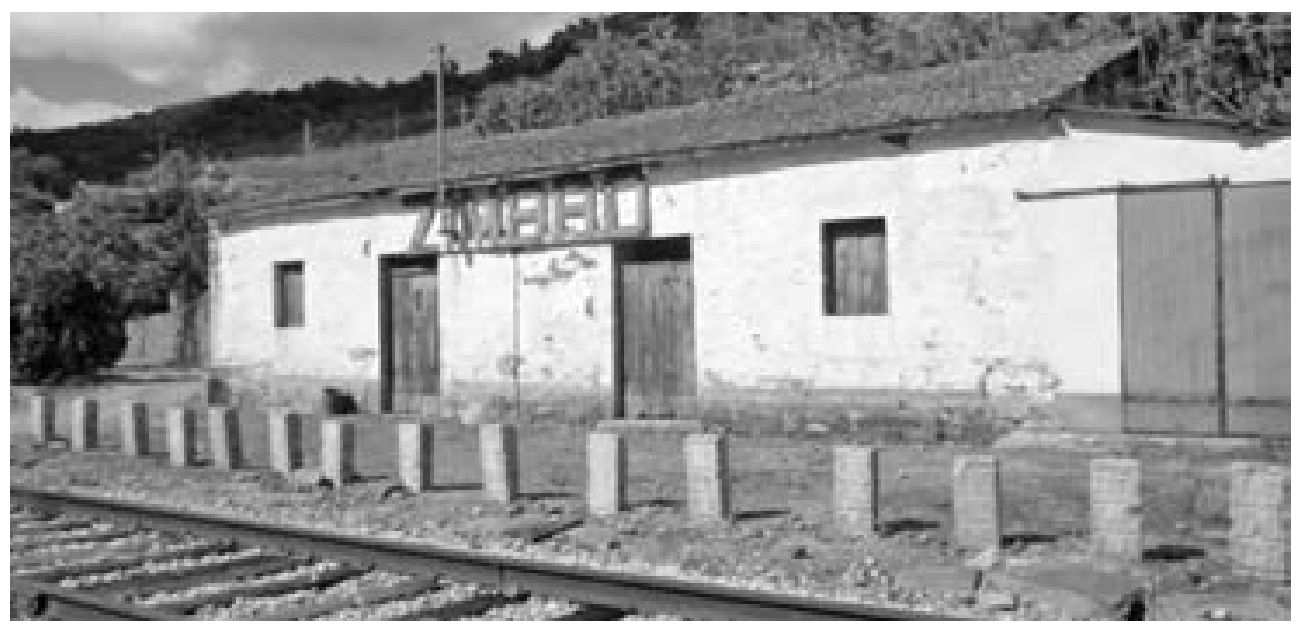

Fig. 145. Antigo armazém da Quinta do Zimbro, em Foz Tua junto à Linha Férrea do Douro ${ }^{543}$ Fonte: Fotografia J. J.S.

\footnotetext{
${ }^{543}$ A construção da linha férrea do Douro (iniciada em 1875, aberta até ao Tua em 1883 e concluída em 1887) cortou nessa altura parte dos terrenos da quinta do Zimbro.
} 

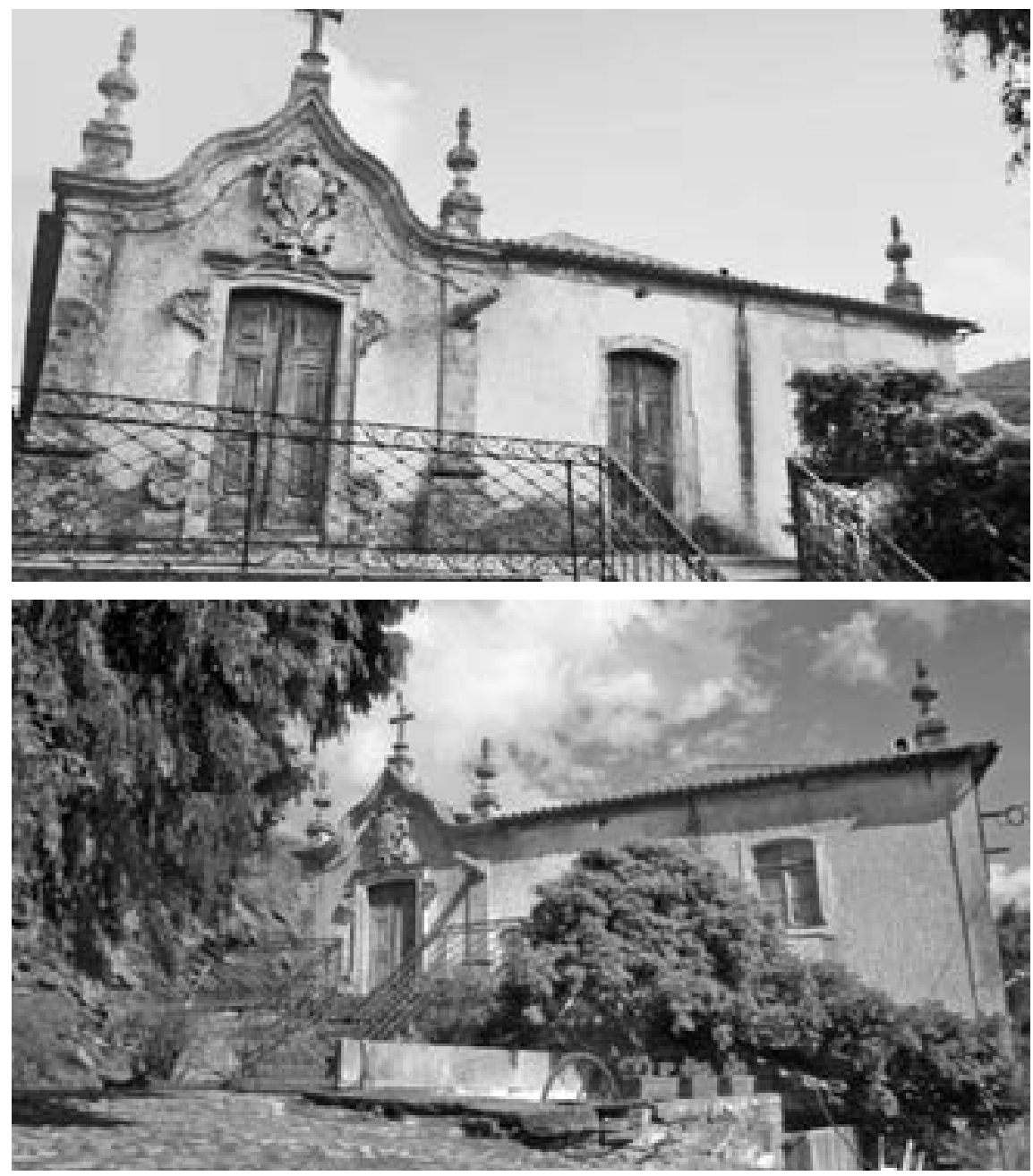

Fig. 146. Antiga casa e capela brasonada, estilo barroco, da Quinta do Zimbro de Baixo — Foz Tua Fonte: Fotografia J. J. S.

Como já anteriormente se pôde ver, durante grande parte do século XX alguns dos aspetos principais de propriedade, gestão e administração da Quinta do Zimbro de Baixo entrelaçam-se com os da Quinta da Senhora da Ribeira e os da Quinta do Bomfim no Pinhão, através da Firma Silva \& Cosens que detém a posse destas três quintas.

Numa perspetiva comparativa, podem observar-se alguns indicadores relevantes para o conhecimento dos recursos e custos da exploração e cultura vitivinícola das quintas da Senhora da Ribeira e do Zimbro de Baixo, semelhanças e diferenças no seu desenvolvimento nas décadas de 1920-1940. É possível deduzir daí que, globalmente consideradas na sua importância e valorização relativas, capacidade instalada, produtividade vitivinícola, investimentos em replantações 
e enxertias, custos e encargos com pessoal, ambas as quintas se equivaliam já bastante, nesta época, tendo-se entretanto alterado a posição e situação entre as duas em termos relativos, em relação ao período em que se tornaram propriedade de G. A. Warre, nos finais do século XIX.

A partir desse período, as dimensões e características mais específicas da Quinta do Zimbro de Baixo acompanham a evolução própria de uma grande e bem apetrechada propriedade vinhateira duriense tradicional, como se poderá observar através de certos aspetos mais típicos, nalguns dos quais se pode mesmo percecionar a influência inglesa já então aí bem implantada.

Os terrenos e culturas principais da quinta encontravam-se então assim resumidamente descritos: horta, terra de cereal, 23.700 videiras, 5 sobreiros, 30 laranjeiras, 30 amendoeiras, 10 árvores de fruta, 520 oliveiras (3 de outros proprietários), terra com fragas e lenha ${ }^{544}$.

Já para o primeiro quartel do século XX, temos uma descrição muito mais completa dos prédios e culturas que então integravam esta quinta que passara, entretanto, para a posse e administração da firma Silva \& Cosens, bem como dos seus respetivos rendimentos líquidos e valores da sisa atribuídos, conforme os números dos artigos nas matrizes em vigor (Quadro 34) ) $^{54}$.

Quadro 34. Prédios urbanos e rústicos da Quinta do Zimbro (set.1911)

\begin{tabular}{|c|c|c|c|c|c|}
\hline Prédios & Designação e culturas & 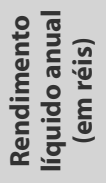 & 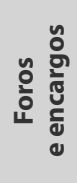 & 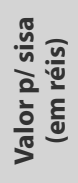 & 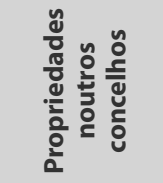 \\
\hline $\begin{array}{c}\text { Zimbro } \\
\text { (art.o n.o 1) }\end{array}$ & $\begin{array}{l}\text { Quinta do Zimbro - casa telhada e sobrado com } \\
\text { armazém, telheiros, pátios, água de poço, jardim, } \\
\text { vinha, oliveiras e outras árvores. Confronta a Nascente } \\
\text { com herdeiros de Manuel de Melo Vaz de Sampaio, a } \\
\text { Norte com caminho de ferro e a Sul e Poente com cami- } \\
\text { nhos públicos }\end{array}$ & 50.000 & nada & 1.800 & $\begin{array}{l}\text { Sabrosa- } \\
\text {-Rendimento } \\
9.500 \\
\text { Alijó- } \\
\text {-Rendimento } \\
438.100\end{array}$ \\
\hline $\begin{array}{c}\text { Zimbro } \\
\left(\text { art.o n. }^{\circ} \text { 2) }\right.\end{array}$ & $\begin{array}{l}\text { Faixa de terreno com vinha e oliveiras e areal inculto } \\
\text { que parte do Norte com caminho público e de Sul com } \\
\text { o rio Douro }\end{array}$ & 10.000 & Idem & 200 & --- \\
\hline $\begin{array}{c}\text { Zimbro } \\
(\text { art.o n.o 3) }\end{array}$ & $\begin{array}{l}\text { Casas de sobrado para caseiros, cardenhos para traba- } \\
\text { lhadores, casas para lagares e para forja, currais para } \\
\text { porcos e galinhas, vinho, oliveira e outras árvores. Parte } \\
\text { do Norte com a estrada distrital e do Sul com o cami- } \\
\text { nho de ferro. }\end{array}$ & 60.000 & Idem & 1.200 & --- \\
\hline $\begin{array}{c}\text { Zimbro } \\
\left(\text { (art.o n. }{ }^{\circ} \text { ) }\right.\end{array}$ & $\begin{array}{l}\text { Vinha, olival e amendoal que parte da estrada distrital } \\
\text { e do Poente com Francisco da Rocha Leão [dono da } \\
\text { Quinta da Chousa no Tua] }\end{array}$ & 20.000 & Idem & 400 & --- \\
\hline
\end{tabular}

[continua]

\footnotetext{
${ }^{544}$ AHS - Matriz predial rústica, art. o 962, u.i.6196.

${ }^{545}$ AHS - Matriz predial de 1911, u.i.6197.
} 


\begin{tabular}{|c|c|c|c|c|c|}
\hline Prédios & Designação e culturas & 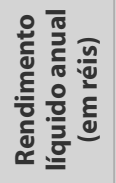 & ํํㄹ 올 & 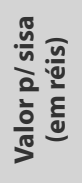 & 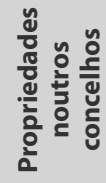 \\
\hline $\begin{array}{c}\text { Zimbro } \\
\text { (art.o n. }{ }^{\circ} \text { ) }\end{array}$ & $\begin{array}{l}\text { Vinha, olival, amendoal, sobreiral e terra de cultivo que } \\
\text { parte de Nascente com Manuel de Mello Vaz de Sam- } \\
\text { paio e herdeiros, e do Poente com Francisco da Rocha } \\
\text { Leão e Carlos de Figueiredo. }\end{array}$ & 130.000 & Idem & 2.600 & --- \\
\hline $\begin{array}{l}\text { Total do } \\
\text { rendimento }\end{array}$ & & 270.000 & Idem & 5.400 & --- \\
\hline
\end{tabular}

Quanto ao património material e edificado da quinta, no mesmo período (1909-1912), é ilustrativa a descrição pormenorizada relativa aos espaços, instalações e equipamentos, com respetivos recheios de mobília, baixelas, roupas, objetos diversos, máquinas, apetrechos artesanais e correspondentes avaliações (Anexo V, Quadro 6).

Em 31 de dezembro de 1919, Abel de Carvalho, o então administrador desta Quinta do Zimbro e que se mantinha como administrador da Quinta da Senhora da Ribeira, dá conta em documento enviado ao Administrador do Concelho de Carrazeda de Ansiães de um roubo verificado na quinta, relatando-o assim na seguinte notificação:

Na noite de 26 para 27 do corrente, indivíduos desconhecidos penetraram na casa da Quinta do Zimbro (Ribalonga) pertença da firma Silva \& Cosens, roubando objetos no valor de 2.812, 90 réis. Alguns dos objetos roubados têm a marca A_s. c. xx, principalmente os de prata e metal fino, roupas de cama e mesa com as marcas $\mathrm{SeC}$ ou SxC_Z, roupa de vestir sem marca alguma, A. F. Warre e outras não têm marca alguma. Os gatunos entraram na casa por meio de escalamento e arrombamento de telhado, tendo arrombado uma porta da casa do gasómetro e tentando arrombar duas portas exteriores do edifício, sem resultado. Os objetos roubados estavam à guarda do administrador da Quinta, assinado. Foram requisitados agentes da polícia judiciária do Porto [... $]^{546}$.

As investigações da Polícia de Investigação Criminal do Porto, prosseguiram durante 3 meses, até 20 de março de 1920, data da informação respetiva (13 páginas) que um agente da mesma polícia enviou de Foz Tua ao Administrador do Concelho de Carrazeda de Ansiães, com indicação de um custo das despesas da investigação (deslocações de comboio, etc.) de cerca de $1.600 \$ 00$. Porém informações sobre este roubo da casa de residência do Zimbro chegavam ainda à quinta, a 30 de maio de 1931 donde se pode depreender ter-se prolongado por mais 10 anos este processo de investigação. Nesta sequência ficam a conhecer-se dados concretos apurados, desde relações e quantidades de objetos encontrados (40 lençóis

\footnotetext{
${ }^{546}$ AHS - Copiador de Correspondência, cx. 2490, pasta 6200, u.i.6194, cota 1/8/1/5.
} 
de linho, toalhas, colchas, cobertores ingleses, talheres, roupa de homem e de senhora, etc.) e objetos em falta (20 lençóis, estojos, castiçais, talheres, roupas de cama, etc.) até à descrição completa, com nomes e idades, dos autores do roubo e dos seus numerosos encobridores, alguns residentes próximo da linha e comboio do Douro. É dado destaque ao facto de entre os autores do roubo se encontrarem os "presos por furto na cadeia de Vila Real evadidos desta cadeia, de alcunha o "Marrapão", de pai incógnito e natural de Sabrosa, o "Cara Linda", do concelho de Armamar, o "Amaro", vendedor ambulante de Carlão, o "Gouveia" do concelho de Lamego $[\ldots]\rangle^{547}$.

Como se deduz, este caso de furto verificado nesta Quinta do Zimbro, precisamente no dia a seguir ao Natal, festa cristã apelidada de festa da família no ideário republicano, num momento pois de grande carga simbólica, terá envolvido uma quadrilha ou rede alargada de indivíduos acusados abrangendo vários concelhos do Douro. Tal envolvência denota um clima de instabilidade e insegurança ligado ao ambiente generalizado de fome, miséria, banditismo e dificuldades de toda a ordem que então se vivia ainda em toda a região do Douro profundamente afetada pelos efeitos da crise vitivinícola e comercial do vinho do Porto.

Na década de 1920, era atribuída à Quinta do Zimbro, uma produção anual de 278 pipas de vinho, superior à da Quinta da Senhora da Ribeira, em mais 15 pipas e com tonéis também mais valorizados, embora os seus prédios tivessem uma avaliação bastante inferior, para efeitos fiscais, como se pode observar comparando a valorização dos prédios rústicos e urbanos do Zimbro (Quadro 35$)^{548}$ com os dados relativos à Senhora da Ribeira na mesma altura (correspondente Quadro 30).

Quadro 35. Quinta do Zimbro — Valores de Prédios (1927)

\begin{tabular}{|c|c|c|}
\hline Descrição & Valores & Base de cálculo \\
\hline Prédios rústicos & $325.000 \$ 00$ & Média 26 pipas a 12.500\$00; \\
\hline Prédios urbanos & $400.000 \$ 00$ & $150 \$ 00 /$ pipa $-36.000 \$ 00=£ 8.000$ \\
\hline Tonéis & $51.700 \$ 00$ & \\
\hline Alambique de cobre & $12.000 \$ 00$ & Total: $813.700 \$ 00$ \\
\hline Mobília & $25.000 \$ 00$ & \\
\hline
\end{tabular}

Nos anos 1930-1940, a empresa Silva \& Cosens com escritórios em Vila Nova de Gaia, que continuava a manter a posse e administração desta quinta, tinha entretanto alargado substancialmente a sua implantação no concelho de Carrazeda em cuja Repartição de Finanças possuía já registados, em seu nome, 16 artigos referentes a prédios rústicos e urbanos com

\footnotetext{
${ }^{547}$ AHS - Cx. 2490, u.i. 6194, cota 1/8/1/5.

${ }^{548}$ AHS - Contribuição predial de 1920 da Sociedade Comercial Silva \& Cosens, cx. 2490, u.i.6194.
} 
rendimentos variáveis, como se conclui de certidões de natureza fiscal emitidas por aqueles serviços entre 1932 e 1942, em resposta a requerimentos do representante legal da empresa, no local, o proprietário João Baptista Moutinho, a residir na Quinta do Zimbro.

Sabe-se assim que, a Quinta do Zimbro era descrita, em 1942, com respetiva atribuição de rendimentos deste modo:

Composta de vinha, 650 oliveiras, casa de habitação tendo no $1 .^{\circ}$ andar 1 armazém e no 2. ${ }^{\circ}$ andar 6 divisões mais uma casa para empregados com 3 divisões e 4 lagares para fabricar vinho, com pomar; confronta com caminhos, António de Melo, António Castro e do Sul com o rio Douro, que é atravessada pelo caminho-de-ferro do Douro e pela estrada. Foi atribuída à casa de habitação o rendimento de $2.420 \$ 00^{549}$.

$\mathrm{Na}$ matriz predial urbana (freguesia de Ribalonga) desse ano o rendimento coletável de $2.178 \$ 00$ era atribuído a um prédio com altos e baixos no Zimbro, com 11 divisões, 1 em baixo para arrumações e 10 divisões em cima para habitação. Tem anexo 1 terreno que lhe serve de recreio e logradouro com a área de $720 \mathrm{~m} 2$ a confrontar com caminho de ferro e caminho público. Na matriz predial rústica, o rendimento coletável era de $13.696 \$ 00$, enquanto o da Quinta da Senhora da Ribeira era de 41.497\$00, ou seja, quase 3 vezes superior, mantendo-se a mesma tendência relativamente a anos anteriores.

Verifica-se por essa altura, a especificidade de nesta Quinta do Zimbro de Baixo na sua parte mais alta confinante com a Quinta do Zimbro de Cima (onde se pode ver ainda hoje um marco de delimitação com a inscrição Silva \& Cosens) ter sido localizado um jazigo de volfrâmio e estanho, e registado por Pedro José de Melo Vaz de Sampaio, o que veio a originar a necessidade de regularização da situação assim gerada. Consta de facto, da cópia de minuta de um contrato reduzido a escritura feita por Themudo Rangel, Bairro de S. João Novo, Porto, a concessão da exploração de minério, nos seguintes termos:

Entre a firma Silva \& Cosens com sede em Vila Nova de Gaia, sendo 1. a outorgante, pelo seu representante o Sr. Maurice Malacaster Symington, negociante, residente na Av. da Boavista, no Porto, e Pedro José de Melo Vaz de Sampaio, solteiro, engenheiro civil, residente em Ribalonga, como 2. outorgante, é declarado que:

A 1. ${ }^{a}$ de que aquele é gerente, é proprietária da Quinta do Zimbro (casa de habitação com jardim, pátio, lagares, telheiro, armazéns, casas para empregados, currais para gados, extensos terrenos de cultivo, monte e areal, pomar, vinhas, oliveiras, laranjeiras, amendoeiras, sobreiros e outras árvores, água e mais pertences) atravessada pela linha de caminho-de-ferro do Douro, sita no Tua;

\footnotetext{
${ }^{549}$ AHS - Certidão das Finanças de Carrazeda, requerida por J. B. Moutinho, representante da Silva \& Cosens, u.i. 6194.
} 
O 2. outorgante fez registar na parte monte desta propriedade e acima das plantações de vinha, um jazigo de volfrâmio e estanho (registo n. ${ }^{\circ} 64$ ), com relação à parte alta dessa quinta mais conhecida por Quinta do Zimbro de Cima;

Resolveram eles regularizar os direitos de cada um em relação à propriedade da mesma quinta do $1 .^{\circ}$ outorgante e aos direitos de exploração e extração do minério quanto ao $2 .^{\circ}$ e então assentaram e convencionaram que:

Este procederá à lavra ativa e não ambiciosa pela exploração desses e outros minérios dentro desta exploração suportando todas as despesas e dos lucros líquidos que se apurarem pagará à $1 .^{\circ}$ outorgante, proprietária do terreno, 50\% desses lucros líquidos, não podendo o concessionário exceder com esta exploração a parte de cima da Quinta do Zimbro e não atingir a sua parte plantada com vinha e árvores, podendo estabelecer passagem para a exploração pelos caminhos já existentes, ao menor prejuízo e finda a exploração deixará o terreno regularizado sem covas, óculos de minas, poços ou outras escavações e pagará ao Estado, Câmara e Junta de freguesia os impostos que venham a ser lançados à propriedade e seus donos por efeito dessa exploração tudo sem responsabilidade alguma para o $1 .^{\circ}$ outorgante;

Que a exploração se deve iniciar já sem interrupções nem demoras que prejudiquem o cultivo e amanho da Quinta e dura por um período inicial de um ano e renovada sucessivamente de seis em seis meses;

As contas devem ser escrituradas e reguladas e controladas pela $1 .^{a}$ outorgante proprietária da quinta, com o direito de fiscalizar diretamente ou por empregados seus o modo como a exploração está a ser feita, a qualidade e quantidade dos minérios a extrair e o 2. ${ }^{\circ}$ outorgante deverá pagar a \% nos lucros nos primeiros 5 dias do mês imediato àquele em que se fizer a exploração [... ${ }^{550}$.

A referência a este episódio revela a existência de um conflito de interesses económicos entre a empresa de negócios do vinho do Porto proprietária desta Quinta do Zimbro de Baixo e um empreendedor mineiro individual, e é, historicamente, tanto mais relevante quanto o mesmo é exemplo da dinâmica local e nacional de corrida à exploração e negócio altamente vantajoso do volfrâmio, minério de múltiplas propriedades e altamente estratégico designadamente em grandes conflitos: I Guerra Mundial (1914-1918), a Guerra Civil de Espanha (1936-1939), sobretudo a II Guerra Mundial (1939-1945) e ainda a Guerra da Coreia (1950-54) conjunturas de elevada subida de cotações e lucros fabulosos ${ }^{551}$.

\footnotetext{
${ }^{550}$ AHS - Minuta de contrato-escritura, u.i.6198.

${ }^{551}$ LAGE, 2002.
} 


\subsubsection{A Quinta do Zimbro de Cima}

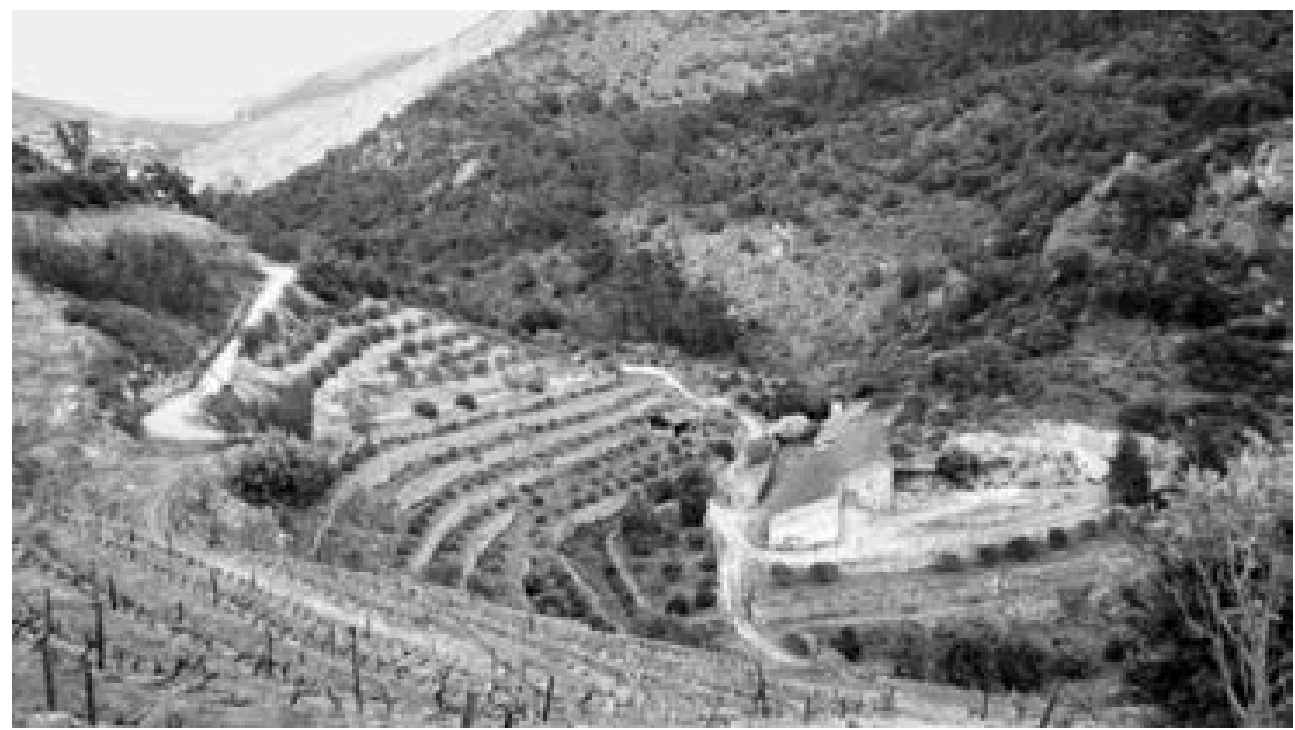

Fig. 147. Quinta do Zimbro de Cima

Fonte: Fotografia de J. J. S.

A Quinta do Zimbro de Cima passou, ainda no período da I República, para a posse do Dr. António Sampaio Chaves, por herança familiar, a partir de seu sogro, João Lopes da Cruz, brasileiro de torna-viagem enriquecido, grande proprietário duriense, negociante de vinhos do concelho de Carrazeda e famoso empreiteiro da Linha do Tua (2..$^{\circ}$ troço de Mirandela a Bragança). Foi aliás este empreendimento ferroviário que levou João Lopes da Cruz à falên$\mathrm{cia}^{552}$ e à perda de seus numerosos bens imóveis dispersos pelas freguesias de Castanheiro, Fontelonga, Lavandeira, Ribalonga, Selores e ainda em Mirandela, penhorados a 18 de março de $1909^{53}$. Por altura da arrematação destes bens em hasta pública, a Quinta do Zimbro de Cima era descrita como «prédio urbano com casas de viver, armazém, lagares, 10 tonéis com 55.000 l. de vinho, vinha, oliveiras e mortórios e os prédios do Alambique, Bidrinho e Cerdeira» em inventário orfanológico «a que se procedeu por óbito de João Lopes da Cruz que foi morador na Quinta do Zimbro, freguesia de Ribalonga ${ }^{554}$.

\footnotetext{
${ }^{552}$ CRUZ, 1906.

${ }^{553}$ PEREIRA, 2014: 328-333. Consultar também Empresas. Companhia Carris de Ferro do Porto. Secretaria geral. Processos e questões diversas. Rescisão de contrato, PT/ADPRT/EMP/CCFP/SG/013/13.084. B/6/1/4 — 14.8. (pasta 8478 - Arquivo Distrital do Porto); Registos notariais. 8. ${ }^{\circ}$ Cartório Notarial do Porto, PT/ADPRT/NOT/ CNPRT08/001/0822, fs. 77-81v. I/34/1 - 138 (pasta 41222 - Arquivo Distrital do Porto); Arquivo Distrital de Lisboa. Fundos judiciais. Tribunal judicial da comarca de Lisboa. Processo de execução hipotecária movido pela Companhia Geral do Crédito Predial Português a João Lopes da Cruz (pasta 94018). Disponíveis em <https://drive. google.com/drive/folders/0ByNRym7cQwTUeThTNkxaRzIwU0E?usp=sharing $>$.

${ }^{554}$ PEREIRA, 2014: 331-343.
} 
Por ocasião da sua venda em hasta pública, a Quinta do Zimbro de Cima foi comprada pelos então donos da Casa Campeão do Porto, retalhista de lotarias, que a terão «dado» à mulher de João Lopes da Cruz, Dona Maria Natividade Magalhães Lopes da Cruz para viver e para que quando e se algo pudesse pagar por ela e/ou seus herdeiros ou, se tal não fosse possível, a amizade a liquidaria depois. Foi paga pelo Dr. António Sampaio Chaves (seu genro), pai do Dr. João Cruz de Sampaio, seu único herdeiro, e avô do Dr. A. João R. de Sampaio, e também, pelo Dr. João Lopes da Cruz Júnior, filho mais velho de João Lopes da Cruz que pagou uma parte que deu à irmã, Dona Felicidade Amélia Lopes da Cruz ${ }^{55}$ (genealogia de João Lopes da Cruz, Anexo V).

Outra versão menos detalhada é a de que esta quinta teria sido desipotecada pelo genro, Dr. António Sampaio Chaves e pelo filho do empreiteiro J. Lopes da Cruz, o médico João Lopes da Cruz Júnior que a cederia mais tarde a sua irmã ${ }^{556}$, doação essa que é também corroborada em entrevistas do bisneto por linha materna de João Lopes da Cruz, Dr. António João Ribeiro de Sampaio, filho do Dr. João Cruz de Sampaio, ligado ao Centro Republicano e Democrático de Carrazeda de Ansiães (1911/1912) de que seu pai fora dirigente (confrontar genealogia ascendente de António João R. de Sampaio) $)^{557}$.

Esta Quinta acabaria assim por regressar às mãos da família Sampaio, de reputados republicanos, do concelho de Carrazeda (Linhares/Parambos), através do casamento de Dona Felicidade Amélia Lopes da Cruz, filha de João Lopes da Cruz com o Dr. António Sampaio Chaves, notário vários anos em Carrazeda ${ }^{558}$ e que seria também vereador republicano eleito da Câmara Municipal deste concelho nos triénios de 1923 a 1925, e de 1926 a 1928, sendo Presidente da Comissão Executiva em $1926^{559}$.

O depoimento de A. João R. de Sampaio (ver Anexo V) é uma breve mas bem elucidativa narrativa da história sucinta das transmissões intrafamiliares desta Quinta do Zimbro de Cima, designadamente durante o período da I República. Encontram-se nesse testemunho, para além das referências à tradição familiar de elites regionais a que pertenceram neste período, os proprietários da Quinta do Zimbro de Cima, outras pistas para a história da Quinta do Zimbro de Baixo, a qual andou largos anos associada à Quinta da Senhora da Ribeira, devido às sucessivas transmissões da sua propriedade para importantes firmas inglesas do vinho do Porto, já anteriormente referidas. Aliás, a transmissão da propriedade da Quinta do Zimbro de Baixo, é semelhante à de muitas outras quintas durienses e ilustrativa da situação recorrente que tem acompanhado as cíclicas crises vitícolas e comerciais do Douro em diferentes momentos históricos.

\footnotetext{
${ }^{555}$ Entrevista ao Dr. António João Ribeiro de Sampaio, Matosinhos a 13 de fevereiro de 2017.

${ }^{556}$ Entrevista de Hugo Pereira a Maria João Alves Martins neta de João Lopes da Cruz e filha primogénita do seu filho médico João Lopes da Cruz Júnior.

${ }^{557}$ LAGE, 2012a: 311-337.

${ }^{558}$ Entrevista a Dr. António João Ribeiro de Sampaio, realizada em Matosinhos, 13 de fevereiro de 2017.

${ }^{559}$ MORAIS, 2006: 295-297.
} 
O Dr. António Sampaio Chaves esteve ligado ao Centro Democrático e Republicano de Carrazeda, fundado em 1911 e com estatutos aprovados em 1912, assinados pelo Presidente da Mesa, António Júlio Ribeiro, pelo 1. ${ }^{\circ}$ secretário Dr. António de Sampaio Chaves e pelo 2. ${ }^{\circ}$ secretário, João Ferreira Aguiar ${ }^{560}$. Estes três dirigentes todos notórios republicanos, de base social radicada em conhecidas elites locais, encontravam-se ligados entre si por laços familiares e de amizade e também de relação direta, enquanto possidentes, com importantes propriedades vinhateiras nesta zona da Região Duriense: a Quinta do Zimbro de Cima, a Quinta do Comparado e a Quinta da Alegria (ver Capítulo 9, subcapítulo 9.3. e Capítulo 10, subcapítulo 10.4.4.).

Já na segunda metade do século XX, a Quinta do Zimbro de Cima, então ainda pertencente ao Dr. João Cruz de Sampaio, na sequência de um intrincado processo de registos de propriedade, vai passar por morte da sua primeira esposa, em dezembro de 1972, e na sequência de partilhas, para o filho, António João Ribeiro de Sampaio. Nascido na freguesia de Cedofeita da cidade do Porto, residente em Parambos, freguesia de Carrazeda e licenciado em Medicina Veterinária em 1978. Foi médico veterinário dos quadros do Ministério da Agricultura e veterinário municipal de vários concelhos transmontanos e durienses (Carrazeda, Vila Flor, Alijó, Murça e S. João da Pesqueira, tendo exercido diversos cargos em diferentes entidades: Presidente da Assembleia Municipal de Carrazeda de Ansiães (1979-1984), Presidente da Câmara Municipal do mesmo concelho (1990-1997); Subdiretor Regional da Agricultura de Trás-os-Montes; Presidente do Conselho Consultivo da Navegabilidade do Douro e ainda do Agrupamento de Municípios da Terra Quente Transmontana e da Associação de Municípios da Terra Quente, para além do exercício, entre 1993 e 2000, de outros cargos na Liga dos Bombeiros Portugueses, e Associações de Bombeiros Voluntários de Carrazeda e comandos distritais.

Este novo proprietário da Quinta do Zimbro de Cima, entre 1976 e 2003, reside atualmente em Parambos na sua casa brasonada, conhecida por Solar dos Sampaios ${ }^{561}$, da família do Dr. Domingos Frias de Sampaio e Mello, ilustre cidadão republicano de Trás-os-Montes, Governador Civil de Bragança, em 1911, Administrador do Concelho de Carrazeda e Diretor do semanário «O Transmontano», órgão do Centro Republicano e Democrático da mesma vila. A família Frias de Sampaio estava ligada por relações de amizade e filiação republicana à família do Dr. João Cruz de Sampaio, filho único e herdeiro de abastados lavradores e letrados influentes de tradição republicana da região.

\footnotetext{
${ }^{560}$ Estatutos publicados em 1912 na Papelaria e Tipografia Académica de L.P. Moreira Lobo. Existe 1 exemplar na Biblioteca Nacional de Portugal, cota BNL - SC 7428/8V.

${ }^{561}$ Entrevista com Dr. A. João R. de Sampaio, Matosinhos, 14 de fevereiro de 2017. A propriedade deste antigo solar de Parambos, de acordo com o entrevistado, seu atual dono, passou da família Frias Sampaio para a família Sampaio Chaves, através do dote de casamento de sua avó, concedido pelo respetivo padrinho, o Dr. Frias de Sampaio.
} 


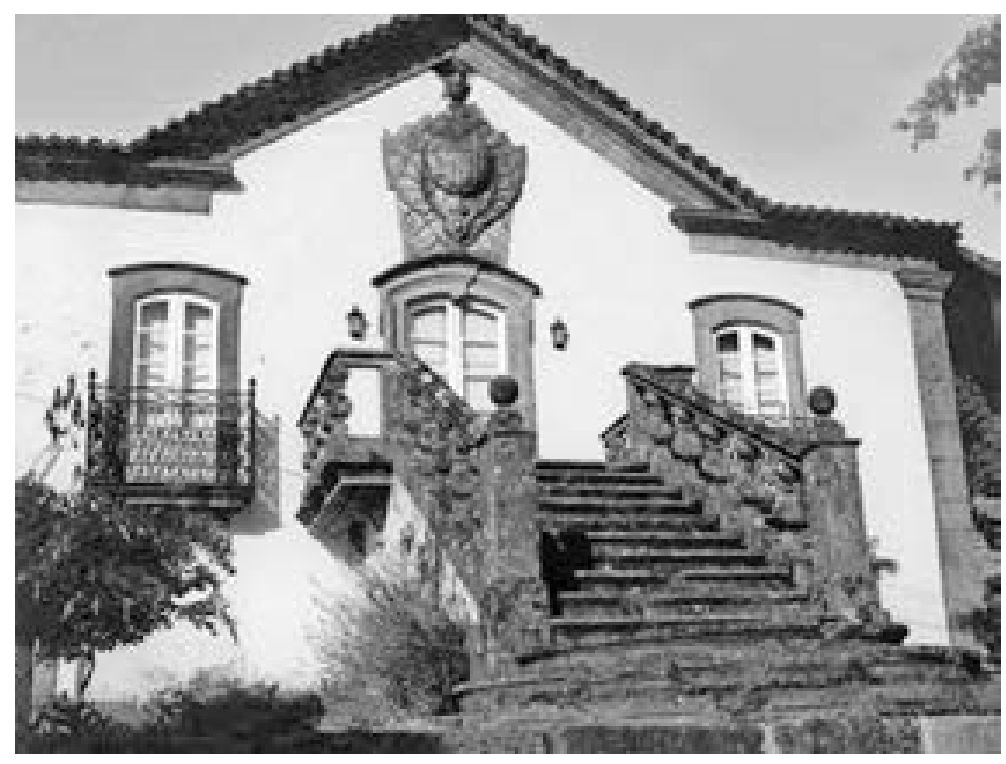

Fig. 148. Solar dos Sampaios (Parambos — Carrazeda de Ansiães)

Descendente desta prestigiada família local (Anexo V, genealogia), o Dr. António João R. de Sampaio entronca ainda com a antiga família Mariz, da Quinta da Alegria, por casamento de sua irmã, Dona Laura Felicidade Ribeiro Sampaio, farmacêutica, com o Eng. António Augusto Fernandes Mariz, único filho sobrevivo de Augusto Alexandre Mariz, também conhecido republicano e antigo dono da Quinta da Alegria, pais do engenheiro Alexandre Mariz, o atual proprietário da Quinta da Alegria de $\mathrm{Cima}^{562}$.

O Dr. A. João R.de Sampaio manteria em sua posse a Quinta do Zimbro de Cima, desde 1976 até 2003, ano em que a vendeu, nela introduzindo ao longo de mais de 3 décadas, grandes transformações e algumas mudanças inovadoras, num investimento continuado que fez desta quinta uma valorizada e moderna propriedade vinhateira duriense.

Esta quinta que, anteriormente, produzia apenas em média $2.500 \mathrm{~kg}$ de uvas para vinho generoso com benefício, cerca de 3,3 pipas, o que era muito pouco, foi nesse período, totalmente reconvertida e mecanizada, numa área aproximada de 20 ha de vinha e 2 ha com plantação de árvores de fruta (laranja, tangerina, limão) acrescidos de mais 1 ha de olival disperso, com plantio em patamares largos, tendo a sua produção média passado de 3 toneladas de uvas para 100 toneladas, e atingindo, só a sua produção de vinho do Porto, um número aproximado entre 110 e 120 pipas.

O vinho da Quinta do Zimbro de Cima foi sempre produzido localmente e vendido durante alguns anos à Croft, e depois à Cockburn's, a partir de 1981. Este proprietário da

\footnotetext{
${ }^{562}$ Entrevista com Dr. A. João R. de Sampaio, Matosinhos, 14 de fevereiro de 2017. Ver também fichas da respetiva genealogia (Anexo V), generosamente facultadas pelo entrevistado, a quem se agradece.
} 
quinta conserva ainda em sua casa, vinhos do Porto do Zimbro do ano de 1870. A adega da quinta foi toda remodelada e apetrechada com os mais modernos equipamentos, tendo sido certificada pela Norma Internacional ISO/TS 9002, de gestão de qualidade.

No início do século XXI, a Quinta do Zimbro de Cima é vendida pelo Dr. António João Ribeiro de Sampaio a Manuel Pinto Hespanhol, descendente de lavradores durienses da Régua e ex-empregado bancário que deixou a Banca, a partir de 1995, para investir na construção de uma empresa familiar vitivinícola com três gerações ligadas à produção do Vinho, dedicando-se à produção e comercialização dos seus próprios vinhos Douro DOC nos quais destaca a marca vinhos do Zimbro ${ }^{563}$. Recentemente falecido, este novo proprietário da Quinta do Zimbro do Cima, integrou, desde os anos 1980, a geração pioneira de produtores e engarrafadores que constituíram no Douro um importante ponto de viragem.

\subsubsection{As Quintas do Tua e da Chousa}

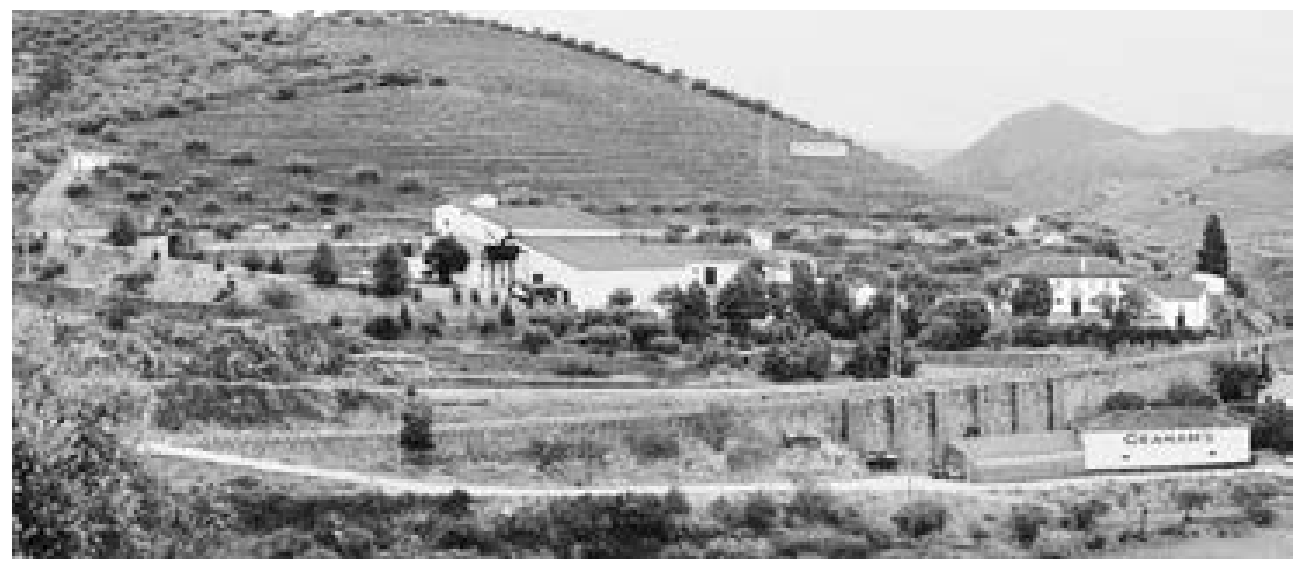

Fig. 149. Quinta do Tua (vinha, adega e armazéns, e antiga casa residencial) — Foz Tua (Carrazeda de Ansiães) $^{564}$

A Quinta da Chousa e a Quinta do Tua (localmente conhecida por Quinta dos Ingleses ou dos Smithes) são duas quintas, em Foz Tua (antiga freguesia de Castanheiro do Norte) cuja antiguidade e tradição se encontram conciliadas com a atual modernidade vitivinícola duriense. Alcandoradas na encosta do rio Tua sobranceira a Foz Tua, aldeia que no concelho de Carrazeda faz fronteira com o concelho de Alijó, ficam situadas à direita da antiga linha férrea do Tua, próximo da atual barragem do Tua e são servidas pela estrada nacional 214 que liga Carrazeda de Ansiães, vila sede do concelho, a Foz Tua.

\footnotetext{
${ }^{563}$ Entrevista do próprio incluída em vídeo promocional disponível em $<$ https://www.youtube.com/watch?v=fP UgPySlOY>. [Consulta realizada em 20/10/2006].

${ }^{564}$ Foto disponível em <https://malvedos.files.wordpress.com/2010/10/tua-property.jpg $>$. [Consulta realizada em 25/2/2017].
} 
Com uma longa história que adiante se seguirá sucintamente, nos finais do século XIX, por ocasião da grande crise filoxérica que atingiu também com profundidade, embora mais tardiamente, os vinhedos do concelho de Carrazeda, foram as duas compradas e modernizadas por novos proprietários nacionais e estrangeiros, ligados a firmas exportadoras e de negócios do vinho do Porto.

Para além da excelência da sua posição na fronteira das sub-regiões de Cima Corgo e do Douro Superior, à época em grande transformação e desenvolvimento, são de destacar, logo no período seguinte da I República, a reconhecida qualidade dos seus vinhos, a iniciativa capitalista e reformadora dos seus proprietários mais consentânea com a dinâmica de empreendedorismo económico duriense, então emergente com a ideologia do regime republicano e a sua nova política protecionista para a Região do Douro.

Atualmente, estas duas quintas pertencem ao Grupo Symington Family Estates, que as comprou à conhecida empresa britânica Cockburn's, em 2006, através da sua firma Graham's, aqui em Foz Tua, dona das melhores propriedades do Vale do Douro: a Quinta do Tua e, defronte, na encosta do concelho de Alijó, a Quinta dos Malvedos, as quais produzem vinhos de excecional qualidade. A firma Graham's, fundada por William e John Graham, em 1820, e hoje reconhecida como um dos produtores de referência de Porto Vintage posicionado na vanguarda da inovação enológica, é uma empresa independente, detida a $100 \%$ pela família Symington, produtores de vinho do Porto desde o século XIX (ver Capítulo 8).

Ainda hoje, também a Quinta das Andorinhas na freguesia do Seixo de Ansiães, concelho de Carrazeda e as quintas do Alvito e das Netas, todas pertencentes, a título pessoal, a membros da família Symington, fornecem uvas para os vinhos da Graham's.

Foi já considerado que a viticultura duriense em bases científicas ${ }^{565}$ teve antecedentes na Quinta do Tua, cuja área de 30 ha integra, atualmente, 25 ha de vinha letra A.

Esta quinta, outrora propriedade de Dona Antónia Ferreira, a quem a comprou, em 1889, a Cockburn's que fez dela, um dos seus centros experimentais de viticultura, teve as suas vinhas totalmente destruídas pela filoxera, a que se seguiu, em 1893, a construção dos seus antigos e sólidos socalcos, com 1,5 m de espessura em média, obra de exímios pedreiros galegos, ainda hoje bem conservada.

$\mathrm{Na}$ década de 1930, as suas vinhas foram um dos primeiros vinhedos experimentais do Douro, tendo John Smithes da Cockburn's ensaiado aqui a plantação de novas castas e novos métodos de cultura da vinha. Mais recentemente, foi ainda a partir desta Quinta e de uma plantação de videiras TN (Touriga Nacional) proveniente de seleção massal ensaiada num talhão estreme de 12.000 pés que, teve origem o conhecido projeto da Vilariça, Quinta do Ataíde (1978/1985), um projeto de investigação visando contribuir para a salvaguarda da diversidade genética das castas do Douro, e levando a cabo a pioneira seleção clonal de castas

${ }^{565}$ MAGALHÃES, 2015: 105-113. 
antigas como a TN. Todo este projeto da Vilariça, igualmente em Assares, foi essencialmente baseado em populações de videiras da Quinta do Tua ${ }^{566}$.

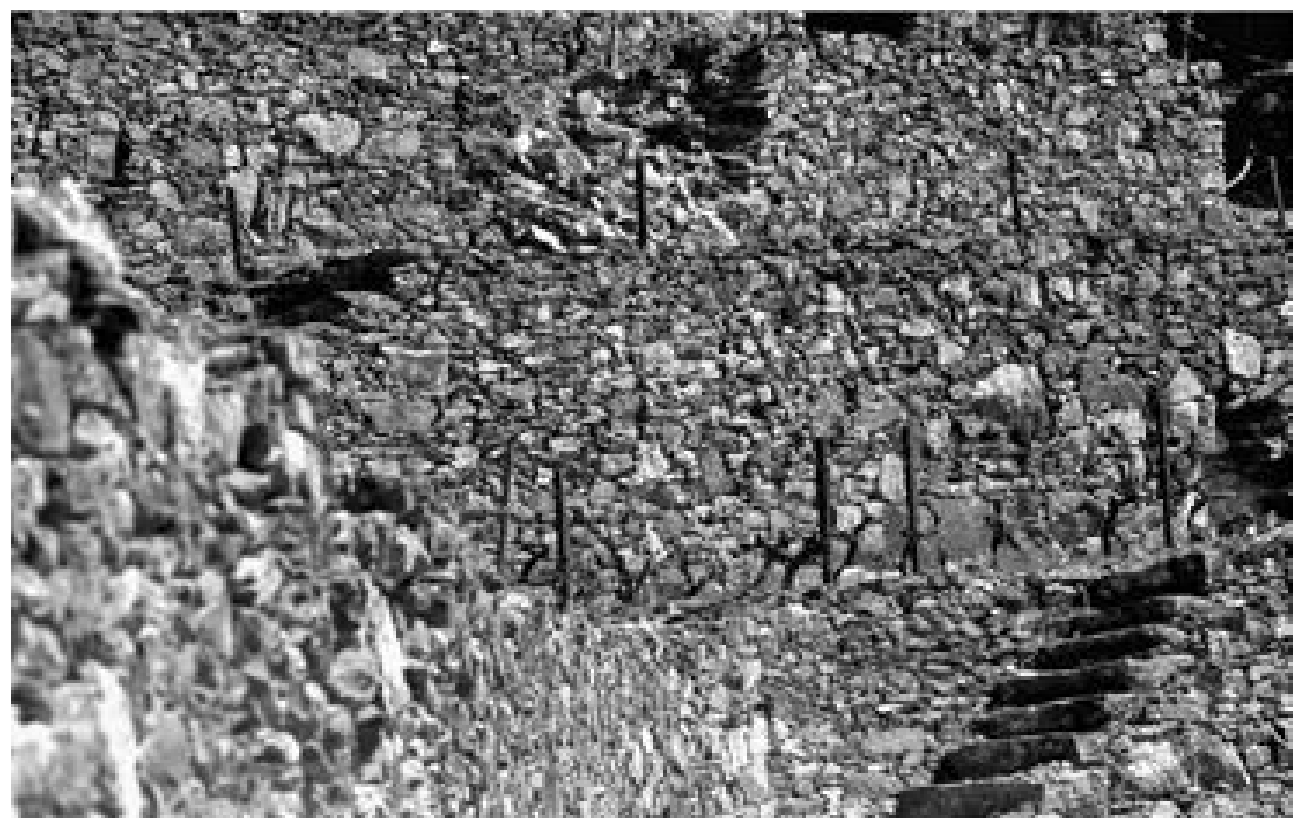

Fig. 150. Quinta do Tua - Socalcos antigos, dos mais sólidos do Douro

Fonte: Fotografia E. Beira

Por sua vez, a Quinta da Chousa, com origem histórica na antiga e grande Quinta da Chousa Velha ou Chousa da Loba (séculos XVII e XVIII), a qual nos se estendia pelas encostas dos rios Douro e Tua, a partir das suas margens, a Sul e Poente, até à aldeia do Fiolhal, na encosta, a Norte, apresenta hoje, numa área bem menor mas totalmente modernizada, uma considerável extensão de vinha nova que tem vindo, desde 1973, a ser plantada em patamares por talhões estremes que permitiram a sua mecanização integral.

Como atrás se sinalizou, esta quinta fora já considerada pela Comissão de Viticultura da Região Duriense (instituição de regulação duriense durante a I República) uma quinta modelo com boas características para instalação do Posto Agrário da Região Duriense tendo-lhe sido então atribuído um valor de venda de $30.000 \$ 00^{567}$.

Como acontece com a generalidade das quintas durienses, a história da propriedade da Quinta da Chousa caracteriza-se por uma constante mudança de mãos: originariamente pertencente à nobre família dos Távoras, foi mais tarde da Viscondessa de Ervedosa ou de S.

\footnotetext{
${ }^{566}$ ESTEVES, 2008: 401.

${ }^{567}$ Relatório da Comissão nomeada por Portaria de 25 de agosto de 1914, para proceder à escolha de propriedade onde possa funcionar o Posto Agrário da Região Duriense, 1926: 72-73.
} 
Jorge de Favaios até 1890, altura em que metade da quinta produzia uma média de 40 pipas de vinho generoso e, sucessivamente, de 1890 até 1930, propriedade de Francisco da Rocha Leão e descendentes, depois do que passou a pertencer ao Dr. António Castro e herdeiros, num período em que entrou em decadência, desde 1930 a 1973, ano em que foi associada à Quinta do Tua, através da propriedade conjunta da firma Cockburn's.

\subsubsection{A Quinta do Tua (ou Quinta dos Ingleses ou dos Smithes)}

Esta propriedade vitivinícola é uma das mais emblemáticas quintas não só do concelho de Carrazeda, mas também da história do Douro Vinhateiro.

Desde a Demarcação Primordial Pombalina da Região Duriense, meados do século XVIII, que existiam vinhas de diferentes proprietários nas terras junto à foz do rio Tua, afluente do Douro, onde se situa a Quinta do Tua, que andava então agregada à grande Quinta da Chousa Velha (ver 7.6.3.2), em cuja extensa área, confrontando com o rio Douro, a Sul, com a Quinta do Zimbro, a Nascente e com propriedades dos moradores da aldeia de Fiolhal, a Norte, se cultivavam cereais, hortas, olivais, laranjais e onde havia várias casas de habitação, lagares, armazéns, estábulos e outras edificações que seriam em grande parte arrasadas pela construção da linha férrea do Tua (1884-1887) $)^{568}$.

Na segunda metade do século XVIII a Quinta do Tua pertencia já a António José de Távora Figueiredo, filho natural de António Luís de Távora Figueiredo, residente no Porto e «descendente da família dos Távoras oriunda da aldeia de Trevões do concelho de S. João da Pesqueira e continuaria em poder dos seus herdeiros até $1864 »^{569}$. Poucos anos depois irá passar para Dona Antónia Ferreira, que arrematou o armazém e a vinha do Tua, em 1871, aquando do processo de execução contra Dona Maria dos Anjos de Figueiredo, movido por Manuel Pinto da Costa, como cessionário de José Nicolau de Almeida, a quem a vinha estava hipotecada.

Dona Antónia Adelaide Ferreira (Régua, 1811-1896), então a maior proprietária vinhateira do Douro, irá fazer desta então ainda pequena propriedade duriense com uma produção média de 6 pipas de vinho generoso onde existia uma casa de habitação reconstruída e ampliada em 1834 que funcionou muitos anos como hospedaria de apoio aos viajantes que seguiam para Trás-os-Montes ou para as quintas do Douro Superior, uma quinta considerável a que acrescentou vinhas, olivais, casas, propriedades e outros bens adquiridos a moradores da povoação de Foz Tua e de aldeias de S. João da Pesqueira, na outra margem do Douro, em anos posteriores (1867, 1871, 1875 e 1877).

Dona Antónia Ferreira, mais conhecida por a Ferreirinha, figura lendária do Douro tornar-se-ia para os agricultores no «exemplo de que os durienses podiam bater o pé aos ingleses que dominavam o negócio do vinho do Porto, a prova de que podiam cumprir o sonho de entrar no comércio», como explica Gaspar Martins Pereira ${ }^{570}$.

\footnotetext{
${ }^{568}$ PEREIRA, \& CORDEIRO, coord., 2013: 181-198.

${ }^{569}$ MORAIS, 2014: 200-201.

${ }^{570}$ Apud CARVALHO, 2011.
} 
Quando as doenças das videiras (sobretudo o oídio e depois a filoxera) devastaram as vinhas e reduziram a capacidade de oferta do Douro, Dona Antónia acumulou e guardou nos seus gigantescos armazéns de Gaia enormes «stocks» de vinhos excelentes provenientes de compras e da produção de suas vinhas, cerca de 1.500 pipas por ano, que depois venderia em condições que lhe permitiram realizar enormes mais-valias com que adquiriu ações de empresas nacionais e estrangeiras, casas na Régua e Vila Real, palácios no Porto e em Lisboa, para além de grandes terras, montes, olivais, azenhas e 24 quintas algumas das quais emblemáticas como a do Vesúvio, na Região do Douro, onde era, no século XIX, dona da maior fortuna e de um património material de dimensão fabulosa, avaliado em 5,9 milhões de réis, o que a tornava senhora de um império agrário e comercial e de uma das maiores fortunas do país da sua época. Os seus herdeiros, dois filhos, dezoito netos e respetivos sucessores geriram durante três gerações parte do seu imenso legado ${ }^{571}$, tendo mantido em sua posse a maior parte das quintas, como a emblemática Quinta do Vesúvio que foi, entretanto, comprada pelo atual maior Grupo de Vinho do Porto, os Symington ${ }^{572}$.

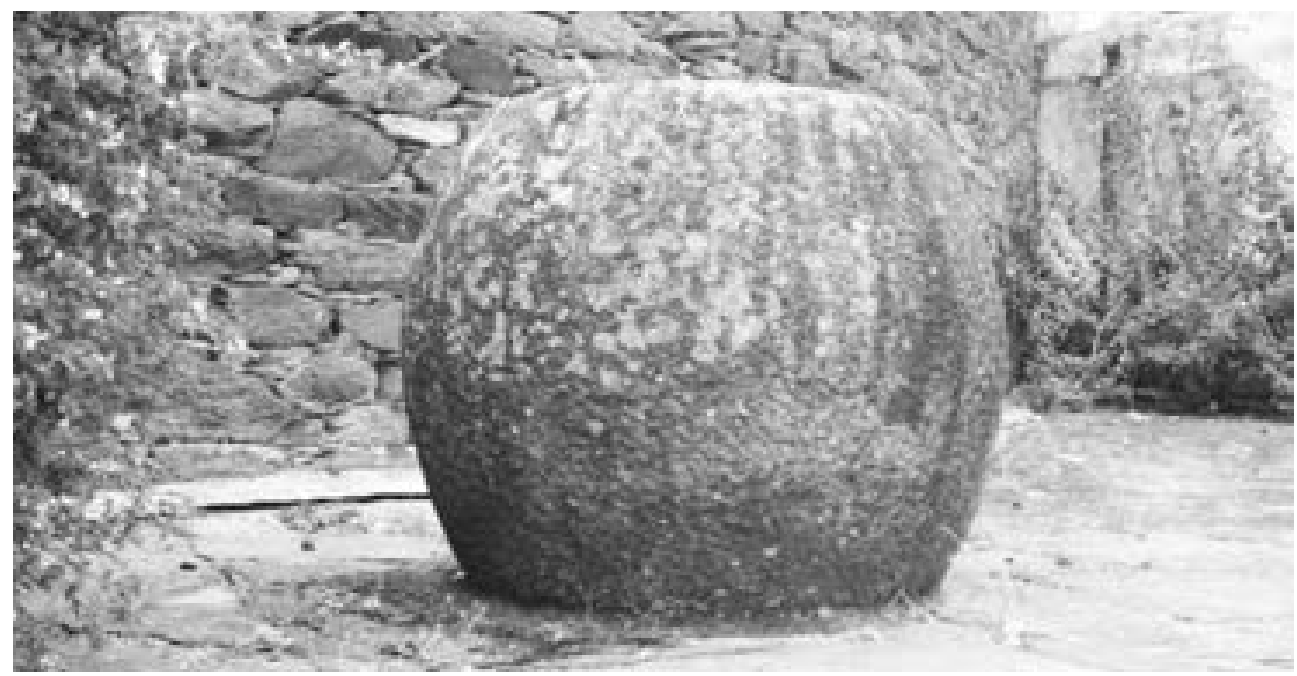

Fig. 151. Quinta do Tua - Prensa de varas de lagar, modelo de fabrico pré-industrial Fonte: Fotografia de J. J. S.

As vinhas da quinta do Tua ficaram totalmente destruídas com a filoxera (1879) e a quinta seria vendida em 1889, por Dona Antónia, poucos anos antes da sua morte, à empresa britânica Cockburn Smithes, representada pelo seu sócio William Roope Teage (Capítulo 8, subcapítulo 8.2.) que a replantou e reformou totalmente remodelando também a sua casa de

\footnotetext{
${ }^{571}$ A Casa Ferreira foi vendida em 1987 à Sogrape, a maior empresa nacional do setor do vinho, com negócios no Chile e Argentina, para além de Portugal.

${ }^{572}$ CARVALHO, 2011. Ver ainda PEREIRA \& OLAZABAL, 1996.
} 
habitação, transformada em 1890 por John Smithes num bonito solar para habitação de veraneio destes novos proprietários da quinta, agora e pela primeira vez estrangeiros.

Como se referiu já, em 1893 dezenas de trabalhadores galegos construíram aqui grandes socalcos de sólida espessura que se conservam ainda hoje como os mais antigos da Região do Douro e os vinhedos da quinta do Tua foram totalmente replantados, tendo-se feito novas experiências de viticultura com porta enxertos de vinha americana, podas e enxertias.

Já no decurso do século XX, na década de 1930, sucedem-se aqui, com J. H. Smith, experiências inovadoras de viticultura com a introdução de novas castas, sendo então a quinta com uma área de 7 ha em 1938, composta de vinha e uma produção de 15 pipas de vinho generoso por ano, 418 oliveiras, com 17 almudes de azeite de produção anual, casa de habitação, armazéns, abegoarias e lagares de vinho.

Como já anteriormente se introduziu, a Quinta do Tua constituiu-se numa das propriedades de eleição da Cockburn's Smithes, empresa que manteria a sua posse durante mais de 100 anos até ao século XXI.

J. H. Smith (1910-1999), um dos mais reputados provadores do Douro e ilustre protagonista, até pela sua genealogia ascendente de origem militar e comercial britânica, da história da Cockburn's, foi figura destacada e emblemática da presença inglesa na região do Douro Vinhateiro e, particularmente, na zona de Carrazeda, onde se tornou amigo especial de reputados lavradores, viria aqui a ficar lembrado pela sua peculiar ligação à Quinta do Tua, uma das primeiras propriedades vinhateiras de relevo adquirida pela firma Cockburn's em Carrazeda de Ansiães (Capítulo 8).

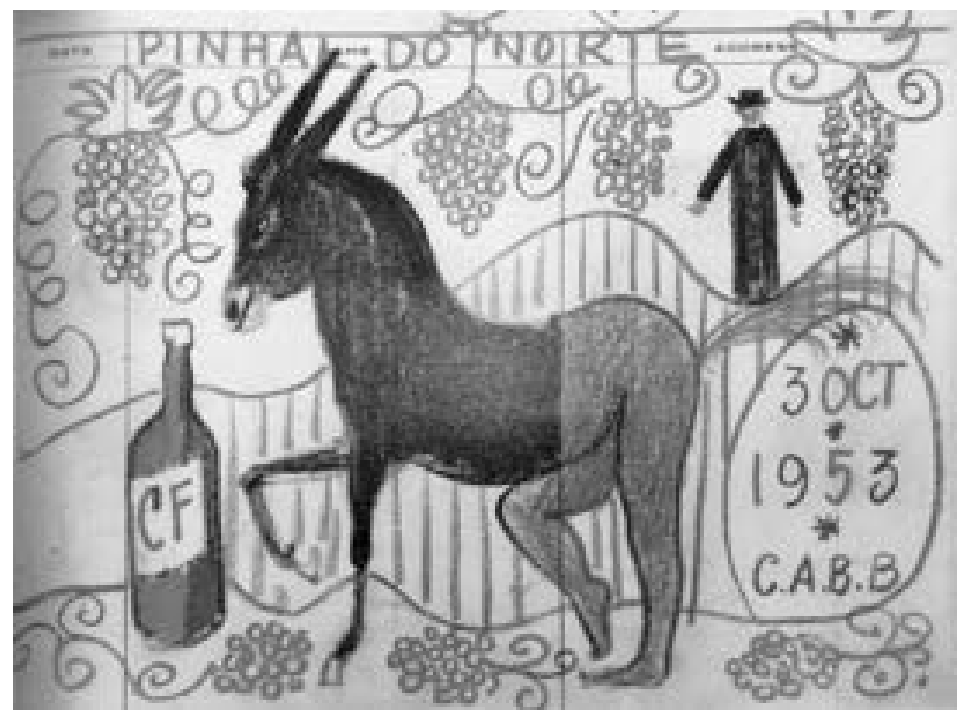

Fig. 152. Desenho de J. H. Smith (1953) - Livro de visitas da Quinta do Tua ${ }^{573}$

\footnotetext{
${ }^{573}$ AHS — Fundo Cockburn's, Livro de visitas da Quinta do Tua, Cockburn's, 1935-1957. Cópia do original.
} 
J. H. Smith, pela sua ligação muito especial a esta histórica quinta, em cujo livro de visitas (1935-1957), escreveu o seu diário local sugestivamente ilustrado (ver figura, foto de um desenho seu), chegou mesmo a tornar-se personagem literária conforme o ilustram os dois poemas seguintes, de grande realismo simbólico, escritos na década de 1980, por António Cabral, conhecido escritor duriense e animador cultural de Vila Real.

Através de sua voz sarcástica e olhar crítico densos de simbologia, o poeta personifica em J. H. Smith, neste poema de 1989, a vocação negocial dos Smithes contrastando-a com os desapossados locais, assim representando as tensões historicamente latentes na relação produção-comércio do vinho do Porto, e na situação recorrente que comanda as frequentes transferências da propriedade no Douro.

\section{A quinta do Sr. Smith}

O trisavô do senhor Smith esteve no alto do Buçaco

E era menino bonito do Duque de Wellington.

Claro!: deu a volta a Portugal

e, como herdara do pai o fino tato

dos honrados comerciantes de Liverpool, comprou uma quinta do Alto Douro, por uma bagatela. [...]

Hoje o sr Smith é o dono da grande quinta:

setenta pipas de vinho de primeira,

além dum extenso olival, dois pomares,

um palacete, a habitação dos caseiros, os caseiros,

trabalhadores eventuais e outras árvores de fruto.

O Senhor Smith vem ali, de cinco em cinco anos,

segundo o velho hábito dos Smiths.

Assiste da janela a uma cargação,

Dizendo 'good!good!' enquanto bebe a delícia

Por copo alto (os cálices são para os portugueses)

ou, então, vai-se até um pomar,

enfiado numas botas amarelas

e ruminando dourados pensamentos.

Quando se despede, o senhor Smith não tem boa cara:

A quinta, hoje, não dar resultado.

Enfim, 'my friend', ser preciso vender a quinta.

A quinta do Sr. Smith 


\author{
A quinta é outra vez do Senhor Smith, \\ Setenta pipas de vinho de primeira, [...] \\ ...e outras árvores de fruto. \\ O Senhor Smith vendeu a Quinta, há umas décadas, \\ Quando o vinho do Porto deu para o torto, \\ mas agora com a subida galopante do precioso \\ néctar voltou a comprá-la. O Senhor Smith tem-te cá um faro! ${ }^{574}$
}

Nos inícios da década de 1940, a Quinta do Tua continuava ainda a produzir algum azeite, mas a produção de vinho tinha-se tornado dominante tendo entretanto subido para 20 pipas de vinho generoso por ano, embora a quinta possuísse já então armazéns, tonéis e cubas com capacidade para 500 pipas onde eram armazenados os vinhos de pequenos e médios proprietários de Carrazeda e de outras quintas próximas comprados pela Cockburn's, proprietária da quinta, que era já então um dos mais fortes compradores dos vinhos desta zona do Douro.

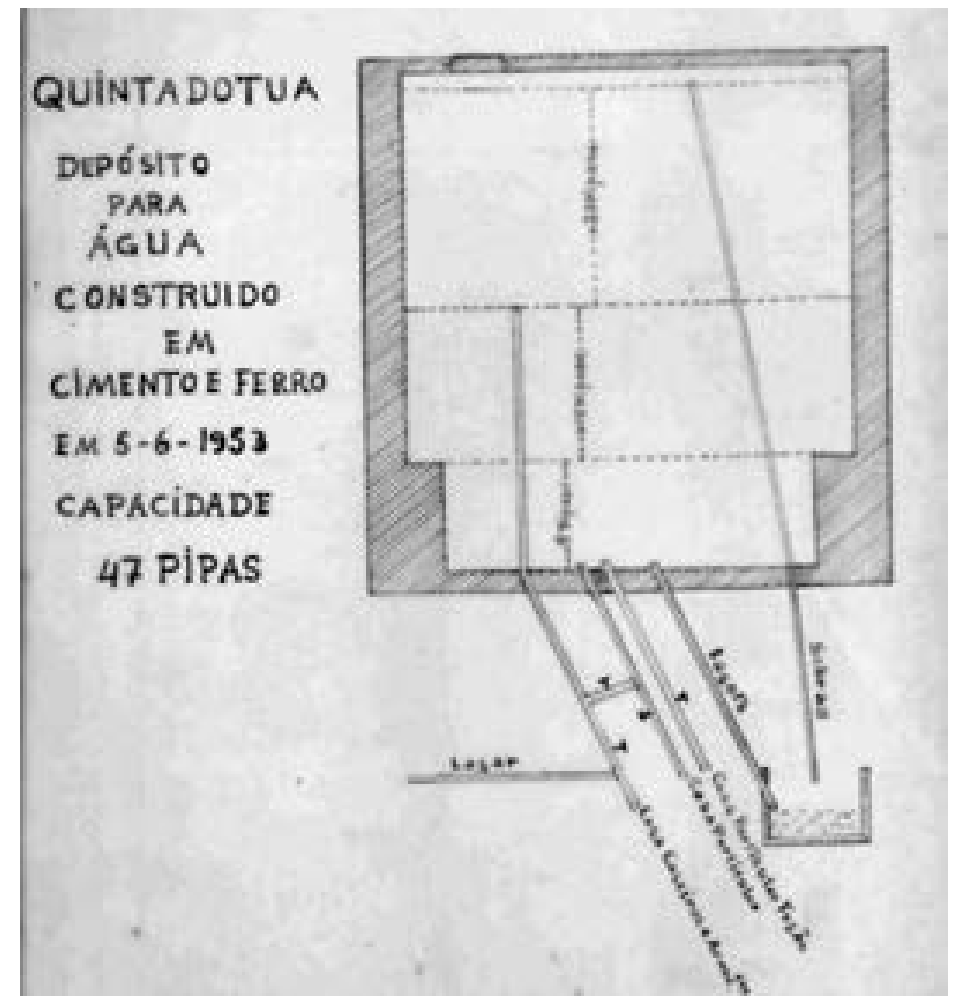

Fig. 153. Planta para construção de depósito de água — Quinta do Tua ${ }^{575}$

\footnotetext{
${ }^{574}$ CABRAL, 1999: 41-42.

${ }^{575}$ AHS - Fundo Cockburn's, Dossier, processos e documentação avulsa do fundo Cockburn's.
} 
Em 1973, a Cockburn's compra também a Quinta da Chousa que passou a constituir com a do Tua uma área de 60 ha, dos quais 29 ha são de vinha, com uma produção anual de 64 pipas de vinho generoso letra $\mathrm{A}$.

A adega da Quinta do Tua, um projeto desenvolvido a partir dos anos 1960, passou a ser, com as Quintas dos Canais e da Senhora da Ribeira, um dos 3 pontos principais de receção dos mostos e uvas compradas a médios e pequenos lavradores de Carrazeda de Ansiães.

Observe-se que a produção anual da Quinta dos Canais, de cerca de 600 pipas, inclui também produções vizinhas dos mostos de quintas de menor dimensão e uvas de pequenos produtores, e a Quinta da Senhora da Ribeira dispõe já de lagares robóticos de notável eficiência que simulam com proximidade a pisa $^{576}$.

\subsubsection{A Quinta da Chousa}

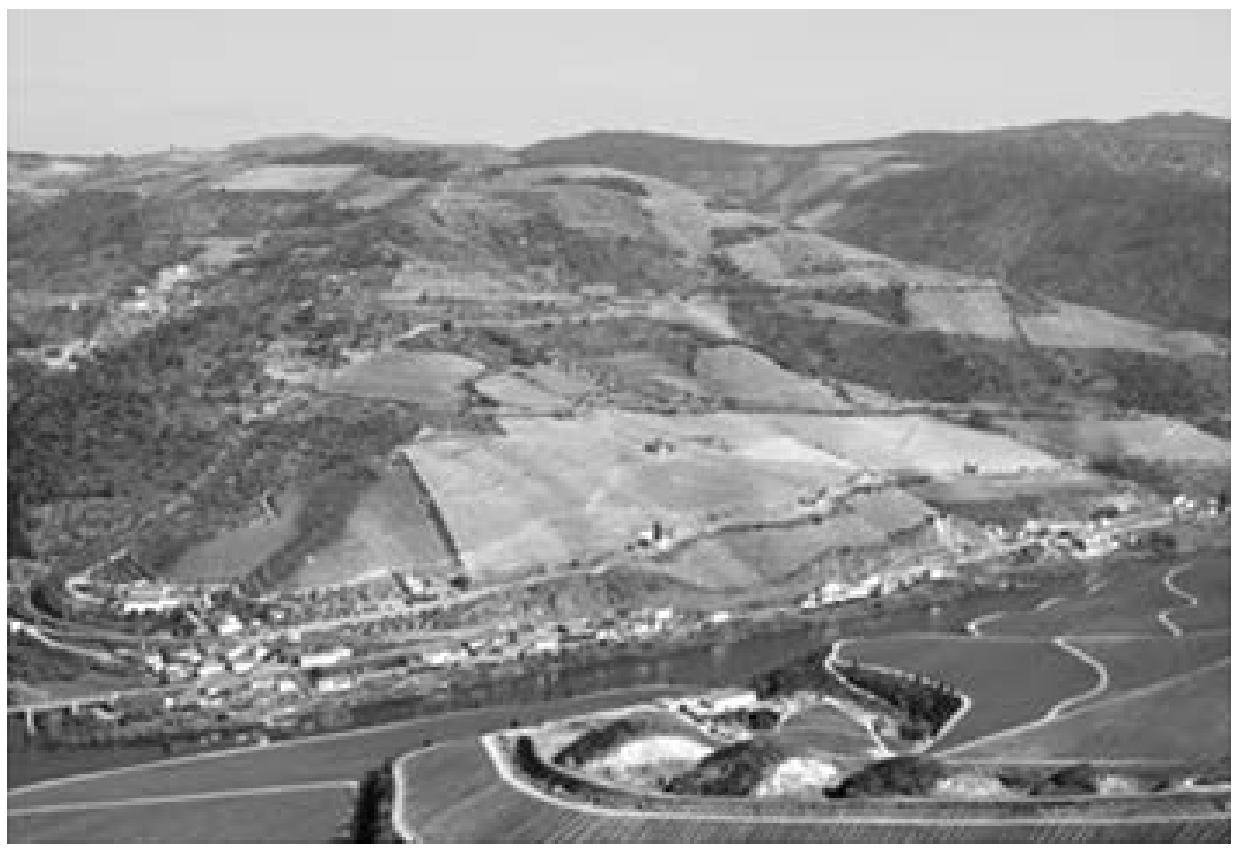

Fig. 154. Carrazeda de Ansiães — Foz Tua — Quinta da Chousa

Foto: Eng. A. Maria

Esta quinta provém da antiga e grande Quinta da Chousa Velha ou Chousa da Loba (Fiolhal/Foz Tua) que foi, entre os séculos XVII e XVIII, da histórica família dos Távoras, uma das mais importantes e conhecidas famílias da antiga nobreza portuguesa. A sua propriedade

\footnotetext{
${ }^{576}$ Entrevistas realizadas em abril de 2016, a J. M. L. e Eng. L. M, antigos funcionários da Cockburn’s com conhecimento e longa experiência nas propriedades da firma no Alto Douro e no concelho de Carrazeda.
} 
foi sendo sucessivamente parcelada, passando por herança para diversos descendentes desta família, não só herdeiros legítimos, como os Figueiredo e Távora de Tralhariz e o importante ramo dos Viscondes de Ervedosa, mas também através de dotes e testamentos feitos a filhos naturais, herdeiros ilegítimos, de que descendem os Figueiredos, os maiores proprietários do Fiolhal a cuja casa e amiga hospitalidade viria a ficar ligado, já no século XX, o notável estudioso de Trás-os-Montes, o erudito e bem conhecido Abade de Baçal (Bragança).

Registe-se o interesse e a pertinência histórica de se poder vir a estudar, mais em detalhe, essas relações da família dos Távora ${ }^{577}$ com esta quinta em análise e as consequências para a sua história, do processo que lhes foi movido pelo Marquês de Pombal, na segunda metade do século XVIII.

Na segunda metade do século XIX, «a quinta da Chousa que pertencia à Viscondessa de Ervedosa, com grandes oficinas e casa de nobre aspeto, encontrava-se em decadência, tendo produzido 40 pipas de vinhos finos e generosos de grande nomeada ${ }^{578}$.

$\mathrm{Na}$ década de 1870, as vinhas da Chousa atingidas pelo oídio, foram depois dizimadas pela filoxera, duas das terríveis doenças das videiras que destruíram os vinhedos durienses. A quinta, que produzira até então cerca de 40 pipas de vinho generoso, entrou em decadência. Vinte anos depois, em 1890, com uma produção reduzida a 1 pipa de vinho e mantendo-se num estado total de abandono, acabou por ser vendida pela viscondessa de Ervedosa a Francisco da Rocha Leão, descendente de António da Rocha Leão, dono de firma e armazém de vinhos de Vila Nova de Gaia, ilustre gaiense ligado à Comissão Administrativa Municipal, em que foi empossado em finais de maio de 1834, aquando da criação do concelho e município de Gaia.

A partir de 1891, este novo proprietário da Quinta da Chousa que, além de vinha, tinha ainda olival, laranjeiras e outras árvores de fruta, iria recuperá-la, completamente, com o trabalho de numerosos galegos. Mandou construir novos armazéns e um pequeno chalé residencial, num morro donde se avistava toda a propriedade e ordenou que se procedesse aos trabalhos de replantação das vinhas com novos bacelos.

Alguns dos traços então mais significativos e características desta quinta são-nos assim descritos por Manuel Monteiro ${ }^{579}$ :

a quinta da Chousa que foi da Viscondessa de S. Jorge é do Sr. Francisco da Rocha Leão, desde 1890. As edificações do tempo daquela titular desapareceram todas com o estabelecimento dos caminhos-de-ferro do Douro e do Tua a Mirandela [...].

\footnotetext{
${ }^{577}$ Os Távoras, condes de S. João da Pesqueira e cumulativamente marqueses, todos eles figuras de grande destaque, em Portugal e na administração do Império Português, sobretudo na Índia, eram senhores de grandes palácios e avultados bens em Mirandela, Mogadouro e mais terras de Trás-os-Montes e do país, com grande poder, privilégios e influência na Corte portuguesa até meados do século XVIII, quando o célebre ministro de D. José I, Sebastião José de Carvalho e Melo (Marquês de Pombal), incrimina, num processo que ficou dramaticamente célebre, esta importante e nobre família, acusando-a de envolvimento no atentado regicida de 3 de setembro de 1758, numa estratégia política de afastamento da poderosa nobreza tradicional palaciana, grupo rival no poder da época.

${ }^{578}$ VILA MAIOR, 1876: 109.

${ }^{579}$ MONTEIRO, 1911.
} 
A entrada faz-se por um portal de ferro junto dos novos e solidíssimos lagares e armazéns que têm capacidade para mais de 500 pipas de vinho e são construídos cerca da linha férrea. [...] O Sr. Rocha Leão é um dos mais eméritos provadores de vinhos é é um dos proprietários que também radicada afeição ganhou ao Douro - a lendária terra da ventura que hoje é um couto de negra miséria.

A sua quinta é limitada ao oriente pela do Zimbro e ao poente pela dos Ingleses, abrange cinco cerros e três vales e sobe desde a fímbria da água até às cristas e arestas daqueles; cinde-a a via férrea e o macadame que leva a Carrazeda.

A replantação da vinha começou em 1891 no morro central, que é o mais cultivado, alargando-se depois aos adjacentes e produzindo já meia centena de pipas de vinho de primeira qualidade. [...] De resto, não só pela boa exposição da quinta, mas também pela especial circunstância de nesta se conjuntar a rocha eruptiva com a metamórfica, os seus produtos são dos mais seletos da terra duriense ${ }^{580}$.

Depois desta profunda reforma, a Quinta da Chousa, embora com uma área bastante mais reduzida, passou a produzir, no início da I República, à volta de 80 pipas de vinho generoso.

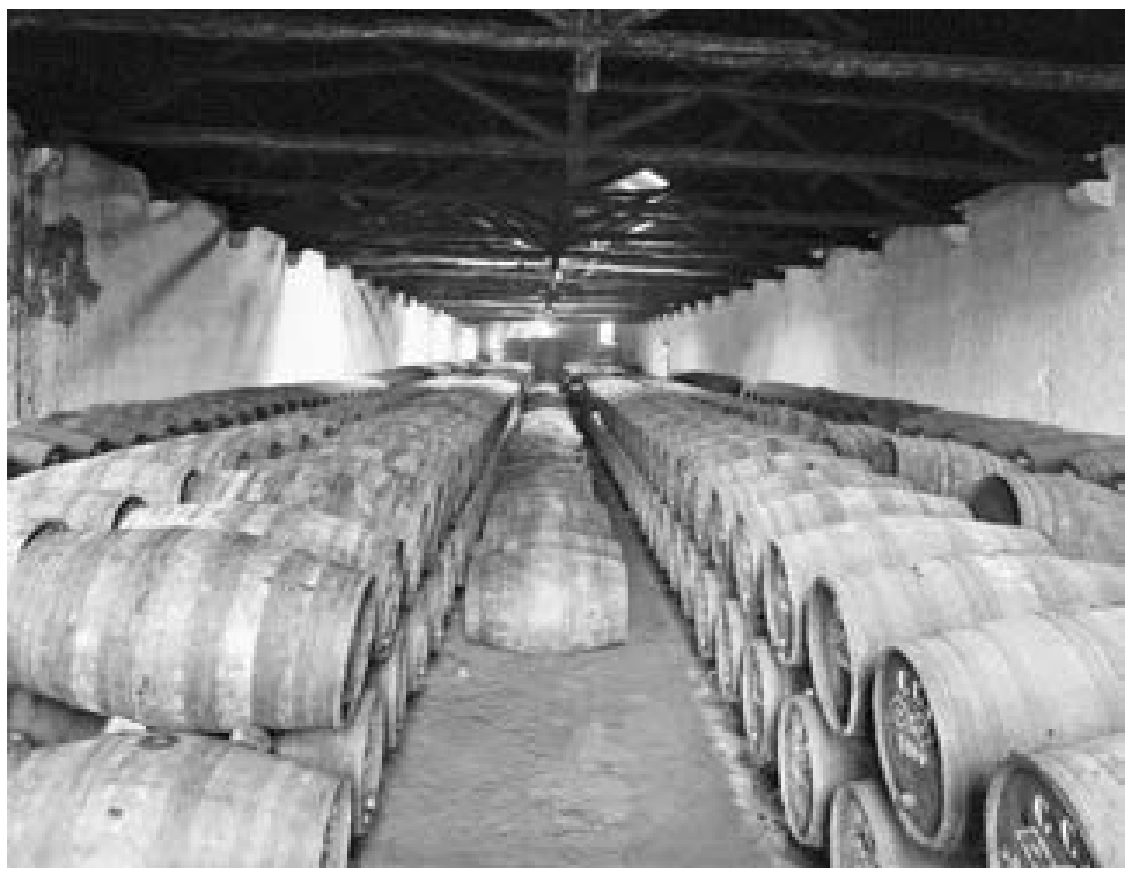

Fig. 155. Foto de Emílio Biel — Caves António da Rocha Leão, V. N. Gaia [1875-1915] ${ }^{581}$

\footnotetext{
${ }^{580}$ MONTEIRO, 1911: 4-16; 9-30; 78-82.

${ }^{581}$ Creditação (C) Centro Português de Fotografia/DGLAB/SEC, PT/CPF/BIE/000006.
} 
Por essa altura, a Quinta da Chousa, com uma área de 25 a 30 ha mas uma produção vitícola em franca recuperação, era já considerada uma quinta modelo, com casa principal de habitação, casa para feitor, cardenho, forja, lagares e adega de vinho instalados em edifícios próprios, encontrando-se equipada com iluminação a acetilene, na forja, e água canalizada de mina, na casa principal.

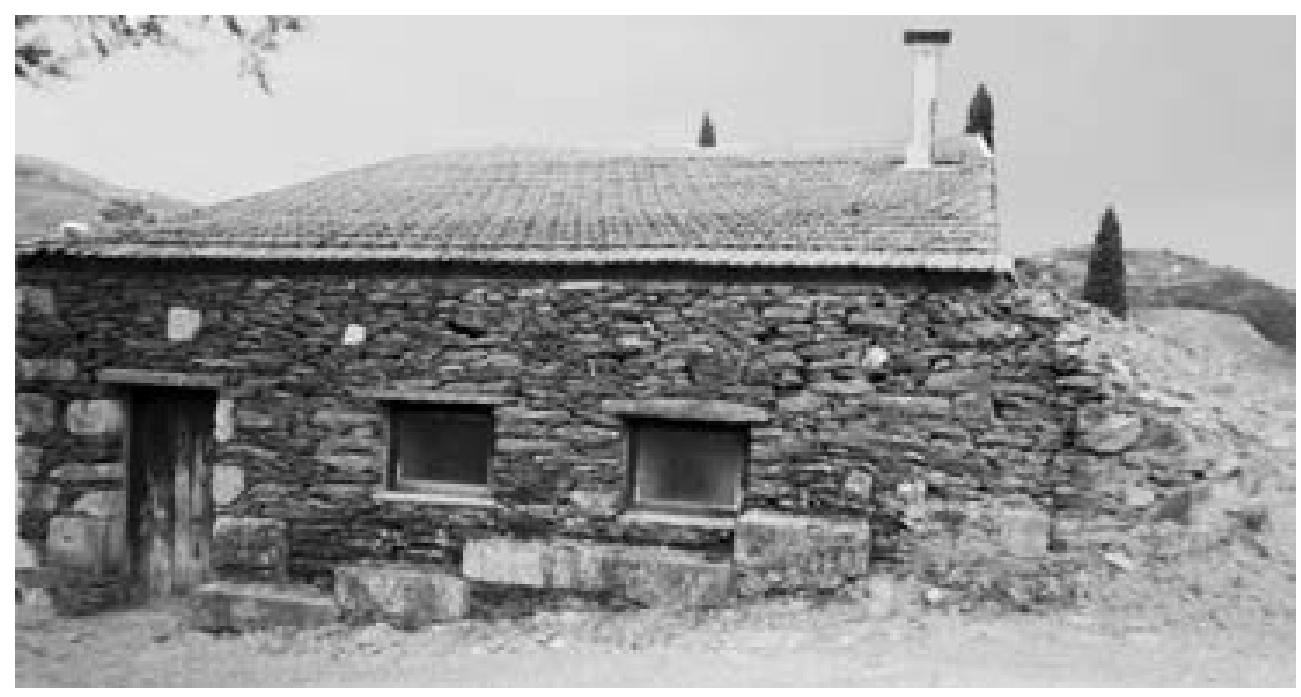

Fig. 156. Quinta da Chousa — armazém recentemente recuperado Fonte: Fotografia J. J. S.

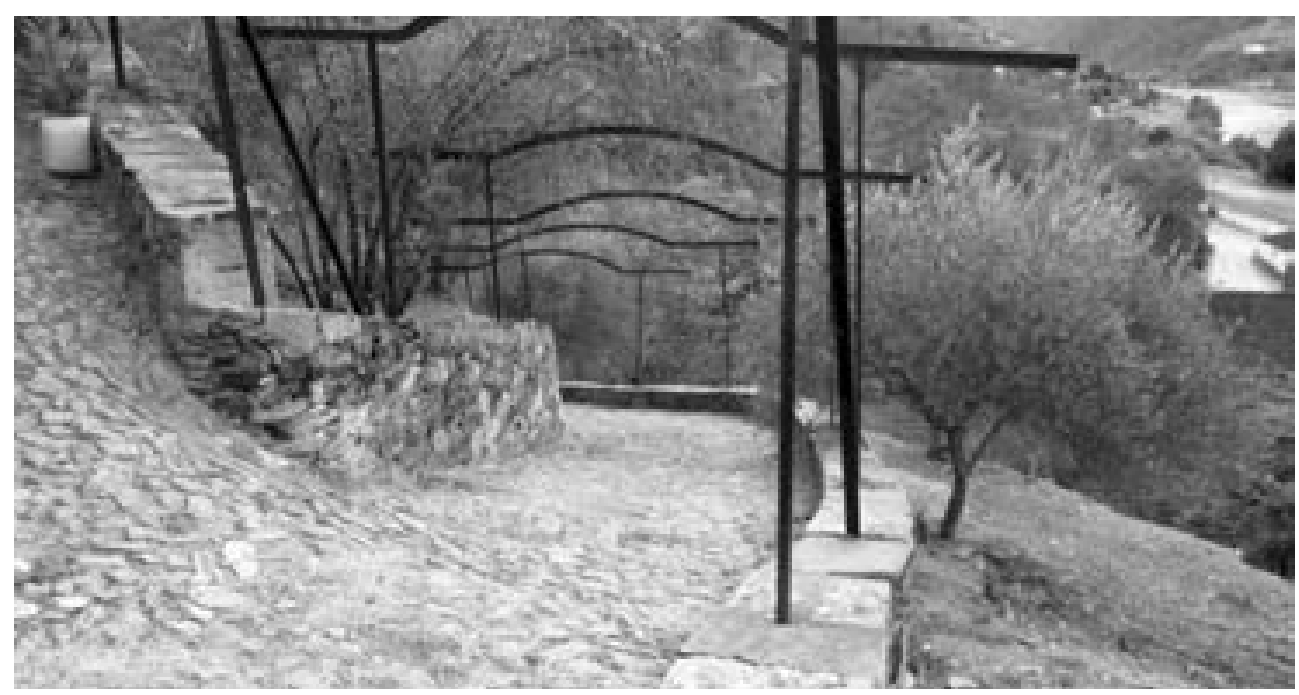

Fig. 157. Quinta da Chousa - passagem com ramada na encosta do Douro Fonte: Fotografia J. J. S. 


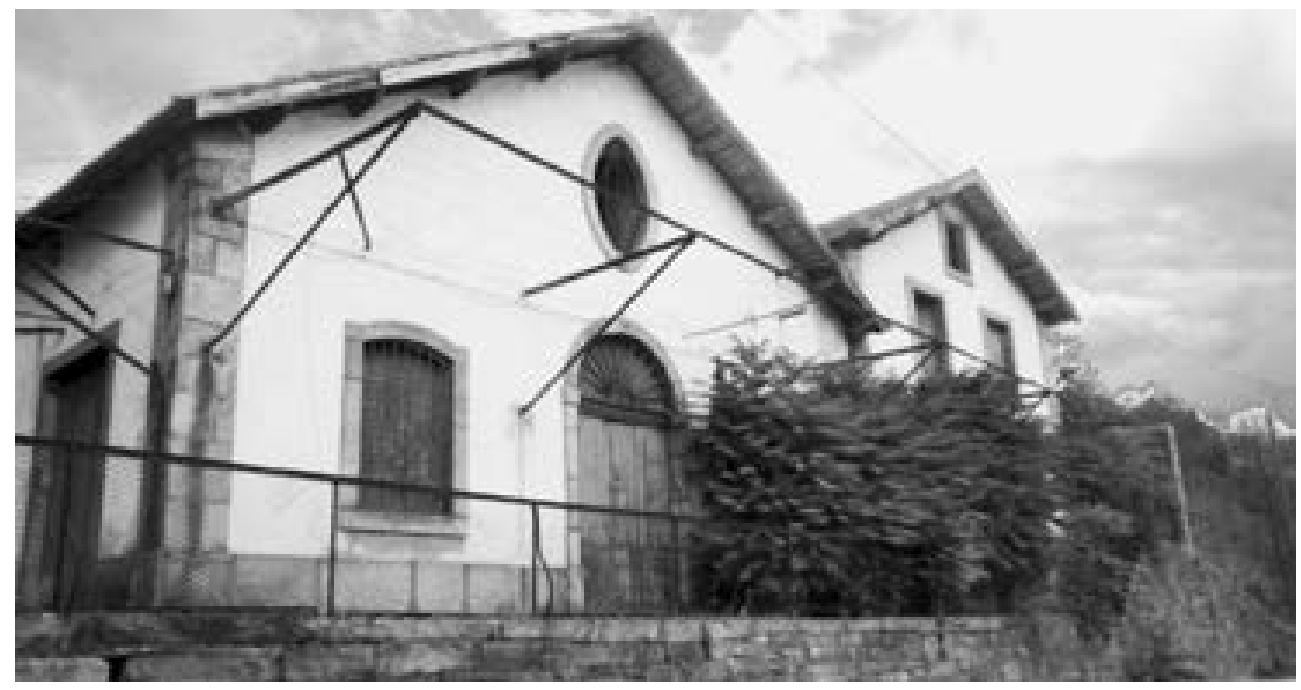

Fig. 158. Quinta da Chousa — Armazéns antigos, junto à Linha do Douro Fonte: Fotografia J. J. S.

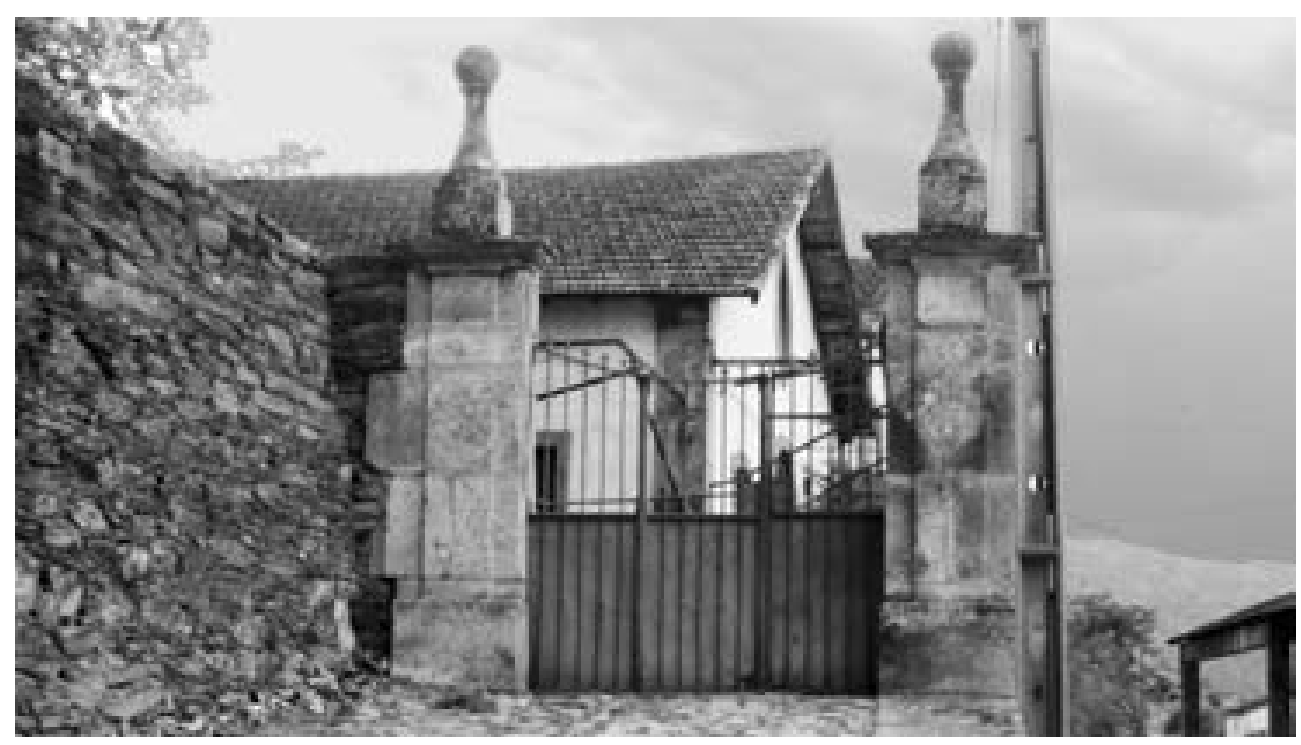

Fig. 159. Quinta da Chousa — Portão de entrada, acesso às casas e armazéns antigos Fonte: Fotografia J. J. S.

Pertencendo já a Quinta da Chousa a António de Castro, a sua produção descera para uma média de 11 pipas de vinho e 1 pipa de azeite, em 1938. Nessa altura, com uma área de cerca de 78 ha, reduzida pela construção da estrada de ligação entre Vila Flor-Carrazeda-Alijó, a quinta era constituída por «vinha, 550 oliveiras, 60 sobreiros, laranjeiras e amendoeiras, casa 
de habitação com quatro divisões no $1 .^{\circ}$ andar, oito divisões no $2 .^{\circ}$ andar e uma estufa, cozinha térrea e quatro divisões, armazém de vinhos e lagares para fabricar vinhos ${ }^{582}$.

Nos anos 1960, a Chousa estendia-se ainda por cinco montes e três vales, entre os rios Douro e Tua, confinando a Norte e Nascente com as Quintas do Tua e do Zimbro, continuava a pertencer aos herdeiros de António de Castro e encontrava-se, novamente, em decadência.

Acabou por ser vendida, em 1973, à firma Cockburn's que viria a substituir os seus velhos socalcos por patamares mecanizados, agregando a sua propriedade e administração às da Quinta do Tua.

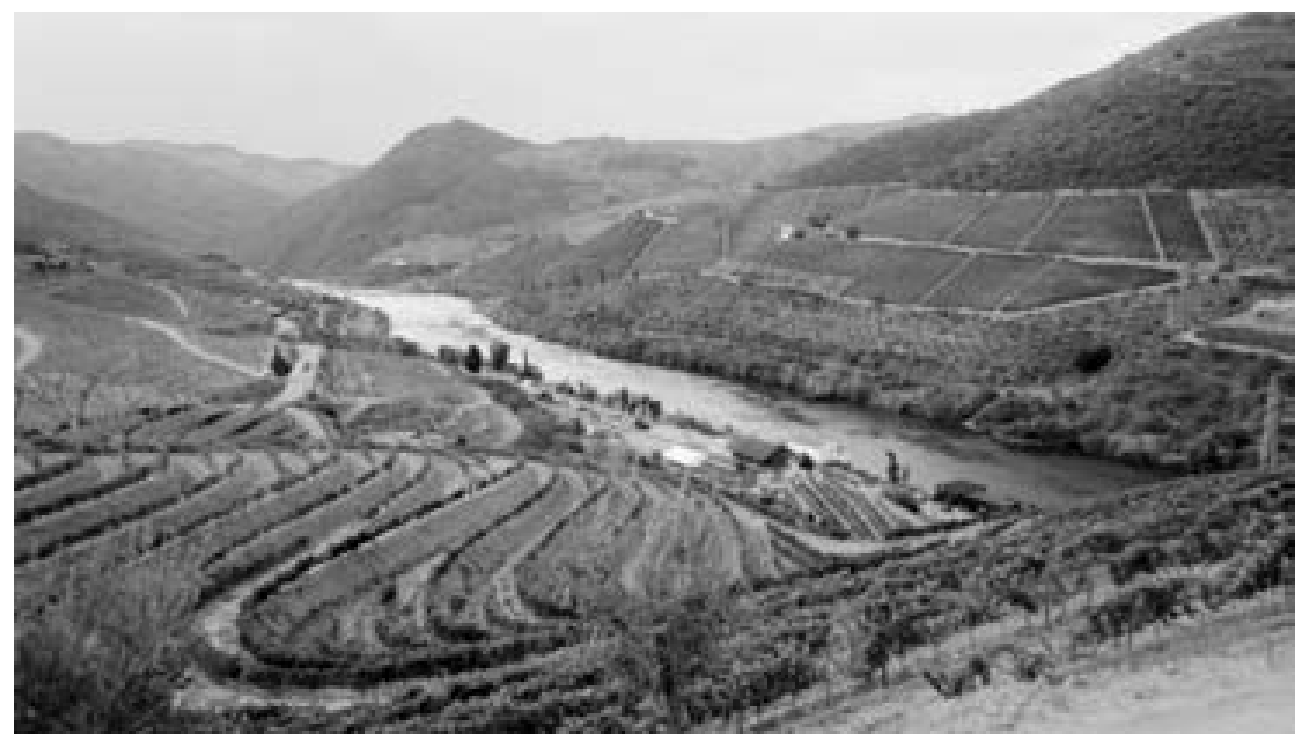

Fig. 160. Quinta da Chousa — Novas plantações com diversas armações do terreno — Foz Tua Fonte: Fotografia J. J. S.

O panorama que se acabou de traçar neste longo capítulo, o mais extenso do presente livro, sobre a história e evolução de um conjunto muito significativo e representativo de importantes e históricas quintas durienses localizadas no território concelhio de Carrazeda de Ansiães, num universo de 1.120 produtores vitícolas, em $2016^{583}$, permite ilustrar a importância tridimensional destas propriedades vinhateiras durienses: quer como unidades de povoamento rural, exploração agrária e coesão territorial e sócio-histórica, constitutivas de um património (i)material e de uma memória coletiva; quer pela posição socioeconómica e cultural estratégica que detêm na região; quer enquanto vetores de definição, liderança e promoção do desenvolvimento regional.

\footnotetext{
${ }^{582}$ MORAIS, 2006: 203.

${ }^{583}$ Dados fornecidos pelo IVDP em 2017, relativos a exploradores com autorização de produção válida no concelho de Carrazeda, em mosto generoso, no ano de 2016.
} 
Como bem sublinha Gaspar Martins Pereira, o maior estudioso do Douro na atualidade, as quintas durienses são entidades polifuncionais e multifacetadas:

Unidades vinhateiras típicas do Alto Douro, as quintas correspondem, no entanto, a uma realidade territorial relativamente excecional. De facto, entre as cerca de quarenta mil explorações vitícolas do Douro, as quintas representam apenas uma pequeníssima parte, da ordem das centenas. Mas a sua estrutura, como unidades de exploração vitícola integrada (reunindo vinhas, centros de vinificação e armazenagem de vinhos, casa de proprietário el ou caseiro e trabalhadores; por vezes, também, azenha de azeite, capela, etc.), a dimensão frequentemente média ou grande [...] e a vocação de comercialização dos respetivos vinhos conferem às quintas um lugar socioeconómico estratégico na viticultura duriense ${ }^{584}$.

O destaque particular que se deu aqui ao estudo e reconstituição sócio-histórica de uma constelação de oito quintas durienses localizadas na fronteira das sub-regiões de Cima Corgo e Douro Superior, evidenciando características dominantes da sua longa história e tradição, legado patrimonial e cultural, modernidade sociotécnica e económica e vitalidade vitivinícola e relevando a sua singularidade diferenciadora e pioneira, em certos aspetos e épocas, de considerável relevância para um conhecimento mais sólido da Região do Douro, permite colmatar uma lacuna existente sobre este tema, ao contribuir para esclarecer uma zona de sombra no estudo das quintas do Douro.

\footnotetext{
${ }^{584}$ PEREIRA, 2013: 10.
} 


\section{CAPÍTULO 8. EMPRESAS ESTRANGEIRAS E NACIONAIS NO NEGÓCIO DO VINHO DO PORTO EM CARRAZEDA DE ANSIÃES}

Um facto, único no mundo, se verifica no Douro, onde o mesmo cacho de uvas, se partido ao meio, permite produzir, em simultâneo, vinho tratado ou generoso e vinho de consumo ou de mesa, conforme salienta um dos mais antigos e conhecidos empresários de ascendência estrangeira na Região Duriense, Cristiano van Zeller, atual dono da Van Zellers \& Co. ${ }^{585}$.

Segundo o mesmo empresário, descendente de uma família tradicional duriense de origem flamenga, a produção global de vinho na região do Douro ronda, atualmente, as 280.000 pipas anuais, das quais, 120.000 são de vinho beneficiado/vinho do Porto. Nos últimos 20 anos, tem-se incentivado muito a produção e comercialização dos vinhos DOC (denominação de origem controlada) Douro que têm crescido mais, em termos de volume, que o vinho do Porto, o que veio permitir rentabilizar cerca de 160.000 litros anuais que eram praticamente desperdiçados em termos comerciais ${ }^{586}$.

Idêntica tendência se verifica também no concelho de Carrazeda de Ansiães, cujo indicador agrícola de «produção vinícola declarada em mosto pelo produtor ${ }^{587}$ permite constatar um aumento recente de 2.501 hectolitros na produção, em 2010-2013.

Algumas empresas nacionais e estrangeiras que se especializaram no comércio de grande volume de vinhos não possuem as suas próprias quintas, mas fornecem-se de terceiros, comprando uvas a pequenos agricultores e vinhos a intermediários ou a adegas cooperativas.

Mas há, e houve também, conhecidas casas exportadoras e produtoras de vinho do Porto, como a Taylor's, a Sandeman, a Fonseca, a Croft, ou as maiores empresas familiares estrangeiras do Douro de que a Symington é hoje o melhor exemplo, que foram ou são ainda empresas proprietárias de importantes quintas e compram uvas e vinho a outras propriedades privadas com as quais desenvolveram relações ao longo dos anos.

Todavia, não deixa de se verificar na história das empresas vitivinícolas do Douro e do vinho do Porto, mesmo nas antigas empresas familiares de estrangeiros, uma enorme dificuldade em manterem-se nas mesmas mãos, por tempo continuado, devido a diversas vicissitudes (falências, mortes, desentendimentos em heranças, antagonismos, etc.).

Excetuam-se alguns casos mais raros, como a «Symington Family Estates», que tendo conseguido manter um equilíbrio familiar a vários níveis, é atualmente o maior grupo empresarial do Douro.

\footnotetext{
${ }^{585}$ Intervenção oral de Cristiano van Zeller nas 4. ${ }^{a s}$ Conferências do Museu de Lamego/CITCEM: Vindos de longe. Estrangeiros no Douro, 2016.

${ }^{586}$ Intervenção oral de Paul Symington nas $4 .{ }^{a s}$ Conferências do Museu de Lamego/CITCEM: Vindos de longe. Estrangeiros no Douro, 2016.

${ }^{587}$ Dados INE, 2009 e 2012.
} 
Como salienta Paul Symington, um dos principais objetivos dos grandes empresários produtores é criar «vinhos míticos» (o Cockburn 1908, o estilo Cockburn 1932 ou o Vintage 1963 ... ) para «criar valor na Região», realidade que complica muito a tarefa do historiador ${ }^{588}$.

Partilhamos inteiramente desta prevenção oportuna de Paul Symington, no que se refere designadamente ao estudo das empresas do vinho do Porto, as quais, em sua densidade histórica e ancoragem familiar, exigem uma análise que atenda à diversidade de «mundos ou lógicas» económico-sociais em cujos processos justificativos de ação operam valores de grandeza próprios a cada uma dessas «lógicas»: doméstica assente no valor da confiança; industrial, baseada na grandeza da eficácia e eficiência; mercantil assente na grandeza da oportunidade; cívica norteada por valores da ética; e de inspiração inspirada na grandeza da criatividade $e^{59}$.

Não obstante se não possa seguir aqui esse quadro teórico heterogéneo, apenas enunciado por razões de economia de escrita, nem por isso se deixa de o subentender, na breve aproximação histórica que se faz neste capítulo a um grupo significativo de antigas empresas estrangeiras do negócio do vinho do Porto com protagonismo de relevo no concelho de Carrazeda de Ansiães e as quais se encontram hoje incorporadas no Grupo Symington Family. Aliás, este grande grupo económico, ao ter absorvido, historicamente, sem o dissolver, um significativo universo de empresas anteriores do mesmo ramo de atividade, pode considerar-se como um expoente e objeto privilegiado de estudo no Douro.

Para além da predominante presença no Douro Vinhateiro do capital e know-how mercantil ilustrada pelo peso dominante histórico e atual dessas empresas, fator significativo de dinâmica e desenvolvimento sustentado da comercialização e produção vitivinícola em Carrazeda de Ansiães, é de considerar ainda a iniciativa empresarial local na fileira dos vinhos, setor económico de especial relevo, o que se faz, destacando dois exemplos concretos mais expressivos e recentes: a empresa Grambeira de produtores/exportadores concelhios de Vinhos DOC Douro, criada na década de 1990; e, fundada em data posterior, a Adega de Vinificação Douro Ansiães, empreendimento de jovem enólogo do concelho, ex-trabalhador da Symington Family, pelo que com a apresentação destas duas empresas encerra-se o presente capítulo.

\subsection{ANTIGAS FIRMAS: SILVA \& COSENS, DOW'S, WARRE E MARTINEZ GASSIOT}

Como se viu anteriormente, na introdução e aproximação conjuntural às empresas e quintas durienses em Carrazeda de Ansiães (Capítulo 7), foram várias as firmas que operaram na comercialização de vinho do Porto neste concelho. Contam-se, porém, em muito menor número as empresas de vinho do Porto que aqui foram simultaneamente negociantes e produtoras de vinhos e donas de antigas e importantes propriedades vitícolas. Nestas acabaria por destacar-se a Cockburn's, pelo seu especial protagonismo histórico na Região do Douro e, em

\footnotetext{
${ }^{588}$ ATAS das 4. ${ }^{\text {as }}$ Conferências do Museu de Lamego/CITCEM: Vindos de longe. Estrangeiros no Douro, 2016. Disponível online em www.museudelamego.pt.

${ }^{589}$ LAGE, 2010a: 339-360.
} 
particular, nesta zona de fronteira entre Cima Corgo e Douro Superior que adquiriu maior relevância no período pós-filoxérico, finais de Oitocentos.

Os representantes da firma luso-britânica Silva \& Cosens, fundada em 1798, foram os primeiros a chegar, em 1877, a Ribalonga, antiga aldeia vinhateira de Carrazeda «grande região vinícola com vinhos melhores do que os do Sul», conforme reconhece Frederic J. Cobb, então administrador da Sandeman ${ }^{590}$. A empresa Silva \& Cosens, titular da célebre marca Dow's de vinho do Porto, foi outra firma de negócios de vinho do Porto a adquirir neste concelho quintas durienses: a da Senhora da Ribeira e a do Zimbro.

Justifica-se então uma apresentação à história institucional das empresas Silva \& Cosens, Dow's, Warre e Martinez Gassiot ${ }^{591}$, protagonistas históricas de relevo no negócio do vinho do Porto na Região do Douro, com particular importância na zona duriense de Carrazeda, que mantiveram ligações entre si e ou com a Cockburn's, encontrando-se, hoje, todas elas incorporadas no universo empresarial do Grupo Symington.

\subsubsection{Silva \& Cosens}

A história da Silva \& Cosens é pouco comum entre todas as grandes casas do Porto. Tudo começou em 1798, quando Bruno Evaristo Ferreira da Silva ${ }^{592}$, um comerciante portuense com grande visão para os negócios, se instalou em Londres, de onde importava vinho e outras mercadorias de Portugal, pondo fim ao monopólio até então praticamente detido por mercadores ingleses. Casou-se com uma senhora inglesa ${ }^{593}$ e foi rapidamente assimilado pela sociedade de Londres, cidade onde os seus vinhos gozavam de boa reputação. Contudo, as guerras entre a Inglaterra e a França punham os seus negócios em risco pelo que Bruno da Silva solicitou «letters of marque», uma autorização real para equipar um navio mercante, de modo a garantir a passagem segura do seu vinho desde o Porto até Bristol e Londres. A sua empresa foi a única casa de vinho do Porto a transportar a sua preciosa carga de barris sob a própria proteção armada através do traiçoeiro Golfo da Biscaia, durante um período em que as firmas menos audaciosas viram as suas vendas diminuir. Após a morte de Bruno da Silva, em 1850, o negócio foi continuado pelo seu filho, John J. da Silva (falecido em 1867), que, em 1862, trouxe para a parceria Frederick William Cosens, um grande negociante de vinhos e exportador de sherry (de Espanha para Glasgow), e notável bibliófilo ${ }^{594}$. Será a partir desta data que o nome da empresa passa a Silva \& Cosens. Posteriormente, Frederick e Edward (filho de John J. da Silva) tornaram-se os parceiros ativos

\footnotetext{
${ }^{590}$ BENNETT, 2010: 280-334.

${ }^{591}$ A história administrativa/familiar/biográfica destas quatro empresas foi elaborada para efeitos de descrição arquivística pela arquivista e investigadora do CITCEM-FLUP, Mestre Ana Paula Montes Leal que nos facultou o seu acesso e permissão de publicação, generosidade intelectual que se agradece. Essa informação pode ser consulta no Anexo VIII.

${ }^{592}$ GEVP, 1948. Em 1844, a firma Bruno Silva \& Co. está ativa no Porto (FORRESTER, 1846).

${ }^{593}$ SELLERS, 1899.

${ }^{594}$ Cf. <http://exlibrisbibliofilia.blogspot.pt/2012/06/frederick-william-cosens.html>. [Consulta realizada em 26/05/2014].
} 
da Silva \& Cosens. Edward da Silva herdou a capacidade de negócio de seu avô e a empresa continuou a prosperar. Conta a história que Edward foi uma figura muito respeitada no comércio de vinho em Londres, tendo sido um dos fundadores da Wine Trade Benevolent Society ${ }^{595}$, associação que sobrevive até hoje como a principal organização britânica de comércio de vinhos ${ }^{596}$.

Com a contínua expansão da empresa, Edward da Silva e Frederick Cosens juntaram-se a George Acheson Warre («GAW»), o único filho varão de George Warre (sócio da Warre Brothers). George Acheson Warre (1842-1913), que trabalhava na Warre's, mas saiu porque se desentendeu com os sócios Noble e Murat ${ }^{597}$, entrou como sócio da Silva \& Cosens em 1868 e tornou-se a sua força motriz em Portugal. Em 1877, a Silva \& Cosens fundiu-se com outra empresa líder do setor do vinho do Porto, a Dow \& Co. Embora menor do que Silva \& Cosens, a Dow \& Co. era um produtor de Porto altamente considerado, com particular boa reputação pelos seus Portos Vintage e, quando as duas empresas foram fundidas, o nome Dow's foi mantido como marca para os vinhos de exportação ${ }^{598}$. Em 1948, é pela marca Dow’s que os vinhos da empresa são conhecidos.

Diz-nos Sellers que, em 1889, à morte de seu pai (Frederick Cosens), Philip John Cosens foi admitido como sócio e, a 1 de julho de 1893, Roderick, o último membro da família Dow a pertencer à firma, também se juntou à casa. Este filho de James Ramsay Dow, que faleceu em 1933, em Inglaterra, manteve-se na sociedade até 1907, ano em que a Silva \& Cosens se inscreveu na Alfândega do Porto sob o n. ${ }^{\circ} 82^{599}$.

Manuel Monteiro ${ }^{600}$ refere que a Silva \& Cosens tinha uma tanoaria a vapor em Gaia e, adjacente, uma serralharia. As suas instalações (modelares e atraindo inúmeros visitantes estrangeiros) tinham «um dínamo gerador de eletricidade» que abastecia todos os seus edifícios dos armazéns da Boavista ${ }^{601}$. Terá sido a única firma estrangeira visitada pelo Rei D. Manuel II, em 1908. Num terreiro contíguo aos armazéns, o rei plantou um carvalho, com a placa: «Silva \& Cosens. The King's Oak, 28-XI-1908».

Em 1912, George Warre resolveu regressar a Inglaterra e convidou Andrew James Symington $^{602}$ a gerir o negócio em Portugal, incluindo as três quintas no Douro - Bomfim, Zimbro e Senhora da Ribeira, situadas, a primeira, no Pinhão, concelho de Alijó, e as duas seguintes nas aldeias de Foz Tua e Seixo, em Carrazeda de Ansiães e os armazéns em Gaia. Após a morte de George Warre, em 1913, deu-se uma troca de posições em que A. J. Symington conseguiu

\footnotetext{
${ }^{595}$ Cf. $<$ http://www.thebenevolent.org.uk/about-us/>. [Consulta realizada em 26.05.2014].

${ }^{596}$ Edward da Silva foi o presidente da Benevolent a partir de 1892, cargo que ocupou durante muitos anos.

${ }^{597}$ MAYSON, 1998.

${ }^{598}$ MONTEIRO, 1911. Ver também: GEVP, 1948; Separata «Douro» relativa à Dow’s: «'Silva \& Cosens' Oporto Proprietors of the 'Dow' Brand».

${ }^{599}$ PINTÃO \& CABRAL, 2011.

${ }^{600}$ MONTEIRO, 1911.

${ }^{601}$ Os «armazéns da Boavista» são os edifícios onde atualmente está instalada a sede da Symington.

${ }^{602}$ Andrew James Symington («A. J.»), nascido na Escócia em 1863, chegou ao Porto em 1882, vindo de Glasgow, tendo começado por trabalhar, por um breve período de tempo, na empresa têxtil da família Graham.
} 
30\% de sociedade na Dow's, mantendo-se sócio da Warre’s. Em 1919, os gémeos Symington, Ron e John, filhos de A. J., juntaram-se ao pai no negócio: Ron na Dow's e John na Warre's. Não obstante, a família Warre continuou a controlar o negócio da Dow's, em Londres ${ }^{603}$, e as presidências da empresa foram ocupadas sucessivamente por George Francis/ «Ginger», Amyas, Philip e Francis. Só em 1961 se deu uma alteração do status quo, quando a família Symington adquiriu o controlo total da empresa. Segundo a descrição da empresa de 1948, são propriedade da firma Silva \& Cosens as Quintas do Bomfim, Zimbro e Senhora da Ribeira. Através dos documentos da Silva \& Cosens ${ }^{604}$ é possível perceber que, antes de serem compradas, as quintas estiveram arrendadas à empresa.

\subsubsection{Warre \& Co}

«A empresa que originou a Warre's foi criada em 1670. Dois ingleses, William Burgoyne e John Jackson abriram escritórios em Portugal, Viana do Castelo» ${ }^{605}$, como Burgoyne \& Jackson — inicialmente uma empresa de comércio geral, com exportação de vinhos, azeite e frutas, e importação de bacalhau seco e lanifícios ingleses. Com o tempo, a empresa foi admitindo novos parceiros e a sua designação alterando-se em conformidade; em 1718, a casa girava como John Clark ${ }^{606}$; em seguida, em 1723, era conhecida como Clark \& Thornton e, final-

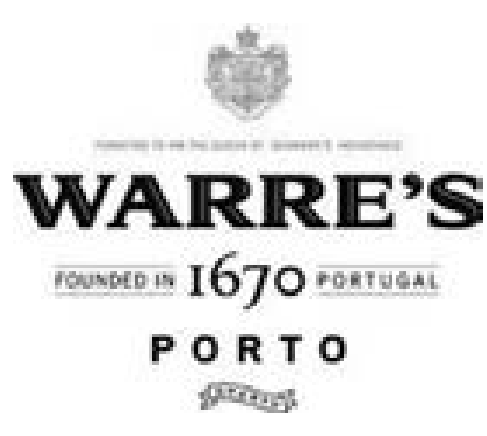

Fig. 161 mente, em 1729, com a chegada do primeiro William Warre $^{607}$ a Portugal, adotou os nomes «Srs. Clark, Thornton \& Warre». Passou, finalmente, em 1777, a Warre \& Sons, após mais algumas entradas e saídas de sócios. A evolução da empresa indicada no Álbum... do GEVP (1948) é a seguinte:

\footnotetext{
${ }^{603}$ Este acordo em que a família Warre era responsável pelas vendas, em Londres, enquanto os Symington eram responsáveis pela produção, no Douro e em Gaia, manteve-se até 1961, ano em que a família Symington adquire o controlo total.

${ }^{604}$ Arquivo Histórico Symington.

${ }^{605}$ GUIMARÃES, 2001.

${ }^{606}$ Segundo MAYSON, 1998, foi John Clark quem trouxe o negócio de Viana para o Porto. SELLERS, 1899, por sua vez, diz que John Clark era casado com Prudence Burgoyne, eventualmente explicando a sua ligação à firma original, Burgoyne \& Jackson, sabendo-se que Clark está no Porto desde 1695, ligado ao negócio dos vinhos e estabelecido, em nome individual, na Rua Nova (ver CARDOSO, 2004: 161-180).

${ }^{607}$ William Warre (i)(1706-1773) nasceu na Índia, onde seus pais e avós eram membros da Companhia das Índias Orientais, aí há muito estabelecida. Em 1745, casou-se com Elizabeth Whitehead, irmã de John Whitehead (parentesco não confirmado por Sellers), o cônsul britânico responsável pela conceção e construção da Casa da Feitoria Inglesa (1790) no Porto. O seu filho mais velho, também William Warre foi o cônsul da «Nação britânica» no Porto, no início do século XIX. O seu quinto filho, James Warre, uma figura proeminente no comércio do vinho do Porto durante 50 anos, foi o pai do mais ilustre membro da família, William Warre (1784-1853) que serviu como militar na Guerra Peninsular. (Disponível em <http://www.warre.com/section.php?id=1094>. [Consulta realizada em 16.06.2012]). O Porto Warre's Warrior Reserve é uma das marcas mais antigas, tendo vindo a ser, ininterruptamente, exportado, desde 1750.
} 


$$
\begin{aligned}
& 1718 \text { - John Clark } \\
& 1723 \text { - Clark \& Thornton } \\
& 1729 \text { - Clark, Thornton \& Warre } \\
& 1734 \text { - Clark, Warre \& Newby } \\
& 1743 \text { - Warre, Newby \& Bowman } \\
& 1749 \text { - Warre, Lesueur \& Trollope }{ }^{608} \\
& 1759 \text { - Warre, Lesueur \& Calvert } \\
& 1762 \text { - Warre, \& Calvert } \\
& 1777 \text { - Warre \& Sons }
\end{aligned}
$$

Até ao fim do século XVIII, a Warre's transformou-se numa das empresas líderes como é ilustrado pelos embarques totais de vinho do Porto em 1791. Neste ano, 21 empresas exportaram 32.670 pipas de vinho do Porto, contabilizando a Warre \& Sons 2.937 pipas, ou seja, cerca de $10 \%$ do total ${ }^{610}$.

William Warre (I) teve sete filhos, sendo o quinto, James Warre, uma figura destacada no comércio de vinho do Porto e pai de outro membro ilustre da família, William Warre (III) ${ }^{611}$, nascido no Porto (1784-1853), oficial do exército britânico, com papel importante nas Invasões Francesas (1808-1812), já que o seu conhecimento da língua e do país era um valor inestimável para seus comandantes, o Marechal de Campo Beresford e o duque de Wellington, acabando por atingir o posto de Tenente-General, com vários louvores por galhardia e títulos, em Portugal e Inglaterra, pela sua contribuição na independência de Portugal.

Em 1854, a Warre \& Cia. aparece com morada na Rua dos Ingleses, 51, que partilha com a C. H. Noble \& Murat ${ }^{612}$, mas, em 1881, está já na Quinta da Boavista (V. N. de Gaia), tal como a Silva \& Cosens e a Dow's. Em 1868, George Acheson Warre ${ }^{613}$ desentendeu-se com os sócios Noble e Murat e abandonou a Warre's ${ }^{614}$ para se juntar a Edward da Silva e Frederick Cosens, tornando-se o dínamo da Silva \& Cosens em Portugal. Em 1877, a Silva \& Cosens fundiu-se com outra empresa líder do vinho do Porto, a Dow \& Co., de James Ramsay Dow. A astúcia financeira de Edward da Silva, a força motriz de George A. Warre e a longa experiência e

\footnotetext{
${ }^{608}$ Thomas Trollope e Daniel Lesueur: Trollope casou com Amelia Page em 1750 (SELLERS, 1899: 227).

${ }^{609}$ John Delaforce (DELAFORCE, 1983) refere que um dos signatários do contrato de arrendamento da casa da Feitoria no tempo do Cônsul Whitehead (c. 1756) era Charles Page, da firma Noble \& Murat; outro era William Calvert, da Warre \& Co. (p. 19). SELLERS frisa que os Warre estão ligados aos Page e aos Noble por casamentos (p. 174). Também diz que Charles H. Noble estava ligado por casamento aos Graham, aos Warre e aos Page (p. 228). ${ }^{610}$ GEVP, 1948.

${ }^{611}$ William Warre (II) era seu tio. Quando William Warre (III) foi trabalhar para a empresa, os sócios eram o seu pai, James, e o seu tio, George (os Noble e os Murat devem ter chegado um pouco mais tarde).

${ }^{612}$ Conf. «Lista de negociantes estrangeiros residentes no Porto em 1854», In Almanaque comercial, judicial e administrativo do Porto e seu distrito para o ano de 1854-55.

${ }^{613}$ «GAW» (1842-1913). Filho de George Warre, sócio da Warre’s (que havia falecido em 1851). Sellers refere que GAW «é dono de muitas quintas no Douro» (p. 56): Quinta do Zimbro e Quinta da Senhora da Ribeira (p. 174). O seu primo, Canon Warre (irmão do reitor de Eton), é dono do Terreirinho, em Gaia, propriedade onde se encontravam os armazéns de alguns dos exportadores.

${ }^{614}$ MAYSON, 1999.
} 
conhecimentos de prova de vinhos de James R. Dow consolidaram a reputação da Dow como um dos principais nomes no comércio do vinho do Porto.

Em 1905, A. J. Symington tornou-se sócio da Warre \& Co. tornando-se, ao fim de alguns anos, o único proprietário desta empresa, embora a família Warre continuasse como proprietária da Dow.

O último Warre reforma-se, em 1965, e ficam três irmãos Symington: Maurice, John e Ronald (filhos de A. J.), assim como o sobrinho mais velho, filho do primeiro irmão; depois, todos trazem consigo os filhos mais velhos — Michael, John e James ${ }^{615}$.

Atualmente a empresa detém três quintas, todas adquiridas já nos séculos XX e XXI pela Symington: a Quinta da Cavadinha em Provesende (desde 1980), a Quinta do Retiro Antigo, no Vale do Rio Torto (desde 2006) e a Quinta da Telhada, no Douro Superior (desde 2006).

\subsubsection{Dow's}

As origens da Dow's ${ }^{616}$ remontam ao século XVIII, quando, em 1798, o comerciante inglês Samuel Weaver se estabeleceu no Porto, segundo a tradição da empresa. Mais tarde, a firma girou sob o nome Vianna \& Weaver.

Contudo, por volta de 1835, James Dow, oriundo de Perthshire, Escócia, casou com Phoebe Carrier ${ }^{617}$, sobrinha de Samuel Weaver. Dow entrou para a firma do tio que passou, então, a ser conhecida por Weaver, Dow \& $\mathrm{Co}^{618}$. Quando Samuel Weaver faleceu, em 1836, a firma passou a designar-se, unicamente, Dow \& Co. ${ }^{619}$.

Sabe-se que, em 1854, James Dow tinha como morada a Rua de Entre-Quintas, no Porto $^{620}$. Pouco tempo antes de falecer, em 1856, James Dow publicou um tratado sobre o oidium que estava, na altura, a devastar as vinhas do Douro, intitulado An Inquiry into the Vine Fungus with Suggestions as to a Remedy. Após a morte de James Dow, o seu filho, James Ramsay Dow, tomou conta do negócio. Em 1877, a Dow's funde-se com a Silva \& Cosens ${ }^{621}$ e James Ramsay passa a gerir o negócio em Londres.

\footnotetext{
${ }^{615}$ RAY, [1970].

${ }^{616}$ SELLERS, 1899.

${ }^{617}$ Tiveram 3 filhos: Weaver Owens, James Ramsay e Stuart L. Dow (cf. SELLERS, 1899).

${ }^{618}$ Em 1837, a Weaver, Dow \& Co. aparece nas listas de exportadores ingleses cedidas por Paul Duguid (DUGUID, 2005).

${ }^{619}$ Richard Mayson avança outra hipótese, mas contradiz-se na data referindo, 1838 numa página e, noutra, 1859 (MAYSON, 1999). Contudo, em 1846, no livro de Forrester, a firma aparece como James Dow (em 1844) e James Dow \& Co. (em 1846) (FORRESTER, 1846).

${ }^{620}$ Conf. a «Lista de negociantes estrangeiros residentes no Porto em 1854», in Almanaque comercial, judicial e administrativo do Porto e seu distrito para o ano de 1854-55. Charles Sellers confirma esta informação, em 1899, dizendo que a família ocupa há muito a quinta (Entre-Quintas tinha várias quintas).

${ }^{621}$ A Silva \& Cosens tem início com o comerciante portuense Bruno da Silva que, em 1798, se instalou em Londres, de onde importava vinho de Portugal. O negócio de transporte do Porto foi continuado pelo filho de Bruno, John da Silva, que, em 1862, trouxe para a parceria Frederick William Cosens. Juntamente com o filho de John, Edward, eles tornaram-se os parceiros ativos da Silva \& Cosens. Com a contínua expansão da empresa, Edward da Silva e Frederick Cosens juntaram-se com George Acheson Warre, que entrou como sócio em 1868. George Acheson Warre (1842-1913) era filho de George Warre, sócio da Warre’s. Segundo Mayson, George Acheson Warre não quis trabalhar na Warre's porque se desentendeu com os sócios, Noble e Murat (MAYSON, 1998).
} 
Embora de menor dimensão do que a Silva \& Cosens, a Dow \& Co. era um produtor de Porto altamente considerado, com reputação destacada pelos seus Portos Vintage e, quando as duas empresas foram fundidas, o nome Dow's foi mantido para efeitos de exportação.

Ainda antes da fusão com a Silva \& Cosens, a Dow's comprara, em 1874, uma propriedade em Vila Nova de Gaia onde construiu novas instalações com a capacidade de cerca 10.000 pipas de vinho. O armazém era muito avançado na sua época, usando tonéis em vez de pipas para armazenamento e tendo um sistema de trasfega com bombas, mangueiras e tubagens subterrâneas. Outra novidade introduzida pela empresa foi a tanoaria a vapor. Quando a Dow's decidiu, em 1894, modernizar a maquinaria, os tanoeiros, com medo de perder o emprego, sequestraram a caldeira (trazida de Inglaterra). O problema foi resolvido e a tanoaria mantida em funcionamento.

Em 1889, segundo Sellers, Philip John Cosens foi admitido como sócio, à morte de seu pai e, a 1 de julho de 1893, Roderick, o último membro da família Dow a pertencer à firma, entrou também como sócio. Este filho de James Ramsay manteve-se na sociedade até 1907, tendo falecido em 1933, em Inglaterra.

George Saintsbury ${ }^{622}$, célebre professor de Oxford, sublinhou a posição única da Dow's: «Não há melhor vinho de exportador que o melhor da Dow's de 1878 e 1890, especialmente». Ainda atualmente, o Dow’s 1896, também produzido «durante a gestão dos Srs. Silva, Warre e Dow», foi considerado outro vinho lendário por James Suckling ${ }^{623}$, que se mostrou impressionado quando o provou, mais de 100 anos após ter sido feito.

A família Symington irá manter uma identidade separada para o Porto da Dow's, cujos vinhos estão estreitamente ligados às quintas do Sol, Bomfim, Zimbro e Senhora da Ribeira, as últimas três originalmente pertencentes à Silva \& Cosens, e todas adquiridas por George Acheson Warre, no século XIX, enquanto sócio e representante da casa ${ }^{624}$ que, à data, era já proprietária da Dow's. Por sua vez, a Quinta do Sol só foi adquirida, nos anos 1980, pela Symington ${ }^{625}$.

Em 2014, além das Quintas do Bomfim e da Senhora da Ribeira, também as Quintas do Santinho, da Fonte Branca, da Cerdeira e do Atalho produziam o vinho Dow's ${ }^{626}$. Hoje em dia, essa produção é assegurada unicamente pelas Quintas do Bomfim, Senhora da Ribeira, Cerdeira e Santinho ${ }^{627}$.

\subsubsection{Martinez, Gassiot \& Co}

A data de início de atividade desta empresa é incerta. Se a tradição da casa indica o ano de 1790, já Sellers ${ }^{628}$ afirma que Sebastian Gonzalez Martinez, natural do Norte de Espa-

\footnotetext{
${ }^{622}$ SAINTSBURY, 1920.

${ }^{623}$ Especialista da revista «The Wine Spectator», uma das maiores autoridades em Porto Vintage.

${ }^{624}$ Cf. AHA - u.i. 6200

${ }^{625}$ MAYSON, 1999.

${ }^{626}$ Disponível em <http://www.symington.com/section.php?id=812>. [Consulta realizada em 20/06/2014]. A Quinta do Santinho, a Quinta da Fonte Branca e a Quinta da Cerdeira pertenciam a membros da família.

${ }^{627}$ Disponível em <http://www.dows-port.com/section.php?id=413>. [Consulta realizada em 09/06/2015].

${ }^{628}$ SELLERS, 1899.
} 
nha, iniciou o seu negócio de vinhos, sob nome próprio, em 1797. Alguns anos depois de se encontrar estabelecido, ter-se-á associado a um português, passando a sociedade a usar a designação Martinez, Lopes \& Co., a qual surge nos registos da Alfândega do Porto entre 1809 e 1812.

Por volta de 1804, Sebastian Martinez tornou-se sócio, em Londres, da casa Christopher Smith \& Co., que, após a sua chegada, tomou o nome de Christopher Smith, Son, Martinez \& Blake. Esta sociedade manteve-se até 1810. O sócio seguinte terá sido John Peter Gassiot (1797-1877). Gassiot era um cavalheiro muito estimado não só em Mark Lane, rua onde se situavam os escritórios da firma, como nos círculos científicos ingleses. Foi fundador e presidente da Royal Society, membro de várias outras associações científicas e tinha, na sua casa de Clapham Common, um laboratório onde fazia experiências, nomeadamente sobre fenómenos elétricos. Além disso, foi magistrado em Surrey e um dos mais conhecidos advogados em Londres. A Martinez juntou-se a C. Jones e a John Peter Gassiot em 1826 e, em 1839, a casa fechou tendo reaberto em 1841 com John Peter Gassiot Jr. e William Armstrong Martinez, neto de Sebastian Martinez ${ }^{629}$. Sebastian Martinez ter-se-á retirado dos negócios em 1849, deixando o controlo da empresa entregue a John Peter Gassiot e aos seus dois filhos, John Peter Jr. e Charles ${ }^{630}$.

Em relação à casa do Porto, Sellers refere que, por volta de 1834, se dá a entrada de um novo sócio, vindo de Inglaterra: William Yarmouth Jones. A casa, até aí conhecida como Martinez, Gassiot \& Co. começa a girar sob o nome Martinez, Jones, Gassiot \& Co., designação que surge nos arquivos da empresa entre 1834 e 1836 e nos registos da Alfândega entre 1837 e 1840, após o que regressa à designação anterior. Na viagem para o Porto, William Jones foi acompanhado por John Fleuriet Delaforce (1805-1881) que, após vários anos como representante da Martinez em Londres, veio estabelecer residência no Porto, onde viveu durante cerca de 50 anos, ocupando um lugar de relevo na direção do escritório. Contudo, a sede da empresa manteve-se sempre em Londres.

A firma era proprietária de uma escuna (a «Betsy») que ligava a cidade do Porto a portos ingleses (Dartmouth, Exeter ou Weymouth...) no transporte de vinho do Porto, antes dos barcos a vapor, e também, mais tarde, de um veleiro (o «Maria Manuela»), com uma capacidade de 99 toneladas, um dos últimos veleiros comerciais a viajar entre o Porto e o Sudoeste de Inglaterra.

\footnotetext{
${ }^{629}$ SELLERS, 1899.

${ }^{630}$ John Peter Gassiot Jr. ter-se-á tornado sócio em 1842 e retirado em 1874. O seu irmão, Charles (1826-1902), entrou na sociedade em 1850, e assumiu a direção da casa em 1870, após a reforma do pai, tendo visitado o Porto algumas vezes. Charles Gassiot acumulou uma grande fortuna e adquiriu uma grande mansão em Elmwood House, Upper Tooting. Era grande aficionado de cavalos, de pintura e colecionador de arte. Sem descendentes, deixou a sua coleção (onde constam autores como Constable, Dyce, Landseer, Millais, e Tissot) à Guildhall Art Gallery. Outro irmão, o Comandante Sebastian Gassiot, RN, foi admitido como sócio em 1872.
} 


\subsection{COCKBURN \& SMITHES: PROTAGONISMO HISTÓRICO}

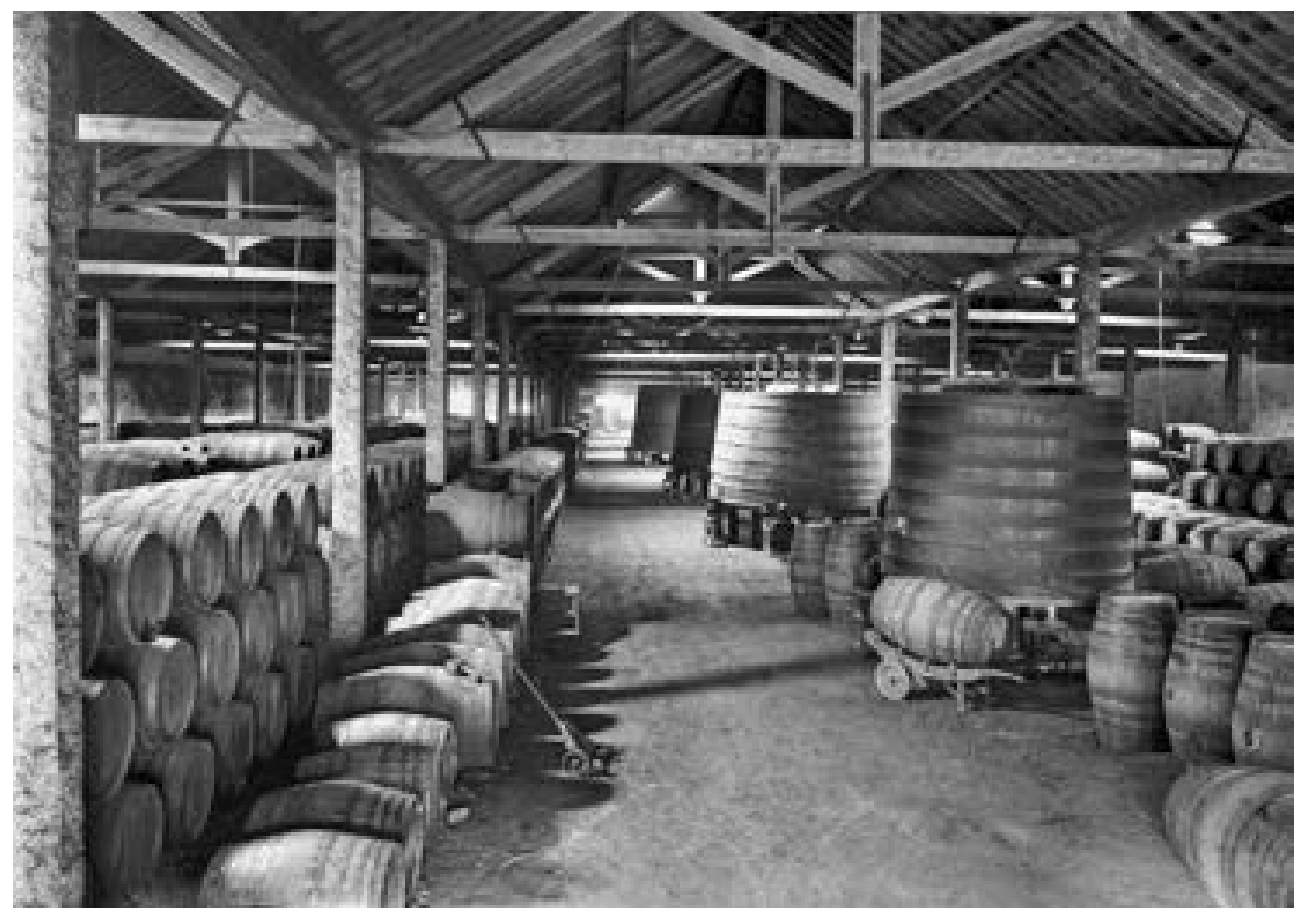

Fig. 162. Foto Emílio Biel — Cockburn, Smithes \& C. ${ }^{a}$, [1870-1910 $]^{631}$

A secular firma britânica Cockburn's, uma das grandes empresas de vinho do Porto que hoje pertence à família Symington, foi fundada em 1815 por Robert Cockburn, segundo a tradição, um soldado escocês que combateu em Portugal durante a Guerra Peninsular e integrou entre 1808 e 1812, sob as ordens do Duque de Wellington o exército Anglo-português que combateu as invasões napoleónicas na Península Ibérica (1809-1811). Foi nesse período que descobriu a região do Douro e os seus vinhos extraordinários que o levaram a fundar a sua própria companhia.

Segundo Sellers ${ }^{632}$, esta firma foi estabelecida no Porto, por volta de 1815, pelos senhores Cockburn, Wauchope \& Co. Tanto os Cockburns como os Wauchopes pertenciam a conhecidas famílias escocesas e crê-se que os Wauchopes já estavam estabelecidos no negócio do vinho em Leith, antes de qualquer uma das familias vir para o Porto. O sócio seguinte terá sido Greig, um capitão da marinha mercante, que esteve intimamente ligado à Feitoria Inglesa e foi, em muitas ocasiões, o bibliotecário principal da instituição. Sobre a data de

\footnotetext{
${ }^{631}$ Creditação - C Centro Português de Fotografia/DGLAB/SEC, PT/CPF/BIE/000003.

${ }^{632}$ SELLERS, 1899.
} 
sua entrada na sociedade, dizem os registos existentes na Feitoria ${ }^{633}$ que a firma circulava com o nome Cockburn, Wauchope, Greig \& Co., já em 1817. Contudo, Sellers (1899) e Bradford (1983) afirmam que Creig só se terá associado à firma em 1828.

De acordo com registos existentes na Alfândega do Porto, no ano de 1829, a firma passou a circular unicamente sob o nome Cockburn, Greig \& Co. Em data incerta, Archibald e Alexandre Cockburn, filhos de Robert, também se tornaram sócios da casa, tendo aberto escritório em Londres, em 1830. Em 1835, o Capitão Hugh Dunlop, RN, juntou-se à sociedade, que se transformou em Cockburn, Greig \& Dunlop. Retirou-se do negócio em $1845^{634}$, passando a firma a designar-se Cockburns Greig \& Co. É possivvel verificar no único copiador que existe no Arquivo que, já desde 1847-48, a firma inglesa se chamaria Cockburn Smithes \& Co, altura em que Henry Smithes entra como sócio, em Londres. No Porto, a designação continuará a ser Cockburn Greig (apesar de, supostamente, William Greig já não estar em atividade na firma, sendo apenas sócio de capital) até 1851, altura em que John Tatham Smithes terá adquirido uma quota na sociedade portuguesa ${ }^{635}$. Durante o tempo que viveu na cidade, John Smithes (que era oriundo de Lancashire) foi uma pessoa muito popular. John era irmão de Henry Smithes que foi, durante muito tempo, o sócio residente em Londres. John Smithes era casado com Miss Cobb, irmã de Charles Davidson Cobb. A Quinta de Campo Bello, no Candal, uma das mais belas propriedades da época nos subúrbios a Sul do Porto, está associada à família Smithes. A casa tinha uma pequena capela anexa onde os residentes britânicos se costumavam reunir para a missa.

Em 1851, John Black, foi admitido como sócio na casa de Londres, tendo-se retirado em 1867. Em 1868, Charles Davidson Cobb e William Roope Teage, que já estavam ligados à firma desde 1863, tornam-se, por sua vez, sócios. Em 1872, Henry Smithes retira-se e, em 1880, é seguido por Archibald Cockburn.

Segundo Vizetelly ${ }^{636}$, por volta de 1880, 'a casa Cockburn, Smithes \& Co., mantinha-se já então, há cerca de 25 anos, como o segundo maior exportador de vinho do Porto'. Os seus armazéns, com seis cumes paralelos, não tinham rival em Vila Nova de Gaia. Os edifícios tinham sido construídos pela Companhia Geral de Agricultura das Vinhas do Alto Douro e minados pelos Miguelistas em 1833, aquando da sua retirada no Cerco do Porto, para evitar que os stocks caíssem nas mãos dos liberais. Alguns anos mais tarde, os edifícios foram recuperados e adquiridos pela Cockburn. Facto interessante: os seus vizinhos mais próximos eram os armazéns da Martinez, Gassiot \& Co. ${ }^{637}$.

\footnotetext{
${ }^{633}$ Citados por DELAFORCE, 1983.

${ }^{634}$ Cf. circular, CB-1988, que refere: «Em consequência de retirar-se do comércio o snr. Hugh Dunlop, sócio da firma da Cockburns Greig \& Dunlop, participamos a vocês que esta firma se acha dissolvida, e que a sociedade continua debaixo da firma de Cockburns Greig \& Cia».

${ }^{635}$ Estes últimos dados foram fornecidos pelo Dr. Pedro Leitão, com investigação sobre a história da Cockburn’s.

${ }^{636}$ VIZETELLY, 1880.

${ }^{637}$ MONTES, Paula Leal - Breve histórico institucional da empresa (texto inédito, construído para efeitos de organização e descrição arquivística, generosamente facultado pela autora a quem se agradece).
} 
Ao longo dos anos a composição societal da empresa foi variando, e muitos foram os sócios sucessivos cujos nomes são referidos em diferentes épocas e por diversos autores, nem sempre em concordância.

Em 1961, a Cockbum Smithes \& Co. absorveu a Martinez Gassiot \& Co., Ltd., tendo, logo a seguir, ambas sido adquiridas pela empresa John Harvey \& Sons, Ltd., sediada em Bristol, Reino Unido (após o que foram geridas como empresas distintas). A John Harvey \& Sons, Ltd., era, ela própria, uma antiga empresa do comércio de vinhos, remontando a 1815. No ano seguinte, a Companhia Harveys of Bristol, pertencente ao mesmo grupo da John Harvey \& Sons, Ltd, passou a associada, vindo a ser substituida pela Allied Lyons Overseas Europe, em 1991 e, após junção com o grupo Domecq, pela Allied Domecq Overseas Europe, Ltd., em 1993. Neste ano, o controlo da empresa dependia do grupo britânico Allied-Domecq, através das participações das suas filiais: 74,94\% do capital era detido pela John Harvey \& Sons, Ltd. e 24,98\% pela Allied Domecq Overseas Europe, Ltd. Os restantes 0,08\% estavam na posse de individuais residentes no território português. Em 1995, a empresa foi alvo de um projeto de fusão, adotando a designação de Cockbum Smithes \& Cia., Lda. Esta nova sociedade comercial resultou da associação das seguintes empresas: Soc. Costa Pina, SA; Carvalho Ribeiro e Ferreira, SA; Tavares e Rodrigues, SA; A Nova Licoreira Portuguesa, Lda.; Indústria de Bebidas Alimentares Costa Pina e Vilaverde, Lda.; Joaquim António Silveira, Lda.

Em finais de 2004, a Martinez Gassiot \& Co., Ltd. é definitivamente integrada na Cockburn Smithes \& Cia., S.A., com uma entrada de ativos por aumento de capital. A Martinez deixa, assim, de ser uma empresa, passando a ser uma marca da Cockburn's.

Em 2005, a Allied Domecq foi adquirida, em aliança, pela francesa Pernod Ricard e pelo grupo americano Fortune Brands, tendo a Cockburn's, unidade de produção, sido comprada pela Fortune Brands, enquanto a Cockburn's, unidade de distribuição, ficou com a Pernod Ricard. Em julho de 2006, a Fortune Brands decidiu alienar as empresas que detinha em Portugal, nomeadamente a Cockburn Smithes \& Cia., SA, a Sociedade Agrícola de Canais, Lda. e a Sociedade dos Vinhos Tuela, Lda., tendo, contudo, resolvido manter a marca de vinho do Porto 'Cockburn's' (vendido em todo o mundo, mas sobretudo no Reino Unido, onde se tornara marca líder) no universo da sua participada Beam Global \& Wine. Assim, os ativos em Portugal foram vendidos, em 2006, ao Grupo Symington, com o qual a norte-americana tem um contrato de produção relativamente à marca 'Cockburn's'. Desta forma, a empresa Cockburn Smithes \& Cia., SA teve que alterar a sua designação social, uma vez que a marca 'Cockburn's' já não era propriedade sua, tendo adotado a nova designação social Martinez Gassiot, Vinhos SA, mantendo-se todos os outros dados da empresa. Em 2010, finalmente, a Symington compra a marca Cockburn's à Beam Global Spirits \& Wine, Inc. e a empresa volta a ser um todo ${ }^{638}$.

${ }^{638}$ LEAL, Paula Montes — Breve histórico institucional da empresa. 
A aposta na inovação e o espírito pioneiro da Cockburn's que investiu na famosa casta Touriga Nacional permitiram-lhe a conquista de novos territórios no Douro Superior onde a Casa Cockburn's foi pioneira na expansão da plantação de vinhas, projetando a marca Cockburn's para um lugar de destaque nos negócios de vinho do Porto.

É bem conhecida a importância da conceituada empresa Cockburn \& Smithes na história dos negócios do vinho do Porto, não só no domínio da sua comercialização e exportação, sobretudo para o mercado britânico que dominou durante décadas sucessivas, mas também ao nível da sua produção, enquanto grande proprietária de quintas históricas e outras propriedades e bens na região Duriense, desde finais do século XIX.

A notável influência e longa presença desta empresa em diversas zonas importantes da região do Douro Vinhateiro alargou-se, também, naturalmente, à relevante área de propriedades vitivinícolas do concelho de Carrazeda de Ansiães, onde (como se apresentou no Capítulo 7 e, especificadamente, nos subcapítulos anteriores do presente capítulo), operaram também outras empresas nacionais e estrangeiras, como a firma espanhola Martinez Gassiot e a Silva \& Cosens, Uma das mais prestigiadas firmas, com 14 marcas de vinho do Porto, e que operava sobretudo nas zonas do Pinhão, Carrazeda de Ansiães, Alijó e Sabrosa. Estas empresas que já adquiriam também os vinhos de várias quintas e pequenos e médios proprietários desta zona duriense de Carrazeda, foram aqui também donas de importantes quintas que acabariam por ser compradas pela Cockburn's.

A Cockburn, designação que foi mudando com a evolução dos seus sócios e capital social, mas mantendo-se sempre como empresa reputada e exportadora privilegiada do mais conceituado vinho do Porto para o mercado britânico, teve, desde cedo, particular e intensa atuação no concelho de Carrazeda. Ao longo dos séculos XIX e XX, foi adquirindo, em pontos privilegiados da área vinhateira do concelho, numerosas propriedades, como adiante se especifica, para além de algumas quintas estratégicas para o seu estabelecimento nesta zona do Douro: a Quinta do Tua, a Quinta de Vale Coelho e a Quinta dos Canais (Capítulo 7). Estas unidades logísticas, para além da produção vitivinícola de especial qualidade, serviram-lhe, essencialmente, de imprescindível recurso de apoio regular na compra de uvas e vinhos aos produtores locais que se manteve durante décadas, numa relação profundamente ancorada e precocemente fidelizada. Esta prática histórica da Cockburn de compra e comercialização dos vinhos do concelho de Carrazeda viria a ser retomada, recentemente, com a incorporação desta firma pelo Grupo Symington.

Far-se-á então, mais adiante, com base em documentos e dados relativos a algumas das quintas que a Cockburn \& Smithes deteve em Carrazeda ${ }^{639}$ e de outras fontes indiretas ${ }^{640}$, uma descrição da atividade desta empresa nas suas vertentes essenciais ligadas ao vinho do Porto: produção, comércio e marca, bem como da sua longa, muito funcional e lucrativa presença no concelho de Carrazeda.

\footnotetext{
${ }^{639}$ Constantes dos seus antigos arquivos nas Coradas (V. N. de Gaia) hoje integrados no arquivo histórico da Symington. ${ }^{640}$ Disponíveis na biblioteca e arquivo do IVDP e Biblioteca Pública Municipal do Porto.
} 


\subsubsection{A firma Cockburn Smithes \& Co., S.A.}

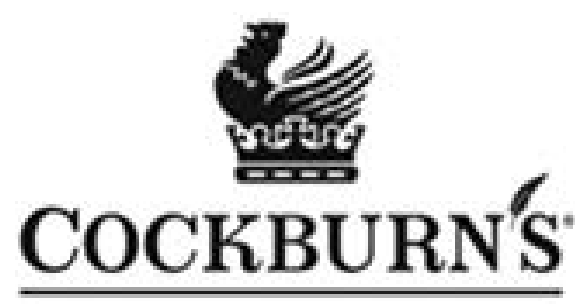

PORT

Fig. 163

O seu símbolo, formado por um galo sobre uma coroa, tornou-se a marca registada da companhia, por influência do famoso Lord Henry Cockburn, irmão de Robert Cockburn, o fundador no Porto da empresa, em 1815, com um velho amigo, da família Smithes, também ligada ao comércio do vinho do Porto, e ambos combatentes na Guerra Peninsular, ou Invasões Francesas ${ }^{641}$.

Este símbolo da empresa, onde num círculo dourado, por cima da data de fundação, se exibe a coroa britânica, continua a destacar-se na avenida central com pavimento tradicional português em basalto branco e negro que atravessa as famosas e muito visitadas caves da Cockburn's, por muitos consideradas como as mais bonitas caves de vinho do Porto em Vila Nova de Gaia. Aqui, um dos locais históricos de visita obrigatória, envelhecem dos melhores vinhos do Porto Cockburn's em cascos e balseiros de carvalho, muitos com mais de 100 anos, feitos e consertados na sua antiga tanoaria, junto aos grandes armazéns nas Coradas - Gaia, cujo funcionamento tradicional continua ainda a poder ser observado sob a explicação de um ou outro dos seus mais antigos tanoeiros.

A Cockburn's, que se encontrava já estabelecida na Grã-Bretanha em finais do século XVIII, fundada no Porto nos inícios de Oitocentos e com escritório em Londres desde 1830, vai promover a partir daí a comercialização do vinho do Porto no mercado britânico que então absorvia quase toda a exportação nacional.

À época, a vida no Porto era difícil e conturbada, ao que não era alheia a participação inglesa, em que se destacou sir Thomas Stubbs, cognominado de «O Imortal», ao serviço do general Beresford, em Portugal, ao lado do Marechal Saldanha, neto do Marquês de Pombal. Tal situação obrigava as famílias inglesas a procurarem maior segurança na área dos seus armazéns em Gaia. Aliás a atmosfera desse período perpassa nalgumas cartas de Archibald Cockburn, datadas de janeiro, fevereiro e março de 1827, e enviadas, do Porto, para seu pai, Robert Cockburn, então em Edimburgo.

Em 1845, John e Henry Smithes juntaram-se à antiga companhia e o nome mudou então para Cockburn \& Smithes.

Desde a sua fundação que esta firma era fornecedora de vinho do Porto da Harvey of Bristol, organização que a comprou, em 1962, havendo já adquirido também em 1961 uma outra antiga e boa firma de vinhos, a Martinez Gassiot \& Co. Ltd, igualmente grande compradora de vinhos generosos de Carrazeda, durante a I República. A Martinez Gassiot é integrada

${ }^{641}$ LEITÃO, 2013. 
nos finais de 2004 na Cockburn's, deixando de ser uma empresa autónoma e passando a ser uma marca da Cockburn's.

Presentemente, a empresa é, como se disse, propriedade da família Symington, que adquiriu, em 2010, a respetiva marca, com uma história única na Região Demarcada do Douro.

\subsubsection{O comércio dos vinhos do Porto e as marcas Cockburn}
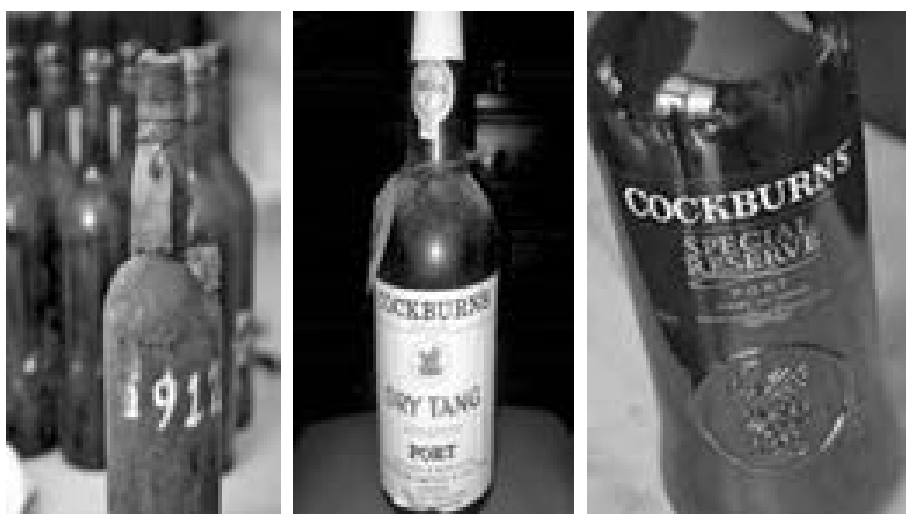

Fig. 164

Após um longo processo de transações da firma designadamente com a Harvey de Bristol, que comprou e fundiu a Martinez Gassiot e a Cockburn (anos 1960, com gestão única até 2004/2005, quando se dá a fusão), o grupo Domecq de Espanha (anos 1990), e o acordo com o grupo americano Beam que comprou a Domecq, a Symington compra, em julho de 2006, a Cockburn, ficando com todos os seus ativos, embora só em 2010, venha a adquirir a marca Cockburn.

Uma das firmas mais importantes no comércio do vinho do Porto, a Cockburn's define-se por características de negócio e empresa familiar, adaptando-se às novas influências, através da sua reorganização e mediante a sua fusão com outras empresas, já associada da Harveys de Bristol, a que desde cedo fornecia vinho do Porto de alta qualidade e depois nos anos 1990, em que deteve o 5. ${ }^{\circ}$ lugar na exportação mundial de vinho do Porto.

Celebrizou-se pela qualidade excecional dos seus vinhos do Porto, com destaque para os Vintages (engarrafados ainda novos, envelhecendo e ganhando depósito, vinhos mais requintados, já que provenientes de colheitas de excecional qualidade e com 2 ou 3 anos de envelhecimento em casco, atingindo 20 anos depois o seu auge).

Essa reputação deveu-se em certa medida ao facto de grandes stocks dos melhores lotes de vinho do ano serem ordinariamente mantidos nos seus armazéns e ainda devido a lotações especiais. 
Conquistou, desde o seu início, o mercado britânico que acabou por dominar e onde se impôs com duas marcas de maior venda: a Cockburn's Special Reserve (marca de topo) ${ }^{642}$ e a Cockburn's Fine Ruby (mais popular).

\subsubsection{A marca em destaque nos mercados internacionais}

Em artigo recente da especialista Robinson ${ }^{643}$ sobre os vinhos Cockburn, a sua presença destacada na competição de provas internacionais de vinhos do Porto e a expansão para a China são objeto de destaque, para além do famoso Vintage de 1896, os «top Cockburn Vintage» de 1908, 1927, 1963 e 2007, este último já produção do Grupo Symington, com dominância de uvas provenientes do Cima Corgo.

Richard Mason, num artigo ${ }^{644}$ em que se propõe fazer a «descoberta do Cockburn's DNA», destaca, caracterizando-os, sumariamente, os Cockburn dos anos: 1896, 1904, 1908, 1912, 1927, 1935, 1945, 1947, 1948, 1950, 1955, 1960, 1963, 1967, 1970, 1977 (não declarado), 2007, Quinta dos Canais (2009) e 2011 (simples). O Cockburn's Quinta dos Canais 2009 é comercialmente apresentado nos mercados com as seguintes características: «Muito escuro e opaco, fechado e aroma recatado, tom floral, opulência e mentolado subjacente. Rico, suave e voluptuoso, inicialmente, bonita textura, com taninos preto-pimenta, cresce na boca, firme e acabamento bem definido. Longo, fino e musculoso. Apenas 106 casos foram engarrafados, e 100 foram enviados para a Austrália. É uma avis rara».

\subsection{4. $\mathrm{O}$ «estilo Cockburn» e J. H. Smithes}

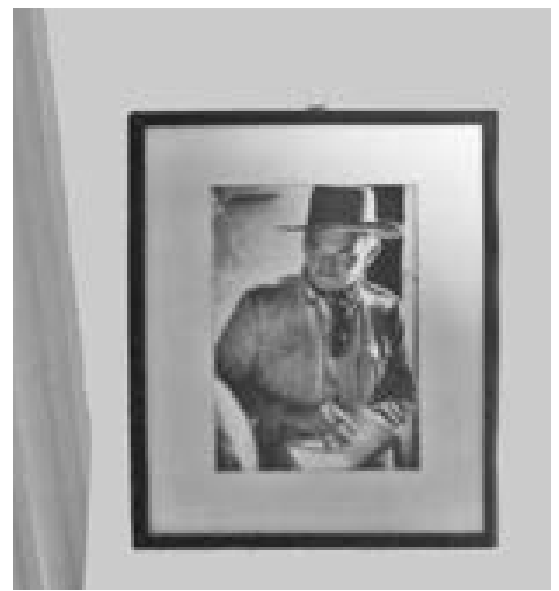

Fig. 165. J. H. Smithes

Fotografia no Solar da Quinta do Tua

J. H. Smithes (1910-1999), personagem inesquecível e marcante no comércio do vinho do Porto, lenda entre os vinhateiros do Alto Douro e nos gabinetes de provas em V. N. de Gaia, encontra-se intimamente ligado ao sucesso das marcas Cockburn, na vertente da produção e provas. Entrou para a firma Cockburn em Londres, em 1930, foi sócio da Companhia do Porto, a partir de 1938, mas, quando deflagrou a II Guerra Mundial, regressou a Inglaterra e alistou-se na RAF (Força Aérea Real). Regressou a Portugal em 1946, tendo-se tornado um dos melhores provadores do Porto.

J. H. Smithes com seu pai, Archie, e os sócios Reggie Cobb e Félix Vigne criaram o afamado

\footnotetext{
${ }^{642}$ LEITÃO, 2013.

${ }^{643}$ ROBINSON, 2012.

${ }^{644}$ MASON, 2013: 64-65.
} 
«Estilo Cockburn» de vinho do Porto que permitiu à firma Cockburn's dominar o mercado britânico. Foi inovador na viticultura e já nos anos 1930 havia iniciado o cultivo de uma vinha na zona de Foz Tua, na Quinta do Tua, localmente conhecida por Quinta dos Ingleses, onde experimentou a reprodução de variedades particulares de uma casta, 40 anos antes de esse método se vir a tornar norma no Douro (ver Capítulo 7).

Como fabricante de vinhos foi pioneiro na introdução de tecnologias e adegas modernas e inovadoras, nos anos 1960. Numa ambiência assim de inovações e pioneirismo a Cockburn's viria a criar em 1969 um novo estilo de vinho do Porto Reserva que teve um papel determinante no desenvolvimento do comércio do vinho do Porto.

Aposentado desde 1970, voltou a Inglaterra onde comprou uma propriedade em States, no sul de Devon, que compôs à maneira de uma propriedade do Douro, com terraços e uma pequena quinta. Manteve, no entanto, ligações com Gaia e com o Douro, e visitas regulares, por ocasião da primavera e período das vindimas ${ }^{645}$.

\subsubsection{A Cockburn's no comércio e produção de vinho do Porto em Carrazeda de Ansiães}

Destaca-se aqui a relação histórica da Cockburn's com os produtores de vinho do Porto de Carrazeda de Ansiães, presença marcante que continua a ser lembrada por muitos dos viticultores das aldeias ribeirinhas do concelho e assinalada por antigos funcionários desta antiga empresa britânica ${ }^{646}$, perfeitamente entrosada na comercialização e também na produção de vinho do Porto neste concelho que aqui se observa com mais detalhe.

Encontram-se bem ilustradas essas dimensões no testemunho elucidativo que se transcreve a seguir, dado o seu significado relevante quer ao nível direto da história nesta zona do Douro desta destacada empresa, quer ao nível do seu particular protagonismo histórico na produção, cultura e comércio vitivinícolas em Carrazeda, quer ainda ao nível da importância e mais-valia que este concelho, dadas as suas características específicas, representava para os seus negócios no Douro.

A Cockburn queria vinhos de qualidades mais elevadas, devido ser uma empresa que lidava com o mercado inglês de maior qualidade e havia uma relação de grande proximidade com essa zona do Douro que se prolongou... comprou Santa Maria nos finais do século XX $X^{647}$ [...] a relação histórica da Cockburn's com o Douro começou com Carrazeda que lhe permitiu ter uma base para comércio e para a produção em adegas [...] por exemplo, a adega

\footnotetext{
${ }^{645}$ PIGNATELLI, 2003.

${ }^{646}$ Alguns transitaram daí para o Grupo Symington onde são hoje destacados quadros superiores em setores técnicos e de administração como o diretor dos arquivos do Grupo, Eng. Luís Martins, que nos tem concedido todas as facilidades no acesso e pesquisa documental no Arquivo Symington e que sobre este assunto nos concedeu em duas entrevistas recentes, informações muito úteis.

${ }^{647}$ A Quinta de Santa Maria (Godim - Régua), produtora de vinho do Porto foi adquirida pela Cockburn's em 1973 e possui dois armazéns, um dos quais é considerado o maior do Douro.
} 
da Quinta do Tua é um projeto dos anos 1960 ... os vinhos eram aí comprados e vinham para Gaia para envelhecerem [...] as quintas e propriedades que ai tinha serviam de pontos de contacto com os lavradores já que as comunicações antes eram difíceis e a Cockburn, dada a sua grande dimensão podia comprar quintas onde podia ficar na altura das vindimas [...] não era tanto a necessidade de produção, mas eram sítios para marcar uma posição logística, porque eles eram comerciantes e precisavam de pontos de contacto com os lavradores [...] os Cockburn e os Smithes tinham ali nas quintas um feitor, um comissário que lhes tratava dos assuntos, compras de vinhos e outros negócios [...] por exemplo a Warre, onde trabalhou um dos Smith, como pertencia à Cockburn a recuperou a Quinta do Bomfim ${ }^{648}$ e usou-a como base ... a Cockburn possuía ainda do outro lado do rio Douro quintas em frente à Quinta dos Canais e à Quinta Bartol, que comprou em S. Xisto, Argozelo, Fonte Santa e Vale de Malhadas em frente à quinta de Vale Coelho. Nestas 'quintas de barco' [...] eram visitadas de barco que ia de um lado ao outro do rio [...] comprava também os mostos $[\ldots]^{649}$.

A entrada da Cockburn's no concelho de Carrazeda de Ansiães, não só como grande firma exportadora de vinho do Porto mas ainda como produtora e proprietária de importantes quintas locais, iniciou-se na segunda metade do século XIX com a aquisição da Quinta do Tua, situada na localidade de Foz Tua, histórico e importante entreposto fluvial transmontano-duriense, e de mais propriedades na zona de Carrazeda, com vinhas muito antigas já incluídas em demarcações subsidiárias da Região do Douro (Capítulo 2).

Esta presença histórica e de grande relevância da Cockburn's nos negócios do vinho do Porto deste concelho, quer ao nível da produção, enquanto proprietária de importantes quintas, quer ao nível da compra e comércio dos vinhos de uma grande maioria de seus pequenos e médios proprietários, prolongou-se de finais de Oitocentos até aos inícios do nosso século, tendo-se mantido durante todo o século XX, e estendeu-se dessa aldeia de Foz Tua (freguesia de Castanheiro do Norte) onde adquiriu outras propriedades entre 1900 e 1910 (Quadro 36), à freguesia do Vilarinho da Castanheira, no outro extremo do concelho de Carrazeda onde adquirira, nos anos 1890, à Casa/Quinta de Lubazim, num vale próximo do rio Douro, terras e vinhas de Vale Coelho, encravadas na área da histórica Quinta de Lubazim.

A Quinta de Vale Coelho na localidade de Freixo de Moz, Lubazim, com uma área de 101.475 m2 de vinhas, aparece já referida em 1893 como propriedade desta firma inglesa que aí construiu uma casa particular com armazém em baixo, outra casa para os caseiros e lagares, e onde continuou a desenvolver a produção de vinho do Porto de elevada qualidade durante de mais de 100 anos (ver Capítulo 7, subcapítulo 7.5.).

\footnotetext{
${ }^{648}$ A história desta quinta localizada no Pinhão, andou associada às Quintas da Senhora da Ribeira e do Zimbro, situadas em diferentes freguesias e zonas vinhateiras do concelho de Carrazeda.

${ }^{649}$ Fragmentos da entrevista realizada ao Eng. Luís Martins, em 21 de abril de 2016, na sede do Grupo Symington, Vila Nova de Gaia.
} 

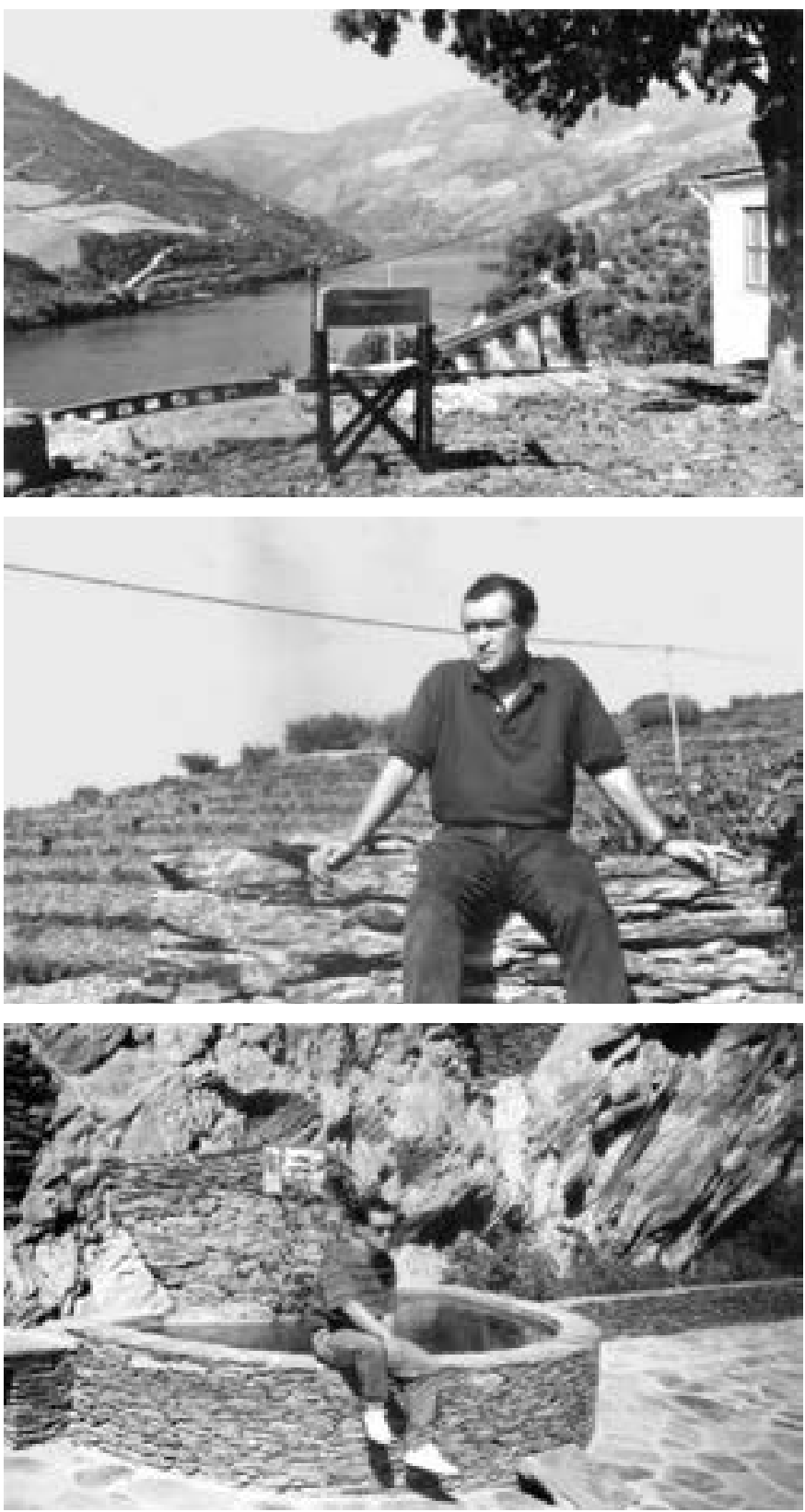

Fig. 166. Quinta de Vale Coelho, anos $1980^{650}$

Fonte: Fotografia de J. M. Lopes

\footnotetext{
${ }^{650}$ Fotografias da coleção particular de J. M. Lopes, ex-funcionário da Cockburn’s para Carrazeda, desde 1974 até aos anos 1990, que nos foi cedida em entrevista realizada em Santa Marta de Penaguião, em março de 2016, e ao qual se agradece.
} 
Para além desta quinta de recreio e da emblemática Quinta do Tua, localizadas nos limites extremos da zona da ribeira do território de Carrazeda - dois importantes pontos logísticos da área duriense deste concelho onde a Cockburn's sempre se quis estabelecer, desde o início da sua presença no Douro - esta empresa tornar-se-ia ainda proprietária da Quinta da Senhora da Ribeira e da Quinta dos Canais, mais duas quintas importantes já atrás apresentadas, assim como de um grande número de terrenos, armazéns, casas, vinhas e oliveiras em diferentes freguesias do mesmo concelho (Capítulo 7).

O movimento das compras de propriedades pela Cockburn's no concelho de Carrazeda de Ansiães, onde se torna evidente a concentração da propriedade vinhateira, mas também noutros pontos estratégicos da Região do Douro Vinhateiro (Régua e Vila Nova de Gaia), num longo período que se inicia em finais do século XIX e se estende para além da primeira metade do século XX, pode ser observado em dois quadros-resumo e documento síntese original da empresa relativo às aquisições que efetuou no Castanheiro do Norte, no período de $1900 \mathrm{a}$ 1910 (ver Anexo VI).

Posteriormente, a Cockburn's viria ainda a adquirir um grande armazém à entrada da cidade de Lamego e outras propriedades vitícolas importantes, designadamente, e como se referiu já, a Quinta da Senhora da Ribeira e a Quinta dos Canais, no concelho de Carrazeda, incrementando aqui a concentração de propriedade iniciada em finais de Oitocentos, a qual irá ganhar uma nova dimensão, a partir de 2006, com o Grupo Symington, como adiante se verá.

No Quadro 36, contabilizam-se dados aproximados de vinho do Porto produzido e comprado pela empresa Cockburn Smithes, em 1995, apenas em algumas freguesias de Carrazeda de Ansiães, da ordem de 1.000 .000 de litros (o mesmo valor da produção média anual de todo o concelho à época da República). Fornece-nos, ainda, por amostragem, indicadores da sua produção própria (mais de 2.000 pipas) e do volume de compras à produção (c. de 200 pipas circunscritas a número restrito de lavradores locais.

A leitura deste quadro permite-nos também observar a grande concentração de armazenamento das maiores quantidades de vinhos em 3 das adegas mais importantes da Cockburn's aqui situadas, respetivamente a da Quinta do Tua, a grande distância das outras, em segundo lugar, as da Senhora da Ribeira e, a seguir, a da Quinta dos Canais. Esta ocorrência sinaliza também a visão estratégica de concentração de negócios e investimento na modernização de instalações e infraestruturas locais da Cockburn's nesta zona da Região do Douro.

Assim, deve salientar-se que, particularmente, no contexto da crise das exportações de vinho do Porto no pós-II Guerra Mundial, a firma Cockburn Smithes, associada desde 1962 ao grupo britânico Harveys of Bristol, irá procurar impulsionar as suas vendas em Inglaterra, designadamente através do lançamento da marca Cockburn's Special Reserve, um vinho de qualidade Premium, cujo abastecimento foi garantido pela expansão das instalações próprias da empresa no Douro ${ }^{651}$.

${ }^{651}$ LEITÃO, 2013. 
Quadro 36. Indicadores de produção e compra de vnho do Porto em Carrazeda pela Cockburn's (1995) ${ }^{652}$

\begin{tabular}{|c|c|c|c|c|}
\hline Lavradores & Freguesias & Adegas & $\begin{array}{l}\text { N.o } \\
\text { de pipas }\end{array}$ & $\begin{array}{l}\text { N. }{ }^{\circ} \text { total } \\
\text { de litros }\end{array}$ \\
\hline Cockburn Smithes & Castanheiro do Norte & Tua & c. 1.979 & c. 787.605 \\
\hline Cockburn Smithes & Seixo de Ansiães & $\begin{array}{l}\text { Senhora da Ribeira (quintas da } \\
\text { Coalheira, Amendoeiras, Vinhais) }\end{array}$ & 97 & C. 54.500 \\
\hline Cockburn Smithes & $\begin{array}{c}\text { Vilarinho } \\
\text { da Castanheira }\end{array}$ & $\begin{array}{c}\text { Vale Coelho } \\
\text { Pescoça }\end{array}$ & $\begin{array}{l}94 \\
29\end{array}$ & $\begin{array}{l}57.512 \\
\text { c. } 16.000\end{array}$ \\
\hline $\begin{array}{l}\text { António Augusto } \\
\text { Fernandes Mariz }\end{array}$ & Linhares & Quinta da Alegria de Cima & 22 & 13.250 \\
\hline $\begin{array}{l}\text { *Sociedade Agrícola } \\
\text { dos Canais Ld. }{ }^{a}\end{array}$ & Beira Grande & Quinta dos Canais & 87 & c. 56.000 \\
\hline $\begin{array}{l}\text { António João } \\
\text { Ribeiro Sampaio }\end{array}$ & Ribalonga & Quinta do Zimbro de Cima & 34 & 18.821 \\
\hline Total: & 6 & 7 & 2.338 pipas & 1.003 .678 \\
\hline
\end{tabular}

Fonte: Mapas de transporte de vinhos de adegas de Carrazeda de Ansiães para a Régua (1995).

Obs.: As maiores quantidades de vinho recebido das adegas foram registadas nos meses de dezembro a maio.

* Esta designação comercial inclui a Quinta dos Canais nesta altura já propriedade da Cockburn's.

\subsection{SYMINGTON FAMILY ESTATES: LIDERANÇA E DOMINÂNCIA ATUAL}

O Grupo Symington Family Estates ${ }^{653}$, administrado pela família Symington, reúne os atributos de principal produtor e líder do mercado do vinho do Porto de categoriais especiais com uma quota de mais de $1 / 3$ dos vinhos do Porto desta tipologia vendidos em todo o mundo, sendo ainda o maior proprietário vitícola da Região do Douro.

É também, como anteriormente se referiu, a maior empresa a produzir e comercializar o vinho do Porto do concelho de Carrazeda, onde é proprietária de oito das suas melhores quintas.

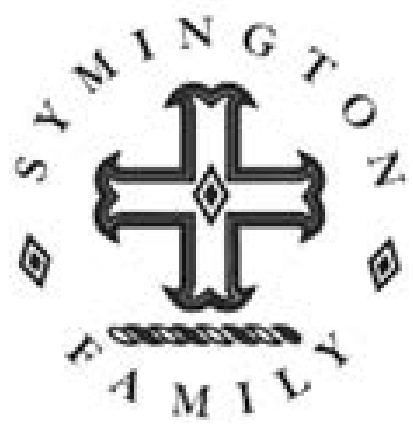

Fig. 167

Os membros da administração da Symington Family, descendentes de uma antiga família britânica, com ascendência escocesa, cujas origens genealógicas em Portugal, remontam a 1652, por via matrilinear através de Beatrice Atkinson, filha de mãe portuguesa e pai inglês, casada em 1891, com Andrew James Symington, chegado de Glasgow, aos 19 anos, à cidade do Porto, onde residi-

\footnotetext{
${ }^{652}$ AHS - Fundo Cockburn's, Mapas de transporte de vinhos, cb. 5733, cx. 42, u.i. 273-278. Cockburn Smithes (Régua, janeiro 1993 a dezembro 1995).

${ }^{653}$ ANTUNES, 2010.
} 
ram. Esta família encontra-se ligada à região do Douro e à produção e comércio de vinho do Porto, desde que se associou à firma inglesa W. \& J. Graham's.

De acordo com a genealogia oficial da família (ver quadro seguinte) ${ }^{654}$, os Symington contam já, hoje, 13 gerações em Portugal.

\section{Família Symington do Porto}

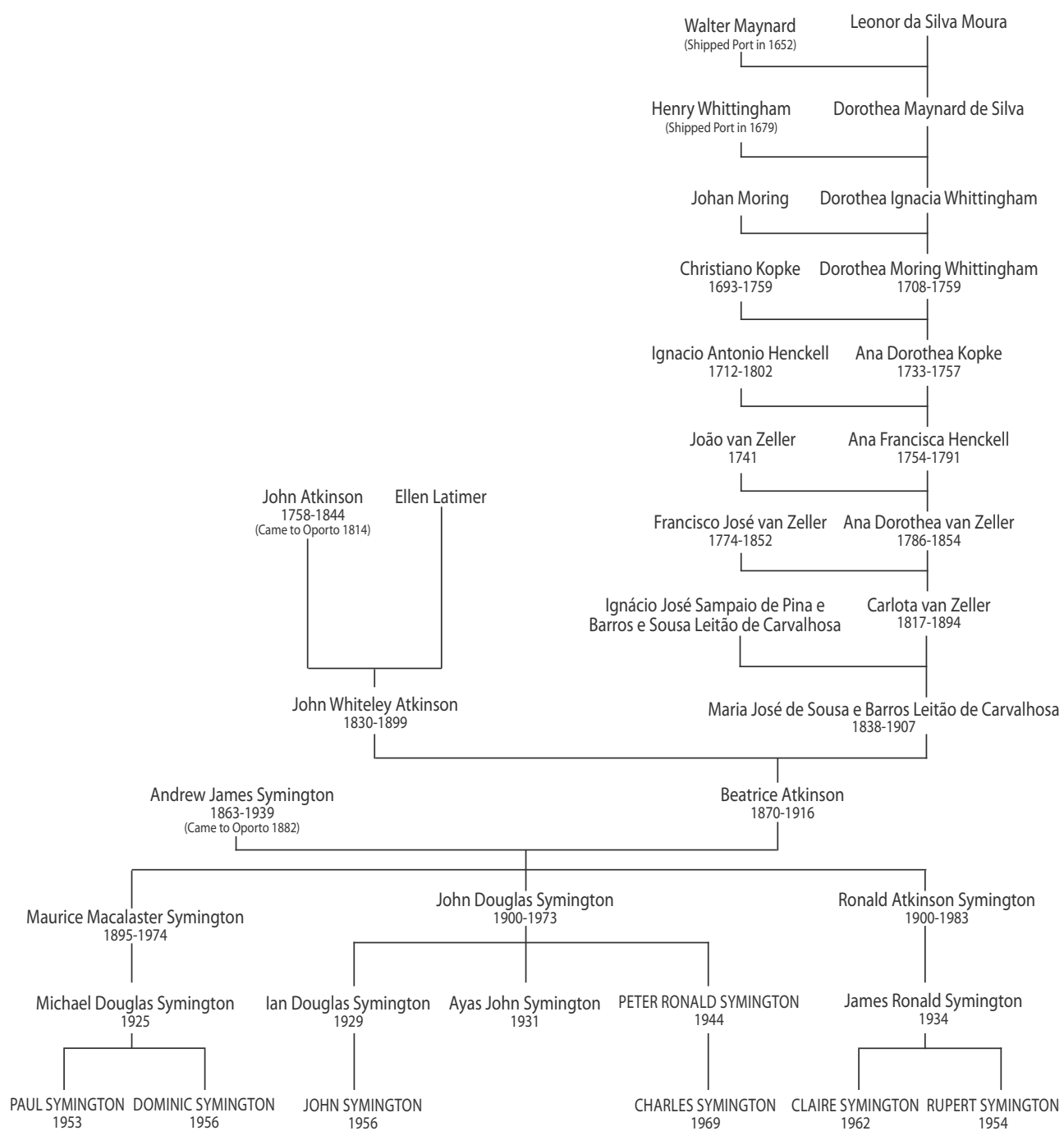

Fig. 168. Família Symington do Porto. 13 gerações no comércio do vinho do Porto. 1652-2006

\footnotetext{
${ }^{654}$ SYMINGTON, 2007: 296.
} 
Beatrice Atkinson era, pelo lado da mãe, Maria José de Sousa e Barros Leitão de Carvalhosa, descendente direta de Walter Maynard, já produtor de vinho do Porto no século XVII, que casou com Leonor da Silva Moura, no Porto onde foi cônsul britânico e um dos primeiros comerciantes de vinho do Porto de que exportou, logo em 1652, 39 pipas para Inglaterra (ver Capítulo 2).

A Symington Family, com uma quota de mercado de $22 \%$ dentre as cinco companhias detentoras de mais de $80 \%$ da totalidade da produção duriense, é o principal produtor de vinho do Porto e vinhos do Douro, onde detém uma área global de terrenos superior a 1.700 hectares dos quais 1000 hectares plantados de vinha e 30 das mais importantes quintas históricas, como por exemplo, a Quinta do Vesúvio, a Quinta dos Canais e as Quintas do Tua e da Senhora da Ribeira no Douro Superior, com marcas tradicionais e reputadas como: Dow's, Graham's, Warre's, Smith Woodhouse, Quinta do Vesúvio, Cockburn's, Martinez, Gould Campbell e Quarles Harris. Na história do vinho do Porto estas marcas são o traço deixado, das empresas, mediada ou imediatamente absorvidas pela Symington, que transporta consigo a memória e o prestígio das antigas casas (ver Anexo VII, quadro das empresas e quintas do Grupo em 2015)

Para além das quintas durienses que foram sendo adquiridas e detidas pelas empresas de vinho do Porto do conglomerado económico, os Symington são ainda proprietários, a título individual, de um número considerável de quintas no Vale do Douro, como por exemplo, no concelho de Carrazeda, a recém-comprada (2016) Quinta da Gafaria, na sequência do desmembramento da antiga Quinta do Comparado, na freguesia de Beira Grande. Cada membro da família possui quintas geridas por si, sendo as uvas fornecidas às empresas de vinho do Porto da Symington Family, o que é caso único na Região Demarcada do Douro.

São também o maior comprador de uvas e mostos do Douro, numa percentagem de 5 a 10\%, de 2.000 lavradores, tendo-se ainda afirmado como o principal impulsionador e responsável das muitas e profundas transformações verificadas nos últimos anos na vitivinicultura duriense: monitorização e controlo da temperatura da fermentação, novas e mecanizadas plantações, seleção especializada de castas, automação de algumas fases da vindima, grande crescimento e afirmação crescente no contexto mundial e na grande escala dos Vinhos DOC - Douro, cuja produção e exportação duplicaram, nos últimos anos, representando já, hoje, $25 \%$ da produção de vinho do Porto ${ }^{655}$.

Os Symington desenvolveram e mantêm na Região do Douro um planeamento geral/ global estratégico que muito tem contribuído para a recente e profunda reformulação do Douro, a única ou rara região vitivinícola do mundo com duas denominações de origem, Porto e Douro.

A Symington Family Estates tem sido o expoente de uma política de concentração e de integração horizontal (firmas) e vertical (quintas), permitindo dominar a cadeia de valor do seu produto, que não descura, porém, uma gestão inteligente na constituição de parcerias a

\footnotetext{
${ }^{655}$ Informações recolhidas em entrevista feita na sede da Symington em Vila Nova de Gaia em 21/4/2016, ao Eng. Luís Martins, antigo quadro da Administração da Cockburn's e atual técnico superior, diretor de pessoal da empresa e do Arquivo Histórico da Symington Family Estates.
} 
longo prazo, sabendo mobilizar os recursos existentes à sua volta. Tem sido, assim, um polo dinamizador da própria região duriense e garante da sua sustentabilidade.

Importa perceber, por conseguinte, as razões do seu sucesso. Os antecedentes do modelo atual de negócio de que se procura identificar os vetores principais radicam no esforço de internacionalização desenvolvido pela 12. a geração dos Symington, (ascendentes diretos dos atuais membros da administração), nos anos 1940-50, que abriu caminho à afirmação conseguida, a partir dos anos 1970, no Reino Unido através do distribuidor John E. Fells Lda, e, de seguida, nos EUA, pela via da Premium Porto Wines Inc.

Os Symington são membros fundadores, desde 1991, do exclusivo Primum Familiae Vini, um grupo composto pelas onze principais famílias de vinho do mundo. Os seus membros são: Antinori, Joseph Drouhin, Egon Muller Scharzhof, Hugel, os Perrins de Beaucastel, Mouton Rothschild, Pol Roger, Sassicaia, Torres e Vega Sicilia. Os critérios de adesão a esta altamente prestigiada associação são simples: todas as empresas têm de ser inteiramente de propriedade familiar e que devem encontrar-se, há muitos anos, entre os melhores produtores das suas respetivas regiões vinícolas, com excelente reputação internacional. Muito poucos conseguem alcançar estas qualificações.

Podem destacar-se cinco momentos charneira na história do desenvolvimento da Symington a que corresponderam tomadas de decisão complexas, cujo pleno acerto se viria a demonstrar pelo decurso do tempo.

1. No pós-II Guerra Mundial, nos anos 1952-55, em que para evitar o destino que vieram a ter companhias como a Sandeman e a Delaforce, firmas de grande prestígio a operar no Douro, teve de abdicar da propriedade de duas das três quintas possuídas, a Quinta da Senhora da Ribeira e a Quinta do Zimbro, vendo-se forçada a vendê-las por forma a garantir a sobrevivência sustentada através da aquisição das quotas de que não eram ainda detentores da histórica empresa Silva \& Cosens e fruto dessa transação entrando no seu património uma das antigas marcas do Douro, a Warre's ${ }^{656}$;

2. Nos anos 1970, veio a mostrar-se da maior importância a aquisição da grande firma Graham's bem como a da pequena Smith Woodhouse de grande valor por à mesma terem estado associados seus antepassados, no século XIX. A firma W. \& J. Graham \& Co. é 100\% propriedade da Symington e, juntamente com outras empresas da família, é a única empresa produtora de Porto de origem britânica ainda nas mãos de uma única família;

3. Em finais do século XX, princípios do atual século, veio a ser o faseado e moroso processo de aquisição da firma Cockburn's, cuja importância histórica já em subcapítulo

\footnotetext{
${ }^{656}$ Existem marcas mais antigas, como, por exemplo, a Kopke, que surge com a família alemã do mesmo nome, originária de Hamburgo e que se fixou em 1636, em Lisboa, onde Nicolau Kopke foi Cônsul Geral da Liga Hanseática. Seu filho, Christiano Kopke, estabeleceu-se em 1638 no Porto, como comerciante e exportador de produtos portugueses, sendo ao mesmo tempo Cônsul no Norte, e deu início à exportação de vinhos de mesa produzidos na região. Quando o vinho — agora designado de vinho do Porto — foi definido em características e reconhecido por isso, a kopke tornou-se uma das marcas líder (1670-1680) (Disponível em <http://www.sogevinus. com/kopke/>. [Consulta realizada em 6/6/2017]).
} 
próprioanterior se realçou, que decisivamente tornou a Symington Family Estates a líder do negócio do vinho do Porto e primeira produtora do Douro;

4. A aposta comercial nas categorias especiais (Premium) é, porventura, hoje, a resultante das boas escolhas feitas ao longo de anos, ao ser viabilizada por deter as suas principais quintas vinícolas nos melhores solos do Douro e ter sabido dedicar-se à investigação especializada das castas e qualidade das uvas transformadas;

5. A constituição de uma Grape Variety Library (Coleção de Castas), a partir de 2014, na Quinta do Athaíde através de um campo experimental ampelográfico, consubstancia a aposta no desenvolvimento científico e inovação técnica aplicada à preservação e colonização do património nacional de castas, o mais rico, em termos relativos, do mundo, com as suas 250 espécies.

Mais recentemente, a empresa vem explorando com sucesso outra linha de produção, a dos vinhos de mesa do Douro, afirmando no mercado marcas como Chryseia (com Bruno Prats), Altano ou Quinta do Roriz, ao que não será alheio o conhecimento de que, caso único no mundo, o mesmo cacho pode fornecer uvas para vinho do Porto e vinho de consumo de elevada qualidade.

A existência de duas denominações de origem, na Região: Porto e Douro, é caso único ou raro no mundo. Tem-se registado nos últimos anos um grande crescimento dos vinhos Douro Doc que se têm vindo a afirmar no contexto mundial, com uma grande escala [...] os Doc Douro já representam hoje 25\% do vinho do Porto e a escala duplicou nos últimos 4 anos [...] a afirmação internacional dos vinhos do Douro [...] sem esquecer que já existia o 'Barca Velha' da quinta de Vale Meão, [...] é recente [...] com prémios em $2013^{657}$.

A família Symington pôde ao longo de sucessivas gerações acumular um inestimável saber, nas áreas da enologia e da viticultura, o qual lhe tem proporcionado a abertura necessária para definir as atividades de I\&D como prioritárias. É disso mesmo exemplo a introdução no ciclo produtivo do primeiro lagar robótico em aço, o qual sem perda da qualidade da pisa da usa, um dos trabalhos mais pesados e melindrosos da produção de vinho, garante maior eficácia. Entretanto, outras adegas da empresa foram também dotadas dos mais modernos sistemas de funcionamento automatizado.

A empresa tem ao seu serviço cerca de 360 quadros técnicos e trabalhadores especializados, bem como 190 trabalhadores rurais. A sua faturação ascende ao valor médio anual de 80 milhões de euros, representando o vinho do Porto uma percentagem superior a 90\% desse montante.

Ao longo dos anos e, mais recentemente, com particular ênfase, a Symington tem obtido uma apreciação pública especializada muito favorável, mormente através de críticas elogio-

\footnotetext{
${ }^{657}$ Entrevista a Eng. Luís Martins, realizada na sede do Grupo Symington, dia 21 de abril de 2016.
} 
sas nas revistas «Wine Spectator» e «Wine Enthusiast» e múltiplos prémios internacionais de grande prestígio no International Wine Challenge, no Decanter World Wine Awards e no International Wine \& Spirit Competition.

O perfil desta grande empresa familiar, atual líder no Douro, com uma estratégia de desenvolvimento sustentado, trabalho e exigência, liderança e parcerias, é-nos traçado por Paul Symington, protagonista das maiores mudanças no Douro e no vinho do Porto nas últimas décadas e Presidente do Conselho de Administração da Symington Family Estates, desde 2007, o qual, com mais seis membros da família ${ }^{658}$ se encontra à frente deste império com muitos anos de história.

A propósito da presença dos Symington no Douro, Paul Symington, precisando e contextualizando sempre as suas considerações ${ }^{659}$, salienta que o negócio do vinho do Porto começou a descolar nos anos 1970-1980 e que, mesmo com o 25 de abril de permeio, o negócio foi fortemente impulsionado, não só em rendimento, mas também em qualidade.

E prossegue, esclarecendo como e porque os Symington marcam uma diferença de atuação no Douro ${ }^{660}$ : «Os nossos lucros de então foram totalmente investidos no Douro». A família conseguiu sempre decidir e fazer as coisas em sintonia. «Somos três ramos da família, e cada um continua hoje a deter exatamente um terço do capital. E as decisões são tomadas por todos e com o mútuo consentimento de todos».

$\mathrm{Na}$ família Symington, a primeira pessoa do singular não se conjuga. «Utilizamos sempre o "nós"». E a ideia era essa, desde o início.

Tínhamos a Quinta do Bomfim [Pinhão], bem como a da Senhora da Ribeira [Carrazeda de Ansiães] e a do Zimbro [Régua]. Nos anos 1950 tivemos de vender a Senhora da Ribeira e o Zimbro, com grande tristeza, tendo conseguido recuperar, em 1998, a propriedade da 1.' destas duas Quintas.

[...] Quando eu comecei, muitas famílias já cá estavam. Mas hoje já não. Cálem, Barros, Burmester e outras marcas viram-se forçadas a perder o controlo e a propriedade para grupos e empresas mais sólidos ao longo da última década. Nós conseguimos, com a nossa estratégia, vencer e assegurar um crescimento sustentado. O nosso lema é 'Manter a família unida, custe o que custar. Uma família unida é imbativel'.

Estamos aqui para trabalhar duro e não para ter uma vida faustosa e relaxada. Todos os dias, o primeiro funcionário a chegar à sede da empresa é sempre um Symington. Temos 360 empregados a tempo inteiro, vinte por cento dos quais já estão em permanência no Douro. E muitos trabalhadores rurais também, claro. A empresa é muito exigente e, no entanto, quando estamos num convívio com clientes ou visitantes, temos de estar totalmente relaxados, como se não tivéssemos mais nada para fazer.

\footnotetext{
${ }^{658}$ SYMINGTON, 2007.

${ }^{659}$ MELO, 2012.

${ }^{660}$ Citações de P. Symington extraídas da reportagem jornalística de MELO, 2012.
} 
Quanto à liderança no setor do vinho do Porto, «reconhecemos que não podemos estar quietos e sozinhos, temos de seguir em frente».

A compra da Cockburn, em 2006, custou muito caro à empresa. «Foi de longe o maior negócio da história da Symington», por valores ainda não revelados. Uma opção defensiva, "porque alguma empresa familiar que comprasse a Cockburn ficaria de repente muito forte».

A Symington antecipou-se, comprando assim os ativos da empresa que produzia o Special Reserve, tido como o vinho do Porto mais vendido no mundo. «Não foi, como muitos interpretaram, para reforçar uma espécie de império, até porque a Gran Cruz, a Fladgate, a Sogevinus e outros são grandes players deste mercado».

«A relação de longa data que estabelecemos com os lavradores que nos rodeiam assenta, em larga medida, em contratos de aperto de mão. Em pleno Verão Quente de 1975, a seguir à Revolução de Abril de 1974, a banca portuguesa foi nacionalizada e não emprestava dinheiro. Durante as quatro semanas de vindima temos de desembolsar muito dinheiro e naquele tempo vimo-nos num grande embaraço, porque não podíamos pagar com a prontidão que gostávamos. Foi explicado aos lavradores com quem tínhamos relações, pelo meu pai e meus tios: 'vamos produzir o vinho e ele fica registado em vosso nome». A confiança saiu reforçada. «Em janeiro de 1976 estávamos a pagar a toda a gente e ao mesmo tempo ficávamos eternamente gratos aos lavradores do Douro».

A sustentabilidade do negócio permitiu novas estratégias.

A lógica foi recentrar esforços no Douro. E os grandes investimentos sucedem-se, especialmente em vinhas e tecnologia. A Quinta dos Canais, em Carrazeda de Ansiães, é o exemplo mais recente. Foi uma das razões principais para a compra da Cockburn: tem umas vinhas fantásticas e de grande qualidade, com as castas corretas plantadas nos locais mais adequados [...] Ficámos um pouco chocados com o equipamento que encontrámos. Enquanto isso não foi sanado, a vinificação das melhores uvas foi feita na Quinta Senhora da Ribeira, a cinco quilómetros.

Um dos grandes desafios que a empresa enfrenta no setor vitícola é, por um lado, elevar num mercado globalizado, a cotação do vinho do Porto de boa qualidade resultante das melhores castas e tempos ótimos de vindima e vinificação por terroir (solo, clima), vintages de elevada qualidade, respeitada e reconhecida pelos melhores viticultores do mundo e, por outro lado, expandir o seu consumo adequando-o à transformação das atuais condições de vida e à grande mudança de gostos.

Para a empresa «a qualidade é muito importante e sem recursos humanos não há qualidade» pelo que é dada prioridade ao investimento na formação local do seu pessoal no Douro designadamente na vertente do enoturismo em que tem vindo ultimamente a apostar. «Temos a melhor equipa de guias turísticos em Gaia». 
Mas a Symington Family enfrenta ainda atualmente, um segundo desafio, o da regulamentação do setor, grande e antiga problemática que levanta questões complexas:

O atual sistema de benefício ${ }^{661}$ adicionado à lei do terço $0^{662}$ não tem feito bem ao negócio do vinho do Porto [...] As reuniões da Casa do Douro são mais para discutir a dívida e questões ligadas à lavoura do que propriamente para falar sobre regulamentação e revisão de regulamentos. Penso que há uma consciência de que o benefício deve ser planeado com algum tempo de antecedência.

O universo de empresas e quintas durienses cuja propriedade era detida, em 2015, pela Symington Family Estates ou pelos seus membros, individualmente, poderá agora observar-se através de sua descrição exaustiva (ver Anexo VII, Quadro).

\section{Symington Family Estates}

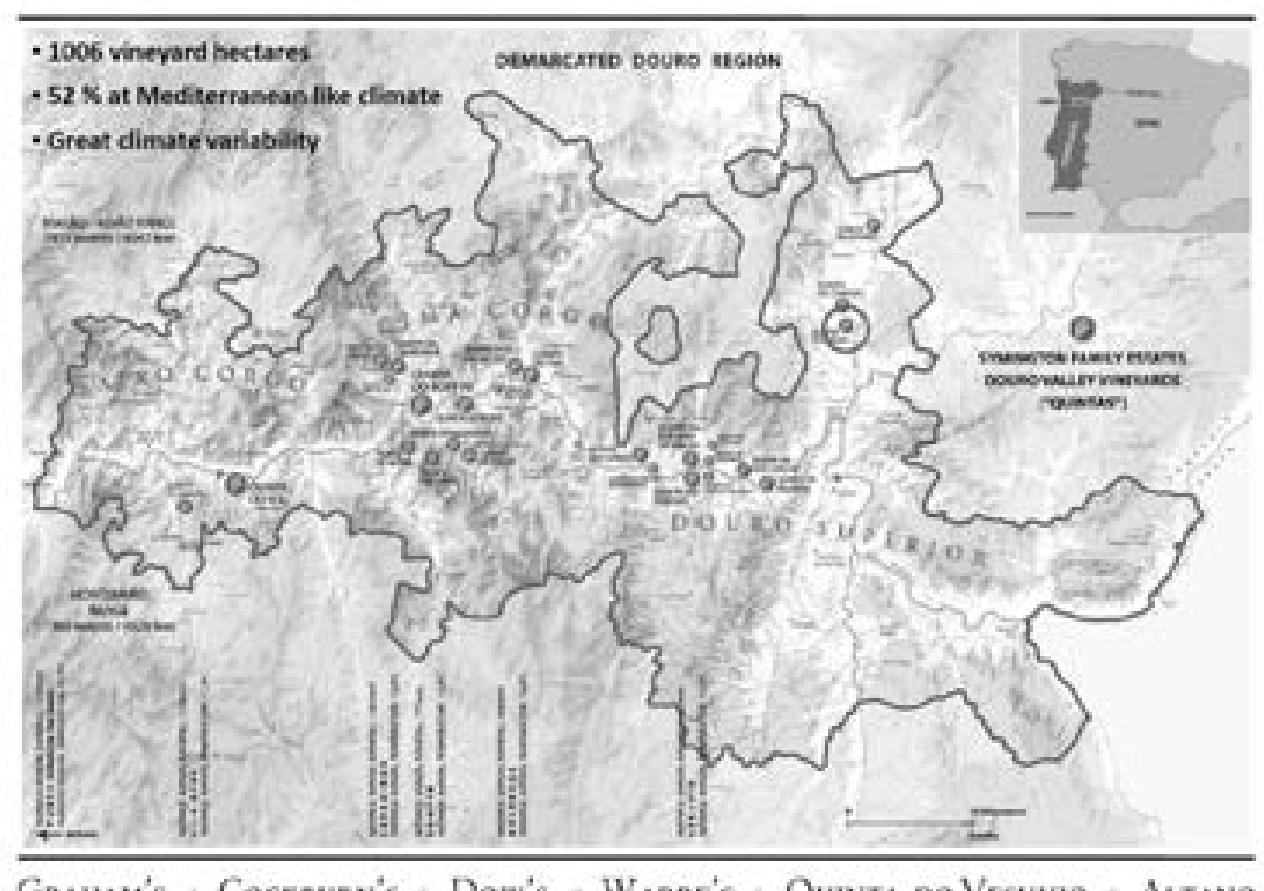

Graham's + Cockburn's + Dow's * Warae's + Qunnta do Vesunio + Altano

Fig. 169. Mapa de localização na RDD das quintas do Grupo Symington Fonte: Site Symington Grape Variety Collections ${ }^{663}$

\footnotetext{
${ }^{661} \mathrm{O}$ benefício é uma espécie de licença para produzir vinho do Porto.

${ }^{662}$ A lei do terço estabelece que dois terços da produção devem ficar armazenados e apenas um terço pode ser vendido, o que, ao gerar excesso de reservas, facilita situações de tipo dumping.

${ }^{663}$ Disponível em <https://www.google.pt/?gws_rd=ssl\#q=symington+grape+variety+collection\&* $>$ [Consulta realizada em 6/1/2017].
} 
O mapa na página anterior permite, por sua vez, uma leitura espacializada do domínio atual dos Symington, com a respetiva localização e distribuição territorial na Região Demarcada do Douro (RDD). Esta representação cartográfica possibilita ainda visualizar a concentração de quintas na zona duriense de Carrazeda de Ansiães, concelho transmontano-duriense de fronteira e as suas respetivas posições entre e/ou nas sub-regiões de Cima Corgo e Douro Superior.

\subsection{EMPRESA GRAMBEIRA — VINHOS DOC DOURO}

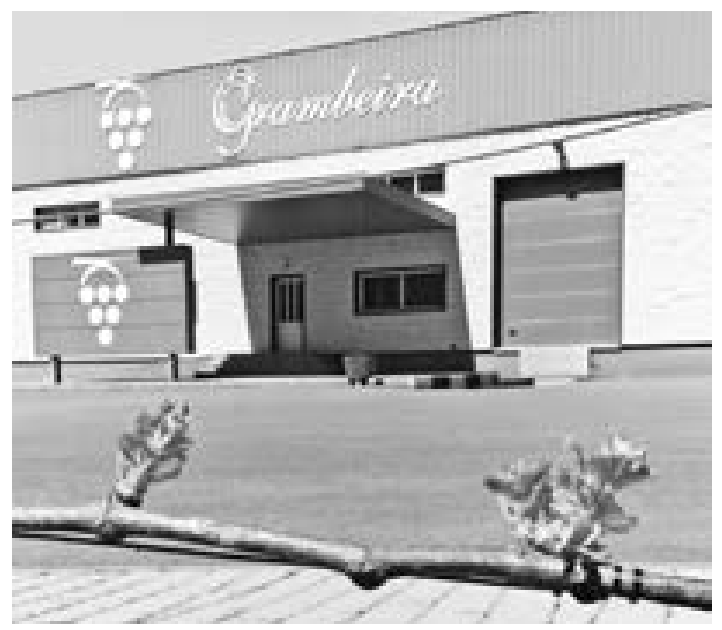

Fig. 170

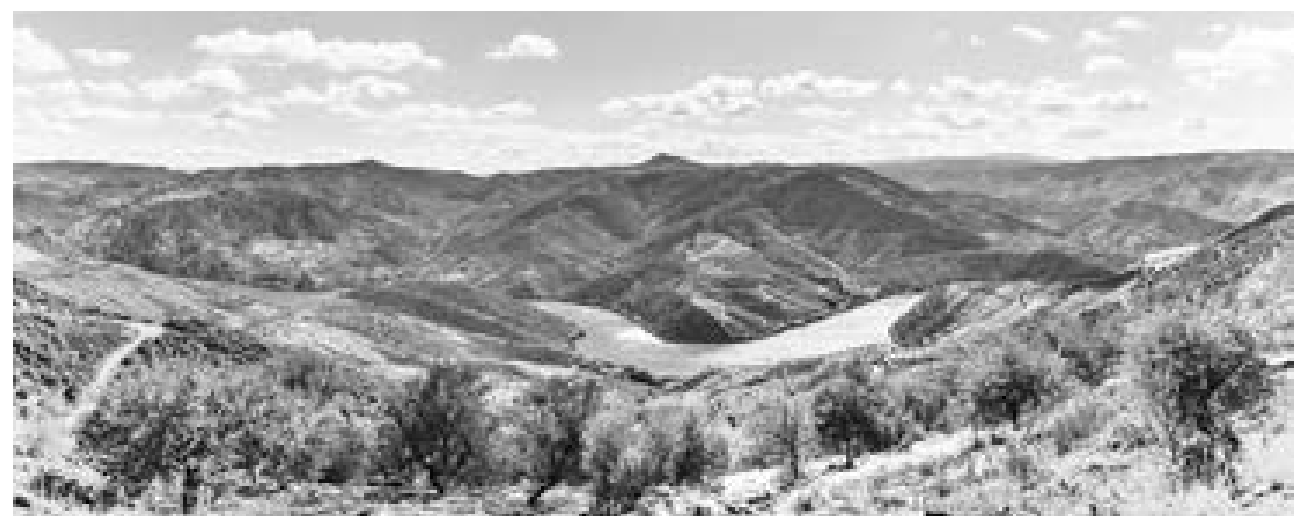

Fig. 171. Vista do Douro (Beira Grande, Carrazeda de Ansiães) ${ }^{664}$

A Grambeira, empresa de vinhos - Douro Superior, é a primeira iniciativa local de produção e engarrafamento de vinhos DOC Douro, no concelho de Carrazeda e resulta de um pro-

${ }^{664}$ Disponível em <https://www.facebook.com/pg/grambeira/about/>. [Consulta realizada em 01/06/2017]. 
jeto vitivinícola arrojado de empreendedorismo familiar local da zona duriense da Beira Grande (Carrazeda), lançado no início da década de 1990, o qual registou de imediato grande sucesso, rapidamente consolidado, como o documenta informação institucional e promocional própria.

\subsubsection{Projeto familiar de empreendedorismo local na fileira dos vinhos}

Em 1994, os 3 filhos da família Meireles, uma família de antigos lavradores viticultores de Beira Grande: Frederico, enólogo de profissão, o irmão mais velho Manuel, oficial do Exército e hoje responsável pelo setor das vendas da empresa, e Afonso, engenheiro agrícola ligado à viticultura e professor dessa área na Escola Profissional do Rodo (Godim-Régua), decidiram transformar uma pequena exploração agrícola familiar localizada nesta zona duriense num negócio moderno e dinâmico de produção de vinhos DOC Douro.

Nesse ano, os proprietários e dinamizadores desta recém-criada firma investiram na reestruturação da modesta adega da família, dotando-a de tecnologia de ponta para a produção de vinho branco e aproveitaram os lagares existentes para vinificar os tintos.

Logo em 1995 ganharam o $1 .^{\circ}$ prémio em vinhos brancos e o $3 .^{\circ} \mathrm{em}$ tintos, num dos concursos então organizados pela Casa do Douro, destinado aos produtores.

Em 1996 iniciaram a fase de modernização das vinhas, com um esforço de reestruturação, replantio e ampliação, anualmente desenvolvido, a par da seleção de castas e plantação por talhões, processo que por ser demorado e muito caro iria continuar a decorrer lenta, mas progressivamente.

Os vinhos são produzidos em condições edafo-climáticas específicas e características desta sub-região duriense, Douro Superior, com solos derivados do xisto e mais agreste em temperaturas (invernos muito frios e verões muito quentes e secos) em que a vinha é sujeita a muito maior stress do que por exemplo no Baixo Corgo.

Em 1998, a construção de uma nova unidade destinada ao engarrafamento, controlo de qualidade e serviços administrativos, investimento que lhes permitiu controlar todo o processo produtivo desde a cultura da vinha e a produção do vinho, representou outro grande avanço deste projeto empresarial.

No ano de 2003, constitui-se, sob a forma jurídica de sociedade por quotas, Frederico Meireles \& Família, Lda, que construiu e inaugurou, em 2004, uma nova adega totalmente modernizada, mas aproveitando toda a tecnologia existente na anterior. Com o propósito de afinar alguns métodos de vinificação, esta nova unidade permitiu introduzir novos conceitos de produção, a par dos contínuos investimentos na viticultura.

Em resultado desse grande e significativo investimento que rondou os 600 mil euros e se traduziu ainda noutras valências e melhorias da empresa, este reforço de capital possibilitou o seu reapetrechamento com modernas tecnologias de vinificação para os tintos e um aumento da capacidade de produção, tendo também permitido redobrar o controlo da qualidade das uvas.

Entretanto, outros investimentos se sucederam ainda com acrescidas mais-valias, na qualidade vinícola: criação em 2013 de uma nova unidade destinada ao estágio de vinhos em 
madeira e em garrafa, nas condições ideais para o seu envelhecimento e refinamento da qualidade dos tintos, abertura de uma loja equipada com sala de degustação e beneficiação e urbanização da área de paisagem envolvente da adega.

Os já seus hoje afamados vinhos (Grambeira Grande Reserva Tinto; Grambeira Reserva Tinto; Grambeira Branco; Val Pedro Tinto; Vinho do Ramo Tinto; Vinho do Ramo Branco) são vinificados a partir de uma variedade de castas: Touriga Franca/ Francesa, Touriga Nacional e Tinta Roriz, Viosinho, Rabigato e Códega de Larinho.

Os vinhos tintos são produzidos a uma cota entre os 150 e os 450 metros de altitude em solos de predominância xistosa, usando para a sua vinificação as castas: Touriga Nacional, Tinta Roriz e Touriga Franca.

Os vinhos brancos são produzidos a partir de uvas cultivadas em solos diferentes, de origem granítica, que localizam-se a cotas mais altas, entre os 450 e os 600m de altitude, usando-se para a sua vinificação a Códega do Larinho, o Rabigato e o Viosinho, antigas castas nacionais e/ou especificamente durienses.

Cada vez mais conhecidos e apreciados, estes vinhos foram-se afirmando no mercado nacional e nos mercados da Europa Ocidental e da América do Norte, onde detêm hoje uma posição de prestígio, tendo-se tornado, pela sua qualidade, uma referência da Região do Douro.

Destacam-se entre os seus Vinhos DOC Douro, os: Grambeira Branco/Grambeira Tinto/Grambeira Grande Reserva/Val Pedro-Douro, os quais têm vindo a arrecadar prémios de qualidade em vários concursos nacionais e internacionais ${ }^{665}$, alcançando um reconhecimento alargado que tem sido essencial para a fidelização dos seus clientes.

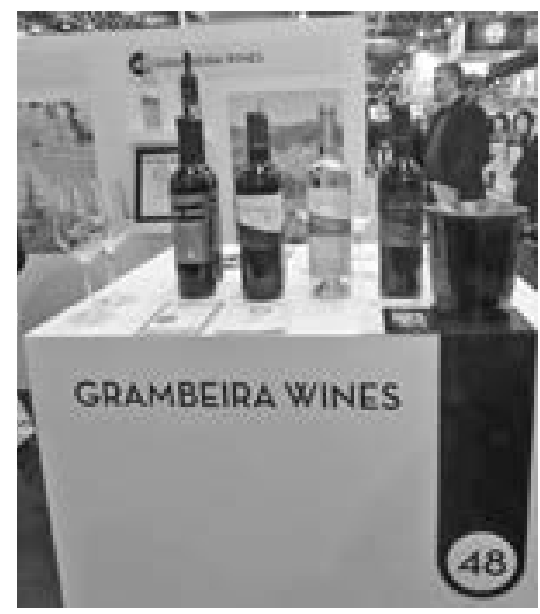

Fig. 172. Principais vinhos Grambeira ${ }^{670}$

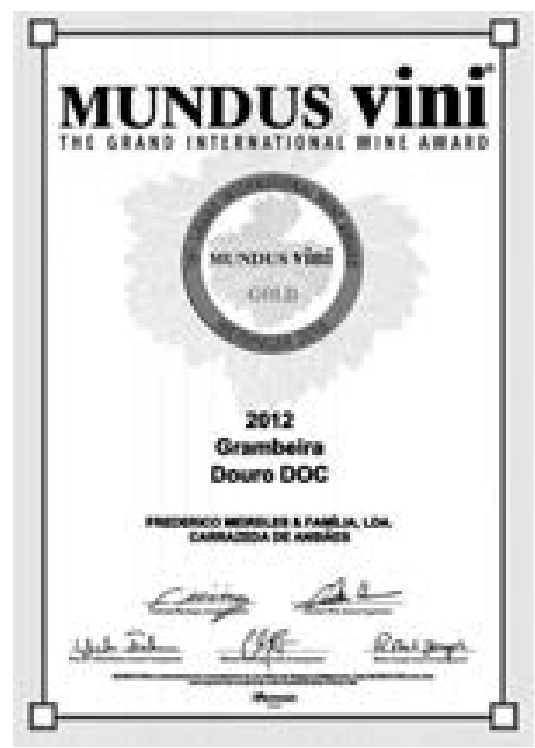

Fig. 173. Prémio internacional $(\text { Itália })^{671}$

\footnotetext{
${ }^{665}$ Disponível em $<$ http://www.vinhoweb.pt/detail.aspx?section=\&idc=46\&ido=11477\&vat $=1>$. [Consulta realizada em 14/05/2017].

${ }^{666}$ Disponível em <https://www.facebook.com/grambeira/photos/>. [Consulta realizada em 01/06/2017].

${ }^{667}$ Disponível em < https://www.facebook.com/grambeira/photos/>. [Consulta realizada em 01/06/2017].
} 
Os 25 prémios alcançados pela Grambeira em apenas 10 anos na fase inicial da sua afirmação entre 1995 e 2005 significam ainda «que o setor dos Vinhos do Douro evoluiu muito no mundo e os enólogos e outros especialistas vitivinícolas tiveram nisso um papel muito grande e decisivo ${ }^{668}$, como reconhece Frederico Meireles, proprietário e sócio gerente desta empresa local de capital nacional, relevante agente económico do concelho de Carrazeda que é ainda um desses novos especialistas pioneiros do Douro atual, com moderna visão estratégica e grande competência técnica e de gestão.

\subsubsection{Uma nova dimensão económica da região: Os vinhos $\mathrm{DOC}$ - Douro}

O engenheiro Frederico Alfredo Meireles, licenciado em Engenharia Alimentar e Enólogo pela Escola Superior Agrária de Santarém, em 1988, é a voz pública mais destacada desta empresa de produção e engarrafamento de Vinhos DOC Douro, única, a nível local neste domínio que regista na Região Duriense os primeiros casos pioneiros, na anterior década de $1980^{669}$, quando se começou a afirmar o novo protagonismo dos vinhos DOP e DOC Douro e a Associação de Viticultores e Engarrafadores de Vinhos do Porto e do Douro (criada em 1986) para facilitar a sua entrada na comercialização direta do vinho, a partir do Douro e respetivos produtores.

A atividade atual polifacetada de Frederico Meireles, como produtor e engarrafador, empresário, executivo e um dos dois sócios gerentes da empresa Grambeira, suporta-se numa vasta experiência que lhe advém de exercer desde 1989 a profissão de enólogo e consultor técnico de Viticultura e Enologia em importantes quintas, empresas e grandes grupos do negócio de vinhos em S. João da Pesqueira, Carrazeda e outros concelhos desta zona da Região do Douro, onde é, ainda hoje, responsável por toda a cadeia de produção vitivinícola (supervisão e desenvolvimento da vinha, maturação e colheita, gestão das instalações e equipamentos, ambiente e segurança, controlo de qualidade, etc.) da Quinta Canaes/Bartol.

Começando por referir-se a esta histórica quinta duriense em Beira Grande (Carrazeda) e às mais recentes gerações de seus proprietários, descendentes de uma antiga e conhecida família luso-espanhola, a que continua ligado há 17 anos, por estreitas relações de trabalho, confiança e fortes motivações alicerçadas numa duradoura amizade familiar que vem já da profunda ligação de seus avós ao «Doutor Espanhol», médico famoso e querido das populações locais, chegado de Espanha por ocasião da Guerra Civil e um dos mais emblemáticos proprietários desta quinta (ver Capítulo 10), o eng. Frederico Meireles salienta aspetos económicos de relevo (questão de rendibilidade, ratios económicos...) nesta zona duriense face à Região, sem deixar ainda de observar o difícil equilíbrio entre vinhas e vinhos.

Sobre a sua mais estreita ligação ao grande negócio emergente dos vinhos DOC Douro, em que trabalha e conhece bem, Frederico Meireles vai referindo e refletindo, como especialista, simultaneamente técnico, viticultor e homem de gestão, sobre recentes binómios durien-

\footnotetext{
${ }^{668}$ Entrevista realizada na sua casa, em Carrazeda de Ansiães 27 de maio de 2017.

${ }^{669}$ BARRETO, 2014: 225.
} 
ses: uvas e vinhas, produção e comércio de vinhos, Vinhos DOC Douro e vinho do Porto (ver Anexo IX, entrevista).

\subsubsection{Uma visão estratégica integradora do e no Douro}

No diagnóstico pragmático feito por Frederico Meireles da Empresa Grambeira há uma aguda perceção dos maiores problemas com que esta zona do Douro, como toda a região, se confronta hoje.

Identifica os principais constrangimentos existentes, a começar pelo da falta de mão de obra e da incapacidade de fixação por não existirem as condições socioeconómicas e culturais de uma política própria de acolhimento e integração dos que continuam a demandar, no Douro, trabalho e condições de vida não encontradas nos países de origem. Mas aponta outras saídas para esta crise como as de uma programada conciliação da formação escolar com o trabalho a tempo parcial, requerendo políticas diferenciadas que se adaptem às necessidades locais.

\section{5. «DOURO ANSIÃES»: INICIATIVA LOCAL DE VINIFICAÇÃO}

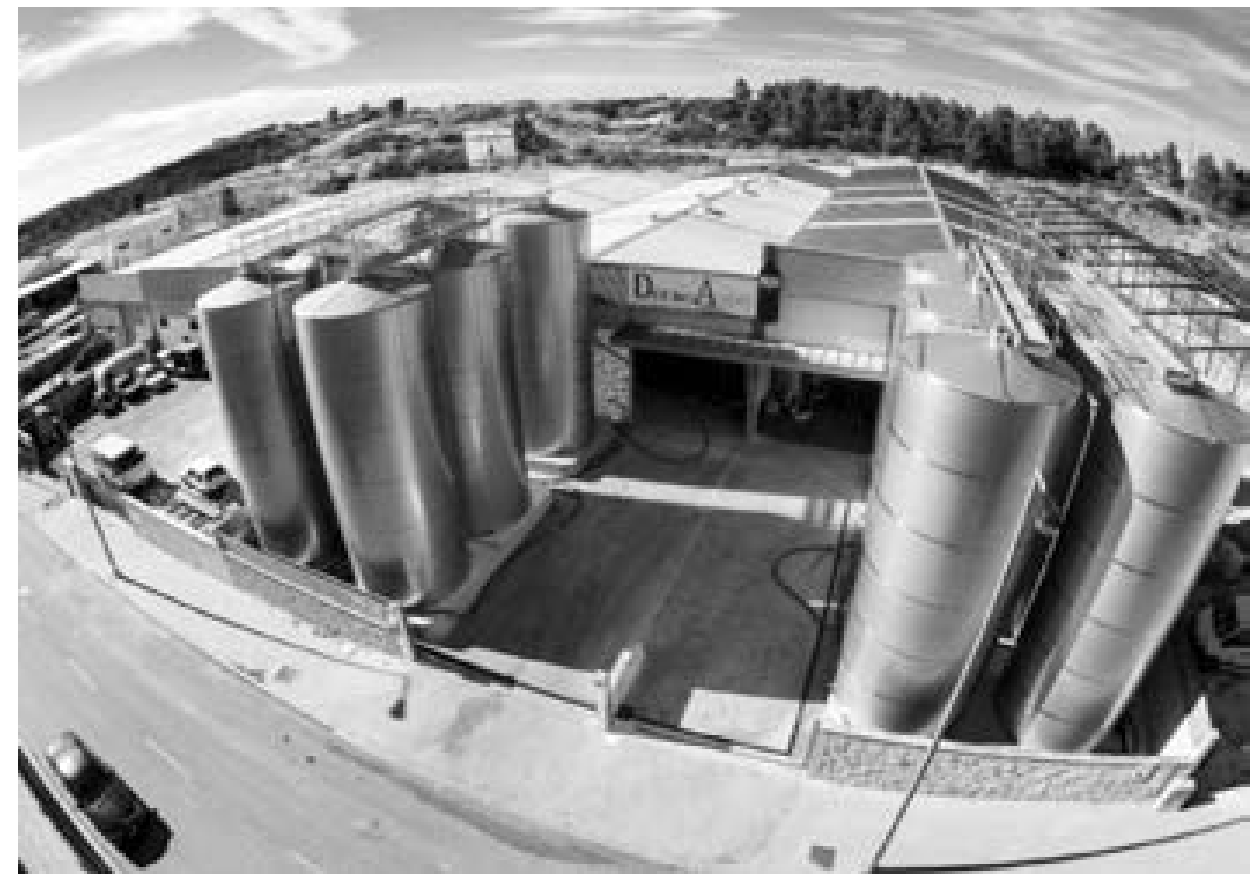

Fig. 174. Empresa «Douro Ansiães» — Carrazeda Fonte: Fotografia de Zito Santos

A Douro Ansiães, Unipessoal, Lda., é uma empresa cuja fundação data de dezembro de 2012, mas com reconhecida e crescente dinâmica designadamente na área concelhia de Car- 
razeda de Ansiães, onde se encontra situada, mais concretamente na zona industrial da vila de Carrazeda, sede administrativa deste concelho.

O seu fundador e atual proprietário, engenheiro Zito Santos, explica assim, no contexto regional, os objetivos e alcance da sua iniciativa empresarial, com impacto na economia do concelho de Carrazeda:

A adega da empresa Douro Ansiães localiza-se na Região Demarcada do Douro na sub-região Douro Superior. Esta adega foi construída com o objetivo de escoar a matéria-prima dos viticultores do concelho de Carrazeda de Ansiães que até então era um enorme sacrifício para os mesmos.

É no Douro Superior que se produzem as melhores uvas em termos de qualidade, pois o solo tem características específicas e as quedas pluviométricas são bastante inferiores, comparado às restantes regiões.

Os Vinhos do Porto produzidos na Douro Ansiães são de qualidade elevada, pois a matéria-prima é boa, logo os vinhos têm que ser bons conjugando o saber enológico com as condições modernas da adega.

O enólogo Zito Santos é um jovem empreendedor de 43 anos que dá continuidade à atividade de seu pai e do avô que já faziam vinhos em Foz Tua, donde é natural a sua família. Esta antiga aldeia vinhateira de Carrazeda, na confluência do rio Douro com o seu afluente Tua foi, historicamente, um importante e movimentado porto fluvial de Trás-os-Montes e Alto Douro, e a sua estação ferroviária é, desde finais de Oitocentos, o principal nó de ligação das linhas férreas do Douro e Tua.

Ele mesmo se nos apresenta assim, cruzando o seu trajeto pessoal e profissional com a trajetória de sucesso desta sua unidade empresarial:

principiei quase a partir do nada, formei-me em engenharia agrícola no Instituto Politécnico de Bragança e na UTAD — Universidade de Trás-os-Montes e Alto Douro, Vila Real. Desde 1999 até 2004 trabalhei no Grupo Symington. Agora, faço consultadoria em fitofármacos a vários viticultores da Região Demarcada do Douro, sou enólogo de diversas quintas no Douro, e proprietário das Quintas do Calvário e do Lameiro Grande em Carrazeda. Em 2005 comecei a vinificar vinho numa pequena garagem com $300 \mathrm{~m} 2$ e em 2012 fundei esta empresa em parceria com a SIVAC, $S A^{670}[$...] foram os donos que me ajudaram muito a lançar neste projeto...

Como considera Zito Santos, a SIVAC mantém relações comerciais com a Douro Ansiães e uma parceria saudável de negócios.

\footnotetext{
${ }^{670}$ A SIVAC, S.A, Sociedade Ideal de Vinhos de Aveiras de Cima, sociedade anónima fundada em 1974, no setor de importação e exportação de bebidas alcoólicas, é uma empresa de média dimensão que emprega 20 a 50 empregados e apresentou um volume de negócios, nos anos de 2012 a 2015, de 10 a 25 milhões de euros, com uma atividade a nível mundial em países da Europa Ocidental, África, América Norte, Ásia-Pacífico e América do Sul.
} 
Subjaz a esta trajetória da Douro Ansiães, uma orientação para aliar à atividade industrial de vinificação a aquisição de propriedades vinhateiras.

A Douro Ansiães é hoje detentora na zona de duas quintas vinhateiras: a Quinta do Calvário, no Vale do Douro (Ribalonga), com uma área de 7 ha e uma produção média de $50.000 \mathrm{~kg}$ de uvas tintas que dão origem ao vinho da marca Vinhas do Tua-Tinto; e a Quinta do Lameiro Grande, no Vale do Tua (freguesia de Pombal de Ansiães), com uma área de 11 ha e uma produção média de $70.000 \mathrm{~kg}$ de uvas brancas. Desta quinta provém o Vinhas do Tua-Branco.

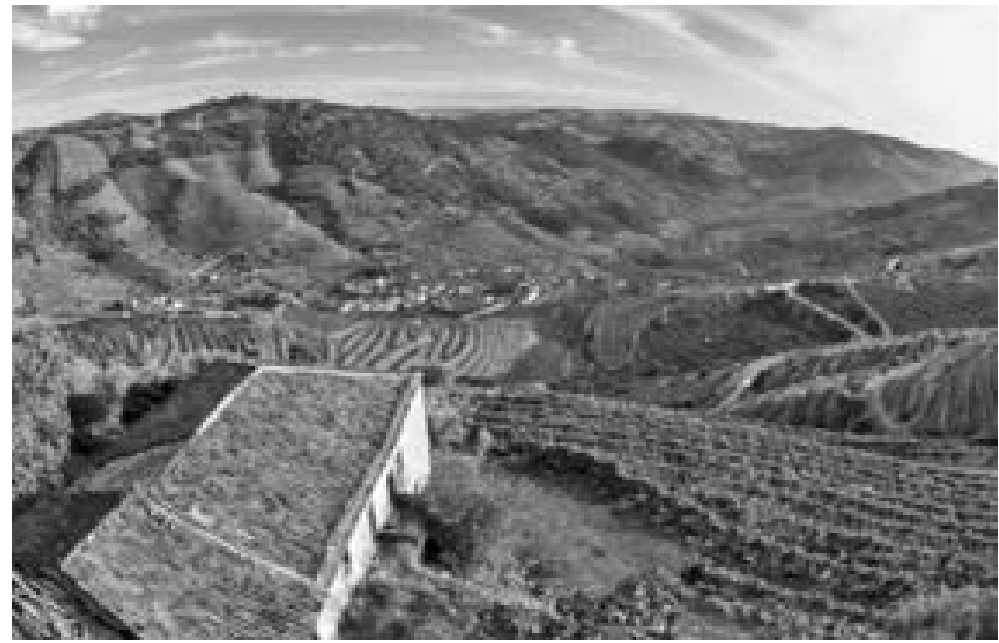

Fig. 175. Quinta do Calvário — vinha nova e casario antigo, com Ribalonga, ao fundo Fonte: Fotografia Zito Zantos

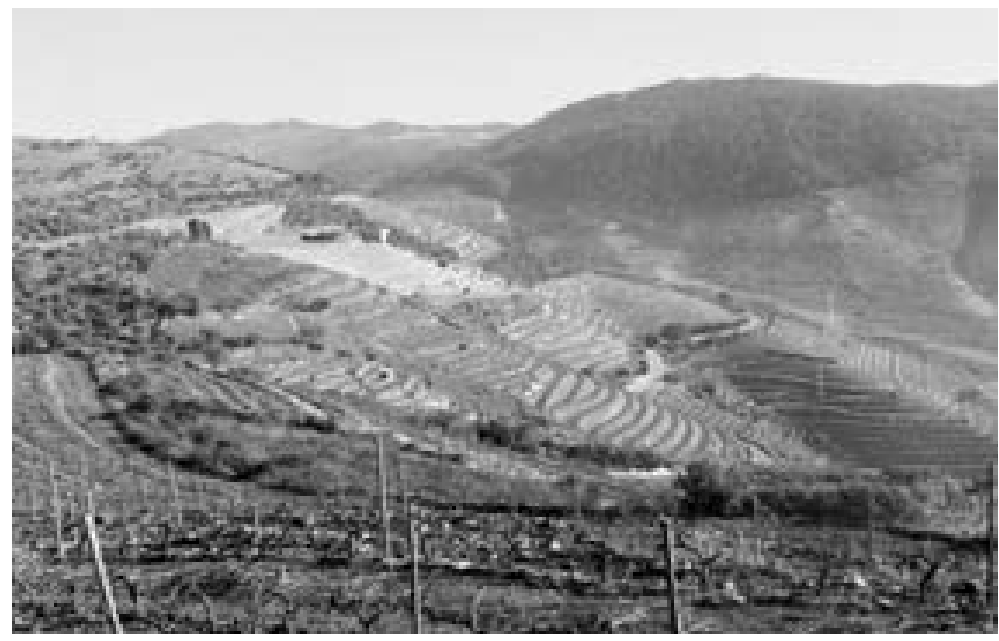

Fig. 176. Localização da Quinta junto à EN 214, entre Castanheiro e Foz Tua Fonte: Fotografia Zito Santos 


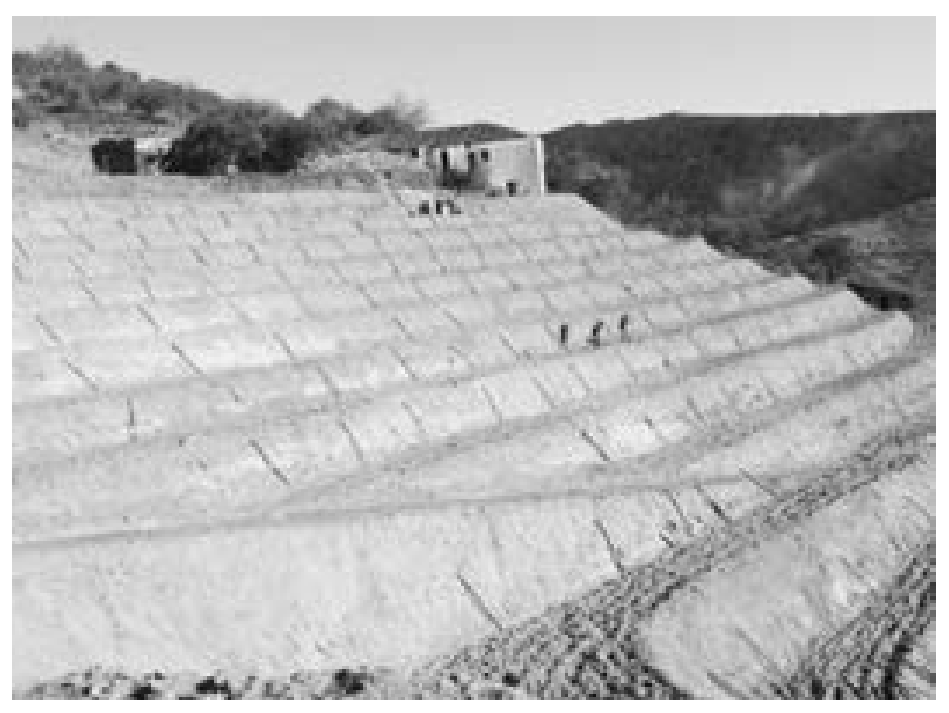

Fig. 177. Quinta do Calvário — surriba recente Fonte: Fotografia Zito Santos

A Quinta do Calvário, uma antiga quinta do concelho do século XIX, encontra-se hoje em fase de modernização, tendo sido toda surribada e replantada com vinha nova, nos últimos 5 anos, pelo seu atual dono. É uma propriedade vitivinícola com casas de habitação e de caseiro, respetivamente datadas de 1842 e 1870, foi ampliada pela compra recente de terras vizinhas e produz, atualmente, 32 pipas de vinho tinto (18 de vinho generoso e 14 de vinhos DOC).

No âmbito da Região Duriense, a Douro Ansiães localiza-se na sub-região do Douro Superior, sendo já hoje uma empresa que se encontra ligada a cerca de 700 viticultores da Região Demarcada do Douro, dos quais a empresa adquire cerca de $3.000 .000 \mathrm{~kg}$ de uvas, matéria-prima que vinifica.

Como concretiza, no contexto da Região Duriense, o proprietário da empresa:

a Douro Ansiães vinifica vinhos generosos para a Symington e Sogevinus. O seu excedente de vinhos de mesa é vendido na sua totalidade à empresa SIVAC. Os viticultores que entregam as uvas na Douro Ansiães pertencem ao Douro Superior. O número aproximado de viticultores da Região Demarcada do Douro ronda os 4.8000 viticultores. A Douro Ansiães vinifica 4.000 pipas de vinho, sendo 2000 pipas de vinho generoso e as restantes 2.000 pipas dividem-se em vinhos Doc e vinhos de mesa. Estes valores variam com as necessidades de mercado de ano para ano. No ano de 2016 foram produzidas na RDD, 111.000 pipas de vinho generoso.

O concelho de Carrazeda, segundo dados de 2016, regista 1.120 exploradores (com autorização de produção válida) e a sua produção é a constante do seguinte quadro: 
Quadro 37. Mosto generoso (distribuído) e área do concelho de Carrazeda (2016)

\begin{tabular}{|c|c|c|c|c|}
\hline MG (litros) & Área apta (m2) & Área não apta (m2) & Área sem enquadramento legal (m2) & Total (m2) \\
\hline 2.596 .793 & 17.111 .354 & 307.533 & 781.745 & 18.200 .632 \\
\hline
\end{tabular}

De acordo com dados do INE, no concelho de Carrazeda de Ansiães a produção vinícola declarada em mosto pelo produtor nos anos anteriores de 2009-2012 foi de $32.697 \mathrm{hl}$, em 2012, e de $30.196 \mathrm{hl}$, em $2009^{671}$.

A vertente de produção da Douro Ansiães abrange os vinhos licorosos e os vinhos comuns ou de mesa (DOC e regionais) nas seguintes quantidades produzidas anualmente (valores aproximados):

Vinho Generoso Tinto - 1.250.000 1
Vinho Generoso Branco - 600.000 1
Vinho Douro DOC Tinto - 100.000 1
Vinho Douro DOC Branco - 50.000 1
Vinho Regional Duriense Tinto - 400.000 1
Vinho Regional Duriense Branco - 120.0001

O Centro de vinificação desta empresa caracteriza-se pela sua modernidade, tecnologia de ponta e equipamento totalmente comandado através de um sistema informático integrado.

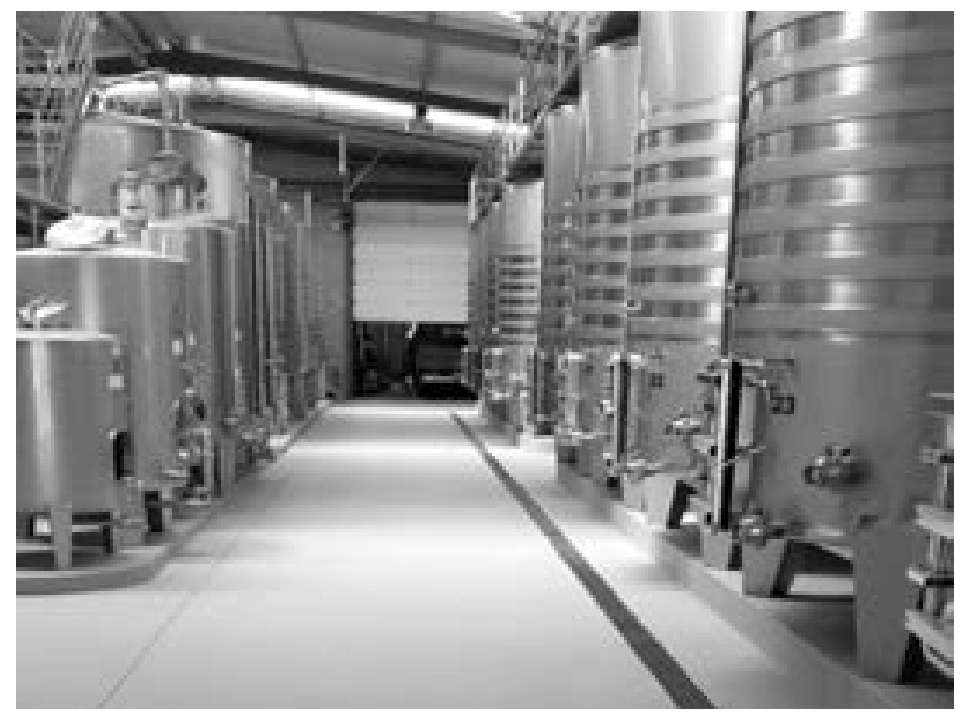

Fig. 178. Douro Ansiães — Espaço interior, nave de vinificação Fonte: Fotografia Zito Santos

${ }^{671}$ INE - http://www.ine.pt. Estatísticas territoriais (2014). Produção vinícola declarada em mosto (hl) pelo produtor; Anual — Instituto da Vinha e do Vinho. 
Trata-se, segundo Zito Santos, de uma «belíssima rede de frio e cubas de fermentação específicas para elaborar boas fermentações. Sistema de prensagem apropriado para os vários tipos de vinhos a obter (prensas pneumáticas e prensas contínuas)».

A sua capacidade de fermentação ascende atualmente a 600.000 l, sendo a capacidade de armazenamento de 2.500 .0001 .

Nesta nave de vinificação, como esclarece o próprio proprietário da adega, como explica Zito Santos:

é vinificado todo o tipo de vinho (Generosos, Mesa e Doc) sempre a temperatura controlada e utilizando as mais modernas técnicas de vinificação. Todas as cubas de fermentação são acompanhadas por bombas de remontagem de turbina polida para não macerar em excesso as massas vinicas aquando das remontagens. As condutas de massas são telecomandadas por um computador em que este direciona as massas para as várias cubas de fermentação através de válvulas pneumáticas. Nas passerelles de aço inox circula água, gás (azoto) e ar. 


\section{CAPÍTULO 9. PRÁTICAS E SABERES DE ATORES SOCIAIS}

Nos dois capítulos anteriores foram apresentados e estudados alguns dos principais operadores da Região Demarcada do Douro em seu protagonismo histórico e intervenção predominante no território económico e social deste concelho de fronteira.

Importa tentar apreender agora a dimensão desta relação com outros operadores na história recente da produção vinhateira local, o que nos leva a adotar uma heurística pluridimensional e multi-perspetivada assente na competência dos atores sociais.

Para esse efeito, selecionou-se no acervo de cinquenta entrevistas realizadas ${ }^{672}$, em demorado trabalho de terreno desenvolvido numa atitude de «proximidade crítica» e «objetivação participante», na perspetiva da sociologia reflexiva ${ }^{673}$, com informantes privilegiados identificados num processo de construção e negociação de confiança recíproca, um reduzido mas significativo conjunto de 11 entrevistas consideradas paradigmáticas de que adiante se transcrevem excertos das narrativas desses atores sociais locais mais representativos e conhecedores do tecido social produtivo e humano da zona vinhateira do município de Carrazeda.

Essa dimensão relacional entre principais operadores sociologicamente compreendidos como «agentes sociais» e o espaço social local entendido num quadro sociológico como «superfície social» e sob este enfoque observada é, necessariamente, antecedida e enquadrada por uma ótica económico-social abrangente da globalização dos mercados do vinho do Porto, relevando-se os seus efeitos locais ao nível da comercialização e produção vitivinícola.

Impõe-se, porém, antes de prosseguir, uma explicação prévia sobre a necessária compreensão analítica dos conceitos sociológicos de «agente eficiente» e «superfície social» aqui aplicados à interpretação do conjunto das narrativas dos atores sociais, cujas individualidades biográficas, posições sociais e saberes competentes, leigos e peritos, se tentam mobilizar enquanto índices de relevante capital de informação para conhecimento de um campo e espaço social de possíveis em que interagem.

Os acontecimentos biográficos definem-se como colocações e deslocamentos no espaço social, isto é, mais precisamente nos diferentes estados sucessivos da estrutura de distribuição das diferentes espécies de capital que estão em jogo no campo considerado. O sentido dos movimentos que conduzem de uma posição a outra [...] evidentemente se definem na relação objetiva entre o sentido e o valor dessas posições num espaço orientado. O que equivale a dizer que não podemos compreender uma trajetória [...] sem que tenhamos previamente construído os estados sucessivos do campo no qual ela se desenvolveu e, logo, o conjunto das relações objetivas que uniram o agente considerado [...] ao conjunto dos

\footnotetext{
${ }^{672}$ Ver em anexo IX, modelo de guião construído e utilizado com adaptações a cada caso.

${ }^{673}$ BOURDIEU, 1989: 51-58. Ver ainda BOURDIEU, 1993.
} 
outros agentes envolvidos no mesmo campo e confrontados com o mesmo espaço dos possíveis. Essa construção prévia também é a condição de qualquer avaliação rigorosa do que podemos chamar de superfície social, [...] isto é, o conjunto das posições simultaneamente ocupadas num dado momento por uma individualidade biológica socialmente instituída e que age como suporte de um conjunto de atributos e atribuições que lhe permitem intervir como agente eficiente em determinados campos. [...] [Sendo] o individuo, a pessoa, o 'eu', 'o mais insubstituivel dos seres'... para o qual nos conduz irresistivelmente uma pulsão narcísica socialmente reforçada $[. . .]^{674}$.

Os informantes privilegiados selecionados compõem uma galeria expressiva da ambiência económica, socioprofissional e cultural geral, que pode intuir-se, através dos excertos de suas narrativas interpretados, sob a prevenção sociológica atrás delineada, como «agentes eficientes» de um processo de construção dinâmica e relacional da «superfície social» característica da zona vinhateira duriense regional e local.

A agregação possível da diversidade de elementos característicos permite então percecionar algumas dimensões e variáveis relevantes que configuram, ao nível social, a significativa fileira vinhateira de Carrazeda na sua história recente, na qual se destaca, desde logo e como dimensão principal, o estabelecimento de parcerias de longo prazo entre grandes operadores e a multiplicidade de pequenos produtores.

\subsection{VISÃO EMPRESARIAL DO DOURO NA ATUALIDADE}

O enquadramento económico-social duriense é, de modo preciso e esclarecedor, apresentado numa entrevista ${ }^{675}$ de Paul Symington, alto representante da Symington Family Estates $^{676}$ e, hoje em dia, um dos mais esclarecidos, conhecedores e destacados porta-vozes do Douro e, simultaneamente, um dos maiores produtores de vinhos do Porto. Em função de tal papel dominante na estrutura fundiária duriense e liderança na atual dinâmica produtiva e negocial dos Vinhos do Porto, pode considerar-se como principal «agente eficiente» interveniente na «superfície social» do concelho de Carrazeda de Ansiães a que se encontra ainda ligado por laços familiares mantendo seus pais períodos de residência na Quinta da Senhora da Ribeira.

Nascido no Porto, define-se como «uma mistura de escocês, português e inglês, que ao lado dos seus primos Johny, Rupert, Dominic e Charles - assegura a continuidade da quinta geração à frente da Symington Family Estates, a mais antiga das famílias inglesas presentes no Douro».

\footnotetext{
${ }^{674}$ BOURDIEU, 1996: 190-191.

${ }^{675}$ PINTO, 2012.

${ }^{676}$ Licenciado em Gestão pela Universidade Westminster (Londres), para além de outras formações de nível superior é, desde 2003, Presidente do Conselho de Administração do Grupo Symington Family Estates. Tem desempenhado diversos cargos no sector empresarial do vinho do Porto, em Portugal e Inglaterra, em que tem sido agraciado com várias condecorações e nomeações de destaque.
} 
Profundo conhecedor da Região Duriense considera, com realismo crítico e um certo desencanto «Está a fazer-se cada asneira no Douro!» dada a forma «pouco planeada como a região duriense tem sido gerida» e, receando pelo desenvolvimento sustentado do Douro avisa que «ganhar prémios não garante a sustentabilidade do Douro nem a das empresas».

Destacado produtor de vinho do Porto no mundo globalizado dos nossos dias, enfrenta a concorrência «das grandes cadeias europeias a vender vinho do Porto abaixo do custo. É muito grave. Estão a utilizar Porto da Região Demarcada e com selo de garantia para atrair clientes e conquistar quota de mercado. É dramático e tem uma influência muitíssimo negativa na imagem do produto. Um Porto a 3,24 euros, como é o caso, é um desastre».

Por isso, considera que deveria custar pelo menos

Cinco euros! Para ficar uma margem mínima para o produtor. É dramático. O consumidor pensará que 3,24 euros, com IVA a 21\% e imposto de álcool a 77 cêntimos, o produto não valerá muito. Marcas a preços superiores ficam sem comprador e reduzem as vendas. [...] Só chamo a atenção para o facto de o grande poder negocial estar nas mãos das grandes cadeias. Sei que estão a fazer o seu trabalho, têm acionistas, seguem a sua estratégia. Somos nós todos que, fazendo compras nessas cadeias, thes damos o poder negocial. Todo o setor agrícola sofre muito com isso. É a realidade em toda a Europa.

A seguir, alerta para o esmagamento do preço do vinho do Porto no produtor, consequências de excesso de produção, e dá o exemplo da Symington ao nível da promoção internacional do vinho do Porto face a novos desafios no mercado mundial, como a alteração dos hábitos de consumo:

Sobretudo se há excesso de produção, como é o caso. Temos lutado, sistematicamente, perante as autoridades, para que não se produza mais. Se a produção continuar a aumentar, não há volta a dar. Se há vinho do Porto a mais, o preço baixa, desvalorizamos o vinho e sofre toda a gente. Mas ninguém quer saber disso. [...] Se há stock a mais, as cadeias aproveitam. Há sempre empresas com stocks a mais e com a banca a dizer para pagarem os empréstimos. Qual é a solução? Vender mais vinho. Mas o mercado não está em crescimento e com esta crise... Vamos lá ver, estou farto de ouvir que tem de haver mais promoção. O meu irmão está no Brasil, um primo meu está em Inglaterra, o nosso diretor de vendas está na Holanda. Estamos constantemente nos mercados. A Symington abre um escritório em Hong Kong, em junho. Um dos nossos vendedores está quatro meses por ano na Ásia e passará a viver lá a partir de junho. Em São Paulo, Moscovo, Vancouver, Nova Iorque, Tóquio estamos a fazer provas. Evêm supostos peritos dizer que tem de haver mais promoção! Então, venham fazê-la. Venham. Se têm ideias melhores do que as nossas... [...] Há é novos desafios, no mercado mundial. A maneira de viver alterou-se. O vinho do Porto está muito associado à formalidade. Quem é que hoje come numa sala de jantar 
formal? Não é um vinho que seja bebido pelos jovens. Alterar estes hábitos implica enormes investimentos, de muitos milhões de euros. Os mais jovens querem aperitivos com gelo, Coca-Cola, água tónica ou vodka. Temos de tornar os nossos vinhos relevantes no dia a dia. O formalismo de decantar um vintage é lindo. Mas um casal jovem que vive num apartamento sem cave, onde vai guardar um vintage? [...]. A experiência diz-me que alterar hábitos de consumo precisa de milhões e milhões investidos sustentadamente entre três e quatro anos. Mas não temos margens para campanhas de publicidade. Resta-nos trabalhar o mercado de nicho, de qualidade.

Quanto a recentes revoltas e protestos dos pequenos viticultores durienses, motivados pela baixa do preço a que lhes são compradas as uvas pelos grandes produtores, que cada vez mais, têm vindo a concentrar em seu poder quintas e terras, pagando mais barato ao pequeno viticultor, comenta: «Entendo-os perfeitamente. Sou lavrador, também tenho uma pequena quinta, vendo as uvas à empresa e esta ainda compra a terceiros. Sei o preço a que compramos. Mas é preciso ver o assunto na globalidade. A sobrevivência das empresas passa por terem uma dimensão suficientemente grande para aguentar as pressões do mercado».

Considera que o pequeno viticultor está na base dessa cadeia de pressão: «Claramente. Não podia ser de outra maneira. Uma negociação muito difícil com uma cadeia tem um impacto muito grande e imediato sobre o lavrador. Se sou pressionado aí, como é que posso pagar mais ao lavrador? Ou a empresa desaparece. Isto não são palavras vãs. Quem estava neste setor há 30 anos? Quantas famílias? Mais de metade das empresas de vinho do Porto mudou de mãos, nos últimos 25 anos. Mais de metade! Havia muitas empresas familiares que desapareceram completamente!»

Relativamente à compra por grandes empresas, como a da sua família, objeta: «E porque é que venderam? Se isto fosse fácil e desse ótimas margens, os donos ainda estavam aqui».

Entende que se há uns que aguentam e outros não, é:

Porque há uma mão familiar. Nesta família, nunca calculamos o valor das vinhas, dos armazéns, dos stocks para saber qual o retorno do capital investido. Se fosse o caso, também abandonávamos isto. [...] Tivemos mais coragem. Quando comprámos a Cockburn's fomos à banca pedir empréstimos enormes. Fizemos isto porque a sobrevivência e a sustentabilidade passa por termos dimensão suficiente. [...] Caso contrário, seriamos 'espremidos pelo mercado' [...] Sem tirar nem pôr. Foi um trabalhão medonho absorver a Cockburn's. Despedimos na nossa empresa e na deles, para integrar. No futuro, o vinho do Porto vai passar por três, quatro, cinco grandes empresas e muitos pequenos produtores de nicho de grande qualidade. As médias têm um problema grande. [...] os pequenos viticultores têm mais possibilidades de sobreviver do que o médio. A grande maioria, tem uma tasca, restaurante, oficina, têm outro emprego. Quem está realmente com grandes dificuldades é o que tem de contratar pessoal, ter tratores e equipamento para gerir uma quinta de 10 a 20 
hectares. Dependemos desses e queremos que tenham viabilidade. A Symington é a que tem mais vinha no Douro e, no entanto, isso corresponde apenas a $20 \%$ das nossas necessidades. Tenho um enorme problema com a falta de planeamento por parte das autoridades. Ninguém planeou nada, foram emitidas demasiadas licenças de plantação. A Casa do Douro e os benefícios atribuídos já não fazem sentido. As vendas de vinho do Porto cresceram nas décadas de 70, 80 e 90 de uma maneira sustentada. O crescimento parou em 2000. Daí para cá, estabilizou ou diminuiu ligeiramente. Mas nunca nenhuma autoridade veio às empresas pedir estatísticas. O IVV, o IVDP, o Ministério da Agricultura deviam ter o bom senso de pedir uma previsão das vendas nos próximos anos. Era o mínimo. [...] Isso nunca foi feito. Tem sido feito um trabalho fantástico nos vinhos DOC, nos últimos dez anos. Mas, em Lisboa, parece que se limitam a ler no jornal que marcas como Vale Meão, Quinta de Vesúvio ou Quinta do Crasto têm boas notas na Wine Spectator! Porque não perguntar quanto vinho será necessário, nos próximos cinco anos? Nunca se fez isso. Portanto, passamos de 40 para 45 mil hectares. Porque é que nunca houve um planeamento? É um escândalo. [...] O controlo da região passa por várias entidades: IVV, IVDP, Casa do Douro. É demasiado. Mesmo entre elas observa-se uma confusão de responsabilidades. Ninguém sabe quem é o dono do cadastro, se a Casa do Douro, se o IVDP, se o Estado. Isto não ajuda nada.

Sobre a atual alternativa do turismo considera:

O Douro estava no limiar de uma grande mudança para o turismo. Mas esta recessão parou muita coisa. Há um boom de turismo no Porto e, quando a A4 estiver pronta, o turismo terá sucesso. Neste momento, não tem grande peso na economia da região. Há vários hotéis, mas com enormes dificuldades no inverno. O Aquapura fecha no inverno, o Solar da Rede fechou completamente. O Vintage House Hotel, que a Taylor's construiu e abriu em 2000, está agora nas mãos da banca — \$ o quarto dono, em dez anos!

Refere como exemplos a seguir o da Quinta Nova ou o da Quinta do Valado, que têm apostado no turismo: «Esse modelo é o adequado para a região. Não os hotéis com golfe, isso é uma asneira grande. Ninguém vai para o Douro duas semanas. O turista vai lá passar três a quatro dias. Os grandes hotéis não terão sustentabilidade. Só hotéis de charme ou palacetes que fazem parte da história da região».

E termina, sublinhando a importância do planeamento turístico:

Está a fazer-se cada asneira no Douro! Toda a câmara ou junta de freguesia, para ser eleita, avisa que vai pôr postos de iluminação nas ruas. E cada ano há mais luz no Douro, à noite. Os senhores do turismo deviam avisar que não é aconselhável pôr luz em caminhos onde não passa nenhum carro. Mas o povo elege o presidente da junta que põe luz. É um 
custo enorme, sem benefícios para as pessoas. [...] Se for num povoamento [...] Não é o caso. Em frente dos Malvedos [em Foz Tua, entre os concelhos de Alijó e Carrazeda], onde o primeiro-ministro britânico passa as suas férias, há um sítio lindíssimo. E apareceram lá, num caminho de terra batida, postos de iluminação! Ligámos para a Câmara e disseram: 'aaah, havia fundos'. 'Ninguém vai lá!', respondemos. E eles: 'Depois da inspeção dos fundos, vamos desligar.' Assim foi. Portanto, temos à nossa frente postos de iluminação porque havia fundos e estão desligados! Bem, é melhor não continuar [...].

\subsection{PERSPETIVA AUTÁRQUICA DO DOURO}

Por sua vez, a posição institucional e administrativa do Presidente do Município Duriense de Carrazeda de Ansiães, José Luís Correia, detentor do cargo nos últimos dois mandatos (2009-2017) pode ser acompanhada através de sua entrevista escrita que nos foi concedida, em 2016 (ver Anexo IX).

Aí, de um ponto de vista global informado por relativo ceticismo, é feito, em articulação com uma análise formal do Douro Vinhateiro, Património da Humanidade, em alguns dos seus constrangimentos atuais, um diagnóstico de algumas das problemáticas económicas da fileira vitivinícola e demográficas (despovoamento) consideradas mais pertinentes neste «concelho da Região Demarcada», onde são «os vales do Douro e do Tua as áreas mais ricas e importantes».

No contexto do diagnóstico concelhio que é esboçado em que o papel, atribuições e responsabilidades próprias da autarquia se encontram diluídas, considera que: «Sem dúvida que a vitivinicultura tem e pode ter cada vez mais um peso muito significativo na economia do concelho; mas para isso é necessário tirar partido da excelente qualidade dos vinhos que produzimos de forma organizada e em escala».

Já no âmbito da sua análise do Douro Património Mundial, considera: «há que defender a classificação pela classificação e não se preocupar com a implementação do Plano de Ação que tem inerente bem como a avaliação da mesma ao fim de catorze anos», ao concluir que «podemos afirmar que durante estes anos tem trazido aos residentes mais condicionantes, mais incómodos a nível de licenciamentos e reconversão de vinhas, do que oportunidades a nível económico e social. A região não deu o salto que era expectável através do turismo e da valorização dos produtos».

\subsection{INFORMANTES PRIVILEGIADOS - MÚLTIPLAS PERSPETIVAS}

Prossegue-se esta aproximação à «superfície social» da área vinhateira de Carrazeda que se procura agora delinear, agregando uma sucinta, mas representativa diversidade de testemunhos e depoimentos de outros informantes privilegiados locais, atores sociais operantes em diferentes atividades do contexto socioeconómico e político-cultural e que intervêm assim em vários campos como «agentes eficientes». 
Estas narrativas de «histórias vividas» abordam diferentes realidades históricas de toda a faixa ribeirinha leste-oeste desta zona vinhateira do Cima Corgo e Douro Superior e são mobilizados como fontes orais relevantes a uma aproximação sociológico-histórica das relações sociais estabelecidas entre «agentes eficientes» e «superfície social» que se visa compreender de modo mais impressivo e extensivo ${ }^{677}$.

Nessa medida, a sua leitura interpretativa transdisciplinar ${ }^{678}$ orienta-se, entre outros, pelos conceitos dominantes da «localidade» e da «região» que interagem recíproca e interativamente com «agentes eficientes» em coconstrução com uma determinada «superfície social» e também pelo princípio teórico «de que todas as medidas são e permanecem ligadas a redes locais e de que os efeitos globais são adições-sobre adições, em regra, de medidas locais» ${ }^{679}$.

Experiências diferenciadas e condições sociais de vida, práticas e relações de trabalho, saberes leigos e técnicos das populações e de diferentes atores sociais (donos de propriedades rurais e quintas vinhateiras, lavradores e produtores vinhateiros, trabalhadores e técnicos vitivinícolas) do e no «local» constroem e são construídos em interações e inter-relações pela «região» à escala nacional, internacional e mundial da comercialização do vinho do Porto, em que operam (in)diretamente empresas estrangeiras e nacionais, empresários, negociantes e produtores de vinhos, técnicos de políticas agrícolas e vinhateiras, políticos locais e ex-autarcas.

Esse conjunto diversificado dos atores sociais aqui evocados, em suas narrativas complementares, onde defendem posições correspondentes a interesses, por vezes divergentes e ou polémicos (Anexo VIII, entrevistas), compõe um quadro plurifacetado, a nível económico-político e sociocultural, que se caracteriza pela sua densidade sócio-histórica e grande representatividade social das forças e dinâmicas em presença neste concelho duriense.

O depoimento de um informante privilegiado ex-Presidente da Câmara de Carrazeda de Ansiães, na década de 1990, subdiretor regional e diretor regional em substituição entre 1981 e 1984, no Ministério da Agricultura começa por traçar uma retrospetiva exaustiva, que enraíza no período da I República, com a história da família Sampaio da elite local, dona, entre outras propriedades, da Quinta do Comparado ou Quinta da Gafaria. Vai depois centrar-se, numa reflexão pessoal crítica em torno de vários tópicos, nas problemáticas, tendências e modelos recentes de desenvolvimento do Douro Vinhateiro, Região Demarcada do Douro e Património da Humanidade, incidindo nos projetos recentes de modernização de vinhedos e vinhos, apoiados por fundos mundiais e europeus, nas décadas 1980/1990, que todavia considera «balões de oxigénio», e destacando respetivas evidências, impactos e limitações no concelho

\footnotetext{
${ }^{677}$ Selecionaram-se apenas excertos de 9 das 50 entrevistas realizadas entre 2012 e 2017 no concelho de Carrazeda de Ansiães a uma grande diversidade de informantes privilegiados (antigo dirigente do Ministério da Agricultura, proprietários e lavradores destacados, pequenos proprietários, antigos trabalhadores nas quintas e propriedades vinhateiras, «foleiros», «arrobeiros» e intermediários nos negócios dos vinhos generosos, etc.), com particular e estreita relação com diferentes dimensões da história contemporânea e realidade atual da Região do Douro.

${ }^{678}$ PEREIRA \& TEIXEIRA, 1998; PEREIRA \& SOUSA, 1988; PARKHURST, 1996; MENDES, 1996: 127-142.

${ }^{679}$ RHEINBERGER, 2013: 40.
} 
de Carrazeda que considera ter «uma história em fronteiras várias», a nível social, geográfico e administrativo (Informante 9.2.1).

Outro informante privilegiado, produtor vinhateiro «simples e pequeno», como se reconhece $^{680}$, enumera alguns dos maiores problemas com que, em sua perspetiva, se defrontam hoje os viticultores - custos de produção elevados e baixos preços de venda das uvas e dos vinhos, diminuição do benefício, etc., ao mesmo tempo que realça as novas possibilidades abertas com a seleção de castas e a melhoria da qualidade dos vinhos, as inovações técnicas na cultura da vinha e produção vinícola, o designado «fenómeno febre dos DOC Douro de há 10 ou 12 anos» e a melhoria atual da formação técnica na Região, graças à ação da UTAD e do Politécnico de Bragança, por contraste às antigas condições de trabalho e produção no Douro (Informante 9.2.2.).

Narrativa, a vários títulos, relevante é, agora, a de antigo funcionário do escritório na Régua, da Cockburn's, principal empresa exportadora do vinho do Porto de Carrazeda, no século XX, que foi também aí, durante mais de 20 anos, o seu responsável técnico direto, no terreno, pelo controlo de qualidade das uvas e dos vinhos provenientes deste concelho, sendo, atualmente, produtor vitivinícola independente ${ }^{681}$.

Caracteriza este depoimento uma voz profundamente crítica da situação atual dos pequenos e médios viticultores, a maioria dos proprietários durienses, a braços com a asfixia, asfixia dos seus interesses próprios, pela conjugação dos grandes negócios do Douro que chama de «glutanização», em vez de globalização, com a inércia e ou favorecimento dos poderes públicos reguladores. Denuncia ainda situações de exploração e injustiças no mercado de trabalho no Douro, que nunca foi visto pelos políticos na sua evolução, o processo de recentes cortes do benefício, que considera favorecerem a produção e comércio das grandes companhias de vinho do Porto em detrimento dos pequenos produtores e lavradores, obrigados a vender cartões de benefício (Informante 9.2.3.).

O testemunho de infância, de um ex-trabalhador sazonal local na Quinta dos Canais ou Quinta do Engenheiro, anos 1960, dá conta, num registo concreto e realista, das condições diárias de trabalho assalariado (jornadas «de sol a sol» e alimentação de subsistência) nesta

\footnotetext{
${ }^{680}$ Conversa informal com J. L. C., professor de ensino primário e proprietário agrícola de Vilarinho da Castanheira, Carrazeda, abril 2014. Este ator social é dono de uma propriedade agrícola com vinha, localizada no Vale do Carvalho, próximo dos Lagares (designação local de um conjunto de quintas situadas na encosta do Douro), freguesia de Vilarinho da Castanheira, adquirida por sua família a Aires Augusto Saraiva de Aguilar e esposa, Dona Hermínia Augusta Proença, residente em Vila Nova de Foz Coa, onde eram tidos como dos maiores e mais ricos proprietários da região do Douro e a cujos descendentes, pertence ainda hoje a grande Quinta das Tulhas, frente ao Museu de Foz Coa. A relação dos bens do casal Aguilar, anexa a escritura de doação de bens e cotas, feita em 1945 no Cartório de Vila Nova de Foz Coa, a seus filhos e herdeiros legítimos, inclui relação de 121 artigos de terras, prédios, propriedades e quintas, com oliveiras e vinha, avaliados em $640.088 \$ 50$ — considerável fortuna à época — distribuídos por vários concelhos e terras de Trás-os-Montes e Alto Douro: Vila Nova de Foz Coa, Castelo Melhor, Moncorvo, Carrazeda de Ansiães e Murça.

${ }^{681}$ J. M. L. 68 anos, natural da Régua e residente em Lobrigos (Santa Marta de Penaguião), dono da Quinta de Nossa Senhora da Graça, pequeno produtor, engarrafador e exportador de vinhos (Vinhos DOC Douro, Pedro Mil Homens, pseudónimo do pai) por iniciativa e conta própria.
} 
grande quinta de Carrazeda de Ansiães. Como recorda este informante (9.2.4.): «costumo dizer que ali fiz o meu Ciclo Preparatório. Com doze anos, andávamos à frente dos bois na lavragem das vinhas, olivais e amendoais, carregávamos à cabeça as latas do caldo para alimentação do pessoal e quando necessário trabalhávamos com a enxada» (Informante 9.2.4.).

Relata também, indiretamente, muito do que aprendeu na sua experiência profissional, um pequeno produtor de vinho fino de Ribalonga ${ }^{682}$, longos anos funcionário no Registo Predial do concelho de Carrazeda onde, profissionalmente, acompanhou o movimento de transferências e concentração de quintas, propriedades, herdades e parcelas com vinhedos, de que tem por isso aguda perceção, associada a um conhecimento assim também adquirido das modalidades de intermediação no negócio de uvas e vinhos, e das ligações locais entre instituições reguladoras na região: Casa do Douro, IVDP e antigos Grémios da Lavoura.

Desvenda uma antiga economia local de transações em pirâmide, tradicionalmente assente na confiança e compromissos verbais, bem como o papel central aí detido pela figura dos «arrobeiros», fazedores de vinho tratado e intermediários no negócio vinícola, junto das companhias exportadoras: Croft, Taylors, Cockburn's e Symington, dos pequenos e médios comerciantes e dos lavradores simples produtores de vinho generoso, tratado ou fino.

Refere-se ainda às boas relações sempre mantidas pelas populações ribeirinhas com os ingleses, às identidades da «ribeira» e da «frieira» no concelho e às movimentações políticas e sociais locais na I República e no Estado novo de que guarda memória indireta e diretamente (Informante 9.2.5.).

Finalmente, três trajetórias de vida, de idades avançadas, documentam a memória social de profissões rurais extintas ou em vias de desaparecer, do mundo vinhateiro duriense: o rogador do pessoal sazonal e os foleiros, o carreiro e o feitor, ao mesmo tempo que deixam entrever e reconstituir o modo antigo da organização e exploração das relações sociais da produção e do trabalho quotidiano nas quintas e à sua volta, permitindo ainda divisar o surto migratório que lhes sucedeu (Informantes 9.2.6. a 9.2.8).

Muitos aspetos concretos dessa realidade histórica emergem da minuciosa descrição apoiada numa memória viva que a prolongada emigração em França não apagou, o rogador de pessoal, a seguir, feitor de quinta em Vilarinho e depois, encarregado de uma destilaria de aguardente vínica ligada à Casa do Douro, a funcionar em Foz-Tua, nos anos 1960, com uma experiência diversificada de trabalho nos limites extremos e opostos da zona vinhateira do concelho de Carrazeda (Informante 9.2.6. ${ }^{683}$.

Por sua vez, um lavrador e antigo carreiro, octogenário natural de Vilarinho da Castanheiro, que trabalhou largos anos, décadas de 1950-1960, nos colonatos rurais de Angola e Moçambique, recorda, em pormenor e com vivacidade, os inúmeros e perigosos carretos

\footnotetext{
${ }^{682}$ T. R., 56 anos, natural e residente em Carrazeda, funcionário público aposentado, ex-presidente da Junta de Freguesia de Carrazeda de Ansiães e, atualmente, pequeno proprietário e produtor vinhateiro em Ribalonga.

${ }^{683}$ S. M., 82 anos, natural de Vilarinho da Castanheira, onde ainda permanece e trabalha, quando não se encontra na Suíça, em companhia da família, aí emigrada.
} 
ou transporte, em carros de bois, de pipas de vinho tratado e de consumo, que durante a sua juventude, anos 1930-40, fez pelas encostas abaixo até aos barcos rabelos, junto à quinta dos Pizarros de Lubazim e «à barca do Freixo que levava à estação de Freixo de Numão». Salienta ainda a existência então de muitos outros pequenos lavradores carreiros das redondezas que com ele carregavam os fardos de palha e feno para os bois e as pipas «litradas» de vinho, referindo, a propósito, que então, «havia no Vilarinho, na Lousa e em Carrazeda, muitos tanoeiros que faziam e consertavam as pipas» (Informante 9.2.7. ${ }^{684}$.

Num contexto de grande proximidade e relações de confiança entre um antigo caseiro e a família proprietária da Quinta da Lavandeira (Castanheiro do Norte), nas décadas de 1950-1960, tem-se acesso à escrituração corrente de gastos e algumas receitas da exploração regular desta propriedade vitivinícola, através de informação disponível em folhas manuscritas de registo e apoio aos seus movimentos diários, deixadas por aquele.

Cruzam-se com os dados de duas entrevistas ${ }^{65}$, as informações concretas, mas rudimentares desses manuscritos relativos à Quinta da Lavandeira deste feitor promovido a caseiro, com pormenores minuciosos e contabilidade rotineira de tarefas e trabalhos diários, necessidades principais, lista de contactos telefónicos, folhas de despesas e receitas, pagamentos a pessoal, etc. Embora reduzida, esta documentação ilustra a atividade corrente desta Quinta, então, como ainda hoje, propriedade da Família Ferrand d'Almeida de Coimbra. São exemplo de pormenores curiosos registados nesses manuscritos sobre gastos, receitas e outros assuntos correntes desta propriedade vitícola e sua localização, deste período as seguintes notas concretas:

- $400 \mathrm{~kg}$ de batata por menos de $1 \$ 50$ ou um transporte em carroça de produtos e mercadorias por $7 \$ 50$ a partir da quinta até à estação de caminho de ferro de Foz Tua;

- transporte de um bidon cheio de azeite para Coimbra, 12\$00; transporte de bidon e sacos que vieram de Coimbra, $46 \$ 50$, pagamento de jornas a 6 trabalhadores, $1.859 \$ 00$, abono de família, 787\$50; eletricidade do armazém, 61\$60; compra de 15 litros de milho para o cavalo; venda de $90 \mathrm{~kg}$ de amêndoa a $9 \$ 30 / \mathrm{Kg}-837 \& 00$; semente de cevada e aveia para semear para o macho, $95 \$ 00$; renda do palheiro, uma cabeçada para o macho, 135\$00, etc./saldo de conta corrente: $1.189 \$ 00$ (folha n. ${ }^{\circ} 20,2-11-1969$ );

- lista exaustiva dos n. ${ }^{\circ} \mathrm{s}$ de telefones de grandes negociantes e compradores de vinhos generosos (Os «semites» no Tua, isto é, os Smithes, donos da Quinta do Tua, a «Croft» no Pinhão, etc.) e de serviços e infraestruturas concelhias de apoio corrente: médicos, hospital, farmácias, Casa do Povo, fornecedores de pão (a «Iria da Padaria»), serviços agrícolas («O Celeiro»), etc.

\footnotetext{
${ }^{684}$ J. M., 94 anos, antigo lavrador com juntas de bois para transporte de pipas de vinho, natural de Vilarinho da Castanheira e residente no Lar de Idosos da Lousa (Moncorvo).

${ }^{685}$ Entrevista informal, 12 de dezembro de 2016, a F. P., solicitador, natural de Castanheiro do Norte, filho mais velho de José Maria da Pena, natural da mesma aldeia, feitor e caseiro da Quinta da Lavandeira e entrevista complementar de F. P., com respostas escritas, de 10 de maio de 2017.
} 
Há ainda outras referências aos diversos trabalhos e cuidados da vinha e do vinho, à aquisição e aplicação de produtos e compostos químicos como a cal hidráulica usada para a calda bordalesa, indispensável ao tratamento das vinhas, a menção à filoxera e outras doenças das videiras, etc.

Indiciam-se e denotam-se, aqui, algumas tendências e mudanças sociais a considerar neste contexto também de relevo para a caracterização económico-social e cultural desta área ribeirinha concelhia (encostas de Castanheiro do Norte e Ribalonga) e suas quintas: papéis económico-sociais dos feitores e caseiros homens de confiança e mediadores dos proprietários das quintas com as populações locais e trabalhadores; boas relações dos donos das quintas com as populações locais; práticas regulares e igualitárias de religiosidade; continuidade de práticas no recrutamento de mão de obra local; contratação de feitores e caseiros na base da confiança e recomendação de ilustres das elites locais; reprodução socioprofissional de feitores e caseiros de quintas; ascensão e mobilidade social das gerações mais novas; históricos movimentos migratórios mais intensos pós-anos 1960 (Informante 9.2.8).

Em síntese, podemos ver como nesse acervo documental de grande riqueza informativa se evidenciam, com relativa clareza dimensões relevantes desta formação social que se pretende apreender: trajetórias de vida e de trabalho dotadas de exemplaridade; uma densidade de memórias e materiais de memória de expressiva vivacidade; e redes extensas de «atores-rede», considerados não tanto como transmissores de informação mas sobretudo como mediadores influentes e tradutores, mais ou menos fiéis, de impulsos e impactos que recebem e com que interagem socialmente ${ }^{686}$.

Importa por isso «tomar a sério» esses «atores-rede» e segui-los ${ }^{687}$, na e para além da exemplaridade abrangente própria da «superfície social», que compõem em interação recíproca com as especificidades dos diversos «agentes eficientes» identificados, interpretando espaciotemporalmente, à luz mediatizada da hermenêutica, as suas narrativas, depoimentos, testemunhos e memórias como fontes de história oral ${ }^{688}$ e, simultaneamente, recursos policromáticos de conhecimento.

\footnotetext{
${ }^{686}$ LATOUR, 2005; LATOUR, 2007; DORES, [s.d.].

${ }^{687}$ A metodologia seguida, pelo seu dinamismo cognitivo compaginável com a temporalidade histórica, assenta na proposta sociológica da teoria ANT que propõe a noção abrangente de «seguir o ator-rede». Tal significa, por um lado, tentar integrar a investigação nas redes animadas pelos humanos em seus elementos mediadores e tradutores, independentemente do estatuto que lhes possa ser atribuído pelo senso-comum e atender, por outro lado, ao registo do que está para além da rede, e tentar ver como e para onde ela continua o que torna possível conhecer ação e contexto, através de mediadores tradutores (alteração de intensidade, direção, sentido, força), dos diversos impulsos, de muitas qualidades e origens, em sínteses de ocasião, e em função das competências dos mediadores.

${ }^{688}$ DELGADO, 2003: 9-25. A história oral é uma metodologia voltada à produção de narrativas como fontes do conhecimento e do saber.
} 


\subsection{CONTRIBUIÇÃO PARA O CONHECIMENTO DA SOCIEDADE DURIENSE NA «FRONTEIRA» ENTRE O CIMA CORGO E O DOURO SUPERIOR}

Com vista a contribuir para um melhor conhecimento deste tema que se torna agora possível enunciar e desenvolver de forma rizomática tentar-se-á então mobilizar o significativo repositório sociocultural que se constituiu empiricamente e acabou de traçar.

Torna-se assim possível apreender uma ambiência e espacialidade social, historicamente construída no passado recente desta zona duriense, a partir de tradições e modernidades, resistências e mobilidades, resiliências e investimentos, persistências e inovações. O que permite percecionar, pelo seu interior profundo, dimensões estruturantes da sociedade do Alto Douro, entre Cima Corgo e Douro Superior, no século passado.

Refira-se a propósito, a forte e duradoura tradição da viticultura do Douro Superior (sub-região dos vales do rio Douro e seus afluentes entre o Cachão da Valeira e a fronteira Norte com Espanha) documentada em várias referências aos trabalhos de cultivo da vinha e fabrico do vinho, conforme achados arqueológicos locais e diversas fontes históricas desde a Idade Média à Época Contemporânea. A essa incontestável tradição vitícola, só muito mais tardiamente, com a entrada dos seus vinhos nos circuitos comerciais, virá corresponder a afirmação de seu significado relevante na economia local. Sobretudo quando comparada com o desenvolvimento mais antigo da vinha e do vinho nas outras duas sub-regiões durienses, Baixo e Cima Corgo onde a viticultura mercantil se afirmou, a partir dos séculos XVII e XVIII ${ }^{689}$. Caracteriza-se assim o Douro Superior, unidade económica e cultural bem distinta do Alto Douro, historicamente de grandes extensões cerealíferas e técnicas rotineiras, por um estádio posterior de desenvolvimento diferenciado, uma expansão e expressão comercial mais recentes, mas intensas, e uma lenta e mais tardia integração na Região Demarcada do Douro (RDD).

Desse longo processo histórico e social de integração deste «Douro Novo» na economia local e da região (finais de Oitocentos), em que tem particular expressão o caso concreto de Carrazeda de Ansiães, marcadamente de fronteira e transição espaciotemporal (o qual podemos, aliás, acompanhar nas duas primeiras partes deste livro), se fazem também eco algumas das narrativas aqui em observação e análise.

Por outro lado, os diversos estratos socioculturais que aí nos é possível também identificar, à luz do conceito da «formação económico-social» ${ }^{690}$, permitem-nos compreender a sociedade nesta zona do Alto Douro na sua complexidade, dinâmica e diversidade, nada uniforme nem linear, onde emergem, conjunturalmente, pertenças identitárias contextuais face a uma ambiência sociocultural contrastante e a um enquadramento regional económico-social e político-ideológico de forte regulação jurídico-institucional.

\footnotetext{
${ }^{689}$ PEREIRA \& TEIXEIRA, 1998: 77-84.

${ }^{690}$ Este conceito, ligado à análise do movimento de sociedades concretas, dentro do processo histórico, constitui-se como um dos elementos fundamentais do materialismo histórico. A definição do seu conteúdo teórico-metodológico dentro do marxismo não é, porém, unívoca. Ver por exemplo ARUTO, 2009.
} 
Para uma mais clara explicação e melhor entendimento analítico dessa verificação importa ainda concretizar algumas das principais características do dinamismo próprio dessa «superfície social», o que se faz através da mobilização dos «agentes eficientes» de maior representatividade e interação na «superfície social» desta zona duriense: o «grande empresário do Douro»; o «político local e autarca»; o «dono de quinta vinhateira e ex-diretor regional do Ministério da Agricultura»; o «quadro técnico de antiga e grande companhia exportadora» no terreno; o "pequeno proprietário e simples produtor vinhateiro»; o «trabalhador sazonal das grandes quintas»; o «feitor e encarregado da destilaria»; o «pequeno proprietário em pluriatividade»; os «arrobeiros»; os «lavradores» e «carreiros», os modernos «enólogos» e «empresários vitícolas locais», cujas narrativas de que é também coprodutor o entrevistador em sua escuta ativa, note-se, se interpretam, a seguir, através da respetiva análise de conteúdo.

Demos conta do acervo de narrativas colhidas ao longo do processo de pesquisa empírica, partindo, em regra, das mais recentes para as mais antigas, cabendo agora fazer a exposição interpretativa do que nelas mais releve para uma compreensão aprofundada deste universo social, começando pela análise dos conteúdos históricos mais antigos até aos mais recentes, pelas razões que adiante se patenteiam.

Identificam-se então, cronológica e mais pormenorizadamente, as problemáticas e questões dominantes que perpassam nos depoimentos e testemunhos do universo de «agentes eficientes» considerado. A sua interpretação, numa perspetiva sócio-histórica, possibilita uma clarificação concreta mais próxima do tecido social e cultural em presença nas suas dinâmicas e persistências próprias, bem como uma aproximação ancorada e mais sólida à sociedade duriense nesta zona de fronteira.

Parte-se das duas narrativas que diretamente se fazem eco dos tempos anteriores ao intenso surto migratório dos anos 1950/60 de que, aliás, esses informantes participaram e os seus discursos sublinham, marcando a diferença entre o tempo dos trabalhos no campo e os tempos posteriores, de emigrados. É possível vivenciar esse corte operado no decurso das suas trajetórias biográficas que veio a significar uma mudança muito profunda na própria evolução da situação económico-social da região, registada designadamente nos testemunhos destes informantes (9.2.6 e 9.2.7.). Estes permitem ainda, pela referência feita à existência dos grandes olivais a par da exploração vitivinícola, alias reiterada noutras narrativas, uma caracterização do peso relativo do vinho na produção agrícola desta sub-região do Douro Superior por contraposição com a monocultura da vinha nas sub-regiões do Baixo Corgo e Cima Corgo, este em menor grau, já nesse período anterior ao surto migratório.

No entanto, o lançamento e a entrada em funcionamento de uma destilaria de aguardente em Foz Tua, década de 1960, amplamente descrito pelo informante (9.2.6), demonstra, por outro lado, a procura de uma autossuficiência no processo produtivo do vinho do Porto longamente reclamada desde o início do século, nesta zona duriense, conforme, historicamente, já referido (Parte II, Capítulo 6). 
Esses três aspetos: fluxos migratórios, ausência do regime de monocultura na estrutura agrária produtiva e procura de maior autossuficiência no processo produtivo do vinho do Porto, adquirem especial relevo na caracterização histórica de Carrazeda de Ansiães como concelho de fronteira com significativa importância para a compreensão do Douro Vinhateiro.

Por sua vez, outros testemunhos (informantes 9.2.4 e 9.2.5, respetivamente, ex-trabalhador sazonal de quinta e pequeno produtor vinhateiro), associados aos anteriores, permitem uma perceção da estrutura económico-social local, rudimentar, mas adaptada aos escassos recursos disponíveis existentes com que as populações foram respondendo às necessidades da sua subsistência até que se viram forçadas a emigrar, procurando melhores condições de vida. Remontando ao tempo em que o transporte do vinho em pipas se fazia de barco ao longo do rio até ao cais de Gaia e posteriormente pelo caminho de ferro, é o protagonismo dos «carreiros» que por azinhagas conduziam as juntas de bois puxando os carros carregados de uma pipa cada um que mais ressalta face à dureza e periculosidade do trabalho e frequência de acidentes graves com perda de vidas humanas verificados. As referências feitas aos «foleiros» introduzem-nos, por sua vez, no mundo do trabalho sazonal, suportado nas deslocações internas à região e limítrofes, de populações carenciadas, que procuravam nas jornas recebidas pelos trabalhos nas quintas durienses algum alívio para a vida miserável de todo o ano. Emicamente, essa sua condição ficaria marcada pelo epíteto que os naturais da zona lhe reservavam. É de notar que o trabalho nas quintas começava, muitas vezes, mal saídos da escola: «Os rapazes, com doze anos, andávamos à frente dos bois na lavragem das vinhas, olivais e amendoais, carregávamos à cabeça as latas do caldo para alimentação do pessoal e quando necessário trabalhávamos com a enxada, e as raparigas eram integradas nos trabalhos das mulheres» (Informante 9.2.4).

Num plano mais interno à dinâmica da zona é a figura do «arrobeiro» que sobressai, como intermediários locais:

têm estruturas e fazem o vinho das uvas deles e das que compram... os grandes negociantes de vinhos punham as aguardentes em função das pipas de vinho que se iam fazer e punham um fiscal para controlar a entrada das uvas, a quantidade de aguardente e depois do vinho feito tinham uma forma de selar os tonéis... vinham em janeiro e fevereiro ver como estavam e deslocalizavam os vinhos já feitos para os entrepostos (Informante 9.2.5).

Outros ofícios e mesteres, outrora de importância na economia da região, como o dos ferreiros, tanoeiros, ferradores foram rareando ou desaparecendo mesmo.

Por fim, e no que à própria forma de organização e funcionamento de cada unidade económica designada «quinta» de que nos dá conta o informante 9.2.8, destaca-se a figura do caseiro, homem de confiança do proprietário, oriundo, por vezes, das aldeias circunvizinhas, mas com provas dadas, como feitor ou encarregado do enquadramento do pessoal assalariado fixo e do sazonal com a colaboração do rogador, até lhe serem atribuídas essas novas funções da maior responsabilidade, na economia do comando, da unidade na ausência continuada do dono da quinta. 
Fig. 179. Latoeiro (Seixo de Ansiães) Fonte: Fotografia de Egídio Santos ${ }^{691}$

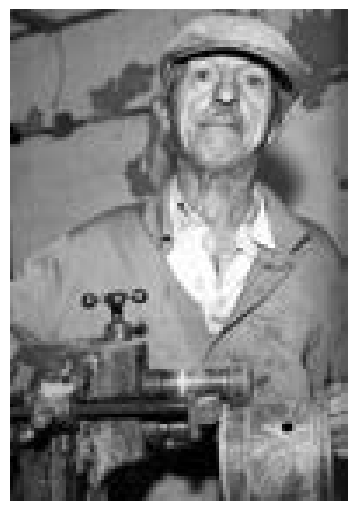

Fig. 180. Vasilhame de latão Fonte: Fotografia de Egídio Santos ${ }^{692}$

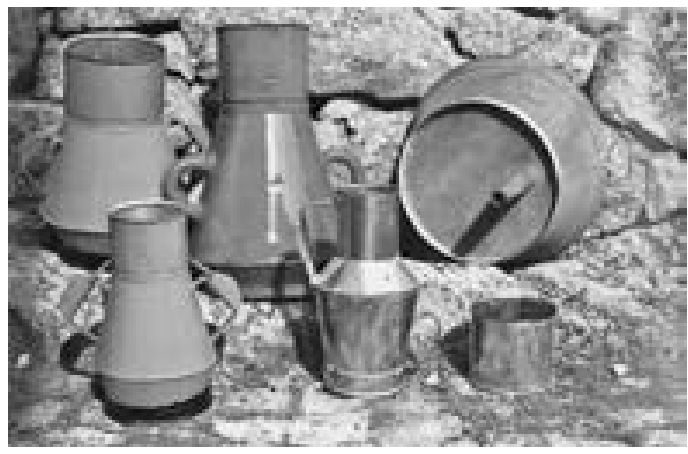

Fig. 181. Tanoeiro — fase de aparar aduelas na arronhadeira (Seixo de Ansiães) Fonte: Fotografia de Egídio Santos ${ }^{693}$

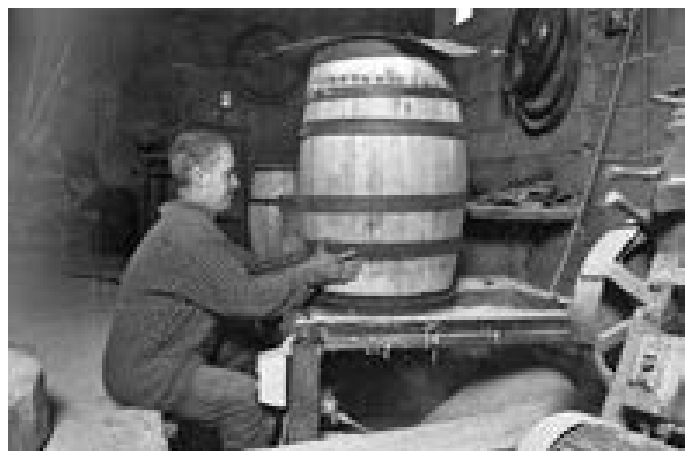

\footnotetext{
${ }^{691}$ Viver e saber fazer..., 2003: 240.

${ }^{692}$ Viver e saber fazer..., 2003: 240.

${ }^{693}$ Viver e saber fazer..., 2003: 240.
} 
A este tipo de mobilidade social que se verificou no Douro tradicional, outras mudanças importantes se vão suceder com o progressivo esbatimento do papel do feitor derivado da escassez de mão de obra e sua redução também por força da mecanização e modernização técnica.

A posterior evolução da organização do trabalho e a introdução de inovações tecnológicas nas culturas da vinha e do vinho, trouxeram para esta zona duriense, como para toda a região, a chegada e fixação de novo pessoal especializado, com formação superior em vitivinicultura adquirida nas universidades e institutos politécnicos mais próximos. Destacam-se então como novos «agentes eficientes», por exemplo os enólogos que introduzem os seus saberes tecnocientíficos e sociotécnicos onde antes dominavam os saberes leigos, alcandorando-se, por vezes, à direção técnica das quintas e/ou assessoria, numa «lógica industrial» (assente na eficácia) diversa da «lógica doméstica» (baseada no valor da confiança) até então prevalecente, lógicas que no caso do Douro Vinhateiro são sempre atravessadas pela «lógica mercantil» caracterizada pela oportunidade, como valor dominante em termos de justificação.

Deste novo protagonismo na atual «superfície social» presente em Carrazeda de Ansiães, entre vários outros exemplos, o caso dos que, sem deixar de exercer essas funções inerentes à sua profissão técnica, se estabeleceram por conta própria, dando origem a novas empresas de iniciativa local, como a Grambeira e a Douro Ansiães, já anteriormente abordadas (Capítulo 8).

Da conjugação dos diversos fatores já enunciados, a estrutura em que assentava um tal modo de subsistência foi sofrendo sucessivos abalos, uns inerentes ao próprio desenvolvimento económico-social, outros induzidos por alterações regulamentares e pelo jogo de interesses das forças em presença. Disto mesmo nos dão parte os relatos de vários informantes (9.2.1 a 9.2.3), designadamente, o que se segue:

Hoje o vinho do Porto está em segundo plano... está um pouco complicado produzir e comercializar... por exemplo em Carrazeda há já algumas empresas, como a Grambeira e a Douro Ansiães que fazem mais dinheiro com os DOC Douro do que com o vinho tratado... cada pipa (mais de 600 garrafas) de maduro a 10€ 694 dá hoje 6.000€; o ano passado, o vinho da casta Touriga Nacional estava a 100€... 1.000€/pipa de vinho tratado... o benefício tem vindo a reduzir [...] (Informante 9.2.2.).

Sobre a dicotomia socioestrutural que é a característica de fundo da formação socioeconómica desta Região acastelam-se as contradições secundárias de que emergem posições dominantes que passado algum tempo submergem até reaparecerem sob novos aspetos dominantes tendo o desenvolvimento das forças produtivas como motor:

\footnotetext{
${ }^{694} \mathrm{O}$ preço médio de uma garrafa DOC Douro, no mercado, é substancialmente menor.
} 
Hoje a qualidade dos vinhos da região do Douro está garantida - houve uma grande seleção de castas, sensibilização para plantar castas selecionadas; desenvolvimento da enologia; instalações com processos mecânicos e moderna cultura das vinhas... surribas em profundidade; resolveu-se o problema das regas e controlou-se o processo da maturação das uvas... controla-se nos gabinetes o stress da vinha e a qualidade da rega [...] (Informante 9.2.2.).

Se há uma relativa concordância na descrição da situação atual já sobre as suas causas as posições divergem, enquanto em relação aos efeitos, os vários depoimentos recolhidos são marcados pelo pessimismo. Daí que, alguns vejam na desregulação decorrente do desmantelamento da Casa do Douro, a causa próxima dos males vividos. Sendo certo que, vindos já de trás, alguns desses males como o da expansão dos vinhedos, durante anos, camuflada sob o regime dos designados "Casais Agrícolas», se hajam intensificado com o advento da democracia quando «as firmas exportadoras criaram prósperos vinhedos mecanizados, baseando-se nas melhores castas e apoiando-se no capital possuído e em pessoal especializado ${ }^{695}$ ", em ordem a, alegadamente, atingirem um autoaprovisionamento. Porém, para outros depoentes, os males denunciados ficaram a dever-se a que «nos últimos anos, deu-se no Douro um grande choque com o corte do beneficio na RDD onde a cada hectare...10.000 m2, correspondem 8 pipas, cerca de 4.400 litros; quando aumentou a área de plantação ...com o PDRITM... como a exportação aumentou foram tirá-lo aos que o tinham e o benefício passou a 2.200 litros por hectare, ou seja, metade» (Informante 9.2.3.).

Observe-se que na altura do PDRITM, as exportações estavam a aumentar, significativamente: de cerca de 118.000 pipas, em 1982, subiram para mais de 140.000, em 1992, e quase 175.000 em 2000, isto, já sem contar com o simultâneo crescimento dos DOC Douro.

De pouco parecem ter valido as sucessivas alterações legislativas como, desde logo, a de 1985 estabelecendo que o acesso das vinhas novas ao «benefício» se concretizaria sem afetar as tradicionais. Aliás, a década de 1990 iniciou-se sob a ação do conflito entre a Casa do Douro (cujos problemas se agravaram desde o negócio com a Companhia Velha) e a Associação dos Exportadores em que se confrontaram os interesses do setor produtivo e o exportador, o seu desfecho acabaria por se traduzir pelo aludido incremento da dominância no setor produtivo por parte dos exportadores.

E se é verdade que «o PDRITM foi o primeiro balão de oxigénio que o Douro levou (anos 1980) que incidiu em 5000 ha de novas vinhas ou reconvertidas o que numa região é muito significativo, tanto mais quanto abarcava as áreas de vinho mais valioso — letras $\mathrm{A}, \mathrm{B}$, C e D» (Informante 9.2.1.), pondo o acento na reconversão de vinhedos tradicionais, não se mostrou bastante nem coerente como, aliás, os que se lhe seguiram como o Programa Operacional e o PAMAF:

${ }^{695}$ PINA, 2004. 
Nós não tratámos da comercialização, mas sim da produção e assim ficámos mais expostos aos mercados porque tínhamos indices de produção superiores (a plantação de vinhas novas que resultou em 5 a 10 vezes mais de produção) aos que o mercado absorvia e às necessidades para consumo próprio. Então, quando se entregavam os vinhos à Casa do Douro, entregavam-se os vinhos de pior qualidade e guardavam-se os de melhor qualidade para fazer algum negócio. Foi nesta altura que começaram a aparecer os produtores engarrafadores principalmente nos vinhos não generosos [...] (Informante 9.2.1).

Pelo mesmo diapasão, afina um outro entrevistado quando afirma:

na parte da comercialização é que falhou.... temos por um lado os Symington que são hoje no Douro a Real Companhia Velha... a que se deve o conhecimento da Região e a propaganda antigos... são as grandes empresas que dão volume aos 200.000 turistas que sobem e descem pois para venderem os seus milhões de caixas de vinho, fazem propaganda das casas e dos lavradores o Douro, anualmente... tiveram um registo centrípeto e secaram tudo à volta... e por outro lado, os pequenos produtores engarrafadores que são a alma da estabilidade das populações e da composição e vitalidade social [...] (Informante 9.2.3.).

Saliente-se, por fim, a relevância político-social de outra narrativa, com uma grande coerência de fundo (Informante 9.2.9), onde para cada problema identificado se apontam as formas de sua resolução desde que se mobilizem os meios e recursos disponíveis, passando a construção do futuro do Douro pela necessidade de se conseguir pôr os agentes económicos e políticos que operam na região a debater e a negociar as questões que se colocam e a procurar, em conjunto, as melhores soluções.

Assim se foram enraizando no tradicional binómio duriense produção/comércio, dois contextos diferenciados de exploração: o do pequeno lavrador e o empresarial, em que este saiu beneficiado ao ter mais facilidade de acesso ao capital que investiu reforçando a sua posição dominante. Este setor empresarial e comercial pôde ainda «incrementar a sua inserção vitícola no Alto Douro através da "transferência” de licenças de (re)plantação, processo jurídico que possibilitava que vinhedos "marginais" classificados como " $G$ ” ou de letras inferiores, localizados a altitudes menos propícias e em solos com elevada proporção de elementos graníticos, fossem "transferidos" para freguesias mais valorizadas, mediante uma licença de renovação» ${ }^{696}$. Os pequenos lavradores, dimensão mais numerosa do setor dos produtores durienses, acabariam confinados a negócios de ocasião, à persistência da exploração abaixo dos custos de produção, à sujeição ao modo desigual de fixação do preço das suas uvas e vinho, ao abandono das suas terras e muitos deles e seus filhos, aos caminhos da migração. Assim se continuando a cavar a desertificação e envelhecimento, sem regeneração de gerações, das populações locais

\footnotetext{
${ }^{696}$ PINA, 2004: 319-342.
} 
durienses já consideravelmente debilitadas e rarefeitas pela emigração massiva das décadas de 1960 e 1970.

Nesta dimensão, Carrazeda de Ansiães (6.373 habitantes, dos quais 2.036 com mais de 65 anos $)^{697}$, apresenta um efetivo populacional que corresponde a cerca de 0,17 da Região Norte e 3,10\% da população do Douro (205 157 habitantes), o qual assume por sua vez um percentual de 5,58 relativamente ao efetivo populacional da região Norte. No entanto, e apesar de Carrazeda se situar numa posição mediana no conjunto dos concelhos da Região do Douro, no âmbito da sua evolução demográfica explicada por um conjunto diversificado de fatores, verifica-se que, já no período de 1900 a 1920, se registou uma perda de população de 14\%, mantendo-se o decréscimo populacional constante entre 1940 e 2011, ano em que se inclui nos 10 concelhos do país que mais população perderam e representando os idosos 31,95\% da sua população tota ${ }^{698}$. A debilidade do tecido demográfico patente nestes indicadores e de que se fazem eco algumas entrevistas é hoje uma das componentes mais visíveis e sentidas da complexa «superfície social» que atrás se pôde observar nesta zona de fronteira duriense, «seguindo os atores sociais tomados a sério», enquanto «atantes» e como «agentes eficientes» considerados mais representativos.

Em síntese, toda a complexa e compósita dimensão social e histórica relevada, como vimos, numa pluralidade de memórias e saberes locais em múltiplas interações sociais, caracteriza-se por um intrincado cadinho sociocultural, historicamente construído, em que se mantém uma efervescência latente e potencial conflitualidade, face à incógnita constante em relação ao sustentado desenvolvimento local e regional duriense, pese embora a sua manifestação em modos diversos, ao longo dos tempos.

Apesar de esta vertente de análise social se encontrar aqui apenas esboçada nas suas linhas determinantes e aspetos dominantes, deixa ainda perceber que subjazem à formação económico-social desta zona duriense, antigas e novas contradições económico-sociais e culturais, revelando-se ora como principais ora como secundárias e assentes em dicotomias a que há quem sobreponha uma alegada dicotomia socioestrutural cujo conhecimento e alcance é, no entanto, necessário continuar a aprofundar.

Tentamos assim prosseguir, superando reducionismos ao pôr o enfoque na composição e dinâmicas sociais como resultado de um longo processo sócio-histórico, com uma abordagem teórico-prática global e integrada ao objeto de estudo que tem orientado todo este nosso trabalho. Esta nova aproximação, que desenvolvemos no capítulo seguinte, ensaia-se no campo da sócio-história cujas perspetivas envolvem a descrição, explicação e compreensão dos fenómenos a partir do seu acontecer histórico no qual o particular é considerado como instância da totalidade do mundo social.

\footnotetext{
${ }^{697}$ Recenseamento geral da População de 2011.

${ }^{698}$ CARRAZEDA DE ANSIÃES. Câmara Municipal, 2014: 40 e segs.
} 


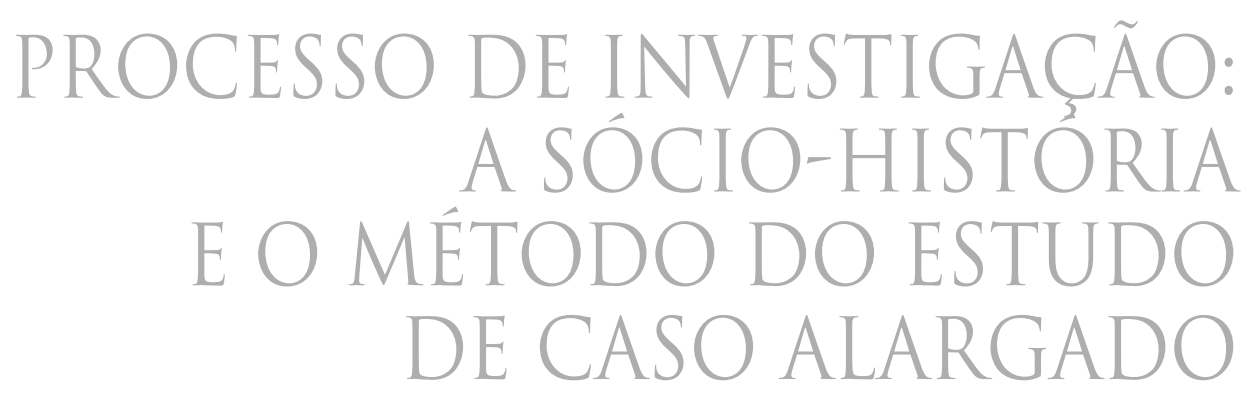




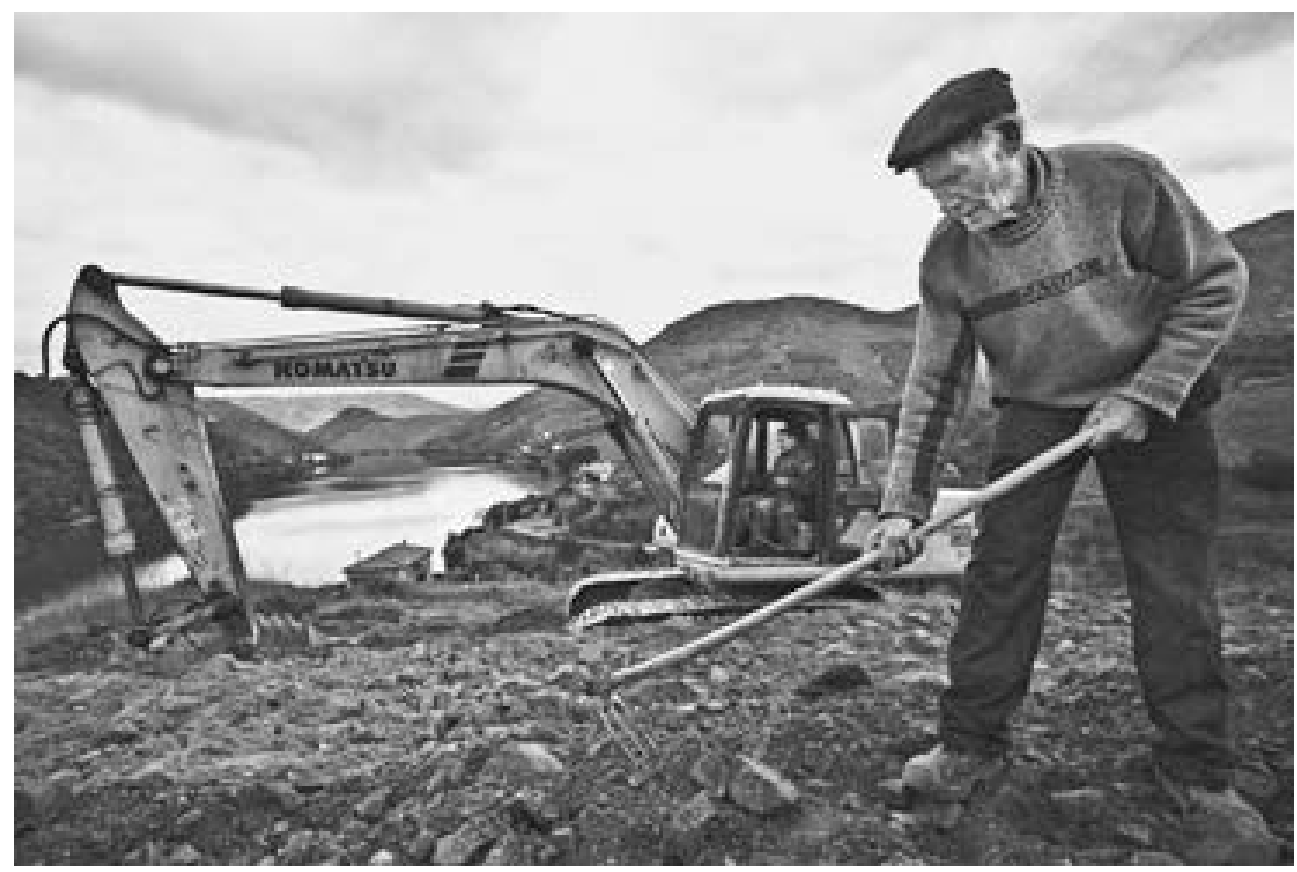

Fig. 182. Mecanização e trabalho braçal no Douro - Carrazeda de Ansiães Fonte: Fotografia de Leonel de Castro

\section{INTRODUÇÃO}

Nesta última parte vamos procurar sintetizar, genericamente, alguns dos principais resultados do processo de investigação realizado, explicitando os suportes teórico-metodológicos do trabalho inédito que foi apresentado nas partes e capítulos precedentes onde se visou a reconstituição sócio-histórica deste caso emblemático da história do «Douro Novo» e do vinho do Porto em suas dimensões relevantes.

É da história de uma deslocação espaciotemporal do peso relativo não tanto em volume mas mais em termos de valor da produção e exportação de vinho do Porto que se trata, a qual, como atrás se salientou, passou por várias fases: desde a abertura a um «Douro Novo» e posterior expansão das vinhas e dos vinhos generosos do Douro para Nordeste da Região Demarcada, a partir dos finais do século XVIII, após a remoção das barreiras geológicas à navegabilidade do rio, única via de transporte do vinho economicamente viável até ao reconhecimento da sub-região do Douro Superior e intensificação da sua área de produção vitivinícola com destaque para os seus vinhos do Porto de superior qualidade e comercialização internacional crescente a cujo reforço se assiste a partir dos finais do século XIX com as profundas transformações posteriores à crise filoxérica da segunda metade de Oitocentos.

Revelam-se como enquadramento conceptual mais adequado a este objeto concreto de investigação o método de análise sócio-histórica e a metodologia de «estudo de caso alargado», 
a cuja mobilização se recorreu para apreender e dar conta da especificidade e abrangência das implicações plurifacetadas dessa nova realidade histórica do Douro Vinhateiro e do vinho do Porto, em que Carrazeda de Ansiães, com uma produção de mosto generoso em 2015, de 2.596.793 litros (4.700 pipas de 550 l) num total de 111.000 pipas da RDD, ou seja, cerca de 4\% do total ${ }^{699}$, detém uma posição económico-social e cultural singular pelo seu muito significativo contributo para a produção de vinho do Porto de categorias especiais.

A sócio-história ${ }^{700}$, corrente da investigação histórica que se tem desenvolvido desde os anos 1990, sobretudo por especialistas em história contemporânea e a qual temos vindo a ensaiar em trabalhos anteriores ${ }^{701}$, na prática de uma «história experimental» ${ }^{702}$, põe em diálogo princípios fundadores da história e da sociologia e combina elementos-chave de outras disciplinas das ciências sociais. É uma abordagem científica interdisciplinar com uma metodologia própria que estuda questões concretas e visa conhecer o peso que tem o passado no presente, ou seja, compreender, à luz do passado histórico como se processa o funcionamento do presente. É um método de investigação pragmático, mas não empirista, pertinente para o estudo do mundo social e das questões económicas, políticas e culturais do tempo presente ou do passado mais longínquo. Interessa-se pela génese dos fenómenos que estuda e pode definir-se por dois aspetos essenciais: o estudo do passado no presente, evidenciando a historicidade do mundo em que vivemos para melhor compreender como o passado interfere no presente; a observação das relações à distância que estão no centro da sua análise, para identificar as ligações e interdependências que se encontram no cerne dos estudos sócio-históricos.

Numa tentativa de transdução operativa de alguns desses principais contributos teóricos para o estudo alargado deste caso concreto recortado num processo histórico de longa duração e inscrito na sócio-história da nossa contemporaneidade, a cuja luz se pode melhor esclarecer, chegamos ao método de análise que aplicamos, o qual assenta nos seguintes fundamentos:

a) práticas e saberes múltiplos e não antropomórficos, o que implica o recurso a uma diversidade de conhecimentos abrangentes, não moldados apenas na ação humana;

b) perspetiva da «historialidade», noção desenvolvida por Rheinberger $(1994)^{703}$, a qual se incorpora enquanto escrita não linear atenta à contingência na história;

c) espaços-tempos como operadores da análise, e não só ou sobretudo, como parâmetros não relativizados;

d) contingência e irreversibilidade científicas enquanto próprias da história e do saber historiográfico;

e) singularidade e regularidade, inerentes à construção social e histórica dos processos analisados;

\footnotetext{
${ }^{699}$ INE. IVDP, 2016.

${ }^{700}$ NOIRIEL, 2006.

${ }^{701}$ LAGE, 2009b.

${ }^{702}$ LEPETIT, 1996: 79-81 e segs.

${ }^{703}$ SELTZER, 2007: 151 e segs.
} 
f) lixiviação dos saberes disciplinares, isto é, atenção necessária à depuração das redundâncias;

g) coprodução entre raízes e opções, ou seja, articulação da procura das origens com as escolhas em aberto;

h) pôr o conhecimento em cultura e na crítica, o que é a pedra de toque para pôr o conhecimento à prova;

i) mobilização das ciências sociais e humanas como «terceira cultura» e ponte entre humanidades e ciências naturais, o que passa pela análise incorporada nas práticas de análise social e historiográfica, da emergência da sociologia, e da historicidade da representação e da narrativa histórica, como disciplinas.

Este amplo entendimento possibilita-nos considerar e ultrapassar a limitação, marca da história das ciências sociais, identificada por Boaventura Sousa Santos, como a «dificuldade em criar um espaço próprio em relação às "duas culturas”, definindo a sua especificidade ora através de uma aproximação aos cânones e critérios de cientificidade próprios das ciências naturais, ora optando por uma aproximação às humanidades e à filosofia, acabando por se situar, assim, entre conceções tendencialmente positivistas e conceções tendencialmente fenomenológicas» ${ }^{704}$.

O método da sócio-história que em linhas gerais, se apresentou, nas suas balizas teóricas e potencialidades, serviu-nos de orientação conceptual em todo o processo de investigação cuja síntese interpretativa se retoma agora nesta última parte, recentrando-a no concelho duriense em estudo e na história recente do Douro e do vinho do Porto, zonas ainda de sombra no conhecimento historiográfico. Daí que os pressupostos enunciados sejam um suporte complexo, mas necessário à análise dinâmica da sociologia histórica do Portugal Contemporâneo em que a longa história do vinho do Porto se inscreve, constituindo exemplo paradigmático e objeto de estudo, aqui reconfigurado e reinterpretado (Capítulo 10).

Como ferramenta base da análise sócio-histórica, foi-nos essencial a opção metodológica que consistiu na operacionalização do método de «estudo de caso alargado», «com potencialidades reconhecidas no campo da sociologia» ${ }^{705}$. Fez-se a sua aplicação através de «tradução», adequada ao processo de investigação historiográfica desenvolvido nas áreas da história social, da micro-história e de renovada história local e regional. Este enquadramento metodológico reelaborado que guiou todo o trabalho empírico de terreno é, metodicamente, sintetizado no Capítulo 11, último deste livro.

\footnotetext{
${ }^{704}$ SANTOS, 1987.

${ }^{705}$ SANTOS, 1983: 11.
} 


\section{CAPÍTULO 10. ANÁLISE SÓCIO-HISTÓRICA DE CARRAZEDA CONCELHO «FRONTEIRA» NO DOURO VINHATEIRO}

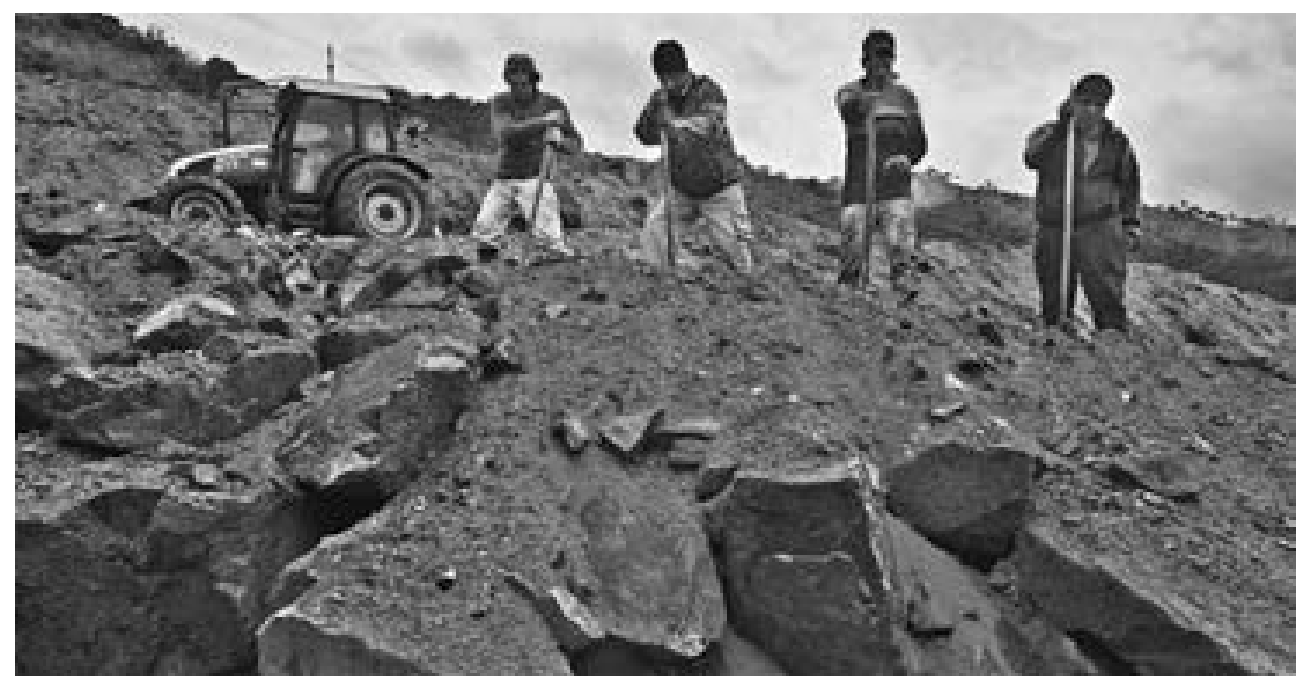

Fig. 183. Surriba — fase do «fazer» solo pela destruição da rocha-mãe

Fonte: Fotografia de Leonel de Castro

Estão agora reunidas as condições para culminar a análise sócio-histórica do concelho de Carrazeda de Ansiães enquanto produtor de vinho do Porto, contributo para a história vitivinícola do concelho que detém, como vimos, uma posição de interface num espaço de fronteira da Região Demarcada do Douro ${ }^{706}$, que se mostrava ainda insuficientemente estudado.

O que atrás se debateu, com atenção à longa duração histórica sempre recentrada na história mais recente dos últimos 100 anos deste concelho singular do Douro Vinhateiro, seguiu processos de investigação e escrita, isomórficos do trabalho local vitivinícola, metaforicamente, nomeados de: armação do terreno (construção meticulosa e sucessiva de antigos geios ou socalcos com enchimento de terra, novos patamares e vinhas ao alto), tratamento da vinha (seleção de castas, plantação de bacelos e disposição dos bardos), vindima (colheita e pisa das uvas) e produção do vinho.

\footnotetext{
${ }^{706} \mathrm{~A}$ RDD estende-se atualmente, «por cerca de 250 mil hectares, sendo que 44 mil são dominados por vinhas e 32 mil estão autorizados a produzir vinho do Porto. Em terra de socalcos encontram-se mais de 100 castas diferentes aptas à produção do respetivo néctar, um número ainda mais significativo se se considerar que no país inteiro contam-se apenas 250 variedades». Para se conhecerem as vinhas de qualidade, no final da década de 1940, o Eng. Moreira da Fonseca, funcionário superior do IVP e, durante 3 anos, presidente da Casa do Douro, criou um método de pontuação dos terrenos, ainda hoje utilizado. Considerando 12 critérios (exs. localização, inclinação, incidência solar ou a idade da vinha...), as vinhas seriam classificadas de $\mathrm{A}$ a I; os terrenos aptos à produção de vinho do Porto situam-se entre as letras A e F. (MARQUES, 2015).
} 
Assim, uma síntese interpretativa da globalidade dos resultados deste trabalho, permite-nos realçar agora, as linhas de caracterização sócio-histórica de Carrazeda de Ansiães, no enquadramento do Douro Vinhateiro e inserção específica no processo secular de produção e comércio do vinho do Porto, «um dos grandes vinhos da História», como afirma António Barreto ${ }^{707}$.

Trata-se dos alicerces sócio-históricos deste concelho produtor do Vinho do Porto, visto na poesia popular como:

Vinho velho dos antigos
Tratado para os lavradores
Generoso para os amigos
Do Porto para os doutores
Há quem chame Vinho do Porto
Ao nosso vinho do Douro
Puseram o nome torto
Ao nosso maior tesouro

Estas duas quadras expressivas de um sentir popular generalizado nesta zona da região duriense, são «rastros» ou «traços» da complexidade sociocultural que envolve a produção e comercialização do vinho do Porto, um «blend» ${ }^{709}$, ainda nomeado «vinho cheirante», «vinho fino», «vinho tratado» ou «vinho generoso».

Partindo, a esta luz, dos resultados de todo o trabalho realizado, desenvolve-se, agora, a análise sócio-histórica deste concelho «fronteira» do Douro Vinhateiro, dimensão transversal ao estudo de caso alargado, reinterpretando tendências nucleares já anteriormente delineadas e que aqui se remobilizam numa compreensão mais clara da reconstituição histórica deste município duriense onde o vinho do Porto se mantém como uma das suas principais riquezas.

\subsection{O VINHO DO PORTO NA «CADEIA DAS MERCADORIAS $»^{710}$}

Produto de relevante importância na vitivinicultura nacional e regional, mas também mercadoria de exportação internacional histórica na economia nacional dos últimos cerca de 300 anos, o vinho do Porto, cujas exportações originaram, mais continuadamente, maiores rendimentos para a balança comercial portuguesa com défices crónicos, tornou-se num dos mais significativos casos do processo económico-social da própria história da mundialização. Já abundantemente

\footnotetext{
${ }^{707}$ BARRETO, 1993.

${ }^{708}$ Informante M. C. natural de Sever-Santa Marta de Penaguião, Vila Real, descendente de antigos produtores de vinho do Porto.

${ }^{709}$ Termo usado para definição do vinho do Porto como resultante do «blend» ou mistura controlada de vários vinhos de um ou mais anos, processo que lhe garante uma qualidade consistente.

${ }^{710}$ ARRIGHI, 1997. Segundo o autor as relações dentro do sistema mundo não podem analisar-se como ligando economias nacionais ou regionais, mas sim como atividades económicas estruturadas em «cadeias de mercadorias» que atravessam fronteiras nacionais.
} 
estudado em diferentes dimensões da sua produção e comércio ${ }^{711}$ é, porém, na perspetiva da sociologia histórica e no âmbito da análise histórico-social que aqui nos importa compreendê-lo.

O setor do vinho do Porto, que nos séculos XVIII e XIX rondava entre $50 \%$ a $80 \%$ de todo o comércio externo nacional, representa ainda hoje cerca de $46 \%$ das exportações totais dos vinhos portugueses (sendo embora menos de $2 \%$ das exportações nacionais). No mercado e no consumo, define-se por quatro tendências dominantes: a da sua estabilização ou ligeiro declínio no volume de exportações, após considerável aumento no período de 1970-2000; estabilização do valor global das exportações; baixa dos preços unitários de venda nacionais e internacionais do vinho do Porto corrente; diversificação de produtos e categorias especiais com preços mais elevados; notável desenvolvimento dos vinhos DOC Douro de média e elevada qualidade e com preços elevados ${ }^{712}$.

Convém ainda lembrar que, se o século XIX foi para o vinho do Porto e vinhos generosos do Douro o da concorrência externa, dos negócios com dominância da comunidade britânica do Porto no setor exportador, da defesa da «marca Porto» contra fraudes e falsificações a par do incremento global da desregulação estatal, já o século XX, iniciando-se com a intervenção ditatorial franquista que «definiu legalmente o que devia entender-se por Vinho do Porto» ${ }^{713}$, viria a tornar-se para os novos tipos de vinho do Porto (do Cima Corgo e Douro Superior) que se impuseram nos mercados internacionais, o «século das definições legais» ${ }^{714}$, assim se admitindo «para o Douro e o seu vinho do Porto uma economia especial» e a existência de uma «economia particular dos vinhos superiores» ${ }^{715}$.

Numa abordagem retrospetiva sintética do último século até à década de 1970, verifica-se que os grandes recordes das exportações de vinho do Porto se registaram na década de 1920, como se pode observar em números globais respetivos (em litros) constantes do seguinte quadro:

Quadro 38

\begin{tabular}{|c|c|}
\hline Anos & Exportações (em litros) \\
\hline 1919 & 54.088 .400 \\
\hline 1924 & 56.357 .300 \\
\hline 1925 & 59.417 .200 \\
\hline 1926 & 52.381 .100 \\
\hline
\end{tabular}

Fonte: Damião Peres $(1928 / 1981)^{716}$

Nos anos de 1919, 1924 e 1925 atingiram mesmo os maiores valores de sempre até então. É deste período a publicação do Decreto n. 7934 de 10 de dezembro de 1921, diploma básico

\footnotetext{
${ }^{711}$ BARRETO, 1988: 373-390.Ver também PEREIRA, 2010.

712 BARRETO, 2014: 265.

713 TENREIRO, 1944.

${ }^{714}$ O Vinho do Porto no Séc. XX (debates parlamentares). Disponível em <http://debates.parlamento.pt/catalogo/r2/ acc/01/10/03/094/1972-02-18?sft=true\#p1205>. [Consulta realizada em 03/11/2016].

715 TENREIRO, 1944.

${ }^{716}$ PERES, 1928-81: 118-119.
} 
para a regulamentação da produção e comércio do vinho do Porto. Mas quando, em 1930, nova crise se abateu sobre o Douro, fez-se sentir novamente a necessidade de uma reestruturação do setor em todos os sentidos. Daí o surgimento de estruturas institucionais de feição corporativa enquadradoras: a) a agremiação dos produtores na Casa do Douro [Federação Sindical dos Viticultores da Região do Douro (Decreto n. 211 883, de 16 de novembro de 1932), depois denominada Federação dos Vinicultores da Região do Douro (Decreto-Lei n. ${ }^{\circ}$ 24948, de 10 de janeiro de 1935)]; b) a associação no Grémio dos Exportadores do Vinho do Porto, de todos os seus comerciantes exportadores (Decreto n. ${ }^{\circ} 22$ 460, de 10 de abril de 1933 e Decreto n. ${ }^{\circ} 23$ 184, de 28 de outubro de 1933); c) e a criação do Instituto do Vinho do Porto (Decreto n. ${ }^{\circ} 22$ 461, de 10 de abril de 1933, e Decreto-Lei n. ${ }^{\circ} 26$ 914, de 22 de agosto de 1936).

A proteção da designação «Porto» no mercado interno assentou em quatro dispositivos: 1) na demarcação da região; 2) no aproveitamento dos melhores mostos produzidos no Douro demarcado, selecionados por método apoiado no respetivo cadastro vitícola; 3 ) na existência do Entreposto onde se encontram todos os armazéns dos comerciantes; 4) numa fiscalização aturada da produção e do comércio ${ }^{717}$.

No entanto, as exportações de vinho do Porto viriam a ser profundamente afetadas com a II Guerra Mundial (1939-1945), conforme se pode deduzir da grande quebra nas litragens médias exportadas por comparação dos seguintes números (em litros) relativos às décadas, imediatamente, anteriores e posteriores:

Quadro 39

\begin{tabular}{|c|c|}
\hline Décadas & Médias de exportação de vinho do Porto (em litros) \\
\hline $1919-1939$ & 43000000 \\
\hline $1946-1955$ & 23745088 \\
\hline $1951-1955$ & 23110732 \\
\hline $1956-1960$ & 23132110 \\
\hline
\end{tabular}

Fonte: Peres, 1928-81

E, embora as exportações se tenham mantido longe dos grandes records verificados na década de 1920, não deixa de ser sensível a sua recuperação até aos anos 1970, a partir dos quais irá atingir patamares muito superiores, ganhando uma nova dimensão. De facto, a exportação de 1970 teria atingido 35.053 .100 l, ou seja $+9 \%$ do que a de $1959,+10,9 \%$ do que a média de 1965-1969 e +21,4\% do que a média de 1960-1965. Relativamente à média de 1946-1955, a exportação de 1970 foi superior em 1162521 (+ 49,6\%), e relativamente à média, de 1956-1965 atingiu mais 9.697.100 $1(+37,7 \%)$.

Considerando, embora, que o comércio do vinho do Porto no século XX é já bem conhecido, através dos estudos de Conceição Andrade Martins ${ }^{718}$ e de Teresa da Silva

\footnotetext{
${ }^{717}$ PERES, 1928/1981.

${ }^{718}$ MARTINS, 1990.
} 
Lopes $^{719}$, é oportuno observar aqui, sinteticamente, a evolução quer da produção quer da exportação do vinho de Porto a partir das décadas subsequentes do século XX até aos nossos dias ${ }^{720}$.

Quadro 40. Produção de vinho do Porto (1970-2016)

\begin{tabular}{|c|c|c|c|c|c|}
\hline Anos & Pipas (pipa/550 I.) & Anos & Pipas & Anos & Pipas \\
\hline 1970 & 75.375 & 1986 & 148.329 & 2002 & 172.404 \\
\hline 1971 & 77.137 & 1987 & 169.177 & 2003 & 138.415 \\
\hline 1972 & 99.666 & 1988 & 153.696 & 2004 & 159.881 \\
\hline 1973 & 157.521 & 1989 & 216.825 & 2005 & 153.666 \\
\hline 1974 & 119.333 & 1990 & 193.194 & 2006 & 157.656 \\
\hline 1975 & 99.787 & 1991 & 147.456 & 2007 & 159.528 \\
\hline 1976 & 110.877 & 1992 & 101.333 & 2008 & 158.521 \\
\hline 1977 & 126.539 & 1993 & 108.184 & 2009 & 140.676 \\
\hline 1978 & 105.616 & 1994 & 136.818 & 2010 & 140.323 \\
\hline 1979 & 123.090 & 1995 & 163.528 & 2011 & 107.354 \\
\hline 1980 & 127.972 & 1996 & 164.651 & 2012 & 122.672 \\
\hline 1981 & 100.536 & 1997 & 166.606 & 2013 & 125.641 \\
\hline 1982 & 109.079 & 1998 & 156.439 & 2014 & 133.295 \\
\hline 1983 & 102.395 & 1999 & 198.973 & 2015 & 140.928 \\
\hline 1984 & 108.861 & 2000 & 194.554 & 2016 & 146.394 \\
\hline 1985 & 120.851 & 2001 & 198.352 & & \\
\hline
\end{tabular}

Fonte:IVDP-Porto

Como se pode observar neste quadro, os volumes de produção de vinho do Porto, no longo arco temporal de mais de meio século, evidenciam uma subida inicial pronunciada na década de 1970 com um pico acentuado em 1973, mantendo-se no patamar superior das 100.000 pipas, até aos inícios dos anos 1980, período em que regista uma considerável subida, atingindo o pico máximo superior a 200.000 pipas, em 1989. Segue-se uma queda abrupta, sucedida, porém, de nova subida que atingiu a plataforma trienal das 200.000 pipas na transição do século XX para o século XXI, altura a partir da qual os volumes de produção sofreram uma quebra até voltarem a tocar, em 2011, o patamar atingido nos anos 1970, tendo, no entanto, voltado a recuperar ainda que parcialmente. Aliás, estas oscilações traduzem relativa instabilidade e variabilidade multifatorial, embora dentro de uma tendência consistente de subida dos volumes de produção.

Já no que se refere, concretamente, à produção de vinhos generosos aptos a serem certificados como vinho do Porto, no caso específico de Carrazeda de Ansiães, concelho de fronteira no contexto das duas sub-regiões: Cima Corgo e Douro Superior, vale a pena deter-nos, mais em

\footnotetext{
${ }^{719}$ LOPES, 2003: 131-149.

${ }^{720}$ Do ponto de vista de uma análise da produção vinícola global, a nível da Região, seria necessário atender-se também à produção de outros vinhos: DOC Douro, Terras Durienses, Moscatel do Douro e Espumantes do Douro.
} 
pormenor, na evolução que registou, após a respetiva integração na RDD, com as demarcações de 1907 e 1908. Verifica-se que, na primeira metade do século XX, a produção de vinhos generosos deste concelho, entre 1916 e 1930, quase duplicou, ao subir de 2.400 pipas para 4.459, tendo atingido neste período, uma média anual de 3.344 pipas e um total de 50.173,8 pipas $^{721}$. Já entre 1933 e 1942, (excetuando 1937 e 1938), a produção total de vinho generoso foi de 23.309 pipas, numa média anual de 2.920 pipas $^{722}$. Mais recentemente, nos anos de 2008 a 2016, pode observar-se, por amostragem, um comportamento de maior estabilidade dos seus volumes de produção, o que se torna ainda mais evidente quando comparado, em igual período, sobretudo com as produções em ritmo crescente, nos últimos anos, da sub-região de Cima Corgo onde, para efeitos de contabilização estatística, foi oficialmente enquadrado (ver quadro e gráfico seguintes).

Quadro 41. Produções de Vinho generoso do concelho de Carrazeda de Ansiães e sub-regiões Cima Corgo e Douro Superior (em litros) ${ }^{723}$

\begin{tabular}{|c|c|c|c|}
\hline Anos & Carrazeda de Ansiães & Cima Corgo & Douro Superior \\
\hline 2008 & 2.567 .720 & 42.915 .247 & 10.433 .771 \\
\hline 2009 & 2.896 .602 & 36.621 .565 & 9.653 .096 \\
\hline 2010 & 3.473 .774 & 37.977 .601 & 11.135 .357 \\
\hline 2011 & 2.658 .899 & 32.687 .758 & 6.864 .334 \\
\hline 2012 & 2.845 .834 & 34.591 .722 & 7.982 .121 \\
\hline 2013 & 2.553 .855 & 34.709 .223 & 9.413 .971 \\
\hline 2014 & 2.444 .183 & 35.507 .808 & 10.550 .565 \\
\hline 2015 & 2.792 .997 & 37.934 .972 & 10.437 .312 \\
\hline 2016 & 3.327 .448 & 40.094 .220 & 10.876 .780 \\
\hline
\end{tabular}

Gráfico 2

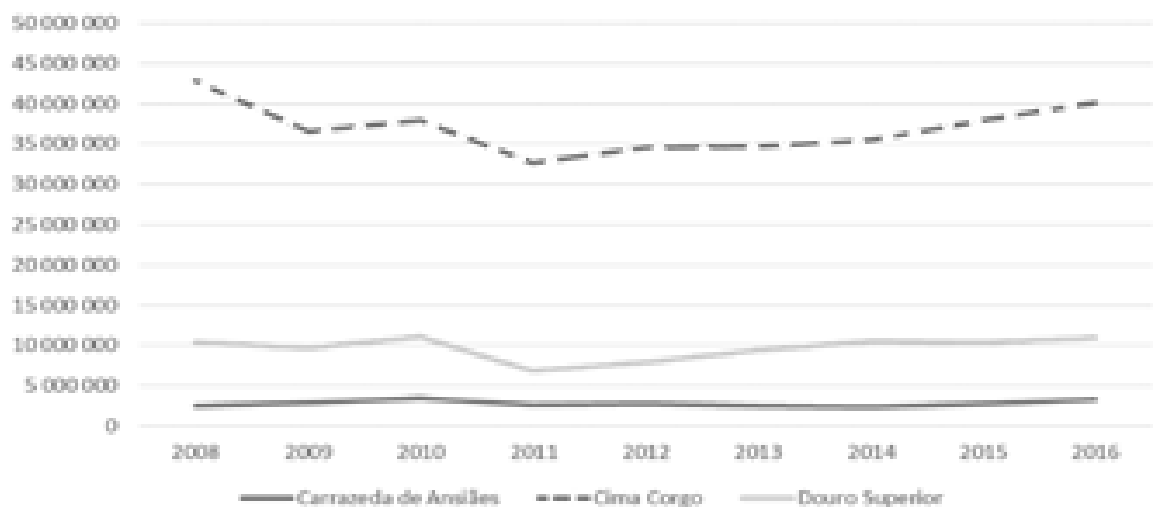

\footnotetext{
${ }^{721}$ Ministério da Agricultura, Produção Agrícola, 1916-1924, Lisboa, Imprensa Nacional; e Anuário Estatístico de Portugal, anos de 1923 a 1932. Ver estudo de Fernando Augusto Figueiredo - Carrazeda de Ansiães: um município do Douro. Estudo sobre o concelho. (FIGUEIREDO: 2017).

${ }^{722}$ Anuário Estatístico de Portugal, anos de 1932 a 1944. Nos anos de 1937, 1938, 1943 e 1944, a produção foi apenas publicada por regiões vinícolas e distritos.

${ }^{723}$ IVDP - Informação Estatística.
} 
Constata-se, no período em observação, que a média de produção de vinhos generosos do concelho de Carrazeda foi superior a 2.800.000 litros (5.090 pipas), o que, considerando uma média aproximada de 38.000.000 litros (69.090 pipas), das produções do Cima Corgo, representa relativamente a esta sub-região uma percentagem inferior a $10 \%$, enquanto em relação ao Douro Superior, com uma média de produção de 9.500 .000 litros, atingiria a percentagem de $29 \%$.

Quadro 42. Exportações de vinho do Porto — volumes e valores (1970-2016)

\begin{tabular}{|c|c|c|c|c|c|}
\hline Anos & Hectolitros (hl) & Milhares de euros & Anos & Hectolitros (hl) & Milhares de euros \\
\hline 1970 & 350530 & 2953 & 1994 & 771001 & 246164 \\
\hline 1971 & 368171 & 3324 & 1995 & 807835 & 261615 \\
\hline 1972 & 434946 & 4401 & 1996 & 807256 & 282213 \\
\hline 1973 & 475907 & 6355 & 1997 & 780850 & 302536 \\
\hline 1974 & 437086 & 9385 & 1998 & 816166 & 315129 \\
\hline 1975 & 379492 & 7696 & 1999 & 824449 & 335193 \\
\hline 1976 & 410967 & 8576 & 2000 & 826417 & 350026 \\
\hline 1977 & 485948 & 12656 & 2001 & 820210 & 343815 \\
\hline 1978 & 521053 & 18736 & 2002 & 797375 & 357688 \\
\hline 1979 & 628690 & 29232 & 2003 & 806602 & 346808 \\
\hline 1980 & 614502 & 36001 & 2004 & 798397 & 337548 \\
\hline 1981 & 546428 & 36699 & 2005 & 807729 & 341930 \\
\hline 1982 & 572865 & 48387 & 2006 & 785278 & 331685 \\
\hline 1983 & 582444 & 64742 & 2007 & 814041 & 342550 \\
\hline 1984 & 592494 & 79009 & 2008 & 767133 & 316223 \\
\hline 1985 & 634596 & 100785 & 2009 & 725973 & 300226 \\
\hline 1986 & 682921 & 123911 & 2010 & 741604 & 315474 \\
\hline 1987 & 684238 & 137667 & 2011 & 718624 & 305592 \\
\hline 1988 & 718351 & 156426 & 2012 & 715274 & 306980 \\
\hline 1989 & 702738 & 168513 & 2013 & 688134 & 313254 \\
\hline 1990 & 686103 & 206184 & 2014 & 673510 & 308420 \\
\hline 1991 & 661608 & 197254 & 2015 & 656811 & 305833 \\
\hline 1992 & 660322 & 195997 & 2016 & 646886 & 307528 \\
\hline 1993 & 711592 & 223252 & & & \\
\hline
\end{tabular}

Fonte: IVDP — Porto

Uma leitura interpretativa da globalidade dos dados apresentados, relativos às duas variáveis principais, volumes e valores, das exportações de vinho do Porto, durante o mesmo período que foi considerado para a produção, revela uma tendência ascendente de volumes e 
valores de exportação ainda que com maiores oscilações nas quantidades do produto, até ao ano 2000, verificando-se a partir daí uma relativa divergência no comportamento das duas variáveis, mais concretamente com a descida constante dos volumes exportados que se fixam abaixo dos 800.000 hectolitros. Ainda nesta variável, observa-se uma flutuação significativa traduzida por uma subida acentuada na década de 1970, seguida de uma quebra na primeira metade dos anos 1980 com recuperação no final e atingindo, na década de 1990, volumes superiores a 800.000 hectolitros, para voltar a descer, a partir de 2013 mantendo-se desde então em volumes inferiores a 700.000 hectolitros.

No que concerne aos valores em milhares de euros atingidos pelas exportações regista-se uma enorme subida global e relativamente constante, a qual partindo de um referencial de cerca de 3 milhões de euros em 1970, atinge em 2000 e numa curva sempre ascendente, um valor superior a 350.000 milhares de euros, o mais alto do período observado, estabilizando em ligeira baixa, desde então, mas sempre em valores que rondam o patamar dos 300.000 milhares de euros.

Ressalve-se, no entanto, que a análise das exportações em valor, para adquirir significado, terá de ter em conta o efeito da inflação. Assim, se atendermos a que entre 2000 e 2016 (Quadro 42), a taxa de inflação dos produtos alcoólicos variou entre 0,9\% (em 2000, ano do maior valor de exportações) e 9,7\% (em 2006, com a taxa de inflação mais alta) — período em que o valor das exportações não baixou dos 300.000 milhares de euros, tendo depois oscilado em baixa relativa, para voltar, a valores levemente superiores, em 2016 — poderá concluir-se que, neste caso, é significativa a análise feita das exportações em valores.

Analisando comparativamente as duas curvas correspondentes às duas variáveis das exportações em apreço, a discrepância verificada entre a diminuição dos volumes exportados e a estabilização dos rendimentos auferidos parece ser um indicador seguro de um maior valor acrescentado com a afirmação de categorias especiais de vinhos do Porto nos mercados internacionais.

Importa, no entanto, e numa perspetiva de contextualização com a globalidade das exportações nacionais, lembrar que a exportação do vinho do Porto, já na década de 1980, representava apenas cerca de $2 \%$ do total das exportações. Todavia, em muitos anos, mais de metade dos valores do comércio externo resultavam da sua venda.

Refira-se ainda que o movimento de exportação de vinho do Porto se tem feito sempre, em especial, para países economicamente desenvolvidos e/ou com potencial de crescimento, como hoje ainda se faz, sobretudo para: França 21,4\%, Reino Unido 13,4\%, Holanda 11,5\%, Bélgica 9,4\%, EUA 8\%, Canadá 3,4\% e Alemanha 3,3\%) ${ }^{724}$, ocorrendo no caso dos EUA e Canadá, incremento de exportação nas categorias de Porto mais elevadas ${ }^{725}$.

Em 2016, a comercialização do vinho do Porto atingiu 77.615.604 litros colocados em 25 países, ocupando o consumo interno o 2. ${ }^{\circ}$ lugar (12.658.023 litros) sendo a exportação de

\footnotetext{
${ }^{724}$ IVDP — Dados relativos a 2013.

${ }^{725}$ LEITÃO, 2013.
} 
64.957.581 litros para 24 países de todo o mundo onde se destacaram como os cinco primeiros mercados internacionais: a França $\left(1 .^{\circ}\right)$, a Holanda $\left(3 .^{\circ}\right)$, o Reino Unido $\left(4 .^{\circ}\right)$, a Bélgica $\left(5 .^{\circ}\right)$ e os $\operatorname{EUA}\left(6^{\circ}\right)^{726}$.

Os indicadores da história económica do vinho do Porto, produto regional e nacional e mercadoria de exportação internacional, que se acabaram de sintetizar permitem na sua globalidade intuir algumas das suas principais flutuações e tendências as quais se encontram por sua vez correlacionadas com a ocorrência de crises, acontecimentos de impacto mundial e profundas mudanças económicas e geopolíticas que têm caracterizado a história mais recente do sistema mundo capitalista.

\subsection{PARA A SÓCIO-HISTÓRIA DE CARRAZEDA CONCELHO PRODUTOR DE VINHO DO PORTO}

Ensaia-se aqui uma análise sincrética, mas integradora que visa explicar fenómenos ocorridos e observados, num processo dialógico de compreensão que supôs a interação do investigador com o objeto de estudo, tornando-se o próprio processo de investigação um momento de aprendizagem, transformação e desenvolvimento progressivo. Como afirma Bakhtin: «Não há uma palavra que seja a primeira ou a última, e não há limites para o contexto dialógico (este se perde num passado ilimitado e num futuro ilimitado)» ${ }^{727}$.

Com esta advertência pertinente e à luz da anterior aproximação sócio-histórica ao vinho do Porto, podem então percecionar-se algumas problemáticas principais, outras tantas dimensões importantes à compreensão da história recente deste concelho, já anteriormente enunciadas nas suas linhas tendenciais mais destacadas e significativas.

Esta abordagem mais ampla de orientação sócio-histórica possibilita destacar no conjunto dessas principais tendências, problemáticas marcantes e características específicas da sócio-história do concelho de Carrazeda de Ansiães.

A história da integração deste concelho na RDD, como já anteriormente descrito (caps. 4 e 5), está ligada desde início a um período conturbado do processo histórico nacional atravessado por grandes convulsões económico-sociais que acabaria por culminar na mudança do próprio regime político que passou, em definitivo, da Monarquia constitucional para a Democracia parlamentar da I República. A nível regional e local também essa ambiência se fez sentir profundamente, cruzando-se ademais com a própria história da produção e comércio do vinho do Porto, sujeito de forma particularmente intensa, nessa época, a uma diversidade de contrafações e práticas fraudulentas que interferiram, como nunca, na comercialização do vinho do Porto nos mercados internacionais.

Recorde-se que a Região do Douro Vinhateiro sempre foi, desde a sua definição jurídico-institucional, sucessivamente demarcada, pelo que a história dos negócios do vinho do Porto

\footnotetext{
${ }^{726}$ IVDP — Dados relativos a comercialização de vinho do Porto engarrafado, 2016. Disponível em <https://www. ivdp.pt/pt/docs/Porto/Quadro\%201_2016.pdf>. [Consulta realizada em 4/5/2017]

${ }^{727}$ BAKHTIN, 1992.
} 
tem corrido a par de uma história das fraudes e contrafações de que foi sendo objeto desde o século XVIII ${ }^{728}$ e a que é inerente a própria natureza da demarcação geradora de condições de exclusão, denúncia e disputa. De facto, a Demarcação «como qualquer linha de fronteira que gera exclusão, esteve longe de ser pacífica, o que ficará bem patente nas muitas transgressões denunciadas durante as sucessivas devassas». Acontece, porém, que tal definição de limites da região vitícola duriense, a primeira no mundo a supor a elaboração de um cadastro e uma classificação das parcelas de terra e respetivos vinhos «de feitoria, de embarque e de ramo», é muito mais do que mais uma linha de fronteira ${ }^{729}$.

Esta é, pois, uma das problemáticas recorrentes e transversais à complexa sócio-história do produto essencial do Douro Vinhateiro demarcado (Vinho de Feitoria, Vinho Fino, Vinho Generoso, vinho do Porto, Port Wine, em suas diferentes designações), a qual assumiu de diversos modos particular evidência e pertinência em certos períodos e cuja dilucidação multiperspetivada é da maior importância como se tentará demonstrar.

\subsection{A PRAGA DA CONTRAFAÇÃO E A AUTENTICIDADE. DENOMINAÇÕES GEOGRÁFICAS}

Retomemos então a análise em concreto da questão das fraudes ou contrafações como as que o comércio exportador do vinho do Porto estava praticando com especial incidência nas vésperas da I República e a que procurou obviar a nova demarcação da região, política protecionista e fiscalização de João Franco, em 1907.

Nesse período, e para além das contrafações realizadas em outros países e em outras regiões, eram também frequentes as fraudes no Douro, o que, por outro lado, levou algumas das principais casas exportadoras a pugnar pela manutenção de «vinhos do Porto genuínos».

A situação à época em matéria de fraudes era tal que o destacado viticultor duriense, Joaquim Carvalhais, personalidade que com Antão de Carvalho e outros seria um dos autores do «Estatuto do Douro» ${ }^{730}$, chega mesmo a denunciá-la, nestes termos: «não é exagero dizer-se que a não ser para a Inglaterra e para a Noruega, quási todo o mais vinho do Porto não era procedente do Alto».

Também os representantes dos viticultores de Carrazeda de Ansiães apresentavam, por sua vez, nas Cortes em 1907, a candente questão das fraudes, assim em termos extremos:

Não contava o desgraçado [o proprietário do Douro] com outro fator, mais cruel do que todos os outros que o tinham torturado: a mercancia ignóbil, a fraude torpe que se

\footnotetext{
${ }^{728}$ A primeira Devassa realizada no território do Alto Douro pelo Desembargador Antonio Mesquita e Moura ocorreu de 1771 a 1775, cerca de 15 anos após a instituição da Companhia Geral da Agricultura das Vinhas do Alto Douro por alvará régio de 10 de setembro de 1756, e à qual se seguiu a Demarcação Primordial do Douro ou Pombalina de 1758, logo corrigida em 1761.

${ }^{729}$ LAGE \& LAGE, 2005: 256-257.

${ }^{730}$ Os redatores deste Estatuto foram, para além de Antão de Carvalho, Camilo de Morais Bernardes Pereira e José Joaquim da Costa Lima.
} 
sentou no limiar das suas adegas, impedindo a saída dos seus vinhos, entretanto que, mar em fora, iam vinhos com o nome do Douro, com o seu nome buscar aos mercados estrangeiros o preço do seu sangue que a fraude arrecadava cinicamente, deixando nesses mercados, como suprema irrisão, o descrédito para o seu produto ${ }^{731}$.

Estas são algumas das representações que os viticultores deste concelho, referindo-se a uma identidade regional em relação com a autenticidade dos vinhos do Douro, constroem dos efeitos perniciosos das falsificações e contrafações inerentes à fraude comercial, prática condenável de concorrência desleal, questão de tal modo relevante que fora considerada num estudo estatístico americano de 1916 , a 3. ${ }^{\text {a }}$ causa de insucessos e prejuízos económicos ${ }^{732}$.

As fraudes e falsificações dos vinhos do Douro desde a produção ao comércio e exportação, são aí denunciadas pelos viticultores do concelho de Carrazeda em Representação à Câmara dos Pares, onde contestam também os favores do governo dispensados à viticultura do sul do país, como argumento mais forte para reclamar, ao mesmo tempo que clamam por justiça mitigadora da "miséria do Douro», e reclamam a eliminação da base 15 de projeto de lei e a proibição da destilação de álcool na região duriense, consignada na lei vinícola então apresentada pelo Parlamento ao Governo.

Estes argumentos e reclamações e a recorrente defesa da Região Duriense e dos autênticos vinhos licorosos do Douro que se veem entrar cada vez mais em descrédito nos mercados estrangeiros são comuns a outras representações apresentadas também pelas Câmaras de outros municípios do Douro, como Alijó, Murça, Moncorvo e Freixo de Espada à Cinta e que vale a pena ter em conta, comparativamente, e em termos das representações sociais e identitárias que nelas se veiculam.

A braços ainda com a «Questão Duriense» que configura uma profunda crise e a diversidade de acontecimentos e factos de miséria e sublevações populares, uma numerosa e reivindicativa Comissão representativa da Região Demarcada do Douro, na qual participam entre muitos outros, Antão de Carvalho e também um comissionado de Carrazeda de Ansiães, o destacado republicano e grande proprietário duriense, António Júlio Ribeiro (subcapítulo 10.4.), vai protestar em Lisboa contra a ratificação do tratado de comércio com a Inglaterra (pedindo aclaração do art. $^{\circ}$ 6..$^{\circ}$ ) e reúne com o Governo a quem são enviadas também por vários concelhos da Região, comunicações telegráficas em apoio da Comissão que reclama providências para se não consentirem fraudes e falsificações do vinho do Porto.

Como se pode deduzir a magnitude e complexidade desta problemática das fraudes obriga-nos a analisá-la num enquadramento teórico que possibilite dar conta dos seus principais fatores e muitas variáveis envolvidas.

\footnotetext{
${ }^{731}$ «Diário do Governo», n. ${ }^{\circ} 74(1907 / 04 / 05) 989$.

${ }^{732} \mathrm{O}$ Vinho do Porto no Séc. XX (debates parlamentares). Disponível em <http://debates.parlamento.pt/catalogo/r2/ acc/01/10/03/094/1972-02-18?sft=true\#p1205>. [Consulta realizada em 3/11/2016].
} 
Relevam desde logo nesta matéria importante e ainda atual, a qual tem sido alvo de muitos estudos e controversas decisões jurisdicionais, duas motivações fundamentadoras básicas: a da concorrência desleal e a da indução em erro do público, as quais se tem pretendido combater. Mas a análise deste tópico no campo da legislação e jurisprudência nacional, comunitária e internacional (designadamente na Organização Mundial da Propriedade Intelectual e na Organização Mundial do Comércio) e, em especial, no domínio da regulamentação vitivinícola, vem-se revelando problemática, com a discussão a centrar-se sobretudo na dilucidação dos seguintes pressupostos: demarcação das diversas figuras comummente abrangidas pelas designações «Denominações geográficas» ou «indicações geográficas»; determinação da tutela face às delimitações de origem, o que se relaciona com eventual degenerescência dessas designações; conflito que se mantém entre as denominações geográficas e a questão da marca. No entanto, pode sintetizar-se em traços largos, que a Denominação de Origem (DO) garante não só uma certa proveniência mas também que o produto contém características qualitativas; isto sem prejuízo da aplicação das normas sobre concorrência desleal. Quanto à marca e ao problema de ser aplicada a produtos não idênticos ou afins aos que têm direito à DO (mormente quando esta é de renome), sejam ou não provenientes da região delimitada, a jurisprudência recente orienta-se para a salvaguarda de que nenhum sinal seja suscetível de induzir o público em erro sobre as qualidades do produto e quanto à sua proveniência geográfica ${ }^{733}$.

Para uma mais ampla compreensão sócio-histórica desta relevante dimensão que se tem vindo a enunciar em seus variados prismas, recorre-se, especificamente, de agora em diante à "sociologia da perceção e economia das contrafações ${ }^{734}$ », com vista à necessária aproximação teórica ao problema recorrente na RDD das fraudes, contrafações e outras falsificações (como publicidade enganosa), as quais se inter-relacionam com a criação da denominação de origem Douro e «marca» vinho do Porto que se interpenetram com a afirmação e construção de identidades de pertença e têm de ser vistas à luz dos correspondentes atores-redes e querelas.

O quadro analítico escolhido reenvia-nos então, à partida, para dois tipos de dossiers que têm de ser considerados: um primeiro dossier composto de processos de contrafação diretamente ligados à concorrência entre firmas nacionais e estrangeiras em torno das mercadorias, como melhor se poderá observar no contexto do comércio dos vinhos do Porto no mercado brasileiro onde a questão da autenticidade é sobretudo um negócio de direito da marca, de garantia jurídica; e um segundo dossier, que concerne mais à validação de produção, à paternidade de matérias-primas e de tecnologias de fabrico do produto, em que a prova se compromete na produção (alcoolização, fermentação, etc.), o qual, como poderá ver-se, é ainda ilustrado por outras dimensões do mesmo caso do comércio dos vinhos do Porto com o Brasil.

\footnotetext{
${ }^{733}$ Esta problemática teórico-prática é exaustivamente desenvolvida e debatida no campo jurídico por Alberto Francisco Ribeiro de Almeida (ALMEIDA, 2000-2001: 275-328).

${ }^{734}$ CHATEAURAYNAUD \& BESSY, 1995.
} 
Mas como a questão das fraudes e falsificações implica também a exigência e retórica da autenticidade, tema não localizado numa esfera determinada, poder-se-á considerar, numa visão crítica, que se continua a acreditar na autenticidade das coisas, é numa busca desesperada da identidade. Nessa medida, impõe-se-nos então e ainda, o que ensaiamos no subcapítulo seguinte, uma abordagem à problemática das identidades locais e regionais que consideramos na sua natureza conjuntural e não essencialista, retomando anterior aproximação introdutória a esta questão (Capítulo 6).

Múltiplas e complexas problemáticas se levantam então em torno de um produto de exportação de grande relevo e significado sócio-histórico na cadeia das mercadorias, como é o caso do vinho do Porto, as quais são omnipresentes no espaço nacional e reveladoras de tensões recorrentes nas formas de construção política da economia, configurando a nível regional e local um enquadramento específico de perceção permeado por contestações e denúncias da sua invocada inautenticidade.

Debates políticos e jurídicos são ainda hoje, e já o eram antes e no período da República, constantemente relançados em torno do problema das «contrafações», quer se trate de definir novos domínios de competência, de completar ou emendar textos legais em função da evolução da jurisprudência ou de os harmonizar com tratados e diretivas internacionais.

Pode dizer-se que há assim dois grandes regimes discursivos sobre a «contrafação»: o que é instalado pela «marca» através de diferentes porta-vozes (imprensa, peritos, associações e federações de produtores) e o que se desenvolve no espaço político por referência a dispositivos legais e regulamentares. Ora, e embora os supondo, optamos por apoiar-nos em fontes históricas diversas, ensaiando uma aproximação mais concreta às contrafações ${ }^{735}$, dado considerar-se que as polémicas sobre as falsificações ou os falsos em história, os debates sobre a origem do produto se encontram no centro do cenário, sendo por isso de mediar as classificações mais gerais.

Como já se explicou, com o novo quadro legislativo sobre a Região Demarcada do Douro de 1907/1908, assiste-se à expansão desta para novas áreas no Alto Douro e Douro Superior em que se inserem novos concelhos como o de Carrazeda de Ansiães, e à implantação de novo modelo institucional que abre um campo de partilha de interesses e problemas comuns e de interações a nível regional e concelhio. Subjaz-lhe assim um outro processo de complexa identificação em que os atores se integram num conjunto mais vasto de referência ou de pertença através do qual os agentes tendem a autonomizar-se e a diferenciar-se socialmente.

Esses mecanismos de identificação funcionam a dois níveis: o da produção de identidades concorrentes - identidades locais e identidade regional —, que coexistem sem se anular reciprocamente; e o da consolidação da identidade social, pela incursão no acesso ao comércio e ao mercado, gerando instabilidade nas estruturas de poder e dando azo a situações de mal-estar e mesmo rebeliões. A facilidade dos acessos ao mercado não enfraquece a contes-

${ }^{735}$ CHATEAURAYNAUD \& BESSY, 1995: 21-22. 
tação, antes condiciona mesmo a vida das populações das aldeias vinhateiras. As identidades hibridizam-se, fazem apropriações, desvirtuando ou acrescentando novos contextos, tão pertinentes e significativos como «o original» num território particular essencialmente unificado pela história, tradições e outros propósitos subjacentes. As populações existem e representam-se a si mesmas sob a forma de longas e contínuas narrativas, cujas origens surgem sempre ancoradas no passado. Entre espaço e atores, sob o controlo estatal e do mercado de uma região como o Douro com denominação de origem do produto e gestão de redes de clientelas, duas lógicas interagem: a da legitimidade mercantil tradicional — o Douro produtor de vinho fino - e a da legitimidade mercantil moderna - a Região Demarcada do Douro Vinhateiro produtora do vinho do Porto, «marca» e «bem» de exportação mundial.

O que exige se considere o estudo do vinho do Porto também enquanto objeto de fronteira, cuja identificação permite materializar convergências e inter-relações entre zonas de transação, permitindo construções heterogéneas e articulações, o que, o consubstancia como meio privilegiado de pôr em relação mundos sociais diferentes.

\section{Falsificações versus autenticidade, denominação de origem e «marca» vinho do Porto}

Intrinsecamente associada ao complexo processo jurídico, político-económico e científico-técnico de defesa da denominação de origem e proteção da marca ${ }^{736}$ encontra-se a manifestação de multímodos fenómenos de falsificação e fraude, quer ao nível da produção das uvas e do vinho quer ao da sua comercialização nos mercados de consumo interno e exportação.

A fama e elevados preços do vinho do Porto, objeto de tentação irresistível, foram sendo sempre acompanhados da ocorrência de fraudes sucessivamente detetadas, denunciadas e combatidas, porém nunca com êxito total.

No plano da forte concorrência e competição do mercado, livre ou condicionado, virá a impor-se a marca vinho do Porto, enquanto produto de origem defendida desde há cerca de 300 anos, quando o mercado britânico era ainda o seu principal destino. A defesa da sua proteção, tornou-se questão internacional, em 1883, na Convenção da União de Paris, onde Portugal, como signatário, foi um dos primeiros países a defender essa política protecionista. Nas posteriores convenções de Madrid (1891) e Bruxelas (1900), Portugal continuou a defender a posição de que ninguém se poderia apropriar do nome vinho do Porto que, com tanto labor, conquistou reputação internacional. Após a Convenção da União de Paris, a que se sucederam inúmeras assembleias internacionais, Portugal continuaria a defender uma apertada fiscalização para prevenir as generalizadas falsificações no estrangeiro do vinho do Porto. Idêntica reivindicação fiscalizadora se verificou também em relação aos vinhos armazenados nos exportadores, logo seguida dos protestos destes, para proteção das marcas de origem dos vinhos, até à legislação de João Franco, que introduziu disposições sobre a garantia da marca

${ }^{736}$ ALMEIDA, 1999. 
de origem do vinho do Porto, medida nunca antes tomada, e logo seguida, nesse sentido, de um acordo comercial com a Alemanha.

A proteção da denominação de origem e defesa da autenticidade do produto através da «marca vinho do Porto» ${ }^{737}$ é um longo e complexo processo histórico nacional e internacional de natureza protecionista e fiscalizadora, em que avultam várias medidas, desde o final do século XIX até ao segundo quartel do século XX, tendo assumido grande protagonismo e predominância nas políticas nacionais, com particular enfoque durante a I República, em que se tornou objeto de constante legislação reguladora e de intensa atividade de proteção, defesa e fiscalização por parte de organismos como a Comissão de Viticultura da Região Duriense e comissões subsidiárias.

O vinho do Porto tem, a partir daí, um porta-voz autorizado que é a «denominação de origem», uma dupla denominação de origem (Douro e Porto) e a «marca».

O direito das marcas ${ }^{738}$ está associado a uma rede de convenções de qualidade supostamente partilhadas pelos consumidores. Há uma grande diferença entre o modelo da marca e o modelo de denominação de origem. No primeiro caso, os sinais distintivos repousam sobre traços materiais, índices (que são objeto de uma propriedade); no segundo caso, trata-se de um conjunto de caracterizações que reenviam para uma descrição dos constrangimentos de fabrico, contribuindo para definir um standard (cuja referência permite garantir a qualidade do produto).

A marca coletiva, de que se pode considerar exemplo «a marca vinho do Porto», compõe um caso intermediário entre os dois, pois que há por um lado proteção de um sinal distintivo e referência a todo um «caderno de encargos».

Num plano de análise mais amplo, o vinho do Porto, meio também de interações humanas, sendo sobretudo um produto importante na cadeia das mercadorias e, nessa medida, indexado a espaços de cálculo, elemento material de trocas, permite que se identifique a interação como transação. Assim, qualquer dúvida sobre a sua autenticidade compromete imediatamente as relações entre duas redes: uma, tecida na sombra, funcionando por malhas ocultas de contrafatores mais ou menos profissionais e obscuras associações de alegados malfeitores; e uma outra controlada pelo Estado e dotada de mecanismos de fiscalização apertada e repressão das fraudes. Do ponto de vista do Estado, a contrafação fora das fronteiras é a que se torna mais prejudicial à economia nacional.

Pode assim dizer-se que o combate entre o verdadeiro e o falso vinho do Porto compõe uma luta de representantes bastante estranha: porque qualquer um dos dois se esforça por contrair o outro. A intensidade da sua oposição joga-se nas mãos de peritos, instituições normativas e fiscalizadoras equipadas de instrumentos e equipamentos de deteção e prova, situações em que interagem humanos, e não humanos, capacidades de perícia e intrincadas redes.

\footnotetext{
${ }^{737}$ GUIMARÃES, 1947: 189-219.

${ }^{738}$ CHATEAURAYNAUD \& BESSY, 1995: 42-43.
} 
Acontece que um falso é sucedido se consegue deslizar num espaço de circulação pré-construído, sem que isso perturbe as trocas, isto é, passando despercebido enquanto tal, já que é conforme a uma representação comum, e, portanto, também a uma certa economia da perceção subjacente ao enfoque teórico aqui seguido.

Mas veja-se em concreto, no exemplo e demonstração seguintes, como o atrás aludido espaço de circulação pré-construído se pôde colocar historicamente na posição defendida em 1913, pela então Comissão de Viticultura da Região do Douro:

Desde a origem da sua exportação até hoje os caracteres típicos do vinho do Porto não têm sido constantes, eles obedecem às imposições dos mercados consumidores. Os primeiros vinhos do Porto fabricados eram aguardentados depois de completa a sua fermentação $e$ assim se obtinham vinhos generosos e não licorosos, mas esses tipos quase desapareceram $e$ hoje os vinhos do Porto são em toda a parte vinhos licorosos. O Porto de 1820 teve um êxito colossal e depois dessa data os processos enológicos mudaram completamente...E hoje pode dizer-se que o vinho do Porto é um vinho licoroso e, como tal, preparado e beneficiado antes de terminada a sua fermentação.

A Port Wine Shippers Association intentando uma ação contra o abuso da palavra Port para vinhos produzidos em Espanha, obteve a seguinte definição de Porto. 'Port', ou vinho do Porto indica o vinho que é carregado do Porto. É um vinho produzido em Portugal, dentro de certo distrito, debaixo de certas condições, e feito de uma certa forma. É aguardentado e a fermentação suspensa em determinada ocasião ${ }^{739}$.

$\mathrm{O}$ argumento desenvolvido nestes termos sobre a alegada autenticidade do vinho do Porto compõe a retórica da Comissão de Viticultura da Região do Douro (CVRD).

Nessa contenda em que é opositora a Associação Comercial do Porto, porta-voz da defesa dos alegados interesses do comércio de vinhos, muitas vezes também viticultor na região duriense, e defensora da tradição invocada por alguns viticultores que pretendem continuar a beneficiar vinho da região, em qualquer altura do ano, a CVRD, defendendo o mecanismo legal criado pelo Governo da República, assente na organização de registos de produção, contas-correntes e certificados de procedência, entendia para obviar a falsificações que o fabrico do vinho licoroso não devia ser permitido depois de 15 de novembro (termo das vindimas).

O governo, com a cedência em relação a ambas as partes, numa política conciliatória de interesses antagónicos, vai tentar pôr cobro, apenas a adiando, a esta disputa que reatualiza uma longa história de interesses antagónicos ou, no mínimo, sempre potencialmente conflituantes entre a produção e comercialização do vinho do Porto, na qual releva a reiteração de medidas de defesa da fama e renome deste produto sócio-histórico contra as falsificações e fraudes reincidentes em espaços sempre lacunares.

\footnotetext{
${ }^{739}$ Relatório da Comissão de Viticultura Duriense..., 1913: 35-36.
} 
Um outro aspeto deste processo, de análise interessante, é a denúncia pormenorizada e concreta das recorrentes fraudes e falsificações praticadas quer ao nível da produção quer ao nível da comercialização e exportação, numa heterogeneidade de situações, funcionando como canos de escape face à forte regulação estatal que cumpria a esta Comissão, por sua vez enredada em lacunas da lei que identificava no decurso da sua aplicação e a que propunha alterações.

A noção de autenticidade, carregada de ambiguidade, por querelas, mudando de sentido de uma configuração para outra, e a fidelidade da marca, são muitas vezes esgrimidas com abundantes e diversos argumentos e explicitação de conflitos e disputas em que os técnicos dirigentes da CVRD, com base em legislação da época que garantia por completo o nome do vinho do Porto como vinho regional (decreto de 27 de novembro de 1908), tomavam posição, reclamando por exemplo a obrigatoriedade das contas-correntes e as declarações de produção até determinada data.

\section{A denominação de origem Douro e Porto e marca vinho do Porto enquanto rede e repre- sentação no jogo das contrafações}

Mas como se pode assegurar a identidade de um produto em que a sua apelação de origem repousa numa dada região e num «saber-fazer» tradicional? A questão da autenticidade não deixa de se continuar a colocar. Emerge nas negociações em torno da «denominação de origem» e no processo de fabrico/produção, no decurso do qual os produtores se esforçam por responder às exigências de qualidade de certos mercados e dos conhecedores. A procura $\mathrm{da}$ autenticidade passa aqui por longos tratamentos, associando um trabalho sobre gestos e combinações de materiais (aguardentes, etc.) e as condições de apuramento final (fermentação, temperatura, higrometria, envasilhamento, etc.), dificuldades que provêm da utilização de uma dada matéria-prima (tipo de castas, com adição ou não, de sacaroses ou da tradicional baga de sabugueiro), testes laboratoriais, provas enológicas e validações de peritos.

É o trabalho conjunto sobre os procedimentos, os produtos e o meio associado que fornece então o melhor compromisso de autenticidade, base sólida para o sucesso do negócio. Donde a importância conferida pelos protagonistas à matéria-prima utilizada, cuja estabilidade é assegurada pela limitação geográfica (vales ensolarados, uma geologia e condições climáticas específicas), o recurso às mesmas, ou idênticas castas, os processos de cultura e fabricação transmitidos pelos antigos, depositados nos utensílios, os equipamentos (vasilhames, etc.) e instalações (lagares, adegas), etc.

Nas negociações em torno da denominação de origem controlada, o constrangimento de autenticidade muda de regime: apoia-se num enquadramento e normalização jurídica em referência a um modelo definido por caracteres gerais.

O produto vinho do Porto tem assim a sua cadeia e redes de representantes que, como todo um sistema de delegação, tende a autonomizar-se da sua base, o vinho do lavrador designado pela expressão émica de «vinho fino» ou «vinho tratado». 
Nesse dispositivo está contida a economia das contrafações: o ponto de apoio sobre as formas e representações que emergem dos coletivos do vinho do Porto (lavradores e produtores, comerciantes, vendedores e compradores, intermediários e consumidores) conferem uma importância central à etiqueta da marca e aos sinais que aí figuram. Mas ao mesmo tempo, os produtores têm de entrar nesse jogo, compor uma etiqueta, valorizar a sua denominação de origem, consolidar a referência na tradição. Eles passam assim de um regime de autenticidade (de matérias-primas e saberes-fazeres) a um regime de autenticação pelas formas. Este segundo regime opõe a objetividade do dispositivo de certificação à subjetividade das perceções (gostos, odores, cores) e, ao fazer isto, introduz uma duplicidade que serve perfeitamente aos contrafatores. Todavia, o primado das representações não pode enganar o conhecedor, capaz de pôr à prova simultaneamente as redes sociotécnicas, as formas convencionais e as produções materiais.

Em conclusão, e como se pôde observar, a contrafação joga frequentemente com a questão da autenticidade de origem, no caso do vinho do Porto, um vinho de alta qualidade. Este tem de ser produzido na própria região onde as uvas são cultivadas, pois isso facilita que a qualidade da matéria-prima seja acompanhada de perto pelo produtor do vinho e que seja criada uma «identidade» entre as características, a qualidade e a região onde é produzido - só assim se podendo a «região» transformar em «marca». Isto ocorre no Douro, como noutras regiões da Europa, que regista o seu nome como marca e supervisiona, classifica e certifica com uma indicação de procedência/proveniência, os vinhos produzidos nessa região tradicional.

Ora, a produção do chamado, localmente, «vinho fino» é um elemento fundamental de construção das identidades de produtores, famílias e instituições no concelho de Carrazeda e nesta zona da Região duriense e isso é percebido e valorizado ao longo de gerações, como um desejo de viabilizar economicamente uma atividade que cumpre um papel fundamental na identidade dos indivíduos, grupos, famílias e comunidade. Donde se pode deduzir que é pois a história que configura o espaço e a produção identitária, flexível e mutável, como se procura evidenciar e demonstrar a seguir.

\subsection{CONSTRUÇÃO DE IDENTIDADES: REGIONAL $^{740}$ E CONJUNTURAIS/CONTEXTUAIS ${ }^{741}$}

Relativamente a esta problemática da afirmação, persistência e consequências das identidades que, como já se viu, se encontra intrinsecamente relacionada com a das contrafações atrás analisada, parte-se do pressuposto de que as identidades são contraditórias, exibindo assim uma dialética própria de relativa complexidade.

Embora se considere as identidades como multímodas e mutáveis, em permanente construção, adaptáveis a conjunturas e contextos diferenciados, isto não implica que se menorizem os seus componentes tradicionais, mais duradouros e resistentes, ancorados no passado.

\footnotetext{
${ }^{740}$ PEREIRA, 1989: 332.

${ }^{741}$ CLIFFORD, 1988.
} 
Encaminha-se então esta outra abordagem pelas noções de identidades regionais múltiplas (pessoais e de grupo, informais, contextuais e conjunturais), ligadas à questão da territorialidade, considerando-se depender a sua constituição e manutenção de uma permanente reconstrução do sistema de valores intrínseco a determinados grupos e seus interesses. Tal implica que o aspeto diacrónico dessas identidades tenha de ser considerado, pelo que se ancora a aproximação feita a esta temática nas inscrições da história, acontecimentos e controvérsias que sobrevêm na construção das cadeias de testemunhos do passado.

\subsubsection{Aproximação teórica ao processo de «construção identitária»}

Neste complexo e fluido processo, a relação com o passado e configuração de memórias é um elemento central. Comunidades e indivíduos ao construírem as suas narrativas de autodefinição, produzem sentidos diversificados de pertença, identificação e exclusão, em função de fronteiras; "a noção de identidade depende da ideia de memória e vice-versa. $\mathrm{O}$ sentido essencial de qualquer identidade é sustentado pela recordação» ${ }^{742}$. Assim, a produção identitária pode ser vista como uma filiação simbólica que demarca os que ficam de um ou de outro lado de uma fronteira imaginária percecionada a partir do que vivemos e/ou nos foi transmitido.

Retomando, então, investigação desenvolvida a partir de testemunhos, memórias e fontes orais locais ${ }^{743}$, cujos resultados se mobilizaram anteriormente (Capítulos 7 e 9), tentaremos agora problematizar a análise interpretativa dos conteúdos desse tipo de fontes nas inter-relações que permitem estabelecer com o processo de construção de «identidades conjunturais», «contextuais» ou «relacionais», as quais aparecem e desaparecem, em função de interesses circunstanciais, nelas se evidenciando fatores de construção de materiais da memória. Estes indiciam, no que se refere à perceção da região do Douro, uma base de identificação assente em vivências do trabalho esforçado, expressão da força subterrânea de forte pertença identitária cuja componente social e socializadora se entretece em dificuldades partilhadas por jornaleiros e pequenos proprietários, base social determinante da produção do vinho do Porto, em todo o Douro mas também neste concelho em particular, onde a proporção de quintas e propriedades de grandes e médios proprietários é muito inferior à grande maioria de pequenos lavradores que possuem em média, como já se disse, cerca de 1,5 hectares de vinhas não voltadas diretamente para a agricultura comercial.

A análise desta realidade sócio-histórica tem ainda de ser polarizada socialmente, o que se tenta fazer numa perspetiva transdisciplinar capaz de operar uma transdução de alguns princípios da Teoria Ator-Rede, método de pesquisa científica, segundo o qual as regiões são constituídas por redes e, o regionalismo, um mundo de áreas com suas próprias regras topológicas. Assim, as identidades como as subjetividades são entendidas como conceitos muito próximos da noção de translação, processo em que a identidade é (re)negociada dentro de redes

\footnotetext{
${ }^{742}$ GILLIS, 1994: 4.

${ }^{743}$ LAGE, 1995; LAGE, 2002.
} 
heterogéneas, pelo que o estudo da formação da identidade dos indivíduos é feito em função de diferentes papéis que podem assumir em seus interesses e aspirações.

Uma outra dimensão da problemática das identidades encontra-se ligada às tradições e territorialidades diferenciadas e ao conceito de fronteira, como espaço de interação cultural com tendências contraditórias que se complementam, o qual permite mapear analiticamente a heterogeneidade dinâmica das zonas de contacto que dividem e unem indivíduos e grupos, na interação do local, através do trabalho, e inter-relações entre quintas e populações envolventes.

\section{Identidade, Identidades ou processos de Identificação?}

O que está aqui em discussão é a problemática da construção identitária, uma problemática de complexa apreensão mas relevante do ponto de vista da sua operacionalidade analítica necessária.

Por isso começamos por nos interrogar: o que queremos significar quando falamos em identidade(s)? Há identidades ou antes processos de identificação? Existe uma identidade regional no Douro? Estas interrogações e os próprios debates que suscitam têm de atender ao contributo de vários domínios das ciências sociais em que se têm vindo a reconfigurar estes conceitos.

A identidade, conceito fundamental para a escola sociológica do interacionismo simbólico ${ }^{744}$, como os de representação e interação, que se mobilizam enquanto interação fluida e móvel que se processa entre pessoas em que cada uma desempenha um papel ou ocupa um status, é um ponto-chave da realidade subjetiva em relação dialética com a sociedade, sendo formada por processos sociais e remodelada por relações sociais, numa ordem social negociada, múltipla, plástica e conjuntural. Os processos sociais implicados na formação e conservação da identidade são determinados pela estrutura social, sendo os tipos de identidades observáveis e verificáveis em contexto, conjuntura e plasticidade.

O seu estudo requer que se atenda ainda ao conceito de interação que ocorre entre as pessoas como membros de grupos, interessando-nos pois também as interações em ambientes institucionais, no caso vertente, os protagonismos da Comissão de Viticultura da Região Duriense, no período da República ou depois, e mais duradouramente no Estado Novo, os da Casa do Douro, cujo funcionamento, desde o seu início, se pauta por dificuldades de vária ordem em que se incluem as ambiguidades das leis sobre o Douro, geradoras de conflitos e construções identitárias.

Mas a questão da identidade é ainda comummente associada à cultura e à memória social, subentendendo assim um conjunto de significados, conceitos e domínios de análise que os aproximam. O que nos leva a colocar outras interrogações importantes neste debate: identidade ou identidades? Somos possuidores de uma identidade ou de várias identidades?

\footnotetext{
${ }^{744}$ Originada na Escola de Chicago nos inícios do século XX e no pragmatismo americano, esta corrente de pensamento que trouxe grandes contributos teóricos e metodológicos para a sociologia, a etnografia e a microssociologia, tem sido desenvolvida e aplicada por, entre outros autores, Berger, Luckman e Anselm Strauss.
} 
Segundo alguns teóricos, cada indivíduo possui uma identidade composta de muitas afiliações e pertenças ${ }^{75}$. Por isso, certos autores diferenciam identidades individuais de identidades culturais/sociais e, portanto, coletivas.

A pertinência destas problemáticas teóricas que atravessam a história, a cultura, a memória social e a identidade, reside no facto de estes conceitos remeterem para processos dinâmicos ou performativos, uma das razões talvez da sua enorme proximidade reflexiva e mesmo conceptual. A memória, como a identidade são representações da realidade, resultantes de elaborações subjetivas que mantêm entre si relações próximas, mas sem nunca se equivalerem. Dessas relações faz inclusive parte a forma como a história é interpretada e apropriada pela memória, uma produção retroativa. Na mesma linha de pensamento, se pode entender que memória(s) e identidade(s) são noções de filiação simbólica, não estáticas nem essencialistas, mas antes e sobretudo efeito de intersecções históricas e relações sociais estratégicas, constantemente (re)negociadas, nos discursos e narrativas de autodefinição que produzem. Por sua vez, o jogo das identidades contraditórias, em constante deslocação e cruzamento, implica e supõe consequências políticas (Stuart Hall) diversas em função dos diferentes contextos e conjunturas históricas em que terá de ser também apreendido.

Assim, o caráter performativo destes enunciados que torna difícil a sua definição geral, complexifica e enriquece a sua operacionalidade analítica, se a entendermos nos seus pressupostos dinâmicos. "A constituição da identidade é um jogo perigoso e elaborado de espelhos. É uma interação temporal complexa entre múltiplas práticas de identificação internas e externas a um indivíduo ou a uma população. De forma a compreender-se esse processo constitutivo é necessário, por conseguinte, situar os espelhos no espaço e o seu movimento no tempo ${ }^{746}$. Este movimento constitutivo de identidades, ou melhor, processo de identificações, adquire uma outra operacionalidade ${ }^{747}$, quando entendido como um alinhamento de traços ${ }^{748}$, rastros ou inscrições que nos permitem a perceção do próprio tempo enquanto um passado que nunca teve presente e, apenas por essas marcas, se transmite a um futuro incerto.

Mas a produção identitária pode ainda ser percecionada com maior exaustividade como uma filiação simbólica que demarca os que ficam de um ou de outro lado de uma fronteira imaginária, pelo que a cultura «não pode ser representada como um "corpus" unificado de símbolos e significados interpretados de maneira definitiva ${ }^{749}$. Do mesmo modo, as identidades correlacionadas com a cultura, em constante refiguração, emergem de um processo cambiante, construído, plural e relacional, sendo pois «conjunturais, contextuais e relacionais» e não essenciais, aparecendo e desaparecendo sobretudo em situações de crise e em função de circunstâncias, interesses e fatores determinados.

\footnotetext{
${ }^{745}$ MAALOUF, 2003.

${ }^{746}$ FRIEDMAN, 1997: 140.

${ }^{747}$ Ver MENDES, [s.d.].

${ }^{748}$ LATOUR \& HERMANT, 1998: 35.

${ }^{749}$ CLIFFORD \& MARCUS, 1991.
} 
Longe de se poder ter uma visão essencialista do processo identitário, há que salientar os fatores históricos e contextuais que originam a predominância ou saliência de determinadas identidades, havendo que indagar dos elementos simbólicos, discursivos, morais e práticos que as compõem, e como se cristalizaram. Neste sentido, há que entender que as identidades predominantes são o produto visível de lutas políticas, sociais e simbólicas, sendo essencial ter em atenção as lógicas de poder subjacentes ${ }^{750}$. Saliente-se que esta luta incessante pelo reconhecimento, pela identidade legítima, cria pressões transformativas sobre as identidades pessoais e sociais, locais e regionais, que no contexto do Alto Douro Vinhateiro e no caso da zona duriense de Carrazeda, supõe, ainda, a articulação desta questão das identidades com a questão da territorialidade, o que implica o conceito de interação dos membros de grupos, designadamente em contextos institucionais, cujo funcionamento se interpenetra também de modo complexo com a problemática das contrafações, como anteriormente se procurou observar, evidenciando dificuldades várias desde as ambiguidades das leis sobre a Região geradoras de conflitos em que se constroem pertenças identitárias.

Neste horizonte mais abrangente de referências e pertenças, tendem a autonomizar-se e a diferenciar-se processos e mecanismos de identificação a dois níveis: produção de identidades concorrentes — identidade local e regional ${ }^{751}$ — que coexistem sem se anular; e consolidação da identidade individual e social.

Esta faz-se por exemplo através do mercado de trabalho sazonal e mais vantajoso nas quintas durienses por contraposição ao trabalho independente ou assalariado no planalto pobre, dualidade sócio-histórica que tem condicionado a história das populações rurais de Carrazeda, concelho vinhateiro que na sua posição de fronteira entre duas sub-regiões da RDD é, em si próprio, constituído por duas áreas distintas: a frieira e a ribeira ou «poça», entre as quais se movimenta(ra)m, sazonalmente, populações e trabalhadores. Assim, num quadro de diferenciação/identificação que é o das relações de trabalho e mobilidades ${ }^{752}$, em que é de considerar que os mais afastados das instituições do poder político se identificam com as pertenças locais/regionais e o exercício do poder se apresenta como «a recompensa dos que sabem explorar os recursos de uma situação e tirar partido das ambiguidades e tensões que caracterizam o jogo social» ${ }^{753}$, se define uma espaciotemporalidade compósita de construção fluida de identidades próprias de natureza algo flutuante e híbrida.

Essa localização e posição de fronteira possibilitam ainda a análise de processos utilizados para recriar a Região, entre e além de suas várias fronteiras. O que se torna também percetível nas representações sociais em sua diacronia e relação com o espaço histórico convencionalmente demarcado que as quintas, enquanto microcosmo social, sempre bordejaram, por aí se podendo encontrar ainda pistas de análise da sociedade rural envolvente. O estudo

\footnotetext{
${ }^{750}$ CLIFFORD, 2008. Ver também HALL, 2006: 7-22.

${ }^{751}$ PEREIRA, 1989: 332.

${ }^{752}$ PARKHURST, 2004.

${ }^{753}$ LEVI., 1989: 1320.
} 
desse complexo processo histórico e social, para além da atenção à ação e atividades desenvolvidas nas e pelas quintas, exige que se suponha o que as transborda, mas com elas mantém intrincada relação, como por exemplo a atividade de exportação dos vinhos que as atravessa e o trabalho das populações aí incorporado, cuja exclusão corresponderia a privar-nos de um tipo de fontes imprescindíveis à compreensão deste objeto, na sua complexidade, quadro fundamental para dar conta das movimentações sociais que tiveram nelas o seu dínamo local/ regional/nacional.

Cruzando necessariamente o ponto de vista do historiador com indagações sociológicas, supõe-se então que se trabalhe um material heterogéneo (documentos de arquivo, entrevistas, testemunhos, histórias de vida e observações fragmentárias), que devidamente cruzado e interpretado possibilitará tecer algo mais do que apenas a história dos indivíduos, e entendê-los em suas múltiplas inter-relações sociais e institucionais. Ao mesmo tempo, essa diversidade de fontes diretas, escritas e orais, «sem deixar de fazer surgir a evidência do documento», serve não só ou não tanto para fabricar um tecido de provas, mas sobretudo para tomar a sério os atores, segui-los e pôr em ação o entrelaçar de interações, estratégias e estruturas diversas, organização e mudança social, indivíduos, sociedade e relações recíprocas, possibilitando, delinear em sua complexidade redes de identidades itinerantes.

Em síntese, esta conjugação pluridisciplinar de métodos de análise que se acabou de traçar, sumariamente, permite a reconstrução reflexiva do acontecimento histórico e a «reposição» de elementos indiciários e des (re) construtivos das realidades históricas em sua reescrita potenciadora de uma inteligibilidade mais expressiva do passado.

\subsubsection{Contextos e processo de afirmação identitária duriense $\mathrm{e}^{754}$}

Parte-se aqui da hipótese de o regionalismo como construção identitária, causa e consequência de lutas reais e simbólicas centradas numa região, num território, com diferentes níveis de identificação e experiências diferenciadas que se enraízam em problemas concelhios, interconcelhios e regionais, em que as relações com o poder político e instituições que o representam localmente se apresentam como fator fundamental na estruturação e diferenciação de experiências e «reportórios» interpretativos diferenciados na base de estratégias de procura de uma unidade possível.

A região do Douro assenta numa base material e cultural bem distinta do Sul, diferença que assoma invariavelmente nas representações autárquicas e dos seus viticultores aos governos, nas representações sociais aí veiculadas, como nos modos conjunturais de construção identitária, de afiliações e estereótipos que afloram em contextos de miséria geradores de solidariedades, nos movimentos de rebelião desesperada e em momentos de profunda crise.

Aliás, as crises económicas por que passou esta região, com tradução em petições, representações e movimentos de rebelião locais e regionais, levaram, historicamente, à criação das

\footnotetext{
${ }^{754}$ Tópico já anteriormente introduzido e contextualizado historicamente no Capítulo 6.
} 
instituições do Douro: em 1756, a Companhia Geral da Agricultura das Vinhas do Alto Douro, em 1907; a Comissão de Viticultura da Região Duriense (CVRD), com a «Questão do Douro»; e, nos anos 1930, com a grande crise de 1929 repercutida na Região, a Casa do Douro.

Em tudo quanto já se expôs, podemos ver como o Douro, a primeira região moderna demarcada e reconhecida do mundo, com condições naturais (solo, topografia, clima) e sócio-históricas distintivas, merece ser discutido como uma região que possui um conjunto diferenciado de identificações. Nestas destacam-se também instituições reguladoras como a Comissão de Viticultura da Região Duriense (CVRD), cujo papel foi central nesse período, na medida em que funcionou como base para a identificação regional dos viticultores do Douro que, a nível local, se pudessem identificar com ela nas suas atribuições de defesa dos vinhos generosos do Douro, da sua fiscalização e da sua produção e comércio, que visava apoiar, como se depreende inclusive dos seus relatórios anuais, registos e estatísticas de produções e existências. A ação da CVRD, onde todos os que possuíam terras com capacidade de produção vinícola, grandes ou pequenos, eram obrigados a registar as suas produções e existências de vinhos generosos, operava para homogeneizar a identificação regional, colaborando na construção da qualidade e marca do vinho do Porto.

Tentando, no âmbito do quadro sociológico esboçado, prosseguir em maior detalhe uma análise interpretativa a esse movimento de representações e sublevações ocorrido em Carrazeda como noutras povoações da Região dos Vinhos Generosos do Douro, socorremo-nos então da noção de identidades, cujos significados se encontram delidos pelo seu uso frequente, optando por falar em «identidade» como um processo em constante reconfiguração, com particular visibilidade em conjunturas de crise e em «identidades conjunturais» no sentido de identidades que deverão aparecer, e desaparecer, em função de interesses conjunturais.

Os protestos violentos que tiveram lugar em vários concelhos da RDD, em 1909, 1910 e anos seguintes, evidenciando fatores comuns à Região (Capítulo 6), revelam a importância de uma base forte de identificação em problemas fiscais conjunturais exprimindo tais manifestações a força subterrânea de afirmação de identidades de pertença a partir de um contexto identitário conjuntural com uma componente fortemente social e política ligada às extremas dificuldades de vida e trabalho comuns a pequenos lavradores donos de pequenas leiras e minúsculos vinhedos incapacitados para a agricultura comercial e jornaleiros vivendo e trabalhando em condições difíceis. Claro que esta análise tem sempre de ser polarizada socialmente já que não se pode esquecer o peso decisivo e a enorme influência das quintas e propriedades na posse de grandes e médios proprietários, embora em proporção muito inferior, a essa grande maioria dos pequenos proprietários e trabalhadores assalariados.

Por outro lado, a prioridade que aqui se confere aos modos de construção de identidades sociais, como políticas e como estratégias de natureza conjuntural, tem em particular atenção a seguinte recomendação histórica:

As identidades sociais devem ser concebidas como realidades dinâmicas que se constroem e se deformam face aos problemas com que os atores sociais são confrontados, como 
formações que se não podem compreender senão examinando o seu desenvolvimento no decurso de um período suficientemente longo. Paralelamente a definição do político não é separável da organização de um campo de forças instáveis e que não cessam de ser reclassificadas. O exercício do poder é a recompensa dos que sabem explorar os recursos de uma situação e tirar partido das ambiguidades e tensões que caracterizam o jogo social ${ }^{755}$.

Trata-se de um processo mediatizado de construção de «identidades primárias», construídas a partir da interação direta, nos laços sociais que se tecem nas redes sociais e na racionalidade limitada dos agentes sociais e que são cruciais na ativação das táticas e estratégias quotidianas de controlo do meio circundante ${ }^{756}$.

Ora, ao partirmos da caracterização em termos de história, de Carrazeda de Ansiães, como de um concelho diferenciado de uma região, em relação à qual se encontra numa situação de fronteira, nos principais indicadores considerados, esta noção de fronteira que, igualmente se identifica, como já referido, no interior do mesmo, com duas áreas distintas: a «frieira», terras do planalto transmontano e a «ribeira», terras do Douro e Tua, entre as quais sempre se movimentaram sazonalmente as rogas para a apanha da azeitona e das vindimas do Douro, não deixa de ter fortes implicações ao nível da sua análise no plano das identidades. $\mathrm{O}$ que se pode ver desde logo, ao nível desse outro contexto de diferenciação/identificação que são as relações de trabalho ${ }^{757}$ intraconcelho e interconcelhos e as interações sociais que nesses contextos se produzem, evidenciando diferenças básicas. Estas mobilidades não enfraquecem a identificação local, antes pelo contrário; os que estão mais afastados do poder político e suas instituições identificam-se mais facilmente com as pertenças locais e a região.

Neste horizonte mais vasto de referência/pertença, tendem a autonomizar-se e diferenciar-se identidades individuais e sociais por mecanismos de identificação a dois níveis: produção de identidades concorrentes que coexistem; e consolidação da identidade social, pelo acesso a um mercado de trabalho na quinta por contraposição ao trabalho no planalto, dualidade que condiciona a vida das populações das aldeias vinhateiras deste concelho.

\section{Produção de identidades relacionais e «identidade regional ${ }^{758}$ no Douro da I República}

A já evocada identidade regional do Douro é feita não só do espaço, mas também, do tempo e da História. A própria paisagem vinhateira e cultural em que hoje reconhecemos a nossa singularidade identitária de valor patrimonial mundial é, também ela, um produto histórico de longas e profundas determinações sociais. No Douro, a cultura da vinha e do vinho mantém-se como o elemento essencial da identidade da Região e das condições principais que a construíram e definiram histórica e socialmente: a atividade vitivinícola, a geografia dos vinhedos e a construção da paisagem, o relevo, a fauna e flora, os rabelos, as quintas seculares,

\footnotetext{
${ }^{755}$ LEVI, 1989: 1320

${ }^{756}$ LAGE, 1995: 85-86.

${ }^{757}$ PARKHURST, 2004.

${ }^{758}$ PEREIRA, 1989: 332.
} 
os percursos da produção de vinhos de excelência e as imagens das grandes marcas de vinho do Porto, o património histórico, a tradição e interações sociais da vindima, os utensílios, e mudanças e transformações da modernidade e contemporaneidade.

Quanto à questão da identidade regional do Alto Douro importa verificar que este possui um conjunto distintivo de identificações, contextos de identificação como as relações de trabalho inter-regionais, e fundamentos institucionais regionais próprios (ex. a Companhia, desde o tempo de Pombal, a Comissão de Viticultura Duriense na República, a Casa do Douro a partir do Estado Novo, etc.) com que os vinicultores do Alto Douro se identificam ou não, mais e menos, mas sempre em função de acontecimentos relevantes em diferentes conjunturas históricas ${ }^{759}$.

Pelos mais diversos fatores de ordem económico-política e social que as «questões relacionadas com a produção e comércio do vinho do Porto (demarcação, Companhia, destilação de aguardente, direitos alfandegários e liberalização do comércio pela barra do Douro) dominaram a política vinícola nacional da primeira metade do século» ${ }^{760}$. Haja em vista, por exemplo, as petições apresentadas nas Cortes vintistas por câmaras e viticultores durienses como os de Carrazeda de Ansiães, S. Mamede de Riba Tua e outros, que pediam a supressão da demarcação da feitoria. Essa contestação política configurava já então um movimento de posições críticas contra as leis da demarcação e monopólio de instituições reguladoras estatais no Douro. Aliás tal tensão de fundo, historicamente latente, entre um Douro do povo e um Douro das elites ${ }^{761}$, ir-se-á manter, com profundas transformações e diversas cambiantes, até ao período de transição da Monarquia Constitucional para a I República Portuguesa, em que ocorreram outras petições de viticultores durienses, de sinal idêntico, também e sobretudo contra a política de liberdade comercial, mas já relacionadas com as Novas Demarcações de 1907-1908.

No caso específico da Região do Douro Vinhateiro, nesta época, destacaram-se diversas representações em torno das seguintes noções: "Questão do Douro», «Miséria Duriense», «Fraude e contrafações», «representações aos governos» «sublevações e motins na Região», «Comissões de Representantes de Viticultores» e o conceito e «marca» vinho do Porto, como aliás se pôde ver no subcapítulo anterior relativa às contrafações e correspondente interdependência com esta questão das identidades.

\subsubsection{Ecos da República e do republicanismo em quintas durienses de Carrazeda}

Depois do enquadramento teórico da problemática da «construção identitária» em que se procurou problematizar o sentido e significado de alguns conceitos e noções teóricas subjacentes ao tema da(s) identidade(s) e processos de identificação, e após a necessária contex-

\footnotetext{
${ }^{759}$ PARKHURST, 2004. Ver também PARKHURST, 1977: 183-191.

${ }^{760}$ MARTINS, 1996: 413-435.

${ }^{761}$ CARDOSO, 2007. Ver também CARDOSO, 2006: 39-53.
} 
tualização dessa problemática na conjuntura histórica duriense da I República, faz-se, nesta sequência, uma evocação comparativa ao ambiente sociológico de dois momentos históricos republicanos: Portugal (1910-26) e Espanha (1931-36) ${ }^{762}$, revelando-se-nos de interesse para esta análise as seguintes noções operatórias: instabilidade, equilíbrio de poderes, mudança social e relações socioculturais.

Sendo esta realidade histórica ainda mal conhecida, por escassez de trabalhos e dificuldade de acesso a arquivos específicos e fontes históricas diretas, constitui uma zona de sombra da história do Douro Vinhateiro que importa aclarar, para o que se procura também contribuir com esta abordagem micro e específica ao processo de construção de identidades relacionais/conjunturais/contextuais designadamente nesta zona do Alto Douro, recorrendo a uma amostragem significativa de quintas vinhateiras durienses no concelho de Carrazeda em que se verificaram processos de identificação e pertenças identitárias com a República e o republicanismo na defesa do Douro. Esta aproximação inscreve-se então na emergente "produção identitária» no Douro, na conjuntura histórica da República e do republicanismo, em que tem lugar a afirmação de uma identidade regional duriense, em relação com a defesa da denominação de origem «Douro» e da marca «Porto» — dimensões relevantes já estudadas por alguns autores destacados quer da história do Douro neste período, quer da história da I República Portuguesa ${ }^{763}$.

A perspetiva analítica transdisciplinar que se vem seguindo permite ainda reconfigurar o local como base de articulação de tempos e escalas, ancoragem da complexidade histórica e social de um sistema de tensão latente próprio da Região Demarcada do Douro na sua estrutura territorial e de denominação de origem do «vinho do Porto» produto de exportação internacional e global na cadeia das mercadorias.

Para uma melhor compreensão desta problemática das identidades na região do Douro e também na zona duriense de Carrazeda torna-se ainda necessário fazer uma breve contextualização temporal e sociológica em perspetiva comparada de duas realidades históricas da República quer em Portugal (1910-1926) quer em Espanha (1931-1936) consideradas em sua potencialidade analítica abrangente.

Não nos detemos aqui nas diferenças cronológicas, especificidade de acontecimentos (como por exemplo a participação na I Guerra Mundial e o ensaio autoritário sidonista no caso português) e diferenciação na composição das elites políticas, entre Portugal e Espanha, a cujos estudos historiográficos se tem também de atender, dada a sua relevância, inclusive no cruzamento recente das disciplinas de História e Ciência Política ${ }^{764}$, mas os quais extravasam da economia desta análise. Tenta-se sobretudo identificar a existência de uma idêntica ambiência geral de medo como emoção social, relacionada com a mudança no equilíbrio de

\footnotetext{
${ }^{762}$ AMPUDIA DE HARO, 2010.

${ }^{763}$ Ver designadamente: PEREIRA, 2014 e ROLLO, 2014. Ver ainda a propósito desta última referência, LAGE, 2012a: 330-334.

${ }^{764}$ CRISTO, 2011.
} 
poderes, traduzida num pano de fundo comum a estes dois momentos republicanos, numa aproximação assente nas contribuições teóricas de Norbert Elias, que privilegiam a análise quer da dimensão cultural das relações sociais tendencialmente ligadas à imprevisibilidade, incerteza e medo, quer das representações sociais construídas em relação com as noções de insegurança vital e de ordem.

É num ambiente assim de pulsação político-social e ideológica marcada pelo medo generalizado e difuso que os diferentes grupos sociais em disputa em cada um dos dois países vizinhos acabou a elaborar representações sociais da situação convulsa, as quais, indo além da correspondência com a realidade objetiva dos acontecimentos tumultuosos, revelaram a sua eficácia e verosimilhança quando foram aceites por setores alargados das populações.

As duas repúblicas viram-se, pois, confrontadas com uma conceptualização como regimes de desordem alegadamente não só por a propiciarem como por não a combaterem o que terá contribuído para conduzir a uma cultura do confronto que também serviu para a perceção de desordem a qual arrasta o risco de desidentificação entre grupos sociais e o aprofundamento de tensões sociais.

O subjacente apelo à autoridade verificado nesse contexto social conturbado, teve em Portugal ainda na I República, ecos como a curta governação do general Pimenta de Castro (janeiro a maio 1915), o afloramento ditatorial sidonista (dezembro de 1917 a dezembro de 1918) e a reação da Monarquia do Norte (janeiro a fevereiro de 1919), retomados em repetição, mas em termos mais alargados e com efeitos autoritários determinantes, com o golpe da Ditadura Militar.

A experiência mais curta e concentrada da II República Espanhola foi brutalmente interrompida por um pronunciamento militar em julho de 1936 e a eclosão da sangrenta Guerra Civil, em Espanha (1936-1939).

Como se pode deduzir, a contextualização histórica da realidade duriense durante a I República, anteriormente esboçada, ficaria incompleta sem esta breve aproximação sociológica às sociedades portuguesa e espanhola que, nesta mesma época, viveram momentos republicanos de mudança histórico-social marcados por novos equilíbrios de poder e paralelismos cujos contornos melhor se evidenciam em termos comparativos ${ }^{765}$.

\subsubsection{Quintas durienses de Carrazeda de Ansiães: espaço de construção de identidades contextuais em conjunturas republicanas}

Partindo da reconstituição micro-histórica de algumas quintas durienses do concelho de Carrazeda produtoras de vinho do Porto, estas unidades económico-sociais e histórico-culturais inseridas numa envolvência territorial própria, permitindo retraçar o local em diversas escalas, enquanto núcleos de articulação espaciotemporal (ver Capítulo 8), podem reconfigurar-se como «instância construtora e solidificadora de identidades» ${ }^{766}$ o que as torna

\footnotetext{
${ }^{765}$ AMPUDIA DE HARO, 2010.

${ }^{766}$ LAGE, 2012c.
} 
suscetíveis de uma abordagem sócio-histórica multiperspetivada que melhor permite apreender a sua complexidade.

Com esse entendimento, selecionaram-se então para uma reaproximação micro-histórica assente em testemunhos, narrativas, memórias e outros materiais de informação quatro exemplos desses microcosmos: as quintas dos Canais, dos Canaes-Bartol, da Alegria e do Zimbro (ver Capítulo 7), consideradas emblemáticas enquanto espaços de construção de identidades republicanas e conjunturais nesta zona do Douro.

No conjunto das vinte e duas quintas do concelho de Carrazeda, ao tempo praticamente único mercado de trabalho das suas populações, as identificadas aqui para esta análise específica, representam um 1/5 da totalidade, caracterizando-se ainda pelo facto de os seus proprietários terem estado diretamente envolvidos na conjuntura histórica e política republicana, tendo contribuído para a afirmação histórica de um republicanismo social e do poder municipal republicano, a nível concelhio e regional.

A mobilização e interpretação dessas fontes históricas diretas provenientes sobretudo de arquivos e entrevistas a informantes privilegiados locais tornou possível percecionar dinâmicas singulares de identificação e (re)construção de identidades na sua diferenciação cultural e simbólica, em função de variáveis territoriais e histórico-políticas concretas. Tentámos também por isso evidenciar, em dois momentos republicanos diferenciados que se fizeram sentir no Douro, o protagonismo histórico destas quintas vinhateiras, através das representações sociais dos perfis republicanos desses proprietários com posição e intervenções destacadas na região e na vida política concelhia, como se procurará demonstrar.

\section{Quinta do Zimbro de Cima e relação com o Centro Republicano e Democrático de Carrazeda de Ansiães}

Na época da I República Portuguesa, esta quinta passaria, para a posse do Dr. João Sampaio Chaves, por herança familiar, a partir de João Lopes da Cruz [Linhares, 1883 - Selores - (s.d.)], brasileiro de torna-viagem enriquecido, grande proprietário duriense, negociante de vinhos e conhecido empreiteiro da Linha do Tua (2. ${ }^{\circ}$ troço de Mirandela a Bragança), atividade que o levaria à falência e consequente hipoteca de seus bens em que se incluíam várias propriedades no Douro.

O seguinte fragmento de narrativa refere a história das transmissões intrafamiliares da Quinta do Zimbro de Cima, durante esse período, a qual, desde finais de Oitocentos, passou a pertencer à conhecida família dos Sampaios, ligada às aldeias de Castanheiro, Parambos e Linhares, do concelho de Carrazeda, uma família de abastados proprietários rurais e conhecidos letrados das elites locais e regionais com reputada tradição republicana.

A história da Quinta do Zimbro na nossa família é a seguinte: a quinta do Zimbro que era do meu bisavô, João Lopes da Cruz, o empreiteiro da Linha do Tua, cujos bens no início do séc. XX entraram em insolvência [...]. O filho mais velho que tinha o mesmo nome [...] 
quis passar a Quinta do Zimbro para o meu avô, António Sampaio Chaves que era republicano [...] ainda está lá em casa o carimbo do Centro Republicano [...] mas como ele era muito orgulhoso e não quis, passou-a para o nome da mulher, a minha avó, Felicidade Amélia Lopes da Cruz, que era irmã dele [... $]^{767}$

É autor deste testemunho o Dr. António João Ribeiro de Sampaio, proprietário da Quinta do Zimbro de Cima durante 27 anos, desde 1976 a 2003, por herança familiar, neto e filho ${ }^{768}$ que é de anteriores proprietários da mesma, em que se destacam o Dr. António Sampaio Chaves, antigo político republicano de Carrazeda, falecido em 1947 e o seu filho e único herdeiro, o Dr. João Cruz de Sampaio [1905-1981], Conservador do Registo Civil da mesma vila, também de filiação republicana, ambos com fortes ligações ao Centro Democrático e Republicano de Carrazeda, fundado em 1911 e desde finais desse ano, com «muitas dezenas de sócios de todas as classes sociais» ${ }^{769}$.

Como já anteriormente se referiu (Capítulo 7, subcapítulo 7.6.2.), este Centro Democrático e Republicano, estruturado em Assembleia Geral, Comissão Política e Comissões Paroquiais e de Propaganda, aceitava como sócios (honorários, efetivos e correspondentes) todas as pessoas maiores ou emancipadas e os menores de 21 e maiores de 18 anos. Os seus estatu$\operatorname{tos}^{770}$ foram assinados por António Júlio Ribeiro, António de Sampaio Chaves e João Ferreira Aguiar, políticos republicanos das elites locais, ligados por laços familiares, de compadrio e de amizade e donos de quintas nesta zona da Região duriense.

António Júlio Ribeiro da Silveira, grande proprietário do concelho de Carrazeda, dono da Quinta do Comparado e ainda de muitos mortórios, possuía outras propriedades vinhateiras nas freguesias de Castanheiro, Seixo de Ansiães, Pombal de Ansiães, Fontelonga e povoação de Campelos. Na sua Quinta do Pousado, em Besteiros, lugar da freguesia de Fontelonga, já tinha instalado na sua casa de residência a mais moderna tecnologia, luz elétrica inclusive, como um elevador a ligar cozinha e copa em andares diferentes, sendo uma sua filha casada com o filho do Dr. António de Sampaio Chaves, de quem era compadre ${ }^{771}$, os quais herdaram despois de sua morte, em 1924, parte da Quinta de Comparado cuja posse mantiveram até ao seu recente desmembramento e venda à Família Symington. Ficaria conhecido como maçon e o «esturrado» da família, ou republicano mais radicalizado. Quando da implantação da República em 5 de outubro de 1910, de que foi um dos primeiros aderentes e dos mais destacados protagonistas locais, detinha já uma enorme área de influência em todo o concelho, sendo-lhe

\footnotetext{
${ }^{767}$ Entrevista a A. J. R. de Sampaio, Carrazeda de Ansiães, novembro de 2011. (Anexo V)

${ }^{768}$ Genealogia do Dr. António João R. de Sampaio (Anexo V).

${ }^{769}$ No concelho de Carrazeda de Ansiães, a par da respetiva Comissão Municipal, estava também organizada a Comissão Paroquial em Castanheiro. ...De Carrazeda de Ansiães. «A Montanha» (24 nov. 1911) 4. Ver obra de Carla Sequeira (SEQUEIRA, 2015: 362).

${ }^{770}$ Publicados pela Papelaria e Tipografia Académica de L. P. Moreira Lobo, 1912. BNL — SC 7428/8V. Ver LAGE, 2012. a: 329-331.

${ }^{771}$ Ver genealogia da família Sampaio (Anexo V)
} 
totalmente fiéis as populações das aldeias de Campelos e Castanheiro e tornara-se o principal líder republicano de Carrazeda. Durante todo o período da I República exerceu diversos e elevados cargos municipais para que foi eleito ${ }^{772}$, tendo sido inclusive: $1 .^{\circ}$ Vice-Presidente da Câmara Municipal Republicana de Carrazeda, eleito, nas primeiras sessões de 7 e 15 de outubro de $1910^{773}$, e posteriormente Vereador efetivo sucessivamente eleito para os triénios de 1917-1919, 1920-1922 e 1923-1925, em que desempenhou o cargo de Presidente da Câmara (1917 a 1919) e o de Vice-Presidente da Comissão Executiva (1923 a 1926).

O Dr. António Sampaio Chaves, notário vários anos em Carrazeda ${ }^{774}$, viria ainda a ser mais tarde, vereador republicano eleito da Câmara Municipal deste concelho nos triénios de 1923 a 1925, e de 1926 a 1928, sendo Presidente da Comissão Executiva em 1926 $6^{775}$. O seu filho, o Dr. João Cruz de Sampaio, Conservador do Registo Civil, viria a relacionar-se estreitamente com os conhecidos irmãos republicanos do Porto, Mário e Carlos Cal Brandão, tendo sido mesmo compadre deste último ${ }^{776}$.

Importa ainda referir que o Dr. António João Ribeiro de Sampaio, descendente direto desta histórica família republicana de Carrazeda, continua a residir na aldeia de Parambos na sua casa brasonada, o conhecido e antigo solar de Parambos dos Frias Sampaio, o qual passou para a sua família Sampaio Chaves ${ }^{777}$ através de dote pelo casamento de sua avó, dado por seu padrinho, o Dr. Domingos Frias de Sampaio. Este ilustre cidadão republicano de Trás-os-Montes foi Governador Civil de Bragança, depois de ter sido Administrador do Concelho de Carrazeda e, em 1910, 2. Presidente eleito da Comissão Municipal Republicana local, para além de Diretor do semanário republicano «O Transmontano», publicado na vila sede deste concelho, em 1911.

Também estreitamente ligada a estas duas prestigiadas famílias republicanas locais, por laços matrimoniais, se encontra ainda a antiga família Mariz da Quinta da Alegria de Cima, cujo antigo dono, Augusto Alexandre Mariz, foi também um conhecido e ativo político republicano, avô do atual proprietário ${ }^{778}$.

\section{Quinta da Alegria de Cima - o republicano positivista (fé na ciência e utopia do progresso e das técnicas)}

A exemplar trajetória de vida e ação pioneira de Alexandre Augusto Mariz, um dos principais obreiros e proprietário desta quinta, notável lavrador duriense e figura respeitada de

\footnotetext{
${ }_{772}$ AMCA — Livros de Actas de 1910-1916; de 1914-1919; de 1916-1919; de 1919-1926; Livros de Actas da Comissão executiva de 1924 a 1926.

${ }^{773}$ AMCA — Livro de Actas das Sessões da Câmara de 1907 a 1910, sessão extraordinária de 7 de outubro, fls. 88v.-89 e sessão ordinária de 15 de outubro, fls. 89v.-90.

${ }^{774}$ Entrevista realizada em Matosinhos a 13 de fevereiro de 2017, com A. J. R. de S., neto deste casal e herdeiro da propriedade desta Quinta do Zimbro.

${ }^{775}$ MORAIS, 2006: 295-297.

${ }^{776}$ Entrevista com Dr. A. João R. de Sampaio — Matosinhos, 14 de fevereiro de 2017 (Anexo V).

${ }^{777}$ Ibidem.

${ }^{778}$ Ibidem.Ver também genealogia da família Sampaio (Anexo V).
} 
republicano convicto de arreigada mentalidade científica, são assim brevemente salientadas, em sua representatividade local/regional e particular relevância na história da Quinta da Alegria de Cima, pelo seu neto, Alexandre Mariz, atual dono da quinta ${ }^{779}$ :

mas voltando ao meu avô ...ficou órfão de pais, aos 16 anos, deixou de estudar e começou a tomar conta das propriedades, ajudado pelo tio que era o dono da casa grande de Marzagão, junto à igreja, no centro da aldeia [vizinha de Linhares] que foi o que deu a casa de meus pais em Linhares, onde eu nasci ...todos os anos ia comprando propriedades e fez o património da casa agrícola grande a que pertence a Quinta da Alegria de Cima ...ele já tinha eletricidade em casa há mais de 100 anos, produzida por um aerodínamo que mandou vir diretamente da América ... lia muito e estava sempre bem informado... também mandava vir diretamente do estrangeiro as máquinas de que precisava para a casa agrícola que já era grande ...era um agricultor já muito moderno, empreendedor e inventivo... sempre trabalhou bastante mas também se resguardava... o Sr. Smith gostava muito de conversar com ele e ficava admirado do que ele fazia e sabia... era um visionário... excecional... uma pessoa muito engraçada e extraordinária [...].

Corroboram este depoimento documentos de arquivo que atestam a prolongada atividade desenvolvida por Alexandre Augusto Mariz, na produção vinhateira e na sólida gestão e administração da grande Casa Agrícola da família Mariz integrante das quintas da Alegria de Cima e do Zimbro e de muitas propriedades em Campelos e Carrapatosa. Republicano democrata de mentalidade científica e aberta ao mundo e ao progresso, Alexandre Augusto Mariz, teve participação ativa na vida política e cívica local, como vereador da Comissão Administrativa de Carrazeda de Ansiães, eleito para a Câmara Municipal, triénio de 1917 a 1919, tornando-se uma personalidade duriense a vários títulos carismática, cuja biografia muito importará fazer, atendendo ao seu contributo para uma outra história mais próxima e interna ao Douro Vinhateiro, à semelhança de algumas boas biografias já disponíveis.

\section{Quinta dos Canais a «Quinta do Costa» — expressão do anticlericalismo republicano}

Ainda o Douro Superior não estava integrado na RDD e já a Quinta dos Canais era referenciada no «Mapa do País Vinhateiro do Alto Douro», de 1843 e na «Carta Douro Portuguêz e Paíz Adjacente» de 1848, onde aparece como uma das únicas 4 quintas assinaladas na margem Norte do Douro Superior ${ }^{780}$. No decurso da sua longa história, a vários títulos representativa e emblemática das quintas durienses, viria a tornar-se a joia da Coroa e os seus vinhos a espinha dorsal dos Vintages da Cockburn's, credenciais herdadas pelo seu atual proprietário o Grupo Symington, acabando por ser hoje considerada a terceira maior quinta do Douro e uma das mais desenvolvidas tecnologicamente.

\footnotetext{
${ }^{779}$ Entrevista a Eng. Alexandre Mariz, Carrazeda de Ansiães, 17 de maio de 2014.

${ }^{780}$ PEREIRA, 2010: 33.
} 
Nos anos 1920/30, em que a Quinta dos Canais era conhecida localmente como a "Quinta do Costa», devido ao seu então proprietário, Francisco Manuel da Costa, conhecido republicano local, a região duriense atravessava uma época contraditória em que as suas populações continuavam a debater-se com condições de vida e de trabalho miseráveis, apesar de se considerar também que o Douro de então, ao ser «arrastado pelo exterior parecia uma ilha de prosperidade» ${ }^{781}$, na medida em que $« 0$ vinho do Porto registara bons resultados nos mercados externos para onde vendeu 74 e 81 mil pipas, em 1936 e 1937, respetivamente, o que correspondia em quantidade, a mais de metade das exportações nacionais de vinho».

O empreendedor capitalista Francisco Manuel da Costa, proprietário emblemático da Quinta dos Canais, que viera ampliando pela compra e junção sucessivas de antigas quintas adjacentes e replantando extensivamente com novos vinhedos, integrou ativamente desde o início da aclamação local da República e, durante todo o período da I República Portuguesa, o poder municipal republicano no concelho de Carrazeda, em que exerceu destacados cargos camarários. Logo em 1910, foi vogal efetivo da Comissão Municipal Republicana e, logo a seguir, Presidente da Comissão Administrativa nomeada em 1913, depois do que viria a ser vereador eleito para o triénio de 1914-1916 e membro efetivo da Comissão Executiva/Senado Municipal e, ainda mais tarde, vereador efetivo da Comissão Administrativa da Câmara Municipal em $1919^{782}$.

A sua identificação pessoal e ideológica como político republicano, maçon e ateu, encontra-se esboçada no seguinte depoimento oral de uma octogenária da aldeia da Lavandeira, ex-trabalhadora nos Canais, desde criança, nesse assim chamado «tempo da miséria». Esta narrativa inclui ainda uma descrição pormenorizada, afetiva e vivencialmente densa, do ambiente e vida quotidiana na quinta, a qual se torna percetível enquanto microcosmo natural e sociocultural, com as suas dinâmicas, funcionalidades e idiossincrasias internas, próprias, em que interagem identidades pessoais e representações sociais rurais da sua envolvente comunitária, histórica política e social.

o Costa era republicano falava com todos... era de Custóias do Douro... foi para o Brasil onde casou com a viúva de um embaixador que lhe deu o ser... veio para cá e comprou a Quinta dos Canais junto à quinta da espanhola... depois é que comprou a quinta da Samorinha, as Forneiras e o Carvalho... Carrazeda é fronteira... ali na Quinta pega com três distritos... Guarda, Viseu e Bragança... essa história do incêndio na quinta... o Costa combinou com o guarda e pegaram o fogo para enganar o seguro... foram presos para Moncorvo... diziam que o Costa era maçónico... nessa altura, a capela no Mariz funcionava... mas ele mandou deitar os santos ao rio... dizia que os santos eram de pau... o Costa era político e tinha inimigos...um dia veio uma porção deles d'além do rio e queriam-no

\footnotetext{
${ }^{781}$ BARRETO, et al., 2016: 58.

${ }^{782}$ AMCA - Livros de actas das sessões da Câmara Municipal de 1907 a 1910; Livros de Actas das Sessões dos órgãos respectivos de 1910-1916 e 1914-1919.
} 
matar... o Costa andava lá metido na política...nunca teve soldados... a quinta ainda era o que valia à pobreza, por aqui $[\ldots]^{783}$.

Nesta entrevista de significado evidente para a história e património cultural (i)material dos Canais acentua-se ainda a natureza de fronteira da Quinta face à sua localização geográfica, nela se indiciando a relação histórica entre territorialidades, mobilidades e processos de (des)identificação e representações sociais da República no mundo rural. As referências à ocupação indiferenciada das mulheres e das crianças nos trabalhos agrícolas da quinta são também expressão da cultura e ambiência popular local, experiências, protagonismos, mundividências e solidariedades, comportamentos e práticas sociais. As representações sociais construídas sobre o "Costa», proprietário dos Canais - rico brasileiro de torna-viagem que ascendeu socialmente através de um «bom casamento», com suas muitas amizades e filiações políticas sigilosas, na outra margem do Douro, envolvido em conflitos e contendas, esboçam um perfil contraditório de figura política de republicano convicto e radical, democrata social carismático, maçon arreigadamente ateu, sendo por isso tido e dito, como pertencente ao grupo dos «esturrados», outra representação social comum no mundo rural, em que é retroprojetada a tensão clericalismo-laicismo anticlerical que atravessou o ideário doutrinário e a conjuntura histórica e politico-ideológica da I República Portuguesa.

Saliente-se, por fim, que a análise global deste depoimento, à luz das considerações teóricas sobre a perceção das identidades conjunturais na perspetiva da história das quintas durienses, adquire mais ampla inteligibilidade, propiciando simultaneamente evidências de um processo de construção de identidades contextuais e relacionais.

\section{Quinta Canaes-Bartol do «doutor espanhol — republicano de ação»: refúgio na Guerra Civil de Espanha (1936-39)}

O que aqui se evoca através de um outro testemunho feminino, mas este em versão escrita pela própria autora, atual dona da Quinta Bartol, uma outra quinta histórica de Carrazeda, cuja propriedade centenária se tem mantido desde meados do século XVIII nas mãos da mesma família luso-espanhola, e por isso localmente mais conhecida como a Quinta do Espanhol e/ou da Espanhola, remete-nos para um outro momento histórico, o da II República em Espanha (1931-36) e início da Guerra Civil em que esta quinta se torna refúgio politico, que como se verá, acaba por conformar as pertenças identitárias da família proprietária da quinta e também os processos de construção de identidades conjunturais que sendo aqui naturalmente diferenciados, continuam embora a ser expressão de uma relação intrínseca que se tem vindo a observar entre quintas durienses e conjunturas e momentos republicanos.

Neste exemplo que se revela do ponto de vista das identidades, compósito mas bastante significativo, podemos encontrar manifestamente expresso um processo de identificação

\footnotetext{
${ }^{783}$ Entrevista de abril de 2011, a C. D., mulher de 88 anos, natural e residente em Lavandeira, ex-trabalhadora sazonal da Quinta dos Canais (Capítulo 7, Quinta dos Canais).
} 
local e regional fortemente enraizado por relação a um princípio reconhecido de pertença nacional diferenciada, historicamente induzido pelas vicissitudes e efeitos da II República em Espanha $^{784}$.

Entretanto, começou a Guerra Civil em Espanha em 1936, que durou três anos. As tropas do General Franco vão conquistando terreno, e aproximam-se de Madrid onde começa a faltar tudo. Os meus pais resolveram deixar-nos na Quinta Bartol com os avós, que estavam lá no verão, como era costume todos os anos. Eles conseguiram fugir do cerco de Madrid e foram também para a quinta. A Guerra acabou em 1939. Infelizmente o meu pai não pôde regressar a Espanha por questões politicas e por ter sido diretor do hospital de San Carlos em Madrid. Assim, ficou toda a família a viver na quinta Bartol. De médico afamado, a viver em Madrid, viu-se num sitio onde não havia luz, telefone, estrada. O correio vinha pelo comboio, onde o iam buscar de barco. ... As notícias ouviam-se no rádio, muito mal. As duas filhas começaram a ir à 'escola', com uma professora que tinha vindo para a quinta, de Lamego, pois estava sem colocação, porque nessa altura tinha fechado a escola normal. Fizeram lá a escola primária e o terceiro ano do liceu ... O meu pai começou a administrar a quinta e transformou-se em médico-lavrador. Médico porque desde manhã cedo que as pessoas cobriam a estrada para a quinta para consultar o meu pai, que era conhecido por Doutor Espanhol. Nunca cobrou dinheiro e até foi por duas vezes chamado a tribunal por queixas dos outros médicos, sendo sempre absolvido. ... meu tio Romão, quando a Guerra Civil terminou, fugiu para Tânger, onde também ficou uns anos exilado. Foi o meu pai que ficou a administrar a quinta Bartol. Finalmente fez-se justiça em relação ao Doutor António Egido; foi reconduzido a todos os seus cargos. Faleceu em 26 de novembro de 1967. Como voltou a ser médico em Espanha, a minha mãe ficou com mais responsabilidades na Quinta Bartol [...].

Este médico, Dr. António Egido, espanhol exilado em Portugal, no contexto da Guerra Civil de Espanha, que ainda hoje, pela sua pratica clínica, de grande humanidade e excecional competência médica, continua na memória viva da população local do concelho de Carrazeda, era «independente do ponto de vista político não tendo pertencido ao lado republicano em Espanha», o que, no entanto, não obviou a que tivesse sofrido «consequências persecutórias por ter tido um cargo de destaque no Hospital de S. Carlos em Madrid, no tempo da República espanhola ${ }^{785}$, hospital então considerado dos republicanos. Nessa sequência, radicou-se na Quinta dos Canaes-Bartol usada então como salvaguarda da sua segurança, esposa e filhas.

\footnotetext{
${ }^{784}$ Documento inédito da autoria da atual proprietária da quinta Bartol, Dr. a Maria da Luz Egido Vicente Franqueira de Campos Serrano, licenciada em Direito pela Universidade de Coimbra, descendente da 4.a geração da família proprietária da Quinta, natural de Espanha e residente em Portugal, primeiro na Quinta Canaes-Bartol, ainda criança e a partir da adolescência no Porto - Foz onde continua a residir, passando algumas temporadas na Quinta e em Salamanca. Os seus filhos mantêm dupla nacionalidade, portuguesa e espanhola (ver Anexo II).

${ }^{785}$ Esclarecimentos de seu neto, Carlos Serrano, formado em Engenharia em Inglaterra.
} 
Este depoimento adquire uma compreensão simultaneamente mais abrangente, profunda e fina quando lido e analisado na perspetiva sociológica e comparativa cujos contornos e potencialidades conceptuais e operativas se esboçaram já anteriormente.

\subsubsection{Significado do protagonismo histórico republicano duriense em Carrazeda}

Em síntese, a partir do anterior panorama de importantes quintas de Carrazeda reportado a conjunturas históricas de republicanismo que acabamos de apresentar, podemos observar que as identidades e identificações políticas de seus proprietários, uma elite de lavradores vinhateiros durienses com relevante protagonismo político republicano, nesta zona do Douro cujas representações sociais os identificam diferencialmente, desde o maçon ateu radical ou «esturrado», como o empreendedor capitalista Francisco Manuel da Costa, «o Costa dos Canais», ao republicano empreendedor e democrata de espirito cientifico, crente no progresso e na técnica, se podem caracterizar por assumirem mais ou menos explicitamente uma natureza conjuntural, contextual e ainda relacional, na medida em que as suas filiações políticas se definem na base de relações familiares e de compadrios.

Como já referido, o Centro Republicano e Democrático de Carrazeda, tinha como objetivos programáticos, entre outros, «criar escolas, agremiações educativas e instrutivas, realizar conferências, reuniões, palestras e missões de propaganda para radicar o ideal republicano em todas as classes sociais». Com esse ideário de doutrina e propaganda republicana de natureza político-cultural arreigadamente iluminista e democrática, esta organização político-partidária, pela sua designação, parece ter-se inspirado nos «precoces afloramentos republicanos de matiz socialista da década de 1838-1848... longamente esquecidos até período recente» ${ }^{786}$. Promoveu a edição de "O Transmontano», semanário de ideário republicano de que se conhecem publicados 24 números de 1911, sendo seu proprietário outro influente republicano local, o Dr. João Trigo Moutinho, de uma antiga família de políticos municipais ${ }^{787}$.

Refira-se que o progressivo enraizamento do republicanismo em Carrazeda já se fazia sentir antes da proclamação da República, desde os primórdios da estrutura republicana na região duriense ${ }^{788}$.

Carrazeda de Ansiães era então considerado o concelho mais republicano do distrito de Bragança ${ }^{789}$, pela sua dinâmica política e pelo papel predominante de figuras republicanas destacadas das elites locais, a nível regional, como é recorrentemente enfatizado nesse semanário

\footnotetext{
${ }^{786}$ PEREIRA, 2016: 12-13.

${ }^{787}$ Pertencia a uma abastada família local detentora de muitas propriedades nas aldeias do Mogo de Malta e Seixo de Ansiães de Carrazeda, a que pertenciam também José Trigo Moutinho que fora presidente da Câmara de Carrazeda em 1896 e Antonio Trigo Moutinho que fora no mesmo ano vereador da Câmara (AMCA — Acta da Sessão de 24 de fevereiro de 1896, fls. 31v-32.).

788 «O Povo do Norte» — notícia sobre as Eleições Gerais de novembro de 1895, em que a lista republicana ganhara contra a lista governamental em Carrazeda de Ansiães. Ver obra de Carla Sequeira (SEQUEIRA, 2015: 360).

${ }^{789}$ «O Transmontano», n. ${ }^{\circ} 23,1911: 2$.
} 
republicano que manteve como seus correspondentes assíduos, outros republicanos e maçons conhecidos em toda a Região do Douro, desde a Régua, o advogado Dr. Bernardino Zagallo, a Mogadouro, o maçon Abílio Salgado ${ }^{790}$.

Todo esse intenso protagonismo republicano em Carrazeda, onde se destacam, como demonstrado, donos de quintas vinhateiras do Douro e proprietários do Vale do Tua, o outro limite ribeirinho do concelho, como por exemplo a antiga e conhecida família republicana dos Veigas, do Pinhal do Norte, irá manter-se, com tendência dominante dos democráticos, que conseguiram a maioria nas eleições de 1913, 1921 e 1922, até finais da I República, apesar das cisões que vinham ocorrendo desde a fragmentação partidária registada, e as novas estratégias dai decorrentes, entre 1912-1926, que puseram em causa a preponderância do PRP no Douro. As divisões internas e cisões no PRP, que já anteriormente se vinham preparando ${ }^{791}$, acentuar-se-iam, mais profunda e radicalmente a partir da Ditadura Militar, quando começaram a ter lugar os exílios e as deportações de republicanos e a verificar-se, também, deserções do campo republicano, como por exemplo aconteceu mais tarde com o proprietário da Quinta das Amendoeiras, que foi Ministro do Interior do Estado Novo ${ }^{792}$.

$\mathrm{Na}$ época da implantação da I República, quem era, em Carrazeda, sujeito de enunciação de discursos de mudança? Podemos encontrar ainda hoje várias vozes de descendentes de republicanos e de outros atores sociais que privaram com os proprietários vinhateiros da ribeira que nos ajudaram a caracterizar as posições diferenciadas destes e o seu grau de envolvimento na organização e definição da intervenção republicana nos destinos do concelho, evidências também comprovadas em fontes do Arquivo Municipal. Importa ainda avaliar, como é que, e até onde, esses protagonistas históricos, congregados no Centro Republicano e Democrático e exercendo funções em sucessivos executivos camarários, foram capazes de dar execução ao programa político republicano com que se comprometeram. A inserção no programa do Centro, em lugar de destaque e com caráter prioritário, da necessidade de criação de escolas, também objetivo da República a nível nacional, correspondia a uma das maiores carências da população concelhia, que registava então uma taxa de analfabetismo de 79\%. Logo em 1911 seriam criadas mais 8 escolas no concelho de Carrazeda, 3 das quais em freguesias do planalto e 5 em aldeias vinhateiras da Ribeira (uma escola mista em associação republicana de Zedes, outra em Mísquel, freguesia de Parambos, outra em Mogo de Malta, e novas escolas em Ribalonga, Coleja, Campelos e Pombal). Em 1913, foi fundada uma escola primária mista, em Foz Tua, freguesia de Castanheiro. Entre esta data e a de 1915 foram criadas mais escolas, ficando todo o concelho coberto por uma rede escolar.

Mas outras metas programáticas por cuja introdução propugnaram foram ainda atingidas, como a criação de postos do registo civil e a dotação de comunicações telefónicas públicas

\footnotetext{
${ }^{790}$ LAGE, 2010.

${ }^{791}$ Para uma excelente síntese e visão de conjunto da dinâmica politico partidária republicana antes e durante o período da I República Portuguesa (1910-1926) ver, designadamente, PEREIRA, 2016: 11-54.

${ }^{792}$ Entrevista com Dr. A. João R. de Sampaio, 14 de fevereiro de 2017. Ver também SEQUEIRA, 2015: 365.
} 
em locais de confluência estratégica e acesso às ferrovias do Douro e Tua, como Castanheiro do Norte e Foz Tua, locais de forte implantação de quintas, na zona da ribeira duriense deste concelho. O alcance de outras é de mais difícil avaliação, mas não parece haver dúvidas, de que lançaram mãos a meios para o conseguir, como por exemplo quanto à difusão do ideário republicano, o da publicação semanal regular do referido jornal republicano de Carrazeda, «O Transmontano», de duração curta mas intensa.

Foi-nos então possível, a partir de e no Douro, nesta zona de fronteira Cima Corgo/ Douro Superior, observar um rasgo espaciotemporal mais abrangente que, reportado a tempos de republicanismo anteriores à implantação da I República portuguesa, nos projetou para um período marcante na história da Europa e do mundo, o da Guerra Civil espanhola que pôs termo, de forma sangrenta e premonitória, à II República Espanhola ${ }^{793}$. Desta outra realidade histórica se encontram também ecos no Douro Vinhateiro, com singular expressão na Quinta Canaes-Bartol de longa tradição luso-espanhola, que foi nesse período refúgio de exilados espanhóis ${ }^{794}$, seus proprietários, fugidos à barbaridade do Cerco de Madrid.

No âmbito da precedente abordagem transdisciplinar da construção identitária na Região do Douro Vinhateiro num arco temporal referido a dois momentos da realidade histórica da República e do republicanismo, em Portugal (1910-1926) e Espanha (1931-36), analisamos elementos materiais e simbólicos de memórias e patrimónios identitários em quatro quintas durienses de Carrazeda de Ansiães, emblemáticas do ponto de vista das vivências e pertenças republicanas dos seus proprietários em conjunturas históricas diferenciadas e numa perspetiva pluriescalar (local/regional/nacional/internacional).

\subsection{ESPAÇO FRONTEIRIÇO E TERRITORIALIDADE SOCIAL}

Como ensina a Teoria dos Atores-Rede, ao tentarmos apreender aspetos da realidade sociológica de um concelho, Carrazeda de Ansiães, enquanto fronteira na Região Demarcada do Douro, temos de ter presente que as regiões são constituídas por redes e territórios, com diferentes níveis de permeabilidade ou de acessibilidade a seres humanos e não humanos e a fluxos dos mais diversos tipos, sendo que, em termos de área, o Regionalismo é um mundo de áreas com suas próprias regras topológicas sobre integridade e mudança.

Assim, o entendimento das identidades em correlação com as noções de «territorialidade» e de «fronteira» não deixa de nos remeter para uma outra dimensão das identidades, relacionada com fenómenos como as tradições e as territorialidades que são, essencialmente culturais e também políticas.

\footnotetext{
${ }^{793}$ Esta dimensão muito relevante e atual da História Contemporânea de Espanha e suas interações com a história de Portugal designadamente no período do Estado do Novo, tem sido objeto no campo historiográfico comparado de vários estudos e trabalhos que adquiriram novo fôlego em Portugal no pós-25 de Abril de 1974 e na Espanha pós franquista com a restauração da democracia. Consultar estudos e revisão da literatura produzidos neste âmbito, por exemplo em ROSAS \& LOFF, eds., 2010.

${ }^{794}$ VAQUINHAS, 2015.
} 
A noção de espaço foi naturalizada enquanto território nacional, no longo processo de constituição dos países modernos, mas o incremento contemporâneo da economia mundializada trouxe a fragilidade das fronteiras e, mesmo, do Estado, o que obriga a ter em conta outros aspetos da questão da territorialidade. $\mathrm{O}$ antropólogo James Clifford chega a dizer que qualquer lugar moderno pode ser tratado enquanto fronteira, processo de identificação territorial em que um mecanismo cognitivo complexo é ativado, envolvendo tradições, identificações em jogo e relações de poder. $\mathrm{O}$ ato de nomear os lugares não é linear, traça-se no confronto da cultura com a exterioridade e, ao disseminar-se socialmente, consolida-se, naturalizando-se como conhecimento adquirido. Estes saberes constituídos formam os conjuntos identitários postos em contacto.

A identidade orienta os modos de sentir e de agir, ao interligar experiências passadas com expetativas futuras e envolve tanto as tradições fixadas na memória quanto um projeto de reprodução imaginado. Pode assim deduzir-se que os recortes da hierarquização social e outros influenciam a idealização do espaço. Tais agrupamentos identitários, por mais movediça que seja a identidade, fornecem a base para a edificação da territorialidade.

A capacidade de assegurar o cumprimento de um projeto remete ao poder. Isto é manifesto ao traçar as linhas de ocupação e exploração dos espaços, demarcando o ato de posse delimitada da terra. Este possuidor costuma tomar a forma de um Estado, podendo este definir áreas de demarcação com regras aplicáveis, expressamente às mesmas, como sucede no caso da RDD e delimitação do seu território em sub-regiões.

Como referente central da territorialização $0^{795}$, os governos instituídos geram um conjunto de elaborações cartográficas, normativas, estatísticas e descritivas, enfim, uma série de mecanismos de produção do imaginário territorial. Os indivíduos e os grupos sociais procuram atingir, influenciar ou controlar recursos e pessoas através da delimitação e do controlo das áreas específicas, os territórios, sendo estes a expressão geográfica primária do poder social. E a territorialidade presta-se então a análises em diferentes escalas e normas de conduta; por outro lado, este conceito, componente do poder, não é só um meio de criação e manutenção de ordem, mas é também um instrumento para criar e manter o contexto geográfico através do qual se vivencia o mundo e se lhe dá significado ${ }^{796}$.

A mobilização adequada ao estudo de caso, destas perspetivas analíticas, torna assim evidente a inter-relação de espaço e sociedade sendo o território a resultante de relações sociais que se estabelecem no espaço e no tempo ${ }^{797}$, como se tem vindo a demonstrar.

A Região Demarcada do Douro (RDD) enquanto territorialidade particular diferenciada de lógica político-administrativa do Estado, uma territorialidade estatal hegemónica, requer que outros territórios que aí existem, como o de Carrazeda de Ansiães, sejam tratados em relação com ela, ou seja «nos termos de suas próprias categorias de enquadramento jurídico» ${ }^{798}$.

\footnotetext{
${ }^{795}$ DELEUZE \& GUATTARI, 1996.

${ }^{796}$ SACK, 1986.

${ }^{797}$ RAFFESTIN, 1993.

${ }^{798}$ NOGUEIRA, 2009: 126-133.
} 
Só assim se pode explicar que o concelho de Carrazeda, não integrado, durante o longo processo histórico de constituição do território da RDD, sucessivamente alargado e dividido nas sub-regiões do Baixo Corgo e Cima Corgo, apenas o venha a ser, mais recentemente, com a criação da sub-região do Douro Superior, passando então a ser reconhecido como pertencente à sub-região do Cima Corgo.

Mas atendendo, por outro lado, «ao caráter consuetudinário do ordenamento de territórios sociais, a sua manutenção depende, em larga medida, da memória coletiva dos grupos que enlaça dimensões simbólicas e identitárias de relação entre os grupos e o seu território ${ }^{799}$. Foi o que se tornou explícito no caso de Carrazeda, «espaço fronteiriço» do Douro, como melhor se pôde apreender através de práticas, saberes e representações sociais e identitárias de atores sociais, em seus lugares de origem e/ou pertença, num espaço geográfico que é também um território social, anteriormente analisadas (Capítulo 9).

Haja aqui em vista, no entanto, a importância desta prática analítica como bem explicita Mónica Nogueira:

na raiz da perceção do território está a perceção do 'nós', a construção básica da identidade $e$, por extensão, a base também do estabelecimento da diferença, visto que os limites do território contribuem para a construção da alteridade. O território é uma representação coletiva da sociedade, a fronteira é a representação coletiva fundamental para o estabelecimento da diferença, para a perceção da alteridade, sendo ao mesmo tempo um componente material (relativo ao espaço) e ideológico envolvendo um conjunto de fenómenos complexos no campo das representações, nas mais diferentes escalas. [...] Há inúmeros exemplos de que é quando se aguçam os sentidos de identificação territorial que emergem expressões políticas de resistência. O território tem presentes em seus limites, a problemática da alteridade - e nesses termos reafirma-se como sendo-lhe intrínseca a dimensão política em sua constituição, os seus fatores culturais e simbólicos imbricando-se de tal forma com os fatores políticos que a sua disjunção só é possível pela prática analítica $[. . .]^{800}$.

Evidencia-se ainda a utilidade do conceito de «fronteira» e «espaços fronteiriços» para mapear analiticamente a complexa heterogeneidade dinâmica que constituem as zonas de contacto (trans)fronteiriças que dividem e unem os indivíduos e os grupos na interação do local, regional, nacional e global. Em termos da interação cultural, as fronteiras são linhas e espaços onde tendências contraditórias se complementam. Como linhas divisórias da diferenciação cultural, espacial e temporal, as fronteiras distanciam o interno da alteridade externa, e como entre espaços compartilhados, ligam-nos. As fronteiras geográficas, mas também as epistemológicas em que nos movemos, que ligam e separam perspetivas cognitivas e culturas diferenciadas, criam espaços diferentes entre os diversos discursos e textos, um tipo de entre

\footnotetext{
${ }^{799}$ NOGUEIRA, 2009: 126-133.
}

${ }^{800}$ NOGUEIRA, 2009: 126-133. 
condição útil para examinar não somente o fluxo rizomático ${ }^{801}$ de um ponto para outro, mas principalmente o efeito deste movimento em termos da formação de subjetividade e identidade. Este conceito de fronteira permite-nos encontrar respostas que tentam dar conta do que significa viver dentro de e entre mundos, e, nesse processo, ser territorializado, desterritorializado e reterritorializado. A localização na fronteira, como local de intervenção crítica, possibilita a análise das múltiplas maneiras utilizadas para recriar a Região dentro de, entre e além de suas várias fronteiras.

Pode então considerar-se a identidade como uma série de respostas a conjunturas específicas — respostas (des/re)articuladas junto com outras identidades, formando um sistema, uma estratégia de diferenças em múltiplos níveis locais e globais ${ }^{802}$. Em outras palavras, o que é importante aqui é a análise de processos mediante os quais identidades são construídas dentro de e através de campos de diferença.

A visão crítica da fronteira e dos espaços fronteiriços permitiu-nos mapear os complexos processos transculturais de apropriação e reapropriação que marcam o espaço socioeconómico e cultural identitário de Carrazeda de Ansiães, localizada entre o Alto Douro e Trás-os-Montes, na interface das sub-regiões de Cima Corgo e Douro Superior, enquanto concelho integrado na Região Demarcada do Douro, no específico contexto e conjuntura histórica da I República, onde ocupa uma posição de fronteira e de hibridismo, hipótese que aqui se procurou deixar mais alicerçada e melhor construída.

A sua eventual experiência de constratividade confere-lhe um papel específico e singular e, consequentemente, a possibilidade de tomada de consciência, por parte de certos grupos sociais, quanto às diferenças e afinidades em jogo, sobretudo em conjunturas de contestação social e popular.

Em conclusão, ao procurar conciliar duas chaves interpretativas: a do reconhecimento de fatores estruturais históricos que remetem a um acervo económico e sociocultural pré-existente, por um lado, e, por outro, a das dinâmicas sociológicas de manipulação sobretudo em contexto de disputa, exigiu-se-nos a superação de modelos teóricos exclusivos, em favor de abordagens mais complexas da diversidade de processos de emergência de identidades, ou melhor, da análise sócio-histórica dos diferentes contextos e processos de identificação.

Pudemos ver como, para além das proposições sobre uma estrutura e conjunturas históricas e sociais, desde a sua enunciação, a necessária ponderação da ação e dos indivíduos no conhecimento histórico, abriram rumos analiticamente promissores que orientaram o nosso esforço de interpretação quer na analise desta problemática sócio-histórica quer nos vários desenvolvimentos deste estudo de caso alargado.

Foi da compreensão de toda esta complexidade sócio-historicamente ancorada que pôde emergir a singularidade do caso de um território de dimensão reduzida por comparação com

\footnotetext{
${ }^{801}$ DELEUZE \& GUATTARI, 2004.

${ }^{802}$ As identidades devem ser analisadas através de uma articulação dupla: como identidades articuladas e numa relação articulada entre si.
} 
o da Região Demarcada do Douro em que se integra. Carrazeda de Ansiães produtor de vinho do Porto hoje a cargo de cerca de 1.260 viticultores ativos num universo de aproximadamente 25.000 no Douro vinhateiro, é porventura exemplar quanto ao valor acrescentado na cadeia de valor da mercadoria vinho do Porto, beneficiando da especificidade de um «terroir» que para além de um conjunto amplo de outros aspetos do meio natural e fatores humanos e culturais na interação espaço histórico-geográfico e sociedade ${ }^{803}$ lhe proporciona a produção de excelentes vinhos de categorias especiais.

\footnotetext{
${ }^{803}$ Ver designadamente «Les Cahiers - Science \& Vie», n. ${ }^{\circ} 140$ (outubro de 2013), p. 10.
} 


\section{CAPÍTULO 11. ENQUADRAMENTO TEÓRICO-METODOLÓGICO: O «ESTUDO DE CASO ALARGADO»}

Recorremos no estudo transdisciplinar até aqui apresentado a um conjunto diversificado de metodologias e técnicas de investigação complementares, próprias de disciplinas científicas de referência das Ciências Sociais, o que nos conduziu à utilização de um método transversal, o «estudo de caso alargado» que se configura potencialmente rico sobretudo quando o enfoque central é a análise sócio-histórica.

Em que consiste então o "estudo de caso», método de investigação usado em diversos campos científicos? Não existindo uma definição unânime, começa-se por descrever de modo sucinto as suas características gerais, potencialidades e limitações.

Trata-se de um dispositivo analítico base dos processos de investigação que examinam um fenómeno social no seu ambiente natural, através da pesquisa e análise de material documental e empírico recolhido a partir de locais sociais específicos, tendo como objetivos principais alargar ou aprofundar o conhecimento científico sobre determinados fenómenos sociais de modo a poder-se aplicar ou construir uma teoria e testar conceitos teóricos e relações entre os mesmos ${ }^{804}$.

Representa uma forma de abordagem versátil que permite trabalhar uma multiplicidade de dados obtidos por diferentes meios, potencia o estudo de um objeto de modo intensivo e aprofundado, possibilita estabelecer relações entre variáveis e escalas e exige uma boa integração do investigador que a assunção do «conhecimento situado» ${ }^{805}$ proporciona e de que depende a natureza dos conhecimentos alcançados. A impossibilidade de generalização positivista dos resultados do estudo e a dificuldade de controlar as variáveis independentes que se traduzem numa limitação a conclusões definitivas, são os seus principais limites que foram devidamente tidos em conta.

A sua utilização deve-se fundamentalmente a três razões importantes: permite estudar um ambiente natural apreendendo o «estado da arte» dos estudos desenvolvidos no tema em observação e formular interpretações teóricas derivadas da prática; possibilita desenvolver a investigação em áreas concretas e matérias específicas do conhecimento com poucos estudos desenvolvidos anteriormente; facilita responder a questões «como» e "porquêe e compreender a complexidade dos processos.

A boa aplicação desta metodologia de investigação que resulta em muito da interpretação do investigador, implica ainda, para além da clara definição dos objetivos e da descrição

\footnotetext{
${ }^{804}$ Dado o peso da infraestrutura documental em estudos de história como este, faz-se uma apresentação genérica do método de estudo de caso na perspetiva da informação seguindo, parcialmente, a sua aplicação aos sistemas de informação; cf. MARTINS \& BELFO, 2011.

${ }^{805}$ HARAWAY, 1991: 183-202.
} 
das fontes e técnicas usadas na recolha e análise dos dados, a justificação criteriosa da escolha do local a que se aplica o estudo de caso e da influência das suas características próprias em conhecimentos anteriores.

Mais especificamente, 0 «estudo de caso alargado» ${ }^{806}$ torna-se capaz de dar conta de uma análise estrutural e fenomenológica que permite aceder a uma abordagem intensiva e globalizante de um fenómeno singular, possibilitando descobrir o que nele existe de essencial e único, porém, característico e paradigmático. Nessa medida, e por melhor se adequar à complexidade do nosso objeto de investigação - singularidade sócio-histórica de um concelho duriense e correspondente inscrição na longa história da Região Demarcada do Douro — privilegiamos o seu uso.

Com enfoque particular nos domínios da história e da sociologia este estudo de caso alargado, denso e relevante para a história do e no Douro Vinhateiro, valorizando a crescente importância vitivinícola do Douro Superior, foi operacionalizado, nas suas várias dimensões, também em função da sua localização de fronteira no plural e para além das fronteiras.

Assim, podemos considerar, homologicamente, este estudo como sendo ele próprio um «objeto de fronteira», no sentido em que possibilita percecionar o caso de Carrazeda de Ansiães concelho de fronteira na história do Douro, enquanto espaço de instabilidade e intersecção de possibilidades ou campo relacional que suscita uma reflexão plurifacetada que incita a debates em torno de problemáticas e processos de construção de identidades contextuais na identidade regional duriense (Capítulo 10).

Atendendo a que os espaços fronteiriços influenciam não só as pessoas como também os objetos, convém explicitar o que nos propósitos deste estudo se entende por «objeto de fronteira ${ }^{807}$. Boaventura de Sousa Santos (2010) propõe analisar o conceito de «fronteira» concebendo-a mais no sentido de extremidade do que no sentido de zona de contacto, com o propósito de deslocar as práticas e os discursos do centro para as bordas com vista a possibilitar uma «vida nas margens sem ser marginal».

Essa definição aponta para a possibilidade de construção de um dispositivo analítico que ousando transgredir saberes convencionais, se revela operacionalmente mais rico e adequado ao entendimento da complexidade das realidades históricas e sociais como as deste caso concreto de estudo.

Tenta-se assim realçar o potencial crítico e reflexivo que a metáfora da fronteira pode acionar ao permitir ainda questionar os seus limites, pois embora as suas linhas estejam definidas, também elas não são fixas, nem unilineares.

\footnotetext{
${ }^{806}$ Começámos por estudar e aplicar este método em adequação com metodologias complementares em estudos anteriores de historiografia experimental, Ver: LAGE, 1995; LAGE, 2010.

${ }^{807}$ STAR, 1989: 387-420; NUNES, 1998: 4-5; SANTOS, 2016: n. ${ }^{\circ} 432$, p. $4-5$.
} 


\subsection{O ESTUDO DE CASO ALARGADO NO DOMÍNIO DA SOCIOLOGIA ${ }^{808}$}

Sinteticamente, o «estudo de caso alargado» tem por base a observação sistemática e caracteriza-se por quatro pontos fundamentais:

intersubjetividade, processo, estruturação e reconstrução teórica. Com a intersubjetividade o investigador torna-se um participante, experienciando o mundo do outro. Na lógica do processo as observações são projetadas no tempo e no espaço permitindo uma perspetiva geral enquadradora. A estruturação possibilita atender às forças extra-locais que moldam os acontecimentos e as situações. A reconstrução teórica parte de um quadro conceptual pré-existente e procura descobrir anomalias e testar essa teoria $[\ldots]^{809}$.

Também designado por «análise situacional ou processual», este método foi desenvolvido pelos antropólogos da Escola de Manchester e explicado nos anos 1950 e 60 por Max Gluckman, Clyde Mitchell e Jaap van Velsen tendo sido recuperado na década de 1990, por Michael Burawoy ${ }^{810}$, defensor de uma etnografia global e da ciência reflexiva baseada em métodos qualitativos.

Foi aplicado de modo exemplar em Portugal, no início dos anos 1980, por Boaventura Sousa Santos, no seu estudo emblemático sobre as relações de poder entre os habitantes de favelas no Recife e os grandes proprietários, os interesses imobiliários e o Estado, reconstituindo a complexidade dos níveis e dos processos legais e políticos aí presentes ${ }^{811}$. Segundo este autor, o estudo de caso alargado

opõe à generalização positivista, pela quantidade e pela uniformização, a generalização pela qualidade e pela exemplaridade. Em vez de fixar a quantidade de casos (observações) adequada, escolhe um caso ou um numero limitado de casos em que se condensam com particular incidência os vetores estruturais mais importantes das economias interacionais dos diferentes participantes numa dada prática social setorial [...]; procura analisar, com o máximo detalhe descritivo, a complexidade do caso, com vista a captar o que há nele de diferente ou mesmo único. A riqueza do caso não está no que há nele de generalizável, mas na amplitude das incidências estruturais que nele se denunciam pela multiplicidade e profundidade das interações que o constituem. Em vez de delinear por fases ou graus sucessivos de abstração o acesso dos 'dados' à teoria, 'o método de caso alargado' propõe [...] o salto da imaginação sociológica entre o mais detalhado e minucioso e o mais geral e inde-

\footnotetext{
${ }^{808}$ Explicita-se, no âmbito de estudos de referência portugueses da sociologia o conceito de estudo de caso alargado, atendendo à relevância do contributo quer da sociologia e da antropologia para a sócio-história, quer, em particular, dos estudos de história social, micro-história e história local e regional, variantes do conhecimento historiográfico.

${ }^{809}$ MENDES, 2003.

${ }^{810}$ BURAWOY, 1998; BURAWOY Michael, et al., 1991.

${ }^{811}$ SANTOS, 1983: 9-59.
} 
terminado. [...] Não isola os factos (objetivos) do contexto de sentido (subjetivo ou intersubjetivo) em que ocorrem. Por isso privilegia o registo das práticas linguísticas, em que, em grande medida, se manifestam as economias interacionais e se delimitam as regiões de significação $[\ldots]^{812}$.

Como qualquer outro método, o método de caso alargado tem limitações e o seu uso indevido faz correr alguns riscos, como o do descritivismo e o da sobreteorização só controláveis se, quanto ao primeiro, o caso for bem escolhido e teoricamente tratado «o que pressupõe o comando das análises estruturais» e, no que respeita ao segundo, por vezes, «correlato de uma apropriação tecnicamente inadequada do caso» exigindo ter em conta que o «caso por mais rico e complexo [...] dificilmente cobre todas as questões teóricas levantadas pela análise estrutural» ${ }^{813}$.

\subsection{MOBILIZAÇÃO DO «ESTUDO DE CASO ALARGADO» NO CAMPO DA HISTÓRIA}

Através desse comando sociológico das análises estruturais, procurou-se fazer a «tradução ${ }^{814}$, no sentido de problematização, alistamento e mobilização desta metodologia de estudo para o caso concreto da investigação sócio-histórica desenvolvida sobre o concelho duriense de fronteira, Carrazeda de Ansiães, enquanto produtor de vinho do Porto de reconhecida qualidade, observado assim com maior enfoque e na longa duração a partir da criação pombalina da Região Demarcada do Douro e das suas sucessivas alterações (Demarcações marianas, de 1907/08, e de 1921) cujos limites foram sendo inscritos num território vinhateiro pré-existente mais vasto.

Nessa medida, este objeto de estudo, como aliás, o próprio objeto empírico é profundamente marcado pelo princípio arcôntico de arquivo, considerado, na sua aceção mais ampla, como comando político e reserva de lugar próprio. A partir do reconhecimento deste princípio estrutural, realizou-se um esforço intelectual e investigativo de «tradução pragmática» em duas dimensões interligadas: a de obrigatoriedade de passagem pelo arquivo nas suas tipologias essenciais de «arquivos institucionais» e "arquivos privados», «arquivos históricos» e «arquivos correntes», e a da grande atividade de justificação e meio de prova que neles assenta o que, por homologia com os trabalhos de vitivinificação, pode dizer-se que culmina na beneficiação e tratamento do produto vínico e sua posterior certificação e comercialização. Aliás, este estádio em que se apura o produto e mercadoria vinho do Porto, para a obtenção de resultados finais traduzidos em atribuições diferenciadas de cartões de benefício anualmente comprovados pelos manifestos de produção escritos, registados e arquivados, passou ainda pelo processo classificatório complexo de ponderação parcelar de matriz quadricular cadas-

\footnotetext{
${ }^{812}$ SANTOS, 1983: 4-5.

${ }^{813}$ SANTOS, 1983: 11-12.

${ }^{814} \mathrm{O}$ conceito de «tradução» é desenvolvido pela Teoria Atores-Rede (LATOUR, 1999)
} 
tral, submetida a valorização relativa pela aplicação de uma tabela de pontuação, assente na análise das características adáfico-climáticas e outras do próprio terreno.

Assim, é o próprio objeto empírico de estudo a suportar-se na construção de uma poderosa infraestrutura documental em permanente atualização que interage, incluindo e excluindo, valorizando ou desvalorizando, com o próprio território institucionalmente controlado ${ }^{815}$ e a sua exploração física na vertente das necessidades económicas e/ou das determinações sociais, a qual tem também de ser examinada através de categorias próprias da «teoria dos recursos» ${ }^{816}$.

Esta verificação dos termos específicos em que ocorre o próprio processo de produção vitivinícola tornou-se fundamental para a construção do nosso próprio plano e guião de investigação até, na medida em que sobre determina a análise rigorosa de outros estudos de caso diferenciados e densos, a qual só pode ser feita em perspetiva multiescalar cruzada nas suas múltiplas variáveis: a escala do território segundo os seus limites político-institucionais; a escala das próprias quadrículas ou unidades estruturantes do território (ex. instituições reguladoras, quintas, empresas, atores, e atantes sociais...) nos seus diversos níveis, dimensões e poderes; a escala da própria produção e respetivo produto laboratorialmente provado, analisado e certificado.

\subsection{OPERACIONALIZAÇÃO DO «ESTUDO DE CASO ALARGADO»}

Concebeu-se e delineou-se o presente caso de estudo, a partir da interligação de escalas micro e macro (já que cada escala revela mas também oculta certos aspetos), ou seja, tendo em atenção os modos multifacetados como os fenómenos económico-políticos e as estruturas macrossociais, institucionais e culturais, foram determinando espaciotemporalmente a construção sócio-histórica da posição de Carrazeda de Ansiães, concelho «fronteira» na RDD, considerado de relevo para uma outra compreensão da Região do Douro Vinhateiro na sua dimensão (trans)nacional. A riqueza e diversidade de informação das variáveis em observação não linear e análise abrangente permitiu-nos identificar e evidenciar a sua representatividade relativa em maior destaque.

Foi ponto de partida da nossa investigação o concelho duriense de Carrazeda de Ansiães integrado na nova RDD em 1907 e a época da I República portuguesa, entre finais da Monarquia e início do Estado Novo, período pouco conhecido da história do Douro, nos planos social, económico e político, coincidente com tempos difíceis de grave crise agrícola e comer-

\footnotetext{
${ }^{815}$ Decreto-Lei n. ${ }^{\circ}$ 254/98, de 11 de agosto de 1998 (que reconhece as denominações de origem controlada (DOC) «Porto» e «Douro»; estabelece regras gerais relativas à delimitação da região, aos solos, às castas, às práticas culturais, à inscrição e classificação das vinhos e à vinificação); Portaria n.o 413/2001, de 18 de abril de 2001 (Regulamento da Classificação de Parcelas com Cultura de Vinha para a Produção de Vinho Susceptível de Obtenção da Denominação de Origem Porto); Regulamento n. ${ }^{\circ} 36 / 2005$ (categorias especiais do vinho do Porto); Regulamento n. ${ }^{\circ}$ 23/2006 (Proteção da Denominação de Origem PORTO); Decreto-Lei n. ${ }^{\circ}$ 173/2009, de 3 de agosto (Estatuto das Denominações de Origem e Indicação Geográfica da Região Demarcada do Douro); Regulamento n. 242 de 2010 , de 15 de março (regime de proteção e apresentação das denominações de origem Porto e Douro e da indicação geográfica da RDD). Disponível em $<$ https://www.ivdp.pt/pagina.asp? $\operatorname{codPag}=48 \& \operatorname{codSeccao}=6 \&$ idioma $=0>$. [Consulta realizada em 23/5/2016]

${ }^{816}$ Boltanski \& Thévenot, 1987; LAGE, 1995: 359-360.
} 
cial, associada ao livre-cambismo e ao movimento duriense de defesa da reposição do regime regulador, grande reconversão da vitivinicultura e profunda reestruturação do espaço regional. O contexto histórico da Região do Douro foi então assinalado por movimentações sociais e personalidades políticas marcantes e por uma vaga de conflitos sociais, protestos públicos, sublevações e motins populares que alastraram a vários pontos do Douro (Carrazeda, Alijó, Favaios, Sabrosa, Vila Flor, Santa Marta de Penaguião e Lamego), relacionados com a «questão duriense», a miséria e a fome que atingiram as populações do Alto Douro, tendo a força alcançada pelas reivindicações regionais para intervenção do Estado suscitado uma forte agitação política e social a partir do último quartel do século XIX e inícios do século XX.

Foram numerosos os fatores que concorreram nesse sentido, destacando-se por exemplo, a restauração da Região Demarcada (1907-1908) e o exclusivo da barra do Douro para a exportação de vinho do Porto produzido na zona duriense, a criação de um entreposto único, a questão do álcool, fraudes e contrafações, a defesa da marca «Porto» e da denominação de origem «Douro», nesse contexto de sublevações populares e reivindicações regionais, com expoente máximo no Motim de Lamego de 1915 e a contestação do art. ${ }^{\circ}$ 6. ${ }^{\circ}$ do Tratado de Comércio Luso-Britânico de 1914, as quais influenciaram o Movimento dos Paladinos do Douro e a afirmação institucional de uma identidade regional duriense. Foi aliás, nesse denso processo histórico e social que se inscreveu também a problematização da complexa construção de identidades no Douro anteriormente apresentada (Capítulo 10).

A própria economia nacional, em que o vinho do Porto continuava então a deter, como hoje, embora menor, um papel importante nas exportações, determinou e determina ainda a atenção do Estado e tem condicionado a intervenção dos governos em regimes sucessivos, cuja dilucidação tem de ser entendida a essa luz, requerendo um estudo em profundidade, transdisciplinar, pluriperspetivado e multidimensional, horizonte de que continuamente nos fomos tentando aproximar.

Ora, tendo partido dos procedimentos próprios da história e dos requisitos metodológicos do estudo de caso alargado que configuraram uma exigência analítica maior a que se atendeu, pusemos ainda em prática um método plural e continuado de investigação e estudo do (trans)local na sua espaciotemporalidade, através do exercício contínuo da «amostragem teórica e comparação constante» próprio da Ground Theory ou Teoria da Ação ${ }^{817}$, que nos possibilitou estabelecer o necessário vai e vem entre o material empírico e a teorização, proporcionando um meio de compreender melhor quer o caráter processual e situacional dos factos sociais quer os processos de mudança social.

Estas foram as principais traves mestras da metodologia com que se operou. Porém, a abordagem sócio-histórica que conseguimos construir na investigação abrangente e denso estudo deste caso paradigmático da e na história social do Douro Vinhateiro a partir da sua mais profunda e recente transformação com a definitiva expansão da vinha e do vinho pelo

\footnotetext{
${ }_{817}$ STRAUSS \& BASZENGER, 1992: 269-300. Ver também STRAUSS \& CORBIN, 1990.
} 
Douro Superior até à fronteira só se tornou possível pela mobilização, articulação e complementaridade de uma diversidade de referências teóricas, substantivas e processuais e de uma pluralidade de métodos e técnicas de pesquisa a que de forma constante se recorreu, conforme progressiva e adequadamente enunciámos.

\subsection{INFRAESTRUTURA DOCUMENTAL E CONSTRUÇÃO DO CONHECIMENTO}

Um passo inicial e decisivo de todo o percurso subjacente a este trabalho de investigação consistiu em traçar a contextura temporal e espacial em que se inscreve e foi operando em todas as fases do seu desenvolvimento. As considerações gerais sobre a pesquisa de terreno pautada pelos preceitos da «objetivação participante» e da «proximidade crítica» e sobre o processo e práticas de pesquisa no domínio dos arquivos, das fontes e dos documentos, permitem enquadrar a vertente incontornável da infraestrutura documental mobilizada.

É óbvio que a pesquisa de fontes e documentos e o trabalho de arquivo em que se consubstancia são as duas faces da moeda corrente das práticas historiográficas. A validade universalizante de que o documento de arquivo é investido, como meio de prova, age e retroage a mais-valia da sua singularidade, reificando-o, o que nos remete para a análise de duplo sentido — o dos poderes ocultos e o das condições de escrita da história - intrínseco à questão central da historicidade da própria história.

Nessa medida, os modos de produção da história e do trabalho dos arquivos em que largamente se suporta, requerem toda uma outra articulação com um conjunto de lições e evidências aprendidas, entre as quais se contam as relativas à historicidade dos próprios arquivos. «Uma ciência do arquivo deve incluir a teoria desta institucionalização, quer dizer simultaneamente da lei que começa por nele se inscrever e do direito que o autoriza. $\mathrm{O}$ direito coloca e supõe um feixe de limites que tem uma história, uma história desconstrutível...», lembra o filósofo francês Jacques Derrida.

Poucas coisas há menos inocentes do que um arquivo e do que o trabalho do historiador e as autoproclamadas custódias da memória, como se disse. Vários exemplos se poderiam dar de que se trata aqui de uma ordem que tanto oculta como revela. Daí que, porventura, o interesse maior dessa massa de documentos resida no que a sua organização e tratamento técnico deixa perceber.

São, e em que medida, os documentos e as fontes de arquivo, mediados pelos protocolos disciplinares da pesquisa, crítica e interpretação, meio de prova e ou validação do conhecimento? Ou não serão antes de «pôr à prova»?! Dupla interrogação fulcral às práticas historiográficas e de considerável importância para a produção do conhecimento histórico.

Mormente a partir da década de 1980 e com destaque para a micro-história da escola italiana, ou para a nova história social dos Annales, de Bernard Lepetit, e sua história experimental, estas interrogações trabalham por dentro a prática historiográfica num movimento de reatualização de, entre outros, o clássico problema das séries documentais e das descrições/ 
análises em diacronia. A pertinência desta perspetiva vertical e lacunar perde alguma da sua antiga eficácia face à questão maior e mais atual do cruzamento de fontes diversificadas e selecionadas de modo indiciário que atende, simultaneamente, ao lugar de observação, aos modos adotados e/ou escolhidos de interpelação das fontes e à vigilância crítica em relação às múltiplas formas de reificação dos factos induzidas por tendências positivistas ou neopositivistas.

Experiencialmente sedimentadas, todas estas observações foram-nos servindo de «aviso à navegação» nos postos de vigia do caso empírico em estudo, denso, concentrado e, paradoxalmente, muito disperso e fluido, de que aliás são, também, em certa medida, reflexo, por um lado, o estado caótico em que fomos encontrar muitos dos documentos de arquivo que trabalhámos, e, por outro, a grande maioria das numerosas fontes materiais que, numa atenção particular à materialidade histórica, ao longo de anos, coligimos e registámos.

Estes contornos metodológicos da questão dos arquivos e da produção da história contemporânea ${ }^{818}$ adquirem alicerces mais sólidos, quando analisados, no plano teórico, na esteira de Derrida, atrás evocada, ou na perspetiva política de Sonia Combe, outra referência básica para que, aliás, este filosofo remete, e a qual, depois de nos alertar para o facto de que «o privilégio do acesso ao arquivo é o fundamento da autoridade do novo historiador do tempo presente», nos lembra que «como toda a fonte, o arquivo necessita de um olhar crítico».

O longo e diversificado trajeto de pesquisa que suportou este nosso estudo, orientando-se entre o mundo das bibliotecas e arquivos e o trabalho de terreno, em pontos e instituições estrategicamente significativos dos processos de produção e negócio do vinho do Porto, levou-nos dos arquivos públicos (nacionais, regionais, distritais e municipais) aos arquivos de quintas e empresas. Para além disso, exigiu-nos modalidades diferentes, mas complementares de abordagem do objeto em estudo, até pelas diferentes entradas e pontos de observação para o mesmo, em função de interesses divergentes e ou opostos: memórias sociais e materiais de memória coletiva; fontes orais e a relação entre estas duas primeiras modalidades; arquivos técnicos e registos; arquivos económicos e políticos; arquivos privados e institucionais. A diversidade de documentos de arquivo a par de uma grande variedade de literatura técnica especializada, em cruzamento com uma multiplicidade de informações e representações obtidas no trabalho de terreno permitiu-nos ao longo de uma sequência de operações multifacetadas, reunir, compilar e trabalhar uma diversificada infraestrutura documental no domínio da história contemporânea do Douro com vista à produção de novas inteligibilidades o que se pretende que este estudo de caso alargado possibilite.

\footnotetext{
${ }^{818}$ Campo historiográfico de grande profusão e heterogeneidade de fontes e arquivos ainda em constituição, geralmente mal acautelados, e objeto de fortes ou difusas limitações de acesso, por fatores vários, a História Contemporânea apresenta problemas próprios, insuficientemente estabelecidos e de difícil resolução, como os que resultam das relações entre práticas historiográficas, práticas de análise social e práticas jornalísticas ou dos meios de comunicação social, em geral. Alguns dos condicionalismos que concorrem para esses problemas, foram resumidos por António Barreto e Maria Filomena Mónica, em entrevista ao «Público» (de 30 de maio de 1999 , Rubrica Cultura), salientando que, no caso da História Contemporânea de Portugal, «os períodos mais recentes... são mais densos, há proporcionalmente mais matéria nestes 50 anos do que nos 800 anteriores. Ou seja, a lupa com que analisamos os últimos 50 anos é muito mais pormenorizada...».
} 


\section{CONSIDERAÇÕES FINAIS}


No presente livro procurou-se dar a conhecer um caso singular do Douro Vinhateiro Património da Humanidade, imponente e vivo anfiteatro natural e humano, histórico, cultural evolutivo, recorrendo a um olhar cinematográfico através de diferentes grandes planos, múltiplas tomadas de vista e lente de grande angular, metodologia de leitura que este objeto de estudo, em sua densidade polivalente e multifacetada, nos impôs como mais adequada.

Poderá considerar-se que a produção e escrita deste livro traduz uma ambição desmedida que, no entanto, requereu um esforço e exigência tal que nos impeliu a tentar aproximar-nos da sensibilidade criativa do sonho de realização de Os Gigantes do Douro (Manuel de Oliveira, 1934) na «história experimental» e «conhecimento situado» em que nos comprometemos.

Tendo partido do contexto histórico geral da Região do Douro no período da I República em que incide esta investigação do estudo de caso alargado de Carrazeda de Ansiães enquanto concelho da Região Demarcada do Douro, antigo e específico produtor de vinho do Porto, para se esboçar uma primeira tipificação descritiva do caso em observação, passamos depois a uma análise na perspetiva sócio-histórica, integrando materiais e exemplos empíricos ilustrativos mas sempre exigentes porque indiciadores de processos complexos, evidências de fundo, partilhadas, coletivas, sobre as quais repousam as atividades e ações mais diversas, em que atores e analistas sociais discutem boas ou más representações, produzem interpretações, desconfiam das aparências, arbitram entre visões do mundo contraditórias. Tentámos que a nossa interpretação de documentos históricos e de algumas histórias narradas se tornasse capaz de apreender configurações gerais e clarificar situações através de pontos de referência conceptuais e metodológicos sucessiva e adequadamente mobilizados em função das aproximações transdisciplinares efetuadas. Em sociologia a que, no quadro de uma nova história social, muitas vezes recorremos, não há objeto social sem «representação» e o desafio das situações limite do que se chama, por vezes, «a prova», é fazer emergir as representações coletivas dispersas sob as rotinas ordinárias. Nem sempre se define com precisão o que é uma «representação social», embora se trate de um conceito maior que veicula a ideia desenvolvida por Durkheim, de que os indivíduos estão ligados por constrangimentos coletivos que ultrapassam as consciências individuais.

A história do vinho do Porto, com seus problemas e atributos inerentes e movimentos sociais que lhe estão associados, é disso um exemplo patente, pois que pressupõe, para poder funcionar, representações sociais múltiplas das entidades e instituições envolvidas com o produto.

Fomos, intercaladamente, suspendendo descrições, caso a caso, para nos comprometermos com problematizações mais teóricas, à medida que o essencial dos temas e conceitos em jogo análise: «fronteira», «representações», «marca», «fraudes», «contrafações», «denominação de origem», «autenticidade», «identidades», «territorialidade» e «região» iam sendo introduzidos no decorrer da narração e interpretação deste caso de figura - Carrazeda de Ansiães enquanto produtor de vinho do Porto - o qual se pode configurar como paradigmático e representativo de um espaço territorial vinhateiro entre Cima Corgo e Douro Superior, da Região Demarcada do Douro, produtora/exportadora da «marca» coletiva vinho do Porto. 
A aplicação do «método de estudo de caso alargado» à análise sócio-histórica de Carrazeda de Ansiães como produtor do vinho de Porto na perspetiva da sua inscrição na longa história do Douro e do vinho do Porto com destaque especial para a sua posição no emergente «Douro Novo» na história recente do Douro Superior, parece-nos ter-se justificado como método de investigação tanto mais certo e adequado quanto permite inclusive compreender os antecedentes à demarcação duriense de João Franco que pela primeira vez abrange este concelho, em que algumas das suas quintas, porém, já de certa forma estavam quadriculadas ainda que não estivessem incluídas na região demarcada. Permitiu assim, pela negativa, a aplicação de um teste ao conhecimento produzido e a consequente verificação de uma singular característica histórica, de certo modo anómala, de aí haver quintas que à escala do cadastro eram já unidades de produção de vinho beneficiado, não o sendo ainda, todavia, na escala da demarcação.

Pode depreender-se da abordagem sócio-histórica empreendida com base nos processos históricos e sociais, por referência à longa duração e em múltiplas escalas, que Carrazeda de Ansiães, nesta sua qualidade de produtor de vinho de Porto se define enquanto concelho de fronteira a vários títulos: como espaço geográfico de Trás-os-Montes e Alto Douro entre Cima Corgo e Douro Superior, integrante de terras de planalto e ribeirinhas, marginado por dois rios (Douro e seu afluente Tua), com dois microclimas e dois tipos de paisagem predominante; enquanto território histórico-social da Região Demarcada do Douro com denominação de origem controlada da produção e exportação da «marca» vinho do Porto e «marca» Douro; e ainda como territorialidade diferenciada mas hegemónica de lógica político-administrativa estatal.

Nesse âmbito, caracteriza-se por uma experiência histórica singular de afirmação de «identidades conjunturais, relacionais e contextuais» como diversas são as possibilidades de englobamento e/ou de composição raramente hierárquicas, tanto mais quanto as identidades sociais, sempre referidas a determinados contextos e conjunturas são sempre relacionais. Disso resulta a sua ubiquidade e a razão porque, em última instância, se pode considerar a identidade como praticamente inapreensível ${ }^{819}$. Pese embora, esteja aqui bem presente a noção de território «expressão geográfica primária de poder social», podendo assim reconhecer-se em certas categorias de identidade, como nas representações, o seu caráter estruturante de formas simbólicas com papel ativo na construção de um mundo objetivo. Em processo de constante reconfiguração, as identidades contextuais adquirem em circunstâncias históricas de crise, especial visibilidade com manifestações sociopolíticas de resistência em que as representações identitárias emergem ou submergem em função de profundas desigualdades sociais, conflitos e mudanças de interesses, movimentações e manifestações de sinais contraditórios.

Foi aliás o que se pôde verificar, por exemplo, pela análise dos protestos violentos, sublevações sociais e motins populares que tiveram lugar em Carrazeda e Foz Tua como noutros

${ }^{819}$ AGIER, 2001. 
concelhos do Alto Douro no período de transição entre os Regimes monárquico e republicano, marcado por profunda crise duriense, e também nos inícios da I República portuguesa, época em que se evidenciaram fatores de insatisfação profunda e de defesa comuns à Região, em que viticultores de Carrazeda deram provas de especial protagonismo, com a afirmação de uma «identidade regional duriense», entendida como prática de identificação regional por relação a uma identidade nacional, enquanto «identidade imaginária ou secundária» que se manifesta numa identificação forte com a localidade e em contexto de regionalismo ou discurso ideológico sobre o território, produto e produtor de lutas simbólicas entre agentes interessados num espaço histórico determinado.

Registaram-se e tentaram analisar-se dinâmicas e processos histórico-sociais, espaços-tempos, acontecimentos e ação humana, noções e conteúdos, conhecimentos e saberes transmitidos e reinterpretados com base em documentos de arquivo, fontes escritas e orais, memórias e testemunhos transmitidos pelos atores sociais, agentes de uma história vivida ${ }^{820}$ no interior e exterior deste concelho vinhateiro duriense enquanto tal integrado em 1907 na Região Demarcada do Douro, apresentando também, historicamente, uma posição de fronteira.

O próprio mapeamento jurídico territorial da Região Demarcada do Douro ou Alto Douro evidencia a posição singular de Carrazeda desde logo pela ausência de contiguidade territorial da sede administrativa com as freguesias da zona vinhateira, na ribeira, conhecida por «os da poça». Aliás, esta designação émica pode significar ambiguidade de afastamento/ proximidade nos processos de identificação alternativa dos da «frieira» pobre, face aos da «ribeira» rica, uma vez que a sede do concelho, no planalto e rodeada pelas suas freguesias limítrofes, embora territorialmente «isolada» da zona vinhateira da ribeira, foi e continua integrada na Região Demarcada do Douro.

A participação no poder municipal de donos de quintas vinhateiras com assumidas posições republicanas, verificada na I República, pode traduzir uma significativa desambiguação na reconfiguração de pertenças identitárias e processos de identificação local/regional. Porém, esta ascensão dominante de abastados proprietários da ribeira ao poder político-administrativo concelhio, mudança mais de natureza ideológico-cultural, não se mostraria suficiente para que pudesse registar alterações de fundo. Acontece que, durante a República que manteve a proteção dos vinhateiros durienses, a base social do republicanismo de tendência democrata, com expressão e protagonismo no concelho rural de Carrazeda, era constituída por uma parte significativa de abastados proprietários vinhateiros e letrados influentes da elite local a cujas casas estavam enfeudadas, por vínculos de trabalho e subsistência, as populações da maioria das aldeias, o que pode explicar, aqui e então, a ausência de oposição aos republicanos.

Acabaram de enumerar-se algumas características marcantes da sócio-história de Carrazeda de Ansiães, concelho ancorado numa longa tradição da cultura da vinha e do vinho (como se apresentou na Parte I), que se consideram poder contribuir para evidenciar a sua

\footnotetext{
${ }^{820}$ Esta noção de história vivida (POMIAN) encontra-se explicitada para o Douro Vinhateiro em LAGE, 1995.
} 
singularidade como reconhecido produtor de vinhos generosos de superior qualidade, de «marcas históricas» de vinhos do Porto e de notáveis Vintages (o que se demonstrou na Parte III, através da história de algumas das suas principais quintas, firmas e empresas estrangeiras de negócios de vinho do Porto que aí operaram e operam). Afirma-se este concelho, a partir dessa sua posição de fronteira na Região Demarcada do Douro (conforme se desenvolveu na Parte II) com uma experiência histórica porventura única, designadamente nos processos de construção de identidades nunca essenciais, antes sempre de natureza contextual, conjuntural e relacional, o que lhe confere um papel específico de contrastividade na Região do Douro Vinhateiro. Esta diferenciação e importância específica (sublinhada na Parte IV) tem sido a nosso ver ignorada e/ou desvalorizada. Importará por isso continuar a desenvolver o seu estudo específico e aprofundado, acompanhando designadamente as mudanças e transformações mais recentes no contexto do Douro Vinhateiro.

Tem antecedentes históricos nesta zona duriense de Carrazeda a constante reclamação dos viticultores do Douro de fixação de um preço justo para os vinhos de pasto ou lisos que ficavam fora do benefício e em que os lavradores se viam confinados ao consumo próprio ou à venda para a queima e destilação de aguardente vínica, quando permitida, pretensão que se afirmou, designadamente e com maior insistência, no contexto do movimento associativo da vitivinicultura duriense em resultado do qual é criada a Federação Sindical dos Viticultores do Douro (1932), instituição de iniciativa autónoma regional, que se tornaria na Casa do Douro, organismo de matriz corporativista. Somente após o sombrio e duradouro período da ditadura do Estado Novo é que, já no início dos anos 1980, tal reclamação deixou de pôr-se nesses termos, com a abertura de mercados para os vinhos DOC Douro; sem que porém se esqueça que boa parte dos pequenos lavradores, no geral envelhecida, sem capital próprio e não podendo endividar-se, continuou sem acesso próprio à comercialização dos seus vinhos, à modernização e condições sociotécnicas exigidas pelo aproveitamento rentável assim alcançado (Capítulo 9).

Acresce que o sistema regulador do Douro, secularmente construído com fortes alicerces de todo um edifício institucional normativo, ameaça hoje abrir fissuras provenientes da introdução nele de um princípio de «livre escolha» ou pelo menos de escolha condicionada para que nunca foi vocacionado e que se traduz pela «concorrência» de as mesmas uvas poderem servir à produção de vinho do Porto ou vinhos de consumo DOC Douro, circunstância única, à escala mundial das regiões vinhateiras.

Associado ou não a tal linha divisória imaginária traçada de modo aleatório, anualmente, a entrega dos manifestos terá recentemente deixado de contar com recetor próximo com o atribulado destino da Casa do Douro; a atribuição do benefício sempre controversa poderá estar a transformar-se, atualmente, numa espécie de um jogo de sorte e azar, havendo já quem pense dever esse dispositivo regulador ser programado a três ou mais anos de distância; o próprio sistema de pontuação, base daquele, parece estar a tornar-se objeto de controvérsia, atento o pouco peso relativo nele conferido às castas. Trata-se de um conjunto de sinais 
que se afigura carecerem de uma nova visão conformadora e que se revelam como outros tantos indícios de «excecional normal» ${ }^{821}$, pista de investigação a seguir no desenvolvimento de estudos futuros.

\footnotetext{
${ }^{821}$ GRENDI, 2009; GINZBURG \& PONI, 1989. Desde os anos 1970 que a micro-história, um novo género historiográfico, desenvolvido pelos historiadores Carlo Ginzburg, Giovanni Levi e Edoardo Grendi, veio alterar rumos e práticas do fazer história, insistindo na importância da escala de observação na pesquisa histórica.
} 
FONTES E BIBLIOGRAFIA 


\section{FONTES}

Arquivo da Comissão de Viticultura Duriense

ACVD - Casa do Douro, Régua.

\section{Arquivo Distrital de Bragança}

ADB — Paróquia de Fontelonga, Registo de Casamentos, Registo de Casamentos 1854/1887, fls. 7, 53; Registo de Casamentos 1894/1894, fls. 2-2v.

ADB - Arquivo Notarial de Carrazeda de Ansiães, Livro de Notas do tabelião Cristóvão José de Sampaio e Sousa Pimentel (1793-1796), fls.120-124v.; Livro de Notas do tabelião José de Morais (1855-1856), fls. 4-7, 125-128; Livro de Notas do tabelião José de Morais (1877), fl. 4 vs.

\section{Arquivo Histórico da Repartição de Finanças de Carrazeda de Ansiães}

AHRFCA — Livro de Matrizes, vol. II, 1929 e 1937 da freguesia da Beira Grande, Carrazeda de Ansiães, art. ${ }^{\text {os }} 2022,2304$ e 2534.

AHRFCA — Livro de Matrizes, vol. II, Matriz Predial Rústica da Beira Grande, Carrazeda de Ansiães, lv. n. ${ }^{\circ}$.

AHRFCA — Livro Antigo de Matrizes, Registo da Matriz de 1912; Registo da Matriz de 1918, da freguesia da Beira Grande, Carrazeda de Ansiães.

\section{Arquivo Histórico do Ministério das Obras Públicas}

AHMOP — Relação das Quintas, e vinhos que em execução da Carta Régia de 28 de Janeiro de 1793, acharão capazes de produzir vinho tinto legal de Embarque os dous Deputados que fizerão a Demarcação subsidiária, Domingos Martins Gonçalves, e Francisco Baptista de Araújo Cabral Montês, e Deputado Inspector dos Vinhos Legaes d’Embarque, MR 35, cx. 29/36, n. ${ }^{\circ} 30$.

\section{Arquivo Histórico Symington}

AHS — Contribuições e matrizes prediais da Sociedade Comercial Silva \& Cosens, cx. 2490, u.i. 6194.

AHS — Documentos avulsos, cx. 2490, u.i. 6194-6200, cota 1/8/1/5.

AHS — Doc. Div. Quintas da Senhora da Ribeira, Zimbro e Bonfim, cx. 2490, u.i. 6194.

AHS — Dossier de documentos de vendas da Quinta da Senhora da Ribeira, u.i. 6196.

AHS — Dossiers de documentação diversa, cx. 2490, u.i. 6200; Correspondência cx. 2490, u.i. 6198; cx. 2490, pasta 6.200, u.i. 6194.

AHS — Fundo Cockburn's, Copiador de Correspondência, anos 1963-1979, cx. 1743, u.i. 5973-5994, mç. M7-5994, cota 1/6/B/5.

AHS - Fundo Cockburn's, Dossier CB-276, cx. 42, u.i. 273, 278, cota 1/1/1/5.

AHS — Fundo Cockburn's, Dossier da Quinta dos Canais.

AHS — Fundo Cockburn's, Dossier de documentos compilados da Quinta dos Canais.

AHS - Fundo Cockburn's, Dossier de Correspondência, 1964-1979, entre Martinez Gassiot e Maria Esperança Bartol Egido; Dossier de Correspondência n. ${ }^{\circ} 8479$, cx. 2562, cota 1/8/4/1.

AHS - Fundo Cockburn's, Dossiers, processos e documentação avulsa do fundo Cockburn's, cx. 1743, u.i. 5973-5994, mç. 7; cx. 269, u.i. 1426-172-269; cx. 269, u.i. 1419-1432, cota 1/1/72;

AHS — Inventário resumido da Quinta da Senhora da Ribeira, [1920- 194?] cx. 2830, u.i. 6154.

AHS — Inventário geral da Quinta da Senhora da Ribeira, 1922-1923, cx. 1777, u.i. 6113-6118, cota 1/3/11/6.

AHS — Lista de preços de uvas compradas nas Quintas da Senhora da Ribeira e do Zimbro, 1911-1929, u.i. 6200.

AHS — Livro de Inventários do Douro Silva \& Cosens, cx. 1772, u.i. 6094-6097, cota 173/10/6; cx. 1772, u.i. 6199.

AHS — Livro de visitas da Quinta do Tua, 1935-1957.

AHS — Livro Silva \& Cosens - Inventários do Douro, cx.1772, u.i.6094-6097, cota 1/3/10/6, p. 60-94, 102-115.

AHS - Mapas de transporte de vinhos, cb. - 5733, cx. 42, u.i. 273-278 - Cockburn Smithes (Régua, janeiro 1993 a dezembro 1995).

AHS — Matriz predial rústica, art. ${ }^{9}$ 962, u.i. 6196; Matriz predial de 1911, u.i. 6197.

AHS — Propriedades da Empresa em Portugal - Dossier CB-276, cx. 42, u.i.273-278, cota 1/1/1/5. 
AHS - Quinta do Vesúvio/Quinta da Coalheira, cx. 2915.

AHS - Quinta do Vesúvio, Correspondência de António Dias de Magalhães, administrador da Quinta do Vesúvio para António José Claro da Fonseca no escritório da Empresa Ferreirinha do Porto, cx. 2934, pasta 2, u.i. 10067.

AHS — Relação de prédios relativa a Imposto de Sisa (1911) da Fazenda de Carrazeda de Ansiães. Quinta da Senhora da Ribeira, cx. 2490, u.i. 6197;

Arquivo Municipal de Carrazeda de Ansiães

AMCA — Acta da sessão de 24 de Fevereiro de 1896, fls. 31v-32.

AMCA — Livros de Actas da Comissão Executiva de 1924-1926.

AMCA — Livro de Actas das sessões da Câmara de 1907-1910, sessão extraordinária de 7 de outubro, fls. 88v-89 e sessão ordinária de 15 de outubro, fls. $89 \mathrm{v}-90$.

AMCA — Livros de Actas de 1907-1910; 1910-1916; de 1914-1919; de 1916-1919; de 1919-1926.

\section{Arquivo Nacional Torre do Tombo}

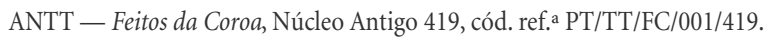

\section{Centro português de fotografia/Direção-Geral do Livro, dos Arquivos e das Bibliotecas/Secretaria de Estado da Cultura}

CPF/DGLAB/SEC - Cópias e créditos de fotografias históricas Emílio Biel, das Quintas Canais/Vargellas e Armazéns de Vinhos em Gaia.

\section{Instituto dos Vinhos do Douro e do Porto}

IVDP - Mapa Douro Portuguez e Paiz Adjacente, J.J. Forrester, 1848, coleção, I.V.D.P. - I. P.

IVDP — Viticultura, Região. Disponível em <https://www.ivdp.pt/pagina.asp?codPag=16>.

INSTITUTO NACIONAL DE ESTATÍSTICA - https://www.ine.pt.

RELATÓRIO da Comissão de Viticultura Duriense: Apresentado em sessão de 30 de Dezembro de 1913. Porto: Empresa Gráfica «A Universal», 1913. Acessível no Museu do Douro, Peso da Régua, Portugal.

RELATÓRIO da Comissão executiva da Comissão de Viticultura Duriense do ano de 1924. «Boletim da Direcção Geral da Agricultura», $13 .^{\circ}$ ano, n. ${ }^{\circ} 5$.

RELATÓRIO da Comissão nomeada por Portaria de 25 de agosto de 1914, para proceder à escolha de propriedade onde possa funcionar o Posto Agrário da Região Duriense. «Boletim da Direcção Geral da Agricultura», $13 .^{\circ}$ ano, n. ${ }^{\circ} 4$. Coimbra: Imprensa da Universidade, 1916.

RELATÓRIO da Sindicância aos acontecimentos ocorridos em Lamego no dia 20 Julho de 1915, do juiz da comarca de Mogadouro, Dr. António Sérgio Carneiro. Semanário Lamacense «A Tribuna». Lamego: Tipografia de «A Tribuna», 1916.

\section{BIBLIOGRAFIA}

«A DEFESA do Douro». Peso da Régua: C. A. C. Frias, 1925.

AFONSO, Ana Maria (2003) - A Casa de Ribalonga no século XVII: a cultura da vinha no contexto do património rural e paisagem agrícola. «Revista População e Sociedade», n. ${ }^{\circ}$ 10, p. 73-291.

AGUIAR, Fernando Bianchi de (2002) - O Alto Douro Vinhateiro, uma paisagem cultural evolutiva e viva. «Douro: Estudos e Documentos», vol. 7, n. ${ }^{\circ}$ 13. Porto: GEHVID, p. 143-152.

coord. (2000) - Candidatura do Alto Douro Vinhateiro a Património Mundial. Porto: Fundação Rei Afonso Henriques. Disponível em: <http://www.ccdr-n.pt/sites/default/files/ficheiros_ccdrn/missaodouro/candidatura_adv_patrimonio_mundial. pdf $>$. [Consulta realizada em 8/5/2015].

ALBUQUERQUE, Maria Amélia Pires de (2012) - Santa Maria de Salzedas: espaço e poder. Tarouca: Câmara Municipal. ALLEN, H. Warner (1946) - Vinho do Porto, o vinho da filosofia. Porto: Instituto do Vinho do Porto. 
ALMEIDA, Alberto Francisco Ribeiro de (1999-2000) - Denominações geográficas e marca. Conferência no 2. ${ }^{\circ}$ curso de pós-graduação de Direito Industrial. Organização da Faculdade de Direito de Lisboa e Associação Portuguesa de Direito Intelectual.

(1999) - Denominação de origem e marca. Coimbra: Universidade de Coimbra.

ALMEIDA, Carlos A. Brochado de (2011-2012) - Estruturas vinárias da Lusitânia e Gallaecia meridional = Wine production structures in Lusitania and western Gallaecia. «De vino et oleo Hispaniae. AnMurcia», vol. 27-28, p. 485-494.

— coord. (2006) - História do Douro e do vinho do Porto: história antiga da região Duriense. Porto: Edições Afrontamento.

ALTO Douro Vinhateiro: Património Mundial: Paisagem Cultural, Evolutiva e Viva = Alto Douro Wine Region: World Heritage: Evolutive and Living Cultural Landscape (2006). Porto: Comissão de Coordenação e Desenvolvimento Região do Norte.

ALVES, Francisco Manuel (Abade de Baçal) (1983) - Os Fidalgos. [S.l.]: Tipografia Académica, p. 527 ss. (Memórias arqueológicas e históricas do distrito de Bragança, v. VI).

(2000) - Memórias Arqueológico-Históricas do distrito de Bragança. Bragança: Câmara Municipal de Bragança, Instituto Português de Museus - Museu Abade de Baçal. Disponível em <https://pt.scribd.com/doc/219407969/Tomo-VI-pdf>. [Consulta realizada em 7/9/2016].

AMORIM, Jaime Lopes (1947) - Aspectos do problema da protecção das marcas de origem vinícolas e sua evolução. Porto: Instituto do Vinho do Porto. Separata dos «Anais do Instituto do Vinho do Porto».

AMPUDIA de HARO, Fernando (2010) - As duas repúblicas: Portugal (1910-1926) e Espanha (1931-1936). Ensaio de interpretação sociológica comparada. "Comunicação \& Cultura», n.o 9. Disponível em <http://comunicacaoecultura.com.pt/wp-content/uploads/07.-Fernando-Ampudia-de-Haro.pdf >. [Consulta realizada em 03/02/2017].

ANDRESEN, Teresa [s.d.] - A paisagem do Alto Douro Vinhateiro: evolução e sustentabilidade. Disponível em <http://www.unizar. es/fnca/duero/docu/p315.pdf >. [Consulta realizada em 15/10/2013].

ANDRESEN, Teresa; REBELO, J. (2013) - Avaliação do Bem Alto Douro Vinhateiro - Paisagem Cultural Evolutiva. Porto: CCDRN/ EMD, CIBIO UP/UTAD, vol. I.

ANTUNES, Filipe Miguel Carvalho Pereira (2010) - A importância dos cavalheiros da indústria na internacionalização do Douro: the leading case: the Symington family estates. Braga: Universidade do Minho. Escola de Economia e Gestão. Dissertação de mestrado. Disponível em <https://repositorium.sdum.uminho.pt/bitstream/1822/12437/1/Filipe\%20Miguel\%20Carvalho\%20Pereira\%20Antunes.pdf $>$. [Consulta realizada em 03/01/2016].

ANTUNES, João Viana; FARIA, Pedro Baère de (2006) - O Povoamento antigo [Região Demarcada do Douro]. In ALMEIDA, A. Brochado de, coord. - História do Douro e do vinho do Porto: história antiga da região Duriense. Porto: Edições Afrontamento, vol. 1, p. 264-268.

«A REPÚBLICA», [S.1.]: [s.n.], 1915. Edições de 18 e 19 de julho.

ARRIGHI, Giovanni (1997) - A ilusão do desenvolvimento. Petrópolis: Vozes.

ARUTO, Pietro Caldeirini (2009) - O conceito de formação económico-social: uma revisão das abordagens marxistas recentes. Florianópolis: Universidade Federal de Santa Catarina. Disponível em <http://tcc.bu.ufsc.br/Economia291382>. [Consulta realizada em 27 de abril de 2017].

ATAS das 4. ${ }^{a s}$ Conferências do Museu de Lamego/CITCEM: Vindos de longe. Estrangeiros no Douro. Lamego: Museu de Lamego: DRCN, 2016.

«A TRIBUNA», Lamego, 1915. Edições de 25 de julho e 29 de agosto.

«A VINHA Portuguesa», ano 25, n. ${ }^{\circ}$ 4, 1910: 117-118.

AZEVEDO, Correia de [s.d.] - O Douro maravilhoso. [S.l.]: [s.n.].

BAKHTIN, Mikhail (1992) - Estética da criação verbal. São Paulo: Martins Fontes.

BARBOSA, Delfim Fernandes Moreira (2006) - O Sistema de Informação Geográfica e a atribuição do beneficio: a vinha na região demarcada do Douro. Lisboa: Universidade Nova de Lisboa. Dissertação de mestrado em Ciência e Sistemas de Informação Geográfica. Disponível em <http://run.unl.pt/bitstream/10362/3620/1/TSIG0021.pdf>. [Consulta realizada em 24/02/2014].

BARRETO, António (1993) - Douro. [S.n.]: Edições Inapa.

(1988) - O vinho do Porto e a intervenção do Estado. «Análise Social - Revista do Instituto de Ciências Sociais da Universidade de Lisboa», vol. XXIV, n. ${ }^{\circ}$ 100, p. 373-390. 
(2014) - Douro-rio, gente e vinho. Lisboa: Relógio d'Água.

BARRETO, António; CARVALHO, Manuel; MIRANDA, Adriano (2016) - O vinho no tempo da guerra. Porto: Público.

BARROS, Amândio Jorge Morais (2008) - Gastão Taborda (1917-1983) e a construção do Douro contemporâneo. Peso da Régua: Fundação Museu do Douro.

BENNETT, Norman R. (2010) - Os mecanismos de comercialização e as estratégias empresariais (1830-1908). In PEREIRA, Gaspar Martins, coord. - História do Douro e do Vinho do Porto. Crise e reconstrução: o Douro e o vinho do Porto no século XIX. Porto: Edições Afrontamento, vol. 4, p. 280-334.

BIEL, Emílio (2016) - O Douro do vinho na obra do fotográfo Emilio Biel. Porto: In Libris.

BOLTANSKI, Luc; THÉVENOT, Laurent (1991) - De la justification: les éconimies de la grandeur. Paris: Éditions Gallimard.

BOURDIEU, Pierre (1989) - O poder simbólico. Lisboa: Difel, p. 51-58.

(1993) - La misère du monde. Paris: Éditions du Seuil.

(1996) - A ilusão biográfica. In AMADO, Janaina \& FERREIRA, Marieta M., orgs. - Usos e abusos da história oral. Rio de Janeiro: Fundação Getúlio Vargas, p. 190-191.

BRADAFORD, Sarah (1983) - The story of Port: the Englishman's wine. New and revised edition. London: Christie's Wine Publications.

BURAWOY, Michael et al. (1991) - Ethnography Unbound. Berkeley: University of California Press.

BURAWOY, Michael (1998) - The Extended Case Method. «Sociological Theory», vol. 16, n. ${ }^{\circ}$ 1. [S.l.]: American Sociological Association, p. 4-33.

CABRAL, António (1999) - Antologia dos poemas durienses. Liboa: Ed. Tartaruga.

CABRAL, Carlos (2011) - Dicionário ilustrado do vinho do Porto. São Paulo: Ed. de Cultura.

CABRITA, Maria João; SILVA, Jorge Ricardo da; LAUREANO, Olga (2003) - Os compostos polifenólicos das uvas e dos vinhos. In I Seminário Internacional de Vitivinicultura. Disponível em <http://www.isa.utl.pt/riav/Pdf/Memoria\%20del\%20Seminario\%202003.3.pdf>. [Consulta realizada em 06/07/2106].

CARRAZEDA DE ANSIÃES. Câmara Municipal (2015) - Diagnóstico social de Carrazeda de Ansiães de 2014. Carrazeda de Ansiães: Câmara Municipal. Disponível em <http://www.cm-carrazedadeansiaes.pt/uploads/writer_file/document/1139/ Diagn_stico_Social_Carrazeda_de_Ansi_es.pdf $>$. [Consulta realizada em 13/03/2015].

CAPELA, José Viriato et al. (2007) - As freguesias do distrito de Bragança nas memórias paroquiais de 1758: memórias, história e património. [Braga]: J.V.C.

(2009) - As freguesias do distrito do Porto nas memórias paroquiais de 1758: memórias, história e património. [Braga]: J. V. C. Disponível em <http://repositorium.sdum.uminho.pt/bitstream/1822/11886/1/PORTO\%20Livro\%20das\%20Mem\%20 Paroq.pdf $>$.

CARDOSO, António Manuel de Barros (1996) - O alvará de instituição da Companhia e os motins do Porto de 1757. «Douro: Estudos e Documentos», vol. I, n.o 1. Porto: GEHVID, p. 55-76.

(1998) - O Douro estrada fluvial nos alvores do séc. XVIII. «Douro: Estudos e Documentos», vol. III, n. ${ }^{0}$ 5. Porto: GEHVID, p. 117-132.

(2004) - Os estrangeiros no Porto do vinho (século XVIII). «Douro: Estudos e Documentos», n. ${ }^{0}$ 17. Porto: GEHVID, p. 161-180.

(2007) - A investigação fundamental na História do Douro e do vinho do Porto: algumas linhas de rumo. «Douro: Estudos e Documentos», n. ${ }^{\circ}$ 22. Porto: GEHVID, p. 13-36. Disponível em <http://ler.letras.up.pt/uploads/ficheiros/9769.pdf >. [Consulta realizada em 16/09/2017].

CARDOSO, António Manuel Monteiro (2006) - O debate sobre a Companhia e as atitudes políticas no Douro (1820-1834). In PEREIRA, Gaspar Martins LEAL, Paula Montes, eds. - O Douro contemporâneo: actas. Porto: GEHVID, p. 39-53.

(2007) - A revolução liberal em Trás-os-Montes (1820-1834): o povo e as elites. Porto: Edições Afrontamento.

CARDOSO, José Luís et al. (2003) - O Tratado de Methuen (1703:) diplomacia, guerra, política e economia. Lisboa: Livros Horizonte.

CARNEIRO, Antório Sérgio (1916) - Relatório da Sindicância aos Acontecimentos Ocorridos e, Lamego no dia 20 de Julho de 1915. «A Tribuna». Lamego: A Tribuna. 
CARVALHAIS, Joaquim (1937) - Vinificação moderna: novo método de fabrico dos vinhos generosos da região do Douro. Régua: Imprensa do Douro.

CARVALHO, Manuel (2011) - Uma mulher de coragem. «Público». Disponível em <https://www.publico.pt/2011/07/03/jornal/ uma-mulher-de--coragem-22331112>. [Consulta realizada em 07/07/2011].

CASTELO, Cláudia (2014) - «Novos Brasis» em África: desenvolvimento e colonialismo português tardio. «Varia Hist.», vol. 30 , n. ${ }^{\circ} 53$.

CASTRO, Alberto Manuel Ochoa dos Santos (2013) - Aplicação de cinco índices bioclimáticos a algumas castas da região de vinho do Porto: estudo de caso em nove estações climatológicas. Porto: FLUP, p. 31-32 e 79. Dissertação de mestrado. Disponível em <https://sigarra.up.pt/flup/pt/pub_geral.show_file?pi_gdoc_id=488209>. [Consulta realizada em 02/01/2016].

CASTRO, Paulo Pizarro de [s. d.]: - História da Quinta de Lubazim. [S. 1.]: [s. n.].

(1998-1999) - Obras hospitalares portuguesas da Ordem de Malta. Filermo: Assembleia Portuguesa dos Cavaleiros da Ordem Soberana e Militar de Malta, separata do vol. 7-8.

(2015) - Momentos de Ventos. In CRUZ, Valdemar; MONTEIRO, Lucília, fot. - Reféns do Douro: documentário. «Revista Expresso", p. 17.

CATROGA, Fernando (1989) - O Laicismo e a Questão Religiosa em Portugal (1865-1911). «Análise Social», vol. XXIV, n. ${ }^{\circ}$ 100, p. 211-273.

(1991) - O republicanismo em Portugal: da formação ao 5 de Outubro. Coimbra: Faculdade de Letras da Universidade de Coimbra, 2 vols.

(2001) - Memória, história e historiografia. Coimbra: Quarteto.

CHARLESTON, José de Sousa Assis (2010) - Grande imprensa e lutas sociais: os jornais e os populares na revolta popular carioca de 1987. Disponível em <www.encontro2010.rj.anpuh.org/.../1276740123_ARQUIVO>. [Consulta realizada em 02/05/2013].

CHATEAURAYNAUD, Francis; BESSY, Christian (1995) - Experts et faussaires: pour une sociologie de la perception. Paris: Métailié. CLIFFORD, Geertz (2008) - A interpretação das culturas. Rio de Janeiro: LTC.

CLIFFORD, James; MARCUS, G. E., eds. (1981) - Retoricas de la Antropologia. Madrid: Ediciones Júcar.

CLIFFORD, James (1988) - The predicament of culture: twentieth century ethnography, literature and art. Cambridge: Harvard University Press.

CLUNY, Isabel (2009) - Joseph James Forrester, uma história do Douro. In O Barão de Forrester: razão e sentimento. Uma História do Douro (1831-1861). [Peso da Régua]: Museu do Douro. Disponível em <https://www.academia.edu/4975032/Joseph_ James_Forrester_uma_hist\%C3\%B3ria_do_Douro $>$. [Consulta realizada em 07/03/2015].

COIXÃO, António N. Sá; TRABULO, António A. Rodrigues (1985) - Banda Musical de Freixo de Numão, 1865-1985: 150 anos ao serviço da cultura. Subsídios para a história da colectividade. Guarda: Tipografia Veritas, p. 34-39; 49.

COLLOT, Michel et al. (1997) - La notion de paysage dans la critique thématique. In COLLOT, Michel, dir. - Les enjeux du paysage. Bruxelles: Ousia.

CONDE, Bartolomeu (1997) - Cacia e Baixo Vouga - Apontamentos históricos e Etnográficos. Aveiro: Câmara Municipal, p. 61-63, apud Museu de Aveiro.

CORDEIRO, Alcino (1941) - Quintas do Douro. Régua: Imprensa do Douro.

CORDEIRO, Menezes (2008) - Da enfiteuse: extinção e sobrevivência. «O Direito», n. ${ }^{0}$ 140, vol. II. [S.1.]: Almedina, p. 285-315.

CORREIA, João de Araújo (1977). Pátria pequena. Régua: Imprensa do Douro Editora.

COSTA, Antonieta (2013a) - O Outeiro das Pedras na perspetiva da paisagem cultural. Disponível em <http://esquilo-pt.blogspot. pt/2013_04_01_archive.html>. [Consulta realizada em 30/04/2013].

(2013b) - The mound of stones. [S.1.]: Lambert Academic Publishing.

COSTA, A. L. Pinto da (1977) - O abandono da prática religiosa como protesto social. O caso dos jornaleiros alto-durienses no primeiro terço do séc. XX. «Douro - Estudos \& Documentos». Porto: Faculdade de Letras da Universidade do Porto, vol. II, n. ${ }^{0} 4$, p. 287-296.

CRISTO, Alexandre Homem (2011) - O conceito de 'República' na historiografia da I República portuguesa (1910-1926) desde 1974. Lisboa: Universidade de Lisboa. Instituto de Ciências Sociais. Dissertação de Mestrado. Disponível em <http://repositorio.ul.pt/bitstream/10451/4107/1/ahc-TESE-final.pdf>. [Consulta realizada em 09/12/2016]. 
CRUZ, João Lopes da (1906) - Construcção do Caminho de Ferro de Mirandella a Bragança. Como a vaidade, egoismo e ambição dos directores da Companhia Nacional de Caminhos de Ferro, acarreta a ruina ao empreiteiro geral, deixando-o reduzido á miseria. Justificação dos meus actos e appêllo aos dignos accionistas da Companhia. Lisboa: Tipografia A Publicidade.

CRUZ, Valdemar; MONTEIRO, Lucília, fot. (2015) - Reféns do Douro: documentário. «Revista Expresso», p. 3. Edição relativa a agosto de 2015.

CRUZEIRO, Maria Manuela (2007) - Pela História Oral. «Passado/Presente: a construção da memória no período contemporâneo». Disponível em <https://ppresente.wordpress.com/textos/pela-historia-oral/>. [Consulta realizada em 08/03/2011].

CUNHA, Kassia Fernandes da (2010) - Paisagens na poética de Jorge de Sena: Peregrinação, visão de mundo e testemunho. Niteroi: Universidade Federal Fluminense. Dissertação de mestrado. Disponível em <http://www.gtestudosdepaisagem.uff.br/ wp-content/uploads/2012/09/Disserta\%C3\%A7\%C3\%A3o-Kassia-Fernandes-da-Cunha.pdf-1.pdf >. [Consulta realizada em 14/10/2013].

DELAFORCE, John (1983) - The Factory House at Oporto. London: Christie's Wine Publications.

DELGADO, Lucília de Almeida Neves (2003) - História oral e narrativa: tempo, memória e identidades. «História Oral», n. ${ }^{\circ} 6$. [S.l.]: Associação Brasileira de História Oral, p. 9-25. Disponível em <https://moodle.ufsc.br/pluginfile.php/819734/ mod_resource/content/1/DELGADO\%2C\%20Lucilia\%20\%E2\%80\%93\%20Hist\%C3\%B3ria\%20oral\%20e\%20narrativa.pdf> [Consulta realizada em 20/1/2017].

DELEUZE, G.; GUATTARI, F. (1996) - Mil Platôs. Capitalismo e esquizofrenia. Rio de Janeiro: Ed 34, vol. 2.

«DIÁRIO do Governo», n. 74: 989. Lisboa, 1907.

DIAS, Geraldo Amadeu Coelho; DUARTE, Luís Miguel, coord. (1999) - Cister no Vale do Douro. Porto: GEHVID.

DIAS, Geraldo J. A. Coelho (2005) - A importância dos mosteiros no mundo do vinho. «Douro: Estudos e Documentos», n. ${ }^{\circ} 20$. Porto: GEHVID. Disponível em <http://ler.letras.up.pt/uploads/ficheiros/9735.pdf>. [Consulta realizada em 16/9/2017].

DORES, António Pedro [s.d.] - Refazer a sociologia, recensão de um trabalho de Bruno Latour. Disponível em <iscte.pt/ apad/ estesp/bibliografia/Latour\%20ideologia.doc $>$. [Consulta realizada em 24/4/2017].

DOURO Reserva Histórica é o Vinho do Porto: Fotografias do espólio Foto Beleza. Porto: Palácio da Bolsa, 2006. Catálogo de Exposição Comemorativa dos 250 anos da Região Demarcada do Douro.

DUGUID, Paul (2005) - Networks and knowledge: the beginning and end of the Port commodity chain, 1703-1860. «The Business History Review», vol. 79, n. ${ }^{\circ}$ 3. p. 493-526. Disponível em <http://people.ischool.berkeley.edu/ duguid/articles/N_ and_K.pdf $>$. [Consulta realizada em 03/05/2013].

(1996) - Lavradores, exportadores, intermediários e capitalistas: componentes da Região do vinho do Porto. «Douro: Estudos e Documentos», vol. I, n. ${ }^{\circ}$ 2. Porto: GEHVID, p. 201-224. Disponível em <http://ler.letras.up.pt/uploads/ficheiros/9324. pdf $>$. [Consulta realizada em 16/9/2017].

ESTEVES, Francisco (2008) - Vinhos do Douro. Lisboa: Colares Editora.

FARINHA, João Carlos (2015) - A cultura da vinha em Portugal e as consequências da adesão à União Europeia: caso de estudo: a Região Demarcada do Douro. Lisboa: Universidade Nova. Dissertação de mestrado em Gestão do Território. Disponível em <https://run.unl.pt/bitstream/10362/16155/1/Dissertação\%20FINAL.pdf>. [Consulta realizada em 20/02/2016].

FARINHA-MARQUES, Paulo; FERNANDES, Cláudia (2014) - Avaliação do património vegetal natural do Alto Douro Vinhateiro 2001 -2012. «GOT - Geografia e Ordenamento do Território», n. ${ }^{\circ}$ 5. Porto: Faculdade de Letras da Universidade do Porto. Centro de Estudos em Geografia e Ordenamento do Território.

FAUVRELLE, Natália (2001) - Quintas do Douro. As arquitecturas do vinho do Porto. Porto: GEHVID/Câmara Municipal de S. João da Pesqueira.

(2007) - Formas de armação do terreno no Alto Douro Vinhateiro: protecção e gestão da paisagem. «Revista População e Sociedade», n. ${ }^{\circ}$ 13, p. 87-96. Disponível em <http://www.cepese.pt/portal/investigacao/publicacoes/13revista.pdf > . [Consulta realizada em 15/08/2013].

(2014) - As quintas vinhateiras na construção do património paisagístico do Douro. «Atas das $2^{\text {as }}$ Conferências do Museu de Lamego/CITCEM», p. 35-51. Disponível em <https://issuu.com/066239/docs/conferenciasmuseulamego_atas_2014>. [Consulta realizada em 02/12/2014]. 
FERNANDES, A. Almeida (1973) - Acção dos Monges Cistercienses de Tarouca. «Revista de Guimarães», n. ${ }^{8}$ 83. Guimarães: Casa de Sarmento.

FERNANDES, Mário G.; MARQUES, Hélder (2011) - Mapas da territorialização vitícola portuguesa (1865-1908). «IV Simpósio Luso-Brasileiro de Cartografia Histórica». Porto: Universidade do Porto. Disponível em <http://eventos.letras.up.pt/ivslbch/comunicacoes/115.pdf >. [Consulta realizada em 23/9/2017].

FERNANDES, Rui (1824) - Descrição do terreno em roda da cidade de Lamego, duas léguas... 1532. Lisboa: Academia Real das Ciências, p. 553. (Inéditos de História Portuguesa, t. V).

FERREIRA, Marieta de Moraes; AMADO, Janaína (2002) - Usos e abusos da História oral. Rio Janeiro: FGV.

FIGUEIREDO, Fernando Augusto (2017) - Carrazeda de Ansiães: um município do Douro. Estudo sobre o concelho. Lisboa: Âncora Editora.

FIGUEIREDO, Fernando (2012) - Pedaços de História: a Quinta da Sra. da Ribeira, os Symington e o vinho do Porto. «Pombal», p. 5. Disponível em <http://arcpa.pt/login/upload/produtos/pdf/jornal_set_2012_net_version.pdf >. [Consulta realizada em 06/12/2012].

FILGUEIRAS, Octávio Lixa (1957) - Os povos germânicos e a navegação do Douro. «Boletim Cultural da Câmara Municipal do Porto», vol. XX, fasc. 1-2. Porto: Câmara Municipal, p. 6.

FONSECA, Álvaro Baltasar Moreira da (1949-1951) - As demarcações pombalinas do Douro vinhateiro. Porto: Instituto do Vinho do Porto. 3 vols.

(1996) - As demarcações marianas no Douro vinhateiro. Porto: Instituto do Vinho do Porto.

FORRESTER, Joseph James (1846) - Second representation made by Offley, Webber \& Forrester of Oporto... Oporto: Commercial Printing Office.

FOUCAULT, Michel (1991) - Tecnologías del yo y otros textos afines. Barcelona: Paidós Ibérica.

FRIEDMAN, Jonathan (1997) - Identity and Global Process. London: Sage, p. 140.

GARCIA, João Carlos dos Santos; BRANCO, Didiana (2009) - Oporto wine in maps (1843-1860): a cartografia inglesa do Douro. «III Simpósio Luso-Brasileiro de Cartografia histórica». Ouro Preto: Universidade Federal.

GIBBONS, John (1984) - Não criei musgo: retrato de uma aldeia transmontana. Carrazeda de Ansiães: Câmara Municipal.

(2004) - Não criei musgo: retrato de uma aldeia transmontana. Carrazeda de Ansiães: Câmara Municipal.

GILLIS, John (1994) - Memory and identity: the history of a relationship. "Commemorations. The Politics of National Identity». New Jersey: Princeton University Press.

GRÉMIO DOS EXPLORADORES DO VINHO DO PORTO (1934) - Lista oficial dos exportadores de vinho do Porto. Porto: [GEVP].

GRÉMIO DOS EXPLORADORES DO VINHO DO PORTO (1935) - Lista oficial dos exportadores de vinho do Porto. Porto: GEVP. GRÉMIO DOS EXPLORADORES DO VINHO DO PORTO (1939) - Liste des exportateurs de vin de Porto... extraite de la Liste Officielle des Exportateurs de Vin de Porto. Porto: GEVP.

GRÉMIO DOS EXPLORADORES DO VINHO DO PORTO (1940) - Liste des exportateurs de vin de Porto... extraite de la Liste Officielle des Exportateurs de Vin de Porto. Porto: GEVP.

GRÉMIO DOS EXPLORADORES DO VINHO DO PORTO (1941) - Liste des exportateurs de vin de Porto... extraite de la Liste Officielle des Exportateurs de Vin de Porto. Porto: GEVP.

GRÉMIO DOS EXPLORADORES DO VINHO DO PORTO (1948) - Lista oficial dos exportadores de vinho do Porto. Porto: GEVP. GRÉMIO DOS EXPLORADORES DO VINHO DO PORTO (1958) - Lista oficial dos exportadores de vinho do Porto. Porto: GEVP. GRÉMIO DOS EXPLORADORES DO VINHO DO PORTO (1960) - Lista oficial dos exportadores de vinho do Porto. Porto: GEVP. GRÉMIO DOS EXPLORADORES DO VINHO DO PORTO (1963) - Lista oficial dos exportadores de vinho do Porto. Porto: GEVP. GRÉMIO DOS EXPLORADORES DO VINHO DO PORTO (1966) - Lista oficial dos exportadores de vinho do Porto. Porto: GEVP. GRÉMIO DOS EXPORTADORES DE VINHO DO PORTO (1948) - Álbum comemorativo da sua instalação definitiva no Palácio da Associação Comercial do Porto. [S. 1.]: GEVP.

GRENDI, Edoardo (2009) - Microanálise e História Social. In Oliveira, M. R. de; ALMEIDA, C., org. - Exercícios de micro-história. Rio de Janeiro: Editora da FGV, p. 27-30.

GUIMARÃES, Agostinho Fernandes (1947) - Notas para uma cronologia do vinho do Porto. «Anais do Instituto do Vinho do Porto». 
GUIMARÃES, Susana (2001) - Prontuário histórico do vinho do Porto. [S. 1.]: Gabinete de História e Arqueologia de Vila Nova de Gaia.

GINZBURG, C.; PONI, C. - O nome e o como: troca desigual e mercado historiográfico. In GINZBURG, C. - A micro-história e outros ensaios. Lisboa: Difel; Rio de Janeiro: Bertrand Brasil, 1989, p. 169-178.

HALBWACHS, Maurice (1994) - Les cadres sociaux de la mémoire. Paris: Albin Michel.

HALL, Stuart (2006) - A identidade cultural na pós-modernidade. Rio de Janeiro: DP\&A.

HARAWAY, Donna J. (1991) - Situated knowledges: the science question in feminism and the privilege of partial perspective. In HARAWAY, Donna J. - Symians, cyborgs and women: the reinvention of nature. New York: Routledge.

HARAWAY, Donna J. (1995) - Saberes localizados: a questão da ciência para o feminismo e o privilégio da perspectiva parcial. «Cadernos Pagu», n. ${ }^{\circ}$. Campinas: Núcleo de Estudos de Género da Universidade Estadual de Campinas, p. 7-41.

[HISTÓRIA DO VINHO DO PORTO]. Disponível em <https://www.taylor.pt/pt/o-que-e-o-vinho-do-porto/a-regiao-dodouro/solo-e-clima $>$ e $<$ http://www.fonseca.pt/pt/as-vinhas/o-vale-do-douro/história/>.

HESÍODO (2012) - Os trabalhos e os dias. Edição, tradução, introdução e notas de Alessandro Rolim de Moura. Curitiba: Segesta. Disponível em <http://www.segestaeditora.com.br/download/ostrabalhoseosdias.pdf >. [Consulta realizada em 10/12/2016.]

HOMENAGEM a José António Ramos-Pinto Rosas, «Douro: Estudos e Documentos», p. 9-17. Disponível em <http://ler.letras. up.pt/uploads/ficheiros/9301.pdf> [consulta 30/9/2017].

O VINHO do Porto. 2. ${ }^{\text {a }}$ ed. Peso da Régua: Instituto do Vinho do Porto, 1937.

LAGE, Maria Otília Pereira (1995) - Comunidade e Fábrica: na linha de fronteira tradição e inovação. Um caso no modo português de industrialização. Braga: Universidade do Minho. Dissertação de mestrado.

(2002) - Wolfram=Volfrâmio: Terra revolvida, memória revolta. Para uma análise transversal da sociedade portuguesa (1930-1960). Guimarães: UM-CIS/NEPS.

(2009a) - De «vinho fino» a 'Port Wine’: Integração de Carrazeda de Ansiães (1907-1908) na Região Demarcada do Douro. Representações e identidades 'conjunturais', na 1. ${ }^{a}$ República. Porto. XXIX Congresso da Associação de História Económica e Social.

(2009b) - Para a sócio-história da indústria mineira em Portugal: fontes e metodologias - um estudo de caso alargado sobre a exploração de volfrâmio em Trás-os-Montes. In Moncorvo. Da Tradição à Modernidade. Porto: CEPESE/Edições Afrontamento, p. 221-248.

(2010a) - A Quinta dos Canais, no Douro Património Mundial. «I Encontro do CITCEM». Guimarães: CITCEM/UM.

(2010b) - Empresa Metalúrgica da Longra, um caso no modo português de industrialização: estudo sob 'os regimes de acção'. «Revista da Faculdade de Letras - História», III série, vol. 11. Porto: Faculdade de Letras da Universidade do Porto, p. 339-360.

(2011) - A Quinta dos Canais, na Região Demarcada do Douro. Lisboa: Universidade Nova. Primeiro Encontro RuralRePort.

(2012a) - O tempo dos lugares. Carrazeda de Ansiães e Torre de Moncorvo na I República. «Revista CEPIHS», n. 2 . Moncorvo: Câmara Municipal, p. 311-337.

(2012b) - O Foral Manuelino de Ansiães (1512). Carrazeda de Ansiães: Câmara Municipal.

(2012c) - Construção de materiais da memória na Região Demarcada do Douro: narrativas orais de antigos trabalhadores da Quinta dos Canais. «Revista CEM - Cultura, Espaço e Memória», n. 2. Porto: Centro de Investigação Transdisciplinar Cultura, Espaço e Memória, p.51-74.

(2013a) - Visconde de Vila Maior: figura histórica de elevado capital simbólico-social na política e na ciência. Perfil bio-bibliográfico. «Revista CEPIHS», n. ${ }^{\circ}$ 3. Moncorvo: Câmara Municipal, p. 11-17.

(2013b) - O Douro Ilustrado do Visconde de Vila Maior, homem de ciência, cultura e ação (século XIX). «Revista CEPIHS», n. ${ }^{\circ}$ 3. Moncorvo: Câmara Municipal, p. 103-121.

(2013c) - Revoltas Populares no Douro Vinhateiro (Carrazeda de Ansiães e Lamego), no final da Monarquia e início da República: representações sociais e identidades a partir da imprensa da época. "Atas das 1as Conferências do Museu de Lamego/ CITCEM». Lamego: CITCEM/Museu de Lamego, p. 21-229.

(2013d) - O Velho a Chave e o Castelo: Carrazeda d'e Ansiães na História. Carrazeda de Ansiães: Câmara Municipal.

(2014) - Dos arquivos particulares, património a preservar, à história da Quinta da Alegria de Cima (Carrazeda de Ansiães 1920 -2014). «Atas das 2as Conferências do Museu de Lamego/CITCEM». Lamego: CITCEM/Museu de Lamego, p. 131-139. 
(2016) - Gigantes do Douro, memória e património histórico: Lutas em defesa da Região Vinhateira (séculos XIX-XX). «Atas das 3as Conferências do Museu de Lamego/CITCEM». Lamego: CITCEM/Museu de Lamego.

LAGE, Maria Otília Pereira; LAGE, Jorge M. B. (2005) - 'SABER SEVER': Geios de escrita e história (St. ${ }^{\circ}$ Adrião de Sever, 1950-1960). Porto: GEHVID-FLUP. Atas do II Encontro Internacional da História do Vinho e da Vinha.

LATOUR, Bruno (1999) - On recalling ANT. In LAW, J.; Hassard, J. eds. - Actor network theory and after. Oxford: Blackwell Publishers, p. 15-25.

(2005) - Re-assembling the social. An introduction to Actor-Network Theory. Oxford: Oxford University Press.

(2007) - Changer de société, refaire de la sociologie. Paris: La Découverte.

LATOUR, Bruno; HERMANT, Emilie (1998) - Paris Ville Invisible. Le Plessis-Robinson Institut Synthélabo. Paris: La Découverte, p. 35.

LEITÃO, Luíz Veiga (1944) - Dominadores sem domínios. «Região do Douro» (Régua, outubro 1943). In CORDEIRO, Alcino, ed. - Publicação dedicada à Casa do Douro, por ocasião da inauguração do seu edifício-sede. Régua: Imprensa do Douro.

LEITÃO, Pedro Almeida (2013) - «Please call me Co’burn» - A Cockburn Smithes e a marca «Special Reserve» no mercado inglês de vinho do Porto (1962-1976). Porto: Faculdade de Letras da Universidade do Porto. Disponível em <https://www.academia.edu/13279301/_Please_call_me_Coburn_A_Cockburn_Smithes_e_a_marca_Special_Reserve_no_mercado_ingl\%C3\%AAs_de_vinho_do_Porto_1962-1976>. [Consulta realizada em 02/02/2015].

LEMOS, Francisco Sande (1993) - Povoamento romano de Trás-os-Montes oriental. Braga: Universidade do Minho.

LEMOS, João Pereira de (1997) - Uma pequena Nota Sobre a Condessa de Tabueira - Dona Maria Aurora Muños. «SAL - Boletim Municipal de Cultura». Aveiro: Câmara Municipal, p. 104.

LENCASTRE, José de (1953) - A Vitivinicultura através de alguns documentos medievais de Arquivos Portugueses (Séc. IX a XV). Porto: Anais do Instituto do Vinho do Porto.

LEONTIEV, A. (1978) - O desenvolvimento do psiquismo. [S.l.]: [S.n.].

LEPETIT, Bernard (1996) - De l'echelle en histoire. In J. Revel, dir. - Jeux d' echelles. La micro-analyse à l'expérience. Paris: Gallimard. «LES CAHIERS - Science \& Vie», n. ${ }^{0} 140,2013$. Paris: [S.n.]

LEVI, Giovanni (1989) - Les usages de la biographie. «Annales. Économies, Sociétés, Civilisations», ano 44, n. 6, p. 1325-1336.

LIDDELL, Alex; PRICE, Janet (1992) - Port wine Quintas of the Douro. London: Sotheby's Publications.

LOPES, Teresa Silva (1998) - Internacionalização do vinho do Porto: 1945-1995. Porto: GEHVID/ICEP.

(2003) - Os mercados do vinho do Porto. In PEREIRA, Gaspar Martins, coord. - O vinho do Porto. Porto: IVDP, p. 131-149.

(2004) - Institutions, leadership and long-term survival. Disponível em <http://www.econ.upf.edu/ebha2004/papers/1A1. pdf $>$. [Consulta realizada em 20/02/2016].

LOUREIRO, Joana - O Douro parado no tempo, nas imagens do século XIX de Emilio Biel. «VisãoSete». Disponível em <http:// visao.sapo.pt/actualidade/visaose7e/livros-e-discos/2016- 12-26-O-Douro-parado-no-tempo-nas-imagens-do-sec.-XIXde-Emilio-Biel>. [Consulta realizada em 16/9/2017].

MAALOUF, Amin (2003) - In the Name of Identity. London: Penguin Books.

MACEDO, Jorge Borges de (1982) - A situação económica no tempo de Pombal. 2. a ed. Lisboa: Moraes Editores.

MACHADO, J. T. Montalvão (1970) - Dos Pizarros de Espanha aos de Portugal e Brasil: História e genealogia. Lisboa: Editorial Franciscana.

MAGALHÃES, Nuno Pizarro de Campos (2014) - O papel e importância das «QUINTAS» na investigação e desenvolvimento da vitinicultura duriense. In Actas das II Conferências Museu de Lamego/CITCEM. Disponível em <http://www.museudelamego. pt/wp-content/uploads/2013/10/2\%C2\%AAs-Atas-do-Museu-de-Lamego-PDF.pdf >. [Consulta realizada em 04/12/2014]. (2015) - Tratado de Viticultura - A videira, a vinha, o «terroir». Nova edição revista e atualizada. Lisboa: Esfera Poética.

MAIO, Vânia Dinis de Jesus (2009) - Arquivo da Casa dos Barros (1753-1955): Reconstituição da Memoria. Porto: Faculdade de Letras da Universidade do Porto, p. 50-51 ss. Disponível em <https://repositorio-aberto.up.pt/bitstream/10216/20192/3/ mestvaniamaioarquivoanexos000084622.pdf $>$. [Consulta realizada em 18/9/2017].

MANUAL de Boas Práticas Vitícolas: região demarcada do Douro, [2010], p. 28. Disponível em <http://www.ivdp.pt/pt/docs/SUVIDUR/MBP_(vs_integral).pdf $>$. [Consulta realizada em 18/9/2017].

MARQUES, Ana Cristina (2015) - Sabe como se faz o vinho do Porto? «Observador» [Online]. Disponível em <https://observador. pt/2015/1003/sabe-vinho-do-porto/>. [Consulta realizada em 18/04/2017]. 
MARQUES, Hélder; FERNANDES, Mário G. (2011) - Mapas da territorialização vitícola portuguesa (1865-1908). «IV Simpósio Luso-Brasileiro de Cartografia Histórica». Porto: Universidade do Porto. Disponível em <http://www.cegot.pt/Files/ Downloads/Documentos-Publicos/Publicacoes/Grupo-3/B\%20-\%20Internacional/3\%20-\%20AtasEncontrosCientificos/5.pdf $>$. [Consulta realizada em 8/1/2015].

MARTINS, Conceição Andrade (1988) - Os ciclos de vinho do Porto: ensaio de periodização. «Análise Social - Revista do Instituto de Ciências Sociais da Universidade de Lisboa», vol. XXIV, n. ${ }^{\circ}$ 100. Lisboa: Universidade de Lisboa p. 391-429.

dir. (1990) - Memória do vinho do Porto. Lisboa: ICS-UL.

(1991) - A filoxera na viticultura nacional. «Análise Social - Revista do Instituto de Ciências Sociais da Universidade de Lisboa», vol. XXVI, n. ${ }^{\circ} 112-113$. Lisboa: Universidade de Lisboa.

(1996) - A intervenção política dos vinhateiros no séc. XIX. «Análise Social - Revista do Instituto de Ciências Sociais da Universidade de Lisboa», vol. XXXI, n. ${ }^{\circ}$ 136-137. Lisboa: Universidade de Lisboa, p. 413-435.

(2008a) - A «era de progresso» da viticultura nacional. In CABRAL, M. V., WALL, K., ABOIM, S., SILVA, F. C. da, org. - Itinerários: a investigação nos 25 anos do ICS. Lisboa: Imprensa de Ciências Sociais, p. 77-79. Disponível em <http://www.ics. ul.pt/rdonweb-docs/Concei\%C3\%A7\%C3\%A3o\%20Andrade\%20Martins\%20-\%20Publica\%C3\%A7\%C3\%B5es\%20 2008\%20n\%C2\%BA2.PDF>. [Consulta realizada em 03/01/2012].

(2008b) - Forrester e o retorno ao velho método de fazer vinho do Porto. Disponível em <http://www.ics.ul.pt/rdonweb-docs/ Concei\%C3\%A7\%C3\%A3o\%20Andrade\%20Martins\%20-\%20Publica\%C3\%A7\%C3\%B5es\%202008\%20n\%C2\%BA1. PDF $>$. [Consulta realizada em 07/03/2016].

MARTINS, J. Carlos L, BELFO, Fernando [2011] - Métodos de Investigação Qualitativa: Estudos de casos em investigação nos sistemas de informação. «Proelium -Revista da Academia Militar», n. ${ }^{\circ}$ 14. Lisboa: Academia Militar, p. 39-71.

MARX, K. (1962) - Nachwort zur zweiten Auflage zu Das Kapital. In: Marx/Engels, Werke (MEGA). Berlin: Dietz Verlag, vol. 23.

MATOS, Fátima Loureiro de (2012) - A paisagem Duriense a partir de uma obra de John Gibbsons. «Revista da Faculdade de Letras - Geografia», III série, vol. I. Porto: Faculdade de Letras da Universidade do Porto, p.59-73.

MATTOS, Armando de (1940) - O barco rabelo. Porto: Tipografia Sequeira.

MAYSON, Richard [1998] - The story of Dow's Port 1798-1998. [S. 1.]: Segrave Foulkes Publishers.

(1999) - Port and the Douro. London/New York: Faber \& Faber.

(2013) - Cockburn's Vintage Port 1896-2007. «The World of Wine», n. ${ }^{\circ} 3$, p. 64-65.

MELO, Fernando; CASTRO, Leonel, fot. (2012) - O vinho os uniu. «Diário de Noticias». Edição de 13 de abril de 2012.

MENDES, José Amado (2001-2002) - Arquivos empresariais: história, memória e cultura de empresa. «Revista Portuguesa de História», tomo XXXV, p. 379-388.

MENDES, José Manuel de Oliveira [s.d.] - Solidamente ancorados: a dignidade e o reconhecimento como recursos identitários. «IV Congresso Português de Sociologia». Disponível em <http://www.aps.pt/cms/docs_prv/docs/DPR462dc720a1251_1. PDF $>$. [Consulta realizada em 12/5/2017].

(1996) - O regionalismo como construção identitária. O caso dos Açores. «Revista Crítica de Ciências Sociais», n. ${ }^{0} 45$. Coimbra: CES, p. 127-142.

(2003) - Perguntar e observar não basta é preciso analisar: algumas reflexões metodológicas. Coimbra: Centro de Estudos Sociais da Universidade de Coimbra, Oficina n. ${ }^{\circ}$ 194. Disponível em <http://www.ces.uc.pt/publicacoes/oficina/194/194. pdf> [Consulta realizada em 20/11/2011].

(2005) - Perguntar e observara não basta, é preciso analisar: algumas reflexões metodológicas. Disponível em <http://www.ces. uc.pt/publicacoes/oficina/ficheiros/194.pdf>. [Consulta realizada em 02/06/2012].

MENDES, Manuel (1964) - Roteiro sentimental: Douro. 2.a ed. Lisboa: Sociedade de Expansão Cultural.

MENEZES, Cordeiro (2008) - Da enfiteuse: extinção e sobrevivência. «O Direito», n. ${ }^{\circ}$ 140. Lisboa: [s.n.], p. 285-315.

MONTEIRO, Manuel (1911) - O Douro: principais quintas, navegação, culturas, paisagens e costumes. Porto: Emílio Biel \& Ca.

(1998) - O Douro: principais quintas, navegação, culturas, paisagens e costumes. Lisboa: Livro Branco.

MORAIS, Cristiano (2006) - Por terras de Ansiães: Monografias. Carrazeda de Ansiães: Câmara Municipal, vol. II.

(2014) - Por terras de Ansiães. Carrazeda de Ansiães: Câmara Municipal, vol. II. 
MORAIS, João Pina de (2003) - No Douro. In MORAIS, Pina - Sangue plebeu. 2. a ed. Lamego: Museu do Douro; Câmara Municipal de Lamego. 1. ${ }^{\mathrm{a}}$ ed. 1942.

MOREIRA, Vital (1994) - Associações públicas e auto-regulação profissional. A casa do Douro. Coimbra. Edição de Autor: vol.I, p. 259-282. Obra com dois volumes.

(1996) - Nas origens da Casa do Douro. «Douro: Estudos e Documentos», vol. 1, n. o 1. Porto: GEHVID, p. 77-94.

(1998) - O governo de Baco: a organização institucional do vinho do Porto. Porto: Edições Afrontamento.

MOSCOVICI, S. (2003) - Representações Sociais: Investigações em Psicologia Social. Petrópolis, Rio de Janeiro: Vozes.

MOTA, Guilhermina (2012) - O Visconde de Vila Maior: alguns apontamentos sobre a sua vida e ação. «Biblos - Revista da Faculdade de Letras da Universidade de Coimbra», vol. X. Coimbra: Faculdade de Letras da Universidade de Coimbra. Disponível em <http://hdl.handle.net/10316.2/32302>. [Consulta realizada em 02/02/2016].

NOGUEIRA, Mónica Celeida Rabelo (2009) - Gerais a dentro e a fora: identidade e territorialidade entre Geraizeiros do Norte de Minas Gerais. Brasília: Universidade de Brasília.

NOGUEIRA, Paulo (2014) - Histórias com história na região demarcada do Douro. Disponível em < http://historiaschistoria.blogspot.pt/2015/10/a-regiao-demarcada-do-douro.html>. [Consulta realizada em 02/10/2015].

NOIRIEL, Gérard (2006) - Introduction à la sócio-historie. Paris: La Découverte.

NORA, Pierre (1984) - Les lieux de mémoire. Paris: Gallimard.

NUNES, João Arriscado (1998) - A ciência dos recursos naturais e a reconstrução da Economia: zonas de transacção e objectos de fronteira. Coimbra: CES.

NUNES, João Arriscado (1993) - Erving Goffman. A análise de quadros e a sociologia da vida quotidiana. «Revista Crítica das Ciências Sociais», n. ${ }^{\circ}$ 37. Coimbra: CES, p. 22-49.

(1995) - Reportórios, configurações e fronteiras sobre cultura, identidade e globalização. Coimbra: CES.

(1996) - Escala, heterogeneidade e representação... «Revista Crítica das Ciências Sociais», n. o 46. CES p. 9-46.

OLIVEIRA, António Braz de; MARINHO, Maria José (1983) - Devassa a que mandou proceder Sua Majestade no Território do Alto Douro pelo Desembargador António de Mesquita e Moura. Lisboa: Biblioteca Nacional.

OLIVEIRA, Aurélio (2006) - As áreas vinhateiras nacionais. As demarcações naturais e administrativas. «Douro: Estudos e Documentos», vol. 12, n. ${ }^{2}$ 21, p. 155-173. Disponível em <http://ler.letras.up.pt/uploads/ficheiros/9753.pdf>. [Consulta realizada em 20/09/2012].

OLIVEIRA, Fernando de (1930) - O motim popular de 1757. Uma página na história da época pombalina. Porto: Instituto de Estudos Históricos.

«O MONTANHÊS do Norte», n. ${ }^{\circ}$ 1. Bragança: [s.n.], 1912.

«O NORDESTE». [S.l.]: [s.n.], 1910. Edição de 22 de abril.

«O PRIMEIRO de Janeiro». Porto: O Primeiro de Janeiro, 1909. Edição de fevereiro.

«O TRANSMONTANO», n. ${ }^{\circ} 1$ a n. ${ }^{\circ}$ 23. Carrazeda de Ansiães: [s.n.], 1911.

«O VILLAREALENSE, Folha Regeneradora», ano 31, n. ${ }^{\circ} 4$. Vila Real: [s.n.],1910.

PARKHURST, Shawn (1997) - Produção de identidade no Alto Douro. «Douro: Estudos e Documentos», vol. 1, n. o 3. Porto: GEHVID, p. 183-191.

(1996) - A região na aldeia: uma etnografia sobre a produção local de Regionalidade no Alto Douro. «Douro: Estudos e Documentos», vol. 1, n. ${ }^{o}$ 1, p. 119-175. Disponível em <http://ler.letras.up.pt/uploads/ficheiros/9293.pdf>. [Consulta realizada em $02 / 02 / 2010]$.

(2004) - Identidade e contextos de identificação regional na zona do vinho do Porto. «VIII Congresso Luso-Afro-Brasileiro de Ciências Sociais». Coimbra: CES.

PATRIMÓNIO Mundial UNESCO: Alto Douro Vinhateiro. (2015). Disponível em <http://www.sabrosa.pt/turismo/douro/index. php?idioma $=$ pt $>$. [Consulta realizada em 01/05/2015].

PEIXOTO, Fernando Aníbal Costa (2001) - A Casa do Douro como resultante da vitivinicultura duriense. «Douro: Estudos e Documentos», vol. VI, n. ${ }^{\circ}$ 11. Porto: GEHVID, p. 197-211.

(2011) - Do corporativismo ao modelo interprofissional: o Instituto do Vinho do Porto e o sector do vinho do Porto (1933-1995). Porto: CITCEM/Edições Afrontamento. 
PEIXOTO, Paulo (2000) - O património mundial como fundamento de uma comunidade humana e como recurso das culturas industriais urbanas. Coimbra: CES. Disponível em < www.ces.uc.pt/publicaçoes/oficina/ficheiros/155pdf $>$. [Consulta realizada em 14/06/2013].

PEREIRA, António Luís; LOPES, Isabel Alexandra Justo (2005) - Património arqueológico do concelho de Carrazeda de Ansiães. Carrazeda de Ansiães: Câmara Municipal.

PEREIRA, Gaspar Martins [s.d.] - História. Porto: um vinho com história. Sítio do Instituto dos Vinhos do Douro e do Porto. Disponível em <http://www.ivdp.pt>. [Consulta realizada em 20.04.09].

_ (1984) - O Vinho do Porto, o Alto Douro e a Companhia na época pombalina (1756-1777), segundo Bernardo José de Sousa Guerra. «Estudos Transmontanos», n. ${ }^{\circ}$ 2. Vila Real: [s.n.].

(1989) - A Produção de um espaço regional: o Alto Douro no tempo da filoxera. «Revista da Faculdade de Letras - História». II série, vol. VI. Porto: Faculdade de Letras da Universidade do Porto, p. 311-353. Disponível em <http://www.ivdp.pt/ pagina.asp?codPag=9>. [Consulta realizada em 09/03/2015].

(1996a) - A viticultura duriense e o vinho do Porto na época contemporânea. Notas para um programa de pesquisa. «Douro: Estudos e Documentos», vol. I, n. ${ }^{\circ}$ 2. Porto: GEHVID, p. 155-165.

(1996b) - A região do vinho do Porto - origens e evolução de uma demarcação pioneira. «Douro: Estudos e Documentos». Vol. I, n. ${ }^{\circ}$ 1. Porto: GEHVID, p. 177-194.

(2003a) - Quintas do Douro: arquivos e investigação histórica. In Actas do Seminário «Os Arquivos da Vinha e do Vinho no Douro». Porto: CEPESE, p. 139-143. Disponível em <https://repositorio-aberto.up.pt/bitstream/10216/20322/2/revpopsoc102003gmpereira000085084.pdf $>$. [Consulta realizada em 04/03/2012].

coord. (2003b) - O Vinho do Porto. Porto: IVDP.

(2005) - O Vinho do Porto: entre o artesanato e a agroindústria. «Revista da Faculdade de Letras - História», III série, vol. VI. Porto: FLUP, 2005, p. 185-191.

(2006) - Porto: um vinho com história. Texto de apresentação do site oficial do IVDP, I.P. Disponível em <https://www.ivdp. pt/pagina.asp?codPag=9>. [Consulta realizada em 12/9/2016].

- (2008) - Nos 250 anos da Região Demarcada do Douro: da Companhia pombalina à regulação interprofissional. In SOUSA, Fernando de, org. - A Companhia e as relações económicas de Portugal com o Brasil, a Inglaterra e a Rússia. Porto: CEPESE, p. 175-185. Disponível em <www.cepesepublicacoes.pt/...regiao-demarcada...douro...pombalina...reg $>$. [Consulta realizada em 15/9/2017].

(2010) - História do Douro e do Vinho do Porto: crise e reconstrução. O Douro e o Vinho do Porto no séc. XIX. Porto: Edições Afrontamento.

(2010) - A evolução do espaço regional. Das demarcações pombalinas ao Douro pós-filoxérico. In PEREIRA, Gaspar Martins, coord. - História do Douro e do vinho do Porto: crise e reconstrução. O Douro e o vinho do Porto no séc. XIX. Porto: Edições Afrontamento, vol. 4, p. 9-49.

(2014) - Quintas do Douro: História, Património e Desenvolvimento. In Atas das 2as Conferências do Museu de Lamego/ CITCEM. Lamego: CITCEM/Museu de Lamego, p. 9-17.

(2015) - O Motim de Lamego, um momento histórico de consagração da denominação de origem «Porto» para os vinhos generosos da Região Demarcada do Douro: Movimentos Políticos e Sociais do Douro (entre o Liberalismo e a Democracia). Atas das 3. ${ }^{a s}$ Conferências do Museu de Lamego/CITCEM. Lamego: Museu de Lamego.

(2016) - Trabalhadores Galegos no Douro Vinhateiro. In Vindos de Longe: Estrangeiros no Douro. Atas das 4. ${ }^{\text {as }}$ Conferências do Museu de Lamego/CITCEM. Lamego: Museu de Lamego.

PEREIRA, Gaspar Martins, FERREIRA, Carla Maria Sequeira (2004) - Da «missão de Alijó» ao «motim de Lamego». Crise e revolta no Douro vinhateiro em inícios do século XX. «Revista da Faculdade de Letras - História», III série, vol. V. Porto: FLUP, p. 59-77.

PEREIRA, Gaspar Martins; OLAZABAL, Maria Luísa Nicolau de Almeida (1996) - Dona Antónia. Porto: Asa. PEREIRA, Gaspar Martins; SOUSA, Fernando de (1988) - Alto Douro: Douro Superior. Lisboa: Editorial Presença. 
PEREIRA, Gaspar Martins, TEIXEIRA, Ricardo (1998) - Apontamentos sobre a vinha e o vinho no Douro Superior. In Terras do Côa, da Malcata ao Reboredo: os valores do Côa. Vila Nova de Foz Côa: Parque Arqueológico do Vale do Côa, p. 77-84. Disponível em <http://www.arte-coa.pt/Ficheiros/Bibliografia/1691/1691.pt.pdf>. [Consulta realizada em 02/01/2016].

PEREIRA, Gaspar Martins; ZELLER, João Van, apresent.; SYMINGTON, Paul, apresent.; BARRETO, António, pref. (2011) - Roriz: história de uma quinta no coração do Douro. [Porto]: Edições Afrontamento; [Vila Nova de Gaia]: Symington Family Estates.

PEREIRA, Hugo Silveira (2014) - Os Beças, João da Cruz e Costa Serrão. Vila Nova de Gaia: Inovatec, Edição Projecto FozTua, p. 328-333. Disponível em <https://issuu.com/foztua/docs/protagonistas_final_1ba46cbc52dc4f >.

PEREIRA, Hugo Silveira; CORDEIRO, José Manuel Lopes, coord. (2013) - The opening of the Tua railroad: the king and royal court went to Mirandela (1887). In MACCANTS, Anne, ed. - Railroads in historical context: construction, costs and consequences. Porto: Universidade do Minho; MIT Portugal Program; IN+, vol. 3, p. 181-198.

PEREIRA, Miriam Halpern (2016) - A primeira República: na fronteira do liberalismo e da democracia. Lisboa: Gradiva.

PERES, Damião, dir. (1928-81) - História de Portugal. Barcelos: Portucalense Editora, suplemento.

PESAVENTO, Sandra Jatahy (2006) - Palavras para crer. Imaginários de sentido que falam do pasado. «Nuevo Mundo Mundos Nuevos», n. ${ }^{\circ}$ 6. Disponível em <https://nuevomundo.revues.org/1499>. [Consulta realizada em 08/04/2011].

PIGNATELLI, Inácio Nuno (2003) - O Douro português: coisas que o Douro nos contou. Porto: Campo das Letras.

PINA, Maria Helena Mesquita (2004) - A expansão e a reconversão vitícola na região demarcada do Douro - algumas problemáticas. Guimarães: Universidade do Minho.

PINHEIRO, Bruno; MAGALHÃES, Marcelo; REIGADA, Tiago (2010) - Uma época histórica, uma cidade, três motins: análise comparativa dos motins do Porto de 1592, 1661 e 1757. «CEM Cultura, Espaço \& Memória», n. ${ }^{\circ}$ 1. Porto: CITCEM/Edições Afrontamento, p. 281-198.

PINTÃO, Manuel; CABRAL, Carlos (2011) - Dicionário ilustrado do vinho do Porto. São Paulo: Ed. Cultura.

PINTO, Cesaltina (5 maio 2012) - [Entrevista a Paul Symington]. «VISÃO» 1000 - Douro. Disponível em <http://visao.sapo. $\mathrm{pt} /$ paul-symington-esta-a-fazer-se-cada-asneira-no-douro=f662704\#ixzz3NmxzvVnX>. [Consulta realizada em $10 / 05 / 2012]$.

PORTUGAL, Instituto da Conservação da Natureza e das Florestas (2016) - Espécies arbóreas indígenas em Portugal Continental. Guia de utilização. Disponível em < http://www.icnf.pt/portal/florestas/gf/prdflo/resource/doc/ICNF_EspeciesIndgenas Edicao2016-2.pdf $>$. [Consulta realizada em 13/3/2017].

QUADRADO, José Gomes (2009) - A integração do nosso concelho [Foz Coa] no Alto Douro Vinhateiro. «Revista Côavisão, Cultura e Ciência», n.o 11. Disponível em <http://dasmos-douro.blogspot.pt/2009/05/2-integracao-do-nosso-concelho-no-alto. html $>$. [Consulta realizada em 06/05/2015].

RAFFESTIN, C. (1993) - Por uma Geografia do Poder. São Paulo: Ática.

RAMOS, A. Luís de Oliveira (2001) - Um especialista do Douro: o Visconde de Vila Maior. «Douro: Estudos \& Documentos», vol. VI, n. ${ }^{\circ}$ 11. Porto: GEHVI, p. 11-14.

RAY, Cyril [1970] - The house of Warre 1670-1970: A three hundred year old tradition. [S.1.]: Warre and Company.

REBANDA, Nelson (2006) - O elemento humano no espaço e no tempo da Calçada de Alpajares. In REBANDA, Nelson, coord. - Pelos caminhos do Douro... [S. 1.]: Comissão Executiva das Comemorações dos 250 Anos da Região Demarcada do Douro, p. 75.

REBELO, João, et al., coord. (2001) - Plano intermunicipal de ordenamento do território Alto Douro Vinhateiro. Caracterização sócio-económica. Vila Real: UTAD - Departamento de Economia e Sociologia, Economia e Sociedade.

RHEINBERGER, Hans-Jörg (2013) - Itérations. Bienne-Paris: Diaphanes.

RIBEIRO, José Alves (2000) - Caracterização genérica da região vinhateira do Alto Douro. «Douro: Estudos \& Documentos», vol. V, n. ${ }^{\circ}$ 10. Porto: GEHVI, p. 11-29.

RICOEUR, Paul (2000) - La mémoire, l' histoire, l’ oubli. Paris: Éditions du Seuil.

ROBINSON, Jancia (2012) - The rarest rubies. «FT Weekend Magazine» [Em linha]. Disponível em: <https://www-ft-com/con tent//a3a52c70-cc33-11e1-839a-00144feabdc0>.

ROGER, Alain (2000) - La naissance du paysage em occident. In SALGUEIRO, Heliana Angotti, coord. - Paisagem e arte. São Paulo: H. Angotti Salgueiro. 
ROLLO, Maria Fernanda, coord. (2014) - Dicionário de História da I República e do republicanismo. Lisboa: Assembleia da República.

ROSAS, Fernando; LOFF, Manuel, eds. (2010) - Salazarismo, Tarrafal, guerra de Espanha: história e memória 70 anos depois. Lisboa: Colibri.

SACK, R. (1996) - Human Territoriality: its theory and history. Cambridge: Cambridge University Press.

SAINTSBURY, George (1920) - Notes on a Cellar-Book. [S.l.]: Thomas Pinney, Ed.

SANTANA, Maria Olinda Rodrigues (2003) - Da vinha e do vinho na documentação foraleira manuelina do Vale do Douro. «Douro: Estudos \& Documentos», vol. VIII, n. ${ }^{\circ}$ 15. Porto: GEHVI, p. 11-24.

SANTOS, Boaventura Sousa (1983) - Os conflitos urbanos no Recife: O caso do Skylab. «Revista Crítica de Ciências Sociais», n. ${ }^{\circ} 11$. Coimbra: CES, p. 9-59.

(1987) - Introdução à Sociologia da Administração da Justiça, «Revista Crítica de Ciências Sociais», n. o 21, p. 11-37.

(1988) - Uma cartografia simbólica das representações sociais... «Revista Crítica das Ciências Sociais», n. ${ }^{\circ}$ 24. Coimbra: CES, p. 193-172.

SANTOS, Jenniffer Simpson dos (2016) - Tradução artesanal: para além das fronteiras entre arte e artesanato indígena. Coimbra: CES, Oficina n. ${ }^{\circ} 432$.

SEEMANN, Jörn (2005) - Metáforas espaciais na geografia: cartografias, mapas e mapeamentos. «Anais do X Congresso de Geógrafos da América Latina». Universidade de S. Paulo. Disponível em <https://www.academia.edu/16357110/Met\%C3\%A1foras_espaciais_na_Geografia_cartografias_mapas_e_mapeamentos>. [Consulta realizada em 6 de Março de 2011].

SELLERS, Charles (1899) - Oporto, old and new. London: Herbert E. Harper (The Wine \& Spirit Gazette).

SELTZER, Michael William (2007) - The Technological Infrastructure of Science, p.151ss. Virginia Tech. Doctoral Thesis. Disponível em <https://vtechworks.lib.vt.edu/handle/10919/28976>. [Consulta realizada em 02/05/2017].

SEQUEIRA, Carla (2000) - A questão duriense e o movimento dos Paladinos, 1907-1932: Da Comissão de Viticultura Duriense à Casa do Douro. [Peso da Régua]: Grupo de Estudos de História da Viticultura Duriense e do Vinho do Porto. Colaboração com CIRDD - Comissão Interprofissional da Região Demarcada do Douro.

(2003a) - Do poder local ao poder regional: o movimento dos paladinos do Douro. «Douro: Estudos e Documentos», vol. 8, n. ${ }^{\circ}$ 16. Porto: GEHVID, p. 63-69. Disponível em <http://academia.edu/1368742/Do_poder_local_ao_poder_regional_o_ movimento_dos_paladinos_do_Douo $>$. [Consulta realizada em 10/01/2012>.

(2003b) - O Vinho do Porto e as movimentações sociais nos anos de 1914-15. «Douro - Estudos e Documentos», vol. VIII, n. ${ }^{\circ} 15$, p. $77-86$.

(2004) - Da 'Missão de Alijo' ao 'Motim de Lamego': repercussões do tratado luso-britânico de 1914 no sector do vinho do Porto. «Revista da Faculdade de Letras - História», série III, vol. 05. Porto: Faculdade de Letras da Universidade do Porto, p. 59-78. Disponível em <http://ler.letras.up.pt/uploads/ficheiros/2375.pdf >. [Consulta realizada em 03/01/2012].

(2006a) - A região vinhateira do Alto Douro, entre o livre-cambismo e o proteccionismo. «Revista Universum», vol. 2, n. ${ }^{\circ} 21$. Chile: Universidad de Talca, p. 138-146.

(2006b) - O tecido sócio-institucional da Região Demarcada do Douro (de finais do séc XIX a meados do séc XX): contributo para a sua caracterização). In PEREIRA, Gaspar Martins e MONTES, Paula, coord. - Actas do Encontro O Douro Contemporâneo. Porto: Faculdade de Letras da Universidade do Porto.

(2010) - O Alto Douro entre o livre-cambismo e o proteccionismo: A «Questão Duriense» na economia nacional. Porto: Faculdade de Letras da Universidade do Porto. Tese de doutoramento. Disponível em <http://repositorio-aberto.up.pt/bitstream/10216/50418/2/tesedoutcarlaferreira000112831.pdf >. [Consulta realizada em 03/02/2011].

(2011) - O Alto Douro entre o livre cambismo e o proteccionismo: A «Questão Duriense» na economia nacional. Porto: CITCEM/Edições Afrontamento.

(2013) - A oposição à Ditadura Nacional e ao Estado Novo na Região Duriense (1926-1949). Actas das $1 .{ }^{\text {as }}$ Conferências Museu de Lamego: CITCEM.

(2014) - Antão de Carvalho e a República no Douro. Porto: CITCEM/Edições Afrontamento.

(2015) - República e republicanismo na Região Duriense, 1910-1926: contributos para a sua caracterização política e partidária. «Revista CEM - Cultura, Espaço \& Memória», n. ${ }^{\circ}$ 6. Porto: Centro de Investigação Transdisciplinar Cultura, Espaço e Memória. 
SERRÃO, Joel; MARQUES, Oliveira, dir. (2004) - Nova História de Portugal, Lisboa: Presença, vol. XI.

SERRÃO, Joel, dir. (1971) - Dicionário de História de Portugal. Lisboa: Iniciativas editoriais, 5 vol.

SILVA, Célia Taborda (1997) - Guerrilheiros e bandidos no Douro na 1. ${ }^{a}$ metade do sec XIX. «Estudos \& Documentos», vol. I (3),

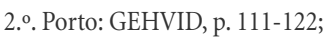

(2007) - Movimentos sociais no Douro no período de implantação do liberalismo. Porto: GEHVID.

(2010) - Movimentos sociais no Douro oitocentista. In PEREIRA, Gaspar Martins, coord. - História do Douro e do vinho do Porto: crises e reconstrução.... Porto: Edições Afrontamento, vol. 4, p. 88-139.

SILVA, Francisco Ribeiro da (1990a) - Absolutismo esclarecido e intervenção popular. Os motins do Porto de 1757. Lisboa: INCM. (1990b) - Porto e Ribadouro no século XVII: a complementaridade imposta pela natureza. «Revista da Faculdade de Letras História», II série, vol. VII. Porto: Faculdade de Letras da Universidade do Porto.

(1997) - Do Douro ao Porto: o protagonismo do vinho na época moderna. «Douro: Estudos \& Documentos», n. ${ }^{\circ}$ 4. Porto: GEHVID. Disponível em <http://ler.letras.up.pt/uploads/ficheiros/8267.pdf >. [Consulta realizada em 18/9/2017].

(2005) - Os ingleses e as circunstâncias políticas dos negócios dos Vinhos do Porto. Disponível em <http://www.cepese.pt/ portal/pt/publicacoes/obras/o-vinho-do-porto-em-gaia-companhia/os-ingleses-e-as-circunstancias-politicas-do-negocio-dos-vinhos-do-porto-1756-1800>. [Consulta realizada em 19/09/2017].

SILVA, Jorge M. Ricardo da Silva (2006) - Composição da uva, do mosto e do vinho. [S.1.]: Laboratório Ferreira Lapa, sector de Enologia. Disponível em <http://www.drapc.min-agricultura.pt/base/geral/files/composicao_uva_mosto_vinho.pdf >. [Consulta realizada em 16/9/2017].

SYMINGTON, Paul (2007) - Perfil da empresa: lideres em vinho do Porto de categorias especiais. «Douro: Estudos \& Documentos», n. ${ }^{\circ}$ 22. Disponível em <http://ler.letras.up.pt/uploads/ficheiros/9782.pdf>. [Consulta realizada em 12/03/2016].

SOARES, Rodrigo de Morais (1878) - Mémoire sur les vins du Portugal. Lisboa: Imprensa Nacional.

SOEIRO, Teresa; ROSAS, Lúcia; FAUVRELLE, Natália (2002) - O património vernacular construído do Alto Douro Vinhateiro: ritmos e valores. «Douro: Estudos \& Documentos», vol. VII, n. ${ }^{0}$ 14. Porto: GEHVID, p. 147-163.

STAR, Susan Leigh; GRIESEMER, James (1989) - Institutional ecology, 'translations' and boundary objects: amateurs and professionals in Berkeley's Museum of Vertebrate Zooly. «Social Studies of Science», n. ${ }^{\circ}$ 19. [S.1.]: [s.n.], p. 387-420.

STRAUSS, Anselm; BASZENGER, Isabelle (1992) - La trame de la negociation: sociologie qualitative et interactionnisme. Paris: L'Harmattan.

STRAUSS, Anselm; CORBIN, Juliet (1990) - Basics of qualitative research: Grounded theory: Procedures and techniques. London: Sage.

TEIXEIRA, Luísa (2014) - Abrigos com pinturas rupestres de Trás-os-Montes e Alto Douro: Pala Pinta, Penas Róias e Cachão da Rapa. [S.1.]: Lema d'Origem.

TEIXEIRA, Sofia Alexandra Rodrigues (2010) - Cister no Douro das granjas cistercienses às quintas durienses. Porto: Faculdade de Letras da Universidade do Porto. Dissertação de mestrado em Ciências da Cultura. Disponível em <http://hdl.handle. net/10348/718>.

TENREIRO, A. Guerra (1944) - Douro, esboços para a sua história económica: conclusões. Porto: Instituto do Vinho do Porto.

TERENO, Maria do Céu Simões (2002) - Contributo para o estudo do património arquitectónico rural cisterciense - antiga quinta do Granjão. Disponível em <https://dspace.uevora.pt/rdpc/bitstream/10174/7385/1/Quinta\%20do\%20Granjão.pdf>. [Consulta realizada em 18/972007].

VALE, Fernando - Mineração no concelho de Viseu. Volfrâmio e Estanho (1886-1986). [S.1.]: [s.n.]. Obra no prelo.

VAQUINHAS, Irene [S.d.] - Em fuga da guerra civil: refugiados espanhóis na Figueira da Foz (1936-1939). Disponível em <http:// academiaportuguesadahistoria.gov.pt/wp-content/uploads/2015/06/IRENE-VAQUINHAS-Em-fuga-da-Guerra-Civil. pdf $>$. [Consulta realizada em 5/12/2016].

_ (2015) - Huyendo de la Guerra Civil: los refugiados españoles en Figueira da Foz (1936-1939). In Pensar con la historia desde el siglo XXI, «Actas del XII Congreso de la Asociación de História Contemporánea». Madrid: Uma Ediciones, p. 4833-4854.

VASCONCELOS, J. Leite de (1937) - O DOURO nos séculos XVII E XVIII. Régua: Imprensa do Douro.

(1938) - O Douro geográfico-etnográfico. Régua: Imprensa do Douro.

(1980) - Etnografia Portuguesa. Lisboa: Imprensa Nacional, vol. III. 
VENTURA, António, intr. (2007) - A Legião portuguesa ao serviço de Napoleão - Tenente Teotónio Banha. Lisboa: Edição Caleidoscópio.

VIEIRA, António et al. (2013) - Terraces («socalcos») in Tua Valley. FozTua International Conference. FozTua, 11-12-13 October. Disponível em <https://meocloud.pt/link/ee23fe86-b176-4b72-98c7-6d1076ee76e7/Vieira_et_al_Landuse_Tua_GIS_ final.pptx $>$. [Consulta realizada em 17/10/2013].

VILA MAIOR, Visconde de (1865) - Preliminares da ampelographia e oenologia do paiz vinhateiro do Douro. Lisboa: Imprensa Nacional.

_ (1876) - O Douro illustrado: album do rio Douro e paiz vinhateiro = Le Douro illustré: album de ce fleuve et de son pays vignoble $=$ The illustrated Douro: an album of the river Douro and adjacent wine country. Porto: Liv. Universal de Magalhães \& Moniz.

(1990) - O Douro Ilustrado: album do Rio Douro e paiz vinhateiro: album ce fleuve et de son pays vignoble: an album of the river Douro and adjacent wine country $=$ Le Douro illustré $=$ The illustrated Douro. Lisboa: Imprensa Nacional-Casa da Moeda, Instituto do Vinho do Porto, Banco de Fomento e Exterior. Ed. fac-similada da ed. de 1876.

VILARINHO DE S. ROMÃO, Visconde de (1896) - Viticultura e viniculture: Trás os Montes e Alto Douro Central. Lisboa: Imprensa Nacional.

VISEU, Albano Augusto Veiga (2007) - Memórias históricas de um espaço rural: três aldeias de Trás-os-Montes (Coleja, Cachão e Romeu) ao tempo do Estado Novo. Porto: Faculdade de Letras da Universidade do Porto. Tese de doutoramento.

VIVER e saber fazer: tecnologias tradicionais na região do Douro: estudos preliminares. Peso da Régua: Museu do Douro, 2003.

VIZETELLY, Henry (1880) - Facts about Port and Madeira. London: Ward, Lock.

WALLERSTEIN, Immanuel (2013) - Uprisings here, there, and everywhere. Binghamton University: Fernand Braudel Center. Disponível em <http://www2.binghamton.edu/fbc/commentaries/archive-2013/356en.htm>. [Consulta realizada em 03/09/2013].

WALLERSTEIN, Immanuel (2012) - Luta de classes no mundo: a geografia do protesto. Binghamton University: Fernand Braudel Center. Disponível em <https://www.binghamton.edu/fbc/commentaries/archive-2012/330pr.htm>. [Consulta realizada em 03/05/2015]. 
ANEXOS 


\section{ANEXO I — CRONOLOGIA (QUADROS)}

Quadro 1. Cronologia das Crises e Movimentos sociais e políticos na Região do Douro (séculos XIX e XX) $)^{822}$

\begin{tabular}{|c|c|c|c|}
\hline Anos & Crises & $\begin{array}{l}\text { Movimentações sociais, } \\
\text { políticas e económicas }\end{array}$ & $\begin{array}{c}\text { Organizações da lavoura } \\
\text { e outras }\end{array}$ \\
\hline 1804 & $\begin{array}{l}\text { Peste no Nordeste Transmon- } \\
\text { tano }\end{array}$ & & \\
\hline $1807-1810$ & $\begin{array}{l}\text { A Corte portuguesa parte } \\
\text { para o Brasil. } \\
\text { Invasões francesas. }\end{array}$ & $\begin{array}{l}\text { Revoltas, guerrilhas e motins popu- } \\
\text { lares contra os invasores. }\end{array}$ & \\
\hline 1812 & & $\begin{array}{l}\text { Feitores pedem imediata extinção } \\
\text { da «Companhia». Petição subscrita } \\
\text { por exportadores ingleses. }\end{array}$ & \\
\hline $1814-1816$ & & $\begin{array}{l}\text { Protestos de agricultores e câma- } \\
\text { ras contra a Companhia G.A.V.D. e } \\
\text { dos viticultores contra a entrada de } \\
\text { vinhos não oriundos da Metrópole } \\
\text { no Brasil. }\end{array}$ & \\
\hline 1819 & $\begin{array}{l}\text { Dificuldades comerciais no } \\
\text { setor do vinho do Porto. } \\
\text { Crise agrícola nacional, mais } \\
\text { intensa no Douro, com «es- } \\
\text { tagnação» do comércio viní- } \\
\text { cola e ruína de lavradores. }\end{array}$ & & \\
\hline $1820-1838$ & & $\begin{array}{l}\text { Companhia Geral das Vinhas do Alto } \\
\text { Douro - grande tema em debate na } \\
\text { sociedade portuguesa; entre } 1820 \text { e } \\
1834 \text {, cerca de } 40 \% \text { dos livros edita- } \\
\text { dos sobre problemas económicos, } \\
\text { tinham como objeto a Companhia. } \\
\text { Petições para abolição de tributos } \\
\text { senhoriais e mudança da legislação }\end{array}$ & \\
\hline $1821-1823$ & $\begin{array}{l}\text { Cortes promulgam as primei- } \\
\text { ras leis que restringem privi- } \\
\text { légios da Companhia. } \\
\text { Grande cheia do Douro ou } \\
\text { «cheia de Marrocos» porque } \\
\text { destruiu uma quinta com } \\
\text { esse nome. }\end{array}$ & $\begin{array}{l}\text { As câmaras da Região Duriense } \\
\text { enviam representações às Cortes } \\
\text { Gerais e Extraordinárias para aboli- } \\
\text { ção da demarcação e exigem que a } \\
\text { «Companhia» seja obrigada a com- } \\
\text { prar na Feira da Régua todo o vinho } \\
\text { separado para embarque que não } \\
\text { tenha sido vendido. }\end{array}$ & \\
\hline
\end{tabular}

\footnotetext{
${ }^{822}$ PEREIRA, 2010: 466-481, SEQUEIRA, 2006b; SEQUEIRA, 2013; MARTINS, 1996: 413-435; MARTINS, $1990: 287$ -463; SILVA, 1997: 111-122; MOREIRA, 1994: 259-282; BARRETO, 2014; PEIXOTO, 2011; COSTA, 1977: $287-296$.
} 


\begin{tabular}{|c|c|c|c|}
\hline Anos & Crises & $\begin{array}{l}\text { Movimentações sociais, } \\
\text { políticas e económicas }\end{array}$ & $\begin{array}{c}\text { Organizações da lavoura } \\
\text { e outras }\end{array}$ \\
\hline $1823-1827$ & $\begin{array}{l}\text { Vilafrancada - Golpe de D. } \\
\text { Miguel e revogação da Cons- } \\
\text { tituição de } 1822 \text {. } \\
\text { Grande descida do preço do } \\
\text { vinho do Porto, entre } 1823- \\
-25 .\end{array}$ & $\begin{array}{l}\text { Levantamentos miguelistas anti- } \\
\text { constitucionais: sublevações, } \\
\text { tumultos e guerrilhas em muitas } \\
\text { freguesias da região em que terão } \\
\text { participado trabalhadores sazonais. } \\
\text { Situação conturbada e conjuntura } \\
\text { de crise política prolonga-se até } \\
\text { 1850. Acalmia da Regeneração. Alas- } \\
\text { tram o bandoleirismo, o banditismo } \\
\text { e os salteadores, ao serviço de clien- } \\
\text { telas e odiados pelas populações. }\end{array}$ & \\
\hline $1825-29$ & $\begin{array}{l}\text { Vindima de má qualidade em } \\
1828 . \\
\text { O comércio do vinho do } \\
\text { Porto assegura a cobertura } \\
\text { de } 30 \% \text { das importações. }\end{array}$ & $\begin{array}{l}\text { Numerosos conflitos políticos e fre- } \\
\text { quentes comportamentos de vio- } \\
\text { lência entre liberais e miguelistas, } \\
\text { na região do Douro. }\end{array}$ & \\
\hline $1831-1833$ & $\begin{array}{l}\text { Péssima vindima devido a } \\
\text { chuvas, em } 1831 . \\
\text { Exportação de vinho do } \\
\text { Porto ( } 16.739 \text { pipas) foi, em } \\
\text { 1832, a } 8 .^{\text {a mais baixa desde }} \\
\text { a instituição da Companhia. }\end{array}$ & $\begin{array}{l}\text { Continuam os violentos conflitos } \\
\text { no Douro entre miguelistas e libe- } \\
\text { rais. } \\
\text { General miguelista incendeia arma- } \\
\text { zéns da Companhia G.A.V.A.D. }\end{array}$ & \\
\hline $1834-1850$ & $\begin{array}{l}\text { Crise no setor do vinho do } \\
\text { Porto, por ação dos agentes } \\
\text { económicos, mas atribuída } \\
\text { ao fim da Companhia, libe- } \\
\text { ralização do comércio e da } \\
\text { produção. Afeta primeiro } \\
\text { os produtores e depois os } \\
\text { comerciantes. } \\
\text { Em } 1837 \text {, crise comercial } \\
\text { como reflexo da crise inglesa } \\
\text { de } 1836-37 \text {. Afeta volumes e } \\
\text { preços do vinho do Porto. }\end{array}$ & $\begin{array}{l}\text { «Cisma» religioso, guerrilhas e } \\
\text { movimentações miguelistas. } \\
\text { Convenção de Évora Monte (1834), } \\
\text { vitória dos liberais e segunda vigên- } \\
\text { cia da Carta Constitucional. } \\
\text { Em } 1836 \text { chegam a Lisboa os depu- } \\
\text { tados eleitos pelo Douro que se pro- } \\
\text { põem restabelecer a Constituição } \\
\text { de } 1822 \text {. Um pronunciamento leva } \\
\text { ao poder a fação defensora da Cons- } \\
\text { tituição de } 1822 \text { (Passos Manuel, } \\
\text { Sá da Bandeira, Ferreira Borges) }\end{array}$ & \\
\hline $1838-1843$ & $\begin{array}{l}\text { Crise vinícola decorrente tal- } \\
\text { vez da abertura dos portos } \\
\text { do Douro ao comércio dos } \\
\text { vinhos de todo o país, decre- } \\
\text { tada } 4 \text { anos antes. Sobre- } \\
\text { produção, grande baixa dos } \\
\text { preços do vinho e falência de } \\
\text { inúmeras casas comerciais, } \\
\text { muitas do Porto, em } 1842 \text {. }\end{array}$ & & \\
\hline
\end{tabular}




\begin{tabular}{|c|c|c|c|}
\hline Anos & Crises & $\begin{array}{l}\text { Movimentações sociais, } \\
\text { políticas e económicas }\end{array}$ & $\begin{array}{l}\text { Organizações da lavoura } \\
\text { e outras }\end{array}$ \\
\hline 1839 & & $\begin{array}{l}\text { Reunião no Porto de lavradores do } \\
\text { Alto Douro com vista à criação da } \\
\text { Associação Agrícola do Alto Douro. }\end{array}$ & $\begin{array}{l}\text { A Associação Agrícola do } \\
\text { Alto Douro, (vida efémera), } \\
\text { é fundada no Porto, sob a } \\
\text { presidência do Visconde de } \\
\text { Samodães. }\end{array}$ \\
\hline $1841-1843$ & $\begin{array}{l}\text { Grave crise no setor do vinho } \\
\text { do Porto: } 1841 \text {, ano de crise } \\
\text { para a lavoura duriense. } \\
\text { «famílias ricas passam a viver } \\
\text { na pobreza»; em } 1843 \text { «o per- } \\
\text { nicioso contrabando e des- } \\
\text { caminho de direitos» afeta o } \\
\text { trânsito de vinho no Porto e } \\
\text { em Gaia. }\end{array}$ & $\begin{array}{l}\text { Em } 1843 \text { na sequência de uma } \\
\text { «Representação» da Câmara de } \\
\text { Lamego expondo "as necessida- } \\
\text { des que oprimem os lavradores» } \\
\text { a Companhia recebe autorização } \\
\text { régia para comprar imediatamente } \\
500 \text { pipas de vinho no Alto Douro. }\end{array}$ & $\begin{array}{l}\text { Tentativa frustrada de cria- } \\
\text { ção na Régua de una Asso- } \\
\text { ciação de Agricultura do } \\
\text { Douro. }\end{array}$ \\
\hline $1843-1845$ & $\begin{array}{l}\text { Crise profunda também no } \\
\text { comércio do vinho Porto. } \\
\text { Detetada pela primeira vez, } \\
\text { a maromba nas vinhas do } \\
\text { Douro, então conhecida por } \\
\text { «mal negro»ou «gomose». }\end{array}$ & $\begin{array}{l}\text { Motins anti fiscais no Porto. } \\
\text { Começa a afirmar-se o movimento } \\
\text { associativo no Douro. } \\
\text { Câmaras municipais de Murça, } \\
\text { Régua, Carrazeda, Lamego, Santa } \\
\text { Marta, Barcos e S. Cosmado enviam } \\
\text { representações à rainha, pedindo } \\
\text { alteração do regulamento da Com- } \\
\text { panhia aprovado por decreto de } 20 \\
\text { de setembro de } 1843 \text {. }\end{array}$ & $\begin{array}{l}\text { Associação de Viticultores } \\
\text { do Douro. }\end{array}$ \\
\hline $1846-1851$ & $\begin{array}{l}\text { Guerra Civil (outubro a } \\
\text { junho) } \\
\text { Revoluções e fome que afe- } \\
\text { tam as exportações de vinho } \\
\text { e azeite. } \\
\text { Mantém-se a crise no setor } \\
\text { do vinho do Porto. }\end{array}$ & $\begin{array}{l}\text { Revolta da Maria da Fonte e reper- } \\
\text { cussões na Região do Douro. Revol- } \\
\text { tas aderentes ao movimento. } \\
\text { Em 1847, o regenador Saldanha } \\
\text { obriga os munícipes de Santa } \\
\text { Marta, Régua, Canelas e Mesão Frio } \\
\text { a integrarem-se no exército for- } \\
\text { mando um «batalhão defensor da } \\
\text { Carta e da Rainha» encarregado de } \\
\text { «manter o sossego público e rebater } \\
\text { as tentativas anárquicas dos sectá- } \\
\text { rios da rebelião que infesta o país» }\end{array}$ & $\begin{array}{l}\text { A Associação de Viticultores } \\
\text { do Douro dirige uma repre- } \\
\text { sentação à Rainha em 1849, } \\
\text { pedindo providências con- } \\
\text { tra a crise e isenção de tri- } \\
\text { butos devido à estagnação } \\
\text { do negócio dos vinhos. }\end{array}$ \\
\hline $1850-1852$ & $\begin{array}{l}\text { Doenças das videiras (oídio } \\
\text { ou cinzeiro em vinhedos do } \\
\text { concelho da Régua) que afe- } \\
\text { tam os produtores }\end{array}$ & $\begin{array}{l}\text { Extinção da Companhia que gera } \\
\text { protestos políticos e sociais }\end{array}$ & \\
\hline
\end{tabular}




\begin{tabular}{|c|c|c|c|}
\hline Anos & Crises & $\begin{array}{l}\text { Movimentações sociais, } \\
\text { políticas e económicas }\end{array}$ & $\begin{array}{c}\text { Organizações da lavoura } \\
\text { e outras }\end{array}$ \\
\hline $1852-1892$ & & $\begin{array}{l}\text { Política económica de tendência } \\
\text { livre-cambista } \\
\text { Durante a Regeneração (1851- } \\
\text {-1868, os regeneradores alternam } \\
\text { no poder com os históricos. }\end{array}$ & \\
\hline 1853 & & & $\begin{array}{l}\text { «Comissão Encarregada de } \\
\text { Indagar as Necessidades do } \\
\text { Comércio do Porto», presi- } \\
\text { dida pelo deputado Ribeiro } \\
\text { de Faria (vida efémera) }\end{array}$ \\
\hline 1855-1857 & $\begin{array}{l}\text { Grande cheia do Douro, em } \\
\text { 1855, a maior dos últimos } 30 \\
\text { anos. Em 1856, a região do } \\
\text { Douro, como o país, é atin- } \\
\text { gida por epidemia de cólera, } \\
\text { o flagelo da febre amarela, } \\
\text { muito mortífera no Porto e } \\
\text { Douro. } \\
\text { Sismos e chuvas torrenciais } \\
\text { destroem culturas e vinhas } \\
\text { na RDD. Carestia de pão e } \\
\text { fomes. }\end{array}$ & & \\
\hline 1858 & $\begin{array}{l}\text { Crise nos vinhos do Douro. } \\
\text { Crise agrícola e comercial, } \\
\text { falências. }\end{array}$ & & \\
\hline 1859 & $\begin{array}{l}\text { Vindima muito fraca. Preços } \\
\text { altos dos vinhos velhos do } \\
\text { Douro }\end{array}$ & & \\
\hline $\begin{array}{c}\text { Década } \\
1850-1860\end{array}$ & Crise vinícola & & \\
\hline 1860 & $\begin{array}{l}\text { Grande cheia do Douro. } \\
\text { Baixa de produção com } \\
\text { alguns vinhos bons }\end{array}$ & & $\begin{array}{l}\text { Constituição da Real Asso- } \\
\text { ciação Central da Agricul- } \\
\text { tura Portuguesa, pioneira } \\
\text { no associativismo agrícola. } \\
\text { A sua direção integra, entre } \\
\text { outros, o Visconde de Balse- } \\
\text { mão. }\end{array}$ \\
\hline 1860-1861 & & & $\begin{array}{l}\text { Associação dos Agricultores } \\
\text { do Douro, a que pertence- } \\
\text { ram } \\
\text { os deputados Canavarro, } \\
\text { Melo Peixoto, Pinto Araújo e } \\
\text { Borges Pinto. (vida efémera) }\end{array}$ \\
\hline
\end{tabular}




\begin{tabular}{|c|c|c|c|}
\hline Anos & Crises & $\begin{array}{l}\text { Movimentações sociais, } \\
\text { políticas e económicas }\end{array}$ & $\begin{array}{c}\text { Organizações da lavoura } \\
\text { e outras }\end{array}$ \\
\hline 1862 & & $\begin{array}{l}\text { Manifestações públicas (12 de } \\
\text { abril), em Vila Real, com 15. } 000 \text { e } \\
\text { 18. } 000 \text { lavradores, pela abolição } \\
\text { de legislação restritiva e liberdade } \\
\text { de comércio dos vinhos. Manifes- } \\
\text { tações anteriores menos participa- } \\
\text { das, com idênticos propósitos, na } \\
\text { Régua, Santa Marta de Penaguião e } \\
\text { Sabrosa. } \\
\text { Proliferam as reuniões e as «mani- } \\
\text { festações pacíficas» de viticultores e } \\
\text { comerciantes vinícolas e o envio de } \\
\text { «representações» ao governo e às } \\
\text { câmaras, a favor e contra a liberdade } \\
\text { de comércio dos vinhos do Douro. }\end{array}$ & \\
\hline 1863 & $\begin{array}{l}\text { Doença das videiras } \\
\text { (Filoxera). }\end{array}$ & & \\
\hline $1865-1866$ & $\begin{array}{l}\text { Início de crise comercial com } \\
\text { a política livre-cambista }\end{array}$ & $\begin{array}{l}\text { A extinção da Companhia e a abo- } \\
\text { lição da demarcação e do regime } \\
\text { restritivo em 1865, "pacificam» a } \\
\text { discussão sobre política vinícola } \\
\text { e abrem um interregno até aos anos } \\
\text { 1890, quando se acende, de novo, } \\
\text { a questão do álcool. } \\
\text { Em } 1866 \text { várias representações de } \\
\text { câmaras da região pedindo nova } \\
\text { demarcação do Douro. }\end{array}$ & $\begin{array}{l}\text { «Companhia Comercial } \\
\text { dos Lavradores do Douro» } \\
(1886) \text {, associação de } \\
\text { lavradores e comerciantes, } \\
\text { aplaudida em todos os con- } \\
\text { celhos durienses. }\end{array}$ \\
\hline $1867-1868$ & $\begin{array}{l}\text { Surge a filoxera no Douro, na } \\
\text { freguesia de Gouvinhas, con- } \\
\text { celho de Sabrosa. }\end{array}$ & $\begin{array}{l}\text { «Janeirinha» - revolta portuense } \\
\text { contra imposto de consumo. } \\
\text { Tumultos populares no Douro con- } \\
\text { tra impostos e desarmotização de } \\
\text { baldios. Outros levantamentos e } \\
\text { divergências entre fações partidá- } \\
\text { rias, conflitos entre aldeias, etc. }\end{array}$ & \\
\hline $1868-1870$ & Grande seca no Douro & & \\
\hline $\begin{array}{l}\text { Início } \\
\text { da década } \\
\text { de } 1870\end{array}$ & & $\begin{array}{l}\text { Manifestações e representações } \\
\text { contra o fim do regime protecio- } \\
\text { nista }\end{array}$ & \\
\hline 1872 & Filoxera alastra & $\begin{array}{l}\text { Cartas de lavradores em jornais e } \\
\text { revistas }\end{array}$ & Comissões antifiloxéricas \\
\hline
\end{tabular}




\begin{tabular}{|c|c|c|c|}
\hline Anos & Crises & $\begin{array}{l}\text { Movimentações sociais, } \\
\text { políticas e económicas }\end{array}$ & $\begin{array}{l}\text { Organizações da lavoura } \\
\text { e outras }\end{array}$ \\
\hline 1875 & & $\begin{array}{l}\text { Sucedem-se, em associações, insti- } \\
\text { tuições e vários pontos do país, as } \\
\text { conferências e os debates sobre a } \\
\text { questão dos vinhos, com destaque } \\
\text { para as intervenções e conferências } \\
\text { de António Augusto de Aguiar }\end{array}$ & \\
\hline 1877 & $\begin{array}{l}\text { Falências de empresas expor- } \\
\text { tadoras de vinho }\end{array}$ & & \\
\hline 1878 & $\begin{array}{l}\text { Filoxera - Vindimas escassas. } \\
\text { Abandono de vinhas }\end{array}$ & & \\
\hline 1880-1881 & & $\begin{array}{l}\text { Surge em 1889, o «Jornal da Régua» } \\
\text { para lutar contra a devastação que a } \\
\text { filoxera causara na região do Douro. } \\
\text { É substituído no ano seguinte por } \\
\text { «A Voz do Douro» que se torna na } \\
\text { folha oficiosa das comissões de } \\
\text { defesa do Douro. }\end{array}$ & \\
\hline 1882-1883 & $\begin{array}{l}\text { Crise de trabalho. Calcula- } \\
\text {-se em } 15.000 \text { ha a área de } \\
\text { vinha já destruída pela filo- } \\
\text { xera no Douro, cujos efeitos } \\
\text { e mudanças provocariam na } \\
\text { Região uma revolução social. }\end{array}$ & $\begin{array}{l}\text { Movimentos operários contra falta } \\
\text { de trabalho e tratado luso-francês }\end{array}$ & $\begin{array}{l}\text { Criação na Régua, em 1883, } \\
\text { da «Companhia de Seguros } \\
\text { dos Arraes do Rio Douro» } \\
\text { para assegurar atividade de } \\
\text { c. } 800 \text { barcos e circulação de } \\
\text { mercadorias que navegam } \\
\text { no rio. }\end{array}$ \\
\hline 1884-1885 & & $\begin{array}{l}\text { Reivindicações para o regresso à } \\
\text { demarcação e pela criação de um } \\
\text { Entreposto em Gaia }\end{array}$ & $\begin{array}{l}\text { Nomeação da «Comissão } \\
\text { de Defesa dos Interesses } \\
\text { do Douro» pela Assembleia } \\
\text { de Lavradores e Negocian- } \\
\text { tes do Porto para estudar } \\
\text { a questão do comércio } \\
\text { dos vinhos nos distritos do } \\
\text { Norte e da qual faziam parte } \\
\text { o conde de Samodães, o } \\
\text { visconde de Vilar d'Allen } \\
\text { e os deputados Taveira de } \\
\text { Carvalho e Pestana da Silva } \\
\text { (vida efémera). }\end{array}$ \\
\hline 1886 & Crise de trabalho. & $\begin{array}{l}\text { Greves operárias, manifestações, } \\
\text { protestos. Comícios e reuniões con- } \\
\text { tra lei de exportações de vinhos } \\
\text { pela barra do Porto e adesão de } \\
\text { municípios contra a liberdade de } \\
\text { comércio e exportações de vinho }\end{array}$ & $\begin{array}{l}\text { Comissão de Defesa do } \\
\text { Douro (CDD) }\end{array}$ \\
\hline
\end{tabular}




\begin{tabular}{|c|c|c|c|}
\hline Anos & Crises & $\begin{array}{l}\text { Movimentações sociais, } \\
\text { políticas e económicas }\end{array}$ & $\begin{array}{l}\text { Organizações da lavoura } \\
\text { e outras }\end{array}$ \\
\hline 1887 & $\begin{array}{l}\text { Graves consequências eco- } \\
\text { nómicas e sociais da filoxera }\end{array}$ & $\begin{array}{l}\text { Cresce o movimento associativo do } \\
\text { Douro }\end{array}$ & $\begin{array}{l}\text { É criada a Liga de Lavrado- } \\
\text { res do Douro }\end{array}$ \\
\hline 1889 & $\begin{array}{l}\text { Agudização dos conflitos } \\
\text { sociais na Europa e eclosão } \\
\text { de inúmeras greves. }\end{array}$ & $\begin{array}{l}\text { Reclamações e protestos de expor- } \\
\text { tadores de vinho, com encerra- } \\
\text { mento de armazéns, contra o con- } \\
\text { trato do governo e Real Companhia } \\
\text { Vinícola. }\end{array}$ & $\begin{array}{l}\text { Funda-se a Liga Agrária do } \\
\text { Norte. }\end{array}$ \\
\hline $\begin{array}{l}\text { Finais } \\
\text { década } \\
1880\end{array}$ & $\begin{array}{l}\text { Crise comercial com retração } \\
\text { dos mercados importadores } \\
\text { e aumento da concorrência } \\
\text { externa. }\end{array}$ & $\begin{array}{l}\text { Defesa da garantia da marca regio- } \\
\text { nal torna-se questão do Alto Douro } \\
\text { que se prolongará pelo séc. XX }\end{array}$ & \\
\hline $\begin{array}{l}\text { Década } \\
\text { de } 1890\end{array}$ & & $\begin{array}{l}\text { Comícios e reuniões para regula- } \\
\text { mentação da lei das marcas regio- } \\
\text { nais de } 1883 \text {, promovidos pela CDD } \\
\text { secundada por Liga dos Lavradores } \\
\text { do Douro. }\end{array}$ & $\begin{array}{l}\text { Comissão de Defesa } \\
\text { Duriense (CDD). } \\
\text { Liga dos Lavradores do } \\
\text { Douro }\end{array}$ \\
\hline $1890-1891$ & $\begin{array}{l}\text { Ultimatum inglês. } \\
\text { Crise económica, financeira } \\
\text { e bancária internacional com } \\
\text { repercussões graves em Por- } \\
\text { tugal e inúmeras falências. }\end{array}$ & $\begin{array}{l}\text { Manifestações antibritânicas. } \\
\text { Greve de tanoeiros em Gaia. } \\
\text { É reconhecida a liberdade sindical } \\
\text { pelo decreto de } 9 \text { de maio de 1891, } \\
\text { revogado em } 1933 \text { com o Estatuto } \\
\text { Nacional do Trabalho. } \\
\text { Revolta republicana no Porto. }\end{array}$ & \\
\hline 1893 & $\begin{array}{l}\text { Crise económica. } \\
\text { Doenças das videiras (mil- } \\
\text { dium e maromba) atacam } \\
\text { fortemente os vinhedos } \\
\text { nacionais. }\end{array}$ & $\begin{array}{l}\text { Comício na Régua e noutros locais } \\
\text { contra as ameaças às marcas regio- } \\
\text { nais e a importação de vinhos espa- } \\
\text { nhóis para juntar aos portugueses e } \\
\text { exportar como nacionais. }\end{array}$ & \\
\hline 1894-1895 & $\begin{array}{l}\text { Crise económica } \\
\text { Míldio afeta vinhas e pouca } \\
\text { produção vinícola. }\end{array}$ & $\begin{array}{l}\text { Movimento de defesa da «marca» } \\
\text { Porto e vinhos do Douro }\end{array}$ & $\begin{array}{l}\text { Primeira Comissão Republi- } \\
\text { cana Reguense }\end{array}$ \\
\hline 1890-1899 & $\begin{array}{l}\text { Forte decréscimo das expor- } \\
\text { tações de vinhos portugue- } \\
\text { ses. } \\
\text { Constituição de brigada téc- } \\
\text { nica (decreto de } 26 \text { de julho } \\
\text { de 1899) para estudar e tratar } \\
\text { a maromba que fez estragos } \\
\text { consideráveis no Douro. }\end{array}$ & & \\
\hline
\end{tabular}




\begin{tabular}{|c|c|c|c|}
\hline Anos & Crises & $\begin{array}{l}\text { Movimentações sociais, } \\
\text { políticas e económicas }\end{array}$ & $\begin{array}{c}\text { Organizações da lavoura } \\
\text { e outras }\end{array}$ \\
\hline \multicolumn{4}{|c|}{ Século XX } \\
\hline 1900 & $\begin{array}{l}\text { Agravamento da crise e a } \\
\text { «questão do douro» torna-se } \\
\text { questão nacional } \\
\text { Proliferação de fraudes e } \\
\text { falsificações dos vinhos da } \\
\text { Região e implicações graves } \\
\text { nas exportações. }\end{array}$ & $\begin{array}{l}\text { Assembleia Geral de Viticultores do } \\
\text { Norte e comerciantes de vinho do } \\
\text { Porto envia às Cortes. } \\
\text { Movimento de defesa regional. } \\
\text { «marca» Porto para os vinhos do } \\
\text { Douro, regresso ao protecionismo, } \\
\text { exclusivo da barra do Douro e porto } \\
\text { de Leixões...) comícios, reuniões, } \\
\text { artigos na imprensa, representa- } \\
\text { ções com exigências regionais. } \\
\text { Representação sobre proposta de } \\
\text { lei de } 6 \text { de abril de } 1890 \text {. } \\
\text { Reclama-se a formação de Compa- } \\
\text { nhias vinícolas }\end{array}$ & $\begin{array}{l}2 .^{\circ} \text { Congresso vinícola } \\
\text { nacional em Lisboa, patro- } \\
\text { cinado pela Real Associação } \\
\text { Central da Agricultura com } \\
\text { mais de } 5000 \text { participantes, } \\
\text { representantes de } 86 \text { câma- } \\
\text { ras do Douro, } 29 \text { sindicatos } \\
\text { e associações agrícolas e } \\
\text { participação da Liga dos } \\
\text { Lavradores do Douro. } \\
\text { Congresso e RACAP domi- } \\
\text { nados pelos interesses viní- } \\
\text { colas do Sul. } \\
\text { Ressurgimento da Comis- } \\
\text { são da Defesa do Douro e } \\
\text { comissões concelhias de } \\
\text { defesa da «genuinidade do } \\
\text { vinho do Porto». } \\
\text { Constituição de Sindicatos } \\
\text { agrícolas por ação direta }\end{array}$ \\
\hline 1901 & $\begin{array}{l}\text { Viticultura nacional atravessa } \\
\text { período crítico, por dificulda- } \\
\text { des de escoamento e depre- } \\
\text { ciação do produto. }\end{array}$ & $\begin{array}{l}\text { Viticultores pedem ao governo } \\
\text { acordos comerciais para abertura } \\
\text { de novos mercados e alteração do } \\
\text { preço das aguardentes (mais caras } \\
\text { no Sul e mais baratas no Norte). }\end{array}$ & \\
\hline 1902 & $\begin{array}{l}\text { Elevada proporção de ter- } \\
\text { renos incultos nos distritos } \\
\text { durienses, face ao conti- } \\
\text { nente. [ } 90.000 \text { ha ( } 8 \%) \text { da } \\
\text { área total e representa } 49 \% \\
\text { da área regional], embora } \\
\text { em decréscimo em relação a } \\
\text { anos anteriores. }\end{array}$ & & $\begin{array}{l}\text { Funda-se em Londres The } \\
\text { Port Wine Shippers Asso- } \\
\text { ciation. }\end{array}$ \\
\hline 1904 & & $\begin{array}{l}\text { Cultura de folhas de tabaco no } \\
\text { Douro, com maior expansão em } \\
\text { Vila Real, Santa Marta, Armamar e } \\
\text { Sabrosa. }\end{array}$ & \\
\hline
\end{tabular}




\begin{tabular}{|c|c|c|c|}
\hline Anos & Crises & $\begin{array}{l}\text { Movimentações sociais, } \\
\text { políticas e económicas }\end{array}$ & $\begin{array}{c}\text { Organizações da lavoura } \\
\text { e outras }\end{array}$ \\
\hline 1905-1906 & $\begin{array}{l}\text { Grave crise no Douro; sus- } \\
\text { pensão da cobrança do } \\
\text { imposto do real de água } \\
\text { que incide sobre o vinho do } \\
\text { Douro que entra no Porto. }\end{array}$ & $\begin{array}{l}\text { De um total de } 390.400 \text { hl de vinho } \\
\text { generoso existente na região } \\
\text { duriense, } 244.400 \text { estão na posse de } \\
\text { viticultores e } 145.900 \text { na dos nego- } \\
\text { ciantes. Os exportadores de vinho } \\
\text { do Douro instalados no Porto defi- } \\
\text { nem o que deve ser considerado } \\
\text { vinho do Porto e Região Demar- } \\
\text { cada. }\end{array}$ & $\begin{array}{l}\text { Comissão Executiva dos } \\
\text { Lavradores do concelho da } \\
\text { Régua edita brochura sobre } \\
\text { a Questão Duriense. }\end{array}$ \\
\hline 1907 & $\begin{array}{l}\text { Crise vitícola nacional e con- } \\
\text { dicionamento da cultura da } \\
\text { vinha. }\end{array}$ & $\begin{array}{l}\text { A cultura do tabaco ocupa no } \\
\text { Douro a maior extensão de sempre } \\
\text { ( } 207 \text { ha). } \\
\text { Golpe de estado e início da dita- } \\
\text { dura de João Franco. } \\
\text { Decreto de } 10 \text { de maio sobre ques- } \\
\text { tão vinícola impõe novo regime } \\
\text { geral para a produção, venda, } \\
\text { exportação e fiscalização dos } \\
\text { vinhos, reserva a barra do Douro } \\
\text { exclusivamente para os vinhos do } \\
\text { Porto e alarga a região demarcada } \\
\text { do Douro (o maior alargamento } \\
\text { de sempre da região produtora de } \\
\text { vinhos generosos do Douro). }\end{array}$ & $\begin{array}{l}\text { Constitui-se na Régua a } \\
\text { Comissão de Viticultura do } \\
\text { Douro formada por Júlio } \\
\text { Vasques, António Montes } \\
\text { Champalimaud e outros. } \\
\text { É criada pelo governo a } \\
\text { Comissão de Viticultura da } \\
\text { Região do Douro, (CVRD) } \\
\text { instituição reguladora e de } \\
\text { fiscalização. }\end{array}$ \\
\hline 1908 & & $\begin{array}{l}\text { Regicídio ( } 1 \text { fevereiro). Demissão do } \\
\text { governo de João Franco e constitui- } \\
\text { ção de outro presidido por Ferreira } \\
\text { do Amaral. É corrigida e muito dimi- } \\
\text { nuída a área da Região Demarcada } \\
\text { do Douro. }\end{array}$ & $\begin{array}{l}\text { O Governo cria o Grémio } \\
\text { dos Exportadores do Vinho } \\
\text { do Porto e uma Comissão } \\
\text { agrícola comercial dos } \\
\text { vinhos do Douro. }\end{array}$ \\
\hline 1909 & $\begin{array}{l}\text { Em dezembro regista-se uma } \\
\text { das maiores cheias de sempre } \\
\text { no Douro. Perderam-se mais } \\
\text { de } 400 \text { barcos e barcaças e os } \\
\text { prejuízos foram incalculáveis. }\end{array}$ & $\begin{array}{l}\text { Grande instabilidade política. } \\
\text { A população de Alijó e de Carra- } \\
\text { zeda, na sequencia de revoltas nou- } \\
\text { tros concelhos do Douro, revolta-se, } \\
\text { ataca as repartições da Fazenda e } \\
\text { da Recebedoria das vilas e queima a } \\
\text { documentação aí existente. Atacam } \\
\text { armazéns no Tua contra a vinda de } \\
\text { vinhos e aguardentes do Sul. }\end{array}$ & \\
\hline
\end{tabular}




\begin{tabular}{|c|c|c|c|}
\hline Anos & Crises & $\begin{array}{l}\text { Movimentações sociais, } \\
\text { políticas e económicas }\end{array}$ & $\begin{array}{c}\text { Organizações da lavoura } \\
\text { e outras }\end{array}$ \\
\hline 1910 & & $\begin{array}{l}\text { Queda da Monarquia e implanta- } \\
\text { ção da I República ( } 5 \text { de outubro). } \\
\text { De } 1910 \text { a 1926, período de grande } \\
\text { instabilidade política; só na pasta } \\
\text { da Agricultura registaram-se } 13 \\
\text { ministros. } \\
\text { O n.o de cultivadores de tabaco } \\
\text { no Douro atinge o seu ponto mais } \\
\text { alto (996) e depois do que decai até } \\
\text { 1916/20. }\end{array}$ & \\
\hline 1910-1911 & $\begin{array}{l}\text { Diminuição da produção de } \\
\text { vinho generoso do Douro } \\
\text { que representa cerca de } 5 \% \\
\text { da produção vinícola nacio- } \\
\text { nal. } \\
\text { Recessão atinge mais forte- } \\
\text { mente a produção do Baixo } \\
\text { Corgo (menos } 70 \% \text { e do } \\
\text { Douro Superior (menos } 55 \% \text { ) } \\
\text { do que o Cima Corgo (menos } \\
26 \% \text { ). } \\
\text { O Cima Corgo produziu } \\
44,2 \% \text { do vinho generoso da } \\
\text { região, o Baixo Corgo } 40,2 \% \text { e } \\
\text { o Douro Superior } 15,4 \% \text {. }\end{array}$ & $\begin{array}{l}\text { A população da RDD sobretudo no } \\
\text { Cima Corgo, registou uma nítida } \\
\text { desaceleração do ritmo de cresci- } \\
\text { mento, talvez por efeitos da filoxera } \\
\text { e da emigração. } \\
\text { [Em } 1911 \text { é aprovada a Convenção } \\
\text { de Washington para a defesa das } \\
\text { marcas de origem]. }\end{array}$ & \\
\hline 1906 & & $\begin{array}{l}\text { Forte pressão das várias «comissões } \\
\text { de defesa» }\end{array}$ & \\
\hline 1907 & & $\begin{array}{l}\text { Decreto de } 10 \text { de maio de João } \\
\text { Franco atende algumas reivindica- } \\
\text { ções durienses: exclusivo da barra } \\
\text { douro e porto Leixões, defesa da } \\
\text { marca porto para vinhos generosos } \\
\text { da região, princípios protecionistas } \\
\text { e nova demarcação, fiscalização da } \\
\text { CVRD. }\end{array}$ & \\
\hline
\end{tabular}




\begin{tabular}{|c|c|c|c|}
\hline Anos & Crises & $\begin{array}{l}\text { Movimentações sociais, } \\
\text { políticas e económicas }\end{array}$ & $\begin{array}{c}\text { Organizações da lavoura } \\
\text { e outras }\end{array}$ \\
\hline $\begin{array}{c}1909-1910- \\
-1912\end{array}$ & $\begin{array}{l}\text { Profunda crise social - } \\
\text { extrema miséria das popu- } \\
\text { lações da Região, vaga de } \\
\text { fomes e desemprego no } \\
\text { Douro } \\
\text { Interrogação recorrente «se o } \\
\text { Vinho do Porto - ou vinho } \\
\text { do Douro - tendia cada vez } \\
\text { mais a ser o vinho de qual- } \\
\text { quer várzea ou lodeiro euro- } \\
\text { peu, de que servia insistir } \\
\text { em o produzir nos famosos } \\
\text { socalcos durienses?». }\end{array}$ & $\begin{array}{l}\text { Motins e revoltas populares em } \\
\text { Carrazeda, Alijo, Favaios, Vila Flor, } \\
\text { Santa Marta de Penaguião contra } \\
\text { impostos, contribuições prediais } \\
\text { em divida, entrada no Douro de } \\
\text { vinhos e aguardentes do sul. } \\
\text { A miséria e desespero em que vivia } \\
\text { a agricultura duriense gerou a } \\
\text { revolta das gentes do Douro. } \\
\text { Sucederam-se os tumultos, com } \\
\text { incêndios e assaltos a repartições } \\
\text { públicas, como em Alijó, e outras } \\
\text { vilas vizinhas, assaltos e destruições } \\
\text { de comboios vindos do Sul, carre- } \\
\text { gados de vinho e aguardente, em } \\
\text { março de } 1915 \text {. } \\
\text { Movimentações de elites regionais } \\
\text { exigindo fiscalização das leis de } \\
\text { proteção do Douro }\end{array}$ & \\
\hline 1914-1915 & $\begin{array}{l}\text { Início da I Guerra Mundial } \\
\text { (1914-18) com adesão de } \\
\text { Portugal e grande instabili- } \\
\text { dade internacional e nacional. } \\
\text { Crise política, económica e } \\
\text { grave crise social } \\
\text { Colheitas fracas, baixa de } \\
\text { preços do vinho e estagna- } \\
\text { ção da procura. } \\
\text { Fortíssimo ataque de míldio } \\
\text { no Douro. }\end{array}$ & $\begin{array}{l}\text { A fome e a miséria alastram na } \\
\text { região face à crise vinícola e geram } \\
\text { revoltas. Movimentações pela } \\
\text { defesa da marca. } \\
\text { Grande Motim de Lamego (jul, } \\
\text { 1915) "Marchas da fome» que } \\
\text { mobiliza padres e elementos de for- } \\
\text { ças partidárias, protestando contra } \\
\text { a carestia, mas sobretudo contra o } \\
\text { artigo } 6 \text {. }^{\circ} \text { do Tratado de Comércio } \\
\text { Luso-Britânico - vinho do porto } \\
\text { todo o vinho do país e não o exclu- } \\
\text { sivo do douro - , que prejudicava } \\
\text { os interesses da região do Douro e o } \\
\text { escoamento dos vinhos durienses, } \\
\text { protesto violentamente reprimido } \\
\text { (12 mortos, feridos e presos). } \\
\text { Revoltas, manifestações, comícios e } \\
\text { outras ações de protesto e descon- } \\
\text { tentamento das gentes do Douro } \\
\text { sucederam-se durante vários anos. } \\
\text { O povo do Douro mostrava estar } \\
\text { farto de ser «a mula de carga dos des- } \\
\text { mandos da vitivinicultura nacional» }\end{array}$ & \\
\hline
\end{tabular}




\begin{tabular}{|c|c|c|c|}
\hline Anos & Crises & $\begin{array}{l}\text { Movimentações sociais, } \\
\text { políticas e económicas }\end{array}$ & $\begin{array}{c}\text { Organizações da lavoura } \\
\text { e outras }\end{array}$ \\
\hline 1916-1921 & $\begin{array}{l}\text { Crise vinícola, política e eco- } \\
\text { nómica. } \\
\text { O comércio de vinho do } \\
\text { Porto com os países nórdicos } \\
\text { para porque declarado «con- } \\
\text { trabando de guerra» pelo } \\
\text { governo português. } \\
\text { A produção de vinho do } \\
\text { Porto quase duplicou mas } \\
\text { os negócios no Douro até } \\
\text { finais de } 1918 \text {, encontram- } \\
\text {-se parados pelas restrições } \\
\text { de exportação para França, } \\
\text { e outros países e falta de } \\
\text { transportes devido à guerra. } \\
\text { A Inglaterra importa } 70.868 \\
\text { pipas de Vinho do Porto. }\end{array}$ & $\begin{array}{l}\text { Comícios e reuniões de viticultores } \\
\text { e comerciantes. } \\
\text { Ação da «Missão de Alijó» contra } \\
\text { os perigos para a Região, do Tra- } \\
\text { tado de Comercio Luso-britânico } \\
\text { de } 1914 \\
\text { Manifestações lideradas em 1921, } \\
\text { pelo «Movimento dos Paladinos» } \\
\text { contra regulamento de } 1918 \text { que } \\
\text { não fiscaliza fraudes praticadas em } \\
\text { Gaia e entrada dos vinhos do Sul no } \\
\text { Douro. }\end{array}$ & $\begin{array}{l}\text { Sindicatos agrícolas e cor- } \\
\text { porações regionais. } \\
\text { Reorganização da Comis- } \\
\text { são de Defesa do Douro em } \\
\text { 1921, presidida por Antão } \\
\text { de Carvalho, presidente da } \\
\text { CVRD, representante do } \\
\text { setor da produção e líder } \\
\text { do «Movimento dos Paladi- } \\
\text { nos». }\end{array}$ \\
\hline 1921 & $\begin{array}{l}\text { O setor exportador do vinho } \\
\text { do Porto atravessa uma crise } \\
\text { de stocks excessivos para o } \\
\text { que terão contribuído abun- } \\
\text { dantes produções de anos } \\
\text { anteriores e instabilidade do } \\
\text { comércio externo. } \\
\text { Crise de exportação para os } \\
\text { mercados francês e norue- } \\
\text { guês que se repercute na } \\
\text { produção afetando produto- } \\
\text { res e trabalhadores agrícolas }\end{array}$ & $\begin{array}{l}\text { Manifestações de protesto, na } \\
\text { Régua, Santa Marta, Meda, Sabrosa } \\
\text { e Foz Coa, que incluem encerra- } \\
\text { mento simbólico de instituições, } \\
\text { contra o governo por não ter defen- } \\
\text { dido os interesses da região. } \\
\text { Movimento liderado por autarcas, } \\
\text { com a participação de viticultores, } \\
\text { comerciantes e industriais locais. } \\
\text { Contestam a falta de fiscalização } \\
\text { contra as fraudes e a entrada de } \\
\text { vinhos do Sul na região demarcada, } \\
\text { em Gaia e na barra do Douro. }\end{array}$ & \\
\hline 1923 & & $\begin{array}{l}\text { Ressurge a questão da marca Porto } \\
\text { quando da criação da marca «Lis- } \\
\text { bonWine». } \\
\text { Novas movimentações em defesa } \\
\text { da marca Porto com apoio das } \\
\text { câmaras e sindicatos agrícolas. } \\
\text { Numerosas reuniões e grande } \\
\text { Comício na Régua, de } 14 \text { de junho. }\end{array}$ & \\
\hline
\end{tabular}




\begin{tabular}{|c|c|c|c|}
\hline Anos & Crises & $\begin{array}{l}\text { Movimentações sociais, } \\
\text { políticas e económicas }\end{array}$ & $\begin{array}{c}\text { Organizações da lavoura } \\
\text { e outras }\end{array}$ \\
\hline 1926-1949 & $\begin{array}{l}\text { Ditadura Militar e Estado } \\
\text { Novo provocam fortes } \\
\text { mudanças políticas e institu- } \\
\text { cionais no Douro-demissão } \\
\text { de republicanos de cargos } \\
\text { políticos, intervenção em } \\
\text { Câmaras, "Sindicalização» } \\
\text { oficial da lavoura duriense, } \\
\text { através da Casa do Douro. }\end{array}$ & $\begin{array}{l}\text { Manifestações de oposição ao } \\
\text { regime num enquadramento } \\
\text { nacional. } \\
\text { Confrontos entre elites situacionis- } \\
\text { tas e oposicionistas e tentativas de } \\
\text { regresso ao regime constitucional } \\
\text { por «via pacífica», (ex. em } 1949 \\
\text { apoio à campanha da candidatura } \\
\text { de Norton de Matos à presidência } \\
\text { da República. } \\
\text { Grande adesão à ARS na Região } \\
\text { do Douro, a partir de 1931, com } \\
\text { formação de delegações da ARS } \\
\text { em: Régua, Alijó, Tabuaço, Freixo } \\
\text { de Espada à Cinta, S. João da Pes- } \\
\text { queira, Mesão Frio, Armamar, Vila } \\
\text { Real, Carrazeda de Ansiães, Santa } \\
\text { Marta de Penaguião, etc. }\end{array}$ & $\begin{array}{l}\text { Aliança Republicana Socia- } \\
\text { lista (ARS), dirigida por Nor- } \\
\text { ton de Matos, Tito de Morais } \\
\text { e outros elementos de dife- } \\
\text { rentes quadrantes políticos } \\
\text { - Frente Única nacional de } \\
\text { oposicionistas ao regime, } \\
\text { defensores de uma via paci- } \\
\text { fica de mudança, através de } \\
\text { eleições. } \\
\text { Comissões concelhias forma- } \\
\text { das por eminentes vultos } \\
\text { locais, como Antão de Carva- } \\
\text { lho, João de Araújo Correia } \\
\text { ou Carlos Richter, reunindo } \\
\text { diversos quadrantes } \\
\text { políticos. }\end{array}$ \\
\hline 1926 & $\begin{array}{l}\text { Crise económica e política e } \\
\text { críticas à atuação da CVRD. } \\
\text { Viragem na história socioins- } \\
\text { titucional duriense }\end{array}$ & $\begin{array}{l}\text { Novas formas de intervenção polí- } \\
\text { tica - grupo de notáveis republica- } \\
\text { nos (Antão de Carvalho e outros) } \\
\text { restabelece «Movimento dos Pala- } \\
\text { dinos» para defesa do Douro e rei- } \\
\text { vindicação da reforma institucional. } \\
\text { Organização de comícios, reuniões } \\
\text { e comissões de estudo. } \\
\text { Defesa da legislação vinícola } \\
\text { duriense, avançada a nível mundial. }\end{array}$ & $\begin{array}{l}\text { Intensificação da defesa do } \\
\text { associativismo e reativação } \\
\text { das Caixas de Crédito Agrí- } \\
\text { cola. }\end{array}$ \\
\hline
\end{tabular}




\begin{tabular}{|c|c|c|c|}
\hline Anos & Crises & $\begin{array}{l}\text { Movimentações sociais, } \\
\text { políticas e económicas }\end{array}$ & $\begin{array}{c}\text { Organizações da lavoura } \\
\text { e outras }\end{array}$ \\
\hline 1927 & & $\begin{array}{l}\text { Ações conspiratórias contra a dita- } \\
\text { dura e várias formas de adesão } \\
\text { duriense à Revolta do Reviralho } \\
\text { (Porto, } 3 \text { fev.) de resistência e opo- } \\
\text { sição à ditadura militar. } \\
\text { Colaboração do escritor republi- } \\
\text { cano Pina de Morais que consegue } \\
\text { a adesão de unidades militares de } \\
\text { Vila Real. Confrontos na Régua e } \\
\text { Intentonas em Alijo e Valpaços. } \\
\text { Apoio político dos Partidos Radical, } \\
\text { Democrático, } \\
\text { Esquerda Democrática, Ação Repu- } \\
\text { blicana e Seara Nova }\end{array}$ & $\begin{array}{l}\text { Apoio político dos Partidos } \\
\text { Radical, Democrático, } \\
\text { Esquerda Democrática, } \\
\text { Ação Republicana e Seara } \\
\text { Nova }\end{array}$ \\
\hline 1930 & $\begin{array}{l}\text { Crise económica internacio- } \\
\text { nal que se refletia no setor } \\
\text { do vinho do Porto atingindo } \\
\text { gravemente a comercializa- } \\
\text { ção do vinho do Porto. } \\
\text { Dura crise económica: des- } \\
\text { cida das exportações, degra- } \\
\text { dação dos preços, produ- } \\
\text { ção sem compradores nem } \\
\text { escoamento. }\end{array}$ & $\begin{array}{l}\text { Miseráveis condições socioeconó- } \\
\text { micas de vida e de trabalho dos } \\
\text { trabalhadores (cavadores, jeireiros } \\
\text { e jornaleiros) do Alto Douro e gri- } \\
\text { tantes diferenças sociais geraram } \\
\text { uma consciência de miséria incon- } \\
\text { formada e de revolta que se genera- } \\
\text { lizou em «protesto social» e «aban- } \\
\text { dono das práticas religiosas» pelas } \\
\text { populações durienses. }\end{array}$ & \\
\hline 1931 & $\begin{array}{l}\text { Crise política e alteração da } \\
\text { institucionalização regional e } \\
\text { local duriense. } \\
\text { Novos perigos ameaçam } \\
\text { o Douro, como o decreto } \\
19.253 \text { de } 19 \text { de maio que se } \\
\text { propõe extinguir as Comis- } \\
\text { sões de Viticultura regionais } \\
\text { e substitui-las por uma Junta } \\
\text { Regional de Agricultura }\end{array}$ & $\begin{array}{l}\text { Continuam os protestos populares } \\
\text { e os movimentos de defesa regio- } \\
\text { nal. } \\
\text { Fragmentação da elite política } \\
\text { regional, com a adesão de vários } \\
\text { republicanos históricos à União } \\
\text { Nacional. }\end{array}$ & $\begin{array}{l}\text { Reorganização da Comissão } \\
\text { de Defesa do Douro subdi- } \\
\text { vidida em comissões con- } \\
\text { celhias, com «figuras mais } \\
\text { prestimosas» da região } \\
\text { (elite económica, cultural e } \\
\text { política local de proprietá- } \\
\text { rios da classe média letrada } \\
\text { de formação superior, em } \\
\text { direções partidárias próxi- } \\
\text { mas do poder, com forte } \\
\text { influência e prestígio na } \\
\text { região e redes de influên- } \\
\text { cias no governo). }\end{array}$ \\
\hline
\end{tabular}




\begin{tabular}{|c|c|c|c|}
\hline Anos & Crises & $\begin{array}{l}\text { Movimentações sociais, } \\
\text { políticas e económicas }\end{array}$ & $\begin{array}{c}\text { Organizações da lavoura } \\
\text { e outras }\end{array}$ \\
\hline 1932 & $\begin{array}{l}\text { Ressurge a questão da marca } \\
\text { Porto e sua defesa aquando } \\
\text { da criação da marca «Estre- } \\
\text { madura» vista como afronta } \\
\text { ao Douro e concorrência des- } \\
\text { leal aos vinhos do Porto. }\end{array}$ & $\begin{array}{l}\text { Movimento de contestação à marca } \\
\text { Estremadura, afirmação das preten- } \\
\text { sões regionais e defesa dos vinhos } \\
\text { do Douro e da marca Porto, lidera- } \\
\text { dos pela Casa do Douro, criada em } \\
\text { novembro de } 1932 \text {. } \\
\text { Representações ao governo da } \\
\text { Comissão Técnica dos Vinhos da } \\
\text { ACP. } \\
\text { Contactos governamentais e par- } \\
\text { tidários, comícios, conferências e } \\
\text { reuniões para formular novo Esta- } \\
\text { tuto do Douro }\end{array}$ & \\
\hline 1933 & $\begin{array}{l}\text { Extinção do direito de liber- } \\
\text { dade sindical com a promul- } \\
\text { gação do Estatuto do Traba- } \\
\text { Iho Nacional }\end{array}$ & & \\
\hline 1941-1944 & & $\begin{array}{l}\text { Clima geral de agitação social e } \\
\text { reclamação de mudanças. Aos } \\
\text { «equilíbrios sociais», invocados } \\
\text { pela propaganda do Estado Novo } \\
\text { na década 1930, sucedem-se a } \\
\text { agitação e o descontentamento } \\
\text { geral. Carestia dos bens alimen- } \\
\text { tares essenciais, racionamento, } \\
\text { contrabando, açambarcamento } \\
\text { e agravamento das condições de } \\
\text { vida, espetro da fome, salários bai- } \\
\text { xos e congelados intransigência } \\
\text { do regime salazarista para com os } \\
\text { protestos dos sindicatos e falta das } \\
\text { liberdades fundamentais, levam } \\
\text { a protestos reivindicativos e con- } \\
\text { frontos entre populações e forças } \\
\text { policiais com milhares de vítimas } \\
\text { (presos, feridos e mortos). } \\
\text { Greves do proletariado industrial, } \\
\text { encerramento de empresas e des- } \\
\text { pedimentos coletivos. Atentados, } \\
\text { assaltos e motins, do Alentejo a } \\
\text { Trás-os-Montes. } \\
\text { Repressão feroz do Governo sala- } \\
\text { zarista. }\end{array}$ & \\
\hline
\end{tabular}




\begin{tabular}{|c|c|c|c|}
\hline Anos & Crises & $\begin{array}{l}\text { Movimentações sociais, } \\
\text { políticas e económicas }\end{array}$ & $\begin{array}{c}\text { Organizações da lavoura } \\
\text { e outras }\end{array}$ \\
\hline $1945-1949$ & $\begin{array}{l}\text { Dissolução da Assembleia } \\
\text { Nacional e anúncio, pelo } \\
\text { Governo do Estado Novo, de } \\
\text { eleições legislativas, o que é } \\
\text { visto pela Oposição, como } \\
\text { oportunidade de mudança } \\
\text { de regime. } \\
\text { Candidatura de Norton de } \\
\text { Matos às eleições presiden- } \\
\text { ciais de 1949, nova opor- } \\
\text { tunidade aproveitada pela } \\
\text { Oposição para contestação e } \\
\text { luta unitária contra o regime } \\
\text { político fascista. }\end{array}$ & $\begin{array}{l}\text { Inicia-se segundo ciclo } \\
\text { de resistência ao regime de dita- } \\
\text { dura, eleitoralista com adesão entu- } \\
\text { siasta dos oposicionistas da RDD ao } \\
\text { Manifesto de } 8 \text { de outubro do MUD } \\
\text {-política frentista. } \\
\text { Campanha de recolha de assina- } \\
\text { turas de apoio ao MUD e sua ação } \\
\text { política. } \\
\text { Comícios, conferências, propa- } \\
\text { ganda político-partidária de opo- } \\
\text { sição democrática e protestos } \\
\text { escritos contra impedimento pelas } \\
\text { autoridades e intervenção da PIDE } \\
\text { de reuniões políticas no Douro, } \\
\text { para preparação das eleições legis- } \\
\text { lativas e presidenciais. }\end{array}$ & $\begin{array}{l}\text { Constituem-se comissões } \\
\text { concelhias e de freguesia } \\
\text { durienses do Movimento } \\
\text { de Unidade Democrática } \\
\text { (MUD) que defende elei- } \\
\text { ções livres, liberdades polí- } \\
\text { ticas e partidárias, com ade- } \\
\text { são de diferentes setores } \\
\text { político-partidários. } \\
\text { llegalização do MUD em } \\
\text { 1948, antes das eleições } \\
\text { presidenciais a que se can- } \\
\text { didatou Norton de Matos. }\end{array}$ \\
\hline $\begin{array}{l}\text { 2. }{ }^{\text {a Metade }} \\
\text { do Séc. XX }\end{array}$ & $\begin{array}{l}\text { Nas explorações vocacio- } \\
\text { nadas para produzir para o } \\
\text { mercado, acentua-se a ten- } \\
\text { são entre recurso a mão de } \\
\text { obra rural ou a maquinaria } \\
\text { que substituiria aquela em } \\
\text { muitas tarefas (meados do } \\
\text { século XX.) } \\
\text { Na vitivinicultura, as constan- } \\
\text { tes dificuldades em escoar } \\
\text { colheitas dão razão aos que } \\
\text { querem reduzir os custos de } \\
\text { produção e alargar a expor- } \\
\text { tação e o consumo no mer- } \\
\text { cado interno. }\end{array}$ & $\begin{array}{l}\text { Os descontentamentos regionais } \\
\text { são mantidos a níveis suportáveis } \\
\text { pelas ações da Casa do Douro e } \\
\text { Junta Nacional do Vinho, organis- } \\
\text { mos do Estado que encontraram } \\
\text { mecanismos para mediar os impac- } \\
\text { tos negativos da produção vinícola } \\
\text { e funcionamento dos mercados. } \\
\text { As elites políticas e económicas } \\
\text { zelam por meios (in)formais pelo } \\
\text { funcionamento do sistema de } \\
\text { acordo com os interesses hege- } \\
\text { mónicos na região. }\end{array}$ & $\begin{array}{l}\text { Adegas cooperativas } \\
\text { (criação e intensificação) }\end{array}$ \\
\hline
\end{tabular}




\begin{tabular}{|c|c|c|c|}
\hline Anos & Crises & $\begin{array}{l}\text { Movimentações sociais, } \\
\text { políticas e económicas }\end{array}$ & $\begin{array}{c}\text { Organizações da lavoura } \\
\text { e outras }\end{array}$ \\
\hline $\begin{array}{c}\text { Décadas } \\
1950-1960\end{array}$ & $\begin{array}{l}\text { Falta de mão de obra assala- } \\
\text { riada local devido à emigra- } \\
\text { ção. } \\
\text { Recorrente crise de trabalho } \\
\text { até meados da década de } \\
1960 . \\
\text { Decréscimo da população } \\
\text { duriense, superior aos valo- } \\
\text { res nacionais (2,6\%), entre } \\
1950 \text { e } 1981, \text { o que se reflete } \\
\text { na diminuição da popula- } \\
\text { ção ativa agrícola (72\% para } \\
46,8 \% \text {, no distrito de Vila } \\
\text { Real, e de } 73,4 \% \text { para } 51,4 \% \\
\text { no de Bragança). }\end{array}$ & $\begin{array}{l}\text { Movimentos migratórios intercon- } \\
\text { celhios começam a perder intensi- } \\
\text { dade. } \\
\text { Os trabalhos das minas, florestas e } \\
\text { batata suspendem muitas idas para } \\
\text { o Douro onde o trabalho era de sol } \\
\text { a sol com meia hora ou menos de } \\
\text { pausa para almoço. } \\
\text { Nos anos 1960, continuam as lutas } \\
\text { de oposição das populações de } \\
\text { várias aldeias do Norte e Centro do } \\
\text { país, contra a florestação dos bal- } \\
\text { dios e representantes do Estado. } \\
\text { Uma aldeia de Sabrosa opõe-se à } \\
\text { GNR e à PIDE contra prisão do pro- } \\
\text { prietário duriense Dr. Luís Roseira. } \\
\text { Atividades agrícolas nas quintas } \\
\text { do Douro e outras casas de lavoura } \\
\text { começam a deixar de ser assegura- } \\
\text { das por assalariados das proximida- } \\
\text { des. } \\
\text { Intensificação do êxodo rural, o raio } \\
\text { de ação de procura de trabalhado- } \\
\text { res alargou-se e passaram a existir } \\
\text { cardanheiros não só na época das } \\
\text { vindimas, mas noutras tarefas. }\end{array}$ & $\begin{array}{l}\text { Desenvolve-se a rede de } \\
\text { adegas cooperativas (24 } \\
\text { adegas com } 15.000 \text { asso- } \\
\text { ciados), importantes insti- } \\
\text { tuições da RDD em: Mesão } \\
\text { Frio (1950); Régua (1951); } \\
\text { Vila Real (1955); Favaios } \\
\text { (1956); Lamego e Arma- } \\
\text { mar (1957); Meda (1958); } \\
\text { Freixo de Numão e Pegari- } \\
\text { nhos (1959); Sabrosa, San- } \\
\text { fins, Alijó e Foz Coa (1960); } \\
\text { Trevões (1961); Pesqueira, } \\
\text { Freixo e Medões (1962); } \\
\text { Cumieira, Santa Marta e } \\
\text { Moncorvo (1963); Vila Flor } \\
\text { (1964); Murça e Vale de Teja } \\
\text { (1965). }\end{array}$ \\
\hline $\begin{array}{c}\text { Década } \\
1970\end{array}$ & $\begin{array}{l}\text { Crises endémicas de falta de } \\
\text { trabalho, desde anos } 1950 \text { e } \\
\text { 1960, com alternativas pon- } \\
\text { tuais e temporárias em obra } \\
\text { públicas das câmaras. Indu- } \\
\text { tor das tensões sociais }\end{array}$ & $\begin{array}{l}\text { Formas de resistência frequentes } \\
\text { dos trabalhadores no Douro aos } \\
\text { patrões e poderes públicos. }\end{array}$ & \\
\hline $\begin{array}{c}\text { Período } \\
\text { Pós-25 de } \\
\text { Abril de } \\
1974\end{array}$ & $\begin{array}{l}\text { Alteração profunda do } \\
\text { regime de organização cor- } \\
\text { porativa do setor vitivinícola, } \\
\text { mantendo-se os pilares fun- } \\
\text { damentais organizativos: o } \\
\text { Instituto do Vinho do Porto e } \\
\text { a Casa do Douro, e a legisla- } \\
\text { ção reguladora. } \\
\text { O Douro vai entrar num pro- } \\
\text { cesso de «fermentação». }\end{array}$ & $\begin{array}{l}\text { Tempos conturbados política e } \\
\text { socialmente: saneamento dos diri- } \\
\text { gentes da Casa do Douro, extinção } \\
\text { dos Grémios da Lavoura e do Gré- } \\
\text { mio dos Exportadores do vinho do } \\
\text { Porto, fundado em } 1933 . \\
\text { Intervenção dos partidos políticos } \\
\text { tendo o Partido Socialista publi- } \\
\text { cado um Plano de Reestruturação } \\
\text { da Região do Douro }\end{array}$ & $\begin{array}{l}\text { Rápida adaptação ao novo } \\
\text { regime de democracia do } \\
\text { Grémio dos Exportadores } \\
\text { do Vinho do Porto com a } \\
\text { tomada de posse da comis- } \\
\text { são instaladora da Associa- } \\
\text { ção dos Exportadores do } \\
\text { Vinho do Porto. } \\
\text { Comissão liquidatária da } \\
\text { Casa do Douro }\end{array}$ \\
\hline
\end{tabular}




\begin{tabular}{|c|c|c|c|}
\hline Anos & Crises & $\begin{array}{l}\text { Movimentações sociais, } \\
\text { políticas e económicas }\end{array}$ & $\begin{array}{c}\text { Organizações da lavoura } \\
\text { e outras }\end{array}$ \\
\hline 1975 & $\begin{array}{l}\text { Crises político-institucionais } \\
\text { O Governo nomeia uma } \\
\text { Comissão de Gestão para a } \\
\text { Casa do Douro, presidida por } \\
\text { um elemento do MFA que } \\
\text { nunca tomou posse. } \\
\text { Entretanto, o Governo cria } \\
\text { a Comissão de Reorganiza- } \\
\text { ção do Setor dos Vinhos do } \\
\text { Porto e Douro, para definir } \\
\text { reestruturação e reforma } \\
\text { dos setores da produção e } \\
\text { do comércio dos vinhos do } \\
\text { Porto e Douro. } \\
\text { A Companhia Geral de Agri- } \\
\text { cultura das Vinhas do Alto } \\
\text { Douro, a Real Vinícola do } \\
\text { Norte de Portugal e a Socie- } \\
\text { dade de Vinhos Borges \& } \\
\text { Irmão são intervencionadas } \\
\text { pelo Governo. }\end{array}$ & $\begin{array}{l}\text { Reposto o direito de liberdade sin- } \\
\text { dical pelo Dec. Lei } 215 \text {-B/75 de } 30 \\
\text { de abril, revogado em 1976, e esta- } \\
\text { belecidas as bases do ordenamento } \\
\text { jurídico das associações sindicais, } \\
\text { alteradas em } 1977 \text { e } 1991 . \\
\text { Violenta oposição dos viticultores } \\
\text { que ameaçaram atirar o indigitado } \\
\text { elemento do MFA da varanda da } \\
\text { Casa do Douro. } \\
\text { Plenário de viticultores elege nova } \\
\text { Comissão de Gestão para a CD, } \\
\text { homologada pelo Governo, mas } \\
\text { logo substituída pela nomeação de } \\
\text { uma comissão instaladora para pre- } \\
\text { parar eleições nos corpos sociais. } \\
\text { Proposta do PPD de reestruturação } \\
\text { da economia vitivinícola da Região } \\
\text { do Douro. }\end{array}$ & $\begin{array}{l}\text { Constituição legal da Asso- } \\
\text { ciação dos Exportadores do } \\
\text { Vinho do Porto. } \\
\text { Constituição em V. N. de } \\
\text { Gaia, da Associação de } \\
\text { Empresas de Vinho do Porto } \\
\text { (AEVP), que sucede ao Gré- } \\
\text { mio dos Exportadores de } \\
\text { Vinho do Porto. Reúne } 16 \\
\text { Associados e detém a vice- } \\
\text {-presidência do Conselho } \\
\text { Interprofissional do IVDP. } \\
\text { ANCEVE - Associação } \\
\text { Nacional de Exportado- } \\
\text { res de Vinhos e Bebidas } \\
\text { Espirituosas, com sede no } \\
\text { Porto que congrega } 150 \\
\text { dos agentes económicos } \\
\text { do setor do vinho, adegas, } \\
\text { cooperativas e produtorese } \\
\text { engarrafadores. }\end{array}$ \\
\hline
\end{tabular}

[continua] 


\begin{tabular}{|c|c|c|c|}
\hline Anos & Crises & $\begin{array}{l}\text { Movimentações sociais, } \\
\text { políticas e económicas }\end{array}$ & $\begin{array}{c}\text { Organizações da lavoura } \\
\text { e outras }\end{array}$ \\
\hline 1976 & $\begin{array}{l}\text { Governo promulga os Prin- } \\
\text { cípios Orientadores para a } \\
\text { Reorganização da Região } \\
\text { do Douro, que previam que } \\
\text { a Casa do Douro passasse a } \\
\text { funcionar, transitoriamente, } \\
\text { como associação de viticul- } \\
\text { tores, mantendo as antigas } \\
\text { funções e podendo exercer } \\
\text { outras «próprias da associa- } \\
\text { ção livre que no futuro será». } \\
\text { O Instituto do Vinho do } \\
\text { Porto passaria a Instituto } \\
\text { dos Vinhos do Porto e do } \\
\text { Douro, sendo criado um } \\
\text { Conselho Consultivo com } \\
\text { representantes de todas as } \\
\text { entidades intervenientes na } \\
\text { fileira, um esboço do inter- } \\
\text { profissionalismo, modelo } \\
\text { de autorregulação utilizado } \\
\text { noutras regiões vitivinícolas } \\
\text { europeias. }\end{array}$ & & $\begin{array}{l}\text { E constituída a Associação } \\
\text { dos Agricultores da Régua e } \\
\text { o Sindicato dos Trabalhado- } \\
\text { res Agrícolas do Distrito de } \\
\text { Vila Real. } \\
\text { Grémios da Lavoura passam } \\
\text { para o património da Casa } \\
\text { do Douro. }\end{array}$ \\
\hline 1978 & $\begin{array}{l}\text { A Comissão de Planeamento } \\
\text { da Região Norte publica } \\
\text { «Contributo para uma pro- } \\
\text { posta de organização do } \\
\text { setor vitivinícola da Região } \\
\text { Demarcada do Douro», } \\
\text { defendendo o modelo de } \\
\text { regulação interprofissio- } \\
\text { nal, para o vinho do Porto } \\
\text { e vinhos do Douro, e pro- } \\
\text { pondo a criação do Instituto } \\
\text { dos Vinhos do Porto e do } \\
\text { Douro. }\end{array}$ & $\begin{array}{l}\text { Subida elevada dos salários que } \\
\text { alerta para a debilidade da viticul- } \\
\text { tura duriense, que dificilmente con- } \\
\text { seguia repercutir no mercado os } \\
\text { elevados custos de produção. } \\
\text { Esse facto com o êxodo rural (desde } \\
\text { década de 1960), abrirá caminho } \\
\text { à mecanização da cultura prosse- } \\
\text { guida na Estação Vitivinícola do } \\
\text { Douro. }\end{array}$ & $\begin{array}{l}\text { Criação do Entreposto da } \\
\text { Régua, nos armazéns da } \\
\text { Casa do Douro (nunca foi } \\
\text { implementado). } \\
\text { Quinta do Infantado inicia } \\
\text { atividade como } 1 .^{\circ} \text { produ- } \\
\text { tor engarrafador no mer- } \\
\text { cado nacional. }\end{array}$ \\
\hline 1979 & & & $\begin{array}{l}\text { Criação da AVIDouro - } \\
\text { Associação de Viticultores } \\
\text { do Douro, com sede em Vila } \\
\text { Real. }\end{array}$ \\
\hline
\end{tabular}

[continua] 


\begin{tabular}{|c|c|c|c|}
\hline Anos & Crises & $\begin{array}{l}\text { Movimentações sociais, } \\
\text { políticas e económicas }\end{array}$ & $\begin{array}{c}\text { Organizações da lavoura } \\
\text { e outras }\end{array}$ \\
\hline $\begin{array}{c}\text { Década } \\
1980\end{array}$ & $\begin{array}{l}\text { Início de nova revolução no } \\
\text { Douro, revolução das condi- } \\
\text { ções técnicas de produção } \\
\text { e de comercialização, em } \\
\text { cooperação entre o tecido } \\
\text { empresarial e a Universidade } \\
\text { (IPVR e UTAD). }\end{array}$ & & $\begin{array}{l}\text { De } 1978 \text { a } 1998 \text { verifica-se o } \\
\text { crescimento de produtores } \\
\text { reconhecidos; } 9 \text { cooperati- } \\
\text { vas em Entre Douro e Minho } \\
\text { e } 14 \text { em Trás-os-Montes. }\end{array}$ \\
\hline 1982 & $\begin{array}{l}\text { Abre-se o Douro a uma } \\
\text { moderna viticultura. }\end{array}$ & $\begin{array}{l}\text { Transforma-se a forma de encarar a } \\
\text { viticultura no Douro. Estudam-se as } \\
\text { condições de produção, aprende-se } \\
\text { em missões de estudo, no estran- } \\
\text { geiro e cá dentro com especialistas } \\
\text { de fora. } \\
\text { Nicolau de Almeida, Bianchi de } \\
\text { Aguiar e Nuno Magalhães publi- } \\
\text { cam, com a ADVID, o livro Mecani- } \\
\text { zação das vinhas de encosta; con- } \\
\text { tribuição para o estudo da vinha ao } \\
\text { alto. }\end{array}$ & $\begin{array}{l}\text { Fundação da Confraria } \\
\text { do Vinho do Porto, com } \\
\text { sede na ACP e que integra } \\
\text { comerciantes, exportadores } \\
\text { e quadros no ativo. } \\
\text { ADVID - Associação para } \\
\text { o Desenvolvimento da Viti- } \\
\text { cultura Duriense, com sede } \\
\text { na Régua e com uma ação } \\
\text { na vertente de experimen- } \\
\text { tação, estudo e divulgação } \\
\text { de novas técnicas de vitivi- } \\
\text { nicultura. }\end{array}$ \\
\hline 1986 & $\begin{array}{l}\text { Em } 1982 \text { e } 1986 \text { a Casa do } \\
\text { Douro é legalmente extinta, } \\
\text { continuando, no entanto, em } \\
\text { funções. }\end{array}$ & & $\begin{array}{l}\text { AVEPOD - Associação de } \\
\text { Viticultores e Engarrafado- } \\
\text { res dos Vinhos do Porto e } \\
\text { Douro. } \\
\text { Produtores/engarrafadores } \\
\text { e adegas cooperativas pas- } \\
\text { sam a poder exportar dire- } \\
\text { tamente do Douro e criar } \\
\text { um canal de diálogo in loco } \\
\text { com a lavoura. }\end{array}$ \\
\hline
\end{tabular}

[continua] 


\begin{tabular}{|c|c|c|c|}
\hline Anos & Crises & $\begin{array}{l}\text { Movimentações sociais, } \\
\text { políticas e económicas }\end{array}$ & $\begin{array}{c}\text { Organizações da lavoura } \\
\text { e outras }\end{array}$ \\
\hline $\begin{array}{c}\text { Décadas } \\
\text { de } 1980 \\
\text { a } 1990\end{array}$ & $\begin{array}{l}\text { O Douro perdeu na década } \\
\text { de } 1980,8,7 \% \text { da popula- } \\
\text { ção e a situação tendeu a } \\
\text { agravar-se com o envelhe- } \\
\text { cimento da população; em } \\
\text { 1990-91 tem um crescimento } \\
\text { natural negativo. } \\
\text { Atinge o ponto de incapaci- } \\
\text { dade de renovação natural } \\
\text { da sua população. }\end{array}$ & $\begin{array}{l}\text { Jovens engenheiros da UTAD pas- } \\
\text { sam a introduzir no Douro novas } \\
\text { técnicas e tecnologias especializa- } \\
\text { das da vinha e do vinho. As quin- } \\
\text { tas já não contratam só caseiros e } \\
\text { feitores mas enólogos, adegueiros } \\
\text { e agrónomos e os trabalhadores e } \\
\text { mão-de-obra sazonal que empre- } \\
\text { gam são maioritariamente emi- } \\
\text { grantes estrangeiros. }\end{array}$ & $\begin{array}{l}\text { Fundação da Confraria dos } \\
\text { Enófilos, sede na Régua, } \\
\text { com } 36 \text { confrades. } \\
\text { A AEVP passa a estar pre- } \\
\text { sente numa associação de } \\
\text { representação do comércio } \\
\text { europeu de vinhos denomi- } \\
\text { nada Comité Européen des } \\
\text { Entreprises Vins (CEEV), em } \\
\text { Bruxelas. } \\
\text { É constituída a Vitidouro - } \\
\text { Associação dos viticultores } \\
\text { aderentes do PDRITM, com } \\
\text { sede na Régua. }\end{array}$ \\
\hline 1991-1992 & $\begin{array}{l}\text { Crise na direção da Casa do } \\
\text { Douro e situação financeira } \\
\text { caótica. } \\
\text { Em 1991, a CD não conse- } \\
\text { guiu escoar os excedentes } \\
\text { dos produtores e das adegas } \\
\text { cooperativas. } \\
\text { O negócio da Real Com- } \\
\text { panhia Velha associado ao } \\
\text { escoamento de } 1989 \text { e 90, } \\
\text { ditam o declínio da organiza- } \\
\text { ção da lavoura duriense e o } \\
\text { envolvimento financeiro do } \\
\text { Estado na CD. }\end{array}$ & $\begin{array}{l}\text { Em 1992, a situação era tão tensa } \\
\text { que, em julho, um enorme aparato } \\
\text { policial impediu a invasão da Casa } \\
\text { do Douro por centenas de viticul- } \\
\text { tores, pertencentes a recém-criada } \\
\text { União de Viticultores do Douro, que } \\
\text { queriam destituir, à força, a Direção } \\
\text { da Casa do Douro, questionando os } \\
\text { casos de atribuição fraudulenta de } \\
\text { beneficio, e o negócio da compra } \\
\text { da participação da Real Companhia } \\
\text { Velha (40\% do capital social por } 48 \\
\text { milhões de euros). }\end{array}$ & $\begin{array}{l}\text { É criada a União de Viticul- } \\
\text { tores do Douro }\end{array}$ \\
\hline 1993 & & & $\begin{array}{l}\text { Ao fim de } 60 \text { anos de exis- } \\
\text { tência, o Instituto do Vinho } \\
\text { do Porto instala uma dele- } \\
\text { gação na região do Douro }\end{array}$ \\
\hline 1994 & $\begin{array}{l}\text { O Governo tenta uma altera- } \\
\text { ção dos Estatutos da Casa do } \\
\text { Douro, que previa a passa- } \\
\text { gem das suas funções públi- } \\
\text { cas para o IVDP, dotando-o de } \\
\text { um Conselho Interprofissio- } \\
\text { nal, com representação pari- } \\
\text { tária da produção e comércio. } \\
\text { Este projeto de Decreto-Lei } \\
\text { retirava instrumentos de con- } \\
\text { trolo e competências admi- } \\
\text { nistrativas à CD. }\end{array}$ & $\begin{array}{l}\text { Onda de protestos na região e rejei- } \\
\text { ção dessa proposta do governo } \\
\text { pelo Conselho Regional de Vitivi- } \\
\text { nicultores da Casa do Douro, ape- } \\
\text { lidando-a de «concentracionista» e } \\
\text { «estatizante». } \\
\text { Publicação do opusculo «Em defesa } \\
\text { da terra do vinho do Porto» onde } \\
\text { se denuncia esse «afrontamento a } \\
\text { região». }\end{array}$ & \\
\hline
\end{tabular}




\begin{tabular}{|c|c|c|c|}
\hline Anos & Crises & $\begin{array}{l}\text { Movimentações sociais, } \\
\text { políticas e económicas }\end{array}$ & $\begin{array}{c}\text { Organizações da lavoura } \\
\text { e outras }\end{array}$ \\
\hline 1995-1998 & & $\begin{array}{l}\text { Afirmação da autorregulação na } \\
\text { gestão das denominações de ori- } \\
\text { gem da RDD. } \\
\text { A Comissão Interprofissional da } \\
\text { RDD assume competências, antes } \\
\text { da Casa do Douro e do Instituto do } \\
\text { Vinho do Porto, passando a ser o } \\
\text { organismo nuclear do edifício ins- } \\
\text { titucional da Denominação de Ori- } \\
\text { gem Porto e, depois, das restantes } \\
\text { Denominações de Origem Contro- } \\
\text { lada da Região. } \\
\text { Concretização da reforma insti- } \\
\text { tucional, com a publicação da Lei } \\
\text { Orgânica da Comissão Interpro- } \\
\text { fissional da Região Demarcada do } \\
\text { Douro (CIRDD), os Estatutos da Casa } \\
\text { do Douro e a Lei Orgânica do Insti- } \\
\text { tuto do Vinho do Porto. }\end{array}$ & $\begin{array}{l}\text { Em 1998, o distrito de Bra- } \\
\text { gança e o distrito do Porto } \\
\text { dispõem de Sindicatos de } \\
\text { Trabalhadores Agrícolas. } \\
\text { Nomeação da Comissão } \\
\text { Instaladora da Comissão } \\
\text { Interprofissional da RDD. }\end{array}$ \\
\hline 2000-2004 & $\begin{array}{l}\text { Completa-se a maior reforma } \\
\text { do Setor Vitivinícola Nacional } \\
\text { e da RDD desde o corporati- } \\
\text { vismo, com os Dec.-lei n. }{ }^{\circ} 212 \\
\text { e n. }{ }^{\circ} 213 \text { de } 2004 \text {. } \\
\text { Esta «nova» reforma legisla- } \\
\text { tiva, inovadora em muitos } \\
\text { aspetos, não põe em causa } \\
\text { os traços essenciais da regu- } \\
\text { lação vitivinícola no Douro. }\end{array}$ & & $\begin{array}{l}\text { É fundada em } 2000 \text { a } \\
\text { «Lavradores de Feitoria», } \\
\text { associação de } 20 \text { lavradores } \\
\text { que em conjunto tratam } \\
\text { e comercializam os seus } \\
\text { vinhos, experiência única } \\
\text { no Douro que abrange as } 3 \\
\text { sub-regiões. }\end{array}$ \\
\hline
\end{tabular}


Quadro 2. Crises e agitação sociopolítica na Região Douro (século XIX)

\begin{tabular}{|c|c|c|c|}
\hline Século XIX & Crises & $\begin{array}{c}\text { Movimentações: } \\
\text { Guerrilhas, bandoleirismo, motins } \\
\text { populares, greves, representações }\end{array}$ & $\begin{array}{c}\text { Organizações autónomas } \\
\text { da lavoura: Comissões, } \\
\text { associações, ligas }\end{array}$ \\
\hline Década 1810 & 3 & 3 & 0 \\
\hline Década 1820 & 5 & 6 & 0 \\
\hline Década 1830 & 5 & 6 & 1 \\
\hline Década 1840 & 5 & 6 & 3 \\
\hline Década 1850 & 6 & 1 & 1 \\
\hline Década 1860 & 5 & 6 & 2 \\
\hline Década 1870 & 3 & 3 & 1 \\
\hline Década 1880 & 5 & 8 & 6 \\
\hline Década 1890 & 6 & 5 & $\mathbf{1 6}$ \\
\hline Total & $\mathbf{4 3}$ & $\mathbf{4 4}$ & \\
\hline
\end{tabular}

Quadro 3. Crises e agitação sociopolítica na Região Douro (século XX)

\begin{tabular}{|c|c|c|c|}
\hline Século XIX & Crises & $\begin{array}{c}\text { Movimentações: } \\
\text { Guerrilhas, bandoleirismo, motins } \\
\text { populares, greves, representações }\end{array}$ & $\begin{array}{c}\text { Organizações autónomas } \\
\text { da lavoura: Comissões, } \\
\text { associações, ligas }\end{array}$ \\
\hline Década 1910 & 4 & 6 & 2 \\
\hline Década 1920 & 4 & 4 & 2 \\
\hline Década 1930 & 5 & 5 & 1 \\
\hline Década 1940 & 4 & 1 & 1 \\
\hline Década 1950 & 3 & 1 & 0 \\
\hline Década 1960 & 2 & 1 & 0 \\
\hline Década 1970 & 3 & 5 & 7 \\
\hline Década 1980 & 3 & 4 & 6 \\
\hline Década 1990 & 3 & 3 & $\mathbf{2 5}$ \\
\hline Total & $\mathbf{3 1}$ & $\mathbf{3 0}$ & \\
\hline
\end{tabular}




\section{ANEXO II — QUINTA CANAES-BARTOL}

\section{Depoimento da Dra. Maria Luz Egido Vicente Franqueira de Campos Ser- rano, atual proprietária da Quinta Canaes-Bartol}

Fontelonga. Uma aldeia perdida no concelho de Carrazeda de Ansiães, escondida atrás dos montes. Ignorada, embora lá morassem várias famílias abastadas, algumas de origem judia.

A essa aldeia chegou o meu bisavô, Ramon Franqueira, espanhol da vizinha Galiza. Seguidor e apoiante de D. Carlos Maria de Borbon, viu-se obrigado a fugir depois de mais uma derrota do seu futuro rei.

Encontrou acolhimento na família Nunes. Don Ramon era oriundo de Santa Maria de Vilar de Ordelas, em Orense, Galiza. Homem de grande fortuna e de grande encanto pessoal, acabou por conquistar uma das filhas do casal, a minha bisavó, Maria da Anunciação Nunes. Casaram em 1858 na Fontelonga e Don Ramon Franqueira nunca mais regressou à sua terra natal. Suponho que pelos mesmos motivos que o fizeram sair de lá. Don Carlos Maria de Borbon viu-se obrigado a abandonar a Espanha após sucessivas derrotas. Saiu em 1888. Despediu-se com esta frase: «Volveré». Mas nunca mais voltou pois o Rei Afonso XII já estava no trono pouco depois. Como explicar que descendendo de uma família muito conceituada, dono de uma grande fortuna e posição social, não tivesse, depois de casar, regressado às suas origens? Mas assim foi.

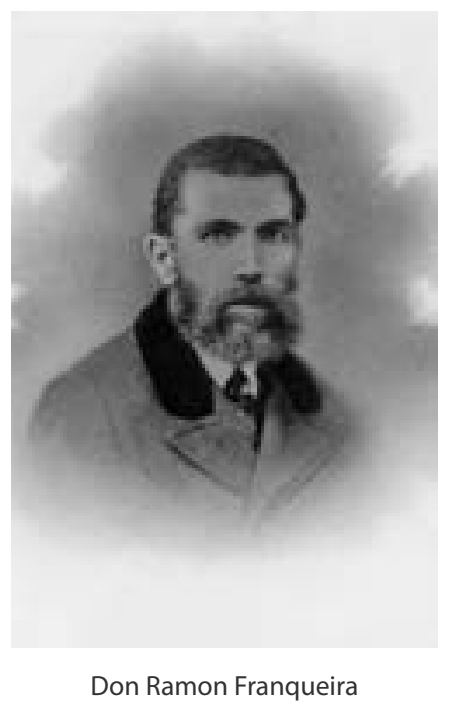

Don Ramon Franqueira

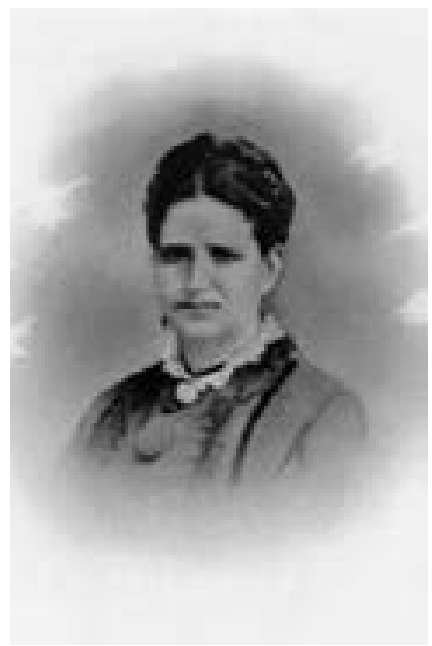

Dona Maria da Anunciação Nunes Franqueira 
Entretanto tornou-se um dos grandes proprietários, não só da Fontelonga mas também do concelho da Carrazeda, onde adquiriu numerosos bens e aumentou e melhorou os que a Dona Maria da Anunciação Nunes Franqueira herdara dos seus pais: a casa da Fontelonga e a Quinta dos Canaes, na margem do rio Douro, ainda de reduzidas dimensões e com uma pequena casa, além de outras propriedades. Don Ramon aumentou muito a área dos Canaes, comprando muitas terras, entre elas a quinta da Barreira e a do Padre Vitorino. Desvendou outros horizontes. No catálogo da exposição universal de Filadélfia, de 1876, está o seu nome com dois produtos das suas manufaturas, em que foi igualmente empreendedor: seda natural de bicho-da-seda e brandy. Ainda hoje na quinta se mantém o velho alambique, onde o brandy era fabricado.

A sua casa estava sempre aberta para os que por lá passavam e pediam ajuda ou trabalho. Uma irmã de Dona Maria da Anunciação casou também com um espanhol, cujo nome desconheço. Só sei que era uma pessoa de bem mas de poucos meios. Tiveram duas filhas. Conheci ainda a prima Lúcia, a viver na Fontelonga, casada com Aníbal Seixas, e outra irmã que vivia no Porto, a prima Conceição Peixoto.

Em 1879, a filha mais velha de Don Ramon Franqueira, de nome Maria Luz, casa também com um espanhol, Don Miguel António de Sá Puente, natural de Vitigudino. Vão viver para essa povoação de Castilha, pertencente ao distrito de Salamanca. Não têm filhos. A filha mais nova de Don Ramon, Adelaide, minha avó, costumava passar com a irmã e o cunhado muitas temporadas. Com 15 anos conhece o meu avô, Juan Bartol, natural de Lumbrales, povoação vizinha de Vitigudino. Era doutorado em farmácia. Tinha tirado o curso em Santiago de Compostela e feito o doutoramento na Universidade de Alcalá de Henares, perto de Madrid. Pertencia a uma família antiga e abastada, também muito empreendedora. Um dos seus primos direitos foi agraciado pelo Rei de Espanha com o título de Conde de Lumbrales, em agradecimento pelos serviços prestados à Coroa. Foi ele o responsável pelo acabamento da linha do Douro em Espanha. Don Juan e Dona Adelaide acabam por casar na Fontelonga, mas vão viver em Vitigudino. O meu avô Juan Bartol construiu uma casa magnifica em Vitigudino, e também a farmácia e o laboratório. Tiveram quatro filhos: três rapazes e uma rapariga, Maria Esperanza, minha mãe. Os dois mais velhos, Romão e José, formaram-se em direito. O primeiro escolheu a carreira de magistrado, o tio José a de advogado do Estado, onde chegou a ser Presidente, cargo que correspondia a ministro. A minha mãe, Maria Esperanza, foi educada em bons colégios de Salamanca e de Madrid, como era hábito nessa altura. Viveram sempre em Vitigudino os meus avós. Entretanto faleceu Don Ramon Franqueira, a 24 de novembro de 1889, deixando a Quinta dos Canaes muito aumentada em área, plantando vinhas e aumentando as casas. Dona Maria da Anunciação tomou conta de tudo e ainda comprou mais propriedades. Anos mais tarde faleceu, deixando como herdeiros os quatro filhos. As herdeiras da quinta foram as duas filhas: Maria Luz e Adelaide com respetivos maridos, Miguel António de la Puente e Juan Bartol, que administraram a quinta em conjunto até falecerem. 


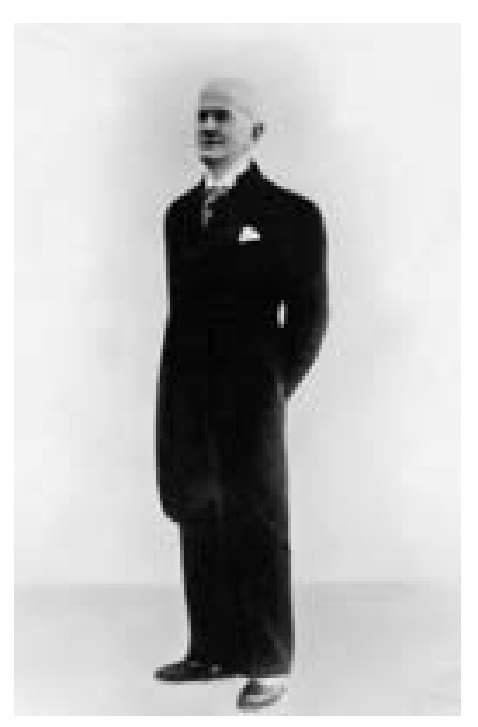

D. Juan Vicente Bartol 823

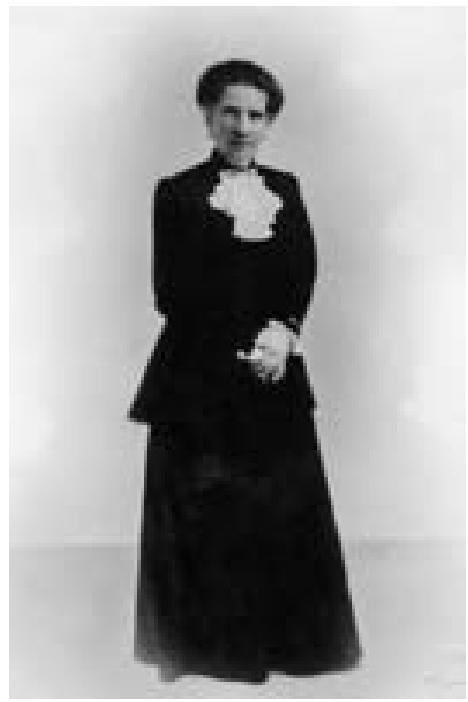

Dona Adelaide Franqueira Bartol

Quando a irmã e o cunhado faleceram, deixaram em testamento a sua parte (metade da quinta) aos meus avós. O avô Juan, apaixonado também pelo Douro, investiu imenso na quinta. Aumentou a casa, os armazéns, os lagares, as ramadas em ferro, etc. Nessa altura não havia dificuldade em arranjar bons caseiros que residissem lá. Todos os meses, o chofer do meu avô, chamado Emílio, ia de comboio para a quinta fazer as contas e ver o que era necessário. Era como uma pessoa de família e de toda a confiança. Quando havia qualquer problema, vinha de carro com o meu avô à quinta. Além disso, os meus avós, que continuavam a viver em Vitigudino, vinham sempre fazer as termas no Gerês e depois nas Pedras Salgadas. A seguir, acompanhavam sempre as vindimas na quinta, onde se juntava depois a sua família toda. Os filhos foram casando, a minha mãe em 1928, com António Egido, natural de Vitigudino. Era formado em medicina na Universidade de Salamanca, onde já era assistente quando casou. Com 31 anos, foi convidado a trabalhar em Madrid no hospital de San Carlos, sendo responsável pelos serviços de cirurgia. Tiveram que ficar a viver em Madrid. Tiveram duas filhas, Maria Luz e Maria Dolores, com menos de um ano de diferença. As duas nasceram em Vitigudino, em casa dos avós, como era costume nessa época.

Entretanto, começou a Guerra Civil em Espanha em 1936, que durou três anos. As tropas do General Franco vão conquistando terreno, e aproximam-se de Madrid onde começa a faltar tudo. Os meus pais resolveram deixar-nos na Quinta Bartol com os avós, que estavam lá no verão, como era costume todos os anos. Eles conseguiram fugir do cerco de Madrid e foram também para a quinta. A Guerra acabou em 1939. Infelizmente o meu

${ }^{823}$ Era primo do 2. ${ }^{\circ}$ Conde de Lumbralles (1899) cujo pai fora impulsionador da construção do troço espanhol da Linha do Douro entre Barca de Alva e Salamanca, pelo que fora agraciado com o título de conde. 
pai não pôde regressar a Espanha por questões políticas e por ter sido diretor do hospital de San Carlos em Madrid. Assim, ficou toda a família a viver na quinta Bartol. De médico afamado, a viver em Madrid, viu-se num sitio onde não havia luz, telefone, estrada. O correio vinha pelo comboio, onde o iam buscar de barco.

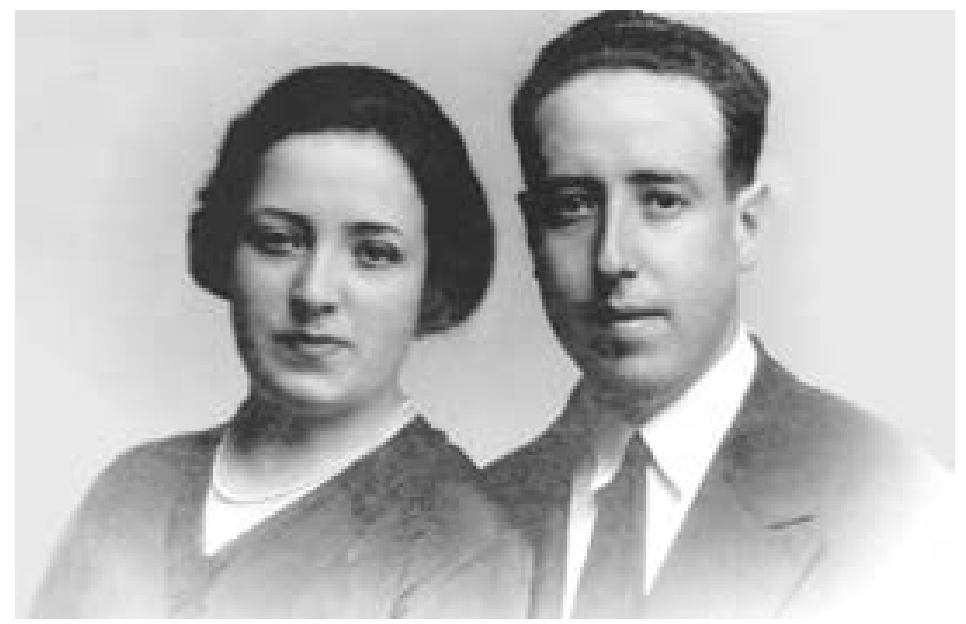

Dona Maria Esperanza Franqueira Bartol e seu marido Dr. António Egido

As notícias ouviam-se no rádio, muito mal. As duas filhas começaram a ir à 'escola', com uma professora que tinha vindo de Lamego, pois estava sem colocação, porque nessa altura tinha fechado a escola normal. Fizeram lá a escola primária e o terceiro ano do liceu, tendo como Encarregado de Educação o Doutor Ferreira Lobo, que vivia na Carrazeda. Os exames da primária fizeram-nos em Espinho e os do secundário no Porto. O meu pai começou a administrar a quinta e transformou-se em médico-lavrador. Médico porque desde manhã cedo que as pessoas cobriam a estrada para a quinta para consultar o meu pai, que era conhecido por Doutor Espanhol. Nunca cobrou dinheiro e até foi por duas vezes chamado a tribunal por queixas dos outros médicos, sendo sempre absolvido. O meu avô Juan Bartol faleceu entretanto, já eu estava a estudar Direito em Coimbra e a minha irmã Medicina no Porto. Por morte dele, a quinta Bartol ficou metade para a minha mãe, Maria Esperanza, e a outra metade para o irmão, Romão Franqueira. O meu tio Romão, quando a Guerra Civil terminou, fugiu para Tânger, onde também ficou uns anos exilado. Foi o meu pai que ficou a administrar a quinta Bartol. Finalmente fez-se justiça em relação ao Doutor António Egido; foi reconduzido a todos os seus cargos. Faleceu em 26 de novembro de 1967. Como voltou a ser médico em Espanha, a minha mãe ficou com mais responsabilidades na Quinta Bartol, tendo começado a administrá-la embora vivesse no Porto. Por sua morte, em 7 de novembro de 1986, as duas irmãs fizeram partilhas, e a quinta passou a pertencer à irmã mais velha Maria Luz, já casada em 19 de junho de 1954, com o indus- 
trial José de Campos Rodrigues Serrano. Mais um apaixonado pelo Douro. Fizeram-se muitas plantações de vinhas, a produção do vinho do Porto subiu imenso, continuamos sempre ligados à Cockburn, sucessores da Martinez Gassiot, que eram os que tinham trabaIhado com o bisavô Don Ramon Franqueira e com Don Juan Bartol. Foram anos de muito trabalho, mas compensados. José Serrano foi mais um dos Homens a fazer grandes investimentos na quinta dos Canaes Bartol. Também as casas da quinta, não só a principal mas também as secundárias para o pessoal melhoraram imenso. Conseguiu-se que uma estrada chegasse até à quinta. A quinta cresceu imenso.

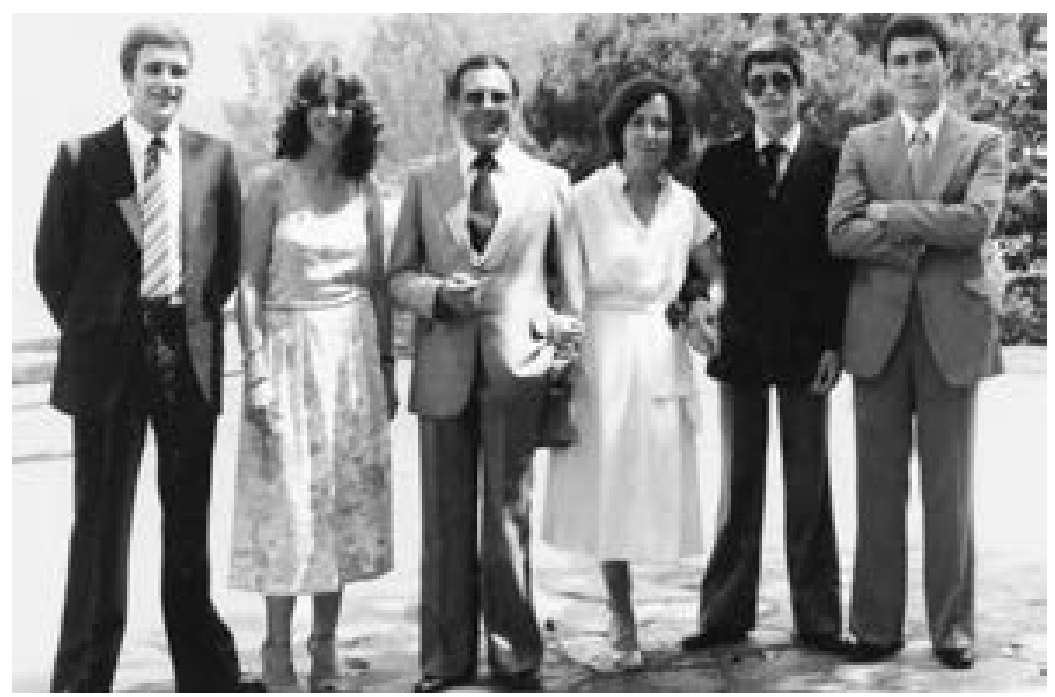

O casal José de Campos Rodrigues Serrano e Maria Luz Franqueira Bartol Serrano e descendentes

Como tínhamos quatro filhos, foi convertida em Sociedade Anónima e convidamos o engenheiro Frederico Meireles, da Beira Grande, para nos ajudar e trabalhar connosco. Por morte do meu marido a 26 de dezembro de 2005, fiquei eu à frente da quinta. Felizmente, tinha já uma equipa muito bem constituída pelo Engenheiro Meireles, gerente na parte agrícola, e com pessoal antigo, na parte das casas e turismo, que estamos a tentar começar, tendo já legalizado a casa nesse sentido. 


\section{ANEXO III — QUINTA DE LUBAZIM}

\section{Genealogia de Manuel de Castro Pereira Teixeira Lobo Pizarro, Senhor de Lubazim}

MANUEL DE CASTRO PEREIRA TEIXEIRA LOBO PIZARRO (1884-1944), doutor em direito pela Universidade de Coimbra, nasceu em Vilarinho da Castanheira, concelho de Carrazeda de Ansiães, a 6 de janeiro de 1884. Casou a 2 de outubro de 1905 com Dona Corina Vilhena de Moura Carvalhais Pegado, filha de José António de MagaIhães Pegado de Seabra e de Dona Maria Teresa de Vilhena de Moura Carvalhais (ver Travanca, pág. 479).

Descendência:

I. António.

II. Luís.

Manuel de Castro Pereira Teixeira Lobo Pizarro, era filho de Sebastião Teixeira Lobo Pizarro (1861 - ?), (filho de Francisco Teixeira Lobo Tavares Sampaio, senhor dos morgadios de Nossa Senhora da Conceição, de Sabrosa, do das Portas da Vila, em Vila Real, do dos Penelas e de Galafura, e de Dona Maria Angelina Pinto Pizarro Pimentel e Castro, senhora dos morgadios de Alfarela e Jales, neta de Tomás Homem de Sousa Quevedo Pizarro, irmão do primeiro Visconde de Bóbeda e do general Pizarro, vultos bem conhecidos nas lutas liberais; bisneta de António Pinto Pimentel de Almeida Carvalhais, sétimo morgado de Ribeira de Sabrosa, avô de Rodrigo da Nóbrega Pinto Pizarro de Almeida Carvalhais, primeiro Barão de Ribeira de Sabrosa, notável vulto político do reinado de Dona Maria II), e de Dona Maria da Purificação de Castro Pereira da Mesquita, filha do Dr. Luís Joaquim de Castro Pereira da Mesquita, nascido na freguesia da Sé do Porto em 26/9/1782 e de sua mulher Dona Delfina Augusta da Silva Cunha, nascida em Freixo de Numão (Vila Nova de Foz Coa) a 27/3/1824, neta paterna de D. Dionísio Inácio de Castro Pereira de Mesquita (1736-1791), Desembargador da Casa da Suplicação de Lisboa ${ }^{824}$.

Neto materno de Luís de Castro Pereira da Mesquita, doutor em direito, senhor da quinta de Lobazim e grande proprietário em Vilarinho da Castanheira, Freixo de Numão e S. João da Pesqueira, e de Dona Delfina Augusta da Silva Cunha.

Bisneto materno de Dionísio de Castro Pereira da Mesquita (ou Dionísio da Mesquita e Castro), doutor em leis e desembargador da Relação do Porto, que nasceu em 1736 e faleceu em Lobazim em 1791, tendo casado em fevereiro de 1774 na capela de Lobazim com sua sobrinha Dona Maria de Castro, filha única de seu irmão Manuel Augusto de Castro da Mesquita, capitão-mor de Freixo de Numão, senhor da quinta de Lobazim e morgadio de Santa Luzia, na mesma quinta, e do morgadio da Purificação Longroura de Vilaroco,

\footnotetext{
${ }^{824}$ MACHADO, 1970: 470.
} 
que nasceu em Vilarinho da Castanheira e casou em 1736 com sua prima em segundo grau, Dona Maria Pereira Malheiro do Lago, senhora do morgadio da Conceição da Póvoa e Horta.

Terceiro neto materno de Manuel de Sousa Cardoso e Castro, senhor da quinta de Lobazim, pagador geral da gente da guerra de Trás-os-Montes, e de Dona Maria Arcângela Pereira Pimentel, que nasceu em Freixo de Numão em 1699 e faleceu em Vilarinho da Castanheira, filha de Fernando Pereira Pimentel, senhor do morgadio de Freixo de Numão, onde nasceu em 14 de maio de 1663, e de Dona Mariana de Sousa da Fonseca, de S. João da Pesqueira, senhora dos morgadios da Póvoa e Horta.

Manuel de Castro Pereira foi governador de Bragança, Vila Real e Porto. Esteve em Espanha e depois na Rússia como embaixador de Portugal, e, com seu primo, o barão de Ribeira de Sabrosa, fez parte de três ministérios, na pasta dos estrangeiros. A ele nos referiremos no volume consagrado aos escritores ${ }^{825}$.

Quarto neto materno de Manuel Tavares da Mesquita e Castro, terceiro capitão-mor de Vilarinho da Castanheira, senhor da quinta de Lobazim e morgadio de Santa Luzia e Purificação, que com sua mãe instituiu na mesma quinta, e de Dona Maria de Almeida Sousa, de Vilaroco, senhora do morgadio de Longroura, no mesmo lugar, filha de Domingos de Almeida, de Vilaroco, fundador do morgadio de Vilaroco a 15 de setembro de 1693, e de Dona Maria de Sousa e Almeida.

Quinto neto materno de António de Castro da Mesquita (segundo capitão-mor de Vilarinho da Castanheira, senhor da quinta de Lobazim, primeiro morgado de Santa Luzia, na mesma quinta) e de Dona Isabel da Mesquita e Castro (sua parente em terceiro e quarto graus, filha de António Tavares, primeiro sargento-mor de Vilarinho da Castanheira, eleito em Janeiro de 1626, filho de Francisco de Tavares, o primeiro deste apelido que residiu em Vilarinho, onde faleceu em 1610, e de Dona Maria de Gouveia, de Vilarinho, onde faleceu em 1603), e de Dona Antónia da Mesquita e Castro (de Penha Longa, que residiu em Vilarinho, onde faleceu em 1645, filha de Manuel Rodrigues, natural do Crato, filho de André Rodrigues e de Dona Leonor Caldeira, e de Dona Isabel de Mesquita, filha de António de Mesquita, sobrinha de Dona Isabel de Castro, filha de Jorge de Castro, adiante citado. Dona Isabel da Mesquita e Castro, atrás citada, instituiu o vínculo da Purificação na quinta de Lobazim por escritura de fevereiro de 1669.

Sexto neto materno de Francisco dos Santos Monteiro de Castro, primeiro capitão-mor de Vilarinho da Castanheira, eleito em 9 de Janeiro de 1669 (filho de António de Castro da Mesquita, senhor da quinta de Lobazim, natural de Vilarinho da Castanheira, onde ainda residia em 1604, filho de Jorge de Castro, fidalgo da Casa Real), e de Dona Marta de Almeida, de Vilarinho - que, com seu marido, instituiu em 1618 o morgadio de Santa Luzia, na quinta de Lobazim - filha de Baltasar de Seixas (filho de Pedro Esteves

${ }^{825}$ ALVES, 2000. 
Pereira, que dizem fora fidalgo, e de Dona Helena de Sousa) e de Dona Beatriz de Almeida, de Vilarinho da Castanheira, filha de Belchior de Almeida e de Dona Maria Sobrinho, de Arosa $^{826}$.

${ }^{826}$ Ver Memórias Arqueológico-Históricas do distrito de Bragança, designadamente o vol. IV, p. 337 (ALVES, 1983: 337). 


\section{ANEXO IV — QUINTA DA SENHORA DA RIBEIRA}

\section{Espaços, instalações e equipamentos em 1909-1912 e em 1922-1943}

Quadro 4. Quinta Senhora da Ribeira: Espaços, instalações e equipamentos (1909-1912)

\begin{tabular}{|c|c|c|c|}
\hline \multicolumn{2}{|c|}{ Designação } & Descrição & Valores atribuídos \\
\hline \multirow{11}{*}{ Área residencial } & Sala de entrada & ----- & 0,850 \\
\hline & Sala de jantar & Mobílias/louças/faqueiro & $79,030 / 29,100 / 10,100$ \\
\hline & Quarto n.० 1 & 2 camas & 23,460 \\
\hline & Quarto n.० 2 & 1 cama & 14,570 \\
\hline & Quarto n.०3 & 2 camas & 13,720 \\
\hline & Quarto n.० 4 & 1 cama & 11,250 \\
\hline & Quarto das criadas & 2 camas & 4,140 \\
\hline & Quarto dos tanoeiros & $\begin{array}{l}4 \text { camas de ferro e enxergões/ } \\
\text { mantas de lã/lanterna/mocho }\end{array}$ & 64,000 \\
\hline & Alcovas & $\begin{array}{l}\text { Mobília/mosqueiro/sacos de } \\
\text { passar borra ( } 50 \text { a 140) }\end{array}$ & 29,040 \\
\hline & Cozinha & ------ & $46,110+22,770$ \\
\hline & Despensa & ----- & 12,640 \\
\hline \multirow{13}{*}{ Área funcional } & Lagares & $\begin{array}{l}3 \text { lagares de pedra/prensas/ } \\
\text { esmagadores/pranchões/crivo/ } \\
\text { chapas encaleiradas/lotes de } \\
\text { forrar cestos } \\
+3 \text { dornas de castanho } \\
\text { + prensa «Mobille». }\end{array}$ & $\begin{array}{l}+10,000 \\
+50,000\end{array}$ \\
\hline & Armazém de vinhos & $\begin{array}{l}\text { Cubas + } 10 \text { tonéis + litros de vinho } \\
\text { GAW } 1897\end{array}$ & $\begin{array}{l}140,110+40,900+ \\
1.435,500\end{array}$ \\
\hline & Casa agrícola & Camas, lavatórios, caldeiras... & 38,820 \\
\hline & Azenha & Ceiras, caldeira, prensa & 104,000 \\
\hline & Tanoaria & ------ & 14,900 \\
\hline & Casa do gasómetro & 30 bicos & 50,000 \\
\hline & Casa dos fornos & ----- & 2,000 \\
\hline & Casa comercial - mobília & roupas de cama & 70,700 \\
\hline & Cavalariça & $\begin{array}{l}1 \text { cavalo/1 jumenta/bigorna de } \\
\text { ferrador/cama para criado... }\end{array}$ & $\begin{array}{l}\text { 3,200 (não inclui valor } \\
\text { dos animais) }\end{array}$ \\
\hline & Forja & utensílios vários & 66,940 \\
\hline & Casa de arrumações & pulverizadores, crivos, barris & 45,000 \\
\hline & Loja de arrumações & carros, carretas, arados & 91,400 \\
\hline & Diversos & Bomba, bancos, corrente de ferro & 32,900 \\
\hline
\end{tabular}


Quadro 5. Quinta Senhora da Ribeira: Espaços, instalações e equipamentos (1922-1943)

\begin{tabular}{|c|c|c|c|}
\hline \multicolumn{2}{|r|}{ Designação } & Descrição & $\begin{array}{l}\text { Período } \\
\text { abrangido }\end{array}$ \\
\hline \multirow{11}{*}{ 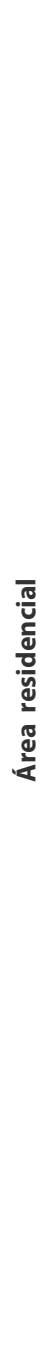 } & Sala de entrada & Mesa, cadeira, capacho & 1922 a 1930 \\
\hline & Sala de jantar & $\begin{array}{l}\text { Relógio, guarda-louça, aparador, mesa, cadeiras de palhinha e } \\
\text { couro, } 4 \text { cadeiras de pau em lona, tapete de esteira, capacho da } \\
\text { porta, jogo de ferros de estufa, trem completo de louça, garrafas, } \\
\text { copos e cálices, talheres, } 24 \text { guardanapos ( } 12 \text { de linho e } 12 \text { de } \\
\text { algodão) }\end{array}$ & 1922 a 1930 \\
\hline & $\begin{array}{l}\text { Quartos n.० } 1 \text {, } \\
\text { n. } 2, \text { n. }{ }^{\circ} 3, \text { n. } 4\end{array}$ & $\begin{array}{l}\text { Colchões de seda, crina e folhelho, almofadas, travesseiros, } \\
\text { bacios, etc. }\end{array}$ & \\
\hline & $\begin{array}{l}\text { Escritório/ } \\
\text { escritório }\end{array}$ & $\begin{array}{l}\text { Mesa escrivaninha, banco, prensa de copiar cartas, balança de } \\
\text { pesar cartas, armário para arrumações, cadeira de palha, tábua, } \\
\text { mesa pequena. }\end{array}$ & 1922 a 1930 \\
\hline & Casa do caseiro & $\begin{array}{l}3 \text { ou } 4 \text { camas, enxergões, } 32 \text { lençóis de algodão, mesas, mesi- } \\
\text { nhas de cabeceira, bancos (mochos), cobertores usados, mantas } \\
\text { de lã e de farrapos, novas e remendadas, toldes de sacos, cal- } \\
\text { deira de folha, espingarda de } 2 \text { canos. }\end{array}$ & de 1922 a 1943 \\
\hline & $\begin{array}{l}\text { Quarto particular } \\
\text { na casa do caseiro }\end{array}$ & $\begin{array}{l}\text { Camas de ferro, colchões de palha e de folhelho, meia cómoda, } \\
\text { mesas de cabeceira, lavatório de ferro e bacios, baldes de folha } \\
\text { e jarros de folha. }\end{array}$ & ----- \\
\hline & $\begin{array}{l}\text { Quarto } \\
\text { dos feitores }\end{array}$ & $\begin{array}{l}\text { Camas de ferro com enxergões, lavatórios ordinários, bacias, } \\
\text { jarro de barro, mesas e bancos (mochos), mesinha de cabeceira, } \\
\text { bacio de agate, candeia. }\end{array}$ & 1922 a 1943 \\
\hline & $\begin{array}{l}\text { Quarto } \\
\text { de criadas }\end{array}$ & $\begin{array}{l}\text { Camas de ferro, enxergões, travesseiros, bacio, lavatório de } \\
\text { ferro ordinário, regador, balde, meia cómoda, placa de metal, } \\
\text { banheira redonda de zinco, caixa para arrumações. }\end{array}$ & $\begin{array}{c}1922 ; \\
1923 ; 1924 ; \\
1930\end{array}$ \\
\hline & $\begin{array}{l}\text { No corredor o } \\
\text { quarto de banho }\end{array}$ & $\begin{array}{l}\text { Biombo, banheira de zinco, capacho da porta, passadeira, } \\
\text { banheira de ferro esmaltado, cadeira, esponjeira de metal. }\end{array}$ & de 1922 a 1930 \\
\hline & $\begin{array}{l}\text { Quarto } \\
\text { dos tanoeiros }\end{array}$ & $\begin{array}{l}\text { (quarto por cima da cozinha) } \\
\text { Camas de ferro e pau, enxergões, mantas de lã, mesas de pinho, } \\
\text { lavatório, jarro, bacio de esmalte, candeia. }\end{array}$ & 1922 a 1942 \\
\hline & Alcovas & $\begin{array}{l}\text { Cómoda (foi para a Quinta do Zimbro), tábua e bancos de pas- } \\
\text { sar a ferro, ferro de engomar, sacos de prensar borras, armário } \\
\text { de arrumação, mosqueiro, sacos de prensa novos, máquina/ } \\
\text { machina de fazer gelo/gello, cestos para roupa. }\end{array}$ & 1922 a 1930 \\
\hline
\end{tabular}




\begin{tabular}{|c|c|c|c|}
\hline \multicolumn{2}{|r|}{ Designação } & Descrição & $\begin{array}{l}\text { Período } \\
\text { abrangido }\end{array}$ \\
\hline \multirow{12}{*}{ 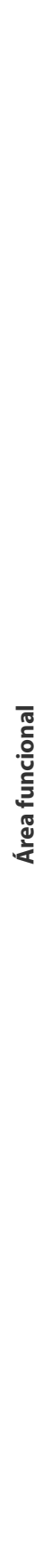 } & Lagares & $\begin{array}{l}\text { Esmagadores para uvas, crivos grandes de folha, prensas, dornas } \\
\text { de castanho, crivo grande de folha }\end{array}$ & 1922 a 1943 \\
\hline & Forja & $\begin{array}{l}\text { Fole, martelos, pistoletes, guilhos, alviões, picos de padeiro, } \\
\text { prumo nível madeira, esquadro, foice roçadoura, cutelos de cor- } \\
\text { tar mato. }\end{array}$ & 1922 a 1943 \\
\hline & $\begin{array}{l}\text { Cozinha } \\
\text { agrícola }\end{array}$ & $\begin{array}{l}\text { Cozinha de ferro. } \\
\text { Panelas, potes e talheres de ferro, tigelas, lanternas, candeias } \\
\text { e candeeiro para petróleo, cestos de conduzir comidas, mesas, } \\
\text { bancos, frigideiras, baldes para cavalos, alguidares de folha, grelha, } \\
\text { têmperas, ganchos de mover os potes e de mexer o lume, lan- } \\
\text { terna, almotelia, caneco para a água, bacias de folha, etc. }\end{array}$ & de 1922 a 1943 \\
\hline & $\begin{array}{l}\text { Cozinha } \\
\text { comercial }\end{array}$ & $\begin{array}{l}\text { Panelas e tachos, máquina de limpar talheres, máquina de fri- } \\
\text { tar carne, máquina de passar batata, latas, púcaros, alguidares, } \\
\text { tabuleiros, saleiros, mesas e cadeiras, mosqueiro de vidro, cal- } \\
\text { deira depósito de cobre, etc. }\end{array}$ & 1922 a 1930 \\
\hline & $\begin{array}{l}\text { Armazém } \\
\text { (louças } \\
\text { e ferramentas) }\end{array}$ & $\begin{array}{l}\text { Balseiros, baldes, calhas de medição, válvulas de tonéis, man- } \\
\text { gueiras de borracha e de desatesto, torneira de atesto, agulhetas } \\
\text { para regar, canados, atestadores, alcoómetros, cálices de provar } \\
\text { vinho, enxós de carpinteiro e de arranhar plaina, marretas, facas, } \\
\text { sacos de prensa, chapas de tonéis, aduelas de carregar, serras de } \\
\text { vão, enxós, etc. }\end{array}$ & de 1922 a 1930 \\
\hline & Tonéis & $\begin{array}{l}11 \text { tonéis referenciados por letras com diferentes capacidades } \\
\text { que perfazem no total } 284 \text { pipas + Depósito de I. } 32 \text { + Cimento } \\
\text { M32 = } 348 \text { pipas. } \\
\text { Lotes de vinhos existentes }-578 \text { litros } \\
\text { Lotes de vinhos existentes }-30.663 \text { litros }\end{array}$ & $\begin{array}{l}1922 ; 1929 ; \\
1930 \\
1928 \\
1930\end{array}$ \\
\hline & $\begin{array}{l}\text { Casa comercial } \\
\text { (roupas) }\end{array}$ & $\begin{array}{l}\text { Lençóis de linho, cobertas, cobertores de algodão, mantas de lã, } \\
\text { lençóis para criados e tanoeiros, várias toalhas, várias cobertas } \\
\text { brancas e de chita. }\end{array}$ & $\begin{array}{l}1922 ; 923 ; \\
1924 ; 1930\end{array}$ \\
\hline & $\begin{array}{l}\text { Casa do } \\
\text { gasómetro }\end{array}$ & Gasómetro com 33 bicos, e candeeiros diversos arrumados. & $1922-1933$ \\
\hline & $\begin{array}{l}\text { Casa das } \\
\text { arrumações }\end{array}$ & $\begin{array}{l}\text { Pulverizadores, crivos de arame, outros crivos, cestos vindimos } \\
\text { e outros, canecos, ceiras para fabrico de azeite, alambique de } \\
\text { cobre, etc. }\end{array}$ & $1922-1939$ \\
\hline & $\begin{array}{l}\text { Loja de } \\
\text { Arrumações }\end{array}$ & $\begin{array}{l}\text { Salgadeira de pedra, escadas de pinho, escadas de castanho, } \\
\text { banco de carpinteiro, carretas, arado, serra de mão, bandeirolas. }\end{array}$ & $1922-1943$ \\
\hline & Despensa & $\begin{array}{l}\text { Caixa para depósito de cereais e também de arrumações, balan- } \\
\text { ças, depósitos e latas para azeite, regadores, talhas de barro, } \\
\text { facas de partir bacalhau e sangrar porcos, masseira de pão, pá de } \\
\text { forno, peneiras, tabuleiro para pão. }\end{array}$ & $1922-1943$ \\
\hline & Aviamentos & $\begin{array}{l}\text { Garibald, panela de ferro, luvas para o fogão, pincel de trolha, } \\
\text { serrotes de poda. }\end{array}$ & $1929-1943$ \\
\hline
\end{tabular}




\section{ANEXO V — QUINTA DO ZIMBRO}

Quadro 6. Quinta do Zimbro de Baixo: Espaços, instalações e equipamentos (1909-1912) ${ }^{827}$

\begin{tabular}{|c|c|c|c|}
\hline \multicolumn{2}{|r|}{ Designação } & Descrição & $\begin{array}{l}\text { Valores } \\
\text { atribuídos (réis) }\end{array}$ \\
\hline \multirow{15}{*}{ 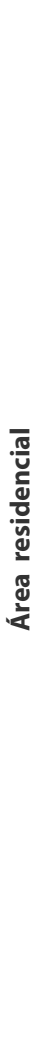 } & Sala de jantar & $\begin{array}{l}\text { Mobília, talheres, termómetro, relógio de parede, um par de } \\
\text { trinchantes, coberta na mesa, talheres de madeira para salada. }\end{array}$ & 91.480 \\
\hline & Salão & $\begin{array}{l}\text { Colchões de arame, candeeiros arrumados, aduelas de pipa e } \\
\text { de quartola, funis, mastro da varanda }\end{array}$ & 10.500 \\
\hline & Quarto n. ${ }^{\circ} 1$ & ----- & 22.840 \\
\hline & Quarto n. ${ }^{\circ} 2$ & ---- & 23.260 \\
\hline & Quarto n. ${ }^{\circ} 3$ & ----- & 14.160 \\
\hline & Quarto n. ${ }^{\circ} 4$ & ----- & 13.560 \\
\hline & Quarto de banho & ----- & 3.550 \\
\hline & Escritório & $\begin{array}{l}\text { Cama de ferro e lona, colchões, caixa para roupa, cálices de } \\
\text { prova, balizador, tamboladeira de porcelana, biombo }\end{array}$ & 12.820 \\
\hline & Quarto das criadas & ----- & 4.960 \\
\hline & Cozinha & $\begin{array}{l}\text { Trem comum de cozinha e trem de panelas em ferro, formas, } \\
\text { latas, tabuleiros, canecas churras, almotolias, chocolateiras, } \\
\text { campainha elétrica, escovas, pingadeiras, terrinas. }\end{array}$ & 101.140 \\
\hline & Despensa & $\begin{array}{l}\text { Máquina de limpar talheres, caixa, mosqueiro, terrinas, limpa } \\
\text { facas, moinhos para café }\end{array}$ & 10.560 \\
\hline & $\begin{array}{l}\text { Corredor/armário } \\
\text { do corredor }\end{array}$ & Candeeiro, passadeira, louças variadas & 24.280 \\
\hline & Casa do caseiro & ----- & 21.000 \\
\hline & Cozinha do caseiro & ----- & 19.240 \\
\hline & Roupas & $\begin{array}{l}\text { Bandeira inglesa, cobertores ingleses, cobertores de lã e de } \\
\text { algodão, colchas, mantas, toalhas de mesa, guardanapos, } \\
\text { panos de mesa, lençóis, cortinas, tolhas de mão e de banho, } \\
\text { manta alentejana, lençóis para tanoeiros, fronhas, aparador }\end{array}$ & 96.900 \\
\hline
\end{tabular}

\footnotetext{
${ }^{827}$ AHS - Inventário referente aos anos 1909-1912; Livro Inventários do Douro Silva \& Cosens, cx. 1772, u.i. 6094-6097, cota 173/10/6, p. 38-60. Ver ainda 3 dossiers com 3 inventários (s.d.) com idêntica descrição: instalações residenciais e funcionais mobílias e baixelas da casa de residência e do caseiro, máquinas e apetrechos de armazém, tanoeira e forja in u.i. 6199.
} 


\begin{tabular}{|c|c|c|c|}
\hline & Designação & Descrição & $\begin{array}{c}\text { Valores } \\
\text { atribuídos (réis) }\end{array}$ \\
\hline \multirow{6}{*}{ 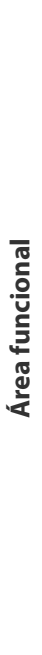 } & $\begin{array}{l}\text { Armazém } \\
\text { de vinhos }\end{array}$ & $\begin{array}{l}\text { Bombas, balsas, mangueiras, calhas de medição, ralos, balsei- } \\
\text { ros, caixão para mostos, púcaro, canada de cobre, funis, adue- } \\
\text { las, balanças para cristais, decimal e pesos, sifões, cadeado de } \\
\text { lavar pipas, pranchões de carregar pipas, cântaros de várias } \\
\text { medidas, torneiras, tabuletas, baldes de escorraçar tonéis, } \\
\text { cavaletes, escadas de ferro para subir às cubas. }\end{array}$ & 137. 280 \\
\hline & Armazém & 3 balseiros e 279 tonéis de diferentes capacidades & $1.255,500$ \\
\hline & Tanoaria & $\begin{array}{l}\text { Javradeiras, batoques, marretas, ponteiros, alavanca de ferro, } \\
\text { carro de mão, formão, cinzéis, sacos de passar barra, caixas para } \\
\text { arrumação, carrinhos, placa de metal, mesa de escrever }\end{array}$ & ---- \\
\hline & Forja & ---- & 9.000 \\
\hline & $\begin{array}{l}\text { Casa } \\
\text { de arrumações }\end{array}$ & ---- & 59.240 \\
\hline & Diversos & $\begin{array}{l}\text { Prensa } \\
\text { Bomba e canos } \\
\text { Cozinha da casa comercial }\end{array}$ & $\begin{array}{c}40.000 \\
30.000 \\
4.500\end{array}$ \\
\hline
\end{tabular}




\section{Depoimento do Dr. António João R. de Sampaio, descendente de antigos pro- prietários da Quinta do Zimbro de Cima e seu proprietário, de 1976 até 2003}

[...] Há duas quintas do Zimbro: a do Sampaio e Melo que fica entre o Tua e Ribalonga, do lado do bairro ferroviário do Tua que tem casa com brasão e capela, que já foi dos Symington, e a minha que vendi ao Manuel Pinto Hespanhol, e que herdei do meu pai, dr. João Cruz de Sampaio, Conservador do Registo Civil em Carrazeda muitos anos e que por sua vez já vinha dos meus avós e bisavós. A Quinta do Zimbro dos Sampaio e Melo já pertence ao Tua, freguesia do Castanheiro; a que era nossa, pertence a Ribalonga, aldeia da mesma freguesia.

A história da Quinta do Zimbro na nossa família é a seguinte: a Quinta do Zimbro que era do meu bisavô, João da Cruz, o empreiteiro da Linha do Tua, cujos bens no início do século XX (1910/1920) entraram em insolvência (pagaram-se as dividas todas, mas as propriedades foram vendidas). O filho mais velho que tinha o mesmo nome, fez medicina em Coimbra (com a ajuda económica da irmã e do cunhado), depois de ter regressado do Brasil para onde tinha emigrado. Em Santos andou a carregar às costas sacos de café e que depois foi médico em Angola, no tempo do Norton de Matos de quem era correligionário. Já estava em Angola quando o Norton de Matos chegou e foi importante na ambientação e obra do general [...] A rua que há aí em Carrazeda com o nome de João Cruz é em homenagem a ele. Quando foi para Angola, quis passar a Quinta do Zimbro para o meu avô, António Sampaio Chaves que era republicano [...] ainda está lá em casa o carimbo do Centro Republicano [...] mas como ele era muito orgulhoso e não quis, passou-a para o nome da mulher, a minha avó Felicidade Amélia Lopes da Cruz, que era irmã dele. E disse que só the pagariam quando pudessem, e se não pudessem não pagavam, mas só queria para ele meia pipa de vinho fino produzido na quinta ainda em tempo do pai em 1890. O meu avô assim fez e engarrafou e guardou — The o vinho que ele nunca levou na totalidade. Ficaram e ainda existem cerca de 15 garrafas. [...] Nunca ninguém mexeu naquele vinho que era do tio João, mesmo depois dele já ter morrido há mais de 20 anos. Eu cheguei a organizar um dossier para registar a marca, mas como já havia outra perdi em tribunal administrativo, mas nesse dossier eu compilei muita da documentação importante da quinta [...] a Quinta do Zimbro que fica entre Foz Tua e Ribalonga e era dos Sampaio e Mello foi comprada pela Família Symington pouco depois de terem adquirido a Quinta da Senhora da Ribeira em 1912, mas foi igualmente vendida mais tarde na década de $1950[\ldots]^{828}$.

\footnotetext{
${ }^{828}$ Entrevista feita ao Dr. António João R. de Sampaio, Carrazeda de Ansiães, novembro de 2011.
} 
Fichas genealógicas dos proprietários da Quinta do Zimbro de Cima ${ }^{829}$

Family Group Record

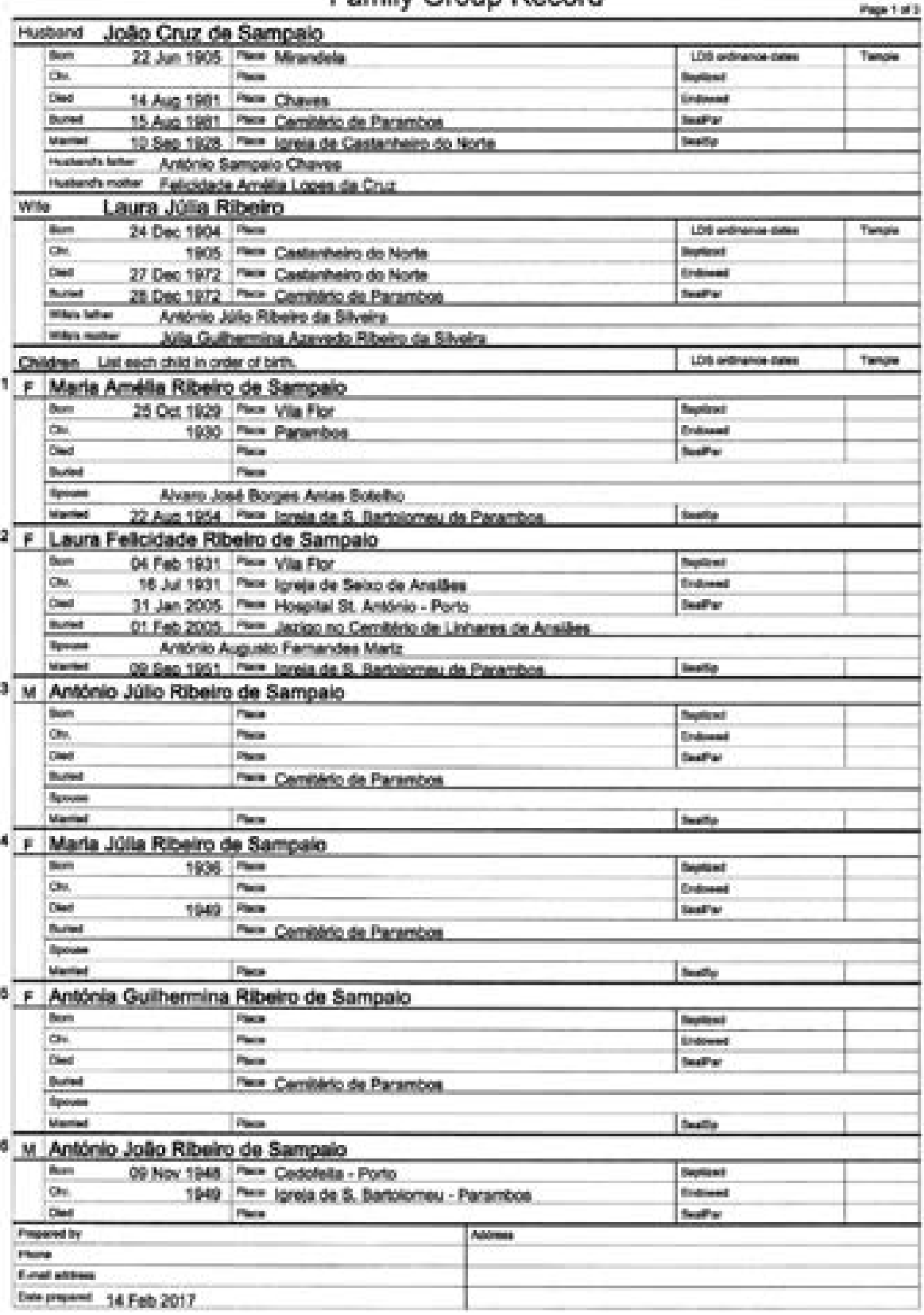

${ }^{829}$ Cópias generosamente cedidas para publicação pelo autor destas genealogias, Dr. Antonio João Ribeiro de Sampaio, a quem se agradece penhoradamente, bem como outras informações relevantes que nos facultou em entrevistas e depoimentos sobre a quinta do Zimbro de Cima de que foi também proprietário até data recente. 


\section{Family Group Record}

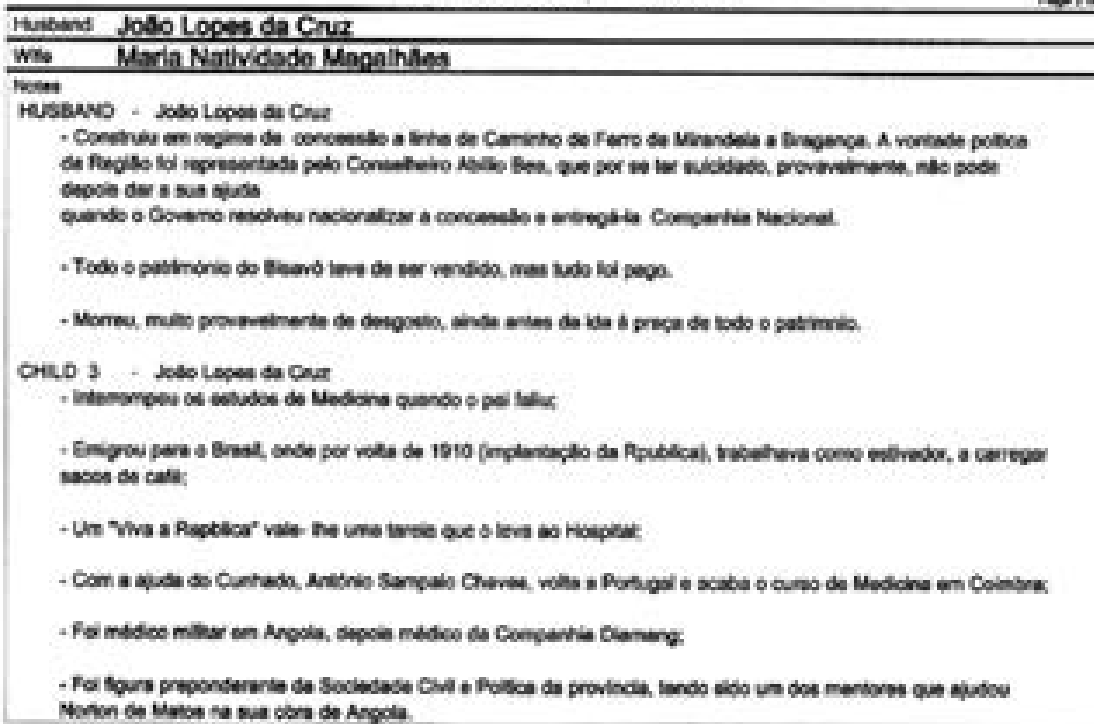




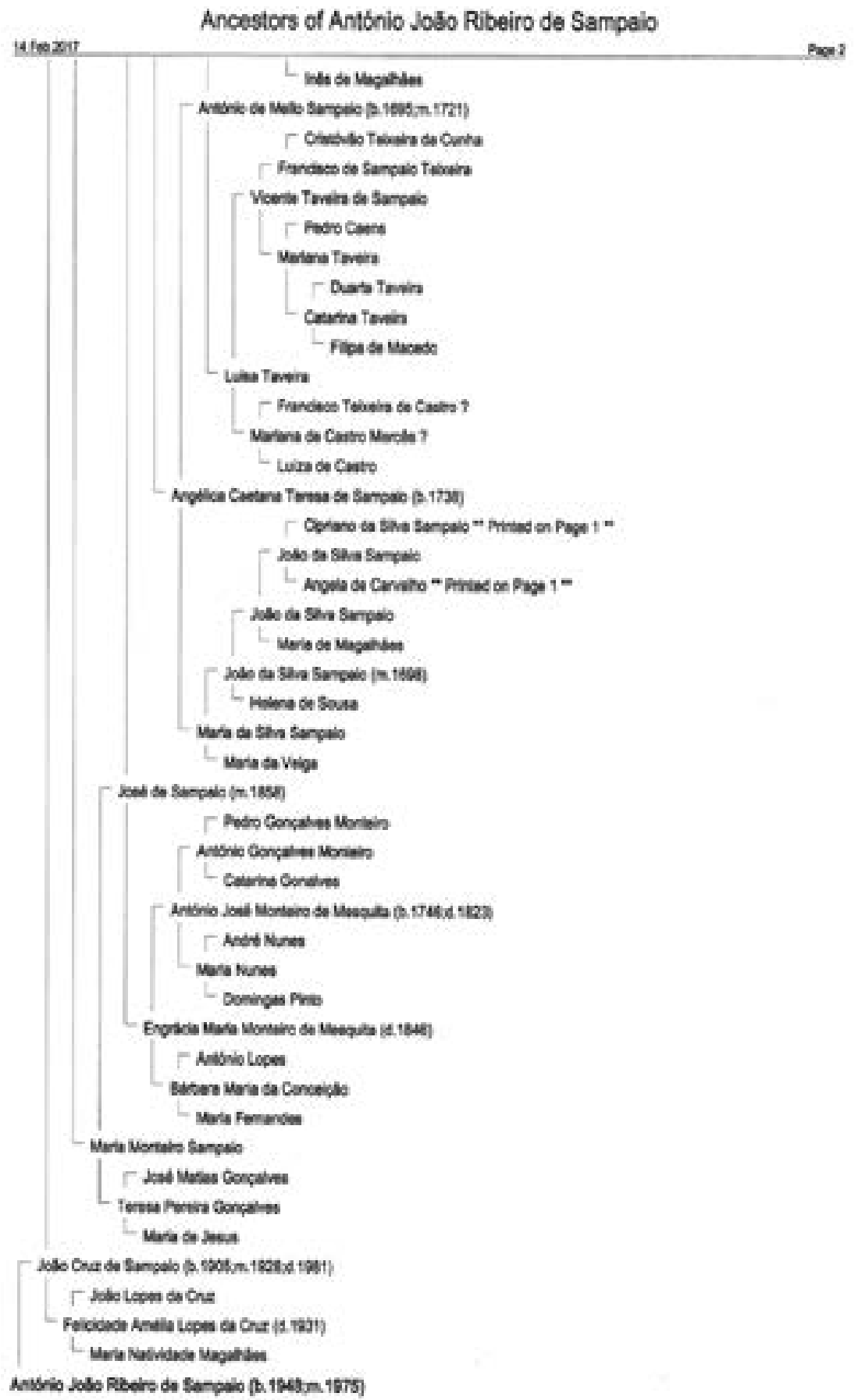




\section{ANEXO VI — EMPRESA COCKBURN \& SMITHES}

Quadro 7. Propriedades Cockburn's adquiridas no concelho de Carrazeda (1886-1943)

\begin{tabular}{|c|c|c|c|c|}
\hline $\begin{array}{c}\text { Localidade/ } \\
\text { (N. }{ }^{\circ} \text { de documento) }\end{array}$ & $\begin{array}{l}\text { Data de } \\
\text { compra }\end{array}$ & $\begin{array}{l}\text { Particularidades } \\
\text { das propriedades }\end{array}$ & Descrição & $\begin{array}{l}\text { Datas de registo/ } \\
\text { Em nome de: }\end{array}$ \\
\hline $\begin{array}{l}\text { Freguesia Castanheiro } \\
\text { do Norte (doc. 1) }\end{array}$ & 1886 & Quinta do Tua & $\begin{array}{l}\text { «Quinta Smithes»/Foz Tua com } \\
\text { casa privada, armazéns, jardins } \\
\text { e lagares }\end{array}$ & $\begin{array}{l}\text { (descrição Jul. } \\
\text { 1957) }\end{array}$ \\
\hline $\begin{array}{c}\text { Freguesia Castanheiro } \\
\text { do Norte }\end{array}$ & 1886 & Casa do Tua & ----- & $\begin{array}{l}\text { Conservatória } \\
\text { de Moncorvo }\end{array}$ \\
\hline $\begin{array}{c}\text { Freguesia Vilarinho } \\
\text { do Castanheiro }\end{array}$ & 1886 & Vale Coelho & ----- & $\begin{array}{l}\text { Conservatória } \\
\text { de Moncorvo }\end{array}$ \\
\hline $\begin{array}{l}\text { Freguesia Castanheiro } \\
\text { do Norte }\end{array}$ & 19/7/1886 & Casas em Foz Tua & $\begin{array}{l}\text { Grupo de casas, anexos e } \\
\text { pequena parcela de terra } \\
\text { inculta }\end{array}$ & $7 / 8 / 1886$ \\
\hline $\begin{array}{l}\text { Freguesia Castanheiro } \\
\text { do Norte }\end{array}$ & $30 / 8 / 1886$ & $\begin{array}{c}\text { Terra com } \\
3 \text { oliveiras e jardim } \\
\text { em Foz Tua }\end{array}$ & $\begin{array}{l}\text { Uma propriedade com árvores } \\
\text { de oliveira em Foz Tua }\end{array}$ & $1 / 10 / 1886$ \\
\hline $\begin{array}{c}\text { Freguesia Castanheiro } \\
\text { do Norte }\end{array}$ & [s.d.] & $\begin{array}{l}\text { Jardim em Foz } \\
\text { Tua }\end{array}$ & Jardim em Foz Tua & 26/7/1889 \\
\hline $\begin{array}{c}\text { Freguesia Castanheiro } \\
\text { do Norte }\end{array}$ & 6/7/1891 & $\begin{array}{l}\text { Vinha e olival } \\
\text { em Foz Tua }\end{array}$ & $\begin{array}{l}\text { Vinha e olival no topo de Foz } \\
\text { Tua }\end{array}$ & $6 / 8 / 1892$ \\
\hline $\begin{array}{c}\text { Freguesia Castanheiro } \\
\text { do Norte }\end{array}$ & [s.d.] & $\begin{array}{l}\text { Armazém } \\
\text { em Foz Tua }\end{array}$ & Armazém em Foz Tua & $3 / 3 / 1892$ \\
\hline $\begin{array}{l}\text { Freguesia Castanheiro } \\
\text { do Norte }\end{array}$ & 9/11/1892 & $\begin{array}{l}\text { Casa e terra } \\
\text { em Foz Tua }\end{array}$ & Uma casa situada em Foz Tua & 9/1/1893 \\
\hline $\begin{array}{l}\text { Freguesia Castanheiro } \\
\text { do Norte }\end{array}$ & $5 / 9 / 1893$ & $\begin{array}{c}\text { Terra } \\
\text { em Foz Tua }\end{array}$ & $\begin{array}{l}\text { propriedade chamada de Luís } \\
\text { de Figueiredo do Fiolhal, con- } \\
\text { sistindo numa terra encravada } \\
\text { acima da linha do caminho } \\
\text { de ferro para Mirandela, com } \\
43 \text { oliveiras e alguma área de } \\
\text { vinha em FozTua }\end{array}$ & $22 / 6 / 1903$ \\
\hline $\begin{array}{l}\text { Freguesia Vilarinho da } \\
\text { Castanheira (doc. 28) }\end{array}$ & 1893 & $\begin{array}{l}\text { Quinta do Vale } \\
\text { Coelho }\end{array}$ & $\begin{array}{l}\text { Quinta do Vale Coelho em } \\
\text { Freixo de Moz - Lubazim com } \\
101.475 \mathrm{~m} 2 \text { de terreno, vinhas } \\
\text { com } 101.000 \mathrm{~m} 2 \text { de terra, casa } \\
\text { privada, armazém e lagares. «A } \\
\text { casa particular com armazém } \\
\text { em baixo e a casa dos caseiros } \\
\text { foram feitos por nós, mais tarde» }\end{array}$ & $\begin{array}{c}\text { Conservatória } \\
\text { de Moncorvo. } \\
\text { Em nome de } \\
\text { Cockburn C. }{ }^{\text {a }} \\
\text { sede em V. N. de } \\
\text { Gaia }\end{array}$ \\
\hline
\end{tabular}

${ }^{830}$ AHS - Lista manuscrita [s.d.] - Dossier CB-276; AHS; Lista datilografada (Gaia, Jul, 1957) - Dossier em língua inglesa (2, jan., 1933), cx. 42, u.i. 273-278, cota 1/1/1/5. Cf. cópia de documento síntese da empresa Cockburn's relativo a propriedades na freguesia de Castanheiro do Norte (1900-1910). 


\begin{tabular}{|c|c|c|c|c|}
\hline $\begin{array}{c}\text { Localidade/ } \\
\text { (N.º de documento) }\end{array}$ & $\begin{array}{l}\text { Data de } \\
\text { compra }\end{array}$ & $\begin{array}{l}\text { Particularidades } \\
\text { das propriedades }\end{array}$ & Descrição & $\begin{array}{l}\text { Datas de registo/ } \\
\text { Em nome de: }\end{array}$ \\
\hline $\begin{array}{l}\text { Freguesia Vilarinho } \\
\text { da Castanheira }\end{array}$ & $21 / 2 / 1897$ & $\begin{array}{l}\text { Terra com vinha e } \\
\text { oliveiras na Pes- } \\
\text { coça — Lubazim de } \\
\text { Cima-Freixo Moz }\end{array}$ & ----- & {$[s . d]$} \\
\hline $\begin{array}{l}\text { Freguesia Vilarinho da } \\
\text { Castanheira (doc. 10) }\end{array}$ & $23 / 2 / 1897$ & $\begin{array}{l}\text { Armazém na } \\
\text { Pescoça - Luba- } \\
\text { zim de Cima. }\end{array}$ & $\begin{array}{l}\text { Uma propriedade consistindo } \\
\text { de vinha, olival e armazém tér- } \\
\text { reo situado na Pescoça - Luba- } \\
\text { zim de Cima }\end{array}$ & $\begin{array}{c}\text { 29/3/1897 } \\
\text { Escritura } \\
\text { Cockburn \& C. }{ }^{a} \\
\text { sede em V. N. de } \\
\text { Gaia }\end{array}$ \\
\hline $\begin{array}{l}\text { Freguesia Vilarinho da } \\
\text { Castanheira (doc. 27) }\end{array}$ & 1898 & $\begin{array}{c}\text { Vinha e olival na } \\
\text { Pescoça }\end{array}$ & Vinha e olival na Pescoça & $\begin{array}{l}\text { Em nome de } \\
\text { negociantes na } \\
\text { praça do Porto }\end{array}$ \\
\hline $\begin{array}{l}\text { Freguesia Vilarinho da } \\
\text { Castanheira (doc. 17) }\end{array}$ & 1904 & $\begin{array}{l}\text { Terra com } \\
9 \text { oliveiras } \\
\text { na Pescoça }\end{array}$ & $\begin{array}{l}\text { Terra com } 9 \text { oliveiras } \\
\text { na Pescoça — Lubazim }\end{array}$ & $\begin{array}{c}\text { Em nome de } \\
\text { Cockburn \& C. } \\
\text { sede em V. N. de } \\
\text { Gaia }\end{array}$ \\
\hline $\begin{array}{l}\text { Freguesia Vilarinho da } \\
\text { Castanheira (doc. 19) }\end{array}$ & 1905 & Terra na Pescoça & Terra com oliveiras na Pescoça & $\begin{array}{c}\text { Em nome de } \\
\text { Cockburn \& C. } \\
\text { sede em V. N. de } \\
\text { Gaia }\end{array}$ \\
\hline $\begin{array}{l}\text { Freguesia Castanheiro } \\
\text { do Norte }\end{array}$ & $25 / 3 / 1925$ & $\begin{array}{l}\text { Terra com olivei- } \\
\text { ras, casa da Lagoa, } \\
\text { terra cultivada e } \\
\text { armazém Ramiro }\end{array}$ & $\begin{array}{l}\text { Um terreno com oliveiras } \\
\text { situado em Lagoa, casa com } \\
\text { sótão situada nos arredores } \\
\text { da póvoa de Foz Tua, pequena } \\
\text { casa em ruínas e terra inculta } \\
\text { em Lagoa Foz Tua }\end{array}$ & $16 / 3 / 1925$ \\
\hline $\begin{array}{l}\text { Freguesia Vilarinho } \\
\text { da Castanheira }\end{array}$ & $25 / 3 / 1925$ & $\begin{array}{l}\text { Propriedade } \\
\text { situada em Pes- } \\
\text { coça ou Cadima - } \\
\text { Lubazim de Cima. }\end{array}$ & $\begin{array}{l}\text { Propriedade consistindo de } \\
\text { vinha filoxerada, oliveiras e } \\
\text { figueiras }\end{array}$ & $30 / 4 / 1998$ \\
\hline $\begin{array}{c}\text { Freguesia Vilarinho } \\
\text { da Castanheira }\end{array}$ & $25 / 3 / 1925$ & $\begin{array}{l}\text { Terreno com } \\
101.475 \text { m2 } \\
\text { na Quinta } \\
\text { do Lubazim }\end{array}$ & ----- & 3/7/1993 \\
\hline $\begin{array}{l}\text { Freguesia Castanheiro } \\
\text { do Norte }\end{array}$ & 15/7/1931 & Terra em Foz Tua & $\begin{array}{l}\text { Um local com olival e muitas } \\
\text { árvores de fruta em Pereira, } \\
\text { arredores do Tua }\end{array}$ & 15/7/1931 \\
\hline $\begin{array}{l}\text { Freguesia Castanheiro } \\
\text { do Norte }\end{array}$ & 3/9/1937 & $\begin{array}{l}\text { Foz Tua - chão } \\
\text { de oliveiras de } \\
\text { João Armindo de } \\
\text { Figueiredo }\end{array}$ & $\begin{array}{l}\text { Terra com oliveiras no lugar } \\
\text { chamado Pereira no Fiolhal }\end{array}$ & $17 / 9 / 1937$ \\
\hline $\begin{array}{c}\text { Freguesia Castanheiro } \\
\text { do Norte }\end{array}$ & $27 / 5 / 1943$ & $\begin{array}{c}\text { Foz Tua - chão de } \\
\text { oliveiras }\end{array}$ & $\begin{array}{l}\text { Terra na colina com oliveiras no } \\
\text { lugar da Martinha, Foz Tua. }\end{array}$ & 29/7/1943 \\
\hline
\end{tabular}

Fonte: Listas de compras de propriedades feitas pela Cockburn's, no concelho de Carrazeda de Ansiães 
Quadro 8. Propriedades COCKBURN's adquiridas na Região do Douro e em Gaia $(1897 ; 1920 / 22 ; 1957)^{831}$

\begin{tabular}{|c|c|c|c|c|}
\hline Localidade & $\begin{array}{c}\text { Data } \\
\text { de compra }\end{array}$ & $\begin{array}{l}\text { Particularidades } \\
\text { das propriedades }\end{array}$ & Descrição & $\begin{array}{l}\text { Data registo/ } \\
\text { em nome de: }\end{array}$ \\
\hline $\begin{array}{l}\text { Vila Nova } \\
\text { de Gaia }\end{array}$ & 1897 & Uma propriedade & ----- & $\begin{array}{l}\text { Cockburn's \& } \\
\text { C.ia - Londres }\end{array}$ \\
\hline $\begin{array}{c}\text { Peso } \\
\text { da Régua }\end{array}$ & 1897 & Uma Casa & ----- & $\begin{array}{l}\text { Cockburn's \& } \\
\text { C.ia - Londres }\end{array}$ \\
\hline $\begin{array}{l}\text { Vila Nova } \\
\text { de Gaia }\end{array}$ & 4/7/1920 & $\begin{array}{c}\text { Armazéns e casas } \\
\text { em Gaia }\end{array}$ & $\begin{array}{l}\text { Armazéns de } 9 \text { cumes, tanoaria, } \\
\text { escritórios, casa de habitação e } \\
\text { dependências, quintais, pátios e } \\
\text { caminhos de acesso a veículos, etc., } \\
\text { na Rua das Coradas, n. } .^{13} \text {, lugar das } \\
\text { Devesas - V. N. Gaia }\end{array}$ & $3 / 8 / 1920$ \\
\hline $\begin{array}{c}\text { Peso } \\
\text { da Régua }\end{array}$ & $11 / 12 / 1922$ & $\begin{array}{c}\text { Casa particular } \\
\text { na Rua dos Camilos, } \\
\text { Régua. }\end{array}$ & ----- & ----- \\
\hline
\end{tabular}

Fonte: Listas de compras de propriedades feitas pela Cockburn's, na Região do Douro.

${ }^{831}$ Lista datilografada de julho de 1957 e listas manuscritas em língua inglesa [s.d.]. AHS — Dossier CB-276, cx. 42, u.i. 273-278. 


\section{PROPRIEDADES ADQUIRIDAS PELA COCKBURN'S EM CASTANHEIRO DO NORTE, (1900-1910)}

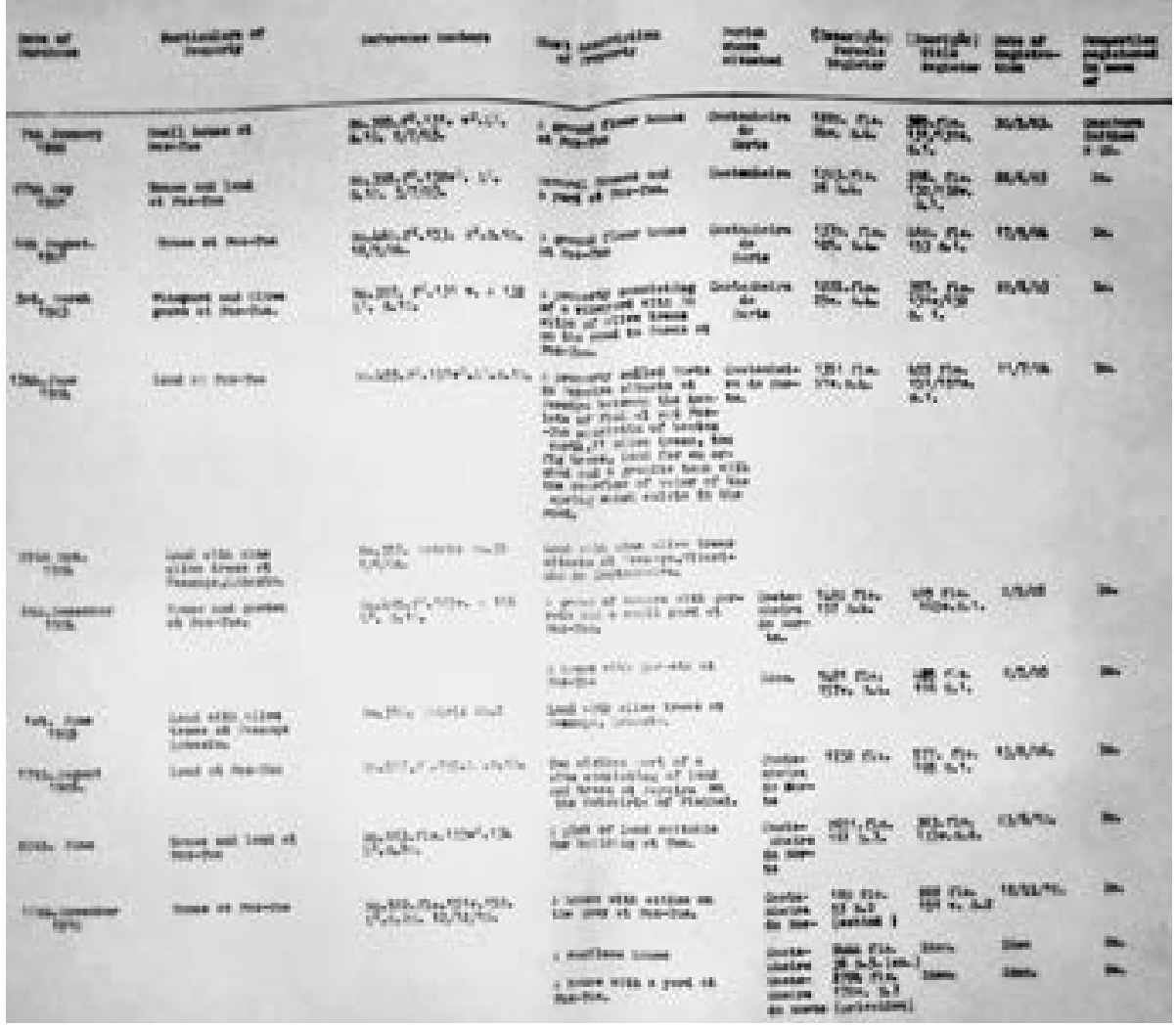

Lista parcial de propriedades adquiridas em Castanheiro do Norte — Carrazeda de Ansiães, (1900-1910) ${ }^{832}$

Quadro 9. Transcrição do documento

\begin{tabular}{|c|c|c|c|c|c|c|c|c|}
\hline $\begin{array}{c}\text { Date of } \\
\text { purchase }\end{array}$ & $\begin{array}{l}\text { Particulers } \\
\text { of Property }\end{array}$ & $\begin{array}{l}\text { Reference } \\
\text { numbers }\end{array}$ & $\begin{array}{c}\text { Short descripton } \\
\text { of Property }\end{array}$ & $\begin{array}{l}\text { Parish } \\
\text { where } \\
\text { situated }\end{array}$ & $\begin{array}{l}\text { (Descrição) } \\
\text { Parcels } \\
\text { registared }\end{array}$ & $\begin{array}{l}\text { (Inscrição) } \\
\text { Title } \\
\text { register }\end{array}$ & $\begin{array}{l}\text { Date of } \\
\text { registration }\end{array}$ & $\begin{array}{l}\text { Properties } \\
\text { registered } \\
\text { in name of }\end{array}$ \\
\hline $\begin{array}{c}\text { 7th. } \\
\text { January } \\
1900\end{array}$ & $\begin{array}{c}\text { Small- } \\
\text {-house at } \\
\text { Foz Tua }\end{array}$ & $\begin{array}{c}\text { N.o.395. } \\
\text { f. } .131 . \\
\text { V.o.L. } .0 .10 \\
\text { 2/7/03. }\end{array}$ & $\begin{array}{l}\text { A ground floor house at } \\
\text { FozTua }\end{array}$ & $\begin{array}{l}\text { Castanheiro } \\
\text { do Norte }\end{array}$ & $\begin{array}{l}\text { 1220. fls. } \\
\text { 24v. B.4. }\end{array}$ & $\begin{array}{c}\text { 395. fls. } \\
\text { 131/131v. } \\
0.1 \text {. }\end{array}$ & $30 / 5 / 03$ & $\begin{array}{c}\text { Cockburn } \\
\text { Smithes } \\
\text { \& co. }\end{array}$ \\
\hline $\begin{array}{l}27 \text { th. } \\
\text { May } \\
1901\end{array}$ & $\begin{array}{c}\text { House and } \\
\text { Land at } \\
\text { Foz Tua }\end{array}$ & $\begin{array}{c}\text { N.o.398. } \\
\text { f.o.132. } \\
\text { V.o.L. } .0 .10 \\
\text { 3/7/03. }\end{array}$ & $\begin{array}{l}\text { Several houses and a } \\
\text { yard at FozTua }\end{array}$ & Castanheiro & $\begin{array}{l}\text { 1223. fls. } \\
26 \text { B.4. }\end{array}$ & $\begin{array}{c}\text { 398. fls } \\
\text { 132/132v. } \\
0.1 .\end{array}$ & $22 / 6 / 03$ & Do. \\
\hline
\end{tabular}

[continua]

\footnotetext{
${ }^{832}$ Propriedades da Cockburn Smithes Ld. ${ }^{\text {\& C C. }}$ (1897 a 1943) (AHS - Dossier CB -276, 42, u.i. 273-278).
} 


\begin{tabular}{|c|c|c|c|c|c|c|c|c|}
\hline $\begin{array}{c}\text { Date of } \\
\text { purchase }\end{array}$ & $\begin{array}{l}\text { Particulers } \\
\text { of Property }\end{array}$ & $\begin{array}{l}\text { Reference } \\
\text { numbers }\end{array}$ & $\begin{array}{c}\text { Short descripton } \\
\text { of Property }\end{array}$ & $\begin{array}{l}\text { Parish } \\
\text { where } \\
\text { situated }\end{array}$ & $\begin{array}{l}\text { (Descrição) } \\
\text { Parcels } \\
\text { registared }\end{array}$ & $\begin{array}{l}\text { (Inscrição) } \\
\text { Title } \\
\text { register }\end{array}$ & $\begin{array}{l}\text { Date of } \\
\text { registration }\end{array}$ & $\begin{array}{l}\text { Properties } \\
\text { registered } \\
\text { in name of }\end{array}$ \\
\hline $\begin{array}{c}6 \text { th. } \\
\text { August } \\
1901\end{array}$ & $\begin{array}{l}\text { House at } \\
\text { FozTua }\end{array}$ & $\begin{array}{c}\text { N. } . .460 . \\
\text { f. } .153 . \\
\text { V. } . \text {.L. } .0 .10 . \\
\text { 18/9/04. }\end{array}$ & $\begin{array}{l}\text { A ground floor house at } \\
\text { Foz Tua }\end{array}$ & $\begin{array}{l}\text { Castanheiro } \\
\text { do Norte }\end{array}$ & $\begin{array}{l}\text { 1370. fls } \\
\text { 101. B.4. }\end{array}$ & $\begin{array}{l}\text { 460. fls. } \\
1530.1\end{array}$ & $17 / 9 / 04$ & Do. \\
\hline $\begin{array}{l}3 \mathrm{rd} . \\
\text { March } \\
1903\end{array}$ & $\begin{array}{l}\text { Vineyard } \\
\text { and Olive } \\
\text { grove at } \\
\text { Foz Tua }\end{array}$ & $\begin{array}{c}\text { N.o.397. } \\
\text { f.o.131.v. a } \\
132 \text { L. } 0.10 .\end{array}$ & $\begin{array}{l}\text { A property consisting of } \\
\text { a vineyard with } 30 \text { alips } \\
\text { of olive trees on the } \\
\text { road to barca at Foz Tua }\end{array}$ & $\begin{array}{l}\text { Castanheiro } \\
\text { do Norte }\end{array}$ & $\begin{array}{l}1222 . f l s . \\
25 v . \text { B.4. }\end{array}$ & $\begin{array}{l}\text { 397. fls. } \\
131 \mathrm{v} / 132 \\
0.1\end{array}$ & $22 / 6 / 03$ & Do. \\
\hline $\begin{array}{l}13 \text { th. } \\
\text { June } \\
1904\end{array}$ & $\begin{array}{l}\text { Land at } \\
\text { FozTua }\end{array}$ & $\begin{array}{c}\text { N. } .455 . \\
\text { f.o.151. } \\
\text { V. } . \text {.L. } .0 .10 .\end{array}$ & $\begin{array}{l}\text { A property called the } \\
\text { Horta do Pereira Situa- } \\
\text { ted at Pereira between } \\
\text { the hamlets of Fiolhal } \\
\text { and Foz Tua consistin } \\
\text { of beaten earth, } 11 \\
\text { olive trees, two fig trees, } \\
\text { land for an orched and } \\
\text { a granite tank with the } \\
\text { overflow of water of the } \\
\text { spring which exists in } \\
\text { the road. }\end{array}$ & $\begin{array}{l}\text { Castanheiro } \\
\text { do Norte }\end{array}$ & $\begin{array}{l}1351 \text { fls. } \\
91 \mathrm{v} . \text { B.4. }\end{array}$ & $\begin{array}{l}455 \text { fls. } \\
151 / 151 \mathrm{v} . \\
0.1 .\end{array}$ & $11 / 7 / 04$ & Do. \\
\hline $\begin{array}{l}25 \text { th. } \\
\text { Oct } \\
1904\end{array}$ & $\begin{array}{l}\text { Land with } \\
\text { nine olive } \\
\text { trees at } \\
\text { Pescoça- } \\
\text {-Lobazim }\end{array}$ & $\begin{array}{c}\text { N. } . .357 . \\
\text { Matriz } \\
\text { N. } .35 \\
1 / 6 / 04\end{array}$ & $\begin{array}{l}\text { Land with nine olive } \\
\text { trees situate at Pescoça, } \\
\text { Vilarinho de } \\
\text { Castanheira }\end{array}$ & & & & & Do. \\
\hline $\begin{array}{c}6 \text { th. } \\
\text { Decem- } \\
\text { ber } 1904\end{array}$ & $\begin{array}{l}\text { House and } \\
\text { garden } \\
\text { At Foz Tua }\end{array}$ & $\begin{array}{c}\text { N. } .495 . \\
\text { f. } .165 \mathrm{v} \text { à } \\
166 . \text { L. } .0 .10 .\end{array}$ & $\begin{array}{l}\text { A group of house with } \\
\text { garrets and a small yard } \\
\text { at Foz Tua }\end{array}$ & $\begin{array}{l}\text { Castanheira } \\
\text { do Norte }\end{array}$ & $\begin{array}{l}1480 \text { fls. } \\
157 \text { B.4. }\end{array}$ & $\begin{array}{c}495 \text { fls. } \\
165 \mathrm{v} .0 .1\end{array}$ & $2 / 5 / 05$ & Do. \\
\hline $\begin{array}{l}1 \text { st. } \\
\text { June } \\
1905\end{array}$ & $\begin{array}{l}\text { Land } \\
\text { with olive } \\
\text { trees at } \\
\text { Pescoça- } \\
\text {-Lobazim }\end{array}$ & $\begin{array}{c}\text { N. } . .310 \\
\text { Matriz N. } .2\end{array}$ & $\begin{array}{l}\text { A house with garrets at } \\
\text { Foz Tua } \\
\text { Land with olive trees at } \\
\text { Pescoça, Lobazim }\end{array}$ & $\begin{array}{l}\text { Castanheira } \\
\text { do Norte }\end{array}$ & $\begin{array}{l}1481 \text { fls. } \\
157 v . \text { B.4. }\end{array}$ & $\begin{array}{l}495 \text { fls. } \\
1660.1\end{array}$ & $2 / 5 / 05$ & Do. \\
\hline $\begin{array}{l}\text { 17th. } \\
\text { August } \\
1906\end{array}$ & $\begin{array}{l}\text { Land at } \\
\text { FozTua }\end{array}$ & $\begin{array}{l}\text { N. } .587 . \\
\text { F.o.195. } \\
\text { L. } .0 .10\end{array}$ & $\begin{array}{l}\text { Two sixthes part of a site } \\
\text { consisting of land and } \\
\text { trees at Pereira on the } \\
\text { outskirts of Fiolhal }\end{array}$ & $\begin{array}{l}\text { Castanheiro } \\
\text { do Norte }\end{array}$ & 1732 fls. & $\begin{array}{l}\text { 577. fls } \\
1950.1\end{array}$ & $13 / 8 / 06$ & Do. \\
\hline $\begin{array}{l}\text { 20th. } \\
\text { June }\end{array}$ & $\begin{array}{l}\text { House and } \\
\text { land at Foz } \\
\text { Tua }\end{array}$ & $\begin{array}{l}\text { N.o.883. fls. } \\
133 \mathrm{v} .0 .134 \\
\text { L. } .0 .20\end{array}$ & $\begin{array}{l}\text { Aplot of land suitable } \\
\text { for building at Tua }\end{array}$ & $\begin{array}{l}\text { Castanheiro } \\
\text { do Norte }\end{array}$ & $\begin{array}{l}\text { 2651. fls. } \\
161 \text { S.7. }\end{array}$ & $\begin{array}{l}\text { 383. fls. } \\
133 v .0 .2\end{array}$ & $23 / 6 / 10$ & Do. \\
\hline $\begin{array}{l}\text { 18th. } \\
\text { Novem- } \\
\text { ber } \\
1910\end{array}$ & $\begin{array}{l}\text { House at } \\
\text { FozTua }\end{array}$ & $\begin{array}{l}\text { N.o.922. fls. } \\
151 v .0 .152 \\
\text { L. } .0 .20 \\
12 / 12 / 10 .\end{array}$ & $\begin{array}{l}\text { A house with attics on } \\
\text { the quay at Foz Tua } \\
\text { A roofless house } \\
\text { A house with a yard at } \\
\text { Foz Tua. }\end{array}$ & $\begin{array}{l}\text { Castanheira } \\
\text { do Norte } \\
\text { Castanheiro } \\
\text { do Norte } \\
\text { Castanheiro } \\
\text { do Norte }\end{array}$ & $\begin{array}{c}180 \text { fls. } \\
53 \text { B.2 } \\
\text { (extint) } \\
\\
2444 \text { fls. } \\
38 \text { B.5. (ex.) } \\
\\
2724 \text { fls. } \\
175 \text { v. B.7 } \\
\text { (privative) }\end{array}$ & $\begin{array}{l}922 \text { fls. } \\
151 \text { v. } 0.2\end{array}$ & $18 / 11 / 10$ & Do. \\
\hline
\end{tabular}




\section{ANEXO VII — SYMINGTON ESTATES FAMILY}

Quadro 10. SYMINGTON FAMILY ESTATES — Empresas e Quintas Durienses (Ano de 2015) ${ }^{833}$

\begin{tabular}{|c|c|c|c|c|c|c|}
\hline \multirow[t]{2}{*}{ Empresas } & \multirow[t]{2}{*}{ Quintas } & \multicolumn{5}{|c|}{ Ficha técnica } \\
\hline & & 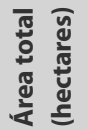 & 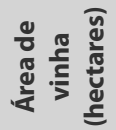 & $\begin{array}{c}\text { Castas } \\
\text { principais }\end{array}$ & $\begin{array}{l}\text { Indicadores } \\
\text { geomórficos } \\
\text { e climatéricos }\end{array}$ & Adegas \\
\hline \multicolumn{7}{|l|}{ Cockburn's } \\
\hline & Canais* & 271 & 96.5 & $\begin{array}{l}\text { Touriga Franca, } \\
\text { Touriga Nacional, } \\
\text { Tinta Barroca, Vinha } \\
\text { Velha, Tinta Roriz, } \\
\text { Alicante Bouschet, } \\
\text { Tinta Amarela }\end{array}$ & $\begin{array}{l}\text { Altitude: } 109-353 \\
\text { metros }\end{array}$ & \\
\hline & $\begin{array}{l}\text { Cachão } \\
\text { de Arnozelo* }\end{array}$ & 30 & 19.6 & $\begin{array}{l}\text { Touriga Franca, } \\
\text { Touriga Nacional, } \\
\text { Alicante Bouschet }\end{array}$ & $\begin{array}{l}\text { Altitude: 112-281 } \\
\text { metros }\end{array}$ & \\
\hline & Vale Coelho* & 19 & 13.4 & $\begin{array}{l}\text { Touriga Franca, } \\
\text { Sousão, Vinha Velha }\end{array}$ & $\begin{array}{l}\text { Altitude: 93-167 } \\
\text { metros }\end{array}$ & \\
\hline \multicolumn{7}{|l|}{ Warre's } \\
\hline & Cavadinha & 45,5 & 29,7 & $\begin{array}{l}\text { Touriga Nacional, } \\
\text { Touriga Franca, Tinta } \\
\text { Barroca. }\end{array}$ & $\begin{array}{l}\text { Altitude: } 180-441 \\
\text { metros; Precipitação } \\
\text { média anual: } 1,050 \\
\text { mm; Temperatura } \\
\text { média anual: } 13.7 .^{\circ} \mathrm{C} .\end{array}$ & $\begin{array}{l}6 \text { lagares } \\
\text { modernos } \\
\text { complemen- } \\
\text { tados meca- } \\
\text { nicamente }\end{array}$ \\
\hline & Telhada & 35 & 32 & $\begin{array}{l}\text { Touriga Nacional, } \\
\text { Touriga Franca, Tinta } \\
\text { Barroca, Tinta Roriz. }\end{array}$ & $\begin{array}{l}\text { Altitude: } \\
\text { 104-243 metros }\end{array}$ & \\
\hline & $\begin{array}{l}\text { Andorinhas } \\
\text { (Pinhão) }\end{array}$ & ----- & ----- & ----- & ----- & \\
\hline & Netas & 23 & 15.3 & $\begin{array}{l}\text { Vinha Velha, Touriga } \\
\text { Nacional, Touriga } \\
\text { Franca }\end{array}$ & $\begin{array}{l}\text { Altitude: } 385-527 \\
\text { metros }\end{array}$ & \\
\hline & Alvito & 28 & 19 & $\begin{array}{l}\text { Tinta Barroca, Vinha } \\
\text { Velha, Touriga Franca, } \\
\text { Touriga Nacional, } \\
\text { Tinta Roriz }\end{array}$ & $\begin{array}{l}\text { Altitude: } 412-578 \\
\text { metros }\end{array}$ & \\
\hline & Retiro & 40.6 & 20 & $\begin{array}{l}\text { Touriga Nacional, } \\
\text { Vinha Velha, Touriga } \\
\text { Franca }\end{array}$ & $\begin{array}{l}\text { Altitude: } 81-276 \\
\text { metros }\end{array}$ & \\
\hline
\end{tabular}

\footnotetext{
${ }^{833}$ Quadro construído a partir de listagem, in LEAL, [s.d.]. Texto inédito, cuja consulta se agradece.
} 


\begin{tabular}{|c|c|c|c|c|c|c|}
\hline \multirow[t]{2}{*}{ Empresas } & \multirow[t]{2}{*}{ Quintas } & \multicolumn{5}{|c|}{ Ficha técnica } \\
\hline & & 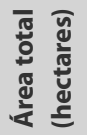 & 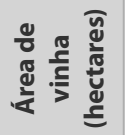 & $\begin{array}{c}\text { Castas } \\
\text { principais }\end{array}$ & $\begin{array}{l}\text { Indicadores } \\
\text { geomórficos } \\
\text { e climatéricos }\end{array}$ & Adegas \\
\hline & $\begin{array}{l}\text { Perdiz (com } \\
\text { Bruno Prats) } \\
\text { [Fornece: } \\
\text { Prats \& } \\
\text { Symington] }\end{array}$ & 27 & 23 & $\begin{array}{l}\text { vinha velha, Touriga } \\
\text { Nacional, Touriga } \\
\text { Franca, Tinta Roriz }\end{array}$ & $\begin{array}{l}\text { Altitude: } \\
\text { 130-321 metros }\end{array}$ & \\
\hline & Roriz & 95.7 & 42 & $\begin{array}{l}\text { Touriga Nacional, } \\
\text { Touriga Franca, Tinta } \\
\text { Roriz, Vinha Velha }\end{array}$ & $\begin{array}{l}\text { Altitude: 94-261 } \\
\text { metros }\end{array}$ & \\
\hline & $\begin{array}{l}\text { Ataíde } \\
\text { [Fornece: } \\
\text { Altano-Vinhos } \\
\text { DOC Douro] }\end{array}$ & 100 & $\begin{array}{c}81.3 \\
\text { Vinha } \\
\text { orgânica }\end{array}$ & $\begin{array}{l}\text { Touriga Nacional, } \\
\text { Touriga Franca, Tinta } \\
\text { Barroca, Tinta Roriz, } \\
\text { Vinha Velha, Alicante } \\
\text { Bouschet }\end{array}$ & $\begin{array}{l}\text { Altitude: 138-175 } \\
\text { metros; Precipitação } \\
\text { média anual: } 510 \\
\text { mm; Temperatura } \\
\text { média anual: } 16.1 .^{\circ} \mathrm{C}\end{array}$ & \\
\hline & Sol & \multicolumn{5}{|c|}{$\begin{array}{l}\text { Em Bagaúste. Não tem vinha. Foi comprada pela Symington nos anos } 1980 \text { e, } \\
\text { em 1996, foi construída uma adega nova onde se fazem os vinhos da Dow, } \\
\text { Graham, Warre, Smith Woodhouse, Quarles Harris e Gould Campbell. }\end{array}$} \\
\hline & $\begin{array}{l}\text { Vesúvio } \\
\text { [Fornece: } \\
\text { Quinta do } \\
\text { Vesúvio] }\end{array}$ & 325.7 & 133 & $\begin{array}{l}\text { Touriga Franca, } \\
\text { Touriga Nacional, } \\
\text { Tinta Roriz, Tinta } \\
\text { Barroca, Alicante } \\
\text { Bouschet, Sousão, } \\
\text { Vinha Velha, Tinta } \\
\text { Amarela }\end{array}$ & $\begin{array}{l}\text { Altitude: 106-462 } \\
\text { metros; Precipitação } \\
\text { média anual: } 471 \\
\text { mm; } \\
\text { Temperatura média } \\
\text { anual: } 16.8 .^{\circ} \mathrm{C}\end{array}$ & $\begin{array}{l}\text { Lagares } \\
\text { tradicionais } \\
\text { de pedra }\end{array}$ \\
\hline \multicolumn{7}{|l|}{ Dow's } \\
\hline & Cerdeira* & 19 & 7.6 & $\begin{array}{l}\text { Vinha Velha, Touriga } \\
\text { Franca }\end{array}$ & $\begin{array}{l}\text { Altitude: } 286-428 \\
\text { metros }\end{array}$ & \\
\hline & Fonte Branca & 36 & 22 & $\begin{array}{l}\text { Tinta Barroca, Vinha } \\
\text { Velha, Touriga Franca, } \\
\text { Tinta Roriz }\end{array}$ & $\begin{array}{l}\text { Altitude: } \\
310-473 \text { metros }\end{array}$ & \\
\hline & $\begin{array}{l}\text { Senhora da } \\
\text { Ribeira* }\end{array}$ & 43.5 & 25 & $\begin{array}{l}\text { Touriga Nacional, } \\
\text { Touriga Franca, Tinta } \\
\text { Barroca, Sousão, } \\
\text { Alicante Bouschet, } \\
\text { Vinha Velha }\end{array}$ & $\begin{array}{l}\text { Altitude: } 105-420 \\
\text { metros; Precipitação } \\
\text { média anual: } \\
471 \mathrm{~mm} \text {; } \\
\text { Temperatura média } \\
\text { anual: } 16.8 .^{\circ} \mathrm{C}\end{array}$ & $\begin{array}{l}\text { Três lagares } \\
\text { modernos } \\
\text { complemen- } \\
\text { tados por } \\
\text { paddle } \\
\text { plungers } \\
\text { (pás de } \\
\text { êmbolo) }\end{array}$ \\
\hline
\end{tabular}




\begin{tabular}{|c|c|c|c|c|c|c|}
\hline \multirow[t]{2}{*}{ Empresas } & \multirow[t]{2}{*}{ Quintas } & \multicolumn{5}{|c|}{ Ficha técnica } \\
\hline & & 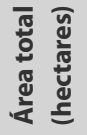 & 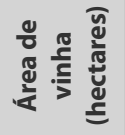 & $\begin{array}{c}\text { Castas } \\
\text { principais }\end{array}$ & $\begin{array}{l}\text { Indicadores } \\
\text { geomórficos } \\
\text { e climatéricos }\end{array}$ & Adegas \\
\hline & Bomfim & 98 & 77 & $\begin{array}{l}\text { Vinha Velha, Touriga } \\
\text { Nacional, Touriga } \\
\text { Franca, Tinta Barroca, } \\
\text { Alicante Bouschet, } \\
\text { Sousão. }\end{array}$ & $\begin{array}{l}\text { Altitude: } 80-371 \\
\text { metros; Precipitação } \\
\text { média anual: } 658 \\
\text { mm; Temperatura } \\
\text { média anual: } 16.2 .^{\circ} \mathrm{C}\end{array}$ & $\begin{array}{l}6 \text { lagares } \\
\text { modernos } \\
\text { complemen- } \\
\text { tados meca- } \\
\text { nicamente }\end{array}$ \\
\hline & Cabeço & 83 & 26 & Vinha Velha & $\begin{array}{l}\text { Altitude: } \\
\text { 112-468 metros. }\end{array}$ & \\
\hline & Santinho* & 82 & 25.5 & $\begin{array}{l}\text { Touriga Nacional, } \\
\text { Touriga Franca, Tinta } \\
\text { Roriz, Vinha Velha }\end{array}$ & $\begin{array}{l}\text { Altitude: } \\
\text { 116-272 metros }\end{array}$ & \\
\hline & Atalho & \multicolumn{5}{|c|}{ Symington - Vinhos, SA Qta. Atalho 5100-780 Sande } \\
\hline \multicolumn{7}{|l|}{ Graham's } \\
\hline & Vila Velha & 145 & 54.5 & $\begin{array}{l}\text { Touriga Franca, } \\
\text { Touriga Nacional, } \\
\text { Tinta Roriz, Vinha } \\
\text { Velha, Tinta Barroca }\end{array}$ & $\begin{array}{l}\text { Altitude: } \\
\text { 80-449 metros }\end{array}$ & \\
\hline & $\begin{array}{l}\text { Lages } \\
\text { (leasing } 25 \\
\text { anos) }\end{array}$ & 71 & 52 & $\begin{array}{l}\text { Vinha Velha, Touriga } \\
\text { Franca, Touriga } \\
\text { Nacional, Tinta } \\
\text { Barroca, Tinta Roriz }\end{array}$ & $\begin{array}{l}\text { Altitude: } \\
\text { 130-401 metros }\end{array}$ & \\
\hline & $\begin{array}{l}\text { Vale de } \\
\text { Malhadas }\end{array}$ & 140 & 32 & $\begin{array}{l}\text { Tinta Roriz, Touriga } \\
\text { Nacional, Touriga, } \\
\text { Franca, Tinta Barroca, } \\
\text { Vinha Velha }\end{array}$ & $\begin{array}{l}\text { Altitude: } \\
\text { 88-326 metros }\end{array}$ & \\
\hline & Tua* & 59.7 & 28 & $\begin{array}{l}\text { Vinha Velha, Touriga } \\
\text { Nacional, Touriga } \\
\text { Franca, Sousão, Tinta } \\
\text { Amarela }\end{array}$ & $\begin{array}{l}\text { Altitude: } \\
\text { 100-262 metros }\end{array}$ & \\
\hline & Malvedos & 163 & 88.5 & $\begin{array}{l}\text { Touriga Franca, Vinha } \\
\text { Velha, Touriga } \\
\text { Nacional, Tinta } \\
\text { Barroca, Tinta Roriz, } \\
\text { Sousão, Tinta Amarela }\end{array}$ & $\begin{array}{l}\text { Altitude: } 90-380 \\
\text { metros; Precipitação } \\
\text { média anual: } 624 \\
\text { mm; Temperatura } \\
\text { média anual: } 160^{\circ} \mathrm{C}\end{array}$ & $\begin{array}{l}3 \text { lagares } \\
\text { modernos } \\
\text { complemen- } \\
\text { tados meca- } \\
\text { nicamente }\end{array}$ \\
\hline \multicolumn{7}{|c|}{ Smith Woodhouse } \\
\hline & Madalena & 7.3 & 5 & $\begin{array}{l}\text { Vinha Velha, Touriga } \\
\text { Franca }\end{array}$ & $\begin{array}{l}\text { Altitude: 124-197 } \\
\text { metros }\end{array}$ & \\
\hline
\end{tabular}

Obs.: O asterisco sinaliza as 7 quintas situadas na área vinhateira duriense (Cima Corgo e Douro Superior) do concelho de Carrazeda de Ansiães: Tua em Foz Tua, freguesia de Castanheiro do Norte; Canais e Cachão de Arnozelo na freguesia de Beira Grande; Senhora da Ribeira, Santinho e Cerdeira na freguesia de Seixo de Ansiães; e Vale Coelho na freguesia de Vilarinho da Castanheira. 


\section{ANEXO VIII — ENTREVISTAS}

\subsection{Guião de entrevistas}

\section{ANEXO}

Guilo de entrevista (n3o estruturada e em profundidade) sobre diversidade regional/hocal de um municiplo no quadro da RDO e do AOW

1. Im sus opindlo, oval a importincia relativa, em termes quantitativos e qualitativos, da área de cultura e producso vitwinicola Ninho do Porto, winho de consumo ede mesa) de Carrazeda de Ansiles no conjunto da RDD?

2. Ao nivel evolutivo dos úttimos 40 anos (pos 25 de Abril), como a caracterizaria, em termos gerais? Quas as principais mudangas I modernizaço tecnica. inovacbes agricolas, etc.)? Problemas e conttrangimentos amtigos que se possam manter e novos? Que novas oportunidades surgiram de malor destaque, ao nivel regional do Douro Vinhateiro e a nivel do municiplo de CA.?

3. Quais as princiasis exploraçdes vinhateiras (quintas, casas agricolas, lavradores) na birea do concelho de Carrateda, em geral, e quals as empresas de maior protagonismo local e a que se deve esse maior protagoniamo?

4. Poderá direr-me, qual fol este ano, producso medsa de Viaho do porto e vinhos DOC da Symington nas was propriedades em Carrazeda de Ansiles? Percentualmente, qual a posicko relativa desta em relacko ao conjunto da produclo no AOV? Qual o significado da produçlo e exportaçlo provenientes do Douro Superior em relaço ao conjunto das propriedades do grupo na RDO?

5. Como ve o presente e o futuro da Regiso do Douro Vinhateiro?

6. I como percepciona a polikbo de Carraseda nesse contexto? Cuais as potencialidades e limitaçbes principais das propriedades e produço vithinicola deste concelho lao nivel de mis de obra, de tecnolozia e novos saberes especializades, novos investimentos, etc.)?

7. Poderá consiberar-se, em sua opiniło, que a produçlo e cultura vitivinicolo da Regito do ADV e em particular, de certos concelhos de entrada mais recente na ROO, como Carrazeda, contribuiram para gerar e alicerçar identidades proprias? Im que termes e como as caracterizaria?

8. Quais slo as quintas da Symington em Carrazeda, desde quando e que outras empresas proprietirias e exportadoras ai re encontram? Como sto as relaçes entre elas? 


\subsection{Transcrição de entrevistas}

\subsubsection{Entrevista escrita do Presidente da Câmara de Carrazeda de Ansiães ${ }^{834}$}

R1: O concelho de Carrazeda de Ansiães não é um dos maiores produtores de vinho do Porto na Região Demarcada do Douro. Contudo, temos assistido, nos últimos anos, à reconversão de muitos vinhos e à transferência de muitos direitos provenientes de zonas de direito a benefício para o Douro (Régua), o que tem contribuído, significativamente, para o aumento de produção de vinho do Porto.

R2: As quintas do Douro estão associadas a uma tradição muito peculiar como entidades empregadoras e como tal geradoras de riqueza. Elas são garantia de muitos postos de trabalho durante quase todo o ano. A viticultura é a atividade que mais contribui para o rendimento do maior número de agregados familiares neste concelho.

R3: No concelho de Carrazeda de Ansiães não tem havido muitas empresas a operar. Destaco algumas das principais porque também estão associadas a produção; a Cockburn Smithes e a Symington. Presentemente o grupo Symington já é detentor de outras empresas e marcas, nomeadamente a da Cockburn's. Este grupo é sem dúvida o maior proprietário no Douro, neste concelho, o maior produtor e empregador na vitivinicultura.

R4: Uma identidade nesta área corresponde a uma afirmação. É um percurso moroso e que exige uma estratégia. Em Carrazeda nunca houve uma estratégia seletiva, prova-o o facto de ser o único concelho da Região Demarcada do Douro que não constituiu uma Adega Cooperativa ${ }^{835}$. Os produtores mais significativos eram ao mesmo tempo exportadores e pouca identificação têm no concelho em termos seletivos.

R5: São, naturalmente, os vales do Douro e do Tua as áreas mais ricas e importantes do concelho.

R6: Quem dominou o comércio de uvas e vinho do Porto no concelho foram as casas exportadoras das quais destaco a Cockburn's, adquirida pelo grupo Symington, que é a maior firma produtora e exportadora sediada no concelho e quanto ao vinho de consumo foi a Casa do Douro que assegurou aos pequenos e médios proprietários o seu escoamento durante muitos anos. Recentemente foram instaladas, no concelho, adegas de produtores engarrafadores ${ }^{836}$ que compram aos lavradores essencialmente uvas, das quais destaco a Grambeira e a Douro Ansiães.

R7: Sendo Carrazeda de Ansiães um concelho da Região Demarcada do Douro sofre da problemática que é conhecida de todos. Os viticultores, nas últimas duas décadas, perde-

\footnotetext{
${ }^{834}$ Entrevista de 2016, a José Luís Correia, Presidente da Câmara de Carrazeda de Ansiães (2009-2017). Respostas escritas a guião previamente apresentado, em entrevista informal efetuada em 2015.

${ }^{835}$ Nas Associações Económicas existentes em Carrazeda de Ansiães destacam-se: 1. ACICA - Associação Comercial e Industrial de Carrazeda de Ansiães; 2. Cooperativa Agrícola Carrazeda de Ansiães; 3. Cooperativa da Rádio Ansiães; 4. Urbeansiães - Associação para a promoção e acompanhamento do Urbanismo Comercial. CARRAZEDA DE ANSIÃES. Câmara Municipal, 2014: 222.

${ }^{836}$ Observe-se que nem a Grambeira nem a Douro Ansiães são produtores-engarrafadores, dado que tal estatuto implica vinificarem uvas de sua produção.
} 
ram cerca de cinquenta por cento dos rendimentos associados à atividade. A explicação está associada à diminuição da litragem do benefício por hectare, à descida do preço/pipa quer de benefício por hectare quer do vinho de consumo. Em contrapartida, o custo da produção aumentou exponencialmente, devido, essencialmente, ao preço dos produtos fitofarmacêuticos e fertilizantes. Sem dúvida que a vitivinicultura tem e pode ter cada vez mais um peso muito significativo na economia do concelho; mas para isso é necessário tirar partido da excelente qualidade dos vinhos que produzimos de forma organizada e em escala.

R8: Quanto a este assunto [Douro Património da Humanidade, Classificação UNESCO, 2001] não podemos generalizar os resultados da classificação. Pode haver uns concelhos que tenham beneficiado mais do que outros, o que é natural, sobretudo devido ao seu contexto geográfico. Contudo, de uma forma geral, a classificação do Douro como Património da Humanidade ficou aquém do expectável. Senão vejamos, a região está cada vez mais despovoada, e mais pobre. A classificação de Património da Humanidade é uma «marca», uma distinção atribuída pela UNESCO que para lá da preservação do Bem serve para o desenvolvimento através das muitas dinâmicas que se criam associadas à classificação. Alguma coisa está a falhar. Já tive oportunidade de expor o meu ponto de vista em sede de decisão do PIOT-ADV (Plano Intermunicipal de Ordenamento do Território do Alto Douro Vinhateiro) ${ }^{837}$. Porém há que defender a classificação pela classificação e não se preocupar com a implementação do Plano de Ação que tem inerente bem como a avaliação da mesma ao fim de catorze anos.

Em conclusão, podemos afirmar que durante estes anos tem trazido aos residentes mais condicionantes, mais incómodos a nível de licenciamentos e reconversão de vinhas, do que oportunidades a nível económico e social. A região não deu o salto que era expectável através do turismo e da valorização dos produtos.

\subsubsection{Ex-autarca e ex-diretor regional do Ministério da Agricultura, produtor vinhateiro de antiga família de proprietários durienses da elite local ${ }^{838}$.}

A Quinta do Comparado deve ter entrado na posse da família Ribeiro com a entrada das libras do Brasil, por volta de 1820, cresceu nas mãos de António Júlio Ribeiro, grande proprietário duriense e conhecido republicano democrata do concelho [ver Capítulo 10]

\footnotetext{
${ }^{837}$ Ver CCDR-N, Missão Douro (Gabinete Técnico) — Plano de Monitorização do Alto Douro Vinhateiro: Paisagem cultural evolutiva e viva. dezembro 2014. Disponível em <http://www.ccr-n.pt/sites/default/files/ficheiros_ccdrn/ missaodouro/plano_de_monitorizacao_19-01-2015.pdf>. [Consulta realizada em 15/5/2016]; ANDRESEN \& REBELO, 2013.

Refira-se que se encontra integrada no território concelhio de Carrazeda de Ansiães, a Paisagem de referência Foz Tua com a área de 537,66 ha, a qual é uma das portas de entrada, patrimonialmente mais significativa, no Vale do Tua e neste concelho. O conjunto de paisagens de referência do Douro Património Mundial é assim hoje constituído: Vale do Rio Corgo; Chanceleiros; Vale do rio Torto; Vale de Figueira; Oliveira; Cambres e Vale do Varosa; Vale do Rio Távora; Vale do rio Pinhão; Foz Tua e Freixo de Numão.

${ }^{838}$ Entrevista em 4 de abril de 2017, Porto, a Dr. J. A. de S., Presidente da Câmara de Carrazeda na década de 1990 e Subdiretor Regional da Agricultura de Trás-os-Montes, 1981-1984.
} 
que era casado com Júlia Guilhermina Ribeiro da Silveira e neto do das libras ...veio a família do Brasil para o Porto onde a grande casa agrícola de Antónia Coelho da Silveira... a trisavó Coelha, que foi mãe de 15 filhos e que era avó dos meus dois avós maternos que eram primos direitos [genealogia da família de J. A. Sampaio da Quinta do Zimbro de Cima, anexo 5] O meu avô materno foi para o Douro, instalando-se em Castanheiro do Norte, foi ele que a partir do Comparado comprou isso tudo no Seixo, Fontelonga, etc. muito que é hoje dos Symington; um cunhado, irmão da Júlia Guilhermina foi diretor do Banco de Portugal aqui no Porto... já era diretor no tempo do Alves dos Reis ${ }^{839}$ (anos 1920) e foi do Conselho de Administração da Ferreirinha, Real Companhia Velha e outro Oficial do Exército da Arma de Engenharia chegou a ser Presidente do Conselho Superior de Obras Públicas no tempo em que foi inaugurada a Ponte sobre o Rio Tua, no Tua, por curiosidade foi já projeto do Eng. Edgar Cardoso (ver parecenças com a Ponte da Arrábida feita quase 30 anos depois). A Quinta do Comparado ou Quinta da Gafaria foi dividida: a Gafaria ficou para os Sampaios da parte da minha mãe; o Pombal, ao lado dos armazéns e junto ao pombal foi para os herdeiros do Armindo de Figueiredo e a Relva, o Fernandes e o casal do Seixo... para os herdeiros de Armando Sobral primo dos Moutinhos da Senhora da Ribeira, da família do homem da Companha dos Algodões em Moçambique.

Na Gafaria, chamava-se assim por ter sido um lugar de exclusão de leprosos e parece que passava por ali uma antiga estrada romana, apareceram moedas e foram encontrados outros restos arqueológicos... havia uma «toca» chamada posteriormente a Pala do Sapateiro; o último a ter vivido aí na parte rochosa de granito... mas a quinta era tudo xisto. Ainda se plantou tabaco aí nas margens do rio - essa era a zona da Quinta do Comparado que fora do Antonio Júlio Ribeiro não cultivada tanto como hoje com vinha, mas com azeite e amêndoa... foi depois o meu pai e descendentes que a replantaram com vinha; era a única quinta que podia ser boa para viver e tinha uma área grande, produzia 200 almudes de azeite, 300 arrobas de amêndoa e mais ou menos 100 pipas de vinho; eu no tempo do meu pai ainda lá plantei cerca de 200 laranjeiras, aí pelos anos 1968-1970.

Esta Quinta do Comparado ou Gafaria esteve nas mãos da família Sampaio desde o início do séc. XX, ou mesmo data anterior, cerca de 50 anos antes da compra dos Canais pelo Costa, até 2015, ano em que foi comprada pelos Symington à minha irmã, casada com um dos Antas Botelho de Celeirós do Douro (Sabrosa).

É evidente a presença dos laços familiares e sua continuidade constante no Douro...

A quinta do Santinho que hoje também é dos Symington, fica a cerca de $2 \mathrm{~km}$ da Senhora da Ribeira, mais à frente de Coleja, quem sobe pelo estradão para Vale Coelho, quem vem do Pinhal do Douro, a seguir à Senhora da Ribeira.

[...] Os arquivos do Douro e sobre a Região deviam ser colocados na ADVID (Associação Desenvolvimento da Viticultura Duriense, IVDP (Instituto dos Vinhos do Douro e Porto)

${ }^{839}$ Artur Virgílio Alves dos Reis (Lisboa, 8 de setembro de 1896 - 9 de junho de 1955) conhecido burlão e cabecilha da célebre falsificação em 1925, das notas de banco de 500 escudos com a efígie Vasco da Gama. 
e Museu do Douro. Quando estava no Ministério da Agricultura de Trás-os-Montes e Alto Douro, com o governo do Mota Pinto, fui subdiretor regional e diretor regional em substituição entre 1981 e 1984, tínhamos informação das quintas que tiveram adegas; antes essa documentação entrava na Alfândega do Porto e desde 1990 na Alfandega de Braga que está entregue do Douro... tínhamos a relação de toda a aguardente que entrava, saia e o saldo por causa da isenção do IVA na aguardente e vinhos para aquele periodo (ex. 100 litros de aguardente para $500 \mathrm{~kg}$ de mosto dá 600 litros de vinho) o Estado taxava sobre os 600, mas já taxava a parte comercial; nós tínhamos 24 horas para enviar as declarações [...]

No tempo do PDRITM (Projeto de Desenvolvimento Rural Integrado de Trás-os-Montes) ${ }^{840}$ havia várias componentes: parte agrícola, infraestruturas, ensino e investigação a cargo da UTAD; a viticultura era um dos 5 modelos: Douro, Terra Quente, Terra Fria, Planalto (Miranda Douro) e Montanha (Montalegre); os modelos foram estudados, integradamente, uma nova visão de desenvolvimento de que foram grandes mentores, entre outros, os Eng. Arlindo Cunha da então C.C.R.N. e Vilhena de Gusmão da D.R.T.M., que deu origem ao PDRITM. [...].

Carrazeda era integrada no Douro e na Terra Fria. Com os empréstimos mundiais e os fundos estruturais da União Europeia o Douro teve nas últimas décadas do século XX alguns balões de oxigénio.

O PDRITM foi o primeiro balão de oxigénio que o Douro levou (anos 1980) que incidiu em 5.000 ha de novas vinhas ou reconvertidas o que numa região é muito significativo, tanto mais quanto abarcava as áreas de vinho mais valioso — letras $A, B, C$ e $D[\ldots]$

Nós não tratámos da comercialização mas sim da produção e assim ficámos mais expostos aos mercados porque tínhamos indices de produção superiores (a plantação de vinhas novas que resultou em 5 a 10 vezes mais de produção) aos que o mercado absorvia e às necessidades para consumo próprio. Então, quando se entregavam os vinhos à Casa do Douro, entregavam-se os vinhos de pior qualidade e guardavam-se os de melhor qualidade para fazer algum negócio.

Foi nesta altura que começaram a aparecer os produtores engarrafadores, principalmente nos vinhos não generosos.

Outro balão de oxigénio, este segundo já nos anos 1990, foram os fundos europeus que começaram a ser injetados no marketing e comercialização dos DOC na Região do Douro.

Mas se o futuro fosse dourado, as Associações não tinham falido quase todas; portanto não era uma questão de produção mas foi sobretudo por questões de perspetivas de negócio; apareceram «freelancers» em Foz Côa, etc. que afogaram ou depositaram no fundo do rio contentores de garrafas para estudar a evolução do vinho e aproveitando o marke-

\footnotetext{
${ }^{840}$ Linha de crédito do Banco Mundial - Projeto de Desenvolvimento Rural Integrado de Trás-os-Montes (PDRITM). Decreto-lei 439-C/89, de 23 de dezembro). O Estado Português, na qualidade de mutuário, celebrou com o Banco Internacional de Reconstrução e Desenvolvimento (BIRD) um acordo de empréstimo, em várias moedas, no montante equivalente a 90 milhões de dólares, destinado ao financiamento parcial do (PDRITM).
} 
ting do valor arqueológico do Vale do Côa que teve a marca de «arte rupestre». Diz-se que, misteriosamente, a maioria do vinho desapareceu... vejam-se ainda hoje as notícias muito recentes da investigação sobre o roubo de garrafas de vinho do Porto dos anos 1930, na Casa do Douro - o custo de cada uma dessas garrafas anda agora à roda de 300 euros.

[...] Quanto à situação, posição de Carrazeda de Ansiães neste contexto, pode dizer-se que os pequenos proprietários saíram beneficiados com o incremento da venda local e algum turismo. Só pela produção agrícola, o seu desenvolvimento não é credivel porque tem que haver também uma integração de recursos económicos, agrícolas e sociais sendo que nos assuntos económicos releva o turismo, não tanto o artesanato; era preciso haver nichos de mercado para venda da produção direta; as feiras anuais e outras formas de promoção que se fazem em Carrazeda para o vinho e para a maçã deviam ser feitas também por exemplo para a castanha e outros produtos. Assiste-se atualmente em Carrazeda ao incentivo de criação de um novo nicho de empresas, mas precisamos de exemplos de iniciativa local como nos vinhos, a Grambeira, e a Douro Ansiães, e na fruticultura as aldeias de Pombal, Brunheda e o antigo presidente da Junta da Fontelonga; é preciso aproveitar esses exemplos de dinâmica económica.

Mas no comportamento de Carrazeda, esses projetos do Douro não foram vantajosos na fixação de populações que estão envelhecidas [...] soluções para dar a volta a isto? Não sei, a desertificação e o envelhecimento populacional é um problema mais geral; mesmo na Europa não há hoje vilas com mais de 500 habitantes: por exemplo, em Espanha há aldeias que acabaram para se criarem certas freguesias mais sustentáveis; a desertificação em Espanha levou à concentração das populações em Valladolid, mas em Portugal, isso não aconteceu embora no Alentejo, haja uma outra perspetiva mais alargada do problema populacional $[\ldots]$

Carrazeda não tem massa crítica para conseguir essa reordenação e reorganização mais concentrada. Nas décadas de 1960/1970 fui dos primeiros a ir lá para cima e a fixar-me aí e a seguir a mim, foram os Barbosas de Zedes e os meus sobrinhos; fomos com vontade de lá ficar mas não encontrámos condições, falta lá muita coisa e sobretudo não há como poder criar uma sensação de confiança, não de segurança, faltam cuidados médicos rápidos e de fácil acesso, sítios onde educar os filhos e netos e, sobretudo o que há precisa de ser articulado e os serviços públicos têm de dar resposta no local e terem quem possa e saiba resolver os problemas... tem de haver condições sociais que possam inverter isso...

Em Carrazeda há lugar para dois ou três nichos de ensino e desenvolvimento: 1) Vale do Tua (povoações de Tralhariz, Fiolhal e Castanheiro até Ribalonga...); Vale do Douro (Senhora da Ribeira e dois núcleos Foz Tua e Ribalonga...); 3) Serra (incrementar a exploração da caça...). Mas se trago para ali gente tenho de lhes criar condições para as pessoas se fixarem por aqui: precisamos de serviços de emergência, unidades de saúde básicas, por exemplo utilizar bem e mais a Corporação dos Bombeiros... 
Na perspetiva da fileira dos vinhos e das quintas, as vinhas beneficiaram na parte tecnológica, hoje são todas de "última geração», têm as castas mais selecionadas mas na parte da comercialização é que falhou: temos por um lado os Symington que são hoje no Douro a Real Companhia Velha, a que se deve o conhecimento da Região e a propaganda pois para venderem os seus milhões de caixas de vinho, fazem propaganda das casas e dos lavradores antigos. São as grandes empresas que dão volume aos 200.000 turistas que sobem e descem o Douro; anualmente, tiveram um registo centrípeto e secaram tudo à volta; temos, por outro lado, os pequenos produtores engarrafadores que são a alma da estabilidade das populações e da composição e vitalidade social...

As alavancas do desenvolvimento mais recente de Carrazeda no Douro foram: o PDRITM, na década de 1980; a Europa e os fundos estruturais na década de 1990; e, se calhar, as grandes crises que deitaram abaixo a estrutura antiga do Douro - o negócio hoje do Douro não é o vinho do Porto mas os vinhos DOC, aí é que se deu o salto qualitativo que o Douro teve, em que o mais valorizado passou a ser o que antes era menos...

Carrazeda tem uma história em fronteiras várias: por exemplo, internamente, as antigas casas senhoriais (os Barbosas em Zedes, os Mariz no Amedo, os Sampaios e Mariz originários de Água Revés em Marzagão e Linhares, os Sampaios de Parambos e Castanheiro provenientes de Provezende - Sabrosa, os Sampaio e Melo em Ribalonga); ao nível administrativo: Trás-os-Montes e Alto Douro, Cima Corgo e Douro Superior (Moncorvo, Carrazeda, Vila Flor, Freixo de Espada-à-Cinta e Vila Nova de Foz Côa) nas 3 sub-regiões do Douro do tempo do Moreira da Fonseca (1943), e depois noutras divisões administrativas, por exemplo a do tempo do ministro Antonio Barreto, a que se deve a nova lei orgânica do Ministério da Agricultura, por volta de 1979 que cria a sub-região do Douro com zonas agrárias; historicamente, nas ligações com a outra margem do rio Douro havia a ligar o concelho as antigas barcas do Douro que iam a leilão e licitação, anualmente; eram quatro: a barca do Tua, a da Senhora da Ribeira, a da Alegria e a do Lubazim, ou Freixo, povoações dos municípios de Carrazeda e Freixo de Espada à Cinta que ligavam

[...] Deveria haver essa documentação no arquivo municipal de Carrazeda que se começou a reorganizar quando aí fui Presidente da Câmara [...]

\subsubsection{Produtor vinhateiro, «simples e pequeno $»^{841}$}

[...] Hoje o vinho do Porto está em segundo plano; está um pouco complicado produzir e comercializar; por exemplo em Carrazeda há já algumas empresas que são produtores/ engarrafadores como a Grambeira e a Douro Ansiães que fazem mais dinheiro com os DOC Douro do que com o Vinho tratado [ou vinho fino, designações locais dos antigos vinhos generosos do Douro ou vinho do Porto]; cada pipa (mais de 600 garrafas) de maduro a

\footnotetext{
${ }^{841}$ Conversa informal com J. L. C., Carrazeda de Ansiães, abril de 2014.
} 
$10 €$ dá hoje 6.000€; o ano passado, o das uvas Touriga Nacional estava a 100€, o que dá 1.000€/pipa de vinho tratado; o benefício tem vindo a reduzir...

[...] Agora vendo à Symington 20 e tal pipas por ano; o cultivo e produção é com mão-de-obra local e trabalho próprio - ainda ontem, andei todo o dia a triturar vides, o que é um trabalho difícil e moroso.

[...] fora a dos ingleses, a exploração familiar é a que é mais rentável, mas ser proprietário médio não dá; hoje aguentam-se aqui os novos produtores/engarrafadores como a Grambeira do Meireles, da Beira Grande, e a Douro Ansiães, uma grande adega na zona industrial que é do Zito do Tua, jovem e grande empresário que tirou o curso no Politécnico de Bragança ...o pai dele é do Tua e já tinha máquinas para surribar.

[...] houve negociações com a UTAD para se fazer o marketing turístico das 19 marcas de vinhos DOC do concelho (Grambeira, Trovisco, Portas de Azenha, etc.) -é um fenómeno febre de há 10 ou 12 anos...

Hoje a qualidade dos vinhos da região do Douro está garantida - houve uma grande seleção de castas, sensibilização para plantar castas selecionadas; desenvolvimento da enologia; instalações com processos mecânicos e moderna cultura das vinhas, surribas em profundidade; resolveu-se o problema das regas e controlou-se o processo da maturação das uvas...controla-se nos gabinetes o stress da vinha e a qualidade da rega... o grande problema é vender as uvas e o vinho...

A qualidade dos vinhos do concelho tem a ver também com a exposição privilegiada virada a Sul; as videiras do lado de cá do Douro são mais vigorosas do que do lado de lá do rio...

Não se trata de uma identidade própria... na ribeira há mais convívio com a gente do planalto que vai trabalhar no Douro... os «foleiros»... era o pessoal que ia trabalhar para as quintas do Vilarinho, que vinha dos lados da Régua, Lamego e da serra com as capas de palha... tenho 59 anos e ainda me lembro...alguns trabalhos no Inverno eram feitos por eles... os trabalhos nos lagares eram já feitos pelos locais... hoje os ingleses têm carrinhas que todos os dias levam gente do planalto para a ribeira... aqui na zona não temos aldeias no Douro... em Vilarinho, junto ao rio sempre houve doenças... as maleitas... havia também as lagaradas e o transporte de bois das pipas de vinho e de azeite para os barcos... alguns antigos como o sr A. (80 anos) que trabalhou na quinta do Lubazim, o sr. J. M. que tem agora mais de 90 anos e está hoje no lar de idosos da Lousa; este homem tinha bois e carretou muitas pipas de vinho para ao rio... morreram muitas pessoas debaixo dos carros de bois que iam de arrasto e chegavam a matar homens nas descidas perigosas para o rio... ao fundo junto aos «Lagares»... uma espécie de aldeamento na ribeira...

[...] a Quinta da Pescoça... hoje é dos Symington ou sócios deles e está desativada mas tem dos melhores muros ou geios antigos do Douro, e tinha um bom lagar.. na estrada do Vilarinho para o Pinhal do Douro... vira-se à esquerda e não para a Senhora da Ribeira... 
a 200 metros onde o rio levou a estrada... passa-se no armazém da quinta para ir para a Lousa, pela estrada de alcatrão...

[...] ao fundo da aldeia do Vilarinho, por baixo da igreja, fica a quinta que fcolhia cerca de 100 pipas de vinho... pertencia à família dos do Lubazim, mas foi há tempos comprada por um francês... o grande valor eram os lagares [ver Capítulo 7, Quinta do Lubazim]

Mas hoje para a maioria dos viticultores do Douro o presente não é risonho e o futuro pode ser negro... Enquanto houve uma entidade que controlou a região... a Casa do Douro... os proprietários sentiam-se mais protegidos... agora ficou-se nas mãos dos exportadores... [...] O Douro é a melhor região para negociar... entregam-se as uvas sem preço e só nos dão o que querem... situação muito insegura... se voltar a haver uma organização... as grandes regiões vitícolas do mundo têm aqui um concorrente... mas era preciso estabilizar o benefício a nível quantitativo e qualitativo... preço e quantidade... garantia de valorizar o vinho e as uvas... o que era produzir vinho há 40 anos e hoje é muito diferente... antes havia o comunicado de vindima... desde que a Casa do Douro deixou de regular preços e produção levou ao abandono da vinha no planalto... e o Douro chegou a uma situação de tanto abandono que é a melhor zona do país para fazer negócios: comprar e vender... está na posse de poucos proprietários... e há grandes interesses... mas o Douro vai ter uma nova geração de produtores... por exemplo no Vilarinho houve transmissões de propriedade... os Aguilar que venderam à minha família...tinham muitas propriedades em Foz Côa... a grande Quinta das Tulhas em frente ao Museu é ainda deles... mas também aqui e noutras zonas de vários concelhos de Trás-os-Montes [...]

\subsubsection{Antigo funcionário da Cockburn's e responsável técnico pelas propriedades da empresa na área vinhateira duriense do concelho de Carrazeda ${ }^{842}$}

Eu trabalhava no escritório da Cockburn's, na Quinta de Santa Maria na Régua, mas visitava todas as semanas as quintas do Alto Douro... de 1979/80 a 2005... enquanto lá estive fiz 30 vindimas... 3 aqui na Régua e 27 no Tua... os Cockburn's entraram em Carrazeda antes dos finais do século XIX... a empresa foi fundada em 1815 ... venderam ao Beam... empresa canadiana... em 2006/2007 e estes venderam aos Symington...

A Cockburn Smithes começou por comprar em Vilarinho da Castanheira na Pescoça... eram armazéns... em Vale Coelho era a quinta... depois a Quinta da Telhada... e só mais tarde é que comprou a Quinta dos Canais ao Eng. Ramiro Sobral que ainda vim a conhecer depois, na Guiné, na construção de estradas... ele esteve nas negociações da venda da Quinta dos Canais, o que o deve ter levado a morrer mais cedo porque os filhos estavam todos para fora... eu fui voluntário para a tropa e depois mobilizado para a Guiné... era o mais velho de 7 irmãos filhos de um funcionário publico que era contra as

\footnotetext{
${ }^{842}$ Entrevista realizada com J. M. L., viticultor duriense e ex-funcionário da Cockburn's, Santa Marta de Penaguião,
} maio de 2015. 
cunhas... sou um dos fundadores da Associação de ex-combatentes da Guiné que tem sede e reúne regularmente em Matosinhos...

Lá no Vilarinho ainda conheci alguns carreiros... assim quase como os que hoje fazem o transporte de andores pelos bois na Festa da Senhora dos Remédios em Lamego... eram os homens que faziam o transporte dos vinhos nos bois para os barcos e caminhos de ferro... cada carro de bois levava uma pipa... os barcos levavam entre 30 a 40 pipas e 80 pipas...

A Quinta dos Canais tem 3 a $4 \mathrm{~km}$ na margem do Douro... é uma quinta lindíssima e com uma área de canais feitos em pedra enorme... depois compraram pequenas propriedades de 3 a 4 ha à volta... foi uma reestruturação agrária através da economia de sobrevivência... reestruturação através da criação de quintas modelo a partir de pequenas propriedades...

...O Douro é vítima da história do país.. o mercado de trabalho... o pessoal como os gados ajoelhavam-se... eram os caseiros a rogar o pessoal que ainda tinha que pedir para ir trabalhar... gente submissa, explorada, vitima de injustiças... por exemplo, na Guiné uma das coisas que me chocou foi a quantidade de analfabetos que lá encontrei... só os pobres é que foram para a guerra... no Douro ainda hoje as pessoas têm vergonha de terem sido pobres...

... a diferença entre as pessoas e os processos do Douro velho e novo não é grande... as coisas são muito idênticas... o que chegava ao Douro era o mesmo e os problemas eram os mesmos: fome e pobreza, os assalariados, o beneficio que valorizava a terra, os vinhos que se iam vendendo bem... 4 a 5 décadas de história no Douro que são idênticas à do país... as mesmas mazelas, os mesmos prejuizos... 40.000 postos de trabalho no Douro se fossem distribuídos pela Região, vivia-se muito melhor... centralização é que é um prejuízo...

João de Araújo Correia falava da Rua da Ralha na Régua com uma dinâmica e movimento constantes desde as $7 \mathrm{~h}$ da manhã até à hora de acabar o cinema à noite... borbulhava de gente: sapateiros, barbeiros, médicos, advogados, 20 e tal patrões com 50 empregados...

[...] desde os anos 1950 que estamos a perder pessoas lá em cima como aqui em baixo... os assalariados não fizeram a luta... foi a necessidade que os levou para fora... as grandes empresas descobriram que comprando os governantes e obrigando-os a mudar as leis faziam as mudanças que queriam... como a Dona Antónia que fez a revolução no Douro que comprou uma data de vinho a preços muito baixos na altura da crise... e a Casa do Douro fez o mesmo... tiraram o benefício aos lavradores e deram-no às empresas...estas compraram grandes stocks de vinho e fizeram dumping... nos últimos anos, houve lavradores que se suicidaram no Douro... como o M. H.... as 80 pipas de beneficio que tinham passaram depois para 20 pipas... o A. de S. e o M. H. foram os primeiros produtores- engarrafadores do Douro e foi isso que eu também tentei fazer: produzir, vender e exportar por conta própria ... o marketing e a história vendem-se bem nos mercados grandes... nas 
empresas auto-suficientes com produção própria, o preço de pipa passou de 1.200 para 900 euros... só ficaram com $80 \%$ do valor...

[...] os porta-vozes do Douro são às vezes petulantes e arrogantes... as mais importantes empresas de hoje são a Sogrape, a GranCruz, a Taylor's, os Symington que compraram várias empresas... é a globalização, isto é, como lhe chamo, a glutanização... o resto são pequenos produtores que tentam vender a esses grandes... por exemplo, o futuro da Senhora da Graça... a minha pequena quinta... é de 15.000 garrafas vinhos DOC Douro/ 80.000 euros por ano mas com produção direcionada para restaurantes nas grandes cidades e para o turismo...

[...] nos últimos anos, deu-se no Douro um grande choque com o corte do benefício na RDD onde a cada hectare.. 10.000 m2... correspondem 8 pipas, cerca de 4.400 litros... quando aumentou a área de plantação... com o PDRITM... como a exportação não aumentou foram tirá-lo aos que o tinham e o benefício passou a 2.200 litros por hectare, ou seja metade... em 2001 deu-se a ida a Lisboa de autocarro em protesto contra este corte do beneficio que se sentiu mais nos que tinham menos hectares de vinha... eu também fui como duriense que sou antes de ser funcionário de uma grande empresa... foram durienses dos partidos políticos todos... o governo tem de governar para todos os portugueses e não para os grandes lobbies...

Os pequenos proprietários precisavam do seu vinho mas precisavam também de dinheiro e viram-se obrigados a vender as suas uvas e os cartões de benefício... uma ilegalidade de que beneficiaram os grandes produtores... os pequenos ficaram só com 3 ou 4 pipas de vinho para consumo próprio durante todo o ano e o resto vendiam cartões de benefício... [...] O Douro nunca foi visto pelos olhos dos grandes políticos em termos de evolução... foi havendo a redistribuição da propriedade familiar e a reestruturação agrária da propriedade... para ser sustentável tem de ter 10 a 20ha em média... e o que fizeram foi com o objetivo de beneficiar os grandes que apenas têm cerca de 50\% dos terrenos... os Symington em Carrazeda têm a Quinta dos Canais com 400 ha, a do Vale Coelho, com 10 ha e vinha velha com castas todas misturadas e que é uma das mais bonitas quintas com casa antiga, uma quinta de veraneio que começou com 6 ou 7 ha e foi sendo aumentada com terrenos e vinhas compradas ao lado ... a Cadima e a Telhada com 40 ha... têm uma área grande de muitos hectares e foram compradas depois... e ainda no vale da Vilariça as quintas do Ataíde e Assares... antes, cerca de 300 pequenos lavradores vendiam as uvas à Cockburn's que fazia os vinhos na Adega da Quinta do Tua... a produção desta é de 30 a 40 pipas de Vinho do Porto e 60 pipas de vinho o total da produção... na Adega de Foz Coa e numa nova adega construída na Quinta dos Canais nos fins dos anos 1990 que fazia 1000 pipas... Só a Quinta dos Canais produzia 600 pipas e compravam aos lavradores à volta... Nas adegas todas produziam cerca de 10.000 pipas de Vinho do Porto... carregava-se o vinho em dezembro e levava-se para as Coradas em Gaia... havia as fases da vinificação, do armazenamento e do engarrafamento... mas eu acho que a linha de engarrafamento deve 
ser feita na de produção... no armazém de vinhos que tinham na Régua, no grande armazém de Santa Maria armazenavam-se 10.000 pipas em cascos e tonéis e nas Coradas em Gaia fazia-se o engarrafamento [...]

\subsubsection{Ex-trabalhador sazonal da Quinta dos Canais, anos $1960^{843}$}

[...] Trabalhei lá na quinta do Engenheiro, em 1966/67, após sair da Escola Primária (costumo dizer que ali fiz o meu Ciclo Preparatório). Com doze anos, andávamos à frente dos bois na lavragem das vinhas, olivais e amendoais, carregávamos à cabeça as latas do caldo para alimentação do pessoal e quando necessário trabalhávamos com a enxada...

[...] Essa era a zona da Forneira e da Mariz (onde até existe a capela da Mariz) da Quinta dos Canais e quando no inverno trabalhávamos para estes lados distanciados das casas da quinta dormíamos num espaço contíguo ao dos bois, nos casebres ainda hoje aqui existentes, entorpecidos pelo fragor - agora saudoso — das quedas de água do Síbio...

Nesse tempo, 1966/67, designávamos a Quinta dos Canais por «Quinta do Engenheiro» cujo nome nunca soube e que nunca por lá vi porque se dizia que trabalhava em África. O caseiro chamava-se Fausto e era do Souto.

Sou natural de Selores mas era da Lavandeira que ia mais gente trabalhar na quinta.

Íamos para lá segunda-feira de manhã e vínhamos para casa no Sábado à tardinha, sempre a pé. ... Não consigo precisar quantas pessoas lá trabalhavam mas posso garantir que, devido à sua extensão, apesar de ser a quinta que menos condições oferecia aos trabalhadores (a alimentação era miserável, passava-se fome além de termos de levar o pão de casa) dava trabalho durante o ano a todo o pessoal que aparecesse incluindo rapazes e raparigas que saiam da escola.

Como nesse tempo só uma minoria continuava os estudos, os outros rapazes iam para esta quinta fazer o que atrás descrevi e as raparigas eram integradas nos trabalhos das mulheres. Nos períodos das colheitas (vindima, azeitona e amêndoa) éramos envolvidos também nesses trabalhos...

Não havia recrutamento, as pessoas sabiam que se aparecessem na Quinta dos Canais havia sempre trabalho...

Saí de lá porque me surgiu a oportunidade de ir trabalhar para Coimbra e perante qualquer alternativa ninguém hesitava.

O horário de trabalho era de «sol a sol», isto é, do nascer ao pôr-do-sol.

Alimentação: de manhã, ao nascer do sol, comíamos do pão que tínhamos levado de casa; pelas 9h, almoço: uma tigela de zinco cheia de caldo de couves; Meio-dia: Jantar que consistia na tigela de caldo seguida da mesma tigela de arroz com feijão intragável por ser tão duro — à quinta-feira o arroz de feijão era substituído por massa de feijão; depois

${ }^{843}$ J. M. P., natural da aldeia de Selores, antigo trabalhador sazonal ainda em criança, na Quinta dos Canais. Entrevista realizada em 2015, via Facebook. 
de «despegarmos», ao pôr do sol, a ceia era já no refeitório, à noite, e repetia a ementa do almoço: caldo de couves [...]

\subsubsection{Pequeno produtor de vinho fino em pluriatividade (Ribalonga e Carrazeda) ${ }^{844}$}

Aqui em Carrazeda houve muitos anos uma delegação da Casa do Douro... funcionava no Hospital Velho, lá em baixo ao pé da Igreja quem vai para o Fundo da Vila... trabalharam lá o sr. Américo Teixeira e o sr Moutinho, do Seixo que era um grande produtor do Douro... estava ligado à Quinta da Senhora da Ribeira e à Quinta das Amendoeiras, a quinta do Ministro... o dr. Trigo de Negreiros... era cunhado do médico Dr. Cabral da Fontelonga...

... a Delegação só encerrou aqui com as crises da Casa do Douro, há coisa de 2 anos... quem lá estava agora era o João Fontes, presidente da junta de freguesia do Seixo...

...o Mário Abreu Lima, dos Barbosas de Zedes, foi vice-presidente do IVDP, instituição que esvaziou de poderes a Casa do Douro ao nível de cadastros, benefícios, etc.... mas durante algum tempo ainda tiveram atividades duplicadas... no IVDP, de cá ainda esteve também o eng. Fernando João Martins...

...Na zona da Senhora da Ribeira há muitas quintas já antigas... a Quinta das Amendoeiras ainda é hoje do filho do Ministro, o Joaquim Trigo de Negreiros e de mais 3 filhos... tem o Vinho Negreiros... a quinta da Coalheira era do Engenheiro Faria, filho do Coronel Faria ... a Quinta da Fonte Santa é dos Moutinhos... a quinta que era do Dr. Cabral é pegada à quinta dos Carris... Consta que o Trigo de Negreiros deu 70 contos pela Quinta da Coalheira... ainda me lembra que o carro dele era um Ford enorme, azul... ainda funcionou nessa quinta de Coleja a escola primária... um pouco mais acima, a quinta do Comparado ou da Gafaria, foi herdada pelo Dr. João Sampaio, de Parambos, pai do Dr. João Sampaio que foi Presidente da Câmara... a parte sul foi comprada pelos ingleses... o Dr. João Sampaio que foi muitos anos o Conservador do Registo Civil de Carrazeda deixou a cada filho uma quinta: a Quinta da Veiga à Dr. ${ }^{a}$ Laura, a farmacêutica casada com o eng Mariz de Linhares; a da Gafaria à Dr. a Amélia, a Quinta do Zimbro de Cima ao Dr. João Sampaio, veterinário...

A Quinta da Alegria de Baixo foi dividida... era de uma filha do Mariz de Linhares... mas ainda foram donos dela os Aguilar... e agora é dos Quevedos, um genro do Dr. Morais, de Linhares que fundou o primeiro Colégio de Carrazeda e também era primo dos Marizes... a quinta da Ferradosa pertencia ao Banco Borges \& Irmão...

Em Ribalonga há a Quinta da Capela que é do Ilídio Monteiro que ainda é família... penso... dos Viscondes Sampaio e Mello, a Quinta do Zimbro de Baixo que também era dos Sampaio e Mello... e a Quinta da Cuveta que era dos Ferrand de Almeida que ainda estão

${ }^{844}$ Entrevista a T. R., realizada em Carrazeda, 3 de abril de 2015. 
ligados à família do Dr. João Sampaio, de Parambos, o antigo Presidente da Câmara, e que agora está dividida: a Quinta da Lavandeira que continua a ser dos Ferrand de Almeida e a parte que é, agora, do Altino de Ribalonga...

Mas para além das quintas havia também e continua a haver muitas herdades, propriedades, parcelas de terra com vinhedos... e havia ainda os «arrobeiros»... algumas tinham um armazém com tonéis, lagares, bombas manuais que faziam o vinho para as diferentes companhias que era transportado primeiro pelos carros de bois até aos barcose depois aos comboios no Tua e mais tarde era já levado por carros e camionetas...

Por exemplo, o António Lima, avô da minha esposa, fazia o vinho tratado para a Quinta da Roeda no Pinhão que pertencia à Croft, que hoje é Taylors... ele era o intermediário... mas ainda hoje ali há em Ribalonga quem faça vinho para a Quinta da Roeda... o dr Mário de Carvalho, neto da Casa Carvalho...

O sr. Augusto Cardoso, o sr Ilídio Monteiro... fazem o vinho para a Symington que adquiriu à Cockburn's, o sr. Altino, a Casa Antonio Carvalho são todos «arrobeiros» intermediários, como era o Antonio Lima, o avô da A... antes em que havia mais dificuldades, menores acessibilidades... têm estruturas e fazem o vinho das uvas deles e das que compram... os grandes negociantes de vinhos punham as aguardentes em função das pipas de vinho que se iam fazer e punham um fiscal para controlar a entrada das uvas, a quantidade de aguardente e depois do vinho feito tinham uma forma de selar os tonéis... vinham em Janeiro e fevereiro ver como estavam e deslocalizavam os vinhos já feitos para os entrepostos: Pinhão e Vila Nova de Gaia, através dos barcos e dos comboios...

Nos novos planos de desenvolvimento do Douro já depois da integração de Portugal na União Europeia com os primeiros projetos do PDRTIM ${ }^{845}$ logo que o proprietário tivesse algum terreno atribuíam-lhe licenças para o plantio de vinha e vinho de origem controlada Douro e Porto... eles adiantavam também dinheiro mas em baixas quantias e o lavrador ia amortizando ao longo dos anos...

Até aí, o Douro tinha muito olival e a vinha era cultivada de modo muito tradicional... havia alturas em que as vinhas davam 5 a 6 pipas por hectare... a 250 contos a pipa de vinho letra A... agora a pipa está a $1000 €$ e com a atribuição de 3 pipas por ha em que os custos de produção aumentam muito mais e a mais-valia para o lavrador cada vez fica menos...e não perfazendo esse limite vinham buscar as uvas a meia encosta e ao planalto pondo em risco a qualidade com a adulteração... a crise que tivemos deve-se em parte a isso...

[...] Hoje há um grande negócio de grandes firmas de aguardentes que são feitas de açucar de beterraba... tinham ali em Espanha na zona de Rioja... a Europa subsidiava o plantio de vinhas na Galiza que serviam só para dar uvas para queima e produção de aguardentes... eram os Symington e outros grandes que estavam metidos nisso...

${ }^{845}$ Ver nota respetiva em entrevista anterior, 9.2.1. 
Essa questão das identidades durienses locais aqui... hoje nem tanto, mas já houve tempos em que se sentiam bem as diferenças... o pessoal da «Ribeira» era gente com maior poder de compra, rendimentos maiores do lavrador, gente mais letrada... hoje na «Frieira» temos o eldorado das macieiras onde 1 hectare que fica mais rentável que o da vinha... antes do 25 de abril, a «Frieira» cultivava para vender à «Ribeira»: batata, forragens para os cavalos... havia também a troca de produtos... palha por azeite e outros... por exemplo, o avô da minha mulher...morreu há 23 anos, em 1992, com 82 anos... vendia tudo para o vinho do Porto e vinha a Marzagão buscar as uvas para fazer o seu vinho consumo para gasto e para dar ao pessoal que trabalhava na quinta...

Na transição da I Republica para o Estado Novo, Ribalonga era uma aldeia onde havia muita maçonaria que esteve ligada ao regicídio... gente de muito dinheiro: os CarvaIhos, o Dr Amândio, o advogado das causas perdidas que vinha para a vila conspirar com o Rui Pimentel dos Mogos e com os Veigas da Farmácia Veiga, grandes republicanos do Pinhal do Norte, amigos do Dr Abel Salazar que, salvo erro, era de Mirandela ${ }^{846}$.. e com o Mário Chuço de Valtorno que era antifascista...

Por cá os ingleses eram muito bem recebidos e davam-se bem com as pessoas daqui... quando vinham antes das colheitas faziam umas merendas, pagavam bem e cumpriam o que contratavam e prometiam...

Os motins e conflitos que se deram aqui no Douro e as lutas que ainda se dão hoje por vezes foram mais contra a regulamentação... por exemplo no tempo da Dona Antónia, a Ferreirinha... os vinhos desceram muito na exportação e ela então comprou todos os vinhos que pôde da região para depois vender a preços muito superiores... nessa altura, final do século XIX e ainda depois, houve grandes descontentamentos e manifestações populares $[\ldots]$

\subsubsection{Rogador de pessoal, feitor e encarregado de destilaria de vinhos (Vilarinho da Castanheira e Foz -Tua) $)^{847}$}

[...] Sou nado e criado no Vilarinho, tenho 82 anos, estou viúvo há 14 anos, tenho 6 filhos todos na Suiça, 8 netos e 3 bisnetos... trabalhei naquela casa do Dr. Arnaldo Fonseca... uma grande propriedade dentro da povoação que colhia 105 pipas de vinho... os meus pais começaram a trabalhar lá e eu estive lá também quase 29 anos... depois emigrei, nos anos 1961, para Espanha onde estive 3 anos na barragem e depois para França onde fiquei 18 anos... voltei para Portugal para tratar de os arrumar... tinha de pensar na vida e depois nos filhos que assim não pensaram... não pensaram bem e então os filhos pediram para emigrar e lá estão... vêm cá de vez em quando e eu também vou estar com eles... ainda

\footnotetext{
${ }^{846} \mathrm{O}$ médico, cientista e artista plástico Abel Salazar nasceu em Guimarães e viveu no Porto/Matosinhos.

${ }^{847}$ Entrevista com S. M., octogenário, realizada no Lar de Idosos de Vilarinho da Castanheira, em 2 de dezembro de 2014 .
} 
há uma semana vim de lá mas desta vez dei-me lá mal... encontrei um genro que estava doente... estive 8 dias em casa de cada um... são todos muito meus amigos... a dada altura encontrei-me aborrecido e estive 5 dias de cama e então quis vir-me embora... vim de camioneta com um de Carrazeda, o Óscar, e dormi duas noites em minha casa que dei a um filho e depois voltei aqui para o lar onde estou melhor do que sozinho em casa... hoje ainda fui tratar de arranjar quem me podasse as vinhas...

Essa minha história antiga aqui no Vilarinho tem muito que contar...eu era ainda um rapaz e comecei a trabalhar aos 13 anos... trazia duas juntas de bois todo o ano e 3 machos a lavrar oliveiras nessa casa onde trabalhavam os meus pais... o dono, esse Arnaldo era da Alfândega do Porto e foi para lá porque se não dava bem com a mulher... só voltou para cá quando ela morreu... ele trazia lá diverso pessoal a trabalhar... também andava lá um tio meu (a mulher era irmã do meu pai) que era muito trabalhador mas não sabia bem o que fazia e tinha um defeito grande que era andar com o pessoal a trabalhar e bebia um bocadinho e então arranjava problemas grandes. Uma ocasião, tinha eu 16 ou 17 anos, era meio homem e estava a correr uma vareta de água debaixo dele e estava como morto. Tentei levantá-lo mas sozinho não conseguia... então veio um rapaz ajudar-me e levámo- lo para casa mas a mulher não o deixou entrar porque não gostava que ele bebesse. Chegou a alturas tantas que o meu pai, mãe e 3 irmãs minhas que estão ainda vivas em Lisboa onde vivem...uma é mais velha que eu, tem 85 anos... tiveram de sair de lá... Eu aguentei sempre lá porque então era o seguinte: lá na casa do tal doutor que era muito boa pessoa, eu trabalhei muito mas também eu fazia e desfazia, punha e dispunha porque era o feitor... às vezes o pessoal que lá andava era muito... 17 homens... mas outras vezes, eram menos... 4 ou 5... dependia dos trabalhos... 3 homens diários eram sempre e 4 homens com as crias e as máquinas...

Um dia qualquer aproximou-se e falou-me da destilaria do vinho «que te vamos mandar para lá» e eu então disse-lhe «sr. Dr. não sei bem como vai ser...» mas tinha um homem mais velho que estava no armazém a medir os almudes ...e eu lá é que tinha de confirmar e assistir a toda a medição, como saía a aguardente, etc.... Eu dormia lá na destilaria 20 dias sem de lá sair e mandava-me o comer pelo próprio que carretava o vinho... (2 vezes por dia)... e ao fim de tudo medido e preparadinho eu vim para casa...mas não sei ler...só sabia contar e fazer as contas do vinho da Casa do Douro... depois um dia o dr. disse-me: - tu amanhã tens que ir comigo à Régua, à Casa do Douro, a confirmar tudo... Então nesse dia à noite, tinha 2 homens em que fazia confiança, mas um cunhado meu em que não confiava... porque ele fazia um olival onde gastou 17 dias e apresentou-se com uma conta de 32 dias...; então no fim eu disse-lhe: - não aproveitaste o tempo e ficas a perdê-lo...; defendi o patrão e não the paguei esses dias que ele meteu a mais... a minha irmã veio perguntar-me por que fiz isso e disse-me que ele era desmazelado e gastou mais tempo... 
A alturas tantas, a vinha era muita e em 3 sitios eu trazia 7 mulheres a compor as videiras... cortar, podas, etc...., 3 homens a deitar o sulfato, 3 mulheres a carretar a água e eu à noite tinha de dar contas ao patrão mas apontava tudo na cabeça e não falhava...

E foi assim a minha vida toda...

Para ir à Casa do Douro, na destilaria diz-me o mestre:-Quem vai ficar aqui? E eu disse-lhe: - vou deixar a minha mãe entregue às mulheres que estão a desfolhar e o sulfato que era de pedra tinha de ser feito com a cal... eu é que o fazia... mas passei-o para outro e fui para a destilaria. Começamos a destilar o vinho e diz-me assim o mestre: - Ó sr. Monteiro, quantas pipas mais ou menos faz de vinho?... mas normalmente para ficar para gasto eu fazia as contas de cabeça... dávamos 1,5 l. todos os dias aos homens desde março até setembro, porque o tempo era mais quente e eles andavam a trabalhar.. e então logo the respondi: - 122 pipas de vinho consumo e meia pipa de generoso para gasto da casa... ainda hoje eu faço também o vinho generoso para nosso gasto... por isso tenho ainda em casa 26 litros de aguardente fina... e os filhos quando vêm, levam e bebem.

Cortar as uvas para o lagar fazia eu e os lavradores, mas para a destilaria era o João Carriço do Pinhal do Douro numa camioneta que levava 9 a 10 pipas de cada vez e fazia 2 transportes por dia para o Tua onde o vinho era depois destilado em aguardente que na Casa do Douro na Régua era distribuída... hoje eu vou comprar a aguardente ao Castanheiro do Norte a um homem que a manda vir para lá...

Passou-se um bom bocado de trabalho mas graças a Deus correu tudo bem... e também deu para criar os 6 filhos... como a trabalhar as próprias terras... levava o pessoal deixava 1 ou 2 homens lá a trabalhar e ia para esse meu trabalho...

Lembro-me de os lavradores do Pinhal do Douro trazerem para aqui o vinho para destilar numa junta de carros de bois... e da Lousa... de Moncorvo também vinham... eu tinha então 28 ou 29 anos... a destilaria era no Tua... sim funcionou ai nos anos 1960... era particular mas por conta da Casa do Douro... depois passou para o Pocinho... eu lá na destilaria ganhava o mesmo que aqui... o pessoal ganhava $14 \$ 00$ a jorna e eu ganhava $17 \$ 00$ por dia... o vinho fino era por conta da companhia e da casa inglesa, os Cockburn's... nós é que levávamos lá o vinho e aí faziam o vinho fino... enchia-se um depósito de vinho e punha-se a destilar e corria a aguardente destilada do vinho do alambique... e quando era da vindima é que metiam aquela aguardente com 7 e 8 graus depois das uvas pisadas... e depois o vinho com a aguardente passava a 17 graus...

A Quinta do Lubazim fica junto à estação do Freixo que fica perto do Pinhal do Douro. Muita gente do Pinhal, da Lousa, do Mourão... eram ranchos... e também vinham da Régua... iam trabalhar para o Lubazim que produzi 160 pipas de azeite e 15 ou 20 pipas de vinho tratado... vinham para aí meses e meses, rotos e descalços... dava muito trabalho ao pessoal daqui... porque eram quintas, estavam sozinhos sem as mulheres para tratar deles... chamávamos-lhe os «foleiros»... eu enquanto trabalhei na casa do Dr. Arnaldo 
cheguei a ir à Fontelonga, à Pena Fria e à Alagoa arranjar pessoal para os trabalhos...marcava com eles para irem ter ao trabalho... esses iam e vinham todos os dias...

A Quinta da Urraca no Vilarinho é pegada com a do Lubazim... mas a quinta da Coalheira fica mais longe é já em Coleja mais perto da Senhora da Ribeira... a Urraca é mais pequena e era do Capitão lobo de Carrazeda... depois que ele morreu foi toda renovada... arrancaram o olival e plantaram vinha... é pequenina mas é boa... tem água, laranjeiras... a quinta do Lubazim fica mesmo junto do rio Douro assim como os armazéns antigos... vinham até aí os barcos que carregavam as pipas... o próprio vinho do Porto era feito à beira do rio...

O Armindo Rico é que transportava o vinho para o barco nas distâncias de 100 a 150 metros... já morreu, há 30 anos... naqueles tempos isso era uma aventura... fazia-se o vinho no armazém onde havia também os lagares para pisar as uvas e envasilhavam-se as pipas de 27 a 28 almudes e ele mais 1 ou 2 homens ajudavam os bois a não escorregarem... mas havia pisos próprios... os barcos que escorregavam mais eram os que andavam à sirga... quando não havia vento tinham de puxá-los da terra... empurrá-los para o rio... os barcos rabelos eram puxados pelos bois na margem do rio Douro [...]

\subsubsection{Lavrador e carreiro de Vilarinho e o transporte de pipas de vinho em juntas de bois, anos $1930-1940^{848}$}

[...] Casei aos 20 anos e estive casado 60 anos... tenho 2 filhos, 4 netos e 8 bisnetos... sempre andei com os bois que eram do meu pai, a fazer «carretos»... quando me casei andavam 3 ou 4 lavradores do capitão Lobo da quinta da Urraca a levar as pipas dos lagares de azeite de 3 proprietários... o Assis, o Luis Cordeiro e o Macedo... lá para baixo para o Douro...para a barca do Freixo que levava à estação de Freixo de Numão...

Saíamos daqui com os bois e as pipas e ímos apanhar a barca no rio... a barca saía do Lubazim dos Pizarros [Capítulo 7, Quinta do Lubazim] ... estes faziam por conta deles o vinho tratado... com os ingleses... descarregavam em Vilarinho no largo do pelourinho e vinham os carros pelo coito fora a levá-las... as pipas de vinho tratado... para o Porto... Lavradores daqui do Vilarinho éramos muitos... eu, o Barbosa, o meu primo Carlos, o Armindo Rico e da Lousa [aldeia mais próxima já do concelho de Moncorvo, fronteira com concelho de Carrazeda] eram o Augusto Fontes, o Marcolino, o Meneses, o Pelúcio. Vínhamos lá de manhã, carregávamos as pipas e íamos pelo meio-dia... os carros de bois vinham a chiar... era uma brincadeira... uma animação... cada carro trazia uma pipinha de vinho de consumo e ao chegar ao Pinhal do Douro bebiamos... eu e um americano... chamávamos-lhe assim porque ele depois foi para a América... viemos aqui à Lousa buscar cada um uma pipa de vinho... os filhos do americano chegavam os almudes

${ }^{848}$ Entrevista com J. M., natural do Vilarinho de Castanheira, realizada no Lar de Idosos da Lousa (Moncorvo), 2 de Janeiro de 2015. 
e os cântaros para a pipa; a dada altura o pai que estava a enchê-los na torneira caiu para trás, bêbedo mas sem provar o vinho... só do cheiro... demorava 2 horas a encher as duas pipas... as pipas vinham para o Vilarinho de camião, de lá de baixo e depois os lavradores transportavam-nas aqui para a Lousa... uma vez fui da Pescoça, logo ali perto do Douro... era só carregar a pipa no armazém e descarregar no barco rabelo que vinha do Porto... isso já era dos ingleses... foi aí por volta de 1940...

Em 1962 já eu vim para aqui de licença de Lourenço Marques para onde fui com o eng. Miguel Tavares do Vilarinho... foi ele que me mandou ir... lá eu era encarregado dos jardins da Câmara de Lourenço Marques... fui para a Carris e depois para a Índia como polícia e de lá para Lourenço Marques donde vim depois da Independência... continuei como polícia no Porto, onde aluguei uma casa e vivi com a minha mulher e a minha sogra e tive lá os meus filhos que pus a estudar.. ele é engenheiro eletromecânico e a minha filha professora primária...

Como eram os dias no transporte das pipas nos carros de bois?!.. o capitão só nos dava água-pé durante todo o dia... o meu pai já fazia também esse transporte que era barato... andei lá no Vilarinho a carretar vinho até quando me casei... ao chegar ao sítio no Douro parávamos os carros... levava uma junta de bois cada um... também andava lá um do Pinhal do Douro... tínhamos uma navalha...metíamos no meio da aduela, batíamos por cima e então chupávamos quanto queríamos de vinho tratado... como era até chegarem as pipas ao barco rabelo: ... era só saírem do armazém e já estava lá o barco que ficava a 15 minutos do armazém... a descer os carros iam bem... a subir era pior mas também os carros já vinham sem nada... era uma pândega nessa altura...

Agora, no Douro, é só vinho tratado... na Lousa e no Vilarinho venderam as cepas das videiras aos ingleses para serem plantadas rente ao Douro... os Pizarros do Lubazim fizeram a vinha junto à casa e daí para cima os olivais ficaram a monte... faziam também vinho tratado, compravam as uvas aqui do Vilarinho e da Lousa e eram carregadas e transportadas com os animais... cavalos, burros, jumentos... mas os lavradores eram muito espertos... no fundo punham as uvas ruins e no cimo as boas, as bonitas... e então uma vez tanto os da Lousa como os do Vilarinho tiveram de as trazer de volta porque havia um fiscal a ver aquilo quando as descarregavam nos balcões e então foram devolvidas... isso acontecia nas vindimas com as cestas e os balsões...

Antes só vendiam as uvas para os Pizarro e pros ingleses... que faziam o vinho tratado... havia um outro sujeito que vendia para o Porto... era o Marcolino... comprava as pipa de vinho tanto aqui na Lousa, como no Vilarinho como no Pinhal do Douro... esse que comprou o vinho levou um caneco ao poço encheu-o de água e deu-mo para eu deitar na pipa como vinho... tantas dessas fez que os Pinhos da Foz foram à falência... naquele tempo, tinha eu 22 ou 23 anos... foi quando casei, num sábado...

Hoje não há quem trabalhe... o Lubazim está tudo por fabricar, só há monte e olivais e nem apanham a azeitona... não sendo o Z. L. que comprou ao pé do rio, perto do Luba- 
zim e alguns da Lousa... é que têm aquilo fabricado porque trabalham muito mas também vendem as uvas que têm 'beneficio'... ali junto ao rio é tudo 'beneficio'...

Na altura em que casei andei na Quinta da Urraca uma semana a fazer carretos... andávamos lá uns poucos do Vilarinho, de Coleja, do Pinhal do Douro... éramos 4 ou 5 lavradores... as pipas passavam num barco para a estação de Freixo onde estava um lavrador de Mós que puxava as pipas do Douro para cima para o comboio... O capitão fazia lá muito vinho tratado... só fazíamos o transporte de vinho... as burras é que faziam o transporte das uvas... as pipas no barco não podiam ir cheias porque se houvesse alguma coisa iamos ao fundo... faltava-lhe sempre um ou dois litros... as pipas litradas eram de 25 almudes, cada almude tem 25 litros...

Havia no Vilarinho, na Lousa e em Carrazeda muitos tanoeiros que faziam e concertavam as pipas...

As pessoas de cá tinham boas relações com os ingleses... havia lá na quinta deles [Vale Coelho] uns caseiros daqui do Vilarinho e casaram lá... eles traziam todo o ano pessoal a trabalhar do Pinhal, do Vilarinho, de Coleja, da Senhora da Ribeira que também é dos ingleses...

Daqui para baixo era muito difícil levar os carros de feno e palha para os bois... até aos Lagares onde eram também os bois que puxavam a roda para moer a azeitona...

- Agora vai pôr aí uma que foi contada pelo meu pai... dos Lagares para cima era muito a subir... uma certa altura vinha um no carro ao pé da Passarola..., então o carro desprendeu-se do jugo dos bois, veio para trás, empinou-se e o que o vinha a conduzir caiue morreu logo ali... Os Pizarros, os Macedos e o Assis é que arranjaram a que a estrada para lá fosse construída...

Eu estive em África, Lourenço Marques, 18 anos... em 1962, quando vim de licença, já lá estava há 6 anos... e então depois vinha todos os anos, um mês e pagavam-me as férias... vim cá casar os filhos... só voltei depois da independência de Moçambique... o dinheiro que lá ficou... passei uma procuração ao Álvaro de Coleja para tratar do dinheiro que eu lá tinha...passava-me uns cheques que cheguei a ir receber a Trancoso na Beira porque era por lá que vinha... quando lá estava emprestei-lhe 20 contos e ele só me pagou 3 contos... primeiro, o Salazar deixava vir o dinheiro que a gente quisesse mas depois fez as aldeias para pretos e brancos, dava-lhes casa e uma junta de bois... ${ }^{849}$ daqui do Vilarinho e de Moncorvo estavam lá uns poucos e então nessa altura já o Salazar não deixava trazer

\footnotetext{
${ }^{849}$ Nas décadas de 1950-60, «o Estado Novo português, investiu na criação de colonatos rurais, em África, destinados exclusivamente (Cela, Angola) ou maioritariamente (Cunene, Angola; Limpopo, Moçambique) a famílias de trabalhadores rurais da metrópole para ali transportadas a expensas públicas. Esses colonatos assentavam na pequena propriedade agrícola e procuravam replicar em África a freguesia rural metropolitana, fixando camponeses pobres à terra, trabalhada pela unidade familiar sem recurso a mão de obra assalariada nativa e inicialmente recorrendo às técnicas rotineiras do carro de bois e do arado. Apresentados no discurso oficial como agentes da civilização portuguesa em África e como modelo para as populações indígenas, os colonos constituíam a classe mais pobre e iletrada entre os 'civilizados'» (CASTELO, 2014).
} 
tanto dinheiro e lá ficou muito... eu tinha de ter um documento a declarar que trazia os filhos a estudar para conseguir ter mais algum cá...

O meu pai ainda esteve 5 anos no Brasil... éramos 5 irmãos... ele casou em Santo Amaro que pertence a Foz Côa... a minha mãe e o meu tio eram de lá...

Bem me lembram esses tempos!... eu era novo quando andava nos carretos das pipas... era um pândega... os carros chiavam cada um de sua maneira... tudo se fabricava... havia celeiros e celeiros cheios de pão... ia eu a Vila Flor com os bois buscar cereal de carro, e do Vilarinho para a Lousa trazia os bois [...]

\subsubsection{Feitor e caseiro da Quinta da Lavandeira, Castanheiro do Norte (décadas $1950-1960)^{850}$}

1. Os nomes datilografados das folhas iniciais [manuscritos facultados pós $1 .^{\circ}$ conversa informal] são de membros da junta de Freguesia do Castanheiro, mas não sei o ano. Entre eles, consta o meu Pai José Maria da Pena. Não temos outros documentos escritos da Quinta, além dos que enviei.

2. O meu pai ingressou como caseiro na Quinta, em 1957. Nasceu em 1904. Tinha, portanto, 53 anos. Lá permaneceu 21 anos com mulher e filhos até estes irem borboleteando... - uma ficou por Carrazeda, dois para o Porto, um para o Brasil e o Zé Alex para Santo Tirso, onde estudou na Escola Agrícola Conde S.Bento.

3. O meu pai foi substituir o anterior caseiro, António da Costa Rodrigues, nosso primo, que faleceu subitamente em Janeiro de 1957. O meu Pai, nado e criado em Castanheiro, não obstante ter propriedades suas, aceitou o repto da Dona Candidinha.

Muitos anos antes já era feitor da Quinta. Logo, a família Ferrand d'Almeida, conhecendo o seu caráter e honestidade, não teve qualquer dificuldade em convidá-lo pois sabia ser pessoa muito conceituada na aldeia e respeitado pelos trabalhadores.

Para o meu Pai foi 'um salto qualitativo', passar de feitor a caseiro!

Este cargo exigia grande idoneidade moral e profissional, uma vez que lidava com muito dinheiro de recebimento de bens que vendiam (azeite e vinho em especial) e compra de artigos, alfaias, salários do pessoal etc. Para além disso, havia a troca de correspondência de e para os patrões, a residir em Coimbra.

4. Trabalhavam na quinta em média 16 assalariados. Por altura das vindimas, vinha sempre ranchada - cerca de 20 trabalhadores, da Lavandeira, junto ao Castelo de Ansiães.

5. O meu pai depois da saída da Quinta, em dezembro de 1978, que o peso da idade não perdoa, regressou à sua casinha no Largo do Cruzeiro, em Castanheiro, entretendo-se a jogar sueca e a espalhar sementes à terra para regalar-se a ver o alfobre crescer!

\footnotetext{
${ }^{850}$ Entrevista com respostas escritas, de F. P., solicitador, natural de Castanheiro do Norte, filho mais velho de José Maria da Pena, natural da mesma aldeia, feitor e caseiro da Quinta da Lavandeira, realizada em 10 de maio de 2017.
} 
6. O caseiro que lhe sucedeu (já também falecido) foi Sérgio Lebreiro, filho do Hilário (mas não o folião de Coimbra...). Entrou, portanto, no ano de saída do meu Pai.

O Sérgio teve a 'bênção' além do meu pai, do Dr. João Sampaio (Pai do ex-presidente da Câmara de Carrazeda), para quem trabalhava.

A Dona Candidinha Ferrand, matriarca da família, pedindo informação ao Dr. João, este disparou: - excelente trabalhador e fico muito triste se o levares!

7. A 'tutora' do meu irmão Zé Alexandre para o estudo na Escola Agrícola de Santo Tirso, foi a professora primária Dona Maria da Luz, do Castanheiro. Isto porque um cunhado, irmão do falecido marido Sr. Matos, também andava a cursar nessa escola.

8. Meu pai, José Maria da Pena, era nado e criado em Castanheiro. Ainda criança, o pai dele (meu avô) partiu para o Brasil e nunca mais deu notícias. Assenta como luva a letra da canção que Carlos Tê tão bem escreveu para Ana Moura!

9. No verão (setembro), a Família Ferrand ia sempre passar as férias à Quinta da Lavandeira com filhos, noras, genros e netos.

A Quinta foi sempre da família Ferrand d'Almeida que residiam em Coimbra onde ele (o patriarca) era professor universitário e foi presidente da câmara de Coimbra.

10. A produção agrícola era essencialmente azeite e vinho generoso, produzido este em grande extensão de terreno, nomeadamente o que descia a encosta da Quinta, subia até à Quinta da Cuveta, descia esta encosta até Ribalonga.

Terra de xisto, batida pelo sol, tinha vinho excelente e sou levado a crer classificado na letra 'A'.

Também no Capelão, localizado no sopé da Igreja Senhor da Boa Morte e Tralhariz, bem exposto, portanto, tinham grande área vinícola.

A atestar pelos cerca de oito tonéis existentes na Quinta da Cuveta, andaria pelas 50 pipas colhidas. De referir que nesta Quinta existiam grandes lagares para a pisa tradicional, com homens, tendo ainda alambique para fabrico de aguardente que boa parte dela seria para o vinho tratado.

11. A família Ferrand era muito conceituada no Castanheiro. Religiosa, aquando das férias, iam todos os Domingos á missa, a pé como todos os demais. Não esquecer que nesses idos, não existia ainda a estrada que dá para a Igreja. Era o velho caminha pedregoso quase a pique!

Não tinham nada de sobranceiros. Muito abertos. Cumprimentavam toda a gente.

Um dia as trabalhadoras da Quinta ficaram muito escandalizadas quando perguntaram à menina Candidinha (filha da Dona Candidinha) o nome da filha ainda criança. Esta disparou: - Maria; - Maria quê, menina?; - Maria, só! Esta história verdadeira, ouvi-a vezes sem conta à minha Mãe! 


\subsubsection{Enólogo, viticultor e empresário ${ }^{851}$}

[...] em 1999 os meus pais disseram-me: - das consultadorias que tens nas várias quintas... deixas quem tiveres de deixar, mas aquela gente enquanto precisar de ti tu não a podes largar... e a partir daí iniciámos essa relação de trabalho que é também de amizade... na altura eu já tinha uma grande atividade, era diretor técnico, administrador e homem de confiança... a quinta Bartol é das mais bonitas daqui... hoje está boa, toda mecanizada e está situada numa zona excelente... os custos de produção são relativamente baixos... o ano passado tivemos o grande problema do míldio que afetou muito a vindima mas conseguiu-se ultrapassar o prejuizo... a produção média da quinta é de 160 pipas de vinho global mas com muito bom vinho do Porto... o problema principal aqui é de rentabilidade... como se diz em gíria corrente «muita carcaça e pouco miolo»... este problema é o mesmo do Douro... por exemplo na quinta Bartol que tem muita área temos 38 ha de vinha... desde 2000 plantámos/reestruturamos lá mais 7 ha de vinha nova... colocamos poucas plantas por hectare nas encostas [...] para se ter uma ideia mais aproximada, enquanto que no Baixo Corgo há densidades de 7.000 plantas/ha no Douro Superior anda à vota de 3.500 a 3.800 plantas/ha...

[...] as vinhas vão ficando mais velhas o que para os enólogos é excelente mas na pele do gestor as produções são cada vez mais baixas [...] se estou a fazer a vinha é diferente de estar a fazer vinhos e se queremos algum equilibrrio temos que ir reestruturando ...são problemas diferentes que hoje se enfrentam...

[...] os grandes programas anteriores para o Douro eram interessantes mas estão a terminar... o 'boom' foi no início da década de 1980 com o PDRITM... ${ }^{852}$ nessa altura plantou-se muita vinha no Douro mas sem as condições sanitárias necessárias a que já hoje se atende... mas depois também os ratios económicos começaram a falhar...

[...] já em 1989 estive ligado a um primeiro e grande projeto de vinhos DOC, a linha Scarpa do Grupo SAPEC, em S. João da Pesqueira [...essa adega foi depois adquirida pela Taylor] uma das maiores exportadoras que trabalha com vinhos do Porto de grande qualidade, com uma grande exigência e de grande escala... a Quinta Bartol que vendia os seus vinhos muito bons aos vizinhos Symington que estão ancorados aqui desde Carrazeda ate à Vilariça, vendem agora à Taylor que se deslocou, como outras grandes empresas, para o Douro Superior com o propósito de melhorarem a qualidade dos seus vinhos [...] a Sogrape não tem como principal aposta o negócio dos vinhos do Porto... não há hoje no Douro volumes de negócios como os da Symington que são enormes... é muito importante para a

\footnotetext{
${ }^{851}$ Entrevista feita a F. M., enólogo, viticultor e dono da Empresa Grambeira, em sua casa, Carrazeda, 27 de maio de 2017.

${ }^{852}$ PDRITM - Plano de Desenvolvimento Rural Integrado de Trás-os-Montes e Alto Douro que contribuiu para que a região do Douro mudasse a sua fisionomia com uma profunda renovação dos vinhedos, a mecanização e a modernização técnica, tecnológica e científica, ao ponto de ser considerado marco de referência essencial da radical transformação e modernidade da Região do Douro, nos últimos 20 anos (BARRETO, 2014).
} 
região que a empresa se mantenha dinâmica e robusta financeiramente, pois tem um peso muito importante na região, mormente no nosso Concelho.

[...] a história dos DOCs no Douro é muito recente... o Barca Velha (anos 1950), criação do Nicolau de Almeida é um caso à parte, mas era um vinho de mesa [...] os primeiros passos nos primeiros DOCs foram dados pela Quinta da Pacheca, Domingos Alves Sousa, de Santa Marta de Penaguião [...] e a seguir outros vão para os DOCs, porque o vinho do Porto com a Lei do Terço para os produtores não compensa o investimento inicial [...] em traços largos, no Douro, antes do PDRITM, o que não era Porto era para destilar aguardente... então depois entrou-se numa nova filosofia... não desperdiçar...

[...] o vinho do Porto requer um investimento muito exigente para a produção [...] é como preparar uma fábrica para produzir durante 3 meses e estar parada o resto do ano todo [...] quando a mesma cepa que dá o Vinho do Porto é a que dá também os outros vinhos... inicialmente, os viticultores do Douro que quiseram dar o salto de investir nos vinhos e não só nas vinhas... precisavam de pôr as colheitas no mercado [...] a maioria não tem capital inicial... para adquirir capital inicial investe-se em Vinho do Porto mas para se desenvolverem têm de rentabilizar as vinhas para produzir mais vinhos para os mercados... então a produção e o comércio sentam-se à mesa e fixam um valor que não tem tanto a ver com a produção mas com o mercado...; o produtor vai então retrair a produção e vamos ter excedentes... isto é um problema que sempre existiu no Douro e ainda hoje existe mas agora com a procura de um ponto de equilibrio entre as uvas e os vinhos que estavam sempre dependentes do Vinho do Porto...

[...] os gestores do Douro têm de encontrar mecanismos saudáveis de gerir a coexistência dos dois produtos «Porto»e «DOC» sem que nenhum deles prejudique o outro pois que não são incompativeis porque a sustentabilidade do produtor do Douro depende disso... fazer acordos seguros e confiáveis em conjunto... não se deve entrar em conflitos onde não pode haver conflitos... [e enfatiza]... o que importa aqui é a Região e temos de ser inteligentes para salvar a região... não há uma identidade na Região...

[...] quando as uvas se vendem em excedente são vendidas abaixo do custo de produção... há variações de ano para ano quer em termos de Porto quer em vinhos de mesa...

[...] No Douro é preciso conseguir que as uvas sejam mais bem pagas para não estarem a ser subsidiadas com o vinho Porto...mas é preciso não esquecer que a região esta a competir com outras regiões vitivinícolas bem diferentes (Alentejo, Algarve...) e sobretudo com o mundo... os custos aí... e tudo... são diferentes... eu acho que o Alentejo é o nosso melhor parceiro do Douro no mundo dos vinhos... começa-se por beber um vinho mais facil, a princípio mais agradável ao consumidor comum mas quando a exigência aumenta, trocam-se depressa pelos vinhos do Douro... mais encorpados, mais concentrados, de melhor qualidade com características mais refinadas...

[...] mas nos últimos tempos e hoje em dia o setor dos vinhos evoluiu muito em todo o mundo e os enólogos tiveram nisso um papel muito grande e decisivo... 
[...] No caso do vinho do Porto... Carrazeda tem uma posição singular... pouca produção mas de grande qualidade... a deslocação no Douro mais para norte, para o Douro Superior dá-se pelas suas condições edafoclimáticas especiais. zona mais agreste em temperaturas, chove menos e a vinha é sujeita a um 'stress' muito maior que no Baixo Corgo... ora se a videira está a produzir em condições mais exigentes, apura mais, é de maior qualidade e também porque a produção é menor, é mais rara, é mais apetecível... no entanto isso ainda se não reflete no preço da pipa de vinho, apesar de termos a letra A... por exemplo algumas Casas Exportadoras, pagam a letra A da Régua e a mesma letra A de Carrazeda ao mesmo preço...

[enumera problemas e políticas económico-sociais e demográficas] ... as grandes limitações e problemas que temos hoje aqui em Carrazeda são a desertificação populacional, uma população envelhecida... e a parte agrícola e a viticultura de montanha requerem muita mão-de-obra... muito mais que a maçã que só precisa de mais trabalhadores na apanha, uma vez ao ano... e também as taxas de natalidade são baixíssimas...temos aqui uma equação de difícil solução... os políticos têm de ajudar a resolver o problema que é a dois níveis: a)... de imediata tesouraria; b) desenvolver políticas a médio e longo prazo que levem à fixação e ao repovoamento do interior... é preciso e urgente oferecer outras condições de vida e de fixação a novas populações que estão aqui a chegar... sabê-las receber e integrá-las na nossa sociedade com condições de vida normais e dignas... no passado a mão-de-obra que vinha aqui para o Douro eram os galegos... agora em Carrazeda a mão de obra na lavoura e na vitivinicultura é sobretudo estrangeira... os trabalhadores que vêm para cá e muitos aqui se fixaram são da Bulgária, da Roménia e do Cazaquistão... fazem as vindimas e a apanha da maçã que são em fases coincidentes e requerem um maior volume de mão de obra... são 400 pessoas todas de comunidades estrangeiras... mas também já começam a vir também estudantes portugueses dos seus 18 e 20 anos...

[...] mas outras medidas são necessárias... já macropolíticas... em Carrazeda em que há duas culturas e duas espacialidades... também em termos de macropolítica podemos vir a dar um contributo por exemplo ao nível da gestão levar os gabinetes e os serviços públicos a pensar global... reorganizar e reajustar horários escolares e de formação com os tempos e trabalhos nos setores produtivos... 


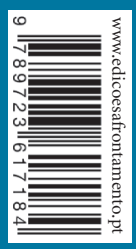

\section{UMCASODEFRONTEIRA NO «DOURO NOVO»}

CARRAZEDA DE ANSIÃES. PARA A

HISTÓRIA DO VINHO DO PORTO

MARIA OTÍLIA PEREIRA LAGE

$\square$ CITCEM

CENTRO DE INVESTIGAÇÃO TRANSDISCIPLINAR

CULTURA, ESPAÇO E MEMÓRIA

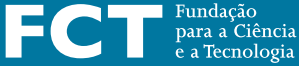

U.PORTO

FLUP FACULDADE DE LERRAS

Cofinanciado por:

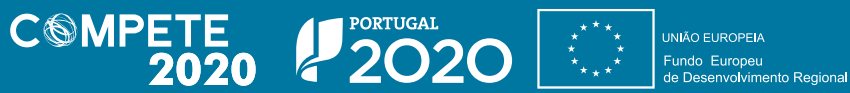

